\title{
HABITAR COLETIVO: OBRAS DIFERENCIADAS CONTEMPORÂNEAS EM SÃO PAULO
}

FABRICIA ZULIN

DISSERTAÇÃO DE MESTRADO [SÃO PAULO | 20I3] ORIENTADOR:RAFAEL ANTONIO CUNHA PERRONE UNIVERSIDADE DE SÃO PAULO | FACULDADE DE ARQUITETURA E URBANISMO | PROJETO DE ARQUITETURA 


\section{HABITAR COLETIVO: OBRAS DIFERENCIADAS CONTEMPORÂNEAS EM SÃO PAULO}

FABRICIA ZULIN 
AUTORIZO A REPRODUÇÃO E DIVULGAÇÃO TOTAL OU PARCIAL DESTETRABALHO, POR QUALQUER MEIO CONVENCIONAL OU ELETRÔNICO, PARA FINS DE ESTUDO E PESQUISA, DESDE QUE CITADA A FONTE.

E-MAIL: fabriciazulin@hotmail.com

Revisão: Noemi Zein Telles

\begin{tabular}{|l}
\hline Z94h Zulin, Fabricia \\
Habitar coletivo : obras diferenciadas contemporâneas \\
em São Paulo / Fabricia Zulin. --São Paulo, 2013. \\
521 p. : il. \\
Dissertação (Mestrado - Área de Concentração: Projeto, \\
de Arquitetura) - FAUUSP. \\
Orientador: Rafael Antonio Cunha Perrone \\
1.Edifícios residenciais - São Paulo (SP) 2. Conjuntos \\
residenciais - São Paulo (SP) 3. Projeto de arquitetura \\
I.Título \\
CDU 711.58(816.11)
\end{tabular}




\title{
HABITAR COLETIVO: OBRAS DIFERENCIADAS CONTEMPORÂNEAS EM SÃO PAULO
}

\author{
FABRICIA ZULIN
}

DISSERTAÇÃO APRESENTADA AO PROGRAMA DE PÓS-GRADUAÇÃO EM ARQUITETURA E URBANISMO DA UNIVERSIDADE DE SAO PAULO PARA OBTENÇÃO DO TÍTULO DE MESTRE EM ARQUITETURA E URBANISMO

AREA DE CONCENTRAÇÃO: PROJETO DE ARQUITETURA

ORIENTADOR: DR. RAFAEL ANTONIO CUNHA PERRONE

[SÃO PAULO| 2013] 

Nome: ZULIN, Fabricia

Título: Habitar Coletivo. Obras diferenciadas contemporâneas em São Paulo

Dissertação apresentada ao Programa de Pós-Graduação em Arquitetura e Urbanismo da Universidade de São Paulo para obtenção do título de Mestre em Arquitetura e Urbanismo

Aprovado em:

Prof. Dr.

Instituição:

Julgamento:

Assinatura:

Prof. Dr.

Instituição:

Julgamento:

Assinatura:

Prof. Dr.

Instituição:

Julgamento:

Assinatura 

Para Bruno Módolo, pelo apoio e carinho do início ao fim. 



\section{AGRADECIMENTOS}

FAUUSP

Dr. Rafael A. C. Perrone

Orientador

Monica Junqueira de Camargo

Luís Antônio Jorge

Membros da Banca de Qualificação

Paulo J.V. Bruna

Hugo Segawa

Monica Junqueira de Camargo

Francisco Spadoni

Regina Maria Prosperi Meyer

Carlos Lemos

Pelas contribuições das disciplinas cursadas

Ruth Verde Zein

Pela orientação inicial na pesquisa

Antonio Carlos Sant'Anna Jr.

Pelo apoio na elaboração do plano de pesquisa

Cristina Xavier

Carlos Ferrata

Maristela Faccioli

Alvaro Puntoni (Grupo SP)

João Sodré (Grupo SP)

Vinicius Andrade (Andrade Morettin Arquitetos)

Joan Villà

Sílvia Chile

Marcos Acayaba

Ararê Sennes (Vista Urbana Arquitetura)

Fábio Mendes (Gui Mattos Arquitetura)

Fabiana Stuchi (Piratininga Arquitetos Associados)

Marcelo Barbosa (Bacco Arquitetos Associados)

Milton Della Pietra (Joy Congero)
Ivie Pietra (Joy Congero)

Neli Shimizu (Vigliecca e Associados)

Hector Vigliecca

Apoena Amaral

Moracy Amaral

Hélio Olga de Souza Jr.

Eduardo Ferroni

Pablo Hereñú

Marie Sorba (Triptyque)

Idea!Zarvos

Não apenas pelos dados fornecidos para a pesquisa como

também pela disponibilidade em explicar os projetos

Zaida Muxí

Josep Maria Montaner

Alessandra Bedolini

Priscylla Lima

Patricia Nahas

Pelo apoio indireto e não menos importante

Rafael A.C. Perrone

Helena Ayoub

Julio Katinsky

$E$ aos outros integrantes do grupo de pesquisa em projeto da FAUUSP

Bruno Módolo

Aos pais

Às minhas irmãs

À amiga e sócia Renata Coradin

Habitar Arquitetas Associadas

Agradecimento especial

Aos funcionários da FAUUSP

À Secretaria de Habitação de Diadema - SP

Aos moradores que abriram as portas de suas

casas para contribuir com a pesquisa

A todos que direta ou indiretamente contribuíram

para o desenvolvimento desta pesquisa 

"A verdadeira viagem de descoberta não consiste na busca de novas paisagens, mas em um novo olhar."

MARCEL PROUST 

Atualmente a paisagem de São Paulo, e também de outras cidades, é marcada por uma produção repetitiva e sem criatividade, mal representada por edifícios habitacionais parecidos e pouco relacionados ao contexto urbano no qual estão inseridos, concebidos por investidores imobiliários que atribuem pouca relevância ao valor autoral do arquiteto como forma de contribuição a seus empreendimentos. Com base neste cenário, a pesquisa partiu de uma pergunta ampla e direta: Onde estão os bons projetos em meio a tanta mesmice? Habitar Coletivo: obras diferenciadas contemporâneas em São Paulo apresenta um estudo das atuais obras de habitação coletiva localizadas na região metropolitana de São Paulo, do início do século XXI, pois, ao que parece, foi um período em que se construiu muito, porém, não necessariamente se construiu bem. Denominar esses estudos de casos como diferenciados, revela-se positivo pelo fato das obras contribuírem com novas possibilidades de agentes, de ocupação de lote urbano, novas técnicas construtivas, novas maneiras de agenciamento do programa, entre outras possibilidades reveladas, muitas vezes rebaixadas na produção comercial usual. Os projetos selecionados foram organizados em três grupos principais: Conjuntos horizontais, Edifícios pouco verticalizados com unidades habitacionais sobrepostas e Edifícios verticalizados com unidades habitacionais sobrepostas. Na segunda parte da pesquisa, Leitura dos projetos selecionados, foram realizadas as análises específicas a partir de dados obtidos primordialmente nos importantes canais de divulgação da produção arquitetônica, como as revistas ProjetoDesign e Arquitetura e Urbanismo; visitas realizadas às obras; conversa e coleta de dados com os escritórios de arquitetura; e redesenho dos projetos. Os textos de cada obra foram organizados a partir de assuntos que se repetem nos diferentes projetos: trajetória do arquiteto; agentes; partido de implantação; espaços exteriores; sistema estrutural e técnica construtiva; envoltória e unidade habitacional. Por fim, após cada leitura são expostas as fichas gráficas correspondentes, também organizadas por temas e escalas principais. A sistematização geral em grupos não engessa comparações apenas entre obras de uma mesma categoria, afinal, são vinculadas a múltiplos sistemas de valoração e possuem cada uma separadamente um conjunto de características muito particulares que, em determinados momentos, são comparáveis ou não a outros projetos, tratando-se, portanto, de uma produção heterogênea e singular. Desse modo, na terceira parte, Análise comparativa e considerações finais por temas presentes nos projetos selecionados, é realizado o cruzamento dos diversos assuntos presentes nos projetos, sendo possível perceber que as obras não representam tipos bem definidos, e sim, possuem ideias que ora pertence a um grupo temático e ora pertence a outro. Também foram identificadas situações de projetos onde os agentes empreendedores principais são os próprios arquitetos, ou situações com empreendedores que valorizam a arquitetura autoral de qualidade, entre outros agentes relevantes a pesquisa. $O$ redesenho dos projetos foi de 
suma importância para algumas conclusões. Também é importante mencionar que não se trata de imaginar que as iniciativas destacadas devam ser entendidas como modelos de "boa arquitetura" a serem seguidos exclusivamente, ao mesmo tempo, os projetos selecionados conseguem expor alternativas superiores em qualidade ao que parece ser a regra do mercado imobiliário que rege decadentemente as cidades.

Palavras-chave: Habitação Coletiva; Edifícios Residenciais; Conjuntos residenciais horizontais;Arquitetura Contemporânea; Pesquisa em Projeto de Arquitetura, arquiteto empreendedor, lote urbano, região metropolitana de São Paulo.

\section{ABSTRACT}

Nowadays, the view in São Paulo and also in other cities is known by a tiring and without creativity production, badly represented for the same habitable buildings which have no connection to the urban context where they belong to, conceived by housing investors who really do not care to the architect's authorship value as a contribution to their project. Basing on this picture the research initiates from one question:Where are the good and innovative projects among the usual and traditional proposals? Collective Housing: A Contemporary and Differential

Proposal in São Paulo presents a current study of collective habitation essays in São Paulo metropolitan region since the beginning of XXI century that was apparently a period of intense construction, although not necessarily a good quality of construction. Calling this paper a differential proposal is positive for the fact that the buildings here proposed contribute to new agents possibilities, urban lots occupation, new building techniques, other options of heading the program, among many possibilities revealed that often are lowered in a usual commercial production. The selected projects were divides in three principal groups: horizontal residential buildings, medium upright buildings with superposed housing units and upright buildings with superposed housing units. In the second part of the paper, reading of the selected projects, particular analysis were made using information retrieved from respectable media channels of architectural production as ProjetoDesign and Arquitetura e Urbanismo magazines' articles, while visiting the projects location, interviewing architecture offices' staff and redrawing the projects. Each proposal text was organized according to the most frequent topics that appear in the different projects: architect's career, agents, implantation party, outdoors areas, structural systems and building techniques, envelopment and housing units. At last, after each reading the corresponding graphic card is exposed and also organized by subjects and main scales. The general group systematization doesn't obligate one to compare projects among the same category, once 
they are connected to multiple valorization systems and own individually a group of peculiar characteristics that in certain moments are comparable or not to other projects, being a mixed and singular production at the same time. In this way, the third part, Comparative analysis and final considerations about selected projects' themes is found a crossing of many projects' subjects where it's possible to notice that the proposals don't represent a well-defined type, otherwise they own ideas that in a moment belong to a thematic group and in another doesn't. It was observed as well situations where the principal entrepreneur agents were architects or situations where the architect's authorship is appreciated by the entrepreneur. The projects' redrawing were essential to some conclusions. Finally it's good to mention that the chosen proposals are not necessarily considered "good architecture" to be exclusively followed, at the same time, the chosen proposals can expose superior alternatives regarding to quality which seems to be the housing market rule that guides the cities in a decadent way.

Key-words: collective housing, residential buildings, horizontal residential buildings, contemporary architecture, research in architecture project, architect entrepreneur, urban lot, São Paulo metropolitan region. 


\section{SUMÁRIO}

I. INTRODUÇÃO

2. APRESENTAÇÃO: A BOA ARQUITETURA DIFERENCIADA

2.I BIBLIOGRAFIA DO CAPÍTULO

3. LEITURA DOS PROJETOS SELECIONADOS

3.I CONUNTOS RESIDENCIAIS HORIZONTAIS

3.I.I VILA BUTANTÃ: ESTÉTICA DA LÓGICA

3.I.I.I INTRODUÇÃO E BREVE TRAJETÓRIA DO ARQUITETO MARCOS ACAYABA

3.1.I.2 AGENTES

3.I.I.3 PARTIDO DE IMPLANTAÇÃO

3.I.I.4 ESPACCOS EXTERIORES

3.I.I.5 SISTEMA ESTRUTURAL ETÉCNICA CONSTRUTIVA

3.I.I.6 UNIDADE HABITACIONAL

3.I.I.7 REFERÊNCIAS

3.I.1.8 FICHAS GRÁFICAS EM ESCALA

3.I.I.9 BIBLIOGRAFIA DO CAPÍTULO

3.I.2 VILA FIDALGA: UNIDADES DIFERENTES UMAS DAS OUTRAS

3.I.2.I INTRODUÇÃO

3.I.2.2 BREVETRAJETÓRIA DA ARQUITETA CRISTINA XAVIER

3.1.2.3 AGENTES

3.1.2.4 INSERÇÃO URBANA

3.1.2.5 PARTIDO DE IMPLANTAÇÃO

3.1.2.6 ESPAÇOS EXTERIORES

3.1.2.7 UNIDADE HABITACIONAL

3.I.2.8 SISTEMA ESTRUTURAL ETÉCNICA CONSTRUTIVA 
3.I.3.I INTRODUÇÃO

3.I.3.2 CONCEPÇÃO DA CONSTRUÇÃO COM PRÉ-FABRICADO CERÂMICO - CPC

3.1.3.3 INSERÇÃO URBANA

3.1.3.4 AGENTES

3.1.3.5 PARTIDO DE IMPLANTAÇÃO

3.1.3.6 ESPAÇOS EXTERIORES

3.1.3.7 SISTEMA ESTRUTURAL ETÉCNICA CONSTRUTIVA

3.I.3.8 ENVOLTÓRIA

3.I.3.9 UNIDADE HABITACIONAL

3.1.3.10 FICHAS GRÁFICAS EM ESCALA

3.I.3.I I BIBLIOGRAFIA DO CAPÍTULO

3. I.4VILA TAGUAII: PARCERIA ENTRE ARQUITETURA E ENGENHARIA

3.I.4.I INTRODUÇÃO

3.1.4.2 INSERÇÃO URBANA

3.I.4.3 PARTIDO DE IMPLANTAÇÃO

3.I.4.4 ESPAÇOS EXTERIORES

3.I.4.5 PERFIL DOS MORADORES

3.1.4.6 AGENTES

3.I.4.7 SISTEMA ESTRUTURAL ETÉCNICA CONSTRUTIVA

3. I.4.8 TÉCNICA CONSTRUTIVA

3.1.4.9 ENVOLTÓRIA

3.I.4. I0 UNIDADE HABITACIONAL

3.I.4. I I FICHAS GRÁFICAS EM ESCALA

3.I.4.12 BIBLIOGRAFIA DO CAPÍTULO

143

152

3.2 EDIFÍCIOS POUCO VERTICALIZADOS COM UNIDADES HABITACIONAIS SOBREPOSTAS

155

3.2.I VILA PEDRO FACHINI: HABITAÇÃO DE INTERESSE SOCIAL NA CIDADE DE SÃO PAULO 
3.2.I.3.2 EXERCÍCIO ARQUITETÔNICO II - BACCO ARQUITETOS ASSOCIADOS PROJETO CARLOS GOMES

3.2.I.3.3 EXERCÍCIO ARQUITETÔNICO III - BACCO ARQUITETOS ASSOCIADOS VILA PEDRO FACHINI

3.2.I.4 INSERÇÃO URBANA

3.2.1.5 PARTIDO DE IMPLANTAÇÃO

173

3.2.1.6 ESPAÇOS EXTERIORES

3.2.1.7 UNIDADE HABITACIONAL

3.2.I.8 A REFERÊNCIA DE FRANZ HEEP

177

3.2.1.9 ENVOLTÓRIA

3.2.1. IO SISTEMA ESTRUTURAL ETÉCNICA CONSTRUTIVA

181

184

3.2.I.I I PERFIL DOS MORADORES

3.2.1.12 FICHAS GRÁFICAS EM ESCALA

3.2.1.13 BIBLIOGRAFIA DO CAPÍTULO

3.2.2 FIORI DI MAGGIO:ARQUITETURA COLETIVA CONTEMPORÂNEA PAULISTA

3.2.2.I INTRODUÇÃO E BREVE TRAJETÓRIA DO COLETIVO DE ARQUITETOS

3.2.2.3 PERFIL DOS MORADORES 
3.3.I.7 SISTEMA ESTRUTURAL,TÉCNICA CONSTRUTIVA E ENVOLTÓRIA 228

3.3.I.8 UNIDADE HABITACIONAL

3.3.1.9 AUSÊNCIA DE PAVIMENTO TIPO

3.3.I.10 POSSIBILIDADE DE AMPLIAÇÃO DAS UNIDADES HABITACIONAIS 234

3.3.I.I I FICHAS GRÁFICAS EM ESCALA

3.3.1.12 BIBLIOGRAFIA DO CAPÍTULO

3.3.2 SIMPATIA 234:ARQUITETURA CONTEMPORÂNEA PAULISTA

3.3.2.I INTRODUÇÃO ETRAJETÓRIA DO ARQUITETO ALVARO PUNTONI E GRUPO SP 243

3.3.2.2 AGENTE

3.3.2.3 PERFIL DOS MORADORES

3.3.2.4 INSERÇÃO URBANA

3.3.2.5 PARTIDO DE IMPLANTAÇÃO

3.3.2.6 ESPAÇOS EXTERIORES

3.3.2.7 UNIDADE HABITACIONAL

253

3.3.2.8 SISTEMA ESTRUTURAL ETÉCNICA CONSTRUTIVA 255

3.3.2.9 ENVOLTÓRIA

255

3.3.2. I0 FICHAS GRÁFICAS EM ESCALA

259

3.3.2. II BIBLIOGRAFIA DO CAPÍTULO

\section{ANÁLISE COMPARATIVA E CONSIDERAÇÕES FINAIS POR TEMAS PRESENTES} NOS PROJETOS SELECIONADOS

4.I.I ALGUNS PARÂMETROS DE INSERÇÃO URBANA DE HABITAÇÃO COLETIVA NA CIDADE DE SÃO PAULO

4.I.2 ALGUNS PARÂMETROS DE IMPLANTAÇÃO NO LOTE URBANO

4.I.2.I ARTICULAÇÕES PAULISTANAS

4.I.3 BIBLIOGRAFIA DO CAPÍTULO

4.2.I ESPAÇOS EXTERIORES 
4.2.I.I METODOLOGIA PARA BUSCA DE NOVOS PARÂMETROS DE QUALIDADE

NOS ESPAÇOS EXTERIORES

303

4.2.I.I.I ESPAÇO EXTERIOR PRÓPRIO

4.2.1.I.2 ESPAÇO EXTERIOR COLETIVO

4.2.I.I.3 ESPAÇO EXTERIOR ENTRE COLETIVO E PRÓPRIO

4.2.I.I.4 ESPAÇO EXTERIOR PRÓPRIO

4.2.1.2 ALGUMAS PAUTAS DE DISCUSSÃO SOBRE O TEMA

4.2.I.3 OUTROS ESPAÇOS EXTERIORES

4.2.I.4 BIBLIOGRAFIA DO CAPÍTULO

4.3 SISTEMA ESTRUTURAL,TÉCNICA CONSTRUTIVA E ENVOLTÓRIA

4.3.I SISTEMA ESTRUTURAL ETÉCNICA CONSTRUTIVA

4.3.I.I COMPARAÇÃO GRÁFICA SISTEMA ESTRUTURAL E TÉCNICA CONSTRUTIVA

4.3.I.2 DESENHO DO SISTEMA ESTRUTURAL

4.3.I.2.I DISPOSIÇÃO DOS PILARES VERSUS VIGAS, PAREDES ESTRUTURAIS,

ENVOLTÓRIA, INSTALAÇÕES E ÁREAS MOLHADAS

4.3.1.2.2 PLANOS ESTRUTURAIS

4.3.I.2.3 SALIÊNCIAS

4.3.1.3 TÉCNICA CONSTRUTIVA

4.3.1.3.I EXECUÇÃO E MONTAGEM

4.3.I.4 MATERIAIS

4.3.2 ENVOLTÓRIA

4.3.2.I COMPARAÇÃO GRÁFICA ENVOLTÓRIA

4.3.3 BIBLIOGRAFIA DO CAPÍTULO

4.4 UNIDADE HABITACIONAL

4.4.I BIBLIOGRAFIA DO CAPÍTULO

4.5 AGENTES

4.5.I AGENTES DA PRODUÇÃO DE HABITAÇÃO COLETIVA CONTEMPORÂNEA

DIFERENCIADA

4.5.2 BIBLIOGRAFIA DO CAPÍTULO
303

304

304

306

307

309

320

321

322

323

335

335

337

338

339

339

341

343

347

362

363

384

385

386

403

407

\section{CONSIDERAÇÕES FINAIS}


APÊNDICE I 



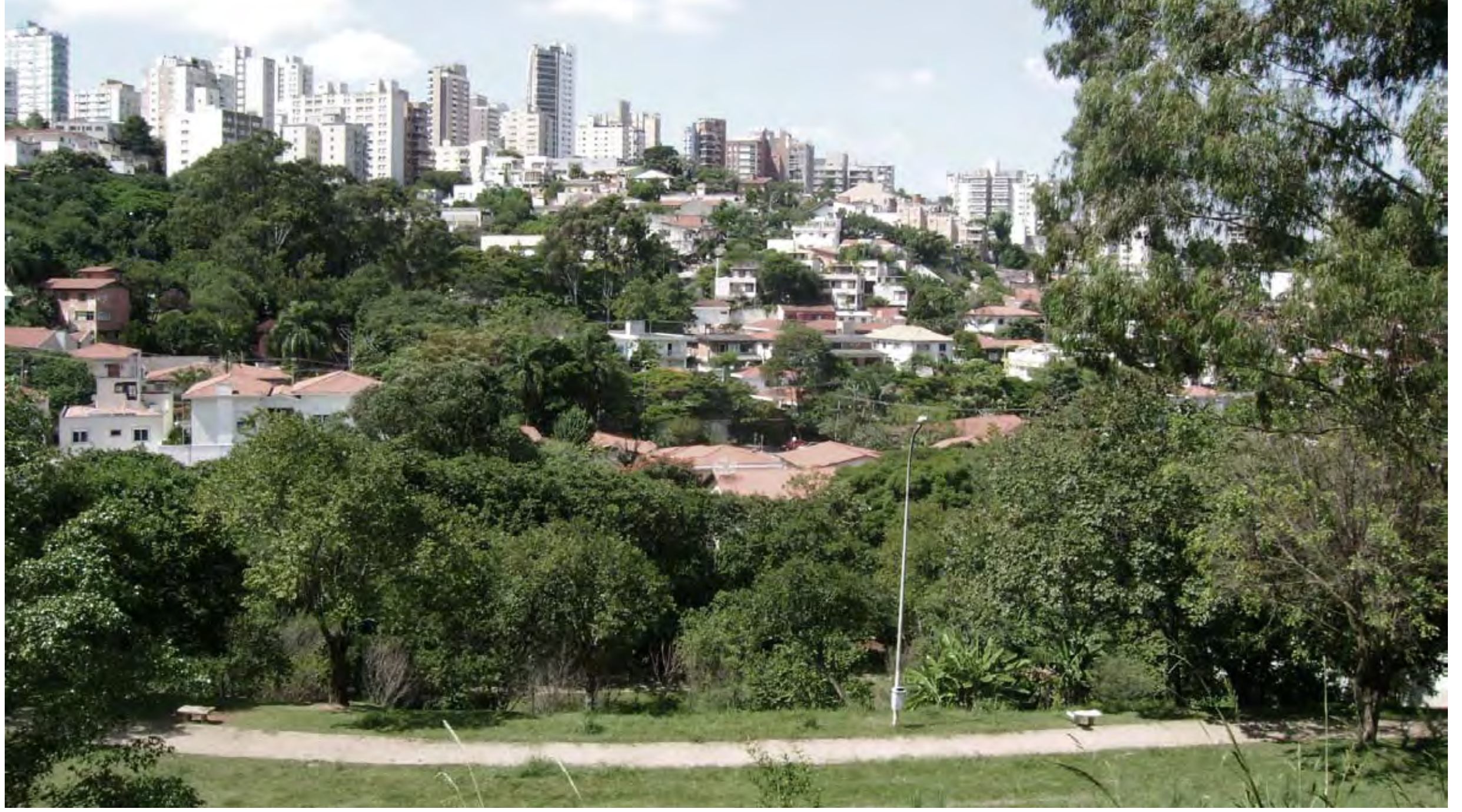

I. INTRODUÇÃO 
Habitar Coletivo: obras diferenciadas contemporâneas em São Paulo apresenta um estudo das atuais obras de habitação coletiva localizadas na região metropolitana de São Paulo, do início do século XXI. Denominar esses estudos de casos como diferenciados, revela-se positivo pelo fato das obras contribuírem com novas possibilidades de agentes, de ocupação de lote urbano, novas técnicas construtivas, novas maneiras de agenciamento do programa, entre outras possibilidades reveladas, muitas vezes rebaixadas na produção comercial usual.

No capítulo 2 de apresentação, A boa arquitetura diferenciada, é feita uma breve explicação do método de seleção dos projetos estudos de casos, expondo algumas etapas de triagem dos projetos, fontes de revelação (como por exemplo, as revistas especializadas), e recorte temporal da pesquisa, destacando algumas mudanças de planos ou leis que interferiram na aceleração da produção de habitação coletiva. No capítulo seguinte, Leitura dos projetos selecionados, os projetos foram organizados em três grupos principais:

- Conjuntos Residenciais Horizontais: Vila Butantã, São Paulo - SP, (Arquiteto Marcos Acayaba);Vila Fidalga, São Paulo - SP, (Arquiteta Cristina Xavier); Canaã, Cotia SP, (Arquitetos Joan Villà e Sílvia Chile) e Vila Taguaí, Carapicuíba - SP, (Arquiteta Cristina Xavier e Engenheiro Hélio Olga);

- Edifícios pouco verticalizados com unidades habitacionais sobrepostas: Vila Pedro Fachini, São Paulo - SP, (Arquitetos Marcelo Barbosa e Jupira Corbucci) e Fiori di Maggio, São Bernardo do Campo - SP (Arquitetos Carlos Ferrata, Apoena e Moracy Amaral, Eduardo Ferroni e Pablo Hereñú);

- Edifícios verticalizados com unidades habitacionais sobrepostas: Fidalga 772,São Paulo - SP(Andrade MorettinArquitetos) e Simpatia 234,São Paulo - SP (GrupoSP). 
As análises específicas dos projetos foram realizadas a partir de dados obtidos primordialmente nos importantes canais de divulgação da produção arquitetônica, como as revistas ProjetoDesign e Arquitetura e Urbanismo; visitas realizadas às obras; conversa e coleta de dados com os escritórios de arquitetura; e redesenho dos projetos. Os textos de cada obra foram organizados a partir de assuntos que se repetem nos diferentes projetos: trajetória do arquiteto; agentes; partido de implantação; espaços exteriores; sistema estrutural e técnica construtiva; envoltória e unidade habitacional. Após cada leitura são expostas as fichas gráficas correspondentes, também organizadas por temas e escalas principais, e por fim, é exposta a bibliografia referente à leitura realizada do projeto.

A definição de grupos pela quantidade de pavimentos (Conjuntos Residenciais Horizontais, Edifícios pouco verticalizados com unidades habitacionais sobrepostas e Edifícios verticalizados com unidades habitacionais sobrepostas) para organização dos projetos, colabora na sistematização por predomínio de características relacionadas e por isso comparáveis (forma de agrupamento das unidades habitacionais, estrutura, agenciamento do programa, tipologia edilícia, etc.), porém, nem sempre as comparações ficam exclusivamente relacionadas a projetos pertencentes ao mesmo grupo, já que são obras com características muito particulares.Assim, a sistematização geral por grupos não engessa comparações apenas entre obras de uma mesma categoria, afinal, são vinculadas a múltiplos sistemas de valoração e possuem cada uma separadamente um conjunto de características muito particulares que, em determinados momentos, são comparáveis ou não a outros projetos, tratando-se, portanto, de uma produção heterogênea e singular.

Desse modo, na quarta parte da pesquisa, Análise comparativa e considerações finais por temas presentes nos projetos selecionados, é realizado o cruzamento dos diversos assuntos presentes nos projetos, sendo possível perceber que as obras não representam tipos bem definidos, e sim, possuem ideias que ora pertence a um grupo temático e ora pertence 
a outro. Também foram identificadas situações de projetos onde os agentes empreendedores principais são os próprios arquitetos, ou situações com empreendedores que valorizam a arquitetura autoral de qualidade, entre outros agentes relevantes a pesquisa. $O$ redesenho dos projetos foi de suma importância para alcance de algumas conclusões. São temas de comparação entre os projetos: Inserção Urbana (no entorno imediato e lote urbano), Espaços exteriores, Sistema Estrutural, Técnica Construtiva e Envoltória, Unidade Habitacional e Agentes.

Estas comparações dentro de diferentes temas abordados no capítulo 4 já fazem considerações finais sobre os projetos e o tema da pesquisa, assim, o capítulo cinco inclui um comentário final de fechamento da pesquisa. 




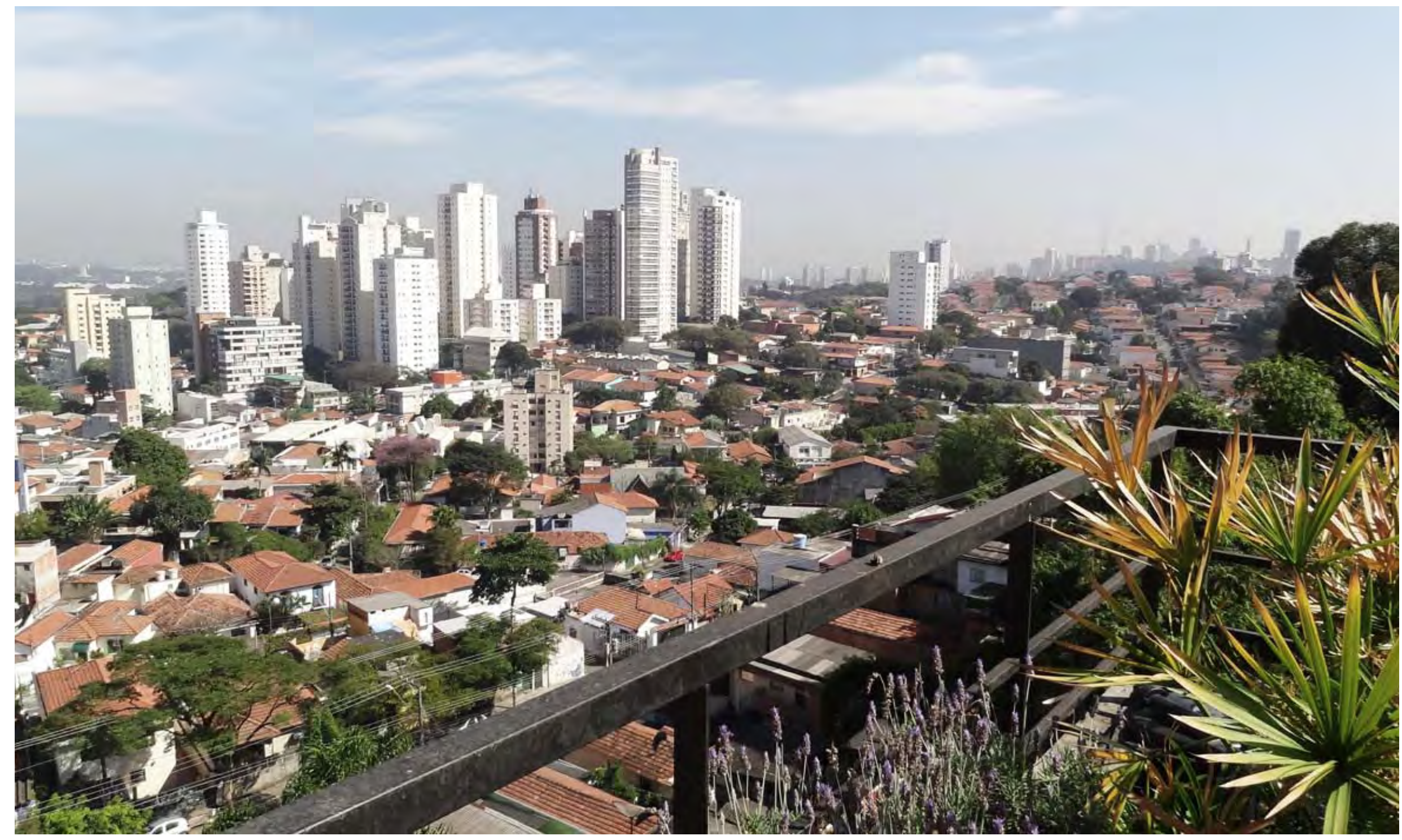

2. APRESENTAÇÃO: A BOA ARQUITETURA DIFERENCIADA 
A pesquisa partiu de uma pergunta inicial: $O$ que está sendo realizado com qualidade, nos últimos anos, no âmbito da habitação coletiva? Ou ainda: Onde estão os bons projetos em meio à tanta mesmice? Assim, num primeiro momento, não tiveram critérios claros e bem definidos para seleção dos projetos a serem estudados. Muito menos foi um processo irracional ou aleatório, contando inicialmente com a percepção, intuição e o "olho" do jovem arquiteto pesquisador, que foi treinado ao longo da pesquisa, afinal, alcançar a mínima visão seletiva e apurada com relação à distinção entre uma arquitetura com ou sem qualidade, é uma habilidade que exige tempo e paciência:Talvez identifiquemos a "boa arquitetura" e outras belezas por nosso olho, treinado, aí sim no modernismo, mas com a liberdade mental e cultural de fugir aos ditames arquitetônicos e politicamente corretos de cada época. (TEPERMAN, 2009, p. 79).

Conjuntamente com o método intuitivo descrito acima, a seleção do primeiro grupo de projetos para esta pesquisa, apoiou-se na triagem que as próprias revistas especializadas em arquitetura e urbanismo já realizam naturalmente, afinal, publicam projetos de bons escritórios de arquitetura, inclusive muitos deles premiados, sendo que, a partir do momento em que são divulgados ou publicados nos canais de comunicação, se tornam públicos e entram na pauta de discussão entre os arquitetos e estudantes de arquitetura. Assim, com base em importantes revistas de arquitetura e urbanismo do Brasil - ProjetoDesign e Arquitetura e Urbanismo, (figuras I a 4), foram encontradas mais de cem obras de habitação coletiva no período de dezembro de 1999 até junho de 201 I' (APÊNDICE I), de diversas partes do Brasil e do mundo e por agentes promotores variados (Figuras 5 a7).

'Depois de junho de 201 I mais projetos de habitação coletiva foram publicados nas revistas e considerados na pesquisa, como poderá ser notada na bibliografia dos capítulos.

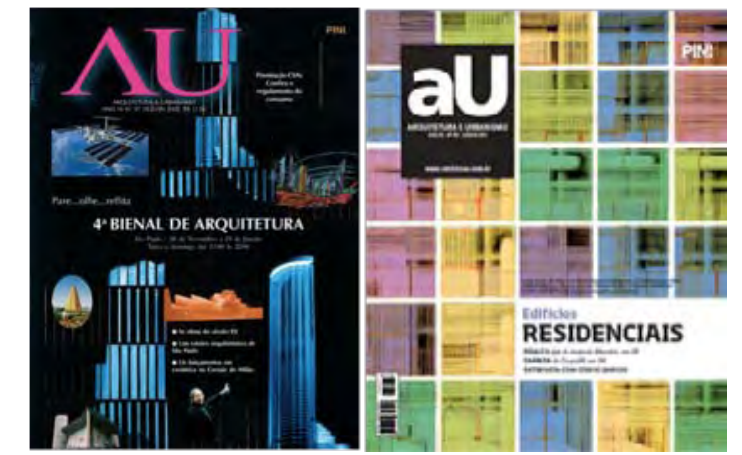

Figuras I e 2 - Revista AU: da Edição 87 (dez 1999) e Edição 207 (junho 20I I), a última é uma edição especial de edifícios residenciais.

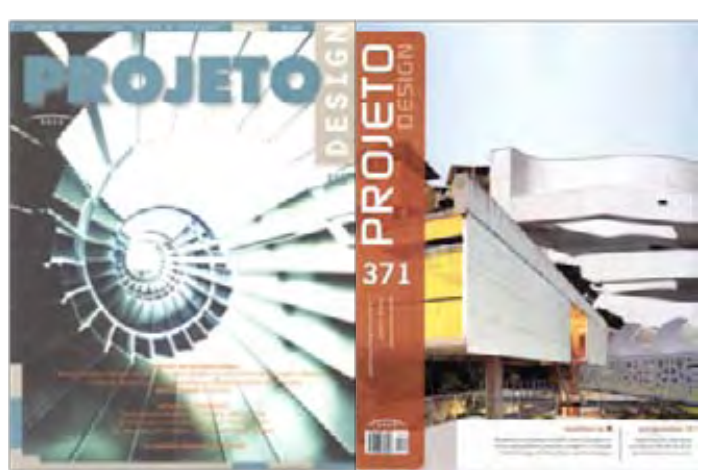

Figuras 3 e 4 - Revista ProjetoDesign: da Edição 238 (dez 1999) e Edição 37 I (jan 201 I), a última é uma edição especial anos 00 , recorte temporal da pesquisa. 


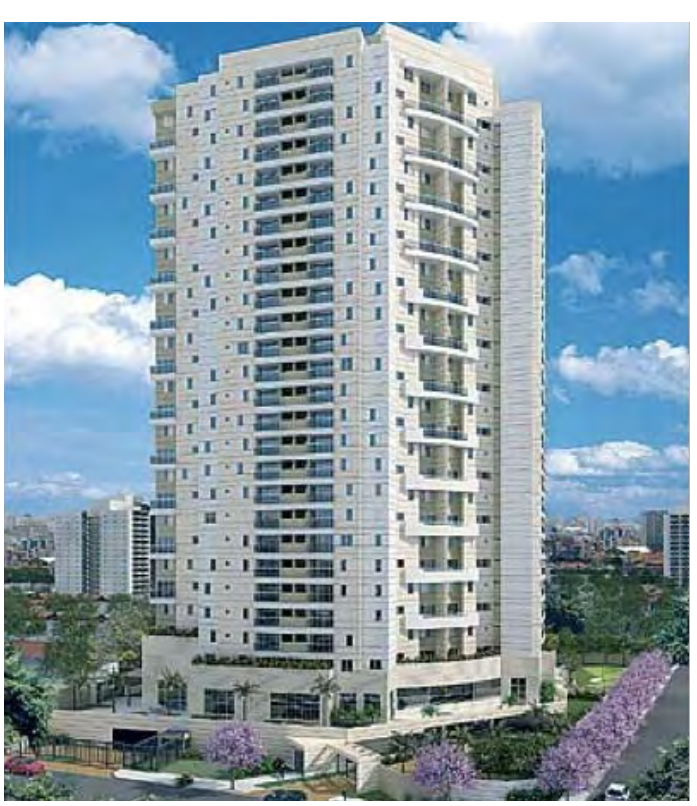

Figura 5 - Condominium Club Up Side e East Side Club Condominium Konogsberger Vannucchi Arquitetos Associados, Paraíso, zona Sul, São Paulo. MELENDEZ, Adilson. Condomínios substituem fábrica onde projeto Brahma fracassou. ProjetoDesign. São Paulo, n.299, janeiro de 2005.

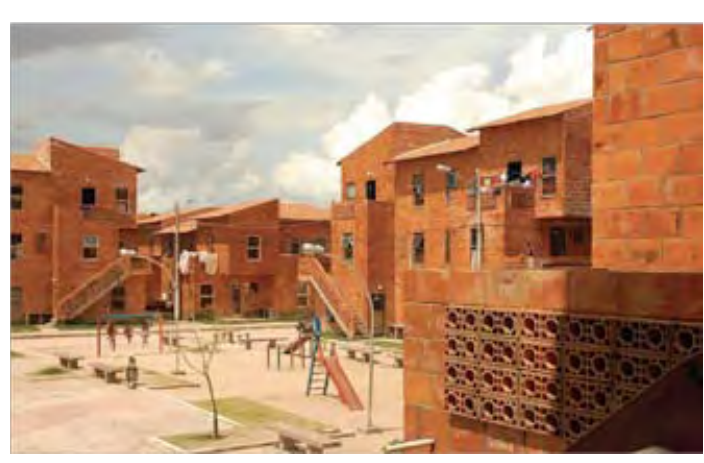

Figura 6 - Vila da Barca (2003-2007) Escritório Cooperativa. Belém, Pará. MOURA, Éride. Poliedros regulares. Arquitetura e Urbanismo. São Paulo, n. I70, p.32-37, maio de 2008.
Há algum tempo nossa editora sugeriu-me um tema para o artigo, sobre o que é boa arquitetura. É surpreendente notar que as editoras de revistas de arquitetura e interiores no Brasil (é curioso, são quase todas mulheres que não são arquitetas), pelo seu contato diário com a nossa profissão, publicam obras que são na média (e na mídia) boa arquitetura, muito embora nem essas editoras saibam o porque de as terem escolhido. (TEPERMAN, 2009, p. 79)

Num segundo momento da pesquisa, houve um processo de filtragem da primeira seleção, mantendo as obras construídas, localizadas na América Latina, e aquelas mais relacionadas ao lote ou quadra urbana onde estão inseridas. Uma hipótese inicial foi de que muitos projetos na cidade, considerados sem qualidade arquitetônica, eram projetos muito similares ou representavam meras replicações de padrões ditados pelo mercado imobiliário. Deste modo, foi levantada a suposição de que lotes urbanos pequenos, irregulares, com topografia acidentada entre outros condicionantes relevantes do lote, seriam aqueles com maiores restrições para implantação de tipologias "carimbos", em sua maioria, promovidas por grandes incorporadoras do mercado imobiliário (como por exemplo, Gafisa, Cyrela, Brascan, MRV, etc.). Depois se somou a esta hipótese outros condicionantes também importantes, como os agentes promotores, o programa, o arquiteto, entre outros, como poderá ser notado ao longo da pesquisa.

Diferentemente do que se imaginava inicialmente, até mesmo nas revistas especializadas são publicados alguns projetos voltados para o segmento comercial, contratados por grandes clientes conhecidos do mercado imobiliário, como os citados acima. Assim, os projetos, que num primeiro olhar pareciam ter o partido do empreendimento definido e conduzido pelo agente incorporador imobiliário, foram descartados da pesquisa, como por exemplo, o Condominium Club Up Side e East Side Club Condominium, da Brascan, de autoria de Königsberger Vannucchi Arquitetos Associados (Figura 5). Deste modo, ficou nítido que não se tratava de uma seleção que partiria apenas de bons arquitetos, como também, de clientes não convencionais ou especiais entre outros condicionantes que colaboram positivamente com o resultado final e, consequentemente, tornam os projetos 
diferenciados e com qualidades. Assim, o que se buscava naquele momento, eram arquiteturas com ideias que se diferenciassem das propostas correntes oferecidas pelo mercado imobiliário, que predominam nas grandes cidades, como São Paulo. Neste caminho, foram selecionados 34 projetos, apresentados na banca de qualificação que ocorreu em fevereiro de 2012 (APÊNDICE 2). (Figuras 8 a 10). Numa fase final e atual foram mantidos apenas os projetos da Região Metropolitana de São Paulo (RMSP), pela facilidade de visita e registro fotográfico, pelas oportunidades de contato direto com os arquitetos autores dos projetos e agentes, incluindo obtenção de material gráfico para as análises necessárias (arquivos digitais em extensão DWG para edição pelo programa AutoCad) e também, pela coerência maior de algumas comparações entre os projetos, em alguns temas relacionados a localização dos mesmos. Assim, foi obtida uma pequena amostra de obras de habitação coletiva contemporânea na região metropolitana de São Paulo do século XXI, com qualidade arquitetônica superior a encontrada na produção mais comum do mercado imobiliário. Consequentemente, surgiram situações de projetos onde os agentes são os próprios arquitetos ou por demanda de clientes especiais, como será notado ao longo da pesquisa.

Os projetos selecionados para uma leitura e análise mais precisa foram:

- Conjuntos Residenciais Horizontais: Vila Butantã (Arquiteto Marcos Acayaba); Vila Fidalga (Arquiteta Cristina Xavier); Canaã (Arquitetos Joan Villà e Sílvia Chile) eVila Taguaí (Arquiteta Cristina Xavier e Engenheiro Hélio Olga);

- Edifícios pouco verticalizados com unidades habitacionais sobrepostas: Vila Pedro Fachini (Arquitetos Marcelo Barbosa e Jupira Corbucci) e Fiori di Maggio (Arquitetos Carlos Ferrata, Apoena e Moracy Amaral, Eduardo Ferroni e Pablo Hereñú);

- Edifícios verticalizados com unidades habitacionais sobrepostas: Fidalga 772 (Andrade Morettin Arquitetos) e Simpatia 234 (Grupo SP).

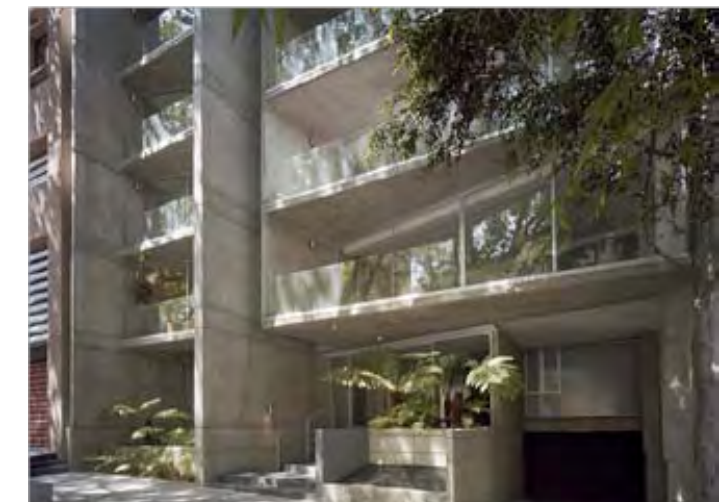

Figura 7 - Temístocles 12 (2006), JSA Arquitetos, Cidade do México, México. LEAL, Ledy Valporto. Jogos de planos e volumes. Arquitetura e Urbanismo. São Paulo, n. 172, julho de 2008. 


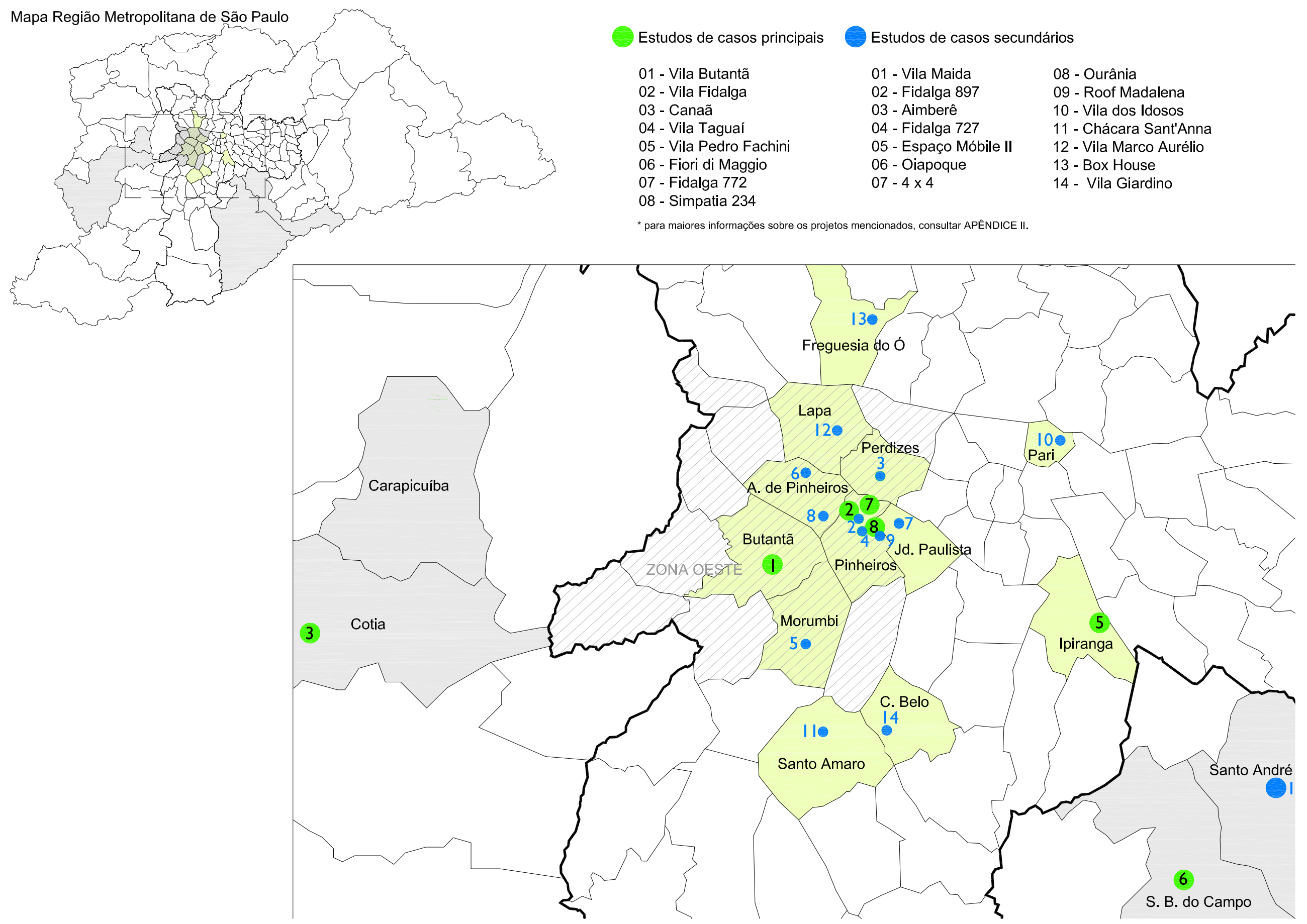


Ao longo das leituras dos projetos e também nas comparações finais realizadas na última parte da pesquisa, outros projetos são citados, de modo a colaborar com o entendimento das diversas situações expostas. $O$ mapa da página anterior representa os projetos envolvidos.

O recorte temporal acabou abrangendo principalmente a primeira década do século $\mathrm{XXI}$, com alguns exemplos citados do final do século anterior e outros do início da década de 2010 . Ao que parece foi um período o qual se construiu muito, porém, não necessariamente, se construiu bem. Segundo Petrucci (2010), diretor executivo e economista-chefe do SECOVI-SP (Sindicato das Empresas de Compra,Venda, Locação e Administração de Imóveis Residenciais e Comerciais de São Paulo), o cenário anterior à década de 2000, era de escassez de financiamento imobiliário muito por consequência do processo inflacionário dos anos 1980, que passa a ser razoavelmente controlado a partir de 1994 com o Plano Real. Houve alguns fatores que influenciaram o mercado imobiliário na década de 2000 em São Paulo, como por exemplo, o Plano diretor estratégico (2002), com redução do coeficiente de aproveitamento dos terrenos e ao mesmo tempo a implantação da Outorga Onerosa (algo que favorece mais as construtoras do que o pequeno proprietário, que teve em alguns casos o potencial do seu terreno diminuído); crédito da Caixa Econômica Federal para financiar as construtoras (2006); entre outros episódios que levaram o Mercado Imobiliário a atingir pico histórico de lançamento de unidades para comercialização: 45,6 mil unidades lançadas no município de São Paulo em 2008.

Ao mesmo tempo, o que parece, é que a escolha foi, na grande maioria dos casos, por construir, não necessariamente construir bem. Esta situação de construção em massa sem qualidade arquitetônica muitas vezes parece estar designado apenas aos empreendimentos de habitação social de promoção pública, por exemplo, os "prédios-caixão"2, porém, não foi exatamente o que ocorreu

${ }^{2}$ Segundo CEF (2012, p. 43), os prédios-caixão se constituem de blocos residenciais de até quatro pavimentos (permitido sem o uso de elevadores) com quatro apartamentos, assemelhando-se a uma grande caixa apoiada no terreno. Foi construído um número expressivo dessas edificações - nos últimos trinta e cinco anos, estima-se que cerca de cinco mil edifícios desse tipo foram construídos apenas na RMR (Região metropolitana de Recife), lembrando que esta não é uma situação isolada da RMR, afinal, foi amplamente utilizada em diversas regiões do território brasileiro na mesma época, incluindo a RMSP.

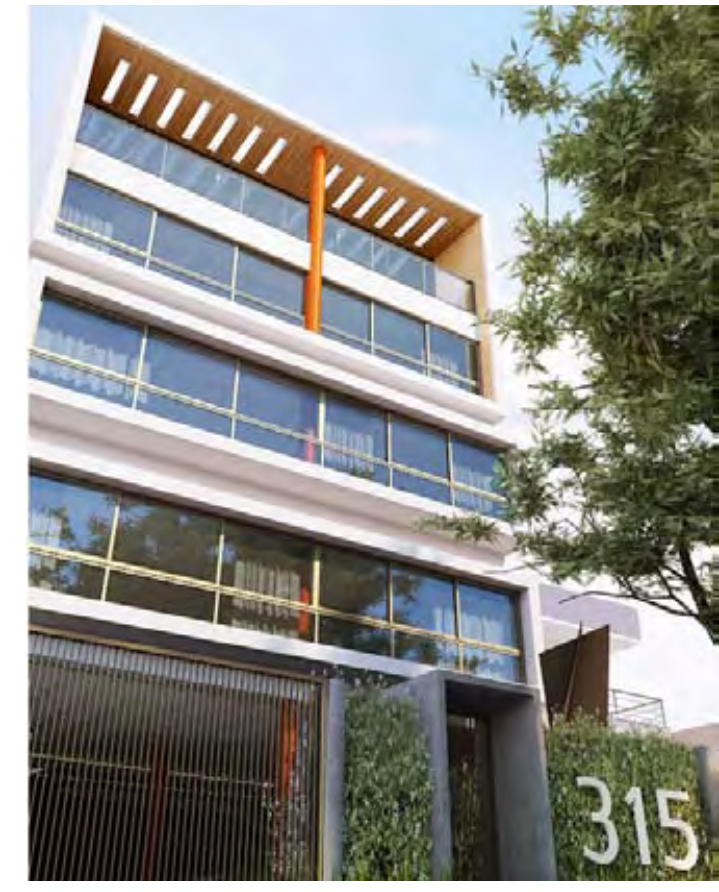

Figura 8 - Amélia Teles 3 I5 (2009-20 I I), Smart!Lifestyle+Design Arquitetos. Novo futuro para os edifícios residenciais de Porto Alegre. Arquitetura e Urbanismo. São Paulo, n. 189, dezembro de 2009.

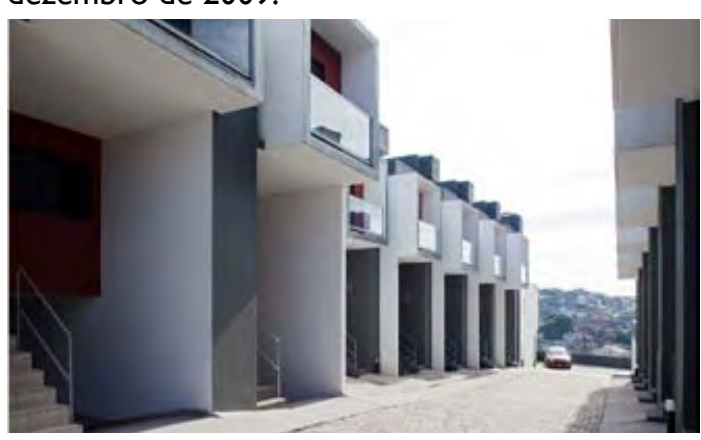

Figura 9 - Box House (2007-2008) Yuri Vital. CAPOZZI, Felipe. Inovação a baixo custo.Arquitetura e Urbanismo. São Paulo, n. 194, p. 48-53, maio de 2010 . PROJETODESIGN. São Paulo, n.348, fevereiro de 2009. 

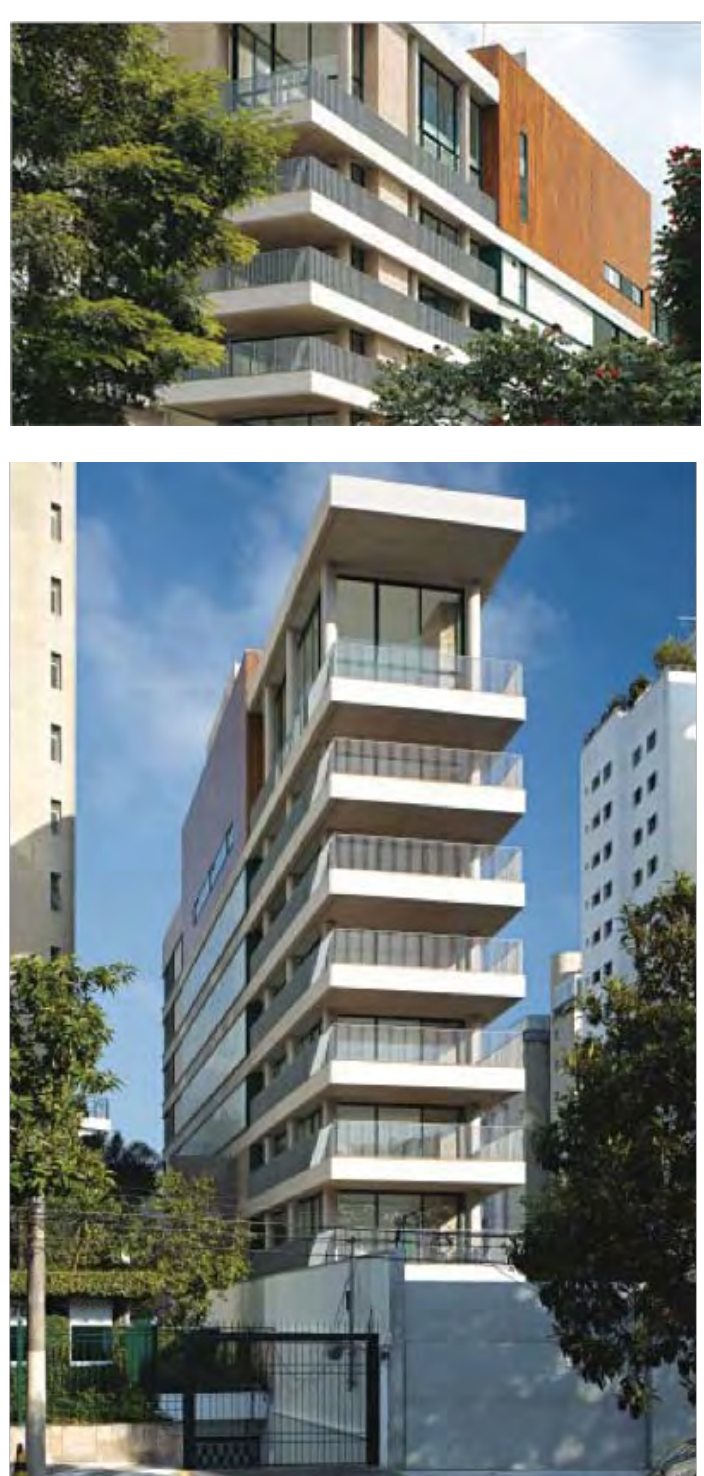

Figura 10 - Panorama (2006-2007), Isay Weinfeld. GRUNOW, Evelise. Retrofit adiciona volume frontal à antiga edificação. ProjetoDesign. São Paulo, n.340, junho de 2008. LEAL, Ledy Valporto. Área livre. Arquitetura e Urbanismo. São Paulo, n. 17I, junho de 2008. no período em questão, já que a construção repetitiva e em grande quantidade atingiu empreendimentos destinados a diversas classes sociais.

Em meio a este cenário, repleto de muita construção e pouca arquitetura, é que se julgou necessário buscar alguns exemplares da boa arquitetura de habitação coletiva, afinal, era preciso resgatar parâmetros positivos que estariam se perdendo em meio a este contexto, ou expor novos parâmetros existentes e pouco percebidos.

$\mathrm{Na}$ sequência serão expostas as leituras individuais dos projetos selecionados, que trazem contribuições diversas para o tema da habitação coletiva contemporânea. Representam uma amostra, pois, conseguem expor apenas algumas maneiras de atuação na cidade, não todas. Também é importante mencionar que não se trata de imaginar que as iniciativas destacadas devam ser entendidas como modelos de "boa arquitetura" a serem seguidos exclusivamente, ao mesmo tempo, os projetos selecionados conseguem expor alternativas superiores em qualidade ao que parece ser a regra do mercado imobiliário que rege decadentemente as cidades. 
2.I BIBLIOGRAFIA DO CAPÍTULO

TEPERMAN, Sérgio. Boa Arquitetura. Arquitetura e Urbanismo, São Paulo, n. 185, p. 79, agosto de 2009.

PETRUCCI, C. Balanço do mercado Imobiliário. 200 I - 20 I O. A década da retomada. São Paulo, SECOVI-SP, 20 I0.

CAIXA ECONÔMICA FEDERAL (CEF). Engenharia para prédios-caixão na região metropolitana de Recife. Brasília, 2012. 




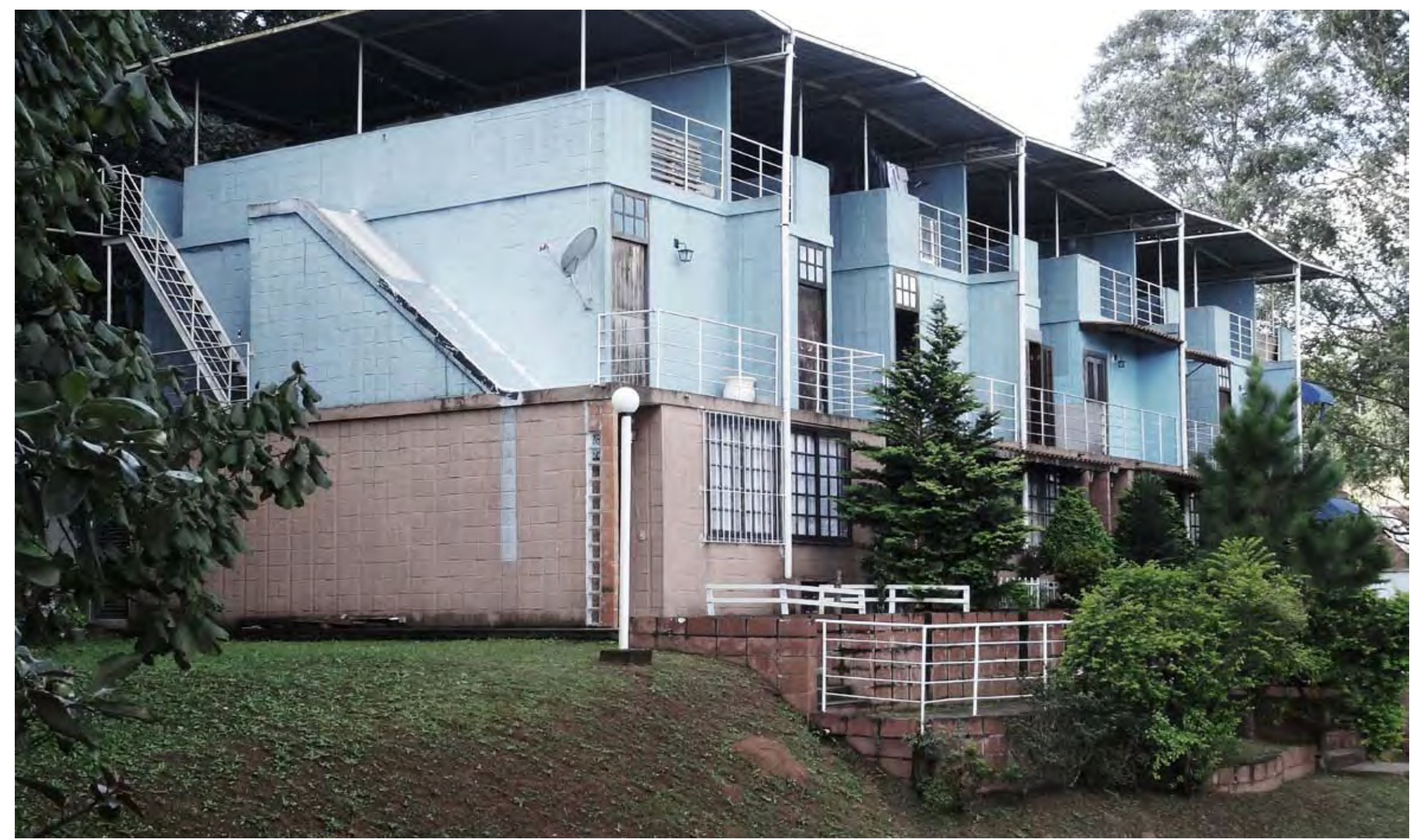

3. LEITURA DOS PROJETOS SELECIONADOS 3.I CONUNTOS RESIDENCIAIS HORIZONTAIS 


\section{I.I VILA BUTANTÃ: ESTÉTICA DA LÓGICA'}

\section{I.I.I INTRODUÇÃO E BREVE TRAJETÓRIA DO ARQUITETO MARCOS ACAYABA}

Em 1967 e primeira metade de 1968, Marcos Acayaba trabalhou como estagiário no escritório dos professores Ernest de Carvalho Mange ${ }^{2}$ e Ariaki Kato, que naquele momento era responsável por importantes projetos, como o da Cidade de Ilha Solteira (Figura 0I), São Paulo. Nesse período pode perceber intensamente e colocar em prática o processo de produção do projeto e sua relação com a construção. As obras da ilha estavam sob responsabilidade do Grupo Camargo Corrêa, pioneira na fabricação de blocos de concreto, sendo, portanto, material muito utilizado nas edificações da cidade e com produção na própria região.Assim, nesse período,Acayaba pode aplicar um método rigoroso de projetar, com modulação, desenhando parede por parede e seus encontros, com a especificação de todas as peças. Esta experiência, sua formação na Faculdade de Arquitetura e Urbanismo da Universidade de São Paulo (FAUUSP) e todos os anos de prática de sua carreira estão refletidos no projeto da Vila Butantã. Foi concebido um módulo repetidor, a unidade habitacional, que pensa estrutura, disposição do programa, instalações e adequação à topografia conjuntamente. A solução adotada, com o uso de paredes portantes laterais, possui um compromisso com o tipo de laje nervurada mista proposta. Esta proposição construtiva acaba por definir os limites entre as unidades habitacionais e resolve a questão da privacidade dos espaços a partir de seu deslocamento vertical e horizontal. Também se utiliza a flexibilidade na implantação do programa na unidade habitacional. Assim, conforme colocado por Segawa (2007, p. 10), há no trabalho de Acayaba a estética da lógica, na qual as soluções devem resultar de uma sensata percepção estrutural, o que não está

\footnotetext{
' SEGAWA, 2007, p. 10.

${ }^{2}$ Ernst Robert de Carvalho Mange (1922 - 2005) engenheiro-arquiteto, formado na Escola Politécnica da Universidade São Paulo (1940-45), faz estágio no escritório de Rino Levi (1943), faz estágio no ateliê do arquiteto suíço Le Corbusier (1947-48) e torna-se doutor e livre-docente da USP (1963).
}

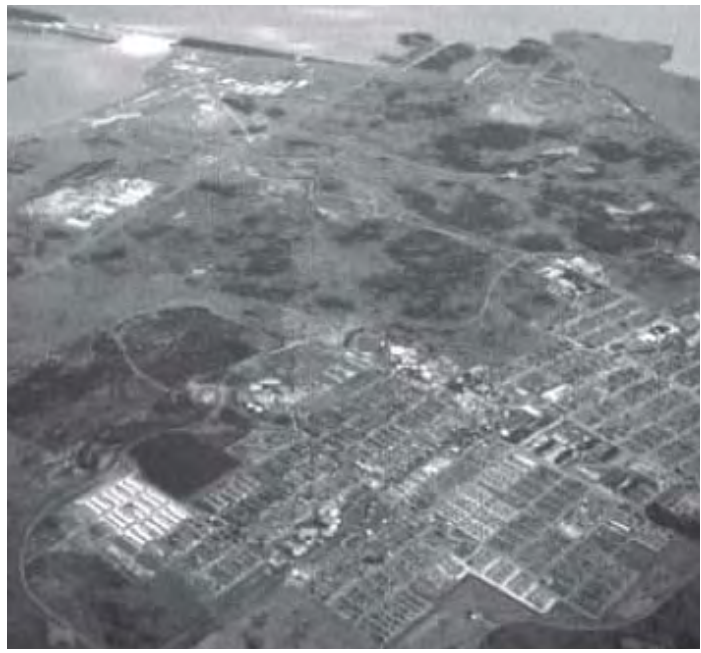

Figura I - Núcleo residencial de Ilha Solteira.

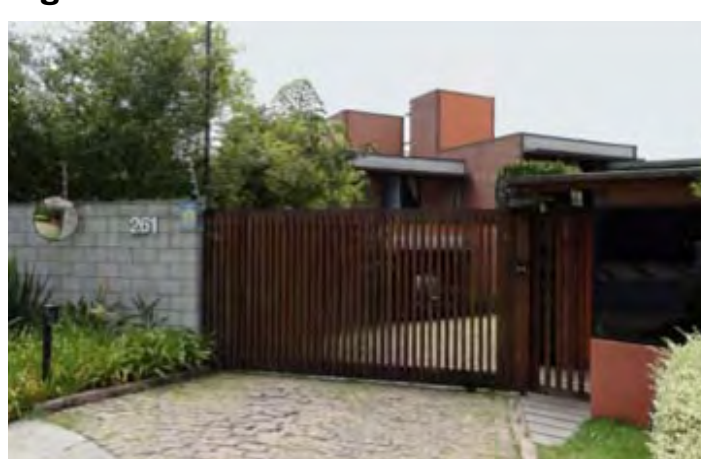

Figura 2 - Entrada Vila Butantã.

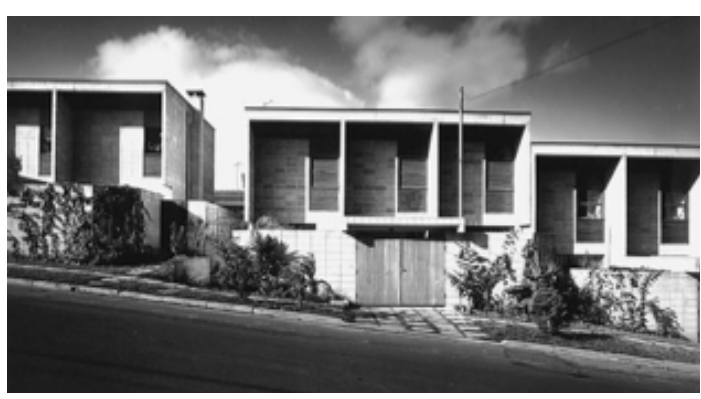

Figura 3 - Conjunto de Casas no Alto da Boa Vista. Foto externa e da entrada. (1973-74). 

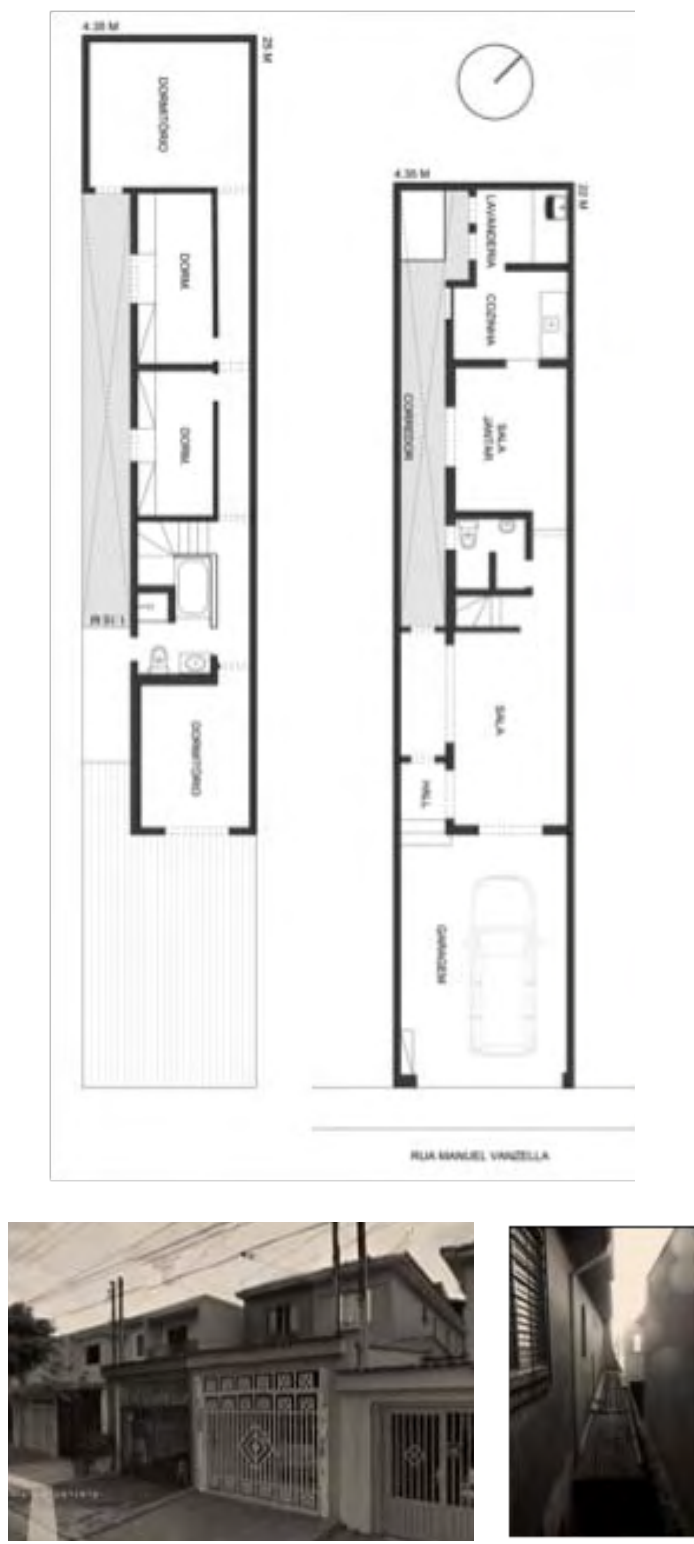

Figuras 4, 5, 6 e 7 - Exemplo de tipologia em lote estreito e comprido, na cidade de São Bernardo do Campo, com problemas de ventilação e insolação. desconforme à clássica definição de Lúcio Costa que acredita que a arquitetura como construção tem o propósito de organizar e ordenar plasticamente o espaço e os volumes decorrentes, considerando determinado meio, técnica, programa e intenção plástica. Acayaba parece ter um impulso maior em favor da lógica como essencial e fundamental ao resultado arquitetônico, de tal modo a pensar o arquiteto como o primeiro operário da futura obra e, ao mesmo tempo, possuir um espírito empreendedor decorrente também desta estrita relação entre arquitetura e construção:

Minha experiência, com a formação que recebi na faculdade e com trinta anos de prática profissional, fez com que eu viesse a pensar o arquiteto como o primeiro operário que participa do processo da obra. (...) Na prancheta ou no computador, o arquiteto deve considerar cuidadosamente as operações que seus companheiros, os outros operários, realizarão depois e, da mesma forma, avaliar com critério todo o material a ser incorporado (ACAYABA, 2007, p. 43).

\section{I.I.2 AGENTES}

De modo complementar, sua atuação no campo privado e residencial inclui uma saudável ausência de pudor em relação ao mercado imobiliário. Prova disso são as incorporações residenciais de que participou, como o Conjunto de Residências no Alto da Boa Vista (I973-74) e a Vila Butantã (I998-2004), na tentativa simultânea de romper o isolamento do arquiteto diante das etapas da obra e de conseguir multiplicar, na prática, isto é, no mercado, a excelência de um modelo arquitetônico bem resolvido (WISNIK, 2007, p. 16)

Não seria o primeiro envolvimento de Marcos Acayaba na incorporação de algum projeto de sua autoria. A primeira oportunidade aconteceu em 1973, vinte e cinco anos antes da Vila Butantã, com o projeto de um conjunto de casas no Alto da Boa Vista (Figuras 3), em sociedade com Maurício Grostein, dono de uma loja de materiais de construção e o advogado Marcelo Huck, respectivamente pai e ex-marido da arquiteta e urbanista Marta Dora, coautora do projeto. 
A legislação da época permitia que terrenos de esquina com no mínimo 12 metros de largura fossem divididos transversalmente. A procura pelo local e oportunidade partiu, portanto, desta informação e da pretensão de buscar uma alternativa para a ocupação dos lotes urbanos na construção de sobrados geminados, que geralmente são estreitos e muito longos, com excessiva área de circulação e com problemas de insolação e ventilação, conforme pode ser observado no exemplo selecionado em São Bernardo do Campo (Figuras 4, 5, 6 e 7).

Encontrou-se um terreno de $500 \mathrm{~m} 2$ no qual, mesmo descontando os recuos de frente $(4$ $\mathrm{m}$ ) e de fundo ( $3 \mathrm{~m}$ ), foi possível implantar 4 sobrados geminados dois a dois, com cinco metros de profundidade e com ampla e arejada fachada (Figuras 8, 9 e 10).

Não apenas a questão do espírito empreendedor ou a busca por novas alternativas para implantação de casas em lote urbano aproxima este projeto da Vila Butantã.A racionalização no uso de componentes, por exemplo, a partir do uso do bloco de concreto armado que dispensa formas, e a proposta modulada e padronizada deste conjunto de quatro casas, também são características presentes na vila contemporânea de Marcos Acayaba e em outros momentos de sua trajetória profissional, como por exemplo no projeto da Sede da Fazenda Pindorama, em Cabreúva (1974-1984) (Figura 12), no qual foram adotados blocos de concreto tanto nas abóbadas de cobertura quanto nas vedações, experiência posterior à residência Milan (1972--1975) (Figura 13) com uma significativa diferença na técnica adotada, com material mais acessível em comparação ao concreto armado, que para a realização da abóboda da experiência anterior precisou de muita madeira e muito trabaIho para execução da forma. Assim, os exemplos citados demonstram, principalmente, a postura do arquiteto em explorar as potencialidades dos materiais e das técnicas disponíveis, e também coloca o projeto como ensino ou aprendizagem de novas soluções, permitindo evolução e ausência de postura conservadora com relação à utilização de determinado material ou técnica construtiva.

Segundo MarcosAcayaba (20I2), esta é uma de suas obras e projetos no qual ele teve a oportunidade de realizar pesquisa em projeto, ou necessidade de desenvolver alguma coisa nova e fazer ensaios

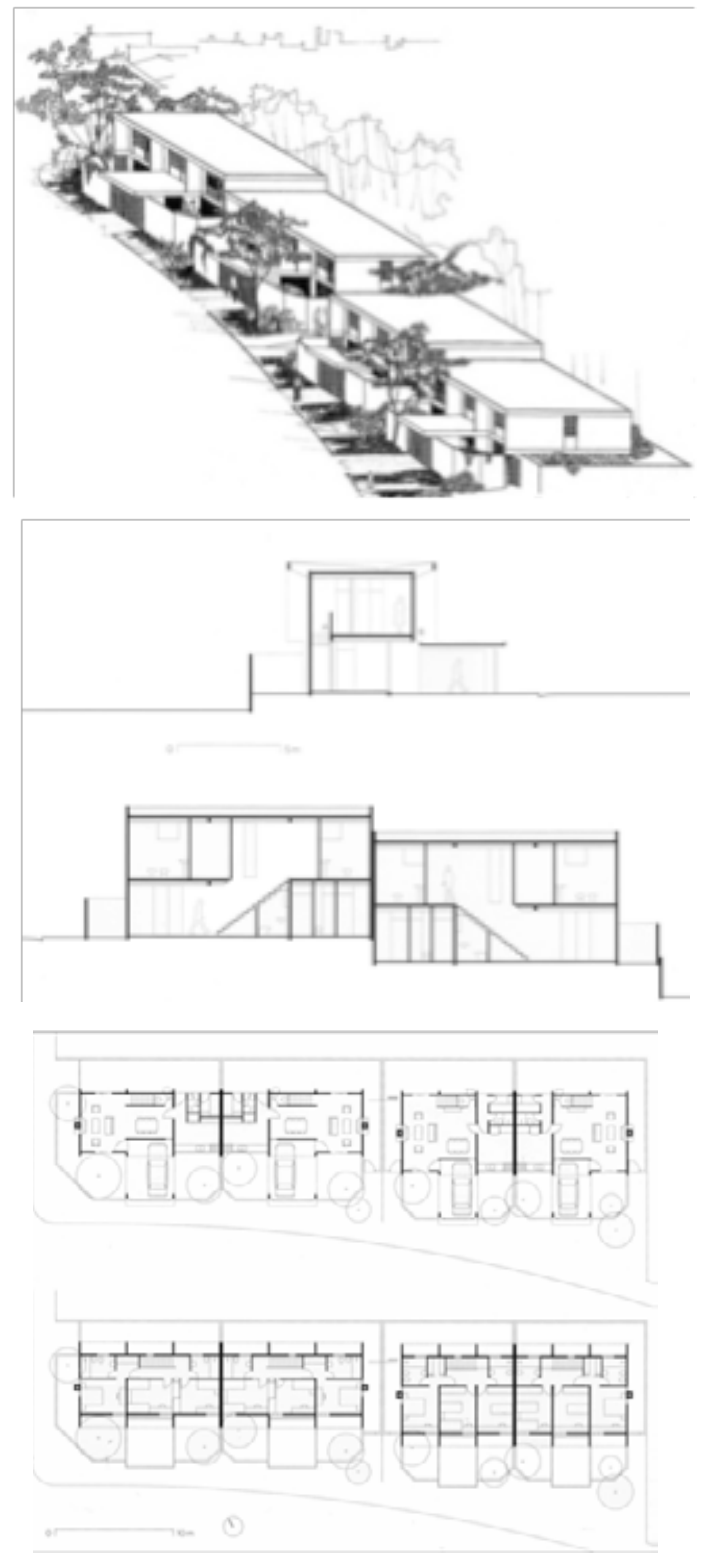

Figuras 8, 9 e 10 - Perspectivas, cortes e plantas do conjunto de casas no Alto da Boa Vista. 


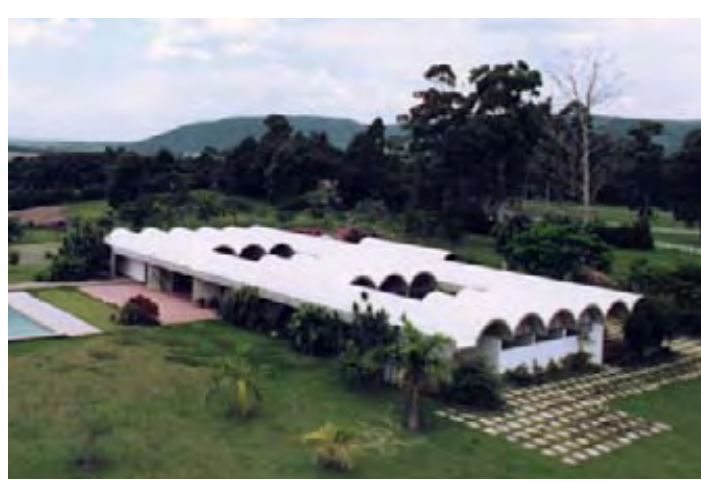

Figura I I - Sede da Fazenda Pindorama, Cabreúva, São Paulo (1974-1975).

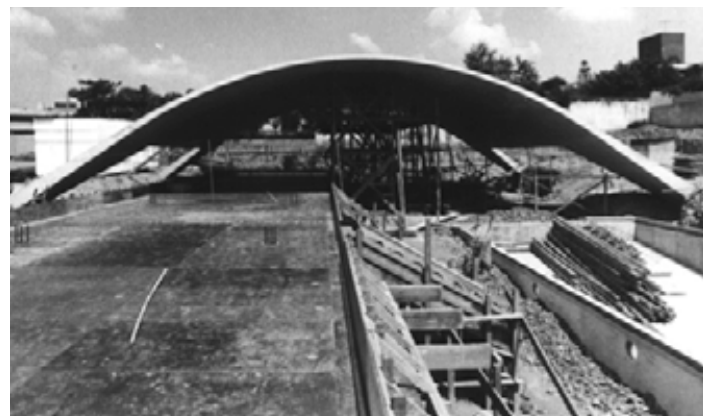

Figura 12 - Residência Milan, Bairro Cidade Jardim, São Paulo (1972-1975). que é inclusive uma característica da escola de arquitetura e urbanismo da USP, afinal, quando o arquiteto ingressou na FAUUSP (1962), esta tinha se desmembrado da escola politécnica da USP havia apenas quartoze anos, sendo possível perceber que ainda mantinha o espírito politécnico,seja pela presença de professores engenheiros-arquitetos, como é o caso de Artigas, que tinha sido inclusive professor da escola politécnica, e outros também muito significativos, dentre os quais o professor Mange.

Segundo relato do arquiteto, o terreno de 4439 m2 na encosta do Morro do Querosene, bairro Butantã, foi revelado por volta de 1994, pelos irmãos Otávio e Fábio Zarvos, na ocasião, sócios de uma construtora. Na época, havia posseiros no local, aproximadamente dez famílias, e o proprietário não pagava IPTU do imóvel há muitos anos. Dez famílias, dividindo uma área com mais de quatro mil metros quadrados, obviamente não se tratava de um local com característica similar a uma densa favela urbana, parecendo mais uma vila rural bem precária. Com tantos empecilhos, o terreno deixou de interessar aos irmãos que estavam em busca de um local para um negócio mais imediato.

Após alguns anos, o processo jurídico estava resolvido pelos sócios e realizadores do empreendimento, arquiteto Marcos Acayaba e engenheiro Hélio Olga Jr., já que conseguiram fazer acordo com os posseiros e com o proprietário, podendo iniciar o levantamento planialtimétrico do terreno e realizar o estudo de implantação. Nada foi rápido, muito menos simples. Um fato recordado pelo arquiteto foi que, após fazer o estudo de implantação, percebeu-se uma incompatibilidade com a metragem da planta registrada. Por sorte, a metragem era maior do que a considerada, e após nova aprovação na prefeitura, tudo ficou resolvido. Com este e outros fatos ocorridos, foram seis anos desde a compra do terreno (1998) até a finalização do projeto (2004).

O objetivo era criar uma tipologia de casas com planta flexível e adequada ao mercado, num procedimento que diverge da costumeira atividade do arquiteto no mercado imobiliário, envolvendo não apenas o projeto, mas o seu relacionamento com as definições da obra, busca pelo terreno como oportunidades de atuação na cidade. Com relação a ter sido uma vantagem ou não de investimento e negócio, as casas foram vendidas na época por aproximadamente $R \$ 1.500 .000,00$ 
cada, e hoje já estão mais valorizadas devido ao altíssimo preço do solo em São Paulo e em suas franjas urbanas, como é o caso desse bairro. Porém, segundo Hélio Olga, do ponto de vista financeiro os resultados foram modestos, valendo mais a pena a iniciativa pelos resultados técnicos obtidos.

Seja pela busca de retalho urbano em bairro na época pouco valorizado ou por tomar frente em todo processo relacionado ao empreendimento, desde a escolha do terreno, aprovação, construção, entre outros assuntos relacionados, esta obra pode ser entendida como uma infiltração urbana, conceito explorado por Fernando Diez, doutor em arquitetura e diretor editorial na revista SUMMA+ desde 1994, canal de publicação de uma série de ações que ele vem investigando, principalmente em Buenos Aires nos últimos anos, comparável a esta atuação em São Paulo:

\begin{abstract}
Una serie de acciones llevadas adelante por jóvenes arquitectos en los últimos años ha mostrado este espíritu que he descripto como "tácticas de infiltración": diferentes maneras de actuar dentro de la ciudad existente, intentando sacar ventaja de oportunidades desaprovechadas, completando el tejido urbano, encontrando ubicaciones convenientes en localizaciones devaluadas $i$ inyectando nueva vida en barrios adormecidos. Actuando no solo como proyectistas, sino también como promotores y constructores (DIEZ, 20I0, p. 35).
\end{abstract}

\section{3.I.I.3 PARTIDO DE IMPLANTAÇÃO}

Este projeto e outros presentes nesta pesquisa foram possibilitados a partir da Lei das Vilas $(1994)^{3}$ que passou a permitir conjunto de casas agrupadas em lotes individuais onde antes só era possível realizar casas unifamiliares. Novamente, a qualidade projetual resultante é incomparável com outros projetos também possibilitados por esta lei.As figuras 13 a 15 expõem um projeto, extraído do mestrado “Condomínios tipo vila em São Paulo"4, que representa um mau exemplo de emprego desta lei.

\footnotetext{
${ }^{3}$ LEI N ${ }^{\circ} 1$ I.605, de 12 de JULHO de 1994 - Dispõe sobre a criação da subcategoria de uso residencial R3-03, conjunto residencial - vila, e dá outras providências.

${ }^{4}$ MARQUES, 2006.
}
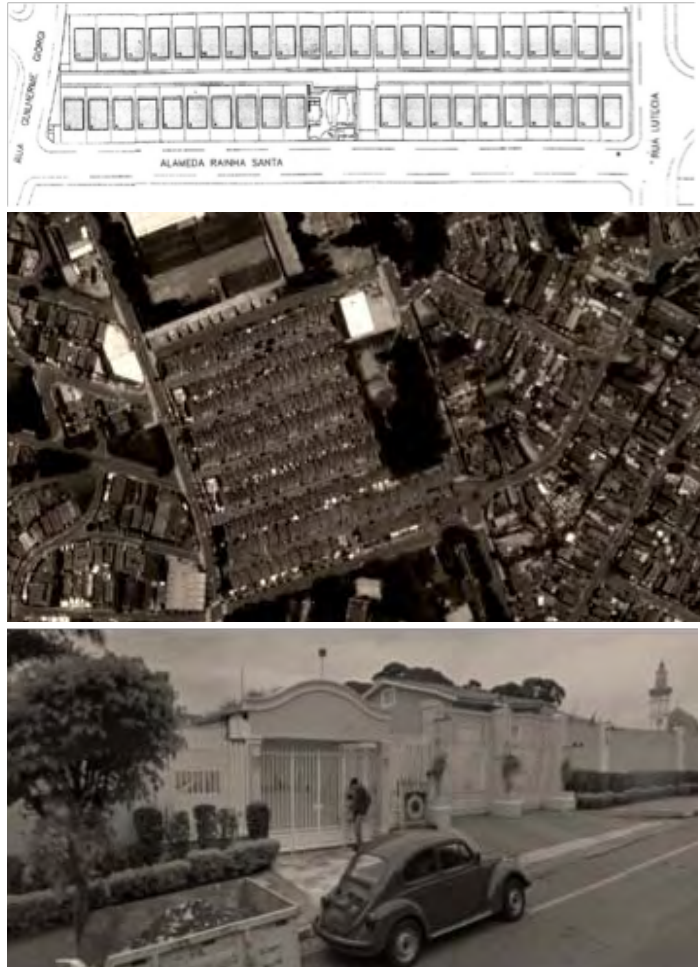

Figuras 13, I4 e I5 - Nova Tatuapé, Residencial I.Arquiteto Danilo Penna: recuos muito estreitos, ruas sem saída, muros extensos. Replicação em série, aumentando os problemas.

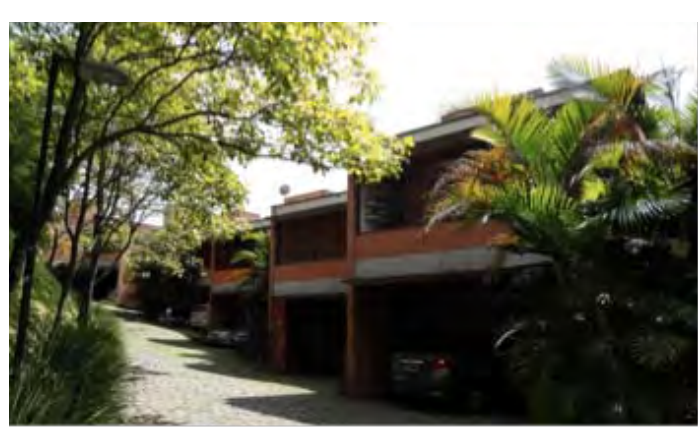

Figura 16 - Foto do trecho do renque de doze casas desde o viário interno da Vila Butantã. 


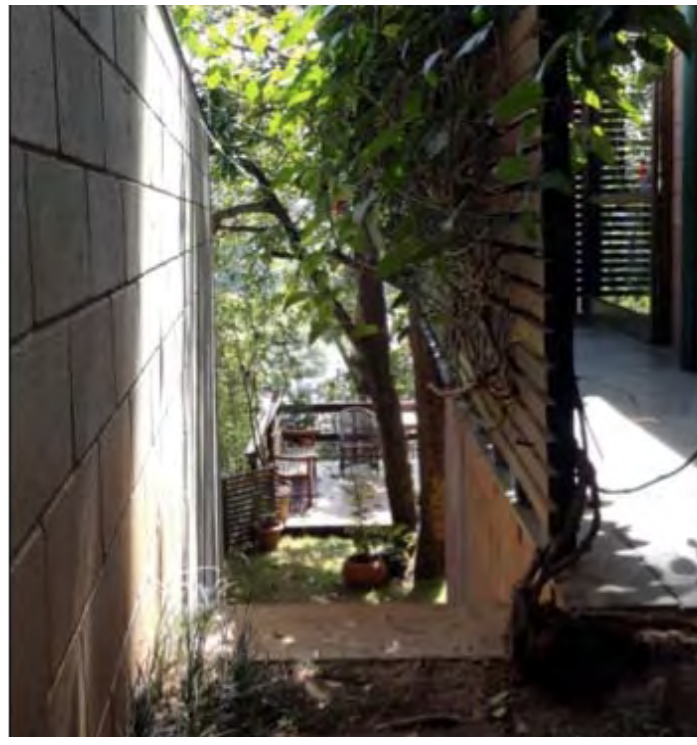

Figura 17 - Primeira casa do renque maior (casa 05), junto ao muro de divisa na Vila Butantã. Espaço externo privativo aberto ao espaço coletivo, similar ao que ocorre na Vila Taguaí.

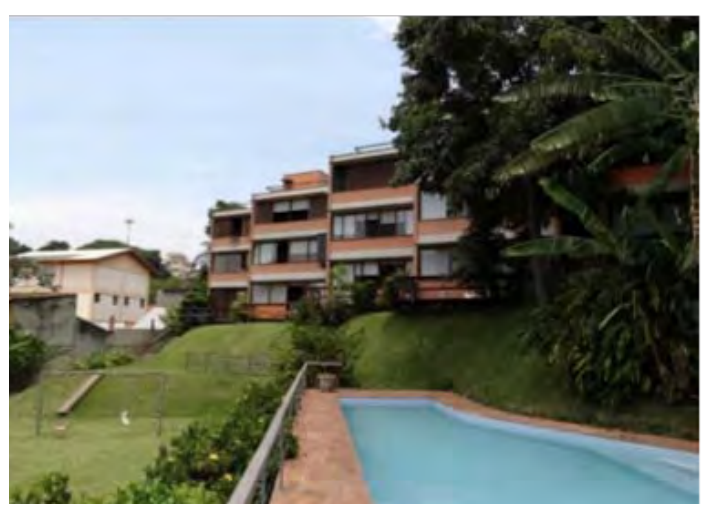

Figura 18 - Vista da área de lazer coletiva em direção às últimas casas do renque de doze casas na Vila Butantã.
Desde que a legislação permitiu a volta de conjuntos residenciais horizontais em São Paulo (a chamada Lei das Vilas, de 1994), o que se observa, do ponto de vista arquitetônico, é uma maioria esmagadora de péssimos projetos: casas em estilo neoclássico, toscano ou "americanizado", com ênfase nos espaços privativos, em detrimentos das áreas comuns (SERAPIÃO, 2006, p. 38).

Algumas qualidades da Vila Butantã relacionadas à implantação podem ser destacadas a partir da comparação com este exemplo ruim: a implantação das casas e do viário segue a topografia original do terreno; presença de espaços para uso comum; não existem muros divisores entre as unidades e mesmo se tratando de casas iguais, está longe de existir monotonia.

Alguns condicionantes foram determinantes na implantação das dezesseis casas: a topografia acidentada do terreno, a orientação e a vista para a paisagem. A implantação das casas em dois renques, um de quatro e outro de doze casas, foi definida a partir das curvas de nível do terreno. Foi criada uma rua que segue esta disposição e que termina no acesso à última casa (Figura 16).

A área de lazer coletiva não possui acesso por automóvel e também não possui conexão visual desde este viário. Ela é acessada coletivamente por uma escada que beira o muro de divisa ao sul da vila. Esta área de lazer está totalmente voltada à fachada nordeste das casas do renque maior, na qual se localizam as áreas sociais, fator positivo, pois assim possibilita visão pelos moradores e diminui a probabilidade de tornar-se um espaço ocioso e com pouca integração com o conjunto. Por outro lado, esta área acaba não tendo relação direta com a parte frontal do conjunto e com o renque de quatro casas, já que o renque maior acaba sendo um divisor de duas áreas principais: a frontal, marcada pelo viário de acesso às casas; e a do fundo, marcada pela área de lazer coletiva. Esta situação foi resultado da busca pelo melhor aproveitamento do terreno com maior número unidades, já que uma área considerável tornou-se inviável para construção devido à topografia acidentada (mais de $1000 \mathrm{~m}^{2}$ para taludes de alta declividade). Permitir total conexão entre as partes significaria ter que diminuir o número de unidades. 
Por outro lado, a topografia acidentada acabou favorecendo uma composição volumétrica mais interessante, que quebra a monotonia das casas iguais. $O$ escalonamento tanto vertical quanto horizontal garante às aberturas principais privacidade, além da vista panorâmica. Esta questão foi enfatizada pelo arquiteto durante a visita (Figuras 18 e 19).

\section{I.I.4 ESPAÇOS EXTERIORES}

Segundo reportagem da revista ProjetoDesign, "Partido Arquitetônico encontra definição entre o módulo e a topografia" , as disposições espaciais reforçam o convívio entre os moradores. Realmente, os espaços exteriores são predominantemente coletivos, mesmo assim, todas as casas possuem cobertura acessível e balcão, configurando os espaços exteriores próprios. Ao mesmo tempo, o espaço representado pela rua de acesso às casas, representa quase metade dos espaços exteriores (46,86\%), e não pareceu ser um local onde exista convívio entre vizinhos. Na verdade, como todas as garagens estão voltadas à rua interna, o espaço em frente da garagem parece pertencer à casa mais próxima, por mais que não existam barreiras físicas definindo isto. Ou seja, a rua é um espaço coletivo à medida que todos os moradores passam de carro para acessar suas casas,

O salão de festas também dificilmente terá um evento de interesse comum aos vizinhos, na verdade ele é reservado para eventos particulares de cada grupo de moradores de uma unidade. Restam, assim, o espaço da piscina e o gramado. Estes espaços são mais utilizados por famílias com crianças. Portanto, esse discurso de privilégio das áreas comuns diz respeito mais à questão de concentrar as áreas livres e evitar quintais isolados com muros (situação comum nos exemplos antagônicos aqui citados) incompatíveis com a difícil topografia do terreno do que à intenção de criar áreas de convívio coletivo.

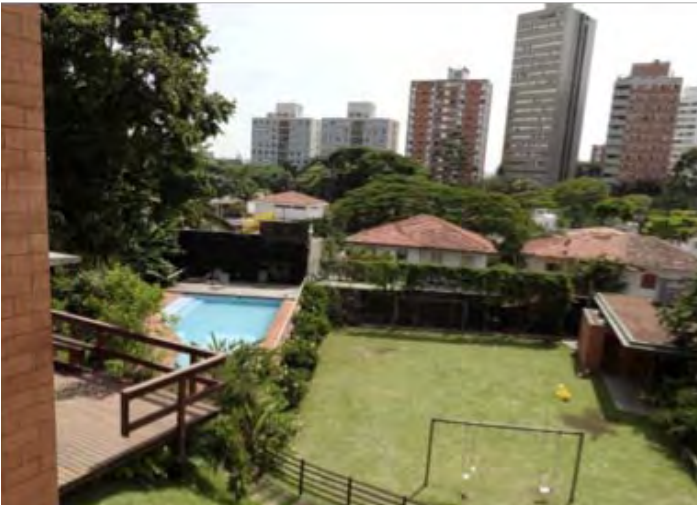

Figura 19 - Prédios na Av. Caxingui da Vila Pirajussara. A torre mais alta, Ed. Quatiara, é projeto de Rui Othake de 1972.

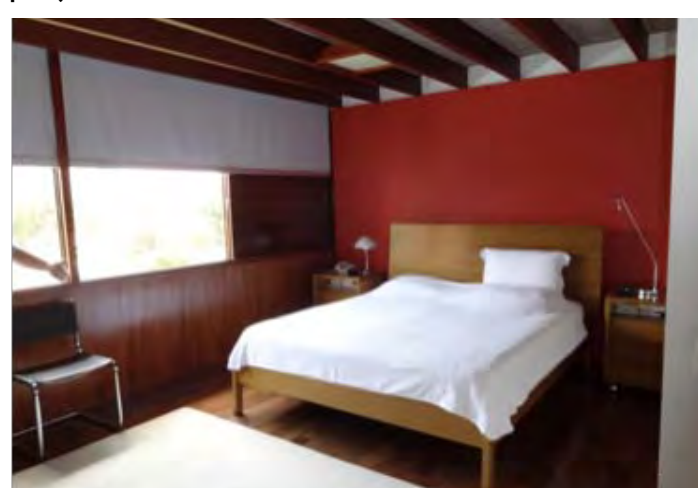

Figura 20 - Dormitório: madeira aparente.

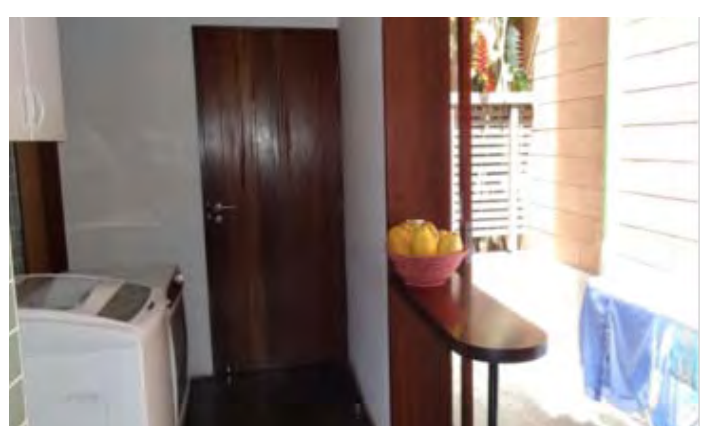

Figura 2 I - Pavimento intermediário: área de serviço. 


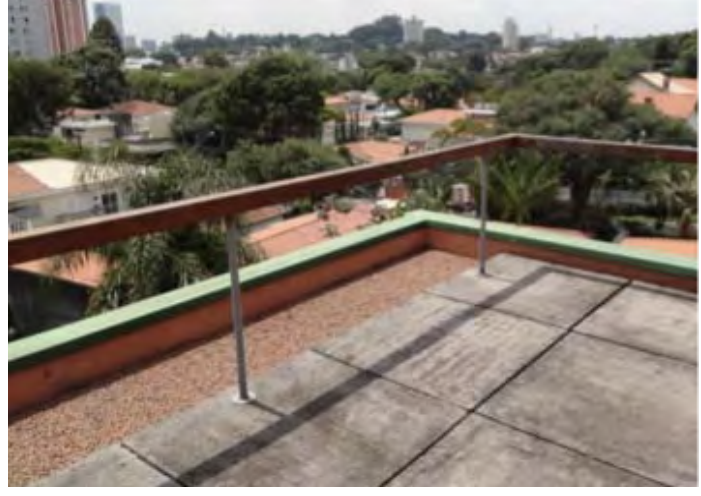

Figura 22 - Detalhe da cobertura acessivel: mesma solução adotada na Vila Fidalga, o guardacorpo é fixado na placa de concreto que por sua vez é fixada no contrapiso, evitando, assim, furações na estrutura e, consequentemente, infiltrações.

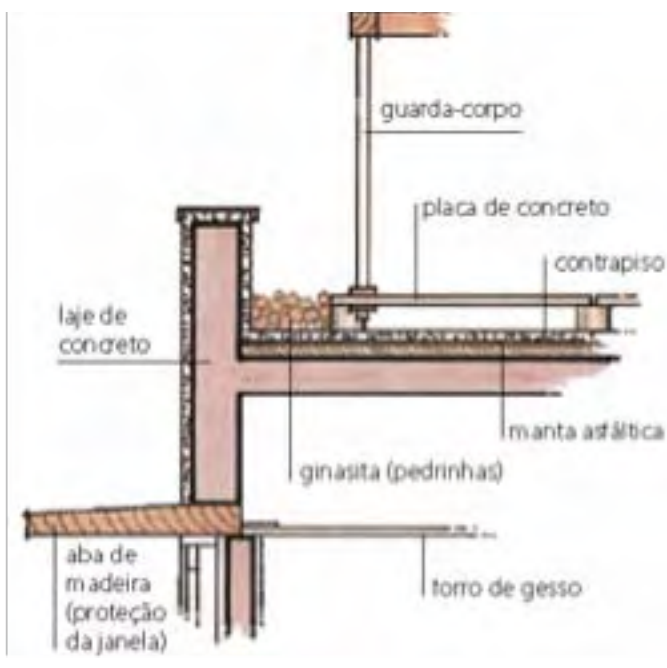

Figura 23 - Detalhe do guarda-corpo,Vila Fidalga.

\section{I.I.5 SISTEMA ESTRUTURAL ETÉCNICA CONSTRUTIVA}

Ainda que todas essas afirmações anteriores se apliquem ao arquiteto Marcos Acayaba, é sua trajetória, sua inventividade e sua postura perante a cidade, que nos permite discernir aqueles fundamentos pressupostos: basta percorrer sua obra e verificar suas contribuições em estruturas de concreto (Residência Milan), ou metálicas (Coliseum), ou recentemente com madeira (Residência Hélio Olga ou Residência Ricardo Baeta). Mas o que mais impressiona, em qualquer situação, é sua espontânea e fluente inventividade. Quase como uma borboleta pousando numa folha, sem (para nós) esforço (KATINSKY, 2007, p. 7).

As casas têm o pavimento intermediário voltado para a rua interna do conjunto e o inferior para o jardim. A inserção na topografia acidentada acabou criando um pavimento inferior junto ao solo desnivelado de três metros, portanto, com necessidade de muro de arrimo. Esses arrimos são os principais elementos para a contenção da encosta ao longo dos dois renques, e são travados pelas empenas laterais das casas de alvenaria armada pigmentada. Também existem muros de arrimo de solo-cimento, cobertos hoje por vegetação, para garantir a contenção de outros trechos sem interferência de construção.

Com relação ao sistema estrutural adotado nas unidades, este projeto contou com um novo sistema de lajes nervuradas mistas de concreto e madeira. Trata-se de uma novidade, inclusive patenteado pelo Departamento de Estruturas da Escola Politécnica da Universidade de São Paulo (POLI-USP). Marcos Acayaba tem o costume de aproveitar as oportunidades profissionais para realizar ensaios, para desenvolver novas técnicas e novos conceitos, assim, em parceria com Hélio Olga, também com este pensamento, conseguiram alcançar essa nova solução. A residência do engenheiro Hélio Olga Jr., de 1990, primeira parceria entre o dois, é o melhor exemplo revelador desta qualidade, pois nela Marcos Acayaba consegue propor com muita sensatez uma solução arquitetônica muito coerente com a situação do terreno: implanta a casa perpendicularmente à rua e com módulos escalonados para permitir melhor aproveitamento de área construída sem 
ter que modificar a topografia original que é extremamente acidentada (mais de 100\% de declividade para o fundo do lote). Depois, junto com Hélio Olga, resolvem a estrutura final da casa:

Entretanto, para que fosse possível pensar melhor o trabalho da estrutura, foi necessário um modelo da mesma. O próprio Hélio o fez. Passamos vários meses discutindo, em cima do modelo e de desenhos, hipóteses de solução para os nós, para o contraventamento etc. $O$ design final dessa casa foi feito a quatro mãos, fruto da discussão sobre a estrutura, principalmente (ACAYABA, 2007, p. 177).

No projeto da Vila Butantã, novamente, a resolução da arquitetura acontece junto com a engenharia, mas, infelizmente, não foi possível adotar a pré-moldagem dos painéis como na casa ícone ou na Vila Taguaí. Segundo Hélio Olga a peça pré-moldada pesaria $750 \mathrm{~kg}$ - com peças de 6 metros de comprimento, superior às peças da Vila Taguaí em tamanho e peso, onde a maior tem I,2 × 4,0 m e peso de $240 \mathrm{Kg}$. A ideia de pré-fabricar a laje e racionalizar ao máximo a montagem das casas foi impossibilitada devido ao tamanho e peso das peças e à topografia, que faria necessário contar com grua, incompatível com a logística possível na ocasião. Como esse equipamento é alugado, para ser vantajoso ele deve ser utilizado em tempo integral. No entanto, a execução deste empreendimento aconteceu em períodos de tempo recortados, ou seja, quando sobrava tempo, também por serem o próprio arquiteto e o engenheiro agentes desta realização. Alugar uma grua e não utilizá-la a todo vapor traria prejuízo ao negócio. Sendo assim, a laje foi moldada in loco. As lajes são compostas por barrotes $(6 \mathrm{~cm} \times 20 \mathrm{~cm})$ de jatobá, e laje de concreto de $4 \mathrm{~cm}$ de espessura, com vãos livres de seis metros, fundidas, sem cimbramento, apoiadas nas empenas de alvenaria armada. A viga de concreto com uma pequena aba para proteção solar também foi moldada in loco.

As instalações hidráulicas são aparentes ou visitáveis, solução compatível com o sistema construtivo adotado, já que nem a parede armada ou a laje nervurada permitiriam grandes furos para passagem de tubulações. Mesmo sendo aparente, tudo foi estrategicamente pensado de maneira a não

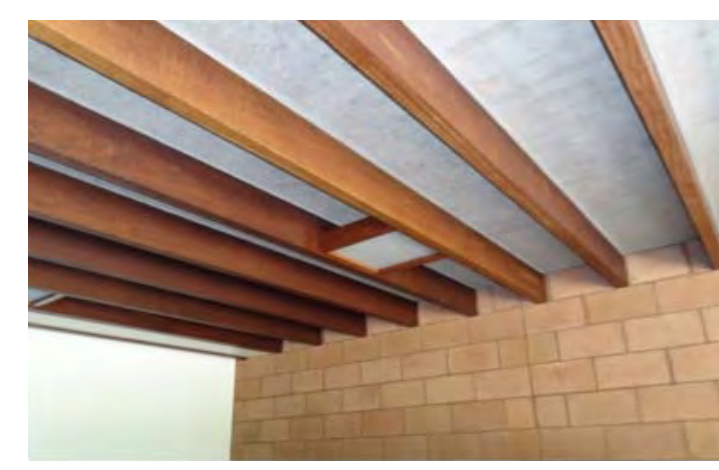

Figura 24 - Detalhe de luminária na garagem.

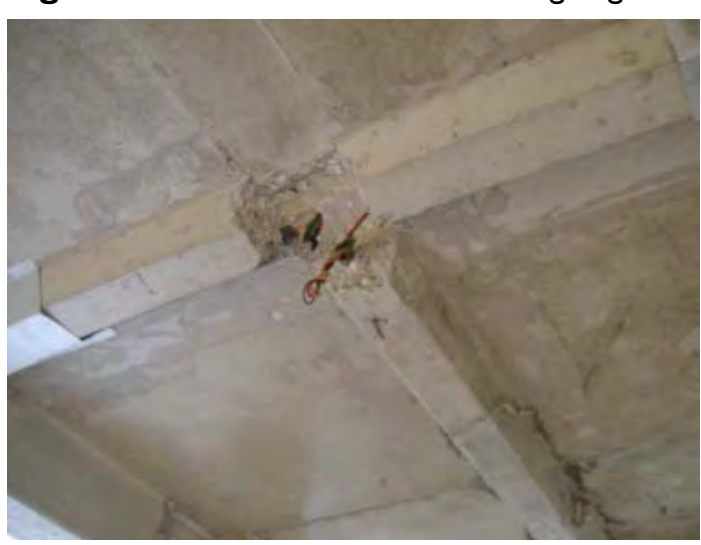

Figura 25 - Ausência de local adequado para instalar luminária na passarela do Conjunto Habitacional Comandante Taylor, Heliópolis.

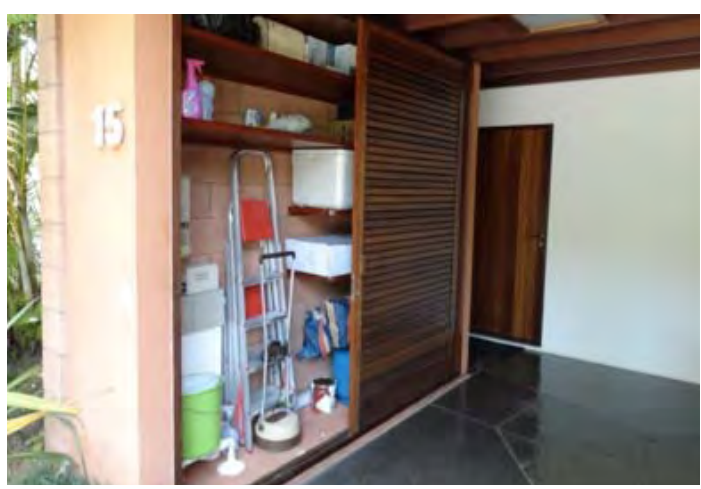

Figura 26 - Armário integrado à estrutura. 


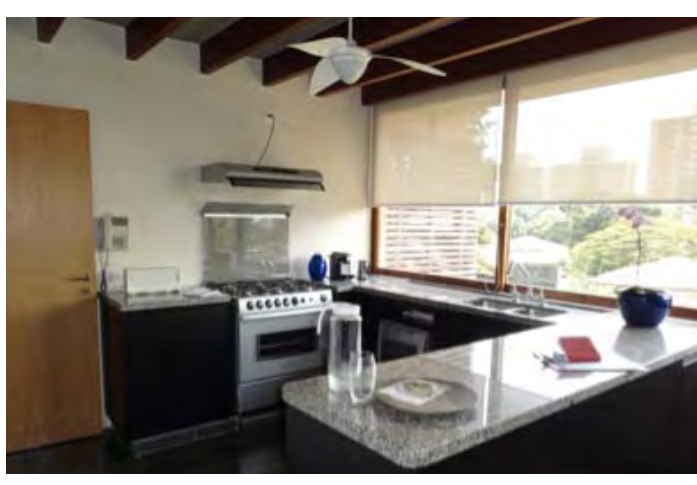

Figura 27 - Cozinha integrada com a sala de jantar, vão de 6 metros sem divisória.

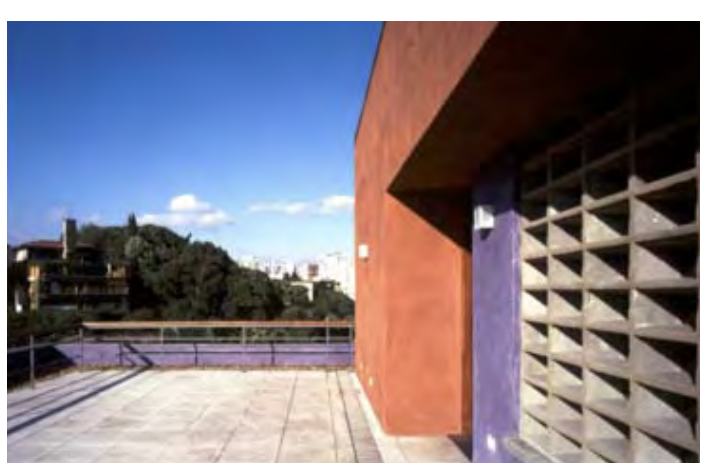

Figura 28 - "Espaço Pacaembu", Marcos Acayaba e Adriana Aun, 1999: mesma solução de guarda-corpo na cobertura.

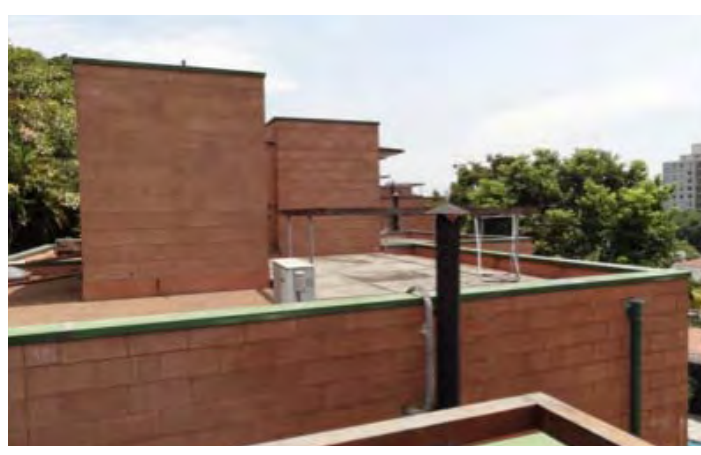

Figura 29 - Terraço acessível,Vila Butantã. existir grandes trechos de passagem de instalações, ficando, portanto, quase imperceptíveis. Até mesmo o detalhe da luminária acomodada entre os barrotes foi pensado com cuidado. Isto fez lembrar um projeto de promoção pública em fase de finalização, em Heliópolis, São Paulo (Conjunto Comandante Taylor), no qual o simples fato de não se ter pensado ou considerado o detaIhe da luminária acarretou um trabalho extra, forçado e mal acabado para acomodar um grande número de luminárias, ao longo das passarelas, situação muito diferente da encontrada neste projeto em análise (Figuras 24 e 25).

Outros componentes complementares ao sistema construtivo são feitos em madeira, como, por exemplo, os caixilhos, as escadas, bancadas do lavabo, tábua de passar roupa fixa na área de serviço, balcão, guarda-corpos entre outros elementos. $O$ balcão ou varanda é suspenso, permitindo que a água escorra. Estas regras com relação ao uso correto da madeira, sempre enfatizado pelo engenheiro Hélio Olga, também serão notadas nos outros projetos de sua colaboração ou coautoria:Vila Fidalga e Vila Taguaí.

Outro detalhe é a solução do terraço, onde o guarda-corpo é fixado na placa de concreto que por sua vez é fixada no contrapiso,evitando assim furações na estrutura e consequentemente infiltrações.Esta soluçãojá vem sendo utilizada em outros projetos,conformepodeserobservado(Figura 28).

Só nesta pesquisa, que engloba projetos recentes, em sua maioria da primeira década do século XXI, três projetos contaram com a participação do Engenheiro Hélio Olga Jr., sendo que em dois deles, na Vila Butantã e Vila Taguaí, foi mais do que uma participação, e sim uma parceria de incorporação e pesquisa em projeto. Desse modo, vale citar brevemente sua trajetória e de sua empresa. Alberto Martins apresenta em Aflalo (2005), a história da ITA Construtora e da família de construtores Olga, onde o vínculo estreito entre arquitetura e tecnologia se mostra muito presentes. Germano Mariutti (1866-1938), avô de Hélio Olga (pai), trouxe para - Brasil conhecimentos de carpintaria da Itália, e monta em 1988, ano que chega ao Brasil, uma serraria em Avaré, interior de São Paulo. Alguns anos depois, já morando em São Paulo, 
se associa com Ramos de Azevedo, tornando-se o maior dos empreiteiros autônomos a trabalhar com este escritório, participando de obras importantes como a do Estádio do Pacaembu, por exemplo.Alguns anos após a morte de Germano Mariutti, Clóvis Felippe Olga e Hélio Olga, filhos de Vicente Olga, comerciante, dariam continuidade ao trabalho do avô com vínculo na construção. Clóvis foi um dos fundadores da Construtécnica, que logo Hélio passa a fazer parte também, tornando-se importante organizador dos canteiros de obra. Nos anos 1950 a Construtécnica cresce, faz, por exemplo, o viaduto da Lapa, um dos primeiros em São Paulo em concreto protendido (foi calculado por Roberto Zuccolo). Neste período os irmãos Olga conhecem o baiano José Zanine Caldas (1919-2002), na época maquetista de talento, e que mais tarde vai criar a Fábrica de Móveis “Z”, para produção de peças industrializadas com chapas de compensado. Em 1970, Hélio inicia a carreira solo, e participa de grandes obras públicas, como por exemplo, a Rodovia dos Imigrantes ou a barragem de Sobradinho. Em 1978, um de seus filhos, Hélio Olga Jr., forma-se em engenharia na Escola Politécnica da Universidade de São Paulo. Clóvis chama seu irmão e sobrinho para auxiliá-lo na execução de algumas casas de sua autoria e de terceiros, como por exemplo, de Zanine, que na época utilizava um método artesanal para construção: montava no chão um gabarito no tamanho real da casa para serrar as madeiras, em seguida, desmontava e enviava as peças soltas para o local onde seria construída definitivamente. Com este método, precisava de alguém em São Paulo que fizesse o percurso inverso e colocasse a casa em pé, e assim entram em cena novamente os irmãos Olgas, nesta fase já contando com apoio de Hélio Olga Jr., que teve sua primeira colaboração em uma casa em Granja Viana de Zanine. Sua própria casa construída entre 1980 e 1982 foi com desenho e peças de madeira fornecidos por Zanine, fazendo com que este arquiteto, designer e maquetista, acabasse marcando o início da carreira do jovem engenheiro.

Em 1980 é formalizada a parceria entre pai e filho, e é fundada a Ita, que significa pedra em tupiguarani,já que a construtora pretendia fazer estruturas de concreto. Sem local adequado para estocar e processar a madeira, nas primeiras casas esta era entregue diretamente na obra e cortada no local.

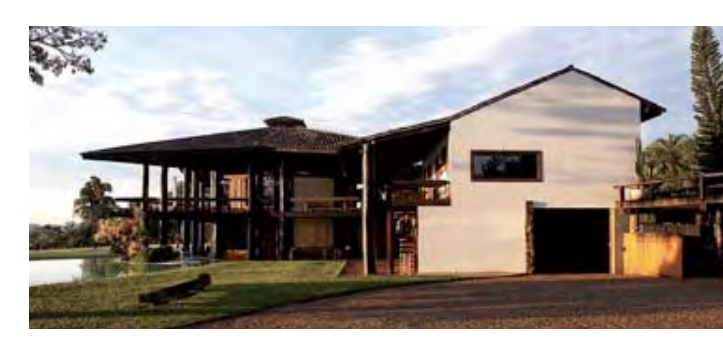

Figura 30 - Residência Bettiol, Lago Sul, Brasília, (1976) - Zanine Caldas.

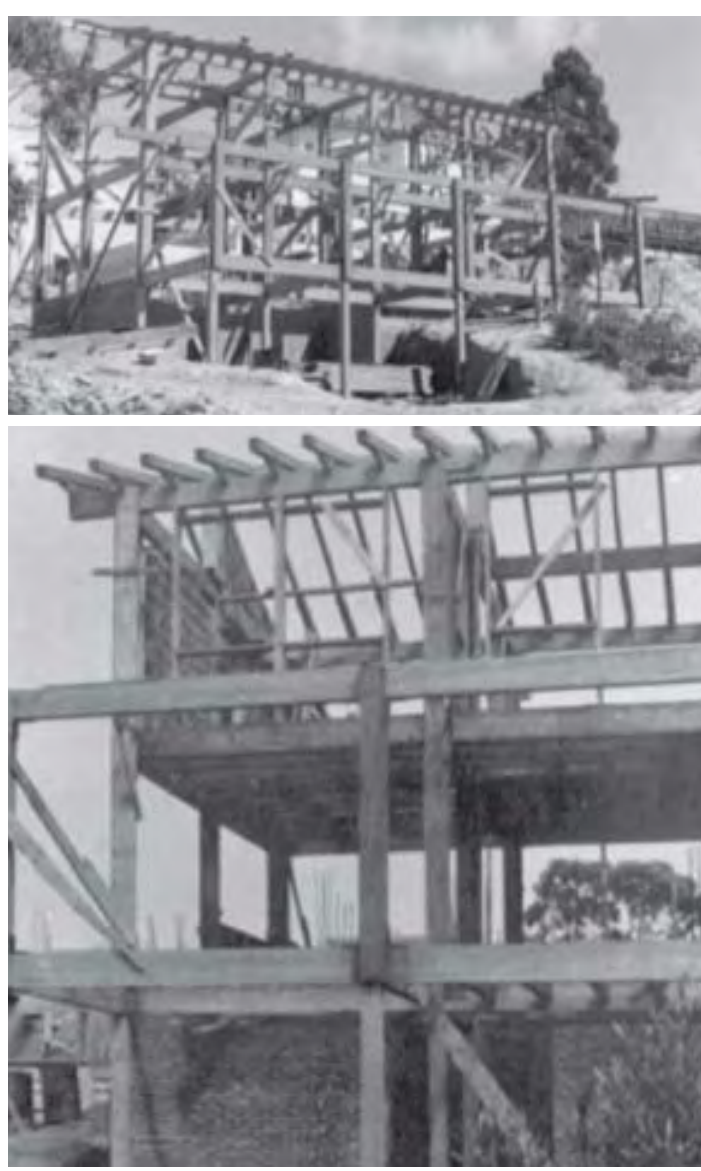

Figuras 31 e 32 - Casa de Hélio Olga Jr. Construída em 1980 - 1982, com estrutura e desenho de Zanine. 


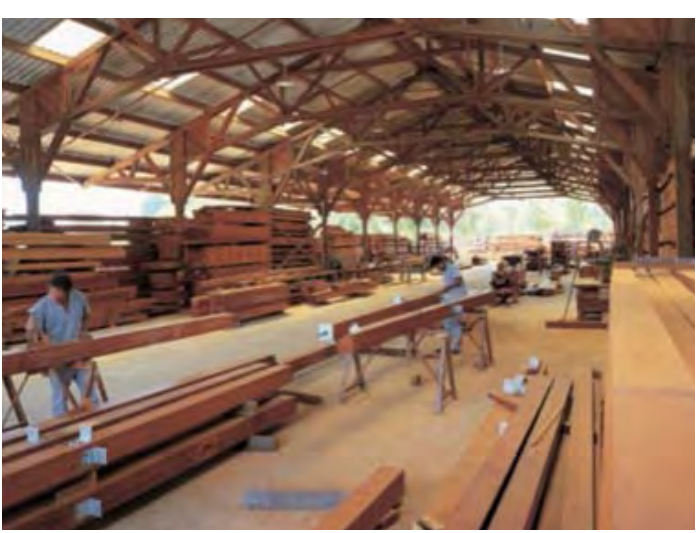

Figura 33 - Galpão da Ita Construtora, em Vargem Grande Paulista, e os funcionários trabaIhando.

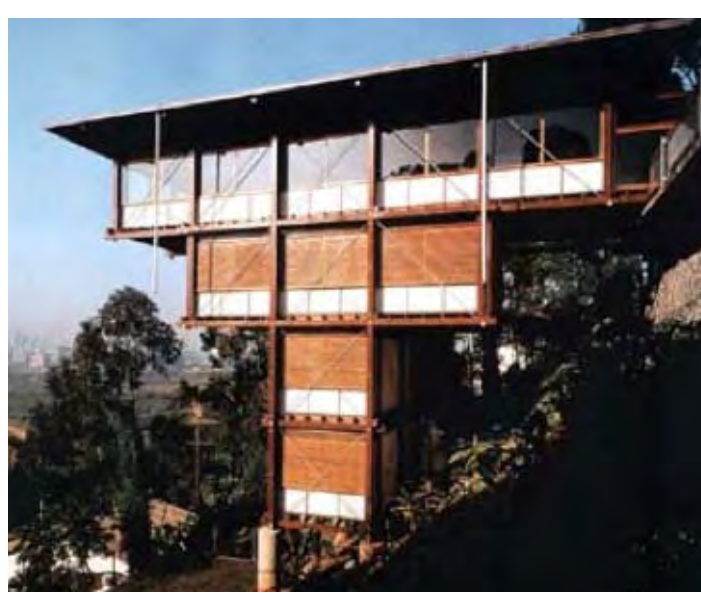

Figura 34 - Residência de Hélio Olga - arquitetura contemporânea com o uso da madeira. 1987-1990.
Em 1984 é que são instaladas as primeiras máquinas de marcenaria e o problema começa a ser sanado. Assim, em 1985, 50\% da receita da Ita provinham das obras em madeira. Com o suprimento de madeira regularizada e uma demanda estável por obras, a Ita pôde dar o passo decisivo: dedicarse exclusivamente à construção de estruturas em madeira. Em 1987 a lta expande as instalações e transfere a oficina e o escritório do Rio Pequeno para o antigo sítio familiar em Vargem Grande Paulista, com área de 90000 m2, onde está instalada até hoje. (Figura 33) Em 1987, também se inicia a construção da atual casa de Hélio Olga Jr. no Morumbi (Jd.Vitória Régia), projeto de Marcos Acayaba, em terreno muito íngreme onde jamais seria possível a execução das peças no canteiro (Figura 34). Houve assim, a passagem do artesanato para a indústria, possibilitada pela ampliação das instalações e pelo aprimoramento da técnica de industrialização das peças. Foi um fato marcante na história da Ita, a partir do uso inteligente da técnica com interferência mínima no local, para tornar aproveitável um lote urbano praticamente inviável, situação cada vez mais comum na cidade de São Paulo. Mas a história da Ita continua, como poderá ser observado no capítulo referente aos projeto da Vila Taguaí, mais recente e em parceria com a arquiteta Cristina Xavier.

\section{I.1.6 UNIDADE HABITACIONAL}

A disposição do programa em três pavimentos, com área total acessível de $186,46 \mathrm{~m}^{2}$ é o resultado do estudo de implantação do número máximo de unidades que o terreno conseguiria alcançar. Com o vão livre de seis metros, as possibilidade de layouts aumentam; também devido à utilização do corte como possibilidade de articulação e agenciamento dos ambientes divididos em andares, prática arquitetônica recorrente na formação dos arquitetos da FAUUSP, influenciados, principalmente, por Vilanova Artigas. Cabe lembrar que Acayaba estudou na FAUUSP entre 1964 e 1969, período de transformação no ensino, a partir da tentativa de se ensinar projeto e não mais composição, e assim, sua trajetória parece carregar esta transição: 
Há, por isso, na obra de Acayaba, uma versatilidade própria de um momento de transição. Nota-se, nela, a presença de um espectro amplo de referências sobrepostas, abstraídas, em alguns casos, dos dogmas que as acompanhavam originalmente. Sabemos que o perigo maior, nessas situações, é a perda equivalente dos pontos de tensão daqueles referentes, redundando em estilismo. $O$ trabalho de Acayaba, contudo, destaca-se na geração pela capacidade de mobilizar esse caldo de influências em direção a sínteses pessoais, autorais, fazendo convergir uma disciplina de racionalização construtiva e uma poética (WISNIK, 2007, p. 14).

O programa é dividido em corte da seguinte maneira: no pavimento intermediário, de chegada, além da garagem aberta com armário, fica a cozinha, que pode ser conjugada ou não com a sala de jantar, e a área de serviço, com possibilidade de incluir dependência para empregada. $O$ espaço livre integrado com a área de serviço faz com que o recuo entre casas não seja residual, sendo bem articulado ao espaço de serviço e sem excesso de circulação já que é dividido com a unidade vizinha a partir da colocação de uma mureta no sentido transversal. Não existem janelas de frente para outras, voltadas para este pequeno corredor, outra estratégia para não retirar a privacidade dos respectivos moradores de cada unidade, situação favorável nesta tipologia de habitação coletiva. $O$ piso inferior possui área reduzida já que se trata do pavimento onde está o muro de arrimo, com apenas uma face para insolação e ventilação. Este espaço também possui flexibilidade na definição do layout, resultado do sistema estrutural e concentração das áreas molhadas. Esse pavimento possui saída para o jardim e para as unidades que estão no renque de doze casas, extensão para a área de lazer coletivo. $O$ piso superior permite a acomodação de até quatro dormitórios. As aberturas principais ficam na face leste e oeste, elas não evidenciam o uso do(s) ambiente(s) interno(s), a não ser pela presença ou não de venezianas. Também não indicam os limites internos dos ambientes, afinal, eles podem ser apenas um.

O programa flexível é acomodado na unidade modular de modo pertinente ao sistema estrutural e construtivo proposto. Não existem adaptações, tudo foi pensado conjuntamente; isto é marcante nesse projeto, além do forte raciocínio em corte, que privilegia níveis descontínuos,

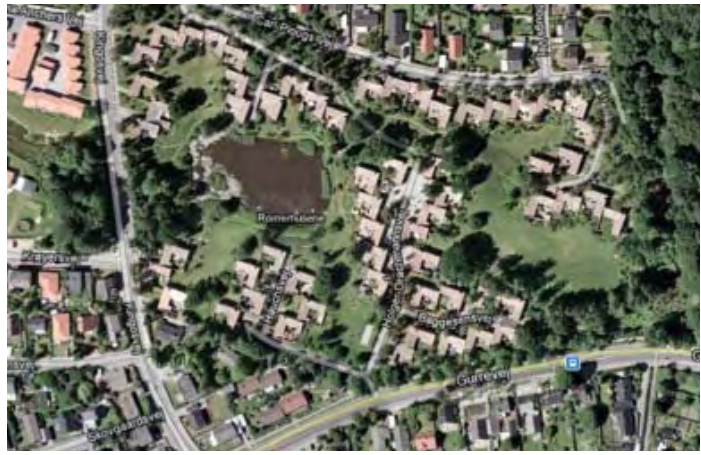

Figura 35 - Implantação Kingohusene (19581960) em Helsingor, de Jorn Utzon.

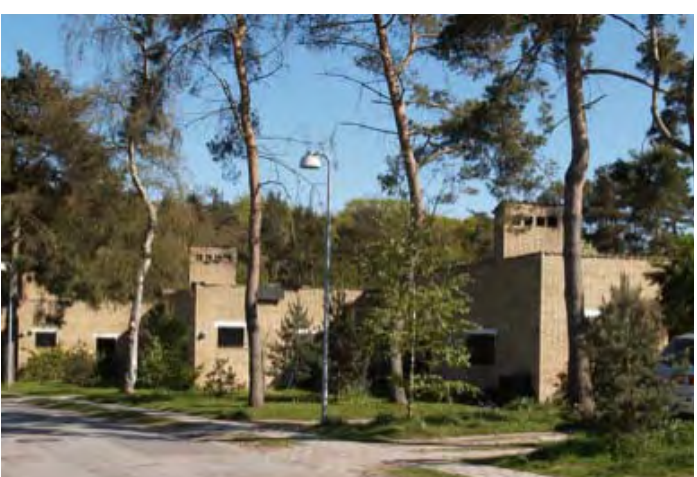

Figura 36 - Kingohusene (1958-1960) em Helsingor, de Jorn Utzon. 


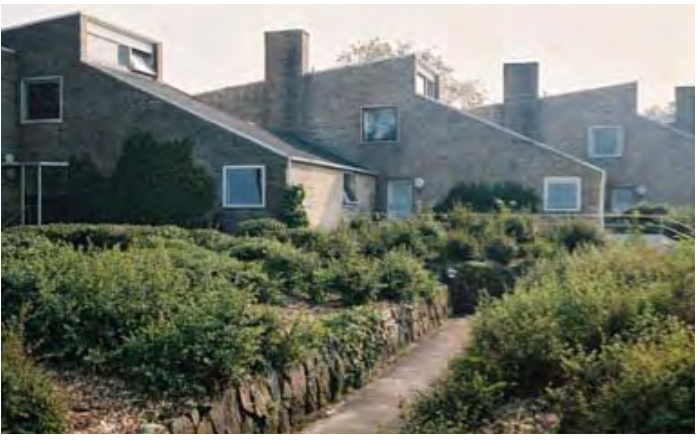

Figura 37 - Conjunto Soholm (1950-1955) em Klampenbold, de Arne Jacobsen.

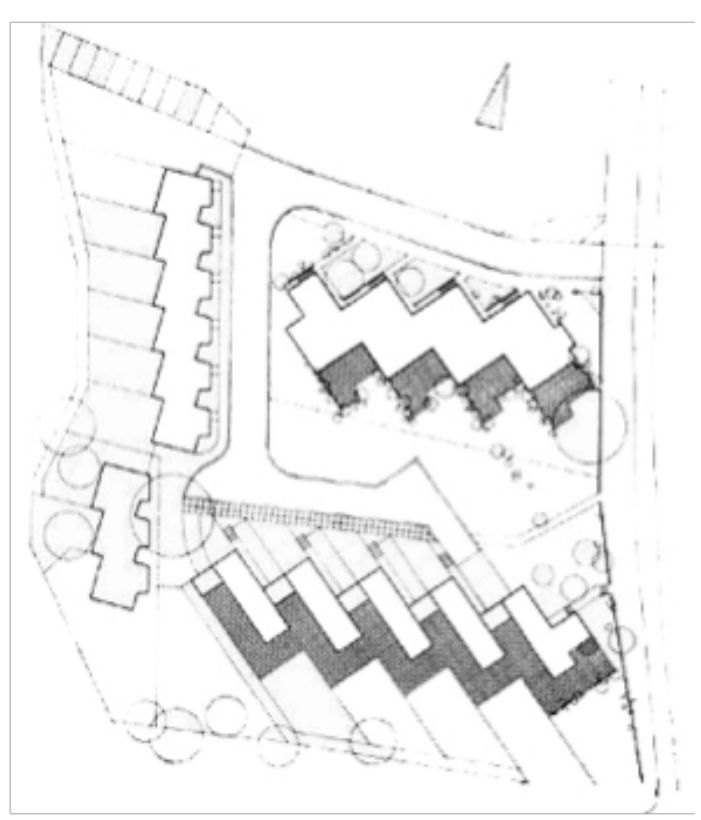

Figura 38 - Implantação conjunto Soholm (1950-1955) em Klampenbold, de Arne Jacobsen. tornando possível também a leitura do terreno e solução arquitetônica e da estrutura adaptada ao mesmo. Kamita (2004) descreve abaixo a representação gráfica dos projetos de Artigas, a partir da leitura analítica da ordem espacial a partir do corte, grande referência na escola paulista de arquitetura e, consequentemente, refletida no trabalho de Marcos Acayaba:

Normalmente, a base da leitura analítica da ordem espacial do edifício é a planta, mas no caso de um partido arquitetônico que privilegia níveis descontínuos sob um imenso teto, o melhor instrumento é o corte.A visão em corte, enfim, dá a noção do espaço como vão profundo, própria do homem ereto que divisa o horizonte. É com ele que temos a apreensão dos inúmeros pés-direitos, das cotas em que as rampas se conectam com os pavimentos, dos detalhes estruturais das lajes intermediárias e de cobertura, dos desníveis no terreno. Podemos nos arriscar a dizer que o raciocínio projetivo de Artigas opera muito mais a partir do corte do que da planta, pois além da projeção tridimensional do espaço, ele proporciona uma percepção analítica do comportamento estático das peças estruturais (KAMITA,2004, p.36-37).

\section{I.I.7 REFERÊNCIAS}

O trabalho do arquiteto Marcos Acayaba é o resultado da preocupação com a construção, com a racionalização, com a geografia específica do lugar e, por fim, com o sucesso do negócio. A questão plástica parece ser consequência do arranjo do sistema construtivo, materiais adotados e inserção na topografia.A beleza se consegue naturalmente, sem esforços unicamente neste sentido. Acayaba escreveu sobre sua filosofia de trabalho:

Tenho desenvolvido projetos nos quais a preocupação com a construção, seus processos de produção e sua manutenção são determinantes, como também a geografia específica do local da obra.Assim, livres de questões de estilos, as formas das minhas construções, quase sempre novas, resultam de processos de análise rigorosos de condições específicas. E, porque tanto o respeito à natureza do lugar quanto o emprego correto dos materiais e da energia necessária para a produção, uso e manutenção são determinantes, os projetos resultam ecológicos. Com o mínimo de meios, procuro sempre atingir a maior eficiência, conforto e, como consequência, a beleza. Onde nada sobra, onde nada falta (ACAYABA, 2007, p. 09). 
Em matéria publicada na revista Projeto Design sobre esta Vila, "Partido Arquitetônico encontra definição entre o módulo e a topografia”, fala-se sobre a característica repertorial de Acayaba em repetir um elemento padronizado, como uma espécie de racionalismo naturalista que remete a alguns autores dinamarqueses, como Arne Jacobsen e Jørn Utzon, sobretudo em projetos de conjuntos residenciais dos anos 1950, como o Soholm (1950/55), em Klampenbold, do primeiro, e o Kingohusene (1958-60), em Helsingor, do segundo (Figuras 35 a 38).

Também o conjunto Habitacional Bakkedraget (habitação com pátio interno) em Fredensborg, Dinamarca (1963) (Figuras 39 e 40), faz uma composição a partir das menores unidades possíveis: acomodação na topografia natural pensada a partir do menor módulo ou unidade. Nesses três projetos citados existem outras características semelhantes às encontradas na Vila de Acayaba. As áreas externas das casas, com suas alvenarias austeras e janelas neutras, não permitem saber o que se passa detrás delas. Na Vila Butantã, nas duas faces principais, por mais que tenham aberturas generosas, o interior fica indeterminado. Pequenas aberturas no piso ático em composição com a fachada como um todo, ajudam nesta indeterminação, assim como na face não geminada, com apenas uma janela, do banheiro, que cria a mesma sensação de impossibilidade de saber qual ambiente a possui. Outra característica é o deslocamento em planta das unidades, que permite certa privacidade de uma unidade para outra. Enfim, assim como nas referências citadas, trata-se de uma simplicidade plástica resultante do atendimento às necessidades estruturais, de programa e acomodação no terreno.

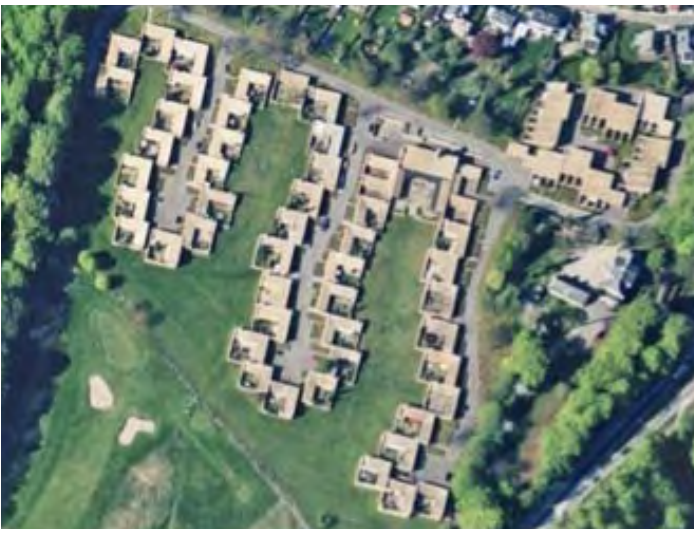

Figura 39 - Conjunto Habitacional Bakkedraget (habitação com pátio interno) de 1963, em Fredensborg, Dinamarca, de Jørn Utzon.

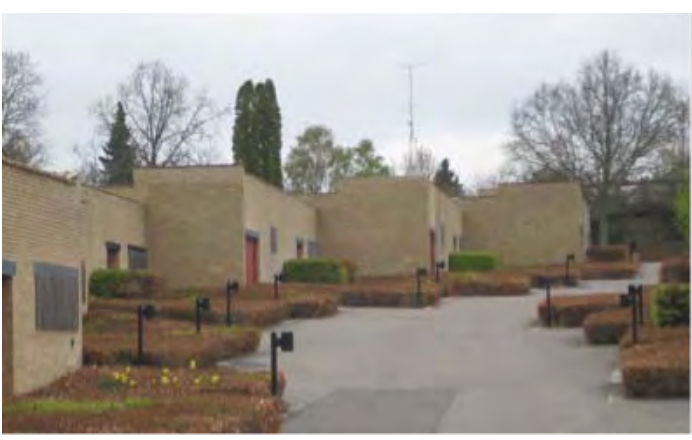

Figura 40 - Conjunto Habitacional Bakkedraget (habitação com pátio interno) de 1963, em Fredensborg, Dinamarca, de Jørn Utzon. 


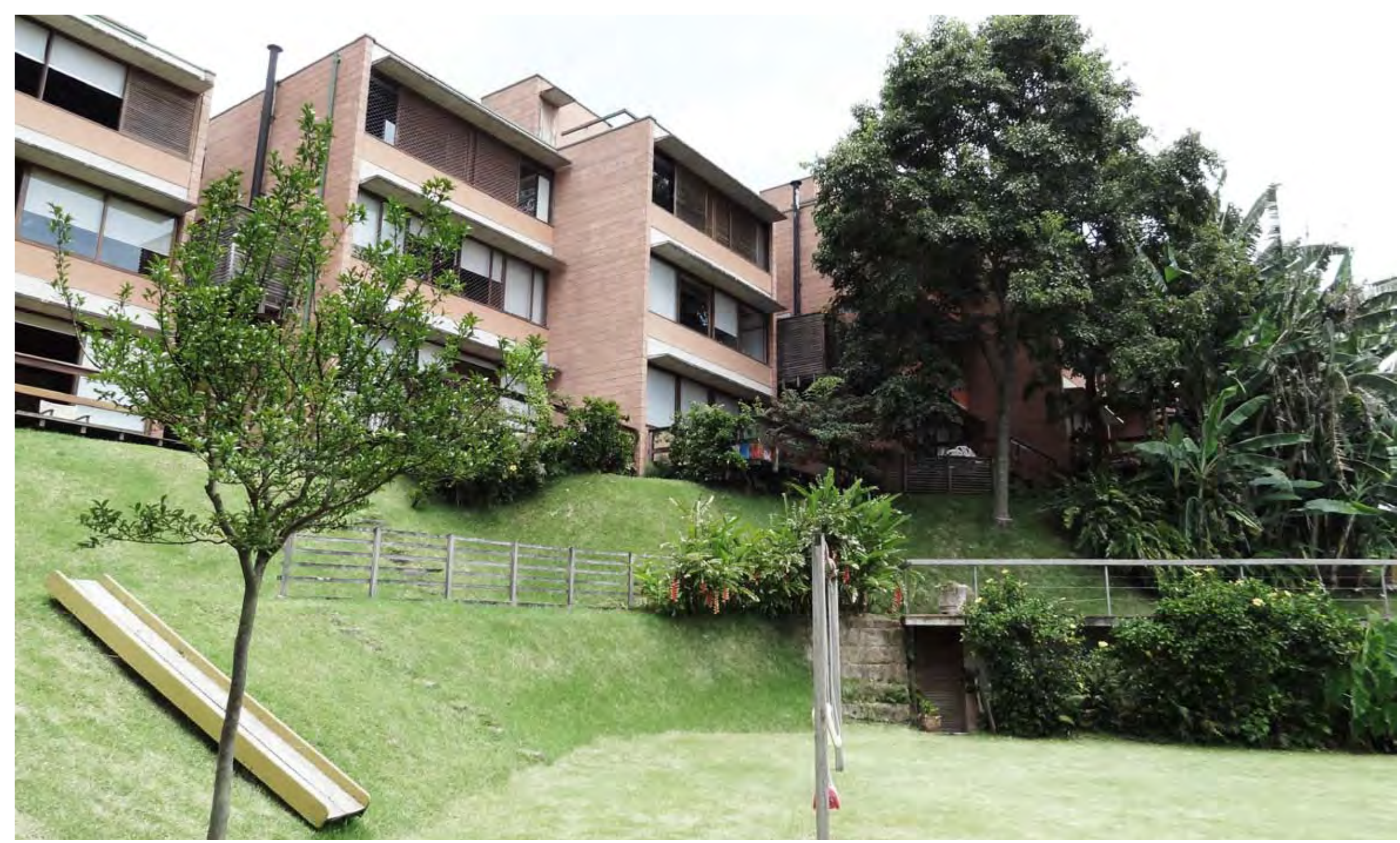




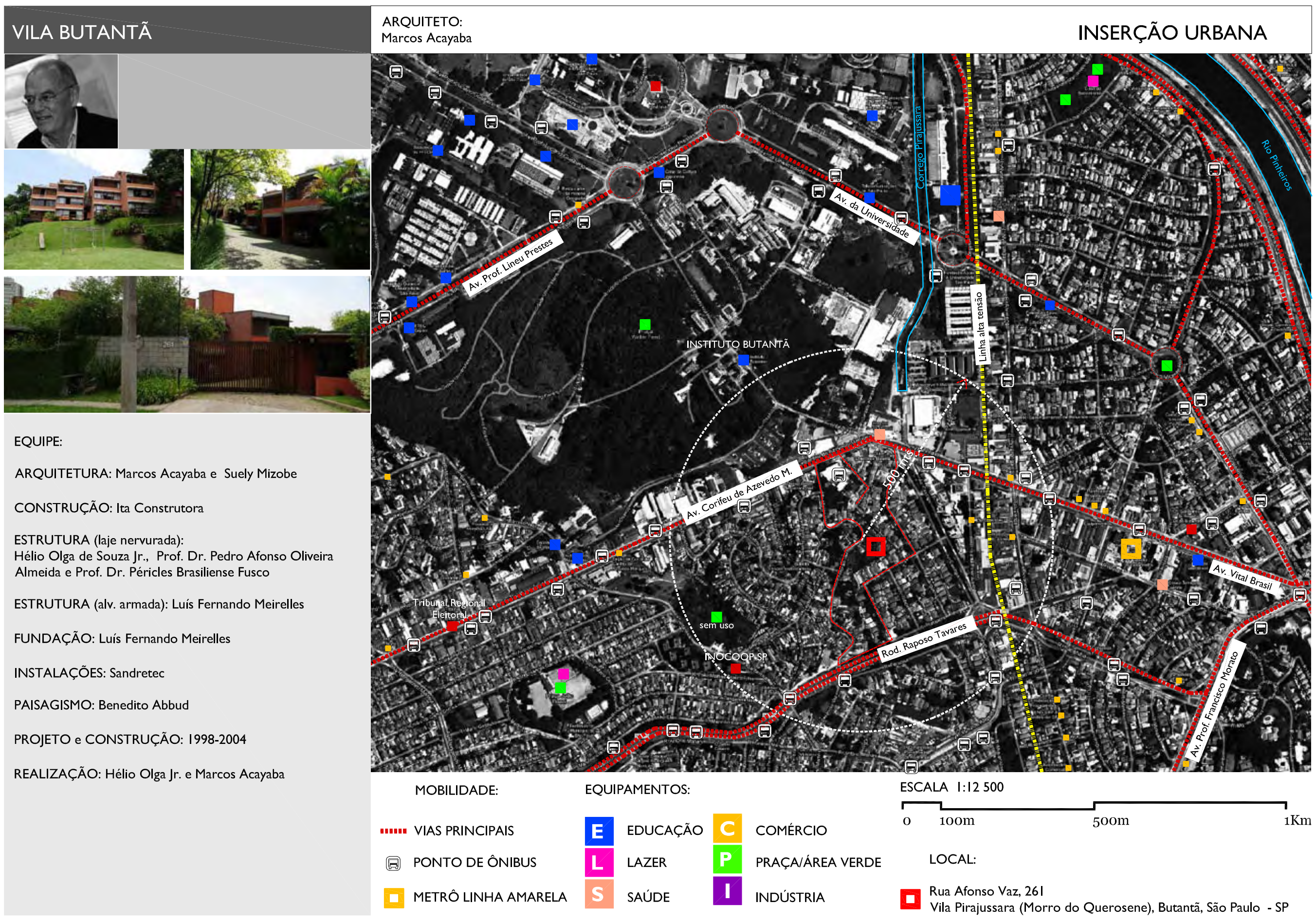




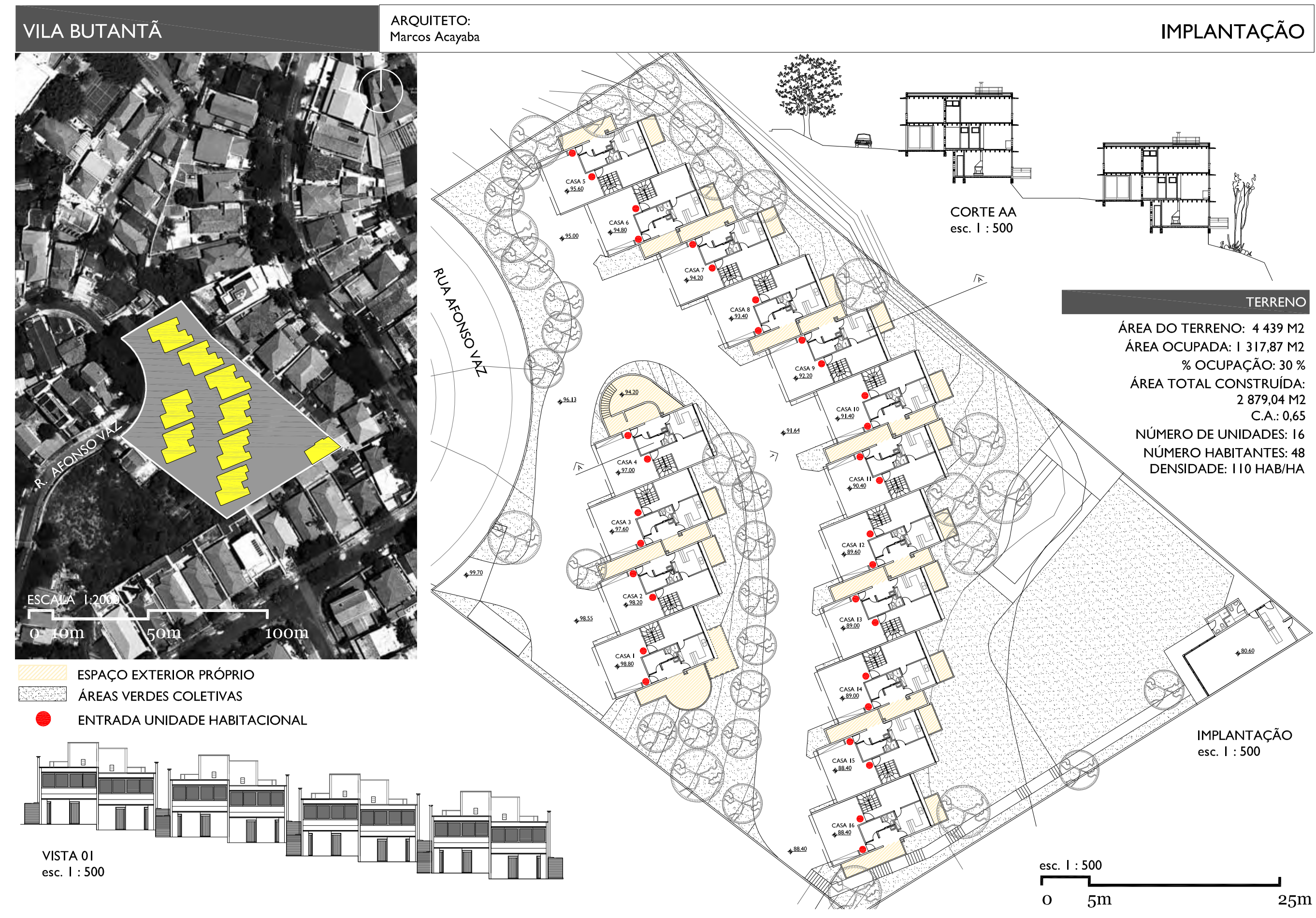




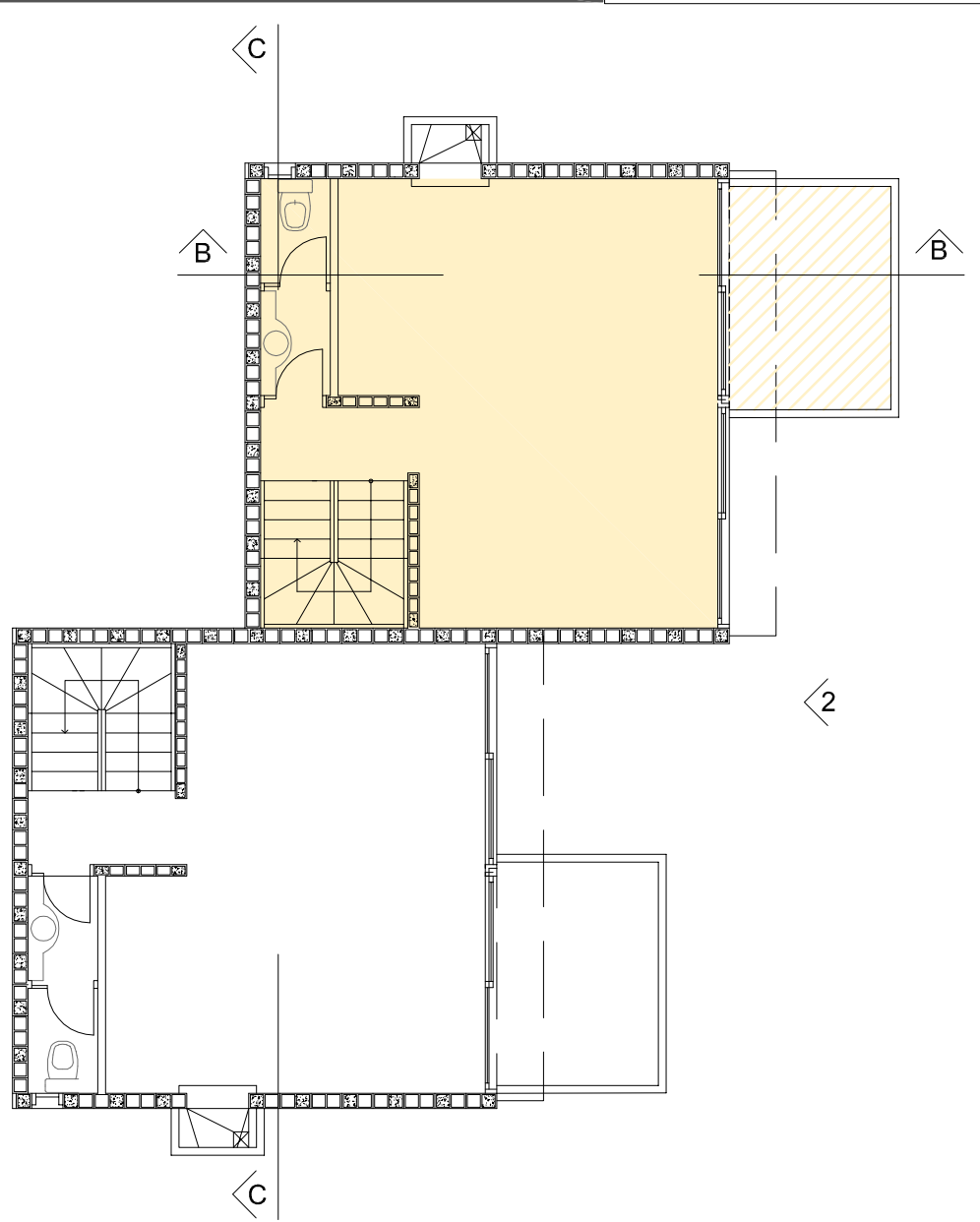

$\widehat{3}$

PLANTA PAV. INFERIOR esc. $1: 125$

ESPAÇO INTERIOR PRÓPRIO ESPAÇO EXTERIOR PRÓPRIO
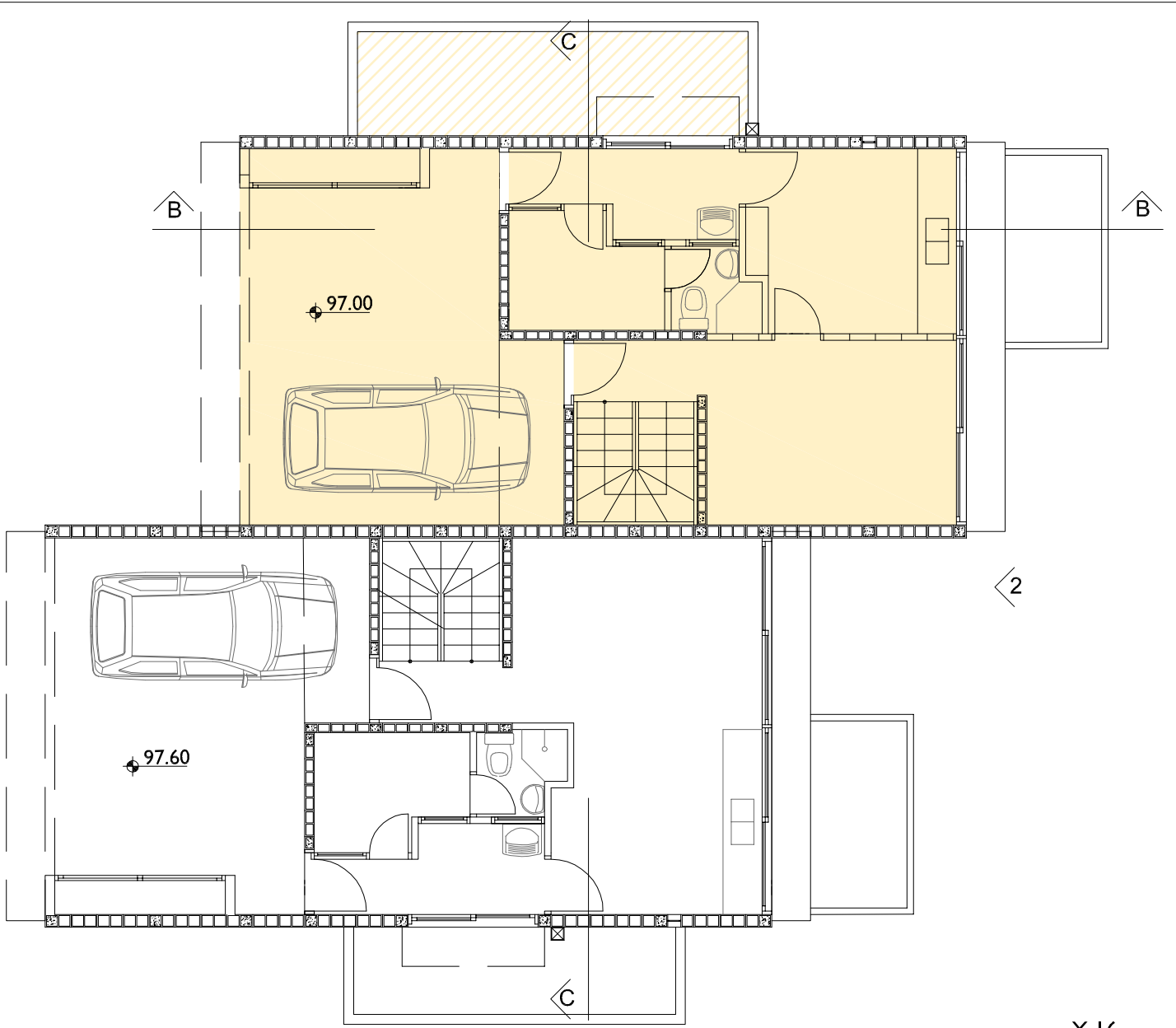

$<2$

$\times 16$

TIPOLOGIA I

PLANTA PAV. TÉRREO esc. $1: 125$

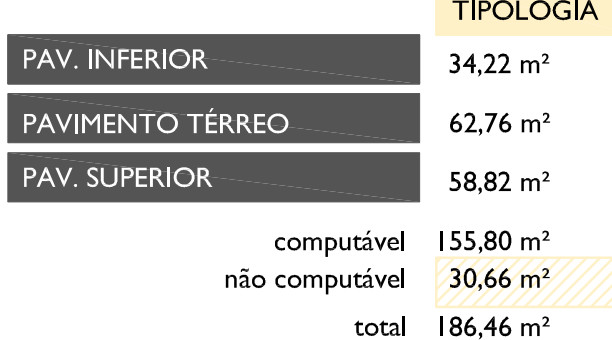

esc. $1: 125$ 


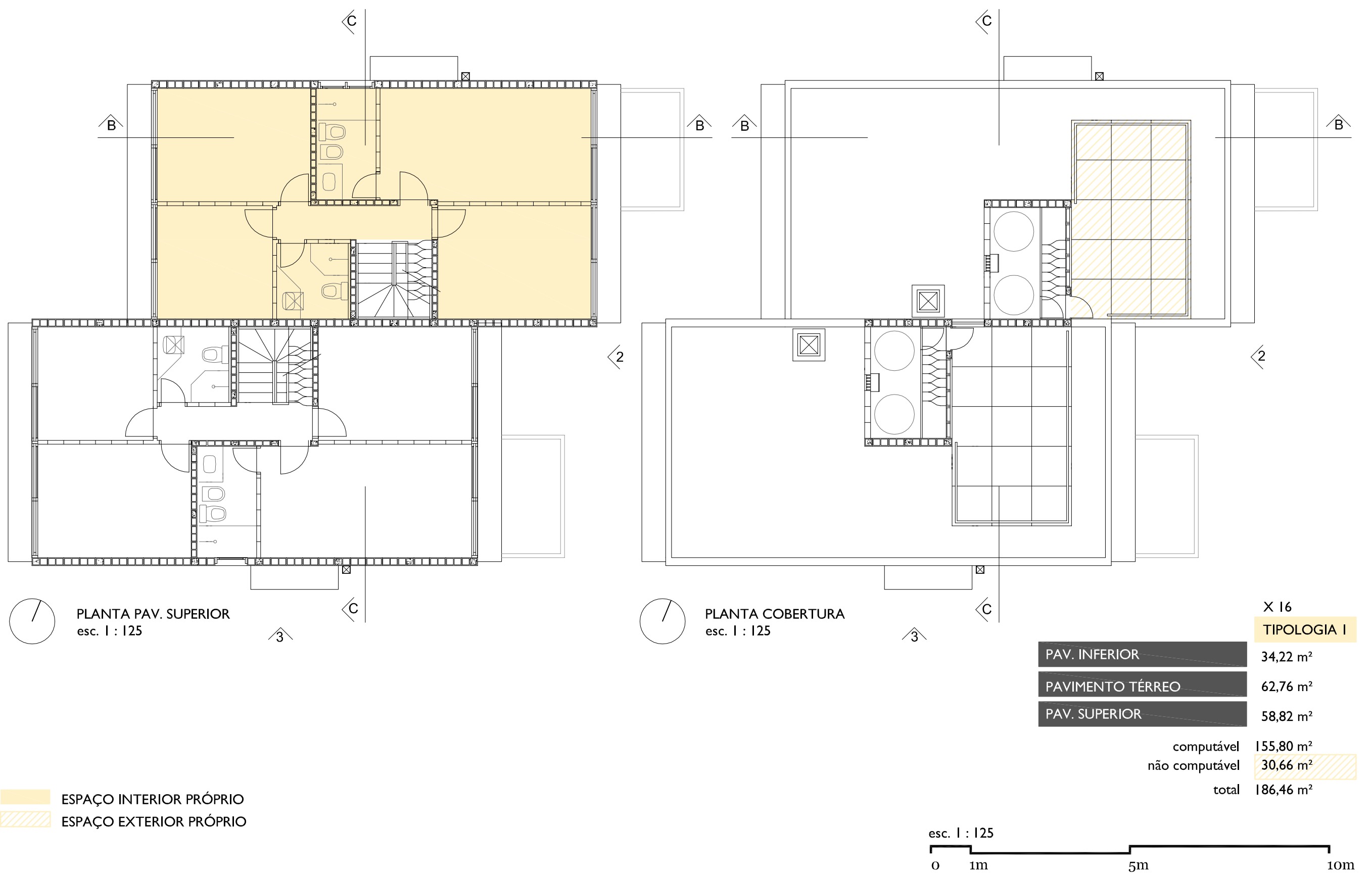



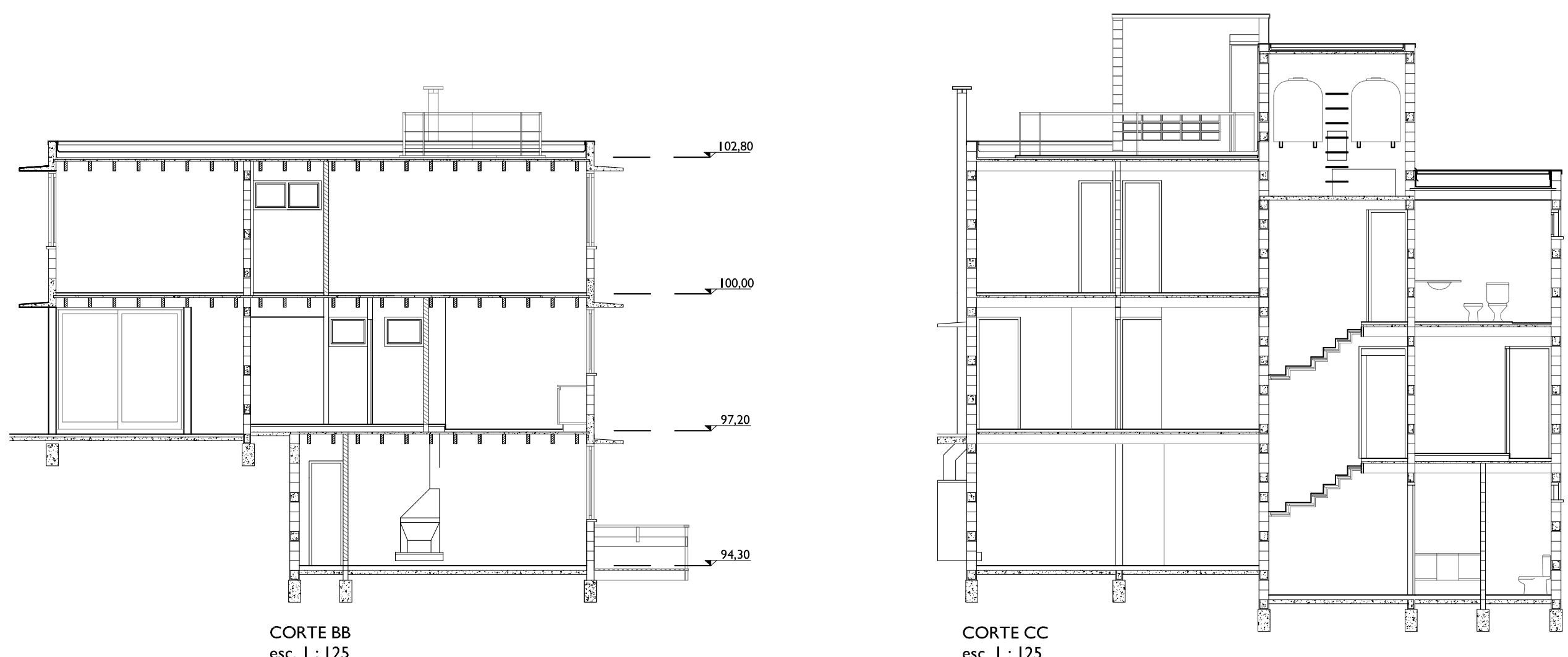

CORTE BB

esc. $1: \mid 25$ 

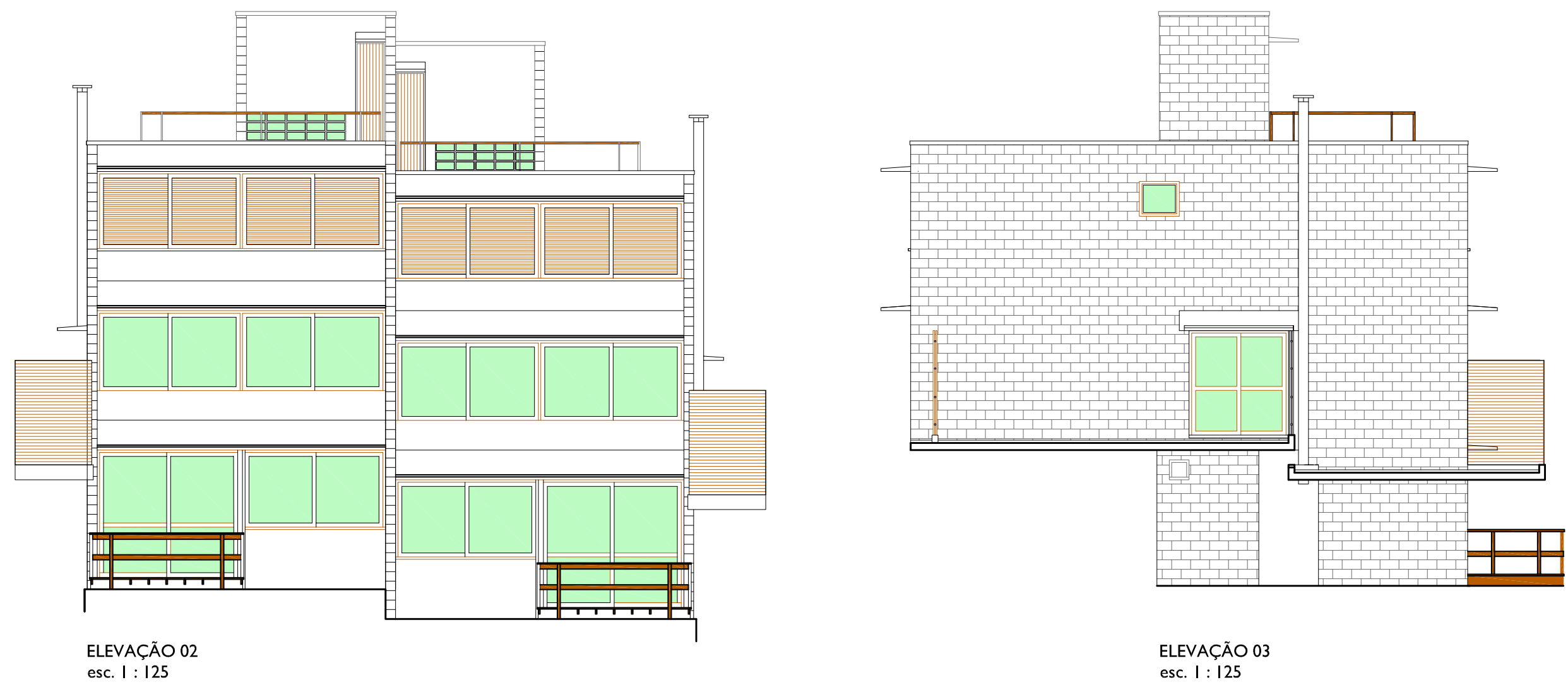

ELEVAÇÃO 03

esc. 1 : 125 
ACAYABA, M. Projeto, pesquisa, construção. 2004. Tese (Doutorado em Arquitetura e Urbanismo). Universidade de São Paulo, São Paulo, 2004. Crônica de uma formação. Em: Marcos Acayaba. São Paulo: Cosac Naify, 2007.

AfLALO, M. (Org.). Madeira como estrutura. A história da Ita. São Paulo: Paralaxe, 2005.

DIEZ, Fernando. Tácticas de Infiltración. Diez años de experimentación en Buenos Aires. SUMMA+, Buenos Aires, n. I07, p. 34-39, abril de 20 I0. ARANTES, P.F. (Org.). Sergio Ferro. Arquitetura e trabalho livre. São Paulo: Cosac Naify, 2006.

FISHER, S. Os Arquitetos da Poli. Ensino e profissão em São Paulo. São Paulo: EDUSP, 2005.

FRENCH, H. Os + Importantes Conjuntos Habitacionais do Século XX: plantas, cortes e elevações. Tradução Alexandre Salvaterra. Porto Alegre: Bookman, 2009.

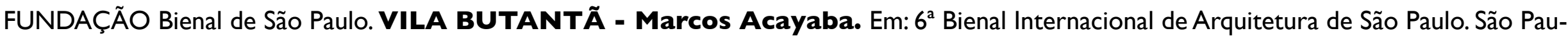
lo: Instituto de Arquitetos do Brasil, 2005.

KAMITA, J. M. Vilanova Artigas. Coleção Espaços da Arte Brasileira, São Paulo: Cosac Naify, 2004, I edição. 
KATINSKY, J. O arquiteto e seu destino. Em: Marcos Acayaba. São Paulo: Cosac Naify, 2007.

MARQUES, R.T. Condomínios tipo Vila em São Paulo. 2006. Dissertação (mestrado em Arquitetura e Urbanismo), Universidade de São Paulo, São Paulo, 2006.

NAKANISHI,T.M. e FABRICIO, M. M. Arquitetura e domínio técnico nas obras de Marcos Acayaba. Risco, Rev. Pesqui.Arquit. Urban. (Online) n.9, São Carlos, 2009.

SEGAWA, H. Marcos Acayaba, delineador de estruturas. Em: Marcos Acayaba. São Paulo: Cosac Naify, 2007.

SERAPIÃO, Fernando. Partido Arquitetônico encontra definição entre o módulo e a topografia. ProjetoDesign, São Paulo, n. 3 I 3, p. 38-45, março de 2006.

Quatro pecados louváveis. ProjetoDesign, São Paulo, n. 313, p. 88, março de 2006.

TSUKUMO, N. M. J. (coord.). Arquitetura na CESP. São Paulo: CESP, 1994.

WISNIK, Guilherme. Exercício de Liberdade. Em: Marcos Acayaba. São Paulo: Cosac Naify, 2007 
VISITA REALIZADA:

Vila Butantã - 09 de fevereiro de 2012

\section{ENTREVISTA:}

Arquiteto Marcos Acayaba - 09 de fevereiro de 2012

\section{LEIS:}

SÃO PAULO (município). Lei n ${ }^{\circ}$ II.605, de 12 de julho de 1994. Dispõe sobre a criação da subcategoria de uso residencial R3-03, conjunto residencial - vila, e dá outras providências.

\section{OUTROS:}

MOREIRA, R. Documentário Ernest Robert de Carvalho Mange - Urbanista. Encontros do Itaú Cultural sobre artistas e outras personalidades da história do Brasil. Disponível em: <http://www.youtube.com/watch?v=cCMdJyXTlxo>.Acesso em: I0/I0/20I2.

ACAYABA, M. Construção em terrenos difíceis. Palestra no Simpósio Internacional WoodWorks. Construindo com madeira no Brasil e na Suíça. São Paulo: FAUUSP, 09 de outubro de 2012 


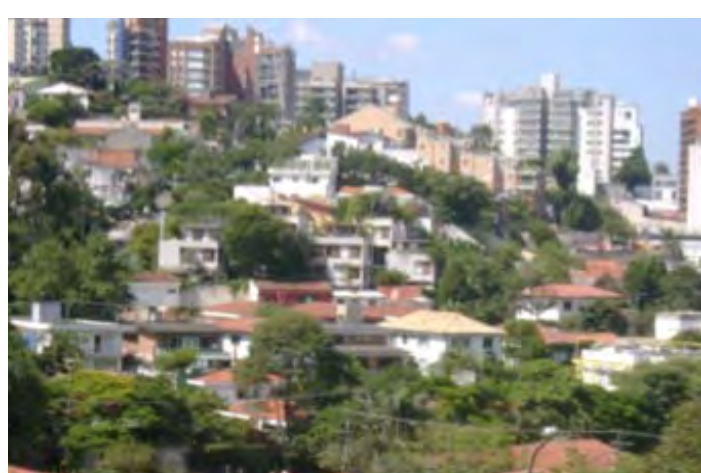

Figura I -Vila Fidalga desde a Praça Dolores Ibarruri.

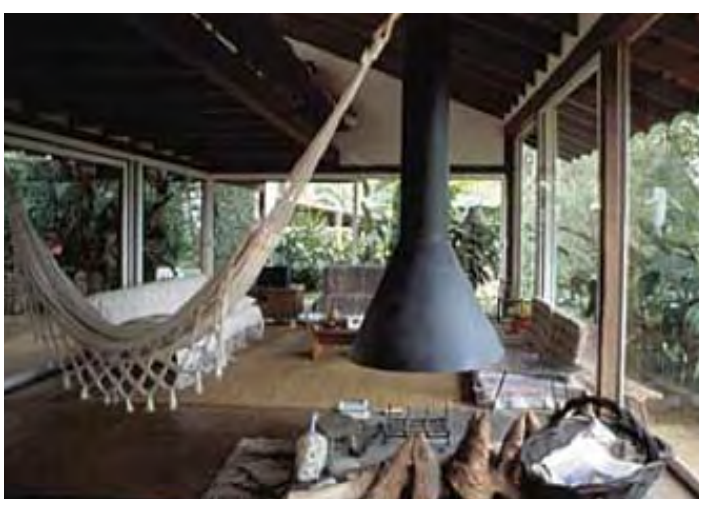

Figura 2 - Segunda casa da arquiteta e pela arquiteta em Carapicuíba, 1992.

\section{I.2 VILA FIDALGA: UNIDADES DIFERENTES UMAS DAS OUTRAS}

\subsubsection{INTRODUÇÃO}

É destaque, neste projeto, a diferença com relação a outros também possibilitados pela Lei de Vilas (1994)', onde geralmente implantam-se casas isoladas, com recuos mínimos entre elas e com deficiência na resolução dos espaços coletivos em relação aos privativos. Já neste projeto, a insolação, orientação e vistas mais interessantes fez com que cada unidade fosse diferente uma da outra, e isto é bastante significativo. Parecem questões básicas para qualquer projeto, porém, por mais incrível que pareça, encontramos atualmente, em nossa cidade, edifícios com unidades habitacionais em que não incide iluminação natural nos cômodos, há unidades voltadas para muros cegos e outras situações como estas, que deixam evidente que o projeto não foi pensado para aquele lugar específico, mas foi utilizada uma tipologia padrão pronta e adaptada para determinado terreno. $A$ Vila Fidalga consegue justamente fazer o oposto, pensar nas especificidades dos detalhes e definir uma implantação com espaços coletivos que balizam os limites dos privativos, consegue ainda criar a possibilidade de personalização interna das unidades, dentro das regras de um projeto desenvolvido para atender alguns desejos individuais dos moradores.

Esta obra é, portanto, excepcional por vários motivos, que vão desde a definição clara dos espaços coletivos e privativos na implantação, até a própria posição do arquiteto de tomar as rédeas do próprio negócio e assumir um empreendimento por completo.Assim, a autonomia que a arquiteta adquire, por ser também agente empreendedor, reflete na boa arquitetura resultante, que não deixa de ser um produto de arquitetura para competição no mercado imobiliário.

' LEI NN II.605, de 12 de JULHO de 1994 - Dispõe sobre a criação da subcategoria de uso residencial R3-03, conjunto residencial - vila, e dá outras providências. 
É uma tentativa de abrir espaço para produtos de arquitetura no mercado imobiliário da cidade. Abrir espaço para que moradores, profissionais de projeto e construção e incorporadores fossem considerados com o devido cuidado e respeito para que o produto final pudesse ser uma contribuição ao bem estar individual e coletivo. Abrir espaço, encontrar um canto, uma brecha para construir valores, sobre valores, humanos (Cristina Xavier, memorial do projeto).

\section{I.2.2 BREVETRAJETÓRIA DA ARQUITETA CRISTINA XAVIER}

Cristina Xavier tem uma trajetória profissional peculiarAntes de cursar arquitetura na FAUUSP (1987-1994), cursou filosofia nesta mesma instituição. Porém, sempre foi envolvida com o tema da arquitetura, afinal, seu pai, João Batista Xavier, é arquiteto e foi professor da FAU durante anos.Ainda como estudante de Filosofia, realizou o projeto de sua própria casa (1984), em Carapicuíba, onde atualmente está instalado seu escritório. Desde esse projeto, já existia a parceria profissional com o engenheiro Hélio Olga, inclusive a casa foi construída com madeira que sobrou da primeira obra de Hélio Olga em parceria com Zanine Caldas, da década de 1980.Trata-se de uma casa rústica, em meio a todo verde existente. Sua segunda casa (1992) foi feita em etapas, com vários tipos de madeira, também sobras de obras de Hélio Olga (Figura 02).As duas casas estão posicionadas uma ao lado da ras casas-laboratórios, pois se aproveitaram da oportunidade de utilizar materiais que estavam sem utilidade, além de resolverem necessidades espaciais à medida que surgiam; ao mesmo tempo, fizeram arquitetura com criatividade e com grande interface com o meio ambiente.A coexistência com a natureza é marcante nestes projetos, o meio exterior é extensão do espaço interior e vice versa.

Sua atuação ainda como estudante já possui uma postura mais amadurecida, já que nesta época realizou alguns projetos residenciais para amigos ou conhecidos, como é o caso da Residência Pato (1988), em Cotia (Figura 03); a Residência A. Pinheiros (1992), em São Paulo; ou até mesmo a Residência Gadotti ( 1994), em São Sebastião.

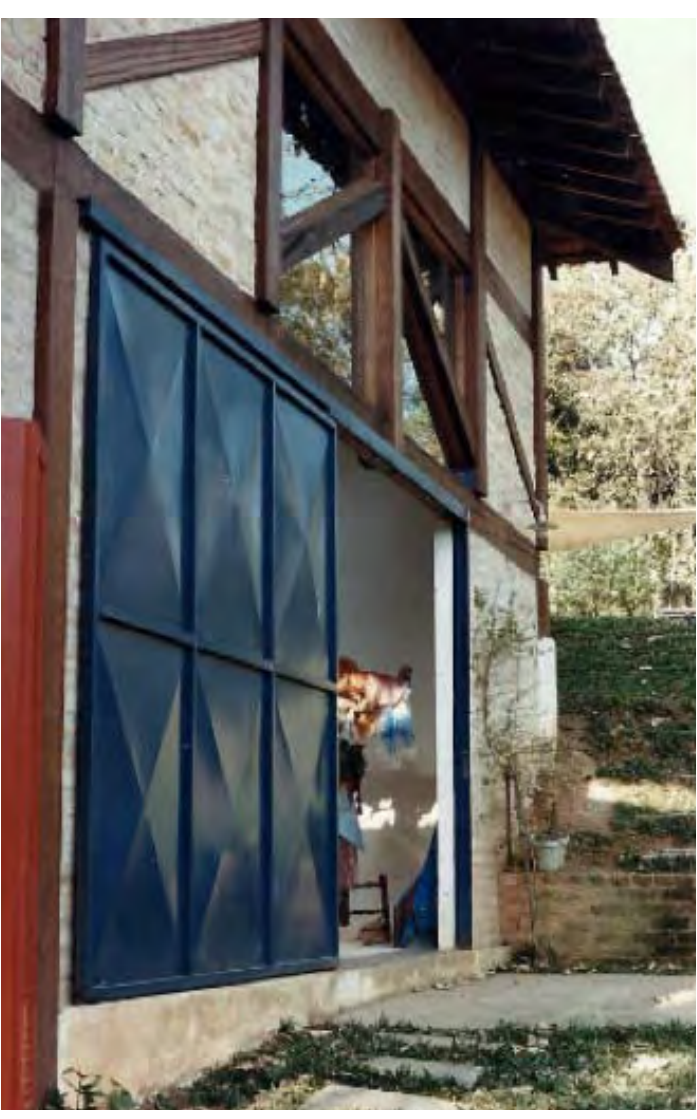

Figura 3 - Residência Pato, Cotia, 1987-1988.

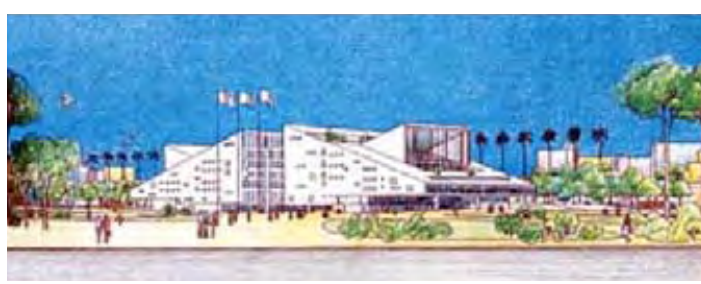

Figura 4 - Projeto concurso para o Paço Municipal de Osasco, 1991. 


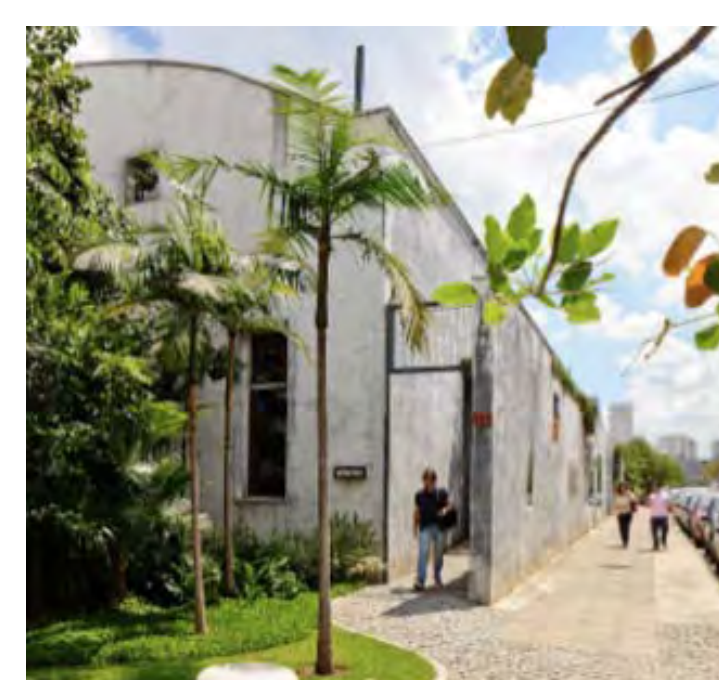

Figura 5 - Reforma da O2 Filmes 2007-2012, São Paulo.

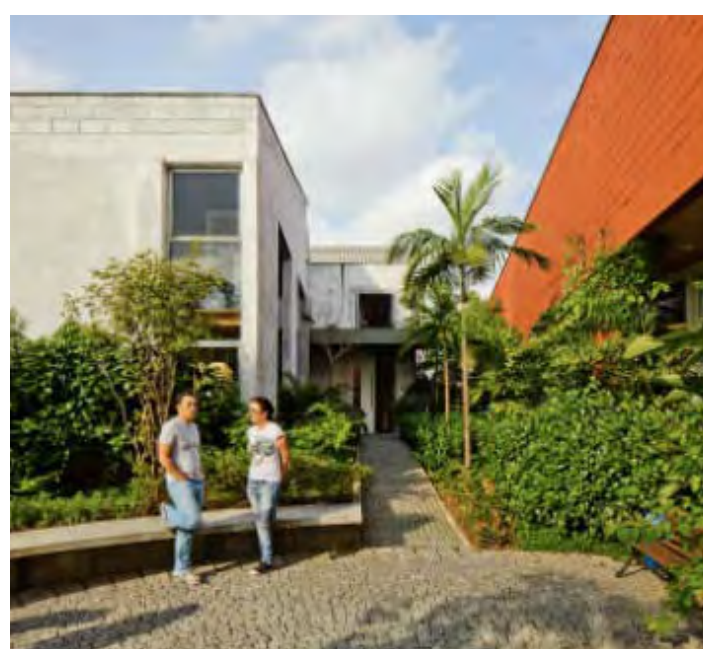

Figura 6 - Reforma da O2 Filmes 2007-2012, São Paulo.
Ainda como estudante da FAU, em 1991, participou do concurso para o Paço Municipal de Osasco com seu pai, João Batista Xavier, do qual saíram vencedores (Figura 04). Segundo palavras do júri, em Melendez (200I), “O caráter simbólico do projeto em consonância com a paisagem urbana local; a adequação e a simplicidade de implantação; a cuidadosa abordagem dos aspectos de isolamento e conforto térmico; e a originalidade da concepção, explicitando a equivalência dos poderes Executivo e Legislativo". Porém, este episódio não teve um final feliz, já que o projeto executivo foi desenvolvido, porém, a obra não saiu do papel.

Apenas dois anos após formada, em 1996, recebe o convite da construtora Zarvos Engenharia (irmãos Otavio e Fabio Zarvos) para projetar um conjunto residencial na Vila Madalena com oito unidades residenciais, também objeto de estudo indireto desta pesquisa, o Fidalga 897.A Lei deVilas estava em vigor há pouco tempo, desde 1994, e este lote, muito inclinado em direção à Rua Fradique Coutinho, possibilitava a aplicação da lei, permitindo a construção de conjunto de casas onde, antes da lei, só era possível casa unifamiliar. Depois deste conjunto residencial, Cristina Xavier projeta a Vila Fidalga (1999-200I) na mesma rua, possibilitada pela mesma lei. Durante toda sua carreira, sempre realizou projetos residenciais de casas unifamiliares e conjuntos multifamiliares. Atualmente, a arquiteta já tem planos de novos empreendimentos de habitação coletiva, porém, com o desejo de adotar uma nova estratégia com relação às incorporações anteriores: do empreendimento partir de um grupo de moradores pré-definidos, ou seja, formar o grupo de moradores e entender suas peculiaridades, antes de iniciar o projeto.

Em 2007, Fernando Meirelles, grande cineasta brasileiro, também arquiteto estudante da FAU nos anos 1970, amigo de Cristina Xavier, a convida para realizar a reforma de seu estúdio, O2 Filmes, que ocupa galpões na Vila Leopoldina, um bairro paulistano com presença de grandes construções industriais antigas, que acabou favorecendo recentemente a ocupação destes espaços por empresas criativas e audiovisuais relacionadas ao cinema ou publicidade, por exemplo; o que levou inclusive a valorização imobiliária do bairro. Trata-se de um projeto bem especial em fase de finalização. 
O longo período de execução se dá pelo fato da arquiteta ter tido um trabalho minucioso de compreender todos os departamentos da empresa, como por exemplo, elenco, financeiro, produção, pós-produção e diretoria; fazer reuniões separadas com os funcionários de cada departamento, para entender o que poderia melhorar o dia-a-dia de trabalho deles; e por fim, ela praticamente se instalou no local para acompanhar todo o processo de reforma, lembrando que a produtora continuou em pleno funcionamento durante a obra.Assim, Cristina tem este profissionalismo de querer entender os desejos dos clientes e atendê-los da melhor maneira possível, é notável esta atitude nos projetos estudados nesta pesquisa inclusive neste que foge do programa residencial, para uma produtora de filmes. Ainda com relação ao projeto da O2 Filmes, foram intervenções completas, desde a arquitetura do antigo galpão, departamentos internos, áreas de convivências, recepção e jardins. Algumas características deixam evidente a autoria da arquiteta, primeiro, a presença dos elementos de madeira, inclusive painéis similares aos utilizados na Vila Taguaí, o interconvívio entre áreas externas e internas, e também, a forte presença do meio natural (Figuras 5 a 8).

Enfim, todas estas obras citadas são apenas para complementar a trajetória desta arquiteta, afinal, três projetos de sua autoria estão presentes nesta pesquisa, e marcam fortemente um período de sua trajetória profissional e características de sua arquitetura.

\section{I.2.3 AGENTES}

Este projeto foi concebido poucos anos depois do Fidalga 897, experiência anterior e embrião, no sentido de dar possibilidade de personalização das unidades habitacionais, que foi sequenciada no projeto da Vila Fidalga e nos projetos da incorporadora Idea!Zarvos mais recentes, que tem como característica marcante a liberdade para o morador fazer a distribuição programática dentro da unidade habitacional da forma como desejar, já que o projeto global coloca mínimos obstáculos neste sentido.

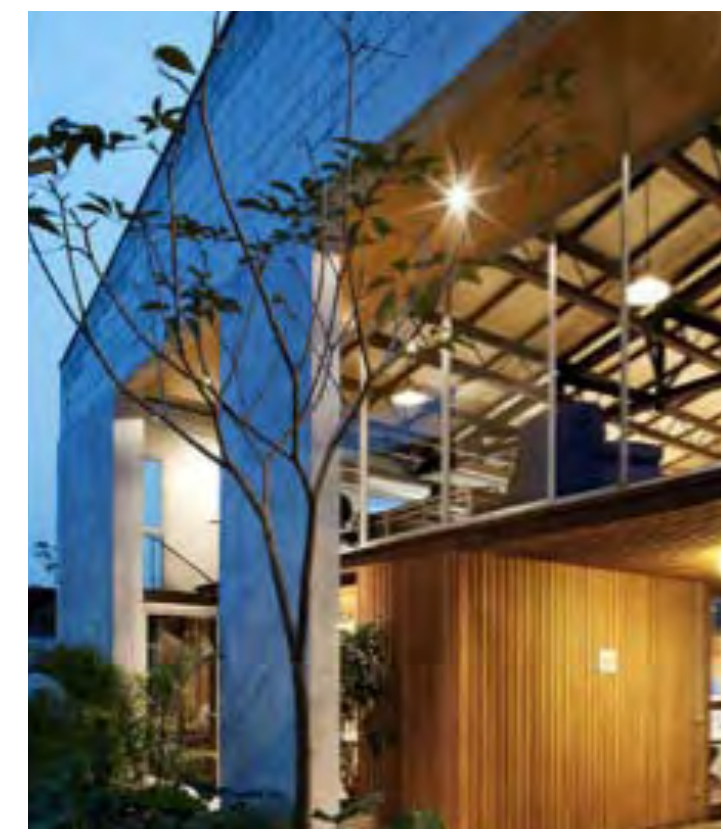

Figura 7 - Reforma da O2 Filmes 2007-2012, São Paulo.

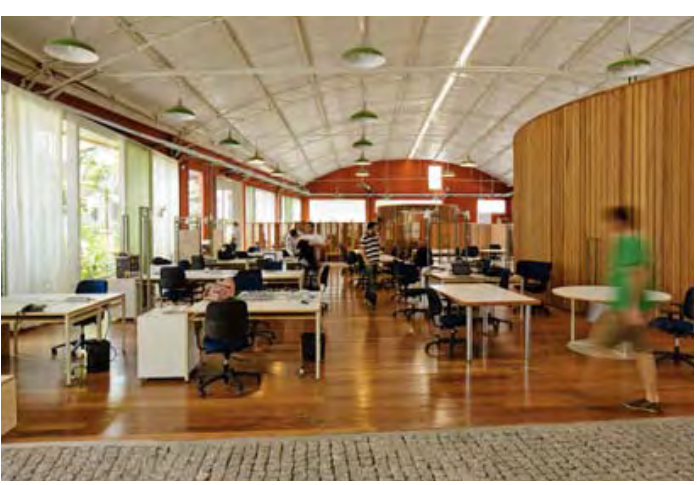

Figura 8 - Reforma da O2 Filmes 2007-20I2, São Paulo. 


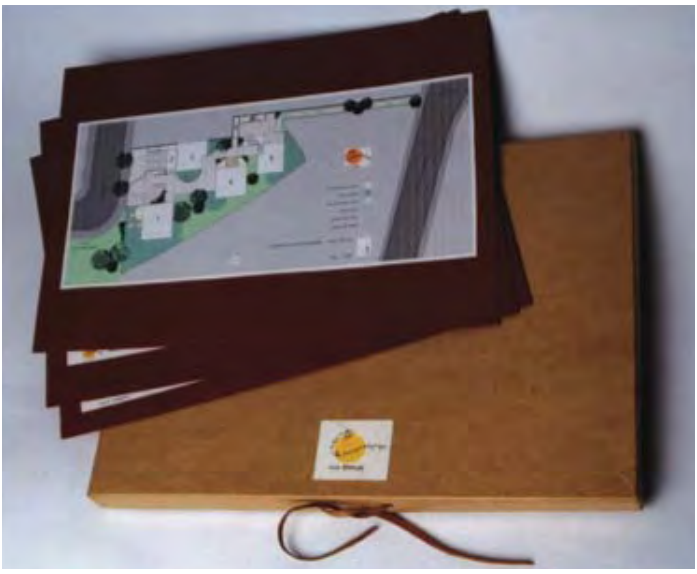

Figura 9 - Material de vendas Vila Fidalga.

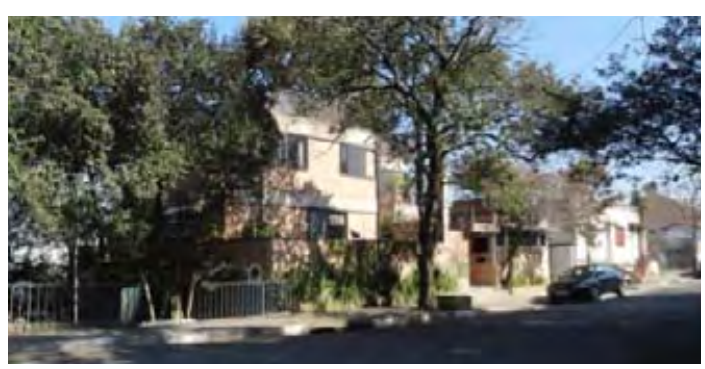

Figura 10 - Trecho da Rua Fidalga com alta declividade e poucos conjuntos habitacionais.

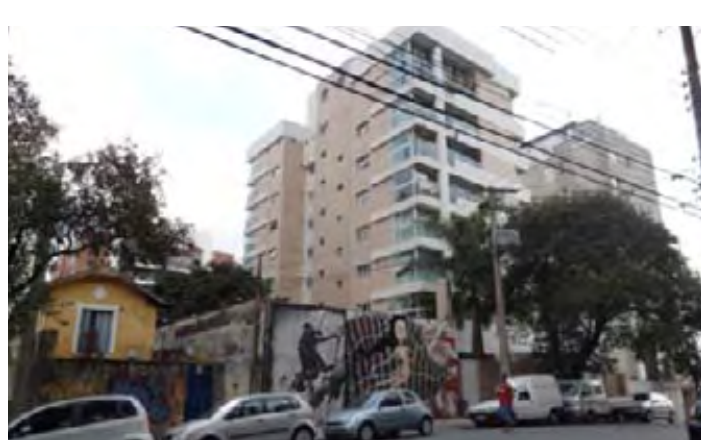

Figura I I - Rua Fidalga, zona de média densidade. Substituição de casas unifamiliares por edifícios ou casas sobrepostas é perceptível.
É possível entender que a realização do projeto de arquitetura do Fidalga 897 e sua participação no processo de atendimento aos clientes, propiciou Cristina Xavier a uma posterior reflexão sobre a qualidade do projeto de arquitetura dentro de um processo maior no mercado imobiliário e sobre quais pontos o projeto deveria se proteger mais para conseguir resguardar sua essência e qualidade, isto quer dizer, não deixar que o processo de personalização das unidades conjuntamente com os moradores ultrapassasse limites, de tal forma a não permitir que o desejo individual prevaleça sobre o coletivo. Este resgate à experiência anterior da arquiteta é importante, pois o avanço do segundo projeto da Rua Fidalga, de sua autoria, com relação ao primeiro, é justamente do espaço coletivo estar firme o suficiente para limitar os espaços privativos, ou seja,"o espaço coletivo como baliza"2. Esta reflexão chegou ao ponto da arquiteta fundar, em 1999, em parceria com Filipe Xavier (seu irmão), Francisco Limongi e Sônia Mindlin, a Taguaí Arquitetura e Incorporação, para realização completa da Vila Fidalga. $O$ engenheiro Hélio Olga Júnior, que estava realizando a Vila Butantã na época, (outro empreendimento em que arquiteto e engenheiro são agentes empreendedores do próprio projeto), foi contratado pela Taguaí para ser o responsável pela construção, enquanto sua irmã, Hebe Olga de Souza, foi a arquiteta que colaborou no acompanhamento da execução da Vila. A arquiteta Cristina Xavier, como sócia da Taguaí, conseguiu ter uma participação efetiva em todas as etapas do processo, que é mais amplo do que a fase de projeto, englobando desde a busca e negociação do terreno, aprovação do projeto legal, construção, incorporação e venda das unidades (figura 9). Este projeto tem o potencial de informar ao público sobre a existência de outras soluções projetuais e de incorporação que não sejam aquelas repetidas pela cidade, retomando, assim, a discussão sobre a relação entre arquitetura e mercado.

\footnotetext{
${ }^{2}$ Expressão utilizada por WISNIK (2002).
} 


\subsubsection{INSERÇÃO URBANA}

O projeto é uma realização de possibilidades abertas com a Lei das Vilas, que viabilizou a construção de condomínios em lotes individuais, situados em zonas em que se permite pouca verticalização. Nesse sentido, a comparação da solução proposta pela arquiteta com as adotadas na maior parte dos condomínios fechados recentes, e que resultaram da mesma lei, é elucidadora (WISNIK, 2002).

A construção deste conjunto de casas - em um único lote, que possivelmente abrigaria uma residência unifamiliar, ou permaneceria vazio devido a sua topografia acidentada, numa zona que se permite pouca verticalização como esta (zona mista de baixa densidade) - só foi possível com a criação da Lei de Vilas em 1994. A Rua Fidalga tem seu zoneamento dividido justamente na Rua Rodésia, em trecho de baixa densidade (caso deste quarteirão, ver figura 10), e média densidade (onde ficam os projetos Fidalga 772 e 727, por exemplo, ver figura II). Possivelmente, a topografia acidentada acabou criando esta diferenciação de densidades, e o que se percebe é que a condição acidentada acabou não sendo um atrativo para os empreendedores que comumente fazem os condomínios na cidade, pois percorrendo o trecho do quarteirão com alta declividade, as únicas iniciativas realizadas a partir desta lei, fora a Vila Fidalga, foram o Fidalga 897 (da Zarvos Engenharia) e outro conjunto na altura do número 955 (Figura 12), realizado pelo engenheiro Fábio Zarvos ${ }^{3}$, posteriormente ao Fidalga 897. Desse modo, percebe-se que as transformações e substituições de casas unifamiliares por edifícios ou casas sobrepostas ficam mais evidentes no trecho da Rua Fidalga de média densidade, possivelmente pela condição topográfica menos acidentada e, consequentemente, pelo potencial construtivo agregado.

O terreno íngreme e irregular onde foi implantada a Vila Fidalga representava um espaço vazio e residual no bairro, um verdadeiro retalho urbano antes da implantação do conjunto de seis casas. Possui acesso por viário inclinado (figura 13) e está ao lado da Praça José Carlos Burle, onde ${ }^{3}$ Os irmãos Otávio e Fábios Zarvos seguiram caminhos distintos, Otávio cria a Idea!Zarvos alguns anos após a separação dos dois.

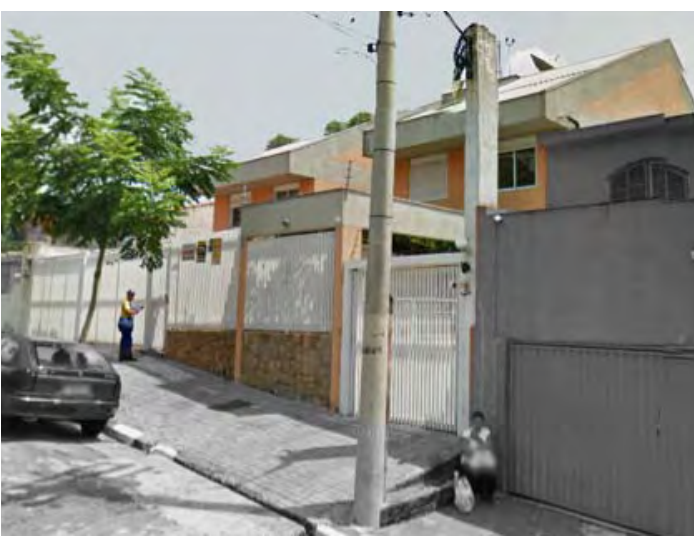

Figura 12 - Vista do Fidalga 955.

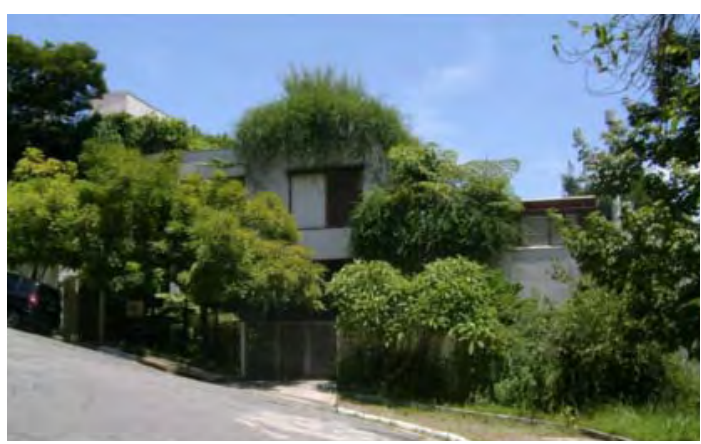

Figura 13 - Vista da Vila Fidalga. Rua inclinada.

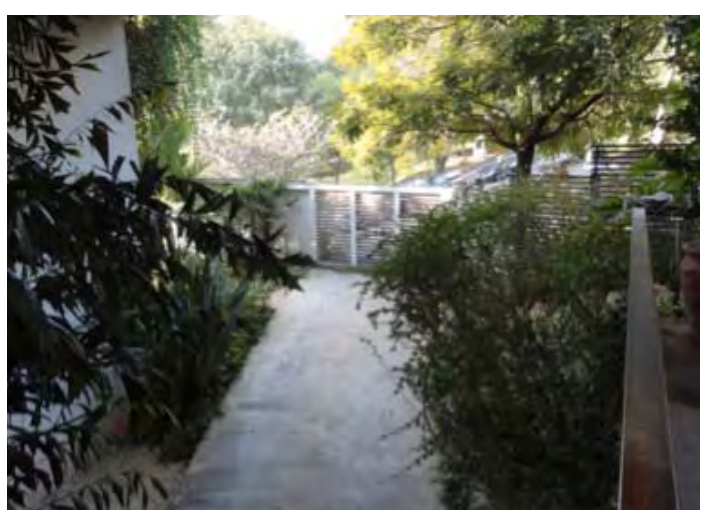

Figura 14 - Vista da Rua Fidalga e praça, destacando o espaço de uso coletivo da vila. 


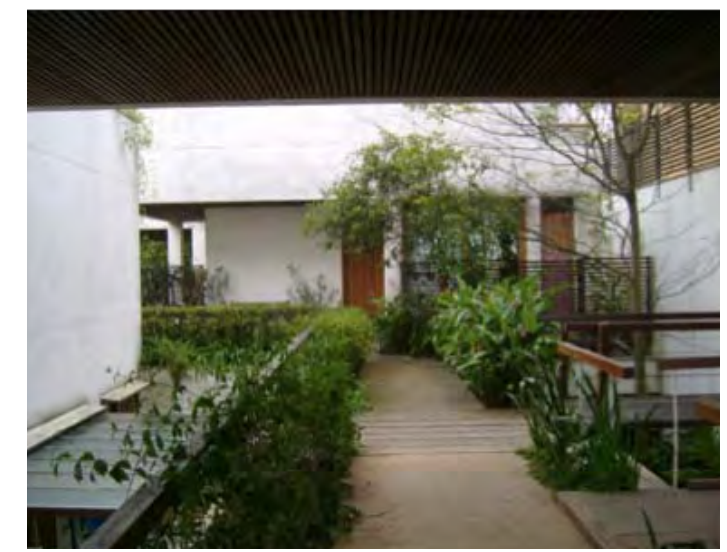

Figura 15 - Espaço de uso coletivo na vila, entre as unidades habitacionais. Ao fundo, casa 3 , à direita, acesso casa 5 e à esquerda, empena da casa 4.

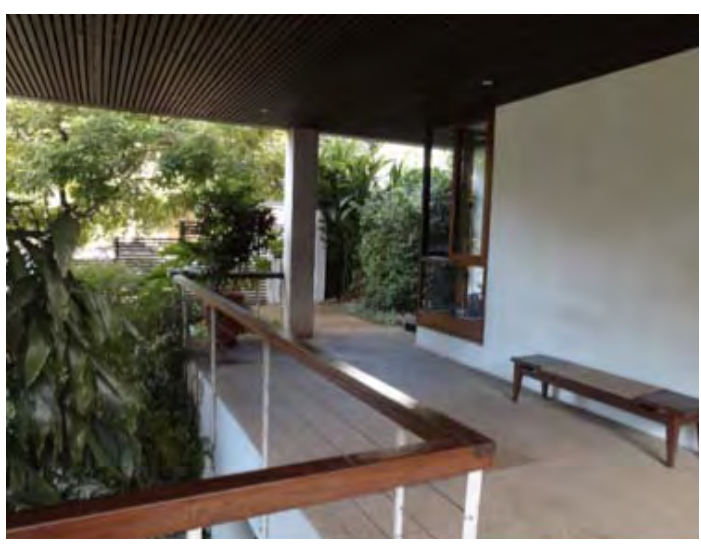

Figura 16 - Espaço de uso coletivo na vila:à direita, espaço para uso do porteiro. funciona a Escola Municipal de Ensino Fundamental Professor Olavo Pezzotti. Parece extensão desta praça, seja pela quantidade de área verde presente entre as casas, seja pela cuidadosa inserção na topografia e meio natural (Figura 14). Neste trecho, a Rua Fidalga está aproximadamente dez metros acima da cota da Rua Fradique Coutinho, além disso, desde a face noroeste da vila, pode-se avistar o bairro Alto de Pinheiros, a Praça Dolores Ibarruri (de onde é possível observar o conjunto à distância), e o Vale do Córrego das Corujas, que separa a Vila Madalena da Vila Beatriz.

\subsubsection{PARTIDO DE IMPLANTAÇÃO}

Foi mencionado pela arquiteta que, ao contrário da maneira que havia sido feito no Fidalga 897 (ver Apêndice 2, obra 4), neste caso, o departamento de aprovação de projetos da prefeitura de São Paulo,APROV, determinou que as casas não poderiam ser sobrepostas, podendo, no máximo, tangenciar seus limites, diferentemente do que a própria lei cita:

Cada unidade habitacional ou a edificação formada por unidades habitacionais superpostas deverá ter no máximo $9,00 \mathrm{~m}$ (nove metros) de altura, medidos a partir do piso do pavimento mais baixo da unidade, incluindo o subsolo, até o limite superior da cobertura; (Lei II.605, de 12 de Julho de 1994).

É importante mencionar a condução da aprovação de um projeto diferenciado como este, pois até os próprios funcionários da prefeitura tiveram dificuldade em entendê-lo e interpretá-lo dentro da lei; conjugou-se também à novidade que a lei representava. Assim, sem conhecimento prévio do projeto, ao caminhar pela vila, é possível ter a sensação que existe sobreposição de casas (Figura 15), no entanto, cada casa possui uma projeção individual no terreno, devido a uma condição da aprovação do projeto legal. A topografia, principais vistas, a definição de acesso para veículos e pedestres, as orientações, a definição dos espaços coletivos, esta norma e outros índices 
urbanísticos, acabaram sendo os condicionantes na definição da localização e posição das unidades, ou seja, dos limites dos espaços privativos, numa distribuição tão particular quanto heterogênea, já que houve uma análise individual para cada unidade, como se fossem seis projetos diferentes e não um renque de casas iguais, como geralmente costuma acontecer.

Assim, com relação à localização e posição das unidades, o projeto traz uma solução diferente das vilas tradicionais, geralmente com casas geminadas, viário comum frontal, e jardim individual, justamente devido a uma análise individual de todos os aspectos mencionados para cada unidade. É diferente também das soluções americanizadas que espalham as unidades isoladamente no terreno. Neste projeto, os limites das casas são dissolvidos e ao mesmo tempo entrelaçados, mesmo possuindo projeção individual. Esta solução, também pode ser notada, porém com menos intensidade até pela densidade do conjunto, no projeto da Vila Taguaí, trabalho mais recente da arquiteta. Estes limites, mesmo que sutis, são fortes o suficiente para não dar margem a uma apropriação individual imprópria de espaços definidos como coletivos pelo projeto, algo que no projeto Fidalga 897 ficou a desejar, já que houve situações de verdadeira “invasão” de espaço coletivo por usos privativos.
O conjunto não tem, assim, nem a escala nem a qualidade espacial de uma vila propriamente dita, mas de uma cidadela (não na acepção defensiva do termo, mas na idéia que ele indica de uma cidade concentrada - mais pela heterogeneidade dos espaços do que pela diversidade de equipamentos) (WISNIK, 2002).

As árvores de grande porte existentes no terreno e mantidas, como goiabeiras, mangueiras e pitangueiras, também foram importantes na definição dos espaços abertos. $O$ espaço é, portanto, heterogêneo e traz surpresas agradáveis (Figura 17). Na Vila Fidalga, a definição de espaços comuns e privativos é resolvida com criatividade e gera condições particulares que a distingue de outros projetos. $\mathrm{O}$ acesso de pedestres às residências é feito por meio de um percurso que adentra o lote, chega a pátios de uso comum, passa por baixo de algumas casas, ladeia outras, atravessa o espaço

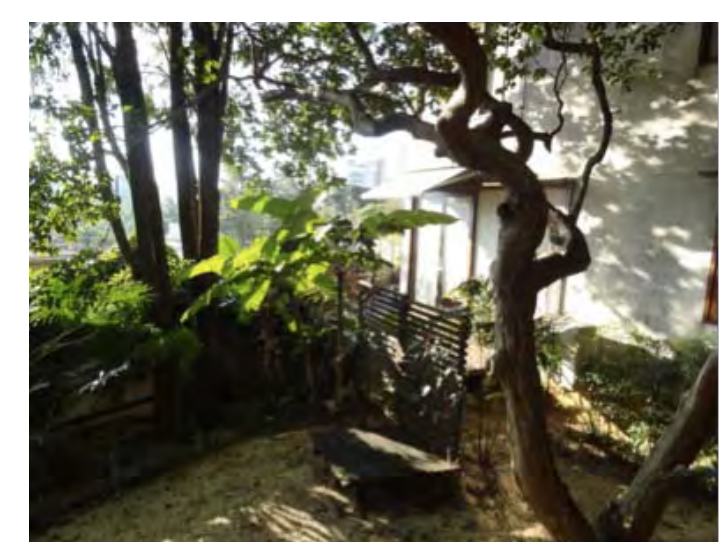

Figura 17 - Árvores existente no terreno foram mantidas.

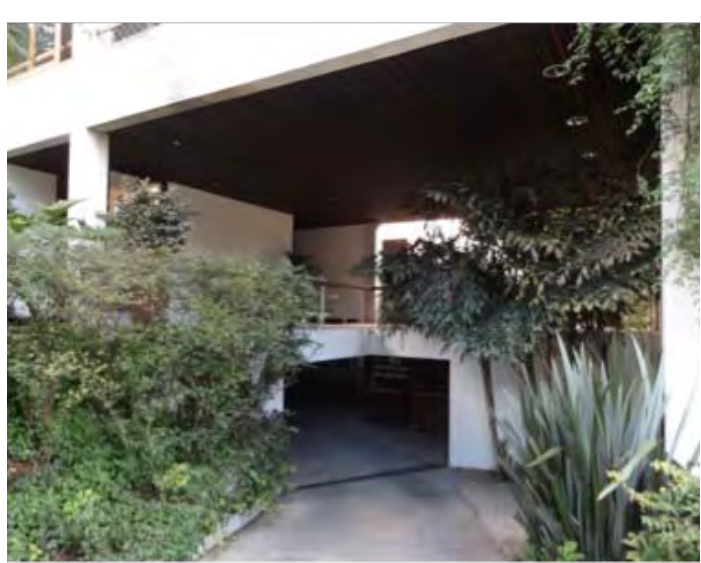

Figura 18 - Garagem abaixo do espaço de uso coletivo. 


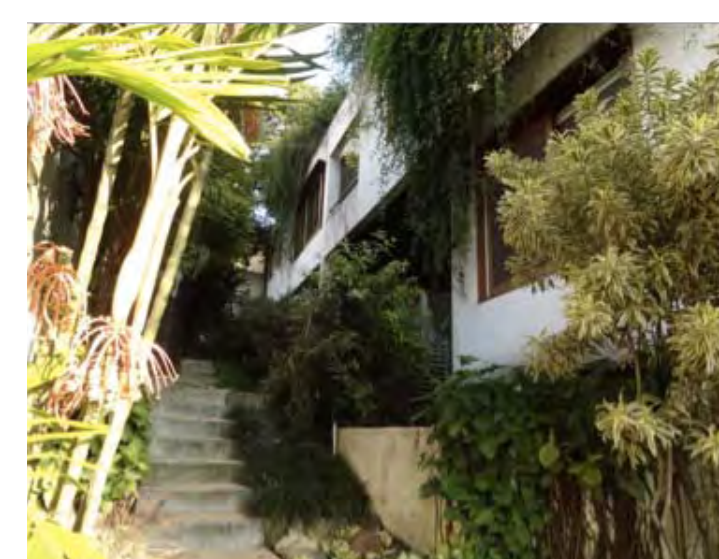

Figura 19 - 02 à direita e acima, casa 01. Uma única arquitetura, sem identificação dos limites.

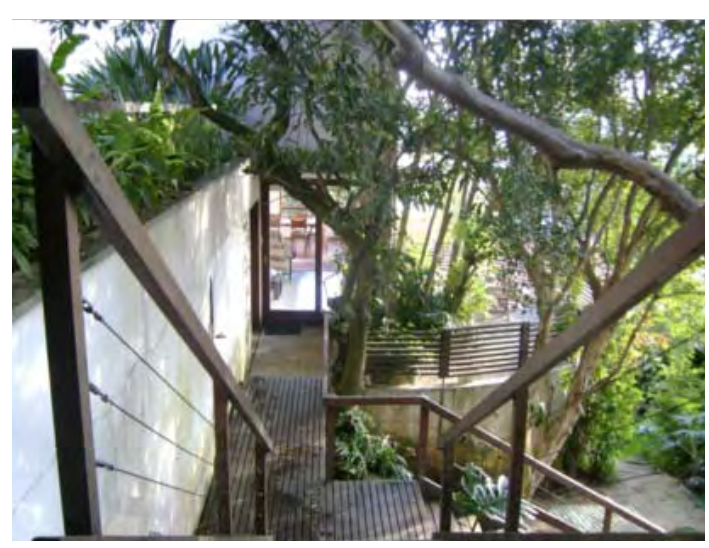

Figura 20 - Casa 04: espaço exterior coletivo x privativo. coberto e, por fim, termina em uma viela que dá acesso à Rua Fradique Coutinho. A arquiteta cogitou, inclusive, a possibilidade de que esta passagem fosse pública, por ligar uma rua à outra. Os acessos de carros e pedestres são bem definidos e distintos. Com relação à definição dos acessos para veículos, a garagem fica na cota inferior, eliminando viário que cruza todo o terreno, e cada vaga fica próxima à entrada da casa correspondente, assim, responde a uma necessidade que os clientes geralmente pedem, porém, sem comprometer as áreas para convívio coletivo ou percursos peatonais (Figura 18).

\subsubsection{ESPAÇOS EXTERIORES}

En la vivienda colectiva de hoy, la reflexión sobre el diseño de esos espacios intermédios como detonadores de la vida en comunidad se vuelve necesaria. Las circulaciones, los lugares de permanencia y acceso, los espacios de uso compartido, así como los que se dejan libres entre las construcciones, conforman el entorno inmediato de la comunidad. Por outro lado, el hecho de que una misma estructura contenga vários núcleos de viviendas demanda, necesariamente, el uso común de diferentes elementos, tales como fachadas, muros divisórios, forjados, estructura portante y conductos de instalaciones. Esos elementos definen las características de la vida en comunidad y generan condiciones de habitabilidad particulares a cada proyecto (BAHAMÓN e SANJINÉS, 2008, p. 45).

Foram definidos três tipos básicos e principais de espaços exteriores: de uso coletivo (tanto os pátios quanto os jardins não privados); espaços entre o coletivo e o privativo, que funcionam como filtros entre estes espaços e possuem localização estratégica para garantia de privacidade entre área privativa e área comum (Figura 21); e por último, os espaços exteriores próprios, como quintais ou terraços privativos. Os espaços exteriores, principalmente os coletivos, foram valorizados neste projeto, seja pela posição da garagem, como também pela diminuição de uma ou duas unidades a mais que o potencial do terreno possibilitaria. Porém, ao mesmo tempo em que não é utilizado todo o potencial construtivo, $1684,55 \mathrm{~m}^{2}$ do terreno são destinados aos espaços exteriores, 
como áreas verdes coletivas, espaços de uso coletivo, vestíbulo externo, e espaço exterior próprio, segundo legenda da ficha gráfica do projeto. Assim, somada a garagem, que não deixa de ser um espaço com possibilidade para realização de atividades coletivas, chega-se a um valor acima da área total do terreno, e não conta como área computável.Assim, houve a tática de "criar terreno", de erguer as casas e ao mesmo tempo aproveitar melhor o espaço criado para uma destinação coletiva.

Desde a rua, pública, até a entrada das unidades, existem espaços estrategicamente posicionados de tal forma a não causar distúrbios nas áreas privativas. Por exemplo, antes da porta de entrada das unidades, transparece uma área com sensação de privativa. Deste vestíbulo externo, parece que tudo que está à volta é privativo, também por não ser possível enxergar portas ou janelas das outras casas (Figura 22). Esta sensação interna de parecer que em determinados pontos exista apenas uma casa também é perceptível da rua: a sensação que dá é que existe apenas uma casa e não seis. Esta frase foi inclusive título de artigo escrito para a revista Casa e Construção: "Por fora parece uma casa, por dentro são seis".

Este cuidado em não deixar aberturas voltadas para os espaços comuns foi enfatizado pela arquiteta durante a visita, quando, inclusive, ela comentou sobre as aberturas zenitais dos banheiros (Figura 23), espaço muito íntimo para possuir aberturas voltadas aos espaços coletivos. Também comentou sobre a inexistência de condutores lançando água pluvial nos passeios coletivos. Para isso, foi criada uma captação interna da água da chuva que cai no terraço da cobertura (existem quatros shafts no perímetro da caixa de escada interna de cada unidade), novamente respeitando o bom convívio no espaço comum (Figura 24). Tais estratégias representam um papel pedagógico e regulador aos espaços de uso coletivo. Para identificar e definir estes diferentes setores, a arquiteta utilizou a tática de diferenciação a partir dos elementos construtivos: cercas de ripas para delimitar os jardins privativos; forros de madeira são utilizados nas áreas comuns e forros de gesso para espaços privativos com interferência no particular.

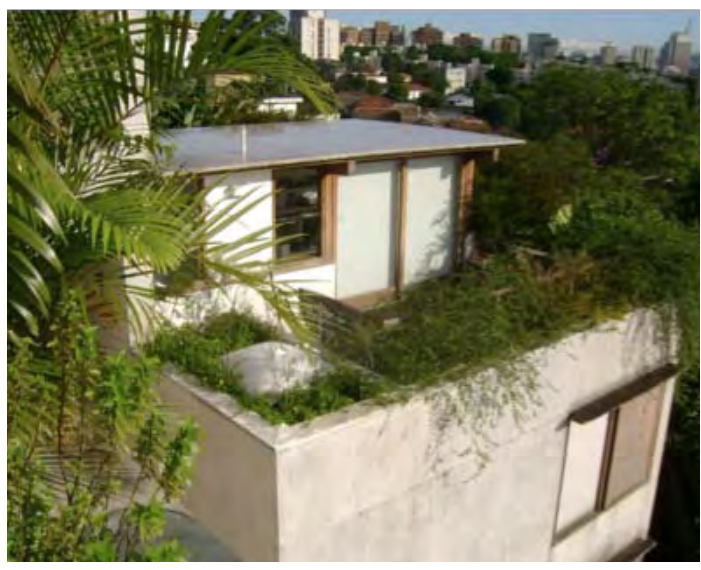

Figura 21 - Casas 06 e 04: exemplo de uma área privativa de interesse comum.

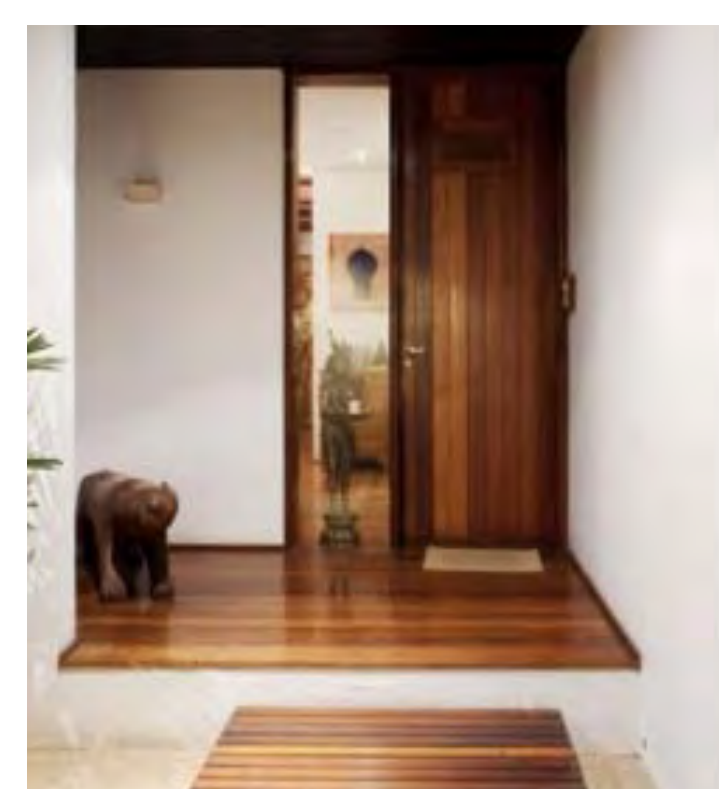

Figura 22 - Casa 02 vista do espaço de uso coletivo: vestíbulo externo, filtro entre as relações coletivas e privativas. 


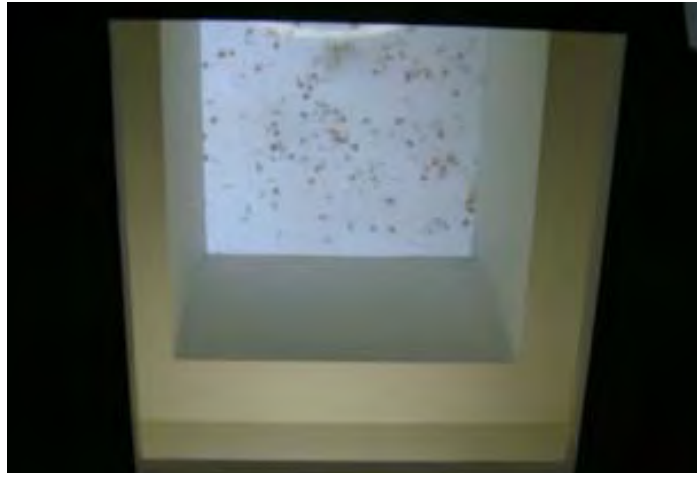

Figura 23 - Detalhe casa 04. lluminação zenital no banheiro.

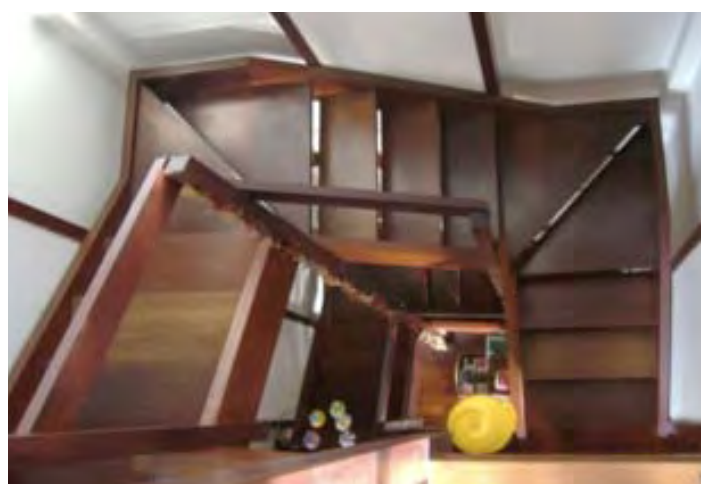

Figura 24 - Detalhe casa 04. Shafts para instalações no perímetro da caixa de escada.

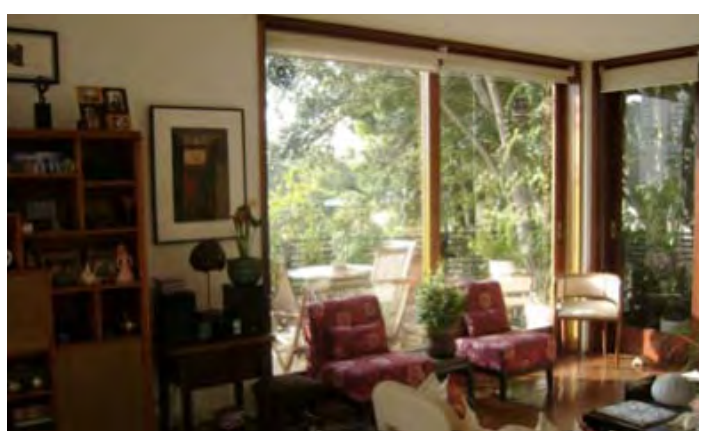

Figura 25 - Casa 04: área social.
Em outras palavras, está contida no projeto da Vila a intenção de subverter duas práticas consolidadas na nossa sociedade, quais sejam, por um lado, o reiterado individualismo no uso dos espaços privados, e por outro, o imobilismo melancólico dos arquitetos acostumados a lamentar o fato de que a atividade projetual esteja, via de regra, refém das exigências redutoras da especulação imobiliária (WISNIK, 2002).

\section{I.2.7 UNIDADE HABITACIONAL}

Algumas definições do projeto não poderiam ser mudadas durante o processo de vendas das unidades habitacionais: os acessos para veículos e pedestres; as áreas comuns; a garagem e a posição das vagas; 0 acesso às casas; o perímetro de cada unidade; enfim, questões relacionadas ao bom entendimento das orientações, topografia e principais vistas. Com relação ao espaço interior das unidades habitacionais, estava previamente definido no projeto: a posição da escada, que de certa forma centraliza também as instalações, já que possui shafts em seu perímetro com função de subida de água, descida de esgoto, descida de águas pluviais e também passagem das instalações elétricas. As áreas molhadas estavam pré-definidas, porém poderiam ser modificadas, desde que ficassem próximas da região da escada, por onde passam as instalações. Ainda com relação às unidades, estavam também determinados os níveis de laje e a área útil de cada pavimento.A estrutura, aberturas e acabamentos também eram elementos que o morador não poderia pedir modificações.

Assim, o atendimento personalizado ao morador, estaria limitado a algumas mudanças na distribuição programática interna, dentro do "casco" pré-determinado da unidade. A casa 0I, por exemplo, teve um banheiro extra, no nível da cobertura; na unidade 05 , havia três quartos no projeto original da incorporação, mas o morador optou por apenas uma suíte e uma grande sala com um estúdio. $\mathrm{Na}$ unidade $\mathrm{03}$, foi colocada a lavandeira no andar superior, junto aos dormitórios, pois no térreo a moradora fisioterapeuta trabalha com seções de RPG (Reeducação Postural Global), portanto gostaria de ter mais espaço no térreo para receber melhor os clientes. 
Situações como estas aconteceram em todas as unidades, praticamente um atendimento personalizado, da mesma maneira que acontece quando um arquiteto realiza um projeto de casa unifamiliar para um cliente, postas algumas limitações necessárias para a viabilidade do empreendimento, visto que já houve um trabalho bem intenso da equipe de arquitetura para atendimento destes desejos individuais. Da mesma maneira que ocorreu no Fidalga 897, durante o processo de vendas, a arquiteta fazia alguns estudos rápidos de layout, para o cliente conseguir visualizar as possibilidades espaciais antes de fechar o negócio. Estes croquis são elementos importantes de venda, para ver se cabe ou não cabe, se fica bom ou não. Mas é importante lembrar que as dimensões das unidades não foram definidas pelos moradores, e que a variação tipológica está relacionada primeiramente ao estudo da orientação, principais vistas, entre outras avaliações já mencionadas. A definição interna dos ambientes com os futuros moradores colaborou para deixar as unidades ainda mais diversificadas. Ao contrário, no projeto da Vila Butantã as unidades são iguais no projeto arquitetônico global, assim, não houve atendimento personalizado como na Vila Fidalga, o próprio arquiteto já definiu algumas variações possíveis na tipologia principal.

As unidades I, 4 e 6 da Vila Fidalga apresentam a mesma distribuição do programa nos pavimentos: no nível da garagem está o setor de serviço e social (Figuras 25 e 26), sendo que o último possui grande integração física e espacial entre o espaço interior e exterior, e está posicionado favoravelmente às principais vistas da cidade (Figuras 27 e 28).

O setor de serviço é amplo e bem completo, com direito a quintal e dependência para empregada,com exceção da unidade seis, em que prevalece um espaço social mais amplo. No pavimento intermediário está o setor íntimo e na cobertura existe um cômodo integrado ao terraço, que pode ser um escritório ou outro uso a gosto do morador.A unidade habitacional três possui um diferencial importante com relação às outras unidades: lavanderia no pavimento intermediário junto aos dormitórios, decorrente de uma particularidade do morador. Esta situação possui lógica se pensarmos no percurso da roupa dentro de casa: está mais relacionado com o banheiro e o quarto do que com a cozinha.

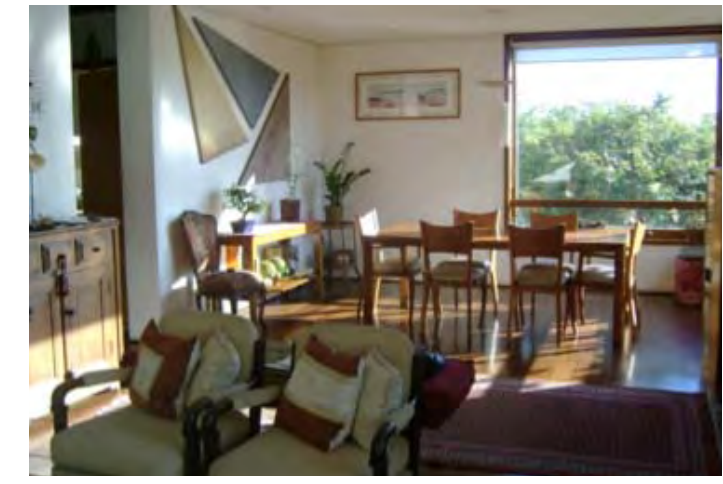

Figura 26 - Casa 04: área social.

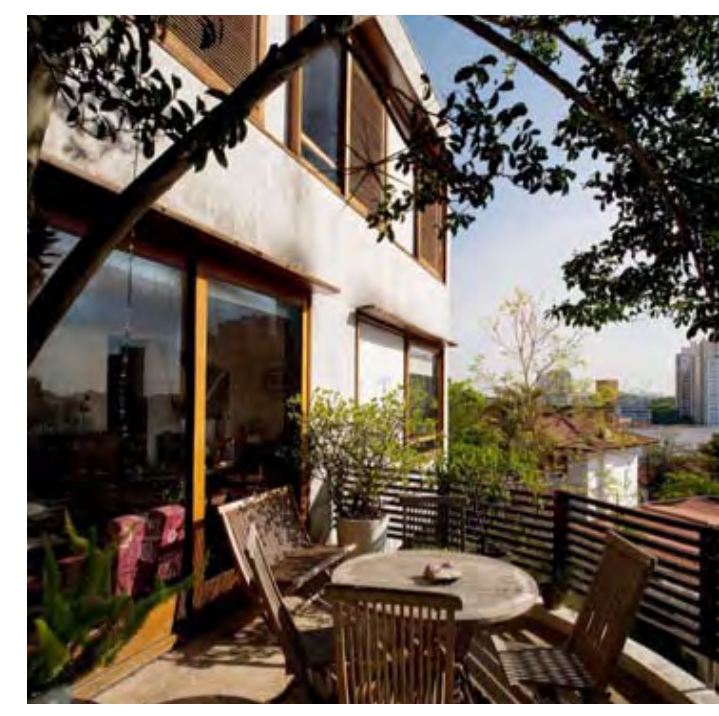

Figura 27 - Detalhe casa 04.Varanda, como extensão do interior, permite comunicação da unidade com o espaço que a rodeia. 


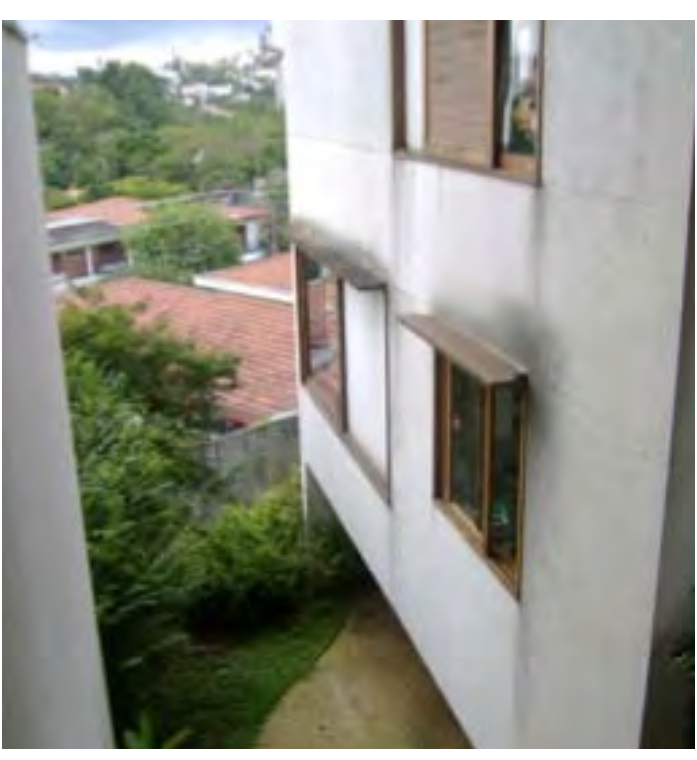

Figura 28 - Brechas com vista para a cidade entre as casas 04 e 06 , algumas supresas que a vila oferece.

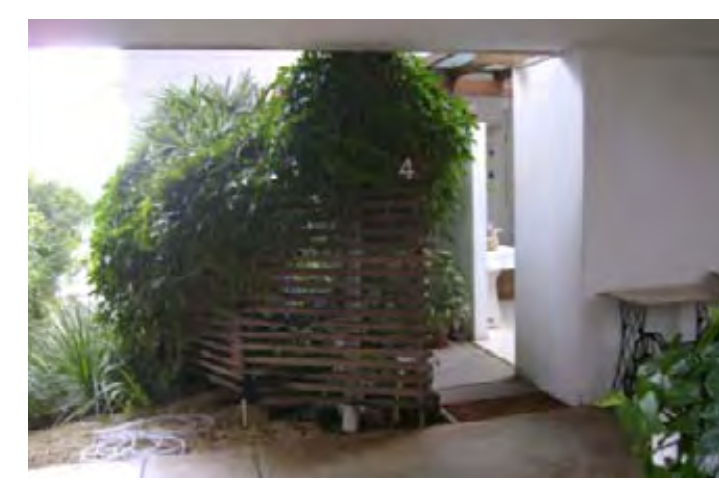

Figura 29 - Casa 04: acesso à área de serviço.
A ausência de dependência para empregada justifica a lavanderia próxima aos dormitórios, mostrando que os cuidados com a roupa provavelmente ficam a cargo dos moradores desta unidade. Essa situação diferencia totalmente essa unidade das outras, assim como o referido morador da mesma, comprovando que dificilmente será bem aceito um conjunto residencial com tipologias pouco flexíveis ou com mesma e rígida organização compartimentada e setorizada entre área social, área íntima e de serviços, já que as situações de cada família, grupo ou moradores nem sempre serão semelhantes. É favorável, portanto, diversidade de tipologias num mesmo conjunto habitacional, principalmente quando esta diversidade é decorrente da discussão do projeto entre usuário e arquiteto. Também, percebem-se situações que deixam transparecer o desejo da arquiteta em reduzir as áreas destinadas à moradia de empregada e espaços de serviços, além de incorporar estas áreas ao corpo da casa, ficando todo programa num volume único (Figuras 29 e 30). Estas situações sugerem à deshierarquização entre os frequentadores da moradia e evita a segregação social dentro do espaço doméstico.

Nos projetos da Vila Fidalga e Vila Taguaí da arquiteta Cristina Xavier, as áreas de serviço estão no corpo da casa, fato que para os dias atuais não representa grande avanço, afinal, a edícula de serviço, de origem rural, e que implica em segregação social, já foi combatida por arquitetos modernos paulistas há algum tempo, como por exemplo, Carlos Millan e João Villanova Artigas.

Marlene Milan Acayaba, em “Residências em São Paulo 1947-1975”, expõem projetos destes arquitetos que representam exceções frente às obras selecionadas por ela, já que, diferente da maioria dos projetos presentes no livro, que utilizam a edícula, como por exemplo: Residência da arquiteta Lina Bo Bardi (1949-195I), Projeto de Daniele Calabi para Tullio Ascarelli (1947-1948), ou dos Arquitetos Galiano Ciampaglia e Miguel Forte para Luís Forte (1952-1955); Carlos Millan e Villanova Artigas, em seus projetos, incorporavam a área de serviço à edificação principal, como acontece, por exemplo, na Residência Olga Baeta (1952) e residência Ivo Vitorito (1962-1964) de Carlos Cascaldi e João Vilanova Artigas; e Residência Roberto Millan (1960) (Figuras 31 e 32) e 
Residência Nadyr de Oliveira (1960) do arquiteto Carlos Millan.

Cristina Xavier, além de incorporar as áreas de serviço ao corpo da casa em seus projetos, não vê necessidade em esconder pátios de serviços, com roupas estendidas, à visão coletiva, como acontece, por exemplo, na casa 4 da Vila Fidalga (Figuras 29 e 30). Esta exposição da área de serviço desde o exterior também acontece na Vila Taguaí, porém, de maneira ainda mais radical, já que deixa de existir dependência para empregados e o acesso principal à unidade acontece justamente junto a esta face dita "de serviço". Esta resolução do projeto desmistifica a ideia de que roupa estendida deve ficar escondida, como se criasse uma aparência de cortiço ao local.

Postas todas estas situações diversificadas do projeto, o que diferencia uma casa de um apartamento é justamente a liberdade de decisão de algumas questões, principalmente, programáticas por parte dos moradores. Uma casa dentro de um condomínio se diferencia de uma casa numa rua qualquer, justamente pela padronização que a acompanha (Figura 33). Assim, o desejo pela casa em lote individual é frequente à medida que as pessoas querem participar de algumas decisões do projeto, e assim, atitudes como estas adotada na Vila Fidalga, que criam algumas possibilidade de participação do usuário nas definições do layout interno, ao menos abre o projeto à discussão e à possibilidade de atendimento a algumas particularidades dos moradores.

Com base em experiências profissionais e dados obtidos na Secretaria de Habitação do município de Diadema, o desejo pela casa, ou melhor, pelo lote individual, e desprezo pelo apartamento ou casas padronizadas por parte dos munícipes, se dá justamente pela liberdade que a primeira opção proporciona. A Secretaria de Habitação desta cidade, localizada no grande ABC paulista, está passando por uma fase de entrega dos últimos lotes individuais a moradores de favelas, já que os projetos atuais em andamento estão apostando na verticalização das soluções edilícias, até mais do que nas primeiras soluções de unidades sobrepostas, que não passavam de três pavimentos (por exemplo, o conjunto na Favela Naval, figura 34) já que é inviável atualmente diante do alto custo da terra e escassez de terrenos na cidade. Só para se ter uma noção, não existem edifícios de habitação

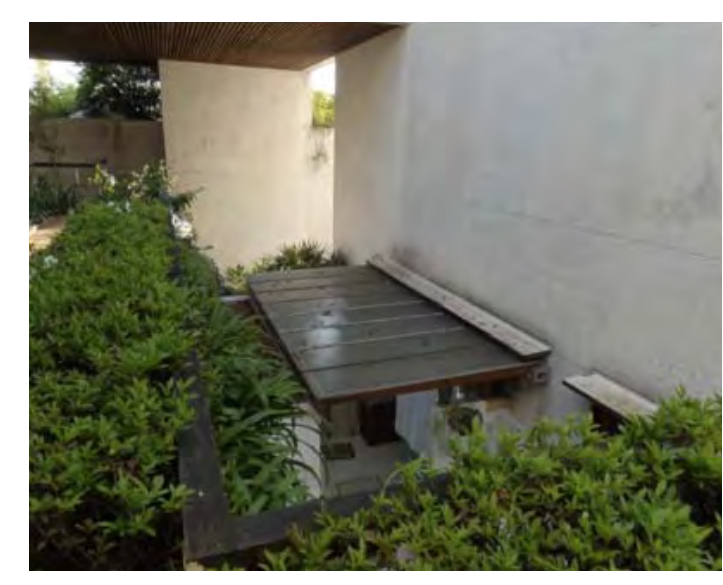

Figura 30 - Casa 04: vista da área de serviço.

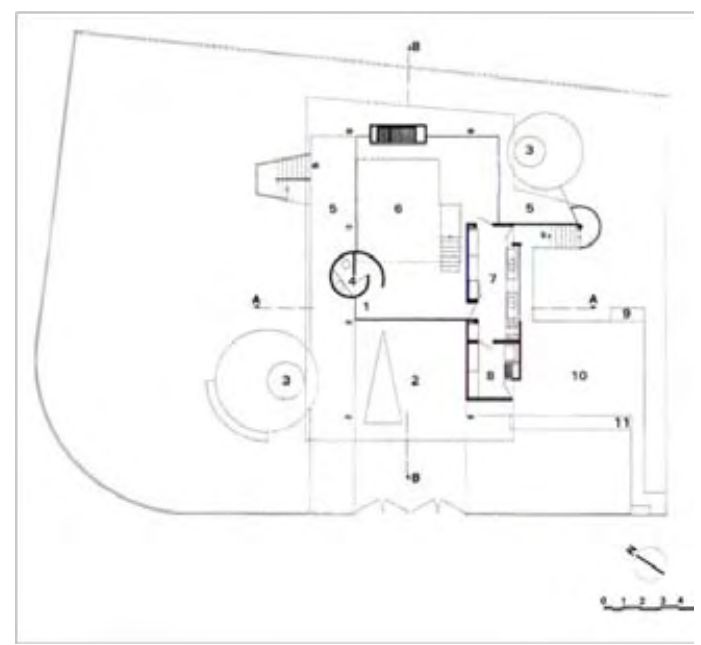

Figura 3 I - Planta térrea da Residência Roberto Millan, 1960, arquitetura Carlos Millan. 


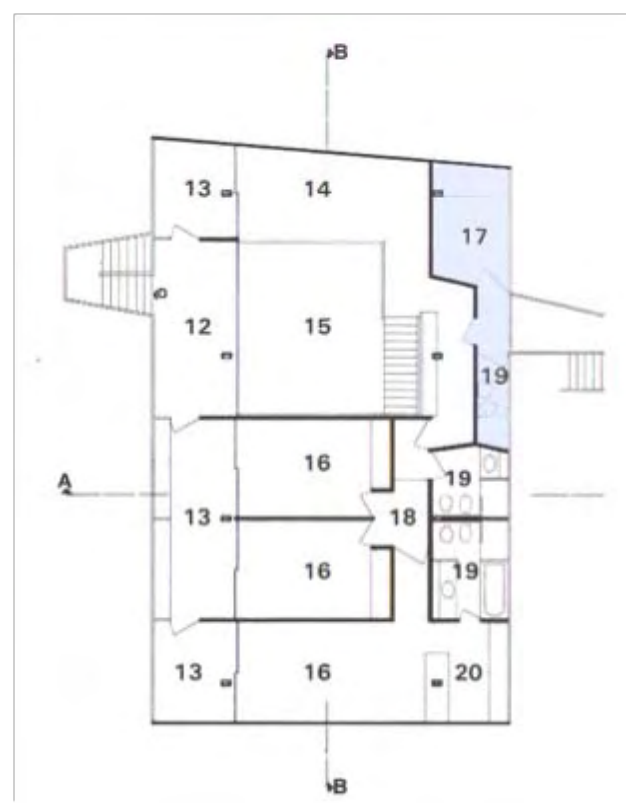

Figura 32 - Planta pavimento superior da Residência Roberto Millan, 1960, arquitetura Carlos Millan. Em destaque, dormitório da empregada.

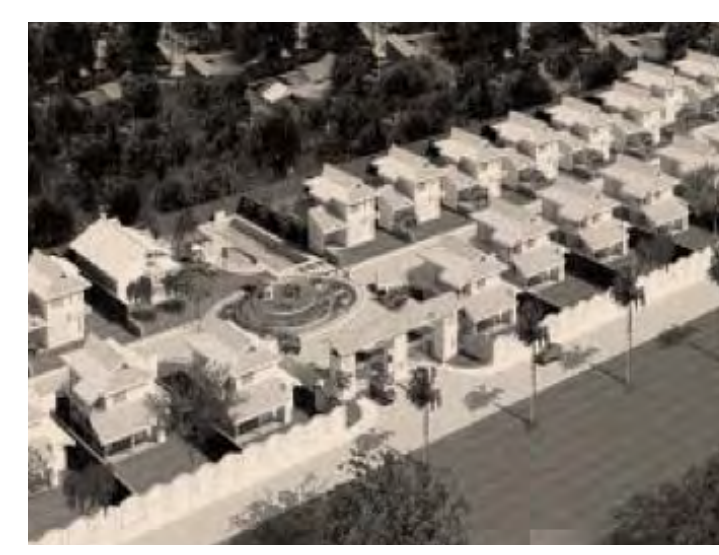

Figura 33 - Condomínio Bosque das Videiras, Aldeia Aldeota, Ceará. Casas padronizadas e espalhadas no terreno. de interesse social, promovidos por esta Prefeitura, com elevador, as primeiras propostas estão sendo discutidas recentemente.Assim, existe uma dificuldade no entendimento por parte dos moradores em ter que viver em apartamentos padronizados, afinal, foge da realidade que estão acostumados até o momento, de total liberdade de construção em seus lotes quase sempre individuais, mesmo em áreas irregulares de favelas (Figura 35).Assim, surge a pergunta: como conseguir encarar o problema do alto custo da terra e escassez de terrenos, e propor, ao mesmo tempo, soluções habitacionais em que o morador consiga ter suas necessidades e desejos individuais atendidos (sem excluir dos desejos individuais as questões relacionadas ao coletivo, que devem ser discutidas levando a opinião de todos os usuários envolvidos)? Este desejo pela liberdade ou personalização das habitações, obviamente, não fica restrito a uma classe social menos favorecida, parece ser uma vontade geral, proveniente do desejo de uma aproximação mais humana da vida e dos pequenos sonhos, e a Vila Fidalga consegue um resultado positivo neste sentido.

\subsubsection{SISTEMA ESTRUTURAL ETÉCNICA CONSTRUTIVA}

Todas as unidades seguem a mesma solução construtiva: estrutura de concreto, composta por pilares de $25 \times 25 \mathrm{~cm}$, vigas de $14 \times 100 \mathrm{~cm}$, lajes maciças de 10 a $12 \mathrm{~cm}$ e fechamento em alvenaria.As pequenas construções nos terraços foram concebidas com estrutura de madeira jatobá, com pilares de $12 \times 12 \mathrm{~cm}$, vigas de $12 \times 20 \mathrm{~cm}$, fechamento em concreto celular e cobertura com manta impermeável Alwitra sobre $\mathrm{MDF}^{4}$.

A Ita Construtora executou e colaborou no desenvolvimento de alguns detalhes em parceria com a arquiteta, como a estrutura de madeira dos ambientes das coberturas, as abas de madeira das janelas e também a placa de concreto que forma o piso elevado da cobertura (Figura 36),

${ }^{4}$ Medium-density fiberboard (MDF) ou placa de fibra de madeira de média densidade: material derivado da madeira e internacionalmente conhecido por MDF. 
detalhe que acontece da mesma maneira na Vila Butantã.

Alguns materiais construtivos principais de acabamento ou peças complementares são encontrados neste projeto: madeira jatobá (caixilhos, guarda-corpos, decks, forros, escadas e último andar das casas) e agregado mineral jateado branco (fulget) nas paredes externas. Internamente, as paredes receberam massa única com pintura látex branca e nas áreas molhadas laminado melamínico branco texturizado. Ainda na parte interna, os pisos são assoalho de madeira e nas áreas molhadas granilite.

A altura das vigas de concreto deve-se à necessidade de garantir a impermeabilização das lajes das coberturas, seja pela proteção térmica criada pelos pisos elevados de placas de concreto e jardins, seja pela existência de I a 3 pontos de coleta de água com grande caimento, ou ainda pela inexistência de instalações embutidas na laje. Novamente, não existem tubulações de águas pluviais voltadas para as paredes das áreas comuns, assim, o telhado conduz as águas para pontos de coleta nos shafts, presentes no perímetro da escada, mais uma estratégia de preservação e resguardo do espaço coletivo em relação ao atendimento de necessidades privativas, como já foi abordado. As instalações hidráulicas e elétricas são posicionadas de forma horizontal entre a laje e forro de gesso nas unidades, e forro de madeira nas áreas comuns, de forma vertical nos shafts ao longo das escadas internas, facilmente acessíveis.

Assim, com relação ao sistema construtivo como um todo, é possível notar principalmente que, mesmo se tratando de uma técnica construtiva convencional, os elementos em madeira diferenciam o comum de maneira muito coerente, fazendo seu uso nos locais ou em detalhes onde é possível fazer uma estrutura mais leve, como balcões, ambientes no terraço, escadas, passarelas, etc., contribuindo para uma execução mais limpa e rápida. Outro ponto é com relação à posição das instalações, de fácil acesso e não prejudicial ao convívio nos espaços coletivos, o que vai de encontro à proposta da arquiteta em buscar um resultado final com garantia de bem estar individual e coletivo.

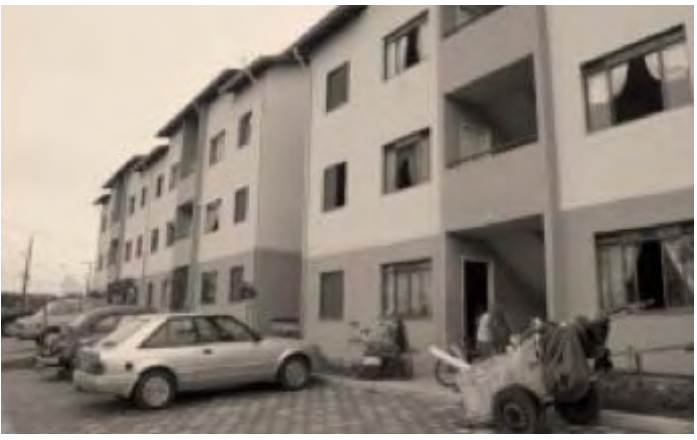

Figura 34 - Conjunto Habitacional Nova Naval, Diadema, São Paulo. Foi concebido em três pavimentos, para não existir um choque cultural muito grande - pois antes essa famílias viviam em favelas -, porém, em limites individuais.

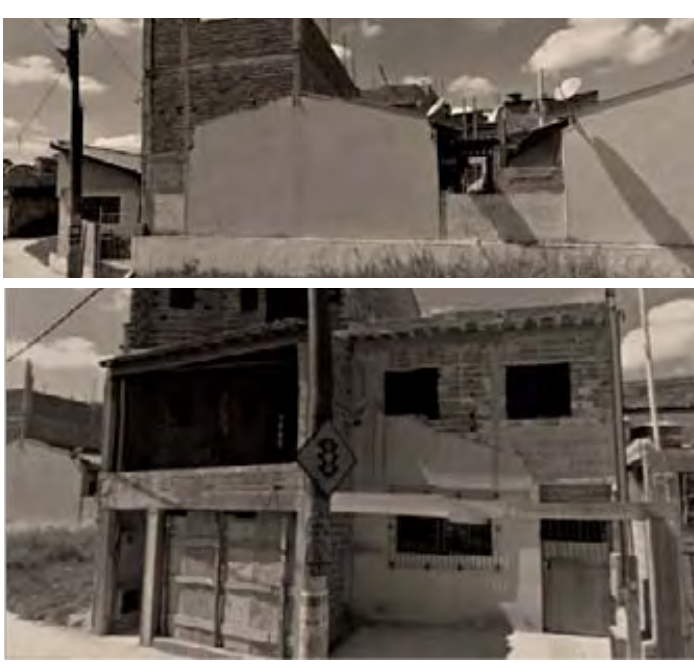

Figura 35 - Casas no Vera Cruz, Av. Dr. Ulisses Guimarães, Diadema, São Paulo. A prefeitura entregou uma casa térrea, de aproximadamente $30 \mathrm{~m}^{2}$, e quase que imediatamente a população a transformou de acordo com suas vontades. 


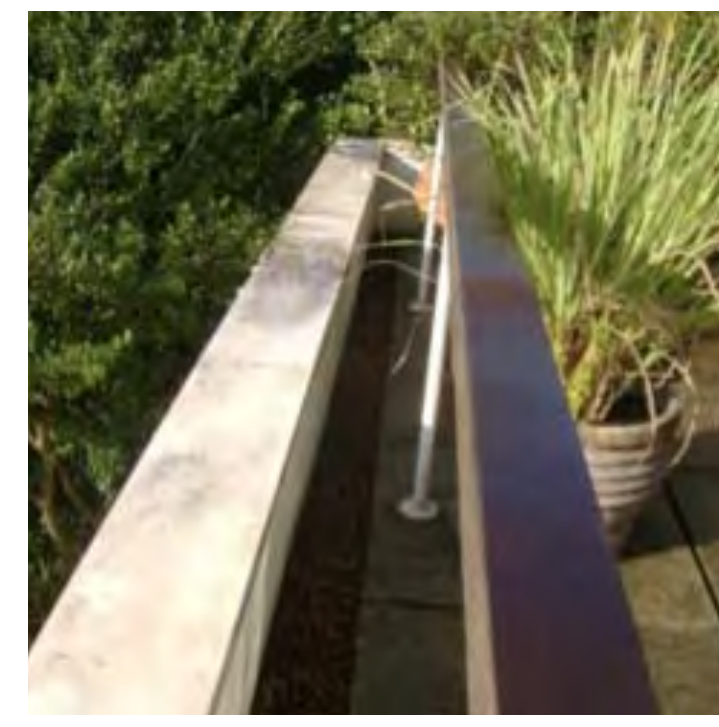

Figura 36 - Detalhe do guarda-corpo no terraço: sem furações na estrutura, evitando infiltrações pela laje.

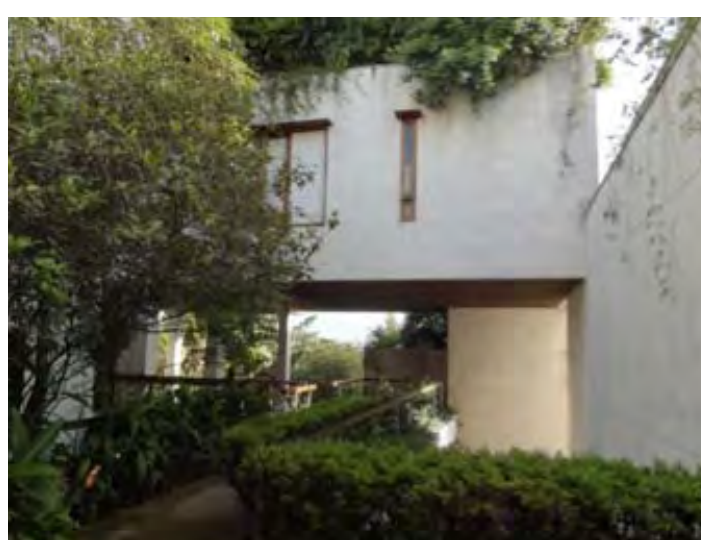

Figura 37 - Casa 05 sobre espaço de uso coletivo e tangenciando casa 04 .
No caso, a severidade formal é dada pela economia dos meios: uma combinação de poucos materiais, em que predomina a madeira (para os caixilhos, guarda-corpos e outros elementos), reforçada pela continuidade dos acabamentos e uma volumetria rigorosa. Composto de um agregado mineral jateado, o revestimento externo das unidades coincide com a superfície utilizada no piso, alterando-se apenas a sua tonalidade. Desse modo, o próprio material contribui para definir, com sua aspereza pregnante, o caráter indubitavelmente público do espaço, refratário aos constantes empréstimos entre público e privado simbolizados, por exemplo, na conotação fria mas doméstica dos usuais pisos cerâmicos (WISNIK, 2002).

\section{I.2.9 ENVOLTÓRIA}

Neste projeto, diferente do Fidalga 772 do Andrade Morettin, a envoltória não se desliga da estrutura, afinal, ela é fundida ao fechamento e praticamente toda revestida por processos de “masseamento". Ainda assim, existem algumas qualidades, na envoltória, capazes de agregar comunicação das unidades habitacionais com os espaços ao redor. As grandes aberturas no setor social, em conjunto com os balcões ou varandas externas, fazem com que a vista da cidade se misture ao espaço interior (figura 27). No setor íntimo, o caixilho corre externamente à envoltória, permitindo $100 \%$ de ventilação, iluminação e visibilidade pelo vão. As janelas do setor de serviço, com exceção da cozinha, acabam se voltando para o espaço exterior próprio e, portanto, não são vistas desde o exterior coletivo, esta situação conjuntamente com a dos banheiros do setor íntimo, que possuem iluminação zenital, contribui ainda mais para a falta de clareza da divulgação do uso interno desde o exterior. Da mesma maneira que fica difícil identificar se são várias casas ou unidades sobrepostas, também fica difícil identificar os usos a partir das aberturas (figura 37). Também percebe-se que o contato com o exterior é bloqueado propositalmente por algumas faces cegas das unidades para resguardar a privacidade de determinados usos privativos em relação aos espaços de uso coletivo. 
Elementos arquitectónicos como ventanas, persianas y balcones, así como otros acabados, permiten esa conexión particular entre lo público y lo privado, y se convierten, a la vez, en elementos compositivos que transmiten una imagen distintiva del proyecto. Su naturaleza envolvente no se limita entonces a ser solo um plano de limite, sino que puede llegar a ser el medio de comunicación del edifício com los espacios que ló rodean (BAHAMÓN e SANJINÉS, 2008, p. I34).

Assim, a envoltória é o limite entre o público e o privado, como meio de comunicação do edifício com os espaços que o rodeiam, para o caso desta vila, mais significativo com os jardins coletivos e a própria vista à distância para a cidade, do que o contato próximo com a rua, já que as casas são mais relacionadas com o espaço coletivo criado dentro do limite do condomínio. $O$ tratamento da envoltória com relação aos espaços coletivos foi pensado no sentido de estes serem conectados ou desconectados em colaboração com o bem estar e coletivo, uma das grandes qualidade deste projeto. 


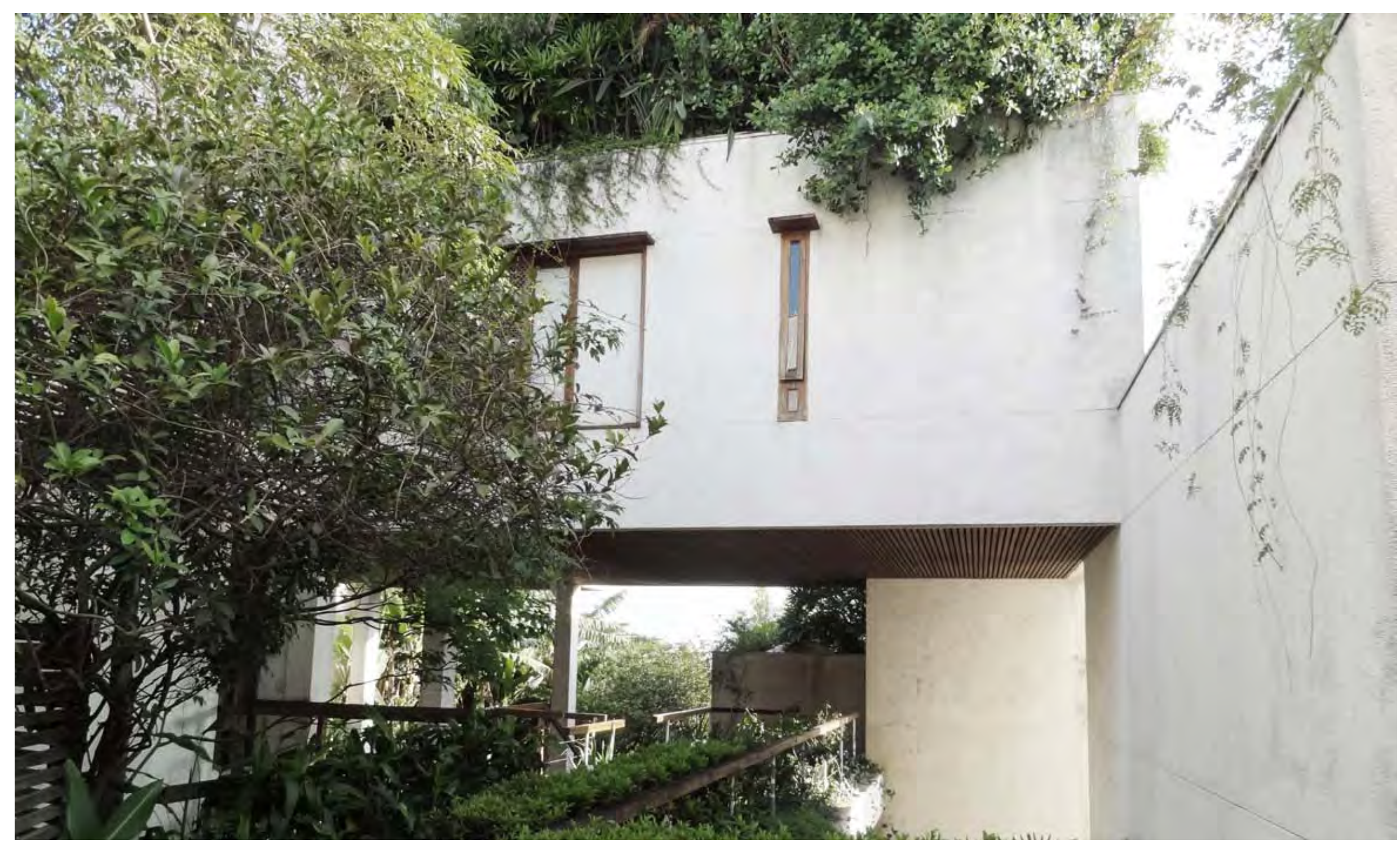

3.1.2.10 FICHAS GRÁFICAS EM ESCALA 


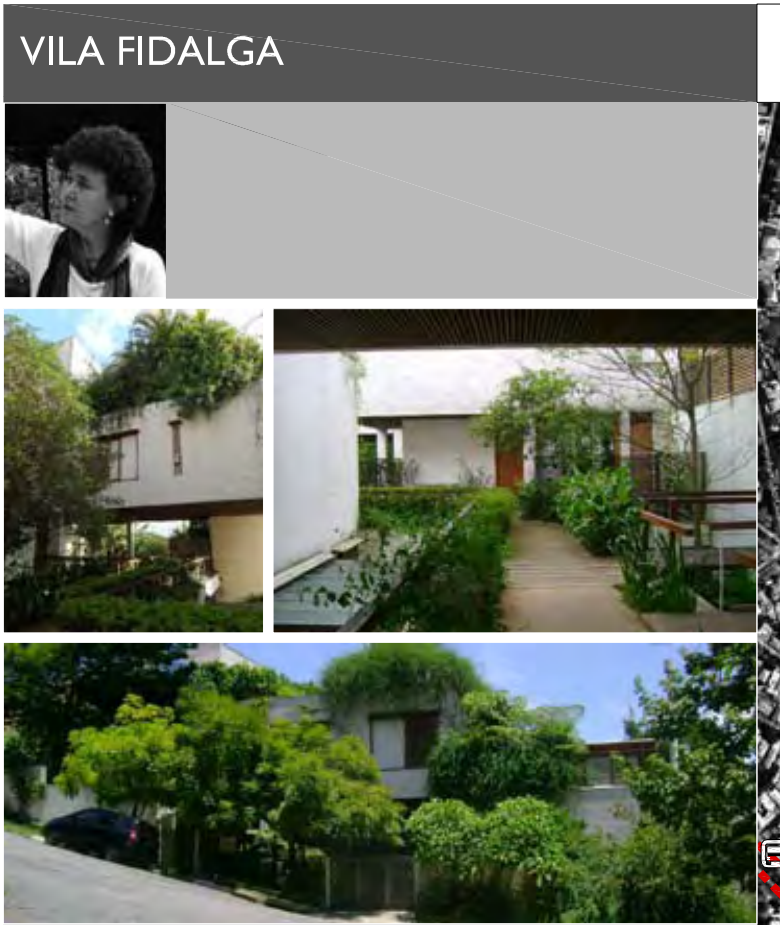

ARQUITETA

Cristina Xavier

INSERÇÃO URBANA

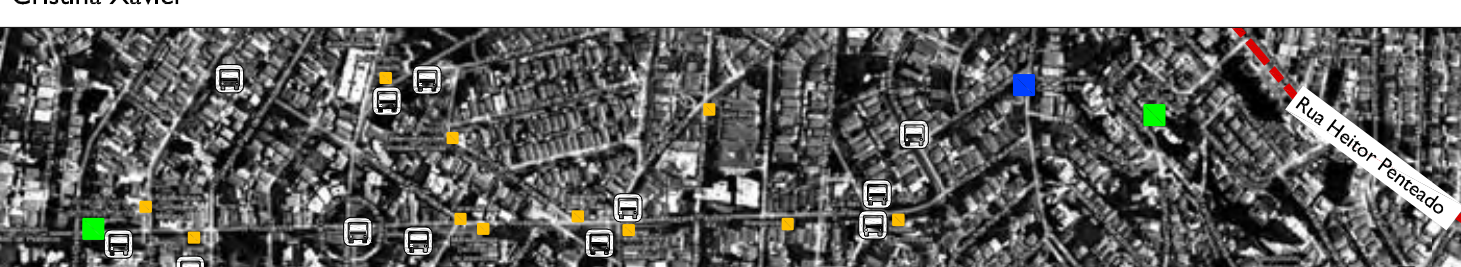

(iv) H.

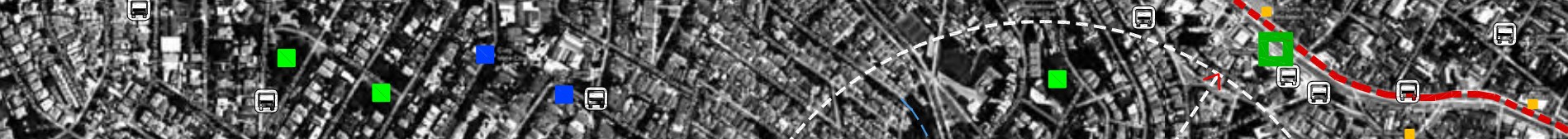

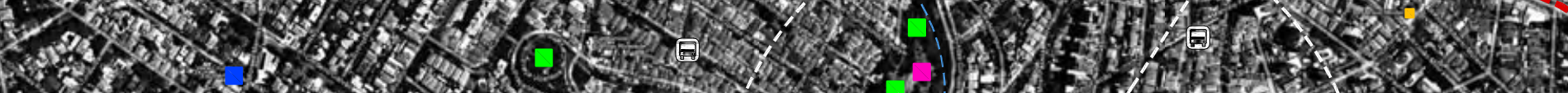
3. 1.

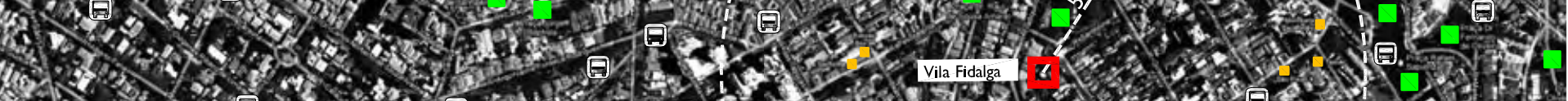
(3)

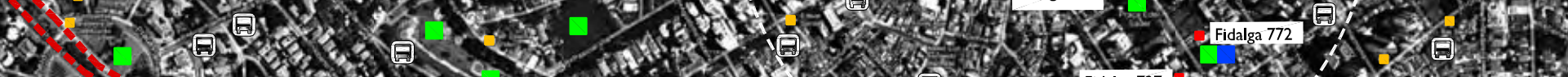

EQUIPE:

ARQUITETURA: Cristina Xavier (autora) João Batista Xavier (colaboração) e Lúcia Hashizume e Patryck Carvalho (colaboração)

CONSTRUÇÃO: ITA Construtora

INCORPORAÇÃO: Taguaí Arquitetura e Incorporação Cristina Xavier, Filipe Xavier, Francisco Limongi e Sônia Mindlin.

ESTRUTURA CONCRETO: Vicente de Stefano ESTRUTURA MADEIRA: Hélio Olga Jr. PAISAGISMO: Maria Cecilia Souza PROJETO e CONSTRUÇÃO: 1999 - 2001

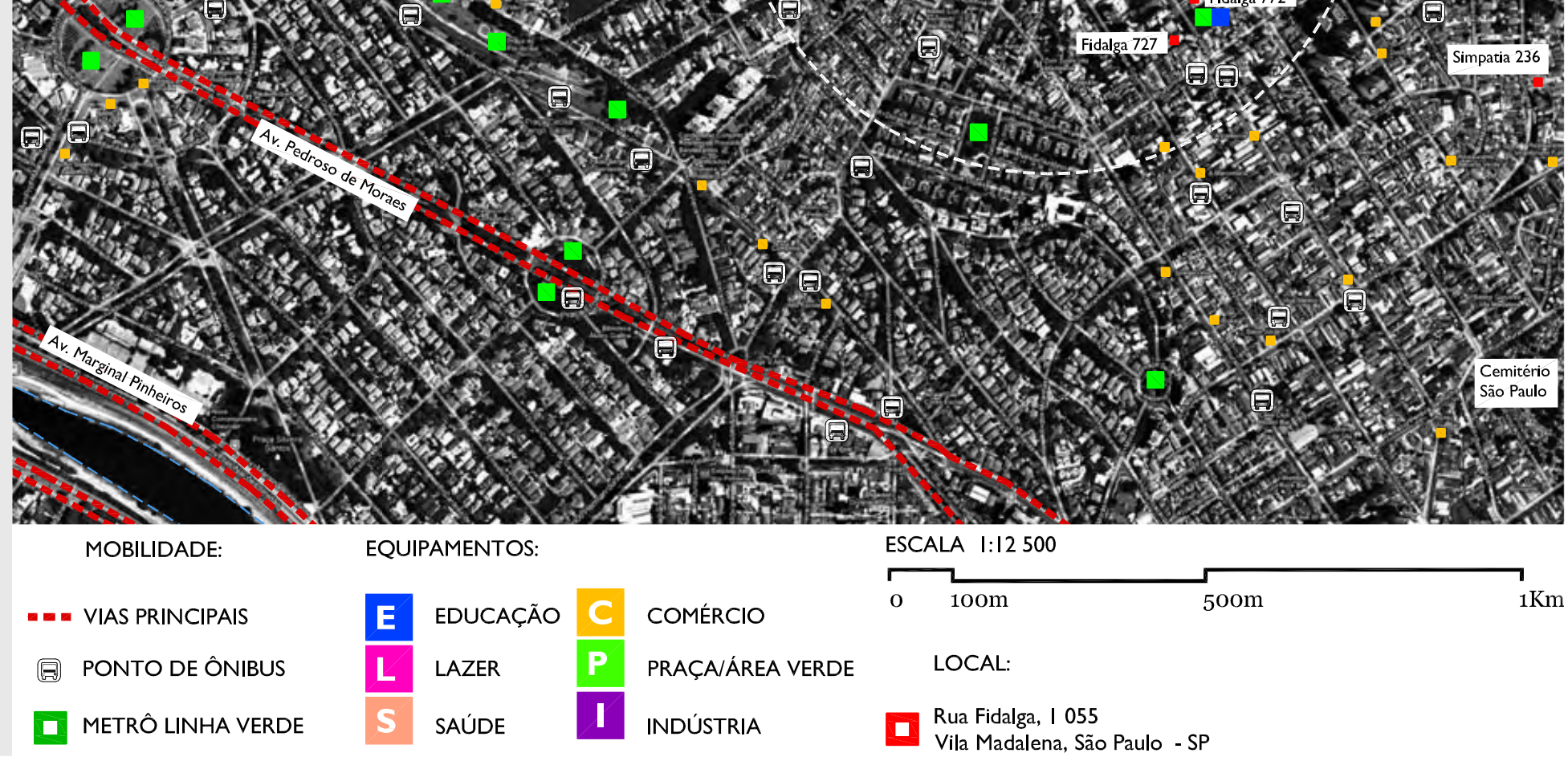



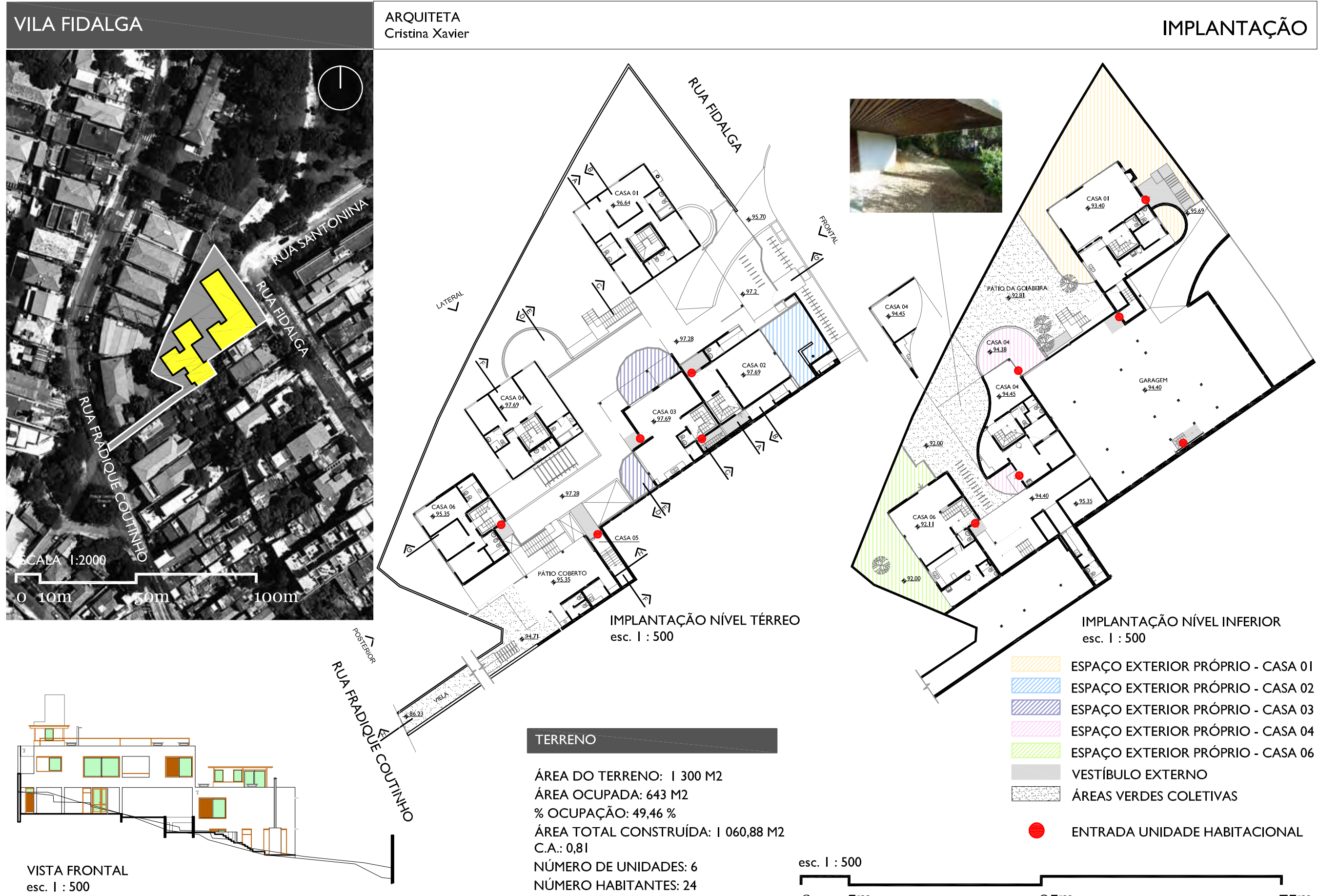

\section{TERRENO}

ÁREA DO TERRENO: I 300 M2

ÁREA OCUPADA: $643 \mathrm{M} 2$

\% OCUPAÇÃO: $49,46 \%$

ÁREA TOTAL CONSTRUÍDA: I 060,88 M2 C.A.: 0,8।

NÚMERO DE UNIDADES: 6

NÚMERO HABITANTES: 24

DENSIDADE: 184,6 | HAB/HA esc. I: 500
PAÇO EXTERIOR PRÓPRIO - CASAOI ESPAÇO EXTERIOR PRÓPRIO - CASA 02 ESPAÇO EXTERIOR PRÓPRIO - CASA 03 ESPAÇO EXTERIOR PRÓPRIO - CASA 04 ESPAÇO EXTERIOR PRÓPRIO - CASA 06 VESTÍBULO EXTERNO

ÁREAS VERDES COLETIVAS

entrada unIDADE habITACIONAL

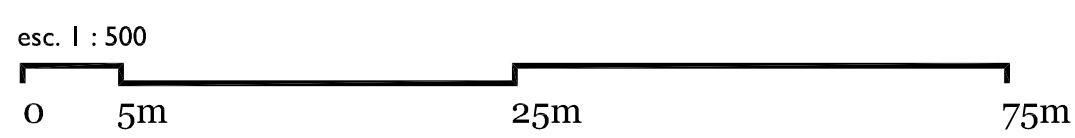




\section{VILA FIDALGA}

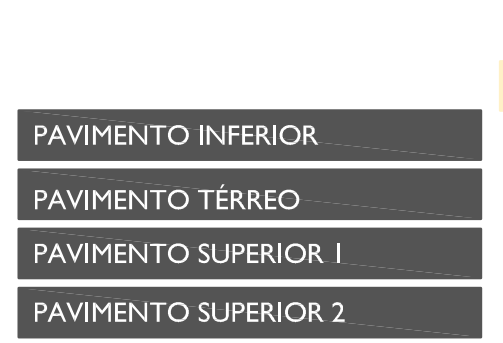

$x 1$
CASA 01
$101,33 \mathrm{~m}^{2}$
$90,00 \mathrm{~m}^{2}$
$14,72 \mathrm{~m}^{2}$

computável $\quad 206,05 \mathrm{~m}^{2}$

não computável $\quad 169,07 \mathrm{~m}^{2}$

total $375,12 \mathrm{~m}^{2}$
$X 1$

$X 1$
CASA 02

$54,91 \mathrm{~m}^{2}$

$140,00 \mathrm{~m}^{2}$

$10,40 \mathrm{~m}^{2}$

$205,31 \mathrm{~m}^{2}$

$140,38 \mathrm{~m}^{2}$

$345,69 \mathrm{~m}^{2}$

$80.09 \mathrm{~m}^{2}$

$237,52 \mathrm{~m}^{2}$

$68,53 \mathrm{~m}^{2}$

CASA 04

X I CASA 05

X I

CASA 06

$84,50 \mathrm{~m}^{2}$

$75,83 \mathrm{~m}^{2}$

$57,75 \mathrm{~m}^{2}$

$10,40 \mathrm{~m}^{2}$

$11,40 \mathrm{~m}^{2}$

$39,47 \mathrm{~m}^{2} \quad 152,65 \mathrm{~m}^{2}$

$\begin{array}{lll}60,40 \mathrm{~m}^{2} & 38,94 \mathrm{~m}^{2} & 84,44 \mathrm{~m}^{2}\end{array}$

$253,70 \mathrm{~m}^{2} \quad 178,4 \mid \mathrm{m}^{2} \quad 237,09 \mathrm{~m}^{2}$
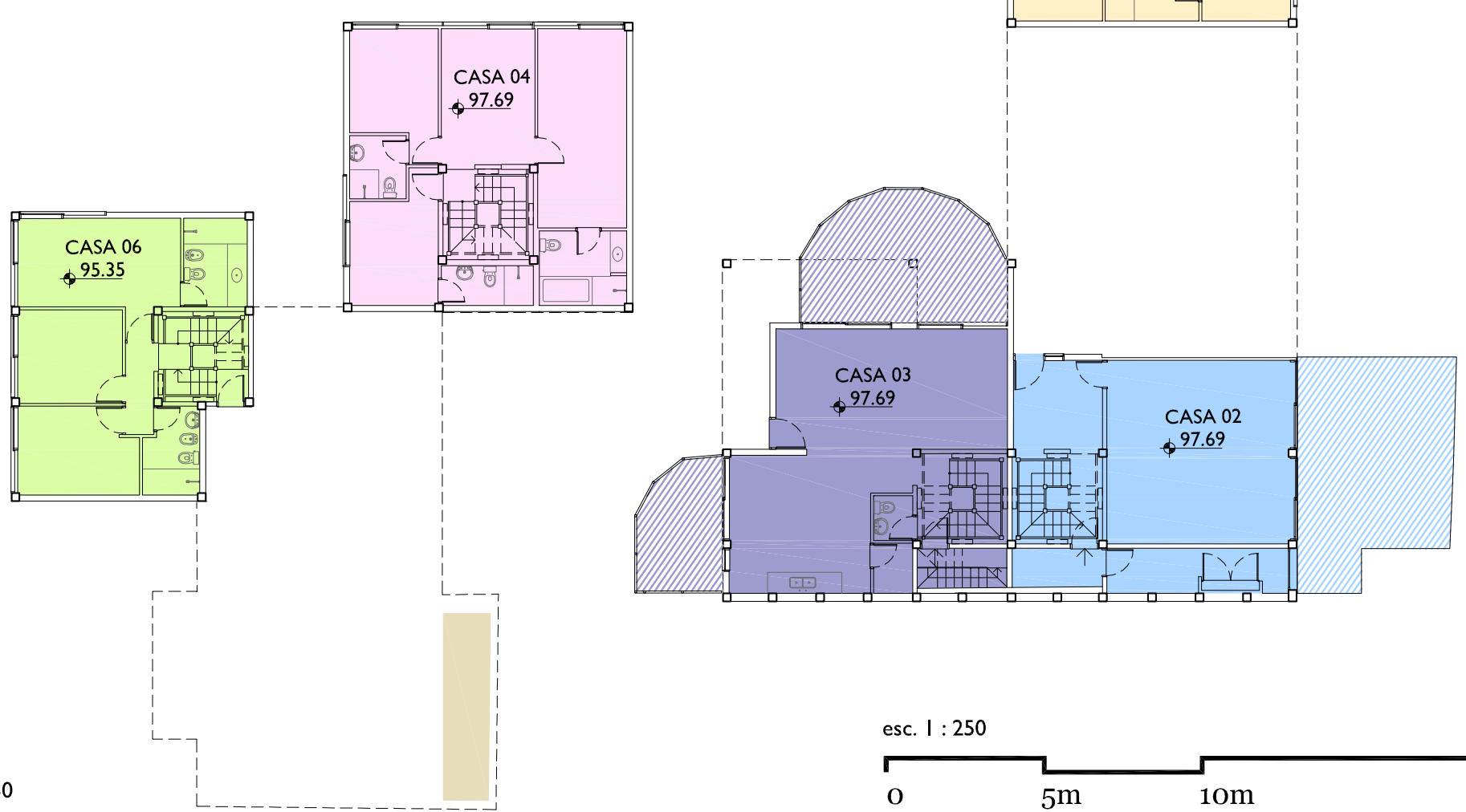

esc. $1: 250$
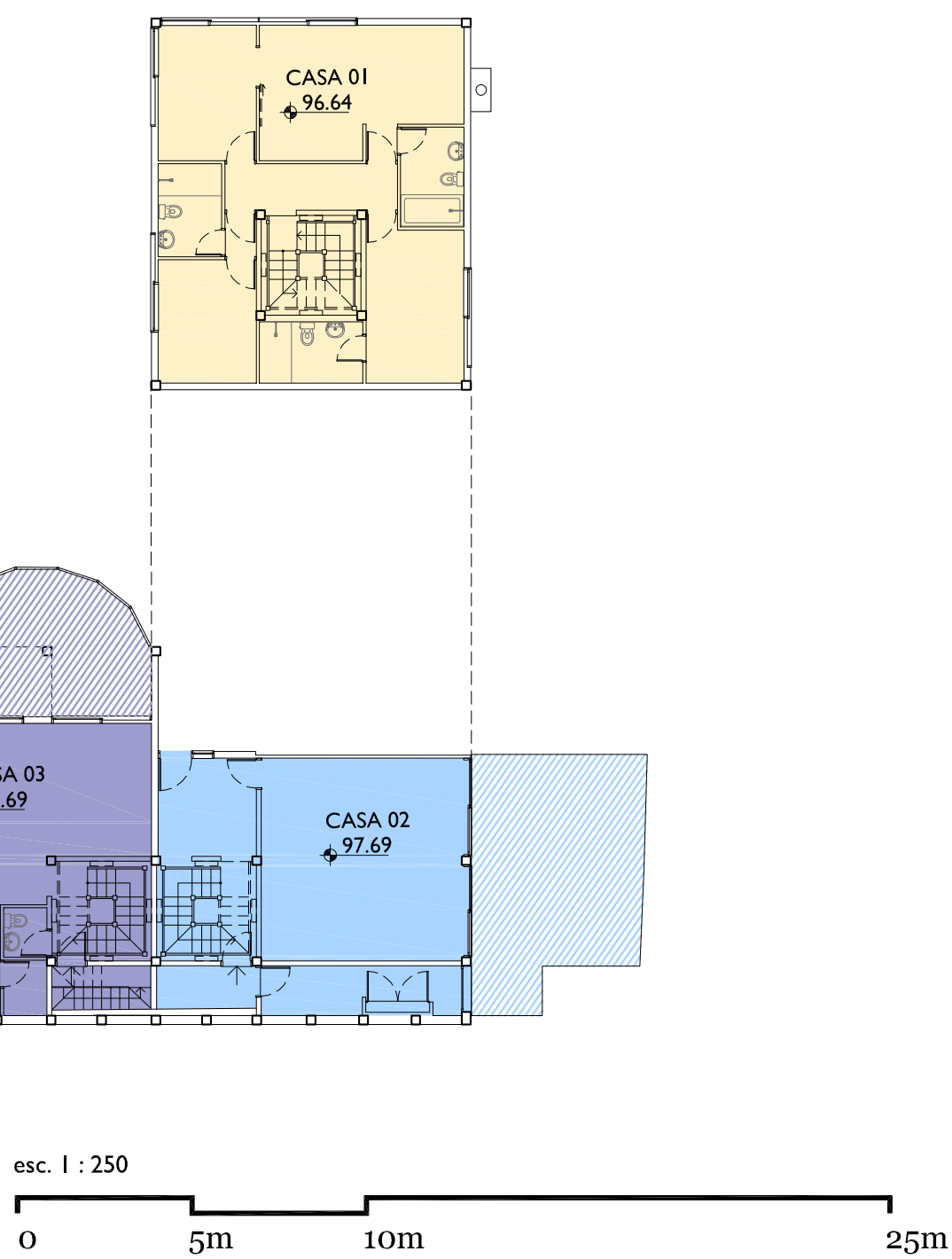


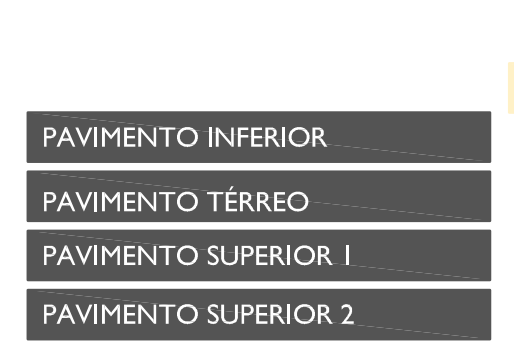

X I CASA OI

$X 1$ CASA 02

X I $101,33 \mathrm{~m}^{2}$ $90,00 \mathrm{~m}^{2}$

$54,91 \mathrm{~m}^{2}$ CASA 03

X I CASA 04 102,75 $\mathrm{m}^{2}$

X I CASA 05

X CASA 06 $84,50 \mathrm{~m}^{2}$ $57,75 \mathrm{~m}^{2}$

$68,53 \mathrm{~m}^{2}$ $75,83 \mathrm{~m}^{2}$ $14,72 \mathrm{~m}^{2}$

$28,07 \mathrm{~m}^{2}$

$10,40 \mathrm{~m}^{2}$

$10,40 \mathrm{~m}^{2} \quad 10,40 \mathrm{~m}^{2}$

$157,43 \mathrm{~m}^{2}$

$193,30 \mathrm{~m}^{2}$

1।, $40 \mathrm{~m}^{2}$

não computável $\quad 169,07 \mathrm{~m}^{2}$

$140,38 \mathrm{~m}^{2}$

$345,69 \mathrm{~m}^{2}$

$80.09 \mathrm{~m}^{2}$

$60,40 \mathrm{~m}^{2}$

$253,70 \mathrm{~m}^{2}$

$38,94 \mathrm{~m}^{2}$

$|78,4| \mathrm{m}^{2}$

total

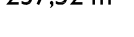

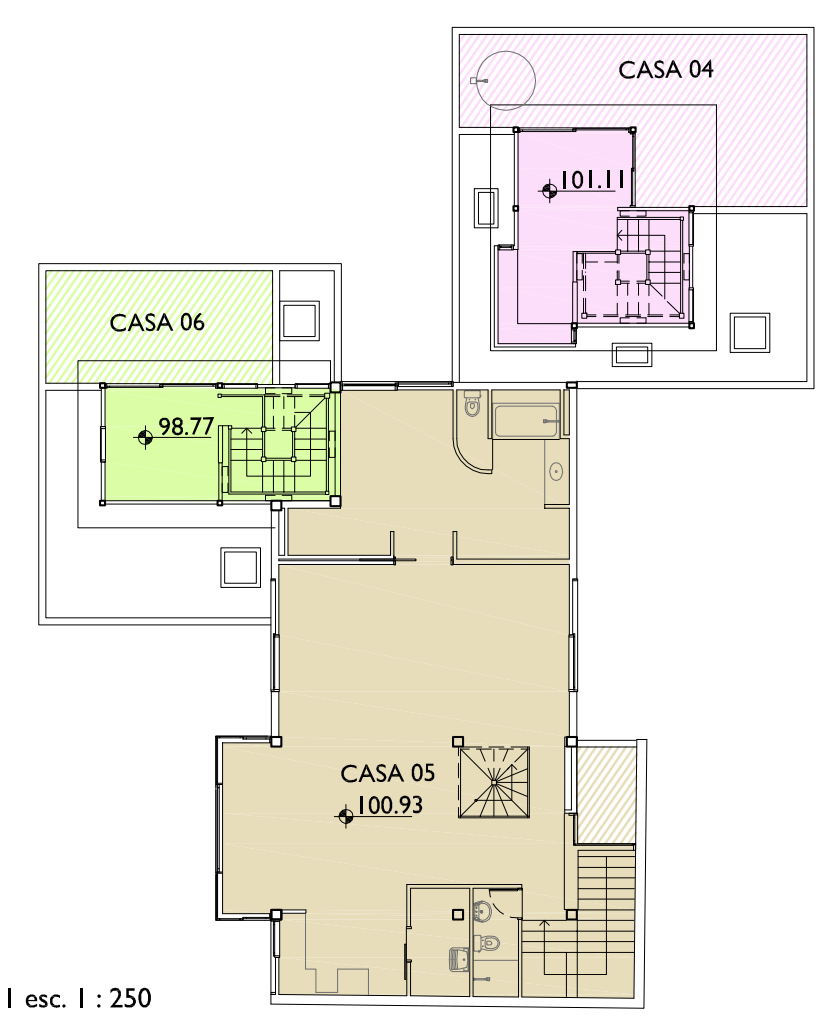

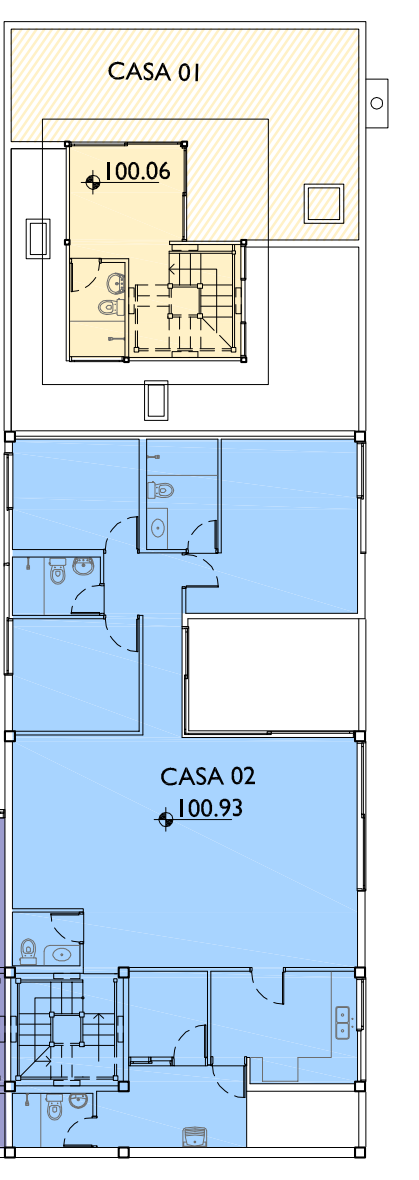

esc. $1: 250$

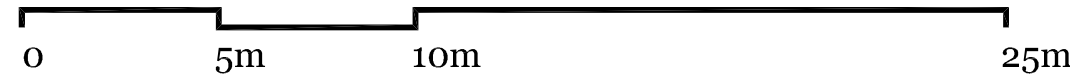




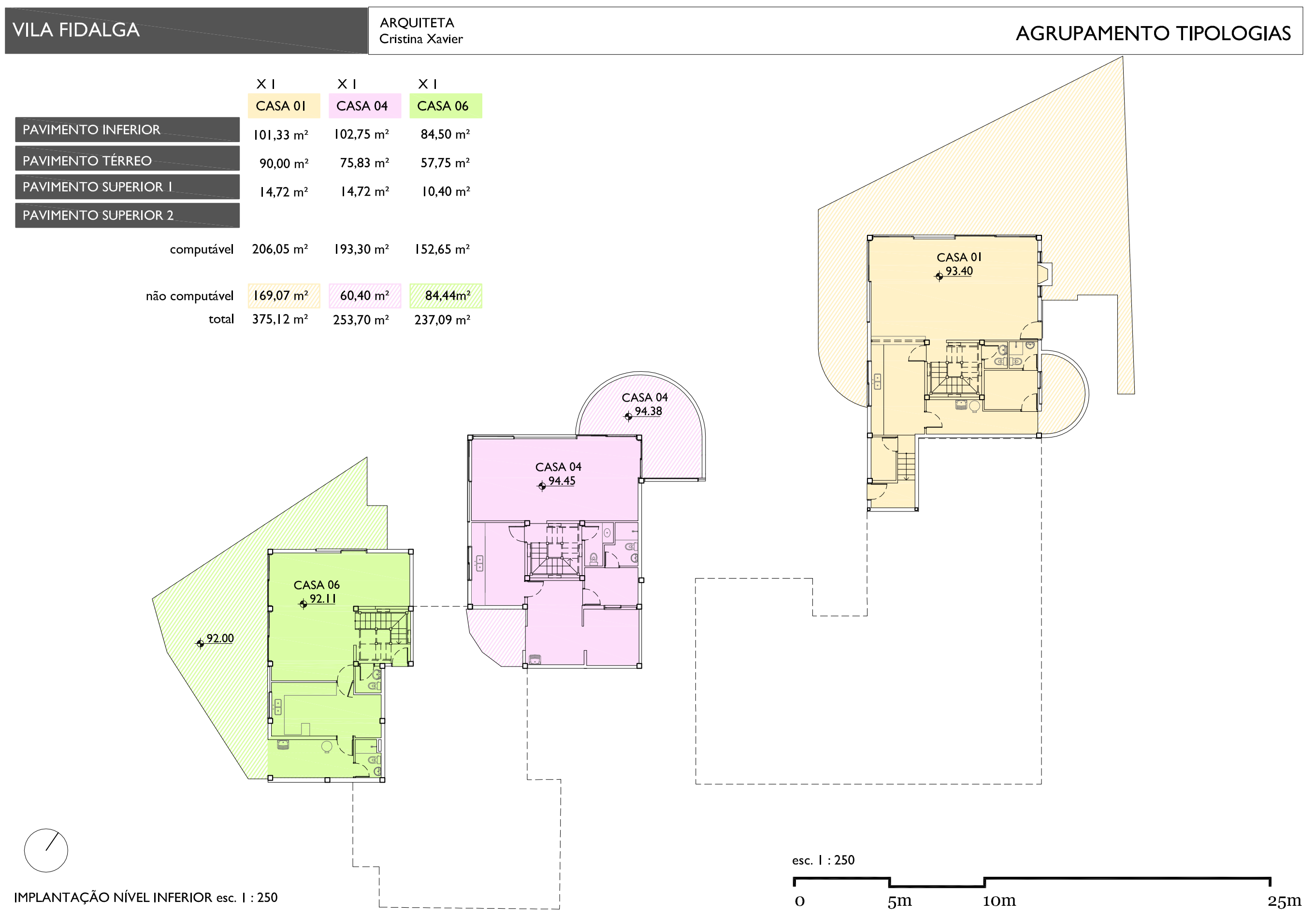




\begin{tabular}{|c|c|c|c|}
\hline & $\times 1$ & $\times 1$ & $\times 1$ \\
\hline & CASA 02 & CASA 03 & CASA 05 \\
\hline \multicolumn{4}{|l|}{ PAVIMENTO INFERIOR } \\
\hline PAVIMENTO TÉRREO & $54,91 \mathrm{~m}^{2}$ & $68,53 \mathrm{~m}^{2}$ & \\
\hline PAVIMENTO SUPERIOR I & $140,00 \mathrm{~m}^{2}$ & $78,50 \mathrm{~m}^{2}$ & $128,07 \mathrm{~m}^{2}$ \\
\hline PAVIMENTO SUPERIOR 2 & $10,40 \mathrm{~m}^{2}$ & $10,40 \mathrm{~m}^{2}$ & II,40 $\mathrm{m}^{2}$ \\
\hline computável & $205,31 \mathrm{~m}^{2}$ & $157,43 \mathrm{~m}^{2}$ & $139,47 \mathrm{~m}^{2}$ \\
\hline não computável & $140,38 \mathrm{~m}^{2}$ & $80.09 \mathrm{~m}^{2}$ & $38,94 \mathrm{~m}^{2}$ \\
\hline total & $345,69 \mathrm{~m}^{2}$ & $237,52 \mathrm{~m}^{2}$ & $|78,4| \mathrm{m}^{2}$ \\
\hline
\end{tabular}
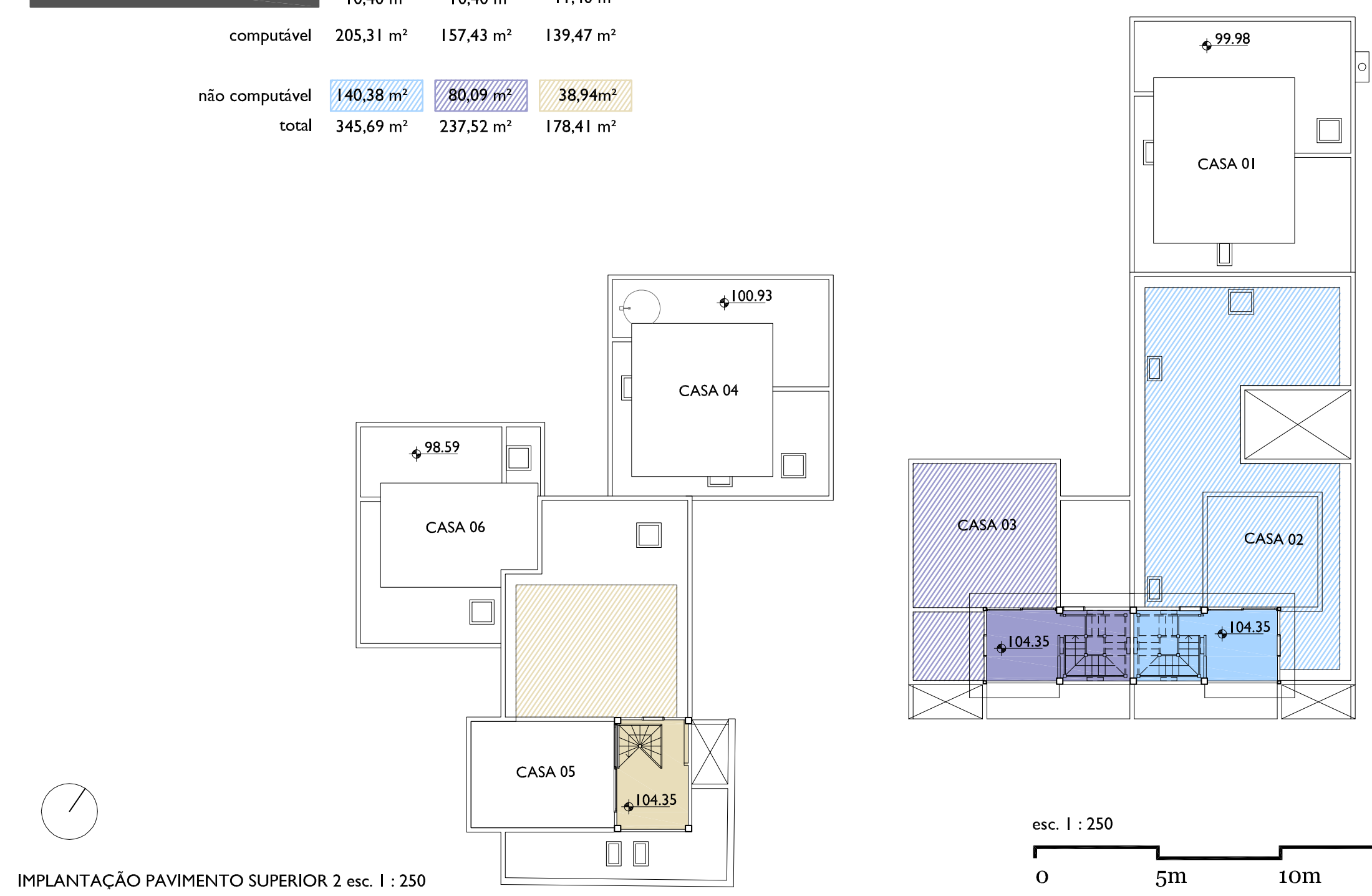

esc. $1: 250$

$\mathrm{O}_{5 \mathrm{~m}} \sqrt{\mathrm{Om}} 25 \mathrm{~m}$



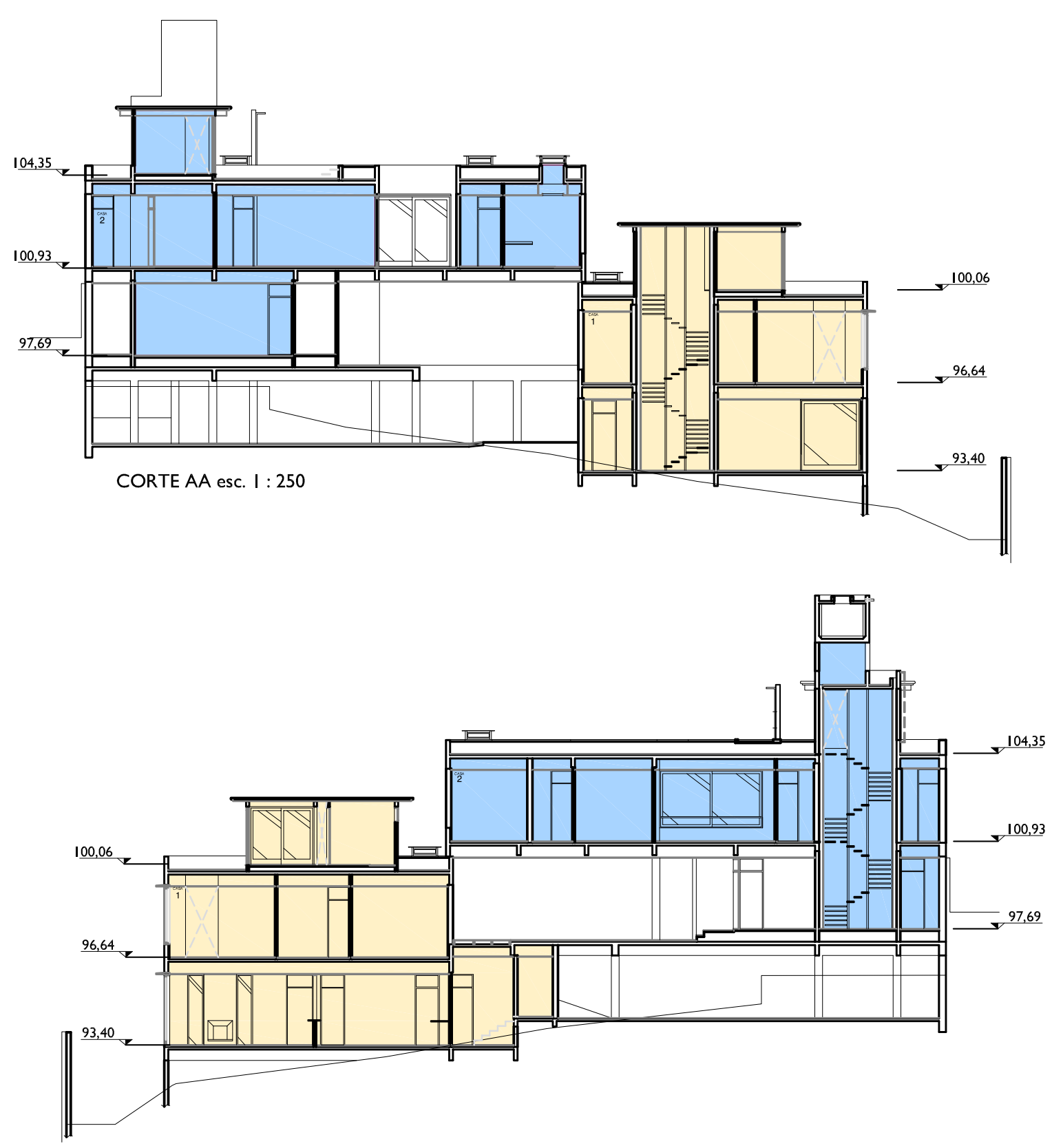

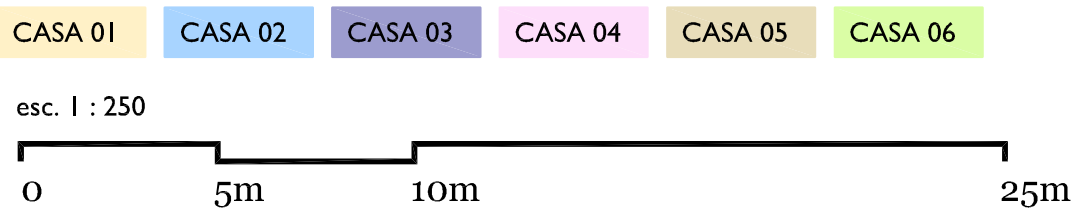




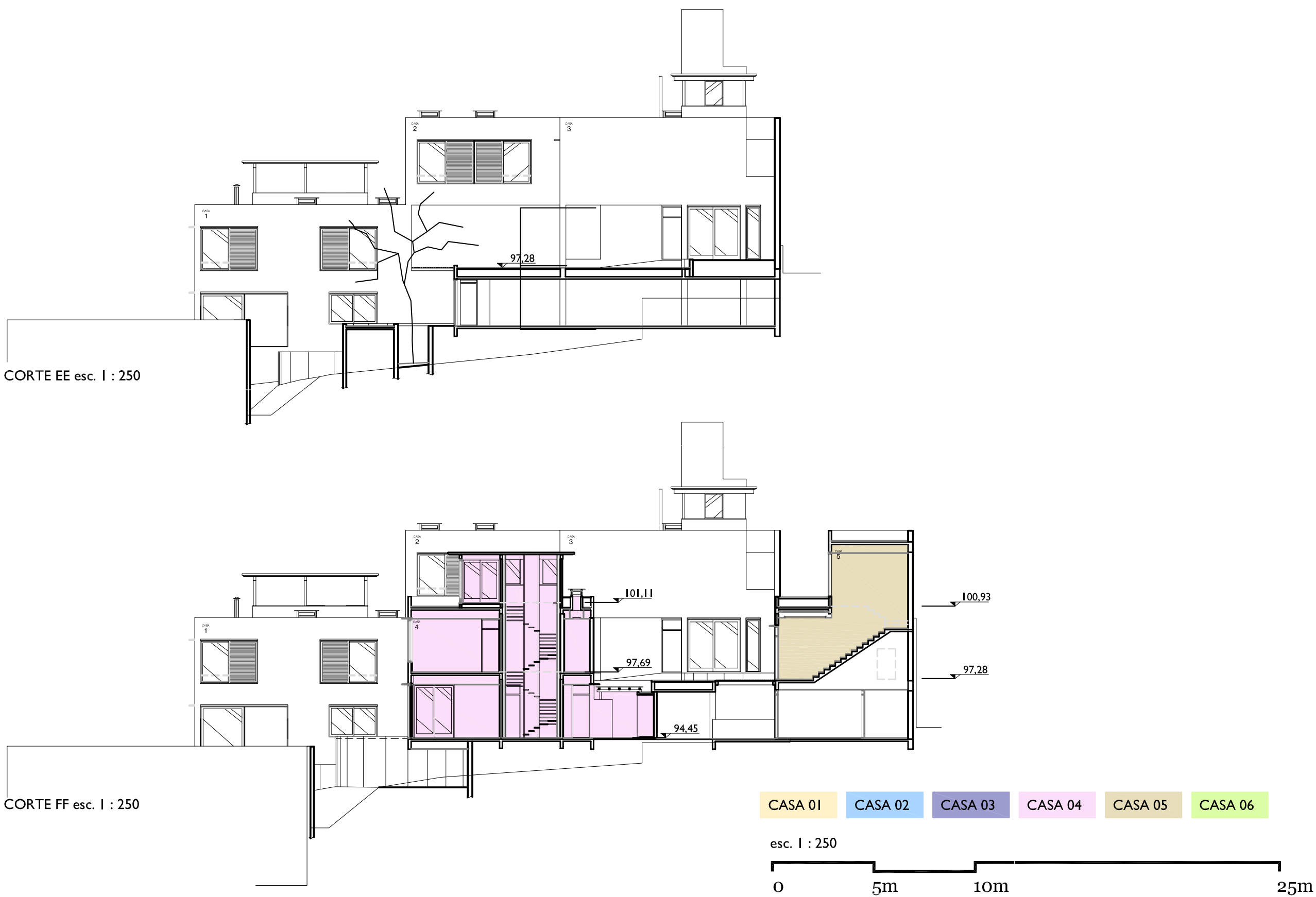



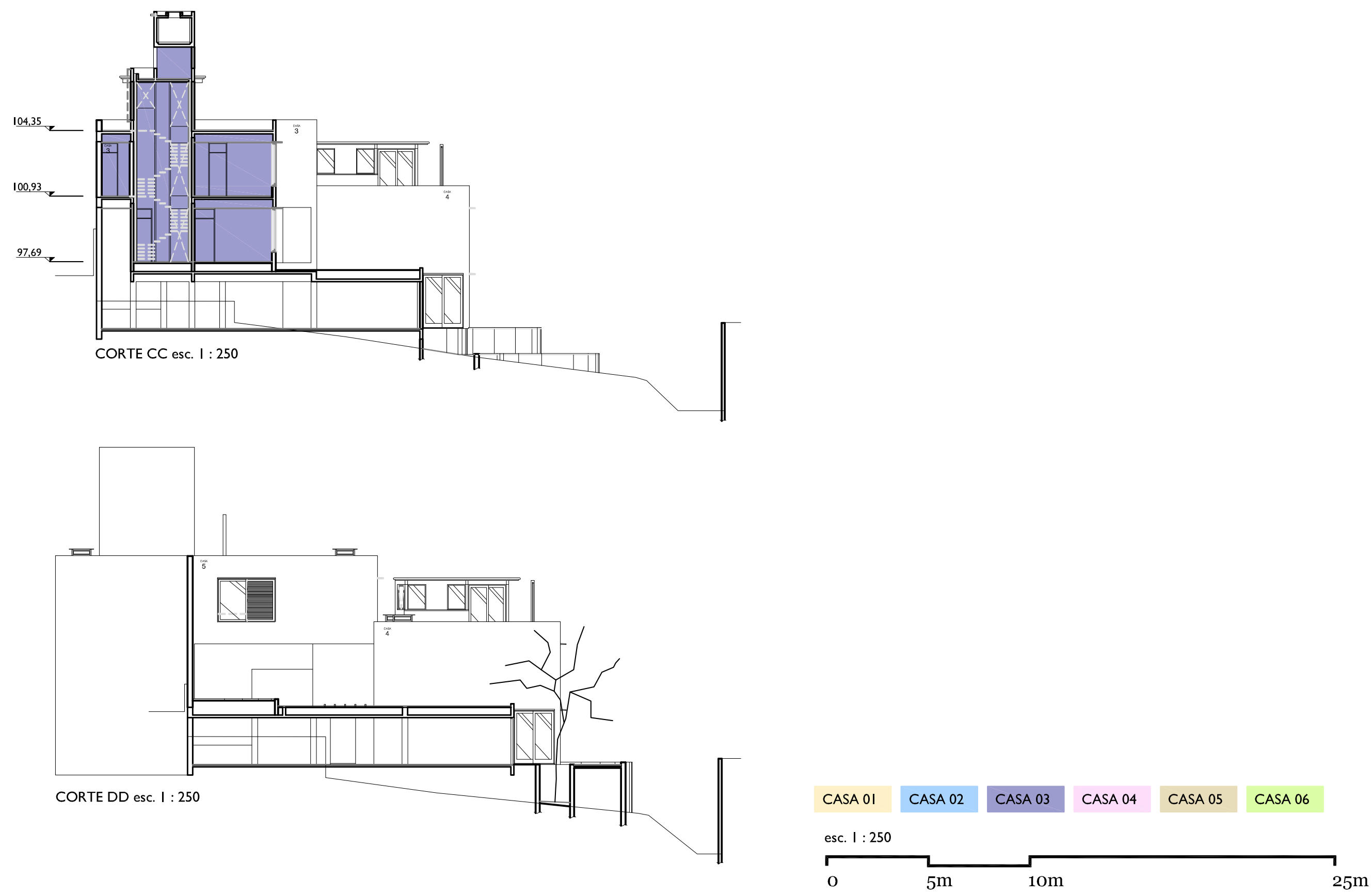


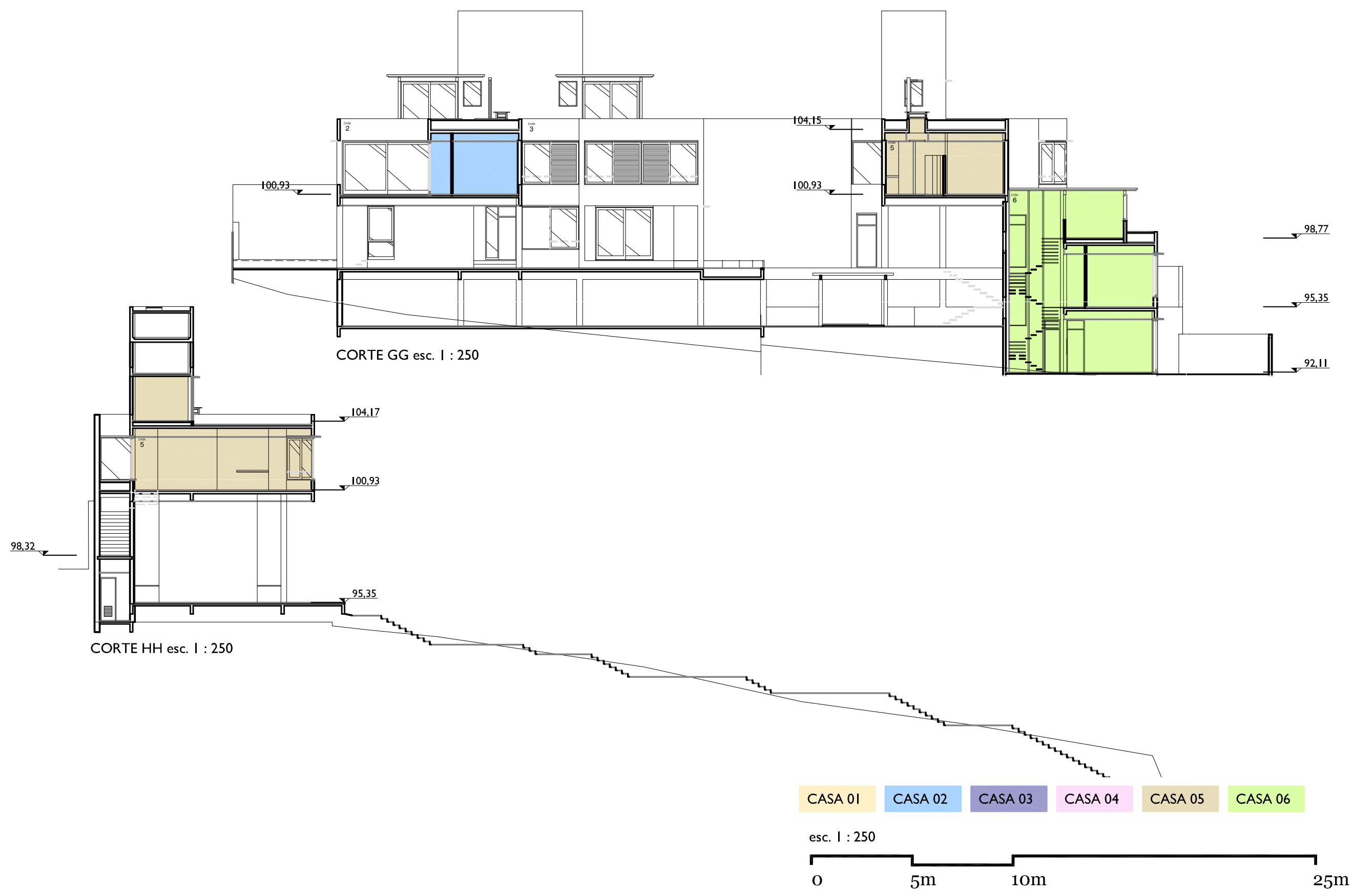




\subsubsection{I BIBLIOGRAFIA DO CAPÍTULO}

ACAYABA. M. M. Residências em São Paulo 1947- I 975. São Paulo: Romano Guerra Editora, 20 II.

BAHAMÓN,A.; SANJINÉS, M. C. Alta densidad: Vivienda Contemporánea. Barcelona: Parramón ediciones, 2008

MELENDEZ,Adilson. O golpe do concurso... ProjetoDesign, São Paulo, n.254, abril de 2001.

PROJETODESIGN. Da Filosofia à arquitetura. São Paulo, n.263, janeiro de 2002.

PROJETODESIGN. Uma vila desafia o mercado imobiliário. São Paulo, n.263, janeiro de 2002.

ARQUITETURA E CONSTRUÇÃO. Por fora parece uma casa, por dentro são seis. São Paulo, abril de 2003.

SANT'ANNA, Antonio Carlos. Concurso Paço em Osasco: Um depoimento comprometido. Arquitetura e Urbanismo, São Paulo, ${ }^{\circ} 37$, Pp.89 a 99, agosto/setembro de 1991.

SANTOS,V. C. Concursos de Arquitetura em São Paulo. 2002. Dissertação (mestrado em arquitetura e urbanismo), Universidade de São Paulo, São Paulo, 2002

SERAPIÃO, Fernando. Quatro pecados louváveis. ProjetoDesign, São Paulo, n. 3। 3, p. 88, março de 2006.

94 WISNIK, Guilherme. O espaço coletivo como baliza. Revista Novos Estudos - CEBRAP, São Paulo, n. 64, novembro de 2002. 


\section{VISITAS REALIZADAS:}

12 fevereiro de 201 I - visita externa (entorno próximo).

5 abril de $201 \mathrm{I}$ - visita completa inclusive com a presença da arquiteta.

II de abril de 20I I - visita externa, observação da Vila desde a Praça Dolores Ibarruri.

\section{ENTREVISTA:}

Arquiteta Cristina Xavier - 14 de dezembro de 2012.

LEIS:

BRASIL. Lei $n^{\circ}$ II.605, de 12 de julho de 1994: Dispõe sobre a criação da subcategoria de uso residencial R3-03, conjunto residencial - vila, e dá outras providências. 


\subsubsection{CANAÃ: BOA ARQUITETURA COMPATÍVEL COM A CULTURA E A ECONOMIA LOCAL}

\section{I.3.I INTRODUÇÃO}

Este conjunto na Rua Grécia e outras obras foram tema do artigo "Joan Villà, construções para a sociedade", escrito pelos arquitetos Josep Maria Montaner e Zaida Muxí (201 I) para o jornal espanhol La Vanguardía, dentro da série "Repensar a práxis arquitetônica", dedicada à obra de arquitetos fora do star system, no entanto, com realizações de grande valor social e criativo. Também em artigo publicado na Revista ProjetoDesign, Junqueira (201 I) coloca esta obra como desafiadora da lógica dos investimentos imobiliários ou da inércia do setor da construção civil. Nas duas citações, a obra é colocada como diferenciada ou desafiadora da lógica existente. Assim, o capítulo tem como objetivo entender como e porque esta obra desafia a lógica da produção habitacional atual de tal maneira a representar uma forma excepcional, dentro de um recorte geográfico e temporal desta pesquisa, de prática arquitetônica. “(...) Dá um passo importante para o enfrentamento das imposições do mercado imobiliário e da indústria da construção civil, levando qualidade arquitetônica a 96 qualquer construção" (JUNQUEIRA, 201 I, p. 91).

Primeiramente, é preciso entender que o projeto Canaã, de 2002, possui o diferencial de utilizar uma técnica construtiva decorrente de um processo que surgiu na Faculdade de Belas Artes de São Paulo (Febasp) nos anos 1980. Em época de pleno crescimento da periferia de São Paulo, o Laboratório de Habitação desta faculdade tinha como premissa inserir uma instituição acadêmica na periferia da cidade e criar uma técnica construtiva a partir do reconhecimento de alguns problemas observados nos trabalhos do canteiro, em obras realizadas por mutirão, portanto, a partir do entendimento da cultura e economia local. Canaã é uma realização arquitetônica que consegue ir além da assimilação e interpretação da cultura popular, como poderá ser observado ao longo do capítulo.

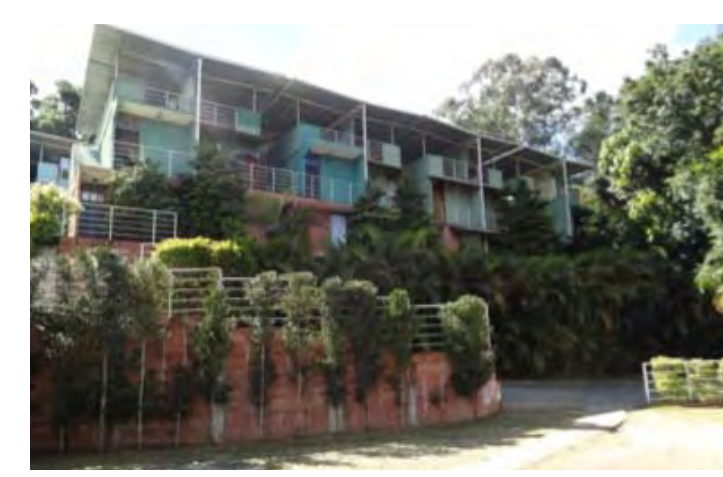

Figura I - Renque de oito casas em harmonia com a topografia existente.

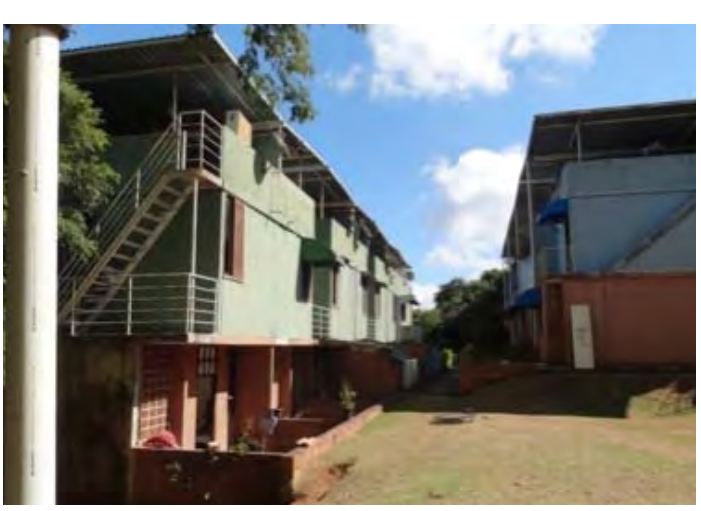

Figura 2 - Vista dos renques. 


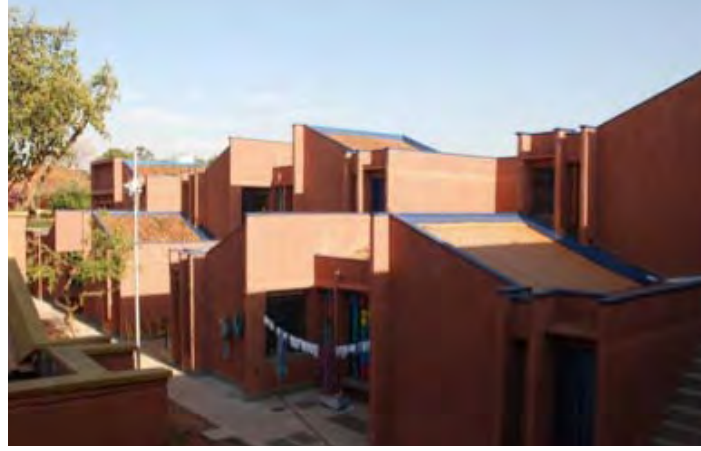

Figura 3 - Moradia Estudantil da Unicamp (1992), Barão Geraldo, Campinas, SP.

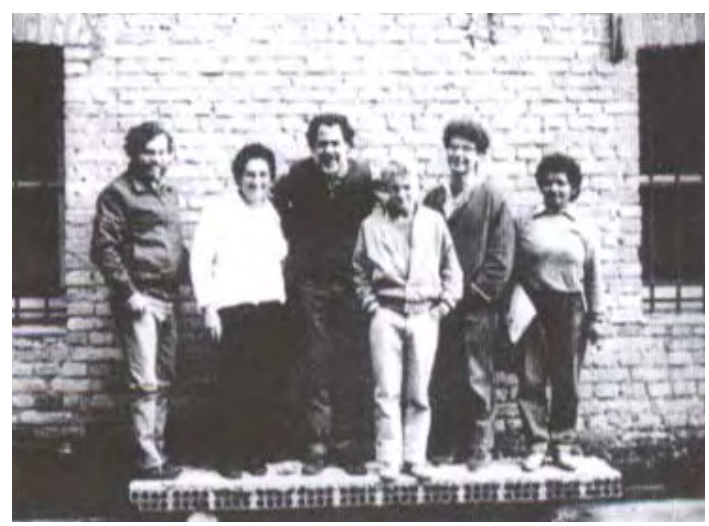

Figura 4 - Ensaio do primeiro painel de laje (1985)

\subsubsection{CONCEPÇÃO DA CONSTRUÇÃO COM PRÉ-FABRICADO CERÂMICO - CPC}

O sistema construtivo será o primeiro assunto a ser abordado, pois a qualidade deste exemplar está muito vinculada a esse fator, trabalhado de maneira integrada com a arquitetura. Este conjunto habitacional em Cotia é o resultado de um envolvimento enorme do arquiteto Joan Villà num longo processo que se iniciou muito antes da concepção do conjunto Canaã. $O$ método construtivo empregado nesta obra, Construção com Pré-fabricado Cerâmico (CPC) -, consagrado no projeto da Moradia Estudantil da Universidade Estadual de Campinas (Unicamp) de 1992 (Figura 3), consta de materiais básicos disponíveis em qualquer depósito de materiais de construção civil: tijolos furados cerâmicos e componentes para concreto armado. A concepção desse método construtivo é importante para compreender porque a obra em estudo é um caso excepcional de habitação coletiva.

Na década de 1980, o número de pessoas vivendo em favelas na cidade de São Paulo estava em crescimento, resultado não apenas da crise econômica como também da especulação do solo urbano em áreas mais centrais, obrigando as famílias de baixa renda a viverem em distantes periferias em casas autoconstruídas pelos próprios moradores, em alguns casos por regime de mutirão'.

Segundo pesquisa dos professores Calos Lemos e Maria Ruth Sampaio, "Habitação popular paulistana autoconstruída", de 1978, 88,5\% das 122 moradias populares levantadas pelos pesquisadores na periferia de São Paulo foram construídas pelos proprietários e raramente por regime de mutirão. Porém, a problemática colocada aqui não se refere à qual regime de construção é melhor e, sim, quais características levaram à criação do método CPC.

O Laboratório de Habitação da Febasp, conduzido pelo Prof. Arq. Jorge Caron ${ }^{2}$ e do qual

'Segundo BONDUKI (1998), as favelas surgem em São Paulo entre 1942 e 1945 devido à crise habitacional na década de 40, consequência de algumas medidas da época, como a Lei do Inquilinato que gerou despejos em massa, surgindo, assim, o desejo da casa própria mesmo que em periferias distantes.A partir dessa época, o número de pessoas vivendo em favelas foi crescendo gradativamente.

2 Para obter mais informações sobre a trajetória deste arquiteto, consultar: RUGGIERO, Amanda Saba. Jorge Caron: uma trajetória. São Carlos: Escola de Engenharia da Universidade de São Paulo, 2006. Dissertação de mestrado. 
Joan Villà fazia parte, em atividade na primeira metade dos anos 1980, tinha como proposta prestar assessoria técnica à habitação e à inserção de uma instituição acadêmica na periferia da cidade; para tanto, os integrantes do laboratório tomaram conhecimento das deficiências que teriam que ser superadas na autoconstrução. Assim, o início da concepção desse sistema construtivo partiu da vontade de melhorar, do ponto de vista dos trabalhos do canteiro, em obras realizadas por mutirão, algumas questões principais enunciadas em Villà (2002), como: a longa duração das obras; a baixa produtividade; os baixos padrões de execução e os altos índices de desperdício.

Segundo Villà (2002), a longa duração das obras realizadas por regime de mutirão dava-se, geralmente, porque sua execução ocorria apenas aos finais de semana, sendo a baixa produtividade também consequência disso, já que há um espaçamento das jornadas de trabalho e grande cansaço provocado pelo ritmo intenso dessa jornada acrescida e contínua à jornada fixa assalariada que ocorria durante a semana. Sabia-se que os baixos padrões construtivos aconteciam, principalmente, pela deficiência na estanqueidade, e os altos índices de desperdício eram agravados nesse tipo de obra, devido à descontinuidade dos trabalhos e aos longos períodos de tempo com os canteiros vazios. Também era notável a presença majoritária e marcante de mulheres nos canteiros de obras e frequentemente decisiva no sentido da negociação e liderança nos assuntos da comunidade, porém, de certa maneira contraditória em relação à função que exerciam durante a construção (Figura 5).

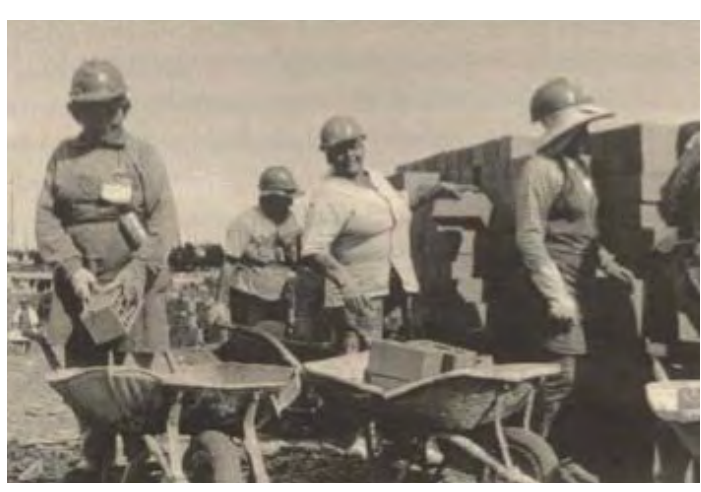

Figura 5 - Mulheres trabalhando na construção de moradias em mutirão autogerido.

Dentro do trabalho amador e superando os seus limites, está o trabalho feminino. (...) Vimos que nos movimentos sociais as mulheres são maioria e têm papel de destaque. Porém, no canteiro, as primeiras funções não chegam nem a ser consideradas "trabalho" pelos homens, uma vez que apenas reproduzem a naturalidade da esfera doméstica. Acontece que elas ainda formam um número maior do que o exigido por essas tarefas. Então começam a entrar no canteiro, inicialmente em trabalhos braçais e totalmente desqualificados, como o carregamento de material e a limpeza do terreno, até assumirem trabalhos "fora do seu lugar", como a ferragem, a concretagem, a alvenaria e instalações. (...) Aos poucos vão revelando uma habilidade surpreendente, deixando muitos homens para trás (ARANTES, 2002, p. 199). 


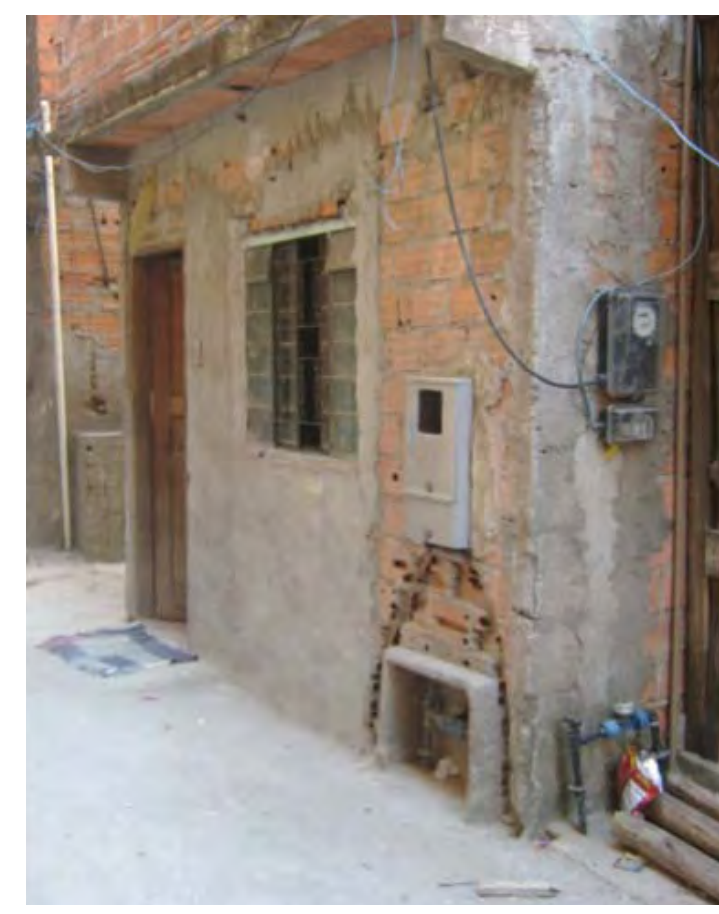

Figura 6 - Autoconstrução com adoção de práticas comuns, por pessoa sem ofício ou habilidade no ramo, Diadema, SP (201 I).
Pode ser acrescida neste quadro que configuram as circunstâncias limitadoras da eficiência das obras realizadas em mutirão, as inadequadas formas de produção adotadas, resultantes da assimilação das práticas correntes e tradicionais da construção civil, por pessoas envolvidas no processo por necessidade e não por possuir um ofício, não sendo, obviamente, construtores de primeira qualidade, mas, sim, amadores (Figura 6).“A técnica utilizada, mais do que aprendida, é vista, vivida, absorvida por contínua vizinhança. Faz parte do conhecimento popular quase espontâneo, que todos herdam, simples prática compatível com nenhuma especialização" (FERRO, 1969, apud ARANTES, 2002, p. 61). Assim, surge o pensamente de que deveria existir uma técnica condizente com a mão de obra existente nos mutirões:

Isto, acreditamos, somente seria possível promovendo mudanças de natureza tecnológica que rompessem com a segmentação dos diversos serviços e, ao mesmo tempo, fossem capazes de eliminar ou reduzir o protagonismo decorrente das habilidades e do saber dos ofícios, dos profissionais especializados, portanto, características praticamente inexistentes no contexto social dos canteiros de obras de mutirão (VILLÀ, 2002, p. 52).

Neste sentido, é possível dizer também que a mão de obra auxiliar existente na construção civil no Brasil atualmente é constituída por trabalhadores assalariados das empreiteiras que, do ponto de vista da qualificação do ofício, é muito semelhante à existente no mutirão. Da mesma forma que a participação da população nos mutirões dava-se pela necessidade de adquirir uma moradia, e não por habilidades profissionais, a procura por trabalho auxiliar na construção civil dá-se pelo simples fato da necessidade, não existindo ofícios decorrentes de ensinamentos em cursos ou escolas de qualificação profissional propriamente dita. Enunciado os problemas, a pré-fabricação foi uma das hipóteses pensadas por Joan Villà e pelo grupo do Laboratório de Habitação, raciocínio lógico no sentido da procura por melhorias nas questões relacionadas ao tempo de duração da obra, redução de desperdícios, qualidade nos acabamentos, etc., porém, num primeiro momento, com pouca perspectiva de implantação 
com relação à mão de obra e logística encontradas nos mutirões, sem especialização para manusear maquinário e recursos para assumir tal tecnologia. A equivocada opinião de entender a mão de obra não especializada incoerente com a pré-fabricação, pode ocorrer, por parecer num primeiro momento, que a pré-fabricação esteja vinculada apenas à construção mecanizada e distante do trabalho humano, algo que revela-se diferente em algumas experiências:

Falar em pré-fabricação nos faz, em geral, pensar em grandes máquinas, indústria sofisticada, construção mecanizada, afastada do contato humano. Obras em que guindastes elevam pesadas peças e imensas alturas e esteiras velozes transportam materiais. Um procedimento construtivo que parece muito distante da situação precária de nossas periferias. Entretanto, experiências bem-sucedidas como a de Lelé com a Renurb (Companhia de Renovação Urbana de Salvador), na capital baiana, nos ensinam que essa é apenas uma versão das várias possibilidades daquilo que a pré-fabricação permite. (ELOY; BOGÉA e REBELLO, 2005, p. 72).

Há também referências arquitetônicas europeias do pós-guerra, até o final da década de 1960, (Figura 7) que se mostraram deficientes na composição e configuração dos edifícios, sendo que a complexidade tecnológica exigida demandava grandes escalas para a viabilidade deles, tornando-os, portanto, problemáticos e insustentáveis. Porém, não se pode concluir, simplesmente por exemplos mal sucedidos, que a arquitetura será desprestigiada devido à industrialização ou também pela pré-fabricação da construção; pelo contrário, ela pode resultar em obras criativas e sem monotonia. Segundo Bruna (2002), Gropius, em 1924, ao tratar do problema da habitação industrializada, já esclarecia sobre a necessidade de harmonizar o projeto e a produção industrial:

O que já nessa época estava claro para alguns espíritos lúcidos empenhados em aproximar e harmonizar o projeto e a produção industrial não foi compreendido pelos arquitetos e construtores do após-guerra, que ergueram extensos e deprimentes conjuntos habitacionais principalmente na região metropolitana de Paris e em alguns países socialistas. (BRUNA, 2002, p. 25).

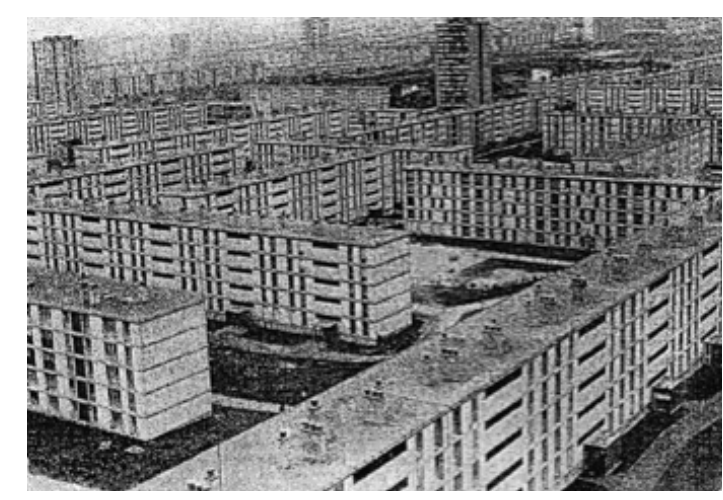

Figura 7 - Sarcelles, França. Conjunto Habitacional dos anos 60. Grande escala, monotonia e grandes problemas sociais. 


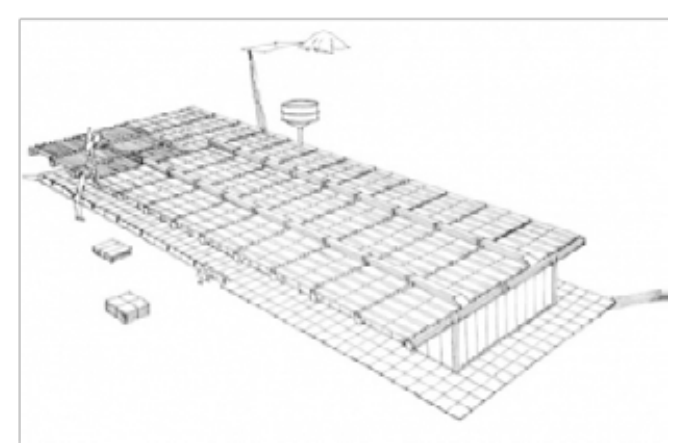

Figura 8 - Escola rural para 50 alunos em esquema de montagem. Abadiânia, Goiás. Desenho de João Figueiras Lima, anos 80.
Também existe em Bruna (2002) a opinião contrária sobre a mão de obra não especializada ser incoerente com a adoção da industrialização na construção habitacional, considerando este tipo de trabalhador pouco qualificado (seja aquele encontrado nos mutirões ou em outras obras), mais incoerente com a técnica construtiva comumente utilizada no Brasil, com execução de peças in loco e artesanalmente, que exige também, ou pelo menos deveria exigir, especialização:

\begin{abstract}
O emprego maciço de mão-de-obra não-qualificada é sem dúvida um dos grandes responsáveis pelo baixo nível de execução da arquitetura contemporânea brasileira, pelo incrível desperdício de materiais e homens-horas registrado e, por seguinte, pelo custo elevado das construções. Os métodos tradicionais, ao contrário do que normalmente se acredita, só se justificam se amparados numa considerável equipe de operários especializados: pedreiros, carpinteiros, pintores, estucadores, eletricistas, serralheiros, etc. A mão-de-obra não-qualificada emprega-se nas obras como serventes e ajudantes, colaboradores enfim dos operários qualificados (BRUNA, 2002, p.25).
\end{abstract}

Assim, com consciência destes diferentes pontos de vistas com relação à racionalização da arquitetura, seja pela industrialização de peças ou apenas pela pré-fabricação, parecia faltar referências adequadas ao Laboratório de Habitação (LabHab) da Febasp à realidade encontrada nos mutirões. Porém, não se excluía a pré-fabricação nesta busca por uma solução aos problemas apontados: “Pensávamos na pré-fabricação, assim mesmo, mas faltavam-nos referências que, adequadas a nossa realidade, nos permitissem ensaiar novos caminhos na superação dos problemas observados nos canteiros de obras por mutirão" (VILLÀ, 2002, p. 54).

O sistema de pré-fabricação de componentes de argamassa armada, que João Figueiras Lima ${ }^{3}$ (Lelé) adotou em unidades escolares e de saúde (Figura 8), experiência notável e genuinamente brasileira, fez com que a possibilidade de pré-fabricação para solução dos problemas de habitação

${ }^{3}$ Segundo Ekerman (2005), além de rápido, o sistema criado por Lelé revela-se útil na manutenção dos empregos da população local, que não perde os postos de trabalho, apesar da industrialização do processo.A rapidez e a engenhosidade das construções permitiu ao arquiteto construir mais de duzentas escolas em cerca de dois anos (1984-1986), sempre utilizando a máxima de que a repetição é a base de uma arquitetura industrializada viável. 
da população de baixa renda fosse novamente considerada, afinal, comprovou que não apenas as deficiências nas questões plásticas dos exemplos do pós-guerra haviam sido contornadas como também havia a consideração do emprego da mão de obra da população local.

A técnica construtiva adotada em unidades habitacionais em cooperativas uruguaias ${ }^{4} \mathrm{da}$ época, pela qual executavam pequenas lajes com o uso de tijolos maciços e nervuras de concreto, tradição presente nas obras de Eladio Dieste ${ }^{5}$, aproximava-se mais daquilo que buscavam (Figura 9). Com escassa espessura, que correspondia à altura de um tijolo $(5 \mathrm{~cm})$, essas lajes eram utilizadas para construção de pequenas marquises, e para vencer os pequenos vãos de espaços como despensas, banheiros e lavanderias, elas tinham uma dimensão que não excedia $1,5 \mathrm{~m} \times 0,25 \mathrm{~m} \times 0,05 \mathrm{~m}$. "A solução dada a estas pequenas lajes, de alguma forma enraizada na tradição da construção com tijolos maciços, frequente em boa parte da América espanhola, adotava procedimentos comuns à cerâmica armada presentes em obras do Engenheiro Eladio Dieste” (VILLÀ, 2002, p. 56).

Sejam as obras de Lelé, as moradias realizadas pelas cooperativas uruguaias, os projetos que utilizam o método CPC ou até a obra de Dieste, todas despertam a discussão do desenho da produção, colocada por Sérgio Ferro no texto $O$ canteiro e o desenho ${ }^{6}$. Neste tipo de referência, construção e arquitetura caminham juntas, e a etapa do canteiro é de suma importância, mas não menos do que a etapa que o antecede.

Os projetos mencionados estão dentro do desenho da produção (e não para produção), pois foram concebidos a partir do pensamento da mão de obra disponível e, consequentemente, de sua inclusão no processo por participação ativa, não como mero trabalho braçal.

\footnotetext{
${ }^{4}$ Para obter mais informações, consultar:NAHOUM, Benjamím. Las cooperativas de vivienda por ayuda mutua uruguaias: uma história com quince mil protagonistas. 2.ed. Montevideo: Intendencias Municipal, 2008.

${ }^{5}$ Para conhecer algumas de suas principais obras, consultar: DIESTE, Eladio. Las tecnologías apropiadas y la creatividad. In: GUTIÉRREZ, Ramón (cood.). Arquitectura latinoamericana en el siglo XX. Buenos Aires: Cedodal, 1998, p. 44.
}

${ }^{6}$ FERRO, Sérgio. O canteiro e o desenho. In: FERRO, Sérgio. Arquitetura e trabalho livre. São Paulo: Cosac Naify, 2006.

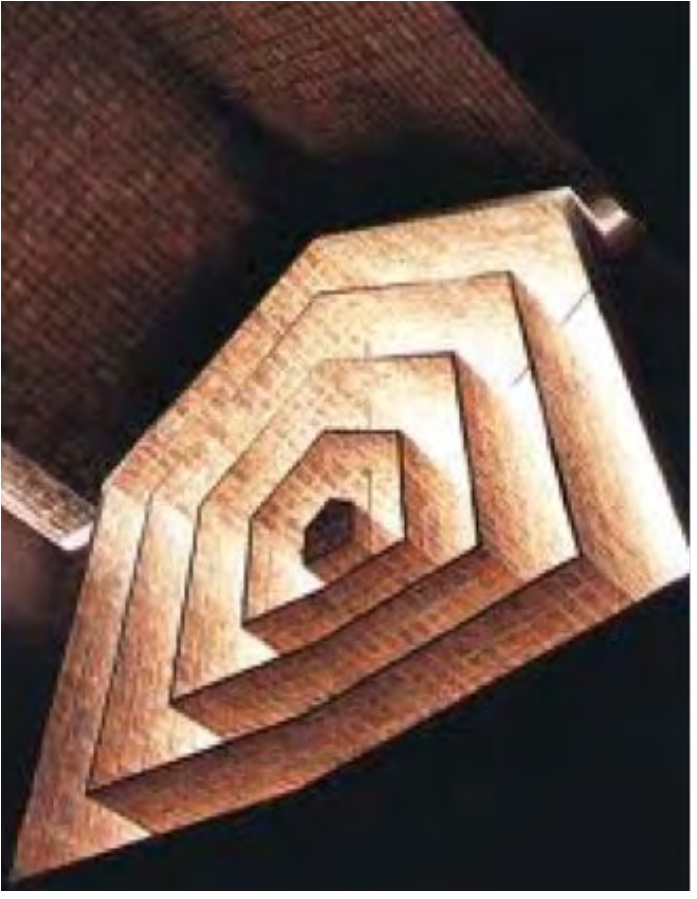

Figura 9 - Igreja de San Pedro em Durazno, Uruguai. Eladio Dieste, 1969-1971. 

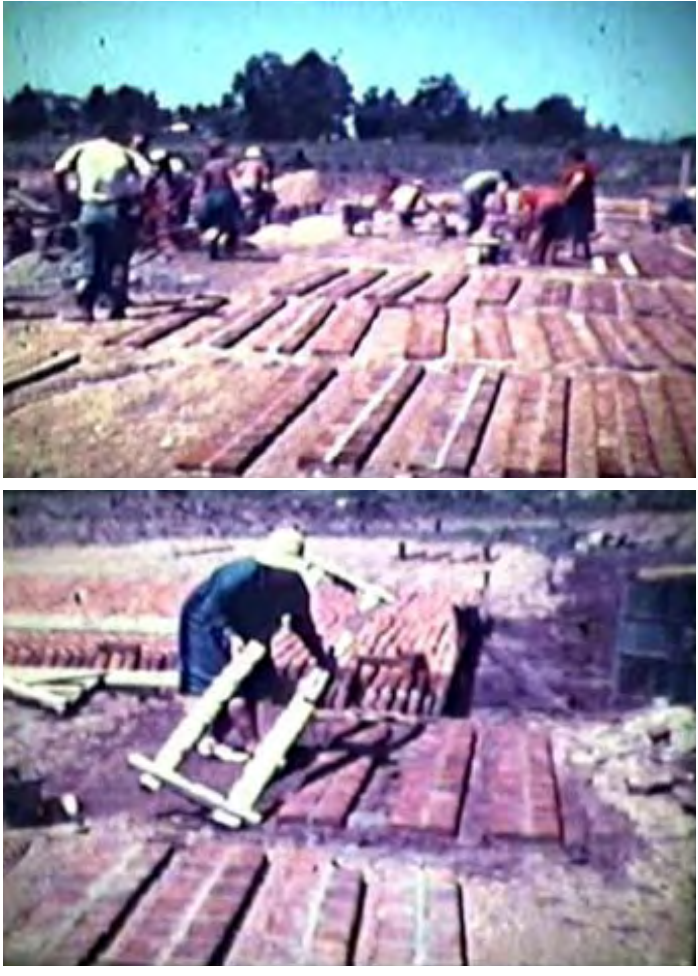

Figura 10 - Cenas do Filme Super 8, das cooperativas Uruguaias. $O$ Eng. Guilherme Henrique Pinto Coelho divulgou muito este filme em São Paulo, principalmente para a comunidade deVila Nova Cachoeirinha, no início dos anos 80.

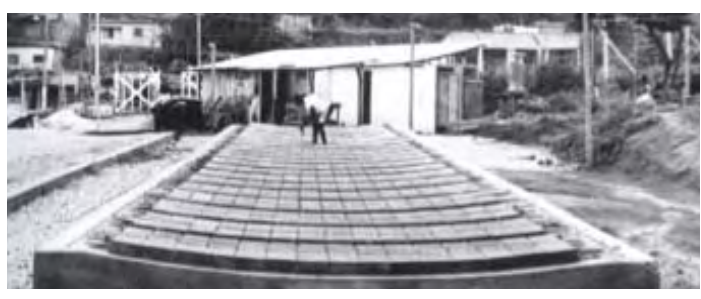

Figura I I - Pista de montagem de painéis CPC em formato curvo.
Assim, se não contarmos as exceções de evidência primária do que há que fazer, o próprio trabalhador deixa que seja encoberta de promovida obscuridade a significação para o conjunto dos atos que exerce. Sem dúvida, por curiosidade deslocada ou dificuldade diante do embrutecimento requerido, alguns seguem a "lógica" (generosidade das palavras) dos encadeamentos de etapas, das esperas, dos cuidados de previsão etc. Mas a maioria - e com maior motivo os trabalhadores sem qualificação ou novos no canteiro, cerca de $70 \%$ do total - não acompanha os porquês do que faz. Não por incapacidade, insistimos (hipótese que implicaria o corolário de imbecilidade "natural" dos operários), mas por justo desinteresse, por melancólico acantoamento defensivo na tarefa imediata e porque a compreensão global, por um a priori instaurador do sistema, é coisa que não lhe cabe.A exclusão é intencional e suas consequências programadas (FERRO, 2006, p. II0).

As pequenas lajes de tijolos das cooperativas uruguaias foram uma referência definitiva no método construtivo desenvolvido no Laboratório de Habitação da Faculdade de Belas Artes de São Paulo e depois aprimorado na Universidade Estadual de Campinas (Unicamp) (Figura 10). O problema das limitações estruturais que impediam uma utilização mais ampla foi solucionado sem aumentar significamente seu peso, com a adoção do tijolo furado de cerâmica vermelha - ou tijolo de oito furos. Segundo Villà (2002), a lembrança desta possibilidade veio, não apenas pela sua maior dimensão ( $9 \times 19 \times 19 \mathrm{~cm}$ ), mas também pelo seu largo emprego no Brasil na constituição das lajes mistas, de concreto e blocos cerâmicos, restando ensaiar esta hipótese em produção horizontal, da mesma maneira como acontecia nas cooperativas uruguaias, em bancadas ou no próprio chão (Figura II).

Assim, em 1985, na Faculdade de Belas Artes de São Paulo (Febasp), foi dado início à confecção de alguns painéis de laje, já que este é o elemento que precisa suportar maiores esforços, sendo realizados ensaios de cargas com $250 \mathrm{Kg} / \mathrm{m}^{2}$, conforme pode ser visto na figura 4 . O ciclo de desenvolvimento desta tecnologia na Febasp encerra-se em 1985 devido a uma greve salarial, que levou à demissão de quase todo o corpo docente, e fechava-se também o Laboratório de Habitação: "Encerrava-se um ciclo que foi uma das melhores e mais inovadoras propostas de ensino de arquitetura em São Paulo, conduzido pelo Prof.Arq. Jorge Caron” (VILLÀ, 2002, p. 59). É importante deixar registrado, também, que alguns anos depois mais de quarenta escritórios de arquitetura se constituiriam 
no suporte técnico de programas habitacionais da prefeitura de São Paulo, na gestão de Luiza Erundina, compostos por ex-estagiários do LabHab ou profissionais que se pautaram por experiências de assessoria técnica a movimentos sociais, muitas das quais haviam desenvolvido e sistematizado. Também, durante seu funcionamento, orientou trabalhos em projeto de assessoria técnica a algumas comunidades, como por exemplo: Recanto da Alegria eVila do Arco-Íris ${ }^{7}$, no Grajaú, zona Sul de São Paulo, entre as represas Billings e Guarapiranga.

Pouco tempo depois, foi implantado um novo Laboratório de Habitação na Universidade Estadual de Campinas - Unicamp, como um dos programas do Núcleo de Desenvolvimento de Criatividade - NUDECRI. Foi uma retomada com mais meios e recursos. Com ensaios produzidos nos laboratórios do Instituto de Pesquisas Tecnológicas (IPT) os componentes básicos para a construção com pré fabricados cerâmicos estariam tecnicamente resolvidos: painel de escada, painel de telha, painel de parede, painel de elétrica e painel de laje. A evolução das obras que utilizaram esta técnica é notável. O primeiro protótipo, de 1986, “casinha da Unicamp”, tinha área de $40 \mathrm{~m}^{2}$ para o núcleo básico inicial de uma casa, com possibilidade de expansão. Convém citar que foi uma iniciativa que alfinetou os embriões que estavam em voga na época, (que chegaram a ter $19 \mathrm{~m}^{2}$ nos projetos da Companhia Metropolitana de Habitação de São Paulo (COHAB-SP) durante a administração

de Jânio Quadros na cidade de São Paulo) já que, com maior área e melhor qualidade arquitetônica e construtiva, o protótipo conseguiu apresentar o mesmo custo. Nas figuras 12 e 13 é possível notar a degradação em casas tipo “embrião", resultante de um projeto pouco definidor de morfologia urbana e que ficou a mercê de um crescimento descontrolado pelos moradores. Em 1987, foi construída a primeira unidade assobradada. À medida que ocorria a evolução da técnica, algumas recomendações para o projeto iam sendo definidas, como, por exemplo, a modulação desejada, questões relacionadas à ampliação das unidades, tipo de fundação e estrutura e a quantidade desejável de trabalhadores para execução das casas, conforme pode ser visto em algumas recomendações destacadas ao lado: ${ }_{7}^{7}$ ários projetos utilizando o método CPC tiveram colaboração dos arquitetos Roberto Pompéia, Debora A. Doukan e Edson Takahashi e cálculo estrutural do engenheiro Yopanan Rebello.

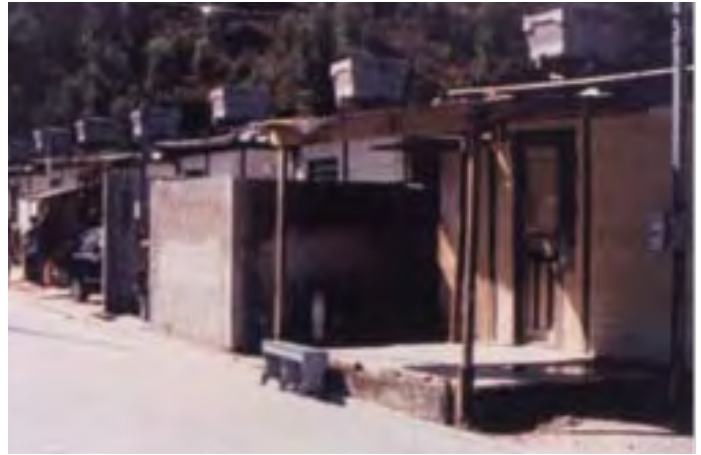

Antes

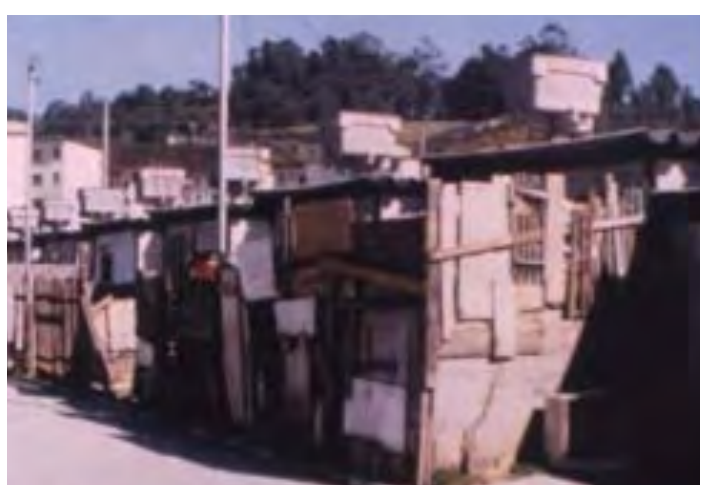

Depois

Figuras 12 e 13 - PCasa-embrião COHAB Raposo Tavares, anos 1980. Segundo diagnóstico do arq. Hector Vigliecca, o espaço frontal sem definição fica a mercê de um crescimento descontrolado dos habitantes. 


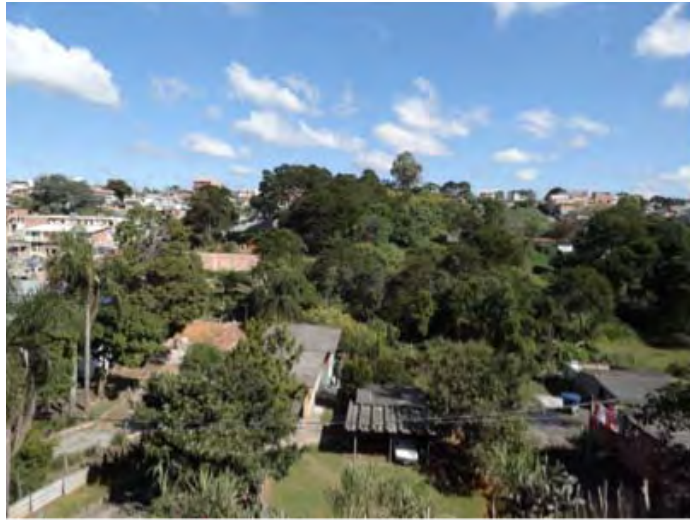

Figura I 4 - Vista para o entorno a partir do terraço de uma unidade do renque amarelo.

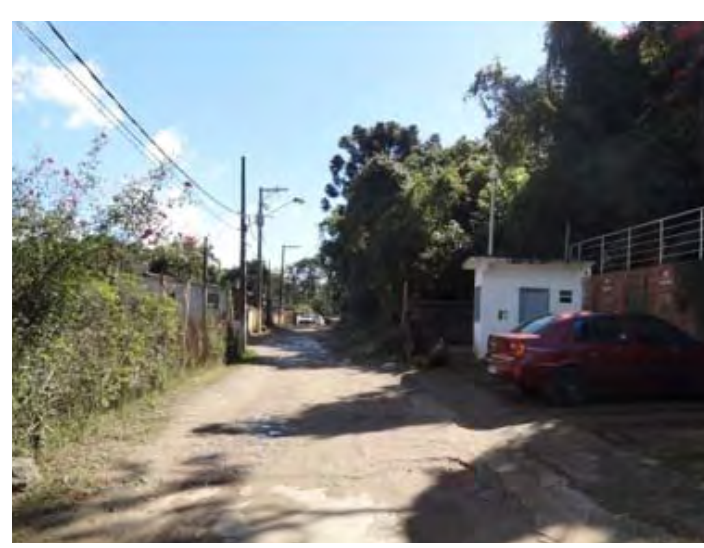

Figura 15 - Rua de acesso ao conjunto. À direita, vagas externas ao espaço condominial.

\begin{tabular}{|l|l|}
\hline Modulação & Malha horizontal de $45 \mathrm{~cm}$ e vertical de $2 \mathrm{~lm}$. \\
\hline Ampliações & $\begin{array}{l}\text { Implantação do núcleo inicial, incluindo as áreas mol- } \\
\text { hadas, junto à testada; execução integral das fundações } \\
\text { e privilegiar a conclusão das partes assobradadas. }\end{array}$ \\
\hline Adequação às condições locais & $\begin{array}{l}\text { Estudo da arte local; recursos disponíveis de mão de } \\
\text { obra; de materiais; hábitos dos agrupamentos famil- } \\
\text { iares e dos espaços comunitários. }\end{array}$ \\
\hline Sistema construtivo & $\begin{array}{l}\text { Fundações preferencialmente do tipo radier e estru- } \\
\text { tura formada apenas pelos elementos parede e laje. }\end{array}$ \\
\hline Mão de obra & Um trabalhador/uma unidade de 40 m² \\
\hline
\end{tabular}

\subsubsection{INSERÇÃO URBANA}

O conjunto de habitação popular Canaã está localizado na periferia de Cotia, Região Metropolitana de São Paulo, há trinta quilômetros da capital paulista e bem próximo à Rodovia Raposo Tavares. Quando se observa o território ao redor do conjunto, as diferentes texturas urbanas e naturais ficam evidentes, tratando-se, portanto, de um território heterogêneo e fragmentado no sentido físico e de ocupação territorial. Podem ser identificados alguns conjuntos de casas em condomínios fechados, algumas favelas ou loteamentos precários, chácaras e fortes zonas industriais em meio a alguns trechos naturais preservados. Sua implantação ocorre numa rua sem saída, na qual o núcleo urbano mais próximo é precário e incapaz de atender positivamente com comércio e serviços mínimos ao uso residencial existente (Figuras 14 e 15). Também encontra-se bastante distante do transporte público, representando um problema, já que a habitação deve sempre estar integrada à estrutura urbana equipada, para garantir acesso aos equipamentos e comércios de primeira necessidade, sem depender de meio de transporte motorizado privado. 
O problema do conjunto é a sua localização; totalmente distanciado de qualquer núcleo urbano, coisa que o separa dos equipamentos e o faz acessível somente com veículo privado. Este erro, tão generalizado, de considerar a habitação como um elemento alheio à estrutura urbana complexa e equipada é recorrente no desenvolvimento fracionado da planificação urbana, do uso do solo e das políticas habitacionais (MONTANER e MUXÍ, 20I I).

\section{I.3.4 AGENTES}

O contratante dos arquitetos, uma pequena construtora, realizava obras pontuais: no geral, casas de médio a alto padrão na região de Granja Viana em Cotia. Em determinado momento, soube perceber que existia uma demanda de baixa renda na região que não era atendida ou considerada pelo poder público. Assim, queria oferecer algo de qualidade não apenas arquitetônica, mas construtiva para este outro público que ele descobrira. Por informações obtidas em publicações e pesquisas na produção de habitação popular, o microempresário chegou até os arquitetos Joan Villà e Sílvia Chile.

Para construir o que seria seu empreendimento pioneiro, o cliente buscou um terreno que tivesse o mínimo de acessibilidade, mas dentro de uma área que tivesse uma demanda previamente caracterizada.A área próxima ao Rio Cotia possui muitas indústrias instaladas, existindo, portanto, trabalhadores moradores da proximidade com potencial de mercado, e foi isso que o fez optar por essa região.

\section{I.3.5 PARTIDO DE IMPLANTAÇÃO}

O terreno de $3.200 \mathrm{~m}^{2}$ foi dividido em três patamares para implantação dos renques com oito casas cada: cota +103 formado pelas casas amarelas, +108 pelas casas verdes e +110 pelas casas azuis. $O$ efeito das cores distribuídas nos patamares é marcante na paisagem, enquanto o uso da cor "terra", no térreo das casas, cria uma relação tectônica entre construção e terreno natural. Devido à topografia acidentada do terreno, foram necessários cinco meses (praticamente metade do 


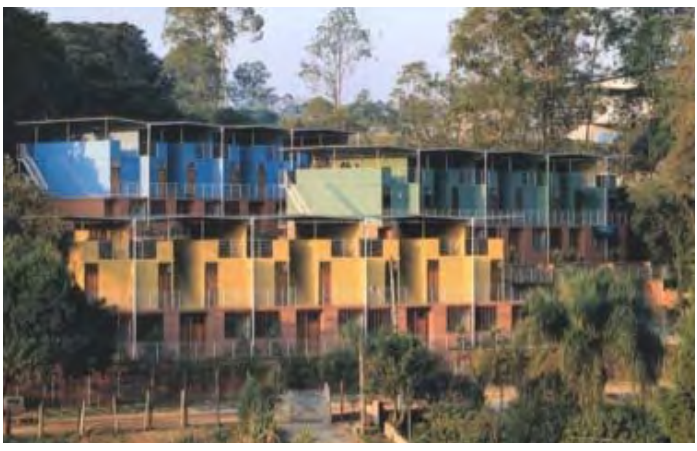

Figura 16 - Três renques, cada um com uma cor e nível diferentes e a base possui cor "terra": destaque e integração na paisagem ao mesmo tempo.

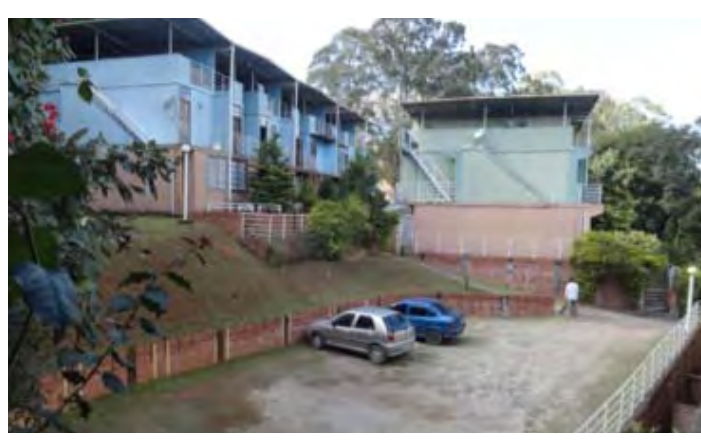

Figura 17 - Pelo projeto, era para existir neste espaço uma quadra esportiva.

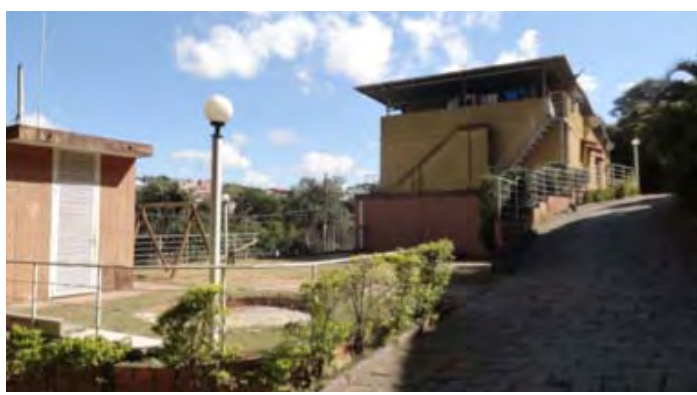

Figura 18 - Pelo projeto, era para existir neste espaço um pavilhão de lazer. período de execução do projeto), para definição dos patamares e estabilização geotécnica, com execução de muros de arrimos e taludes (Figura 16).

Diferente de outros projetos estudados nesta pesquisa, este, em especial, possui autonomia do objeto - unidade habitacional - com relação ao terreno, ou seja, poderia ser replicado em outros lugares. Interessante é notar que, neste caso, essa possibilidade de replicação não desqualifica a obra, pois o objeto, por si só, possui significados que podem ser levados a outras localidades. Não é o lote a condicionante determinante para este projeto, mas, sim, a criação anterior de técnica construtiva e tipologia adequada às limitações ou até mesmo vontades populares.

\subsubsection{ESPAÇOS EXTERIORES}

No projeto, os espaços negativos, representados pelas vias de circulação e espaços para o lazer comunitário, são distribuídos em três áreas principais: pavilhão de lazer, quadra poliesportiva e recreação infantil. A execução destas áreas não chegou a ser concluída, o pavilhão de lazer, por exemplo, não foi construído. Assim, essas áreas ficaram, de certa maneira, comprometidas, pela ausência de mobiliário urbano, brinquedos, área com sombra ou até pela falta de demarcação do campo esportivo projetado, o que evitaria a ocupação do espaço como parada imprópria de automóveis, como pôde ser observado no dia da visita, por exemplo. Porém, a simples definição do que seriam os espaços positivos consequentemente acabou por definir espaços negativos que proporcionam visibilidade e garantia de insolação e ventilação das casas. Outra solução positiva nesta implantação foi a definição de vagas para automóveis no recuo frontal do terreno, externamente ao conjunto. Esta condição cria uma situação vantajosa ao pedestre em toda área interna, já que a circulação de veículos ocorre apenas em casos excepcionais, como por exemplo, para entrada de ambulância, caminhão do corpo de bombeiros etc. Também representa uma economia de área já que o acesso às vagas acaba ocorrendo pelo próprio viário público (Figuras 17 e 18). 


\section{I.3.7 SISTEMA ESTRUTURAL ETÉCNICA CONSTRUTIVA}

Para a execução da obra, o empreiteiro apoiou-se em dois ou três mestres de obra que participavam dos seus empreendimentos habituais. A partir destes mestres, acabou por montar uma equipe com média de 24 pessoas, conforme orientação dos arquitetos, em média um funcionário por casa. Por mais que não tenha sido uma construção em regime de mutirão, a mão de obra auxiliar contratada, do ponto de vista da qualificação do ofício, era muito similar à encontrada na autoconstrução por ajuda mútua, nesse sentido, a técnica construtiva adotada, CPC, foi muito apropriada às condições locais e mão de obra disponível no momento, pois permitia um aprendizado rápido dentro das características estabelecidas pelo projeto de seriação de peças e processo de montagem.As arquitetas Sílvia Chile e Débora Daukan, que fizeram por muito tempo parte do corpo técnico do laboratório de experimentação da Unicamp, realizaram o treinamento da mão de obra.

Os painéis pré-fabricados foram produzidos por meio de superfície horizontal da própria fundação radier da edificação, já para sua execução foram utilizados equipamentos simples, como espaçadores, desempenadeira, frisador e outras ferramentas comuns utilizadas na construção civil. Assim, esta obra foi realizada com o mesmo método utilizado nas outras obras de tecnologia CPC,

que resumidamente acontece da seguinte maneira, como pode ser observado abaixo:

Sobre a superfície plana é disposto um gabarito de madeira para recebimento de camada de areia para posterior posicionamento dos tijolos cerâmicos furados. As peças cerâmicas são acomodadas junto aos lados da moldura, de maneira a ficar um vão de $4 \mathrm{~cm}$ de espessura no meio, para preenchimento com concreto e armadura. Antes de serem montados, os painéis já devem receber todas as instalações elétricas e hidráulicas necessárias, e revestimento de chapisco nas faces internas. Os painéis podem ser manuseados para empilhamento cerca de dois dias após a confecção e ficam prontos para montagem depois de uma semana. (Figura 19)

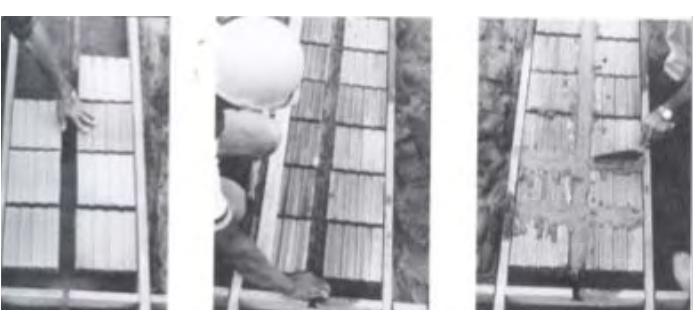

Figura 19 - Execução de um painel Pré-fabricado Cerâmico. 


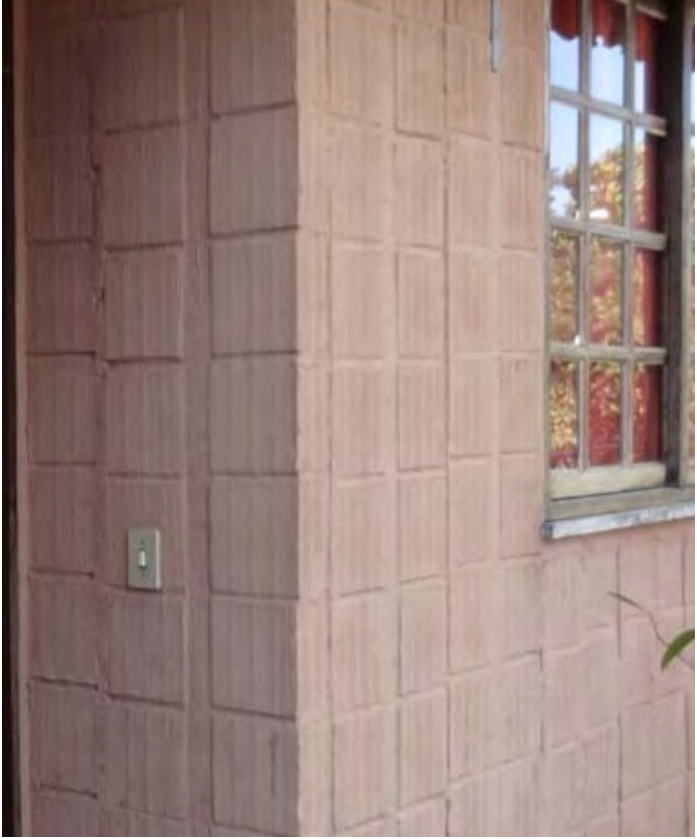

Figura 20 - Qualidade de acabamento dos painéis pré-fabricados: juntas regulares, ortogonalidade e efeito plástico da marcação rebaixada da junção de $4 \mathrm{~cm}$ de concreto entre os blocos cerâmicos. Mesmo com a pintura, a técnica está aparente.
Outra característica importante é o peso, que não chega a $100 \mathrm{~kg}$, podendo ser carregado e manuseado com facilidade por duas pessoas, e acaba facilitando também a mão de obra feminina, que no caso deste projeto foi praticamente inexistente, situação diferente da encontrada nos mutirões inspiradores desta técnica. "Partir desses ingredientes tão banais para chegar à arquitetura de sábia simplicidade confirma o dito popular de que apenas os gênios são capazes de enxergar o óbvio" (JUNQUEIRA, 2006).

\subsubsection{ENVOLTÓRIA}

A aplicação de pintura texturizada nas faces externas das casas foi uma questão colocada, acima de tudo, pelo cliente, mas que os autores souberam entender perfeitamente. $O$ tijolo aparente é comum nas obras autoconstruídas das favelas, e muitas vezes são executados com pouca qualidade: juntas irregulares, falta de ortogonalidade e estanqueidade. Por outro lado, o micro empreendedor não queria um revestimento que encarecesse seu negócio, então, para fugir desta possível imagem depreciativa e do alto custo, foram apenas pintadas as faces externas (Figura 20).

Mesmo com uma qualidade evidente dos painéis cerâmicos por si só, afinal são elementos com efeito plástico e estético muito interessante, os arquitetos desde sempre estavam abertos à possibilidade do revestimento, afinal, a cultura local e geografia brasileira são muito variáveis, existindo regiões onde os painéis dificilmente ficariam sem revestimento (foi citado pelos arquitetos, até por experiência própria, o sul do país) e outras onde é cultuada a cerâmica e o tijolo a vista (foi citado pelos arquitetos o nordeste do país, por exemplo).Vale a pena esclarecer que o uso do tijolo aparente, no Brasil, é diferente do que acontece, por exemplo, na Colômbia, onde está relacionado a uma escola arquitetônica criada por Rogelio Salmona, que tem o uso do tijolo aparente como uma marca de suas obras. Em São Paulo, por exemplo, a nossa escola é do concreto aparente, do mestre Artigas, e a cultura do tijolo aparente é pouco presente, pois mesmo as casas do final do século XIX e início do século $X X$, executadas com tijolos maciços, tinham suas paredes revestidas. 
Roberto Pompéia, em sua tese de doutorado "Os laboratórios de habitação no ensino da arquitetura. Uma contribuição ao processo de formação do arquiteto" expõe uma experiência de projeto na cidade de Socorro, executado em regime de mutirão, com o uso do painel pré-fabricado cerâmico, que teve um episódio estritamente relacionado à aceitação ou não do revestimento do painel. Depois de finalizada a construção das unidades habitacionais, um candidato a prefeito prometeu o revestimento das casas, algo que os moradores desejavam, senão não existiria a promessa:

\begin{abstract}
O episódio do reboco das casas flagra as contradições entre o ideal dos arquitetos e o desejo dos futuros moradores. É claro que, para os mutirantes, a casa acabada é aquela rebocada e pintada. A beleza e a variedade tonal dos tijolos aparentes só eram percebidas pelos arquitetos. Mais uma vez, confirma-se a necessidade de construir junto com a comunidade um repertório arquitetônico que seja mais autêntico e livre dos cenários impostos pela sociedade de consumo. Tanto os moradores têm de construir um novo repertório com esse conhecimento arquitetônico mais elaborado da técnica e da estética, como os "Arquitetos Educadores" devem tentar aproximar-se da cultura desse cliente. Assim, o resultado não virá de um outro lado isoladamente; virá da integração de ambas as partes (POMPÉIA, 2006).
\end{abstract}

Em nenhum momento é questionada, tanto pelos arquitetos Joan Villà e Sívia Chile ou por Roberto Pompéia, a ausência do revestimento no painel levando-se em consideração a eficiência do conforto ambiental da unidade habitacional. As unidades do conjunto em Cotia possuem a pintura externa, e as paredes internas são revestidas. Durante a visita ao local, foi realizado do reconhecimento do interior de algumas casas e não foi observado manchas de umidade. Os painéis parecem ser estanques, e também o revestimento em pelo menos uma das faces acaba impedindo entrada de insetos ou mesmo umidade. Também se acredita que, para o caso de habitação de interesse social, se existe algo que possa ser executado pelos próprios moradores, incluindo as mulheres, este algo é o revestimento, já que se trata de um ofício mais fácil de ser realizado. Ao mesmo tempo, nem tudo deve ficar a mercê dos moradores, por exemplo, a escolha de três cores, uma para cada renque de casas do conjunto em Cotia, conferiu muita qualidade ao conjunto, algo que se ficasse de livre
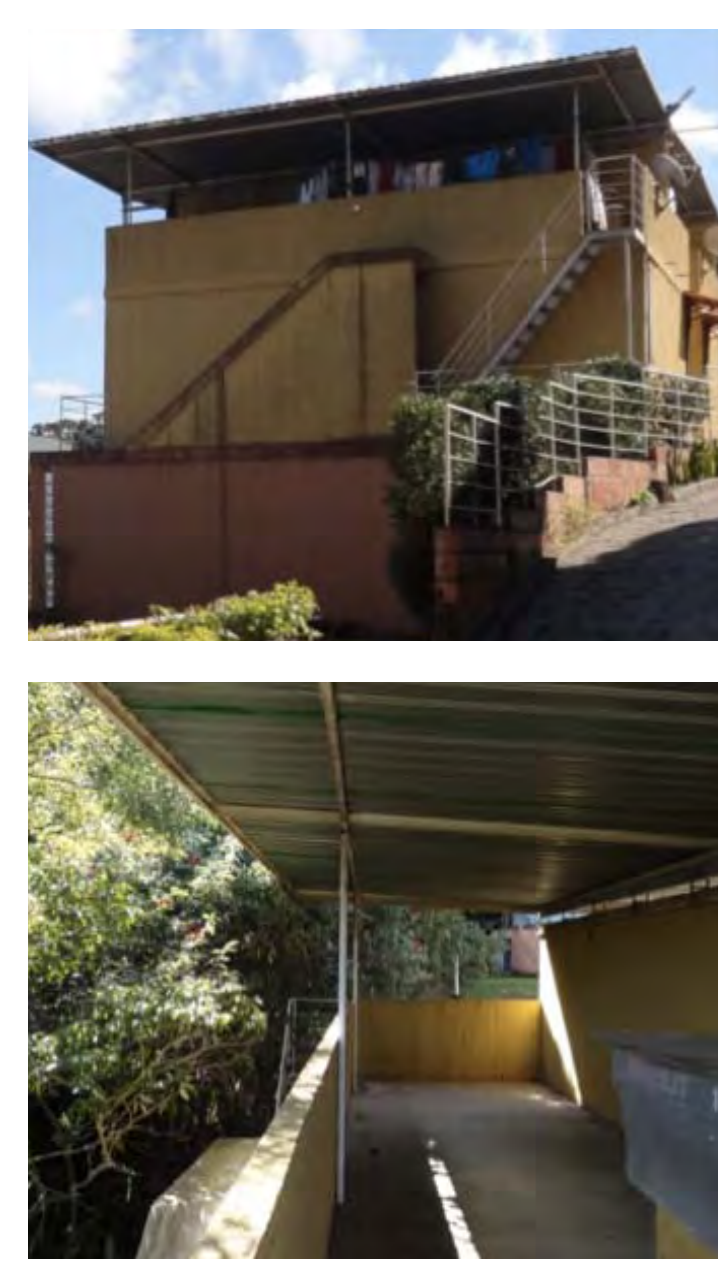

Figuras 2 I e 22 - O terraço coberto: partiu da observação e do desejo popular por este espaço para usos diversos. 


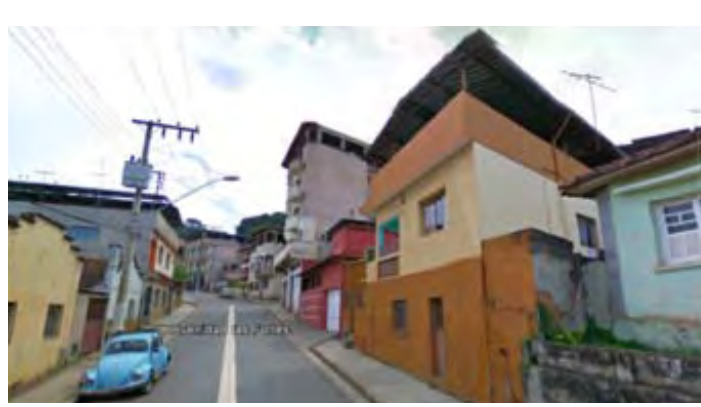

Figura 23 - Casas em Congonhas do Campo, Minas Gerais: uso corrente do "lajão" coberto.

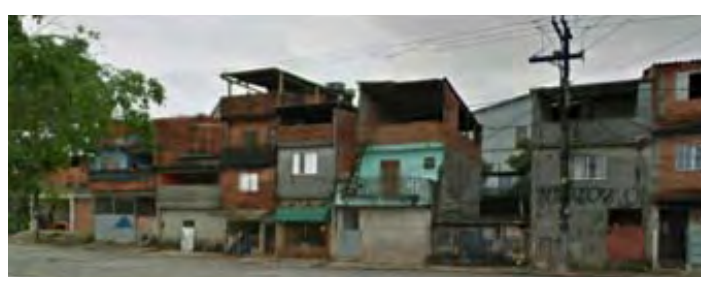

Figura 24 - Casas autoconstruídas no Bairro Alvarenga, em S. B. do Campo, divisa com a cidade de Diadema (20I I).

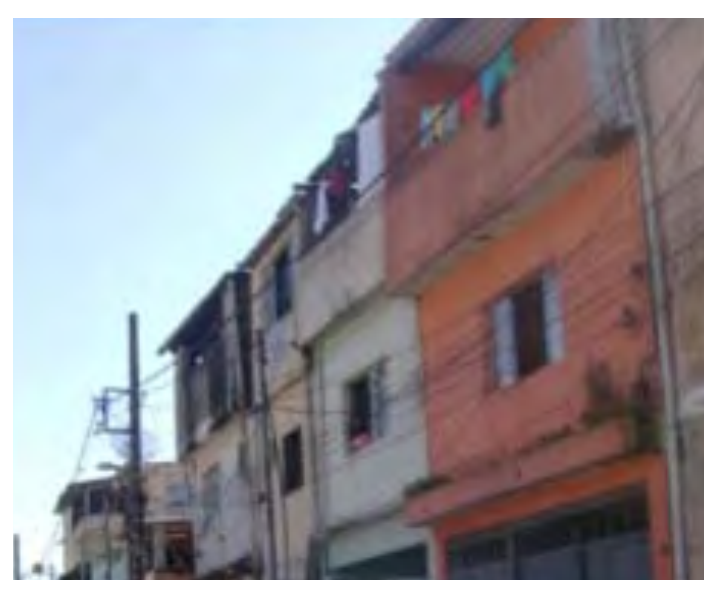

Figura 25 - Casas no Jabaquara, favela Alba, SP (200I). escolha dos moradores teria um resultado diferente. Assim, é preciso existir um limite à vontade individual, sendo desejáveis, soluções pensadas para o coletivo, nem sempre o pensamento para o coletivo, parte dos moradores.

\subsubsection{UNIDADE HABITACIONAL}

O terraço coberto das unidades habitacionais é uma solução muito significativa neste projeto. De acordo com Joan Villà e Sílvia Chile (20I2), já havia muito tempo que gostariam de fazer algo deste tipo, pois em sucessivas viagens para o Espírito Santo, Bahia, interior de Minas Gerais e outras localidades do Brasil, puderam perceber que a partir de uma determinada cota geográfica, em regiões de clima mais quente tanto no interior quanto na costa, a solução do "lajão" coberto era recorrente (Figuras $2 \mathrm{I}$ e 22). $O$ terraço coberto costuma acomodar atividades diversas nos exemplos populares correntes, como se fosse um espaço "coringa" da casa: lavanderia e consequentemente espaço para estender roupa, espaço para animais de estimação, para reunião ou para acomodar um dormitório extra. É muito comum, em bairros periféricos de São Paulo, por exemplo, deixar este espaço reservado para futura ampliação, e depois de ampliado, fazer um novo “lajão" coberto no pavimento acima. Isto causa uma verdadeira verticalização, necessária também pela escassez de áreas livres, que acaba por obrigar o adensamento no próprio lote. Fazendo uma busca rápida no Google Earth na cidade de Congonhas do Campo, em Minas Gerais, citada na entrevista pelos arquitetos, foi possível localizar esta tipologia com facilidade (Figura 23). Nos bairros mais periféricos de São Paulo ou cidades com forte presença de imigrantes nordestinos, essa solução também é comum. Ainda é importante o fato de que, muitas vezes, essa solução não é tão improvisada quanto os exemplos de São Paulo mostrado nas próximas fotos (Figuras 24 e 25), existindo certos tipos de cuidados na construção. Esse fato, inclusive, coloca em prova a importância primordial do arquiteto nas realizações arquitetônicas de qualidade: 
(...) E muitas vezes soluções não tão improvisadas como as que a gente vê na periferia de São Paulo, mas sim com cuidado dos apoios, das águas dos telhados, coisas muito mais trabalhadas. Mas que não tinha a presença evidente do arquiteto, portanto, onde a própria vontade de fazer melhor estava latente (VILLÀ, 20I2).

O que os arquitetos puderam perceber é que esta era uma solução; que do ponto de vista popular, emergia como uma solução muito desejada. Assim, estavam bastante decididos a experimentá-la, e a oportunidade foi dada neste projeto por ter um cliente especial aberto a novas soluções. O cliente chegou a comentar com os arquitetos que esperava uma solução mais criativa do que a dos protótipos realizados no canteiro da Unicamp, queria inovação no desenho a partir da técnica que comumente utilizavam. Os arquitetos conseguiram responder com sabedoria e, de certa forma, essa provocação foi muito estimulante para eles. $O$ elemento leve da cobertura, em formato "borboleta", foi algo que superou os desenhos anteriores.

Este espaço e a posição da escada externa estão estritamente relacionados, afinal, estamos falando de programas secundários, que podem ser inseridos posteriormente na habitação. Uma explicação coerente seria a de que, muitas vezes com escassos recursos, é possível construir apenas uma casa inicial térrea, com área aproximada de 20 a $30 \mathrm{~m}^{2}$. Com uma construção tão pequena, é im-

provável que deixem a escada à espera ou que pensem num projeto no qual o espaço para a escada já esteja reservado, inclusive deixando o buraco na laje para sua posterior implantação.Assim, a escada é feita quando surge a necessidade, ficando, portanto, na parte externa. Os arquitetos conseguiram transparecer essas referências populares em sua obra.Ao mesmo tempo, existe outro possível raciocínio, originado de algumas propostas de habitação do movimento moderno, a serem incorporados a esta interpretação Em alguns projetos derivados do pensamento do movimento moderno, a escada externa e o terraço-jardim semicoberto estão presentes.A Maison Dom-ino, 1914-15, desenhada por Le Corbusier (Figura 26) quando ele era ainda muito jovem, já apresenta a escada externa, mas por motivos obviamente diferentes dos encontrados nos assentamentos populares citados acima.

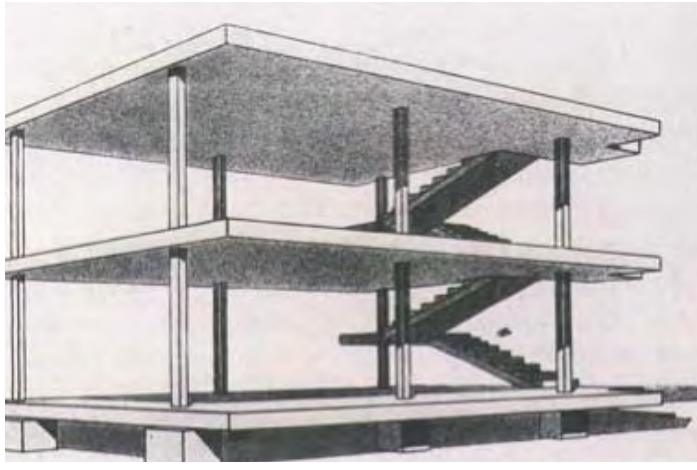

Figura 26 - Esqueleto estrutural da Maison Dom-ino, |9|4-I5. Le Corbusier.

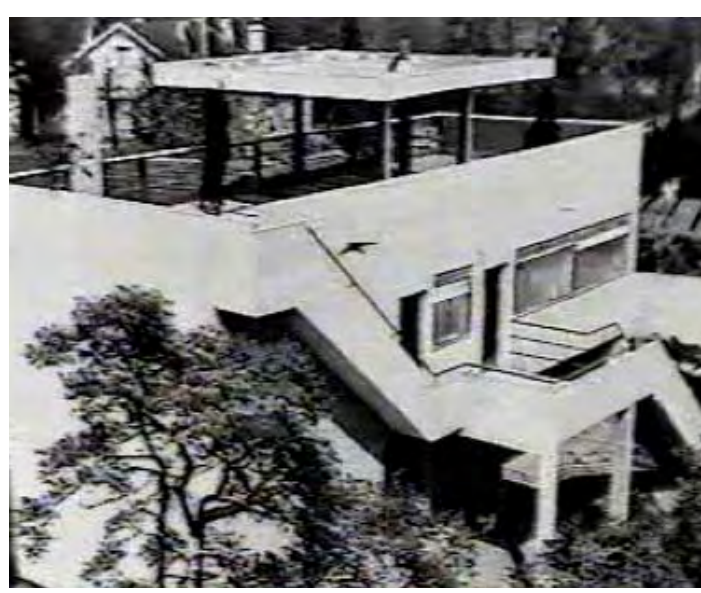

Figura 27 - Casas em Pessac, França. tipologia 4 com dois pavimentos independentes e com terraço acessível. 

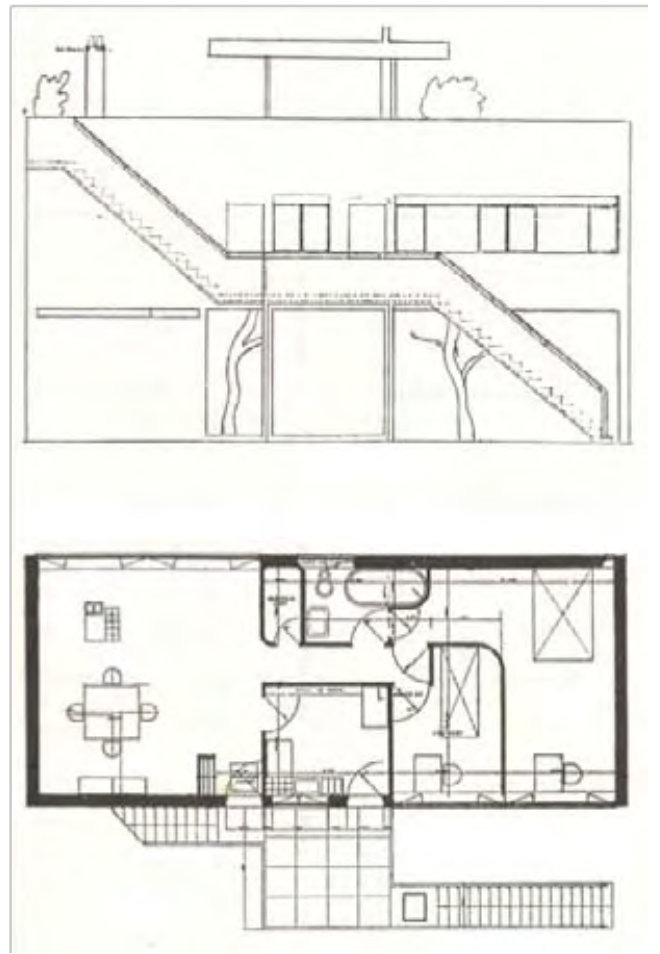

Figura 28 - Elevação e planta da tipologia 4, do projeto de Le Corbusier em Pessac, França.
Joan Villà coloca que esta solução, da escada externa adotada por arquitetos do movimento moderno, aparece com o conceito da industrialização da arquitetura: para manter as lajes iguais, a escada ou qualquer outro elemento vertical seria um elemento perturbador da estrutura de planos horizontais. Em outro projeto de Le Corbusier, em Pessac, França, a tipologia 4, de casas sobrepostas, possui a escada inteiramente externa e acessando o terraço-jardim comum às duas casas, porém, isto não ocorre nas outras tipologias deste bairro projetado e construído em 1927. Na tipologia três, dois tríplex geminados, a escada só fica externa no último nível, para acessar o terraço, e aí já não fica claro se a escada é externa por questões da pré-fabricação ou se por outros motivos programáticos ou espaciais.

Assim, a obra de Joan Villà e Sílvia Chile parece ter resultado nesta tipologia de terraço coberto com acesso pela escada externa principalmente pelas referências populares; por outro lado, foi favorável a posição externa da escada, pois da mesma forma que para os arquitetos do movimento moderno os elementos verticais deveriam, preferencialmente, não perturbar os planos horizontais, neste caso também, pois os painéis de CPC não podem perder a modulação de $47 \times 47$ nos planos horizontais, sendo favorável posicionar a escada externamente ou criar vazios para sua inserção.

Assim, ingredientes conhecidos chegam a uma arquitetura sábia e simples ao mesmo tempo. Algumas coincidências acontecem, mundos e motivos distintos e distantes encontram-se em soluções parecidas, porém, maiores explicações para este fato ainda não são possíveis. $O$ que pode ser afirmado é que os arquitetos partiram de referências populares e eruditas ao mesmo tempo:

Trata-se da capacidade de aprender da arquitetura popular e autoconstruída, com a qual se relaciona desde os anos oitenta e que lhe permitiu conhecer os modos de vida e o seu reflexo nos elementos arquitetônicos imprescindíveis, como a escada por fora, que não é um capricho compositivo, senão que aporta a possibilidades de crescer, subdividir ou arrendar; e a reserva de espaço nas coberturas, que corresponde à cultura popular da autoconstrução e à previsão de um espaço na parte superior para instalações, reuniões, novos dormitórios ou para estender a roupa. Com a sua obra, Joan Villà consegue uma sintonia inédita entre arquitetura culta e popular (MONTANER e MUXÍ, 20I I). 
Dessa forma, seja pela arquitetura das unidades ou pela técnica construtiva que considera a realidade dos assentamentos populares do Brasil, o arquiteto Joan Villà consegue conciliar utopias, tanto do movimento moderno e da crença na industrialização, quanto a utopia de uma arquitetura revolucionária inspirada no canteiro ou utopias mais recentes, que colocam a participação do usuário nos processos de realização dos projetos como algo fundamental e, desta maneira,consegue-se ir mais além:

Entre as utopias da modernidade, uma das mais resistentes à crítica, porque se apresenta como verdade inconteste, é a ideia de que só pela industrialização massiva se pode chegar a resolver a questão habitacional. Outra contra-utopia mais recente é a noção de que a arquitetura só poderá cumprir de fato sua tarefa se contar com a participação do usuário, questionando fundamente o papel do arquiteto como manipulador exclusivo da arquitetura. As soluções propostas, nas obras aqui reunidas, tentam conciliar de maneira viável todas essas utopias, propondo uma terceira: a de que a boa arquitetura pode e deve se feita em quaisquer circunstâncias, por mais difíceis que se apresentem as situações econômicas e sociais (Ruth Verde Zein, em VILLÁ, 2005. p. 4).

Vale a pena citar, a partir deste projeto, algumas soluções programáticas relacionadas aos desejos existentes no habitar contemporâneo.As casas são enfileiradas, assim, a solução de criar um afastamento da porta de entrada, criando um vestíbulo externo, garante um filtro entre espaço exterior coletivo e interior privativo, além de proteger a entrada. Nos renques azul e verde, esta situação de filtro é ainda mais forte devido ao desnível existente, vencido por uma pequena escada que antecede cada entrada das unidades. Observando o interior do sobrado, a escada que acessa o segundo pavimento está posicionada logo à frente da entrada. Esta é outra situação muito encontrada e desejada nos bairros populares das periferias, nos quais, mesmo quando se constrói a casa inteira, considera-se a hipótese de futuras situações de recebimento temporário de filhos ou parentes que venham por ventura a morar na casa, garantindo um possível isolamento dos dois pavimentos e criando verdadeiras casas sobrepostas. A cozinha é integrada a um pequeno quintal externo, com a lavanderia
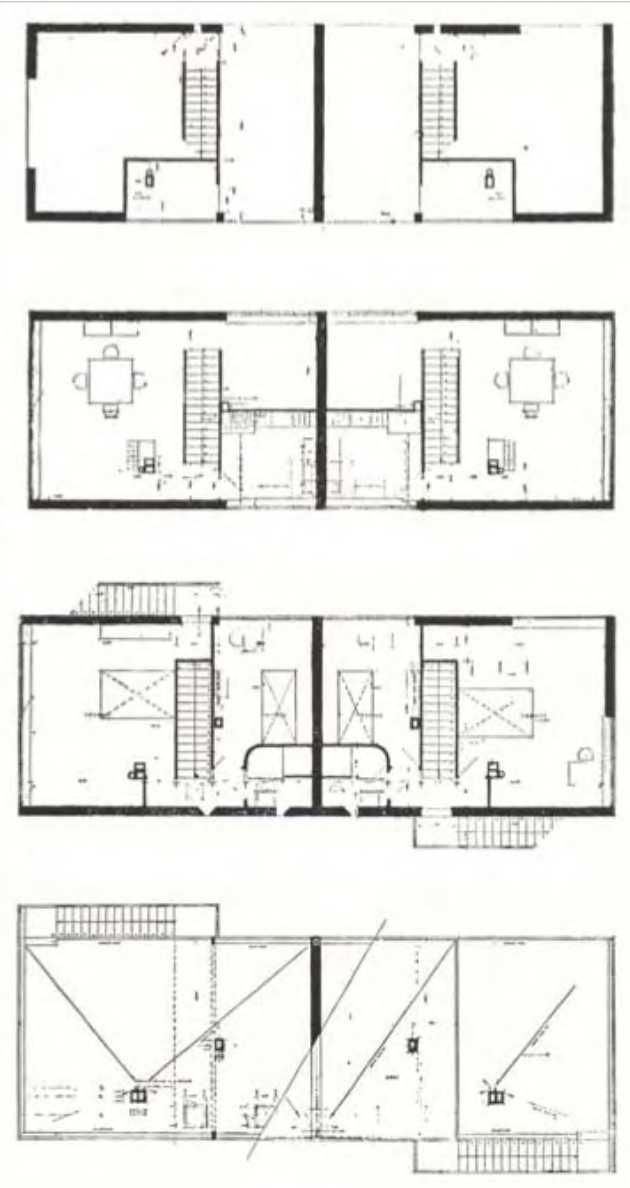

Figura 29 - Plantas da tipologia 3, do projeto de Le Corbusier em Pessac, França. 


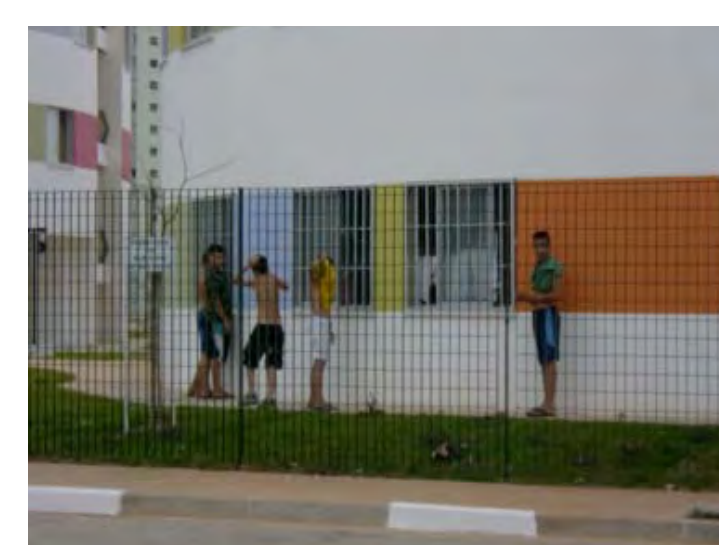

Figura 30 - Crianças espiando apartamento do térreo no conjunto habitacional "SABESP" em Heliópolis, São Paulo. e com a sala.Pode causar um estranhamento o fato da lavanderia não estar integrada ao quintal externo. Mesmo assim, trata-se de uma lavanderia com grandes dimensões, também por incorporar o espaço embaixo da escada, lembrando que existe o terraço que também pode ser utilizado como lavanderia.

No andar superior existem dois dormitórios com tamanhos iguais e um banheiro compartiIhado, assim, não cria-se hierarquia entre os moradores da unidade. A varanda, em um dos dormitórios, possibilita maior contato visual com o espaço público e comunitário, segundo Jacobs (2009), os “olhos da rua”.Ambos conceitos são defendidos no livro "Habitar el Presente" de Montaner e Muxí (2006). O quintal privativo do térreo acaba resguardando o dormitório, afastando-o do espaço de passagem nas áreas coletivas. Esta solução é algo que parece óbvio, mas que é pouco considerada em projetos de habitação de interesse social, principalmente de promoção pública, nos quais os apartamentos térreos acabam sendo prejudicados e, consequentemente, desvalorizados pela falta de privacidade que o projeto proporciona (Figura 30).

As principais mudanças feitas pelos moradores após a ocupação dizem respeito à individualização da escada que acessa o terraço, originalmente comum a cada duas unidades; o levantamento de muro ao redor do jardim privativo e inclusão de algumas proteções nas janelas, pequenos telhadinhos cerâmicos. Em sua maioria, as mudanças estão relacionadas à necessidade ou desejo de proteger mais as áreas privativas, diminuindo ao máximo o que seria o convívio ou contato com os vizinhos. 



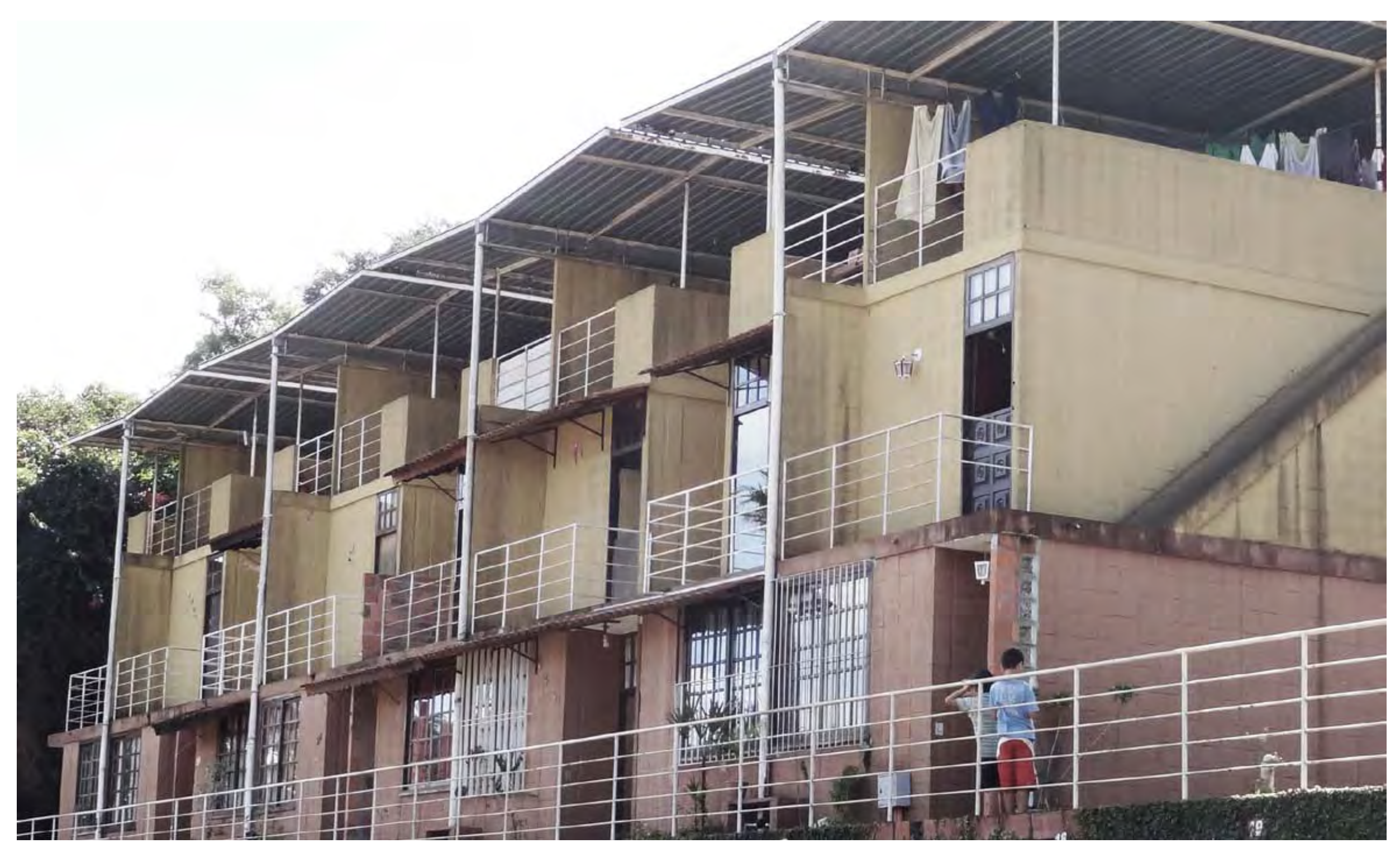

3.1.3.I0 FICHAS GRÁFICAS EM ESCALA 


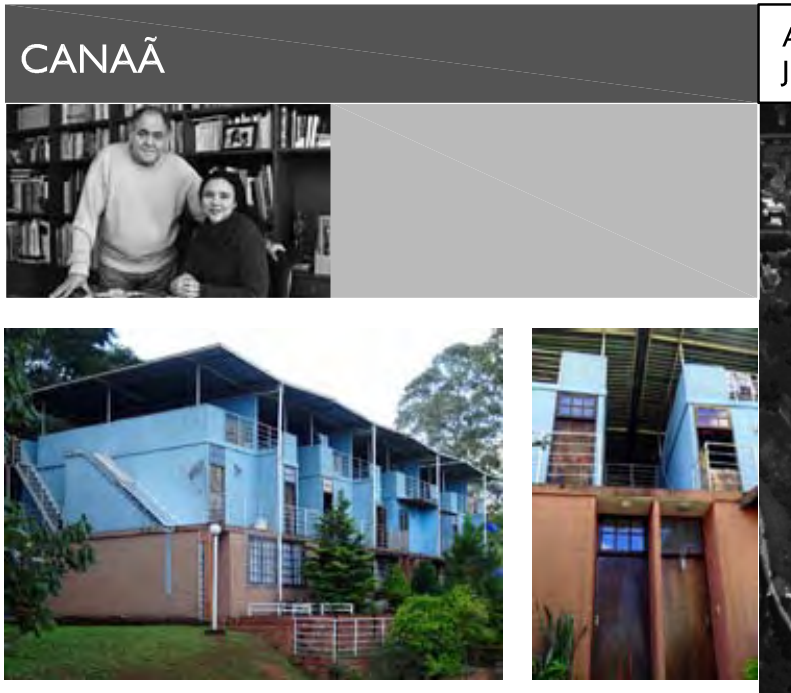

ARQUITETOS:

INSERÇÃO URBANA
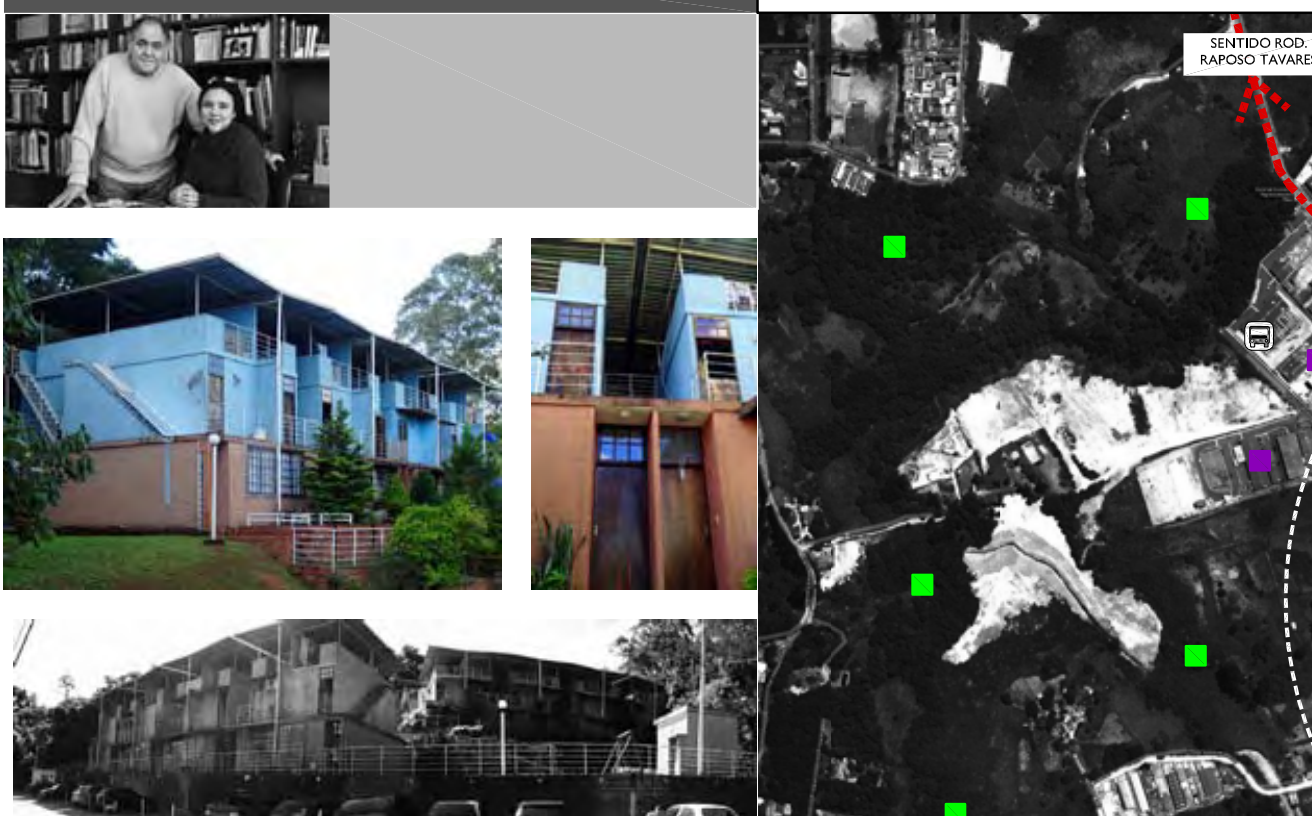

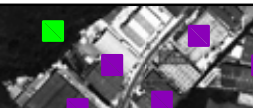
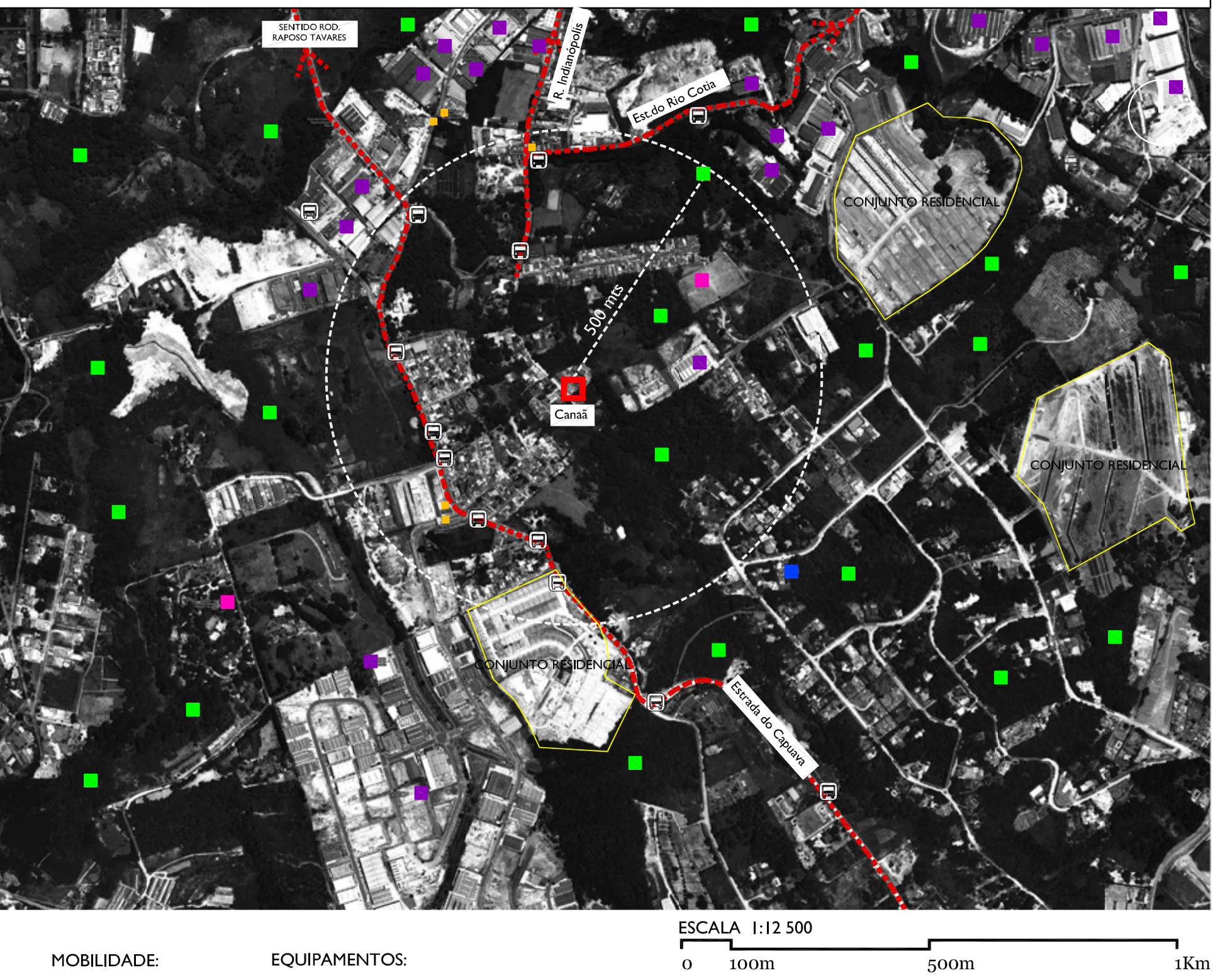

EQUIPE:

Joan Villà e Sílvia Chile (autores); Claudia Mota e Guilherme Mazori (equipe).

CONSTRUÇÃO: Zénica

ESTRUTURA/ PAINEL CPC: Yopanam Rebello

TREINAMENTO MÃO-DE-OBRA: Débora Daukan

INSTALAÇÕES:

Elétrica e Hidráulica: Edson Takahashi;

Saneamento: Luis Fernando Carvalhães;

Drenagem: Edson Garcia da Silva Jr.

PROJETO e CONSTRUÇÃO: 200I-2002

(1)

3

... VIAS PRINCIPAIS

圆 PONTO DE ÔNIBUS
E EDUCAÇão C comércio

\begin{tabular}{llll}
\hline L LAZER & PRAÇA'́rea Verde \\
\hline$S$ & I
\end{tabular}

LOCAL:

Rua Grécia,
Cotia - SP 

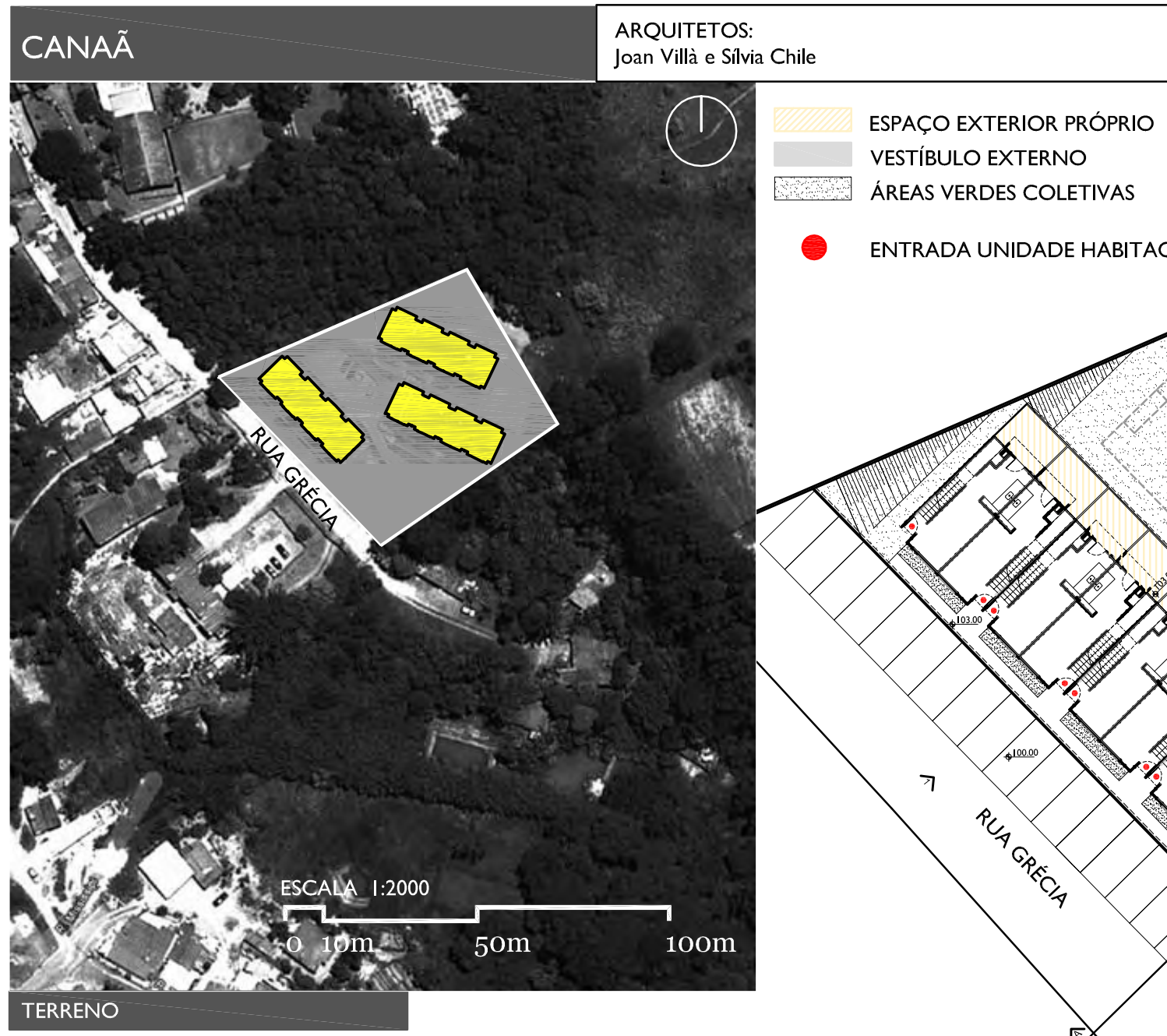

ÁREA DO TERRENO: $3200 \mathrm{M} 2$

ÁREA OCUPADA: $871 \mathrm{M} 2$

\% OCUPAÇÃO: $27 \%$

ÁREA TOTAL CONSTRUÍDA: 2256 M2 C.A.: 0,70

NÚMERO DE UNIDADES: 24

NÚMERO HABITANTES: 96

DENSIDADE: $300 \mathrm{HAB} / \mathrm{HA}$

\section{番}

$256 M 2$

1 


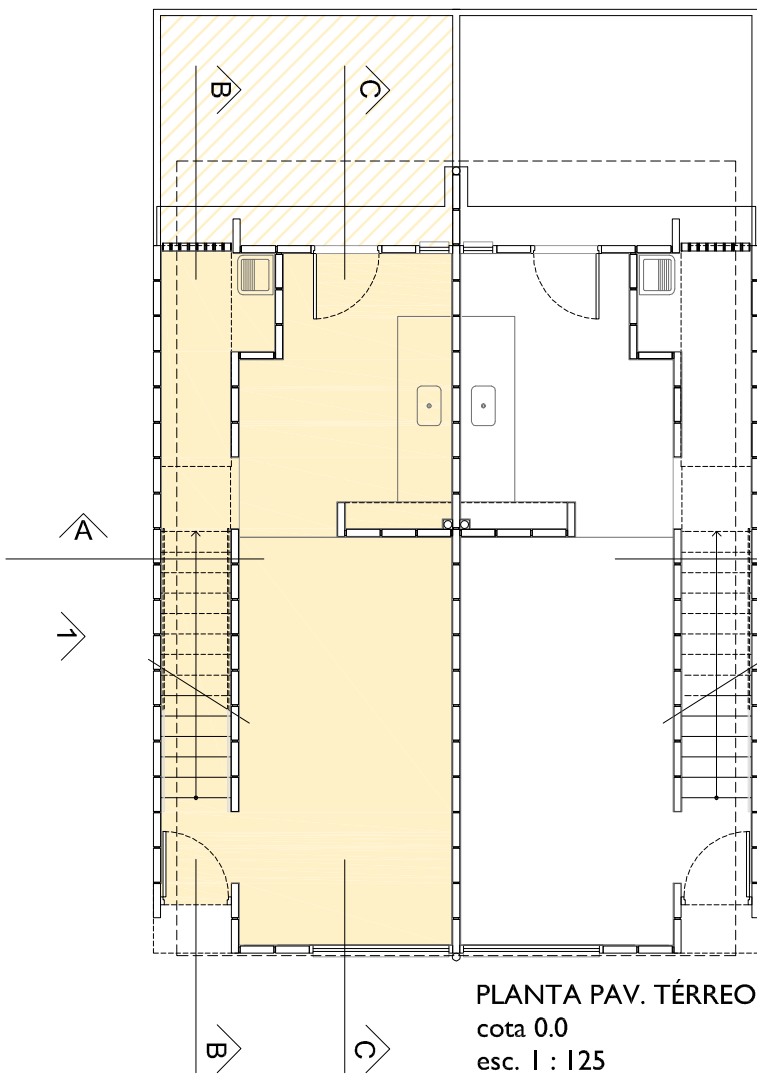

ESPAÇO INTERIOR PRÓPRIO ESPAÇO EXTERIOR PRÓPRIO

\section{ÁREAS TÉRREO}

$\begin{array}{lr}\text { SALA } & 13,98 \mathrm{~m}^{2} \\ \text { COZINHA } & 8,75 \mathrm{~m}^{2} \\ \text { LAVANDERIA } & 3,07 \mathrm{~m}^{2} \\ \text { CIRCULAÇÃO } & 4,19 \mathrm{~m}^{2} \\ \text { QUINTAL } & 10,75 \mathrm{~m}^{2} \\ & \\ \text { ÁREA TOTAL } & 40,65 \mathrm{~m}^{2} \\ \text { AREAS TOTAL UNIDADE: } 94,21 \mathrm{M} 2\end{array}$

A

A

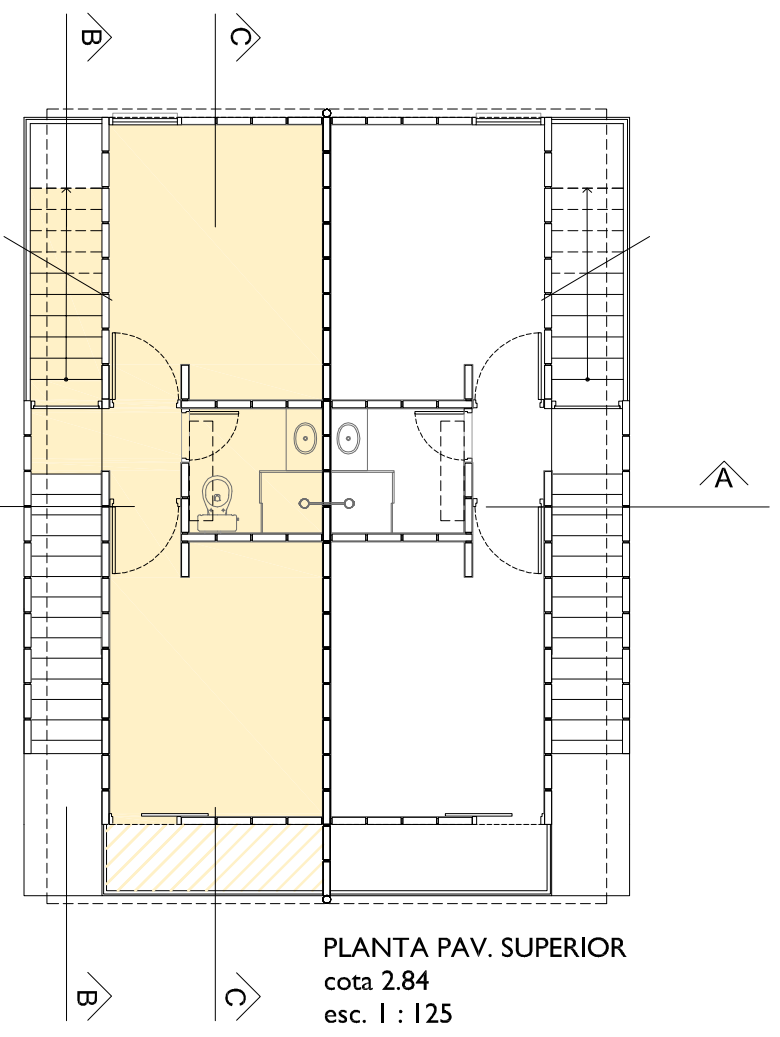

$\widehat{A}$

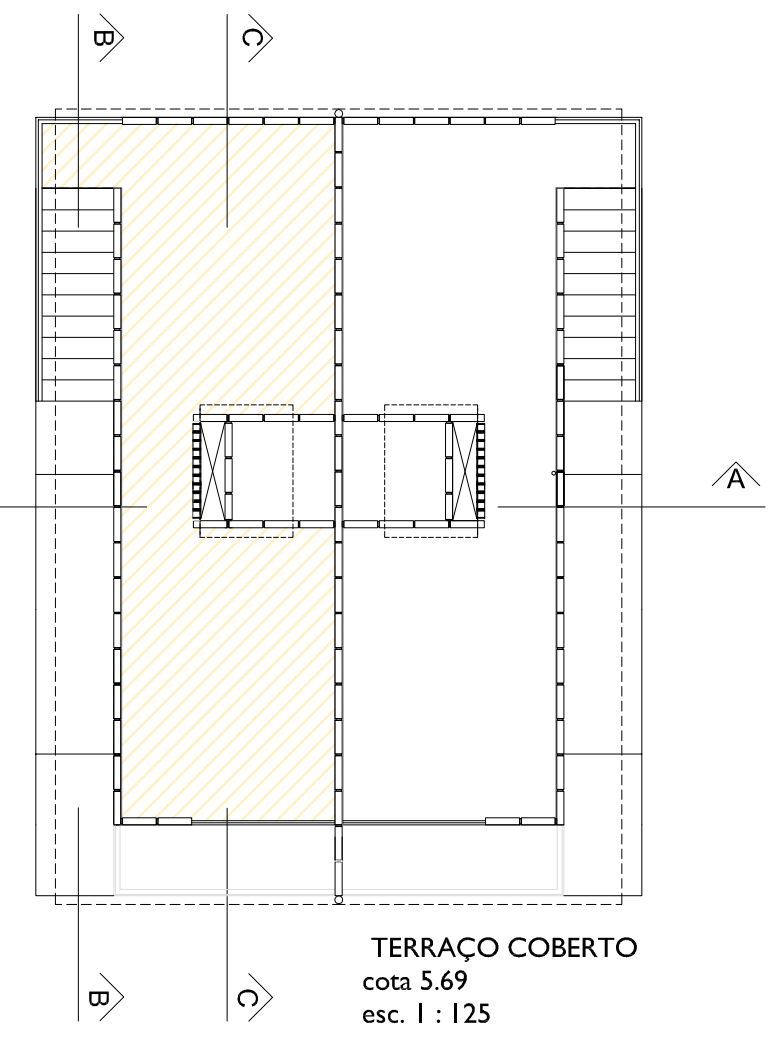

$\times 24$

TIPOLOGIA I

$29,90 \mathrm{~m}^{2}$

$27,01 \mathrm{~m}^{2}$

\section{DORMITÓRIO I $\quad 9,82 \mathrm{~m}^{2}$}

DORMITÓRIO $2 \quad 9,37 \mathrm{~m}^{2}$

VARANDA $\quad 2,31 \mathrm{~m}^{2}$

WC $2,31 \mathrm{~m}^{2}$

$\begin{array}{ll}\text { CIRCULAÇÃO } & 2,67 \mathrm{~m}^{2} \\ & 5,15 \mathrm{~m}^{2}\end{array}$

ÁREA TOTAL $29,32 \mathrm{~m}^{2}$
ÁREA TERRAÇO

COBERTURA

ÁREA TOTAL

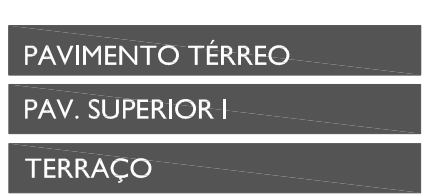

computável $\quad 56,91 \mathrm{~m}^{2}$ não computável $\quad 37,30 \mathrm{~m}^{2}$ total $94,21 \mathrm{~m}^{2}$

$24,24 \mathrm{~m}^{2}$

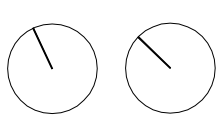

esc. $1: 125$

$\overbrace{0}^{\text {esc. } 1: 125} \overbrace{5 \mathrm{~m}}^{1 \mathrm{~m}}$



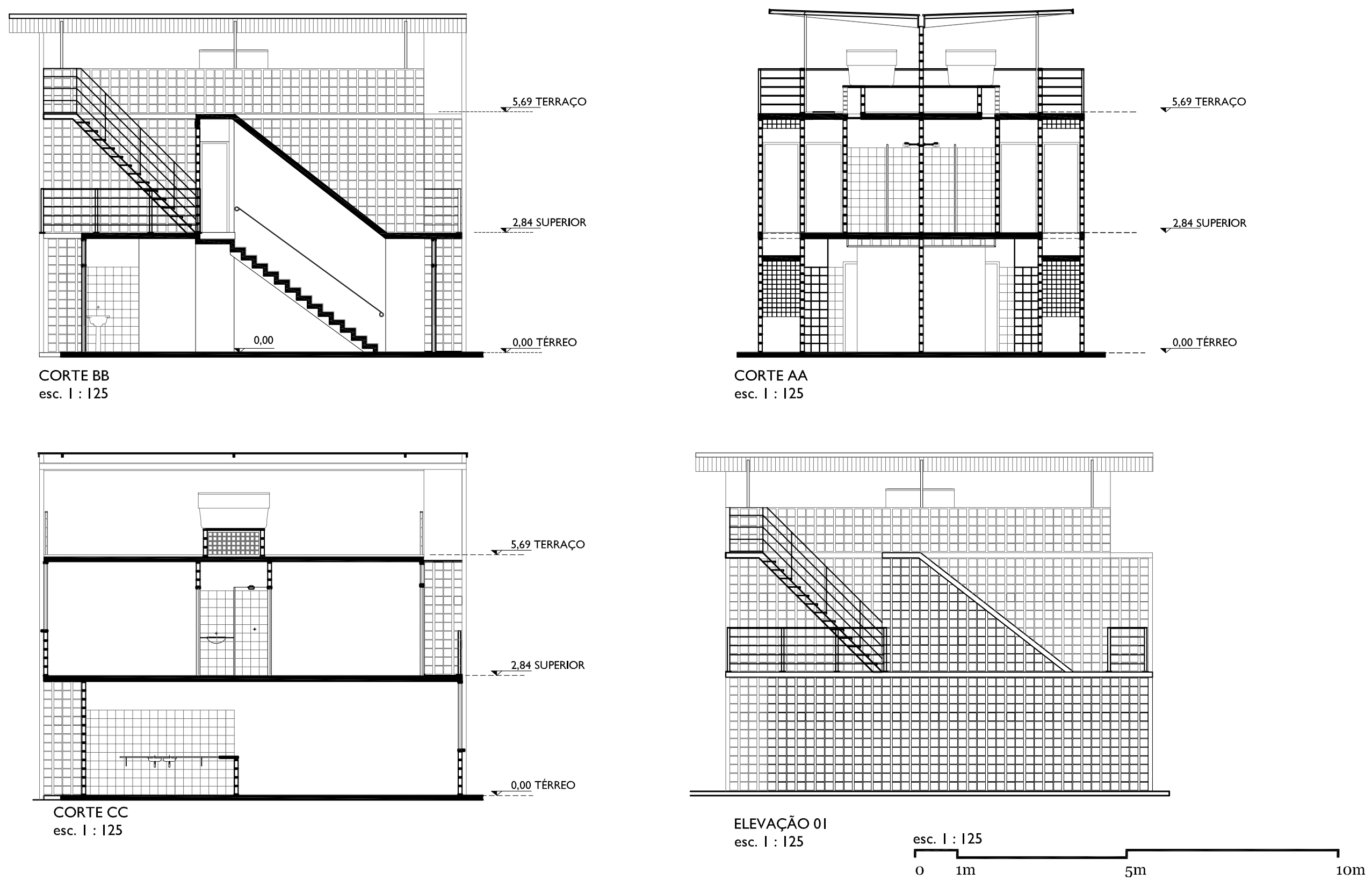


\section{I.3.I I BIBLIOGRAFIA DO CAPÍTULO}

ARANTES, P. F. Arquitetura Nova. Sérgio Ferro, Flávio Império e Rodrigo Lefévre, de artigas aos mutirões. São Paulo: Editora 34, 2002.

BASTOS, M.A. J.; ZEIN, R.V. Brasil: arquiteturas após I 950. São Paulo: Perspectiva, 2010.

BAVARELLI, J. E. O cooperativismo uruguaio na Habitação Social de São Paulo. Das cooperativas FUCVAM à Associação de Moradia Unidos de Vila Nova Cachoeirinha. 2006. Dissertação (Mestrado em Arquitetura e Urbanismo), Universidade de São Paulo, São Paulo, 2006.

BONDUKI, N. Origens da Habitação Social no Brasil. São Paulo: Estação Liberdade, 1998.

BOUDON, P. Pessac de Le Corbusier: Estude socio-architecturale, 1929-1985. Aspects de L'urbanisme, Dewey: Dunod, 1985.

BRUNA, P.J.V. Arquitetura, Industrialização e Desenvolvimento. $2^{\mathrm{a}}$ ed. São Paulo: Editora Perspectiva, 2002.

DIESTE, E. Las tecnologías apropiadas y la creatividad. In: GUTIÉRREZ, R. (Coord.). Arquitectura latinoamericana en el siglo XX. Buenos Aires: Cedodal, 1998, p. 44.

EKERMAN, S. K. Um quebra-cabeça chamado Lelé. São Paulo:Vitruvius, 064.03, setembro 2005. Disponível em: < http://www.vitruvius. com.br/revistas/read/arquitextos/06.064/423>. Acesso em: I2/09/20I2.

ELOY, Edison; BOGÉA, Marta; REBELLO,Yopanan. Invenção: popular e erudito. Arquitetura e Urbanismo, São Paulo, n. I4I, dezembro de 2005.

FERRO, S.A casa popular (1969). Em: FIORI, P.A. (Org.). Arquitetura e trabalho livre. São Paulo: Cosac Naify, 2006.

O canteiro e o desenho (1976). Em: FIORI, P.A. (Org.). Arquitetura e trabalho livre. São Paulo: Cosac Naify, 2006.

JACOBS, J. Morte e vida de grandes cidades. $2^{\mathrm{a}}$ ed. São Paulo: Martins Fontes, 2009.

JUNQUEIRA, Monica de Camargo.Arquétipo verdadeiro. ProjetoDesign, São Paulo, n. 37I, p. 90, janeiro de 20 I I.

.Arte como construção. Arquitetura e Urbanismo, São Paulo, n. I46, maio de 2006.

LINO, S. F. A obra de Eladio Dieste: flexibilidade e autonomia na produção arquitetônica. São Paulo:Vitruvius, 096.04, maio 2008. Disponível em: < http://www.vitruvius.com.br/revistas/read/arquitextos/08.096/I42 >. Acesso em: I3/06/20I 2.

MARICATO, E. Brasil, Cidades alternativas para a crise urbana. Rio de Janeiro: Editora Vozes, $200 \mathrm{I}$. 
MONTANER, J. M.; MUXÍ, Z. M. Habitar el presente. Vivienda en España: Sociedad, ciudad, tecnología y recursos. Madri: Ministerio de Vivienda, 2006.

Joan Villà, construções para a sociedade. La Vanguardía, Barcelona, maio de 20I I.Tradução Sílvia Chile.

OLIVEIRA, Roberto de.Arquitetos tentam mudar a sina da falta de criatividade que transforma os projetos de moradia popular em caixotões sem alma e sem graça. Revista da Folha, caderno Morar, São Paulo, agosto de 2007.

POMPÉIA, R.A. Os laboratórios de Habitação no ensino da arquitetura. Uma contribuição ao processo de formação do arquiteto. 2006. Tese (doutorado em Arquitetura e Urbanismo), Universidade de São Paulo, São Paulo, 2006.

RUGGIERO,A. S. Jorge Caron: uma trajetória. 2006. Dissertação (mestrado em Arquitetura e Urbanismo), Escola de Engenharia de São Carlos, Universidade de São Paulo, São Carlos, 2006.

SAYEGH, Simone. Arquitetura popular brasileira. Arquitetura e Urbanismo, São Paulo, n. I26, setembro de 2004.

SERAPIÃO, Fernando. Brasileiro nas cores e nas intenções. ProjetoDesign, São Paulo, n. 278, abril de 2003.

VILLÀ, J. A construção com componentes pré-fabricados cerâmicos: sistema construtivo desenvolvido entre 1984 e 1 994, em São Paulo. 2002. Dissertação (mestrado em Arquitetura e Urbanismo), Universidade Presbiteriana Mackenzie, São Paulo, 2002.

Construções. São Paulo: Centro Universitário Belas Artes de São Paulo, 2005.

ZULIN, F.Viviendas en la Calle Grécia: Buena Arquitectura compatíble con la cultura y economía locales. X Seminario Investigación Urbana y Regional. Políticas de vivienda y derechos habitacionales. Pontifícia Universidad Javeriana y Instituto Javeriano de Vivienda y Urbanismo. Bogotá, 2012.

VISITA REALIZADA:

Canaã: 29 de Maio de 2012

ENTREVISTA:

Arquitetos Joan Villà e Sílvia Chile - 29 de junho de 2012 


\section{I.4 VILA TAGUAÍ: PARCERIA ENTRE ARQUITETURA E ENGENHARIA}

\section{I.4.I INTRODUÇÃO}

AVila Taguaí representa mais um empreendimento da pesquisa que desafia o status quo', seja pela utilização de novo método construtivo - que é alcançado a partir de pesquisa para desenvolvimento de um novo tipo de painel de madeira estrutural, realizada pela Ita Construtora, que tinha este desejo muito tempo antes de acontecer de fato este empreendimento - como também pela resolução da técnica de maneira integrada com a arquitetura, representando uma parceria forte entre arquitetura e engenharia. É uma obra contemporânea exemplar com o uso da madeira e que traz importante avanço no aprimoramento da construção com esse material, consequência de uma trajetória com muito conhecimento no ramo que a Ita Construtora possui.A frase abaixo consegue expressar o que esta obra representa: mistura de raciocínio técnico com uma preocupação que vai além do racional e que consegue, portanto, tornar esta obra expressiva em ambos os sentidos, técnico e espacial.

\begin{abstract}
Dependem do projeto muitas simplificações possíveis: o uso de módulos que facilitam medições, o emprego de materiais de construção de dimensões constantes (o bloco de concreto), a padronização dos caixilhos que auxilia a produção, as instalações elétricas e hidráulicas aparentes e centralizadas, a sistematização de detalhes de acabamento, etc. Todos estes procedimentos têm consequências favoráveis. Estas preocupações em nada prejudicam a caracterização arquitetônica mais expressiva. Ao contrário, fazem surgir oportunidades formais inteiramente novas (FERRO; LEFÉVRE, 1965, apud ARANTES, 2006, p. 4I).
\end{abstract}

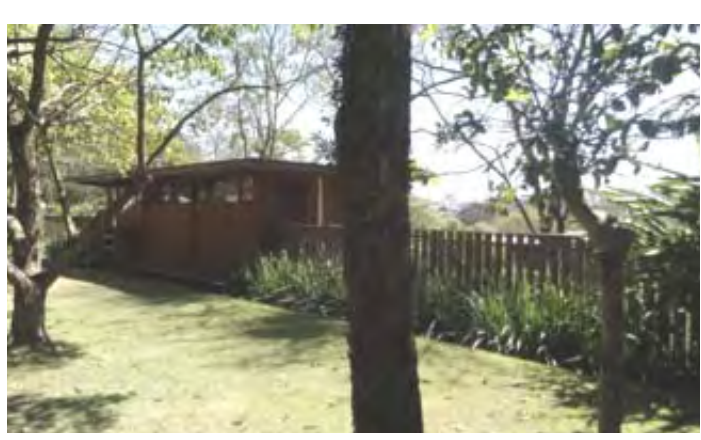

Figura I - Entrada Vila Taguaí: exemplo singular de vila contemporânea. 


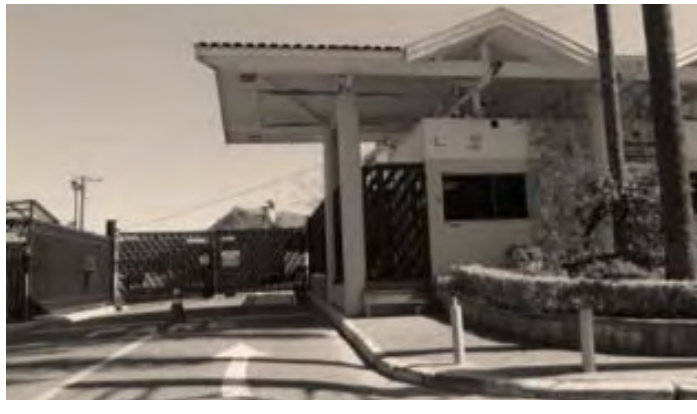

Figura 2 - Portaria de condomínio fechado próximo à Vila Taguaí.

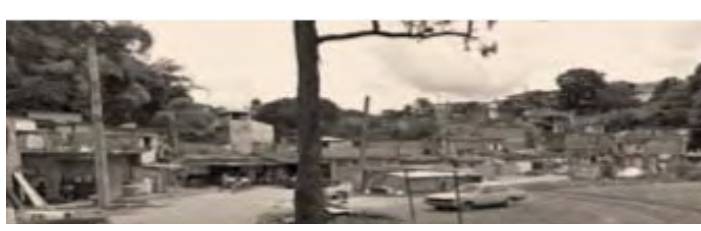

Figura 3 - Favela próxima à Vila Taguaí.

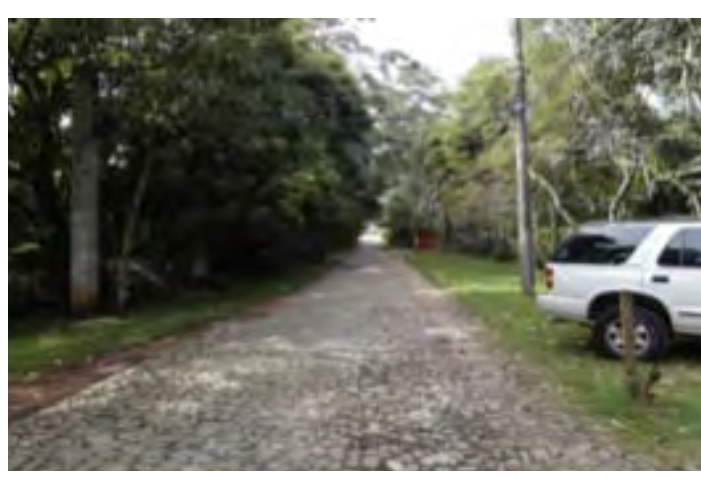

Figura 4 - Estrada Taguaí, tratamento diferenciado da pavimentação.

\subsubsection{INSERÇÃO URBANA}

A Vila Taguaí fica a aproximadamente vinte quilômetros de São Paulo, sendo o principal acesso pela Rodovia Raposo Tavares.AVila fica na altura da Estrada da Aldeia, caminho que leva também à Aldeia de Carapicuíba, erguida em meados do século XVI por padres Jesuítas. Quando se observa o território ao redor, as diferentes texturas urbanas e naturais ficam evidentes, tratando-se, portanto, de um território heterogêneo tanto no sentido físico como social. Por exemplo, podem ser identificados trechos com inúmeras casas em condomínios fechados de alto padrão e, em outros casos, algumas favelas ou loteamentos extremamente populares (Figuras 2 e 3).

A localização acaba não sendo de fácil acesso para quem não tem carro e precisa ir até São Paulo todos os dias. Porém, existem perfis de famílias que conseguem e sentem prazer em morar em local mais afastado da cidade e com relação direta com a natureza. $O$ artigo publicado na Folha de São Paulo, "Paulistanos trocam a capital por condomínios no interior", esclarece este desejo de alguns paulistanos em morar em locais mais distantes do agito de São Paulo, mesmo possuindo emprego na capital. Independentemente de ser favorável ou não urbanisticamente, este desejo existe, e este projeto ao menos consegue atendê-lo com qualidade, sem muros ou isolamentos:

A paisagem ao redor de São Paulo está mudando. Entre as fazendas e plantações que circundam a cidade, é possível notar cada vez mais casas de alto padrão surgindo atrás de muros. É um movimento formado por um novo tipo de migrante: paulistanos das classes A e B que trocaram o agito e a insegurança da capital por uma vida mais confortável em condomínios fechados fora da metrópole. Esses condomínios e loteamentos nos arredores de São Paulo se transformaram numa das febres do mercado imobiliário. Nos últimos três anos, surgiu um a cada cinco dias, segundo levantamento da Embraesp (Empresa Brasileira de Estudos de Patrimônio) (RIBEIRO, 20I I). 
A Vila Taguaí representa, portanto, outra possibilidade de atendimento a essa demanda com solução diferenciada da oferecida pelo mercado imobiliário. $O$ projeto da Vila estimula o convívio entre os moradores a partir da inexistência de limites rígidos entre as casas ou entre o condomínio e a estrada pública. Obviamente não é nada próximo ao convívio existente numa área central proporcionado por espaços públicos com qualidade, porém, já não tem uma esfera tão individualista como a dos empreendimentos antagônicos aqui citados. No entanto, é uma preocupação a criação de manchas urbanas distantes da capital, e que em muitas situações dependem do meio de transporte individual. No caso da Vila Taguaí, existe uma linha de ônibus que tem interligação com a estação de metrô Butantã, linha amarela, mas o ponto mais próximo fica a aproximadamente I km da Vila².

$\mathrm{Na}$ estrada Taguaí, onde fica a Vila que leva seu nome, nota-se uma preservação da mata existente e ausência de limites físicos marcantes entre a via e os limites dos terrenos, diferente do que acontece, por exemplo, nos condomínios fechados, em que a própria classificação já aponta isto. Trata-se de um trecho territorial com características distintas dos dois tipos existentes citados: nem favela, nem isolamento em ilhas “protegidas". A estrada é pavimentada de maneira muito suave, com pedras que formam um mosaico que permite a infiltração da água da chuva. Não existe uma calçada convencional, formada por guias e sarjetas, mas, sim, margens gramadas que permitem a infiltração da água da chuva com dimensão adequada para parada de carros na diagonal (Figura 4).A arquiteta Cristina Xavier teve participação nestas pequenas e importantes decisões arquitetônicas no espaço público da estrada, assim, já é possível identificar algumas características de sua arquitetura desde o espaço exterior aos limites da Vila Taguaí. Inclusive tais características no espaço externo são estendidas ao interior da Vila.

Conforme relato de Cristina Xavier, existem muitos arquitetos que moram na região, inclusive há também nesta estrada sem saída, quase de frente para a entrada da Vila Taguaí, uma casa ícone

${ }^{2}$ Informações sobre a linha de transporte público existente: Linha 492TRO Carapicuíba (Parque Jandaia) / São Paulo (Metrô Butantã), via São Paulo (Rodovia Raposo Tavares). Disponível em: <http://www.emtu.sp.gov.br//Sistemas/linha/resultado_imp. htm?numlinha=19193>. Acesso em: 29/09/2012.
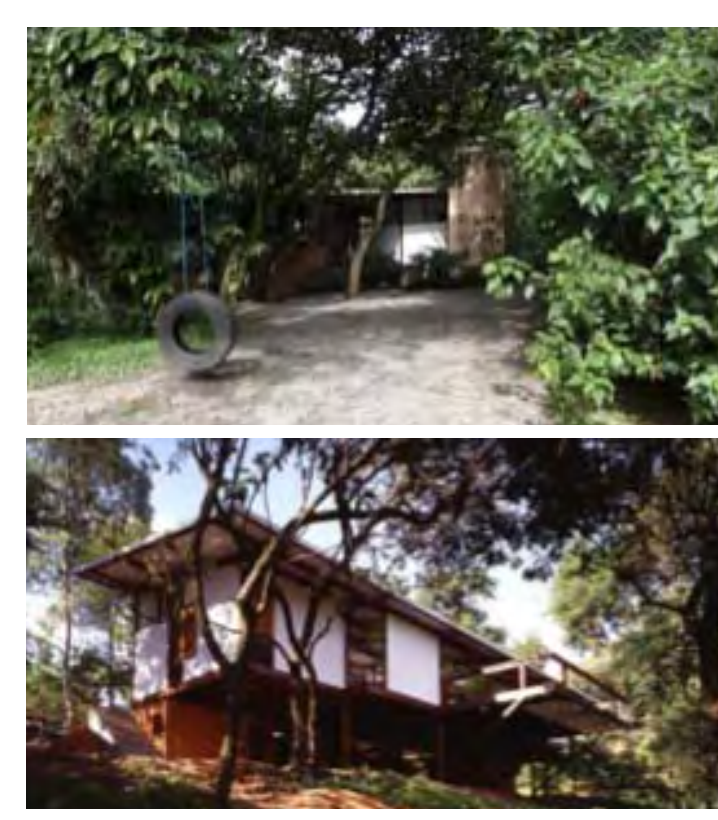

Figuras 5 e 6 - Casa em Carapicuiba, UNA Arquitetos, 1998.

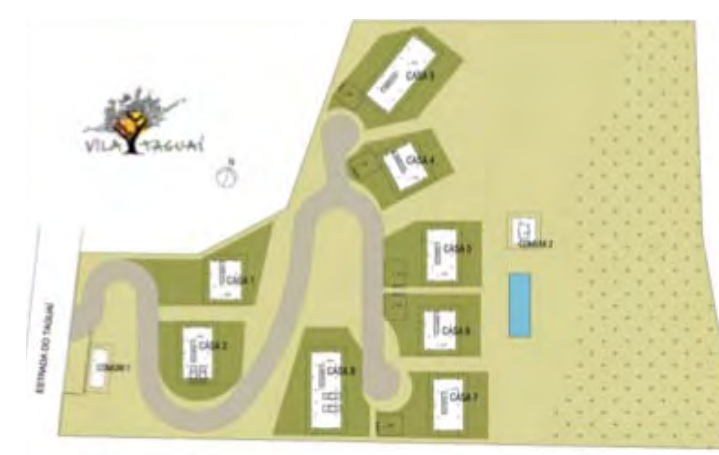

Figura 7 - Representação da implantação no folheto de vendas, com definição do que seria o limite do lote, situação que, na realidade, não fica evidente. 


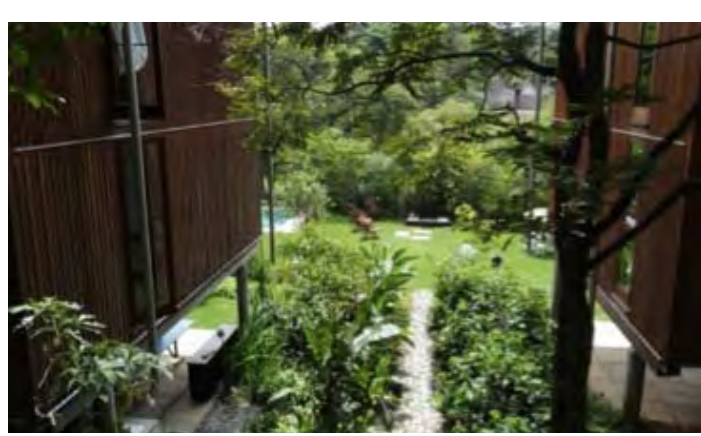

Figura 8 - Espaço entre casas 6 e 7: caminho de pedras que leva ao espaço de lazer comunitário ao fundo e inexistência de cercamentos ou divisas entre as casas.

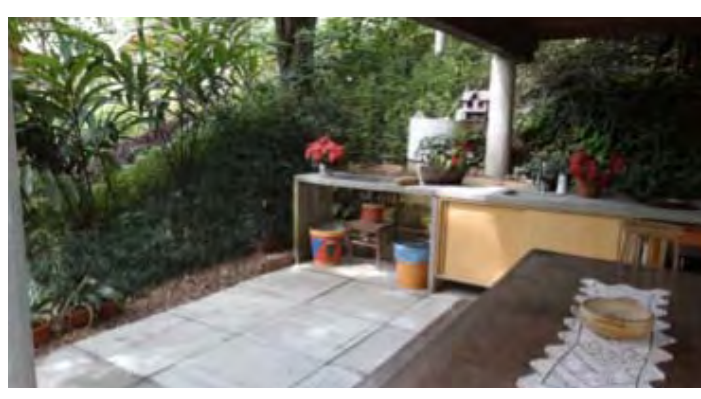

Figura 9 - Espaço no nível dos pilotis: ambiente intermediário entre o coletivo e o privativo.

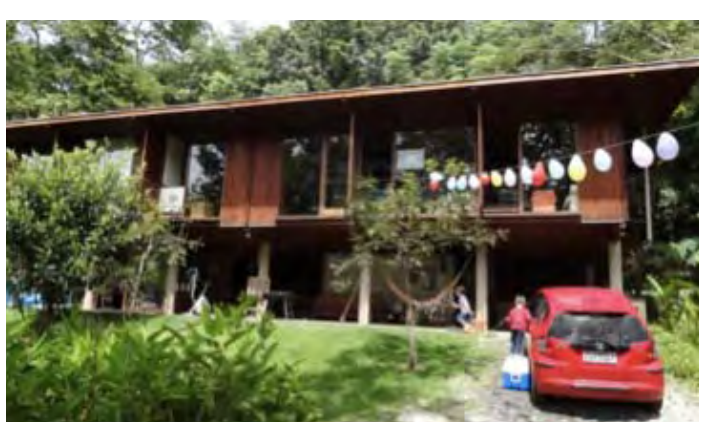

Figura 10 - Casa 5: ocupação do espaço do nível dos pilotis. da arquitetura paulistana projetada pelo escritório UNA Arquitetos, concebida no final dos anos 1990, inclusive com projeto da estrutura de madeira elaborado pelo engenheiro Hélio Olga, também autor e sócio da Vila Taguaí (Figuras 5 e 6). Existe assim, neste trecho final da estrada, toda uma atmosfera a favor da boa arquitetura.

\section{I.4.3 PARTIDO DE IMPLANTAÇÃO}

O lote no qual foi implantada a Vila possui aproximadamente $12.000 \mathrm{~m}^{2}$ e grande declividade em direção ao fundo do vale. Devido às grandes proporções, o arranjo formado pelas oito casas diferencia-se do realizado no lote de $1.300 \mathrm{~m}^{2}$ da Vila Fidalga, também de autoria da arquiteta Cristina Xavier, no qual havia uma quase sobreposição de espaços e distanciamentos menores que pediam maiores cuidados na definição dos espaços coletivos.

Na Vila Taguaí é criada uma faixa não edificada ao fundo do terreno, onde existe um brejo, e assim as casas ficam mais concentradas na parte frontal do terreno, de tal maneira a preservar ao máximo a topografia e as espécies vegetais existentes. Mesmo concentrada, as casas possuem distanciamentos favoráveis entre si, com percursos livres e sem qualquer tipo de cercamento. Foram definidos caminhos com pedras para duas escalas - automóveis e pedestres - que aparecem como continuidade da estrada de acesso ao conjunto de casas. Como já foi dito, não existem limites rígidos entre áreas coletivas e privativas, sendo os limites entre estes dois tipos de espaço definidos pelos jardins privativos, sem cercamentos. Assim, diferentemente do que aparenta o folheto de vendas (Figura 7), os limites entre as casas são muito sutis. O nível dos pilotis do terraço já evidencia um espaço caracterizado e pertencente aos moradores de uma determinada casa, porém, não existem barreiras que demonstrem essa divisão, situação diferente da que ocorre em condomínios horizontais promovidos frequentemente pelo mercado imobiliário, nos quais as casas possuem recuos estreitos e, portanto, muros de divisa muito próximos (Figura 12). Na Vila Taguaí, a tática de regular 
os espaços privativos pelo coletivo é feita através de jardins, que são grandes e com clareiras de onde surgem os terraços, sob pilotis. Trata-se da mesma tática da Vila Fidalga, porém, numa área maior e mais densa com relação à arborização existente. Mesmo sendo um limite suave e sutil, é um limite regulador dos espaços privativos em relação às áreas coletivas, que devem ser preservadas e destinadas ao benefício comum dos moradores.

\section{I.4.4 ESPAÇOS EXTERIORES}

Com exceção do espaço sob pilotis de cada uma das oito unidades, todo o térreo é coletivo, com predomínio das áreas verdes. Posicionada mais ao fundo do terreno, há uma área de lazer coletiva com piscina e um espaço coberto (pequena área de $16 \mathrm{~m}^{2}$ ) para múltiplas atividades: espaço para brincar, para fazer ginástica, para ouvir música, ler um livro, enfim, um espaço neutro com diversas possibilidades de aproveitamento. $A$ área de lazer é voltada às aberturas de algumas casas, tornando-se bastante visível e bem aproveitada pelos moradores. A natureza é muito presente e bem integrada a estes espaços coletivos, colaborando com as áreas de lazer, ou nos próprios percursos existentes ao longo do conjunto (Figura 8).

\section{I.4.5 PERFIL DOS MORADORES}

Durante a visita, foi possível delinear um pouco o perfil dos moradores: famílias com crianças pequenas; famílias com cachorros; jovens casais, alguns que, inclusive, não precisam trabalhar fora de casa todos os dias, pois o acesso à internet já possibilita transformar a casa em lugar de trabalho; a própria arquiteta e sua família, mas, principalmente, trata-se de um público diferenciado que se importa e tem consciência das soluções de baixo impacto ambiental, presentes na Vila.

No dia da visita, um sábado, foi possível presenciar os vizinhos organizando uma confraternização

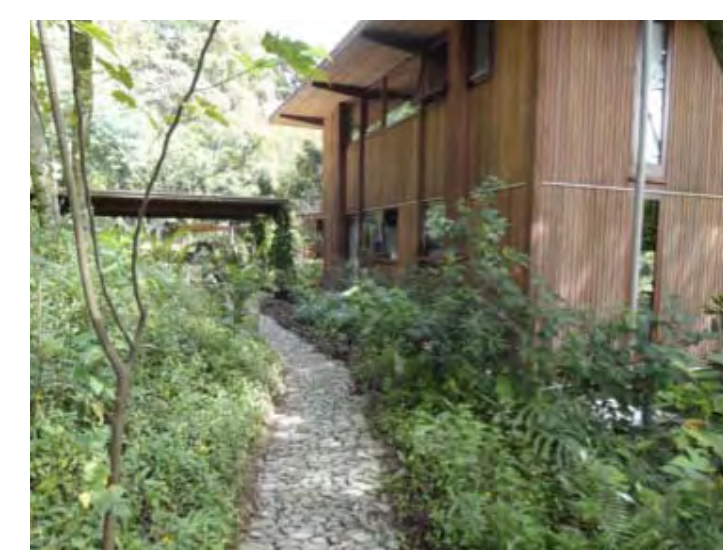

Figura I I - Casa 3: acesso no nível intermediário.

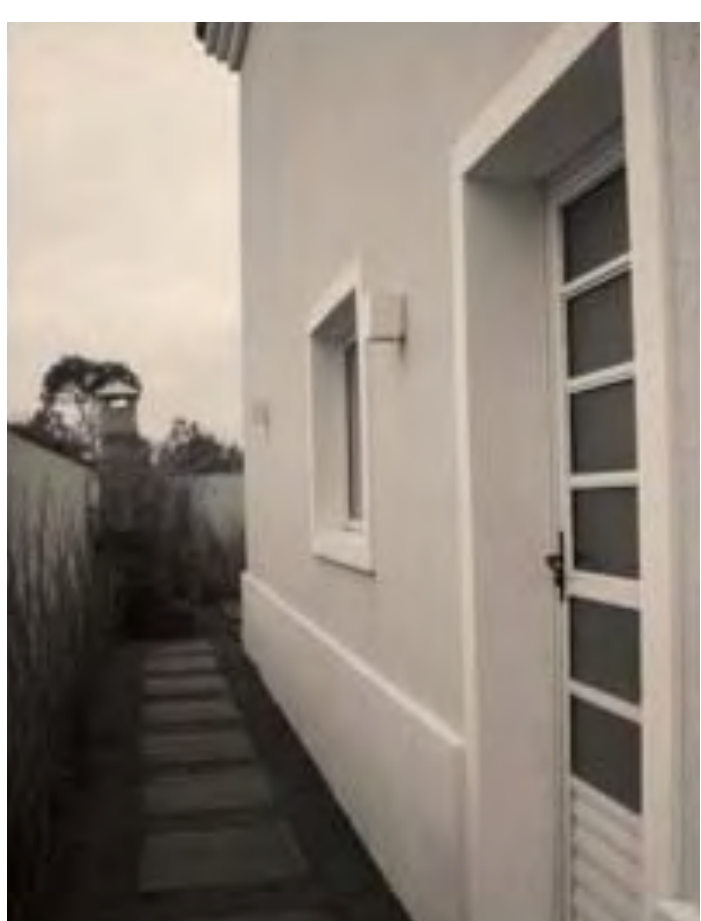

Figura 12 - Casa em condomínio fechado em Carapicuíba: recuo mínimo entre as casas e muro de divisa. 


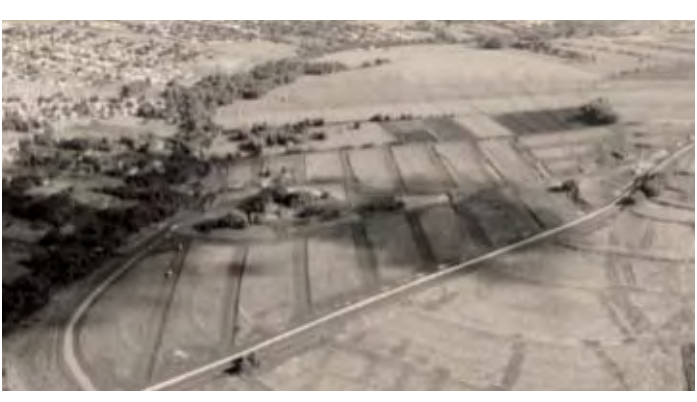

Figura 13 - Condomínio recém loteado na cidade de Sarandi, vizinha a Maringá, no estado do Paraná - muro com mais de I km de extensão, isolamento do uso residencial e nenhuma preocupação com a preservação do meio ambiente, mesmo beirando córrego.

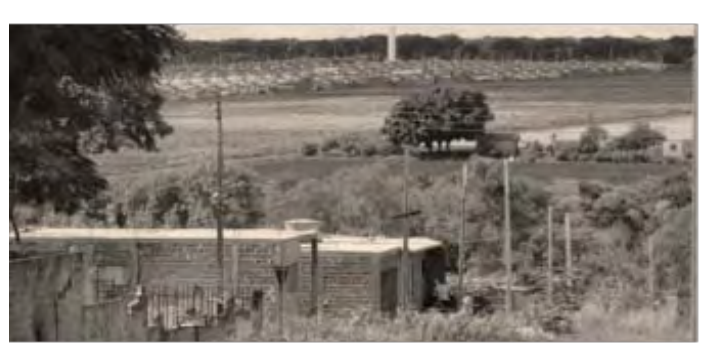

Figura 14 - A existência de conjuntos residenciais isolados, tanto aqueles destinados à população de baixa renda, quanto para população da classe $A$ e $B$, está relacionada, também, ao custo do solo muito elevado nas cidades. Foto de um conjunto promovido pelo programa "Minha Casa Minha Vida” em Sarandi, Paraná. que seria aberta aos moradores do trecho final da estrada, para que todos conhecessem a Vila onde moram: sinal de satisfação e também de entrosamento entre os vizinhos da Vila e da estrada.Assim, percebe-se que a escolha pelo imóvel partiu não apenas do espaço privativo das unidades, mas da Vila como um todo.Assim, para um cliente comum, estas questões arquitetônicas passariam despercebidas, porém, neste caso, os moradores querem que a Vila mostre quem eles são.

É interessante a própria arquiteta morar em uma das unidades e poder participar das decisões pós-ocupação. São simples necessidades, como, por exemplo, a criação de um pequeno espaço cercado para cada unidade ou para aquelas em que existem cachorros, pois são muitos na Vila e isto pode se tornar um problema. Uma simples necessidade como esta poderia ter uma solução desastrosa, porém, com a arquiteta presente, chegarão numa solução que não enfraquecerá o conceito da Vila e que permitirá um convívio harmonioso entre vizinhos.

\subsubsection{AGENTES}

O projeto representa mais uma parceria entre a Arq. Cristina Xavier e o Eng. Hélio Olga Jr., sendo o primeiro caso em que os dois juntos são empreendedores do próprio projeto. Estes exemplares em que arquitetos (e engenheiros também para este caso) qualificados assumem todo o processo do empreendimento dificilmente resultam em soluções padronizadas, ao contrário, representam verdadeiros laboratórios de criação e experimentação. Segundo a arquiteta, a concepção desta Vila partiu principalmente da intenção do Engenheiro Hélio Olga de criar uma nova técnica construtiva, a partir de realização de pesquisa, baseada no aproveitamento total da madeira, a partir da utilização de pequenos retalhos maciços que sobram e que ficam quase sempre sem aproveitamento. Quando começaram a pesquisar o local para realização deste projeto, acabaram optando por esta gleba em Carapicuíba por motivos de custo do terreno, facilidade de aprovação na prefeitura, além da escassez de terrenos na capital paulista. Uma das polêmicas da época para aprovação de projetos 
no município de São Paulo era, por exemplo, considerar garagem ou áreas cobertas como área computável. Na verdade, até 2004 , as construções de prédios eram realizadas sem que as garagens fossem computadas no cálculo do coeficiente de aproveitamento. Ao sancionar a Lei $n^{\circ} 13.885^{3}$ a então prefeita da cidade de São Paulo, Marta Suplicy, vetou incisos que estabeleciam as áreas não computáveis para efeito do cálculo do Coeficiente de Aproveitamento do Solo. Assim, as garagens passaram a integrar nos cálculos, o que elevou os custos das construções, já que para acrescentar essa área a seus projetos os construtores precisariam pagar a outorga onerosa. Isso fez com que o número de projetos para a construção de edifícios na cidade caísse substancialmente. Caso a Vila fosse em São Paulo, por exemplo, o espaço sob pilotis contaria como área construída.Também havia outra questão relacionada à legislação sobre edificações de madeira, que implica em afastamentos entre as construções e limitações de gabarito de altura que acabaram por inviabilizar a construção com madeira em um terreno na Vila Madalena, como era a intenção dos dois empreendedores inicialmente; já que se tratava de um lote pequeno, portanto os afastamentos deixariam pouco espaço livre edificável para realizar o projeto. Dentro deste cenário e com um objetivo muito específico de trabalhar com a madeira de forma integral, Hélio Olga Jr. e Cristina Xavier optaram por uma gleba fora de São Paulo e a poucos metros do escritório da arquiteta.

Mesmo sendo uma região na qual o mercado imobiliário já atua, este terreno, em especial, não possuiu características desejáveis para a construção de empreendimentos comuns, a começar pela topografia acidentada e a necessidade de preservação da massa arbórea existente. Assim, a busca por esta oportunidade já representa uma infiltração urbana. Abaixo, Fernando Diez explica o conceito e expõe que uma das maneiras de infiltração urbana está relacionada à localização do terreno, entre outros fatores:

${ }^{3}$ LEl No 13.885, de 25 de Agosto de 2004 estabelece normas complementares ao Plano Diretor Estratégico, institui os Planos Re-
gionais Estratégicos das Subprefeituras, dispõe sobre o parcelamento, disciplina e ordena o Uso e Ocupação do Solo do Município de São Paulo.

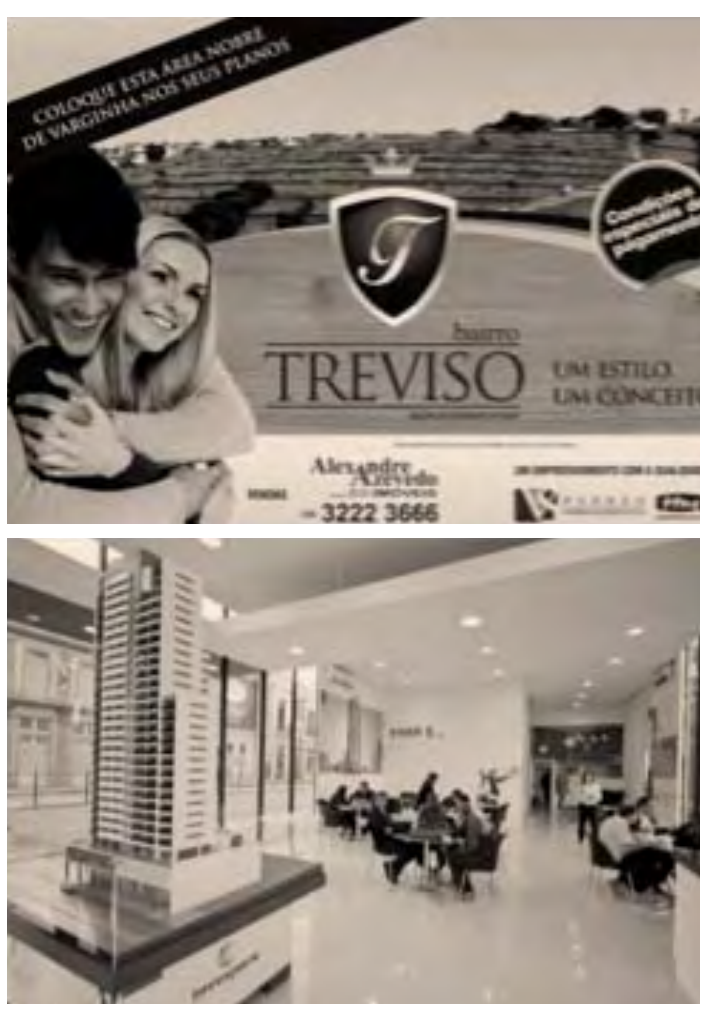

Figuras 15 e 16 - Exemplo de folheto publicitário e stand de vendas típicos do mercado imobiliário, mas que, para a Vila Taguaí, foram inexistentes. 
Figura 17 - Folheto de vendas da Vila Taguaí: apresentação arquitetônica e não publicitária.

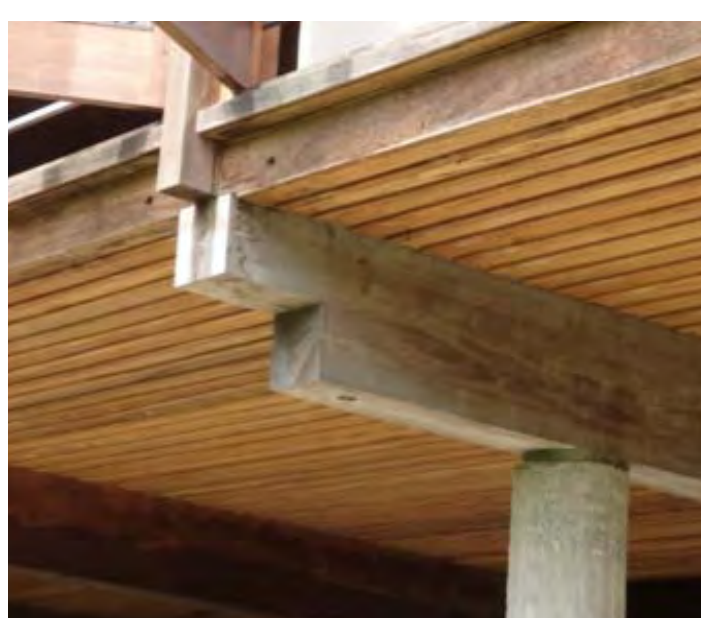

Figura 18 - Detalhe do painel laje apoiado nos pilotis de concreto.
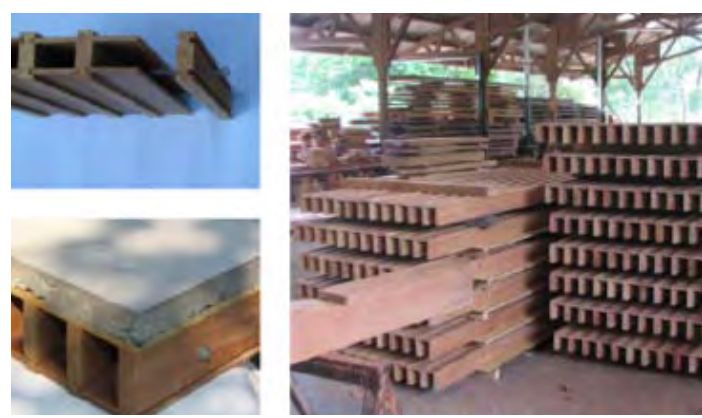

Figura 19 - Detalhe do painel, módulo construtivo do projeto.
Este tipo de infiltración sobre el território urbano y las reglas establecidas de las inversiones inmobiliarias es llevado adelante por jóvenes arquitectos interesados en construir arquitectura experimental, pensando más allá de la demanda estandarizada por las convenciones del mercado. En busca de esa oportunidad, se movilizan para encontrar y reunir sus próprios inversores y para conseguir terrenos en localizaciones que presentan una oportunidad, antecipándose a las tendências inmobiliarias e inclusive generando nuevas tendências de localización. As veces estas oportunidades consisten en encontrar lotes que son de bajo costo debido a sus forma incovenientes, en los que otros no son capaces de encontrar la manera de alojar convenientemente los departamentos convencionales (DIEZ, 20I I, p. 36).

Um detalhe importante na venda das casas, ação também comandada pela dupla, foi o fato de iniciar a prospecção de clientes somente após a finalização da construção de ao menos duas unidades. Isto também está relacionado com o caráter experimental deste projeto, inclusive eles sentiam-se mais confortáveis em ter certeza do resultado final antes de iniciarem as vendas. Assim, diferente da maneira como acontece em muitos outros empreendimentos (Figuras 15 e 16), não foi uma venda apoiada apenas em panfletos ou maquetes, foi mostrado o produto pronto. É difícil explicar algo que foge dos padrões imobiliários, de repente, poderia não ser aquilo que o cliente esperava. O processo de venda, segundo a arquiteta, foi “indolor”: alguns olhavam e já viam que não era o que esperavam e outros já gostavam e compravam sem muita demora.

\section{I.4.7 SISTEMA ESTRUTURAL ETÉCNICA CONSTRUTIVA}

As unidades habitacionais da Vila Taguaí foram definidas a partir de um painel de madeira nativa cumaru, que seria o módulo construtivo do projeto. Este painel tem espessura de $8 \mathrm{~cm}$ e é autoportante, portanto, sem a necessidade de pilares. É formado por pequenas vigotas espaçadas por $10 \mathrm{~cm}$, e o espaço entre as vigotas é preenchido por duas réguas paralelas, ficando um vazio por onde passam, por exemplo, as instalações elétricas (Figura 19). Para as lajes, o painel é semelhante, 
só que com um camada de $5 \mathrm{~cm}$ de concreto magro, por onde passa também a fiação elétrica, além de melhorar a acústica (Figura 20). $O$ painel de cobertura tem isolante térmico e também manta termoplástica para impermeabilização.A dimensão dos painéis pode variar de $0,20 \mathrm{~m}$ a $3 \mathrm{~m}$, seguindo uma modulação de $10 \mathrm{em} 10 \mathrm{~cm}$, e em altura de $1 \mathrm{~m}$ a 5,5 m. As dimensões finais de cada painel e sua leveza facilitam a pré-fabricação na oficina, o armazenamento, o transporte e a montagem em obra (Figura 2I).

O painel é montado na fábrica em algumas semanas e, após a concretagem da fundação e pilares, é feita a montagem das casas no local. A montagem de cada unidade da Vila Taguaí durou aproximadamente 40 dias (Figura 22). O painel possui cerca de 80 quilos, o que facilita o manuseio na obra. Não é aplicada proteção na madeira, afinal, segundo Hélio Olga, o material é um excelente condutor térmico, e quando aplicado verniz, ou outro tipo de proteção, ele acaba perdendo sua capacidade de trocas de calor. As redes hidráulicas, de esgoto, passam por shafts, na face oeste, não existindo furos nos painéis tipo laje. Assim, tudo foi projetado com total consciência do que o sistema construtivo permitiria (Figuras 23, 24 e 25). Foi pensada conjuntamente a arquitetura dos espaços e as instalações, o que, estranhamente, não acontece normalmente. Porém, a boa arquitetura deve pensar nos espaços sempre em concordância com as necessidades das instalações, evitando adaptações absurdas nos projetos para conseguir solucionar a parte técnica.

No projeto da Vila Taguaí pode-se perceber o cumprimento de algumas regras sobre o uso correto da madeira: não existem situações de contato da madeira com o solo, assim, a casa é elevada por pilares de concreto armado e a caixa da escada que chega ao solo foi executada com blocos de concreto; quando existem decks, eles não encostam no chão, permitindo que a água escorra; nota-se o uso de grandes beirais pra proteger a madeira, além de rufos para escorrer a água nas faces exteriores. Com relação às soluções de baixo impacto ambiental, as unidades contam com placas para captação de energia solar na cobertura, para aquecimento da água, contam também com estação de tratamento de esgoto próprias, para reuso da água em vasos sanitários e irrigação, reduzindo $30 \%$ do consumo de água.

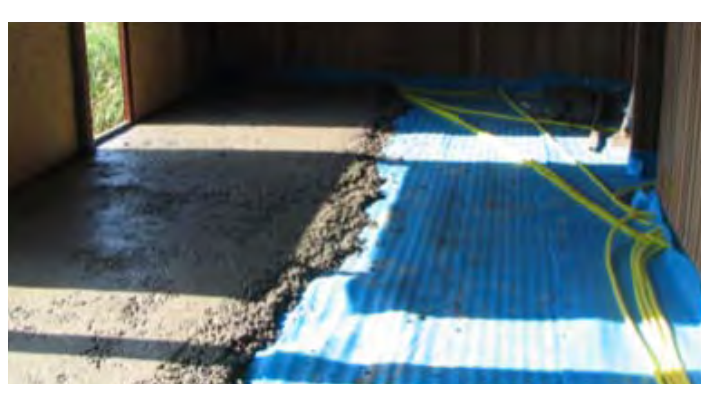

Figura 20 - Execução da camada de $5 \mathrm{~cm}$ de concreto magro no painel tipo laje.

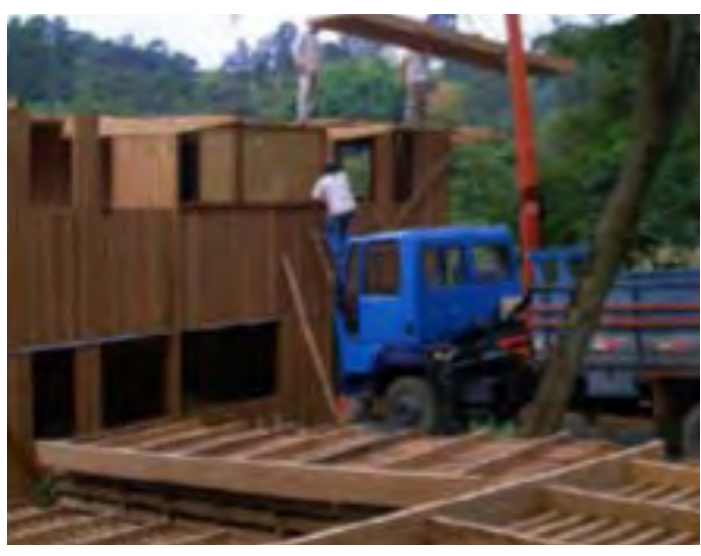

Figura 2 I - Painéis estruturais de madeira: estocagem e montagem na obra.

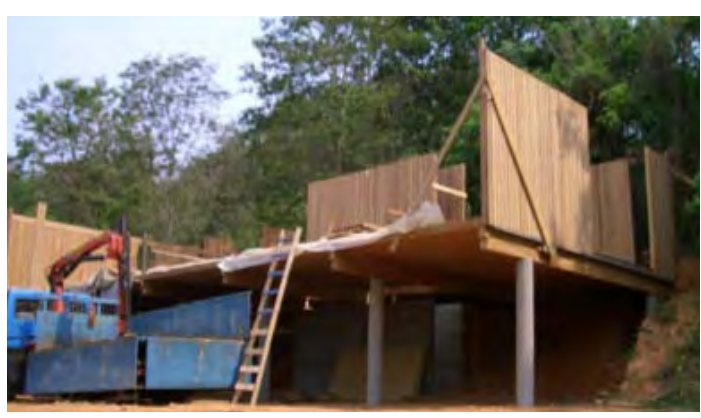

Figura 22 - Montagem da casa com as peças pré-fabricadas. 


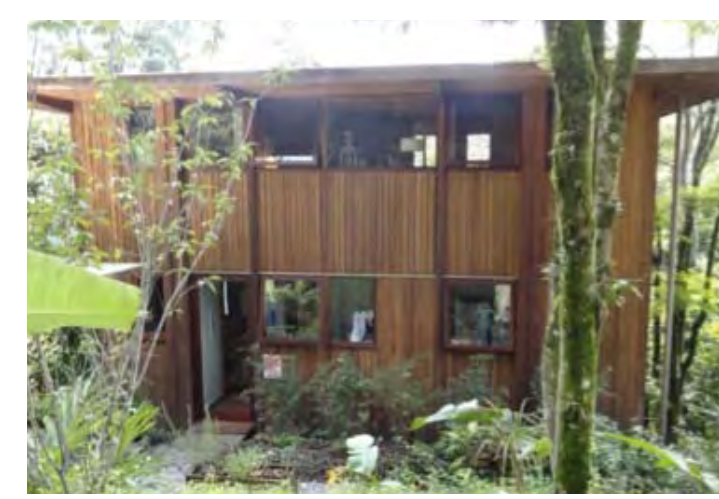

Figura 23 - Shafts externos, visíveis na fachada.

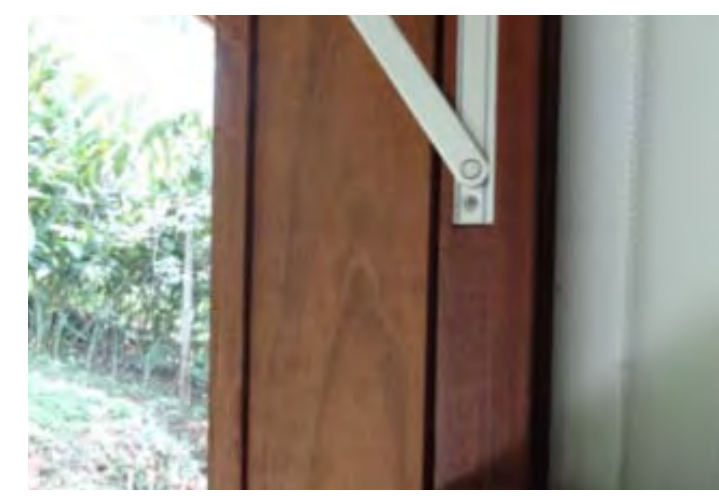

Figura 24 - Shafts em destaque.

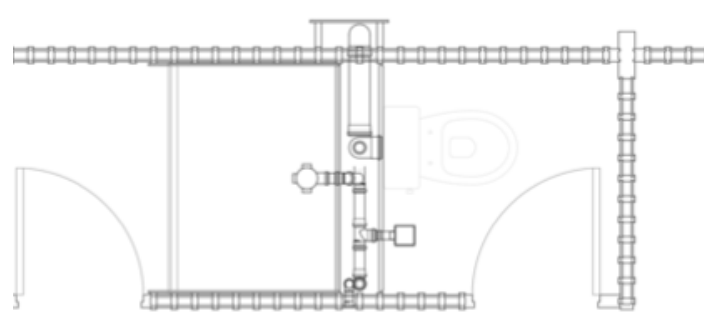

Figura 25 - Detalhe dos shafts visto em planta.
3. I.4.8 TÉCNICA CONSTRUTIVA - A importância da Vila Taguaí no aprimoramento da utilização da madeira na contrução.

\begin{abstract}
Se a primeira foi marcada pela pesquisa de volumetria (seis unidades diferentes), a segunda teve como destaque o desenvolvimento de uma técnica construtiva (a partir de uma laje de concreto apoiada em vigotas de madeira). Ao limitar ao mínimo as áreas privativas, ambos os empreendimentos, localizados em São Paulo, desafiaram o status quo (SERAPIÃO, 2010 p. 45).
\end{abstract}

A frase acima refere-se a dois outros projetos presentes nesta pesquisa que também contaram com a participação do Engenheiro Hélio Olga Jr:Vila Fidalga, no qual foi construtor do projeto da arquiteta Cristina Xavier; e Vila Butantã, no qual foi empreendedor junto ao arquiteto Marcos Acayaba. São projetos de estrutura mista, em que o uso da madeira acabou ocorrendo apenas em alguns detalhes, mas o caráter construtivo é forte e bem integrado com a concepção arquitetônica. A Vila Taguaí representa mais um empreendimento que desafia o status quo, principalmente pela inovação representada pela técnica construtiva e pela maneira como a arquitetura e a engenharia, técnica e invenção, alcançaram um padrão de relacionamento que é intrínseco ao ato de construir, mas que se encontra, muitas vezes, rebaixado ou pouco valorizado.

Na Vila Taguaí, o uso da madeira é integral e com industrialização de todos os elementos, portanto, resultando em grande racionalização da construção e pertinente com os objetivos de criação de painel feito com parte da tora que não servia para a produção das peças que eram usadas no sistema pilar/viga.Assim, representa um tipo de obra que aproveita ao máximo os restos de madeira maciça, e, ao mesmo tempo, a utiliza de maneira qualificada, e não para formas ou escoramentos, já que os painéis são estruturais. Hélio Olga comenta sobre a questão da má utilização da madeira nas tecnologias convencionais, com o concreto como matéria prima principal e a madeira apenas como suporte à construção, e posterior descarte: 
O Brasil consome hoje $1.783,3$ mil metros cúbicos de madeira por ano na construção civil. Desse total, $33 \%$ são utilizados de forma não qualificada, isto é, como andaimes, escoras, formas de concreto, tapumes, barracos e mais um sem-número de usos não nobres que terminam como descarte, aumentando o índice de desperdício provocado pelas técnicas construtivas tradicionais (OLGA, 20I2a).

Assim como em outros projetos executados por Hélio Olga, como sua própria casa no Morumbi, as casas da Vila têm uma aparência contemporânea, resultado do uso adequado da técnica construtiva junto com a definição arquitetônica das aberturas, do equilíbrio formal, da qualidade dos espaços, e outros detalhes que a arquiteta Cristina Xavier soube resolver com muita consciência técnica e criativa ao mesmo tempo. Novamente, diferente do que se pode imaginar, a madeira representa uma alternativa interessante na produção contemporânea de arquitetura:

\begin{abstract}
Faz-se de madeira quando o material é indicado e pertinente. Esse é o pressuposto de uma boa arquitetura, de uma boa obra. Partindo de um sistema construtivo errado, tudo vai dar errado. Mas o projeto de minha casa - com quatro andares e balanços grandes - foi muito bom, pois quebrou a imagem de que a madeira é frágil, que só serve para a casinha cheia de pilares. Deu idéia de que a madeira é um material contemporâneo (Hélio Olga em MELENDEZ e SERAPIÃO, 2002)
\end{abstract}

Porém, uma dificuldade hoje para construir com madeira é a legislação de um modo geral. Apenas para entender a situação, um projeto que inspirou a criação deste painel da Vila Taguaí, com pedaços menores da madeira, foi o projeto Wohnanlage Ölzbündt, em Dornbirn,Vorarlberg, Áustria, do arquiteto Architekten Hermann Kaufmann ZT GmbH (Figura 26). Trata-se de um edifício de habitação coletiva, com 13 unidades justapostas, e três pavimentos, construído com painéis préfabricados de madeira. Tecnicamente, este tipo de solução poderia ser perfeitamente realizada pela ITA, porém, nossa legislação não permitiria tal tipologia edilícia (Figura 27). Segundo o código de Obras e Edificações de São Paulo ${ }^{4}$, as edificações que possuírem estrutura e vedação de madeira são

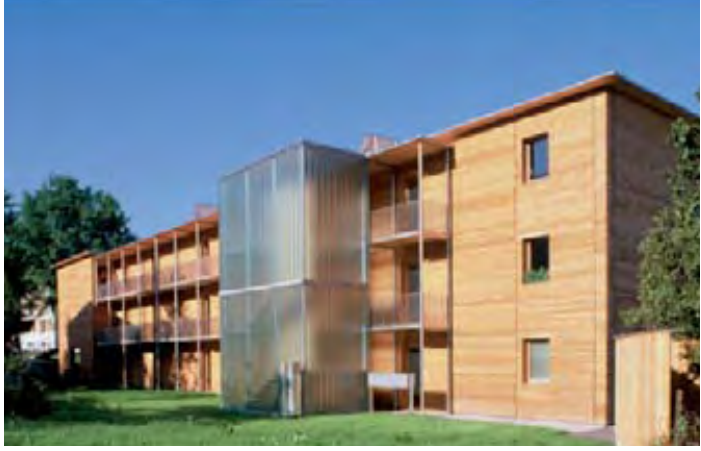

Figura 26 - Wohnanlage Ölzbündt, em Dornbirn,Vorarlberg, Áustria, do arquiteto Architekten Hermann Kaufmann ZT GmbH.

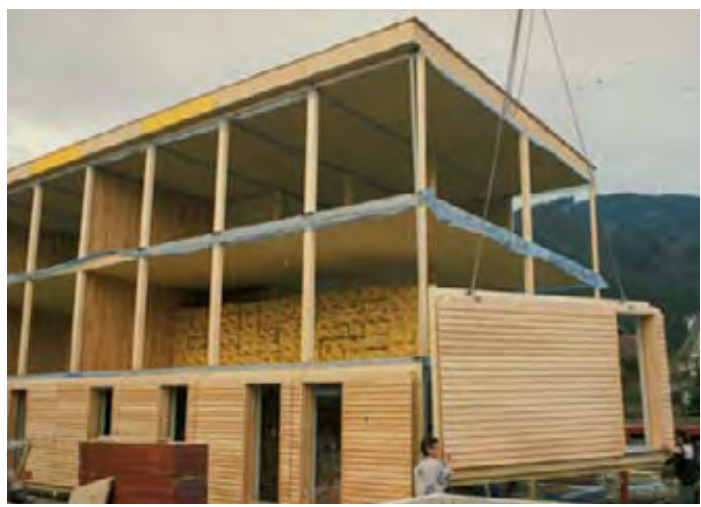

Figura 27 - Montagem com painéis préfabricados do projeto Wohnanlage Ölzbündt, em Dornbirn, Vorarlberg, Áustria, do arquiteto Architekten Hermann Kaufmann ZT GmbH. 
condicionadas ao máximo de dois andares, altura máxima de oito metros, afastamento mínimo de três metros de qualquer ponto das divisas ou outra edificação, e afastamento mínimo de cinco metros de outra edificação de madeira ${ }^{5}$. Só isto já impossibilita a construção de uma casa isolada num lote urbano de seis metros de frente, como é comum existir em São Paulo. Pensando num terreno maior, para a construção de um edifício de habitação coletiva, com unidades agrupadas como o exemplo austríaco, também ficaria condicionada a uma norma do código de obras que define as distâncias máximas a serem percorridas nos corredores de circulação horizontal ou caixas de circulação vertical de uso coletivo 6 . Por exemplo, segundo a norma, no andar de saída da edificação, ou seja, no nível térreo, a distância máxima a ser percorrida de qualquer ponto até o exterior (para o caso de uma circulação aberta), é de quarenta e cinco metros numa edificação de estrutura convencional. Para o caso da madeira, a distância ficaria reduzida a um terço, ou seja, a quinze metros. Fazendo um estudo rápido, daria para agrupar no máximo duas unidades pequenas no térreo (de $50 \mathrm{~m}^{2}$ aproximadamente), com uma escada central. Pensando no andar superior, a distância, novamente segundo - COE, seria de 25/3 m, ou seja, um pouco mais de oito metros de qualquer ponto do andar até a escada.Assim, o COE permite - e isto deve ser verificado caso a caso (e quem chegar a outro resultado por favor, se manifeste) - soluções de casas unifamiliares agrupadas, porém, térreas e de dois andares, mas isoladas, tipologia que está ainda muito atrasada com relação a outras permitidas na Europa, como o exemplo austríaco citado. Isto apenas fazendo uma avaliação pelo COE, sem contar outras normas específicas existentes que possivelmente restringiria ainda mais a situação, como as normas de segurança contra incêndio existentes.

Também existe a questão cultural, baseada na crença de que a construção com tijolo e cimento seja mais sólida e resistente, mesmo sendo a madeira um material presente na nossa cultura ${ }^{4}$ LEl Lei Municipal n. I I.228 / 1992 - Código de Obras e Edificações do Município de São Paulo e Decreto Municipal n. 32.329/1992 - Regulamenta o Código de Obras e Edificações do Município de São Paulo, e dá outras providências.

${ }^{5}$ Seção 9.6 "Edificações de Madeira", item 9.6.3, da Lei Municipal n. II.228 / 1992.

${ }^{6}$ Seção 12 "Circulação e Segurança”, item 12.8 "Disposição de escadas e saídas”, tabela I2.8. I., que coloca as distâncias máximas a serem percorridas. 
há muito tempo, mas que ao mesmo tempo é pouco compreendida em seus atributos e propriedades, conforme colocado por Olga (2012) abaixo. Aqui, novamente, pode ser colocada a crença de que, por o diferente dar mais trabalho, seja para as empreiteiras convencionais que estão acostumados a práticas comuns e que, portanto, não demonstram interesse neste tipo de atuação simplesmente por sair da rotina de trabalho que estão acostumados; ou até nos órgãos de aprovação de projeto, que também teria que parar para entender uma situação edilícia a qual não estão acostumados a lidar; preferindo continuar no convencional:

"Vou assoprar, assoprar até a casa cair", já dizia o Lobo Mau, e com ele, toda uma
cultura baseada na solidez do tijolo e do cimento, herdada do nosso passado colo-
nial. Constrói-se como se construía há 200 anos, apenas, em alguns casos, com es-
tilos diferentes. O novo sempre causa estranheza e a adoção de outras tecnologias
é sempre complexa. Porém, no caso da madeira estamos falando de um material
presente na nossa cultura há alguns milênios, mas pouco compreendida em seus
atributos e propriedades. Vejamos a questão do fogo, argumento sempre presente
quando o assunto é construção em madeira. Naturalmente todos nós sabemos que
a madeira queima muito bem, algumas mais do que outras, pela experiência no uso
de lareiras e fornos de barro. Esse é exatamente o melhor atributo da madeira: quei-
ma devagar e não produz tóxicos voláteis como revestimentos sintéticos, tecidos,
laminados polivinílicos e melamínicos. Permite a fuga do interior com mais tempo
e segurança. No entanto as companhias de seguro têm dificuldades em qualificar
as casas de madeira. As casas pré-fabricadas raramente se qualificam para financia-
mentos públicos ou privados. (...) As construçães contemporâneas que combinam
materiais e fazem uso extensivo da madeira sugerem soluções não convencionais
e, portanto, geram mais pesquisa pela novidade. Isso dá trabalho e as empreiteiras
convencionais inflam seus preços sobre tudo que não é convencional. É difícil com-
preender como um processo industrializado, com baixo gasto energético e com
mão de obra qualificada custe mais do que o similar convencional (OLGA, 20I2b).

Martins (2005) coloca que tornar a construção em madeira é uma opção viável, ao menos para a classe média, é um dos desafios de longo prazo da Ita, e a Vila Taguaí é, deste modo, um marco nesta conquista gradual: "Para isso, e atenta às tendências recentes da construção em madeira na Europa, 


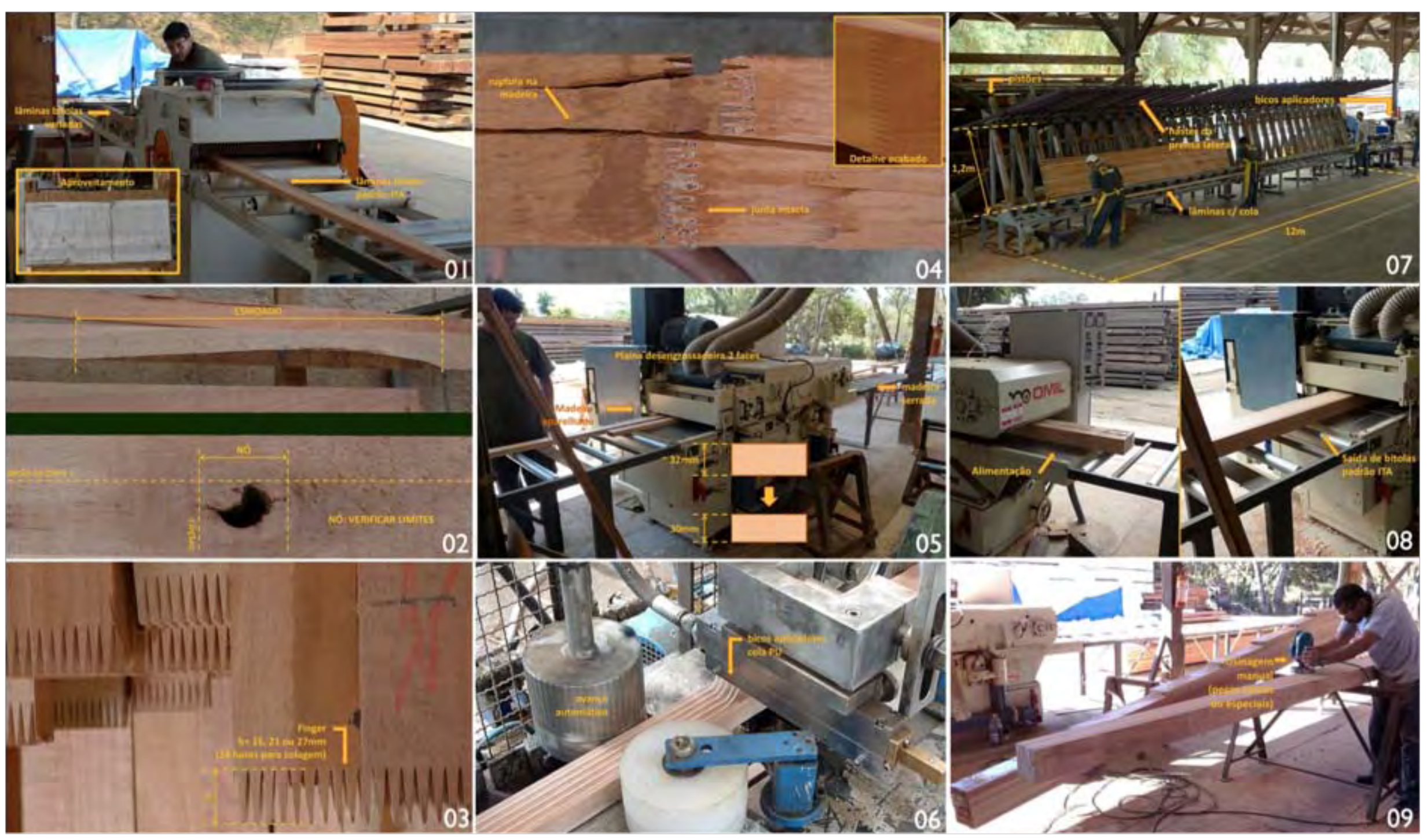

Figura 28 - Etapas de fabricação de madeira laminada colada de eucalipto na Ita Construtora: após a recepção da matéria prima e controle por amostragem (densidade, umidade, módulo de elasticidade), é realizado o desdobro (foto 0I) e determinação das perdas (foto 02). Após eliminar os trechos defeituosos da madeira, as lâminas são unidas no sentido do comprimento, pelo processo denominado "Finger-jointe" (foto 03). Na sequência, a colagem é feita manualmente com cola PU (foto 04) e após esta etapa é realizado o controle por amostragem, ou seja, ensaios para determinação da capacidade de carga. Depois, é realizada a padronização da espessura das lâminas ( $30 \mathrm{~mm}$ ), no processo denominado aparelhamento (foto 05). São coladas as lâminas resultantes com cola PU novamente, porém, no sentido da altura da seção (foto 06). Na sequencia, a prensa é alimentada (foto 07) e a laminação é concluída com o fechamento da prensa, que proporciona peças de até $12 \mathrm{~m}$.A usinagem normalmente é realizada manualmente (foto 09) e depois é aplicado "stain" (hidrofugante, cupinicida, fungicida). Novos ensaios por amostragem são realizados após a peça MLC pronta. 
começa a desenvolver o sistema de paredes autoportantes, feitas com pedaços menores de madeira maciça, montados em novo raciocínio estrutural" (Alberto Martins em AFLALO, 2005, p. 30).Assim, em 2005, já estava em processo a concepção do método construtivo que foi posteriormente utilizado na Vila Taguaí, de paredes estruturais a partir do uso de pedaços menores de madeira maciça. É também importante mencionar, que mesmo sendo uma obra marco de utilização da madeira, somente após a realização da Vila Taguaí é que foi iniciada uma reflexão sobre o grau de sustentabilidade do uso da madeira nativa. Ou seja, somente após esta experiência é que começaram a refletir, por exemplo, sobre a complexidade do transporte deste tipo de madeira e que, portanto, a logística também deveria ser sustentável. Então algumas evoluções só ocorrem após a passagem por experiências significativas como esta.

Neste sentido, a Ita vivencia um novo momento em sua trajetória profissional, apostando na utilização da madeira laminada.Até 2009, a Ita empregava madeiras nativas em suas construções, do tipo Angelim Vermelho, Jatobá e Cumarú. A partir desta data, iniciou-se a produção de laminado de eucalipto, que, segundo o próprio Eng. Hélio Olga, possui um processo fabril que conta primeiramente com uma matéria prima buscada na própria região; segundo, que, com o processo denominado finger-joint, é possível eliminar trechos de madeira com defeitos e unir os pedaços de lâminas sem defeitos; é um processo em que há um controle maior das dimensões e padronizações das espessuras e permite, a partir da junção de vários trechos de madeira, uma grande seção, de até $12 \mathrm{~m}$ de comprimento e, inclusive, formatos variados de acordo com a definição do desenho arquitetônico, como pode ser observado nas atuais obras que já estão utilizando este tipo de madeira. Assim, hoje a melhor opção de madeira para a lta é o eucalipto certificado, por ser mais sustentável. Assim, deixou-se de utilizar a madeira nativa logo após esta experiência da Vila Taguaí (Figura 28).

Para o futuro, o próximo passo da construtora é um aumento de capacidade de construção pré-fabricada e aumento dos vãos das estruturas, para realização de obras maiores, como institucionais ou até mesmo públicas. Isto vem sendo realizado recentemente a partir da obtenção da

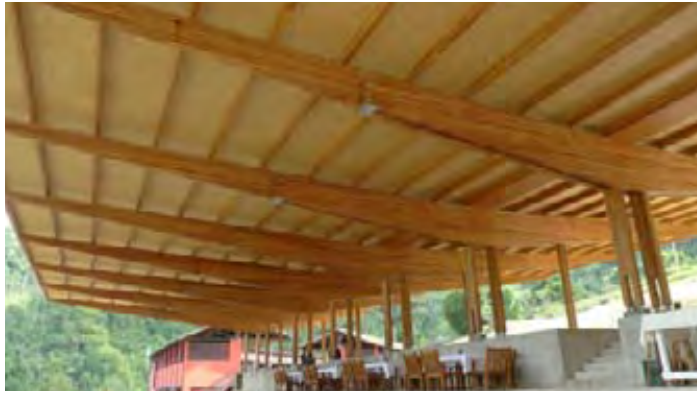

Figura 29 - Haras Polana, Arquiteto Mauro Munhoz.

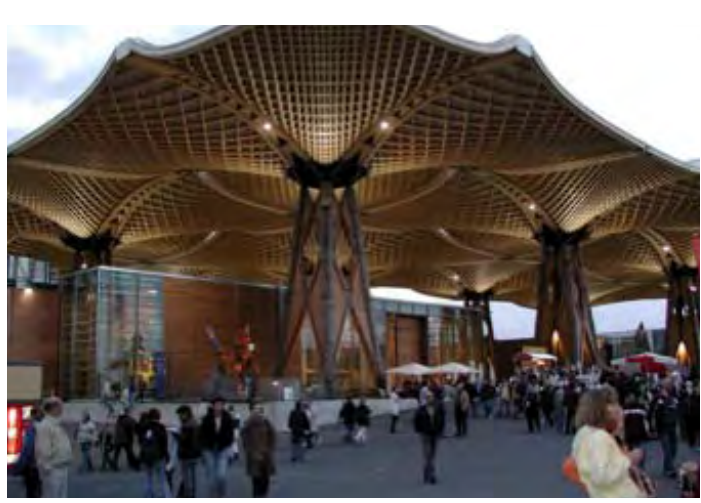

Figura 30 - Hannover Expo 2000 (Germany) by Thomas Herzog and Julius Natterer.

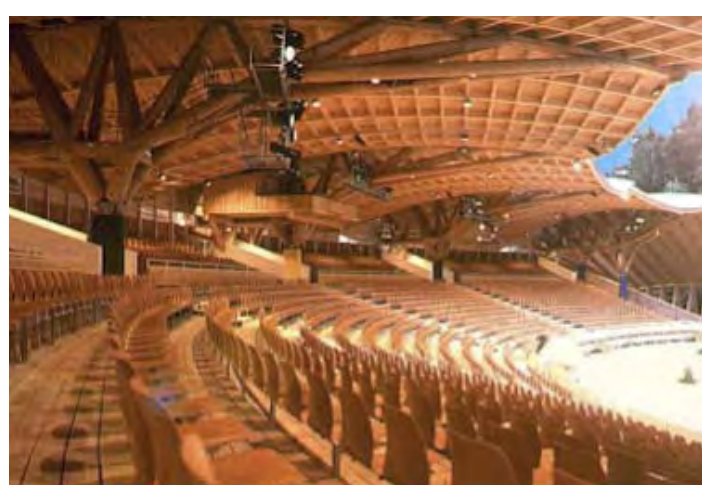

Figura 3 I - Estádio Altusried,Alemanha, do arquiteto Alsturied Mohr, 1999. 


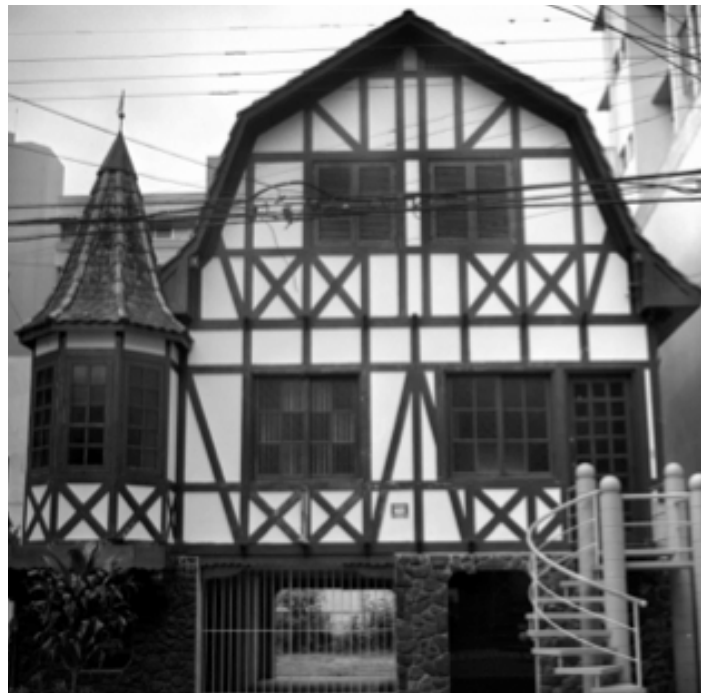

Figura 32 - Remanescente de casa enxaimel, em Blumenau, Santa Catarina.

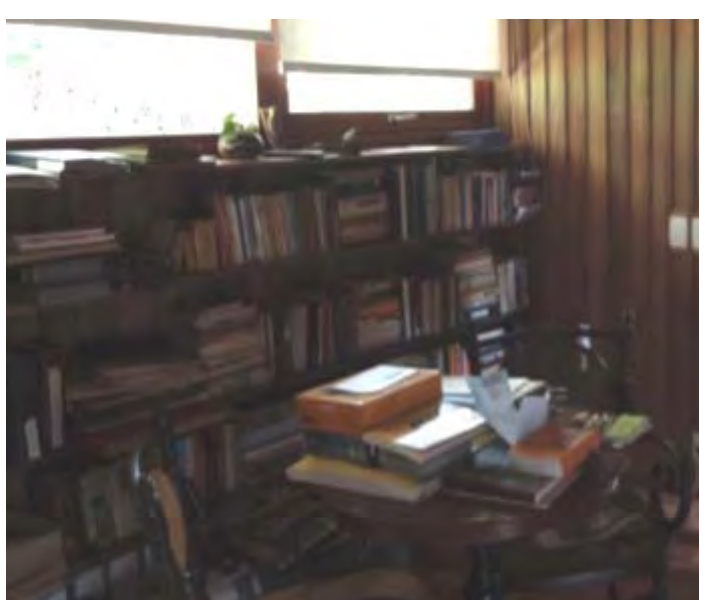

Figura 33 - Espaço junto aos quartos, na VilaTaguaí, unidade 5. prensa de 12 metros para trabalhar com madeira laminada colada (MLC), com peças de eucalipto, tipo de madeira que proporcionará alta capacidade de carga e baixo peso próprio, permitindo componentes de pequenas dimensões, grandes envergaduras e com formas livres: grande flexibilidade com curvaturas (Figura 29).

Também vale citar, neste sentido, algumas referências para a Ita, como a do engenheiro civil alemão Julius Natterer, professor da Universidade de Lausanne, Suíça, sócio do escritório IEZ Natterer $\mathrm{GmbH}$,com obras de estrutura de madeira avançadas e totalmente dentro do quadro atual da arquitetura contemporânea.Também o arquiteto Hermamm Kaufmann, engenheiro Conrad Merz e toda a produção dos arquitetos e engenheiros da região doVorarlberg (Áustria), onde o uso da madeira é muito grande e a maioria das construções é de ótima qualidade construtiva e arquitetônica (Figuras 30 e 31 ).

Cultura e ambiente, mais do que qualquer outro atributo, são os formadores da diversificada linguagem encontrada no mundo, quando o assunto são as edificações que usam um dos primeiros materiais construtivos da história da humanidade. $A$ qualidade das construções e a inteligência dos projetos e técnicas estão com as culturas que usam regularmente a madeira como matéria prima há mais tempo. Os países escandinavos e os povos da Europa central há muito vem elaborando processos e técnicas de construção e manutenção da madeira. $\bigcirc$ Japão chegou a um grau de economia e sofisticação sem paralelos na história por força de uma situação insular que os obriga a tirar proveito de todos os atributos da madeira, sem desperdício. Através de encaixes elaborados e modulação racional, as construções japonesas, em geral, suportam variações climáticas extremas e até eventos sísmicos, com pouco dano e sem perder suas principais características. Há muito que perceberam que a melhor proteção dada à madeira é a propria madeira e que aceitar as mudanças estéticas do envelhecimento do material faz parte da linguagem. $\mathrm{Na}$ Alemanha, Suiça e Áustria, a madeira faz parte do vernáculo local e foi modelo de exportação cultural por décadas, com variações em todo o mundo, inclusive o Brasil, com o medieval "enxaimel" presente principalmente no vale do Itajaí, Santa Catarina. Entretanto, enquanto os imigrantes congelaram modelos no tempo, nos países de origem a tecnologia e a linguagem evoluíram para modelos perfeitamente adaptados para seu tempo e local, em sintonia com os mais sólidos princípios sustentáveis. Um pequeno enclave na Áustria, o Vorarlberg, já legou mais exemplos de pesquisa e produção em pouco tempo, do que muitos países o fizeram em décadas. $\mathrm{Na}$ França, onde todas as construções devem conter pelo menos 12\% de madeira, 
apesar do aumento do consumo fixado com base no Protocolo de Kyoto, as florestas são sub exploradas e há extensivo uso em edificações públicas, além das residências de caráter social. Nos Estados Unidos, embora o sistema hegemônico use a madeira extensivamente, a linguagem dominante não evolui há mais de meio século (OLGA, 2012b).

\section{I.4.9 ENVOLTÓRIA}

Notam-se poucas aberturas nas faces laterais, para travamento da estrutura.Assim, optou-se pelas grandes aberturas na face nordeste, onde ficam as salas e os quartos. Os panos de vidros e venezianas permitem serem totalmente abertos, inclusive ficando a janela sem peitoril, e possuem sistema de travamento das folhas que permite vários níveis de ajuste de abertura.

A fachada sudoeste tem aberturas em fita na parte superior, é onde ficam concentrados os banheiros, cozinha e área de serviço. É proposital a despreocupação em não criar mecanismos para esconder a roupa no varal ou aparência de face de serviço.

Sobre este tema de esconder ou criar mecanismos de separação da área social da de serviço, na Vila Fidalga, projeto anterior da arquiteta Cristina Xavier, a dependência de empregada fica no corpo principal da casa e em local não escondido, afinal, é voltada para o espaço de convívio coletivo do conjunto. Na Vila Taguaí, esta situação chega ao extremo: não existe dependência para empregada e a porta de entrada principal é justamente na face sudoeste, na qual estão concentradas as áreas molhadas, incluindo as áreas de serviço.

Esta distribuição programática está relacionada a uma solução mais enxuta e com concentração das áreas com instalações hidráulicas e de esgoto numa mesma fachada, inclusive devido à posição dos shafts. Está também relacionada com a definição das aberturas, as orientações e principais vistas, afinal, optaram por fazer as aberturas maiores no sentido em que cai o terreno, portanto no sentido da vista em direção ao vale; enquanto que no sentido oeste, local de melhor acessibilidade, visto as condições topográficas do terreno, foi colocado o acesso principal.

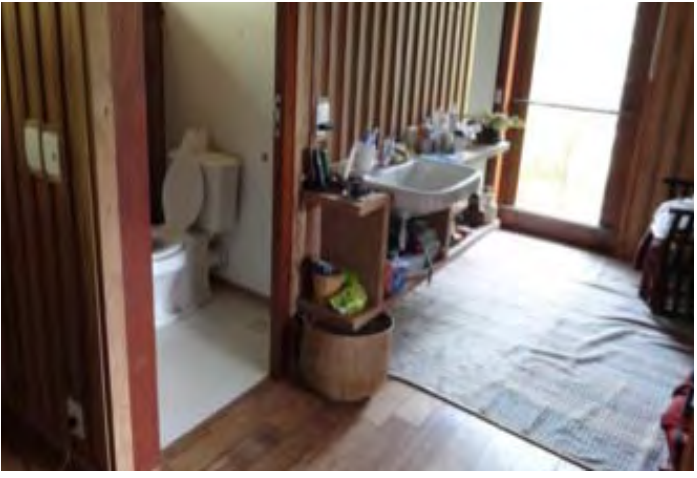

Figura 34 - Peças sanitárias separadas, Vila Taguai, Unidade 5

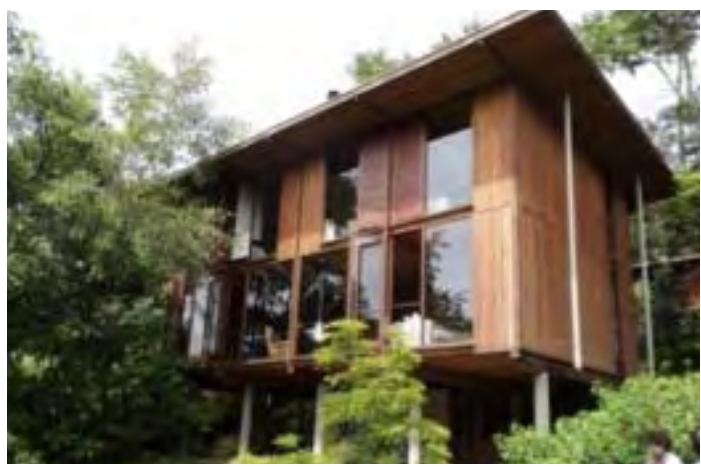

Figura 35 - Arquitetura Contemporânea com o uso da madeira, Vila Taguaí, unidade 4.

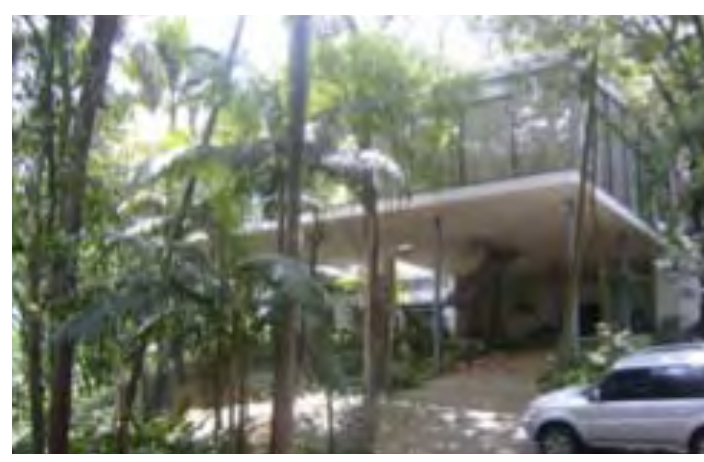

Figura 36 - Foto atual externa da Casa de Vidro, Morumbi, da arquiteta Lina Bo Bardi, 1951. 


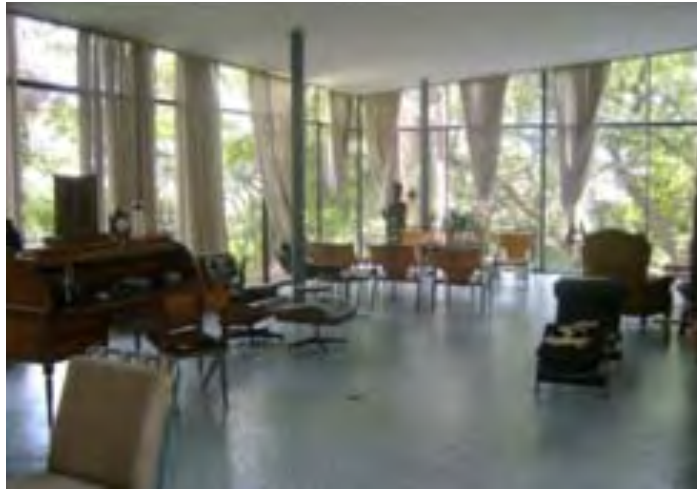

Figura 37 - Foto atual interna da Casa de Vidro, Morumbi, da arquiteta Lina Bo Bardi, 1951.

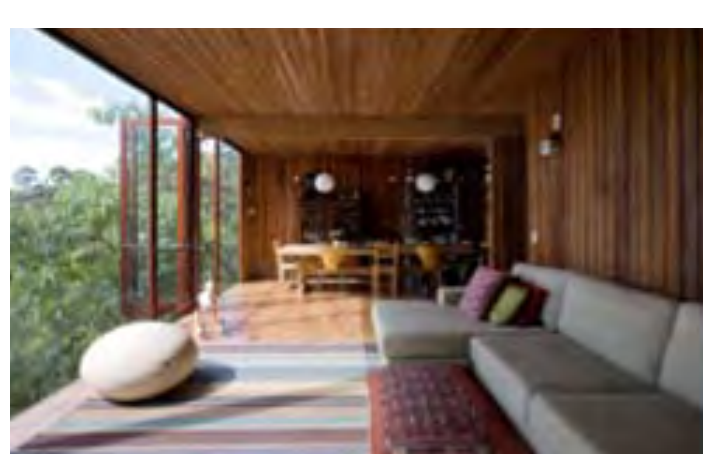

Figura 38 - Área social unidade Vila Taguaí: mesma sensação de vertigem da Casa de Vidro de Lina Bo Bardi.
A escolha por simplesmente excluir a dependência para empregada e por não encarar a fachada de serviço como sendo uma face que deva ser mais escondida, ou ao fundo, como normalmente se faz, está relacionada a uma decisão que se diferencia dos valores mais comuns da nossa sociedade, que em muitos casos ainda segue uma distribuição programática atrasada com relação ao perfil atual da sociedade, diversificada e sem segregação social.

\section{I.4.I0 UNIDADE HABITACIONAL}

Se comparado com outros projetos de baixa densidade em terrenos fora da área urbana, podemos dizer que as plantas das unidades são enxutas, com ambientes pequenos (com dimensão máxima em um sentido de $3,0 \mathrm{~m}$, conforme modulação do painel laje). Aumentar os ambientes significaria ter que aumentar o vão, e assim seria preciso utilizar lajes com maior espessura. Para este primeiro experimento, não era o caso. As unidades, portanto, não possuem metragem exagerada, possuem entre 190 a $240 \mathrm{~m} 2$, o que representa pouca área útil construída para um terreno de $12.000 \mathrm{~m} 2$ que comporta apenas 8 unidades. Não era intenção da arquiteta ocupar o terreno demasiadamente, pelo contrário, o partido foi de preservar ao máximo a área natural livre e permeável. Só este fato já é um raciocínio sustentável, acima de certificados ambientais entre outros que aqui pouco interessam. No interior da unidade, algumas características chamam a atenção: um espaço próximo aos quartos que pode ser utilizado como sala íntima ou escritório (Figura 33).Também todas as peças sanitárias estão em ambientes independentes: ambiente para o chuveiro, outro para o vaso sanitário, e a pia é externa (Figura 34). Não existe, a princípio, quartos tipo suíte nem dependência para empregados. A falta de espaços que privilegiam o individualismo na área externa é também estendida para o interior das unidades. Assim, neste projeto, o habitar coletivo está dentro da Vila e dentro das unidades, onde também são privilegiados os espaços de convívio social.Ao mesmo tempo, a unidade é flexível e pode atender outras preferências. 
O piso inferior, espaço sob pilotis, é um espaço remanescente da acomodação da unidade à topografia original do terreno, que minimiza a movimentação de terra, arranjo ou solução típica da arquitetura paulista. Resulta num espaço muito bem aproveitado e agradável, com diversas possibilidades de uso. Representa uma integração com a paisagem no sentido topográfico e visual, pois já representa um espaço externo. Os pilotis fazem com que o volume do edifício fique solto do chão, assim como a Casa de Vidro da arquiteta Lino Bo Bardi de 1951, a Residência Antônio Cunha Lima do Arquiteto Joaquim Guedes, de 1963, ou até mesmo o projeto de Lúcio Costa não construído de 1934 -Vila operária de Monlevade (Figuras 35 a 40).

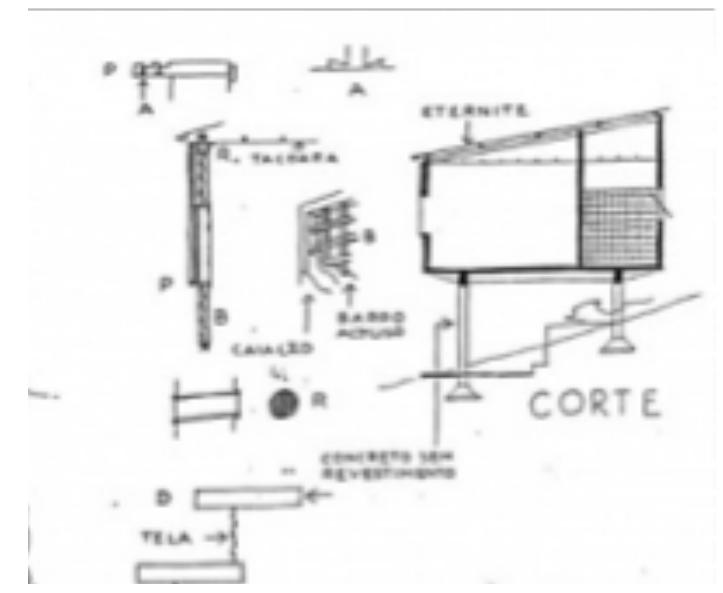

Figura 39 - Detalhes do projeto apresentado por Lúcio Costa para a Villa de Monlevade, 1934.

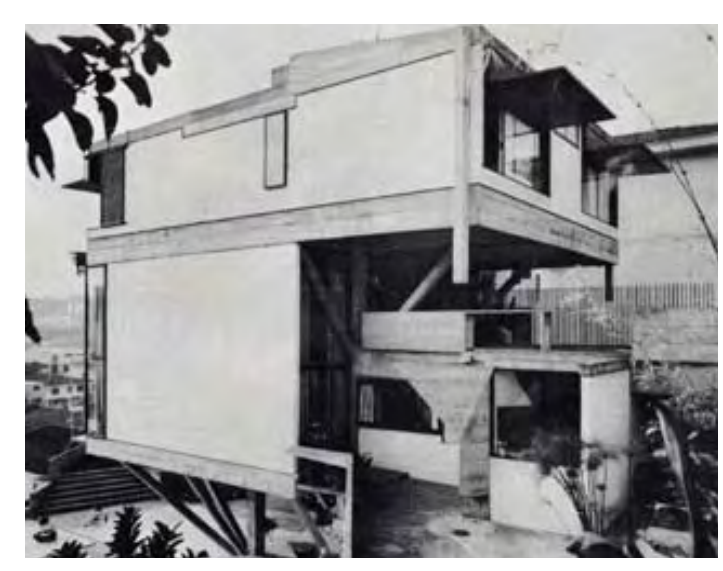

Figura 40 - Residência Antônio Cunha Lima, Arquiteto Joaquim Guedes, Pacaembu, 1958-63. 


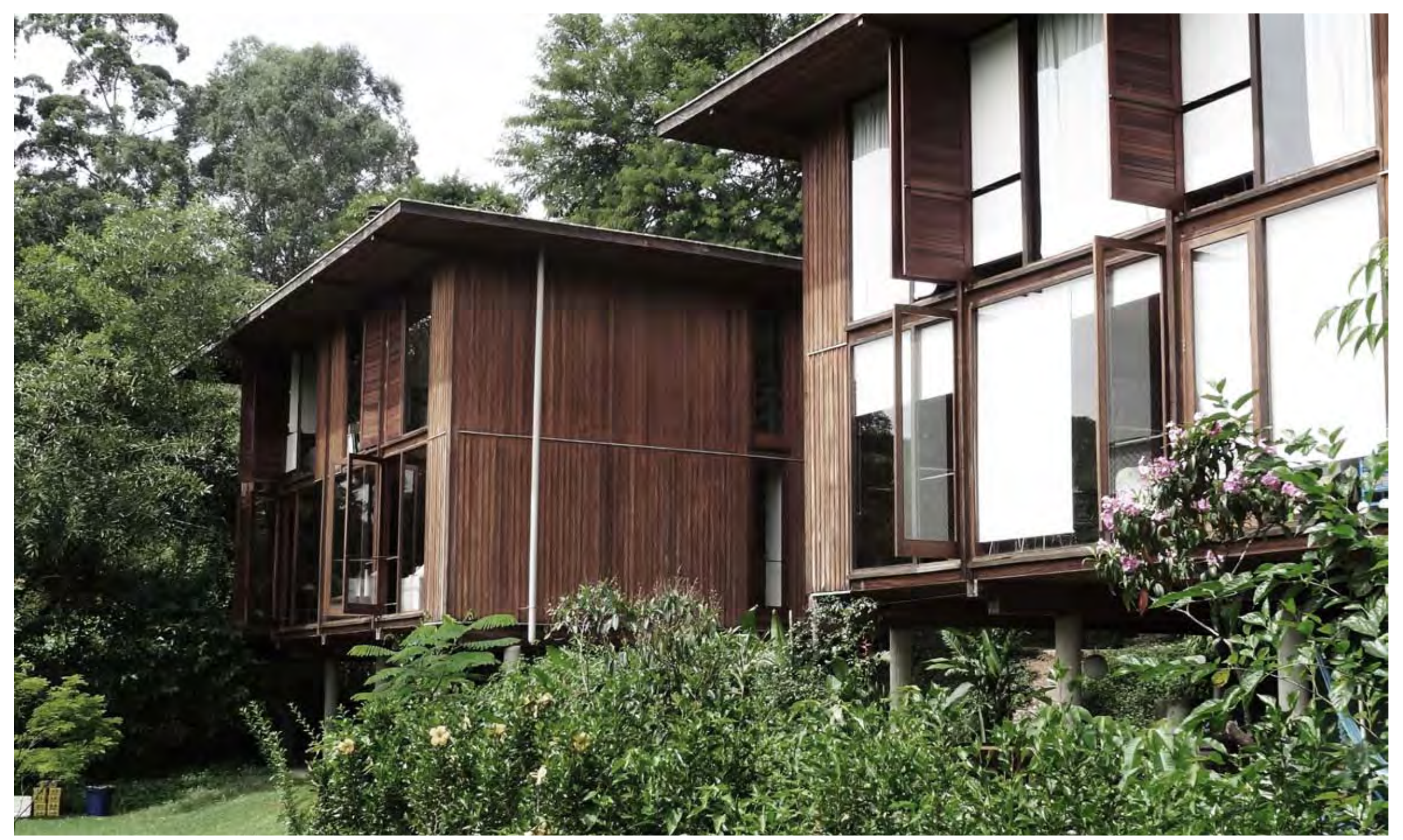




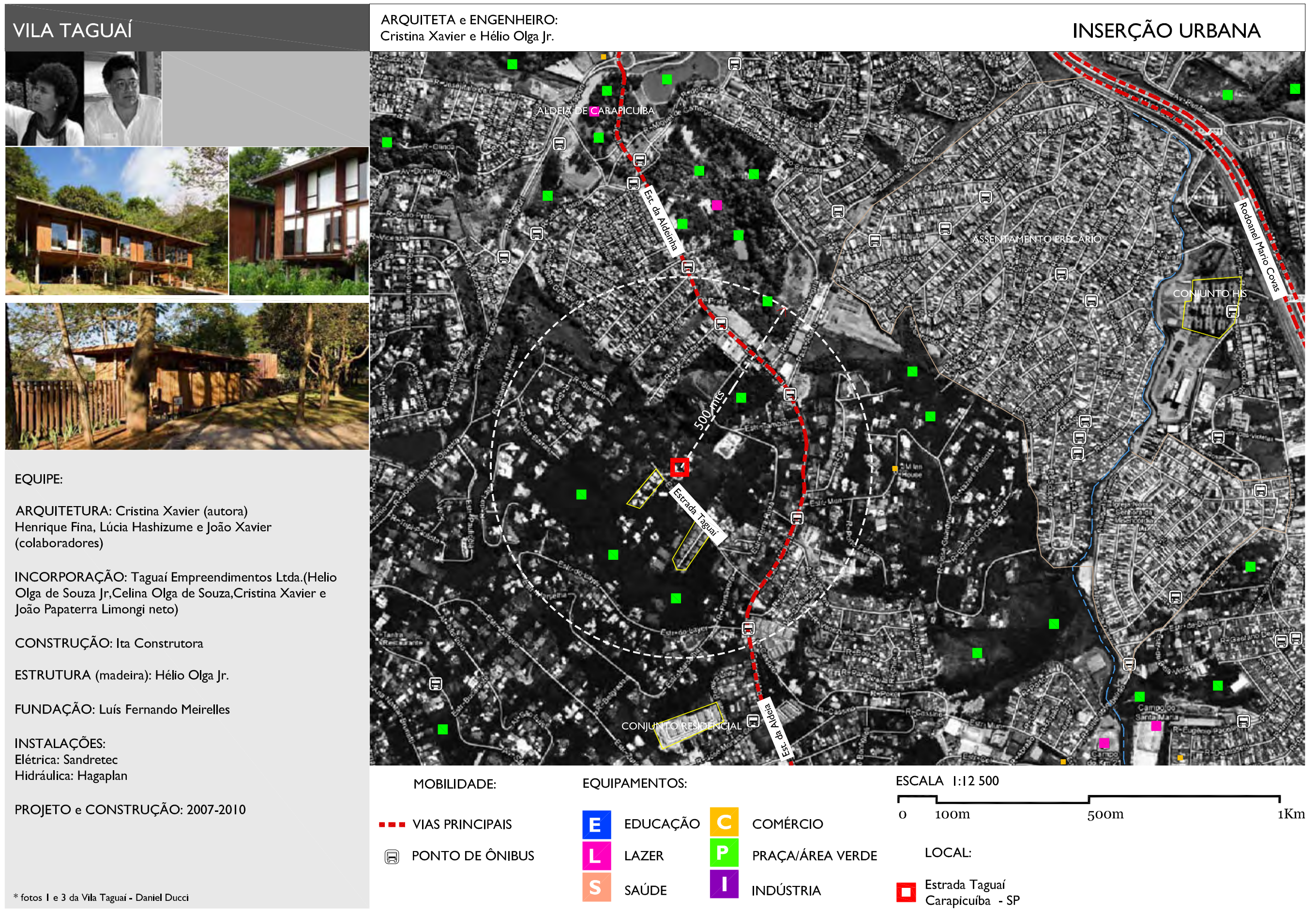




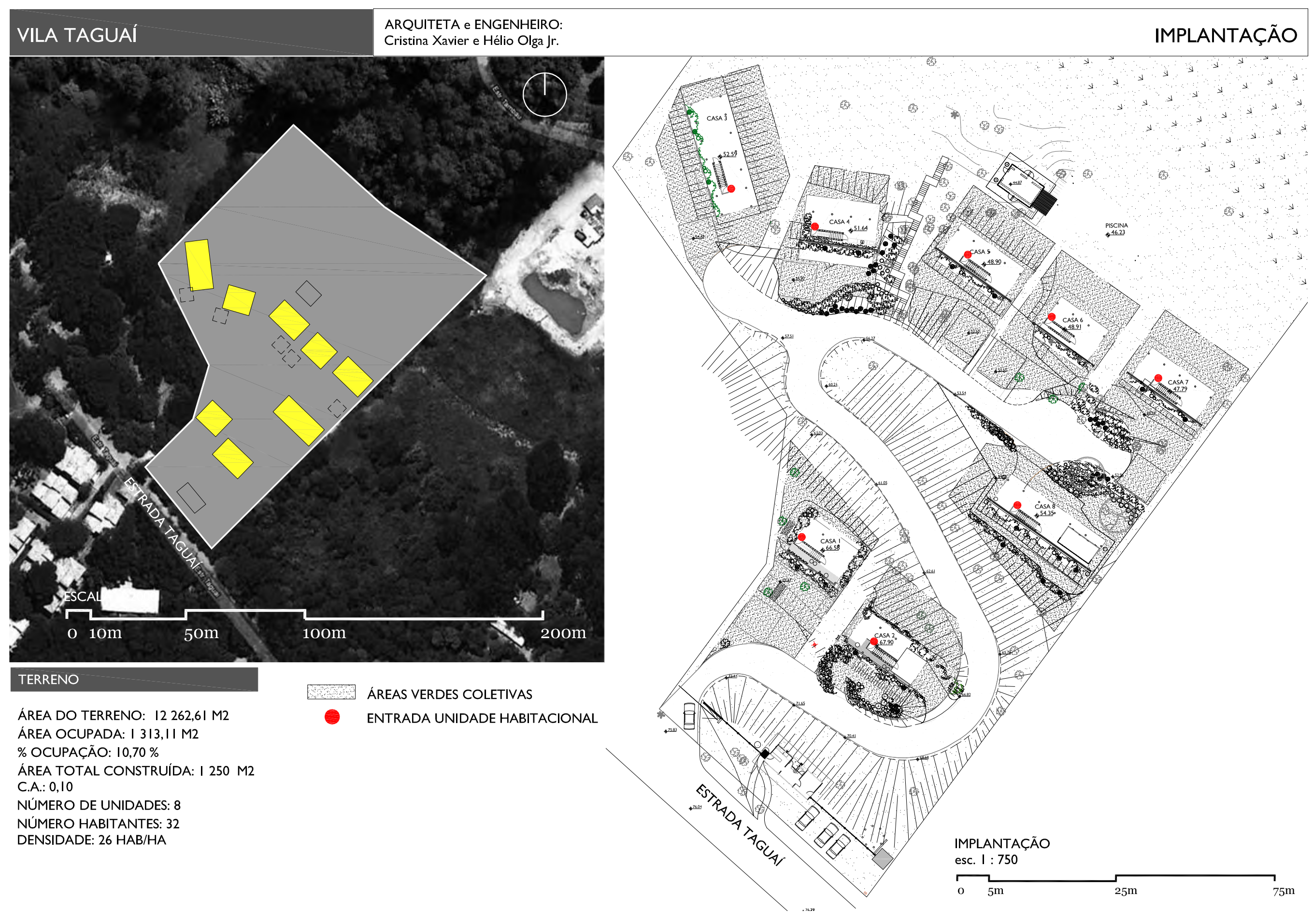



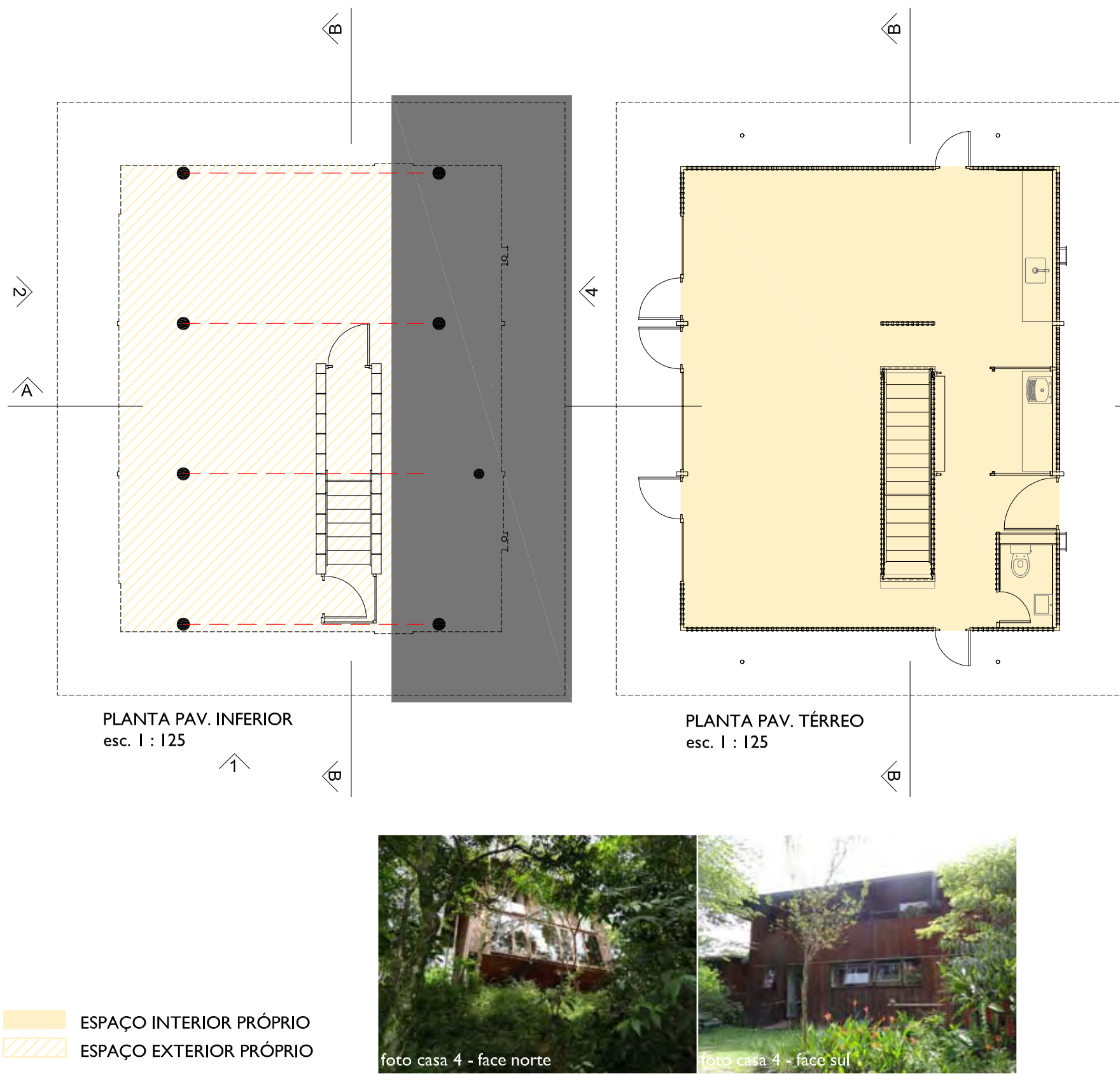

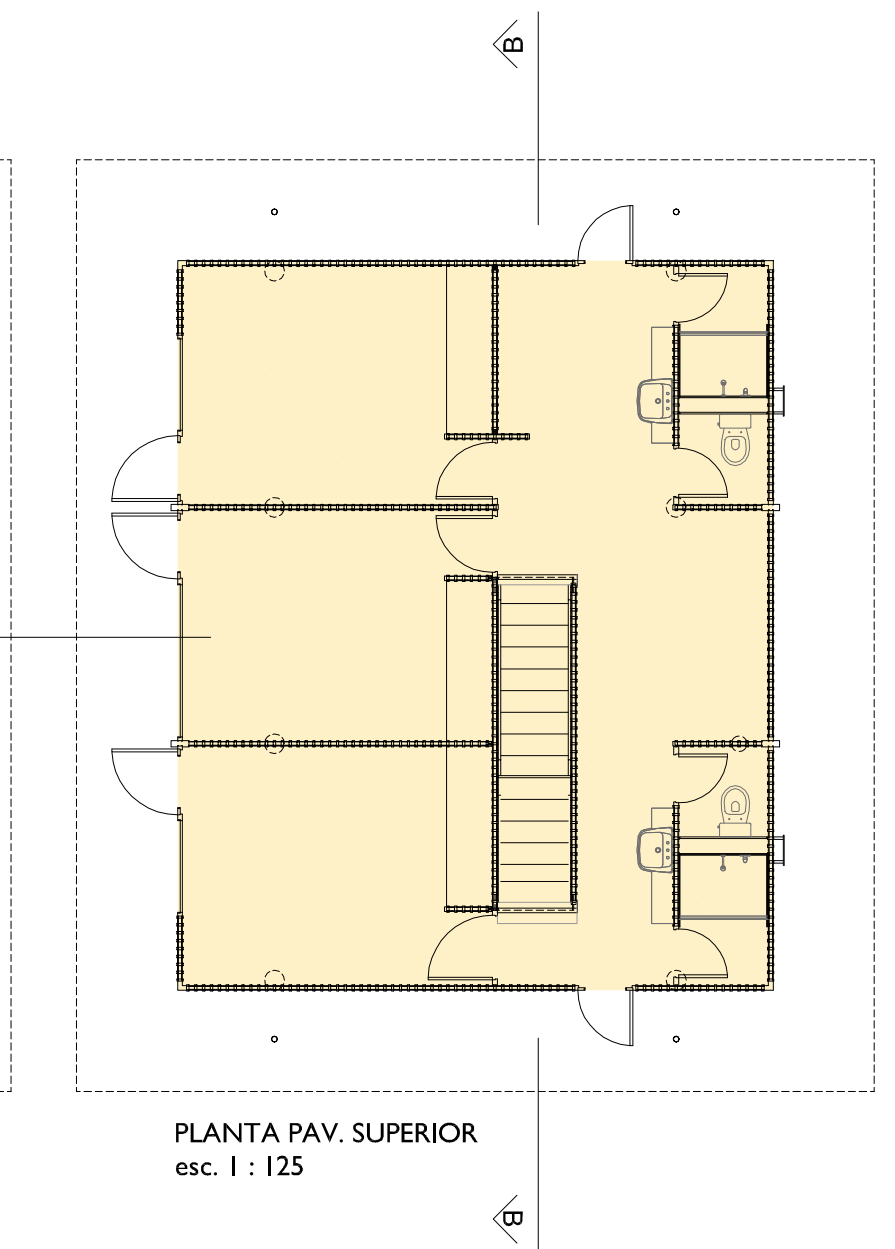

$\times 3$

TIPOLOGIA I

$70,00 \mathrm{~m}^{2}$

$70,00 \mathrm{~m}^{2}$

AVIMENTO TÉRREO

PAV. SUPERIOR

computável $\quad 140,00 \mathrm{~m}^{2}$ não computável $\quad 50,86 \mathrm{~m}^{2}$ total $190,86 \mathrm{~m}^{2}$ 


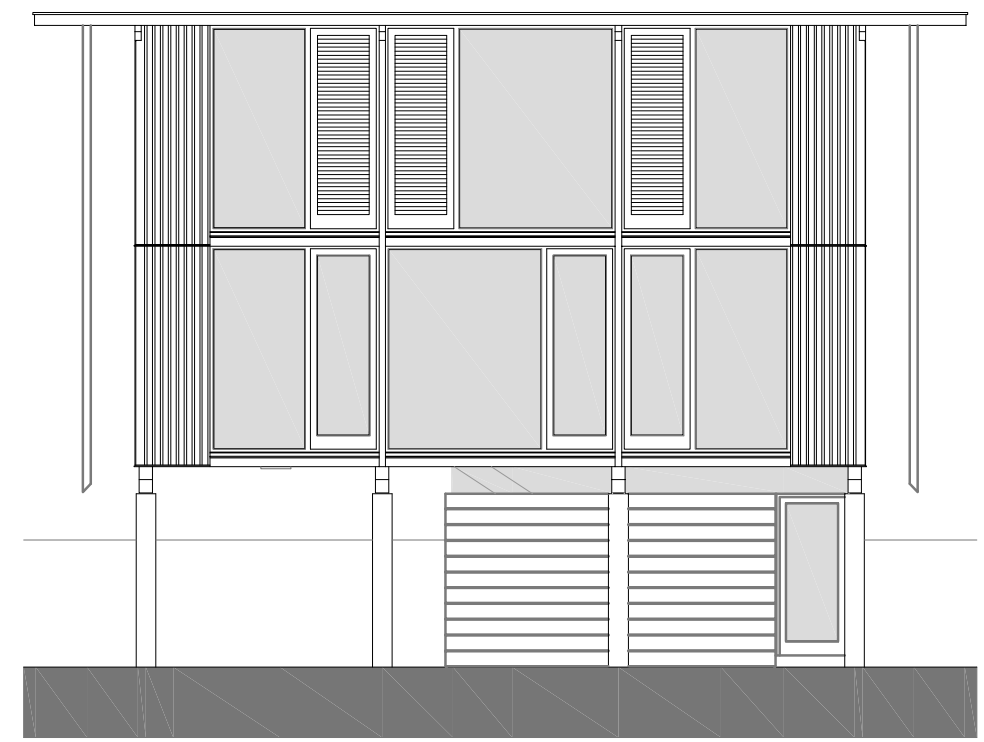

ELEVAÇÃO 02

esc. 1 : 125

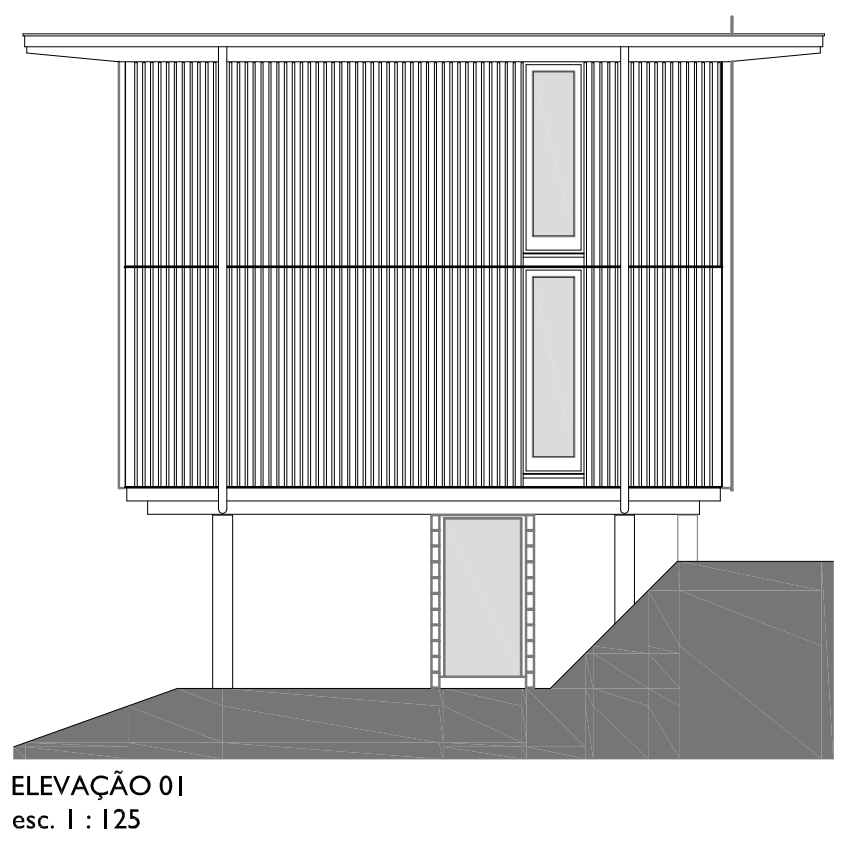

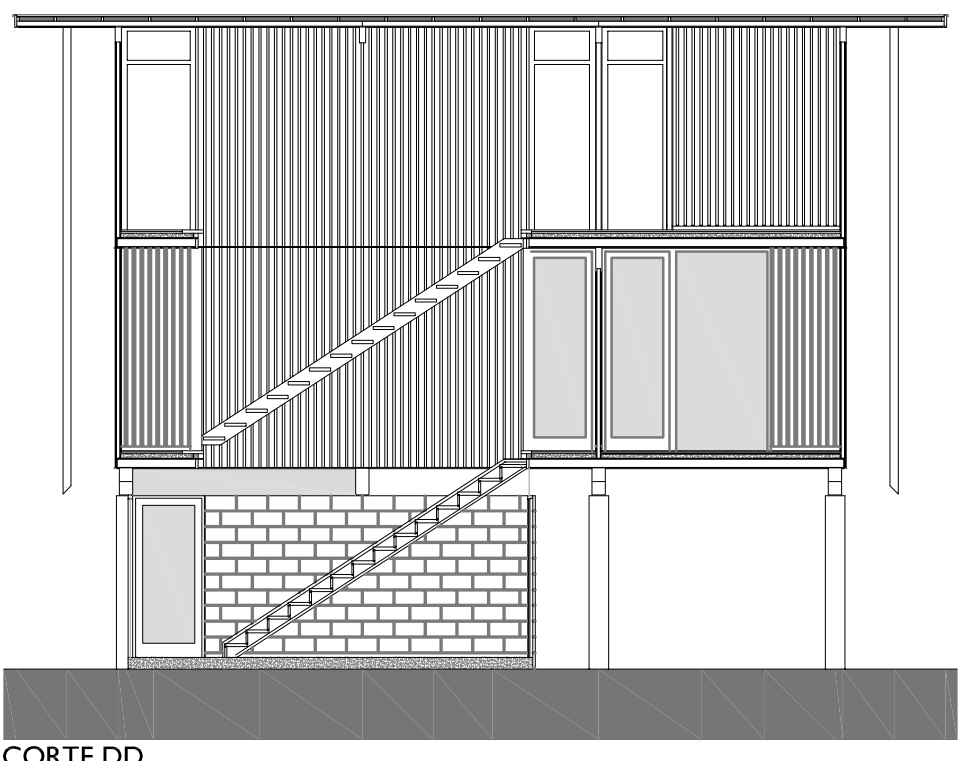

CORTE DD

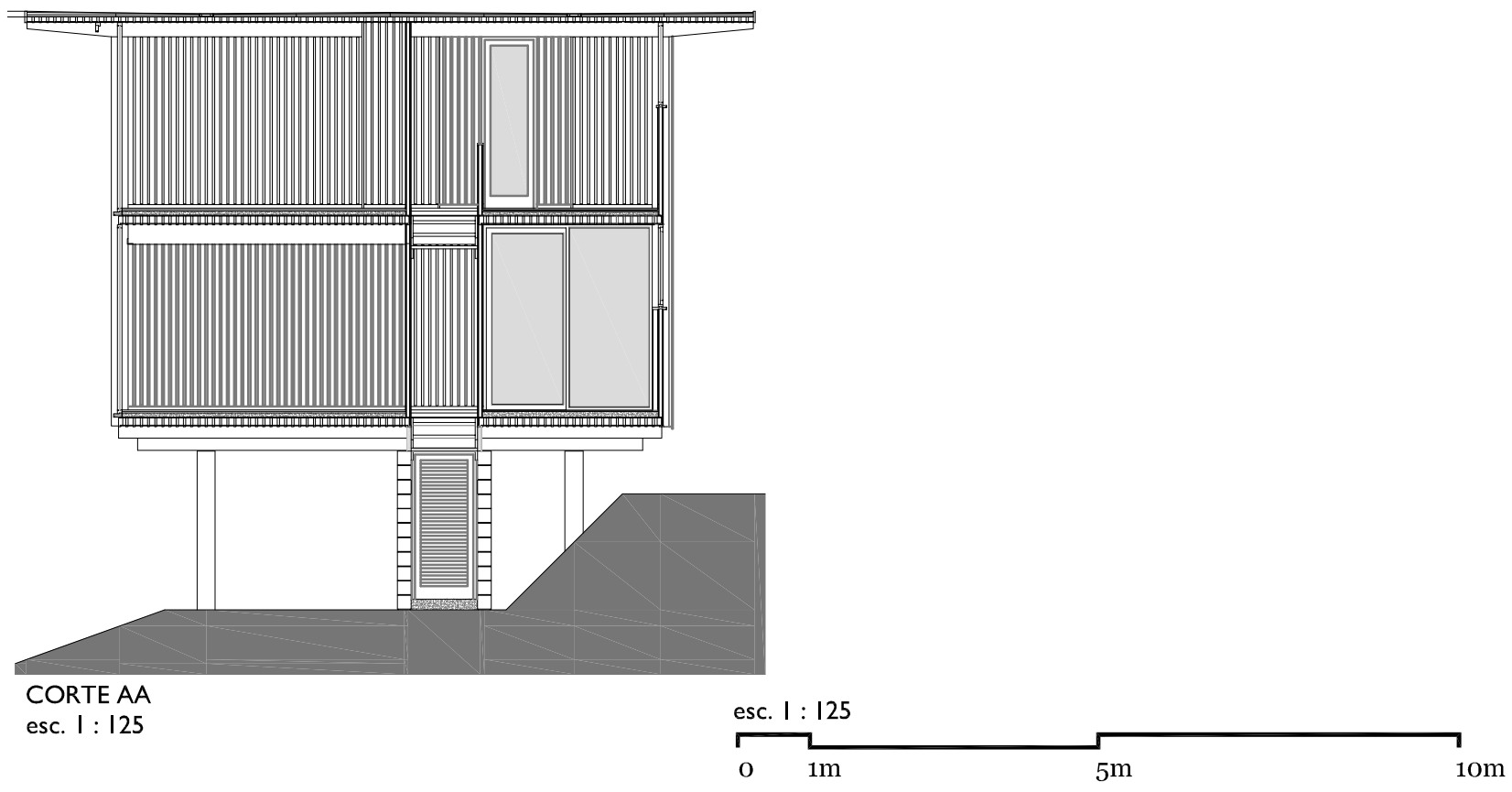




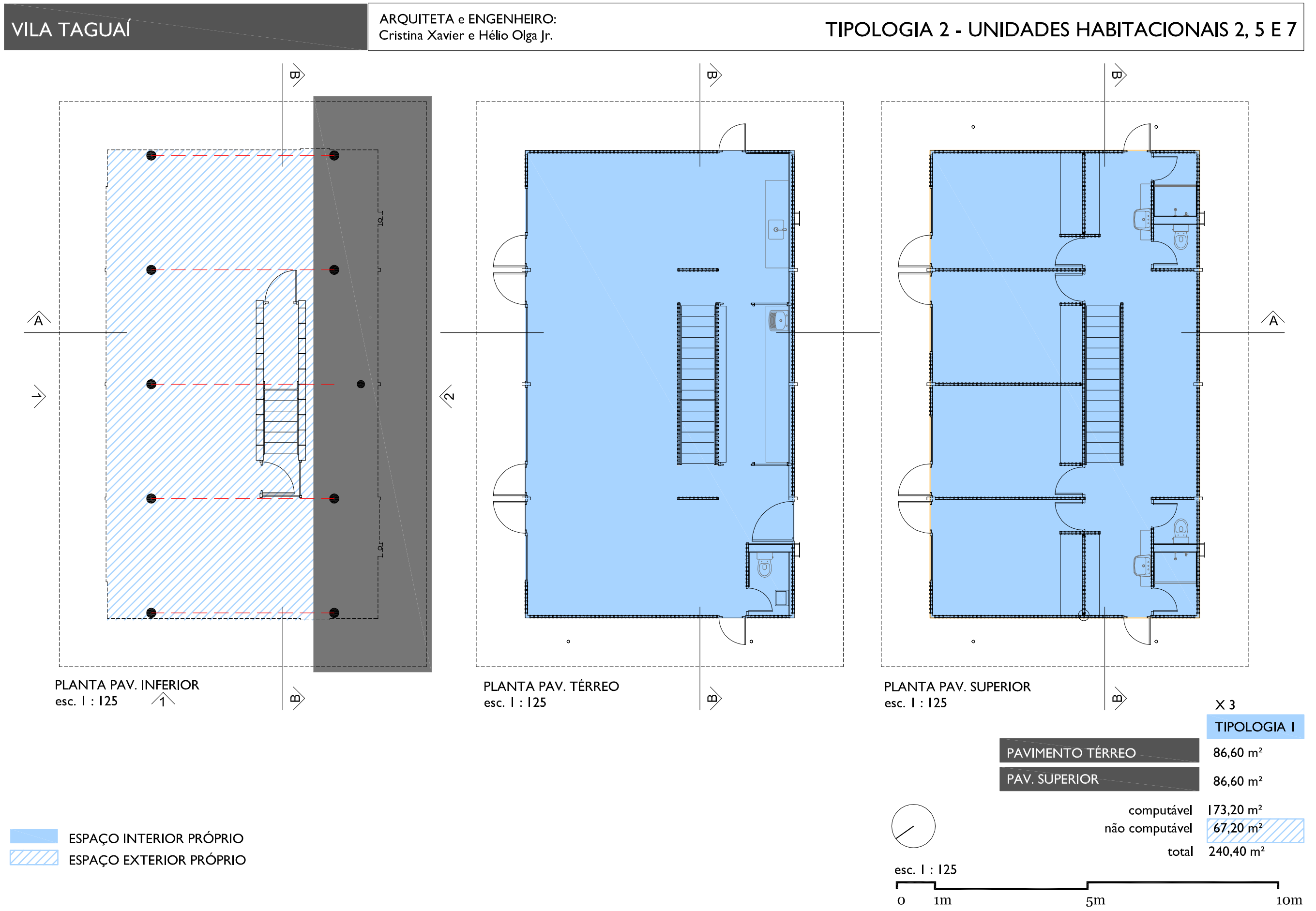




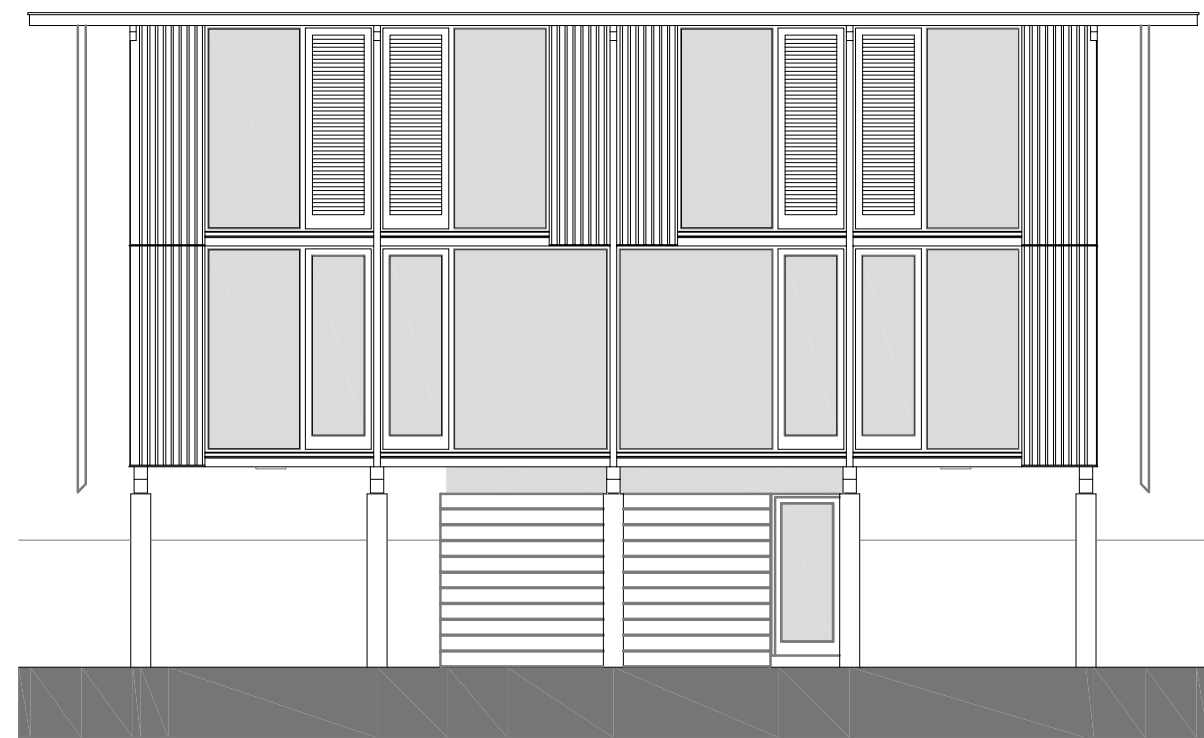

ELEVAÇÃO 0 esc. $1: 125$

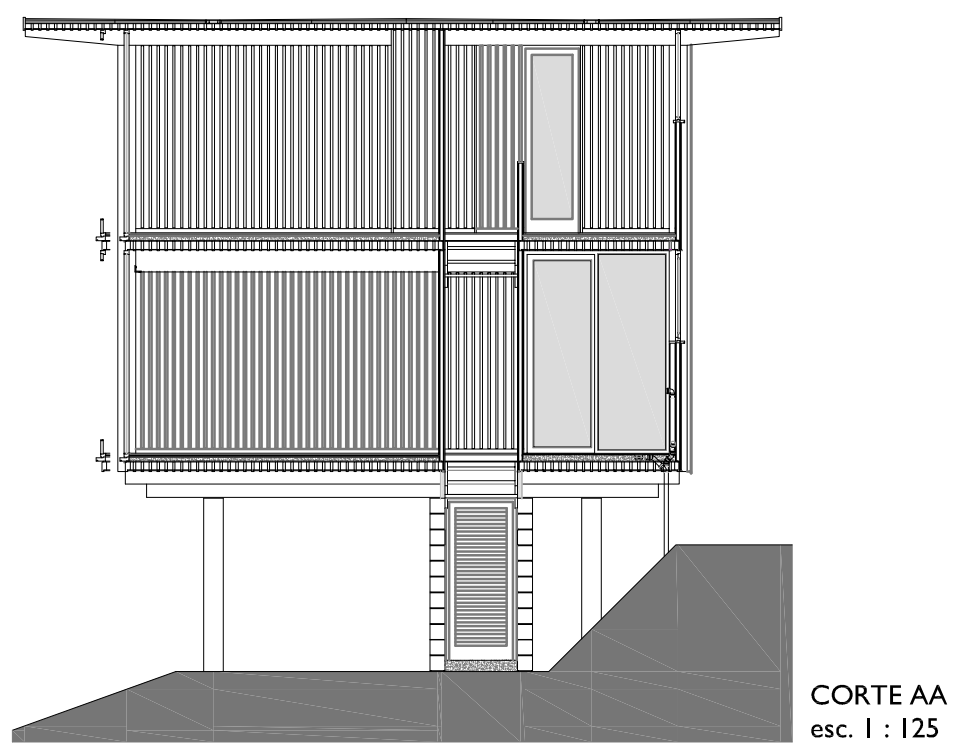

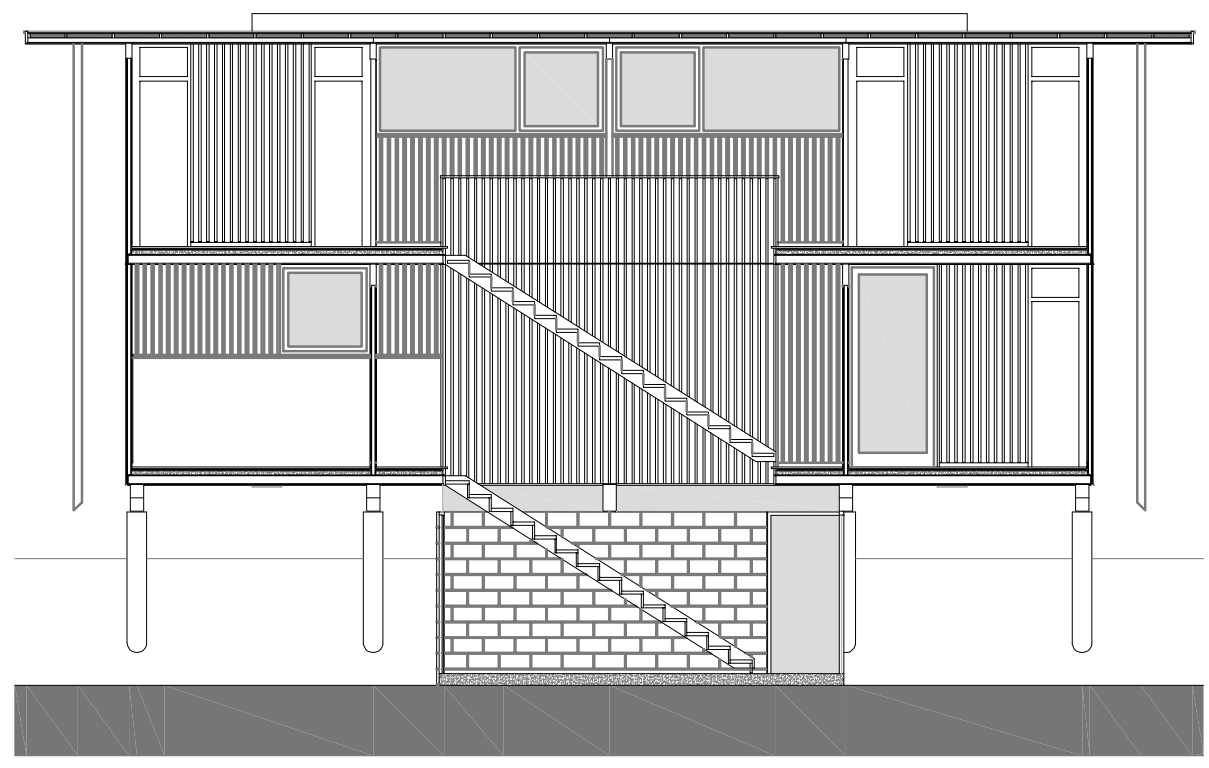

CORTE BB

esc. $1: 125$

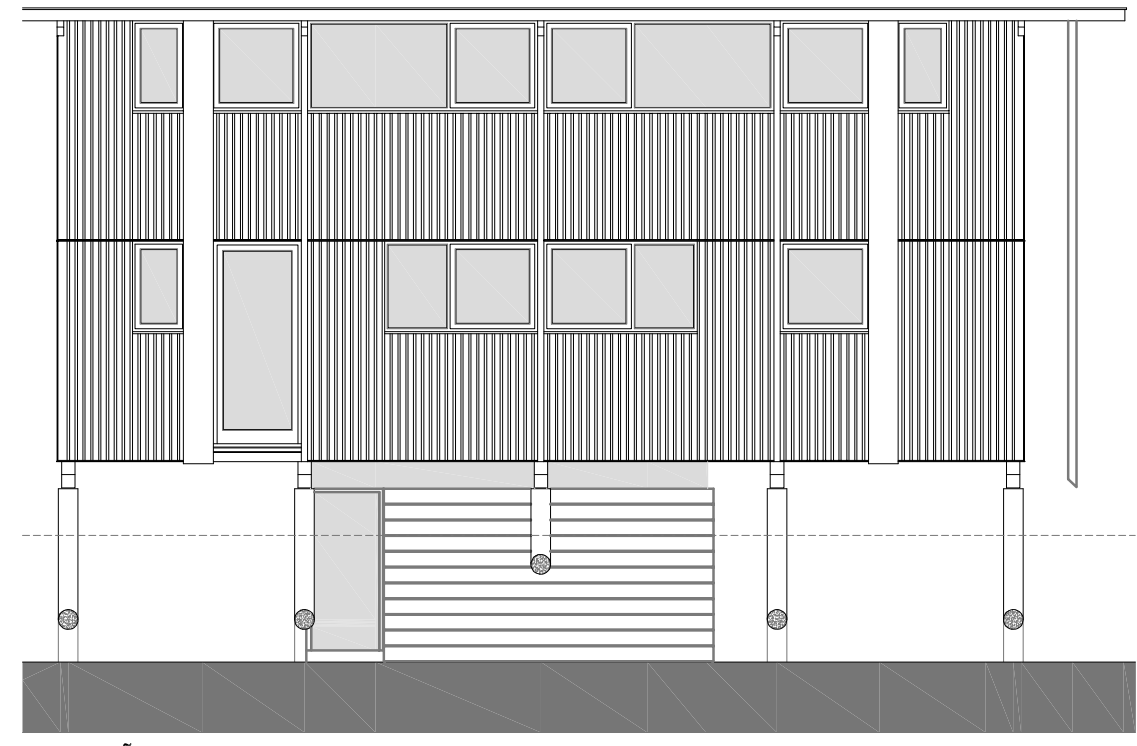

ELEVAÇÃO 02

esc. 1 : 125

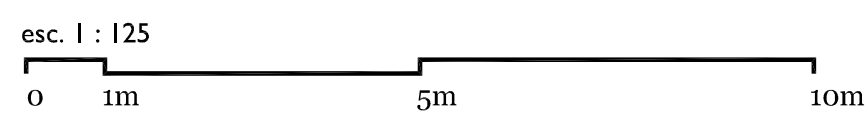




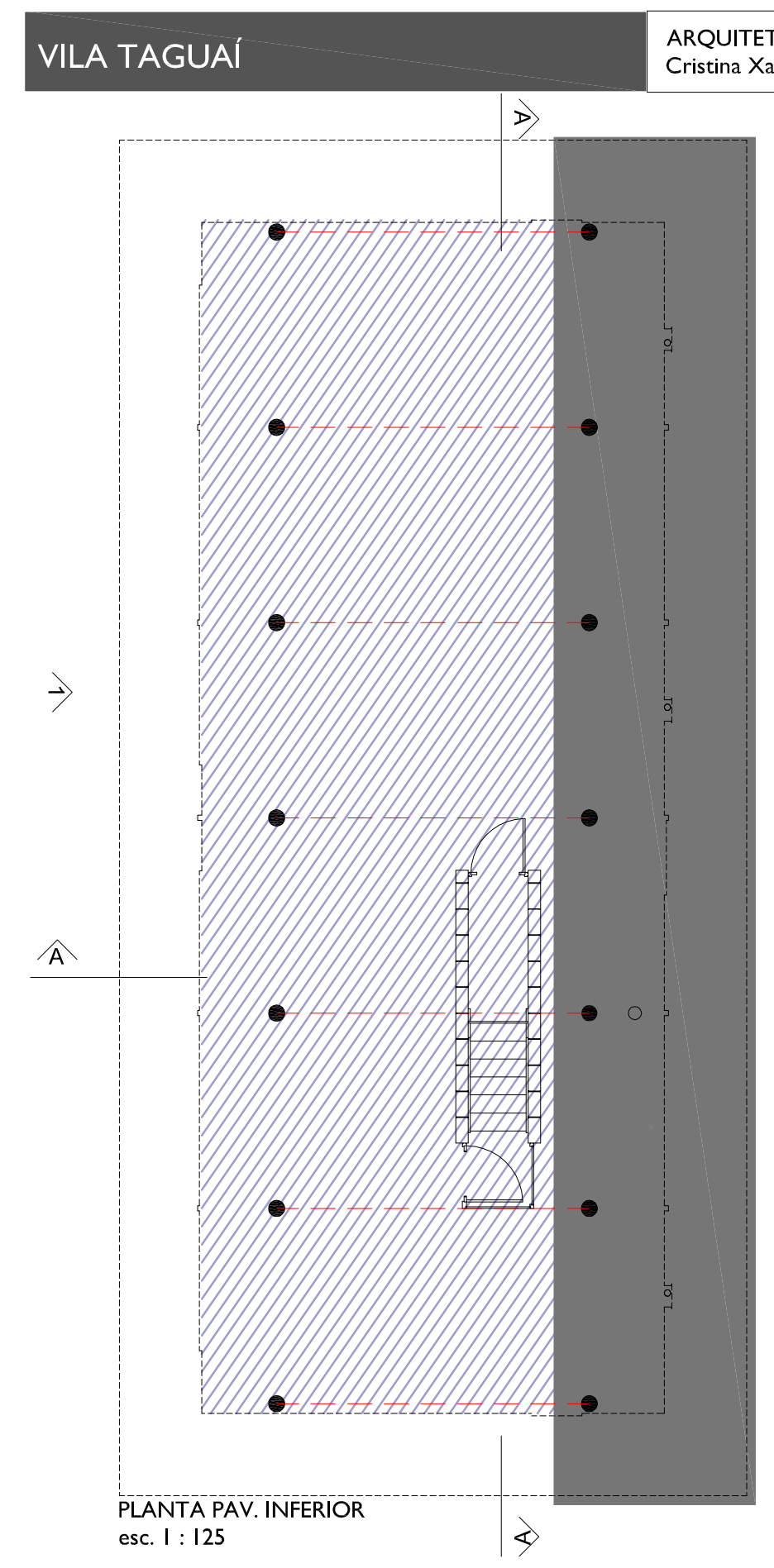

TIPOLOGIA 3 - UNIDADES HABITACIONAIS 3 E 8

ESPAÇO INTERIOR PRÓPRIO VIIIJ ESPAÇO EXTERIOR PRÓPRIO

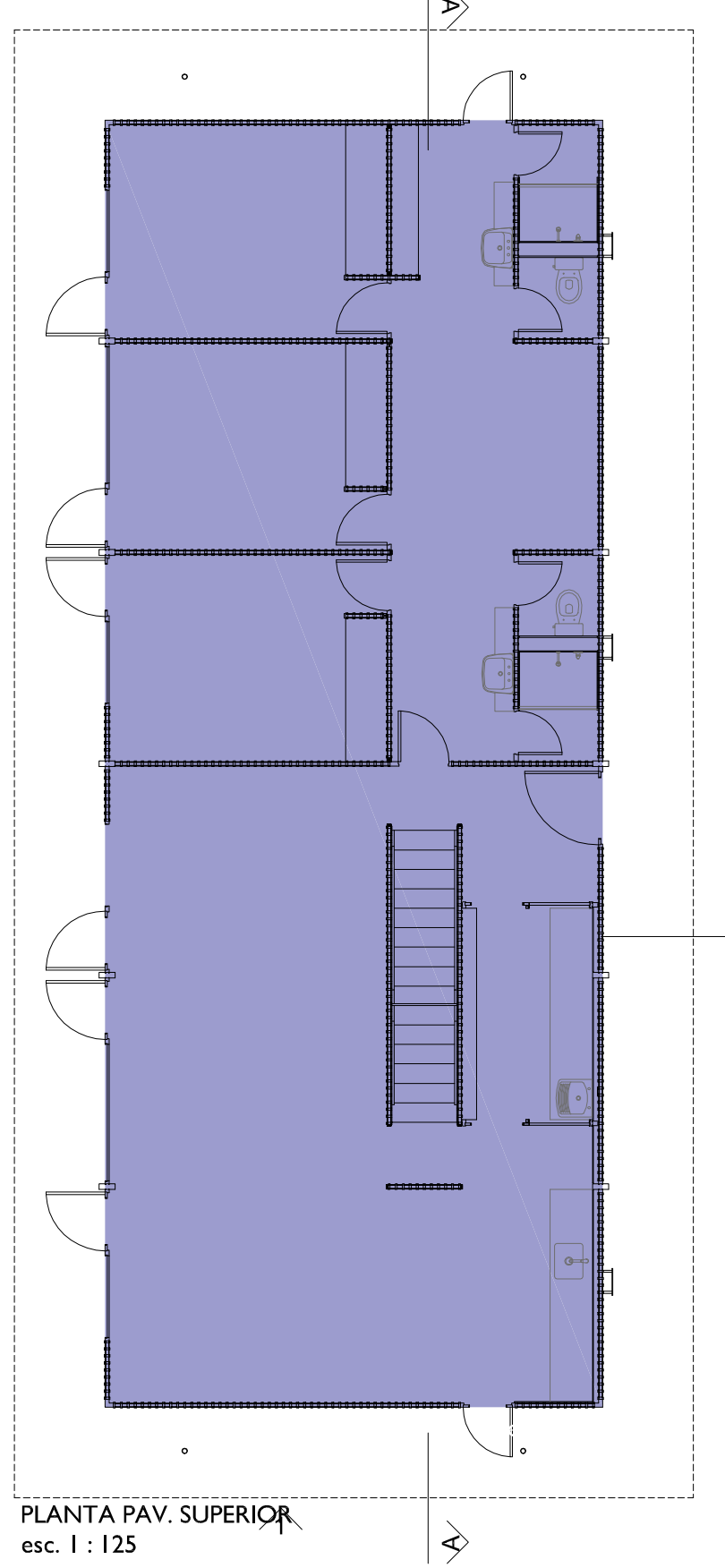

A

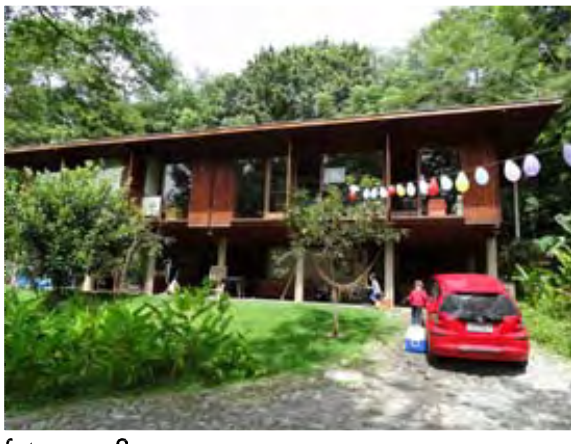

foto casa 8 TIPOLOGIA I

PAVIMENTO TÉRREO

PAV. SUPERIOR

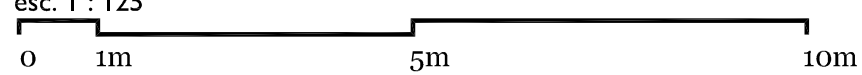




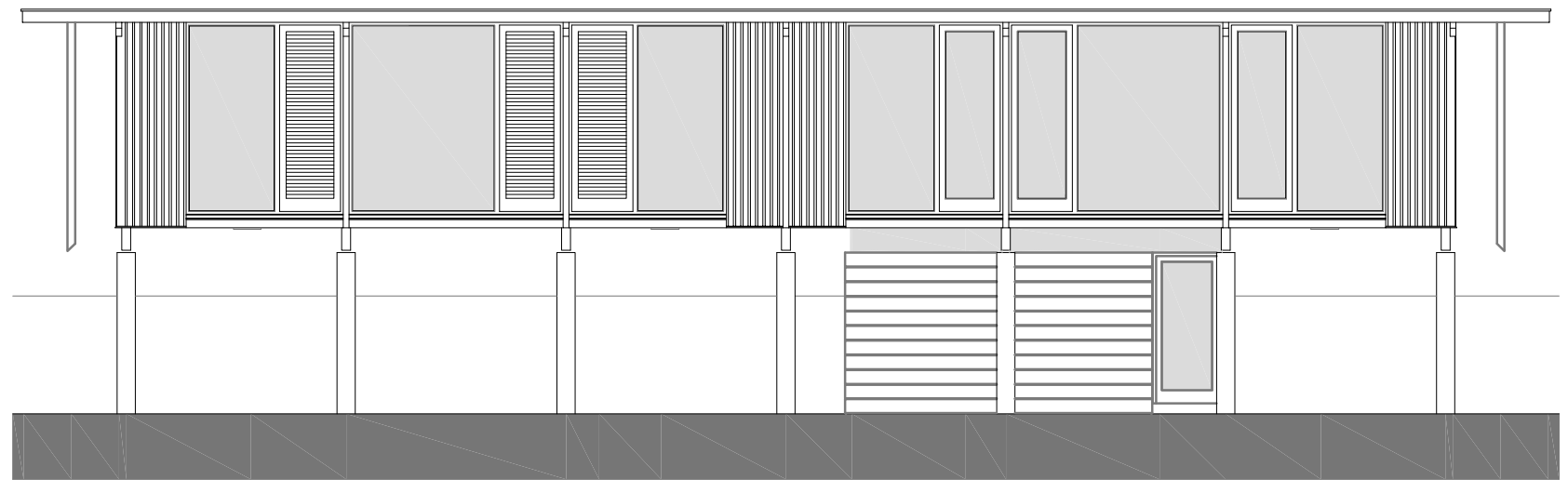

ELEVAÇÃO 0 |

esc. I : 125

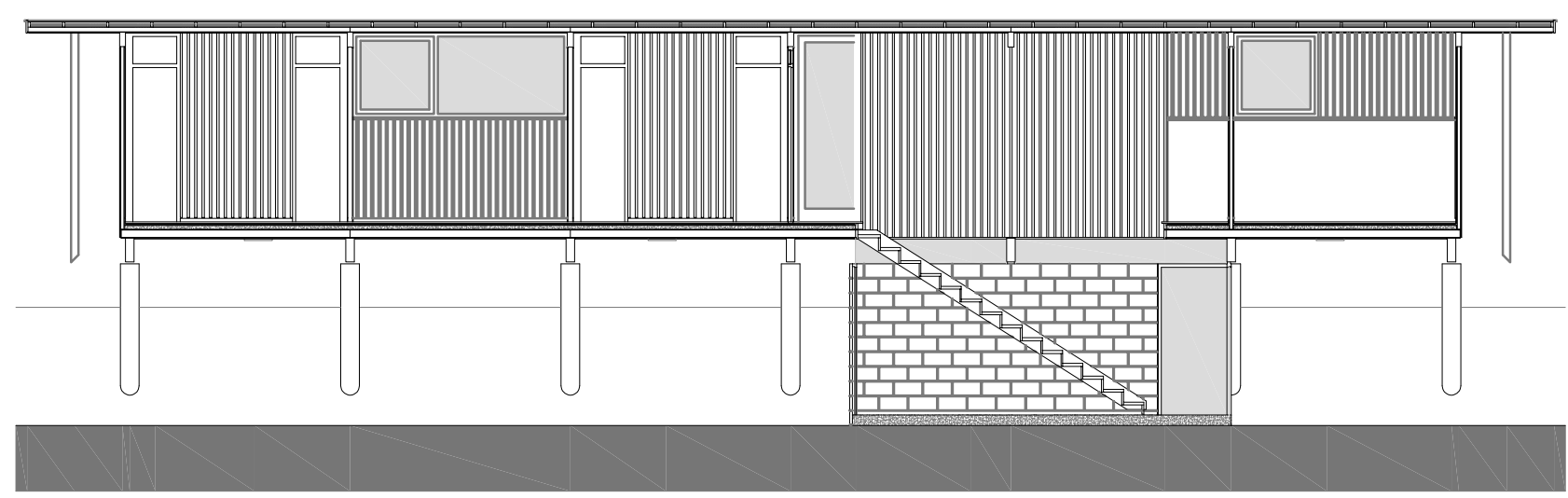

CORTE AA

esc. $1: 125$

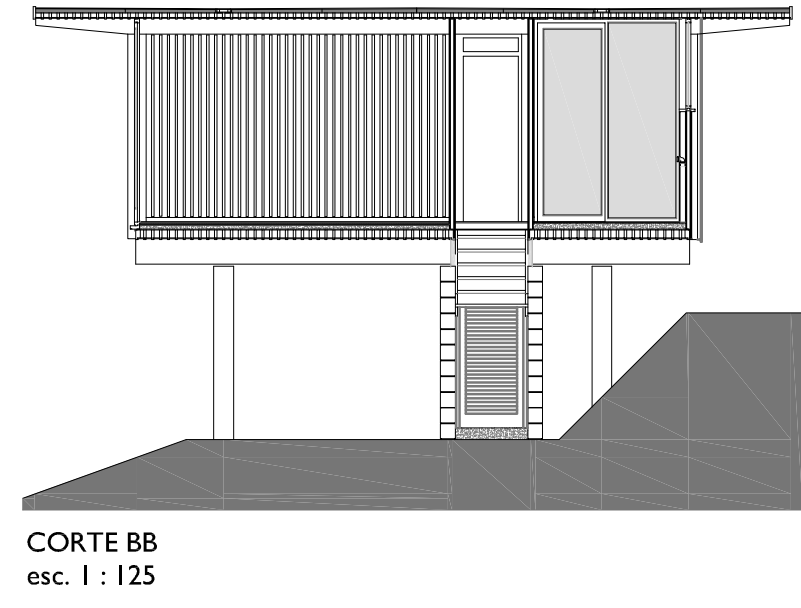

esc. $1: 125$

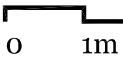

$5 \mathrm{~m}$ 
AfLALO, M. (Org.). Madeira como estrutura. A história da Ita. São Paulo: Paralaxe, 2005.

ARANTES, P.F. (Org.). Sérgio Ferro. Arquitetura e trabalho livre. São Paulo: Cosac Naify, 2006.

LESSA, Kátia. Os condomínios empobrecem SP. Folha de São Paulo, São Paulo, 05 de maio de 201 I.

OLGA, H. A linguagem da madeira no mundo contemporâneo. 20 I 2b. Disponível em: <http://www.itaconstrutora.com.br/>.Acesso em: I5/I2/2012.

OLGA, H. Experiência Brasileira na fabricação de laminado colado de eucalipto. 20I2a. Disponível em: <http://www.itaconstrutora.com.br/>.Acesso em: 15/12/2012.

RIBEIRO, Bruno. Paulistanos trocam a capital por condomínios no interior. Folha de São Paulo, São Paulo, 29 março de 201 I.

SERAPIÃO, Fernando. Experimental, conjunto de casa transpira soluções ambientais. ProjetoDesign. São Paulo, n.369, p. 44-53, novembro de 2010.

PROJETODESIGN.A reação ao neoclássico e a promessa para o futuro. São Paulo, n.37I, p. 88, janeiro de 201 I.

MELENDEZ, Adilson; SERAPIÃO, Fernando. Entrevista Hélio Olga Jr. ProjetoDesign, São Paulo, n.264, fevereiro de 2012.

VISITA REALIZADA:

Vila Taguaí - 17 de março de 2012.

ENTREVISTAS:

Arquiteta Cristina Xavier - 17 de março de 2012 e 14 de dezembro de 2012. 
LEIS:

SÃO PAULO (município). Lei n 11.605 , de 12 de julho de 1994. Dispõe sobre a criação da subcategoria de uso residencial R3-03, conjunto residencial - vila, e dá outras providências.

SÃO PAULO (município). Lei n 13.885, de 25 de Agosto de 2004. Planos Regionais Estratégicos das Subprefeituras de São Paulo.

SÃO PAULO (município). Lei n II.228, de 25 de junho de 1992. Código de Obras e Edificações do Município de São Paulo. Dispões sobre as regras gerais, e específicas a serem obedecidas no projeto, licenciamento, execução, manutenção e utilização de obras e edificações, dentro dos limites dos imóveis, revoga a Lei $n^{\circ} 8.266$ de 20 de junho de 1975, com as alterações adotadas por leis posteriores, e dá outras providências.

SÂO PAULO (município). Decreto Municipal n 32.329 de 23 de setembro de 1992. Regulamenta a Lei n 11.228 de 25 de junho de 1992 - Código de Obras e Edificações, e dá outras providências

OUTROS:

BACHOFNER, R. Construção em madeira pelo país. Simpósio Woodworks: construindo com madeira no Brasil e na Suíça. São Paulo: FAUUSP, 09 de outubro de 2012.

OLGA, H. Construções em madeira no Brasil: situação atual e perspectivas. Simpósio Woodworks: construindo com madeira no Brasil e na Suíça. São Paulo: FAUUSP, 09 de outubro de 2012. 



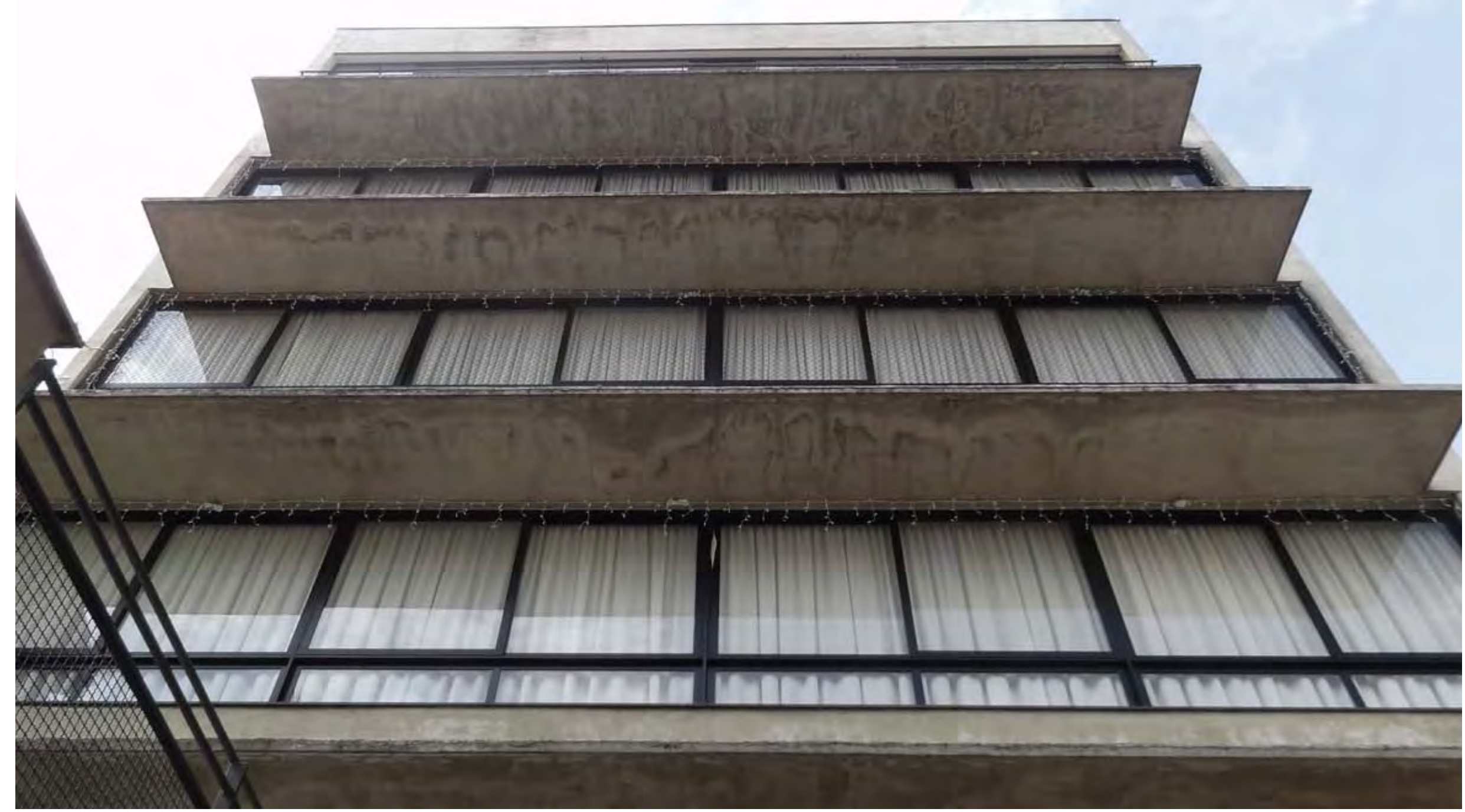

3. LEITURA DOS PROJETOS SELECIONADOS 3.2 EDIFÍCIOS POUCO VERTICALIZADOS COM UNIDADES HABITACIONAIS SOBREPOSTAS 


\subsection{VILA PEDRO FACHINI: HABITAÇÃO DE INTERESSE SOCIAL NA CIDADE DE SÃO PAULO}

\subsection{I.I INTRODUÇÃO}

O projetoVila Pedro Fachini tem como característica fundamental a inserção de habitação de interesse social (HIS) em área urbana consolidada e bem localizada na cidade de São Paulo, em lote exíguo, e que mantém a população residente do local, que antes do novo edifício, viviam sem a mínima condição de habitabilidade. Esta iniciativa consegue descartar a falsa ideia de inviabilidade econômica e projetual deste tipo de atuação em lote pequeno e com necessidade de projeto sob medida, inclusive trazendo novas possibilidades de ocupação de lote urbano com habitação coletiva. Estas realizações, por mais que ainda não aconteçam em escala suficiente para representar um forte potencial de requalificação urbana, ainda assim conseguem melhorar pequenos trechos do bairro e levar civilidade' a moradores marginalizados e segregados da vida social do meio onde vivem (Figura 0I).

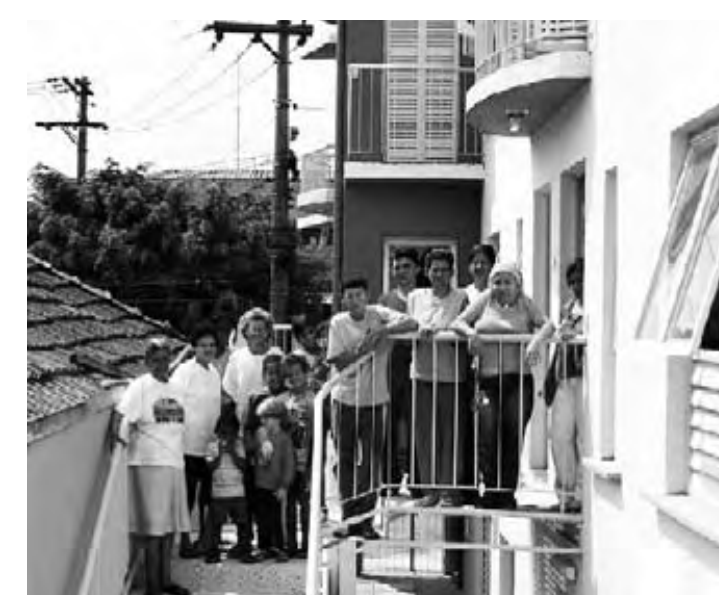

Figura I - Moradores da Vila Pedro Fachini.

Projetos como os de substituição de cortiços em lote urbano, em São Paulo, podem responder a algumas dessas preocupações. A partir de uma combinação de programas voltados às ações em área central, desapropriações e compra de edifícios, linhas de financiamento e demandas organizadas foi possível qualificar a cidade por meio de novas possibilidades de ocupação do lote (WISSENBACH, et al; 2006, p. 86).

\footnotetext{
Segundo o novo dicionário AURÉLIO da Língua Portuguesa, CIVILIDADE significa o conjunto de formalidades observadas entre si pelos cidadãos em sinal de respeito mútuo e consideração. Polidez, urbanidade, delicadeza, cortesia. Este termo foi utilizado por VIGLIECCA (20I2) na conferência "Construir a Cidadania" onde foi enfatizada a importância do projeto de interesse social em permitir que os moradores tenham, principalmente, civilidade, ou seja, respeito pelo seu espaço privado e pelo espaço público, entender que o público deve ser cuidado e bem recebido pelos cidadãos porque a eles pertencem.
} 


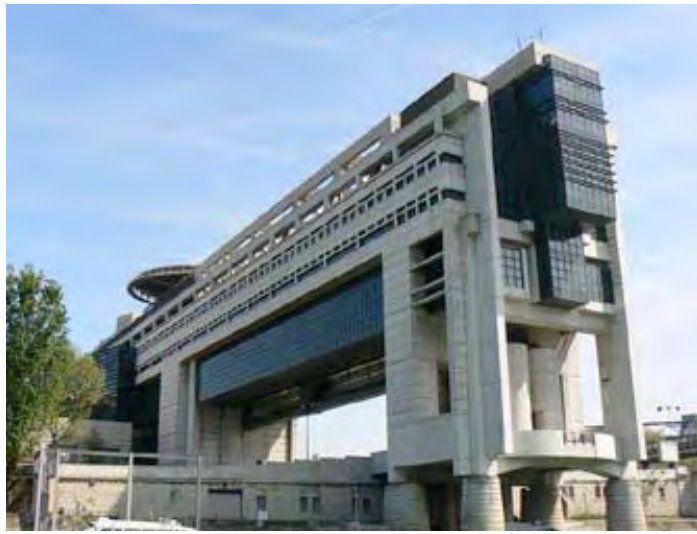

Figura 2 - Ministério das Finanças na França (1989). Arquitetura Chemetov + Huidibro, escritório no qual Jupira Corbucci trabalhou durante sua estadia na França na década de 1980.

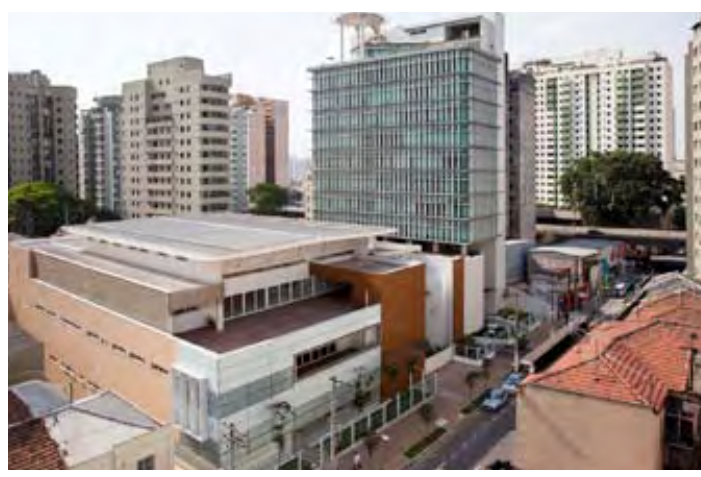

Figura 3 - Ao fundo, Sede do Conselho Regional de Contabilidade do Estado de São Paulo, edifício construído a partir de Concurso Nacional do qual Marcelo Barbosa, Roberto Amá e Jupira Corbucci saem vencedores em 1991. Em primeiro plano, projeto da ampliação realizado em 2008 pelo escritório BACCO Arquitetos Associados, contratado por notório saber.

\subsubsection{BREVE TRAJETÓRIA DO BACCO ARQUITETOS ASSOCIADOS}

Tanto Marcelo Barbosa como Jupira Corbucci, hoje líderes do escritório BACCO Arquitetos Associados, formaram-se em 1984, o primeiro pela Universidade Mackenzie, e o segundo pela Pontifícia Universidade Católica (PUC) de Campinas. Década de crise geral no país, a "década perdida" da economia brasileira que vai chegar ao extremo no final daqueles anos com uma hiperinflação, e ao mesmo tempo, com muitas apostas de melhorias com as "Diretas Já", que coloca fim na ditadura militar no Brasil. Com relação à atividade profissional do arquiteto, além de sentir esta crise no mercado profissional, também houve a transição do modo de trabalhar, do desenho manual feito na prancheta ao uso do computador que vai ocorrer no final dos anos 1980, quando os arquitetos se veem obrigados a obter conhecimento deste novo modo de trabalho que não era aquele que haviam aprendido na universidade. Este era o cenário dos primeiros anos como arquiteto formado, para o caso de Marcelo Barbosa, já que Jupira Corbucci estava, durante este período, na França, trabalhando no escritório Chemetov + Huidibro, autor do projeto do Ministério das Finanças na França (1989) (Figura 02).

Com relação ao início da formação do escritório BACCO Arquitetos Associados, Marcelo Barbosa trabalhou em parceria com Roberto Amá $^{2}$ a partir de 1989, antes de associar-se com Jupira Corbucci. Quando Corbucci retorna ao Brasil, no início da década de 1990, estava em voga um projeto de Barbosa com Amá, um Flat para idosos. Corbucci propôs colaboração neste trabalho, inclusive porque estava envolvido em projetos deste mesmo tema na Europa, relacionados à habitação para idosos. Porém, esta colaboração acabou não acontecendo, pois o projeto foi interrompido e acabou não sendo realizado. Numa outra oportunidade, em 1991, Barbosa o convida para participar do concurso Nacional de Propostas para a Nova Sede do Conselho Regional de Contabilidade (CRC)

${ }^{2}$ Roberto Amá (1963-2006) era membro atuante da Asbea, autor do Manual de Escopo e Projetos feito com o Arq. Henrique Cambiaghi. Formado pela Louisiana State University (EUA), em 1984, e com experiência em escritórios americanos, o arquiteto Roberto Amá criou, em 1989, o escritório Amá Arquitetos Associados, escritório de projetos e consultoria em arquitetura e urbanismo. 
do Estado de São Paulo ${ }^{3}$, do qual saem vencedores. Este seria o primeiro trabalho dos dois arquitetos em parceria. $O$ projeto resgata características do movimento moderno ao mesmo tempo em que considera a escala do bairro na inserção urbana do novo volume:

\begin{abstract}
Vencedor de concurso público realizado em 1991, o projeto deste edifício de escritórios, leva em consideração elementos característicos do bairro e de seu complexo entorno imediato. Todos esses dados estão sintetizados nos volumes da base e da torre - uma releitura do modernismo brasileiro -, que permitem dois níveis de apreensão do partido arquitetônico: o embasamento sintoniza a escala do pedestre e do casario existente; o corpo vertical remete à escala dos prédios e da paisagem (Memorial do projeto CRC - Conselho Regional de Contabilidade, São Paulo, 1991 - BACCO).
\end{abstract}

Segundo Santos (2002), os critérios definidos pela comissão julgadora ${ }^{4}$, para análise dos trabalhos, estavam baseados no melhor aproveitamento do terreno, na funcionalidade e aproveitamento do prédio para o uso proposto, nas relações com o entorno e na imagem ambiental, no resultado plástico da proposta, nos materiais, técnicas construtivas e custos previstos.

Em 2008, o escritório BACCO foi contratado para fazer o projeto da ampliação do CRC. A profachada ou elementos que competissem com o volume do primeiro projeto, ganhador do concurso de 1991. Foi criada, deste modo, uma diferenciação do novo com relação ao pré-existente, mas em harmonia e em correlação (Figura 03).

O escritório BACCO tem como principal cliente a AmBev, para o qual realizam praticamente todos os projetos dos Centros de Distribuição.Trata-se de uma arquitetura na qual o

\footnotetext{
${ }^{3}$ Segundo dissertação de mestrado de Valéria Cássia dos Santos, "Concursos de Arquitetura em São Paulo" (2002), o concurso teve dezenove equipes inscritas, entre elas recebem menção honrosa Valério Pietratóia, Projeto Paulista de Arquitetura, Marco Antonio Bambicini e Rino Levi Arquitetos Associados. O projeto desenvolvido pela equipe vencedora, Amá e Barbosa Associados, tem a execução do edifício concluída em 1996.

${ }^{4}$ Jurí do concurso: José Serafim Abrantes (presidente),Arq. Sebastião Ankerkrone,Arq. Berthelina Alves Costa,Arq. Jean Gastron Lima Humbert, Arq. Riscardo Barbosa, Eng. Henrique Lima Neto e Eng. Plínio de Carvalho Neto.
}
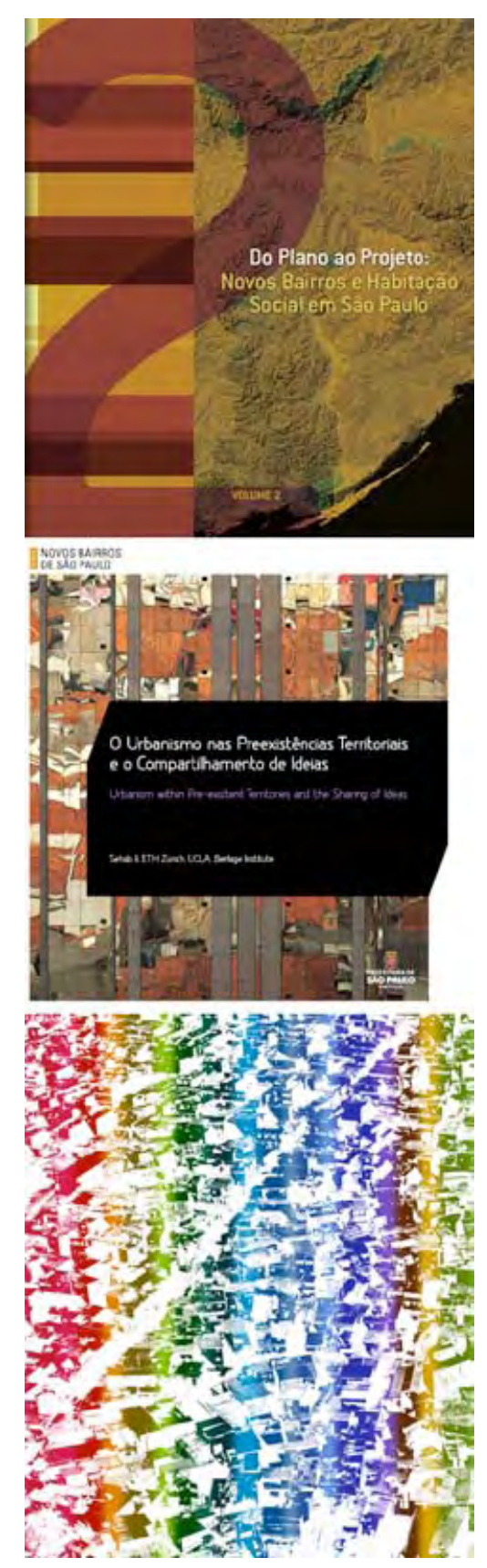


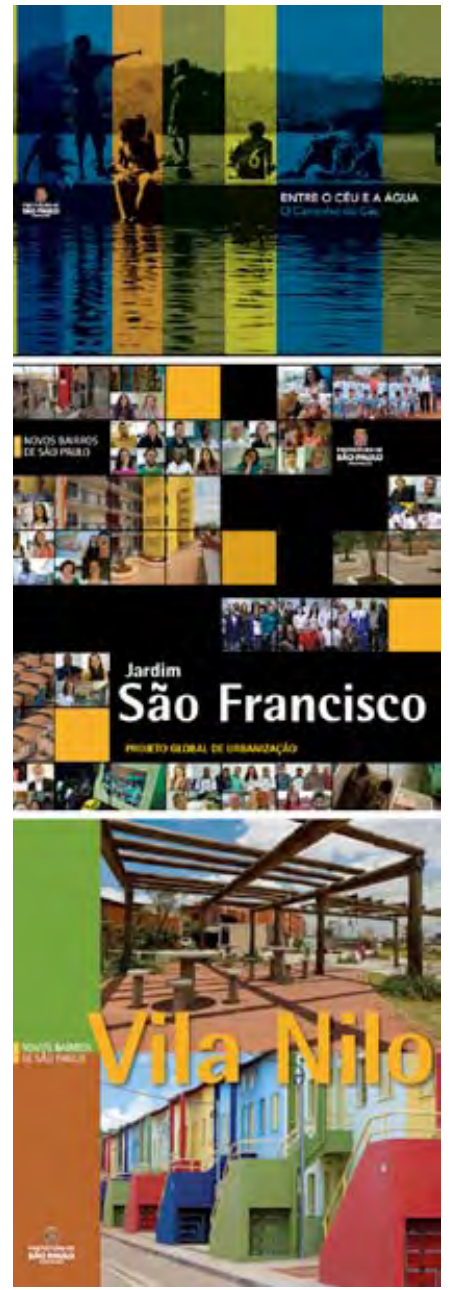

Figura 4 - Publicações no âmbito da arquitetura de habitação social lançadas recentemente pela Secretaria de Habitação da Prefeitura de São Paulo. I. Do Plano ao Projeto: Novos Bairros e Habitação Social em São Paulo (2012). 2. O Urbanismo nas Preexistências Territoriais e o Compartilhamento de Ideias (20I2). 3. Livro Renova São Paulo (20II). 3. Entre o Céu e a água - O Cantinho do Céu (20I2). São Francisco (20I2). Vila Nilo (20I I). desafio está mais na resolução planejada da logística em associação com a distribuição funcional,e por que não dizer harmoniosa do programa.A concepção estrutural e especificação de materiais não fogem do que normalmente é proposto em arquitetura industrial: estrutura pré-moldada em concreto, fechamento e cobertura em telhas metálicas e alvenarias em bloco, revestidas em massa e pintura.

Com relação à atuação do escritório em projetos de habitação coletiva e também social, participaram de diversas concorrências que ocorreram na Secretaria de Habitação de São Paulo (SEHAB/SP) e Companhia Metropolitana de Habitação de São Paulo (COHAB/SP), na gestão da prefeita Marta Suplicy (200 I-2004), das quais saíram vencedores em três situações distintas de projeto: Vila Pedro Fachini, Edifício Senador Feijó e Conjunto Carlos Gomes, todas do mesmo programa, "Morar no Centro", o qual tem como objetivo melhorar as condições de habitação de quem já vive no Centro de São Paulo. Pode-se entender estes projetos como três exercícios arquitetônicos de projeto de habitação coletiva inserida na malha urbana consolidada, cada um com uma situação urbana peculiar e com condicionantes diferentes, existindo a situção de projeto em lote exíguo em bairro pouco verticalizado, para o caso da Vila Pedro Fachini; a reabilitação de construção existente tombada pelo patrimônio histório, para o caso do Edifício Senador Feijó; ou proposta de edifícios entre grandes empenas cegas em trecho mais denso e verticalizado do centro de São Paulo, para o caso do Conjunto Carlos Gomes.

\subsubsection{AGENTE PÚBLICO DE HABITAÇÃO SOCIAL COLETIVA}

O agente responsável pela realização da pequena vila na Rua Pedro Fachini foi a SEHAB/SP e $\mathrm{COHAB/SP}$. Dentro desta pesquisa, trata-se do único estudo de caso de promoção pública de HIS, afinal, o conjunto Canaã, em Cotia, dos Arquitetos Joan Villà e Sílvia Chile, por mais que atenda uma população de baixa renda, foi de promoção privada. 
As revistas ProjetoDesign e Arquitetura e Urbanismo foram as fontes primárias para adquirir pistas do que estava sendo realizado no âmbito da habitação coletiva contemporânea na região metropolitana de São Paulo, de exemplares publicados no século XXI, escolhendo projetos diferenciados daquilo que normalmente é proposto na cidade, e com a função de mostrar, a partir dos projetos selecionados, como é possível fazer diferente e, ao mesmo tempo, com qualidade. Uma tática para seleção de projetos diferenciados foi escolher aqueles nos quais a situação do lote urbano exigiu um projeto sob medida, ou seja, onde dificilmente seria possível utilizar algum projeto previamente concebido para outra situação que não fosse para aquele lote, prática usual tanto das grandes construtoras do mercado imobiliário privado, quanto dos agentes públicos que ainda constroem edifícios "carimbos". Exceções foram abertas para casos de projetos diferenciados por outros motivos, por exemplo, pela técnica construtiva, como é o caso do conjunto em Cotia de Joan Villà e Sílvia Chile ou até mesmo a vila de madeira de autoria de Cristina Xavier e Hélio Olga.

Foram mais de 200 revistas folheadas em busca de exemplares de habitação coletiva dentro destes critérios, sendo encontrados mais de 100 projetos de habitação coletiva, lembrando que nem todos os projetos tiveram uma matéria exclusiva completa, alguns realmente só foram citados e ao menos ilustrados com uma imagem, mas já representava uma pista do que estava sendo produzido no âmbito da habitação coletiva paulista na década de 2000. Destes, pouquíssimos são de habitação social. Isto pode significar que o foco de atuação da profissão do arquiteto, ou o motivo de sucesso profissional entre os arquitetos principalmente, pelo menos pela maneira como é colocado em evidência na mídia especializada, é destinado, em sua maioria, aos estratos sociais de alta renda. Isto é colocado por Ferreira (20II) no artigo sobre a visibilidade da arquitetura autoral pouco voltada à HIS:"A visibilidade da arquitetura autoral, voltada para as camadas de alta renda, na mídia arquitetônica, tem como contrapartida a ausência quase completa dos projetos voltados para as classes mais baixas, em especial a habitação de interesse social".

De certo modo, esta situação vem se mostrando diferente a partir de diversas

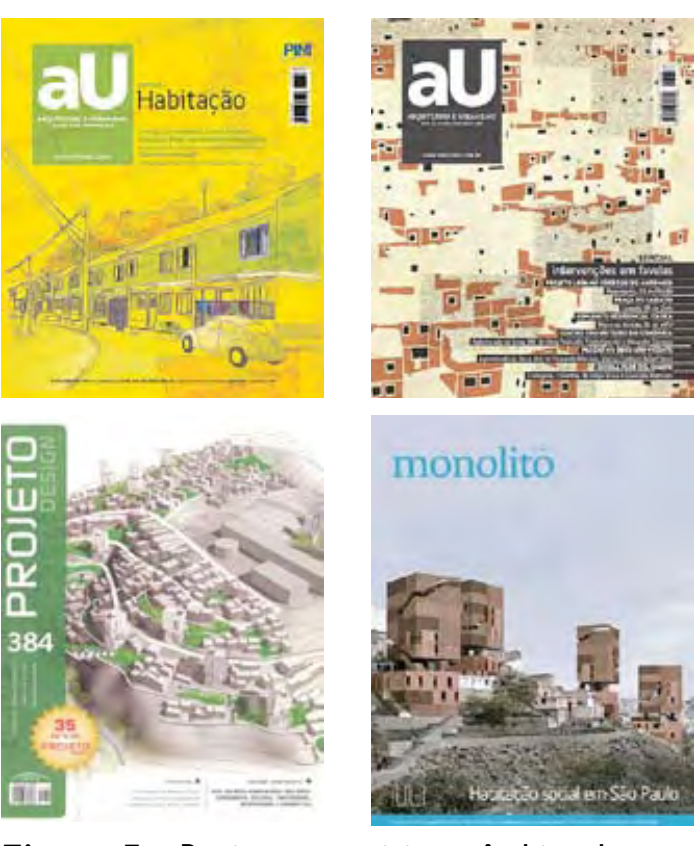

Figura 5 - Revistas especiais no âmbito da habitação social ou intervenções em favelas, algo, que começou a ficar mais frequente a partir do ano de 2009 aproximadamente. Fonte: revista Arquitetura e Urbanismo n. 186, setembro de 2009; revista Arquitetura e Urbanismo n.200, novembro de 2010; Revista ProjetoDesign n.384, fevereiro de 2012 e revista Monolito n.07, fevereiro/março de 2012 . 


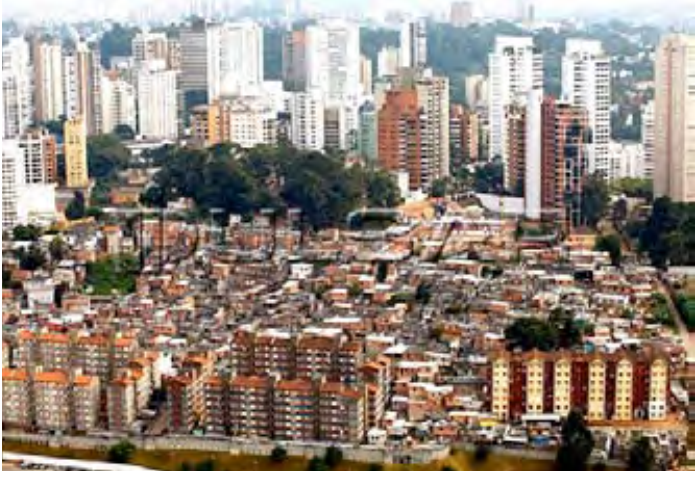

Figura 6 - Projeto Cingapura em primeiro plano (construído durante a gestão do prefeito Paulo Maluf na década de 1990), ao fundo, favela Real Parque, São Paulo. publicações lançadas recentemente pela SEHAB/SP, organizadas principalmente por Elizabete França (Figura 04), inclusive expandindo a divulgação das realizações da secretaria e dos arquitetos contratados para as revistas especializadas em arquitetura, com mais força a partir de 2009 aproximadamente, com publicação de matérias especiais na revista Arquitetura e Urbanismo ${ }^{5}$, ProjetoDesign ${ }^{6}$ e, mais recentemente, na Monolito ${ }^{7}$ (Figura 05). Isto mostra um pouco da retomada da atuação dos arquitetos voltada para uma produção de interesse social. Porém, ainda é muito pouco, se compararmos com toda produção sem qualidade que vem sendo realizada ou já foi realizada pelos governos públicos no âmbito de HIS (Figura 06).

Entre os projetos que foram encontrados nas revistas, porém, não selecionados como estudo de caso, é possível citar alguns principais de habitação social: Intervenções em Paraisópolis (2008-20l I), com projetos de urbanização e provisão de novas unidades habitacionais, realizado pela equipe liderada pelo Arquiteto Edson Elito; o Residencial Alexandre Mackenzie (2008-2009), em Nova Jaguaré, escritório Boldarini Arquitetura e Urbanismo; as Intervenções em Heliópolis, por exemplo, o Conjunto SABESP (2008-20I2) realizada pela equipe liderada pelo arquiteto Rui Othake; os três promovidos pela SEHAB/SP; o Conjunto Mutirão Paulo Freire (200I-20I0), do USINA Centro de trabalhos para o Ambiente Habitado 8 ; projetos realizados pelo escritório Vigliecca Arquitetos Associados para a prefeitura de Osasco, como por exemplo a Urbanização da área Colinas D’Oeste/Morro do Socó (2007-20 I0); saindo da RMSP, os projetos de habitação social nas favelas do Rio de Janeiro, como por exemplo o Conjunto Residencial Itaoca (2008-2009), no Morro do Alemão,

\footnotetext{
${ }^{5}$ ESPECIAL Habitação. Arquitetura e Urbanismo, n. 186, set, 2009.

ESPECIAL Intervenções em favelas. Arquitetura e Urbanismo, n. 200, nov, 2010.

${ }^{6}$ GRUNOW, Evelise. Moradia Social vai requalificar a cidade. Concurso Renova SP. ProjetoDesign, n. 384, fev, 2010.

SERAPIÃO, Fernando. Quando a favela vira cidade. Urbanização de favelas, concursos, intercâmbios e verbas milionárias incitam debate sobre projetos de interesse social em curso na capital paulista. ProjetoDesign, n. 369,nov, 2010.

${ }^{7}$ Habitação Social em São Paulo. Monolito, n. 7, fev/mar, 2012.

${ }^{8}$ Empresa constituída por profissionais de diversos campos e com atuação conjunta com os movimentos sociais de moradias, no caso deste projeto junto com a Associação Paulo Freire, filiada ao Movimento Sem-Terra Leste I (UMM) e financiamento da COHAB-SP.
} 
dos arquitetos Jorge Mario Jaurégui e Mauricio Santos; ou em Porto Alegre, como por exemplo o Condomínio Princesa Isabel (2004-2006) do escritório Meta Arquitetura e Departamento Municipal de Habitação de Porto Alegre (DEMHAB - PA); e fora do Brasil, os projetos do ELEMENTAL ${ }^{9}$, no Chile, como por exemplo, o Quinta Monroy (2003-2004) ou Lo Espejo (2003-2007), projetos muito divulgados nos canais de comunicação do Brasil e de todo mundo na área de arquitetura (Figura 07). A relação completa dos projetos encontrados e pré-selecionados nas revistas ProjetoDesign e Arquitetura e Urbanismo pode ser consultada no apêndice 0I. Com relação ao assunto chave colocado no mestrado, de buscar exemplares diferenciados da arquitetura habitacional contemporânea, buscando edifícios ou conjuntos mais inseridos na malha urbana consolidada, e com pouca possibilidade de replicação, parecia que estes projetos acima citados, e outros, fugiam da escala de análise se comparado com os outros exemplares presentes nesta pesquisa de promoção privada. Também, como premissa ou critério de seleção, as obras deveriam estar concluídas, e nem todos estes projetos citados estavam neste estágio. Não se pode dizer que não são diferenciados, afinal, fogem da linha de projetos homogeneizados e padronizados que normalmente órgãos públicos realizam no âmbito da HIS, porém, trata-se de um outro recorte, de conjuntos inseridos em favelas ou para atendimento próximo a estes locais e com características peculiares.

Por outro lado, existem dois projetos do escritório liderado pelo arquiteto Hector Vigliecca, ambos inseridos no programa "Morar no Centro", Vila dos Idosos (2003-2007) (Figura 8) e Casarão do Carmo (2003) (Figura 9), que estão dentro do recorte desta pesquisa, principalmente pelo fato de estarem inseridos na malha urbana consolidada da cidade de São Paulo, onde os condicionantes préexistentes do lote ou da quadra urbana são refletidos no resultado final da proposta.

\footnotetext{
${ }^{9}$ ESPECIAL ELEMENTAL partiu de discussões e pesquisas acadêmicas com interesse em buscar perguntas capazes de melhorar o tema da habitação social.Alejandro Aravena, arquiteto e professor da Pontifícia Universidade Católica do Chile, é o principal criador e diretor executivo desde 2006. Devido ao grande sucesso da iniciativa, a ELEMENTAL associou-se também à companhia petrolífera Chilena, COPEC, revelando assim um interesse também comercial.
}

Figura 7 (página ao lado) - Alguns projetos de Habitação de Interesse Social publicados nas revistas ProjetoDesign ou Revista Arquitetura e Urbanismo na década de 2000.

0I. Conjunto Paraisópolis (2008-20II). Paraisópolis, São Paulo. Arquiteto Edson Elito .

02. Conjunto Alexandre Mckenzie (20082009). Nova Jaguaré, São Paulo. Boldarini Arquitetura e Urbanismo.

03. Conjunto Residencial Itaoca (20082009). Morro do Alemão, Rio de Janeiro. Arquitetos Jorge Mario Jaurégui e Mauricio Santos.

04. Conjunto Mutirão Paulo Freire (200I 2010). Cidade Tiradentes, São Paulo. Projeto do USINA - Centro de trabalhos para o Ambiente Habitado.

05. Conjunto SABESP (2008-20I2), Heliópolis, São Paulo. Arquiteto Ruy Ohtake.

06. Condomínio Princesa Isabel (20042006). Porto Alegre. Meta Arquitetura.

07. Urbanização da área Colinas D'Oeste/ Morro do Socó (2007-20 I0). Osasco, RMSP. Vigliecca Arquitetos Associados.

08. Quinta Monroy (2004). Iquique, Chile. ELEMENTAL. 


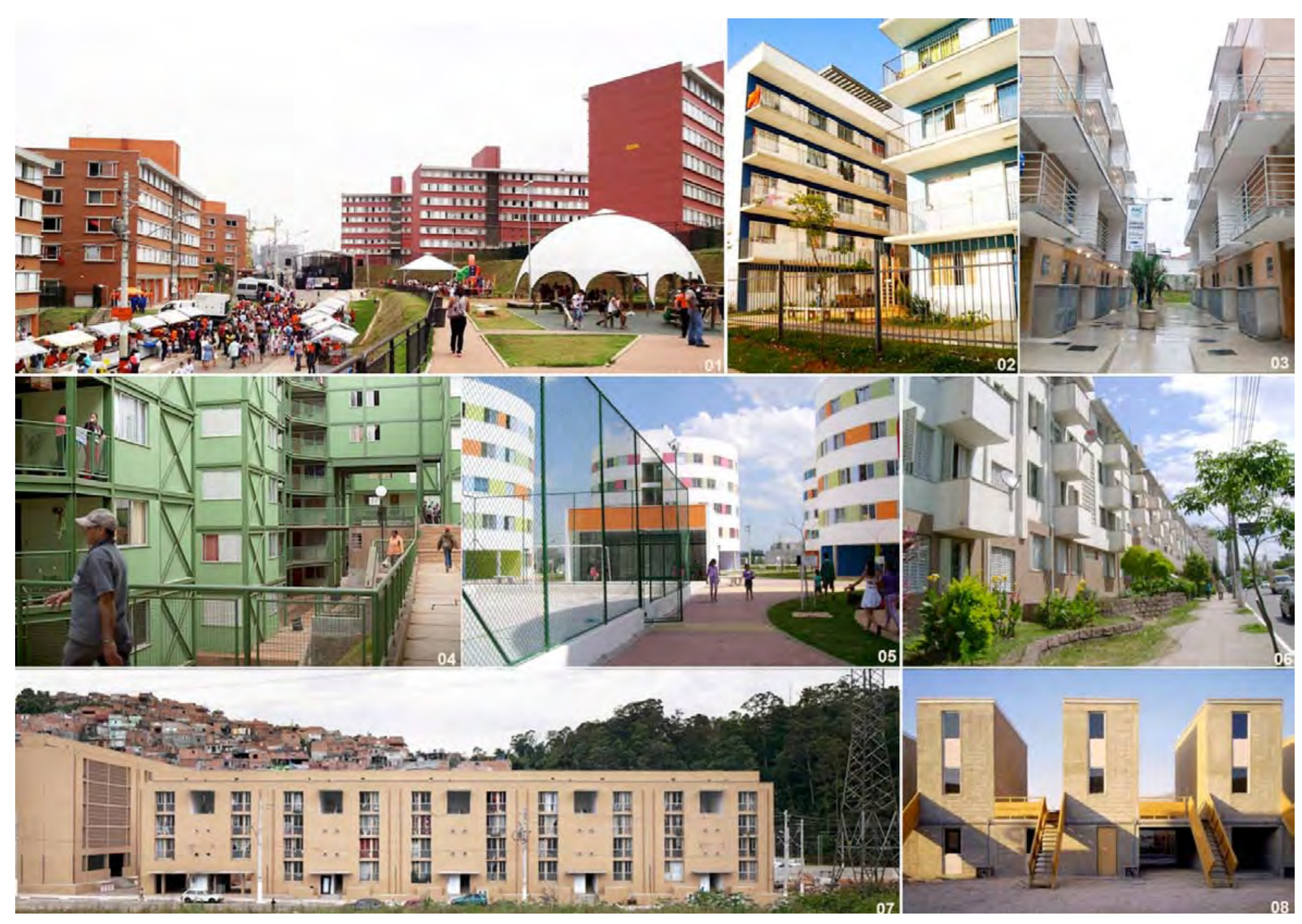




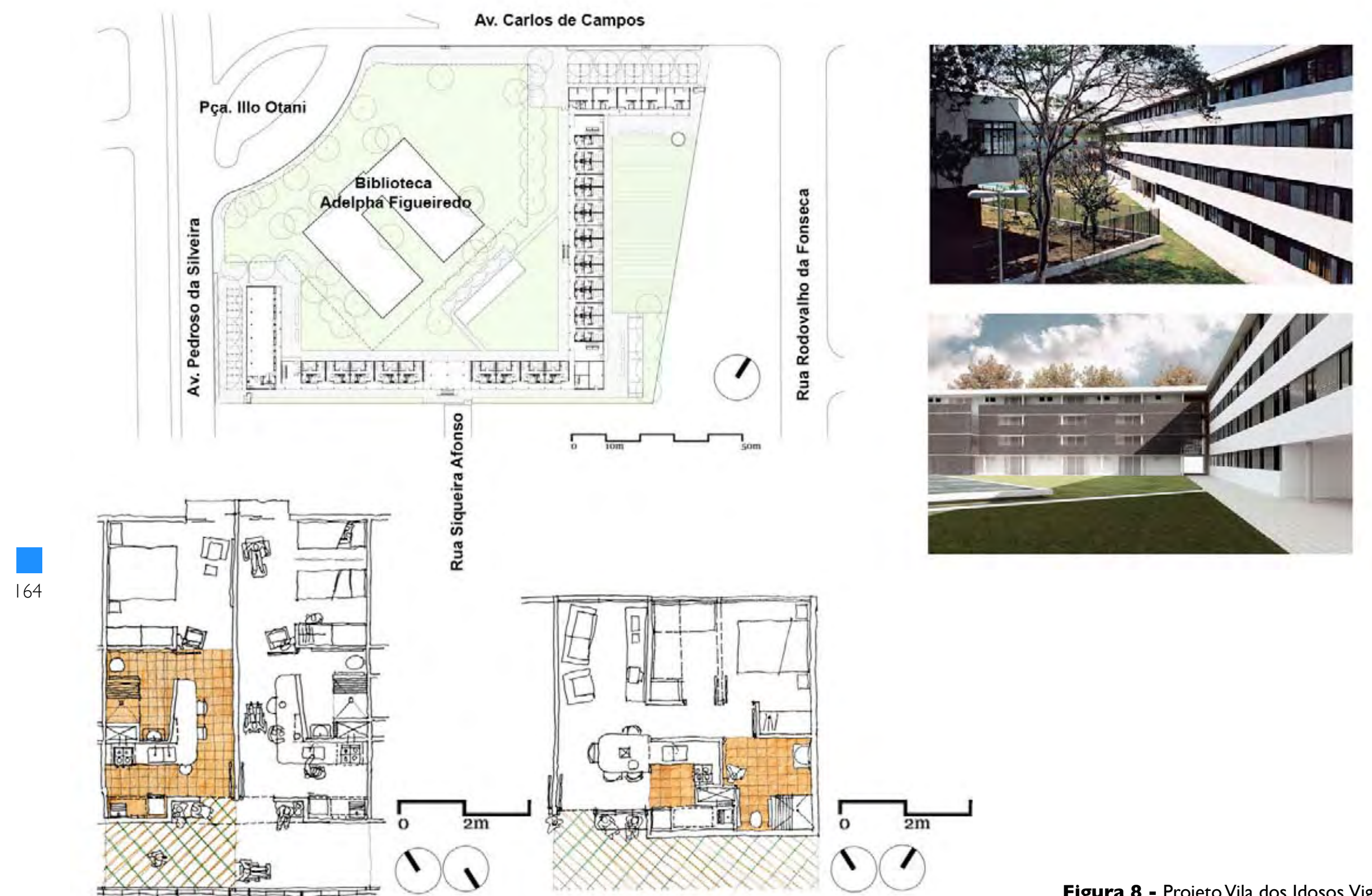

Figura 8 - Projeto Vila dos Idosos.Vigliecca Arquitetos Associados. 

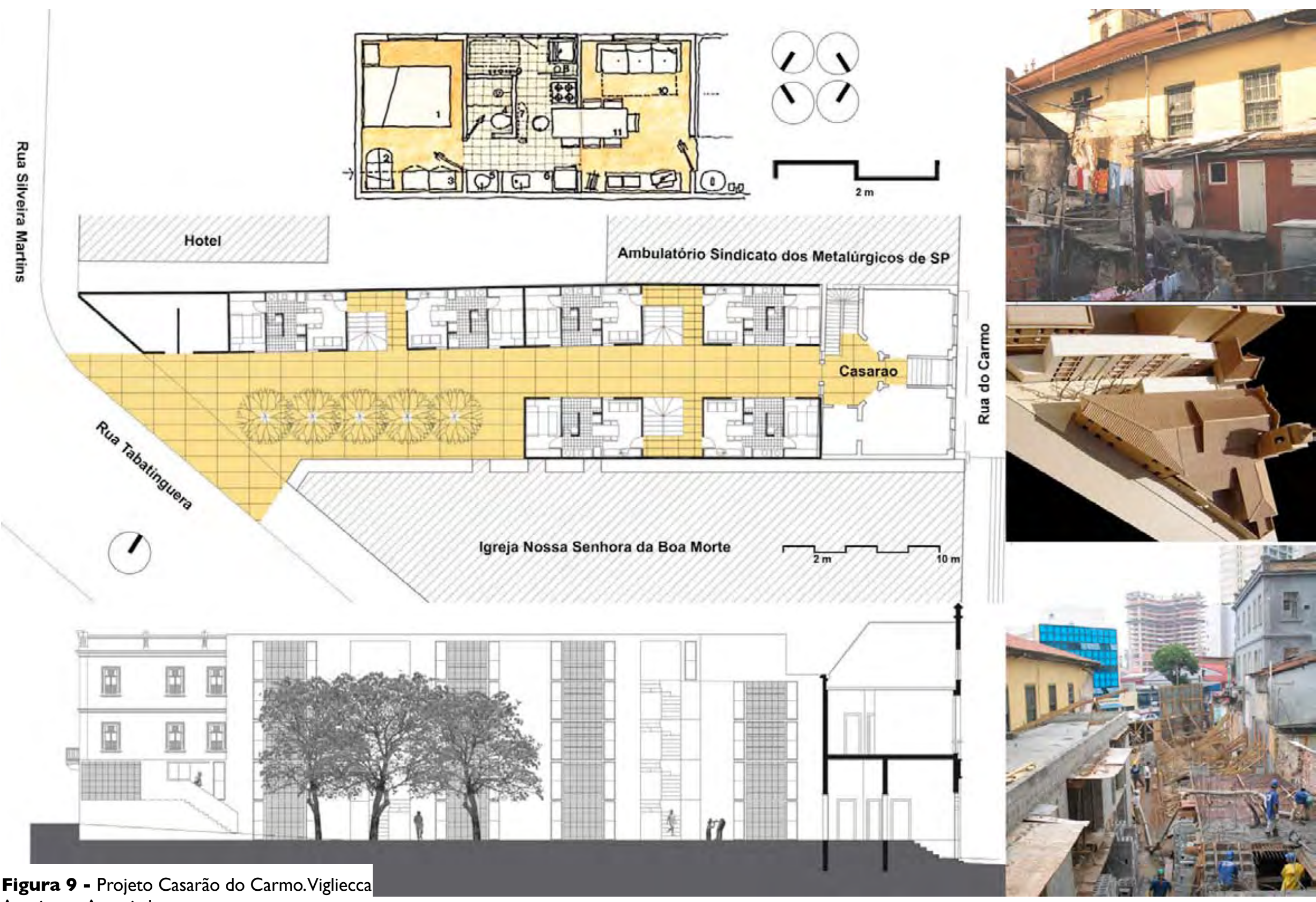

Figura 9 - Projeto Casarão do Carmo.Vigliecca Arquitetos Associados. 
Ao mesmo tempo, não caberia colocá-los como estudo de caso, já que o projeto da Vila dos Idosos não foi executado em conformidade com o mesmo; e no caso do Casarão do Carmo, a construtora faliu e a obra ficou praticamente abandonada e não concluída ${ }^{10}$.

Os projetos citados acima possuem o objetivo principal de criar habitação na qual o indivíduo se sinta responsável pelo espaço que ocupa, trazendo as seguintes questões chaves: Quais condições podem ser dadas a estes habitantes para serem participantes da cidade? Como o habitante consegue adquirir compromisso com a cidade?

Não queremos confundir arquitetura com objeto de design, o que vem acontecendo aqui e em várias partes do mundo. Na verdade, estamos sempre construindo um entorno externo, arquitetando a cidade, com um compromisso que vai além da definição construtiva e refinada. Quer dizer, entendemos sempre que a arquitetura é, antes de qualquer coisa, um compromisso com a questão pública (VIGLIECCA, 20I2).

Os projetos do Hector Vigliecca partem da premissa de criação de espaços públicos, sem cercamentos e não condominiais, com a sensata opinião de que a construção de condomínios fechados é a decadência de uma cidade, afinal, a ideia destes tipos de conjuntos é apropriar-se de um espaço que, na verdade, condiciona todo o bairro, pois modifica as relações entre as pessoas que habitam os arredores daqueles muros. Prova de que esta proposta é pouco aceita e implantada na cidade, apenas depois de anos, HectorVigliecca, está finalmente alcançando este objetivo no recente projeto Favela Parque Novo Santo Amaro V, finalizado no final de 20I2, pela SEHAB/SP, já que é criado um parque público no fundo de vale junto a novos edifícios habitacionais" (Figura 10).

\footnotetext{
${ }^{10}$ Informações obtidas em:VIGLIECCA, H. Construir a Cidadania. Conferência Museu da Casa Brasileira. São Paulo, MCB, $28 / /$ I I/I 2. "No conjunto Habitacional Rio das Pedras, 1991-2003, também do escritório liderado pelo arquiteto Hector Vigliecca, promovido pela prefeitura de São Paulo e construído em regime de mutirão, também havia o conceito de criar áreas públicas junto ao espaço habitacional. No entanto, os próprios moradores cercaram o conjunto após a finalização da construção, configurando um condomínio particular irregular. Depois houve outras experiências com a municipalidade, onde a exigência pelo cercamento passou a ser da própria prefeitura (por exemplo, na Vila dos Idosos), talvez pelas tantas experiências frustrantes neste sentido. Depois de muita conversa e reflexão, a prefeitura permitiu a aprovação do Parque Santo AmaroV com espaço de lazer público. Como a finalização é recente, é preciso esperar a reação dos moradores: será cercado ou não?
}

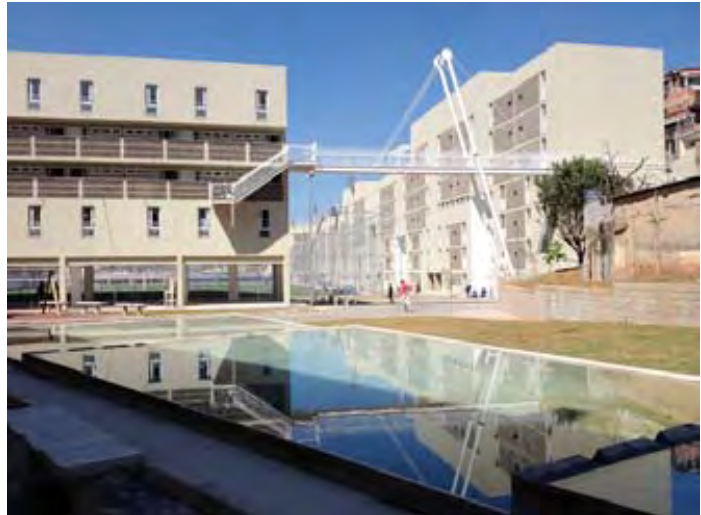

Figura 10 - Projeto Parque Novo Santo Amaro V. Vigliecca Arquitetos Associados. 
Enfim, com estes exemplos citados, é possível compreender que são exceções os projetos de habitação social que conseguem tirar proveito de espaços mais centrais na cidade e que comprovam a viabilidade de se utilizar verdadeiros retalhos urbanos para inserção de habitação social, como é o caso do Casarão do Carmo (que além dos benefícios descritos consegue também criar espaço público junto a habitação) ou da Vila Pedro Fachini, o único dos projetos citado nas publicações ProjetoDesign e Revista Arquitetura e Urbanismo que se encaixa no recorte desta pesquisa já que foi executado e em concordância com o projeto arquitetônico, representando uma proposta concretizada. Conforme colocado anteriormente, o escritório BACCO Arquitetos Associados realizou três projetos para a SEHAB/SP e COHAB/SP dentro do programa "Morar no Centro". Um deles é o estudo de caso principal deste capítulo,Vila Pedro Fachini, porém, vale a pena expor as soluções dadas para as outras problemáticas, inclusive para visualizar o raciocínio projetual do escritório em projetos de habitação coletiva inserida na malha urbana consolidada, como acontece nos exemplos que serão expostos a seguir.

\subsection{I.3.I EXERCÍCIO ARQUITETÔNICO I - BACCO ARQUITETOS ASSOCIADOS PROJETO SENADOR FEIJÓ}

Trata-se de um projeto de reforma de um edifício da década de 1930, na Rua Senador Feijó, que originalmente abrigava, além de dois estabelecimentos comerciais no térreo, 20 unidades habitacionais nos pavimentos superiores, que posteriormente foram convertidas em unidades de habitação para um Hotel, que funcionou até o início deste século ${ }^{12}$. O projeto de reforma resultou em 45 unidades, nove por andar, para serem utilizadas no programa de locação social, administrada pela $\mathrm{COHAB} / S P$.As unidades possuem área útil que varia entre 25 e $35 \mathrm{~m}^{2}$, entre quitinetes e apartamentos com um dormitório. $O$ redesenho das plantas originais e mudança da distribuição do programa foi a de maior influência e presença dos arquitetos, já que a fachada do edifício não poderia ser

12 Informações obtida em PIOCCHI, S. Relatório Técnico da COHAB/SP. São Paulo, 2005. 
modificada por se tratar de um edifício tombado pelo patrimônio histórico.Abaixo, outros projetos que fizeram parte deste mesmo programa:

\section{Programa Morar no Centro - Reforma e Reciclagem de Prédios} para Habitação / Locação Social

\begin{tabular}{|llll|}
\hline Projeto & Local & Provisão U.H. & Arquitetura \\
\hline Riachuelo & República & 100 & Paulo Bruna Arquitetos Associados \\
Hotel São João & Santa Cecília & 35 & Armando \& Marcondes Arquitetos Associados \\
Hotel São Paulo & República & 152 & Fábrica Urbana - Centro de Estudos e Projetos da Cidade \\
Senador Feijó & Sé & 45 & Barbosa \& Corbucci Arquitetos Associados \\
\hline
\end{tabular}

\subsection{EXERCÍCIO ARQUITETÔNICO II - BACCO ARQUITETOS ASSOCIADOS PROJETO CARLOS GOMES}

Outro exercício seria o projeto do Conjunto Carlos Gomes, que infelizmente não foi exe168 cutado. Localiza-se na conhecida “ferradura da Av. 23 de Maio", entre a Rua Doutor Rodrigo Silva e fundo para a Av. 23 de Maio, um edifício inserido numa imagem que é muito recorrente no centro de São Paulo, de lote entre grandes empenas-cegas, onde a relação com as pré-existências se faz necessária. $O$ projeto prevê 64 unidades habitacionais além de estacionamento independente. $O$ partido de implantação configura a solução mais interessante da proposta: o que normalmente se faz é deixar os recuos e implantar o novo edifício no miolo do lote. Porém, algumas pré-existências conduziram o projeto para outro caminho: havia árvores ao fundo do terreno, voltadas para a Av. 23 de Maio, uma imagem urbana com a qual as pessoas estavam acostumadas, portanto, na opinião dos arquitetos, deveria ser mantida. Outra pré-existência seriam as empenas cegas dos edifícios limitrofes

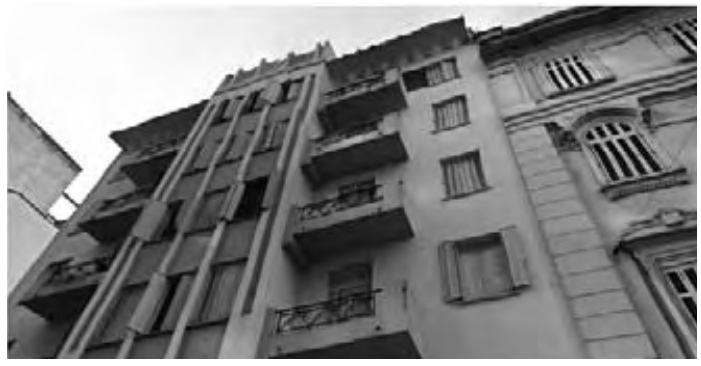

Figura I I - Edifício Rua Senador Feijó - unidades para locação social - COHAB/SP. 


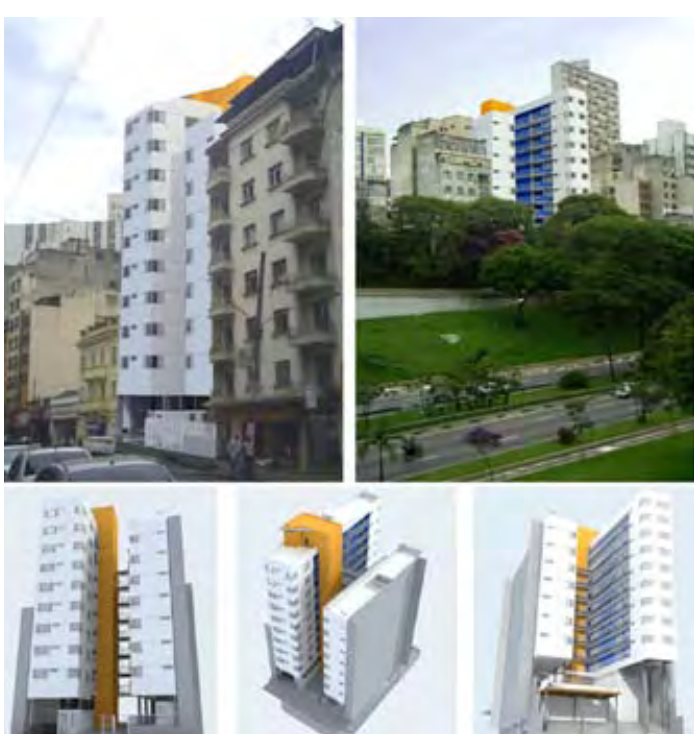

Figura 12 - COHAB Carlos Gomes, São Paulo, 2004. Projeto elaborado pelo escritório BACCO Arquitetos Associados para a COHAB a partir de uma licitação pública. $O$ edifício possui estacionamento independente e 64 unidades habitacionais. ao lote, que foram consideradas no projeto, de tal modo a não criar aberturas do novo edifício voltadas a grandes paredões. Utilizou-se o artifício de posicionar a circulação vertical e horizontal para o vazio central do lote. Junto às árvores mantidas foi criado um deck para convívio coletivo. Por fim, o vazio permite que o edifício esteja aberto para as duas vias e direcionado às árvores, evitando a criação de um paredão ao fundo do lote urbano, como às vezes acontece em situações nas quais existem mais de uma face do terreno voltada ao viário. Abaixo, outros projetos que fizeram parte deste mesmo programa:

\section{Programa Morar no Centro - Edifícios de Habitação em áreas vazias para Locação Social}

\begin{tabular}{|c|c|c|c|}
\hline Projeto & Local & Provisão U.H. & Arquitetura \\
\hline Carlos Gomes & Liberdade & 64 & Barbosa \& Corbucci Arquitetos Associados \\
\hline $\begin{array}{l}\text { Pari I } \\
\text { (Vila dos Idosos) }\end{array}$ & Pari & 145 & Hector Vigliecca e Associados \\
\hline Olarias & Pari & 137 & Fábrica Urbana - Centro de Estudos e Projetos da Cidade \\
\hline Assembléia & Sé & 160 & $\begin{array}{l}\text { Concurso Habita Sampa - } 1^{\circ} \text { lugar Andrade Morettin } \\
\text { Arquitetos Associados }\end{array}$ \\
\hline $\begin{array}{l}\text { Cônego Vicente } \\
\text { Marino }\end{array}$ & Barra Funda & 235 & Concurso Habita Sampa - I’ lugar Frentes Arquitetura \\
\hline
\end{tabular}

\subsection{I.3.3 EXERCÍCIO ARQUITETÔNICO III - BACCO ARQUITETOS ASSOCIADOS VILA PEDRO FACHINI}

Vila Pedro Fachini foi promovida pela SEHAB/SP e COHAB/SP, sob coordenação de Tereza Herling, Celso Sampaio e Alexandre Hodapp O. Marques, com recursos provenientes do Fundo Municipal de Habitação pela linha de financiamento "Programa de Cortiços - Morar no Centro / PMSP" 
Esta proposta da prefeitura, de substituição de cortiços em lote urbano, iniciou-se anteriormente, entre 1989 e 1992, quando foi definido um programa de produção habitacional para encortiçados, garantindo aos moradores a permanência no mesmo local pelo sistema de construção em mutirão ${ }^{13}$. Nessa ocasião, foram construídos o Projeto Celso Garcia, no Brás, com 182 unidades e o Projeto Madre de Deus, na Mooca, com 45 unidades (Figura 13).

Na gestão da Prefeita Marta Suplicy, o assunto voltou a ser pauta na prefeitura de São Paulo e foi criado um programa habitacional designado para atendimento de encortiçados no centro de São Paulo.A Vila Pedro Fachini representa um caso desta retomada, e também outros projetos que foram realizados pelo mesmo programa, no mesmo período e com mesma situação de implantação em lote urbano de pequenas dimensões em bairro consolidado, incluindo o Casarão do Carmo e outros projetos, conforme a tabela abaixo:

\section{Melhorias das condições de vida em moradias coletivas multifamiliares - Cortiços}

\begin{tabular}{|llll|}
\hline Projeto & Local & Provisão U.H. & Arquitetura \\
\hline Casarão do Carmo & Sé & 25 & Hector Vigliecca Associados \\
Vila 25 de Janeiro & Luz & 33 & integra - Cooperativa de Trabalho Interdisciplinar \\
Imoroti & Cambuci & 8 & Peabiru - Trabalhos Comunitários e Ambientais \\
Pedro Fachini & Ipiranga & 12 & Barbosa \& Corbucci Arquitetos Associados \\
\hline
\end{tabular}

O projeto na Rua Imoroti (Figura 14), por exemplo, apresenta uma situação urbana bem semelhante à do projeto na Rua Pedro Fachini, o lote apresenta mesmas dimensões (porém topografia diferente), e o entorno próximo similar, um trecho do bairro Cambuci dividido entre galpões industriais e casas térreas de antigos operários das indústrias ao redor, muitas delas atualmente desativadas.

\footnotetext{
${ }^{13}$ Informações no catálogo do programa: “Morar no Centro”, da prefeitura de São Paulo, 2004.
}

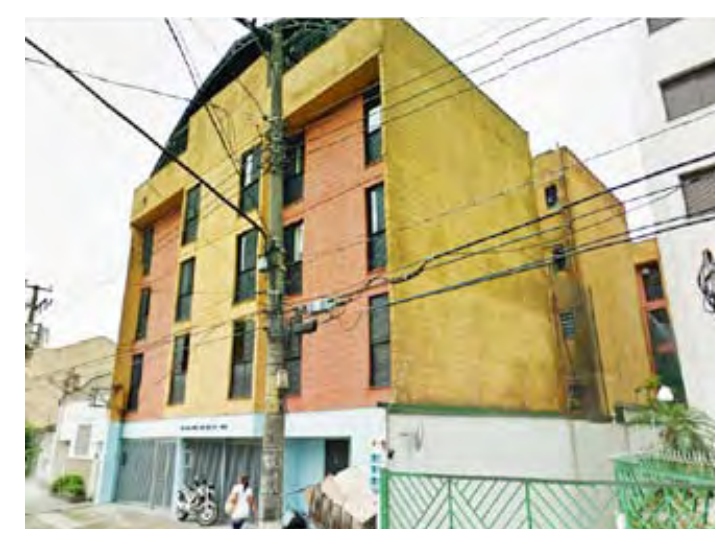

Figura 13 - Edifício Madre de Deus, localizado na Rua Madre de Deus, Mooca, São Paulo. $O$ projeto inicial foi desenvolvido pela Superintendência de Habitação Popular (HABI), coordenada pelo Arq. Claudio Manetti.A execução do empreendimento foi realizada mediante o estabelecimento de um convênio com a associação especialmente formada para a construção por mutirão:Associação de Construção por Mutirão Madre de Deus. O projeto foi desenvolvido pela assessoria técnica $A D$, que também foi responsável pelo acompanhamento das obras. 

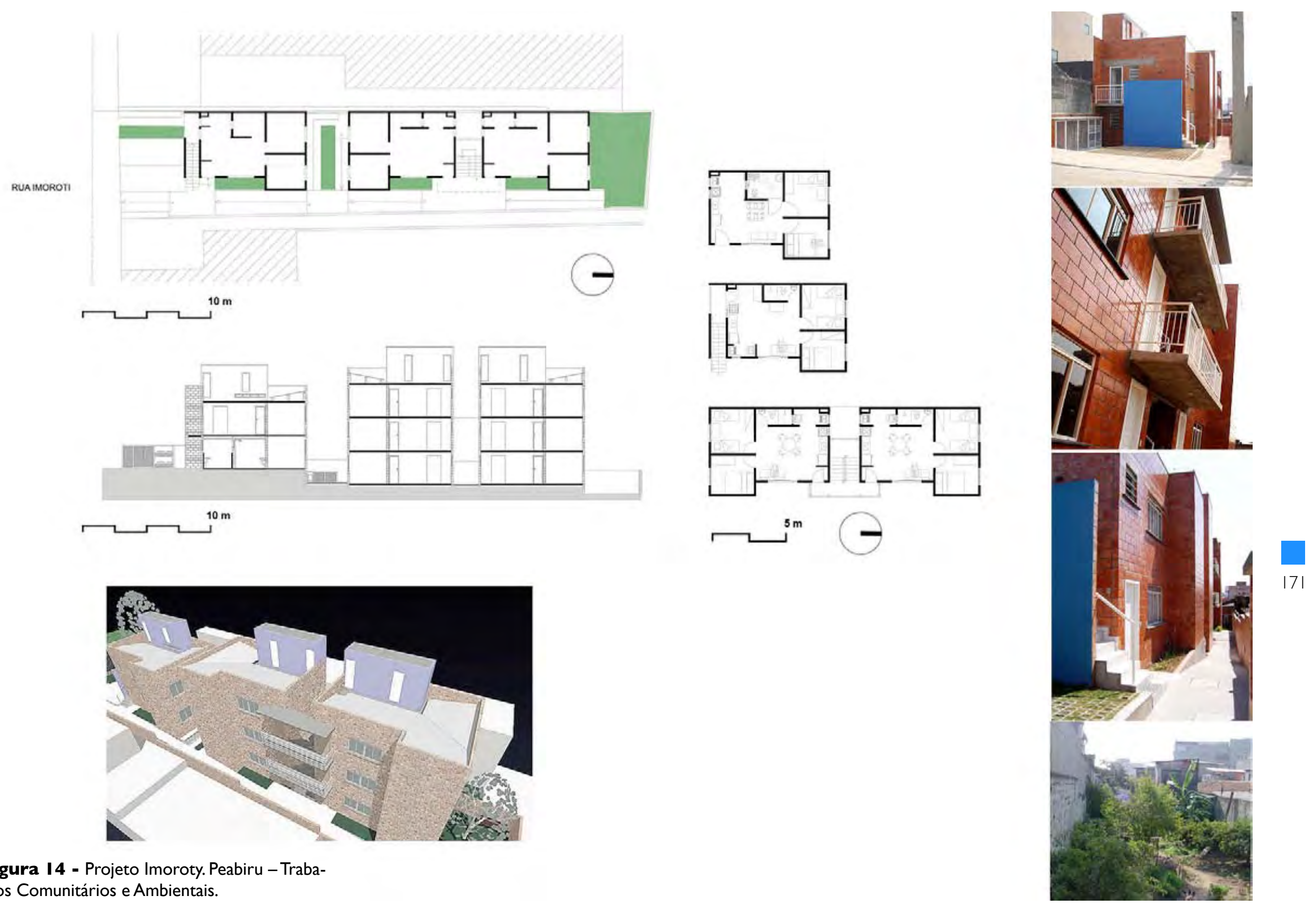

Figura 14 - Projeto Imoroty. Peabiru - Traba-

Ihos Comunitários e Ambientais. 
O zoneamento é o mesmo, ambos projetos estão localizados, segundo o mapa de uso e ocupação do solo do Plano Regional Estratégico (PRE) ${ }^{14}$, em zona mista de alta densidade, mas que, de qualquer forma, recuo versus gabarito de altura máximo permitido acaba sendo mais restritivo, não permitindo alcançar o coeficiente máximo de aproveitamento em nenhuma das propostas (pela lei, 4,0).A comparação destes dois projetos possibilita perceber que, mesmo com condicionantes do lote e taxas de uso e ocupação do solo semelhantes, as propostas apresentam partidos e soluções arquitetônicas diferentes.

\subsection{I.4 INSERÇÃO URBANA}

AVila Pedro Fachini está localizada no bairro do Ipiranga, próxima à estação Tamanduateí de trem e de metrô. Fica aproximadamente a seis quilômetros do centro de São Paulo, e pertence a um longo eixo industrial do Brás até a região do Grande $A B C$, paulatinamente ocupado desde o início do século passado até a década de 1950. O entorno imediato é predominantemente horizontal, com presença de galpões industriais (alguns desativados ou com mudança de uso), e também com presença de uso residencial e misto, com pequenos comércios para atendimento do dia a dia, que não chegam a atingir um grau de satisfação máxima para quem mora neste trecho de bairro, afinal, nem todos os comércios, equipamentos ou serviços são encontrados no entorno imediato. Nota-se, portanto, duas escalas de lotes com edificações correspondentes: os de pequena testada e significativa profundidade e os grandes que ocupam quase toda quadra. $O$ lote ocupado pelo edifício-vila possui testada de $8 \mathrm{~m}$ e profundidade de $40 \mathrm{~m}$ e está entre duas casas térreas (Figura I5). A CO$\mathrm{HAB}$ pedia dezoito unidades e três metros de recuo lateral exigidos por lei. $O$ custo estimado por unidade não era dos maiores, por fim, foi de R\$28.270,00 (WISSENBACH, et al; 2006, p. 86).

$\overline{{ }^{14} \text { Lei Municipal 13.885/04 - Plano Regional Estratégico. }}$

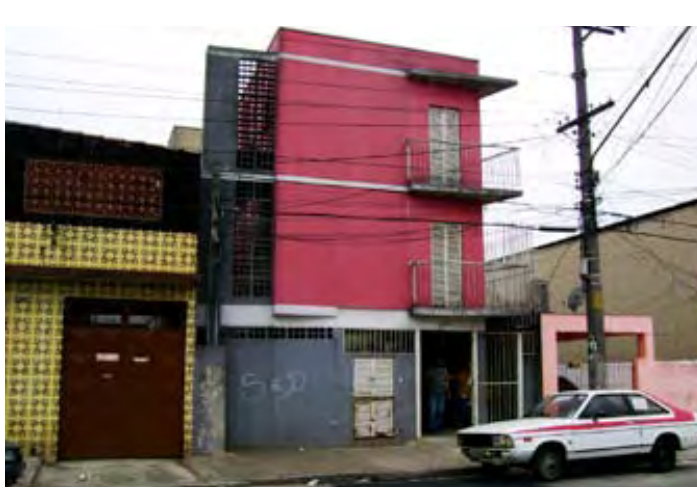

Figura 15 - Vila Pedro Fachini. Situação do lote urbano.

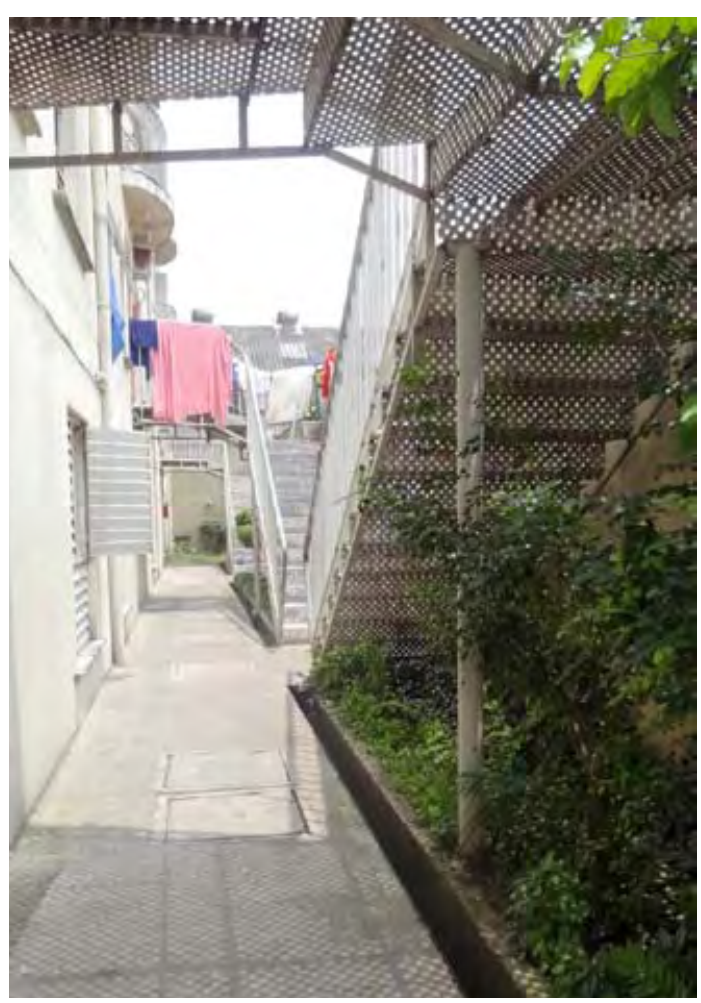

Figura 16 - Vila Pedro Fachini. Escadas no recuo de três metros. 


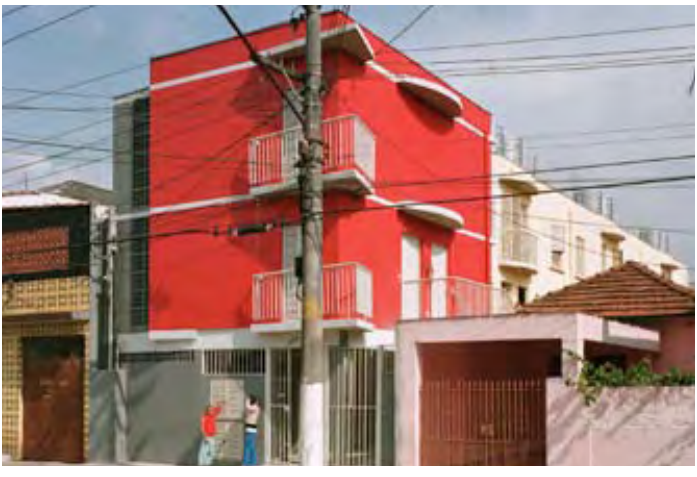

Figura 17 - Vila Pedro Fachini.Vista lateral do conjunto desde a Rua Pedro Fachini.
Estes foram os primeiros dados para resolução do problema. Também de acordo com a normativa, a definição do gabarito de altura acima de doze metros deveria respeitar o recuo mínimo exigido de três metros nos dois lados. Porém, para uma frente de lote tão pequeno, oito metros, e com um entorno predominantemente horizontal, a escolha por três pavimentos foi coerente.

\subsection{I.5 PARTIDO DE IMPLANTAÇÃO}

A estratégia adotada pelo escritório, para viabilizar o prédio e inserir as unidades habitacionais com o mínimo conforto, foi de tirar a escadaria do corpo do edifício, e colocá-la no recuo obrigatório e, com isso, ganhar mais espaço para as unidades habitacionais (Figura 16). Com a solução da escada com chapas metálicas perfuradas e o fato das escadas estarem coladas no muro de divisa, portanto, afastadas do edifício, conseguiram comprovar que a sombra na edificação seria amenizada. Também, o fato de utilizar unidades tipo dúplex diminui a quantidade de lances de escada externa e suaviza este elemento na fachada.Assim, as doze unidades possuem organização espacial compacta e são resolvidas num bloco único vagonar de três pavimentos: no térreo, apartamentos, e no nível superir, unidades dúplex (Figura 17).

Mesmo com solução compacta e tirando a escadaria do corpo da edificação, seria impossível conseguir alcançar ao número de dezoito unidades que a COHAB/SP pedia inicialmente. Houve muita negociação com a contratante neste sentido, e isto é algo que normalmente acontece em trabalhos desenvolvidos para órgãos públicos, pois nem sempre os números desejados ou estimados são compatíveis com a situação espacial disponível. $O$ arquiteto tem o papel muito importante de exposição da melhor situação arquitetônica, mas isto requer muito esforço de sua parte. Porém, é o que possibilita um resultado diferenciado e com qualidade:"O arquiteto, quando ele quer, ele consegue definir alguns parâmetros diferentes daqueles que, às vezes, o cliente institucional coloca, e a gente tem que bater o pé, fazer com qualidade, a gente tem que ter esta meta" (BARBOSA, 20I2). 
Com relação à interface com as construções vizinhas, o simples fato de encostar o bloco vagonar na empena cega do vizinho soluciona o paredão existente, criando aberturas para o recuo de três metros e permitindo uma fachada lateral mais interessante solta do limite do lote.

A proposta também não propicia contraste acentuado entre o gabarito de altura do edifício novo e as construções do entorno imediato.

Porém, com relação à integração com o espaço público, fazendo uma comparação com uma versão preliminar do projeto (Figura 18), a frente do conjunto era mais aberta e com maior visibilidade em direção ao espaço público da rua, o que propicia, inclusive, maior sensação de segurança aos frequentadores tanto do conjunto quanto do espaço público da rua:

A percepção de segurança está relacionada com a capacidade de ver e ser visto, ouvir e ser ouvido, saber por onde se está indo e poder pedir ajuda. Os espaços de circulação não devem gerar cantos inseguros e, portanto, devem ser transparentes e visíveis a partir de outras partes do edifício e das unidades (MONTANER, et al; 2012, p. 292).

Pelo que se pode perceber, olhando a versão do projeto mais próxima ao que foi executado, os espaços necessários para abrigo de gás, lixo, medidores de eletricidade e água acabaram obstruindo toda a frente do conjunto e, assim, diferente da proposta origninal, a sensação que se tem quando se chega ao local é de reclusão (Figura 19). Não apenas a visibilidade foi prejudicada, como também um pequeno canteiro com arborização e espaço para estar dos moradores. Então, o resultado mostra que questões relacionadas às instalações de redes de infraestrutura devem ser, preferencialmente, levadas em consideração desde o início no projeto, para que esta necessidade funcional não se sobreponha à qualidade dos espaços comunitários, não ocorrendo, assim, uma situação indesejável como a que aconteceu na Vila Pedro Fachini:
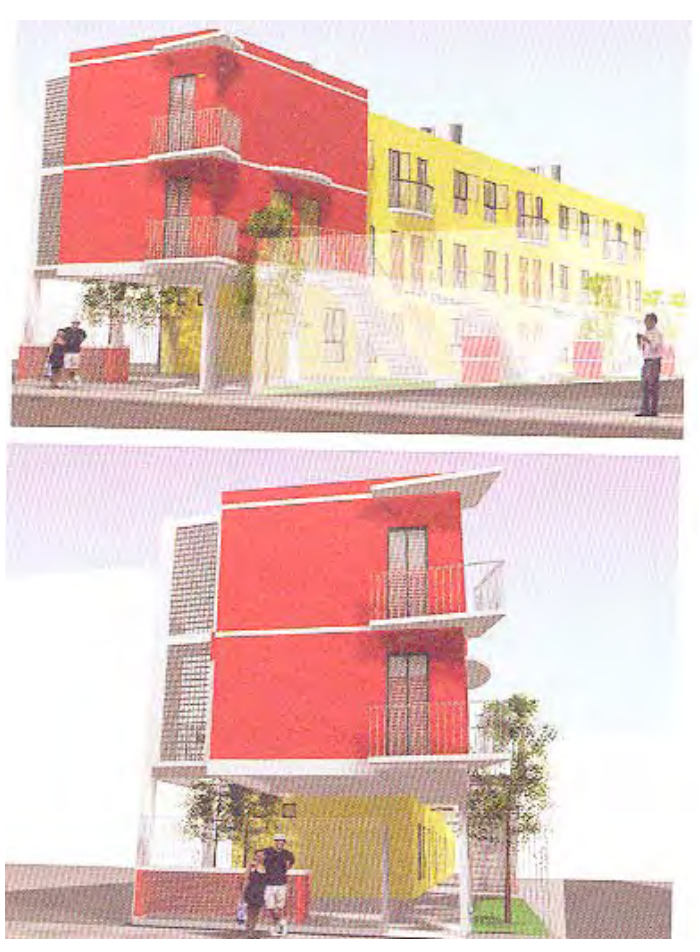

Figura 18 - Maquete eletrônica da versão preliminar do projeto.

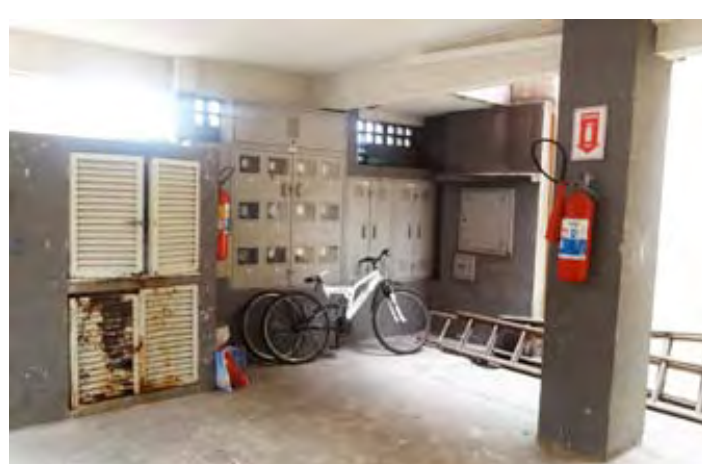

Figura 19 - Vista do espaço, no recuo frontal de cinco metros, onde ficam as caixas de instalações. 


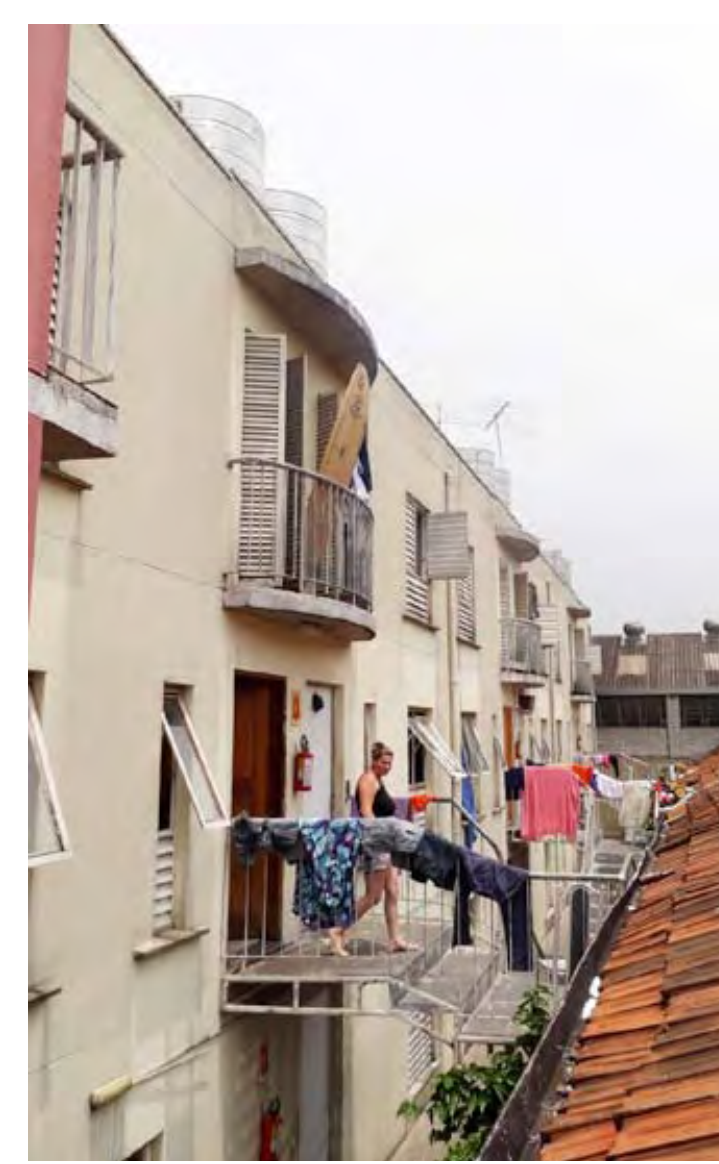

Figura 20 - Vila Pedro Fachini.Varandas e escadarias como meio de contato audiovisual do edifício e seus moradores com o espaço externo.
É necessário que os medidores fiquem em lugares facilmente acessíveis, e de acesso direto às áreas comuns do edifício e do conjunto. Dessa forma, se garante a facilidade de acesso em casos de emergência. Deve-se levar em consideração que esta necessidade funcional não deve se sobrepor à qualidade dos espaços abertos ou comunitários onde estes medidores estejam localizados (MONTANER, et al; 2012, p. 296).

Ao mesmo tempo, foram criadas pequenas varandas nas unidades tipo dúplex, e as próprias escadas no recuo, que permitem um contato visual direto entre o público e o privado, um meio de comunicação do edifício proposto e seus moradores com o espaço que o rodeia, seja por meio visual ou auditivo. Desta maneira, por mais que seja um ato singelo e de certa maneira isolado, o edifício leva vida ao espaço que o rodeia (Figura 20).

Os ambientes privados que dispõem de uma relação mais direta e próxima com a cidade são os espaços exteriores das unidades. São os lugares intermediários que relacionam a atividade pública com o retiro privativo e potenciam a socialização do habitante. Tanto varandas, coberturas e galerias, como pátios - comuns ou privados - incidem favoravelmente na identificação espacial do ser humano com a cidade, ao mesmo tempo que podem propor perspectivas agradáveis e melhoras do controle climático. (MONTANER, et al; 2012, p. 306).

\subsubsection{ESPAÇOS EXTERIORES}

O principal espaço de uso e convívio coletivo nesta pequena vila é o corredor com largura de três metros e as escadas. Segundo o arquiteto Marcelo Barbosa (2012), as escadas representam o espaço onde as crianças brincam, conversam, é a área de lazer da vila. Foi especificado pelos arquitetos a execução das escadas em aço galvanizado a fogo, de modo a garantir maior durabilidade da pintura e evitar muito gasto com manutenção. Hoje, após quase 10 anos da construção do edifício, nota-se uma necessidade geral de manutenção dos espaços coletivos. 
As esquadrias e portas de ferro estão enferrujadas, e nas escadas, com o tempo, a tinta acabou descascando. A especificação de materiais duráveis para este tipo de empreendimento é fundamental, ao mesmo tempo, um trabalho de organização da comunidade pode garantir ainda mais benefícios, que para conjuntos desse porte acaba sendo mais facilitado pelo número reduzido de moradores. Hoje os moradores ainda não conseguem manter as áreas externas do conjunto por gestão própria, e solicitam que a prefeitura faça, o que ainda não aconteceu.

O espaço frontal, referente ao recuo de $5 \mathrm{~m}$, também poderia representar um espaço para uso e principalmente convívio coletivo, porém, conforme explicado, a maneira como foi solucionado, acaba recebendo uma função mais de abrigo de instalações.

Pelo pouco espaço e falta de filtros entre as entradas da unidade, janelas no térreo e o corredor de convívio coletivo, pode ocorrer prejuízo na privacidade dos ambientes das unidades térreas de maior contato com o corredor. No conjunto Imoroti (Figura 14), por exemplo, são criados jardins à frente das unidades térreas, que acabam evitando a circulação de pessoas muito próximas às janelas e entradas das unidades térreas. $O$ estudo de caso desta pesquisa, Vila Fidalga, é o que melhor consegue solucionar estas questões relacionadas ao bem estar individual e coletivo, porém, existe uma metragem maior por unidade, e assim, para uma comparação mais eficaz, o exemplo do Imoroti é mais apropriado. Outro projeto para comparação de soluções é o do Casarão do Carmo (Figura 09), que acaba optando por elementos vazados na grande abertura da lavanderia, e para o ambiente de estar, janelas mais altas e estreitas, com uma pequena reentrância que colabora minimamente com a privacidade deste ambiente. Também posiciona as entradas das unidades em canto mais reservado, solução desejável em casos como este, ainda mais por se tratar de uma passagem pública. A pergunta elaborada nos "Instrumentos de Avaliação de Projetos" estimula o arquiteto a pensar nestas questões durante o projeto: "Caso tenham sido propostas unidades no térreo, a privacidade destas está sendo resolvida através de elementos arquitetônicos ou paisagísticos que evitem a circulação de pessoas e bicicletas muito próximas às aberturas (como, por exemplo, jardins junto às janelas)?" (MONTANER, et al; 20I2, p. 294) 


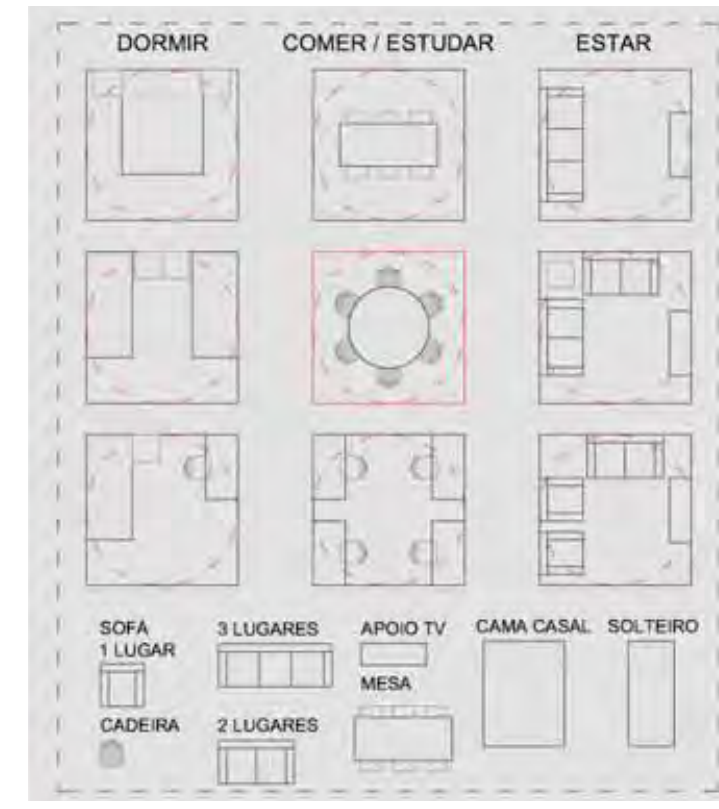

Figura 21 - Layouts em que foram traçados círculos com diâmetro de 2,80 m, mostrando uma boa adaptação do mobiliário básico nesta proporção.

\subsection{I.7 UNIDADE HABITACIONAL}

Os edifícios de habitação coletiva devem ter a capacidade de adequar-se aos diferentes grupos de convivência existentes na sociedade contemporânea. Com o objetivo de favorecer a integração social e evitar qualquer possível discriminação, os edifícios residenciais devem oferecer a seus habitantes uma adequada diversidade de tipologias, podendo prever inclusive os possíveis mecanismos de associação/ junção ou dissociação das unidades. Além disso, deve-se evitar a exclusão daqueles que possuem outras capacidades motoras ou sensoriais, motivo pelo qual deve-se tentar alcançar a plena acessibilidade das unidades e dos espaços comuns. Sempre que possível, o edifício de habitação deve corresponder ao perfil dos habitantes para os quais estão sendo construídos. (MONTANER, et al; 20I2, p. 290).

Foram propostas sete tipologias diferentes nesta vila, o que traduz a diversidade e ao mesmo tempo o desafio e necessidade de se encaixar doze unidades em lote tão exíguo. Os apartamentos no térreo, com aproximadamente $35 \mathrm{~m}^{2}$, possuem apenas um dormitório e quintais internos (aproximadamente 3,0 x 2,0 m), sendo mais apropriados para idosos, casais sem filhos e solteiros.

Os dúplex têm área de aproximadamente $43 \mathrm{~m}^{3}$, com dois dormitórios e são acessados externamente por escadas que ficam no recuo de três metros. Com isso, os acessos são quase individualizados, já que cada escada serve apenas duas unidades, e no térreo cada unidade é acessada diretamente pelo corredor externo coletivo.

Analisando as unidades habitacionais, a começar pelos ambientes não especializados, ou seja, aqueles que não necessitam de instalações diferenciadas e cujo uso será determinado pelo usuário a partir de suas necessidades, é preferível que tenham um diâmetro mínimo, recomendado por Montaner Muxí Arquitectes (2008), de 2,80 m para poderem abrigar os mais diferentes tipos de layouts (Figura 2I), e que tenham condições de ventilação, iluminação e dimensões similares, de tal maneira a não criar situações de hierarquia entre moradores da unidade e, ao mesmo tempo, definir um espaço mais neutro e flexível para diferentes apropriações. 
Nota-se, no projeto da Vila Pedro Fachini, que alguns cômodos possuem dimensão de 2,30 x 2,60, abaixo do mínimo desejável, e que os dormitórios possuem proporções diferentes, sendo um mais favorecido que o outro.

\begin{abstract}
As unidades devem ser adaptadas às diferentes formas de vida de seus ocupantes, tanto na diversidade de hábitos como de grupos familiares. As condições de habitabilidade para estes ambientes não especializados são semelhantes às de ambientes destinados a repouso, estar ou estudo nas habitações e, portanto, não devem possuir tamanhos ou formatos singulares predeterminados para um uso específico, favorecendo, deste modo, a apropriação adequada às necessidades de cada morador. (MONTANER, et al; 20I2, p. 300).
\end{abstract}

A posição do banheiro com relação à localização dos dormitórios é favorável, já que o banheiro não fica sendo exclusivo ou prioritário de um dos ambientes para repouso (Figura 22). Também o lavatório externo ao local de banho e vaso sanitário é favorável numa situação em que o banheiro é feito para atendimento de todos os usuários da unidade, permitindo uso simultâneo e eficiente das peças sanitárias. Com relação ao único banheiro adaptado, num primeiro momento, este parece estar com dimensões acima do que a norma exige. Porém, verificou-se que o banheiro a edificações, mobiliário, espaços e equipamentos urbanos”, que define espaços mínimos para manobras com cadeira de rodas e posição de barras de apoio entre outras regras, e, conjugou-se à norma, a prévia definição do sistema estrutural. Deste modo, daria para diminuir um pouco algumas dimensões do banheiro adaptado, porém, sairia do desenho do sistema estrutural definido. Por fim, optou-se por cumprir a norma e lógica estrutural simultaneamente.

Dados da Secretaria de Habitação de Diadema em 2012 apontam rejeição pelas unidades adaptadas, inclusive pelos portadores de necessidade especial. Em reunião com os moradores para definição de vizinhança para o Conjunto Piraporinha I, empreendimento com recursos federais

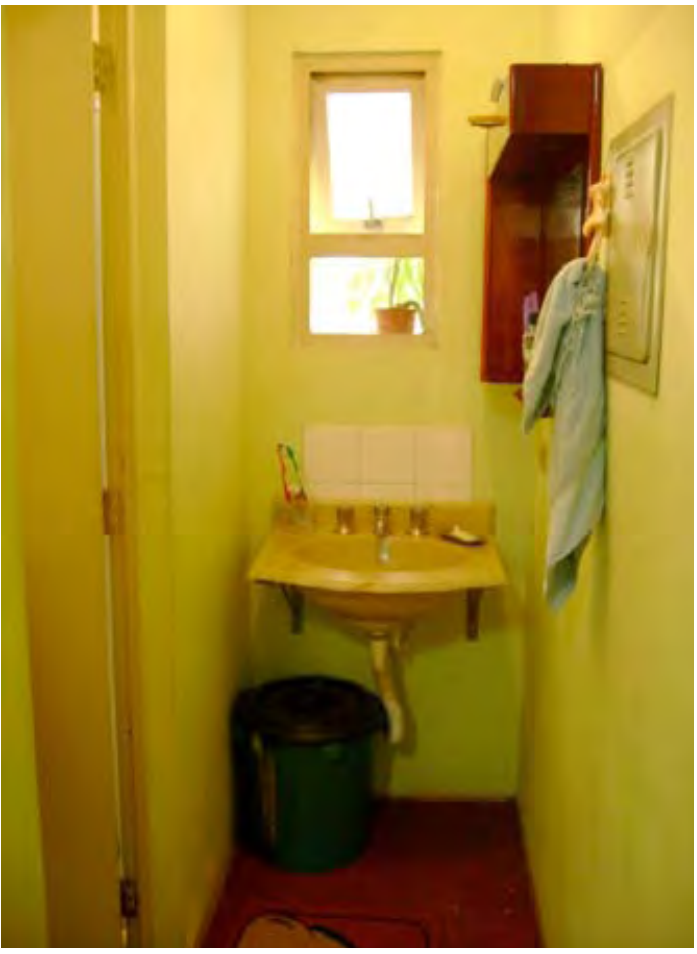

Figura 22 - Vila Pedro Fachini.Vista do lavatório externo. 
provenientes do Programa de Aceleração do Crescimento (PAC) e prefeitura de Diadema, houve recusa das unidades adaptadas, até mesmo por um morador cadeirante. As unidades térreas também foram pouco desejadas, até mesmo pelos idosos, que diziam preferir subir lances de escada a ter que ficar junto às áreas coletivas, não apenas pela falta de privacidade que proporciona, mas pelo receio de facilidade de furtos ou outras situações que, do ponto de vista dos moradores, são frágeis com relação à segurança.

Neste sentido, está em pauta repensar a normativa de acessibilidade para unidades habitacionais de interesse social, e também repensar sobre a possibilidade do uso do elevador em empreendimento de interesse social para atingir a acessibilidade universal. Afinal, não adianta solucionar o banheiro com barras, vaso elevado e diâmetro livre de $1,50 \mathrm{~m}$ e prejudicar os outros cômodos da unidade, já que a metragem da unidade adaptada acaba, quase sempre, sendo igual à das outras unidades do conjunto habitacional. No caso da Vila Pedro Fachini, o único dormitório não poderia ser diminuído, assim, as adaptações foram solucionadas também nos outros cômodos.

Em 2010 foi criado pelo Governo do Estado de São Paulo um manual com DIRETRIZES DO DESENHO UNIVERSAL NA HABITAÇÃO DE INTERESSE SOCIAL, que, dentre outras coisas, faz um estudo dos projetos padrões da Companhia de Desenvolvimento Habitacional e Urbano $(\mathrm{CDHU})$, e como seria o projeto da unidade habitacional aplicando estas diretrizes.

Entre diversas recomendações expostas no manual, sugere-se buscar soluções que atendam aos princípios do desenho universal, de tal modo a ser benéfica a todas as pessoas. Para alcançar a acessibilidade absoluta, as propostas precisam estar preparadas para suportar modificações a várias necessidades especiais que possam surgir:

O Decreto Federal $n^{\circ} 5.296 / 04$, artigo $10^{\circ}$, determina que "a concepção e a implantação dos projetos arquitetônicos e urbanísticos devem atender aos princípios do Desenho Universal". A diferença entre uma habitação com Desenho Universal e uma habitação adaptada a pessoas com deficiência está na concepção do projeto. 
Uma habitação adaptada é voltada unicamente para pessoas com deficiência, seguindo as regras previstas pela NBR 9050. Possui vaso elevado no sanitário, barras no banheiro, porta do sanitário abrindo para o lado externo, espaço de $60 \mathrm{~cm}$ ao lado externo das portas para sua adequada abertura, enfim, uma série de requisitos específicos. Por outro lado, uma habitação com Desenho Universal pode ser utilizada por todas as pessoas, inclusive indivíduos com deficiência e mobilidade reduzida, e permite adequações. Ou seja, prevê paredes preparadas para suportar uma eventual instalação de barras, se necessário; possibilita o reposicionamento de divisórias, propiciando a ampliação de um dormitório, sem implicações ou comprometimentos estruturais, entre outros itens (GOVERNO DO ESTADO DE SÃO PAULO, 2010, p.35).

Outro tema de discussão, que o projeto Pedro Fachini traz, é com relação à importância do espaço exterior próprio da unidade habitacional. Considera-se como espaço exterior próprio aquele intermediário ou de transição entre um espaço aberto e o interior da unidade, proporcionando melhoras térmicas e economia de energia a longo prazo, além de oferecer perspectivas agradáveis e continuidade visual.

Neste projeto, além das varandas e dos patamares das escadarias, existem pátios internos à unidade que representam espaços exteriores próprios. Nesta situação em que a edificação é encostada na empena cega do edifício vizinho, o pátio interno foi criado com outros objetivos principais, mais relacionados ao benefício térmico já que possibilita renovação de ar e incidência de iluminação natural em pontos que, sem o pátio, ficariam comprometidos. Os arquitetos optaram para que este espaço fosse uma extensão da área de serviço (Figura 23), com tanque e máquina de lavar nesta área externa.Ao mesmo tempo, numa unidade habitacional pequena como esta, seria desejável que este espaço desse mais amplitude ao estar, pois, por mais que exista abertura da sala para este espaço, ela não é do tipo porta-balcão e não possui continuidade com o piso. No projeto da Vila Maida, é adotada esta mesma tática projetual, para uma situação edilícia parecida, na qual o edifício é encostado na empena cega da construção vizinha, porém, foi estabelecida uma amplitude maior com relação ao interior versus exterior, conforme pode ser observado na figura 24 .

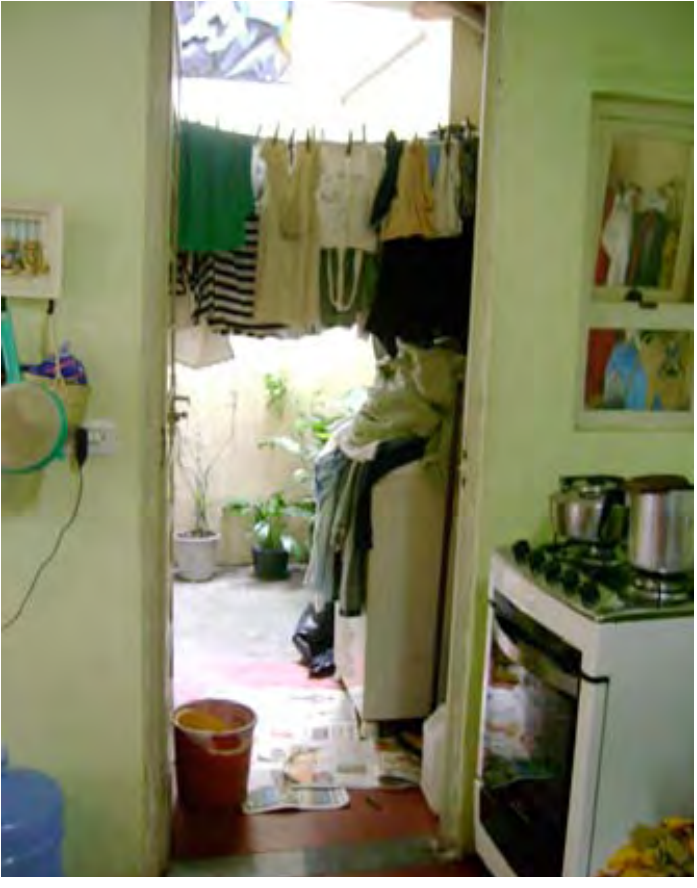

Figura 23 - Vila Pedro Fachini.Vista do Pátio Interno como extensão da cozinha.

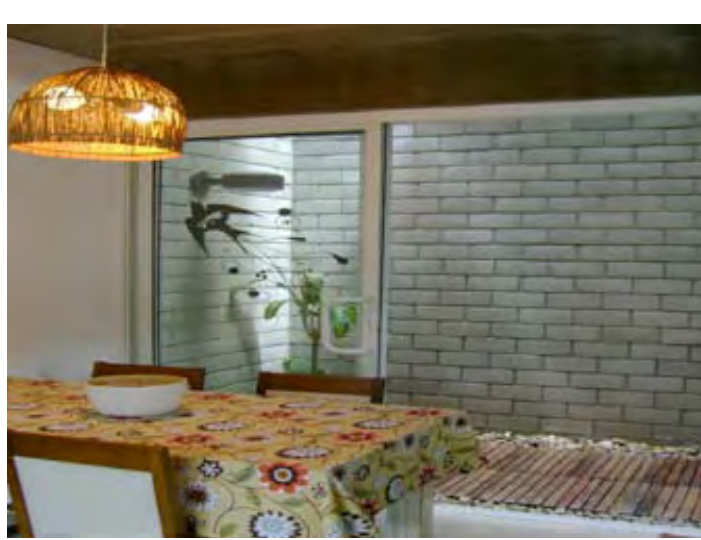

Figura 24 - Vila Maida. Pátio interno integrado com o espaço de estar da unidade habitacional. Arquiteta Maristela Faccioli. 


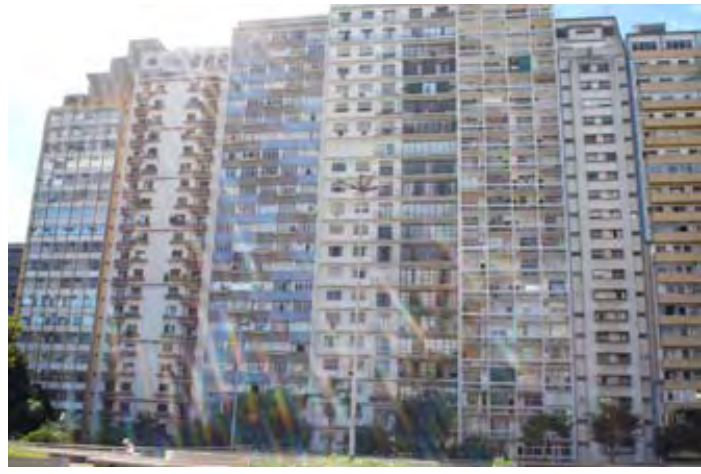

Figura 25 - Edifício Icaraí (terceiro edifício da direita para a esquerda). Arquiteto Franz Heep.

\subsection{I.8 A REFERÊNCIA DE FRANZ HEEP}

Em 1952, Heep desenvolveu os primeiros edifícios de quitinetes. Esses projetos possuem alguns elementos recorrentes e constituem a marca registrada do arquiteto: eles criaram uma referência de qualidade para o início do mercado de incorporação. Entre esses elementos estão: caixilharia com ventilação cruzada nas partes superior e inferior; floreira e lâmina de concreto, geralmente curva, que separa externamente as unidades habitacionais; os terraços, que protegem os apartamentos da insolação excessiva; o apartamento com planta bem-resolvida, que, apesar de diminuta, possuía living-dormitório, armário embutido, banheiro e pequena cozinha. Esses edifícios apresentavam ainda características similares de planta, geralmente com unidades dispostas lado a lado, com acesso por corredor único e circulação vertical destacada do corpo da edificação. Destacam-se os edifícios Marajó (1952), Normandie, Arapuan, Icaraí e Maracanã (todos de 1953), Araraúnas (1955), Iporanga (1956) e Arlinda (I959). (BARBOSA, 2002).

Marcelo Barbosa havia terminado sua dissertação de mestrado em 2002, “A obra de Adolf Franz Heep ${ }^{15}$ no Brasil" e aproximadamente um ano depois, inicia com seu sócio este projeto na Rua Pedro Fachini por solicitação da COHAB/SP.Algumas características notadas no projeto podem levar a crer que os arquitetos se referenciaram no arquiteto Franz Heep, como por exemplo: as unidades são bastante compactas, com concentração das áreas molhadas e, ao mesmo tempo, possuem aberturas bem posicionadas e amplas, inclusive existindo mais de uma janela por ambiente (o que para habitação social é raro) ou grandes aberturas para o caso das portas balcão dos dormitórios das unidades tipo dúplex. Logicamente, trata-se de uma situação mais tímida se comparada com os projetos de Franz Heep, com caixilho piso-teto que conferem uma bela vista à cidade, por exemplo, no caso do Edifício Icaraí, na Praça Roosevelt (Figura 25).

${ }^{15}$ Adolf Franz Heep (1902-1978) forma-se arquiteto na Escola de Artes e Ofícios de Frankfurt em 1926 e logo trabalha com Adolf Meyer no departamento Municipal de Construções da cidade. Depois, em Paris, trabalha com André Lurcat e com Le Corbusier. Depois em associação com o arquiteto polonês Jean Ginsberg realiza vários edifícios de apartamentos em Paris. Imigra para o Brasil, São Paulo, em 1947, em mesma situação a outros arquitetos racionalistas europeus, como o austríaco Bernard Rudofsky e a italiana Lina Bo Bardi, por exemplo. Em São Paulo, trabalha com Jacques Pilon, e depois com Henrique Mindlin. Nos anos 50, abre escritório próprio e passa atuar principalmente no mercado de incorporações voltadas para edifícios residenciais, desenhando desde apartamentos de luxo em Higienópolis até quitinetes no centro de São Paulo. 
As caixilharias foram feitas sob medida, com grelhas de ventilação permanente para os dormitórios e área social, situação possivelmente referenciada nos projetos de Franz Heep também.

A utilização de grelhas com ventilação permanente em empreendimentos de HIS, quando existem, é mais frequente na área de serviço e cozinha (como é o caso do projeto do arquiteto Edson Elito em Paraisópolis, Figura 26), ou para o banheiro (projeto do Marcos Boldarini para o conjunto habitacional Alexadre Mackenzie, Figura 27) não sendo muito comum sua utilização em ambientes para repouso (Figura 28).A decisão de colocar a escada de circulação para fora do corpo do edifício está relacionada ao lote exíguo e à necessidade de inserir muitas unidades habitacionais no terreno. Esta estratégia de destacar a escada ou caixa de circulação do corpo principal é presente em alguns projetos de Franz Heep, como por exemplo, o Edifício Icaraí, na Praça Roosevelt em São Paulo.

Em lote de $15 \mathrm{~m}$ de testada, o arquiteto Heep conseguiu dividir este espaço para quatro unidades com 3,5 m de largura, retirando a escada do corpo principal do edifício. Para a Vila Pedro Fachini, assim como no edifício lcaraí de Franz Heep, a postura de adotar a escada externa está relacionado à condição do lote urbano e o desejo de conseguir alcançar o maior número possível de unidades habitacionais, levando-se em consideração uma insolação e ventilação desejáveis.

\begin{abstract}
Os apartamentos possuem uma planta retangular de $11,50 \mathrm{~m}$ de profundidade por 3,50 m de largura, fato que foi possível devido à divisão do lote de 15,00 me de frente por quatro unidades, e não por cinco, o que resultaria num apartamento de 2,75 de largura, medida mais comum entre as kitchenettes produzidas neste período (LUCCHINI, 20I0, p. 82).
\end{abstract}

Novamente, a escada externa entra como discussão na pesquisa (ver capítulo 3.1.3). No conjunto residencial Canaã, foi uma decisão baseada no sistema construtivo com painéis pré-fabricados e também na crença do desejo popular pela escada externa que leva a um espaço de ampliação futura da unidade. Para este caso, foi uma situação de encaixe do edifício no lote urbano.

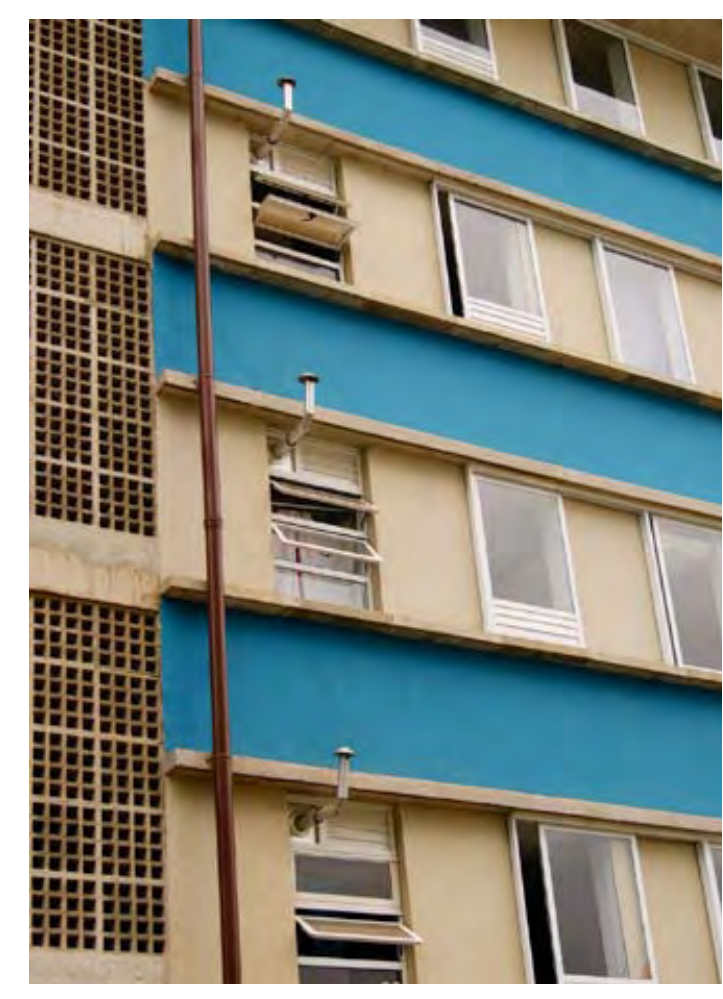

Figura 26 - Projeto Paraisópolis. Arquiteto Edson Elito. 


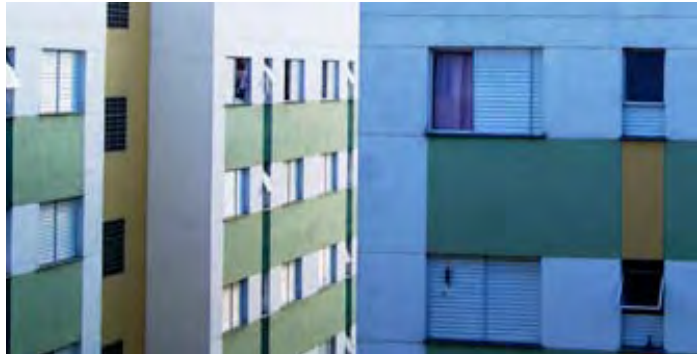

Figura 27 - Projeto Alexandre Mackenzie, Boldarini Arquitetura e Urbanismo.
Tanto Marcelo Barbosa quanto Hector Vigliecca citaram, durante a entrevista, o arquiteto Franz Heep como lição de como se fazer arquitetura numa área urbana consolidada com a criação de novas soluções para adequações a diversos tipos de situações urbanas ${ }^{16}$.

Segundo Barbosa e Corbucci (2006), a época de chegada de arquitetos estrangeiros a São Paulo na década de 1940, incluindo Franz Heep, coincide com uma alteração no mercado da contrução na cidade: início do ato de incorporar ${ }^{17}$ imóveis, e não simplesmente imóveis para obtenção de renda, com aluguel, por exemplo. Isto, consequentemente, levou a uma concorrência entre as construtoras, que passaram a exigir dos projetistas talento e novas soluções arquitetônicas.

As inúmeras experiências levadas a cabo por Heep e Korngold, na área central e no bairro de Higienópolis nesta fase de transição, onde o projetista, na cadeia produtora da indústria imobiliária tinha voz ativa para criar soluções inovadoras na ocupação do lote, interpretando a legislação urbana vigente - mais subjetiva que normativa - propor novos materiais, estruturas independentes e programas compactos, foram determinantes para o sucesso de vários lançamentos no mercado imobiliário da época, pois não tinham parâmetro. Eram únicos (BARBOSA e CORBUCCI, 2006).

Com o boom imobiliário da década de 1960, houve uma banalização das soluções criadas por excelentes arquitetos, uma reprodução simplificada, em muitos casos, para diminuir custos e prazos, situação esta que persiste. Hoje a minimização da importância do projeto arquitetônico ao empreendimento se dá pelo fato deste ser mais um produto imobiliário, concebido pelo incorporador ou equipe de marketing, na qual o arquiteto possui um papel fundamental e não secundário. Assim, soluções são reproduzidas de maneira banalizada.

${ }^{16}$ Entre os projetos citados neste capítulo, dois projetos se sobressaem na relação com as pré-existências ou pontos de contato do pré-existente com o projeto novo a ser implantado. No caso do HectorVigliecca, o projeto Casarão do Carmo resolve vários pontos de contato com pré-existências: igreja, hotel e outras edificações vizinhas. O mesmo pode-se dizer do Conjunto Carlos Gomes, do escritório BACCO Arquitetos Associados.

17 Segundo FERREIRA (2009), incorporar significa: realizar (o dono, o compromissário ou o titular de opção de venda de um terreno) contrato para construção de (edifício de apartamentos, lojas, etc.) em condomínio, começando logo a vender, em prestações, as futuras unidades. Reunir-se, juntar. 
O que ocorre na produção atual de edificações para o mercado imobiliário é que o projeto arquitetônico fica subordinado à lógica do mercado que visa o lucro e o retorno do capital invertido. É na definição do produto imobiliário feita pelo incorporador sem a participação do arquiteto, onde fica claro que o projeto arquitetônico tem sua importância minimizada, reproduzindo formas consagradas pelo mercado (BARBOSA e CORBUCCI, 2006).

Interessante é perceber que uma produção de habitação coletiva, realizada em sua maioria para o mercado privado da década de 1950, para o caso dos projetos do Franz Heep, serviu de referência para Marcelo Barbosa e Jupira Corbucci, HectorVigliecca e muitos arquitetos paulistas que se deparam com situações diversas de lote urbano, que muitas vezes exigem soluções compactadas ou até soluções edilícias inovadoras e diferenciadas para ocupação do espaço na cidade, mostrando que o lote urbano pode ser um condicionante significativo para o projeto arquitetônico.

\subsection{I.9 ENVOLTÓRIA}

As fachadas voltadas à rua e ao corredor coletivo fogem da mesmice que edifícios de HIS costumam possuir. Há diferentes tipos de janelas, saliências, varandas, patamares das escadas metálicas, as próprias escadarias, e a variação de cor, com a definição da cor vermelha para o corpo frontal, solto do chão (em que, infelizmente, a situação fica mais evidente pelo desenho do que no local, já que a face frontal térrea foi fechada), e o outro corpo, pousado no chão, com cor amarela. Há um desenho e trabalho da fachada, com janelas que, mesmo diferentes umas das outras, não deixam evidentes os usos internos. Existem janelas de dois tipos para o ambiente de estar, por exemplo, e não há um padrão para aberturas dos dormitórios. Neste projeto, o contato com o exterior se dá mais por estes elementos descritos presentes na fachada do que pelo próprio térreo do conjunto habitacional.

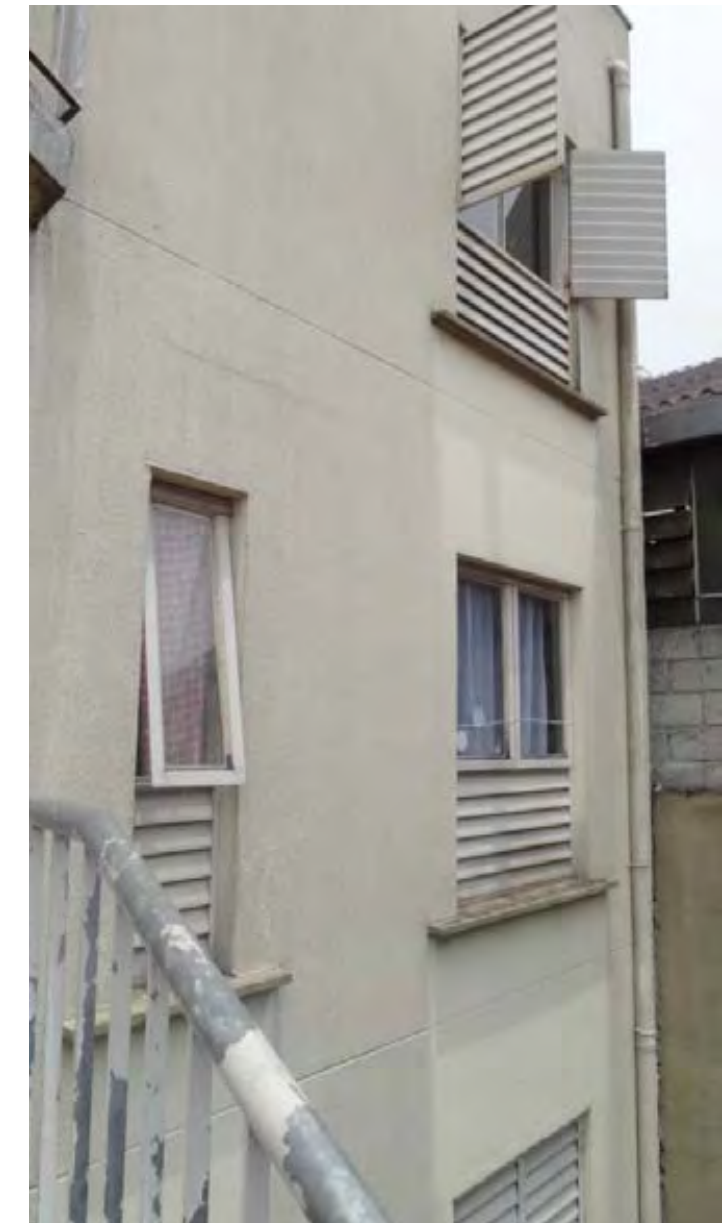

Figura 28 - Pedro Fachini. Caixilhos com grelha de ventilação permanente nos dormitórios e ambientes de estar. 


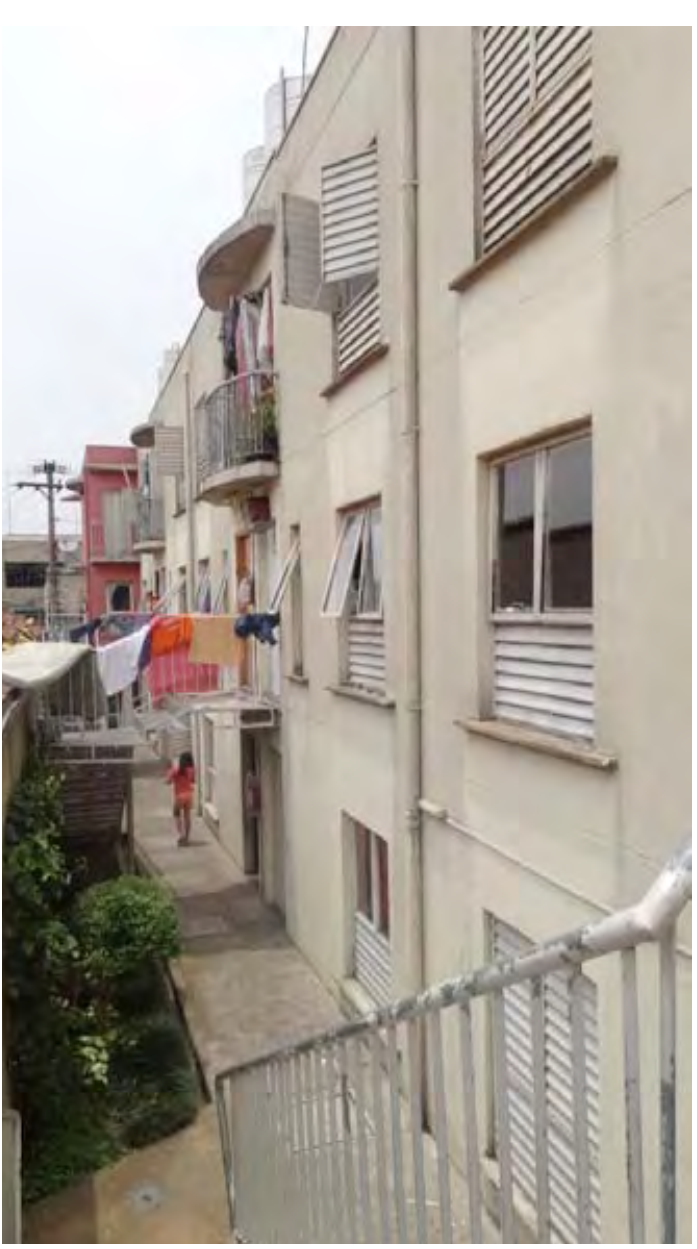

Figura 29 - Envoltória Vila Pedro Fachini. Mesclas e variedades de tipos de aberturas e cores da fachada.

\subsection{I.I 0 SISTEMA ESTRUTURAL ETÉCNICA CONSTRUTIVA}

Pelo sistema estrutural definido, quase todas as paredes são estruturais, permitindo pouca flexibilidade no interior da unidade, ou seja, pouca possibilidade de pequenas adequações ou reformas, já que os ambientes são previamente definidos. No geral, as paredes não estruturais estão definindo as áreas molhadas, e estas áreas dificilmente necessitam de mudanças, sendo mais favorável a possibilidade de remoção de paredes nos ambientes de estar, dormitórios ou cozinha, para permitir integração com a sala, por exemplo. Na Vila Maida, outro exemplo, mesmo utilizando alvenaria estrutural, a definição do sistema construtivo levou em consideração a modulação dos cômodos e, portanto, deixam os espaços abertos a outras possibilidades de ocupação e permitem maior fluidez espacial, de relação com interior versus exterior. Também o agenciamento do programa em três pavimentos contribui para a criação de diversas possibilidades de layout.

Segundo os autores do projeto, optou-se pela alvenaria estrutural, na Vila Pedro Fachini, pelo baixo custo e facilidade de construção para um edifício com apenas três pavimentos. Também foram definidos alguns elementos pré-fabricados, como lajes, batentes e vergas, que colaboraram na rápida e eficiente execução do edifício.

Para encaixar o orçamento no espaço reduzido do terreno e na urgência das famílias, que ficaram hospedadas num hotel durante os seis meses de construção, aplicou-se a alvenaria estrutural, sistema rapidamente executado, de baixo custo, com redução de desperdício e que abriu a possibilidade à utilização de revestimento texturizado sobre os blocos de concreto. (GEROLLA, 2009, p. 30).

Diferentemente do que se pode imaginar, não é a técnica construtiva, para este caso, a alvenaria estrutural, que leva a uma solução de projeto com pouca flexibilidade. A definição do desenho da estrutura é que define a flexibilidade do interior. 
Por exemplo, o projeto já citado, em Paraisópolis, realizado pelo escritório do arquiteto Edson Elito, mesmo utilizando a alvenaria armada, não engessa o espaço interior da unidade: as áreas molhadas são concentradas e define-se as paredes estruturais de tal maneira a deixar um grande espaço livre de estrutura, que permite remoção de paredes e redefinição dos cômodos (Figura 30)."Se valora por un lado El sistema estructural (dibujo) según libera parte o todo El espacio de la vivienda, permitiendo diferentes organizaciones espaciales. Y por otro en qué medida inciden las decisiones estructurales y/o constructivas en la forma final de edificio" (MONTANER e MUXÍ, 2006, p. 74).

\subsection{I.I I PERFIL DOS MORADORES}

Foi na gestão da ex-prefeita Luiza Erundina (1989-1993) que, pela primeira vez, olhou-se para os moradores alojados no terreno na Rua Pedro Fachini, onde, na época, existia um cortiço que acomodava aproximadamente oito famílias. Estas famílias foram deslocadas, já na época, para construção de um conjunto habitacional. Infelizmente, nos mandatos seguintes, este caso foi abandonado e as famílias foram obrigadas a voltar ao local e construírem barracos. Na gestão Marta Suplicy (200 I-2004), o assunto foi retomado e inserido no programa "Morar no centro".

O projeto foi feito para os moradores locais - oito famílias; algumas unidades extras abrigaram outras famílias da demanda da prefeitura. Trata-se de um perfil de famílias com maior vulnerabilidade social, ou seja, mais expostos à exclusão social e pobreza. Foram identificadas, nas recentes visitas realizadas ao local: mães solteiras; senhoras sozinhas; mulheres sozinhas e com dependência ao álcool; além de outros casos de moradores mais típicos, como casais com filhos.

A fragilidade encontrada nos moradores, na época em que ainda moravam no cortiço, meIhorou depois que passaram a viver neste pequeno conjunto residencial. 
"Quando você constrói um prédio decente, a sua referência é outra; não carregamos mais aquele estigma de corticeiros" (Ciro Sampaio, morador da Vila. Em GEROLLA, 2009, p. 27). O arquiteto Marcelo Barbosa (20I2) conta a responsabilidade que ele sentiu quando foi apresentar o projeto aos moradores pela primeira vez, pois não era apenas um projeto, era um sonho que eles tinham.Ao mesmo tempo, havia também descrença, afinal, já fazia tempo que a prefeitura dizia que iria construir um edifício para eles morarem dignamente.

Ao menos, os moradores possuem mais civilidade, e hoje não há tanta distinção e segregação destes moradores com relação aos outros que moram na mesma rua.

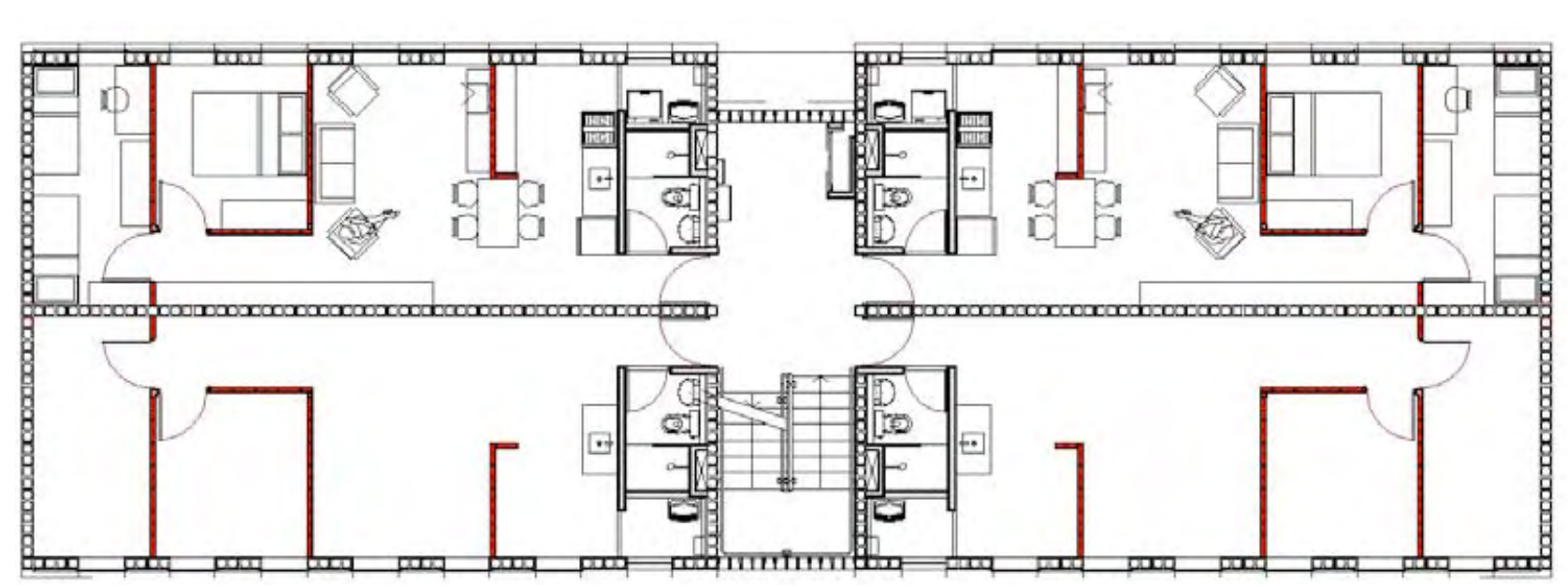

Figura 30 - Tipologia pavimento-tipo "Prédio Conectável" utilizada no projeto do Conjunto Paraisópolis. Arquiteto Edson Elito. Paredes não estruturais em vermelho. 



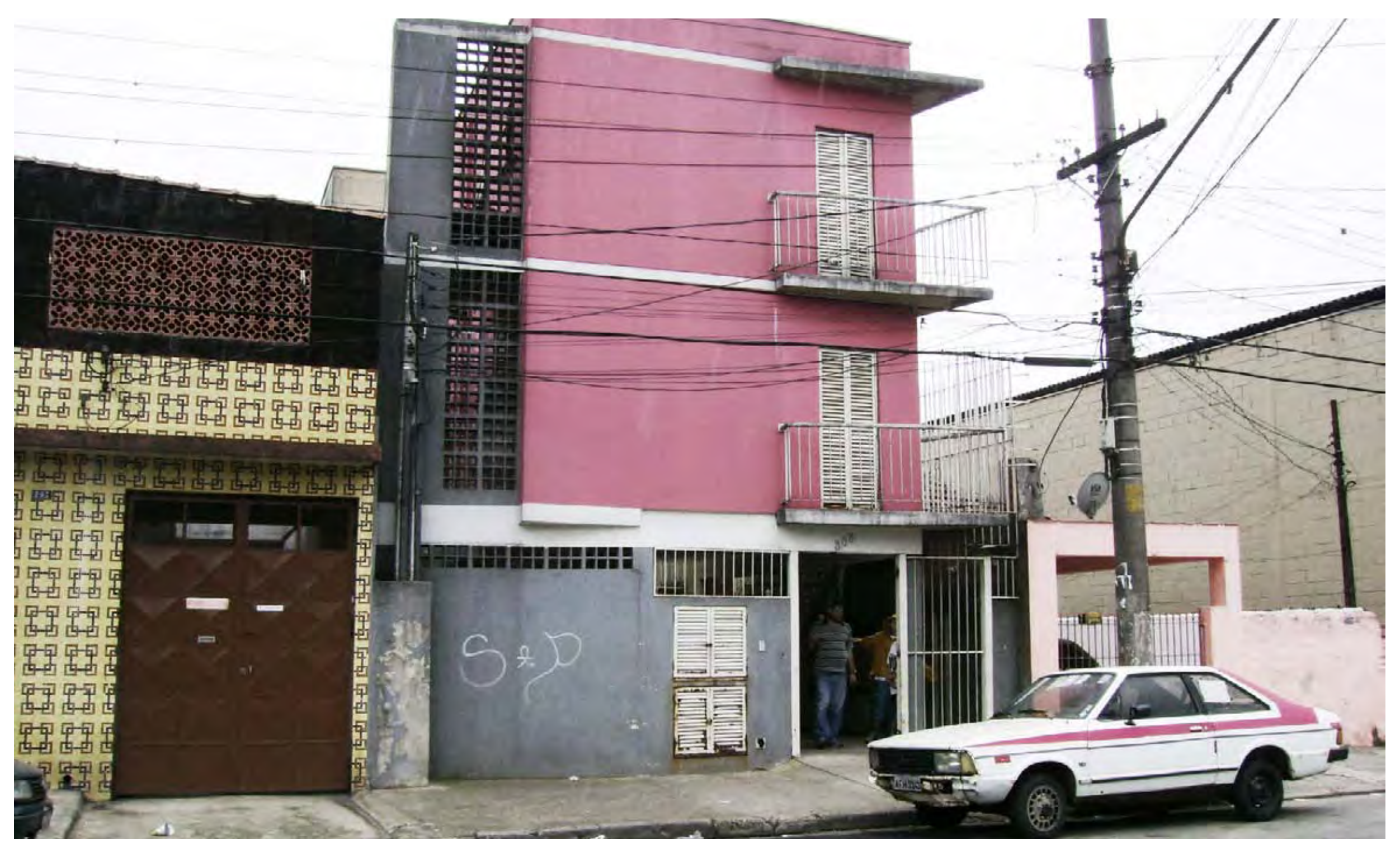

3.2.I.I 2 FICHAS GRÁFICAS EM ESCALA 


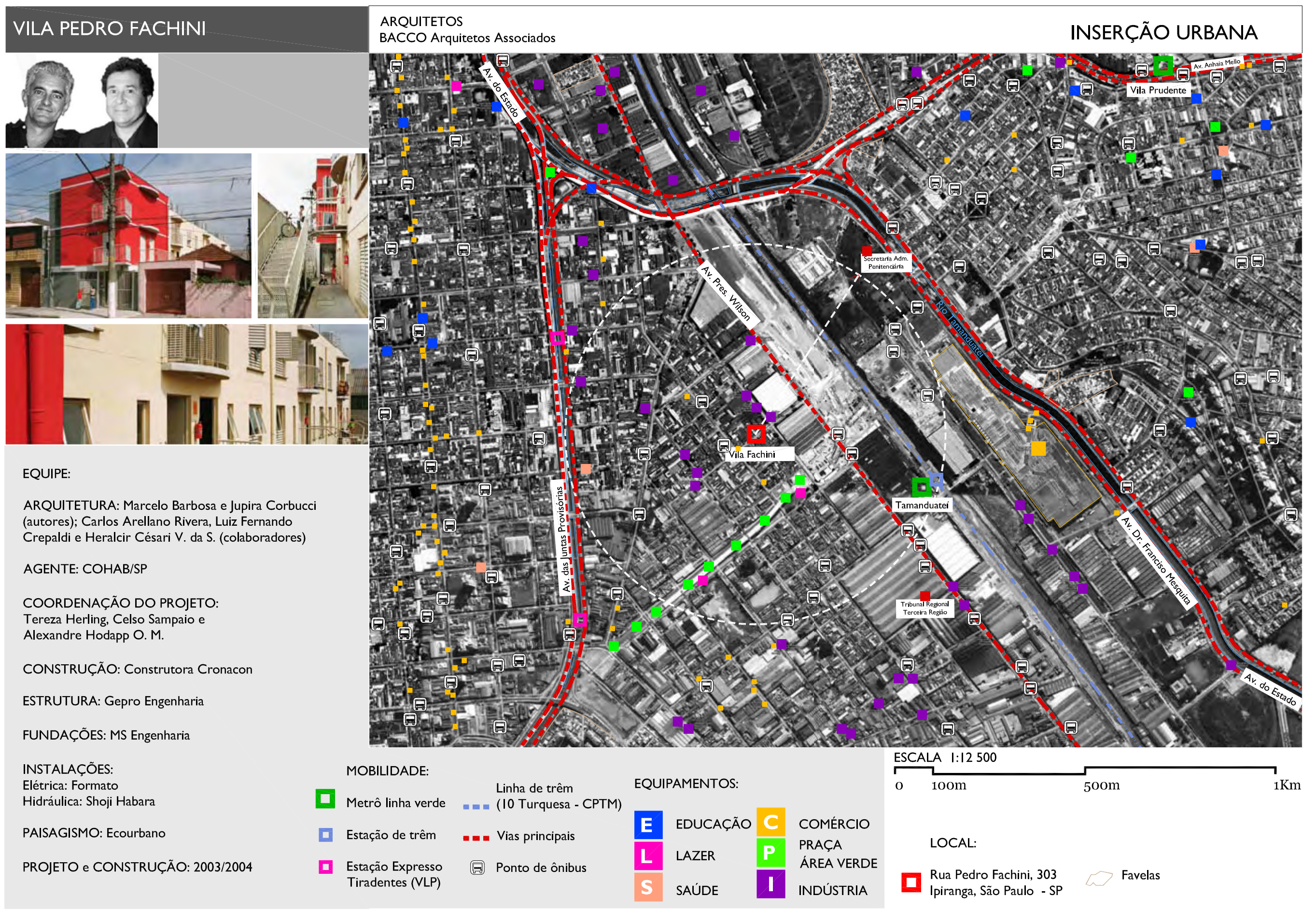




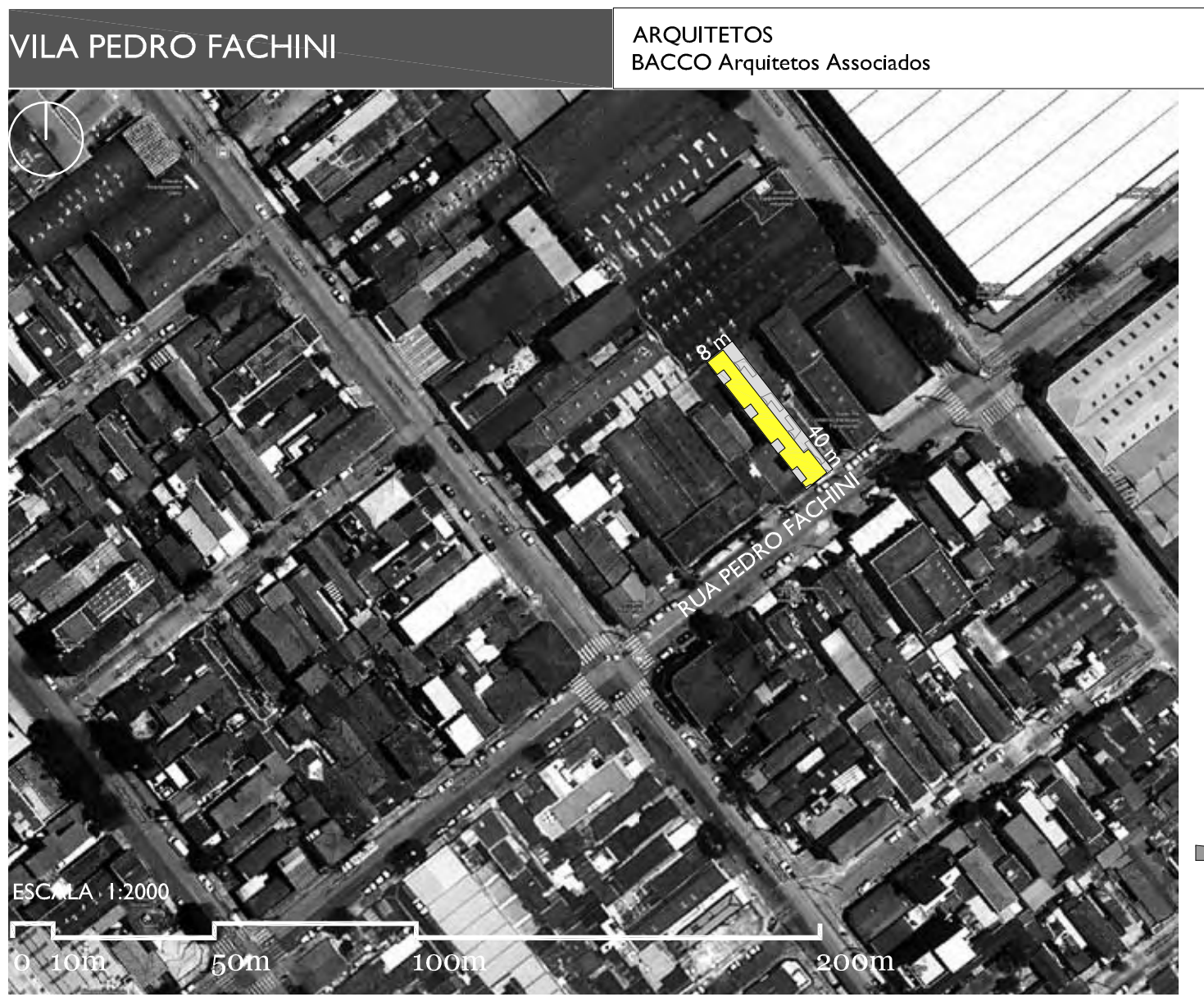

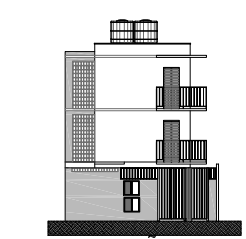

ELEVAÇAO FRONNTAL esc. I:500

\section{IMPLANTAÇÃO}

TERRENO

ÁREA DO TERRENO: $320 \mathrm{M} 2$ ÁREA OCUPADA: $182,00 \mathrm{M} 2$ \% OCUPAÇÃO: $56,87 \%$ ÁREA TOTAL CONSTRUIIDA: 525 M2 C.A.: 1,64

NÚMERO DE UNIDADES RESIDENCIAIS: 12 NÚMERO HABITANTES: 36 DENSIDADE: I $25 \mathrm{HAB} / \mathrm{HA}$

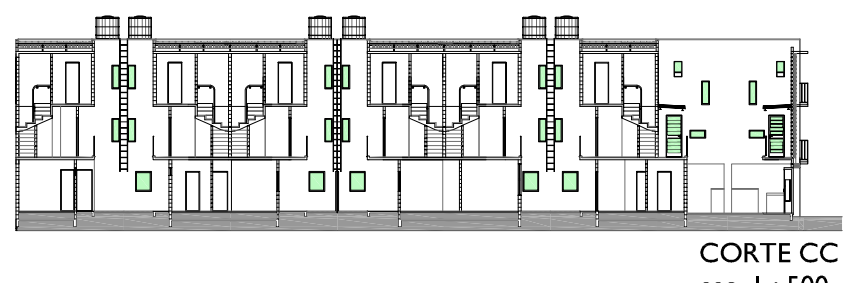

CORTE $1: 500$

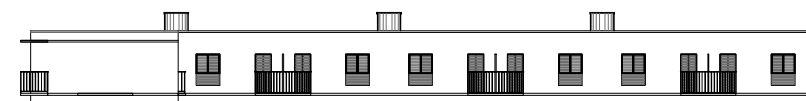

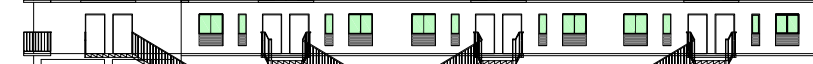

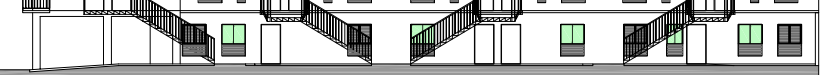
ELEVAÇÃO LATERAL
esc. $1: 500$

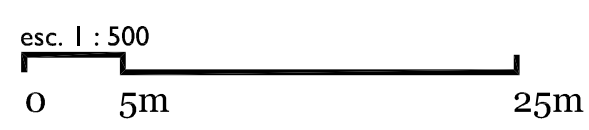

ESPAÇO EXTERIOR PRÓPRIO- U.H. OI ESPAÇO EXTERIOR PRÓPRIO - U.H. 02 ESPAÇO EXTERIOR PRÓPRIO - U.H. 03 ESPACCO EXTERIOR PRÓPRIO - U.H.04

ÁREAS VERDES COLETIVAS

- ENTRADA UNIDADE HABITACIONAL

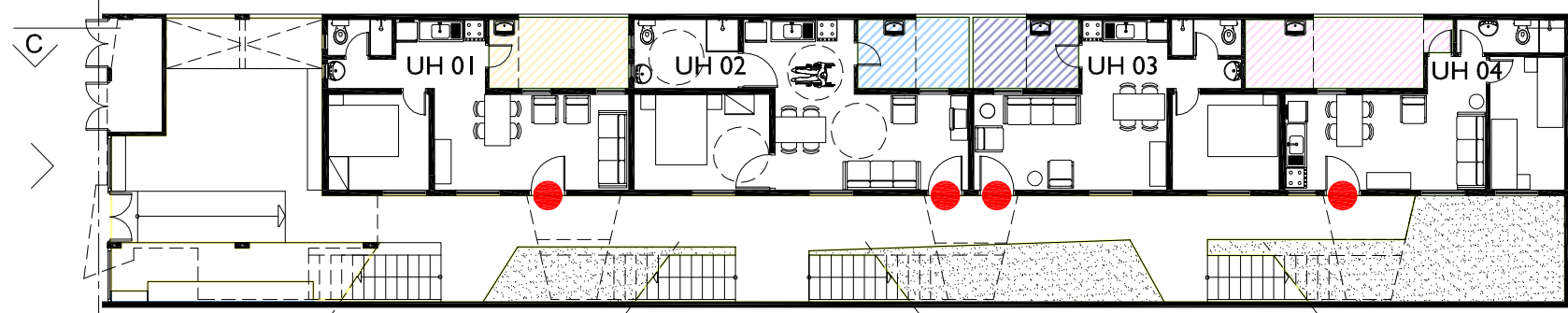

IMPLANTAÇÃO TÉRREO esc. I: 250

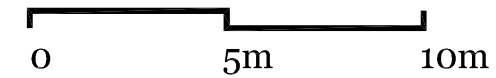




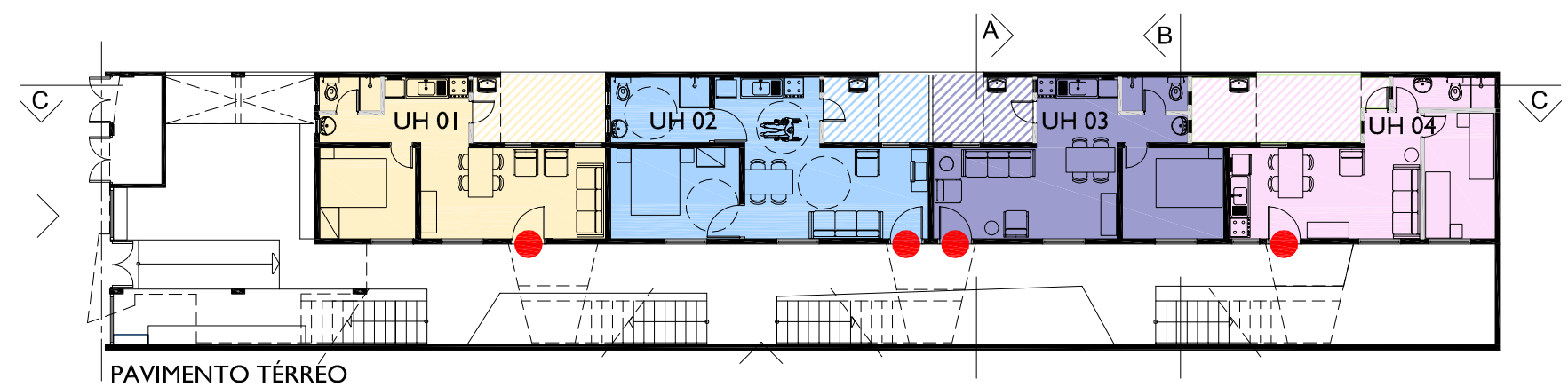

PAVIMENTO TÉRRÉO esc. $1: 250$
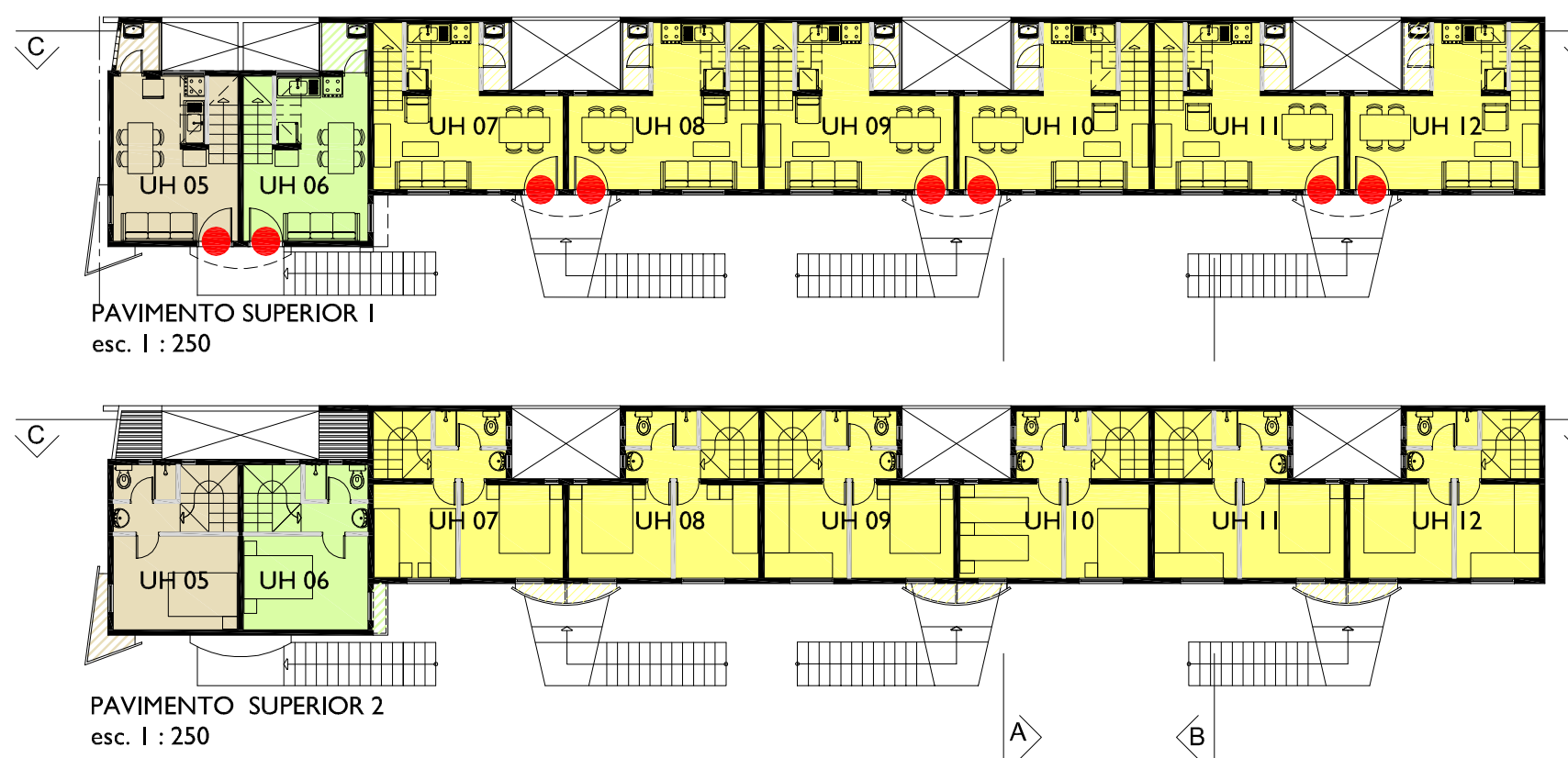
esc. $1: 250$

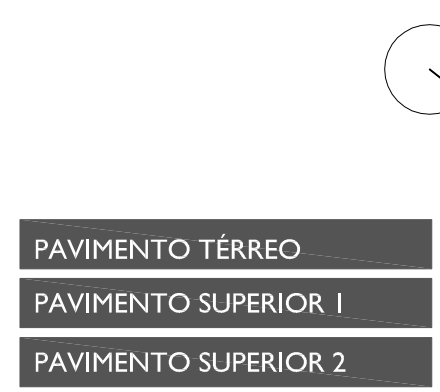

computável $\quad 29,06 \mathrm{~m}^{2}$ não computável $\quad 7,03 \mathrm{~m}^{2}$ total $36,09 \mathrm{~m}^{2}$

$29,06 \mathrm{~m}^{2}$

\section{$\mathrm{UH} 02$}

UH 03

$34,46 \mathrm{~m}^{2}$

UH 04

UH 05

CASA $07-12$

$17,28 \mathrm{~m}^{2}$

$\begin{array}{lll}13,60 \mathrm{~m}^{2} & 13,60 \mathrm{~m}^{2} & 17,28 \mathrm{~m}^{2} \\ 15,60 \mathrm{~m}^{2} & 15,60 \mathrm{~m}^{2} & 20,90 \mathrm{~m}^{2}\end{array}$

$34,75 \mathrm{~m}^{2}$ $5,75 \mathrm{~m}^{2}$

$34,46 \mathrm{~m}^{2}$ $5,7 \mathrm{~m}^{2}$

$26,05 \mathrm{~m}^{2}$ $29,20 \mathrm{~m}^{2}$ $2,77 \mathrm{~m}^{2}$ $29,20 \mathrm{~m}^{2}$ $2,22 \mathrm{~m}^{2}$ $38,18(x 6)=229,08 \mathrm{~m}^{2}$ $1,95(x 6)=11,70 \mathrm{~m}^{2}$

$4 \mid 1,80 \mathrm{~m}^{2}$ $45,19 \mathrm{~m}^{2}$

$\begin{array}{lll}40,50 \mathrm{~m}^{2} & 40,21 \mathrm{~m}^{2} & 35,84 \mathrm{~m}^{2}\end{array}$

$31,97 \mathrm{~m}^{2}$

$31,42 \mathrm{~m}^{2}$

$40,13 \mathrm{~m}^{2} \quad 240,78 \mathrm{~m}^{2}$

$456,99 \mathrm{~m}^{2}$

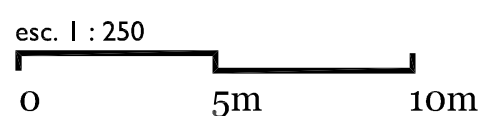



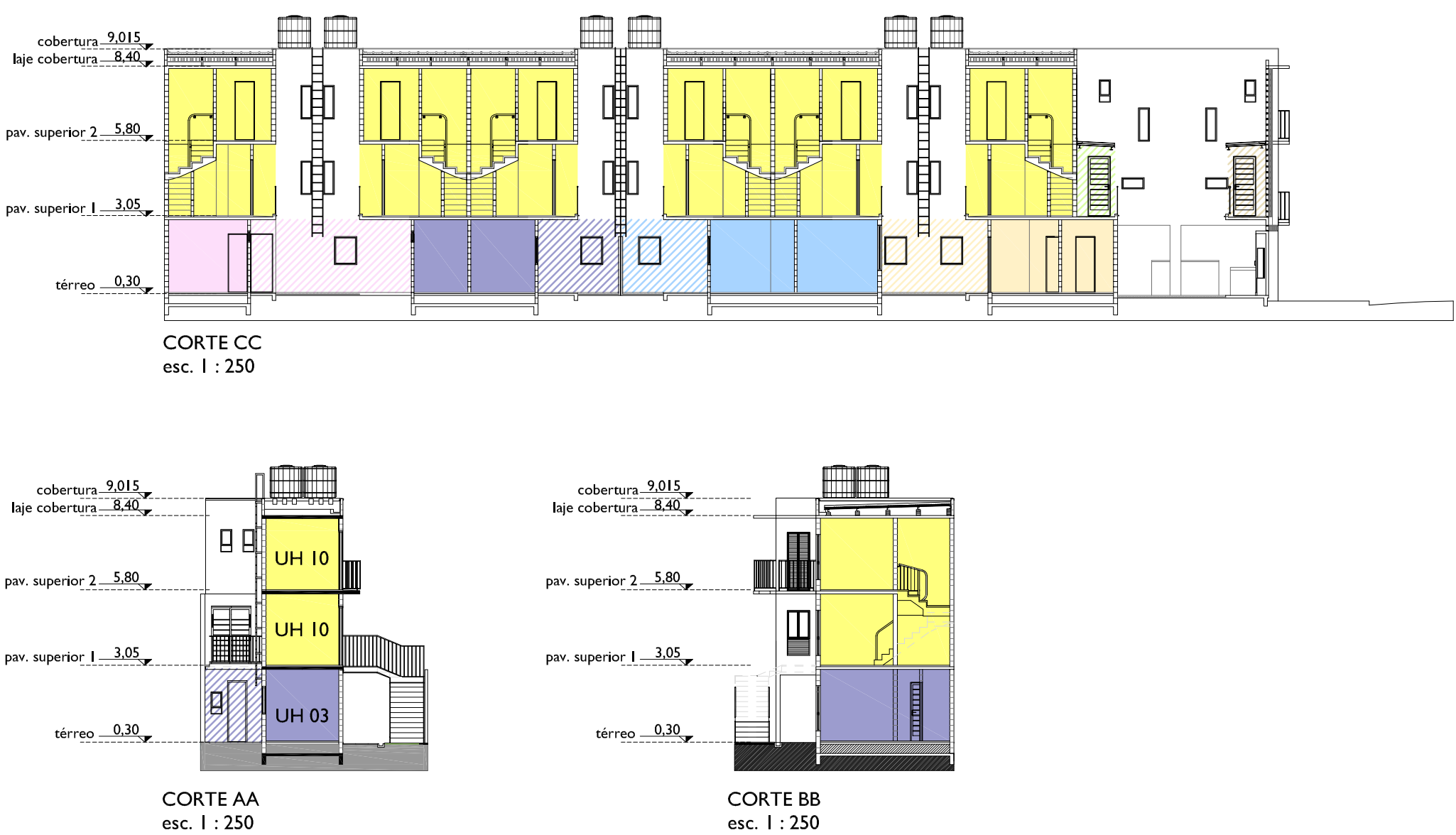

\begin{tabular}{|c|c|c|c|c|c|c|c|c|}
\hline & UHOI & $\mathrm{UH} 02$ & $\mathrm{UH} 03$ & UH 04 & UH 05 & UH 06 & CASA $07-12$ & TOTAL \\
\hline PAVIMENTO TÉRREO & $29,06 \mathrm{~m}^{2}$ & $34,75 \mathrm{~m}^{2}$ & $34,46 \mathrm{~m}^{2}$ & $26,05 \mathrm{~m}^{2}$ & & & & \\
\hline PAVIMENTO SUPERIOR I & & & & & $13,60 \mathrm{~m}^{2}$ & $13,60 \mathrm{~m}^{2}$ & $17,28 \mathrm{~m}^{2}$ & \\
\hline PAVIMENTO SUPERIOR 2 & & & & & $15,60 \mathrm{~m}^{2}$ & $15,60 \mathrm{~m}^{2}$ & $20,90 \mathrm{~m}^{2}$ & \\
\hline $\begin{array}{l}\text { computável } \\
\text { não computável }\end{array}$ & $\begin{array}{r}29,06 \mathrm{~m}^{2} \\
7,03 \mathrm{~m}^{2}\end{array}$ & $\begin{array}{l}34,75 \mathrm{~m}^{2} \\
5,75 \mathrm{~m}^{2}\end{array}$ & $34,46 \mathrm{~m}^{2}$ & $\begin{array}{r}26,05 \mathrm{~m}^{2} \\
9,79 \mathrm{~m}^{2}\end{array}$ & $\begin{array}{r}29,20 \mathrm{~m}^{2} \\
2,77 \mathrm{~m}^{2}\end{array}$ & $\begin{array}{r}29,20 \mathrm{~m}^{2} \\
2,22 \mathrm{~m}^{2}\end{array}$ & $\begin{aligned} 38,18(\times 6) & =229,08 \mathrm{~m}^{2} \\
1,95(\times 6) & =11,70 \mathrm{~m}^{2}\end{aligned}$ & $\begin{array}{l}411,80 \mathrm{~m}^{2} \\
45,19 \mathrm{~m}^{2}\end{array}$ \\
\hline total & $36,09 \mathrm{~m}^{2}$ & $40,50 \mathrm{~m}^{2}$ & $40,21 \mathrm{~m}^{2}$ & $35,84 \mathrm{~m}^{2}$ & $31,97 \mathrm{~m}^{2}$ & $31,42 \mathrm{~m}^{2}$ & $240,78 \mathrm{~m}^{2}$ & $\overline{456,99 \mathrm{~m}^{2}}$ \\
\hline
\end{tabular}

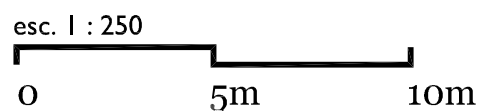




\subsection{I.I3 BIBLIOGRAFIA DO CAPÍTULO}

ARQUITETURA E URBANISMO. Especial Habitação. São Paulo, n. 186, setembro de 2009.

ARQUITETURA E URBANISMO. Especial Intervenções em favelas.. São Paulo, n. 200, novembro de 2010.

BACCO Arquitetos Associados. Portfólio. Disponível em: <www.bacco.com.br/.> Acesso em: 24/I I/201 2.

BARBOSA, M. C. Adolf Franz Heep: um arquiteto moderno. 2012. Tese (Doutorado em Arquitetura e Urbanismo). Universidade Presbiteriana Mackenzie, São Paulo, 2012.

Do público ao privado: a habitação coletiva na obra de Franz Heep. ProjetoDesign, São Paulo, n. 272, setembro de 2002. São Paulo, São Paulo, 2002.

BARBOSA, M. C; CORBUCCI, J. COHAB Pedro Facchini, uma proposta habitacional viável. Seminário Internacional da LARES - Latin American Real Estate Society. São Paulo, setembro de 2006.

Ferreira, A. B. H. (Ed.) Novo dicionário Aurélio da Língua Portuguesa. $4^{\mathrm{a}}$ Ed. São Paulo:Positivo Livros, 2010.

GEROLLA, Giovanny.Vila Operária. Arquitetura e Urbanismo. São Paulo, n. I86, p. 27-3I, setembro de 2009.

GOVERNO DO ESTADO DE SÃO PAULO. Diretrizes do Desenho Universal na Habitação de Interesse Social no Estado de São Paulo. São Paulo, março de 2010.

GRUNOW, Evelise. Moradia Social vai requalificar a cidade. Concurso Renova SP. ProjetoDesign, n. 384, fevereiro de 2010.

MONOLITO. Habitação Social em São Paulo, n. 7, fevereiro/março de 2012.

LUCCHINI. E. J. Adolf Franz Heep: edifícios residenciais. Um estudo da sua contribuição para a habitação coletiva vertical em São Paulo nos anos 1950. 2010. Dissertação (Mestrado em Arquitetura e Urbanismo). Universidade Presbiteriana Mackenzie, São Paulo, 2010.

MELENDEZ,Adilson. Bacco completa 20 anos e leva projeto por notório saber. ProjetoDesign, São Paulo, n. 386, p. 102 , abril de 2012.

MONTANER,J.M.;MUXÍ,Z.M.Habitar el Presente.Vivienda en España:Sociedad, ciudad,tecnología y recursos. Madri:Ministerio deVivienda,2006.

MONTANER, J. M.; MUXÍ, Z. M.; ZULIN, F.; CORADIN, R. Instrumentos de Avaliação de Projetos. En: Do plano ao projeto: Novos Bairros e Habitação Social em São Paulo. Coleção: Política Municipal de Habitação: Uma construção coletiva. São Paulo: Secretaria Municipal de Habitação, Prefeitura de São Paulo, 2012, p. 252-313.

MONTANER MUXÍ ARQUITECTES. Definición, condiciones y critérios de diseño para la vivienda del siglo XXI en Andalucía, 2008. 
PIOCCHI, S. Relatório Técnico da COHAB/SP. São Paulo, 2005.

PREFEITURA DE SÃO PAULO. Catálogo do Programa “Morar no Centro”. São Paulo, 2004.

PROJETODESIGN. Uma vila vertical. São Paulo, n.297, dez.2004.

RUBANO, L. M. Habitação social: temas da produção contemporânea. São Paulo, Vitrúvius, 2008. Disponível em: <http://www.vitruvius.com.brl revistas/read/arquitextos/08.095/I53>.Acesso em: 04/0I/20II.

SANTOS,V. C. Concursos de Arquitetura em São Paulo. 2002. Dissertação (Mestrado em Arquitetura e Urbanismo). Universidade de São Paulo, São Paulo, 2002.

SERAPIÃO, Fernando. Quando a favela vira cidade. Urbanização de favelas, concursos, intercâmbios e verbas milionárias incitam debate sobre projetos de interesse social em curso na capital paulista. ProjetoDesign, n. 369, novembro de 2010.

TRONCOSO. Úrsula. Enfrentar a cidade real. Arquitetura e Urbanismo. São Paulo, n. 225, p. 48-57, dezembro de 2012.

USINA. Centro de Trabalhos para o ambiente habitado. Disponível em: <www.usinactah.org.br>.Acesso em: 02 de janeiro de 2012.

VIGLIECCA, Hector. Memorial do Projeto Vila dos Idosos. Disponível em: <www.vigliecca.com.br>.Acesso em: 02 jan. 2012.

WHITAKER, J. S. Perspectivas e desafios para o jovem arquiteto no Brasil. Qual o papel da profissão? São Paulo, Vitrúvius, 20II. Disponível em: <http://www.vitruvius.com.br/revistas/read/arquitextos/I2.133/3950>. Acesso em: 24 novembro de 2012.

WISSENBACH,V.; BONDUKI, N.; RUBANO, L. M.; MARICATO, E. Habitação social: direito à arquitetura. São Paulo, 2006. No prelo.

ZEIN, R.V. e BASTOS, M.A.J. B. Brasil: Arquiteturas após 1950. São Paulo: Perspectiva, 20I0. P. 303-3I8.

VISITAS REALIZADAS:

Vila Pedro Fachini - 10 de outubro de 2010 e 28 de dezembro de 2012.

ENTREVISTAS:

Arquiteto Marcelo Barbosa - 03 de dezembro de 2012.

Arquiteto HectorVigliecca (cedida pela arquiteta Alessandra Bedolini) - Novembro de $20 \mathrm{II}$.

LEIS:

ASSOCIAÇÃO BRASILEIRA DE NORMA TÉCNICA (ABNT). NBE 9050 - Acessibilidade a edificações, mobiliário, espaços e equipamentos urbanos. Rio de Janeiro, RJ, 2004.

BRASIL. Decreto-lei $n^{\circ}$ 5.296, de 02 de dezembro de 2004. Estabelecem atendimento prioritário, normas gerais e critérios básicos para a promoção da acessibilidade das pessoas com deficiência ou mobilidade reduzida. Idoso e Deficiente, prioridades - Regulamenta as Leis 10.048 de 2000 e 10.098 de 2000. 
SÃO PAULO (município). Lei n 13.430, de 13 de setembro de 2002. Plano Diretor Estratégico de São Paulo.

SÃO PAULO (município). Lei n 13.885, de 25 de Agosto de 2004. Planos Regionais Estratégicos das Subprefeituras de São Paulo.

SÃO PAULO (município). Lei n II.228, de 25 de junho de 1992. Código de Obras e Edificações do Município de São Paulo. Dispões sobre as regras gerais, e específicas a serem obedecidas no projeto, licenciamento, execução, manutenção e utilização de obras e edificações, dentro dos limites dos imóveis, revoga a Lei $n^{\circ} 8.266$ de 20 de junho de 1975, com as alterações adotadas por leis posteriores, e dá outras providências.

SÃO PAULO (município). Decreto Municipal n 32.329 de 23 de setembro de 1992 . Regulamenta a Lei n 11.228 de 25 de junho de 1992 - Código de Obras e Edificações, e dá outras providências.

SÃO PAULO (município). Decreto Municipal n 44.667 de 26 de abril de 2004 . Regulamenta a Lei $n^{\circ} 13.430$ de 13 de setembro de $2002-$ que institui o Plano Diretor Estratégico, relativas às Zonas Especiais de Interesse Social e aos respectivos Planos de Urbanização, e dispõe sobre normas específicas para a produção de Empreendimentos de Habitação de Interesse Social Habitação de Interesse Social e Habitação do Mercado Popular.

SÃO PAULO (município). Decreto Municipal n 45.127 de 13 de agosto de 2004. Altera disposições do Decreto $n^{\circ} 44.667$, de 26 de abril de 2004, que dispõe sobre Zonas Especiais de Interesse Social e seus respectivos Planos de Urbanização, produção de Empreendimentos de Habitação de Interesse Social, Habitação de Interesse Social e Habitação do Mercado Popular; regulamenta os artigos $4^{\circ}$ e $5^{\circ}$ da Lei $n^{\circ}$ I3.657, de 3 I de outubro de 2003, que concedem isenção de taxas incidentes sobre as edificações que discrimina; prevê a dispensa do pagamento de preços públicos nas hipóteses que especifica; e estabelece normas de competência.

SÃO PAULO (município). Decreto Municipal n 47.702 de 19 de setembro de 2006. Dá nova redação aos artigos 31 e 52 do Decreto $n^{\circ} 44.667$, de 26 de abril de 2004, bem como dispõe sobre as edificações de Habitação de Interesse Social - HIS e de Habitação de Mercado Popular - HMP implantadas fora dos perímetros das Zonas Especiais de Interesse Social - ZEIS.

196 BRASIL. Lei n 10.048, de 08 de novembro de 2000. Dá prioridade de atendimento às pessoas que especifica, e dá outras providências.

BRASIL. Lei $n^{\circ} 10.098$, de 19 de dezembro de 2000. Estabelece normas gerais e critérios básicos para a promoção da acessibilidade das pessoas portadoras de deficiência ou com mobilidade reduzida, e dá outras providências.

OUTROS:

VIGLIECCA, H. Construir a Cidadania. Conferência Museu da Casa Brasileira. São Paulo, MCB, 28 nov. 2012. 


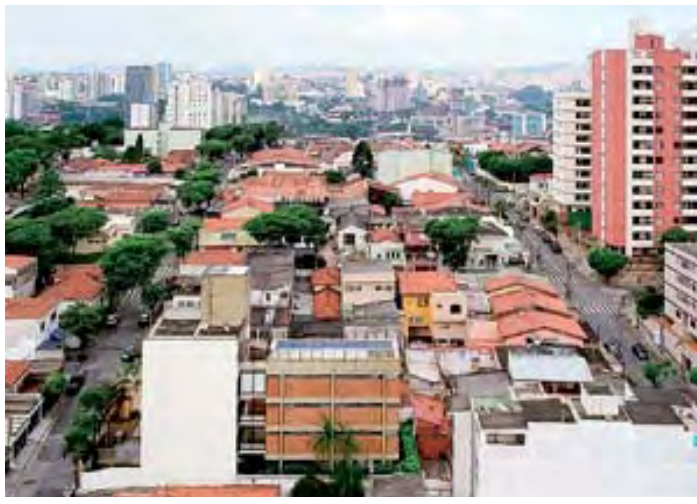

Figura I - Fiori di Maggio. Inserção do Edifício na Rua Santa Adelaide, em trecho do bairro predominantemente horizontal.

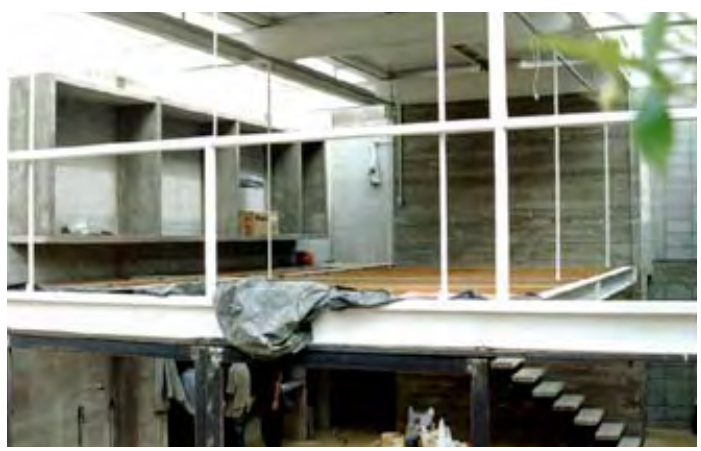

Figura 2 - Residência na Lapa em construção, de 1998-1999, Bela Vista Arquitetos.

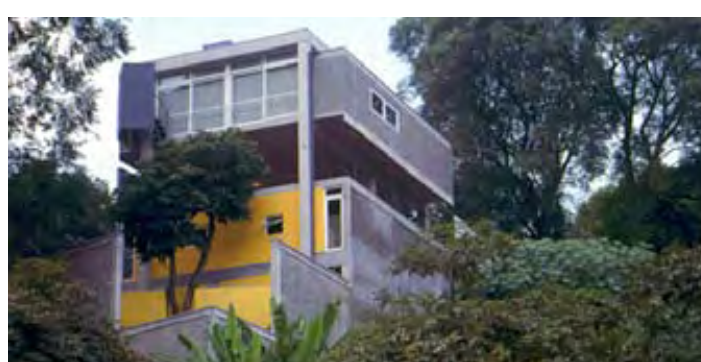

Figura 3 - Casa em Perdizes, 1996-1998, SPRB, na qual Pablo Hereñú colaborou ainda como estudante de arquitetura.

\subsubsection{FIORI DI MAGGIO: ARQUITETURA COLETIVA CONTEMPORÂNEA PAULISTA}

\subsubsection{INTRODUÇÃO E BREVETRAJETÓRIA DO COLETIVO DE ARQUITETOS}

O projeto para o edifício de habitação coletiva Fiori di Maggio (Figura 0I) foi encomendado aos arquitetos Carlos Ferrata,Apoena e Moracy Amaral, Eduardo Ferroni e Pablo Hereñú em 1999 por Milton Della Pietra, dono da construtora Joy Congero, por indicação de seu filho que era amigo dos arquitetos. Pode-se afirmar' que nenhum dos autores do Fiori di Maggio estava oficialmente formado quando foram convidados a elaborar o projeto em São Bernardo do Campo, apesar de já estarem estudando arquitetura há tempo suficiente para conseguir propor um projeto com qualidade e adequado aquilo que havia sido encomendado pelo cliente.

'BelaVistaArquitetos' era o nome do coletivo ou escritório,formado pelos estudantes de arquitetura mais o recém-formado Carlos Ferrata, que elaborou o projeto do edifício Fiori di Maggio. Outros projetos foram elaborados durante esta formação de equipe.Por exemplo, a Residência na Lapa (Figura 2) (1998-1999), que, assim como no Fiori di Maggio, teve como partido tirar proveito da exiguidade do lote, de 7,5 × 15 metros. No período de estudantes, em atividades paralelas ao 'Bela Vista Arquitetos' ou anterior a este coletivo, colaboraram em diversos escritórios de arquitetos reconhecidos de São Paulo: Álvaro Puntoni,Angelo Bucci,Alvaro Razuk, Ciro Pirondi,André Vainer e Guilherme Paollielo, Paulo Mendes da Rocha, MMBB, UNA Arquitetos, Brasil Arquitetura, entre outros (Figuras 3 e 4) ${ }^{2}$.

' Em 1999, Carlos Ferrata estava se formando pela Faculdade de Arquitetura e Urbanismo Anhembi Morumbi (FAUAM), enquanto os irmãos Moracy e Apoena Amaral e Almeida já haviam cursado três anos de arquitetura e urbanismo na Universidade Bráz Cubas (UBC) e estavam no quarto ano da FAUUSP, instituição de ensino que optaram pela transferência em 1996. Pablo Hereñú e Eduardo Ferroni ingressaram na mesma instituição no ano seguinte aos irmãos, em 1997, e assim a FAUUSP foi o local de encontro deste grupo de arquitetos.

${ }_{2}$ Carlos Ferrata, por exemplo, colaborou no projeto Conjunto KKK (1996-200I) do Brasil Arquitetura. Juntos, ou individualmente, quase todos colaboraram em projetos do escritório SPBR e MMBB em suas diversas formações. Por exemplo, Pablo Hereñú colaborou no projeto Casa em Perdizes, em 1996, e também fez parte da equipe que desenvolveu o projeto 'Poupatempo em Itaquera', de 1999, de Paulo Mendes da Rocha em colaboração com o MMBB. Eduardo Ferroni colaborou no projeto da Residência em Aldeia da Serra, de 200I. Com exceção de Carlos Ferrata, os quatro participaram do Concurso para a Nova Sede da FAPESP, em I998, sob coordenação de Alvaro Puntoni e Angelo Bucci, apenas para citar alguns exemplos. 
O ‘Bela Vista Arquitetos' teve duração até aproximadamente 200 I, ano em que Pablo Hereñú e Eduardo Ferroni estavam se graduando pela FAUUSP, e ano também em que os jovens arquitetos, em associação com os arquitetos Alvaro Puntoni e Angelo Bucci, participaram do Concurso Público Nacional para a sede do CREA no Ceará (200I), no qual receberam a $3^{\text {a }}$ colocação. O projeto, na Rua Santa Adelaide, Fiori di Maggio, levou alguns anos para ser executado, por motivos relacionados à aprovação na prefeitura que serão esclarecidos mais adiante. Então, antes mesmo da finalização da obra, que ocorreu em 2007, os arquitetos passaram a seguir caminhos diferentes, mas não muito distantes e com constantes encontros.

Pablo Hereñú e Eduardo Ferroni juntaram-se aos Arquitetos Cooperantes em 2002, espaço que reuniu, até 2010, um grupo variado de arquitetos associados em colaborações diversas. Tratava-se, novamente, de uma formação flexível de profissionais, na qual as participações ocorriam de maneira não rígida, ou seja, juntos ou individualmente continuavam colaborando com diferentes escritórios paulistanos já citados ${ }^{3}$.

Um projeto que exemplifica a dinâmica na formação da equipe, para o caso dos Arquitetos Cooperantes, foi o projeto que ganhou Menção Honrosa para o Conjunto Cônego Vicente M. Marino no Concurso HabitaSampa ${ }^{4}$ (Figura 5). Também recebem menção honrosa para o Cônego Vicente as equipes lideradas por Álvaro Puntoni ${ }^{5}$ (Figura 6), e Luciano Margotto Soares ${ }^{6}$ (Figura 7). Isto mostra a liberdade em que trabalham, já que, em outros momentos, estes grupos de arquitetos não eram concorrentes em concursos e, sim, membros da mesma equipe.

É marcante o método de trabalho destes arquitetos com equipe flexível, um ato que acaba por distanciá-los de uma filosofia comum,já que existe uma mistura ou integração de repertórios diferentes:

\footnotetext{
${ }_{3}^{3}$ Por exemplo, Eduardo Ferroni fez parte da equipe que desenvolveu o projeto para a escola FDE, em Campinas, 2003, de autoria do MMBB.

${ }^{4}$ Projetos para Locação Social, 2004, promovido pela Secretaria Municipal de Habitação, COHAB - SP e organizado pelo Instituto de Arquitetos do Brasil, de São Paulo.

${ }_{5}^{5}$ GRUPO SP: Álvaro Puntoni, Jonathan Davies e João Clark Sodre.

${ }^{6}$ Núcleo de Arquitetura: Luciano Margotto Soares, Marcelo Luiz Ursini e Sergio Salles.
}

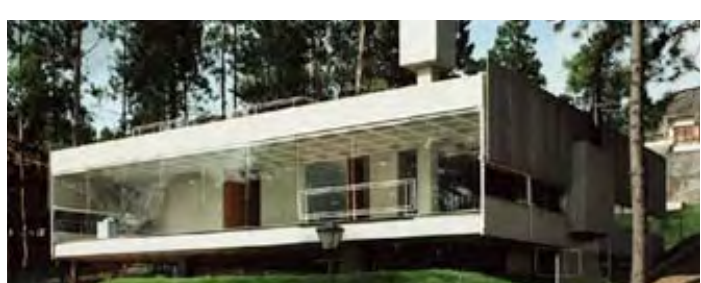

Figura 4 - Residência em Aldeia da Serra, 200I MMBB. Eduardo Ferroni colaborou.

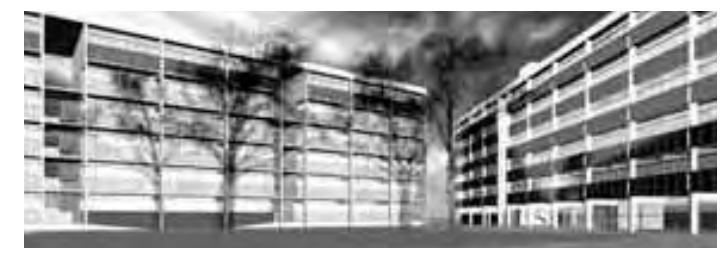

Figura 5 - Concurso HabitaSampa 2004.

Menção Honrosa 2: Conjunto Cônego Vicente M. Marino. Arquitetos Cooperantes.

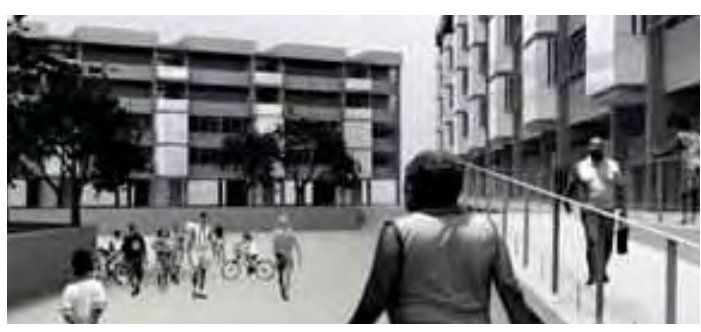

Figura 6 - Concurso HabitaSampa 2004 Menção Honrosa 5: Conjunto Cônego Vicente M. Marino. Equipe GRUPO SP.

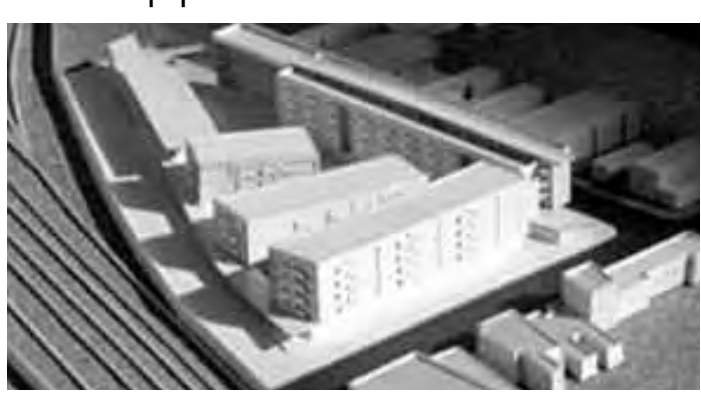

Figura 7 - Concurso HabitaSampa 2004.

Menção Honrosa I: Conjunto Cônego Vicente M. Marino. Equipe Núcleo de Arquitetura. 


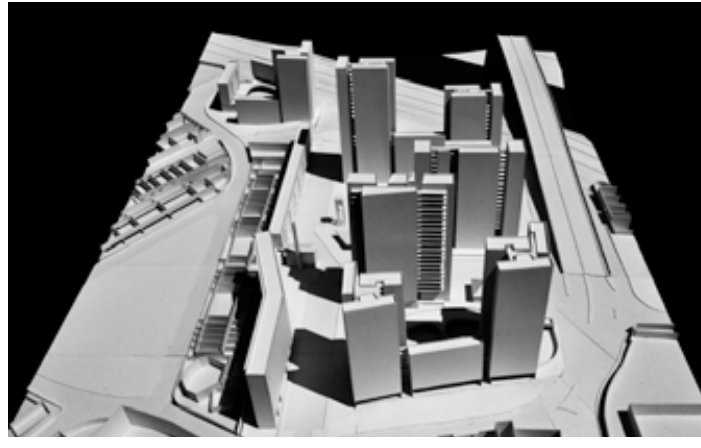

Figura 8 - Conjunto Ponte dos Remédios, $201 \mathrm{I}$, Marcos Acayaba e H+F arquitetos.

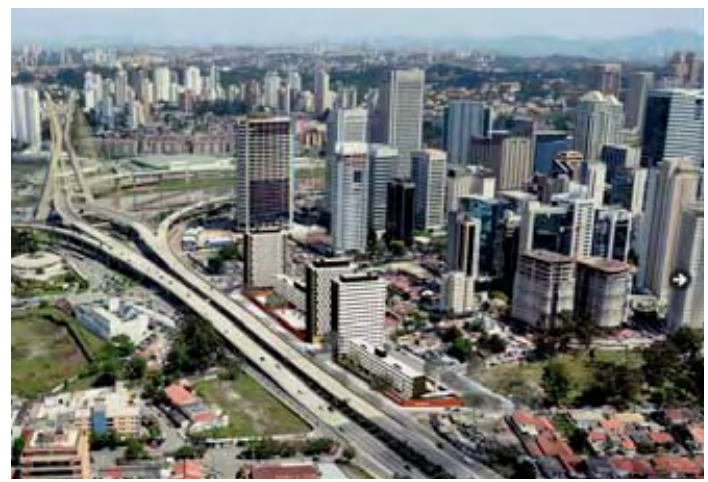

Figura 9 - Conjunto Jardim Edith. São Paulo, 2008-20I2, MMBB e H+F arquitetos.

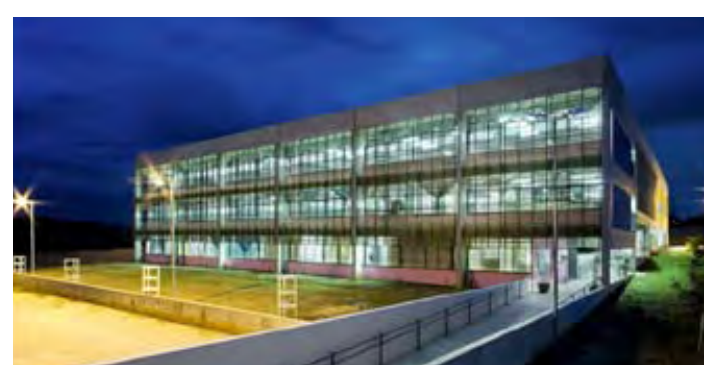

Figura 10 - Escola Estadual Aparecidinha, 2006-2009, Sorocaba, Centro Arquitetura.
'O grupo não segue uma filosofia comum, nega essas classificações de 'escola paulista' ou 'escola carioca'. 'Temos repertórios diferentes, mas também afinidades que permitem troca. Uma delas é a crença no trabalho coletivo', afirma Hereñú” (HELVÉCIA; STEPHAN; SHROEDES, 2007).

Em 201I, os Arquitetos Cooperantes deixam de existir e as empresas que faziam parte desse grupo hoje são escritórios autônomos, como, por exemplo, Galeria Arquitetos ${ }^{7}$, Metrópole Arquitetos $^{8}$ e H+F Arquitetos - formado pelos arquitetos Eduardo Ferroni e Pablo Hereñú, que desde o ingresso na FAUUSP até hoje mantêm a parceria profissional.

Atualmente, o escritório $\mathrm{H}+\mathrm{F}$ Arquitetos vem realizando também trabalhos no âmbito da habitação de interesse social, para a SEHAB/SP, em parceria com o Arquiteto Marcos Acayaba e também, novamente, com o MMBB9 (Figuras 8 e 9). Carlos Ferrata funda o Centro Arquitetura ${ }^{10}$ (Figura 10 e II) em 2002, e Moracy Amaral foi integrante deste escritório de 2002 a 2010 . Carlos Ferrata mantém o escritório até hoje, enquanto Moracy Amaral passou a trabalhar no escritório Edo Rocha Espaços Corporativos a partir de 2010. Também participaram do concurso HabitaSampa, no qual obtiveram o $3^{\circ}$ prêmio para o conjunto Assembléia (Figura 12)'!.

${ }^{7}$ Galeria Arquitetos tem como integrantes:Arq. Fernanda Neiva,Arq. Fernanda Palmieri e Arq. Gil Mello.

8 Metrópole Arquitetos tem como integrantes:Arq.Anna Helena Villela e Arq. Maria Julia Herklotz.

${ }^{9}$ Com o arquiteto Marcos Acayaba: proposta urbanística para o Perímetro de Ação Integrada Cabuçu de Cima 8, premiada no concur-

so Renova SP em 20I I (em desenvolvimento), e também, o projeto do conjunto Ponte dos Remédios (em execução). Com o MMBB, o Conjunto Jardim Edith (em execução), contrapartida da Operação Urbana Água Espraiada.

${ }^{10}$ Como exemplos de projetos interessantes elaborados pelo Centro Arquitetura, pode-se citar a Escola Estadual Aparecidinha, em Sorocaba, de 2006-2009, com colaboração de Moracy Amaral e Almeida; o projeto para a Casa em Bragança-SP, de 2008-2009, de Carlos Ferrata com colaboração da arquiteta Patrícia Grimaldi Abub, que inclusive recebeu menção honrosa no $10^{\circ}$ Prêmio Jovens Arquitetos; entre outros projetos de autoria do Centro Arquitetura ou de colaboração com outros escritórios.

1 Equipe que obteve a $3^{\mathrm{a}}$ colocação no concurso HabitaSampa, conjunto Assembléia: Ricardo Bellio, Alexandre Mirandez, Carlos Ferrata, Cássia Buitoni, César Shundi, Daniel Pollara, Luciana Yamamura, Marcelo Pontes de Carvalho, Mariana Viegas e Moracy Amaral. 
O primeiro prêmio para o Conjunto Assembléia ficou para o escritório Andrade Morettin, autores do edifício de habitação coletiva que também faz parte desta pesquisa: Fidalga 772. Apoena Amaral e Almeida foi sócio do escritório Soma Arquitetos ${ }^{12}$ de 2004 até 2010. Depois do SOMA Arquitetos, no final de 2010, Apoena Amaral funda o 2+V ARQUITETOS Associados ${ }^{13}$

Todos os arquitetos são mestres ou mestrandos pela FAUUSP na área de concentração de "Projeto de Arquitetura" ou "Projeto Espaço e Cultura". Todos são docentes na Escola da Cidade e separadamente, também lecionam em outras instituições de ensino da cidade de São Paulo ou até mesmo fora do Brasil, como é o caso do Pablo Hereñú que é professor visitante da Universidade da Florida, nos Estados Unidos, desde 2007. Mesmo com tantas atuações profissionais e vários prêmios em concursos de arquitetura, a primeira colocação no $8^{\circ}$ Prêmio Jovens Arquitetos, promovido pelo IAB-SP (Figura 13), categoria obra executada, pelo edifício Fiori di Maggio, representa o que seria um primeiro prêmio de um projeto no qual o mérito foi todo deles, representando um momento significativo na trajetória profissional desses arquitetos.

\subsubsection{AGENTES}

Arquitetura no Brasil não é assunto para a mídia, não acham importante, é excluída. O que a mídia faz é seguir a moda. Nos outros países se discute mais. A cidade de São Paulo é projetada pelo mercado imobiliário e a obra arquitetônica de qualidade acabou sendo uma exceção.A crítica, aqui, não faz parte do contexto, como no Chile ou na Argentina, onde ela é levada a sério - isso para citar apenas a América Latina. O que se constrói hoje na Itália, França, Espanha, Portugal é de uma riqueza enorme, tem muito significado para a cultura do país. No Brasil, a arquitetura é feita a duras penas e a crítica é consequência disso (Eduardo de Almeida em: SABBAG, 20I I).

${ }^{12}$ Integrantes do SOMA ARQUITETOS:Apoena Amaral e Almeida,Alessandra Gizella da Silva e José Luiz Brenna. Este escritório elaborou o projeto de paisagismo para o Edifício Simpatia 234, do GRUPO SP, em 2007 (também parte desta pesquisa); e para o campus universitário em Nazaré Paulista, projeto do UNA Arquitetos para um concurso em 2005.

${ }^{13} \mathrm{O} 2+\mathrm{V}$ ARQUITETOS Associados recebeu, em parceria com Costa e Macedo Arquitetos, menção honrosa no Concurso Público Nacional de Arquitetura para a Sede da CNM em Brasília, que ocorreu no final de 2010; mesmo ano em que recebe a primeira colocação na Premiação IAB-SP na categoria Design com a "Mesa esconde-esconde". O arquiteto Apoena Amaral mostra uma atuação muito variada, incluindo trabalhos também na área de design e paisagismo.

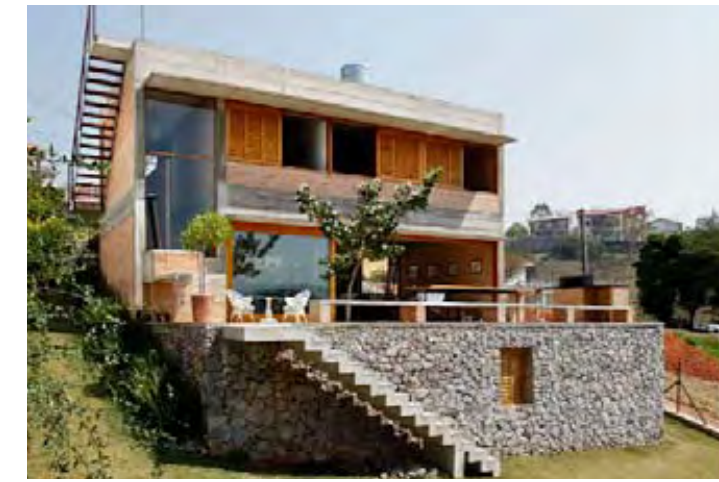

Figura I I - Casa em Bragança, São Paulo, 2008-2009, Centro Arquitetura.

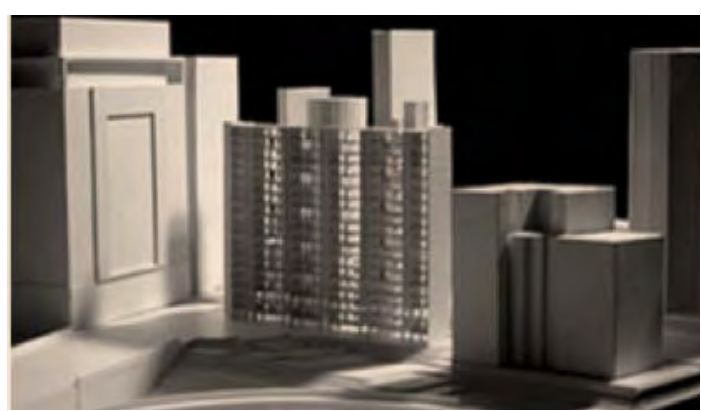

Figura 12 - Concurso HabitaSampa 2004. $3^{\circ}$ Prêmio: Conjunto Assembleia.

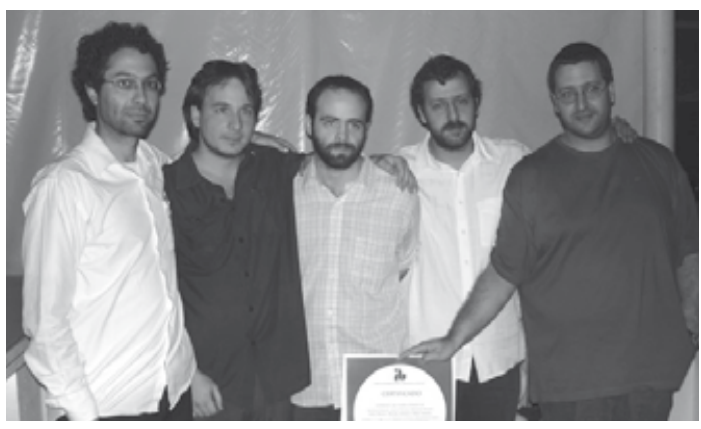

Figura I3 - Arquitetos recebendo o prêmio no $8^{\circ}$ Prêmio Jovens Arquitetos, promovido pelo IAB-SP, categoria obra executada, com o projeto do Edifício Fiori di Maggio. 


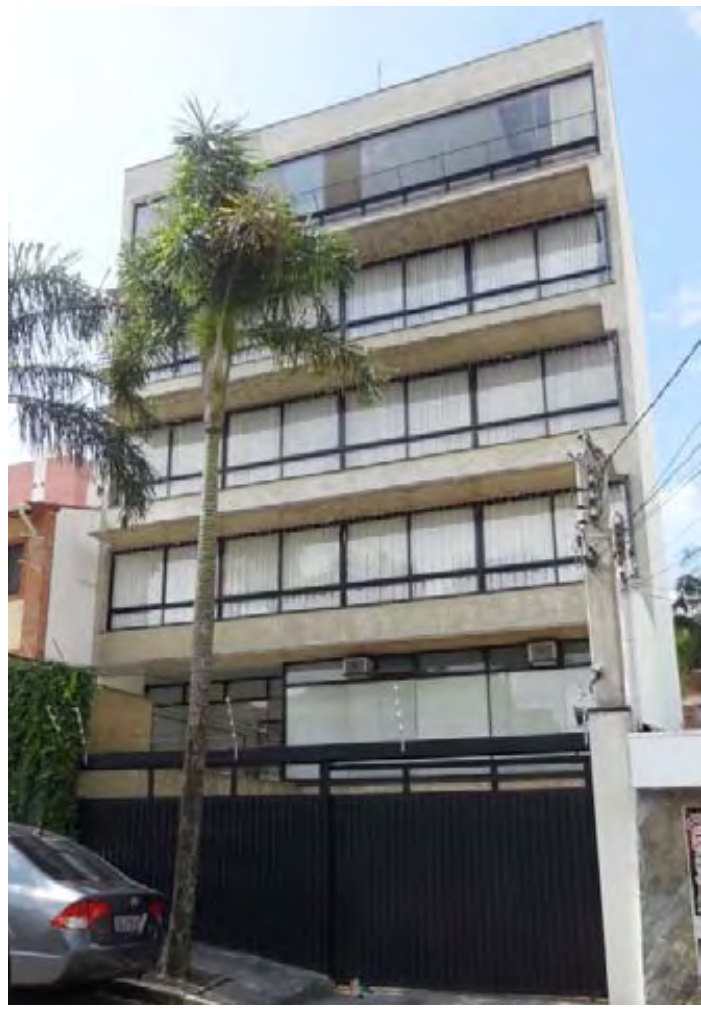

Figura I4 - Fachada do Edifício Fiori di Maggio na Rua Santa Adelaide, em São Bernardo do Campo, São Paulo.
Milton Della Pietra apostou em jovens profissionais para a concepção do edifício que era um verdadeiro sonho da família. O próprio programa definido pelo cliente demonstra essa peculiaridade de estar voltado exclusivamente às necessidades familiares, devendo o projeto abrigar: três unidades habitacionais, uma para cada filho ${ }^{14}$; um espaço para a sede da construtora da família, que preferencialmente deveria ter acesso independente e com boa visibilidade desde a rua; espaços para lazer coletivo, inclusive com a utilização da cobertura para festas familiares; e vagas para estacionamento.

O terreno que abrigaria este edifício seria resultante da junção de dois lotes, sendo que o escritório da Joy Congero já estava previamente instalado em um deles.A necessidade de não interromper as atividades comerciais foi enfatizada pelo cliente, e acabou definindo etapas na construção do edifício.Assim, desde a definição do terreno, já existe uma diferença substancial com relação ao mercado imobiliário, que geralmente procura terrenos maiores para adotar soluções padronizadas (figura I4).

A concepção de um modelo de edificação de proporções menores e de uso misto era outra tipologia que os jovens arquitetos tinham planos de experimentar. Carlos Ferrata argumenta que o mercado imobiliário estabeleceu uma fórmula para empreendimentos residenciais composta de lotes extensos e torres de grande altura e muitos pavimentos, sempre dissociadas da rua. Na opinião do arquiteto, seria interessante se houvesse também novas possibilidades de ocupacão do território com exemplares de edifícios implantados em lotes reduzidos (NAKAMURA, 2007, p. 39).
${ }^{14} \mathrm{~A}$ unidade do primeiro andar, designada originalmente para o filho do Milton que é amigo dos arquitetos autores deste projeto, nunca foi ocupada por ele. Em 2010, quando realizei a primeira visita a este edifício, este apartamento estava em reforma e o Milton informou que ia morar nele com sua esposa. Em dezembro deste ano, em nova visita, o casal já estava instalado nesta unidade. Porém com isso, acharam preferível transferir a empresa Joy Congero para outro local, ficando apenas o escritório corporativo com uma biblioteca, e também uma academia (em instalação), para uso da família, no espaço que antes era ocupado pela empresa. O motivo é que nem sempre é desejável morar e trabalhar no mesmo local, já que, segundo Milton, foi preferível separar estas duas atividades. 
É também importante perceber que a relação entre a família Della Pietra com os arquitetos foi de muita proximidade, cada detalhe foi definido com o cliente, da mesma maneira que acontece na concepção de um projeto de uma residência unifamiliar, no qual cada possibilidade é discutida e as soluções são sob medidas.

Esta pesquisa expõem maneiras de driblar a incorporação e o lucro imobiliário de forma a garantir mais qualidade projetual e cuidado de inserção de habitação coletiva na cidade, essa atuação representa, portanto, uma possibilidade em meio a outras expostas neste trabalho. Carlos Ferrata (2010) cita como referência de iniciativa também exemplar de empreendedorismo habitacional o Edifício Havaí (Figura 15), de 1983, do Arquiteto Carlos Barossi ${ }^{15}$, no qual um grupo de pessoas organizaram um condomínio, compraram um terreno e viabilizaram a construção do edifício habitacional com quatorze unidades tipo duplex.

Evidentemente, atender quatorze famílias exigiu táticas mais exaustivas de flexibilidade, algo que para o edifício Fiori di Maggio, com apenas três unidades, não se fez necessário.

\subsubsection{PERFIL DOS MORADORES}

O projeto foi designado a uma família, duas filhas e um filho, que, por sua vez, já possuem sua própria família, existindo inclusive netos. Trata-se de um programa para um público específico, pois todos os integrantes fazem parte de uma mesma família. Este perfil acabou levando à criação de espaços de lazer tanto no térreo, quanto na cobertura, onde acontecem as reuniões familiares. Ao mesmo tempo, cada subfamília tem sua própria unidade, preservando os momentos de privacidade. O filho, ator, acabou preferindo não morar em São Bernardo do Campo, para ficar mais próximo ao meio artístico do qual faz parte e, assim,

\footnotetext{
${ }^{15}$ A admiração de Carlos Ferrata pelo arquiteto Antonio Carlos Barossi, resultou na organização de um livro, primeiro da coleção "Arquiteturas", que inclui as principais obras do arquiteto. Um projeto de habitação coletiva citado como referência pelo arquitetos Carlos Ferrata do arquiteto Antonio Carlos Barossi, é o edifício Havaí, de 1983, em co-autoria com Jaime Cupertino e José Sales Costa.
}

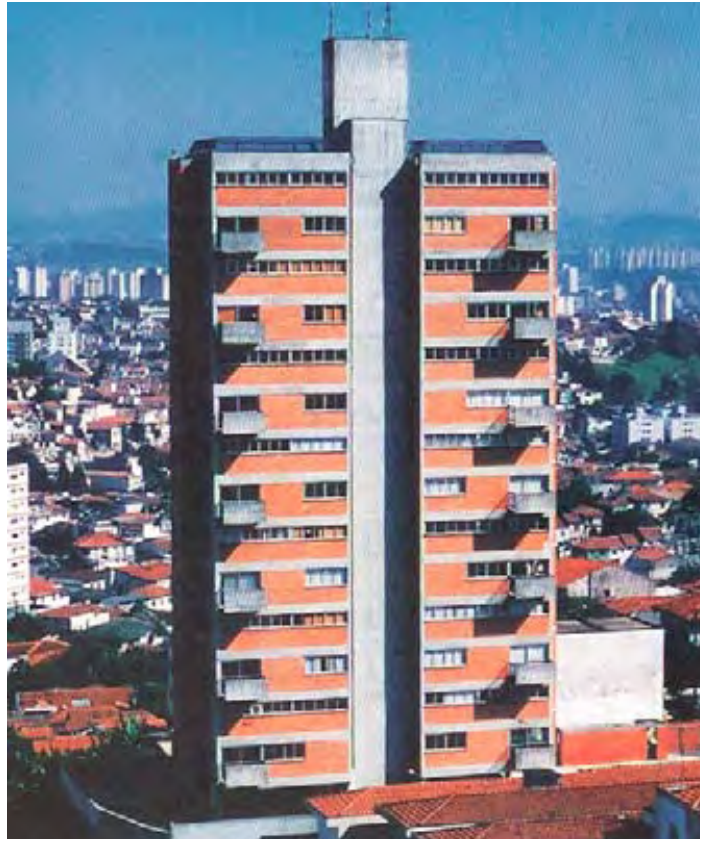

Figura 15 - Edifício Havaí, 1983. Antonio Carlos Barossi, Jaime Cupertino e José Sales Costa.

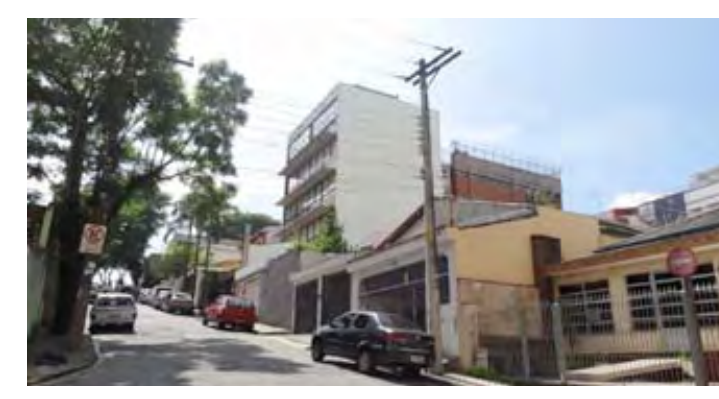

Figura 16 - Vista do Edifício Fiori di Maggio desde a Rua Santa Adelaide. 


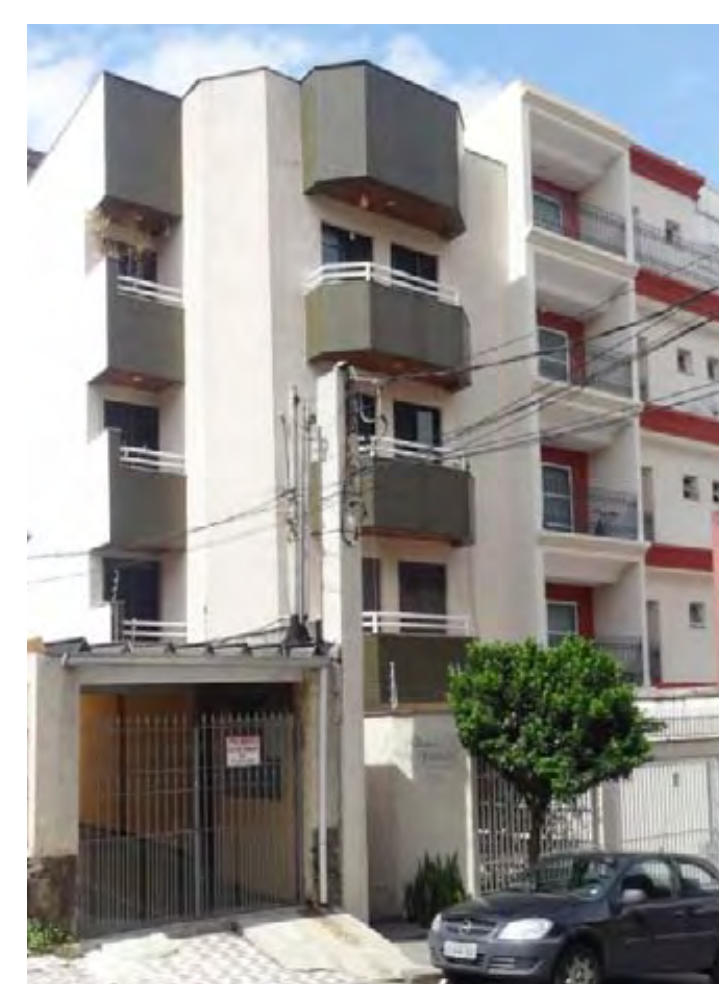

Figura 17 - Edificações na Rua Santa Adelaide.

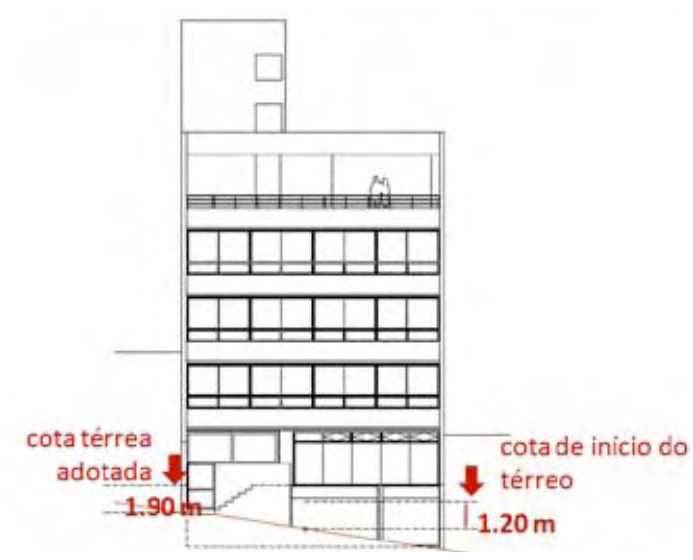

Figura 18 - Esquema vista frontal e relação do gabarito máximo de altura permitido.
Milton e sua esposa acabaram ocupando sua unidade. Uma das filhas do Milton é engenheira e trabalha na empresa da família. Um dos genros de Milton é professor de educação física e o outro possui empresa voltada para produção de peças de mármores e granitos para construção civil. Estas informações são importantes à medida que deixam evidente algumas situações criadas no projeto: 0 espaço da empresa no mesmo lote das unidades habitacionais, a cobertura para lazer, entre outras situações.

\subsubsection{INSERÇÃO URBANA}

O Edifício Fiori di Maggio está localizado em São Bernardo do Campo e está próximo a importantes equipamentos da cidade: o Paço Municipal, o estádio Primeiro de Maio, o Poupa Tempo, a Rodoviária Ítalo Setti, o principal Shopping da região, entre outros. Está próximo também de duas interligações importantes com a cidade de São Paulo: Rodovia Anchieta, via transporte particular; e trólebus intermunicipal, que faz conexão com a estação Jabaquara do metrô.

A quadra urbana onde está localizado este edifício é, em sua maioria, residencial, com gabarito de altura predominantemente horizontal e apenas alguns pontos em que lotes unifamiliares estão sendo substituídos por torrres habitacionais, ou para este caso e alguns outros, a substituição está acontecendo de forma menos agressiva, adotando solução de pequeno edifício de habitação coletiva que não possui escala exagerada em comparação com a existente.

Dois lotes estreitos e profundos foram unidos para acomodar o edifício Fiori di Maggio, fato não inédito na quadra urbana em questão (Figuras 16 e 17). As restrições legislativas referentes ao aproveitamento, dimensionamento e ocupação do lote ${ }^{16}$ foram condicionantes do partido arquitetônico de implantação, já que as principais regras guiaram, de certa maneira, a volumetria do edifício.

${ }_{16}$ LEl N 4446, de 12 de agosto de 1996. Estabelece o zoneamento para o Município de São Bernardo do Campo, regulamenta o uso do solo nas diversas zo nnas; define gabaritos e dá outras providências. Projeto de lei n ${ }^{\circ}$ 14I/95 - Prefeito Walter Demarchi. 
Por exemplo, a opção por encostar o bloco frontal nas divisas, permitido pela legislação, teve como consequência um edifício de pouca altura, mais relacionado com a escala da rua.

Este edifício passou por algumas dificuldades em obter a aprovação para a execução, isto por que houve mau entendimento da regra que diz que deve-se considerar a cota térrea aquela que estiver no máximo a I,20 m acima da via pública. A via pública em questão é inclinada e, portanto, deveria ter sido considerado o ponto médio da mesma com relação ao lote. Como isso não aconteceu, a obra ficou com altura superior à permitida, aproximadamente 70 $\mathrm{cm}$ (Figura 18). Este foi um dos motivos do intervalo de tempo tão longo entre a concepção do projeto e o término de sua construção, já que, durante alguns anos, a obra ficou paralisada.

\subsubsection{PARTIDO DE IMPLANTAÇÃO}

O escritório pré-existente da Joy Congero deveria continuar em pleno funcionamento, mesmo com a obra em andamento, porém, não foi esta situação que determinou o partido de criação de dois blocos para distribuição do programa, já que, inicialmente, este foi concebido com o intuito de propiciar boas condições de iluminação e ventilação naturais a todos os ambientes de um programa extenso em um lote exíguo de $12 \mathrm{~m} \times 36 \mathrm{~m}$. Assim, a torre junto à rua possui aberturas no sentido norte-sul. Já a segunda torre, recuada das divisas, permite aberturas no sentido leste-oeste. A solução de comunicar as torres por passarelas envidraçadas, que marcam a transição de um setor a outro, possui referência no trabalho do arquiteto Luiggi Snozzi, mais especificamente em um edifício de habitação coletiva de 1973 em Celerina, na Suíça (Figuras 19 e 20), no qual o arquiteto interliga as áreas íntimas e as sociais por passarelas.

Esta característica adotada acabou colaborando com a execução da obra em etapas: primeiro construiu-se o bloco do fundo, na sequência o escritório foi transferido para o primeiro andar deste novo bloco, depois demoliu-se a casa antiga na parte frontal do terreno, onde estava o escritório, e por fim deu-se início à execução do bloco frontal, colado nas divisas laterais do terreno.

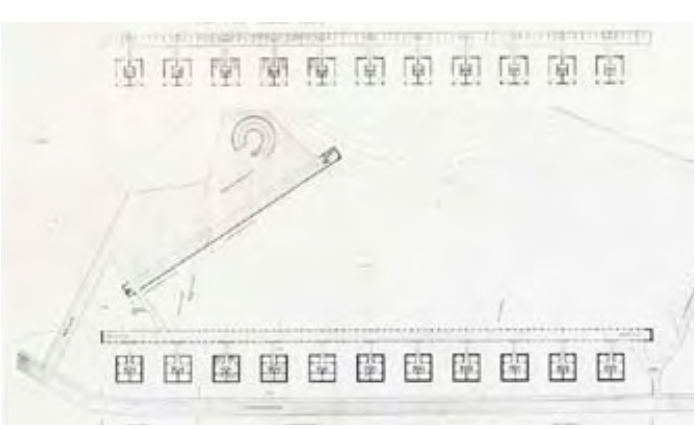

Figura 19 - Implantação do conjunto de habitação coletiva, de 1973, em Celerina, na Suíça, do arquiteto Luiggi Snozzi.

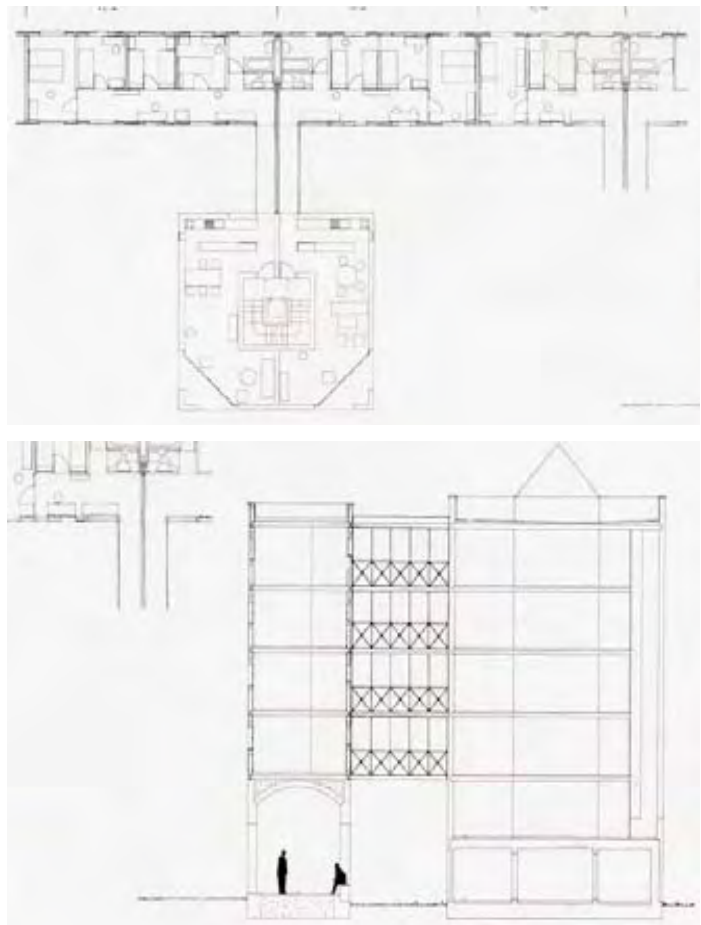

Figura 20 - Planta tipo e elevação do conjunto de habitação coletiva, de 1973, em Celerina, na Suíça, do arquiteto Luiggi Snozz. 


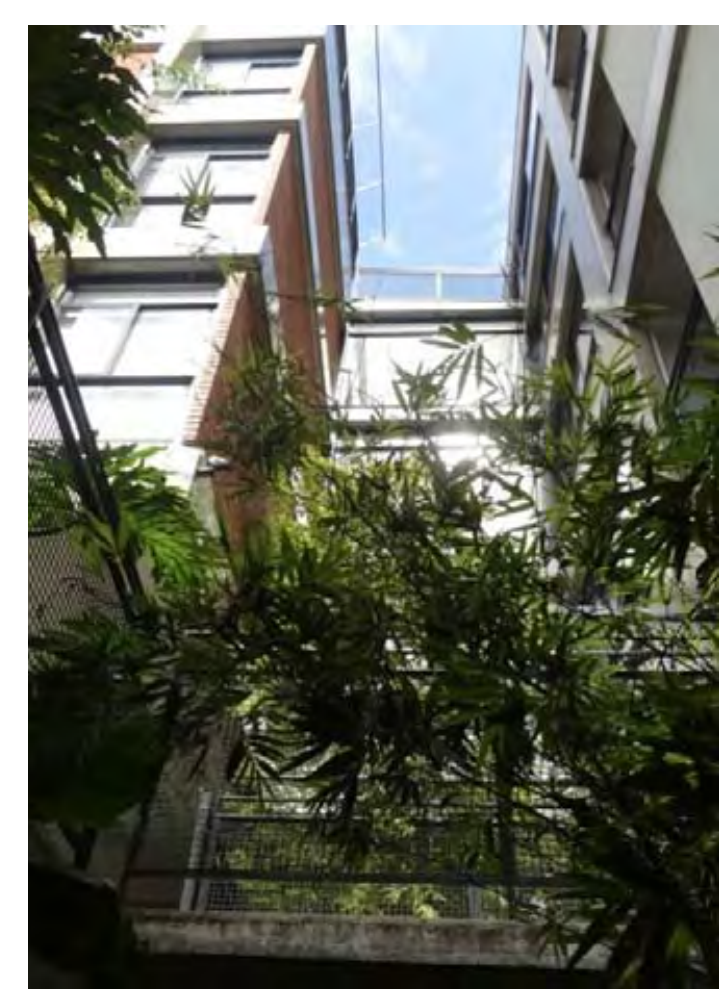

Figura 2 I - Fresta de três metros entre os dois volumes do Fiori di Maggio, que chega até o nível inferior, onde há um jardim.

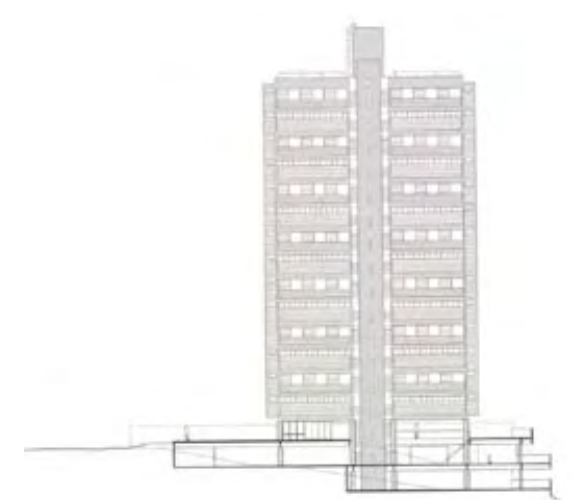

Figura 22 - Corte Edifício Havaí.
Outra referência para os arquitetos, que de certa maneira influenciou na decisão de dividir o programa em dois blocos, foi o edifício habitacional Lagoinha ${ }^{17}$, de 1959-1960, único edifício vertical do arquiteto Carlos Millan, construído. Neste projeto de Carlos Millan, o programa foi implantado em dois blocos, deslocados, um em relação ao outro, em meio pavimento, no terreno exíguo em formato “L”. O bloco frontal é suspenso sobre pilotis, e abre parte do terreno ao passeio público. Já o bloco do fundo não fica suspenso. Esta característica de suspender um bloco, também existente no projeto de Celerina, foi adotada no Edifício Fiori di Maggio pelos jovens arquitetos. A solução de Millan é uma alternativa ao espaço urbano convencional em uma cidade na qual os espaços públicos são concebidos como sobras das demarcações das áreas privadas. A grande diferença é que Millan concebe o edifício suspenso junto à rua, e no caso do edifício em São Bernardo, o volume suspenso fica ao fundo, já que para este caso seria mais lógico o escritório na parte frontal do terreno. Neste sentido, o Simpatia 234, do GRUPO SP, outro estudo de caso desta pesquisa, consegue se aproximar mais da solução adotada por Millan, afinal, cria um térreo suspenso e com conexões visuais com o espaço público da rua, portanto, de modo similar, cria uma alternativa ao espaço urbano convencional, mesmo dentro de um limite privado.

\subsubsection{ESPAÇOS EXTERIORES}

Para resolver a questão da privacidade do espaço de uso coletivo no térreo, foi criada uma fresta de três metros entre os dois volumes, que chega até um jardim no nível inferior, como filtro de separação entre a sala comercial e o espaço de lazer dos moradores. $O$ vão entre os dois edifícios é atravessado, nos pavimentos superiores, por pontes envidraçadas, que ajudam na

${ }^{17}$ Este edifício foi projetado para o construtor e investidor Mário Masetti, com localização na Rua Arthur de Azevedo, Bairro Cerqueira César em São Paulo. O prédio tem oito apartamentos de dois dormitórios com $89 \mathrm{~m}^{2}$ e $83 \mathrm{~m}^{2}$. 
separação não apenas dos setores social e íntimo das unidades habitacionais, como também permite que a privacidade do térreo seja resolvida sem interferência do uso comercial no espaço de lazer restrito aos moradores (Figura $2 \mathrm{l}$ ).

Além de colaborar com a privacidade do espaço de uso coletivo no térreo, a fresta com visibilidade até o subsolo é uma solução que torna o espaço da garagem mais agradável, pois permite incidência de luz natural. Também proporciona ao térreo, mesmo que parcialmente, uma sensação de duplicação, novamente característica típica da escola paulista de arquitetura, citado, por exemplo, no capítulo sobre o Edifício Simpatia 234 e que também acontece no Edifício Havaí, citado anteriormente, que também representa uma referência para os arquitetos. No edifício Havaí, foi criado um rasgo na laje do térreo que permite agenciar o programa de lazer em dois níveis, posicionando uma quadra esportiva no nível inferior, por exemplo, (Figura 22).

$\mathrm{Na}$ cobertura do Fiori di Maggio está posicionado outro espaço de uso coletivo. $\mathrm{Na}$ área descoberta, em cima do edifício recuado das divisas, está a piscina. A área da piscina é conectada por passarela ao outro bloco, onde foi criada uma área semicoberta, para reuniões, festas entre outros usos para o lazer coletivo. Assim, neste projeto, devido a uma demanda familiar específica, os espaços exteriores são predominantemente coletivos, inclusive na cobertura, situação que raramente acontece nos projetos de habitação coletiva atuais, que geralmente definem a cobertura como terraço de lazer privativo (Figura 23).

\subsubsection{UNIDADE HABITACIONAL}

O programa da unidade habitacional foi dividido em dois volumes separados e conectados por passarela transparente. $O$ primeiro, frontal, acomoda o setor social e de serviço e possui aberturas com orientação norte-sul. $O$ setor social possui aberturas com caixilhos voltadas à face norte, que se estendem do piso ao teto, permitindo vista para a cidade, especialmente para $\circ$ vale da Rodovia Anchieta.

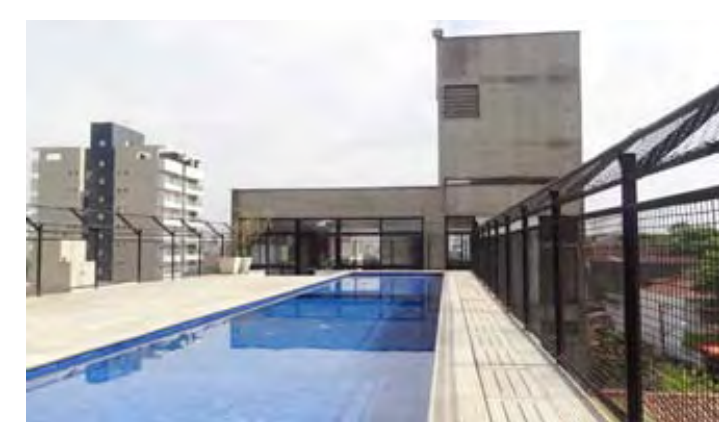

Figura 23 - Cobertura Fiori di Maggio.

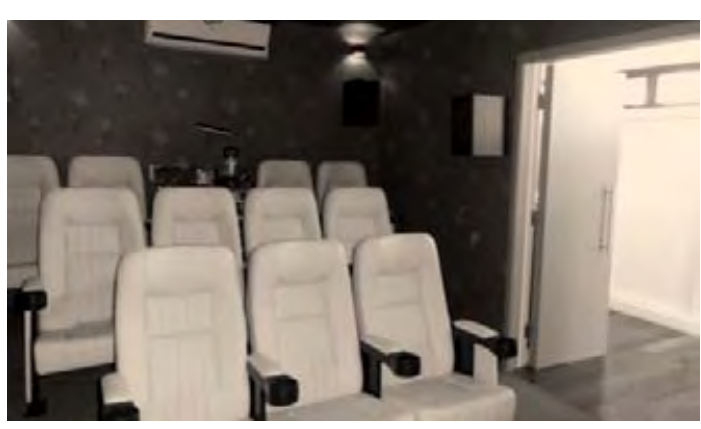

Figura 24 - Espaço flexível transformado em cinema na unidade habitacional do primeiro andar do Edifício Fiori di Maggio.
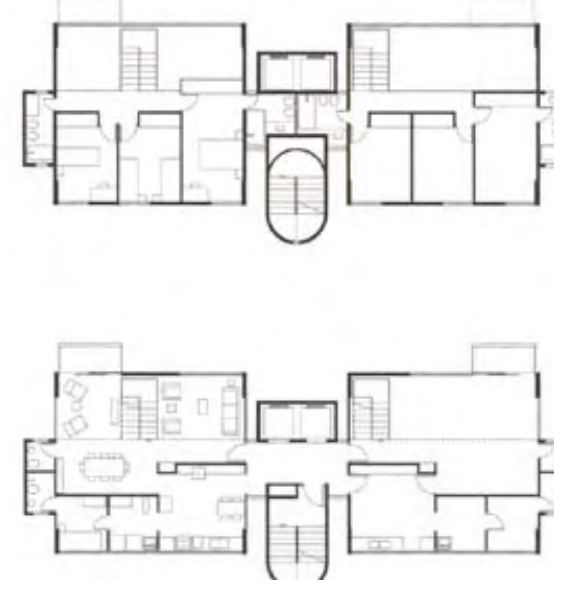

Figura 25 - Unidade habitacional Ed. Havaí 


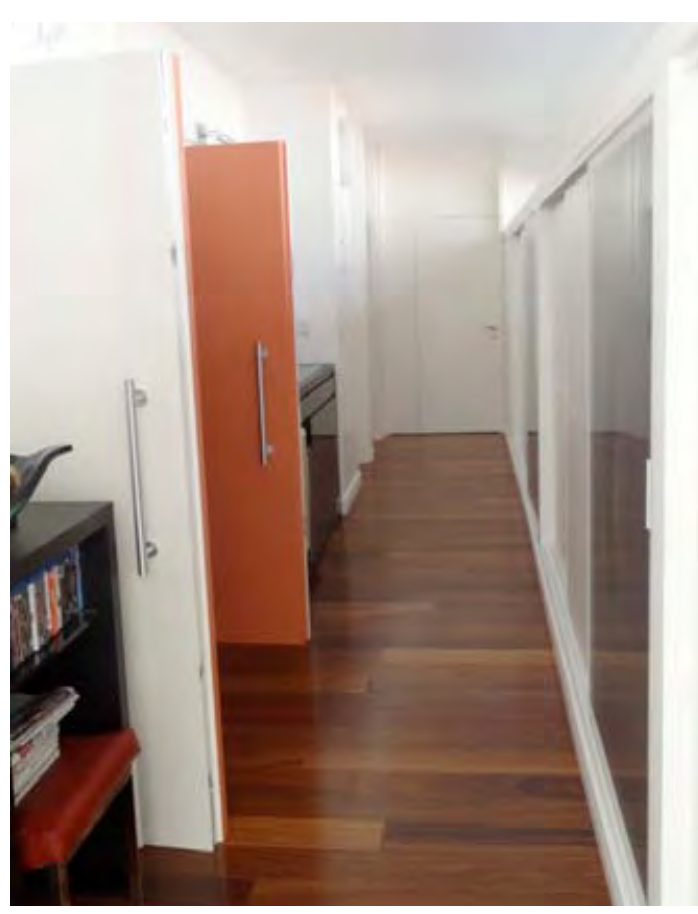

Figura 26 - Armários no corredor da unidade habitacional do Fiori di Maggio.
O espaço possui um vão livre de quase $12 \mathrm{~m}$, o que permite flexibilidade na disposição do layout e sensação de amplitude espacial. Para proteção solar, foram projetadas pestanas de concreto aparente que funcionam como quebra-sol na fachada norte voltada para a rua.

Já o setor de serviço, também inserido no volume frontal, é composto pela cozinha e lavanderia, com aberturas voltadas para o sul. A lavanderia acaba sendo descolada das janelas pelo corredor da entrada de serviço. Neste sentido, existe uma situação que não é muito funcional, já que acaba-se utilizando este espaço do corredor para estender a roupa (varal de chão), atrapalhando a passagem no corredor de serviço. Com relação à integração da cozinha com a sala, a planta de layout definido pelos arquitetos sugere uma integração entre a cozinha e o ambiente social, a partir da extensão de um balcão de trabalho até a sala.

O segundo edifício é recuado das divisas do terreno, contendo, assim, aberturas na direção leste-oeste, ideais para acomodar o setor íntimo. $O$ espaço acomoda previamente dois dormitórios, um deles suíte, e há também um espaço flexível com possibilidade para acomodar até dois dormitórios extras ou outro espaço, conforme escolha dos moradores, como sala de televisão, espaço com computador, etc. Em última visita realizada no edifício, em dezembro de 20I2, houve uma reforma na unidade do primeiro andar, e este espaço flexível foi transformado numa pequena sala de cinema, com direito a poltrona e telão (figura 24).

A estrutura é posicionada no perímetro dos blocos, porém, as instalações não. Desta maneira, a flexibilidade fica limitada aos dois espaços citados, tanto da sala, já que possui um grande vão livre, ou este outro espaço citada no setor íntimo, que é livre de paredes ficando, portanto, disponível para acomodar alguma atividade que o morador desejar. No edifício Havaí, referência citada anteriormente, as instalações foram resolvidas na periferia junto à estrutura, situação ideal que não foi alcançada no projeto Fiori di Maggio. A seguir a citação de Barossi (2005) sobre a solução no Edifício Havaí:"Os apartamentos foram pensados como um casco, uma carcaça vazia, com as instalações resolvidas na periferia, dentro da perspectiva da flexibilidade total.Todas as instalações e estrutura ocupam a periferia" (BAROSSI, 2005, p. 9). 
O Edifício Havaí, conforme comentado anteriormente, precisou de um projeto que atendesse diferentes tipos de grupos de moradores (quatorze famílias), com diversas e distintas necessidades. Segundo Ferrata e Shundi (20I2), a solução da unidade em dois pavimentos, tipo dúplex, com pédireito duplo no espaço social, foi uma alternativa não apenas para driblar a legislação e o alto custo inicial, como também para permitir um espaço para ampliação, a partir da instalação futura de um mezanino pelos próprios moradores (Figura 25), da mesma maneira que a Zarvos costuma oferecer a seus clientes, como por exemplo no Fidalga 772, 727 e Edifício 4 × 4. Outra tática, foi a adoção de dois tipos de escadas, e a posição de acordo com a vontade de cada morador, o que acabou gerando um jogo nas aberturas da fachada, da mesma maneira que acontece no Simpatia 234, do Grupo SP, ou no Edifício Ourânia, do arquiteto Gui Mattos, ambos realizados pela Zarvos. Essas táticas não foram necessárias no Fiori di Maggio, pois a quantidade de unidades acaba permitindo maior facilidade de atender especificamente cada morador sem necessidade de "malabarismos" arquitetônicos.

Voltando ao Fiori di Maggio, todos os dormitórios têm aberturas voltadas a leste. É destaque a quantidade de armários no corredor - muito importante em todas as categorias de habitação, seja de interesse social, mercado popular, ou como esta, privada $^{18}$ - para que exista área suficiente para acomodar o programa de necessidades da unidade habitacional e ainda acomodar uma quantidade ideal de armários. Acima dos armários estão as aberturas a oeste (Figura 26).

Em ambas as torres, a distribuição dos espaços permitiu criar ventilação cruzada e dispor de cômodos de acordo com a melhor orientação. A criação das passarelas de conexão dos setores amplia as possibilidades de aberturas além de permitirem vistas interessantes em direção às áreas arborizadas na periferia do pavimento térreo, que segundo Carlos Ferrata, acaba conferindo um status de passeio ao simples ir e vir de um bloco a outro.

${ }^{18}$ Este No livro "Habitar El Presente”, dos arquitetos Josep Maria Montaner Zaida Muxí, são definidos quatros temas principais para avaliar projetos de Habitação Coletiva, um dos temas é "Sociedade", e dentro deste tema, um dos itens de valoração do projeto diz respeito à presença dos espaços de armazenamento dentro da unidade habitacional.Valorizam-se situações como esta no Fiori di Maggio, com armários no corredor, que podem ser utilizados por todos os usuários da habitação, sem necessidade, de estar dentro do dormitório, por exemplo. Este tipo de situação pode ser transferida para projetos de habitação de interesse social, já que, devido à restrição de metragem quadrada das unidades, muitas vezes os dormitórios são pequenos ,e assim, a criação de espaços para armazenamento ou outras atividades (mesa para estudo, por exemplo) no corredor, seria pertinente.

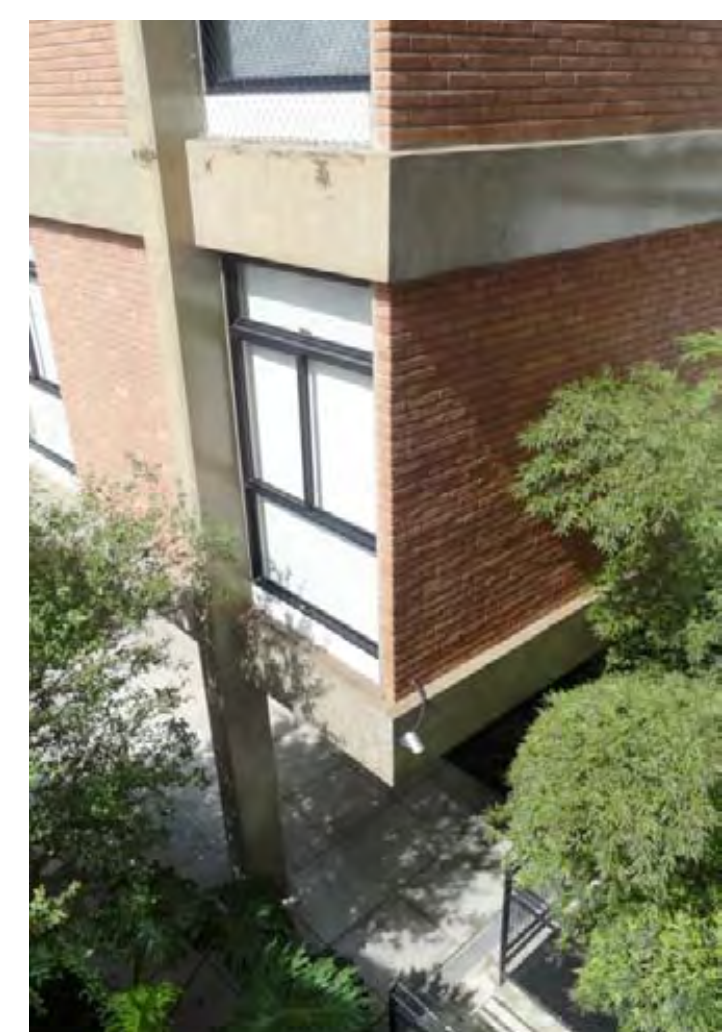

Figura 27 - Detalhe no canto da fachada leste do Edifício Fiori di Maggio. 


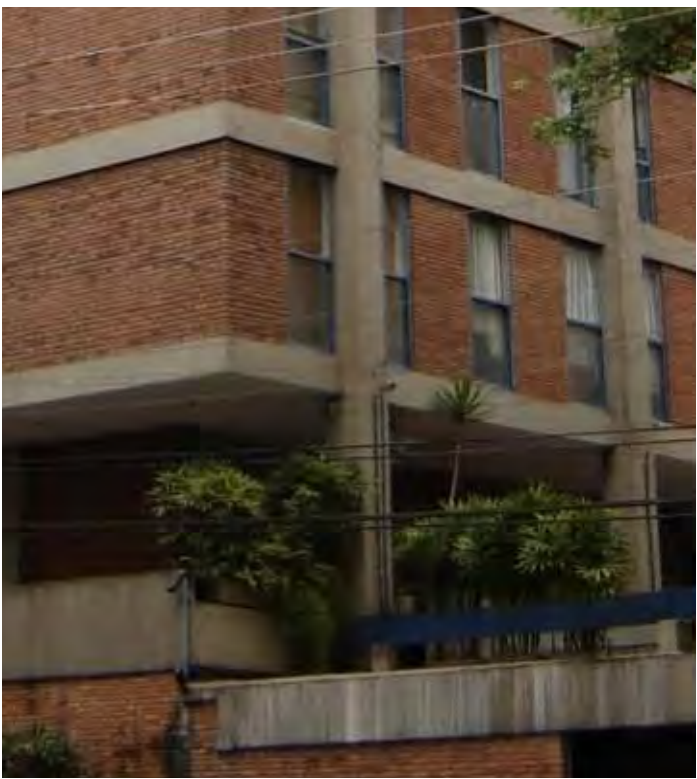

Figura 28 - Edifícios Gemini I e II, Eduardo de Almeida, 1968. Rua Graúna, São Paulo.

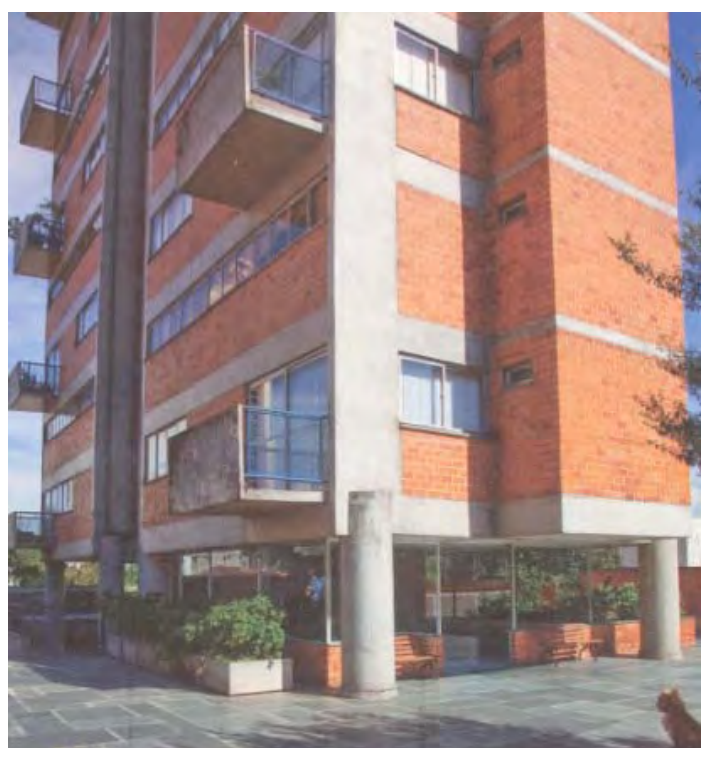

Figura 29 - Edifício Havaí.

\subsubsection{SISTEMA ESTRUTURAL,TÉCNICA CONSTRUTIVA E ENVOLTÓRIA}

Os edifícios têm estrutura convencional, de concreto armado moldado in loco, com exceção das lajes, tipo painel treliçada. Cada edifício tem um tratamento diferenciado nas vedações. $O$ edifício frontal utiliza quase que completamente o vidro como vedação nas faces norte e sul, e as outras faces, encostadas na divisa, são em blocos revestidos. Para o caso do edifício que fica ao fundo, é utilizado o tijolo de barro aparente externamente (Figura 27). A solução que combina estrutura em concreto armado com fechamentos em alvenaria de tijolos aparentes lembra a do Edifício Gemini (Figura 28), projeto do final dos anos 1960, do arquiteto Eduardo de Almeida, citado por Carlos Ferrata também como referência importante para o projeto.

O detalhe do balanço estrutural que define os cantos livres de pilares, como também os rasgos verticais junto aos pilares que definem as aberturas (emolduradas com caixilhos em alumínio e pintura eletrostática preta), são outras situações que deixam evidente a referência citada. Foram utilizados materiais convencionais no edifício da Rua Santa Adelaide, porém, o interessante é a característica da construção como organização do sistema, ou seja, o desejo de organizar os elementos plásticos do edifício a partir de seus elementos estruturais, presente, por exemplo, no Gemini e também em outras referências citadas, como o caso do Edifício Havaí (Figura 29), com blocos cerâmicos estruturais aparentes (que garantem o contraventamento da vedação), e estrutura de concreto armado aparente. 



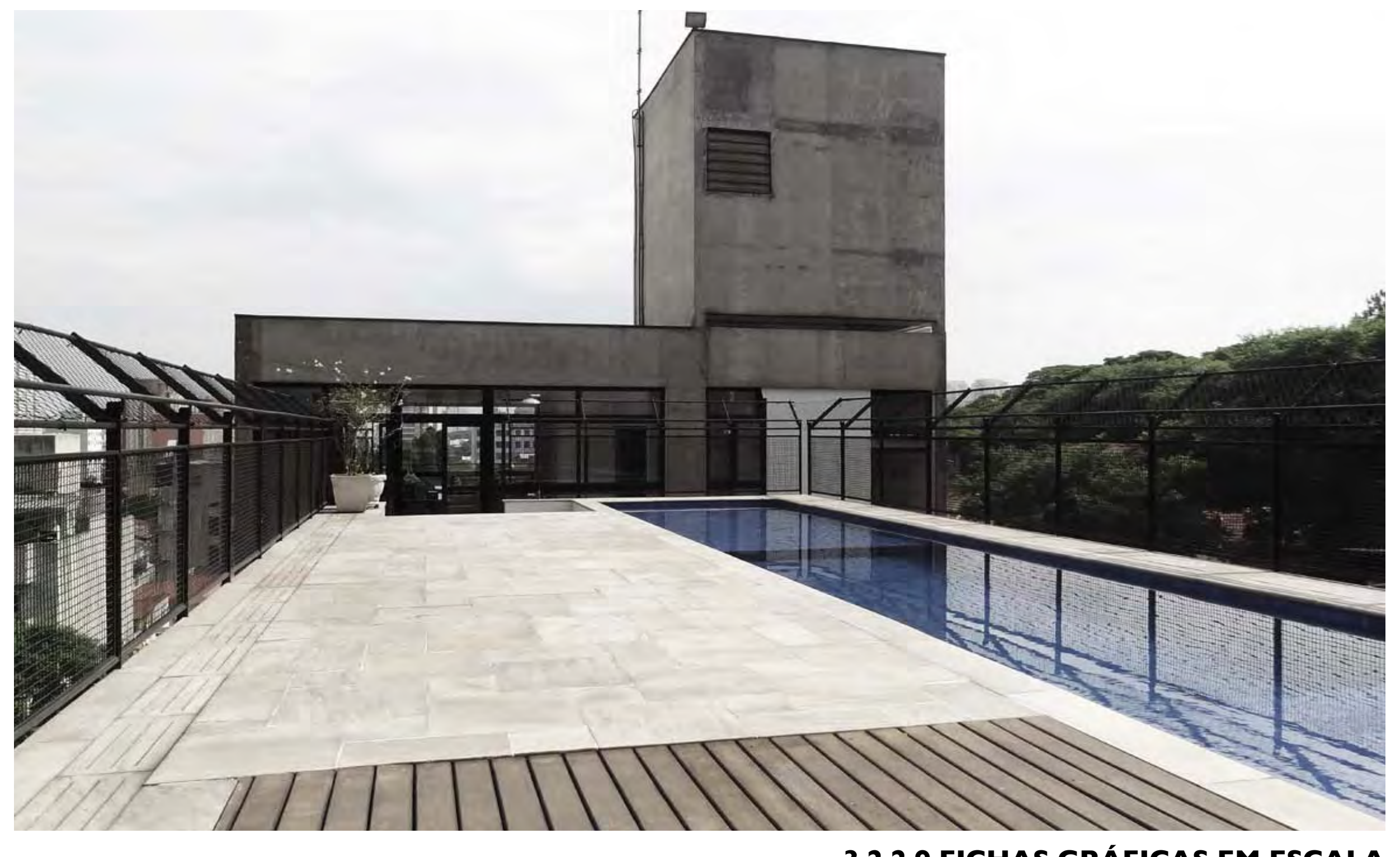




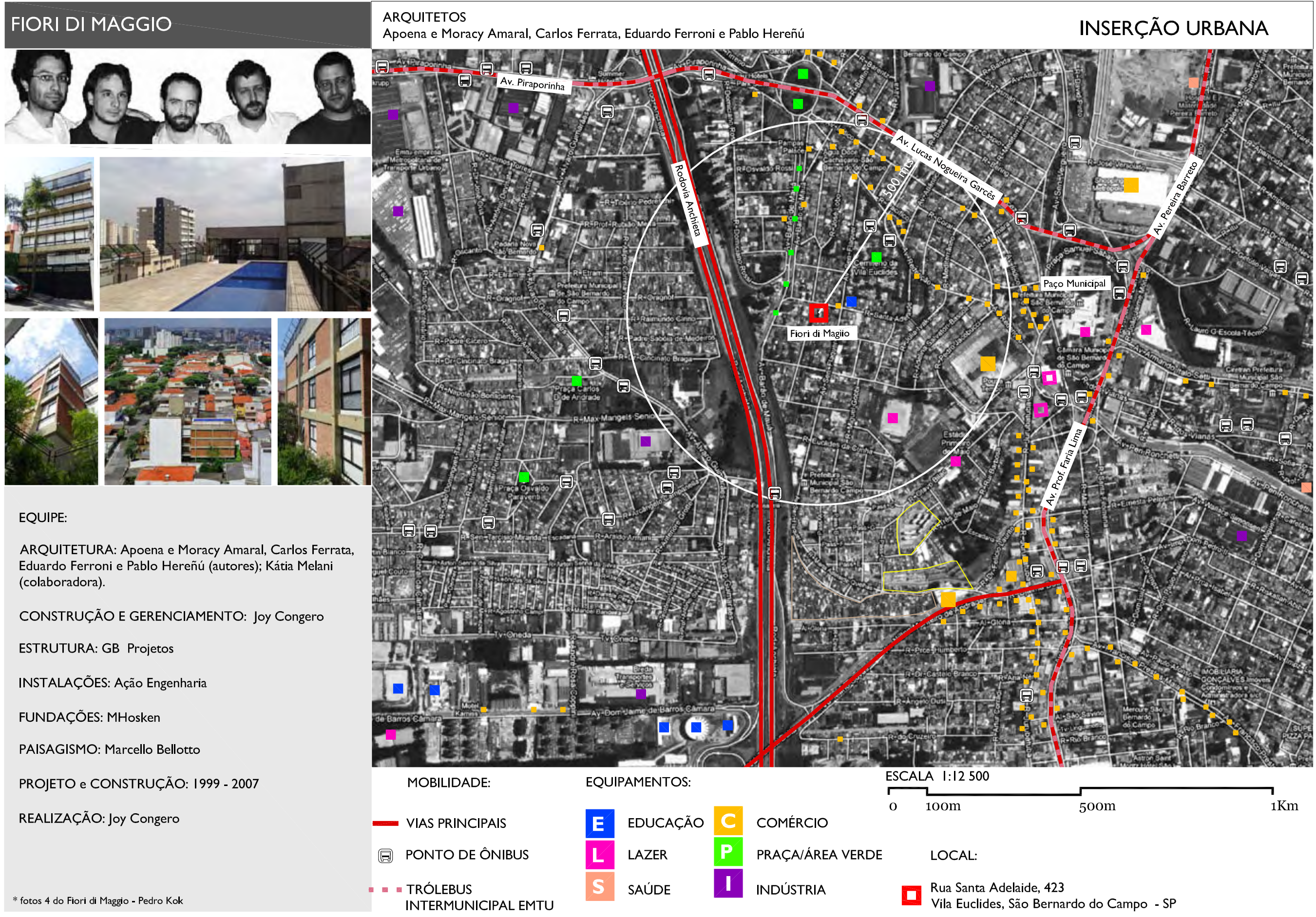




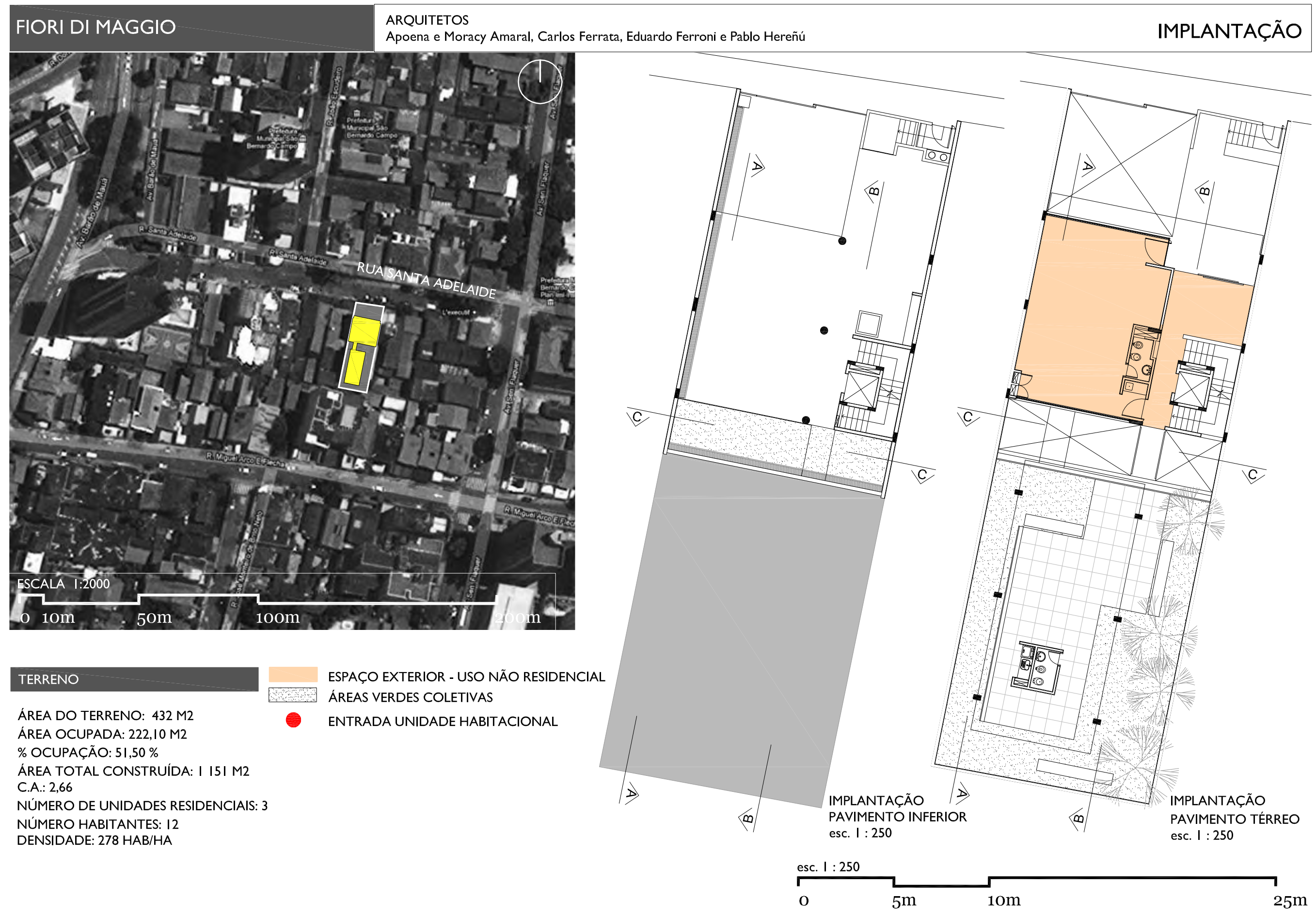




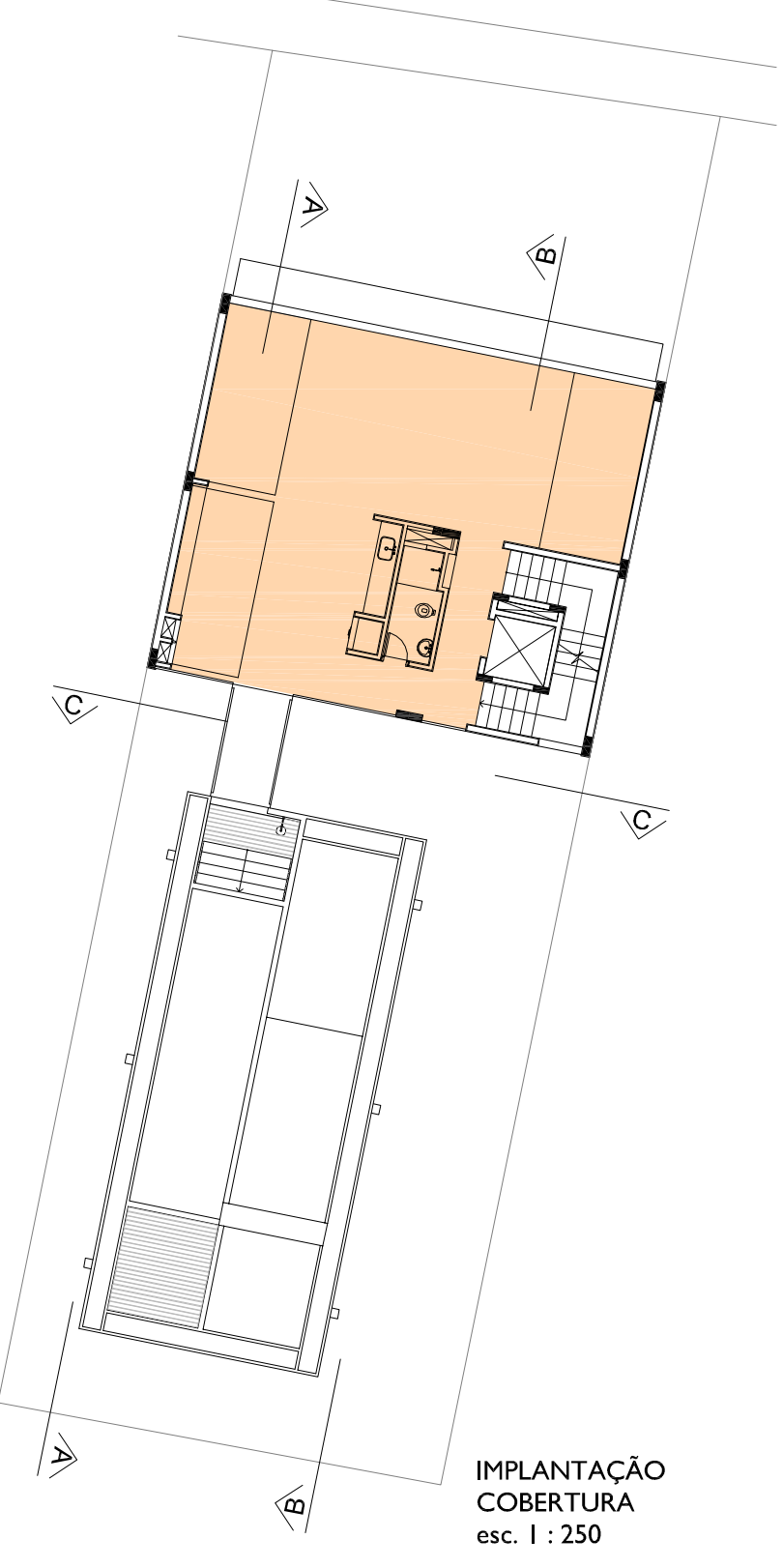

ESPAÇO INTERIOR PRÓPRIO ESPACO EXTERIOR - USO NÃO RESIDENCIAL

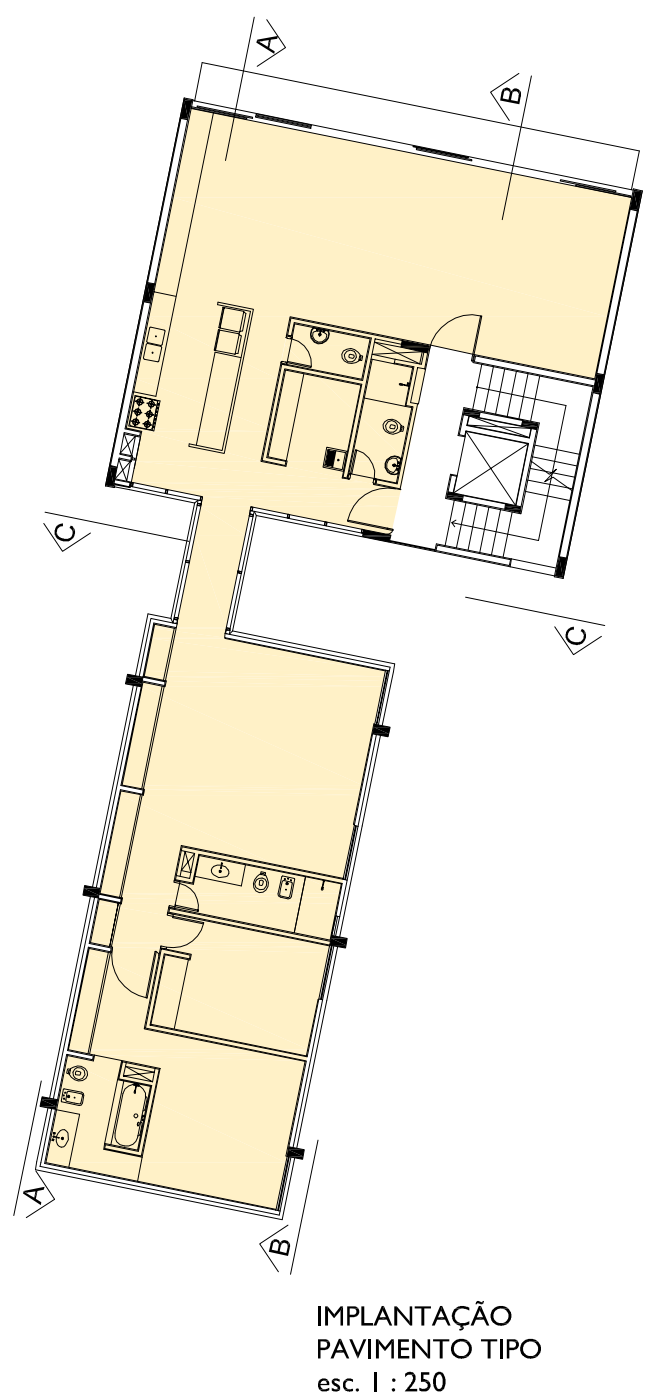

$\times 3$

TIPOLOGIA I USO NÃO RES.
PAVIMENTO TÉRREO

PAVIMENTO TIPO

COBERTURA
$81,39 \mathrm{~m}^{2}$

$175,45 \mathrm{~m}^{2}$

computável $\quad$ 175,45 m²

total $175,45 \mathrm{~m}^{2}$
$95,51 \mathrm{~m}^{2}$

$176,90 \mathrm{~m}^{2}$
$176,90 \mathrm{~m}^{2}$

\begin{tabular}{llll|} 
esc. I : 250 & & & \\
0 & $5 \mathrm{~m}$ & $10 \mathrm{~m}$ & $25 \mathrm{~m}$ \\
\hline
\end{tabular}




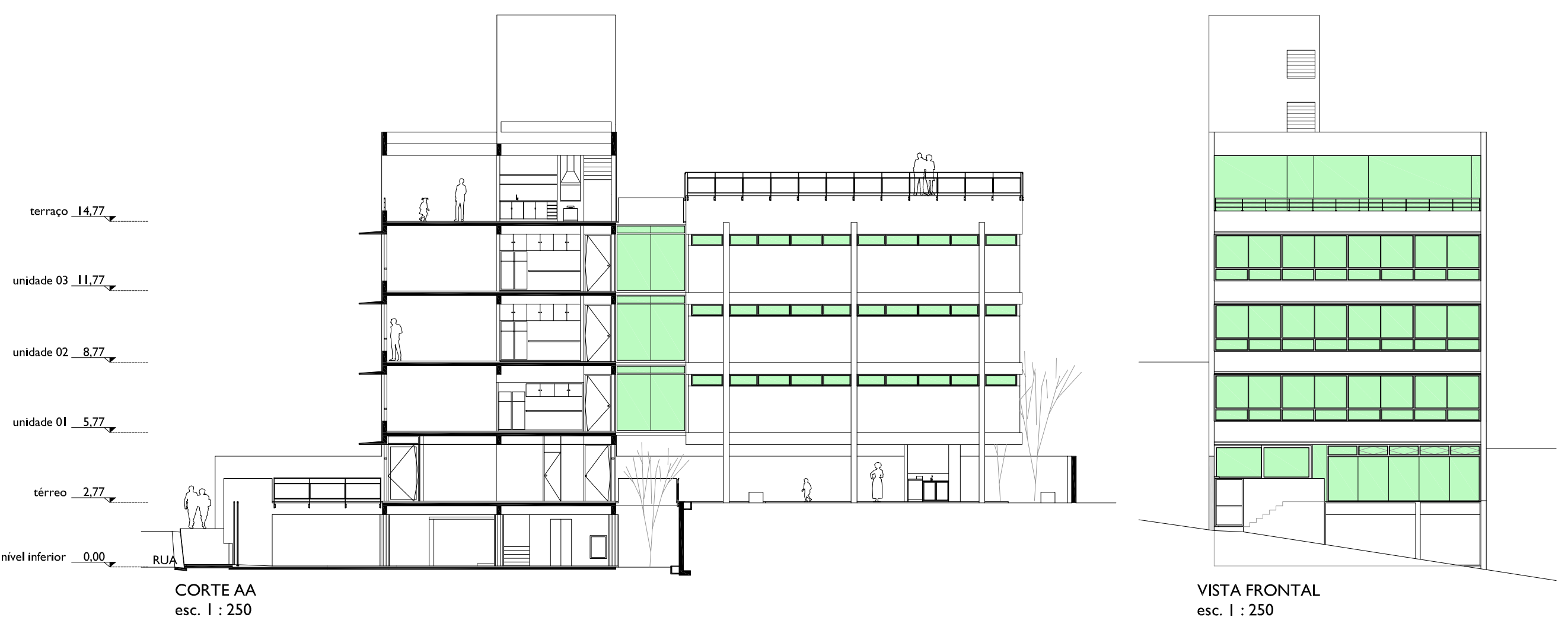

esc. I : 250

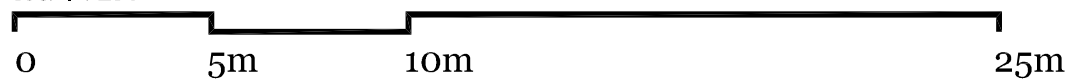




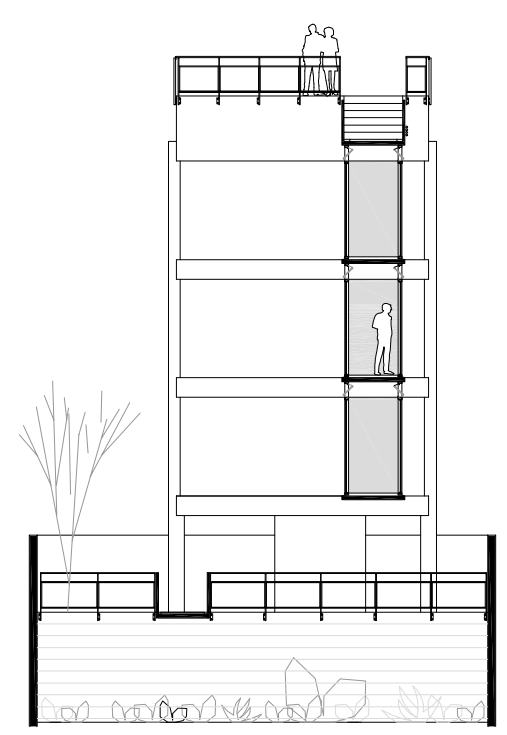

CORTE CC esc. $1: 250$

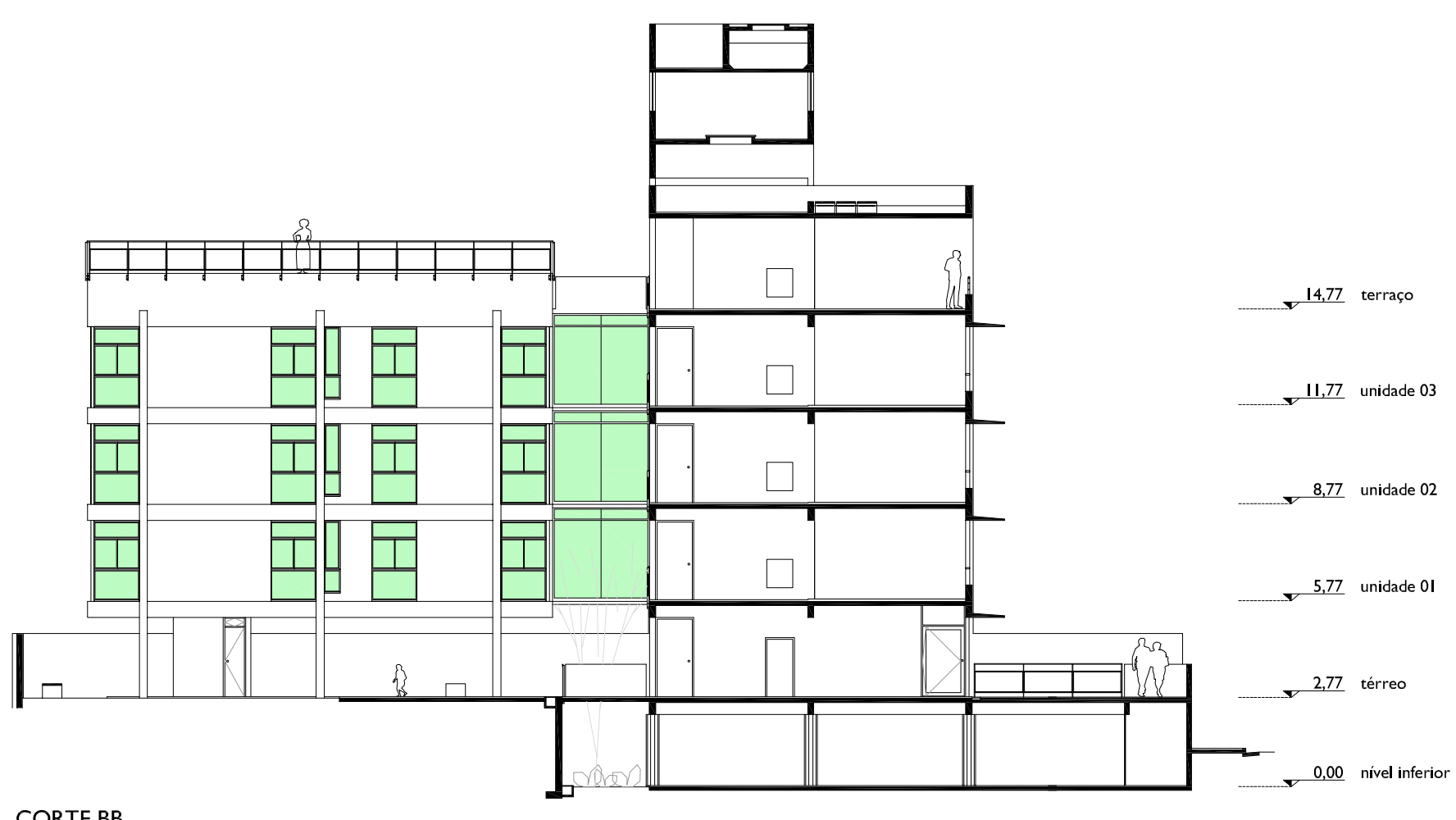

CORTE BB

esc. $1: 250$

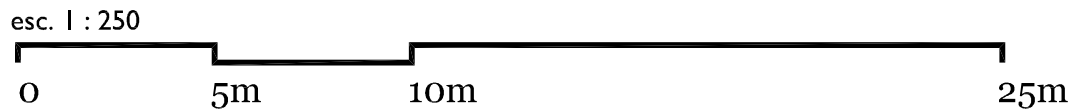


BAROSSI, A. C. Trabalhos profissionais e uma identidade. Ensino de projeto na Faculdade de Arquitetura e Urbanismo de São Paulo. 2005. Tese (Doutorado em Arquitetura e Urbanismo). Universidade de São Paulo, São Paulo, 2005, p. 09.

FERRATA, C.A.; SHUNDI, C. I. (Orgs.). Antonio Carlos Barossi. São Paulo: Hedra :: Editora da Cidade, 2012.

GRUNOW, Evelise. Partido mantém integridade, apesar da obra tumultuada. ProjetoDesign, São Paulo, n. 353, p. 50-53, julho de 2009.

HELVÉCIA, Heloísa, STEPHAN, Danae e SHROEDES, Renato. Criação Coletiva. Nova geração de arquitetos doma a vaidade, dispensa o personalismo e começa a ganhar mais espaço trabalhando em equipe. Revista da Folha: Morar, São Paulo, 3 I/08/2007.

IMBRONITO, M. I.Três Edifícios de Habitação para a Formaespaço: Modulares, Gemini e Protótipo. Em: Docomomo 5, 2003, São Carlos. 5. Seminário DOCOMOMO Brasil, 2003.

KOK, P. Registros Fotográficos De Arquitetura. As obras dos jovens arquitetos da FAUUSP. 2009. Monografia (Trabalho Final de Graduação pela faculdade de arquitetura e urbanismo). Universidade de São Paulo, São Paulo, 2009.

MATERA, S. Carlos Millan: Um Estudo Sobre a Produção em Arquitetura. 2005. Dissertação (Mestrado em Arquitetura e Urbanismo). Universidade de São Paulo, 2005.

MONTANER,J.M.;MUXÍ,Z.M.Habitar el Presente.Vivienda en España:Sociedad,ciudad,tecnología y recursos. Madri:Ministerio deVivienda,2006.

NAKAMURA, Juliana. Repertório de Idéias. Grupo de Jovens arquitetos projeto edifício residencial com referências de Luigi Snozzi, Eduardo de Almeida e Carlos Millan. Arquitetura e Urbanismo, São Paulo, n. I62, p. 34-39, set. 2007.

PHAIDON(Org.):ALMEIDAAA.(Org.).The Phaidon Atlas of 2 I st Century World Architecture.London:PHAIDONPRESS,2008.v.0 I. I 63 p.

SABBAG, Haifa Yazigi. Eduardo de Almeida. Indiferente aos dogmas do modernismo e da escola paulista, o arquiteto fala sobre seus quase 50 anos de atividade profissional. ProjetoDesign, São Paulo, n.376, jun. 20II.

VISITAS REALIZADAS:

Fiori di Maggio - 17 de setembro de 2010 e 19 de dezembro de 2012.

Conjunto Gemini - 08 de setembro de 2005.

ENTREVISTAS:

Arquiteto Carlos Ferrata e o empreendedor Milton Della Pietra - 25 de outubro de 2010.

LEIS:

SÃO BERNARDO DO CAMPO (município). Lei $n^{\circ} 4.446$ de 12 de agosto de 1996. Estabelece o zoneamento, regulamenta o uso do solo nas diversas zonas; define gabaritos e dá outras providências. Projeto de lei $\mathrm{n}^{\circ}$ |4l/95 - Prefeito José Demarchi.

SÃO BERNARDO DO CAMPO (município). Lei n ${ }^{\circ} 5.716$ de 23 de agosto de 2007. Dispõe sobre o uso e ocupação do solo para o Município de São Bernardo do Campo, define parâmetros reguladores, e dá outras providências. 



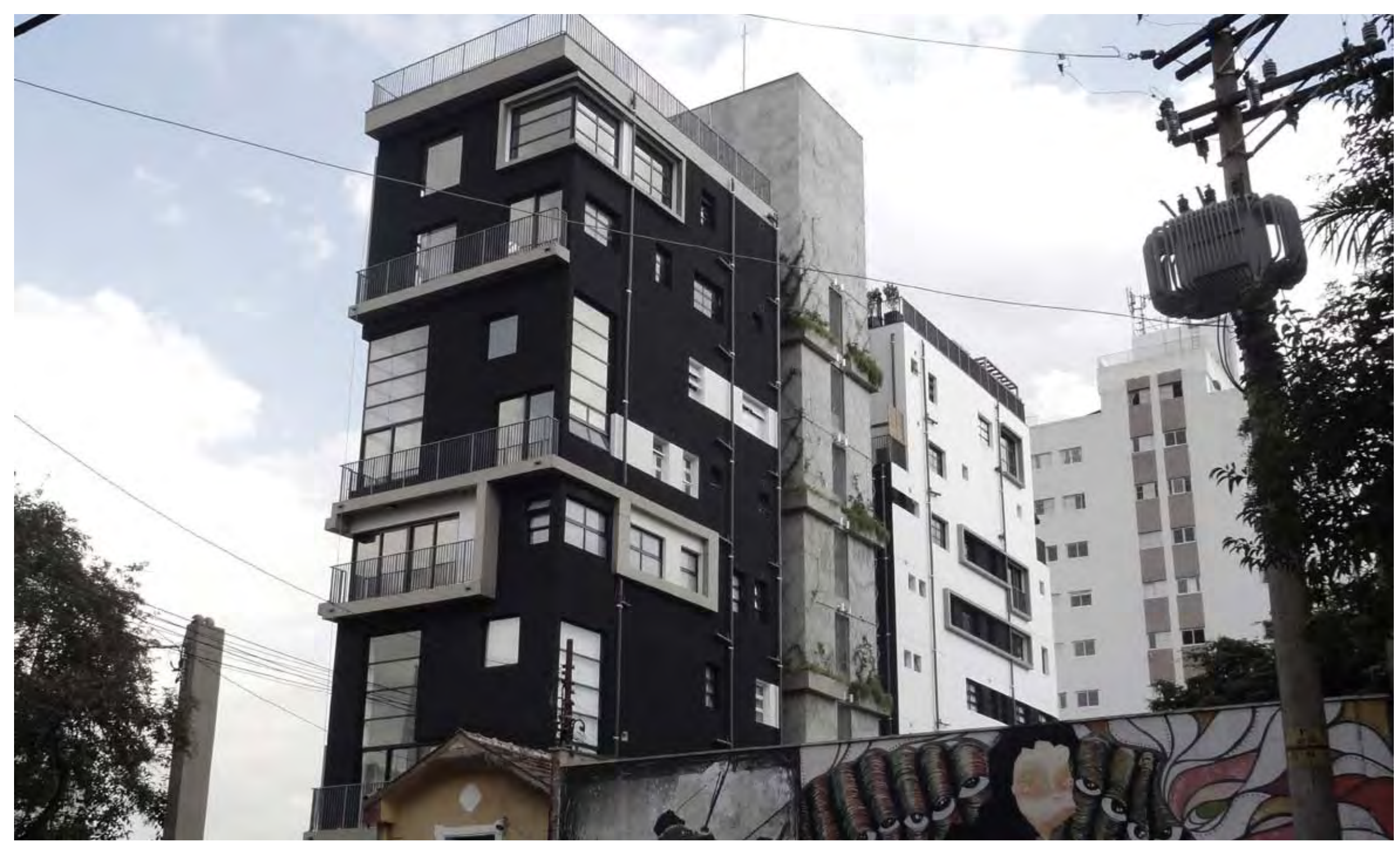

3. LEITURA DOS PROJETOS SELECIONADOS 3.3 EDIFÍCIOS VERTICALIZADOS COM UNIDADES HABITACIONAIS SOBREPOSTAS 


\subsection{FIDALGA 772: ENVOLTÓRIA CONTEMPORÂNEA}

\subsection{I.I INTRODUÇÃO}

Depois do edifício Aimberê (2005-20I2), o Fidalga 772 foi a segunda experiência do Andrade Morettin, com a incorporadora Idea!Zarvos', incorporadora com forte atuação na Vila Madalena nos últimos anos, e que deposita confiança em arquitetos reconhecidos para realizar os projetos de seus empreendimentos.

O avanço do Fidalga 772, em relação ao Aimberê, foi o de conseguir adotar um sistema construtivo que considera mais o processo da execução da obra, sendo, portanto, mais pertinente com a linha de pensamento e trajetória do escritório. Este edifício convence o cliente a não ficar limitado a técnicas construtivas mais usuais, afinal, trouxe benefícios na qualidade e racionalização dos métodos construtivos e arquitetônicos em seu empreendimento.

\subsubsection{INSERÇÃO URBANA}

Este edifício está localizado num trecho sem saída da Rua Fidalga, local onde também se encontra outro edifício da incorporadora Idea!Zarvos, Fidalga 727, projetado pelos arquitetos do Triptyque. Nessa mesma rua também estão outros empreendimentos residenciais recentes, que foram possibilitados pela junção de lotes ocupados anteriormente por residências unifamiliares, que estão transformando a imagem do antigo bairro popular Vila Madalena².

O terreno do Fidalga 772 resultou da junção de duas matrículas, com área total de $860 \mathrm{~m}^{2}$. O formato é extremamente irregular, afinal, a intenção era ter incorporado um terceiro lote, no qual existe uma casa térrea (Figura I), mas que não foi possível, já que a proprietária não teve interesse em participar do negócio.

\footnotetext{
' Este Para maiores informações sobre a incorporadora Idea!Zarvos, ver capítulo 4.5 "Agentes da produção de habitação coletiva contemporânea diferenciada".

2 Existe, inclusive, um grupo denominado "Movimento pela Vila" de cidadãos interessados em preservar a história e características da arquitetura relevante deste bairro, apresentando posição contra a verticalização comercial sem critérios ou estudos de impacto sobre o trânsito e a vida dos cidadãos. Disponível em: <http://movimentopelavila.com.br>.Acesso em: II jun. 2012.
}

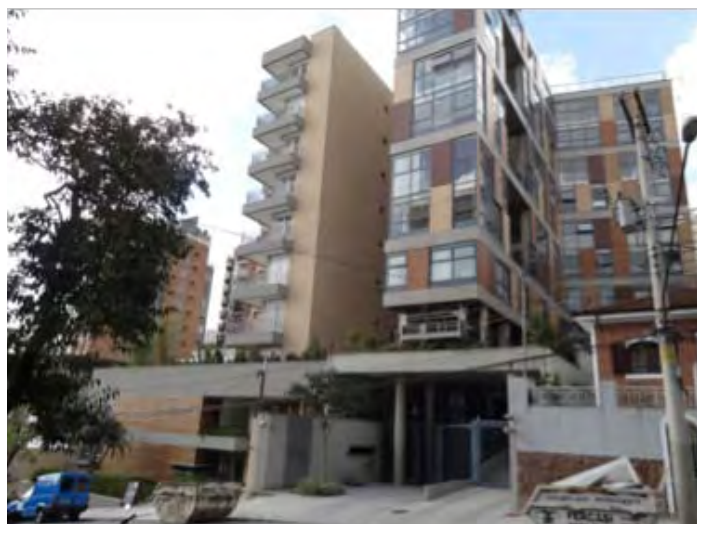

Figura I - Relação do edifício Fidalga 772 com as construções vizinhas existentes.

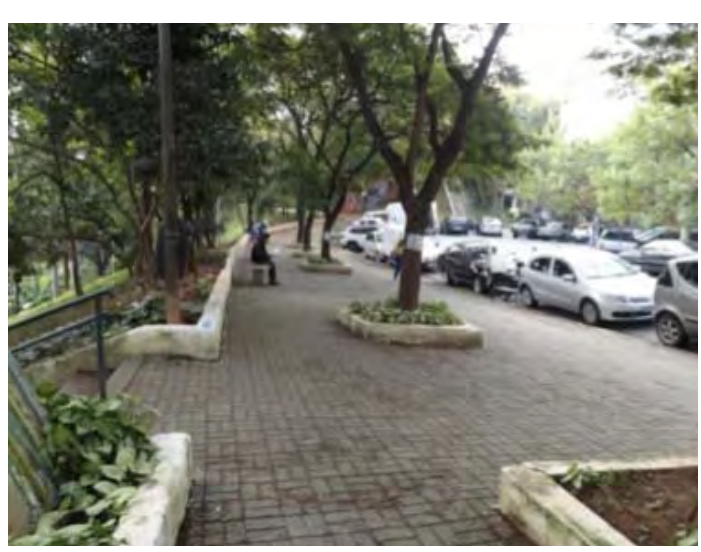

Figura 2 - Trecho sem saída justamente devido à topografia acidentada presente no bairro. 


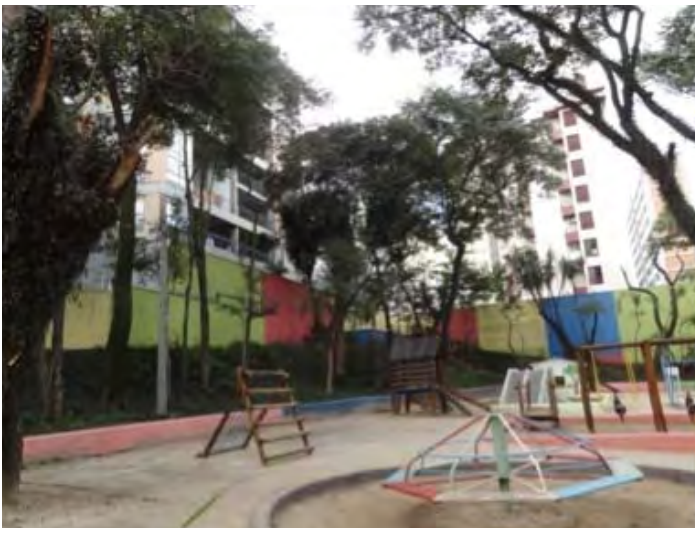

Figura 3 - Relação do pátio da escola municipal e a face sudeste do edifício.

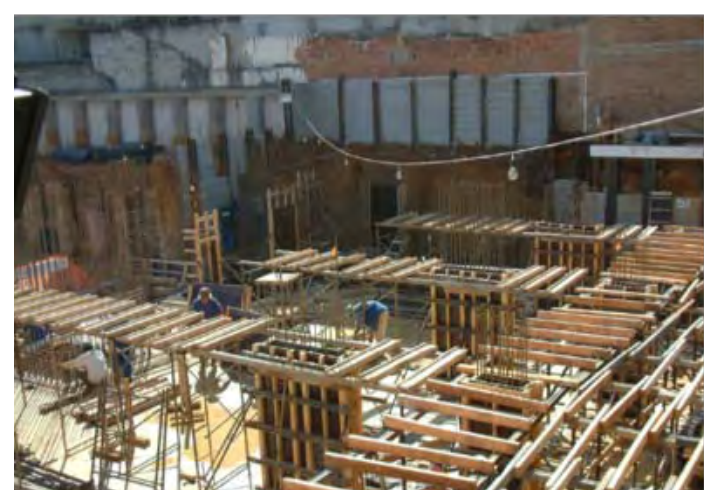

Figura 4 - Nota-se, pela foto da obra, o sinal de corte de terra ao fundo do terreno, comprovando o forte aclive que existia antes da obra.
Assim, chegou às mãos dos arquitetos Vinícius Andrade e Marcelo Morettin o desafio de projetar um edifício de habitação coletiva em um terreno de formato irregular, de pequeno porte, que dificilmente interessaria a um empreendedor comum com "fórmulas" prontas de projeto, afinal, dificilmente projetos padronizados se encaixariam nesta situação. Os terrenos buscados pela Idea!Zarvos geralmente possuem estas características de serem pequenos e resultantes da junção de lotes menores, principalmente na Vila Madalena, conforme poderá ser notado em outros exemplos aqui estudados. Esse tipo de terreno, nas mãos de bons arquitetos, quase sempre resulta em projetos qualificados por sua diferenciação.

\subsection{I.3 PARTIDO DE IMPLANTAÇÃO}

O edifício foi implantado em “L”, fazendo uma transição que contorna a geometria do terreno, porém, com uma leve inclinação de uma das faces, conseguindo-se, assim, suavizar a inserção deste objeto na paisagem. A face mais extensa tem orientação sul e está voltada para um pátio arborizado de uma escola municipal (Figura 3). Segundo os autores do projeto, foi uma sorte ter essa face voltada ao sul, pois é um lado que pode ser aberto à paisagem, apta a ser envidraçada.já a face norte, recuada apenas três metros do lote vizinho, fica muito próxima ao Edifício Fidalga 800, do escritório Reinach Mendonça Arquitetos Associados, resultando em uma relação de falta de privacidade e uma sensação de fosso sem iluminação e ventilação quando se observa as faces dos dois edifícios vizinhos lado a lado. Esta é uma situação que se repete na cidade de São Paulo, acaba sendo resultado do recuo obrigatório e, de certa maneira, da tipologia edilícia adotada de forma isolada no lote.

Com relação à implantação do edifício em corte, o terreno original possuía um acentuado aclive em direção ao fundo (Figura 4), permitindo, assim, de acordo com a Legislação de 
Parcelamento, Uso e Ocupação do Solo (LPUOS)3 , que o térreo oficial estivesse seis metros acima do nível da rua, o qual, portanto, é correspondente ao segundo subsolo; acima deste, na sequência, vem o primeiro subsolo e depois o térreo.

O fato do térreo não estar projetado no nível da rua, não partiu dos arquitetos.A Idea!Zarvos conta com uma equipe que faz todo o estudo da legislação existente, da viabilidade do terreno e de todos os dados relevantes para a elaboração do projeto, de tal maneira que ele proporcione uma situação de negócio vantajosa. Assim, quando este projeto foi encomendado aos arquitetos, o cliente já sabia exatamente quais as melhores possibilidades para se construir no lote. Os dois níveis de subsolo não contariam como área construída e caso não se seguisse a alternativa do desnivelamento, ou o edifício não teria garagem, ou o número de unidades diminuiria consideravelmente, situação que não se encaixaria dentro do cálculo estimado pelo empreendedor. $O$ que se percebe é que, quando o arquiteto toma as rédeas do próprio negócio, naturalmente ele também considera o melhor aproveitamento dos índices de ocupação do solo permitido. Foi o que levou a arquiteta Cristina Xavier e o Engenheiro Hélio Olga a escolheram o terreno em Carapicuíba para a Vila Taguaí, por exemplo, justamente para escapar das Leis de São Paulo ${ }^{4}$ que na época consideravam garagem ou áreas cobertas como áreas computáveis.

\footnotetext{
${ }^{3}$ Este Conforme o PRE (2004), seção IV,Art. I87: Para fins do disposto nesta lei, o nível do pavimento térreo não poderá exceder a cota de I (um) metro acima do nível médio entre as cotas das extremidades da testada do lote, quando o desnível na testada for menor ou igual a 2 (dois) metros.

$\S 1^{\circ}$ - Quando o desnível na testada do lote for superior a 2 (dois) metros, o piso do pavimento térreo poderá estar situado em qualquer cota intermediária entre os níveis, mais elevado e mais baixo:

$\S 2^{\circ}$ - O disposto no parágrafo anterior se aplica também, para os casos de desníveis superiores a 2 (dois) metros em relação à profundidade do lote.

$\S 3^{\circ}$ - Nos casos de terrenos com acentuado declive ou aclive em relação ao logradouro ou aos imóveis contíguos, o nível do pavimento térreo será definido caso a caso pela Câmara Técnica de Legislação Urbanística - CTLU.

${ }^{4} \mathrm{Na}$ verdade, até 2004 , as construções de prédios eram realizadas sem que as garagens fossem computadas no cálculo do C.A. (coeficiente de aproveitamento). Ao sancionar a Lei $n^{\circ}$ 13.885, a então prefeita da cidade de São Paulo, Marta Suplicy, vetou incisos que estabeleciam as áreas não computáveis para efeito do cálculo do Coeficiente de Aproveitamento do Solo. Assim, as garagens passaram a integrar nos cálculos, o que elevou os custos das construções, já que para acrescentar essa área a seus projetos os construtores precisariam pagar a outorga onerosa.
}

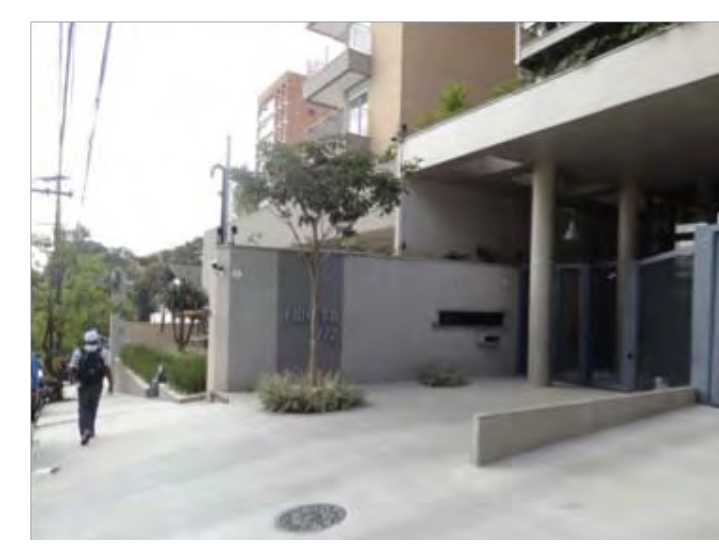

Figura 5 - Entrada do Edifício Fidalga 772 e terraço no térreo oficial voltado para a rua. 


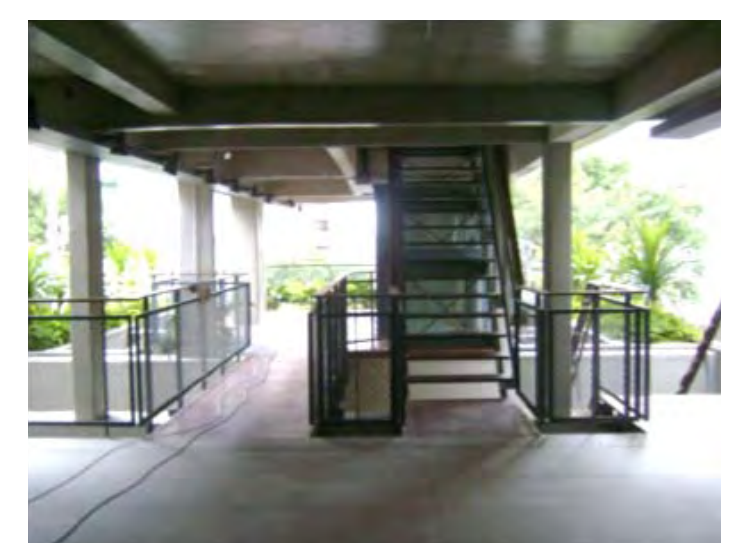

Figura 6 - Térreo oficial. Ao fundo, terraço voltado à rua.
Na parte frontal, no nível da rua, o portão é recuado do limite do lote, criando alargamento na calçada onde convivem entrada de automóvel e pedestre, um elevador e uma escada que levam ao piso térreo. Observando a foto da entrada do edifício (Figura 5), nota-se que, por mais que o térreo não esteja integrado ao nível da rua, existe uma possibilidade de contato visual desde o terraço criado seis metros acima do nível da mesma (Figura 6). Também existe certa transparência no nível da rua, que é mais adequado para a cidade do que os grandes muros que contornam os condomínios de edifícios ou vilas projetados recentemente em São Paulo. São pequenos atos que não chegam a representar ganhos aos espaços públicos lindeiros, mas que, dentro de condições pré-determinadas, representam uma inserção cuidadosa na cidade. Já existe um ganho entre uma alternativa e outra.

\subsection{I.4 AGENTES}

Algumas questões foram pré-definidas pela Idea!Zarvos antes mesmo da primeira reunião com os arquitetos: o número de vagas e a posição das garagens; a proporção dos espaços para uso coletivo; os espaços privativos no térreo, principalmente nas unidades-casas; o uso privativo da cobertura; o número de unidades e a metragem delas, inclusive a flexibilidade total da planta. Mesmo assim, os projetos contratados pela Idea!Zarvos, se comparado a outros do mercado mais comum, possuem um avanço com relação à importância dada ao arquiteto, já que, mesmo delimitando questões antecedentes ao projeto e pós projeto, como a venda ou definição do interior, ainda assim possibilita que este seja desenhado e desenvolvido pelo arquiteto criteriosamente selecionado.

Se compararmos com outros empreendimentos atuais, a dupla incorporador-vendedor acaba definindo por completo o produto, ficando o arquiteto apenas responsável por questões menores, de composição de fachada, de encaixe de peças prontas, sem nenhuma inovação ou característica específica relevante. Por exemplo, exclui-se o arquiteto da definição da técnica construtiva e do sistema estrutural, não são pesquisados materiais novos, não são desenhados os 
caixilhos e quase não se nota diferença entre um empreendimento e outro, já que os espaços são os mesmos, apenas com pequenas diferenças de arranjos.Villa (2002) expõe esta problemática existente nos exemplos de edifícios de apartamentos típicos de mercado imobiliário:

\begin{abstract}
Nota-se, neste cenário da produção de apartamentos, que o arquiteto é o agente menos consultado sobre o desenho dos apartamentos. Grande parte das premissas de projeto é decidida pela dupla incorporador-vendedor, sendo este último o que tem contato com o comprador no stand de vendas, e se arroga, por isso, a missão de definir padrões. Frente a estas questões nota-se o questionamento do papel do arquiteto na definição do projeto, já que historicamente este foi sendo transformado em função das solicitações sócio-culturais e econômicas da sociedade.Também evidencia-se, por uma série de motivos, que o arquiteto deixou de deter o controle total do projeto no mercado imobiliário atual, reduzindo sua atuação à solução de questões programáticas e estéticas. Houve uma espécie de distanciamento do arquiteto no que se refere aos processos que antecedem o momento em que ele é convocado para conceber um empreendimento e, portanto na definição de produtos. Por outro lado deu-se nos últimos vinte anos uma lenta e gradual degradação da imagem do projeto e dos próprios projetistas, com a consequente perda da dimensão real e ampla destes (VILLA, 2002, p.27-28).
\end{abstract}

Porém, se compararmos as obras da Idea!Zarvos com outros projetos nos quais o arquiteto é o empreendedor, como a Vila Fidalga, Butantã e Taguaí, nestes o avanço é ainda maior, e o arquiteto acaba sendo o agente principal e fundamental não apenas do projeto como dos processos anteriores e posteriores a ele. Participa da escolha do local, do estudo de viabilidade, faz o projeto, é o responsável pela obra, descobre técnicas construtivas e materiais novos, vende as unidades e, por fim, volta várias vezes ao conjunto, isto quando não mora nele e acaba acompanhando o período de pós ocupação, fazendo acertos de alguns pontos do projeto que ficaram a desejar ${ }^{5}$. Esse é o caminho para uma boa arquitetura, porém, como poderá ser notado ao longo desta pesquisa, não é o único.

\footnotetext{
${ }^{5}$ Isto aconteceu, por exemplo, na Vila Taguaí, de autoria da Arquiteta Cristina Xavier.
} 


\section{Tire o que é neo e} descubra o que é

\section{apenas clássico.}

Se você escolhe de carro a celular pelo design, néo pode escolher o lugar onde vai morar apenas olhando uma planta baixa.

Boa arquitetura náo é apenas aquela que distribui bem os quartos, a sala $\theta$ a cozinha. Isso é o mínimo que vocé pode esperar. Boa arquitetura 6 aquela em que toda a funçä́o está em sua melhor forma, tanto do lado de dentro quanto do lado de fora. Sem exageros, sem enfeitinhos, sem supérfluos e principalmente, sem seguir modas.

Porque a moda passa um dia. E o verdadeiro clássico é aquele que resiste ao tempo.

Figura 7 - Trecho do folheto publicitário do Fidalga 772.
O perfil de cliente que a Idea!Zarvos busca é predominantemente mais jovem, composto principalmente por solteiros ou casais, com nível superior de escolaridade e bem resolvidos profissionalmente. É um tipo de público que se interessa por design e que consome produtos por sua beleza. Foi interessante ouvir do zelador que um casal de idosos foi visitar uma das unidades do Fidalga 772 e saiu decepcionado com a falta de acabamento, afinal, estão acostumados com fachadas com frisos e ornamentos, os neoclássicos, outro tipo de produção que o mercado costuma oferecer. Mas, conforme artigo publicado no jornal Folha de São Paulo, em 22 de maio de 201 I, ilustrado pelo Fidalga 772, isso está mudando:

Depois de mais de uma década de ditadura do neoclássico, os prédios paulistanos
chegaram ao século 2 I. Agora, com a fachada limpa, os lançamentos começam a
exibir linguagem arquitetônica contemporânea. (...) De acordo com Nádia Somekh,
um projeto contemporâneo se caracteriza pela qualidade e flexibilidade dos espa-
ços, pelo diálogo do projeto com a cidade, além do respeito à natureza, com o uso
de novos materiais e racionalização do processo construtivo. Esses itens, alguns
projetos que se vendem como contemporâneos não têm. (CORREA, 20I I).

A última frase desta citação traz uma questão importante, de que a boa arquitetura residencial contemporânea não é simplesmente aquela que deixa de ser neoclássica. O estilo com "fachada limpa" acaba sendo também sinônimo de economia em acabamentos. Assim, não se trata apenas de tirar os frisos e ornamentos, é preciso responder com qualidade à questão do diálogo com a cidade (talvez a menos atendida), entre outras questões que estão sendo descobertas e inseridas como parâmetros da boa arquitetura habitacional contemporânea a partir das obras estudadas neste trabaIho. A frase extraída do folheto de vendas do Fidalga 772 (Figura 7) expõe uma crítica direta aos empreendimentos neoclássicos de São Paulo, além de relatar um pouco como seria o tipo de morador 
morador imaginado pela Idea!Zarvos; por exemplo, aquele que valoriza o design do produto, podendo compreender que a arquitetura está sendo considerada da mesma maneira que um celular ou um automóvel: como um objeto de consumo.

Serapião (2009) revela o perfil da primeira compradora de uma das unidades do Edifício Aimberê, também projetado por Andrade Morettin: publicitária, 33 anos, estava em dúvida entre um apartamento antigo e espaçoso, com pé-direito alto, no bairro de Higienópolis (local onde morava anteriormente), porém acabou optando por uma unidade no Edifício Aimberê. Perfil de uma jovem, bem-sucedida e com alto poder aquisitivo.

\subsection{I.6 ESPAÇOS EXTERIORES}

A Idea!Zarvos possui um conceito de reduzir as áreas comuns ao máximo, com o argumento de que a localização privilegiada dos edifícios faz com que a cidade ofereça os espaços de convívio comunitário, e não o edifício. Portanto, o habitar coletivo aconteceria, nesses casos, em comunhão com a cidade, e não dentro de um condomínio cercado por muros (Figura 8). No pavimento térreo do edifício Fidalga 772, não se nota a presença de playgrounds, salão para festas ou piscina, apenas um pequeno espaço de chegada com vista para a rua e acesso aos andares superiores. Isto está relacionado ao perfil de morador que a Idea!Zarvos busca, aquele que não está interessado em áreas de uso coletivo (Figura 9). Diferente do que acontece na maioria dos outros empreendimentos do mercado imobiliário de São Paulo, nos quais as áreas de uso comum acabam sendo os grandes atrativos para venda de apartamentos, mais por ganha de status do que pelo uso propriamente dito. Segundo Tramontano (1998) o processo de forte valorização das esferas coletivas dos edifícios de apartamentos surge a partir dos anos 1970 para compensar as perdas de área das unidades, principalmente nos empreendimentos de alto luxo, e isto se manifesta com força até hoje pelos equipamentos de uso coletivo: salão de festas, playgrounds, espaço gourmet, entre outros. É importante mencionar o fator da ganha de status a partir desses espaços, colocado por Villa (2002):

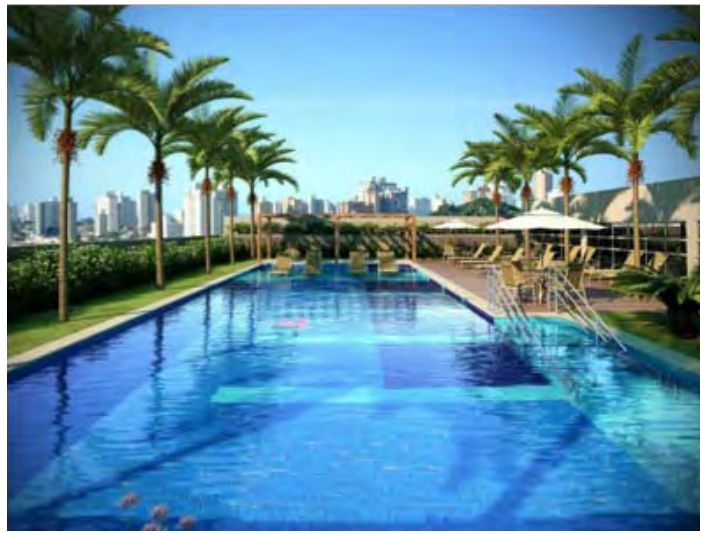

Figura 8 - Imagem de área de lazer coletiva em folheto de vendas da GAFISA.

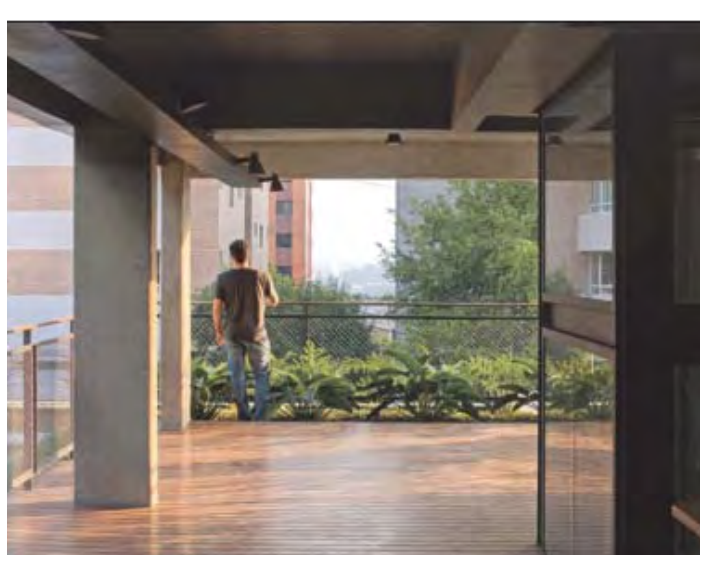

Figura 9 - Imagem da área de uso coletivo no Fidalga 772: área reduzida e sem espaços para atividades coletivas. 


\section{Um}

05.POR PRÉDIOS QUE

APROXIMEM SEUS

MORADORES DO MELHOR

QUE A CIDADE TEM A

OFERECER.

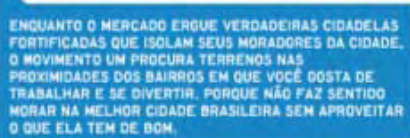

Figura 10 - Entre os 10 mandamentos do Movimento Um, o quinto é com relação ao Habitar Coletivo em comunhão com a cidade.
Não bastava que os edifícios de apartamentos fossem dotados de variada gama de equipamentos coletivos. Tornava-se importante explicitar de que forma estes poderiam incluir no status social dos moradores. Itens essenciais para se viver bem passaram a ser enfatizados na maioria dos lançamentos de apartamentos da cidade de São Paulo (VILLA, 2002).

Percebe-se que muitas dessas áreas de lazer coletivas, encontradas na maioria dos empreendimentos lançados recentemente em São Paulo, acabam sendo pouco utilizadas durante o ano, novamente comprovando uma aquisição mais por ganha de status do que pela real necessidade. $A$ divulgação dos edifícios da Idea!Zarvos segue outro caminho, é direcionada para um público jovem que costuma usufruir da cidade, que fica muito tempo fora de casa, tanto nas horas de trabalho, como também nas horas vagas. Assim, a frase publicada no site "MOVIMENTO UM", parece seguir este raciocínio (Figura 10):

Enquanto o mercado ergue verdadeiras cidadelas fortificadas que isolam seus moradores da cidade, o movimento um procura terrenos nas proximidades dos bairros em que você gosta de trabalhar e se divertir, porque não faz sentido morar na melhor cidade brasileira sem aproveitar o que ela tem de bom (MOVIMENTO UM, 20I0).

Segundo o COE de São Paulo7, o pavimento térreo, quando destinado exclusivamente às áreas comuns do prédio, inclusive apartamento de zelador até 60,00 m $\square$ de área, não deve ser computado para fins de coeficiente de aproveitamento do lote ${ }^{8 .}$

${ }^{6}$ Isto Empresa ou Manifesto Imobiliário, formado pela Zarvos (direção da incorporação e o acompanhamento das obras), Axpe, idealizada por José Cazarin (vendas) e CP3, de Rafael Canto Porto e Tonico Canto Porto (construção). Alguns mandamentos deste movimento: variação no tamanho das unidades; edifícios com poucas unidades; apartamentos individualizados; localização na Vila Madalena entre outros. Disponível em: < www.movimentoum.com.br>. Acesso em: 2010. Observação: encontrava-se fora de ar em julho de 2012.

${ }^{7}$ Art. 13 - O artigo 182 da Lei $n^{\circ} 8.266$, de 20 de junho de 1975, passa a vigorar com a seguinte redação: (Revogado pela LM II.228/92 e Reativado pelo art. 25 do DM 32.329/92) Art. 182 - Para os edifícios de apartamentos, aplicam-se, ainda, as seguintes disposições:

I - O pavimento térreo, quando destinado exclusivamente às áreas comuns do prédio, inclusive apartamento de zelador até $60,00 \mathrm{~m} \square$ de área, não será computado para fins de coeficiente de aproveitamento do lote.

8 Interessante é perceber, que os grandes marketings do mercado imobiliários para venda de apartamentos são: as amplas áreas coletivas; as varandas ou espaços gourmets e as coberturas, sucesso para as vendas que não entra no cálculo de área computável. 
Porém, mesmo com esta suposta vantagem, optou-se por incluir unidades-casas no térreo, afinal, o tipo de morador ao qual o empreendimento é direcionado não possui interesse em espaços de uso coletivo e no status que esse tipo de espaço pode trazer.A questão de existir ou não áreas de uso coletivo dentro de um condomínio não é um parâmetro qualitativo de projeto, afinal, existem boas soluções tanto para um caso, quanto para outro. Cada empreendedor defende sua proposta, seja aquele que vende grandes áreas de lazer coletivas ou aquele que, desde a busca pelos terrenos - que dificilmente serão maiores que $1000 \mathrm{~m}^{2}$-, já pré-estabelece um projeto com áreas coletivas mais enxutas, que precisam do bairro como sua extensão, situação perfeita para um determinado público que Otávio Zarvos soube enxergar.

\subsection{I.7 SISTEMA ESTRUTURAL,TÉCNICA CONSTRUTIVA E ENVOLTÓRIA}

As principais diferenças entre o Fidalga 772 e o Aimberê são o sistema construtivo e a definição dos materiais. No Aimberê foi adotado técnica convencional de construção, com estrutura em concreto armado moldado in loco e fechamento em alvenaria, todo masseado e pintado.Também por insegurança do empreendedor naquele momento, não foi dada a oportunidade de escolha de adotaram, no Aimberê, o conceito de moldagem do monobloco, como se estivessem esculpindo o volume (Figura II).Assim, foram criados rasgos na fachada e reentrâncias que acomodam varandas e criam faces adicionais para ventilação e insolação. Com relação ao acabamento, foi criada uma diferenciação para as faces externas do monobloco bruto, que ficaram rugosas e mais rústicas; já quando escavadas, as superfícies novas resultantes ficaram lisas e brancas (Figura 12). Foi essa a maneira encontrada pelos arquitetos para conseguir uma diferença de materialidade diante do tipo de vedação pré-estabelecida. ${ }^{9}$

${ }^{9}$ Apenas como referência, esta característica de esculpir o monobloco aparece com frequência em projetos do arquiteto chileno Alejandro Aravena, como pode ser observado no exemplo da Figura II.

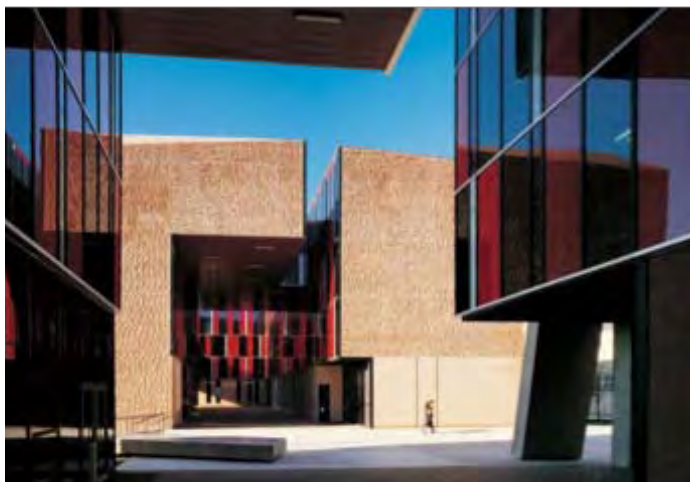

Figura I I - St. Edward's University New Residence and dining hall de autoria do arquiteto chileno Alejandro Aravena.

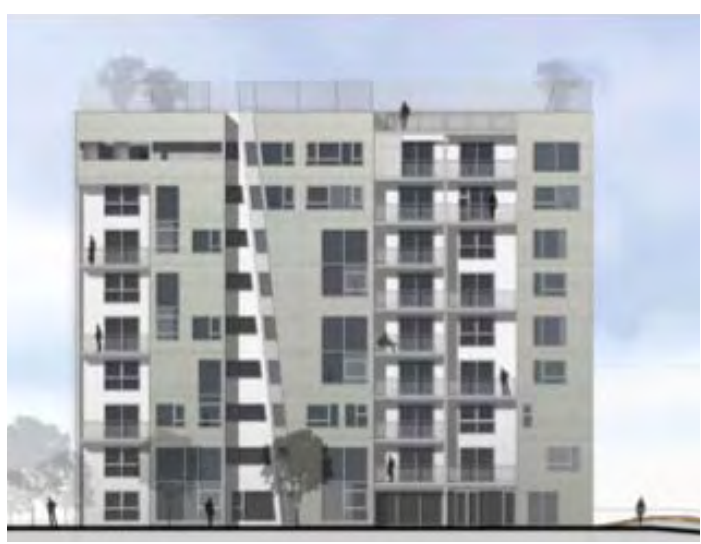

Figura 12 - Edifício Aimberê: monobloco esculpido, as faces externas são mais rugosas e rústicas e as faces escavadas são brancas e lisas. 


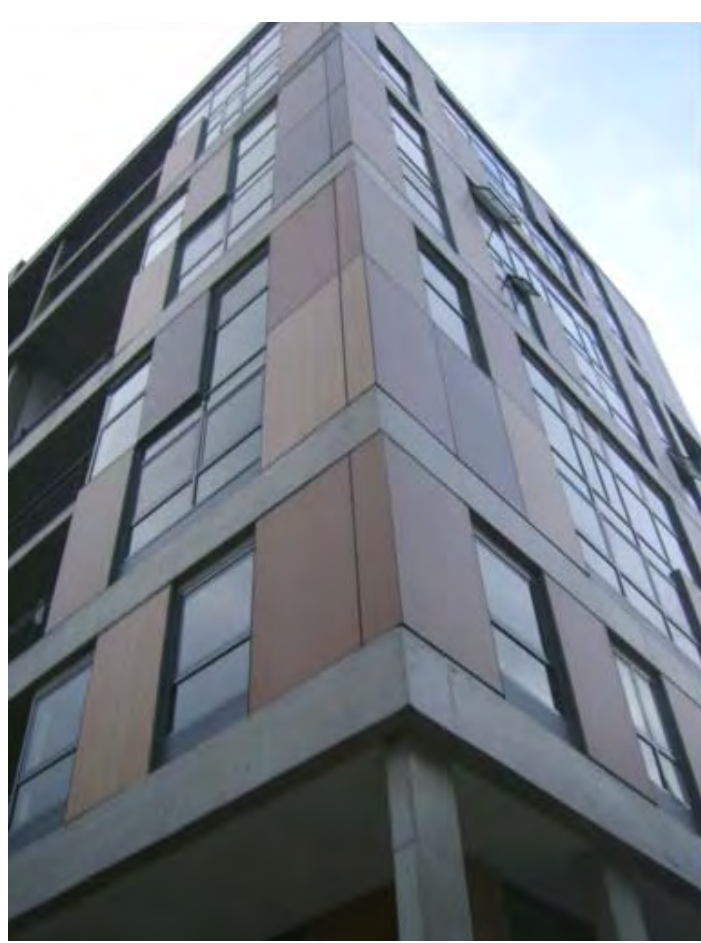

Figura 13 - Fachada Fidalga 772.

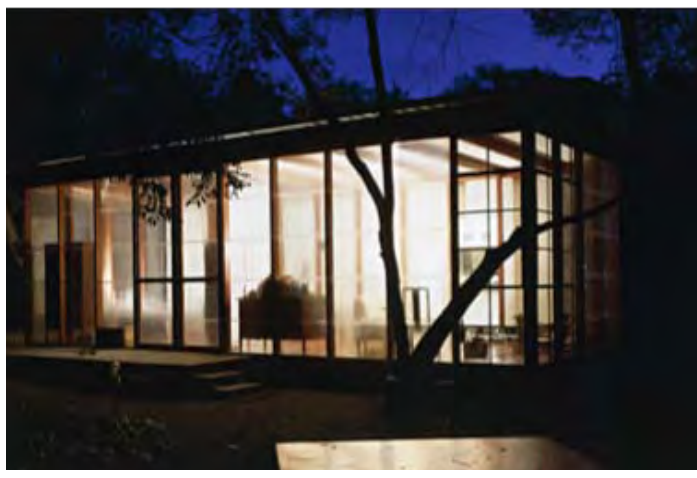

Figura 14 - Casa em Carapicuíba (1997).
O grande avanço do Fidalga 772, em relação ao Aimberê, é o sistema construtivo adotado que considera o processo da construção, pensando não apenas na sua agilidade mas inclusive em sua qualidade. A superestrutura (fundação e estrutura) foi toda moldada in loco, mas só a partir do momento em que o concreto estava terminado e alguns trechos de alvenaria executados (caixa de escada e outros pontos, conforme pode ser observado na planta) é que o edifício passou para uma fase de obra mais seca: as instalações foram colocadas com a estrutura pronta, fechadas com gesso acartonado e todo fechamento externo foi feito em uma estrutura de perfis de alumínio fixados sobre a periferia do prédio, que recebeu, da mesma maneira, o caixilho com vidro ou os painéis High Density Fiberboard (HDF), laminados especiais para fachada (Figura 13). Não existiu, portanto, a fase de acabamento convencional de fachada, com masseamento e pintura. $O$ cliente foi convencido, a partir deste projeto, que a mescla do sistema convencional com sistemas de fechamentos independentes, sem toda sujeira que ocorre normalmente na fase de acabamento das alvenarias, traz benefícios não apenas de qualidade, como também econômicos. $O$ sistema puramente convencional, inclusive, não é coerente com o próprio conceito da empresa: por que pensar numa planta totalmente livre e ter uma fachada imutável? O sistema construtivo e os materiais adotados no Fidalga 772 representam um avanço ao que normalmente ocorre nos empreendimentos do mercado imobiliário, muitos em alvenaria estrutural, sem inovação na envoltória e com janelas iguais para cada tipo de ambiente. Assim, nesta obra, a disposição das aberturas e fechamentos leva a revelação do interior para a cidade e não da cidade para o interior, devido à indeterminação dos usos internos que esta fachada proporciona (Figura 14):

(...) Como o véu de policarbonato da casa em Carapicuíba ou as peles de brises da $\mathrm{CAF}$ em Caracas, as fachadas não pretendem ser completamente transparentes. $\mathrm{A}$ revelação do interior para o ambiente urbano é mediada pela presença da superfície limítrofe, seja através dos materiais utilizados, seja pela disposição das aberturas e fechamentos. O que importa é a contenção da variação do interior na sua expressão urbana através da afirmação das superfícies do volume. Uma demonstração de responsabilidade na conformação visual da cidade. (ANELLI, 20 I2, p. 37). 
A envoltória deste edifício é a mediadora do interior para o exterior e vice-versa. Ao mesmo tempo em que revela desde o ambiente interior a cidade, pelo tamanho das aberturas e trechos transparentes, ela indetermina desde o exterior os ambientes e suas funções. $O$ caixilho que alterna vidro e painéis - efeito de transparência e opacidade, recorrente no trabalho dos arquitetos - habilita a ideia de indeterminação do uso interno, de uma maneira quase aleatória mostra a possibilidade de mobilidade da envoltória ou flexibilidade existente no seu interior (Figura 16).A flexibilidade do interior está muito relacionada à capacidade de mobilidade da fachada. Diferencia-se, portanto, de uma fachada comum, na qual é possível identificar, a partir do exterior, os ambientes e seus usos correspondentes, com situações de hierarquias entre ambientes e usuários, ou de uma configuração destinada a uma família nuclear estável que não representa mais a única forma de agrupamento de moradores na contemporaneidade. Tipos de janelas para quartos, para sala, para cozinha, para banheiro, nada disso é perceptível nesta fachada, a proposta é inovadora nesse sentido. Nos edifícios neoclássicos de São Paulo, a arquitetura se resume a uma preocupação de fachada, aqui, diferentemente, passa a ser uma preocupação integrada entre sistema construtivo, técnica construtiva, posição das instalações e fechamentos internos e externos.

Nós do escritório sempre tivemos a preocupação em desenvolver projetos que considerem o processo da construção. Que tenha, na medida do possível, um sistema pré-fabricado, que permita uma obra mais racional, mais rápida e seca. Isso é uma coisa que a gente vem desenvolvendo há muitos anos, cuja transferência para edifícios residenciais ainda é muito difícil, basta observar a cidade onde vivemos. (ANDRADE, 20I2).

Esta preocupação em desenvolver projetos que considerem o processo da construção, nos quais a escolha dos materiais acontece de maneira específica para cada um, pode ser notada em vários projetos da dupla Andrade Morettin, tratando-se de uma característica que marca a trajetória do escritório. Por exemplo, na casa em Carapicuíba, de 1997, os volumes são configurados pelos sistemas construtivos e pelos materiais industrializados.

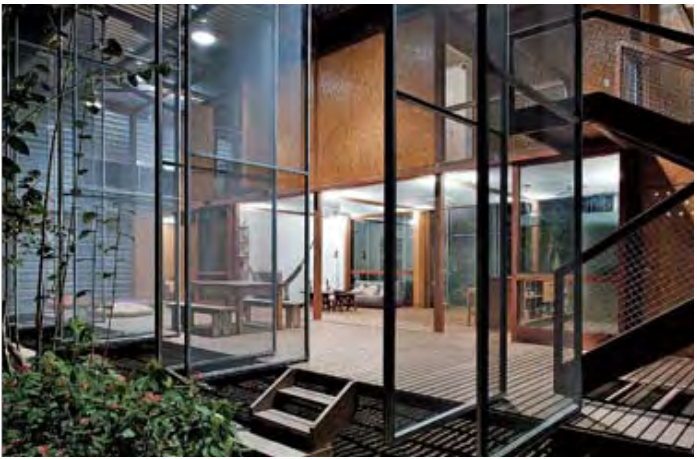

Figura I5 - Casa em Ubatuba (2006).

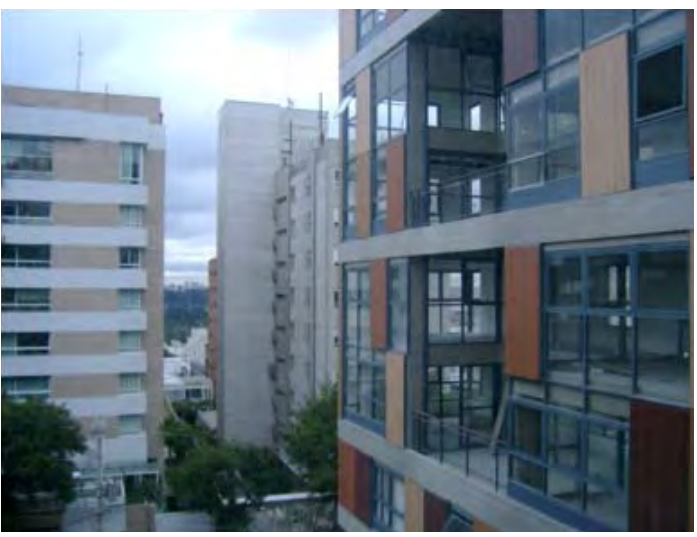

Figura 16 - Fidalga 772: revelação da cidade pelas fachadas que mesclam painéis transparentes e opacos. 


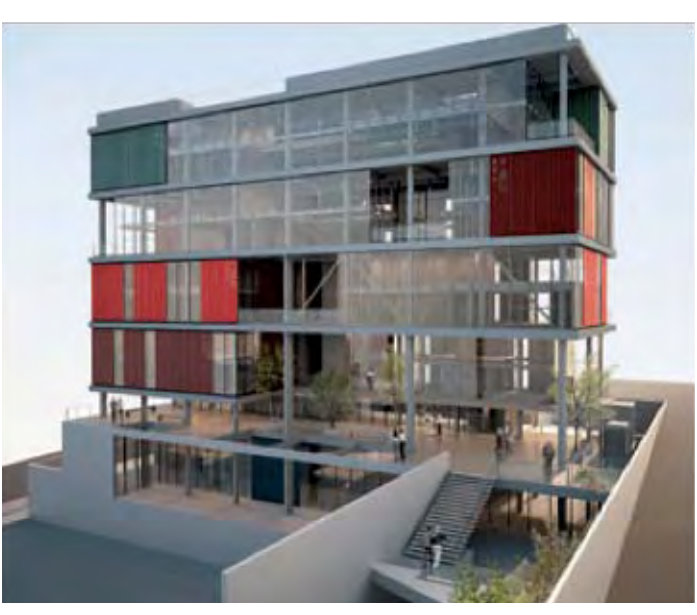

Figura 17 - Edifício de escritórios na rua Wizard (2009 - em execução).
O efeito ótico de transparência e opacidade, recorrente no trabalho de Andrade Morettin, é fruto de filtros de diversos materiais. Essa concepção apareceu já com vigor no policarbonato da casa em Carapicuíba, o primeiro projeto de autoria deles a ganhar as páginas de mídia especializada em quase 30 publicações, da Itália à Rússia.Também singularizou a escola em Campinas (com telhas metálicas translúcidas) e a casa A.B. (vidro serigrafado). Em todos os casos, o desenho acurado e industria vai ao encontro de uma materialidade inespecífica. (SERAPIÃO, 20I2, p. I5).

O Fidalga 772 traz um avanço com relação ao processo de execução, porém, ainda há muito que evoluir. Este é um processo que vem sendo conquistado aos poucos, e por isso não apareceu no primeiro projeto com a Idea!Zarvos, Aimberê, e nem é alcançado de forma plena neste projeto, já que teve muita execução de alvenaria e a superestrutura foi moldada in loco convencionalmente, conforme relatado.

O edifício de escritório na Rua Wizard (Figura 17), Vila Madalena, posterior ao Fidalga 772, é a prova de que os arquitetos conseguiram convencer o cliente sobre a importância da consideração do processo construtivo no projeto. Esse edifício é composto por cinco lajes de concreto com fechamentos de materiais leves (telhas metálicas e caixilhos de vidro).A construção, através da montagem a seco de componentes industrializados, não é um processo de fácil aceitação no Brasil, sendo assim, os agentes desta realização estão um passo à frente neste campo de atuação.

\subsection{I.8 UNIDADE HABITACIONAL}

A proposição inicial de possibilitar total flexibilidade na definição do layout partiu de Idea!Zarvos, com a intenção de oferecer aos seus clientes o atendimento de suas necessidades individuais a partir da personalização das unidades. Assim, elas deveriam ser adaptadas às necessidades atuais ou futuras dos moradores; para isso, foram estabelecidas algumas práticas que podem ser observadas na maioria dos edifícios residências lançados pela incorporadora.

Uma das práticas é a inexistência de "árvores" da tubulação de esgoto posicionadas sob a laje 
de piso e dentro do apartamento de baixo, como é comum nas instalações sanitárias dos edifícios de apartamento. $O$ projeto do 772 modificou esse costume - quando se define o local do banheiro, suspende-se o piso da área do boxe e utiliza-se bacia de saída lateral. Conforme caso do Fidalga 772 e outros casos, foram definidos vazios para passagem das prumadas, levando a liberdade a graus extremos e, assim, o banheiro ou a cozinha podem estar em qualquer lugar na unidade. As tubulações também podem passar pelas fachadas e criar uma aparência fora do convencional.

Porém, existem dois entraves com relação a esse conceito: primeiro, a total liberdade favorecerá mais ao primeiro morador de cada unidade. Inclusive, se na resolução do interior for definida situações menos flexíveis e mais fixas, deixando a flexibilidade futura somente possível a partir de verdadeiras obras de reforma.

O que acaba sendo garantida pelo projeto arquitetônico original, que define a estrutura no perímetro e as instalações em shafts a parte, é a possível liberdade de se colocar e tirar paredes internas de onde se quiser e posicionar áreas molhadas onde se desejar.Tal situação pode evitar futuros riscos na estrutura do edifício, como é comum acontecer nos realizados em alvenaria estrutural, ou que possuem pilares e vigas passando por dentro do apartamento, ficando sujeitos a uma reforma irregular que elimine ou danifique elementos estruturais, resultando em verdadeiras catástrofes.

O segundo ponto é o custo que essa liberdade toda possui e se o resultado obtido compensa. Será que é necessário dar a possibilidade de total escolha da posição do banheiro ou da cozinha? Isto seria o mesmo que não considerar o estudo de insolação e ventilação da unidade, principais vistas, conforto acústico e outros dados relevantes para a resolução de uma unidade habitacional. A flexibilidade deveria ter limites, por exemplo existir dois possíveis locais para o banheiro, mas já determinado que estivessem na face menos privilegiada. Enfim, a resolução do interior é também importante e deveria estar a cargo dos arquitetos que conceberam o edifício.

Conforme relato do arquitetoVinicius Andrade (2012), esta postura de realizar edifícios com a planta totalmente modificável vem mudando, no mais recente trabalho que eles estão realizando

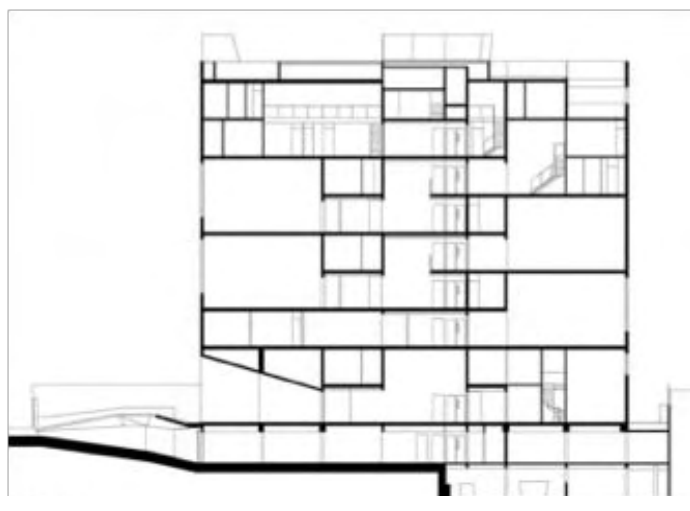

Figura 18 - Edifício Aimberê: desde a primeira proposta para a Zarvos os arquitetos seguem a linha de raciocínio a partir do corte. 


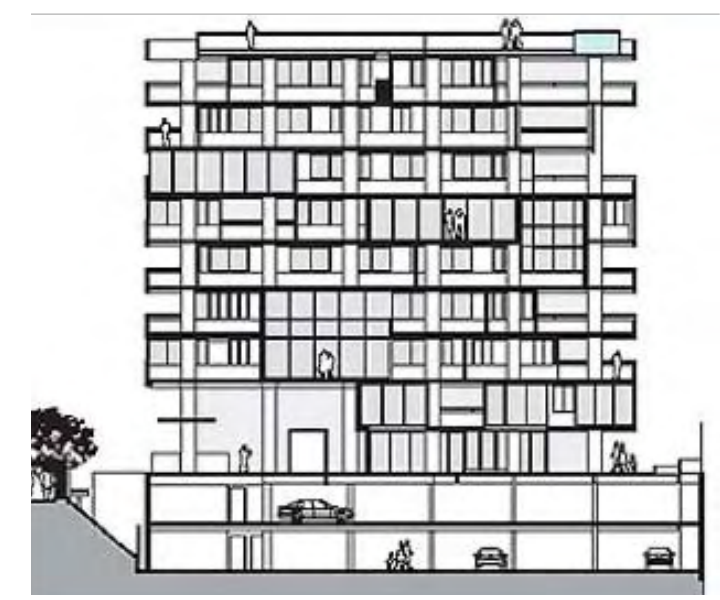

Figura 19 - Edifício Ourânia, do arquiteto Gui Mattos, ausência de pavimento-tipo.

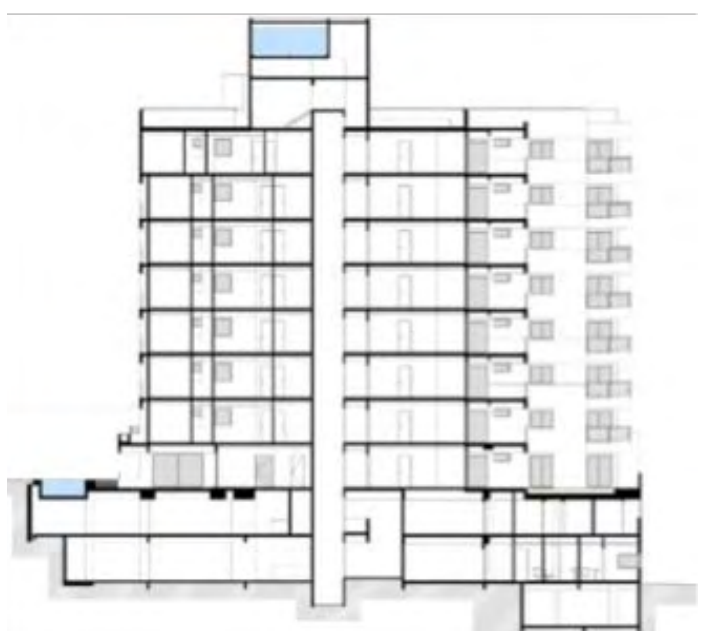

Figura 20 - Fidalga 800, Reinach Mendonça: pensado a partir da planta, resultando em estratificação horizontal e pavimentos-tipo idênticos. para a Idea!Zarvos, o Edifício Madalena, já não existe toda essa flexibilidade. As unidades são de 50 $\mathrm{m} 2$ e destinadas principalmente para pessoas que moram sozinhas. Otávio Zarvos percebeu as dificuldades tanto no custo, como também no atendimento. Os edifícios anteriores acabaram sendo verdadeiros experimentos, e esse conceito pode ser melhorado. "É realmente muito complicado. No começo, estávamos muito mais abertos a esse tipo de solução e vimos que o custo é muito alto. Tanto o custo financeiro quanto o de atendimento". (Otávio Zarvos em: FLORESTA, 20 I I, p. 68).

Schneider (2006) também aponta algumas dificuldades na planta flexível em seu estudo, principalmente com relação ao custo benefício. Também diz que os moradores evitam reformas futuras e que preferem a modificação dos ambientes por elementos móveis:

A solução do problema de moradia por meio de plantas flexíveis teve pouco sucesso. A questão do isolamento acústico pode ser dificilmente contornada, os custos para as lajes suspensas (espaço livre para passagem de cabos e distribuição do sistema elétrico para iluminação), para calefação no piso etc., não conseguiram justificar as vantagens da configuração flexível das plantas. A prática demonstra que a maioria dos moradores evita mais tarde as despesas de modificar a posição de uma parede e preferem a alternativa de participação na fase do projeto. Edifícios e formas de moradia são ainda pensados como algo estático, no qual cada um se instala, adaptando-se às condições dadas. $O$ resultado é que a flexibilidade, hoje, reduziu-se ao tamanho do apartamento: espaços de caráter neutro (em prédios de apartamentos tipo, em sua maioria em frente às escadas de acesso) podem ser combinados em diferentes apartamentos. Tamanhos e formas de ambientes podem ser modificados de maneira limitada através de elementos móveis (SCHNEIDER, 2006, p. 38).

\subsection{I.9 AUSÊNCIA DE PAVIMENTO TIPO}

Uma característica deste edifício e do Aimberê é a ausência de pavimento-tipo. Esta solução partiu da exigência da Idea!Zarvos por uma variação no tamanho das unidades, porém, poderiam surgir diversas soluções, inclusive em pavimentos-tipo idênticos e com estratificação horizontal típica, 
mas os arquitetos optaram por uma solução pensada a partir do corte e não a partir da planta.Segundo Vinicius Andrade (20I2), pela falta de experiência nesse tipo de encomenda, partiram do hall de entrada das unidades, pensaram que se alternassem os vazios consequentes do pé-direito duplo fariam um hall menor ou inexistente em alguns andares e em alguns momentos o mesmo seria privativo.

Assim, as plantas ficaram uma diferente da outra. Também tiveram a ideia de criar a possibilidade de vender o espaço e não a unidade, ou seja, a venda aconteceria a partir da vontade do comprador. Isto aconteceu de fato no Fidalga 772, quando, em uma das coberturas, foi comprado também o espaço abaixo, e isto mudou toda a ocupação do edifício. Esse tipo de solução não é comum em outros projetos, acontece apenas em alguns estudos de casos secundários nesta pesquisa, como, por exemplo, no Fidalga 897, da Arquiteta Cristina Xavier e no edifício Ourânia, do arquiteto Gui Mattos, porém cada um apresenta um partido e um conceito diferente.

No Ourânia, por exemplo, existiu a intenção de alternar andares diferentes, e principalmente de criar halls que atendessem a apenas uma unidade por vez. Porém, existem dois elevadores separados e um de serviço central, ou seja, só foi possível a individualização do hall a partir da criação de um elevador adicional de serviço (Figuras 18, 19 e 20).

\subsection{I.I0 POSSIBILIDADE DE AMPLIAÇÃO DAS UNIDADES HABITACIONAIS}

Esta proposta apresenta também espaços para possíveis ampliações da unidade a partir da instalação de mezanino em espaço com pé-direito duplo. Essa característica do pé-direito duplo também foi uma das exigências da Idea!Zarvos, e está presente em outros projetos: Aimberê, $4 \times 4$, Ourânia e Fidalga 727. O pé-direito duplo em apartamentos não é nenhuma novidade, principalmente em empreendimentos de luxo do mercado imobiliário, o que não é comum é dar a possibilidade ou não da instalação do mezanino.

Existem algumas possíveis respostas para esta solução: pode ser decorrente do limite do coeficiente de aproveitamento, isto quer dizer, não poderia ser criada mais laje que contabilizassem área construída, assim, reserva-se um "estoque área a ser construída" dentro do edifício. Conjuga-se a esta situação, mais possibilidades de personalização do interior pelo morador (Figuras 2le 22).

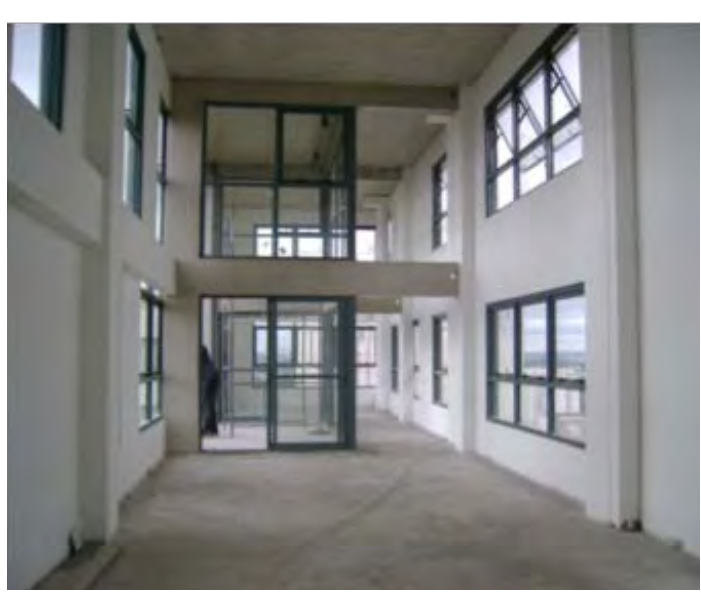

Figura 21 - Espaço com pé-direito duplo: viga já preparada para instalação do mezanino.

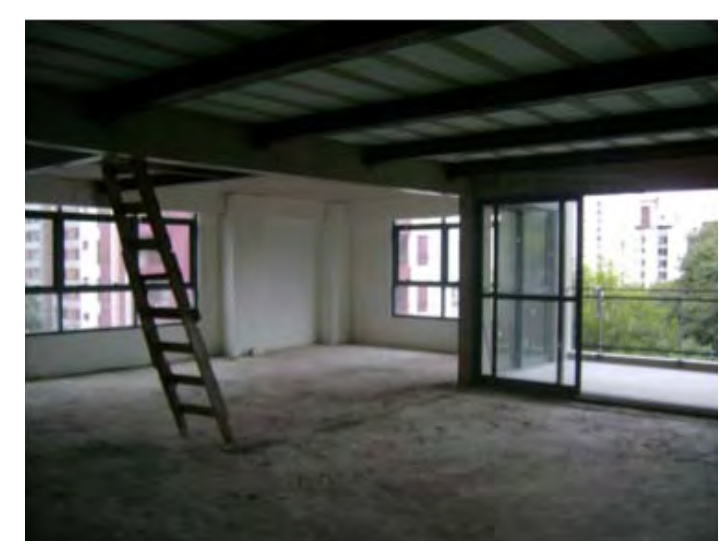

Figura 22 - Apartamento com mezanino instalado. 


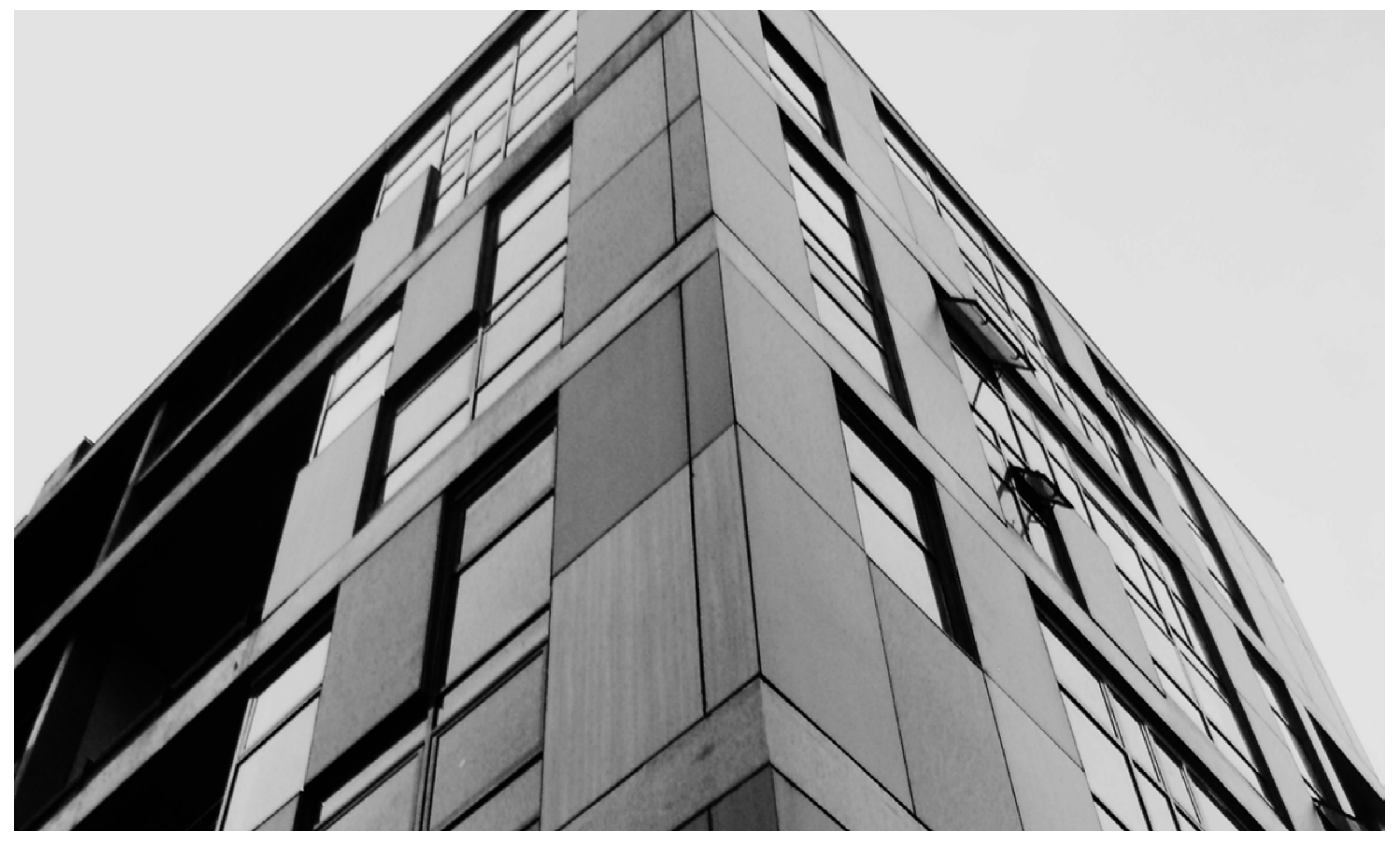

3.3.I.I I FICHAS GRÁFICAS EM ESCALA 


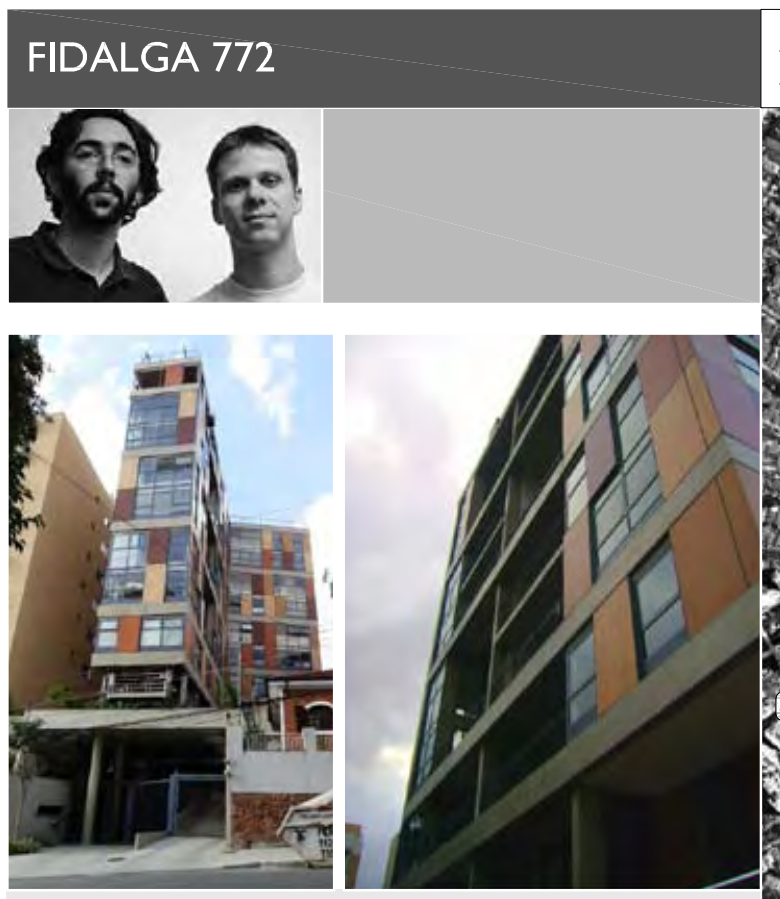

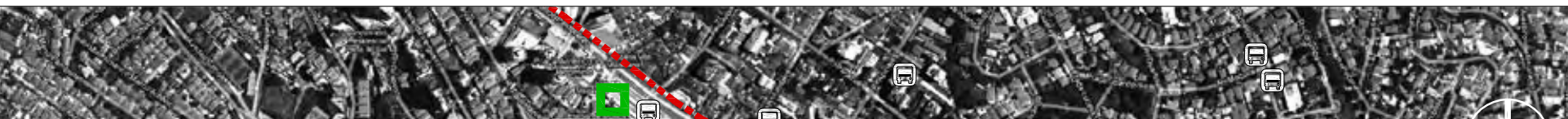

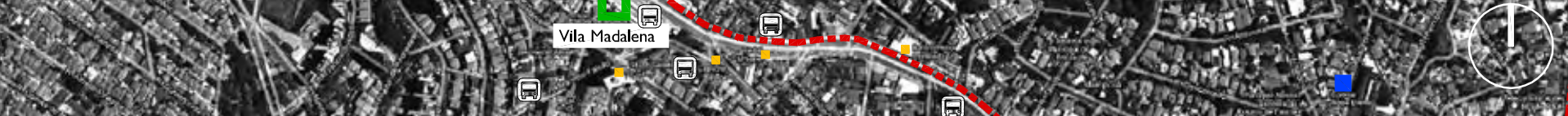

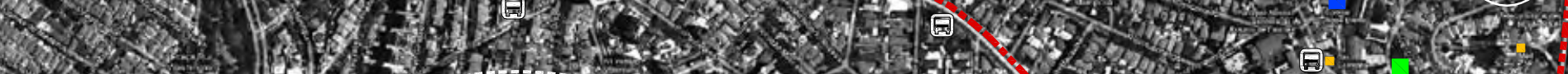

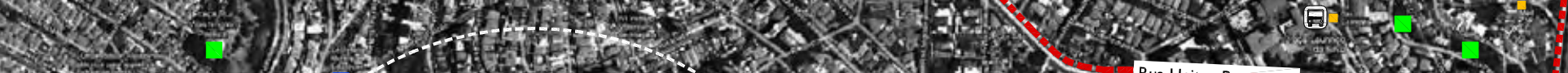
2.

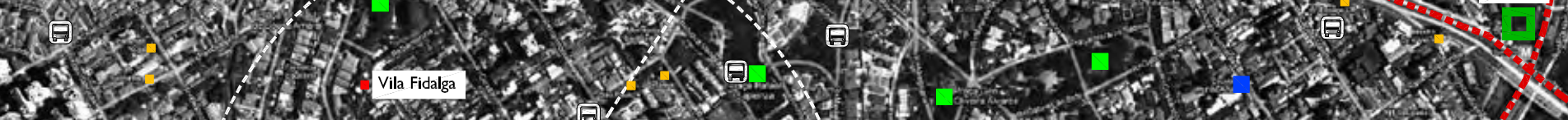
1.7.

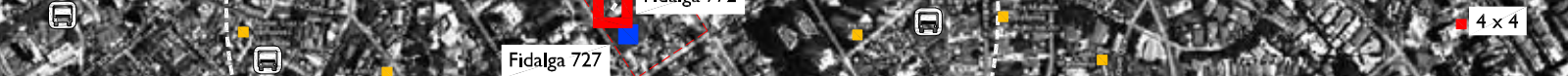

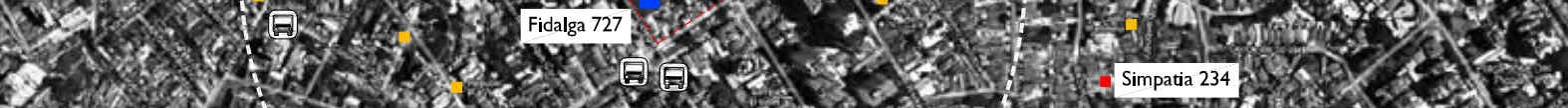

\section{EQUIPE:}

ARQUITETURA: Vinicius Andrade e Marcelo Morettin (autores); Marcio Tanaka e Marina Mermelstein (coordenadores); Florian Schmidt-Hidding, Marcelo Maia Rosa, Renata Andrulis (colaboradores)

INCORPORAÇÃO: Idea!Zarvos

CONSTRUÇÃO: CP3

ESTRUTURA: Esteng Estrutural Engenharia INSTALAÇÕES: Gera Serviços de Engenharia PROJETO e CONSTRUÇÃO: 2007-20II

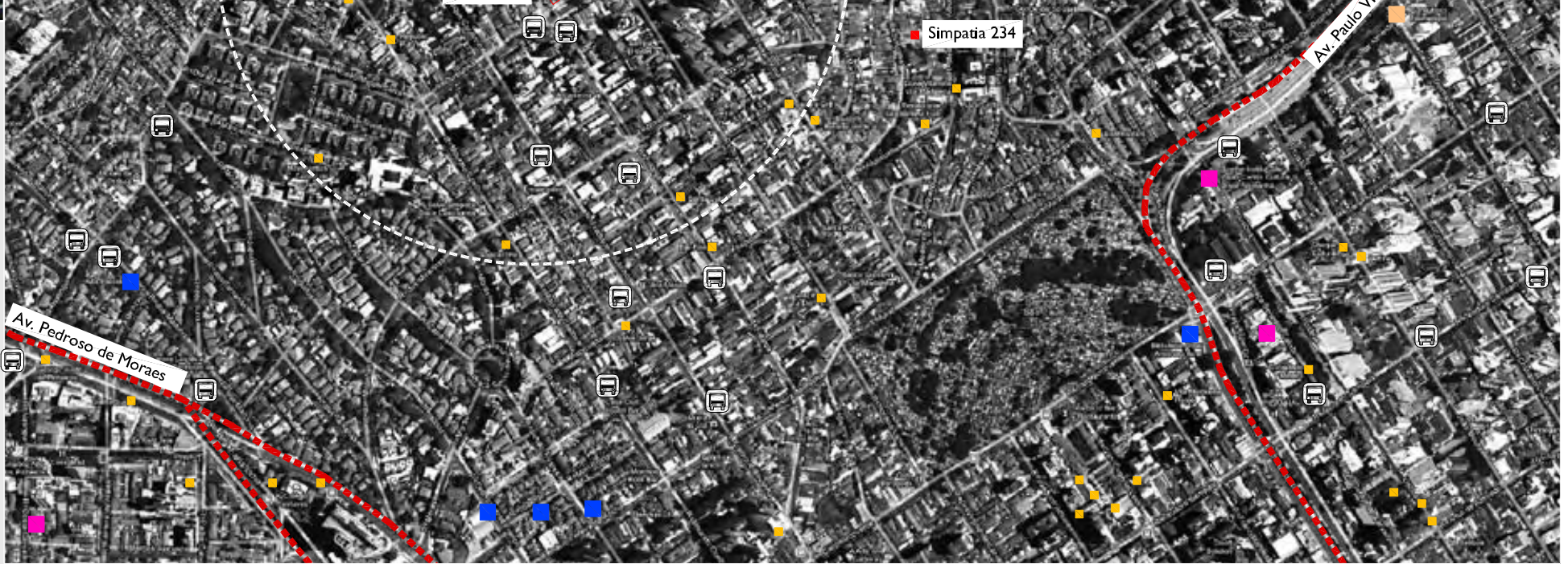

\section{MOBILIDADE:}

... VIAS PRINCIPAIS

(日) PONTO DE ÔNIBUS

n METRÔ LINHA VERDE
EQUIPAMENTOS:

E educação C comércio

L LAZER PRAÇA/ÁREA VERDE

S SAÚDE
ESCALA 1:12500

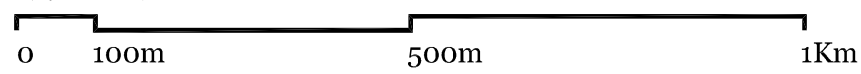

Rua Fidalga, 772

Vila Madalena, São Paulo - SP

- Outros projetos em estudo 

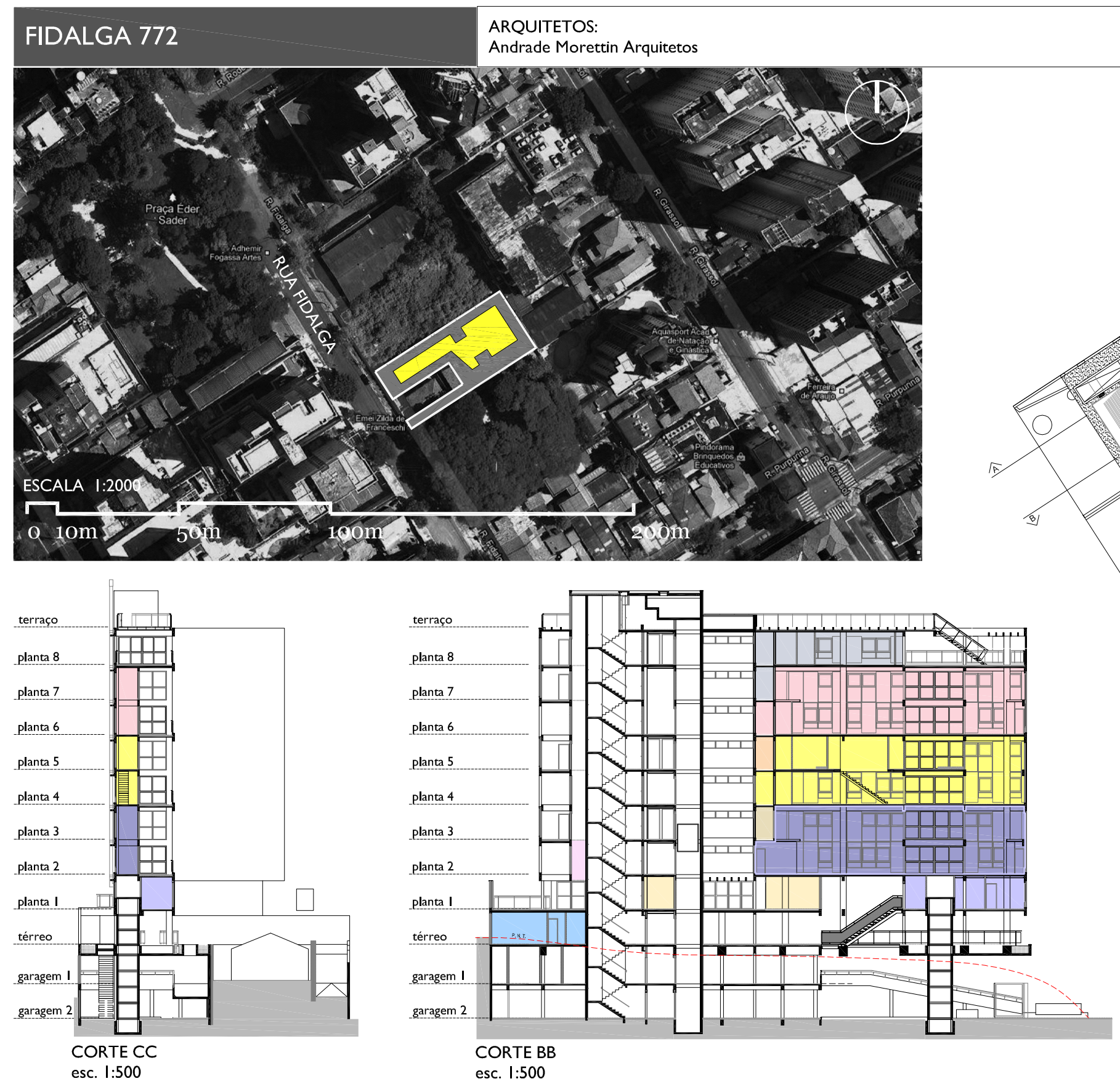

ÁREA DO TERRENO: $860 \mathrm{M2}$

ÁREA OCUPADA: $374 \mathrm{M} 2$

\% OCUPAÇÃO: $43 \%$

ÁREA TOTAL CONSTRUÍDA: 3775 M2

C.A.: I,90 (c.a. máx. 2,0)

NÚMERO DE UNIDADES RESIDENCIAIS: 13

NÚMERO HABITANTES: 26

DENSIDADE: $302 \mathrm{HAB} / \mathrm{HA}$

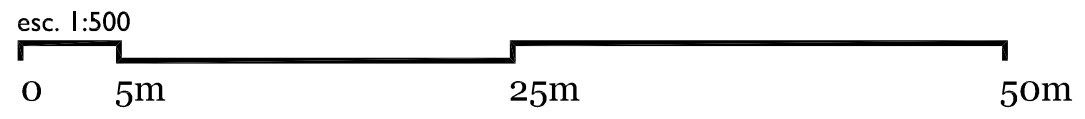




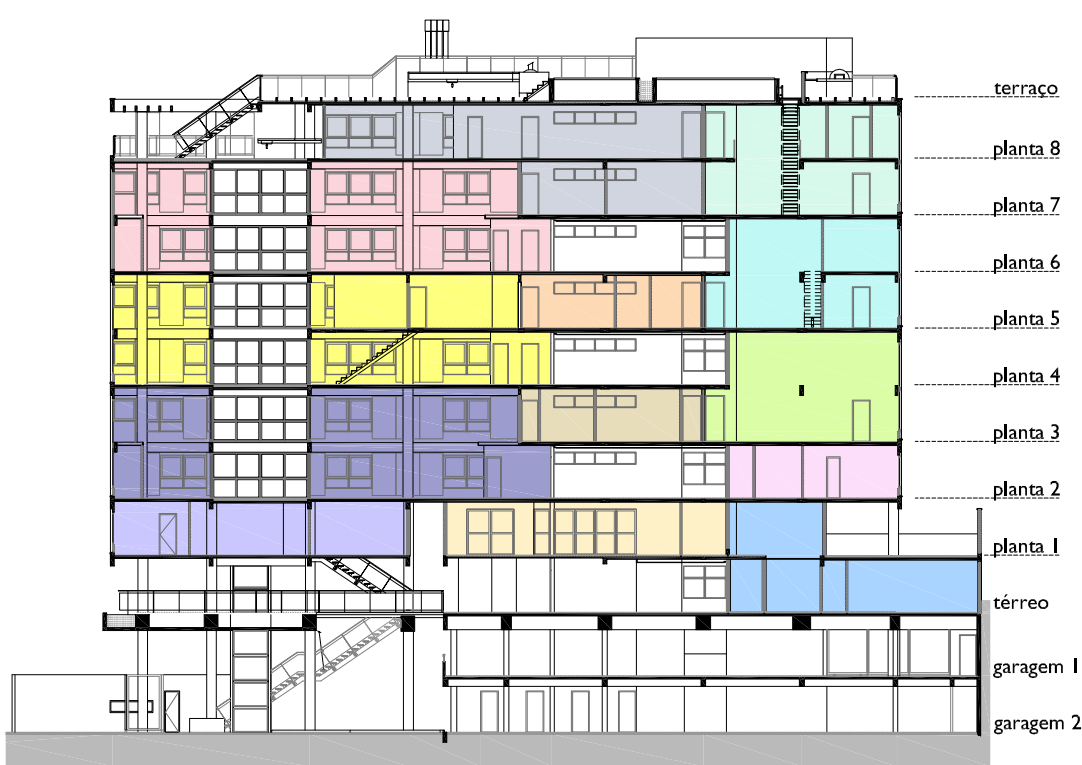

\section{CORTE AA}

esc. I:500

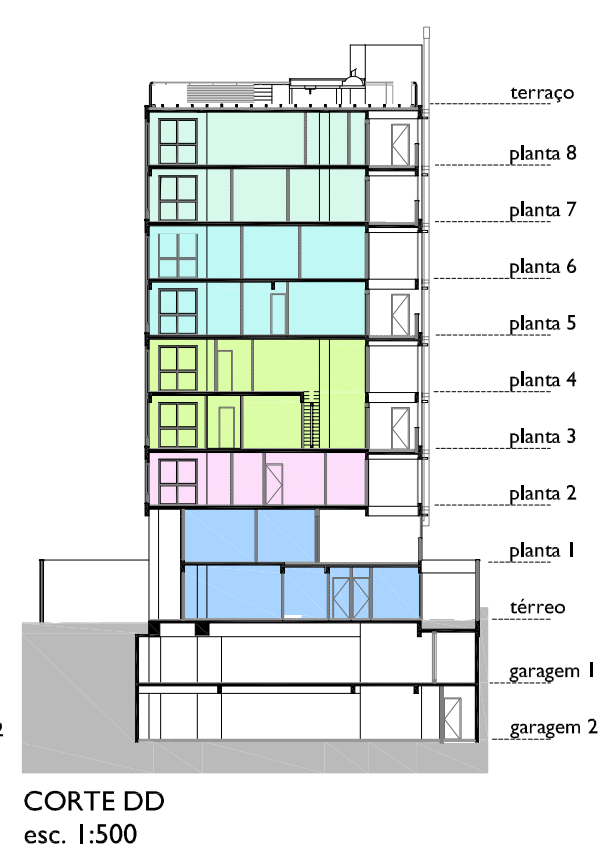

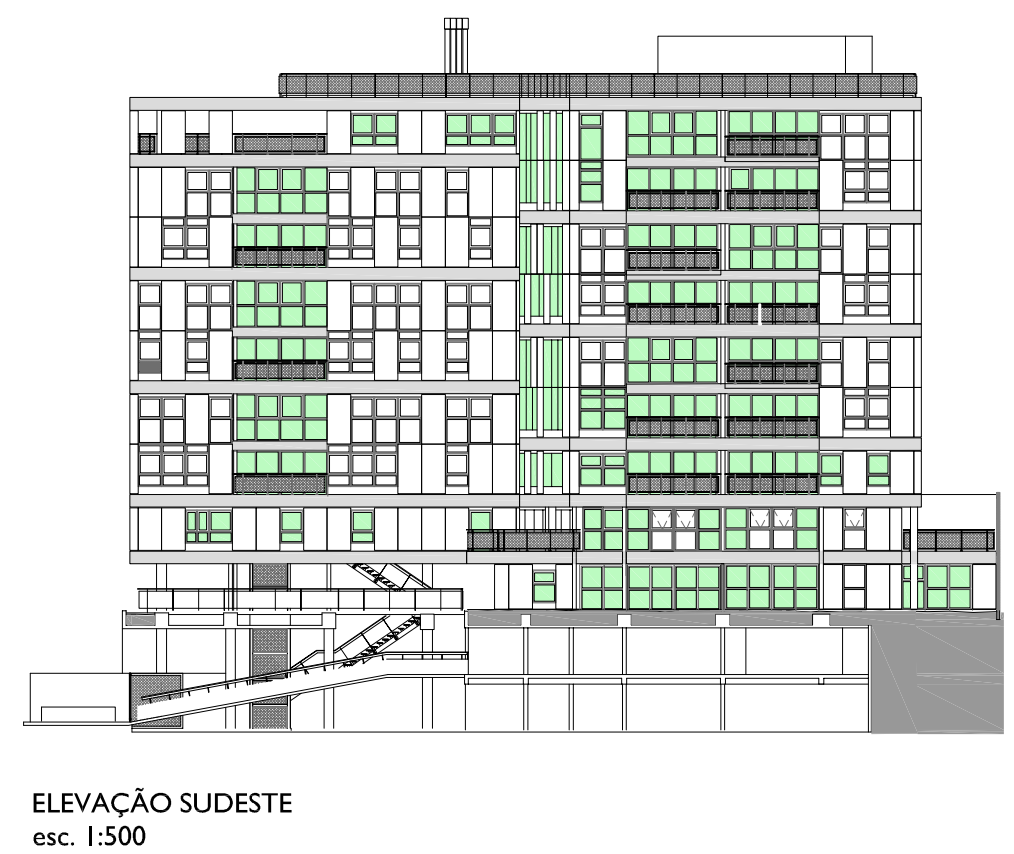

ELEVAÇÃ SUDESTE esc. 1:500

\begin{tabular}{|c|c|c|c|c|c|c|c|c|c|c|c|c|c|c|}
\hline & ZELADOR & СОВ. 82 & СОВ. 81 & LOFT 61 & LOFT 52 & LOFT 5 I & LOFT 4I & LOFT 32 & LOFT 31 & APTO. 22 & LOFT 21 & CASA 02 & CASA 01 & TOTAL \\
\hline PAVIMENTO TÉRREO & $50,46 \mathrm{~m}^{2}$ & $91,79 \mathrm{~m}^{2}$ & $79,98 \mathrm{~m}^{2}$ & $85,86 \mathrm{~m}^{2}$ & $91,79 \mathrm{~m}^{2}$ & $79,87 \mathrm{~m}^{2}$ & $85,94 \mathrm{~m}^{2}$ & $90,99 \mathrm{~m}^{2}$ & $80,01 \mathrm{~m}^{2}$ & $155,44 \mathrm{~m}^{2}$ & $86,52 \mathrm{~m}^{2}$ & II5,83 $\mathrm{m}^{2}$ & $73,68 \mathrm{~m}^{2}$ & \\
\hline PAVIMENTO SUPERIOR I & & $79,57 \mathrm{~m}^{2}$ & $115,72 \mathrm{~m}^{2}$ & & $52,65 \mathrm{~m}^{2}$ & $29,47 \mathrm{~m}^{2}$ & $57,15 \mathrm{~m}^{2}$ & $42,62 \mathrm{~m}^{2}$ & & & & $20,35 \mathrm{~m}^{2}$ & $46,65 \mathrm{~m}^{2}$ & \\
\hline computável & $50,46 \mathrm{~m}^{2}$ & $171,36 \mathrm{~m}^{2}$ & $195,70 \mathrm{~m}^{2}$ & $85,86 \mathrm{~m}^{2}$ & $144,44 \mathrm{~m}^{2}$ & $109,34 \mathrm{~m}^{2}$ & $143,09 \mathrm{~m}^{2}$ & $133,6 \mid \mathrm{m}^{2}$ & $80,01 \mathrm{~m}^{2}$ & $155,44 \mathrm{~m}^{2}$ & $86,52 \mathrm{~m}^{2}$ & $136,18 \mathrm{~m}^{2}$ & $120,33 \mathrm{~m}^{2}$ & I $612,34 \mathrm{~m}^{2}$ \\
\hline não computável & & $167,99 \mathrm{~m}^{2}$ & $192,57 \mathrm{~m}^{2}$ & $13,91 \mathrm{~m}^{2}$ & $19,21 \mathrm{~m}^{2}$ & $26,61 \mathrm{~m}^{2}$ & $13,89 \mathrm{~m}^{2}$ & $26,61 \mathrm{~m}^{2}$ & $13,78 \mathrm{~m}^{2}$ & $28,05 \mathrm{~m}^{2}$ & $13,92 \mathrm{~m}^{2}$ & $181,92 \mathrm{~m}^{2}$ & $151,78 \mathrm{~m}^{2}$ & \\
\hline vazio & & $11,35 \mathrm{~m}^{2}$ & $9,84 \mathrm{~m}^{2}$ & $78,95 \mathrm{~m}^{2}$ & $36,70 \mathrm{~m}^{2}$ & $32,96 \mathrm{~m}^{2}$ & $21,90 \mathrm{~m}^{2}$ & $46,73 \mathrm{~m}^{2}$ & $62,40 \mathrm{~m}^{2}$ & & $78,95 \mathrm{~m}^{2}$ & $49,49 \mathrm{~m}^{2}$ & $52,95 \mathrm{~m}^{2}$ & $482,00 \mathrm{~m}^{2}$ \\
\hline total & $50,46 \mathrm{~m}^{2}$ & $350,70 \mathrm{~m}^{2}$ & $398,11 \mathrm{~m}^{2}$ & $178,72 \mathrm{~m}^{2}$ & $200,35 \mathrm{~m}^{2}$ & $|68,9| \mathrm{m}^{2}$ & $178,88 \mathrm{~m}^{2}$ & $206,95 \mathrm{~m}^{2}$ & $156,19 \mathrm{~m}^{2}$ & $183,49 \mathrm{~m}^{2}$ & $179,39 \mathrm{~m}^{2}$ & $367,59 \mathrm{~m}^{2}$ & $325,06 \mathrm{~m}^{2}$ & $2094.56 \mathrm{~m}^{2}$ \\
\hline
\end{tabular}

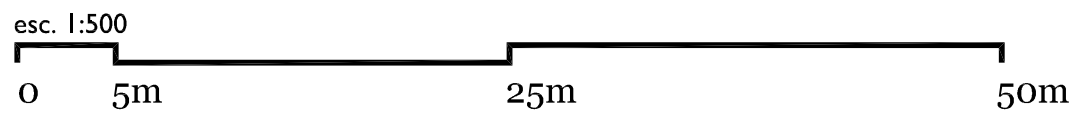




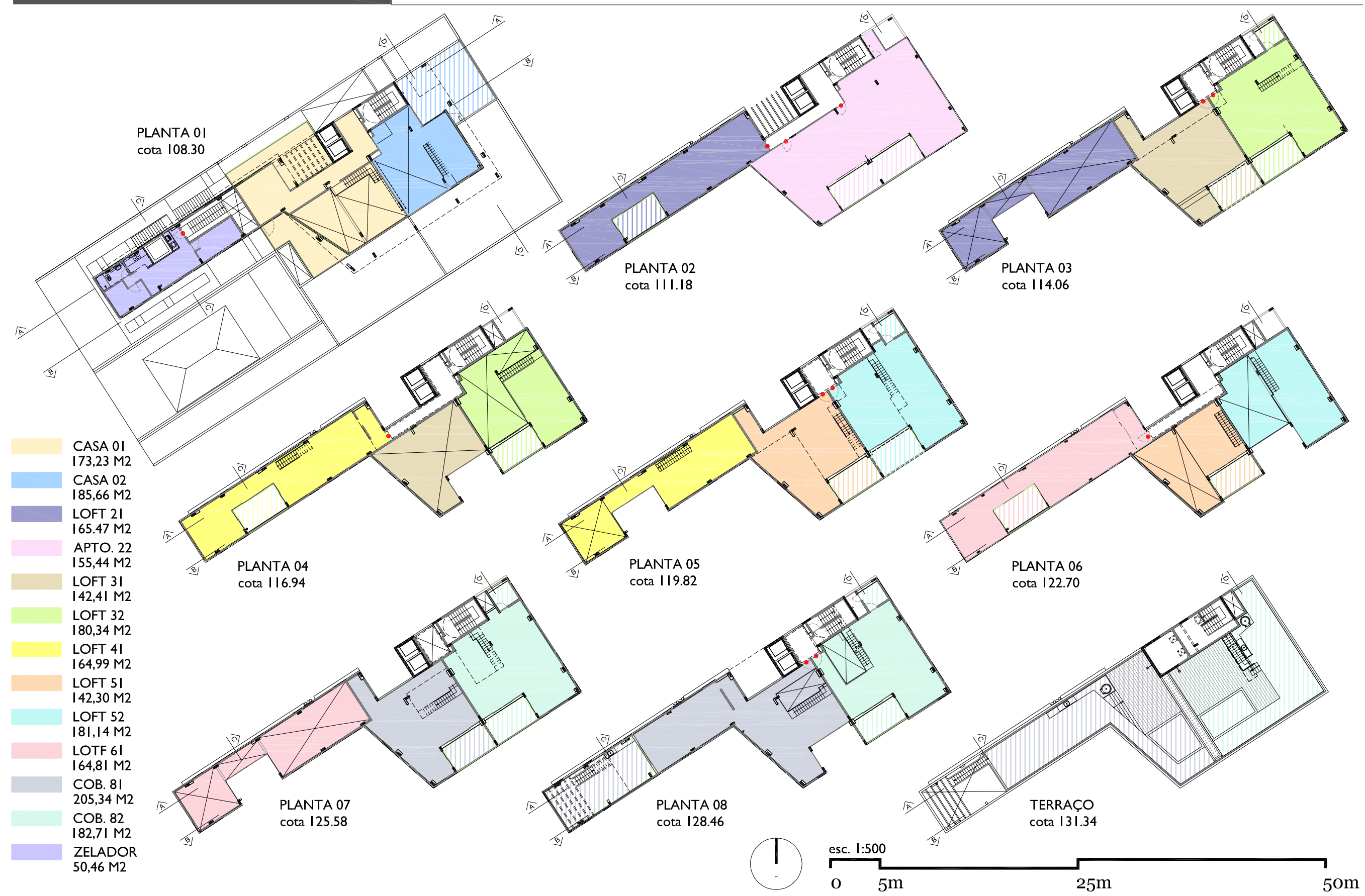


ANELLI, Renato.Tênue transparência. Monolito, São Paulo, n.II, p. 32-37, abril/maio de 201 I.

ARQUITETURA E URBANISMO. Investidores trazem nova proposta de arquitetura aos edifícios residenciais paulistanos. São Paulo, n. I6I, p.I2 , agosto de 2007.

ARQUITETURA E URBANISMO. São Paulo terá mais um edifício com o selo do movimento um. São Paulo, n. I82, p. 10 , maio de 2009.

CORREA,Vanessa. Arquitetura de São Paulo embarca no estilo contemporâneo. Folha de São Paulo, Cotidiano, cl, 22 de maio de 201 I.

HOLCK, Teodoro. Suave abraço. Arquitetura e Urbanismo, São Paulo, n.207, p. 46-53, junho de 201 I.

LEAL, Ledy Valporto.V. Jogo de morar. Arquitetura e Urbanismo, São Paulo, n. 196, p. 34-4I, julho de 2010.

MELENDEZ, Adilson. Diversidade de tipologias e medidas, em desenho inusitado. ProjetoDesign, São Paulo, n.353, p. 62 - 67, julho de 2009.

PROJETODESIGN.A reação ao neoclássico e a promessa para o futuro. São Paulo, n.37I, p. 89, janeiro de 201 I.

SERAPIÃO, Fernando. Edifício de apartamentos na Rua Fidalga. Monolito, São Paulo, n.II, p. I22-129, abril/maio de 201 I. 
SERAPIÃO, Fernando. Mudança de ares. ProjetoDesign, São Paulo, n.353, p. 68-79, julho de 2009.

SCHNEIDER, F. (Org.). Atlas de plantas: habitação. Barcelona: Editorial Gustavo Gili, 2006. Iª Edição em Português.

SUMMA+.Variación y flexibilidad. Buenos Aires, n. 107, p. 28-33, abril de 2010.

TRAMONTANO, M. C. Novos modos de vida, novos espaços de morar, Paris, São Paulo, Tokyo uma reflexão sobre a habitação contemporânea. 1998. Tese (Doutorado em Arquitetura e Urbanismo), Universidade de São Paulo, São Paulo, 1998.

VILLA, S. B. Morar em Apartamentos: a produção dos espaços privados e semi-privados nos edifícios ofertados pelo mercado imobiliário no século XXI em São Paulo e seus impactos na cidade de Ribeirão Preto. 2008. Tese (Doutorado em Arquitetura e Urbanismo), Universidade de São Paulo, São Paulo, 2008.

VISITAS REALIZADAS:

Fidalga 772 - 09 de maio de 2012 e 29 de março de $201 \mathrm{I}$.

$4 \times 4-18$ de abril de 2011 .

\section{ENTREVISTAS:}

Arquiteto Vinicius Andrade - 05 de março de 2012

Arquiteto Fábio Mendes (do escritório Gui Mattos, autor do edifício 4 × 4 e Ourânia) - 22 de abril de 20 II. 
LEIS:

SÃO PAULO (município). Lei n 13.430 , de 13 de setembro de 2002. Plano Diretor Estratégico de São Paulo.

SÃO PAULO (município). Lei n 13.885, de 25 de Agosto de 2004. Planos Regionais Estratégicos das Subprefeituras de São Paulo.

SÃO PAULO (município). Lei n ${ }^{\circ}$ II.228, de 25 de junho de 1992. Código de Obras e Edificaçães do Município de São Paulo. Dispões sobre as regras gerais, e específicas a serem obedecidas no projeto, licenciamento, execução, manutenção e utilização de obras e edificações, dentro dos limites dos imóveis, revoga a Lei n 8.266 de 20 de junho de 1975, com as alterações adotadas por leis posteriores, e dá outras providências.

SÂO PAULO (município). Decreto Municipal n 32.329 de 23 de setembro de 1992. Regulamenta a Lei no II.228 de 25 de junho de 1992 - Código de Obras e Edificações, e dá outras providências.

\section{OUTROS:}

ANDRADE,V.; MORETTIN, M. Mudança de Rumo. Conferência Museu da Casa Brasileira. São Paulo:ARQBACANA, MCB, 25 de maio de 2011 . 


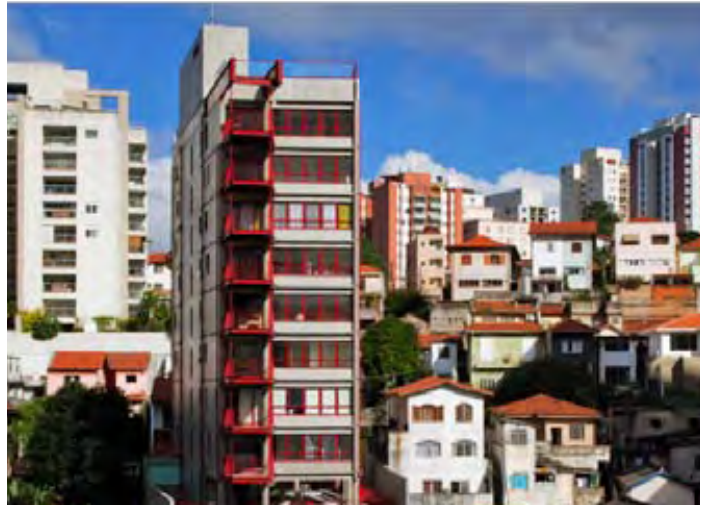

Figura I - Edifício Simpatia 234 e sua relação com o bairro.

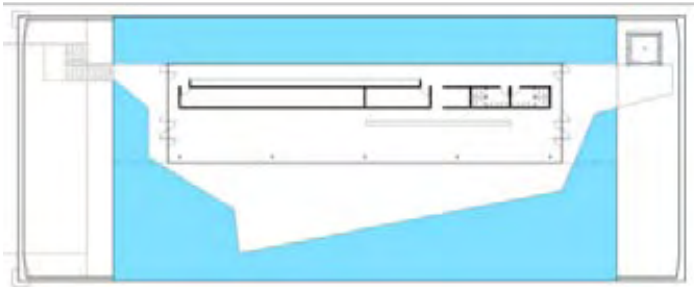

Figura 2 - Planta Baixa do projeto vencedor para o Pavilhão do Brasil na EXPO92, em Sevilha.

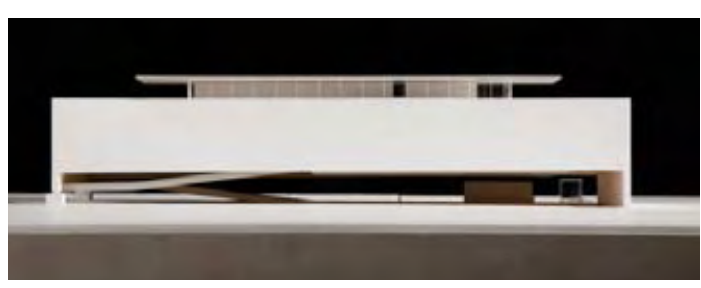

Figura 3 - Maquete do projeto vencedor para o Pavilhão do Brasil na EXPO92, em Sevilha.

\subsubsection{SIMPATIA 234: ARQUITETURA CONTEMPORÂNEA PAULISTA}

\subsubsection{INTRODUÇÃO ETRAJETÓRIA DO ARQUITETO ALVARO PUNTONI E GRUPO SP}

Alvaro Puntoni formou-se em arquitetura pela Universidade de São Paulo (USP) em 1987 e, na sequência, fundou com Angelo Bucci e Alvaro Razuk (1987-1992) o escritório cujo nome era um manifesto naquele período - 'Arquitetura Paulista'. Um projeto importante e muito polêmico desta fase foi o apresentado para o Concurso para o Pavilhão do Brasil em Sevilha, em 1992, o qual obteve a primeira colocação' (figuras 2 e 3). Havia, na época, uma produção pouco homogênea da arquitetura, com vertentes pós-modernas, outras modernas e outras ainda pouco entendidas. $A$ proposta apresentava grandes vãos e poucos materiais, praticamente concreto aparente e vidro, características da arquitetura brutalista paulista e, portanto, de evidente filiação com a escola de Vilanova Artigas, o que trazia algumas críticas duras daqueles que a entendiam como uma produção ultrapassada do movimento moderno. No entanto, com o passar do tempo, olhando para a produção do século XXI de Alvaro Puntoni e outros arquitetos da mesma geração e formação, inclusive alguns também participantes do concurso para o Pavilhão de Sevilha, notam-se que as referências da arquitetura paulista são aplicadas de maneira ainda mais criativa e fecunda, demonstrando maturidade e evolução profissional destes arquitetos, e superação das limitações colocadas pela crítica da época:

Ao longo dos anos de 1990, uma nova geração de arquitetos, da qual estes autores fazem parte, foi ganhando maturidade e experiência profissional, o que se reflete nitidamente em seus trabalhos, demonstrando cada vez mais uma maior adaptabilidade, mais ampla compreensão do território da arquitetura e mais acurada inteligência no uso dos materiais, cuja paleta foi ampliada de maneira criteriosa. Além disso, e mais importante ainda, esses arquitetos revelam maior adequação no manejo das referências eletivas, que parece ter passado de uma apropriação mais ou menos mimética de contribuição de seus mestres

' Equipe vencedora do primeiro prêmio: Alvaro Puntoni, Angelo Bucci e João Oswaldo Villela (autores). Colaboradores: Geraldo Vespaziano Puntoni, Edgar Dente, Fernanda Barbara, Clovis Cunha e Pedro Puntoni (historiador); França \& Ungaretti (Estrutura); e Francisco Triviño (Maquete). 
(fato aceitável e natural no entusiasmo juvenil de recém-formados), para um manejo menos literal, mais próprio e certamente muito mais criativo desse mesmo repertório, fincado na sua tradição local, ou seja, na arquitetura da escola brutalista paulista dos anos de 1960-1970 (ZEIN; BASTOS, 20I0, p. 29I).

Depois do escritório 'Arquitetura Paulista', Puntoni continua trabalhando com Angelo Bucci até 1996, ano em que seu parceiro migra para o escritório de arquitetura $\mathrm{MMBB}^{2}$, atuando no mesmo até 2002. De 2002 a 2004, Alvaro Puntoni é integrante do SPBR, escritório de arquitetura dirigido por Angelo Bucci até hoje. Neste período, é realizado o projeto da Casa em Carapicuíba (figuras 4 e 5), projeto que teve como condicionante a junção das atividades morar e trabalhar em concordância com a topografia acidentada, que acabou resultando num volume único do escritório, saltado e visto desde a rua, enquanto o restante do programa nos níveis inferiores acompanha a topografia difícil do terreno (não deixa de ser uma situação parecida ao que acontece no Simpatia 234, como poderá ser notado mais adiante).

O projeto de Carapicuíba apresenta uma estrutura em concordância com uma necessidade espacial e de divisão programática - morar versus trabalhar. Esse projeto foi publicado na edição especial da revista ProjetoDesign de janeiro de 201 I como melhor exemplar da tipologia "casa unifamiliar" nos anos $2000^{3}$, mesmo recorte temporal desta pesquisa, porém, com seleção de projetos de habitação coletiva. Só em 2004 é criado o GRUPO SP, escritório composto por arquitetos formados em diferentes momentos, numa organização flexível que admite colaborações e parcerias e que, nos últimos anos, tem participado principalmente de concursos de arquitetura. Outros autores do projeto Simpatia 234 são os arquitetos João Sodré e Jonathan Davies, o primeiro, formado também pela FAUUSP, em 2005, é membro do GRUPO SP desde a fundação até hoje, e vem colaborando em projetos de grande importância para a trajetória do escritório.

\footnotetext{
${ }^{2}$ Equipe MMBB Arquitetos iniciou suas atividades em 1990. Atualmente formado pelos arquitetos Fernando de Mello Franco, Marta Moreira e Milton Braga, teve o arquiteto Vinicius Gorgati entre seus sócios de 1990 a 1992 e, posteriormente, o arquiteto Angelo Bucci, de 1996 a 2002.

${ }^{3}$ Ver LEONÍDIO, Otávio. O túmulo do samba. ProjetoDesign, São Paulo, n.37I, jan. 20II, p. 96 e 97.
}

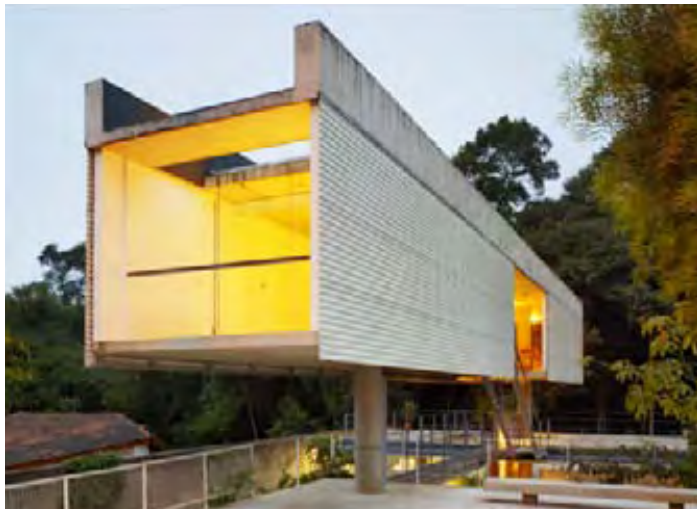

Figura 4 - Volume saltado do escritório da Casa em Carapicuíba (2003-2007).

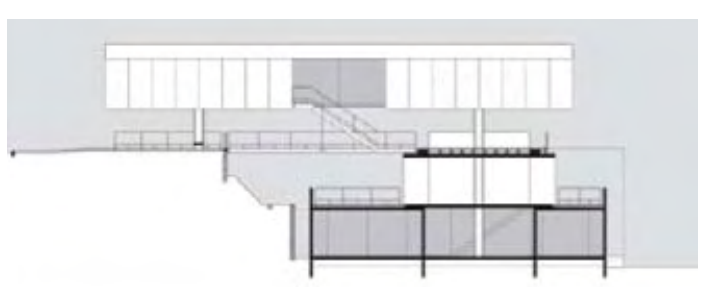

Figura 5 - Corte transversal da Casa em Carapicuíba (2003-2007).

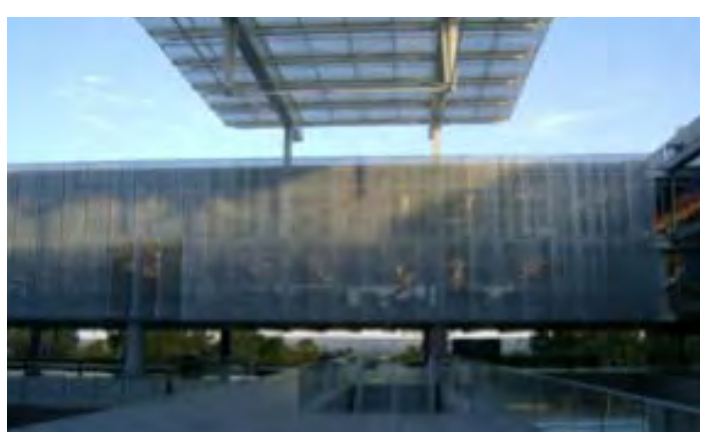

Figura 6 - Pátio interno da Sede para SEBRAE em Brasília (2008-2010). Projeto de Alvaro Puntoni, Luciano Margotto, João Sodré e Jonathan Davies. 


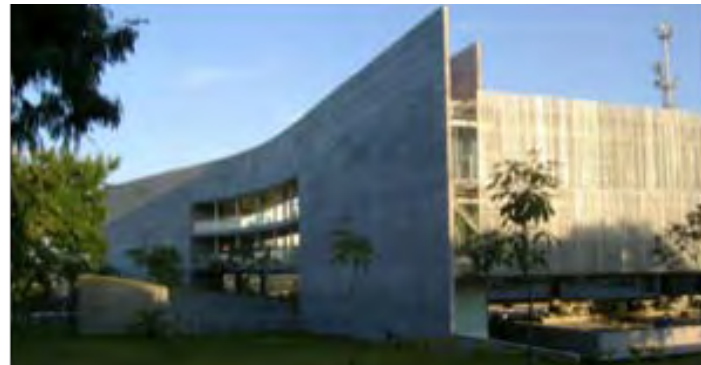

Figura 7 - Empena Estrutural em concreto moldado in loco. SEBRAE Brasília (2008-20I0).

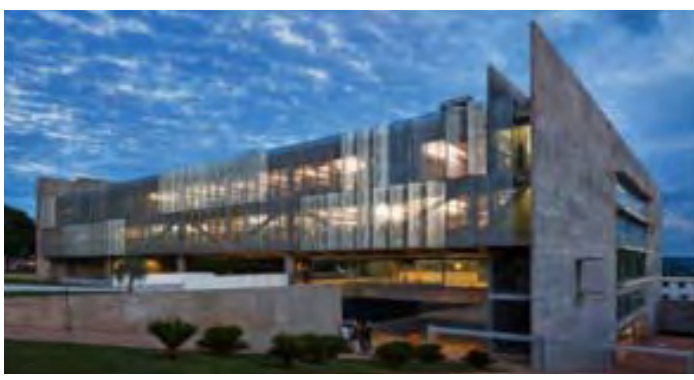

Figura 8 - Vista externa geral. Duas empenas estruturais e os painéis metálicos quebra-sóis que garantem a integridade do conjunto. Sede para SEBRAE em Brasília (2008-2010).

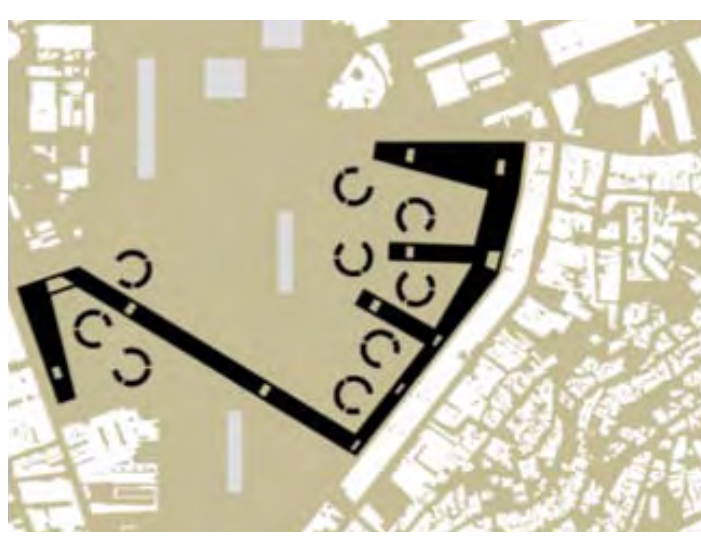

Figura 9 - Projeto para o Concurso Porto Olímpico RJ, 20I I. GRUPO SP, Republica Arquitetura, Marcos Acayaba, Libeskindllovet e Urbano.
Jonathan Davies graduou-se pela Belas Artes, em São Paulo, em 2002. Esta entidade flexível, que é o GRUPO SP, é caracterizada pela disponibilidade de associação com diferentes arquitetos e outros profissionais, o que permite uma atuação aberta a novas perspectivas de possibilidades de trabalhos.

Também acreditam na importância dos concursos de arquitetura como forma de debate arquitetônico e possibilidade de inserção profissional, da mesma forma que acreditam no exercício da profissão com a perspectiva de sua discussão e publicação possível no ambiente acadêmico:

\begin{abstract}
É na Escola que podemos de forma criteriosa e organizada verificar hipóteses de trabalho que muitas vezes são dificilmente articuladas na vida habitual de um escritório de arquitetura. Além disso, é somente no âmbito acadêmico que podemos articular dimensões temporais que extrapolam as contingências das demandas concretas e objetivas e realizar ensaios e especulações que, sem dúvida, contribuirão na construção de espaços mais dignos (GRUPO SP, 20I I).
\end{abstract}

Esta equipe flexível vem realizando uma arquitetura de qualidade e também de compromisso urbano. $O$ escritório do Arquiteto Luciano Margotto ${ }^{4}$, República Arquitetura, é uma parceria frequente. Desta associação foram concebidos, por exemplo, o projeto da sede para a SEBRAE em Brasília (figuras 6, 7 e 8), em 2008, do qual obtiveram a primeira colocação no concurso nacional; o projeto, também promovido via concurso, para o Porto Olímpico do Rio de Janeiro (figuras 9 e 10), em 20II, que contou também com o Arquiteto Marcos Acayaba e o escritório Libeskindllovet na equipe; também mais recentemente, estão desenvolvendo para a Secretaria de Habitação da prefeitura de São Paulo (SEHAB) projetos em pequenos retalhos urbanos, para provisão de novas unidades habitacionais, dentro dos limites da Operação Urbana Consorciada Água Espraiada (OUCAE) (figuras II, 12 e 13). Não apenas o GRUPO SP, mas outros escritórios de São Paulo reconhecidos, por exemplo, nas mídias especializadas em arquitetura, estão sendo contratados pela SEHAB, revelando uma postura de mudança nos projetos de interesse social de promoção pública, com projetos

${ }^{4}$ Luciano Margotto Soares integrou o escritório 'Núcleo de Arquitetura', fundado em 1989 por três arquitetos formados em 1988 na FAUUSP, ele próprio, Marcelo Luiz Ursini e Sergio Luiz Salles Souza. Em 2010 fundou o República Arquitetura, onde atua. 
que fogem de padrões pré-estabelecidos, que passam a ser, em muitos casos diferenciados, pela própria plástica do edifício, como nestes casos da Operação Urbana Água Espraiada, também por sua escala de implantação: pequenas infiltrações em retalhos urbanos de interesse social, em zonas bem localizadas e valorizadas na cidade:

\begin{abstract}
Mesmo cara, não significa que essa estética seja inacessível. Ela começa a aparecer em regiões periféricas, por meio da prefeitura. Elisabete França, da Sehab, tem trabalhado com arquitetos que também assinam projetos de design arrojado no setor privado, como Vinicius Andrade e Marcelo Morettin; Marina Acayaba e Juan Pablo Rosenberg, do AR Arquitetos; Alvaro Puntoni, do Grupo SP; e Fernanda Barbara e Fábio Valentim, do Una (TEIXEIRA, 20I2).
\end{abstract}

A maioria dos arquitetos e escritórios citados na frase acima já realizaram trabalhos para a Idea!Zarvos, deste modo, acredita-se que a SEHAB esteja propondo algo parecido ao que a Idea!Zarvos vem realizando, chamando bons arquitetos para realizar os projetos em busca de uma arquitetura autoral, diferenciada, não mais neutra e pasteurizada. Este é o atual momento que estamos vivendo na arquitetura paulista, no qual o GRUPO SP mostra-se presente e muito atuante.

\subsubsection{AGENTES}

O projeto do Edifício Simpatia 234 foi encomendado pela Idea!Zarvos Idea e, segundo Otávio Zarvos (2009), de todos os empreendimentos da Movimento Um, é o de linguagem mais modernista e mais característico da escola paulista de arquitetura, por possuir ênfase estrutural e empenas laterais contrapostas às fachadas envidraçadas, pelo painel artístico de Andrés Sandoval, pela busca do prisma puro, entre outras características que podem ser observadas. Ao mesmo tempo, a escola de arquitetura paulista, do mestre Artigas, não representa a referência que Otávio Zarvos ou o próprio José Cazarin (criador da Axpe, responsável pela comercialização dos imóveis) mais apreciam, estando mais atentos à arquitetura contemporânea internacional, incluindo a produção de alguns

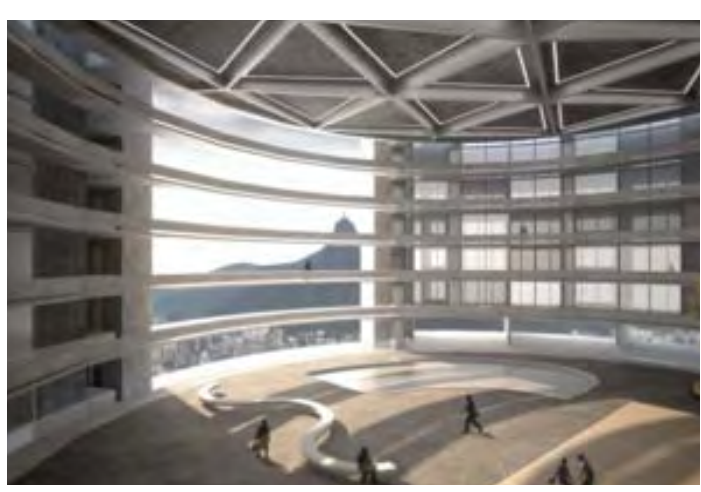

Figura 10 - Perspectiva. Projeto para o Concurso Porto Olímpico RJ, $201 \mathrm{I}$.

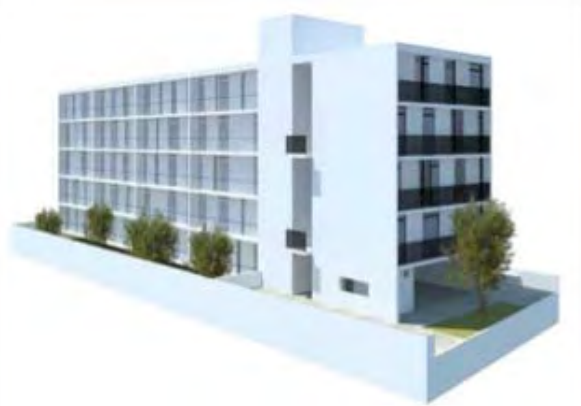

Figura I I - Projeto para SEHAB SP (20I2), Rua Porcelana, Operação Urbana Água Espraiada. GRUPO SP e República Arquitetura.

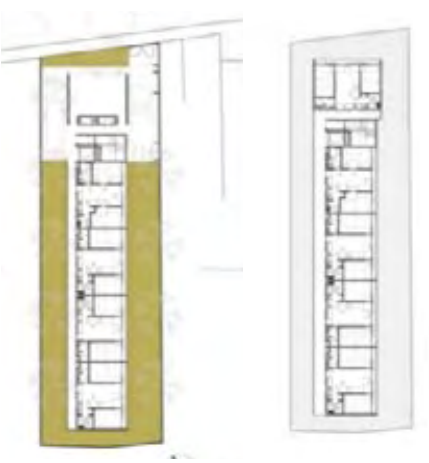

Figuras 12 e I 3 - Implantação e Pavimento Tipo do projeto para Rua Porcelana. 


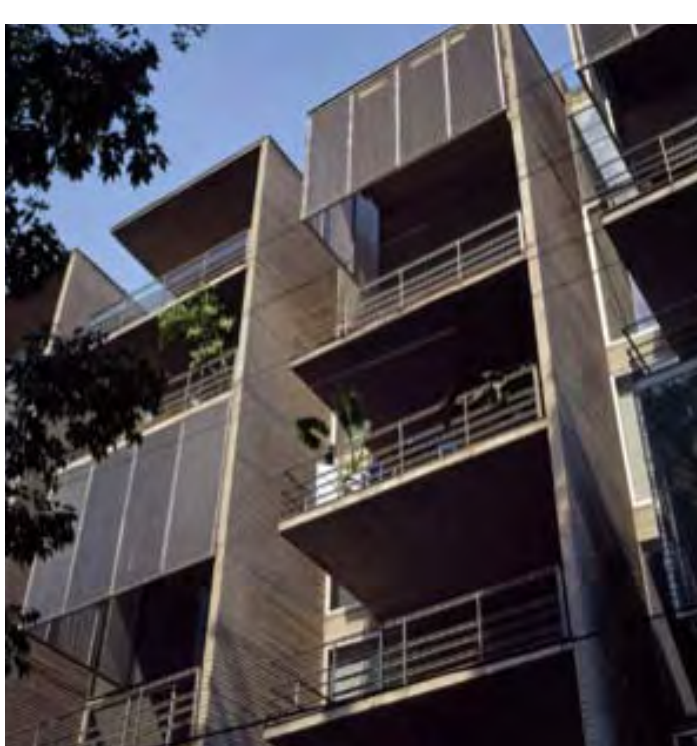

Figura 14 - Edifício Amsterdam 315, Cidade do México, 2005. JSa Arquitetura.

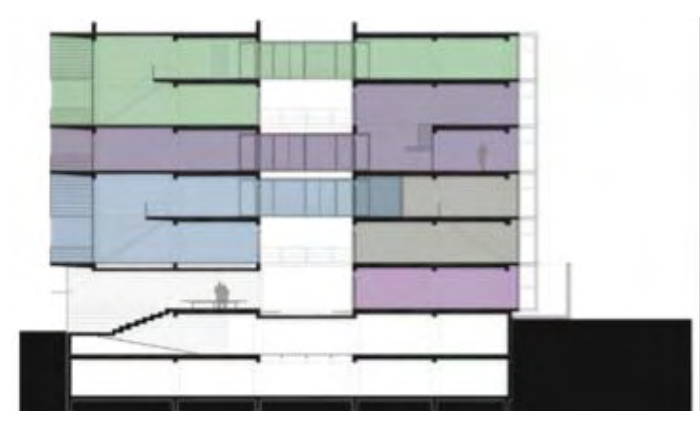

Figura 15 - Corte Edifício Amsterdam 315. países da América Latina como Chile, México e Argentina, por exemplo. Arrisco citar nomes como JSa (antes Higuera + Sanchez) no México (figuras 14 e 15) ou Adamo-Faiden Arquitectos da Argentina, entre outros escritórios que possuem trabalhos publicados em revistas especializadas em arquitetura, como a SUMMA+ ou o 30-60 cuaderno latinoamericano de arquitectura, por exemplo.

Zarvos atribui a procura a um "enriquecimento cultural” de parcela dos brasileiros, que leem sobre arquitetura e design em sites, livros e revistas internacionais e valorizam o desenho em produtos de tecnologia como os da Apple. Cazarin, que viaja constantemente para países próximos como Argentina, México e Chile para acompanhar as novidades arquitetônicas, diz que há "prédios maravilhosos" sendo construídos ali e no mundo todo (PIZA, 2009).

O segundo projeto do GRUPO SP pela Idea!Zarvos foi o Itacolomi 445 (figura 16), em Higienópolis, um edifício de apenas seis unidades e todas com pé-direito duplo, também com possibilidade de reformulação da planta, entre outras características comumente solicitadas por este empreendedor. Mesmo a Idea!Zarvos solicitando ou definido algumas questões do projeto - como, por exemplo, a proporção dos espaços para uso coletivo, o uso privativo da cobertura, o número de vagas e a posição das garagens, o número de unidades e a metragem delas e, inclusive, a flexibilidade total da planta - ainda assim existe liberdade para se propor uma boa arquitetura.

Porém, os arquitetos afirmam que houve mais liberdade no primeiro projeto, Simpatia 234, do que no segundo em Higienópolis. A liberdade acessível pode ter uma relação com o Bairro: um concentra um grande número de artistas, bares etc., por isso é popularmente conhecido como um bairro “descolado", enquanto o outro, Higienópolis, é mais íntegro ou brioso, além de ser um território que a Idea!Zarvos não domina tanto como a Vila Madalena. 


\subsubsection{PERFIL DOS MORADORES}

O perfil de cliente da Idea!Zarvos é predominantemente jovens, solteiros ou casais, com nível superior e bem resolvidos profissionalmente. É um tipo de público que se interessa por design e que consome produtos por sua contemporaneidade. Esta é uma característica que acompanha todos os projetos realizados pela Zarvos, incluindo o Simpatia 234.

Por serem obras conceituais, com projetos únicos, mais complexos e, portanto, mais caros, elas estão restritas a incorporadoras recentes, de pequeno e médio porte. O público alvo também é diferente: os compradores são pessoas interessadas em design e que podem pagar $\mathrm{R} \$$ I milhão por um apartamento de $100 \mathrm{~m}^{2}$ (TEIXEIRA, 20I2).

\subsubsection{INSERÇÃO URBANA}

\begin{abstract}
Uma ideia que aproxima os arquitetos em São Paulo é a construção do vazio.A cidade que moramos e vivemos é marcada por sua densa ocupação que dificulta a percepção seja de sua topografia original, seja dos seus poucos espaços não ocupados, sobretudo aqueles definidos e configurados pelo sítio original, pelos fenômenos geográficos, o assoalho primitivo. Um dos desafios para os arquitetos paulistas neste século talvez seja insistir a construção do vazio como quem abre clareiras e possibilitam novas dimensões e espaços para o convívio em nossa cidade (GRUPO SP, 20I I).
\end{abstract}

O Simpatia 234 está localizado no Vale do Córrego Verde, regato hoje canalizado que, neste trecho em especial, passa sob a Rua Medeiros de Albuquerque (figura 17). Está sendo desenvolvido no momento, com participação da Associação do Bairro, um plano urbanístico para a Vila Madalena (figura 18) que tem como conceito principal um parque linear que acompanha a várzea deste rio, sendo o desenho dos percursos uma metáfora do antigo leito.

O plano está sendo desenvolvido pelo escritório novaiorquino Davis Brody Bond em parceria com a própria Idea!Zarvos, que teve a iniciativa do plano devido à quantidade de empreendimentos

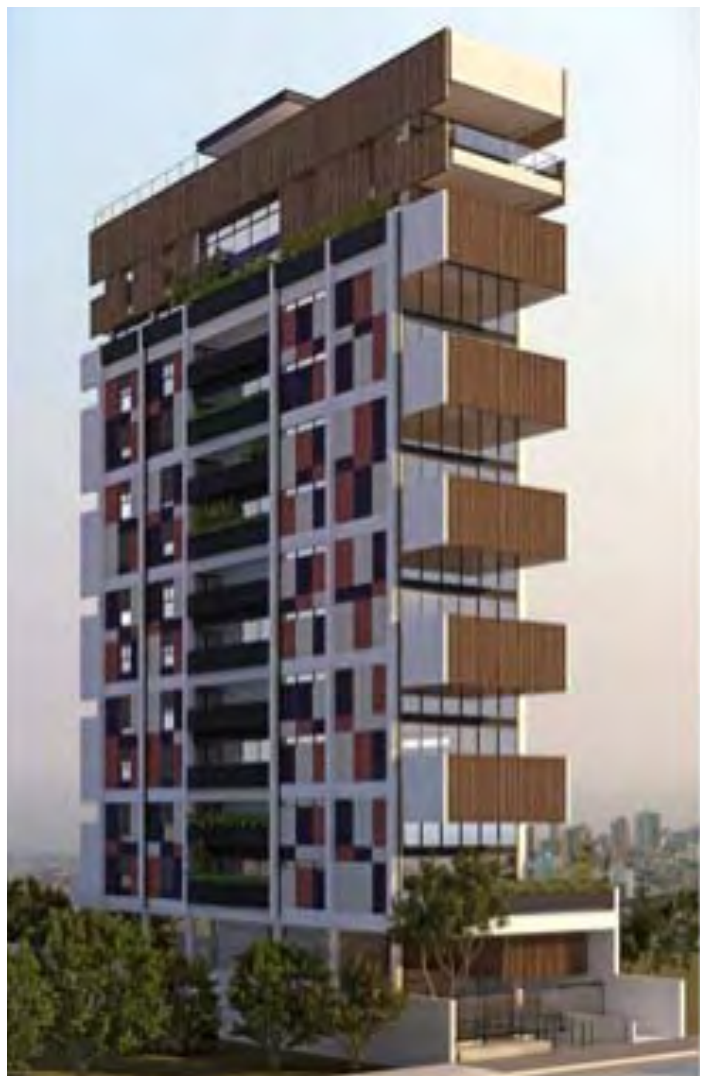

Figura 16 - Edifício Itacolomi 445 em Higienópolis, São Paulo. GRUPO SP e Zarvos (2012). 


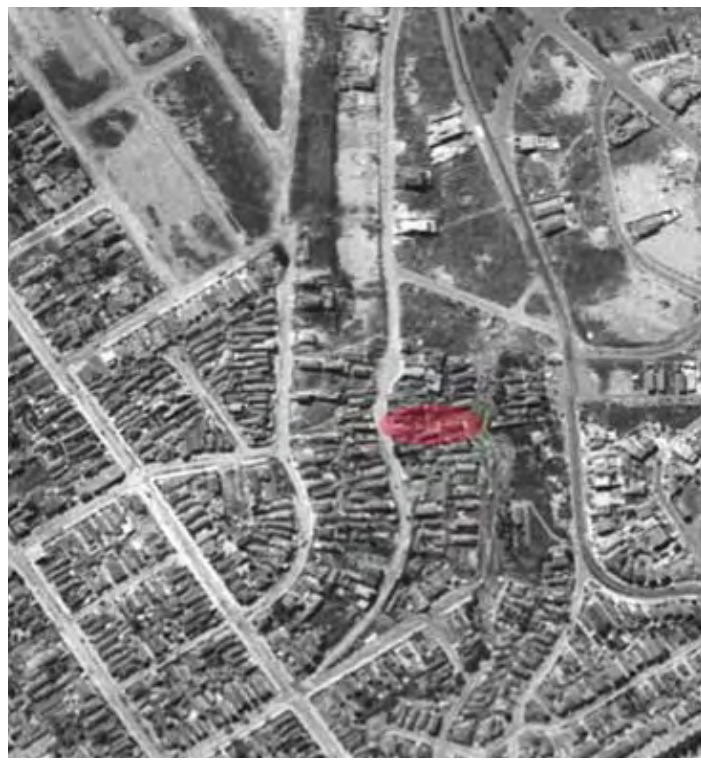

Figura 17 - Foto aérea Vila Madalena (1958),

Destaque do local onde está hoje o edifício Simpatia 234 e o leito original do Córrego Verde.

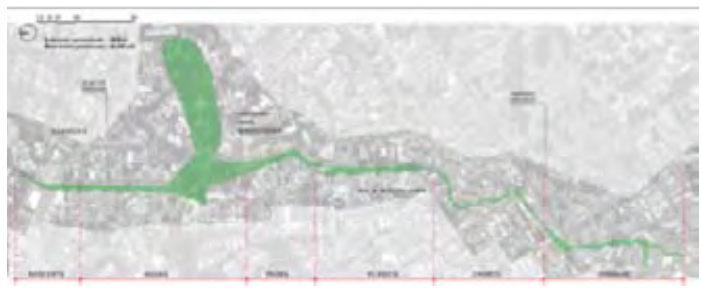

Figura 18 - Plano de Davis Brody Band para a Vila Madalena (2012). que lançaram na região nos últimos anos, como uma maneira de responder positivamente àqueles que estão preocupados com a verticalização excessiva no bairro.

Com relação à ocupação do entorno próximo ao Simpatia 234, de acordo com o PDE da cidade de São Paulo5 , o edifício está situado em zona mista de média densidade, em constante transformação, já que muitas casas unifamiliares estão sendo substituídas por habitação coletiva, como é o caso deste projeto. $O$ edifício Simpatia 234 está próximo à divisa com o bairro Jardim das Bandeiras, zona exclusivamente residencial de baixa densidade.

Em contraposição, é possível avistar desde as aberturas do edifício, uma zona mais verticalizada, de alta densidade, que fica entre as ruas Rodésia, Girassol, Wisard e Jericó, mostrando as variações morfológicas e de ocupação presentes nesse trecho do bairro, de casas que ainda resistem a serem transformadas em prédios, e outros trechos já transformados (figura 19 e 20).

A paisagem do bairro da Vila Madalena é uma paisagem em transformação. Do alto
do edifício da rua Simpatia pode-se admirar um de seus vales, ainda com muitas áreas
verdes, uma boa quantidades de casas e algumas construções mais altas. É um bairro
que guarda uma escala própria: a da proximidade com a rua (TRONCOSO, 20I I).

Com relação à escala de proximidade com a rua, colocado por Troncoso (201 I), é possível perceber uma perda de sua força no bairro, e vários problemas que levam a isso foram apontados no plano do Bairro em elaboração. Por exemplo, são apontadas: a falta de qualidade nos trajetos peatonais devido, por exemplo, à supremacia do carro em detrimento do pedestre; a falta de infraestrutura urbana; as ruas degradadas e com declividade acentuada; a característica dos quarteirões grandes; entre outros fatores que inibem a circulação dos pedestres. Outra questão são os espaços públicos em más condições, podendo citar como exemplo praças não ativadas ou subutilizadas. Mas a descaracterização das ruas e fachadas (street wall) deve-se, principalmente, à construção de novos prédios na região, mais verticalizados, porém, sem mudança na estrutura viária.

${ }^{5}$ Lei Municipal 13.430/02 - Plano Diretor Estratégico de São Paulo e Lei Municipal I3.885/04 - Plano Regional Estratégico. 
Goulart (2010, p. 16) fala sobre essa questão de obras do presente estarem inseridas em tecidos do passado, afinal, mudanças do traçado urbano acabam sendo frutos de uma adaptação mais lenta. $O$ bairro da Vila Madalena está se transformando sem mudar seu viário, o que pode ser uma situação problemática à medida que é preciso verificar se a compactação a partir do uso máximo dos coeficientes de aproveitamento de uso e ocupação do solo, previsto pelo plano diretor, está em concordância com a capacidade de fluidez das vias existentes. "Em cada época, a arquitetura é produzida e utilizada de um modo diverso, relacionando-se de uma forma característica com a estrutura urbana em que se instala" (GOULART, 2010, p.15).

O terreno, no qual está implantado o edifício Simpatia 234, foi originado da junção de três matrículas, nas quais anteriormente existiam casas unifamiliares. Numa primeira versão do projeto, o lote era reduzido e voltado apenas para a Rua Simpatia, já num segundo momento, ganha mais área com a inclusão da matrícula voltada para a Rua Medeiros de Albuquerque. $O$ novo terreno resultante desta junção tem frente para duas ruas, Simpatia, definida como a frente principal, e Rua Medeiros de Albuquerque. Sua topografia é acidentada, e com declividade em direção ao fundo do Vale, ou seja, para a Rua Medeiros de Albuquerque.

Este tipo de terreno com frente para duas ruas criou uma nova possibilidade de inserção do projeto na paisagem, fez com que a implantação em corte fosse vinculada às características do lugar, afinal há uma conexão física entre as cotas das ruas com desnível de oito metros entre elas, mas também uma conexão visual, permitida pela criação de um térreo transparente e permeável. $O$ partido de implantação é diferenciado do que comumente é proposto em situações como esta, onde uma face acaba se tornando fundo delimitado por grande muro, como se não existisse um trecho de cidade voltada a ela, e ainda tornando a calçada pouco acolhedora para o transito de pedestres. Somente na quadra do edifício Simpatia 234 e na quadra da frente, entre a Rua Simpatia e Madalena, é possível identificar três situações como esta descrita, uma delas, inclusive, em projeto promovido pela própria Idea!Zarvos, construído em 2005, o 'Roof Madalena' (figura 21), do escritório de arquitetura Rocco Associados:"Eu me envergonho de um edifício que fiz: o terreno tinha duas ruas e

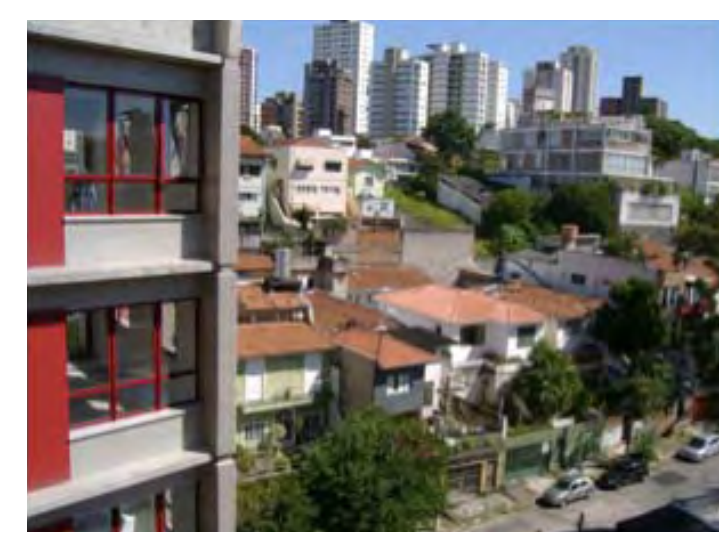

Figura 19 - Edifício Simpatia 234 em primeiro plano. Ao fundo, zona verticalizada que avança aos poucos sobre casas unifamiliares.

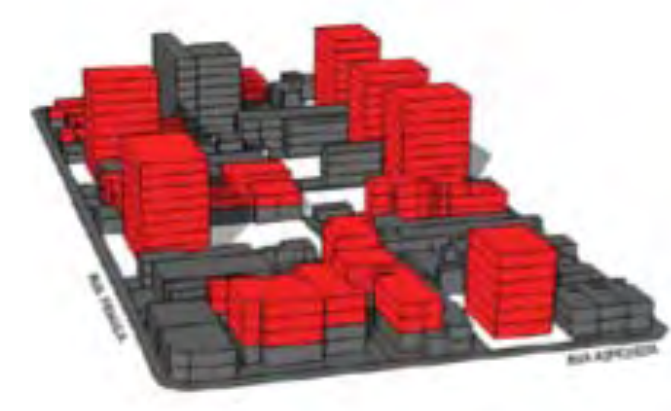

mex mabeses

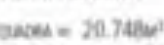

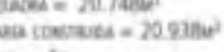
ca.ts

vis masesion Masulucto do nonescia: consturativo maveus cas $=2 \mathrm{x}$

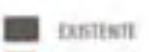

- imuspo

Figura 20 - Potencial construtivo. Plano para a Vila Madalena de Davis Brody Band (20I2). 


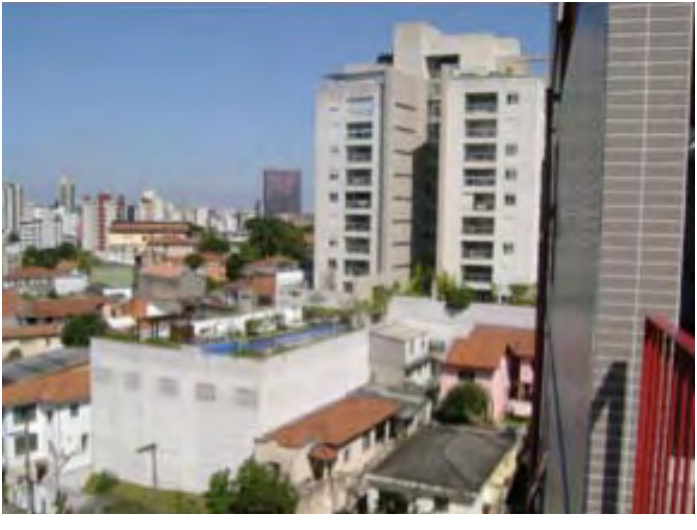

Figura 2 I - Edifício Roof Madalena (2003-

2005) Rocco Associados, promovido pela Zarvos.

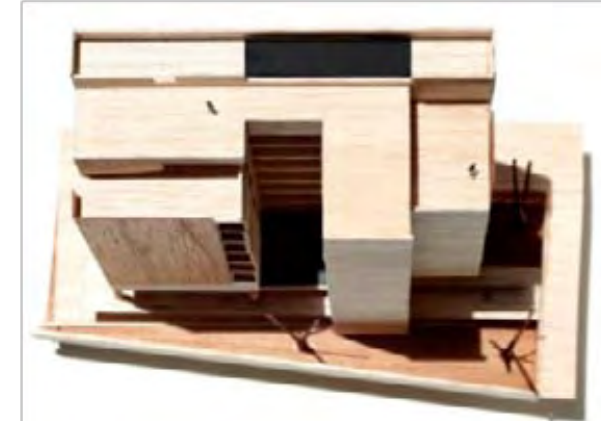

Figura 22 - Primeira versão do Simpatia 234, antes da junção da terceira matrícula.

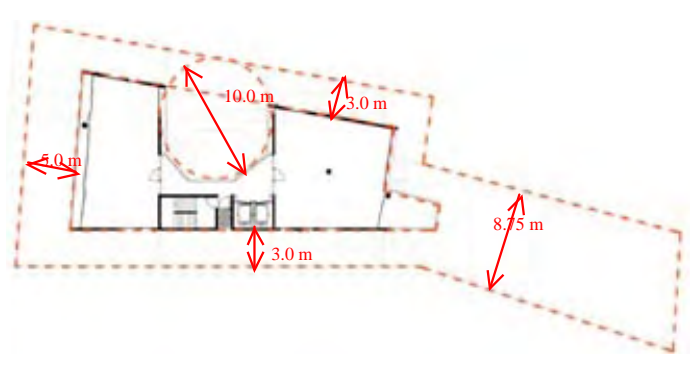

Figura 23 - Regras de uso e ocupação do solo interferiram no formato do edifício. aquela que não dava acesso à edificação ficou com um muro enorme. Para mim, era o fundo, mas hoje sei que é parte da cidade. Quando passo por lá até viro a cara" (Otávio Zarvos, em SERAPIÃO, 2009, p. 73).

\subsubsection{PARTIDO DE IMPLANTAÇÃO}

Numa primeira versão do projeto, o lote era reduzido e voltado apenas para a Rua Simpatia, proporcionando um edifício mais compacto e com ângulos retos (figura 22). Após adição do terreno voltado para a Rua Medeiros de Albuquerque, o desenho torna-se irregular e diretamente relacionado ao contorno do lote e aos recuos e espaços livres exigidos (figura 23). Este projeto é um excelente exemplo de como o atendimento a determinadas regras da legislação pode interferir diretamente no partido, inclusive o vazio entre os dois blocos e o formato do hall de acesso aos apartamentos é consequência da regra que diz que é preciso área livre com diâmetro de dez metros para insolação e aeração mínimas. Porém, isto não significa dizer que qualquer arquiteto que se deparasse com esses dados chegaria numa mesma solução.

As pré-existências foram condicionantes mais significativas para este projeto: - a topografia, o próprio traçado da quadra, os limites do lote e os cheios e vazios das construções vizinhas (figuras 24 e 25). A consideração das pré-existências na definição do projeto é algo corrente no trabalho do escritório, como pode ser observado com mais intensidade, por exemplo, na proposta para o Porto Olímpico do Rio de Janeiro, de 201 I (figura 9).

Para o caso do Simpatia, o gabarito de altura e escala acaba não sendo proporcional às construções vizinhas, porém, a base, formada pelos térreos, faz uma adequação gradual da escala das construções vizinhas com a deste edifício para não gerar contrastes muito grandes.

A possibilidade de conexão e a intenção de visibilidade em direção ao vale tiveram como consequência um vazio no térreo, assim como sua duplicação, separando o edifício da base mais sólida do bloco de habitação mais evidente. Esses dois térreos passam uma noção de espaço único, isto devido à presença de vazios e árvores que unem os dois pavimentos (figura 26). 
O pátio interno, ou espacialidade interior criada a partir da disposição do conjunto, é o local mais relacionado com o espaço público da cidade, mesmo que visualmente, como é o caso deste edifício de habitação coletiva. $O$ pátio, como térreo duplicado, é um elemento criado com frequência nos projetos de Puntoni e do Grupo SP.

A criação do amplo vazio volumétrico que acaba por duplicar térreos é característica marcante da arquitetura brutalista paulista, bem representada pelo próprio prédio da FAUUSP', de 196I.Alvaro Puntoni dissemina estas características em seus projetos, sendo o vazio um espaço de passagem, de ampliação do espaço público e local de integração de programa, conforme pode ser reforçado no memorial dos projetos da sede do SEBRAE nacional e também na sede da CAPES (figura 27), ambos em Brasília. No caso do Simpatia 234, mesmo não sendo um trajeto público, por questões de determinação do cliente, acaba por criar-se esta permeabilidade de tal maneira que seja possível senti-la desde a rua, mesmo sem cruzar o terreno até o outro extremo.

São dois térreos. Optou-se por abrir um plano construído abaixo do nível da soleira, integrando-o verticalmente ao nível dos acessos, como térreos multiplicados, iluminados e ventilados pelo espaço livre que os circunscrevem, o que lhes concede expressão arquitetônica. O chão do edifício, público, é construído, portanto, distinto do terreno natural que o circunda, destinado às áreas verdes permeáveis (GRUPO SP, sobre sede SEBRAE em Brasília).

Uma estrutura aérea e outra subterrânea permitem a construção de um vazio horizontal que corresponde ao espaço da passagem, a construção de uma superfície de convergência que amplia o chão da cidade. No plano tipológico, a proposta confirma a inteligência das condições de natureza urbanística preexistentes. Mantém a silhueta estabelecida no entorno. Faz referência clara à paisagem e emancipa-se ao trata a reconstrução das divisas, com praça rebaixada, pontes e vazios orientando a solução da implantação (GRUPO SP, sobre sede CAPES em Brasília).

\footnotetext{
${ }^{6}$ Projeto prédio da FAUUSP na cidade universitária:Vilanova Artigas e Cascaldi, 1961.
}

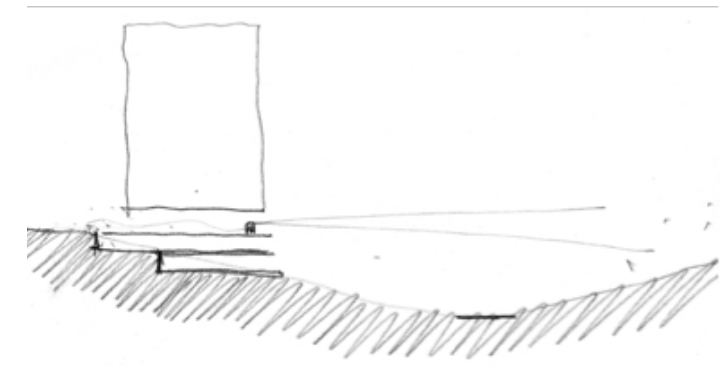

Figura 24 - Partido de implantação. Considera a relação da topografia com principais visuais.

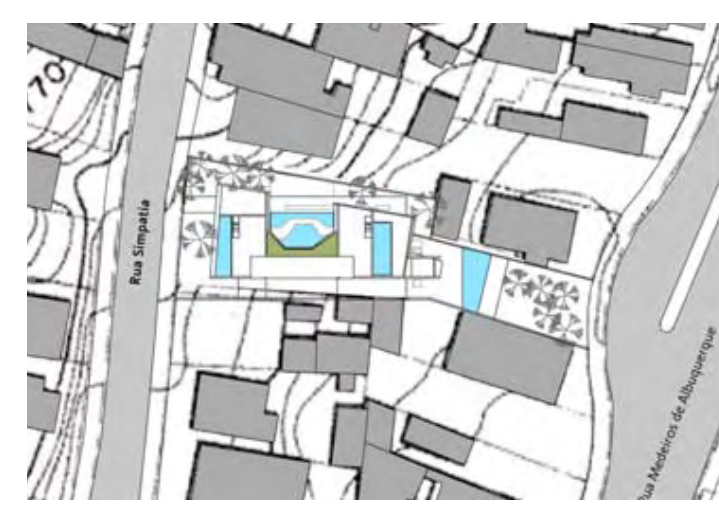

Figura 25 - Partido de implantação. Considera as pré-existências das construções vizinhas.

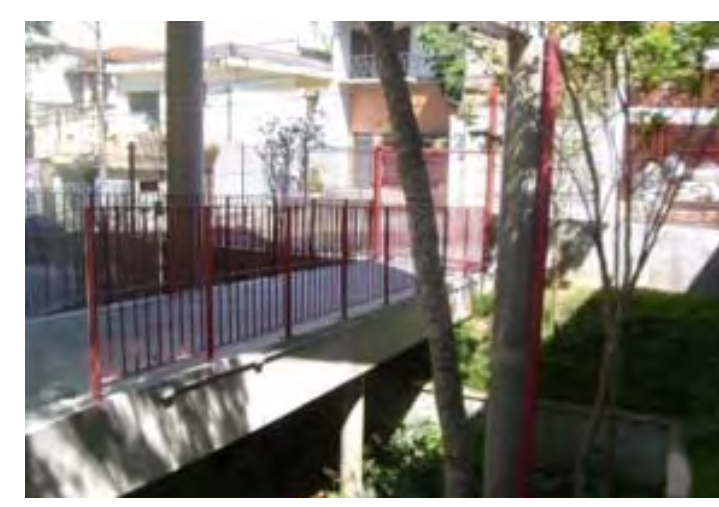

Figura 26 - O térreo com visibilidade para a rua e duplicado com o subsolo. 


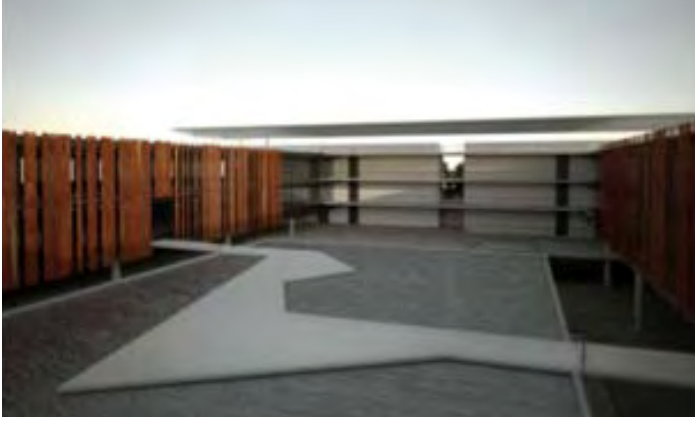

Figura 27 - Projeto CAPES Brasília, 2007. Menção honrosa. GRUPOSP e Republica Arquitetura.

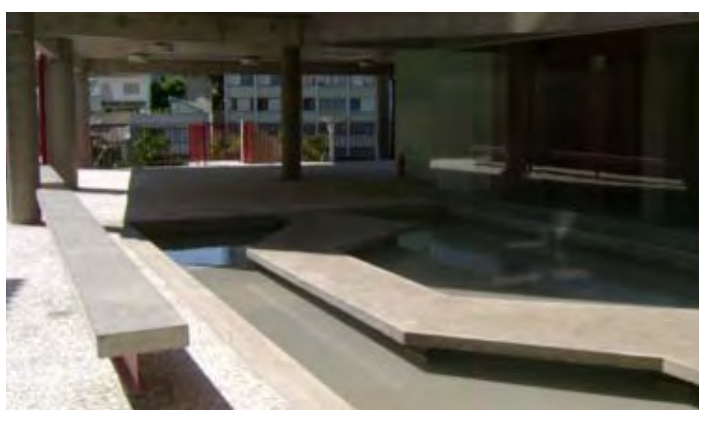

Figura 28 - Espelho d'água do Simpatia 234. Característico dos projetos do GRUPO SP.

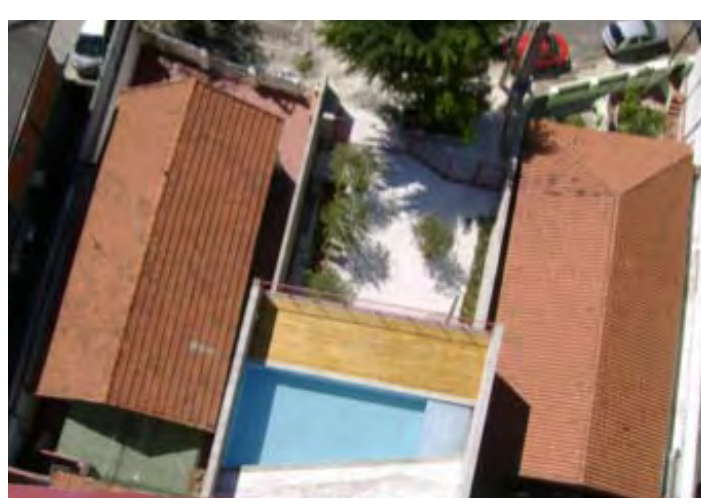

Figura 29 - Pracinha "generosidade urbana", conforme autores. Rua Albuquerque Medeiros.
A visibilidade da Rua Simpatia para o interior do lote e o cuidado em permitir que visuais sejam aproveitados não apenas pelos moradores como também pelos pedestres representam uma contribuição à cidade. Outra situação de contribuição urbana é na Rua Medeiros de Albuquerque, na qual o gradil é afastado aproximadamente cinco metros do limite do terreno e uma área com banco e sombra é oferecida ao público (figura 29), segundo os arquitetos, uma generosidade urbana.

\subsubsection{ESPAÇOS EXTERIORES}

O edifício é dividido em dois blocos - Simpatia e Medeiros - e o espaço de acesso às unidades, um lugar aberto denominado pelos arquitetos de "varanda de convivência", destaca-se por ser todo aberto e com piso tipo mosaico português igual aos dois térreos, representando, portanto, uma continuidade do espaço de uso comum do pavimento térreo (figura 30). $O$ alargamento em direção aos acessos das unidades reforça ainda mais uma intenção de aproximação entre vizinhos ou de valorização do coletivo ao extremo. Tal situação é diferente da existente na Vila Fidalga, por exemplo, onde surge um espaço que filtra as relações entre o coletivo e o privado à medida que se vai aproximando do acesso à unidade, ou como ocorre, também de maneira similar, no edifício $4 \mathrm{x}$ 4, do arquiteto Gui Mattos (figura 3I).

É muito perceptível o quanto os arquitetos incentivam os espaços coletivos no projeto. Esta valorização fica evidente com a criação de lavanderia coletiva, com relação direta ao jardim da Rua Medeiros de Albuquerque. Para desprazer dos arquitetos, essa lavanderia não foi executada e todos os moradores optaram por lavanderia dentro do apartamento. Outra situação que cogitaram inicialmente, e que logo foi descartada pelo contratante, foi a de fazer da cobertura uma área de uso coletivo. A cobertura representa um potencial de venda ainda maior quando integrada às unidades do último andar, assim, esta possibilidade foi eliminada sem muita discussão ou dúvida por parte da Idea!Zarvos. Portanto, é preciso entender que os arquitetos seguem determinações mercadológicas, e mesmo cumprindo-as conseguem uma arquitetura superior em qualidade e diferenciada da oferecida pelo mercado imobiliário mais comum. 
No caso deste projeto, os espaços de uso coletivo não são o grande atrativo de vendas como geralmente acontece em muitos empreendimentos da cidade de São Paulo, mas, mesmo assim, em comparação com outros projetos da Idea!Zarvos, este os valoriza mais, seja pela ampliação desta área como também pela solução que adota no pavimento térreo, de duplicação e extensão tanto no sentido vertical como horizontal.

Apenas como comparação, o edifício $4 \times 4$, também realizado pela Idea!Zarvos e pelo arquiteto Gui Mattos (figura 32), apresenta em corte uma topografia acidentada, com aclive de $13 \mathrm{~m}$ em relação ao nível da rua. Depois de definido o local de implantação da torre de habitação no fundo do lote, sabia-se que se teria de subir muito para acessar o prédio, assim, foi criado dois acessos para pedestres, um que chega até a caixa de circulação vertical do segundo subsolo e o outro que chega até o pavimento térreo por meio de grande escadaria com algumas paradas estratégicas. Com mesma tática do Simpatia 234, porém com menos intensidade, o primeiro subsolo possui aberturas que permitem entrada de luz natural e também possui vegetação que chega até o segundo subsolo, com recuos iguais aos dos pavimentos superiores e com taludes na borda. Tal situação tira o aspecto opressivo que garagens costumam ter. Ao mesmo tempo, esse efeito é sentido melhor no primeiro subsolo, e assim, justamente o pavimento que está no nível da rua (segundo subsolo), não é favorecido com intensa iluminação natural. Assim, no $4 \times 4$, o aclive do terreno não favoreceu a solução adotada, diferentemente do projeto do Simpatia 234 , que consegue integração tanto com a Rua Simpatia quanto com a Rua Medeiros de Albuquerque, além de efetivamente alcançar o efeito de iluminação nos pavimentos inferiores.

\subsubsection{UNIDADE HABITACIONAL}

A exigência da Idea!Zarvos por plantas com total flexibilidade de arranjo dos ambientes para responder desejos individuais dos moradores é atendida de maneira diferente por cada arquiteto. No caso deste projeto, existem duas unidades habitacionais por pavimentos, que são dois espaços totalmente livres e com formato irregular (resultante do próprio formato do terreno, conforme

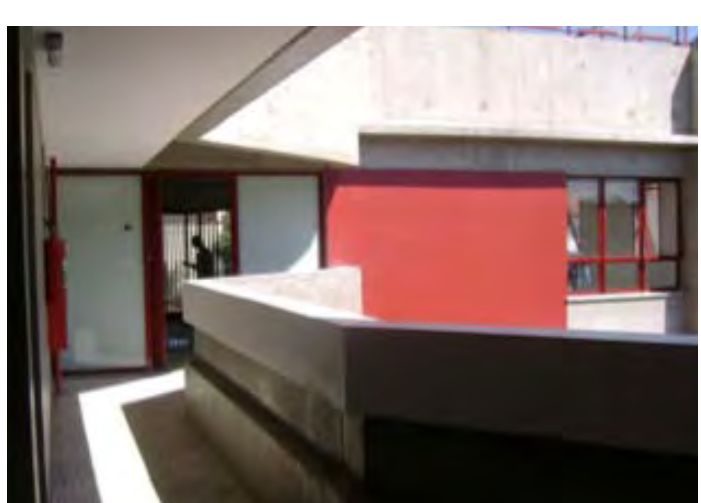

Figura 30 - Varanda de convivência.

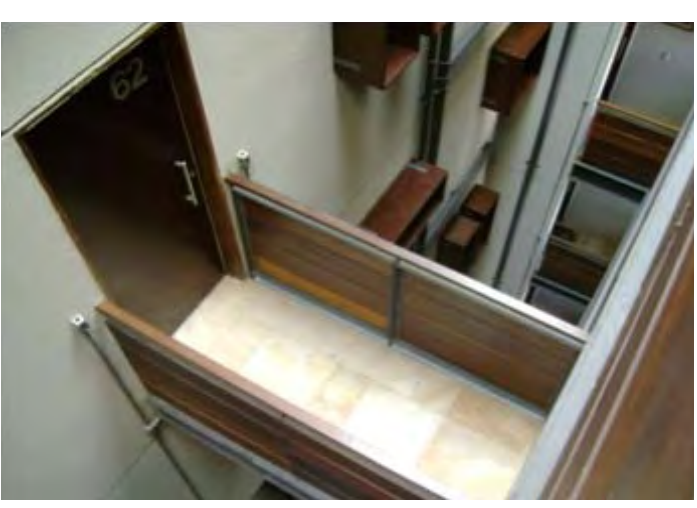

Figura 3 I - Edifício 4 × 4, Gui Mattos. Criação de um espaço mais resguardado que antecede a entrada da unidade habitacional.

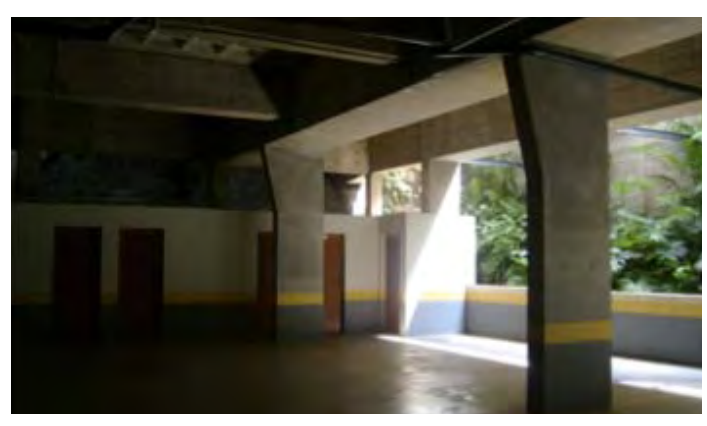

Figura 32 - Edifício $4 \times 4$. vazios desde o térreo para entrada de luz natural na garagem. 


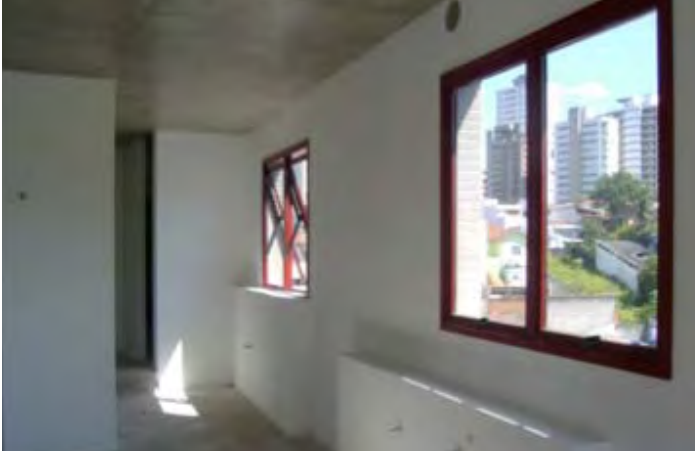

Figura 33 - Definição da posição das áreas molhadas pelo próprio morador.

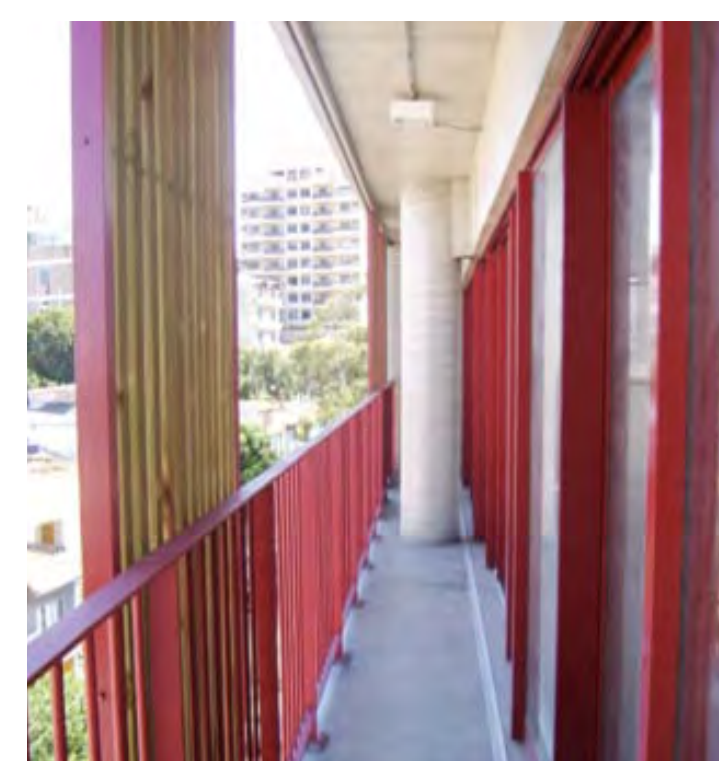

Figura 34 - Chapas de madeira dão movimento à fachada voltada para a Rua Simpatia. explicado anteriormente), mas que geram pavimentos-tipos idênticos, diferentemente do que acontece, por exemplo, no projeto Fidalga 772 do Andrade Morettin, no qual se faz ausente o pavimentotipo. Assim, o edifício possui quatro tipologias de unidades habitacionais (na verdade duas matrizes e duas variações nas unidades de cobertura a partir destas matrizes), porém, com variações de plantas que extrapolam esta quantidade, isto porque as plantas são livres, com estrutura e prumadas de água e esgoto no perímetro, junto aos pilares, o que permite que as áreas molhadas - banheiros, lavanderias e cozinhas - possam estar em qualquer lugar da planta (figura 33).

Como já foi citado em outros projetos da Idea!Zarvos, este conceito de personalização é uma solicitação comum a quase todos os seus empreendimentos, e teve início, porém, não aplicado desta maneira, no edifício Fidalga 897, da arquiteta Cristina Xavier.Trata-se de oferecer um pouco do que acontece num projeto de uma casa unifamiliar, na qual o morador acaba participando, principalmente, das decisões de distribuição do programa na casa. Trata-se do entendimento do desejo pelo não padronizado, motivo de repúdio à tipologia apartamento que muitas pessoas possuem.

\subsubsection{SISTEMA ESTRUTURAL ETÉCNICA CONSTRUTIVA}

O edifício possui estrutura convencional, moldada in loco, de concreto armado, incluindo as lajes maciças. Pensou-se, inicialmente, em utilizar laje pré-moldada em formato de cubetas, porém, o formato irregular do edifício acabou levando ao uso da laje moldada in loco.As vedações são em bloco cerâmico ou painéis de vidro. As varandas da tipologia maior são metálicas e fixadas na própria estrutura do edifício. Existem três tipos de guarda-corpo neste projeto: metálico, com barras verticais espaçadas II cm entre si; o guarda corpo em concreto armado; e, no terraço, o uso misto do ferro com vidro. Existem algumas paredes de alvenaria que lembram chapas metálicas, isto devido à pintura acrílica na cor vermelho queimado sobre massa corrida. Foi utilizada, assim, uma mescla de técnica construtiva convencional, com elementos soltos da estrutura, como é o caso das varandas metálicas, ou chapas de madeira que dão movimento à fachada principal (figura 34), ou até mesmo as próprias tubulações das instalações externas aparentes. 


\subsubsection{ENVOLTÓRIA}

Foram definidas algumas aberturas fixas nas unidades - porta de entrada, portas da varanda, etc. -, mas praticamente as duas laterais tiveram suas aberturas à mercê da definição de cada morador, estabelecendo-se apenas um módulo padrão de janela e o limite de quatro módulos por face (figura 35). Percebe-se, como resultado, uma fachada em que a aparência aleatória das aberturas remete à situação real das composições presentes nas cidades. João Sodré (201 I) comenta que seria preferível a existência de uma malha com posição fixa das janelas, na qual o morador apenas definiria qual módulo gostaria que fosse aberto ou fechado, pois, na solução adotada, foram criadas situações em que as janelas estavam deslocadas poucos centímetros entre elas no sentido vertical, não alcançando o efeito desejado.

As varandas, também elementos importantes na envoltória do edifício, contribuem para o movimento da fachada e contato com o espaço público da cidade. As cores e materiais da envoltória são fortes e heterogêneas, existindo faces com grandes trechos totalmente lisos, nas quais o vermelho tem aparência de uma chapa metálica; as varandas da fachada da Rua Albuquerque Medeiros também são vermelhas e metálicas e contribuem para o destaque ainda maior na paisagem; 0 concreto aparente (sendo este o edifício da Idea!Zarvos no qual se faz mais evidente o uso deste material, já que nos outros projetos o concreto fica aparente em raros casos, por exemplo, nos pilares em formato de "X" do Fidalga 727, do Triptyque); a fachada com revestimento cerâmico, que cria uma superfície rugosa; a madeira como brise na face leste da Rua Simpatia; o vidro, inclusive no guarda-corpo das coberturas, diferenciando-os dos guarda-corpos dos pavimentos inferiores que são metálicos; e para finalizar, um painel artístico, de $10 \mathrm{~m} \times 2,80 \mathrm{~m}$ do artista Andrés Sandoval (também formado na FAUUSP) que deixa ainda mais interessante toda a composição. Neste projeto, nas fachadas que não foram definidas pelos moradores, o uso interno não é perceptível desde o exterior; para as outras faces, a posição quase que aleatória das aberturas, deixa evidente a variação interna na disposição do programa, mostra que um pavimento é diferente do outro, quebra a estratificação horizontal do projeto devido à interferência dos moradores.

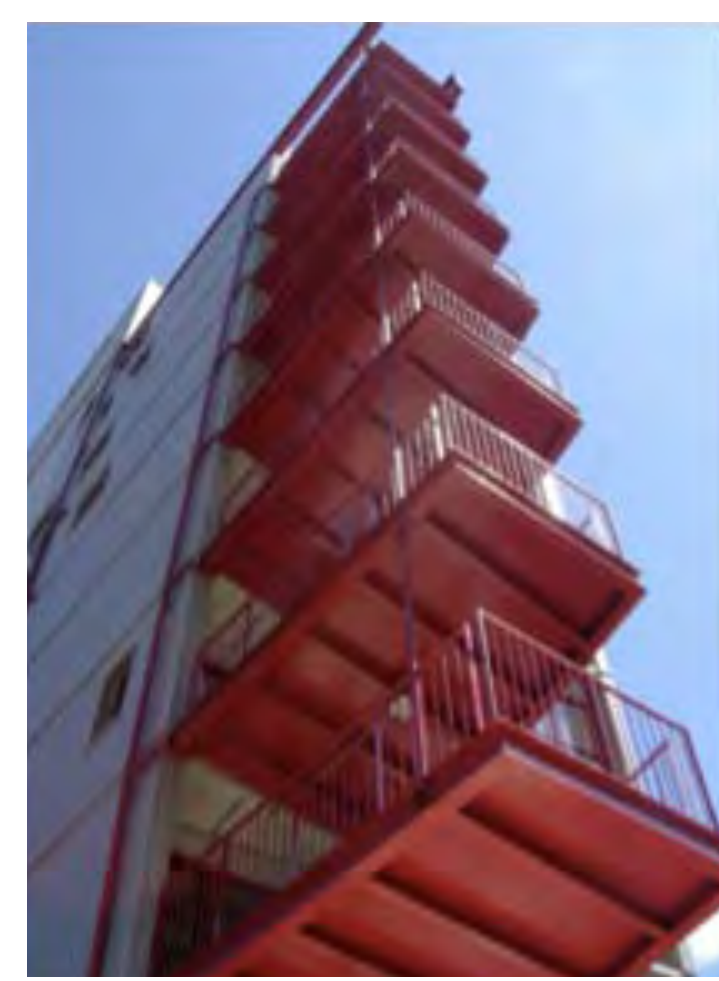

Figura 35 - Varanda metálica e aberturas (definidas pelos moradores. 


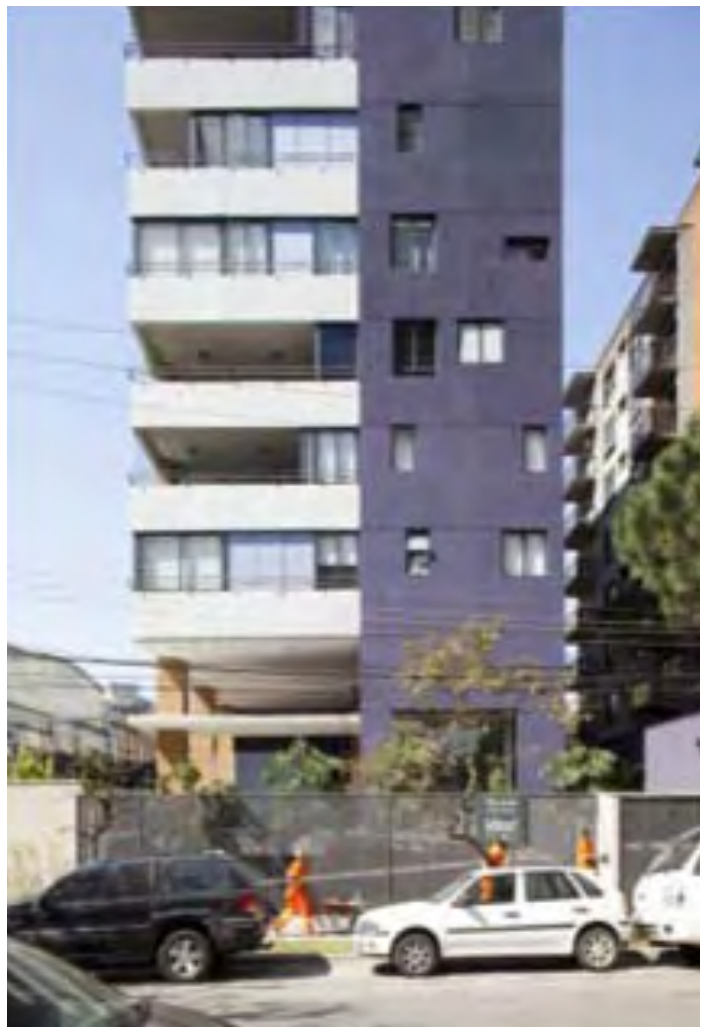

Figura 36 - Edifício Ourânia, arquiteto Gui Mattos, também com aberturas definidas pelos moradores.
Os projetos todos dão muito valor à variedade de texturas e materiais e a fachadas cheias de ritmos e recortes. Além de formas assimétricas, cores marcantes e baixa estatura, eles têm em comum a intenção de que os apartamentos tenham ótima luminosidade, jardinagem distribuída, varandas amplas e plantas flexíveis - como se fossem casas. Dificilmente há dois apartamentos iguais, pois são adaptáveis às necessidades de cada morador (PIZA, 2009).

Assim, afirmando a colocação de Zein e Bastos (2010), a paleta dos materiais e cores foi ampliada de maneira criteriosa ao longo da trajetória profissional do arquiteto Álvaro Puntoni, passando de uma apropriação mimética da contribuição dos mestres da escola paulista de arquitetura, para um manejo mais criativo do mesmo repertório, bem exemplificado neste projeto que consegue criar uma situação de composição que representa uma evolução e amadurecimento da escola paulista de arquitetura em sua essência. 



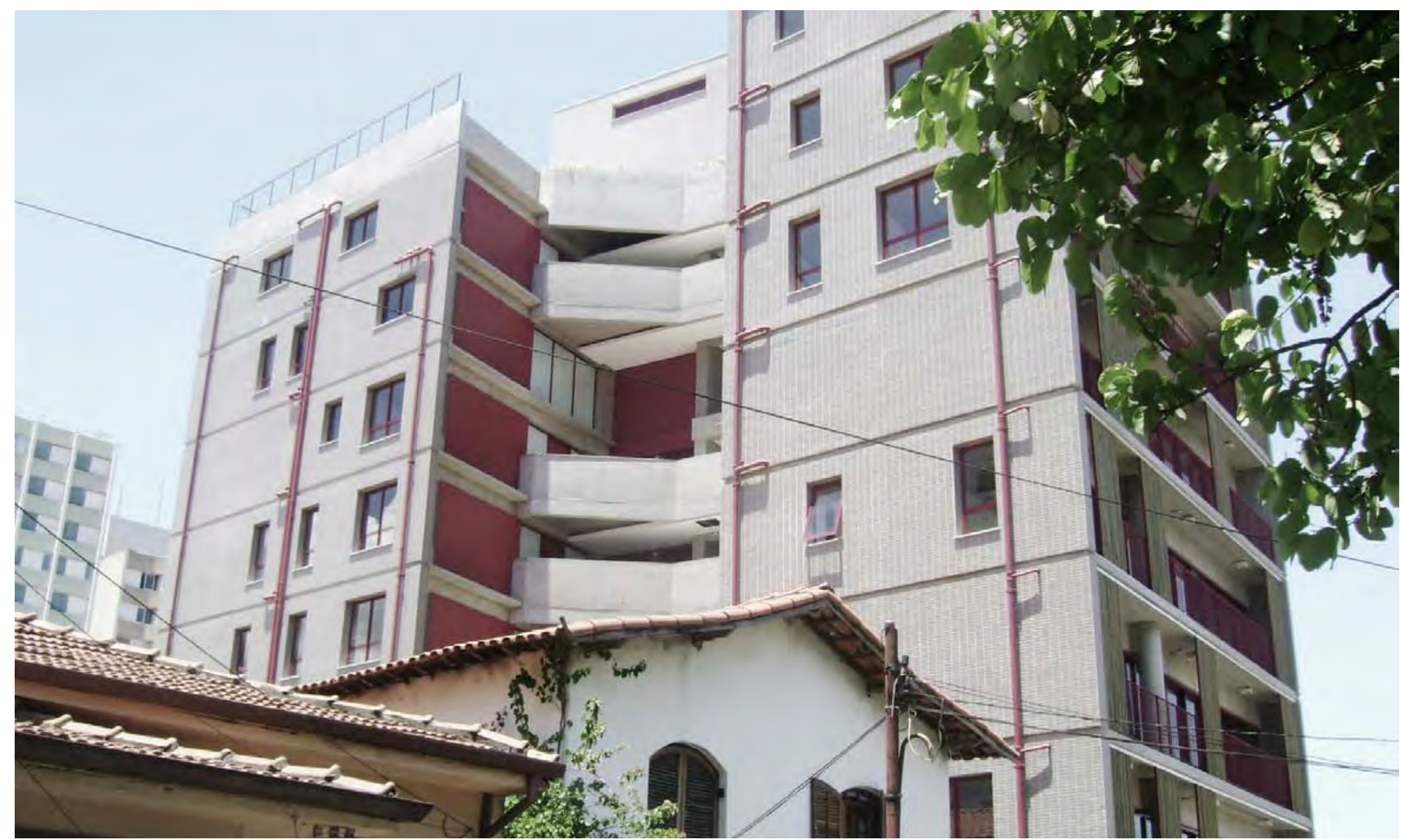

3.3.2.10 FICHAS GRÁFICAS EM ESCALA 


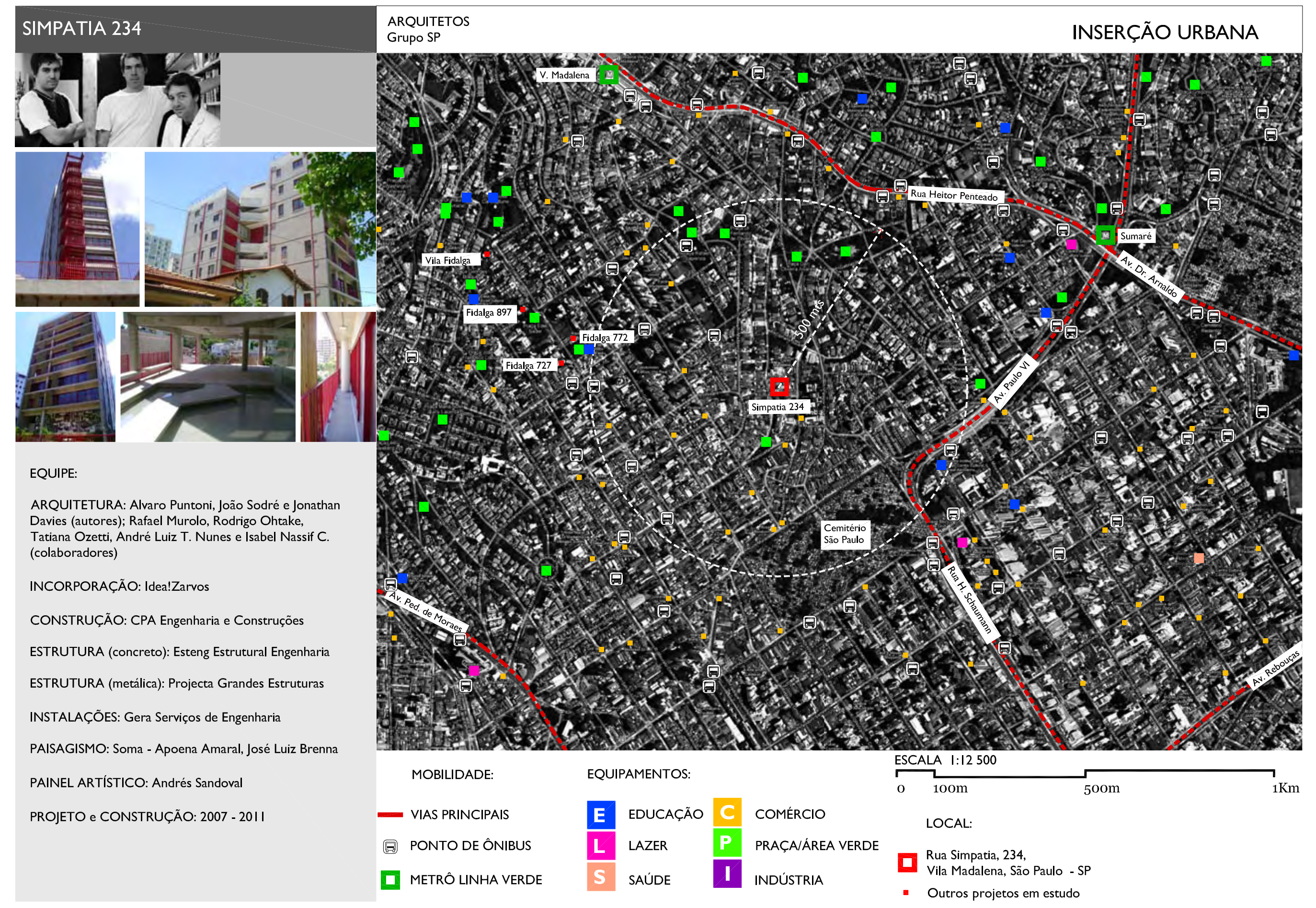




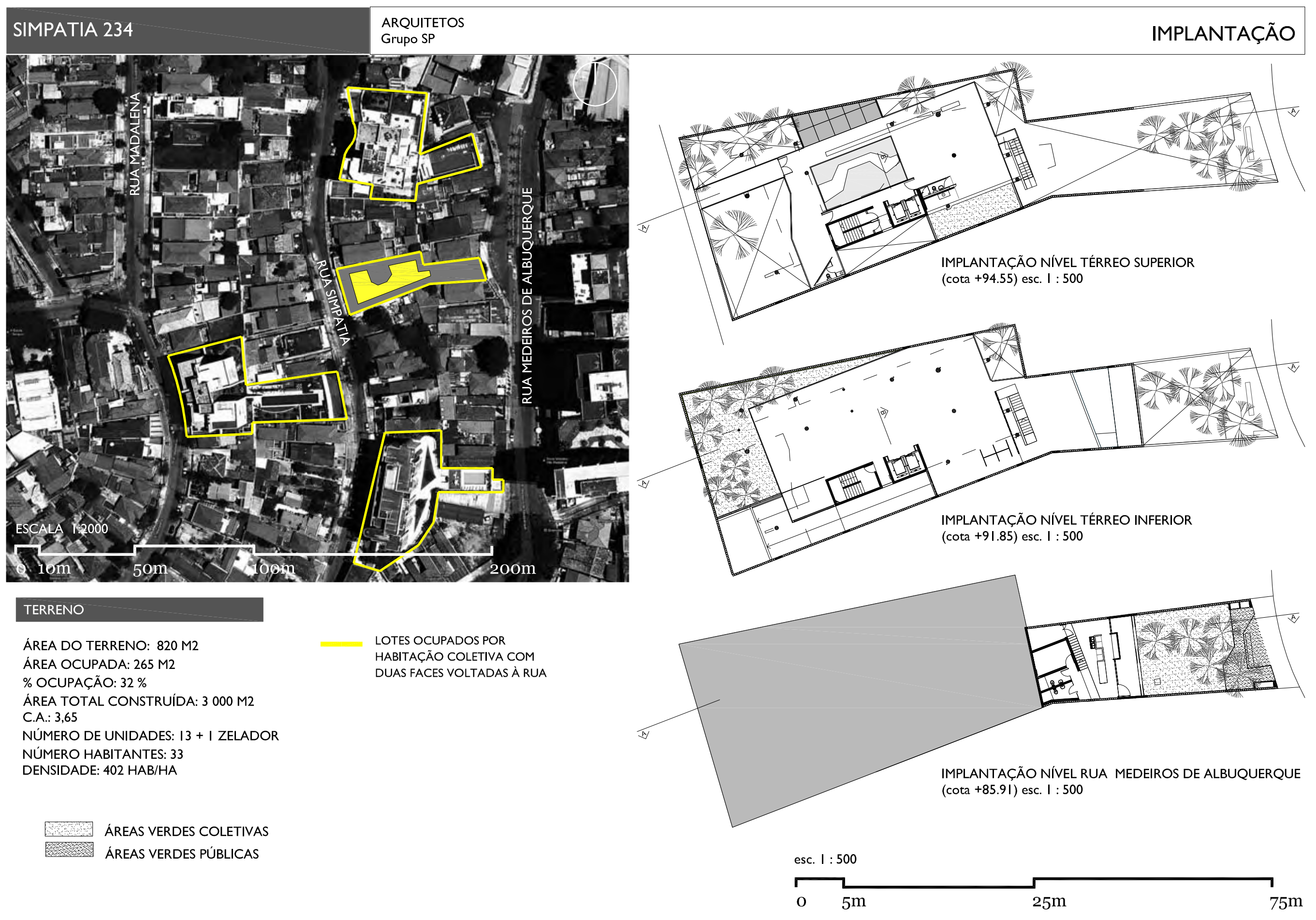



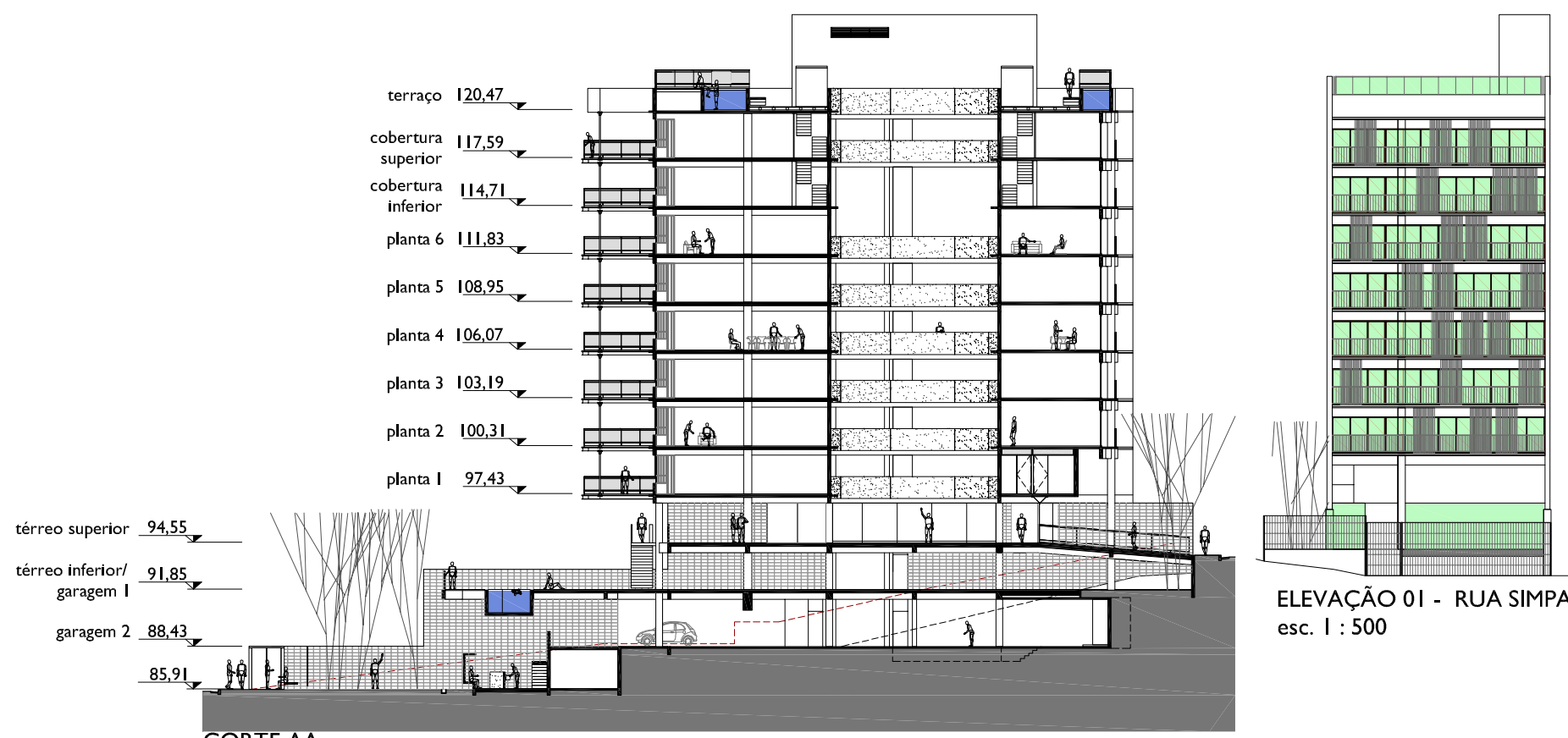

ELEVAÇÃO OI - RUA SIMPATIA esc. I : 500

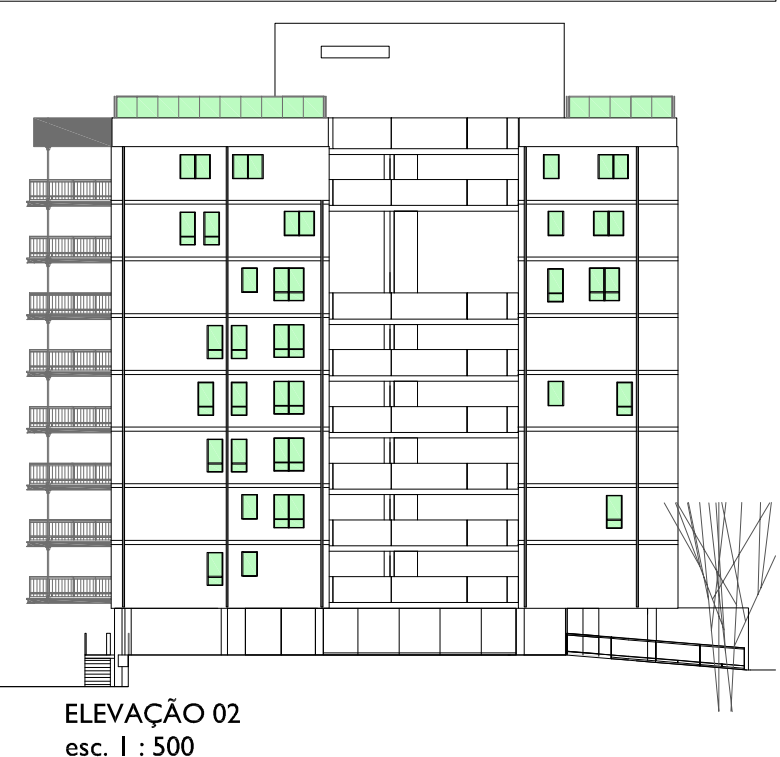

CORTE AA

esc. $1: 500$
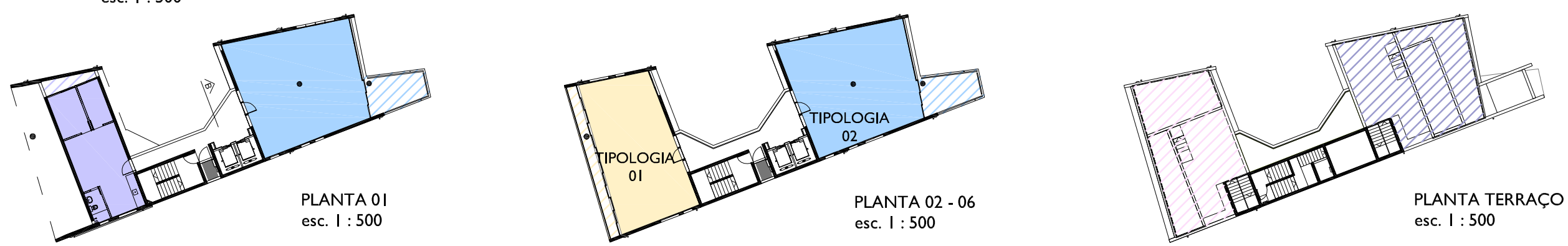

\begin{tabular}{|c|c|c|c|c|c|}
\hline & XI & $\times 6$ & XI & $\times 5$ & $\times 1$ \\
\hline & ZELADOR & TIPOLOGIA 0I & COBERTURA & TIPOLOGIA 02 & COBERTURA \\
\hline PAVIMENTO TÉRREO & \multirow[t]{2}{*}{$47,94 \mathrm{~m}^{2}$} & \multirow[t]{2}{*}{$89,37 \mathrm{~m}^{2}$} & $89,37 \mathrm{~m}^{2}$ & \multirow[t]{2}{*}{$75,95 \mathrm{~m}^{2}$} & $75,95 \mathrm{~m}^{2}$ \\
\hline PAVIMENTO SUPERIOR & & & $89,37 \mathrm{~m}^{2}$ & & $75,95 \mathrm{~m}^{2}$ \\
\hline computável & $47,94 \mathrm{~m}^{2}$ & $89,37 \mathrm{~m}^{2}$ & $178,74 \mathrm{~m}^{2}$ & $75,95 \mathrm{~m}^{2}$ & $|5|, 90 \mathrm{~m}^{2}$ \\
\hline não computável & $4,08 \mathrm{~m}^{2}$ & $14,79 \mathrm{~m}^{2}$ & $98,10 \mathrm{~m}^{2}$ & $11,48 \mathrm{~m}^{2}$ & $86,99 \mathrm{~m}^{2}$ \\
\hline total & $52,02 \mathrm{~m}^{2}$ & $104,16 \mathrm{~m}^{2}$ & $276,84 \mathrm{~m}^{2}$ & $87,43 \mathrm{~m}^{2}$ & $238,89 \mathrm{~m}^{2}$ \\
\hline
\end{tabular}

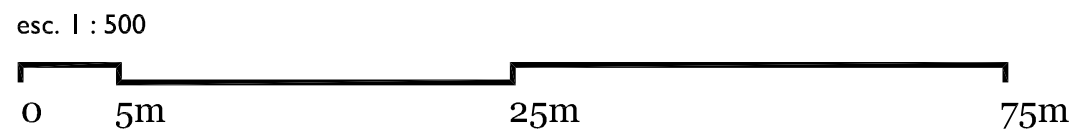




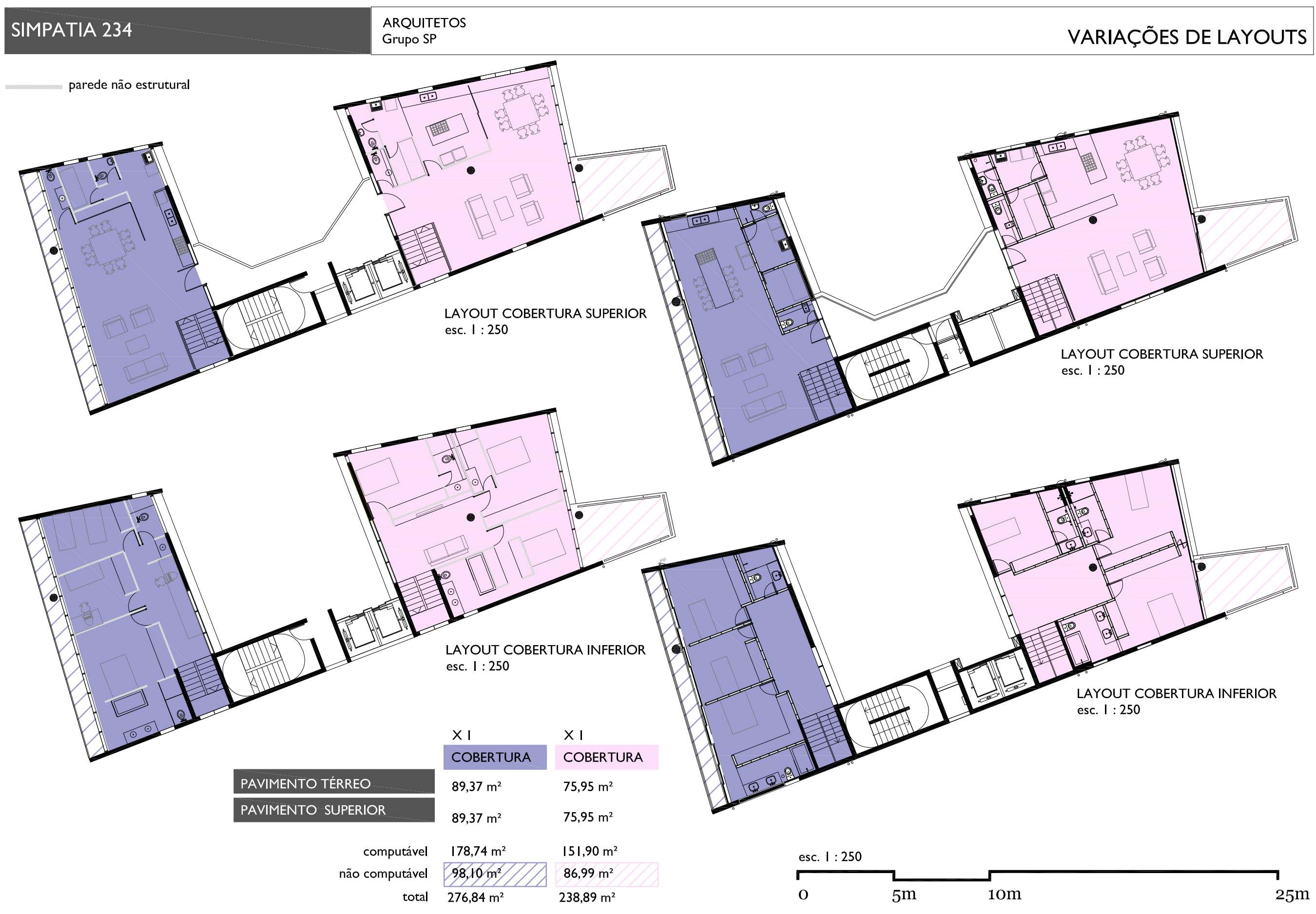




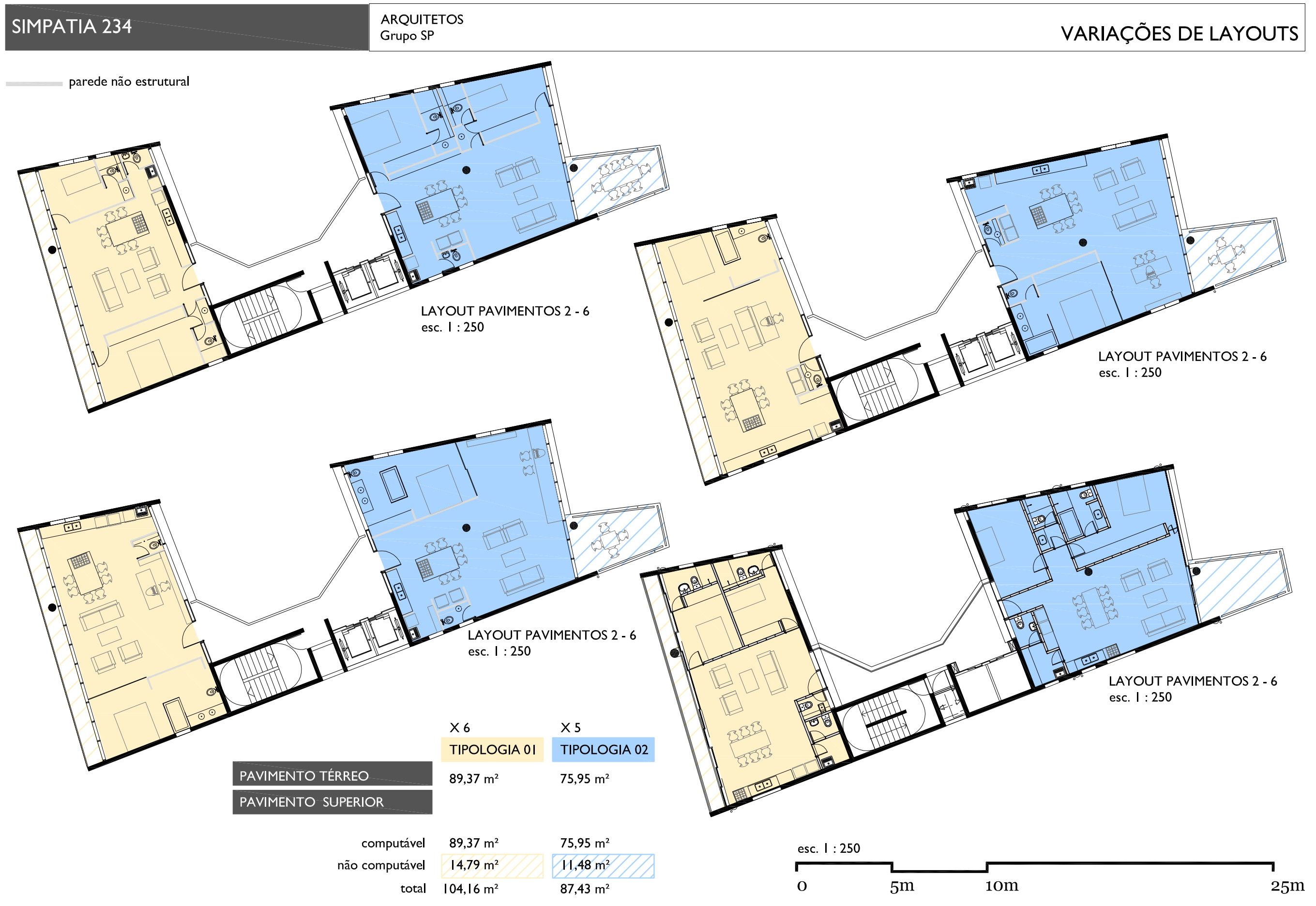




\subsubsection{I BIBLIOGRAFIA DO CAPÍTULO}

ANELLI, Renato. Expo 92, Sevilha: O Concurso para o Pavilhão Brasileiro. ARQTEXTO (UFRGS), v. 16, p. 106-127, 2010.

LORES, Raul Juste. Arquitetura é Investimento. Folha de São Paulo, São Paulo, 2 - 8 de setembro de 2012.

LUCCAS, Luís Henrique Haas. Arquitetura contemporânea no Brasil: da crise dos anos setenta ao presente promissor. Arquitextos Vitruvius. São Paulo, n. 101.00, ano 09, outubro de 2008. Disponível em <http://www.vitruvius.com.br/revistas/read/arquitextos/09.101/99>.Acesso em: 0l/09/20II.

MELENDEZ, Adilson. Na Década que Separa Sevilha de Orlândia, Mudaram os Arquitetos ou Mudou a Crítica? ProjetoDesign, São Paulo, n. $25 \mathrm{I}$, janeiro de $200 \mathrm{I}$, p. I 34 .

MILHEIRO,A.V.; NOBRE,A. L.;WISNIK, G. Coletivo - 36 projetos de arquitetura paulista contemporânea. São Paulo, Cosac Naify, 2006. p. $36-39$.

PIZA, Daniel. Em alta, os prédios ‘com design'. O Estado de São Paulo, São Paulo, 8 de fevereiro de 2009.

PUNTONI,A. Estruturas Habitacionais Urbanas - Um ensaio de ocupação de vazios na Ladeira da Memória. 1998. Dissertação (Mestrado em Arquitetura e Urbanismo), Universidade de São Paulo, São Paulo, 1998.

Paulo, 2005.

Estruturas Habitacionais Urbanas. 2005. Tese (Doutorado em Arquitetura e Urbanismo), Universidade de São Paulo, São

SABBAG, Haifa Y. Beleza com conteúdo. Arquitetura e Urbanismo. São Paulo, n. I45, p.48-55, abril de 2006.

SANTOS,V. C. Concursos de Arquitetura em São Paulo. 2002. Dissertação (mestrado em arquitetura e urbanismo), Universidade de São Paulo, São Paulo, 2002.

SEGAWA, Hugo. Pavilhão do Brasil em Sevilha: deu em vão. Projeto, São Paulo, n. I38, fevereiro de 199 I. 
SERAPIÃO, Fernando.A década da "geração de Sevilha", do Pritzker de Mendes da Rocha, dos estrangeiros e do novo milagre. ProjetoDesign, São Paulo, n.37I, janeiro de $201 \mathrm{l}$.

SERAPIÃO, Fernando. Residência em Carapicuíba. ProjetoDesign, São Paulo, n.342, agosto de 2008.

SERAPIÃO, Mudança de ares. ProjetoDesign, São Paulo, n.353, p. 68 -79, julho de 2009.

SUMMA +, Construindo a Topografia e o Vazio. Buenos Aires, n. I20, p. 82-87, março de 2012.

TEIXEIRA, Regiane. Fora da mesmice. Cidade vive boa safra de prédios residenciais com visual ousado, que já começam a despontar fora do setor privado e dos bairros nobres. Folha de São Paulo, São Paulo, 2 - 8 de setembro de 2012.

TRONCOSO, Ursula. Simpatia gera gentileza. Arquitetura e Urbanismo, São Paulo, n.207, p. 54-6I, junho de 201 I.

ZEIN, R.V.; MASTOS, M.A.J. Brasil:Arquiteturas após 1950. São Paulo: Perspectiva, 2010.

ZEIN, Ruth Verde.A arquitetura em exposição: Sevilha 92. Projeto, São Paulo, n. I38, fevereiro de 1991. 
VISITAS REALIZADAS:

Edifício Simpatia 234 - 12 de fevereiro de 201 I e II de abril de 201 I.

\section{ENTREVISTA:}

Arquitetos Alvaro Puntoni e João Sodré - 28 de abril de 2011

OUTROS:

BOND, D. B. Ideias para um desenvolvimento sustentável da Vila. Estudos preliminares, agosto de 2012.

BOSH, F. P.; MAIA, G.; MENEGUETTI, M.;AZEVEDO,V. Entrevista Angelo Bucci e João Paulo Meirelles de Faria - SPBR. ENTRE, novembro de 2009. Disponível em <http://www.entre.arq.br/pdfs/Entre_SPBREntrevista.pdf>.Acesso em: I0/I0/20I I.

GRUPO SP. Disponível em: <www.gruposp.arq.br>.Acesso em: 10/10/2011.

LEIS:

SÃO PAULO (município). Lei n 13.430, de 13 de setembro de 2002. Plano Diretor Estratégico de São Paulo.

SÃO PAULO (município). Lei n 13.885, de 25 de Agosto de 2004. Planos Regionais Estratégicos das Subprefeituras de São Paulo. 



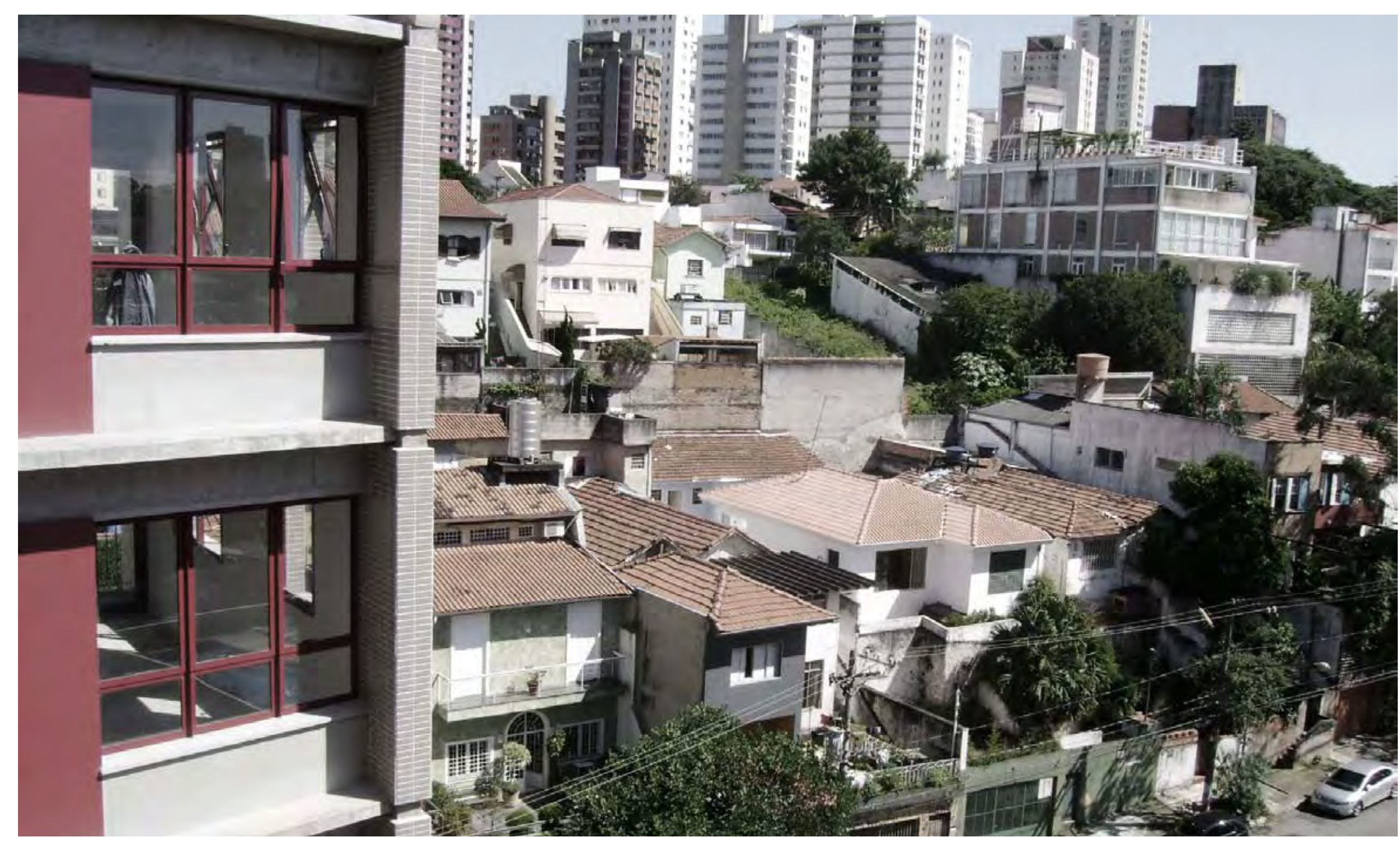

4. ANÁLISE COMPARATIVA E CONSIDERAÇÕES FINAIS POR TEMAS PRESENTES NOS PROJETOS SELECIONADOS 4.I INSERÇÃO URBANA 


\section{I.I ALGUNS PARÂMETROS DE INSERÇÃO URBANA DE HABITAÇÃo COLETIVA NA CIDADE DE SÃo PAULO}

Acredita-se que uma inserção urbana de habitação coletiva com qualidade, primordialmente considera e potencializa a integração com as estruturas naturais, edilícias e urbanas existentes, de tal maneira a conseguir dar continuidade à rede urbana.

A maior parte dos estudos de casos selecionados está inserida em lote urbano, de pequena proporção, sem grandes possibilidades de definição de novos traçados viários, parcelamentos de grandes quadras ou implantação de grande quantidade de unidades habitacionais, situações que, quando não trabalhadas de maneira adequada, podem atingir uma problemática ainda maior com relação à inserção urbana, e que, assim, exige cuidado redobrado (Figuras I, 2 e 3). Porém, a inserção urbana pode se mostrar ineficiente até mesmo em empreendimentos em lotes urbanos, a partir de soluções com total descompromisso com a situação urbana em que se encontra, sem considerar a morfologia urbana, resultando em novos volumes divergentes da escala urbana existente.

Assim, a habitação coletiva em lote urbano, exige também cuidado e criação de parâmetros de qualidade para sua inserção. A escala destoante com a da cidade é algo que foge da qualidade arquitetônica do edifício por si só, mas que, ao mesmo tempo, é uma visão urbana que cabe ao arquitetônicos, sem contribuição com a situação urbana que o rodeia (Figura 4).

¿Monumentalidad o integración? La polémica siempre es deseable y ésta ha surgido entorno al edificio Mirador en Sanchinarro, Madrid, (2005) de Blanca Lléo y MVRDV. En esta relación de la vivienda colectiva con la ciudad se plantea la duda de si el bloque de viviendas puede convertirse en un monumento, tal como sucede en este caso, o si es mejor que quede integrado en la trama urbana y que ofrezca auténticos espacios colectivos. No hay nada más paradójico que el impacto mediático conseguido por el edificio Mirador y su encumbramiento como símbolo cuando se levanta, precisamente, gritando contra la mediocridad del urbanismo y la arquitectura que lo circunda; un mal urbanismo que intenta ser redimido por una vivienda monumento. (MONTANER, MUXí, 2006, p. 38).

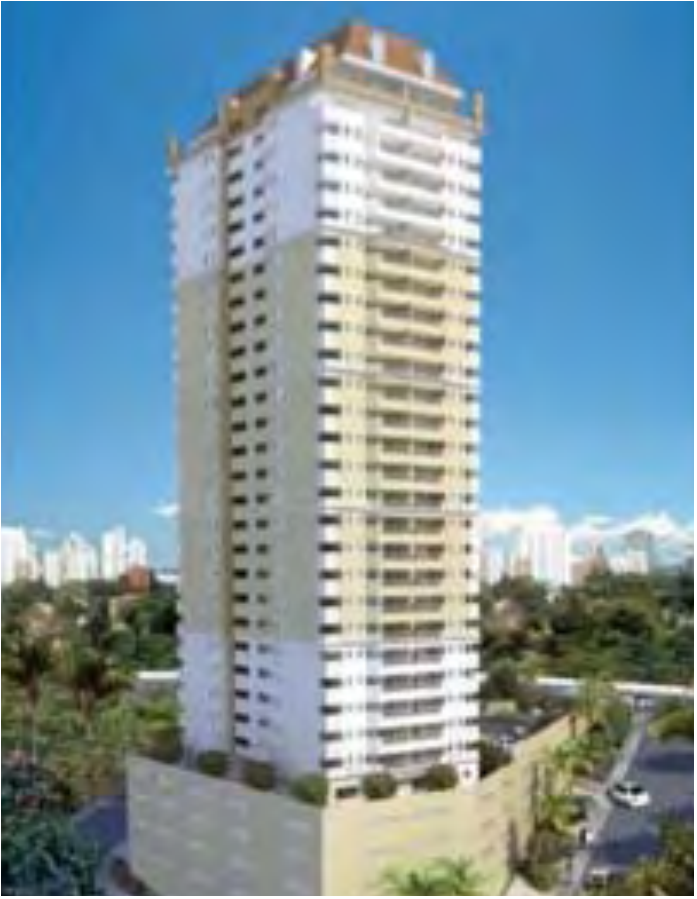

Figura I - Inserção de empreendimento em quadra urbana.Villagio Maggiori, São Bernardo, São Paulo. 2 torres, 25 andares e 200 apartamentos, em $5000 \mathrm{~m}^{2}$ (quota de aproximadamente 25 $\mathrm{m}^{2}$ vinculada a cada unidade habitacional.

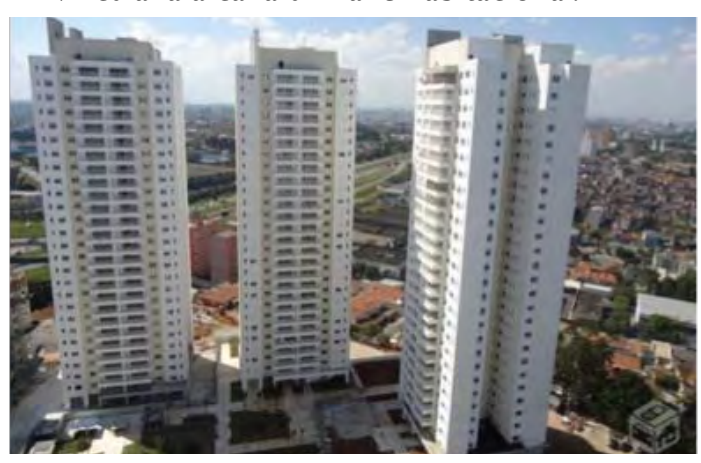

Figura 2 - Inserção de empreendimento em gleba urbana. Ânima Clube, São Bernardo, SP. 10 torres de 26 andares. 1000 habitações. 


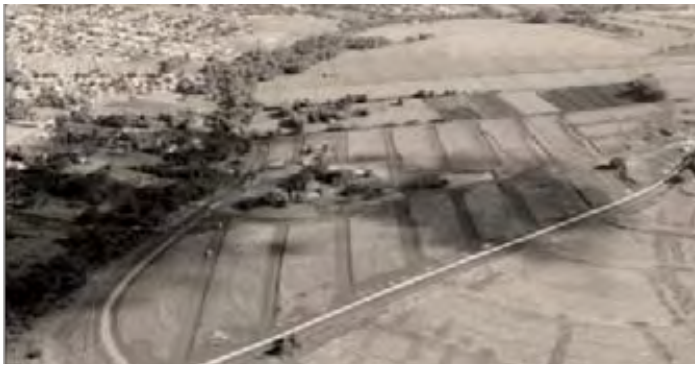

Figura 3 - Inserção de loteamento em gleba rural, Sarandi, Paraná. Muro com mais de I km de extensão, isolando o uso residencial, sem preocupação ambiental, mesmo ao lado do córrego.
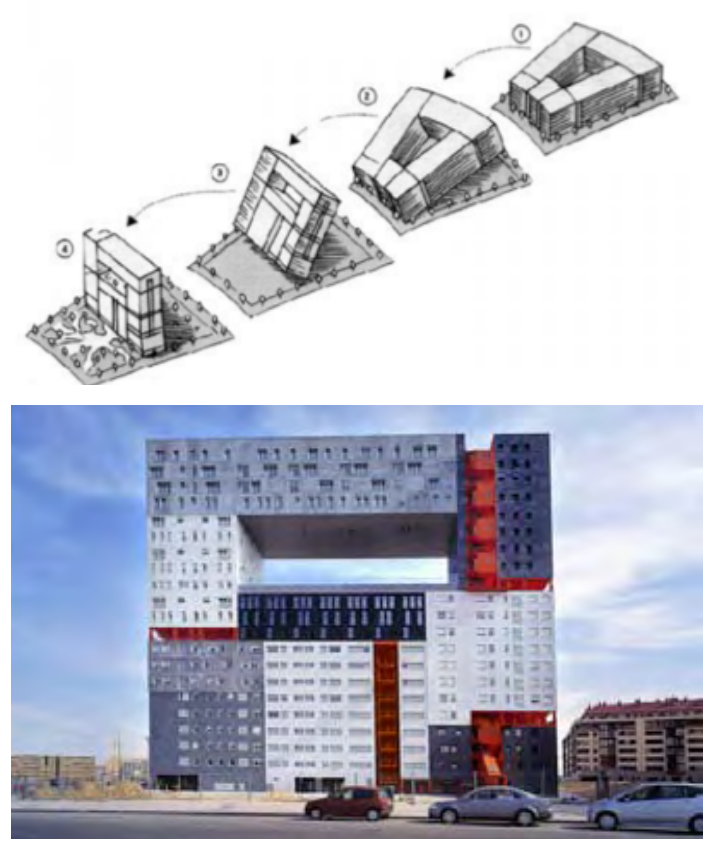

Figura 4 - Escala monumental do Mirador (2004), Madri, MVRDV + Blanca Lléo.
Deste modo, para o novo se integrar ao existente da forma mais amena possível, é importante considerar a localização, os usos, atividades e equipamentos a morfologia urbana, a densidade construtiva e populacional no bairro, o gabarito de altura das construções, a topografia e meio natural, os eixos de conexão da malha urbana, o alinhamento das construções e buscar conexões com o espaço público, física ou visual, ou seja, criar espaços com FLUIDEZ URBANA (Figura 5).

Entende-se por uma boa localização da habitação, aquela de fácil acesso principalmente por transporte público coletivo, e bem servida de infraestrutura e serviços. É importante o conhecimento de situações de boa localidade já que em muitos casos a busca por elas faz parte do trabalho do arquiteto, principalmente quando ele é agente empreendedor do seu projeto. Hoje a periferização da habitação não ocorre apenas por conjuntos destinados à população mais carente, o espraiamento da cidade ocorre também pela presença de condomínios fechados destinados à classe social mais favorecida economicamente. Também vale ressaltar, que o custo de vida pode ser mais elevado nestas "ilhas protegidas", seja pelas taxas condominiais para manter um local onde vivem menos pessoas ou até custos de deslocamento, por isso pessoas mais ricas conseguem se manter melhor nestas localidades mais periféricas. Os estudos de casos selecionados conseguem expor situações de inversão social da periferização, por exemplo, o único empreendimento de habitação social selecionado, Vila Pedro Fachini, está localizado de modo integrado à malha urbana com condicionantes diversas aos da Vila Taguaí ou Canaã, que estão em áreas suburbanas rodeadas por condomínios fechados, verdadeiras "anticidades" e também de isolamento social e cultural:

Ao longo de nossa história, é visível a ausência de políticas públicas voltadas para o bem estar das classes sociais como um todo - ao contrário, houve o favorecimento de determinadas classes em detrimento de outras, não dá para negar. Mas, o que hoje acontece em toda a parte é que o crescimento espraiado não resulta apenas em pobreza, mas sim na proliferação de "ilhas", ou ainda, das "anticidades" que são os condomínios fechados - ou seja, além da 'periferização' dos pobres, ocorre os 
'bolsões' dos ricos, o isolamento, em suma, a negação do espaço público e conseqüentemente da cidade. (ALVIM, 20I2).

Em vários países da América do Sul, as extensões suburbanas de baixa densidade tornaram-se o modelo de ocupação preferido pelas classes mais abastadas que, em alguns casos, tiveram os recursos econômicos para enfrentar estes valores mais elevados. (CORTI, DIEZ, DI PECO, KOMMERS e SORIA, 20I2, p. 26).

Assim, julga-se importante avaliar a boa localização não apenas pela facilidade de acesso para quem mora ou trabalha no conjunto habitacional, mas também pela necessidade de consciência da situação não favorável e insustentável do espraiamento da região metropolitana de São Paulo, defendendo-se, assim, a cidade compacta. Mais do que isso, é preciso entender que o projeto dentro dos limites do lote pode possuir qualidade arquitetônica fantástica, porém, é necessário fazer uma prévia avaliação de sua inserção na cidade, e isto deve estar correlacionado ao projeto e somar a sua qualidade (Figuras 6 e 7). "Muchos proyectos, aunque propongan una buena solución para la vivienda tipo, no pueden ser consideradas ejemplares. La calidad de las viviendas es inseparable del tejido urbano en el que se insertan y por ello el proyecto urbano es imprescindible" (MONTANER, MUXí, 2006, p. 40)

$\mathrm{Na}$ ficha gráfica de cada projeto selecionado, foi elaborado um mapa em escala I: 12 500, que abrange um trecho de raio de um quilometro ao redor do projeto, havendo o reconhecimento dos equipamentos existentes, estrutura viária principal, relação de áreas verdes ou vazias e aquelas ocupadas e outros elementos urbanos mais significativos. Esta leitura propiciou às análises realizadas uma série de informações que poderiam servir aos estudos de implantação de novos projetos. Para a ficha síntese, fez-se o recorte do mapa, reduzindo-o para um raio de $500 \mathrm{~m}$, distância possível de ser percorrida a pé, ideal para chegar a estabelecimentos de comércio e serviço para atendimento das necessidades do dia-a-dia, como por exemplo, padaria, mercado, farmácia, creche, etc.

Com base nestas peças gráficas, foram avaliados nos estudos de caso dentre outros elementos a existência de comércio local nos arredores da habitação e a proximidade dela com transporte público coletivo, sendo mais desejável a de acesso ao metrô ou trem.
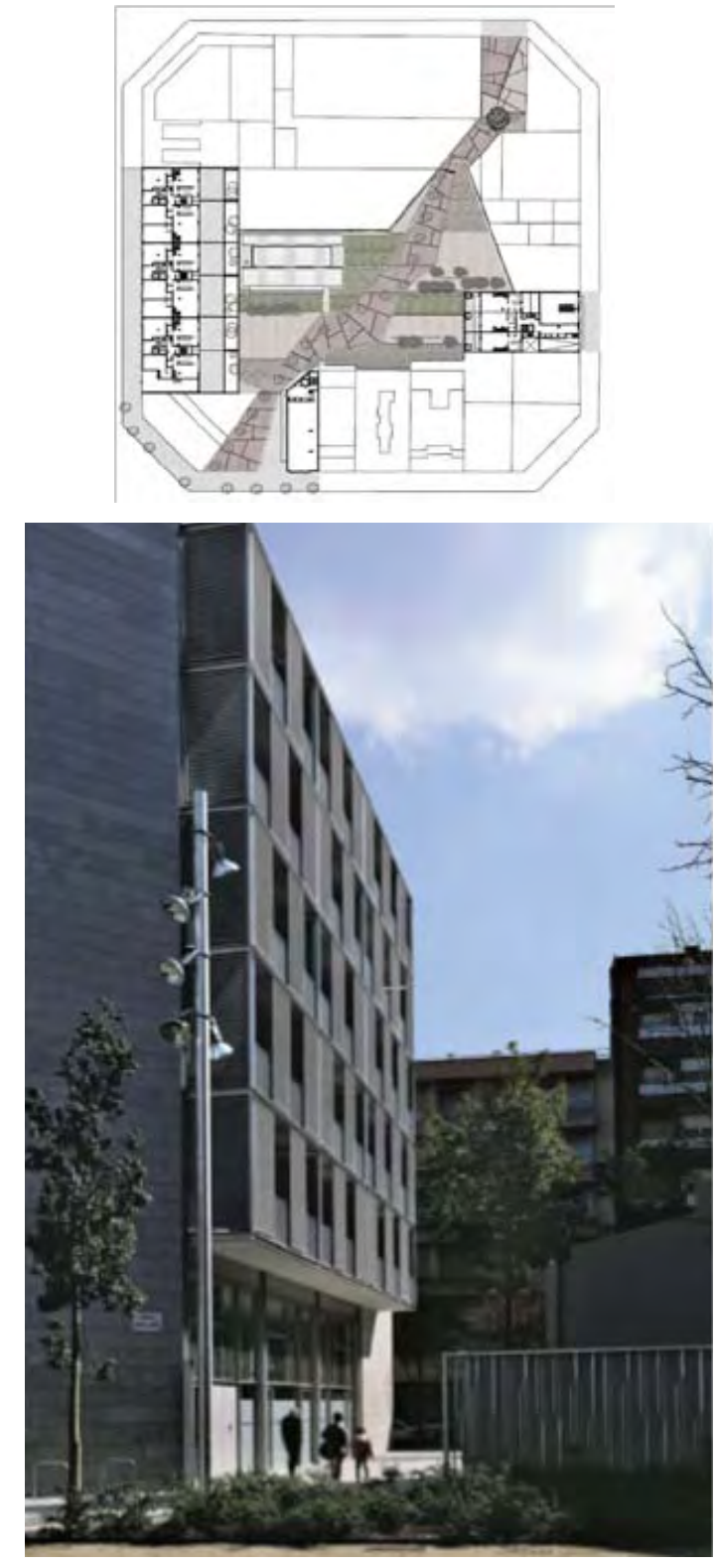

Figura 5 - Habitação num ensanche de BarceIona (200I-2003), Carlos Ferrater Arquitectos Asociados. Arquitetura flúida com a cidade. 

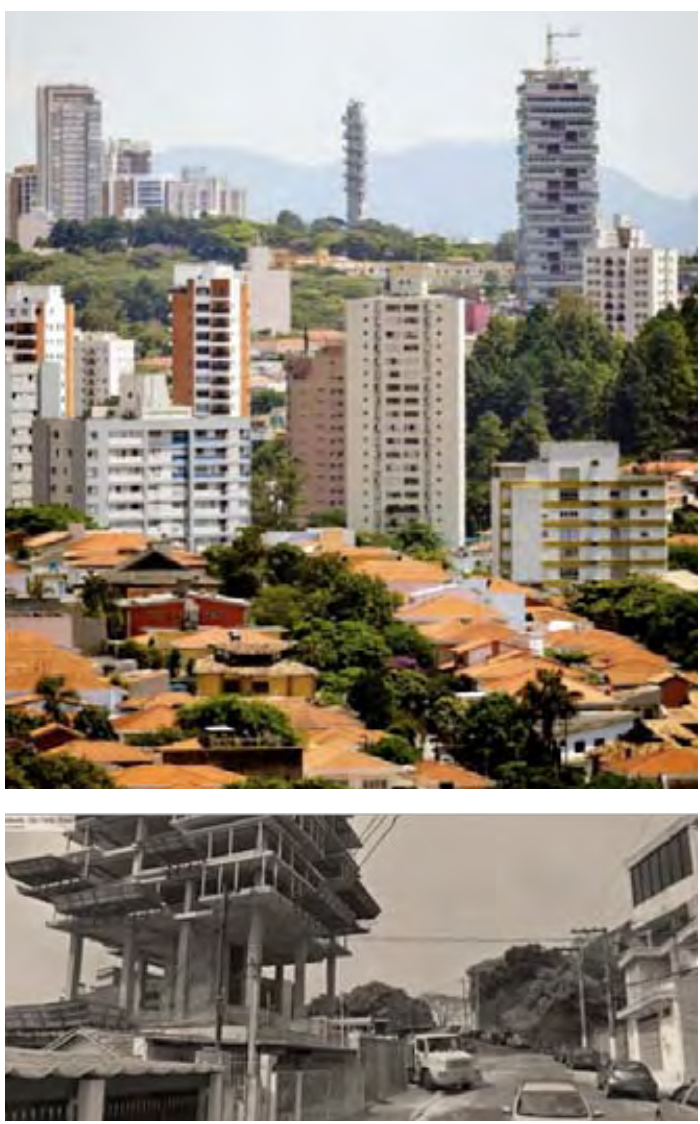

Figuras 6 e 7 - Na primeira foto, à direita ao fundo, está o edifício $360^{\circ}$, localizado na Rua Camboriú, 65I,Alto de Pinheiros, do Arquiteto Isay Weinfeld e incorporação da Idea!Zarvos. Nota-se um contexto urbano com variações morfológicas, tapete formado por casas térreas, alguns edifícios verticalizados e algumas torres mais altas, entre elas, $\mathrm{o} 360^{\circ}$. A distância, o edifício $360^{\circ}$ consegue mostrar sua beleza arquitetônica plástica e estrutural e imposição na paisagem. Pela segunda foto, do mesmo edifício, o que parece, é que foi concebido para ser observado de longe: está totalmente fora do contexto local e não possui relação com a rua.
Quando o entorno não propicia uma condição favorável, o novo projeto pode, ao menos, incorporar usos essenciais no pavimento térreo, por exemplo.

Com relação à localização, os projetos Canaã eVila Taguaí, representam exceções por estarem localizados em zona não urbana, inclusive em local próximo aos referidos condomínios-clubes afastados da cidade, e também a assentamentos precários, característica da Região Metropolitana de São Paulo, com contraste social constantemente sob nosso olhar.

A Vila Butantã está na franja urbana de São Paulo, à beira da Rodovia Raposo Tavares, porém, consegue alcançar a infraestrutura do transporte público de massa, pois está a aproximadamente a um quilometro da estação Butantã, da linha amarela do metrô.

Os outros projetos, Fiori di Maggio,Vila Pedro Fachini, Simpatia 234,Vila Fidalga e Fidalga 772, estão localizados em bairros mais consolidados, os três últimos estão na Vila Madalena, bairro com grande diversidade e com a linha verde de metrô passando nas suas adjacências. Este bairro tem passado por um processo de intensa verticalização nos últimos anos. Ao mesmo tempo em que alguns problemas antigos se mantêm, como por exemplo, das enchentes, outros novos surgiram, como do trânsito. Neste sentido, estão acontecendo discussões participativas com a comissão de moradores que resultou num plano para o Bairro (previsto no Plano Diretor Estratégico da cidade de São Paulo), elaborado em parceria entre a incorporadora Idea!Zarvos e o escritório de arquitetura Davis Brody Bondy. Cabe mencionar, que os projetos desta pesquisa localizados na Vila Madalena, carregam a opinião, e isto vem da incorporadora Idea!Zarvos, da redução dos espaços coletivos privativos do empreendimento, em favor do melhor aproveitamento das condições positivas do bairro, com praças, comércio, equipamentos esportivos, etc., ou seja, são da opinião contrária aos condomínios-clubes, como será exposto mais adiante no tema "ESPAÇOS EXTERIORES".

O Canaã, projeto que surgiu da percepção do empreendedor da existência de trabalhadores fabris da região, com alto potencial aquisitivo, ao menos teve o cuidado de fazer uma inserção harmoniosa na paisagem e de prever áreas de lazer para os moradores, 
único tipo de uso compatível e cabível no limite do terreno na situação rural em que se encontra. Abrir este espaço de lazer ao uso público, apenas com uma parceria com a municipalidade.

Já com relação à avaliação da densidade construtiva, de ocupação do solo e populacional existente no bairro, quando o novo edifício ultrapassa a densidade existente, é necessário que o projeto crie situações de modo a não gerar quebra ou grandes contrastes com a situação previamente existente, de tal modo que as transições sejam equilibradas e proporcionais.

O projeto Vila Taguaí, por exemplo, está inserido praticamente em meio à mata virgem no Vale de Carapicuíba, portanto, buscou baixíssima densidade construtiva e populacional, uma maneira de respeito também ao meio natural ao qual está inserida. Outra tática é observar o gabarito de altura das construções existentes e também os eixos de conexão da malha urbana assim como o alinhamento das construções, e tentar relacioná-los com o projeto novo. A integração amena busca conexões com o espaço público, física ou com as principais visuais, condomínios cercados por muros, representam ruptura física e visual, e prejudicam o espaço urbano existente externamente aos muros, tornando a calçada ou local público que os tangenciam, inóspito e inseguro. Os projetos Simpatia 234 e Fidalga 772 conseguem criar uma situação de conexão visual favorável com a rua.

\begin{abstract}
Outro aspecto de destaque é a generalização do padrão dos "condomínios-clube", que marcam nossas cidades pela ruptura que impõem à malha urbana, com imponentes muros e grades, que comprometem a fluidez urbana e, principalmente, a integração entre usos e grupos sociais, pressupostos ao exercício de verdadeira vida urbana. (FERREIRA, 20I2, p. 76).
\end{abstract}

Alguns projetos conseguem boa inserção urbana pois consideram a topografia existente, evitando excessiva movimentação de terra, e identificam as principais vistas, por exemplo, a partir da análise e consideração da inclinação do terreno, uma forma de abrir o projeto à cidade, portanto, outro tipo de conexão visual, que os projetos Vila Butantã,Vila Taguaí, e Simpatia 234 bem representam. 
As necessidades urbanas estão intimamente relacionadas com as características geográficas, demográficas e morfológicas de cada bairro. Será necessário que as intervenções atendam a fatores locais como a relação entre o construído e a topografia, as densidades populacional e construtiva e as tipologias e volumetrias dominantes no bairro. $O$ equilíbrio entre a proposta e a realidade existente favorecerá a integração dos habitantes com os novos espaços. Trata-se de escolher a morfologia urbana (casas sobrepostas / blocos /quadra fechada / quadra semiaberta / torres ou edifícios isolados) que atenda melhor os objetivos: cumprir com a quantidade de unidades habitacionais requeridas, resultar em impactos positivos para o entorno e responder adequadamente às relações urbanas (público-privado). (MONTANER, et al; 20I2, p. 278)

Na sequência, serão expostas as situações de inserção urbana em que se encontram os estudos de caso selecionados. Eles foram organizados num sequência que parte da situação em meio mais natural, até a em meio mais urbano e consolidado. Assim, podem ser divididos nas seguintes situações:

- Em meio natural: Canaã e Vila Taguaí;

- Em franja urbana: Vil Butantã;

- No limite com grandes vazios urbanos: Vila Pedro Fachini;

- Em bairro consolidado: Fiori di Maggio, Simpatia 234,Vila Fidalga e Fidalga 772. 


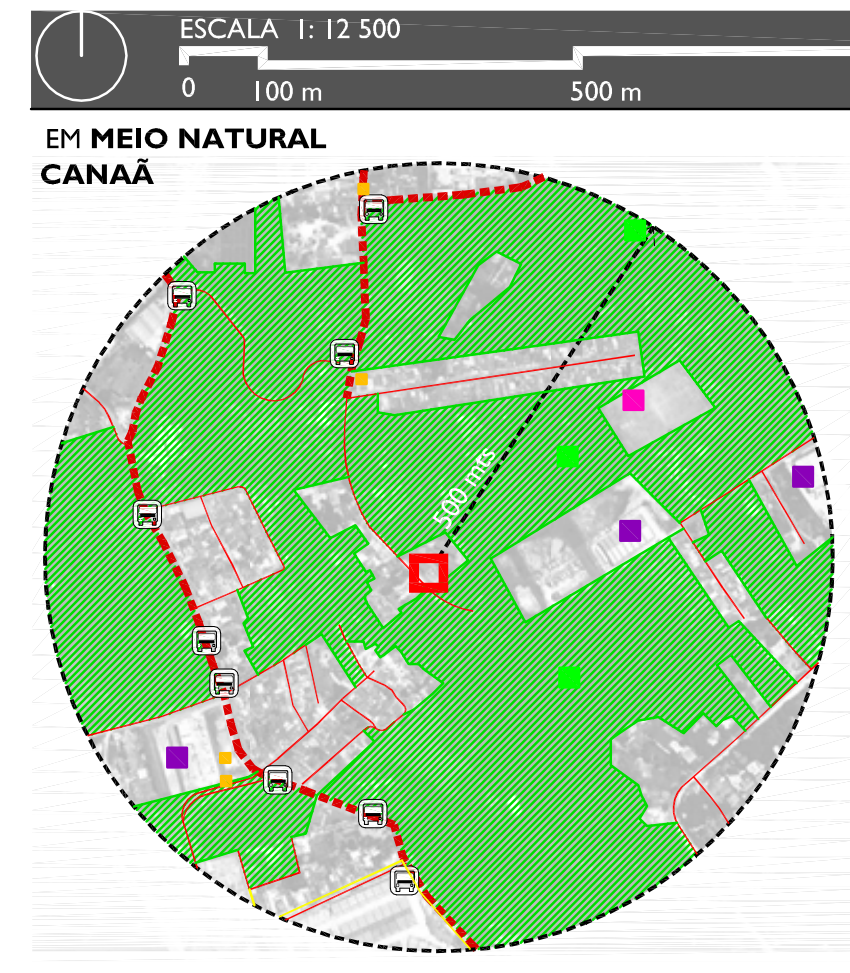

principais elementos no entorno: assentamentos populares:

hácaras;

es conjuntos residenciais fechados dustriais:

massas arbóreas ou vazios.

serviços urbanos: quase ausência de comércio e serviços para atendimento do dia-a-dia e outros equipamentos.

localização e acessibilidade: difícil acesso via transporte público.

fluidez urbana:

densidade, c.a. e taxa de ocupação do projeto no limite para área pouco

urbanizada como esta. A rua é pouco ativa pela própria condição suburbana do local, 0 conjunto, ao menos propricia boa visibilidade para a rua e considera topografia existente.

ÁREA DO TERRENO: $3200 \mathrm{M} 2$ \% OCUPAÇÃO: $27 \%$ C. A.: 0,70

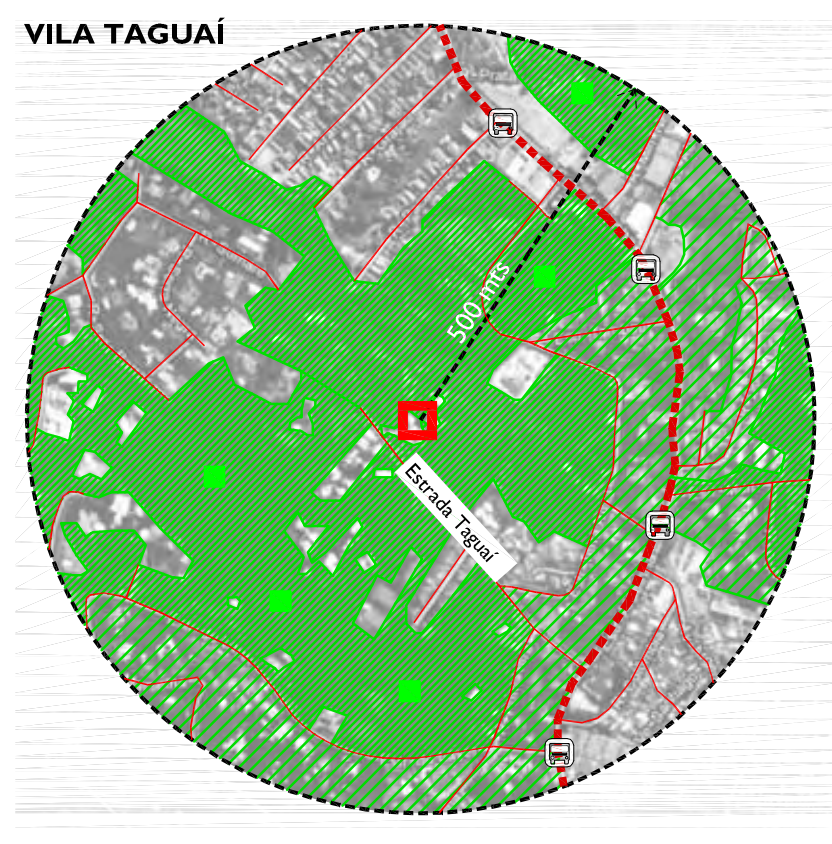
principais elementos no entorno:
assentamentos precários (favelas); chácaras;

grandes conjuntos residenciais fechados, massas arbóreas ou vazios.

serviços urbanos: quase ausência de comércio e serviços para atendimento do dia-a-dia e outros equipamentos.

localização e acessibilidade: difícil acesso via transporte público.

fluidez urbana:

densidade, c.a. e taxa de ocupação do projeto favorável para área com grande presença de massa arbórea, a intervenção, é portanto, amena ao local. $O$ projeto preserva as características ambientais do ocal.

ÁREA DO TERRENO: 12 262,61 M2 \% OCUPAÇÃO: $10,70 \%$ C. A.: 0,10

DENSIDADE: 26 HAB/HA

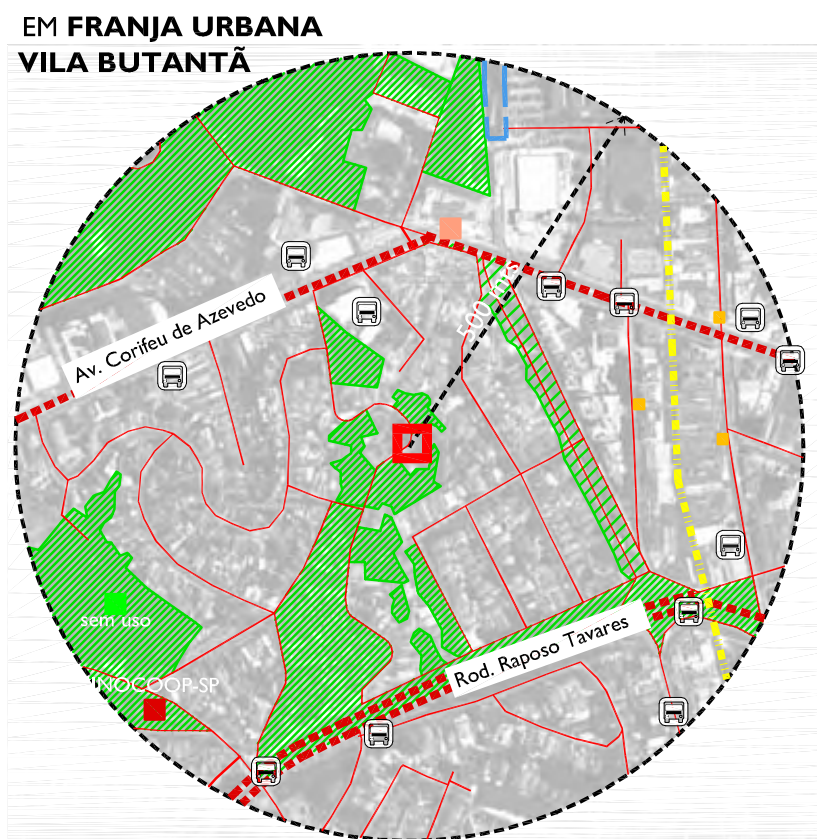

principais elementos no entorno instituiçoes de ensino mossas arboreas ou

ovia express

serviços urbanos: quase ausência $d e$ omércio e serviços para atendimento do dia-a-dia no entorno imediato.

localização e acessibilidade: mesmo estando na franja urbana da cidade, à beira da Rodovia Raposo Tavare, possui boa cessibilidade via transporte público, principalmente pela estação Butantã do metrô (à menos de $\mathrm{lkm}$ )

fluidez urbana:

A intervenção é amena ao local, considerando a topografica, densidade e morfologia existente no entorno.

\section{ÁREA DO TERRENO: 4439 M2} \% OCUPAÇÃO: $30 \%$ DENSIDADE:

\section{NO LIMITE COM VAZIOS URBANO}

VILA PEDRO FACHINI

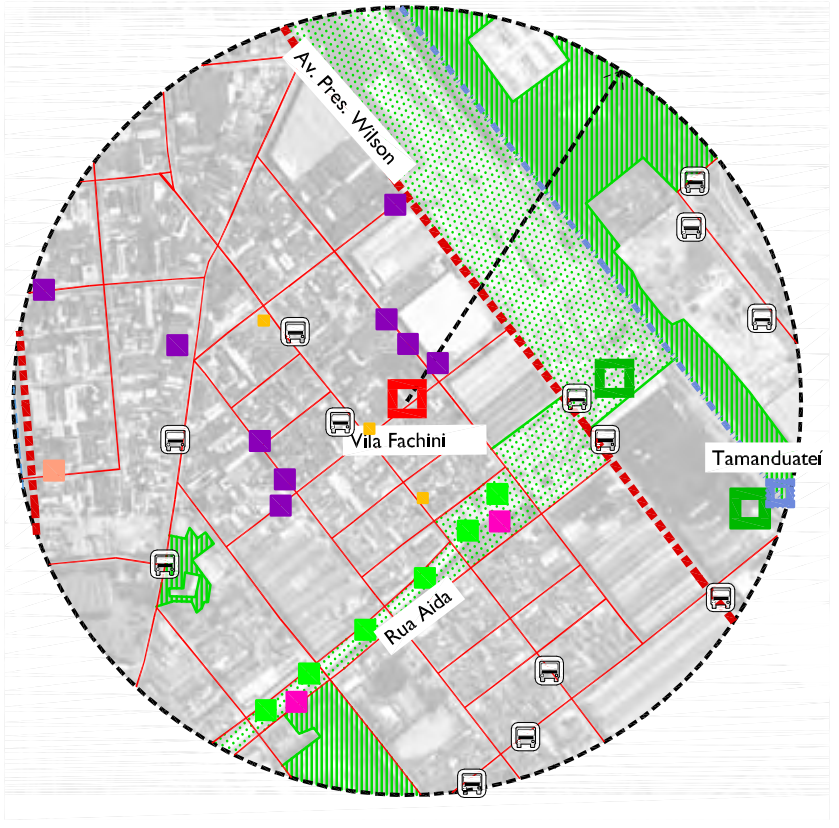

principais elementos no entorno: polos industriais

corredor verde (Rua Aida)

Vias expressas

Transporte de massa

serviços urbanos: Está relativamente proximo $(\sim / \mathrm{km})$ a dois polos comerciais importantes: Shopping Central Plaza e Rua comercial Silva Bueno.

ocalização e acessibilidade Possui ótima acessibilidade via transporte público.

fluidez urbana:

A intervenção é amena ao local considerando morfologia urbana existente mantendo ocupantes originais do local. A densidade populacional é alta, porem, pelo fato de ser uma ação pontual, năo chega acarretar problemas urbanos, e sim, no

ÁREA DO TERRENO: $320 \mathrm{M2}$ \% OCUPAÇÃO: $56,87 \%$ C. A.: I,64
DENSIDADE: I I 25 HAB/HA convivio entre os moradores do conjunto. 

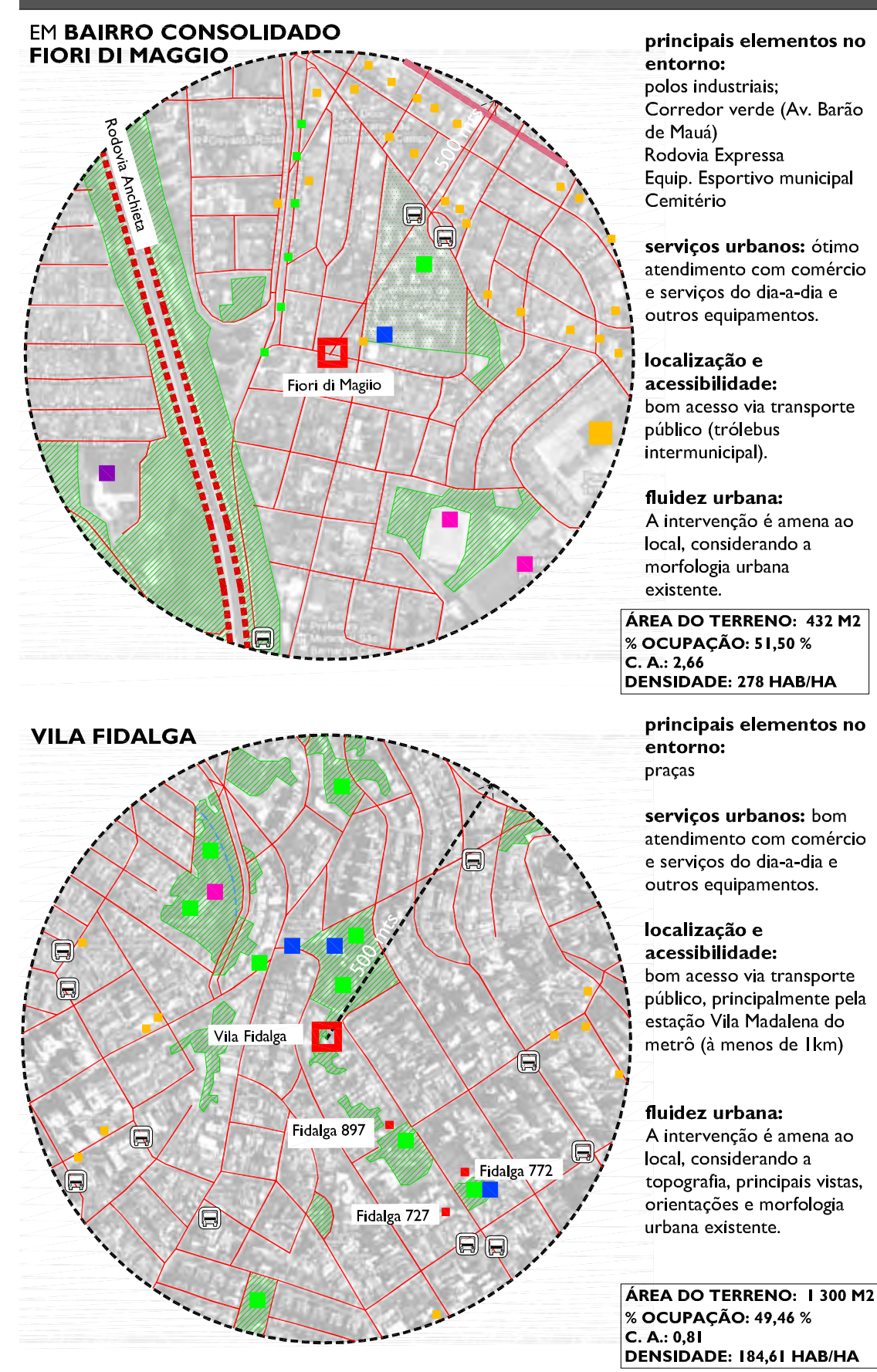

principais elementos no entorno:

polos industriais;

Corredor verde (Av. Barão de Mauá)

Rodovia Expressa

Equip. Esportivo municipal Cemitério

serviços urbanos: ótimo tendimento com comércio e serviços do dia-a-dia outros equipamentos.

\section{localização e}

bom acesso via transporte

público (trólebus

intermunicipal).

fluidez urbana:

A intervenção é amena ao

local, considerando a

existente.

ÁREA DO TERRENO: $432 \mathrm{M}$

ÁREA DO TERRENO: 432

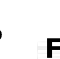 \\ FIDALGA 772}

FIDALGA 77

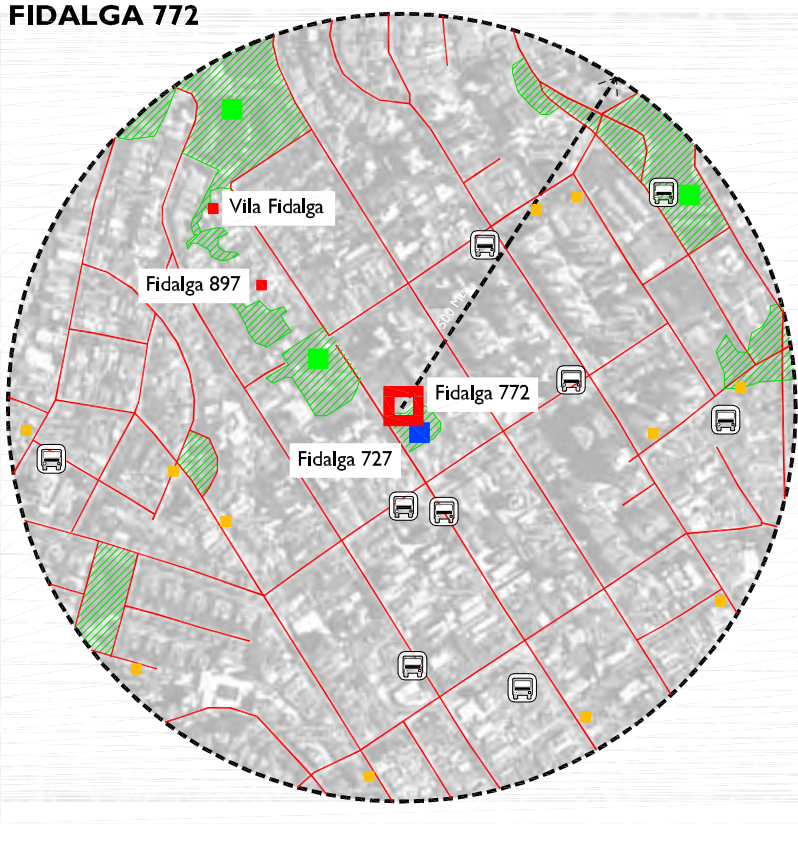

principais elementos no

principais

praças

serviços urbanos: ótimo atendimento com comércio e serviços do dia-a-dia outros equipamentos.

\section{localização e}

acessibilidade:

bom acesso via transporte

público, principalmente pela

estação Sumaré do metrô (à

estação Sum

fluidez urbana:

A intervenção é amena ao

local, considerando a

topografia e principais vistas

principalmente.

ÁREA DO TERRENO: $820 \mathrm{M} 2$

\% OCUPAÇÃO: $32 \%$

DENSIDADE: 420 HAB/HA

principais elementos no entorno:

praças

serviços urbanos: bom atendimento com comércio e serviços do dia-a-dia e outros equipamentos.

\section{localização e}

acessibilidade:

público, principalmente pela

estação Vila Madalena do

metrô (à menos de $\mathrm{lkm}$ )

fluidez urbana:

A intervenção é amena ao

local, considerando

principais vistas e

morfologia urbana

existente.

ÁREA DO TERRENO: $860 \mathrm{M}$

$\%$ OCUPA
C. A.: I,9

C. A.: 1,9
DENSIDADE: 302 HAB/HA inserção urbana

\section{LEGENDA:}

IOCALIZAÇÃO

ÁREA VERDE

VAZIO/OUTRO USO

--- HIDROGRAFIA

MOBILIDADE:

- u VIÁRIO PRINCIPAL

VIÁRIO SECUNDÁRIO

PONTO DE ÔNIBUS

ESTAÇÃO METRÔ

linha verde

ESTAÇÃO TRÊM

linha 10 - azul turquesa

\#॥=- LINHA DE TRÊM

- - TRÓLEBUS

\section{EQUIPAMENTOS:}

E educação

lazer / esporte

saúde

C comércio / serviço

P praça / área verde indústria 


\section{I.2 ALGUNS PARÂMETROS DE IMPLANTAÇÃO NO LOTE URBANO}

O bairro necessita de pessoas habitando-o para mantê-lo vivo. Por isso é bem-vinda a ocupação de retalhos urbanos com moradia, destinada a diferentes classes sociais, não apenas para extinguir trechos inseguros pela condição de vazio, como também para aproveitar oportunidades em boas localidades na cidade.

A avaliação final do conjunto de projetos a partir da análise das condicionantes do lote urbano é coerente com o raciocínio de seleção das obras, já que foram escolhidas aquelas com pouca possibilidade de replicação pela cidade e com projetos desenvolvidos para terrenos específicos.

Conforme pode ser observado na tabela síntese "partido de implantação no lote urbano", com relação à posição na quadra urbana, a maioria dos lotes é cercada por terrenos vizinhos com apenas uma face significativa voltada ao viário público, sendo exceção o Simpatia 234 , mas que mesmo possuindo duas faces voltadas à rede viária, apenas uma configura a entrada principal do conjunto. Este tipo de situação em quadra urbana consequentemente proporciona situações de interferências do contorno do lote, edificações vizinhas e relação com a rua.

Utilizando o método de análise gráfica, destacaram-se as seguintes características:

- Implantação do lote na vista aérea em escala 1:2000, destacando seu contorno, projeção da edificação e destaque do viário de acesso ou que faz limite com o lote. Este desenho colabora na visualização da interferência do contorno do lote na definição do volume projetado sob o mesmo;

- Esquemas dos projetos em corte em escala 1:750, destacando o perfil topográfico natural e o definido no projeto do terreno, o número de pavimentos, volumes em corte e em vista (conforme posição do corte) e garagens subterrâneas. É importante a visualização da interferência do lote na definição do volume projetado também em corte, principalmente quando a alta declividade representa uma condição significativa no partido de implantação; 
- Destaque em implantação e em corte das faces direcionadas às melhores visuais: em direção a vales, a massas arbóreas, etc.

- Destaque de algumas regras da legislação mais significativas.

Também, com base no conjunto de obras selecionadas e análise dos dados referentes aos projetos, foram identificados tamanhos distintos de lotes, tipos de declividade e formatos, conforme pode ser observado no quadro síntese "partido de implantação no lote urbano".

Las tácticas de infiltración exigen tomar riesgos. Como todo avance sobre fronteras desconocidas, la exploración demanda una dosis de valentia tanto como cierta prudência. Valentía y creatividad, trabajando en terrenos antes evitados por sus formas inconvenientes o escasas superfícies, descubriendo nuevas localizaciones en Barrios postergados o poco conocidos, proponiendo nuevos tipos de vivienda que rompem con la partición convencional del espacio doméstico y los espacios comunitários. (DIEZ, 2010, p. 35).

Esta busca por uma identificação nos projetos de tamanhos, formatos e também inclinações topográficas distintas, foi com intenção de tentar verificar se, conforme colocado por Diez (2010), “formas inconvenientes" (irregulares), “escassas superfícies” (lotes pequenos), e também a topografia (pois São Paulo apresenta superfície muito acidentado), caberiam, supostamente, como condições relevantes para elaboração do projeto, e mais, se resultariam em projetos criativos e inovadores. Também, trata-se de terrenos geralmente "evitados" por empreendedores comuns, por exemplo, o caso do terreno da Vila Fidalga ou da Vila Butantã, situações na qual não ocorreu substituição de construção existente para implantação de um edifício novo, pois na verdade, representavam vazios ou retalhos urbanos de pouco interesse para o mercado imobiliário, que precisava, de certo modo, da "valentia" e conhecimento dos próprios arquitetos como empreendedores de seu próprio negócio para assumir os riscos da situação atípica encontrada. 
Por fim, as obras foram sistematizadas na tabela síntese "partido de implantação no lote urbano", a partir de características significativas no partido arquitetônico de implantação comum entre alguns projetos, chegando às seguintes considerações:

I. TAMANHO MÉDIO + MÉDIA DECLIVIDADE + FORMATO IRREGULAR

\section{Projeto: Vila Fidalga (Arquiteta Cristina Xavier)}

Abaixo condicionantes significativas na definição da implantação:

- Regras da legislação: as unidades habitacionais não poderiam ser sobrepostas, ou seja, os limites das unidades poderiam tangenciar-se, porém, todas as unidades devriam ter projeção individual no lote;

- Formato irregular do lote;

- Topografia;

- Principais visuais: em direção a oeste;

- Orientações.

Estas condições foram consideradas criteriosamente pela arquiteta autora do projeto, de tal modo a resultar em seis unidades habitacionais diferentes umas das outras. Cada parcela de terreno definido para cada unidade apresentava uma situação peculiar de vista principal, orientação, topografia, que acabou permitindo pouca padronização do projeto arquitetônico das unidades.

2. TAMANHO GRANDE + ALTA DECLIVIDADE + IRREGULAR

Projetos: Vila Butantã (Arquiteto Marcos Acayaba), Canaã (Arquitetos Joan Villà e Sílvia Chile) e Vila Taguaí (Arquiteta Cristina Xavier e Eng. Hélio Olga Jr.)

Abaixo condicionantes significativas na definição da implantação destes projetos:

- Topografia: alta declividade;

- Principais vistas;

- Orientações. 
Mesmo tratando-se de terrenos com formatos irregulares, por terem grande área, a irregularidade acaba não sendo a situação mais difícil para o projeto, assim, a topografia acidentada acaba sendo a condição mais significativa para a implantação, e ao mesmo tempo favorece uma composição volumétrica mais interessante, que acaba quebrando a monotonia das casas iguais (principalmente nos casos da Vila Butantã e Canaã, já que na Vila Taguaí as casas não são iguais). Os três projetos, localizados sob uma condição mais envolvida com o meio natural, possuem uma localização que favorece maior preservação do meio ambiente e baixa densidade, por isso também as questões relacionadas à incidência da legislação de uso e ocupação do solo acabaram não sendo as mais relevantes para definição destes projetos, sendo mais significativas, as questões relacionadas às ótimas orientações, principais vistas e topografia do terreno.

Os volumes das unidades habitacionais são praticamente autônomos com relação ao contor-

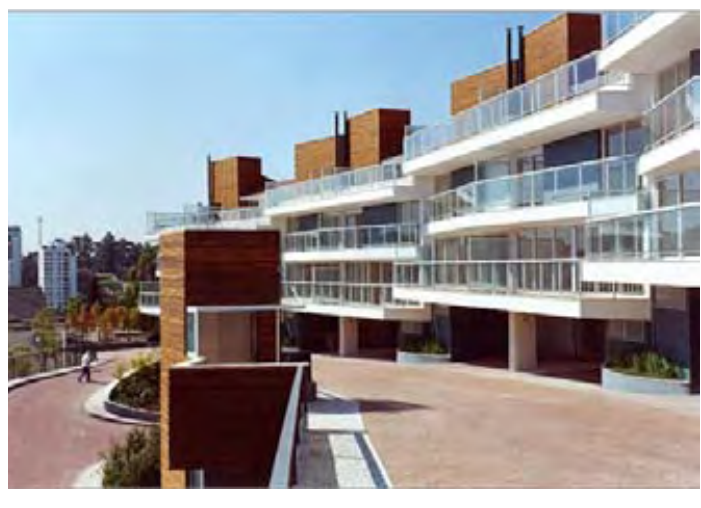

Figura 8 - Inserção em lote com alta declividade, grande e irregular: Espaço Móbile II (projeto e construção 2002/2003), Mauro Munhoz Arquitetura. Localizado na Rua Dom Paulo Pedrosa, I50, Morumbi, São Paulo, em lote de 3229 $\mathrm{m}^{2}$. 12 unidades habitacionais justapostas, e com pouca variação tipológica. Possui maior compromisso com o contorno do lote urbano em comparação aos três exemplos que representam este grupo:Vila Butantã, Canaã e Vila Taguaí. no dos limites do lote, ao mesmo tempo, não são autônomos da topografia.A possibilidade de adaptação das unidades e replicação em terreno com topografia íngreme se faz possível, principalmente na Vila Taguaí onde é preservado o perfil original do terreno com apenas os pilares chegando até o solo.

Assim, representam casos diferenciados, não tanto pela situação de implantação no lote urbano, mas sim por representarem experiências interessantes e inovadoras, no sentido da criação de novas técnicas construtivas aliada ao fato do arquiteto ser empreendedor do seu próprio projeto (para o caso das vilas Taguaí e Butantã) criando alternativas a habitação convencional promovida pelo mercado imobiliário, portanto, também estão “infiltrando a arquitetura", conforme significado da expressão criada por Fernando Diez:

Sacando ventaja de sus espacios vacantes, aumentando las superfícies de uso, en lo que llamo infiltrando la arquitectura. A una escala mayor, en una suerte de infiltración del tejido urbano, jóvenes arquitectos trabajan tanto como diseñadores como promotores de sus proprios proyectos, explorando oportunidades ocultas en la ciudad, alternativas a la vivienda convencional, encontrando una brecha en el mercado inmobiliario donde la experimentación pueda ser llevada adelante y tener êxito. Es lo que llamo infiltrar la ciudad. (DIEZ, 20 I0, p. 36). 


\section{Projeto: Fidalga 897 (Arquiteta Cristina Xavier)}

Abaixo condicionantes significativas na definição da implantação:

- Regras da legislação: as unidades habitacionais poderiam ser sobrepostas, desde que não ultrapassassem o gabarito de altura igual a nove metros, ou seja, de três pavimentos (porém, vale registrar que as construções nos terraços do bloco ao fundo do lote fogem desta regra);

- Topografia: alta declividade

- Principais visuais;

- Orientações.

Estas condições foram consideradas pela arquiteta autora do projeto, de tal modo a distribuir as unidades habitacionais em dois blocos, para permitir melhores oportunidades de espaço, insolação e ventilação de todas as unidades. Os blocos foram implantados de tal modo a manter ao máximo o terreno natural original.As grandes aberturas e terraços foram direcionados às principais visuais. Este terreno está localizado numa parcela do BairroVila Madalena, ao lado de uma praça, que já foi conhecida como "Buraco da Rodésia", cenário de problemas no bairro, como depósito de lixo ou situações de perigo e insegurança aos moradores, conforme pode ser observado pelo relato do livro da cronologia do governo da Prefeita Luiza Erundina em São Paulo:

22 Julho 1989 - A Administração Regional de Pinheiros promove reunião com moradores das imediações das ruas Fidalga e Rodésia, na Vila Madalena, para decidir o que fazer com o buraco da Rodésia. A área, um barranco de quase 500 metros quadrados, vinha servindo como depósito de lixo e ponto de marginais. A prefeitura urbanizou o local, colocando grama e iluminação pública, construindo escadarias e rampas de acesso. Os moradores acabam votando e escolhem uma área de lazer, com equipamentos para crianças e adultos. $O$ lugar é transformado em praça. (PATARRA, 1996). 

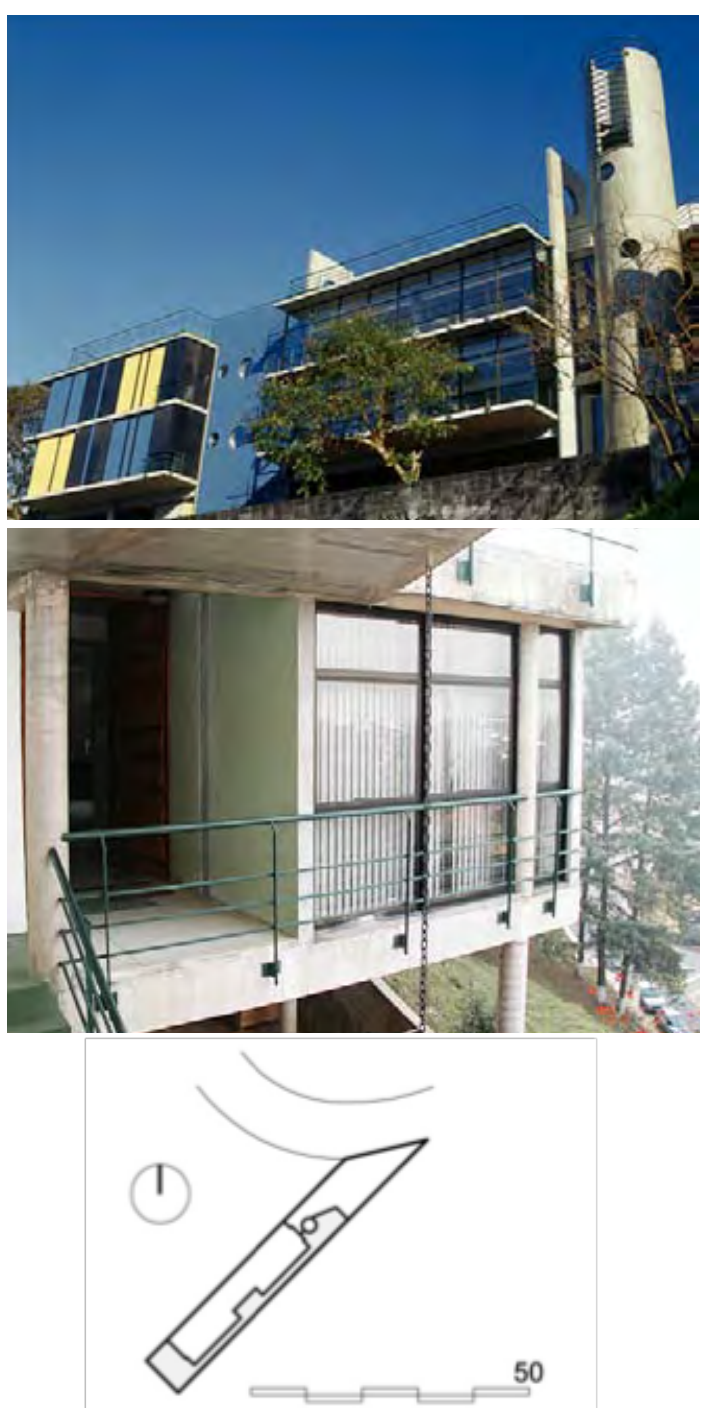

Figura 9 - Inserção em lote com alta declividade e regular: Edifício Oiapoque (2001/2003),Vista Urbana Arquitetura, Localizado na Rua Aecri, Alto de Pinheiros, SP em lote de $550 \mathrm{~m}^{2}(8,25 x$ $50 \mathrm{~m})$. Duas habitações sobrepostas. Arquiteto empreendedor do projeto.
Isto também, porque se tratava de um trecho sem conexão com o viário, até mesmo pela topografia extremamente acidentada. Abaixo relato do arquiteto Nabil Bonduki, morador deste trecho da Rua Fidalga durante anos:

Por volta do final dos anos 70 e início dos anos 80 , foi o período que eu fiz a reforma da minha casa na Vila Madalena, que inclusive é onde eu moro até hoje. Eu comprei a casa, que por sinal era velha e ficava num buraco, na Fidalga com a Rodésia, uma área de depressão, não tinha rua, um trechinho bem desconhecido, bem fim de mundo. (...) (BONDUKI, 20I2)

Assim, o projeto está localizado em um terreno muito íngreme, com mais de 30 graus de inclinação, ao lado de uma praça que conecta por uma escadaria a Rua Fidalga à Rua Fradique Coutinho, passando pela rua sem saída Rodésia, de onde é possível perceber a inserção deste conjunto na topografia. Esta praça também conecta a parte alta da Rua Fidalga, onde estão duas obras desta pesquisa; o Fidalga 897 e Vila Fidalga, ambos da Arquiteta Cristina Xavier; com a parte baixa, onde estão os edifícios Fidalga 772 e 727, do Andrade Morettin e Triptyque respectivamente. Este empreendimento, um dos primeiros da Zarvos na Vila Madalena, consegue, portanto, encontrar uma localidade que pouco interessava ao mercado imobiliário ou a própria municipalidade, ao mesmo tempo, soube perceber a situação urbana em que se encontrava, pois o local estava recebendo melhorias e teria um potencial de valorização ainda maior integrado a uma proposta de habitação coletiva no local, que independentemente a qual classe social comporta, em associação com outras melhorias no local, acabou beneficiando o trecho de rua. 


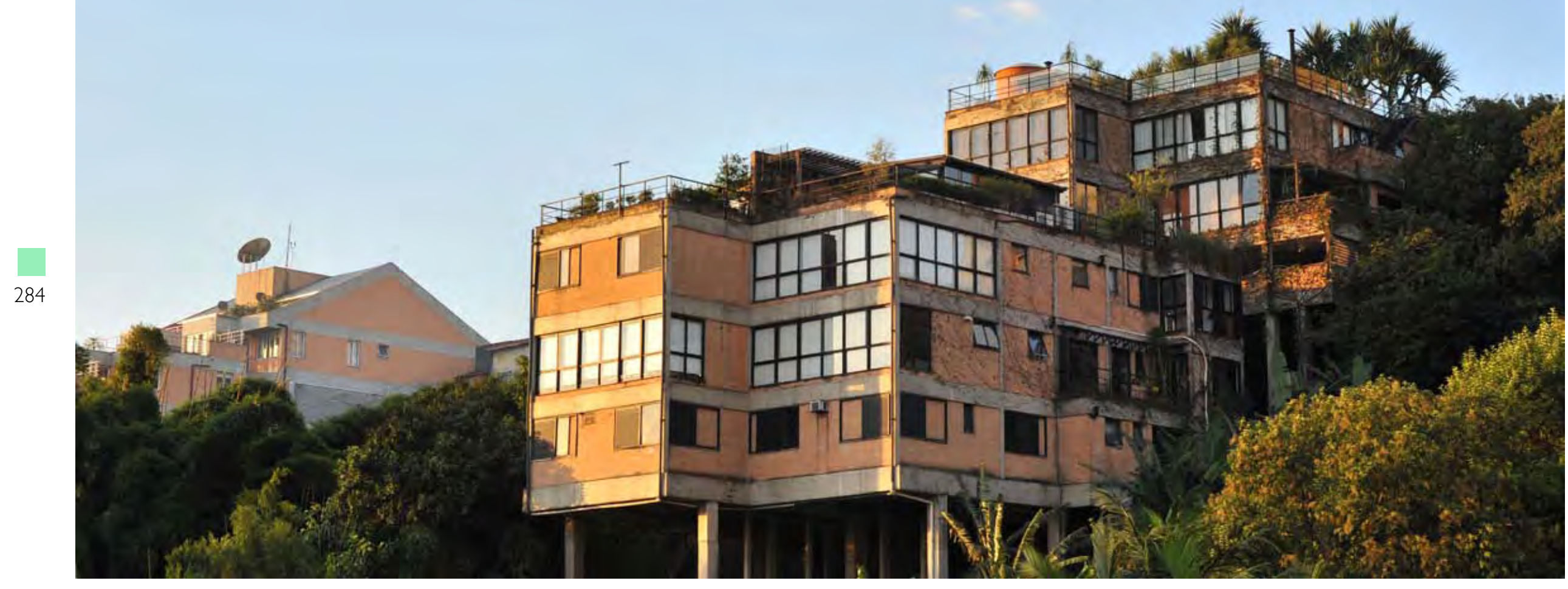

Figura 10 - Fidalga 897 visto desde a Rua Fradique Coutinho com a Rodésia. 

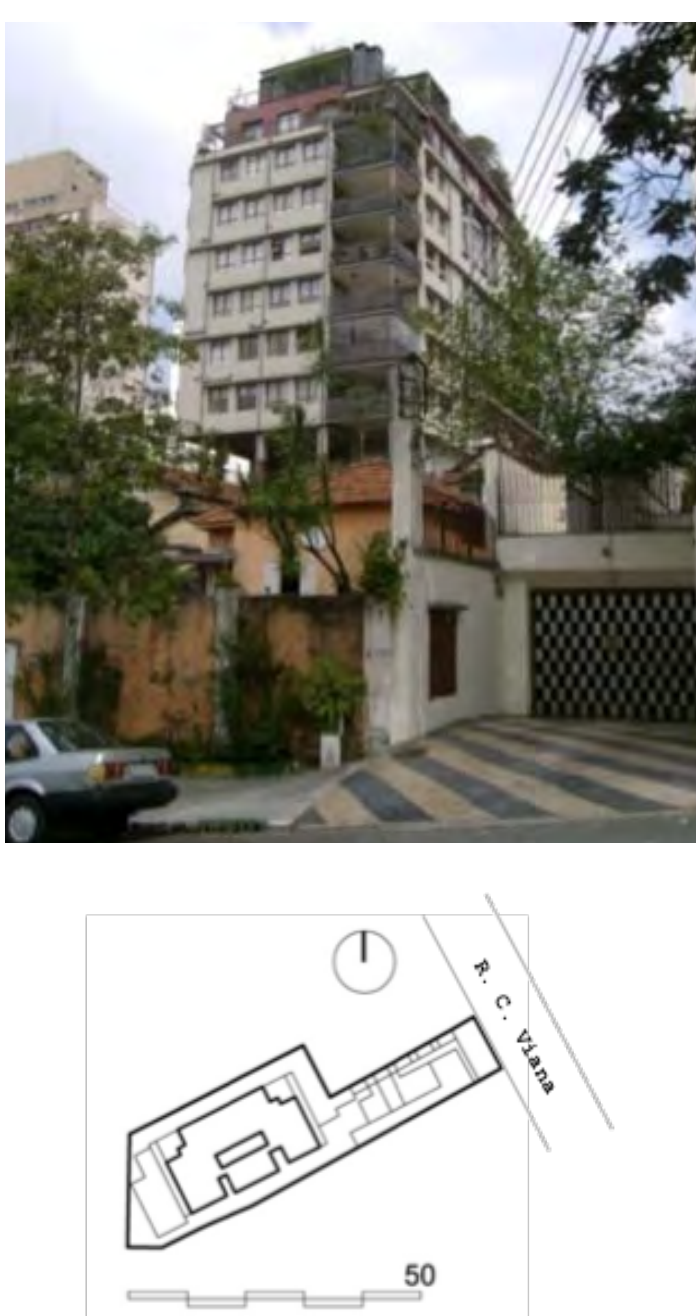

Figura I I - Inserção em lote médio e irregular: Edifício $4 \times 4$ (projeto e construção 2006/2008), do escritório Gui Mattos Arquitetura. Localizado na Rua Cristiano Viana, Jardim América em lote de $1063 \mathrm{~m}^{2}$. Apresenta 18 unidades habitacionais sobrepostas e trata-se de mais uma realização da Idea!Zarvos.

\section{TAMANHO MÉDIO + IRREGULAR}

\section{Projeto: Simpatia 234 (GRUPO SP) e Fidalga 772 (Andrade Morettin)}

Abaixo condicionantes significativas na definição da implantação:

- Regras da legislação: recuos de 3m e 5m. Área externa livre com no mínimo 10m de diâmetro. Definição do nível do pavimento térreo para o caso do Fidalga 772: segundo legislação de São Paulo, para terrenos com aclive com relação a rua, o pavimento térre deve ficar, no máximo, a um metro do ponto médio do nível natural do terreno.

\section{- Formato irregular do lote;}

\section{- Principais visuais;}

- Orientações.

Os recuos obrigatórios e o formato irregular do lote resultaram em implantações que segue contornos do lote e reserva espaço livre com diâmetro de $10 \mathrm{~m}$. Para o caso do Simpatia 234, esta exigência fica mais evidente, pois acabou definindo o formato das passarelas de acesso às unidades.

No Simpatia 234, a possibilidade de conexão, já que o lote está voltado a duas vias públicas, e a intenção de visibilidade em direção ao vale, tiveram como consequência um vazio no térreo que permite vista privilegiada. Para o caso do Fidalga 772, o edifício foi implantado em “L”, fazendo uma transição que contorna a geometria do terreno, com uma leve inclinação de uma das faces, sendo esta a que proporciona vista privilegiada em direção à área arborizada da creche no terreno vizinho à este projeto.

É importante mencionar, que mesmo se tratando de declividades média e alta, estas não foram muito significativas para o projeto, já que se adotou a solução de corte de terra para implantação do estacionamento no nível do subsolo.

Ao mesmo tempo, os dois projetos mantém um trecho pequeno de terreno original no subsolo, reduzindo um pouco a área destinada à garagem de veículo, até mesmo para possibilitar entrada de luz natural e reduzir um pouco o caráter opressivo que estas áreas costumam possuir. Este assunto será abordado na conclusão sobre o tema "ESPAÇOS EXTERIORES". 


\section{Projeto: Aimberê (Andrade Morettin) e Fidalga 727 (Triptyque)}

Abaixo condicionantes significativas na definição da implantação:

- Regras da legislação: recuos de $3 \mathrm{~m}$ e $5 \mathrm{~m}$. Área externa livre com no mínimo $10 \mathrm{~m}$ de diâmetro.

- Formato do terreno: estreito e comprido;

\section{- Orientações.}

Estas condicionantes levaram à implantação do edifício conforme contorno do terreno, utilizando recuo frontal alongado para reservar a área livre com no mínimo $10 \mathrm{~m}$ de diâmetro.

\section{I.2.I ARTICULAÇÕES PAULISTNAS}

Os quatros projetos apresentados, inseridos em lotes de médio porte, todos naVila Madalena - Simpatia 234, Fidalga 772,Aimberê e Fidalga 727 e outros citados nesta pesquisa (Figura 13), estão em zona mista de média densidade, são edifícios que possuem gabaritos de altura de aproximadamente 25 metros (máximo permitido para esta zona), isolados pela própria condição do lote versus legislação de uso e ocupação do solo e adensam o quarteirão ainda em pontos isolados gerando uma descontinuidade na morfologia urbana do bairro, já que as construções originais ou mais antigas do bairro são mais baixas. Estes quatro projetos foram publicados recentemente na revista portenha SUMMA +, e são reconhecidos por Fernando Diez como "articulações paulistanas" (Figura I5).

Segundo a proposta do Plano de Bairro da Vila Madalena (que ainda não virou lei), a ideia é conter as verticalizações excessivas, criar adensamentos pontuais de forma controlada, e preservar a escala das construções lindeiras ao viário, ou seja, evitar torre em excesso que geralmente são propostas pelo mercado imobiliário que acabam por descaracterizar as ruas (Figura 14). Há uma divisão de opiniões entre os moradores, entre aqueles que querem "congelar" o bairro, e aqueles a favor da verticalização e valorização imobiliária, situação vigente no momento.
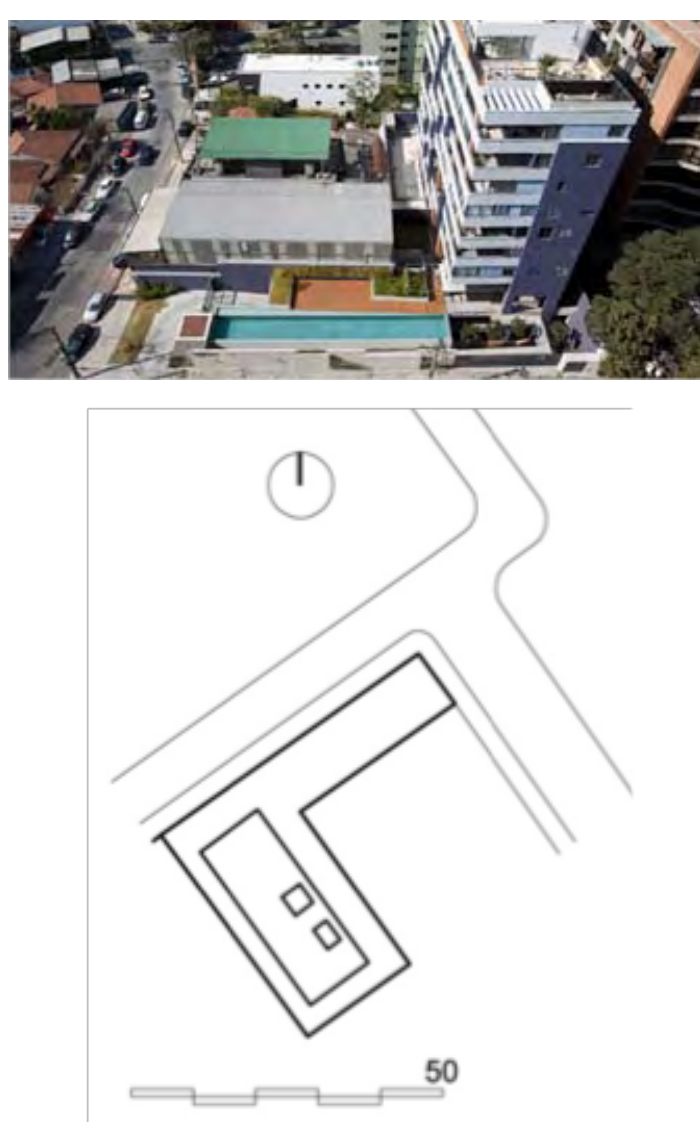

Figura 12 - Inserção em lote médio e irregular: Edifício Ourânia (projeto e construção 2007/2008), Gui Mattos Arquitetura. Localizado Rua Ourânia, 77, Alto de Pinheiros, SP. $1104 \mathrm{~m}^{2}$ com 15 habitações diversificadas. 


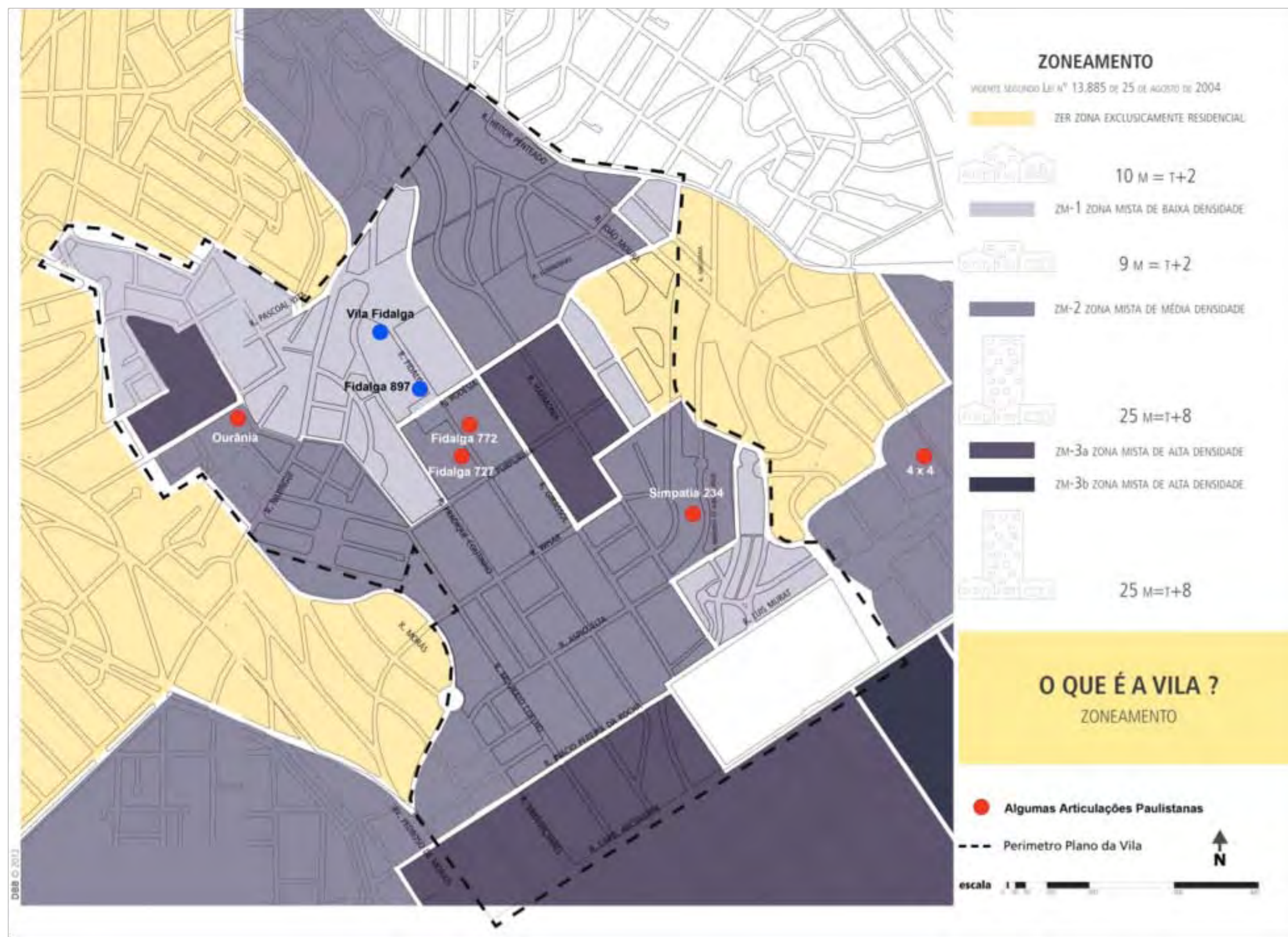

Figura 13 - Projeção da carta de uso e ocupação do solo do Plano diretor de São Paulo no Bairro da Vila Madalena. Em vermelho, destaque para algumas "articulações paulistanas" citadas nesta pesquisa (marcação autora). 
O plano, mesmo sendo apresentado por Otávio Zarvos, um construtor, o que pode causar certa desconfiança, parece tentar propor algo mediano, nem tão conservador, mas também a favor do adensamento controlado (Figuras 16 e 17). Assim, caso o plano realmente se torne realidade, será contida a substituição de boa parte das construções nas quadras urbanas (mas não de todas), e assim a afirmação de Diez (20I2) com relação a estas atuações na Vila Madalena pode se tornar realidade:

\begin{abstract}
Uma quarta situação mostra edifícios isolados mais laminares, que adensam o tecido dos quarteirões de São Paulo, mas não ameaçam substituí-lo completamente, e é o que caracterizamos aqui como "articulações paulistanas". Neste caso, os apartamentos são empilhados verticalmente dando forma a uma situação urbana descontínua, com edifícios altos e baixos em um bairro de classe média que passou por contínuas transformações; um processo análogo ao que tem acontecido no bairro portenho de Palermo desde meados dos anos 90. (CORTI, DIEZ, DI PECO, KOMMERS e SORIA, 20I2, p. 27)
\end{abstract}

Portanto, pode-se entender estas atuações na Vila Madalena conjuntamente com o Plano de Bairro previsto, como "articulações paulistanas", já que, diferentemente da situação que ocorreu e ainda ocorre em bairros de Buenos Aires, como Núñez ou Colegiales onde as "táticas de infiltrações" urbanas criaram uma corrente que foi contagiando pouco a pouco trechos até encher de vida vários bairros portenhos, na Vila Madalena, a situação proposta é para conter os grandes empreendimentos imobiliários, mas ao mesmo tempo criar pontos (os edifícios padrão Idea!Zarvos) que articulem e qualifiquem a situação diversificada mantida.

De todo modo, a "articulação" parece mais brusca que a "infiltração”, seja pela escala das obras pontuais ou pela forma como se propõe a inserção no bairro, já que ele está formado e consolidado. A pergunta seria:Aquilo que já está formado; os espaços públicos, principalmente o sistema viário; comporta estas articulações? O plano de bairro incentiva a criação de passagens públicas a partir da transferência do potencial construtivo para os terrenos a serem incorporados, contendo assim, os adensamentos desenfreados, já que estariam vinculados à criação de espaços públicos, na própria

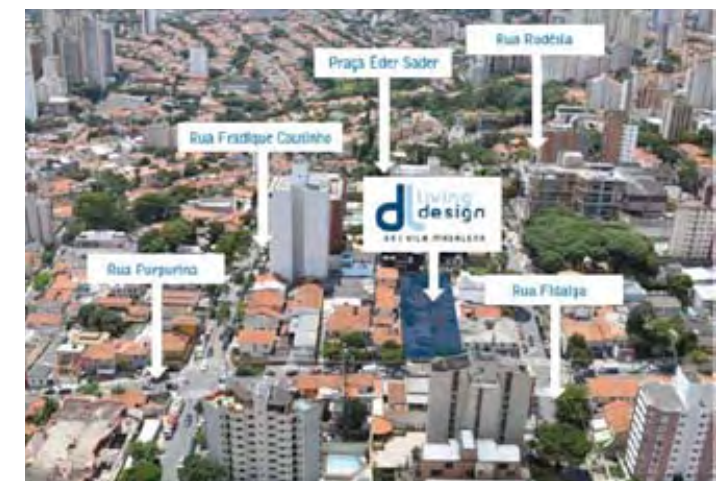

Figura 14 - Divulgação de empreendimentos imobiliários. O que diferencia a inserção urbana das realizações da Idea!Zarvos das outras realizações? Principalmente a boa arquitetura, que se abre para a cidade e a rua, evitando propor um clube condominial. É diferente de empilhar andares, o que acontece nas maioria das outras realizações. A imagem revela edifícios com grandes empenas cegas, janelas pequenas, piscinas e cercamentos, levando monotonia à cidade, é possível, mesmo que de longe, ver grandes, Uma escala de implantação com maiores proporções se comparada ao edifício Fidalga 772. 


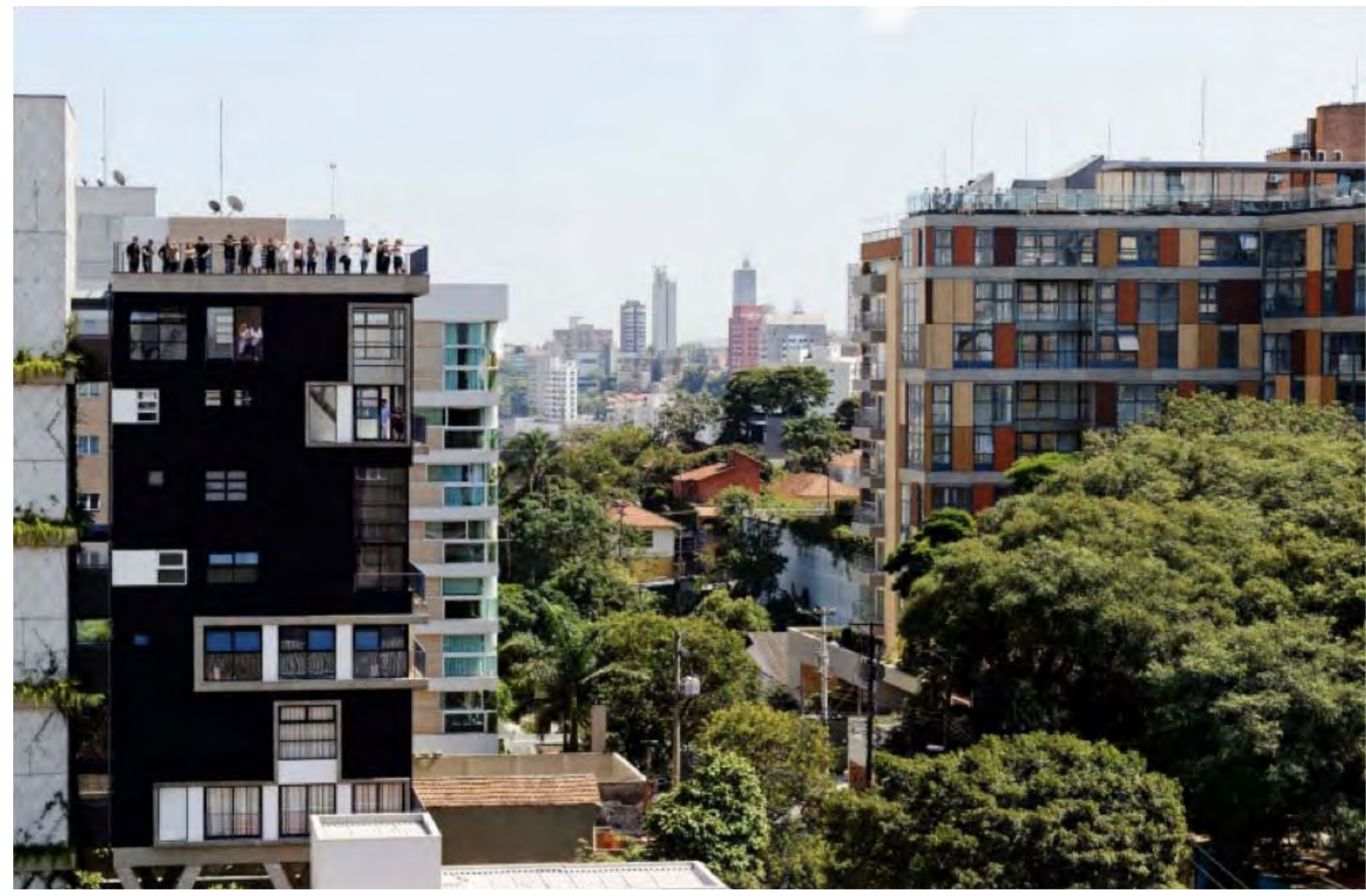

Figura 15 - Fidalga 727 (esquerda) e Fidalga 772 (direita). Denominados por Fernando Dize, da revista SUMMA+ de "articulações paulistanas. 


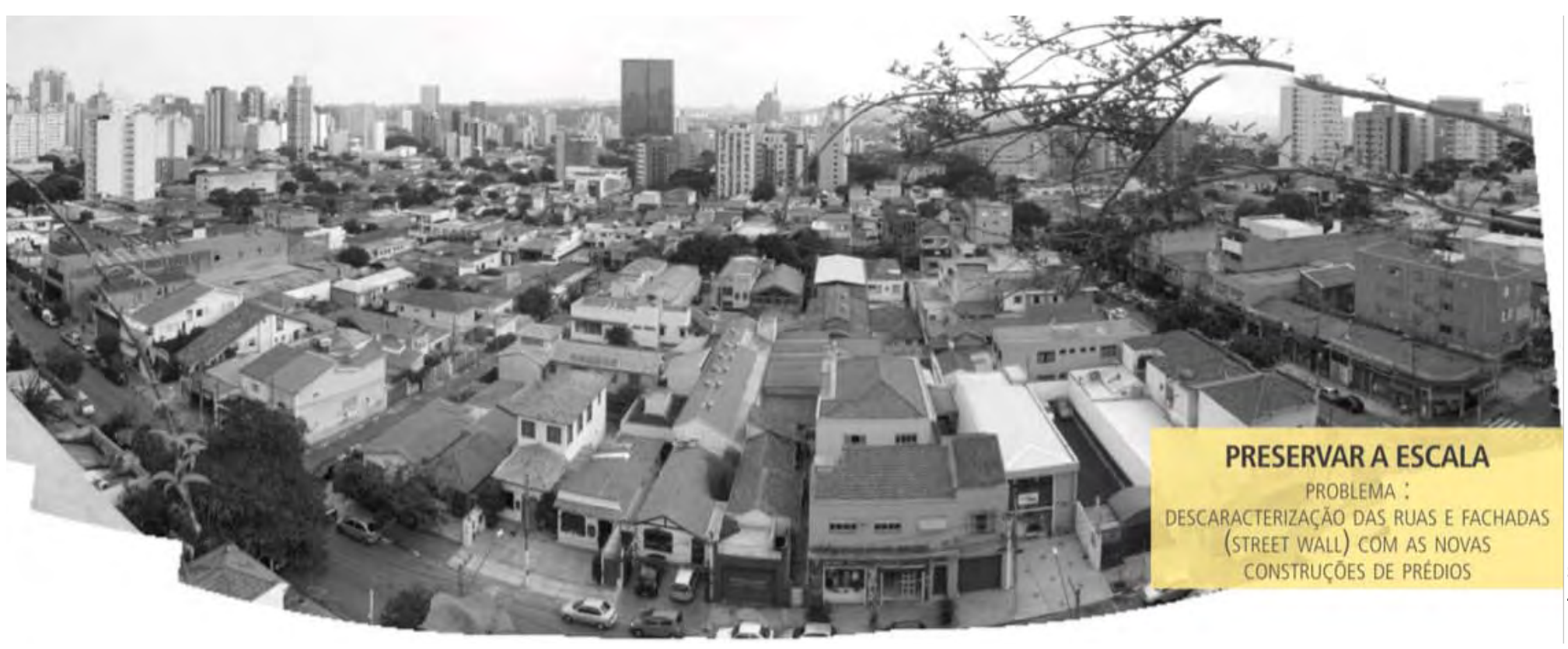

Figura 16 - Pelo plano de bairro da Vila Madalena, a preocupação exposta é com relação a descaracterização das ruas e fachadas devido a presença de novas construções de prédios.

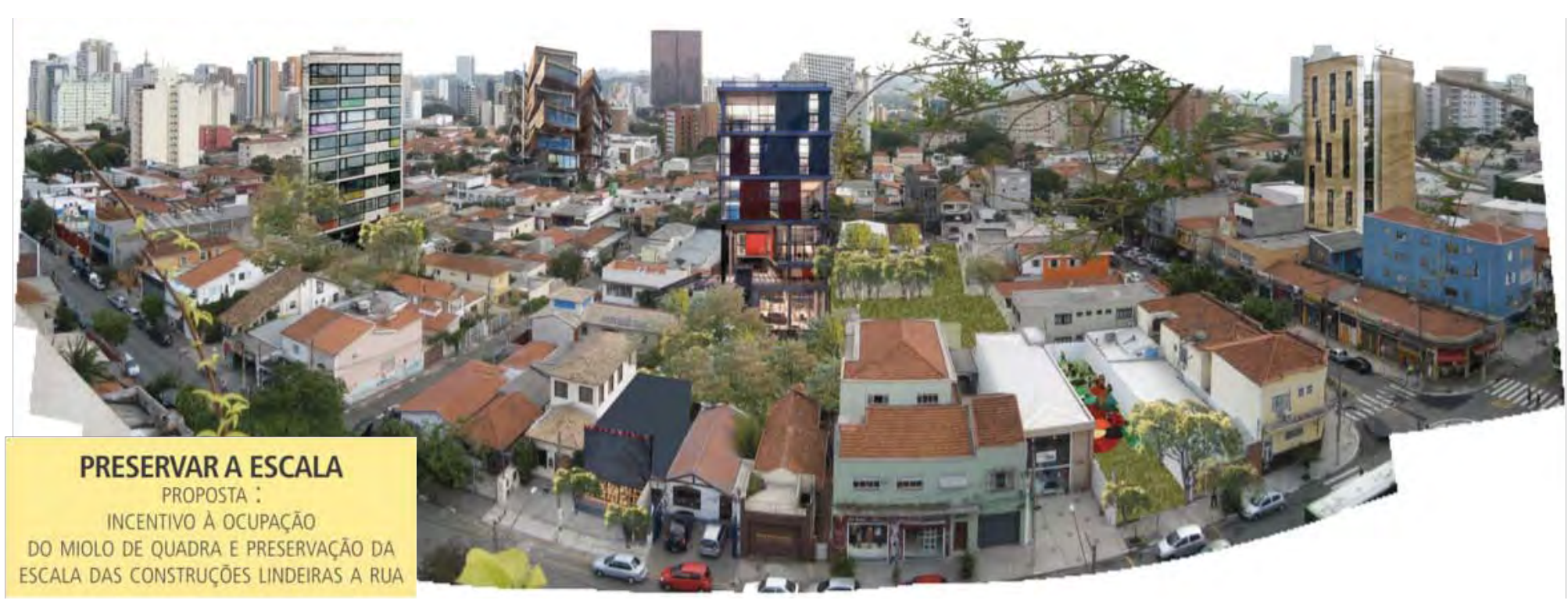

Figura 17 - A solução para o problema é incentivar a ocupação do miolo de quadra e preservação da escala das construções lindeiras. 


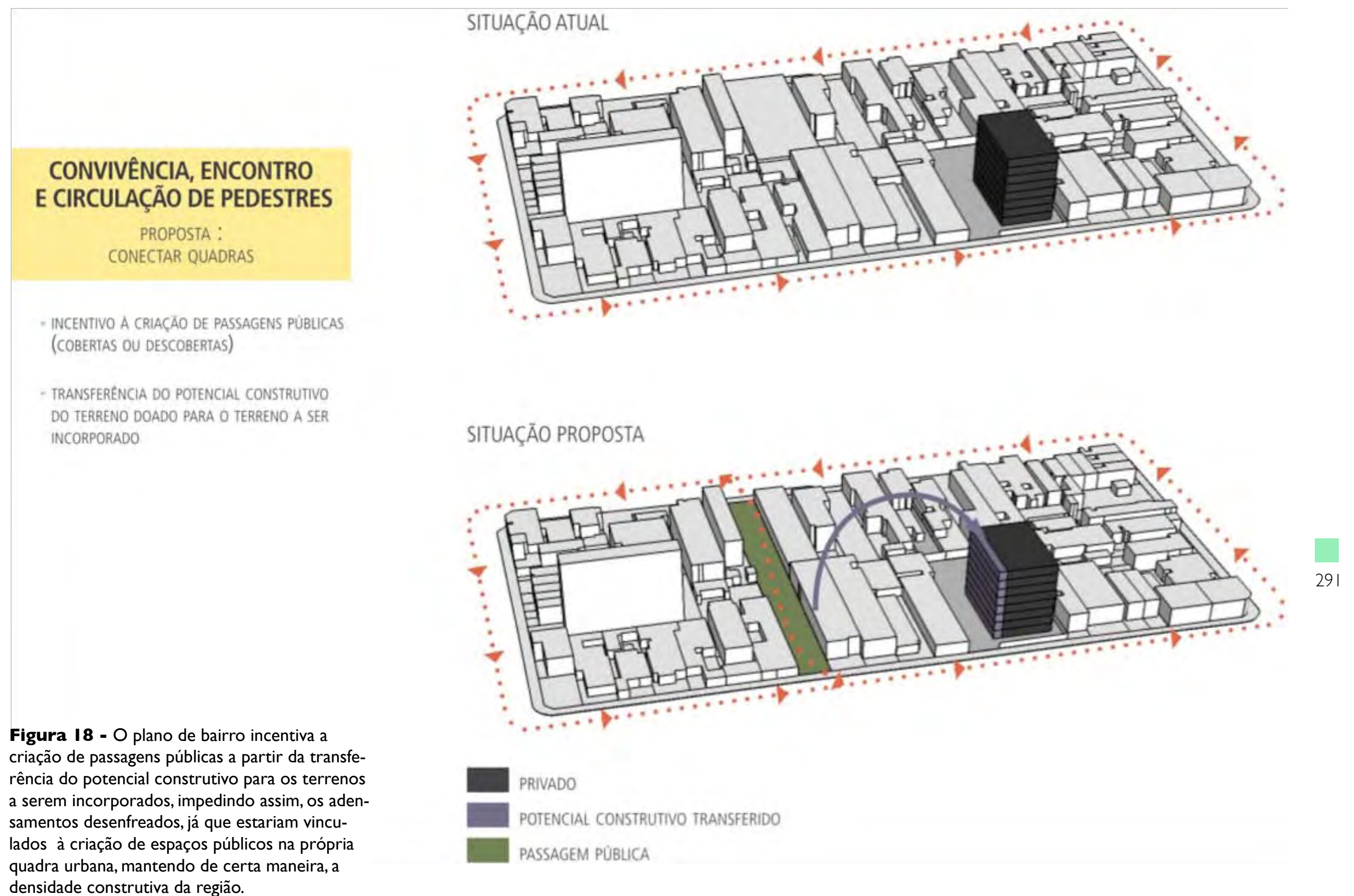


quadra urbana, mantendo de certa maneira, a densidade construtiva da região (Figura 18). Assim haveria colaboração das incorporadoras na criação de espaços públicos ou melhoria dos existentes.

Caso não sejam realizadas as propostas conforme previsto no plano, e não tenha esta contrapartida em espaço público adicional, estas articulações podem desconfigurar o bairro, como inclusive já vem acontecendo. Parece tarde propor isto para um bairro originalmente popular que vem sofrendo grandes transformações nos últimos anos, porém, antes um plano tardio do que perder o bairro por completo para o mercado imobiliário.

\section{TAMANHO PEQUENO + REGULAR}

Projeto: AFiori di Maggio (Arquitetos Carlos Ferrata, Apoena e Moracy Amaral, Eduardo Ferroni e Pablo Hereñú), Vila Pedro Fachini (arquitetos Marcelo Barbosa e Jupira Corbucci) e Vila Maida (Arquiteta Maristela Faccioli)

Abaixo condicionantes significativas na definição da implantação:

- Regras da legislação: recuos obrigatórios.

- Formato do terreno: estreito e comprido;

- Tamanho do lote: pequeno;

- Orientações.

Para o caso do Fiori di Maggio, estas condicionantes consideradas conjuntamente, levou a implantação em dois blocos interligados por passarela envidraçada. O bloco frontal, junto à rua, encostado nas laterais do terreno, possui aberturas no sentido norte-sul, o bloco posterior, recuados das divisas, permite aberturas no sentido leste-oeste.

Para o caso da Vila Fachini e Vila Maida, a edificação foi implantada junto a uma das laterais do terreno, enquanto que a outra lateral, respeitou o recuo obrigatório de $3 \mathrm{~m}$. Os dois projetos possuem apenas três pavimentos, limite viável no caso de um terreno com frente pequena. Foram criados vazios junto à divisa, pátios internos nas unidades habitacionais,
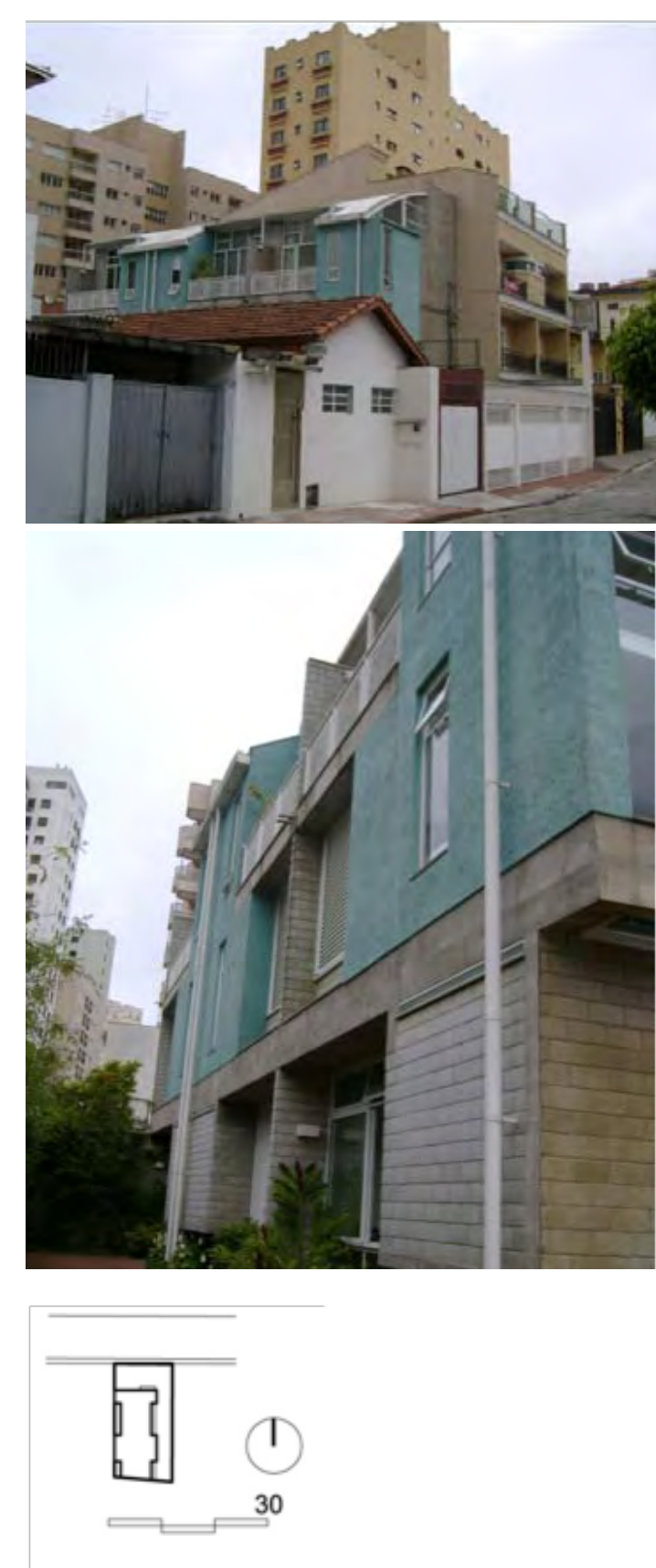
Figura 19 (página ao lado)- Exemplo de projeto que apresenta situação de inserção em lote pequeno e regular:Vila Maida (projeto e construção 2004/2006), da arquiteta Maristela Faccioli. O projeto está localizado na Travessa Santo Hilário, 60, Santo André, Grande São Paulo, em lotes de 220 m2. Apresenta 3 unidades habitacionais e trata-se de um empreendimento realizado pela própria arquiteta conjuntamente com primos engenheiros (Família Maida). consequência da situação de lote estreito. Para o caso da Vila Fachini, a situação de lote exíguo e a necessidade de implantar o maior número possível de unidades habitacionais, levaram a posicionar as escadas de acesso às unidades superiores no recuo de três metros. Estas intervenções, em lotes pequenos amenos à situação urbana do entorno, são as que mais se assemelham às “infiltrações urbanas" nos bairros portenhos, porém, como são muito pontuais, anda não conseguem ter a mesma força para qualificar grandes trechos do bairro, apenas melhoram aquele pequeno trecho de rua. Mas, talvez com paciência e trabalho é possível que estas atuações se espalhem pela cidade.

As vantagens da gestão daquilo que é grande não podem se separar das suas dificuldades. Da mesma forma que as vantagens daquilo que é pequeno não podem prescindir do tempo e da paciência para frutificar, as escalas intermediárias podem ser um ponto de compromisso, mas neste número não sobrou espaço para analisar se são capazes de negociar entre as vantagens e os problemas daquilo que é grande e daquilo que é pequeno. (DIEZ, 20I I, p. 67).

Assim,como colocado por DIEZ(20I I), as escalas intermediárias "articulações paulistanas" podem ser um ponto de compromisso ou simplesmente boas arquiteturas, com soluções arquitetônicas interessantes, porém, dentro do seu limite de lote.É preciso esperar para ter certeza desta afirmação. 


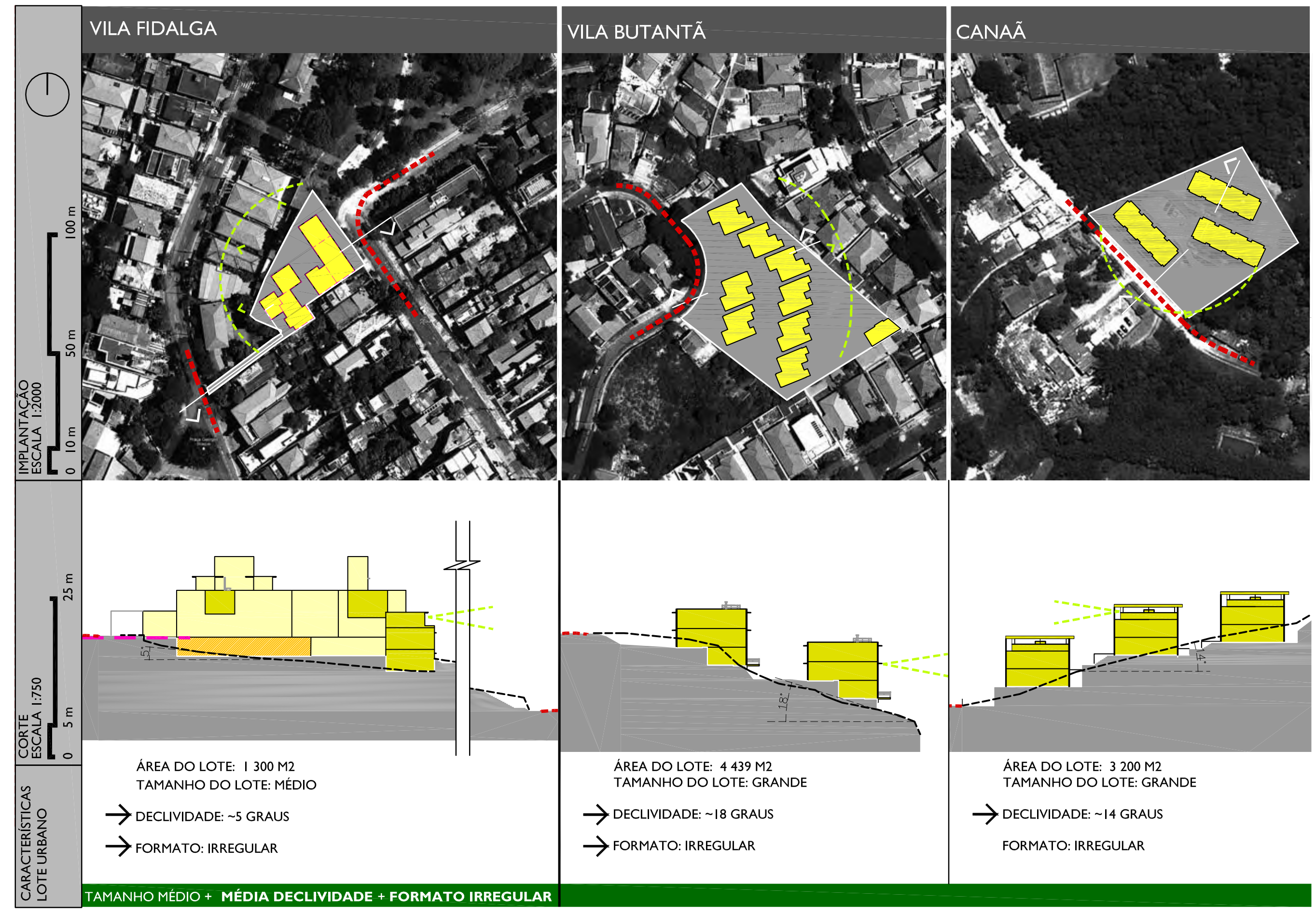




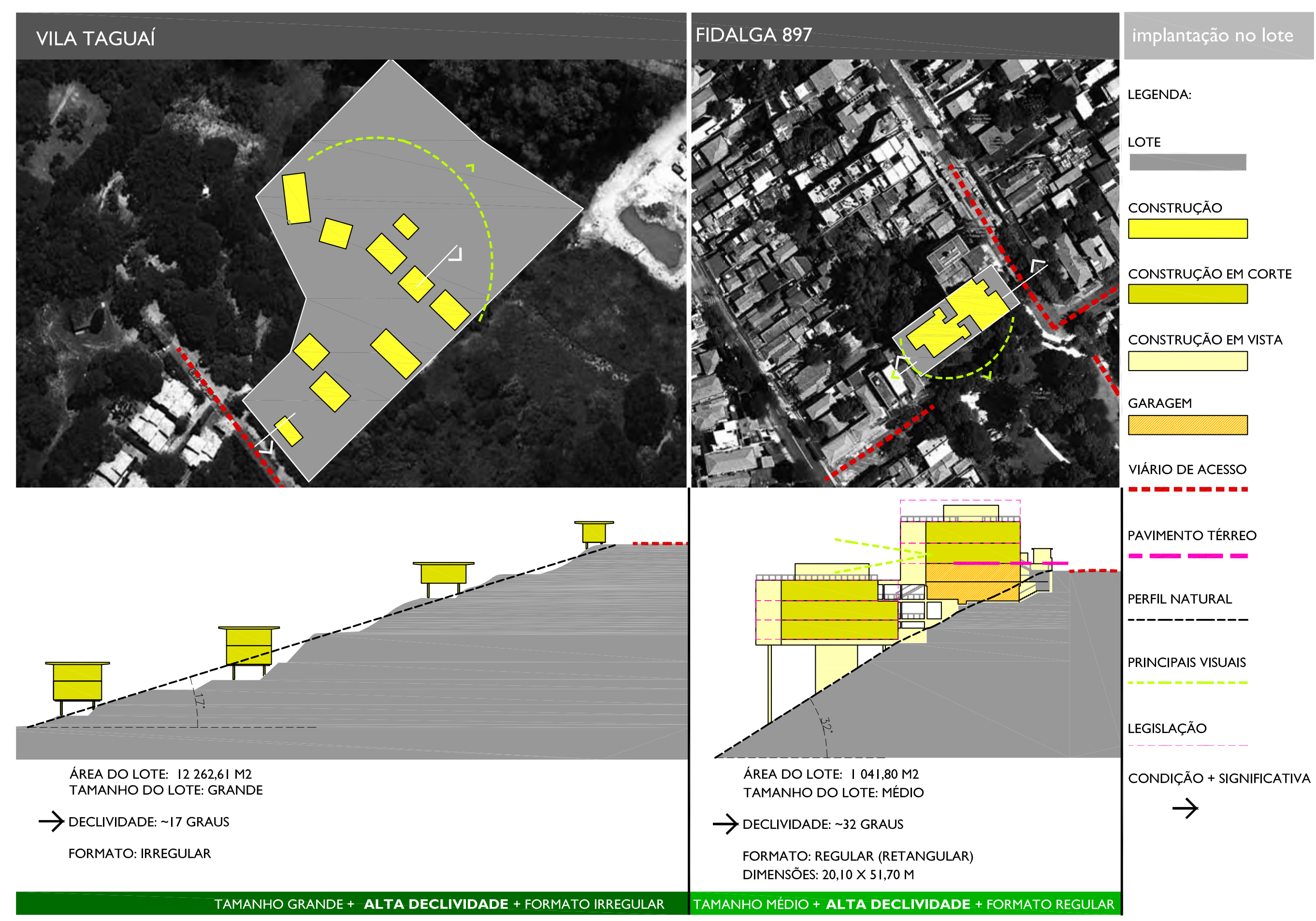




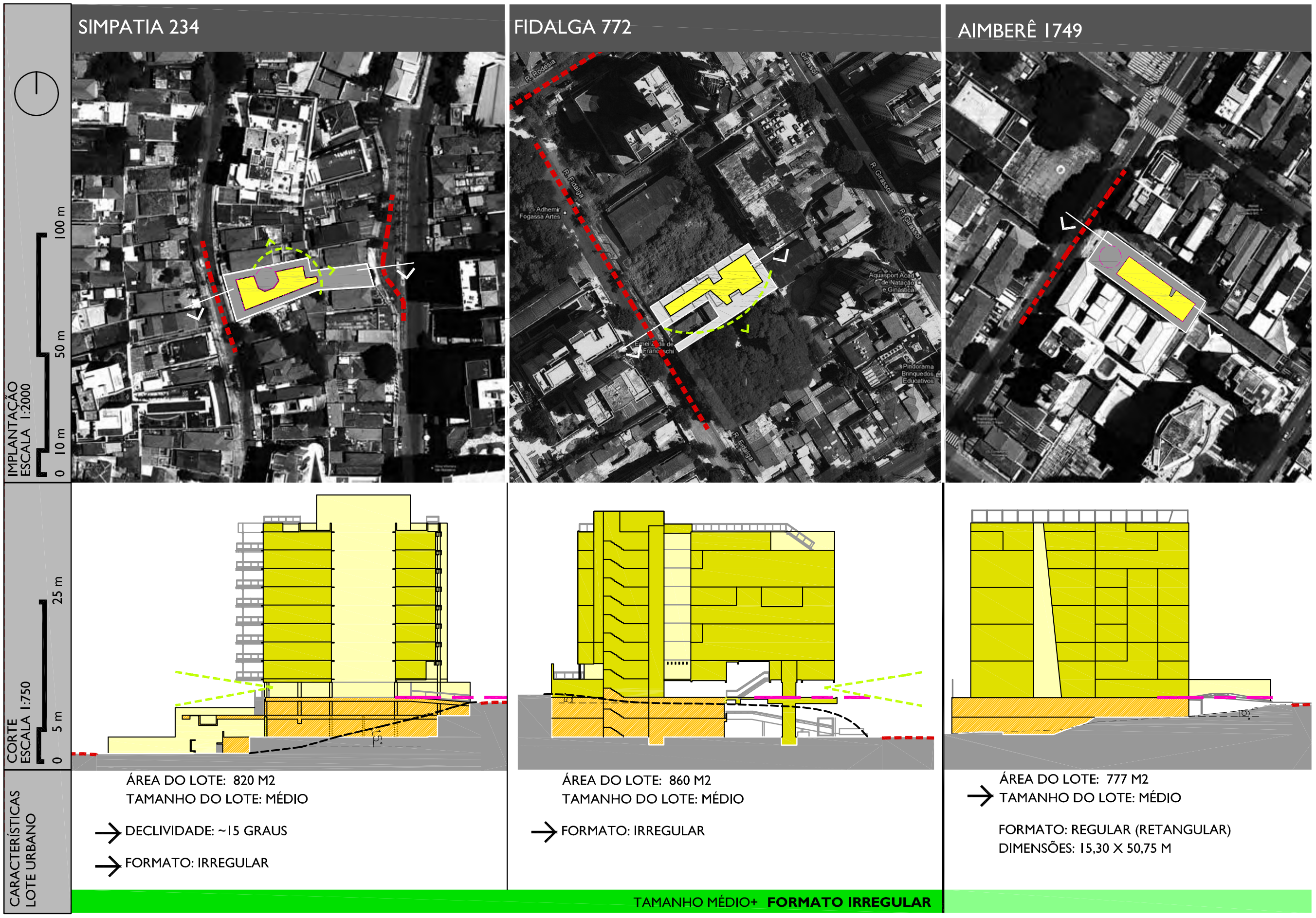




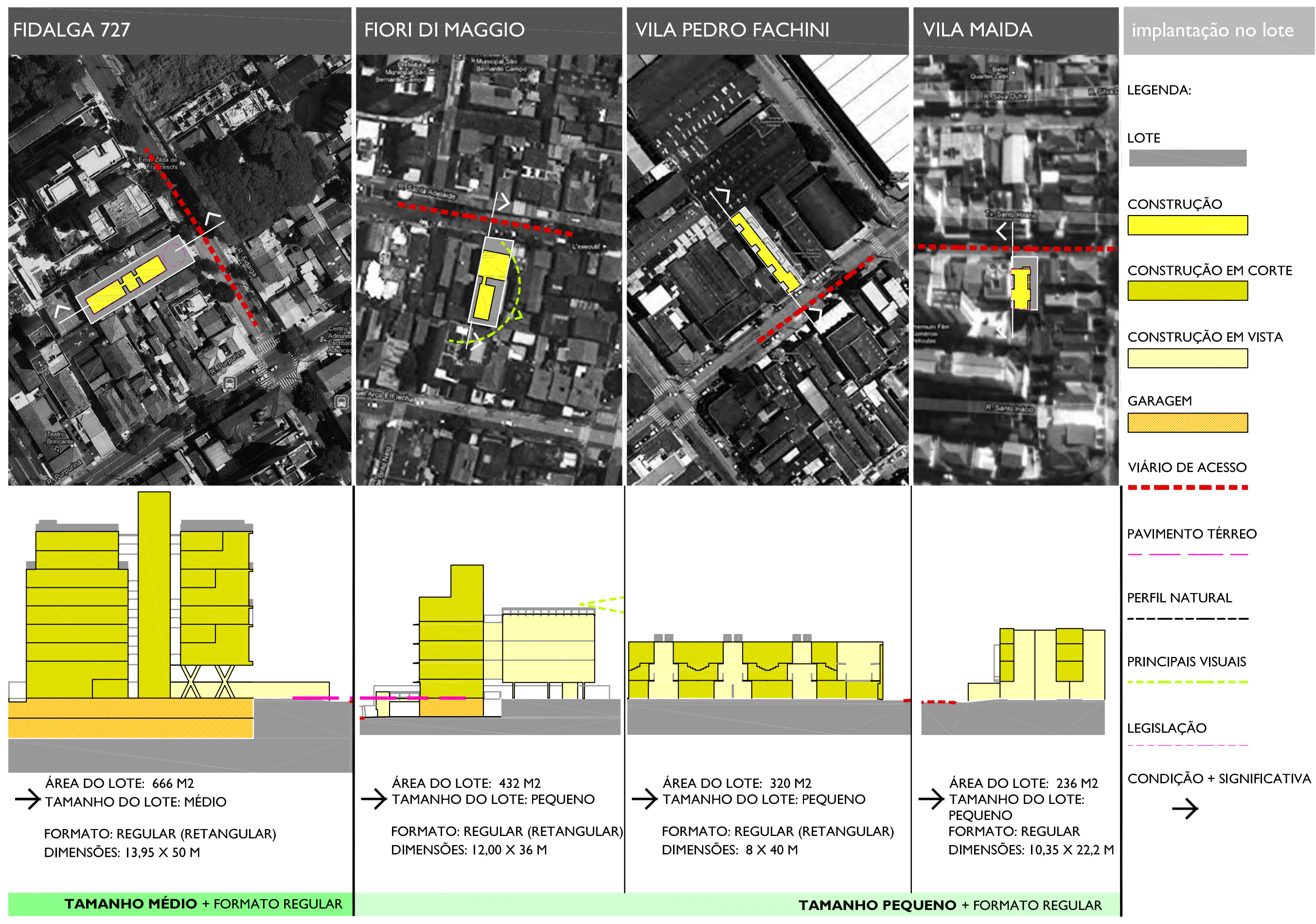


ALVIM,A. B. Por uma cidade compacta. São Paulo, SP20 14, março 2012. Disponível em: <http://sp2040.net.br/>.Acesso em:09/0 I/2013.

BONDUKI, N. Outras Histórias. Nabil Georges Bonduki. MUSEU DA PESSOA, 30 de Setembro de 2008. Disponível em: http://www.museudapessoa.net/MuseuVirtual/.Acesso em: 13/05/2012.

CERCHIARA, Débora.Vivir em Grupo. SUMMA+, Buenos Aires, n. I01, p.42-43, abril. de 2009.

CORBIOLI, Nanci. Entre o público e o privado. ProjetoDesign, São Paulo, n.287, p., janeiro de 2004.

CORBIOLI, Nanci. Proposta assegura total flexibilidade de layout. ProjetoDesign, São Paulo, n.353, p. 54 - 6I, julho de 2009.

CORTI, Carolina; DIEZ, Fernando; DI PECO, Martín; KOMMERS, Rodrigo W; SORIA, Soledad. Estratégicas de aglomeração e convivência. SUMMA+, Buenos Aires, n. I20, p.26-27, março 2012.

DIEZ. Fernando. Grande versus pequeno. SUMMA+, Buenos Aires, n. I I3, p.66-67, novembro de 201 I.

DIEZ. Fernando. Tácticas de Infiltración. Diez años de experimentación en Buenos Aires. SUMMA+, Buenos Aires, n. 107 , p.34-39, abril de 20 I0. FERREIRA, J.S.W. (Coordenação). Produzir casas ou construir cidades? Desafios para um novo Brasil Urbano. Laboratório de Habitação e Assentamentos Humanos da FAUUSP. São Paulo: LABHAB, FUPAM, 2012.

GEROLLA, Giovanny. Fachada customizada. Arquitetura e Urbanismo, São Paulo, n.20I, p. 45-49, dezembro de 2010.

298 MELENDEZ,Adilson. Mirante de concreto. ProjetoDesign, São Paulo, n.287, p., janeiro de 2004.

MONTANER, J. M.; MUXÍ, Z. M. Habitar el Presente. Vivienda en España: Sociedad, ciudad, tecnología y recursos. Madri: Ministerio de Vivienda, 2006.

MONTANER, J. M.; MUXÍ, Z. M.; ZULIN, F.; CORADIN, R. Instrumentos de Avaliação de Projetos. Em: Do plano ao projeto: Novos Bairros e Habitação Social em São Paulo. Coleção: Política Municipal de Habitação: Uma construção coletiva. São Paulo: Secretaria Municipal de Habitação, Prefeitura de São Paulo, 2012, p. 252-3I3.

PATARRA, I. O governo Luiza Erundina. Cronologia de quatro anos de administração do PT na cidade de São Paulo, de 1989 a 1992 . São Paulo: Geração Editorial, 1996.

SAYEGH, Simone. Para (vi)ver como se quer. Arquitetura e Urbanismo, São Paulo, n. I83, p. 40 - 47, junho de 2009.

SERAPIÃO, Fernando. Mudança de ares. ProjetoDesign, São Paulo, n.353, p. 68 -79, julho de 2009. 


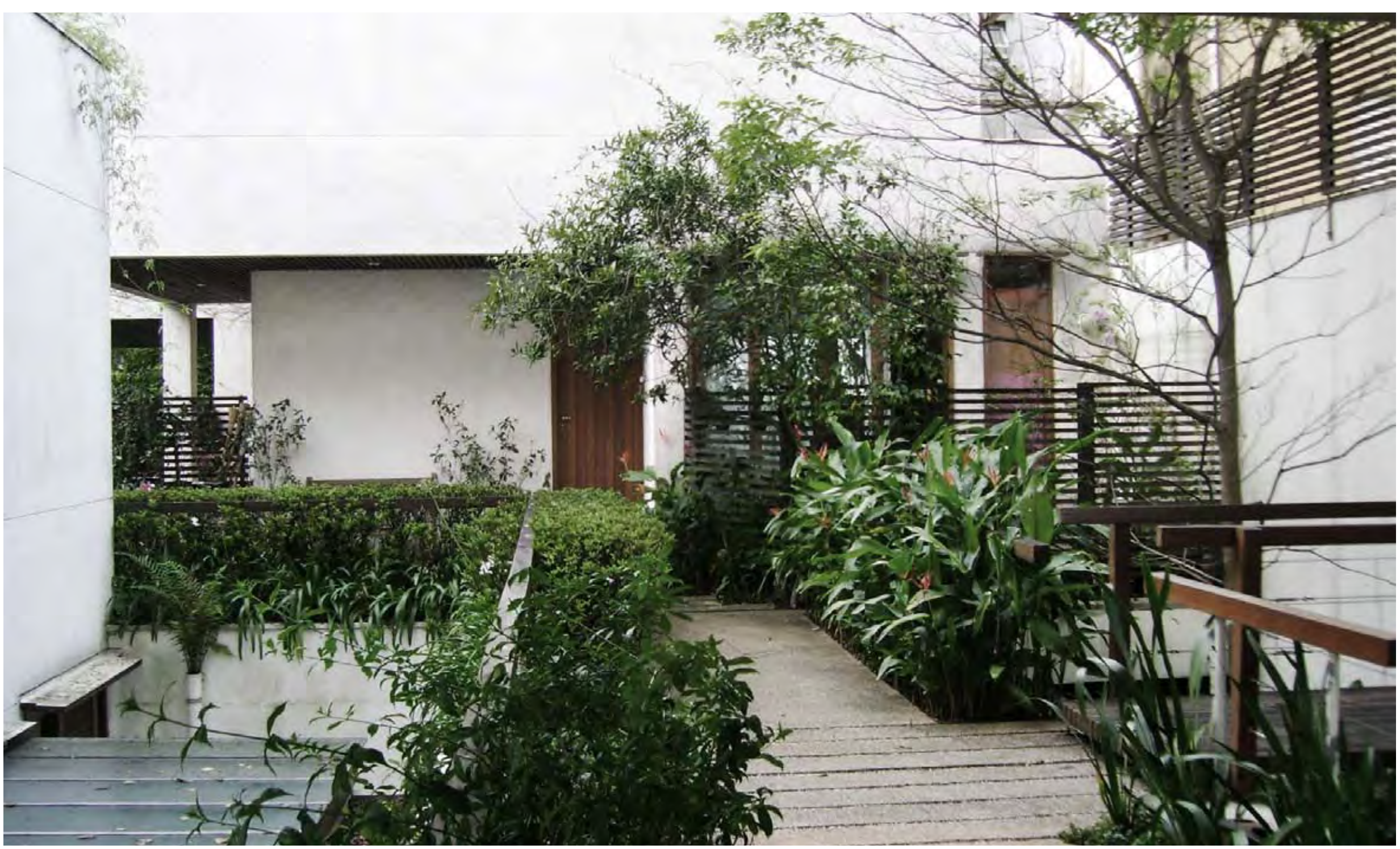

4. ANÁLISE COMPARATIVA E CONSIDERAÇÕES FINAIS POR TEMAS PRESENTES NOS PROJETOS SELECIONADOS 4.2 ESPAÇOS EXTERIORES 


\subsection{ESPAÇOS EXTERIORES}

Los espacios comunales tienden a cumplir una función de umbrales entre el interior y el exterior del proyecto, entre los espacios compartidos por la ciudadanía en lo público y los espacios compartidos por los núcleos de viviendas en lo privado. (BAHAMÓN e SANJINÉS, 2008, p. 47)

Los espacios intermedios son fundamentalmente lugares de relación, extensión de lo privado en lo público y viceversa, de lo público sobre lo privado. Son espacios de proximidad que potencian la sociabilización. (MONTANER,MUXí; 2006, p. 34 e 35).

Espaços exteriores são os espaços entre o limite do espaço interior da unidade habitacional e o limite do espaço público. A falta de relação entre os espaços exteriores com a arquitetura do edifício nos empreendimentos realizados pelo mercado imobiliário vem tornando a habitação coletiva ainda pior nestes casos. Existe na cidade de São Paulo e em outras cidades no Brasil, não apenas tipologias edilícias carimbadas em terrenos de maneira aleatória, como também, um tratamento das áreas exteriores sem relação com o projeto do edifício. É possível identificar nos lançamentos imobiliários, espaços genéricos, sem relação com as características peculiares do local o qual está sendo implantado e muito menos ao projeto do edifício. Ou seja, sempre as mesmas soluções, inde-

Os carimbos que se repetem são arranjos pré-definidos para a disposição das edificações, vagas de estacionamento, áreas verdes e de lazer, na tentativa de minimizar custos e racionalizar a construção. (...) Também o paisagismo não é objeto de preocupação em boa parte dos empreendimentos habitacionais do segmento econômico. As áreas verdes dos condomínios são projetadas no pouco espaço que resta após implantação dos edifícios e alocação das vagas de estacionamento no terreno. $O$ paisagismo se resume à disposição de alguma vegetação, de forma pontual. (FERREIRA, 20I2, p. 75).

$\mathrm{Na}$ lista abaixo foram identificados alguns problemas relacionados aos espaços exteriores nos empreendimentos padrão mercado imobiliário na cidade de São Paulo:

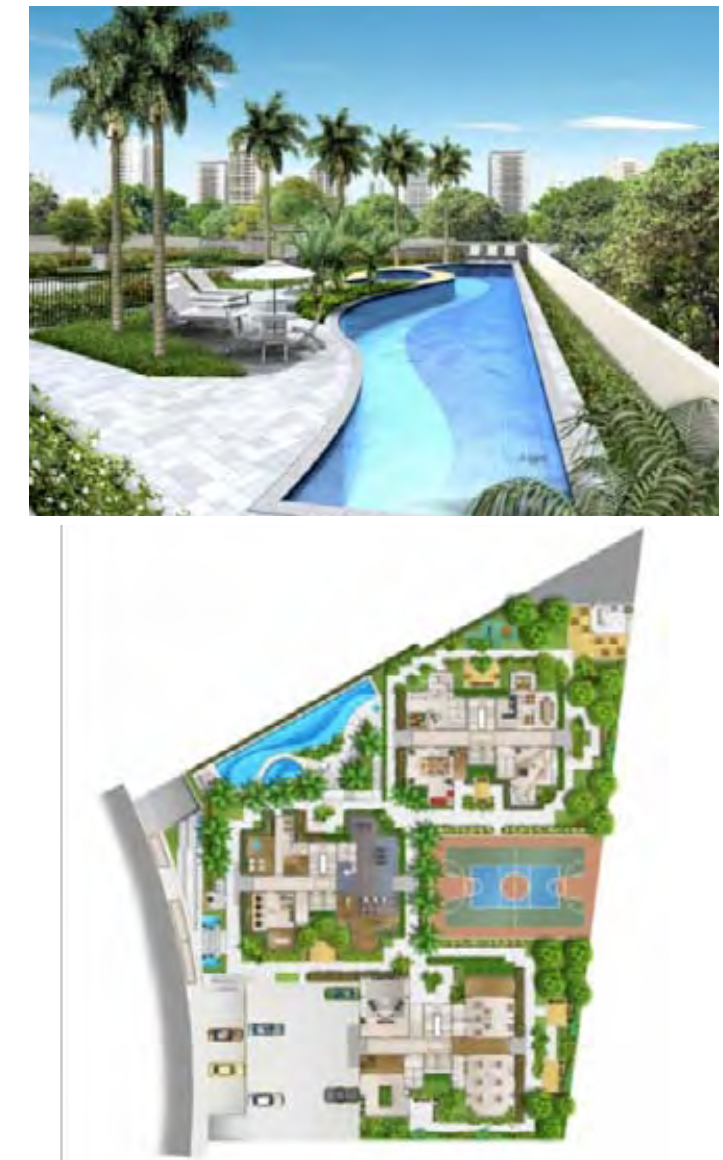

Figura I - Essenza Residencial Club. Área das piscinas e implantação do condomínio-clube. 


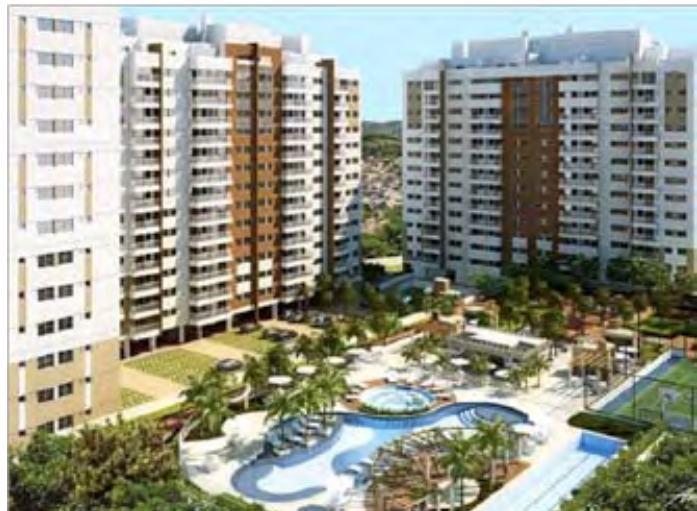

Figura 2 - Pátio Carioca Residencial Clube.

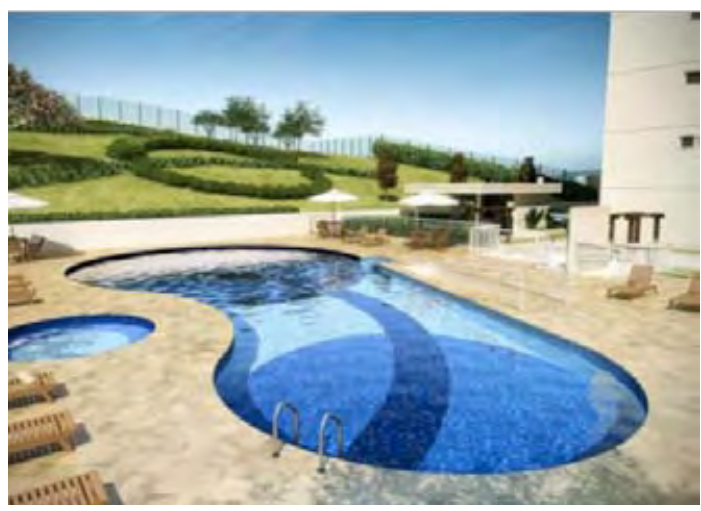

Figura 3 - Brookfield llha das Flores, Goiânia.

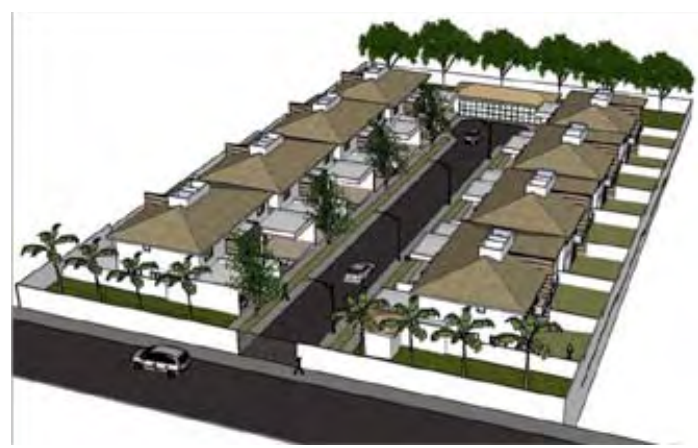

Figura 4 - Vila residencial Medeiros, em Jundiaí.
- Assim como colocado por Ferreira (20/2), existe uma dissociação entre o projeto do edifício e o projeto do pavimento térreo,ou seja,o edifício é uma construção padrão,e depois,o projeto paisagístico do térreo faz todo um desenho diferente, porém, sem concordância com o projeto do edifício;

- As áreas de lazer são implantadas nos espaços que literamente "sobram" no térreo, sem reflexão sobre questões de integração com os principais percursos, para se evitar espaços residuais;

- Também, pela verticalização excessiva, há uma dissociação entre as janelas ou varandas com as áreas de lazer e com o espaço público, relação importante para maior contato visual e auditivo,por exemplo, das mães com os filhos que estão brincando, conforme colocado por Schneider (2006):

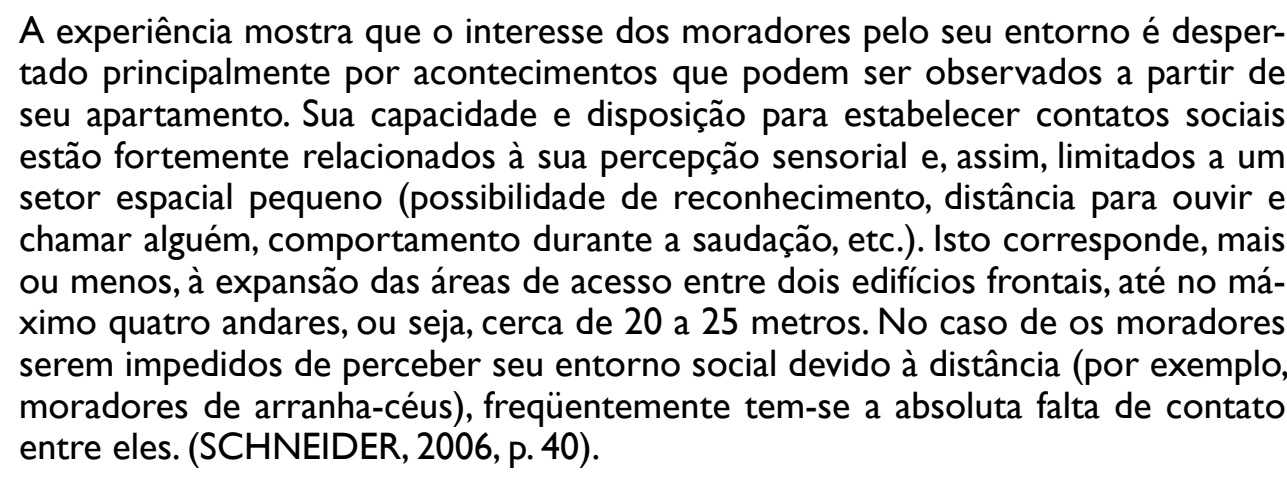

- Muitas vezes são criadas varandas voltadas para outra face de edifício, de outro bloco, novamente não pensando na questão da privacidade e sem direcionar as varandas às principais visuais ou melhores situações de insolação, por exemplo;

- As garagens são lugares inóspitos com única e exclusiva utilidade de se guardar veículos. No edifício $4 \times 4$, diferentemente, para reduzir gastos com contenções, criou-se taludes com a crista no térreo e a base no subsolo, permitindo que a luz natural e paisagismo estejam presentes também no pavimento inferior. Segundo Fábio Mendes (20I I), co-autor do projeto "Não é aquele ambiente opressivo de subsolo" (Figura 05 e 06); 
- São criados inúmeros espaços para atividades coletivas no térreo (também por não entrar no cálculo de área computável), porém, nem sempre estas áreas possuem um bom aproveitamento, tornando-se residuais ou pouco utilizados. Segundo Wissenbach (2008) pode-se entender que um dos motivos por estas áreas não serem bem aproveitadas, pode estar relacionado a uma concepção como atributo de vendas, e não para serem de fato utilizadas pelos moradores:

Uma grande expressão desse processo estaria nos chamados condomínios-clube, isto é, empreendimentos residenciais com equipamentos de lazer (piscina, quadra, e depois espaço gourmet, garage band, cinema etc.). É importante notar que nem sempre tais equipamentos, chamados nos termos dos profissionais do setor imobiliário de facilidades, partem de uma demanda real, mas de concepções inicialmente desenvolvida pelos setores de marketing e muitas vezes imitadas por outras empresas. Com isso, para os incorporadores, mais do que construir estas "facilidades" para serem de fato usadas pelos respectivos moradores, o importante é saber se tal atributo ajuda nas vendas dos apartamentos e na disposição dos consumidores a pagarem este tipo de equipamento. (WISSENBACH, 2008, P. 90).

- Problema da falta de contato, ao menos visual, dos espaços exteriores com o espaço público da rua, prejudicando o trecho de bairro o qual o empreendimento está implantado, pois muros cegos trazem situações de falta de segurança para a área que o ladeia.Vigliecca (2012) colocada a importância de se pensar o projeto além dos limites condominiais, e Wissenbach (2008) confirma o teor prejudicial dos condomínios-clube ao espaço urbano que o rodeia:

Não queremos confundir arquitetura com objeto de design, o que vem acontecendo aqui e em várias partes do mundo. Na verdade, estamos sempre construindo um entorno externo, arquitetando a cidade, com um compromisso que vai além da definição construtiva e refinada. Quer dizer, entendemos sempre que a arquitetura é, antes de qualquer coisa, um compromisso com a questão pública (VIGLIECCA, 20I2). A sua proliferação estaria associada a uma demanda social por um aumento de sensação de segurança e, portanto, da realização das atividades de lazer dentro de ambientes privados. Certamente esse processo, tem implicações sobre o espaço urbano, já analisado por autores, expressa tanto no abandono do espaço público como na presença nos altos muros, marcando um forte processo de segregação urbana. (WISSENBACH, 2008, P. 91 ).

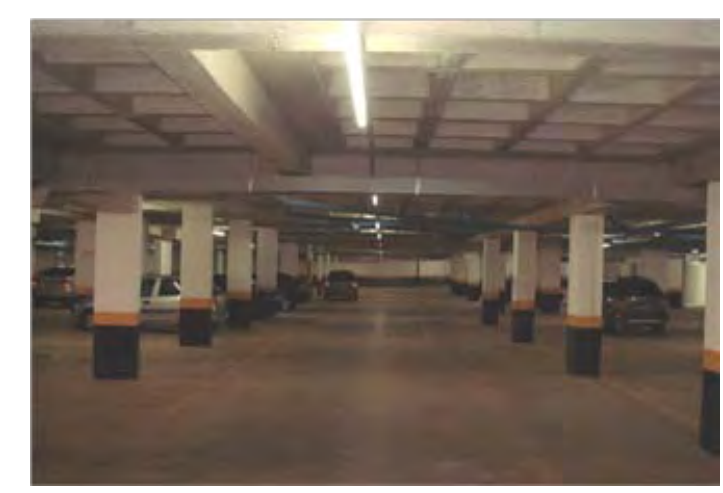

Figura 5 - Detalhe subsolo em edifício residencial típico do mercado imobiliário.

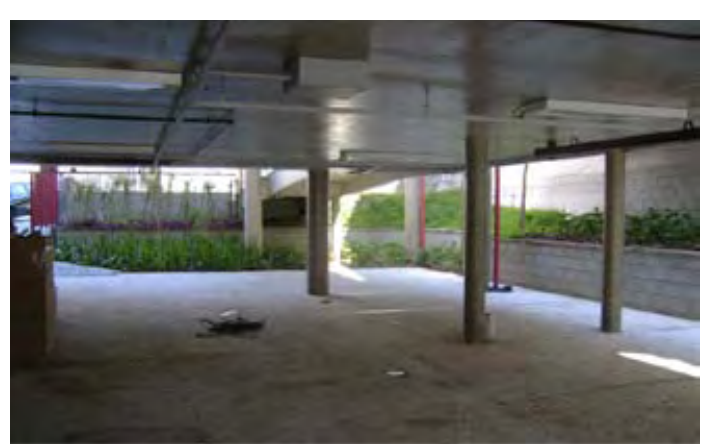

Figura 6 - Pavimento inferior, subsolo para garagem, no Simpatia 234: paisagismo, incidência de iluminação natural e especificação do mesmo piso ao existente no pavimento térreo. 


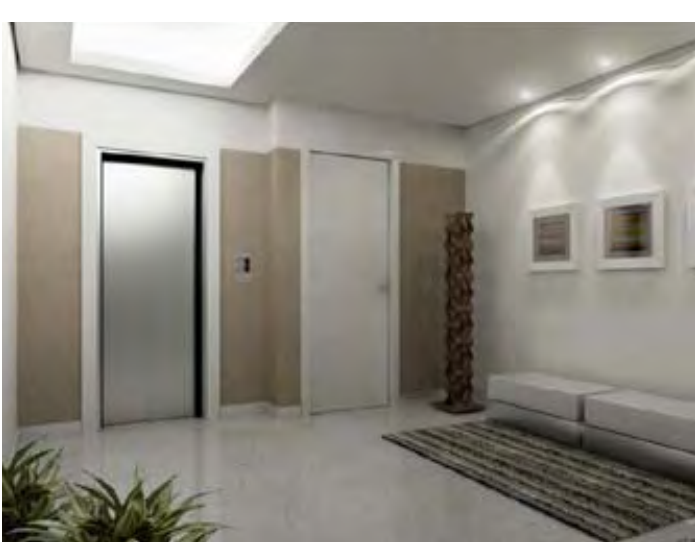

Figura 7 - Hall de entrada dos apartamentos: ausência de contato físico ou visual com o ambiente exterior.
- Hall do elevador que antecede os apartamentos: frieza e isolamento do exterior. Em muitos casos, não apresentam aberturas ou mínimo contato físico ou visual com o ambiente exterior.

Assim, questiona-se: Como propor espaços que sejam agradáveis, úteis e com convívio harmonioso tanto individual como coletivo? Quais parâmetros poderiam surgir a partir das obras selecionadas que, mesmo que parcialmente, pudessem mudar alguns paradigmas atuais?

4.2.I.I E METODOLOGIA PARA BUSCA DE NOVOS PARÂMETROS DE QUALIDADE NOS ESPAÇOS EXTERIORES

Foram destacados nos projetos selecionados como estudos de caso principais, os tipos de espaços exteriores, conforme relação e descrição abaixo:

\subsection{I.I.I ESPAÇO EXTERIOR PRÓPRIO}

Este tipo de espaço é quase inexistente nos projetos selecionados, assim, identificou-se um único tipo de situação, de "Extensão do passeio público":

- Extensão do passeio público: doação de espaço do lote, geralmente recuos não edificantes, para ampliação do passeio público, onde ao menos seja possível a colocação de banco com sombra sem atrapalhar o trânsito de pedestres. Infelizmente, nos projetos selecionados, apenas dois utilizam esta tática, Fidalga 772 e Simpatia 234, porém, ainda é muito pouco. $O$ ideal seria buscar continuidades com o tecido da cidade e criação de espaços públicos que atravessassem o lote, com maior fluidez urbana, algo que está distante de ocorrer na cidade de São Paulo. $O$ projeto citado no capítulo 3.2. I, Casarão do Carmo, do Arquiteto HectorVigliecca, propõe uma situação que agrega muita qualidade neste sentido de integração com o espaço público, porém, não teve a execução concluída. 


\subsection{I.I.2 ESPAÇO EXTERIOR COLETIVO}

Espaço entre o público e o privado das unidades habitacionais, estabelecendo tanto relações com o espaço público como também entre os moradores. Nos projetos, estes espaços ainda predominam com relação a outros aqui elencados (exceção Fidalga 772, onde predominam os espaços exteriores próprios). Foram identificados nos projetos os seguintes tipos de espaços exteriores coletivos:

\section{- Pátios, caminhos, passarelas, escadas;}

\section{- Áreas verdes, jardins;}

- Terraço na cobertura.

Quando estes espaços contam com espaços complementares a eles, os "espaços exteriores entre coletivo e próprio", que filtram ainda mais as relações ou atividades entre o espaço privado da unidade e o espaço coletivo, as situações de distúrbios ou incômodo são reduzidas, por exemplo, como ocorre na Vila Fidalga.

\subsection{I.I.3 ESPAÇO EXTERIOR ENTRE COLETIVO E PRÓPRIO}

Trata-se do filtro entre o espaço coletivo e o privativo da unidade habitacional ou entre duas áreas privativas, com função de resguardar a privacidade necessária e ao mesmo tempo não extinguir os espaços coletivos que são também importantes.

Este espaço geralmente falta nos projetos, principalmente naqueles onde o espaço do lote é escasso, como ocorreu, por exemplo, na Vila Pedro Fachini ou Vila Maida. Foram identificados nos projetos os seguintes tipos de espaços exteriores entre o coletivo e próprio: 
- Vestíbulo externo: protege a porta da entrada habitação, a partir de várias maneiras, como por exemplo, criação de patamar mais elevado com relação ao nível do espaço exterior coletivo; criação de escadas de acesso quase particulares; criação de reentrância que protege a porta; passarelas deslocadas e destacadas da passagem coletiva. Para este espaço possuir qualidade o ideal é que não precise de grandes barreiras físicas de controle da permanência coletiva, ou seja, que seja possível perceber que já se trata de uma zona mais privativa naturalmente.

O tipo “casa geminada”, portanto, certamente tem um potencial a ser desenvolvido. Esse desenvolvimento deve ser centrado na solução das deficiências mencionadas, associadas à individualização e à privacidade. Um dos desafios colocados é a criação de espaços abertos sem o recurso a muros de divisa, tão usados atualmente (...) Também o acesso às diferentes unidades deve merecer uma atenção especial, se o que deseja é atender à necessidade de individualidade. Nesse contexto, a individualidade não se refere tanto aos atributos do projeto, mas, principalmente, à transição suave entre o espaço público e as entradas. Uma área aberta reservada, protegida das intempéries, em frente à porta de entrada, pode ser fundamental para preservar a sensação de estar chegando em sua própria casa. (PFEIFER;BRAUNECK, 2009, p. I6).

Os moradores costumam colocar nestes espaços objetos particulares, como quadros, vasos, tapetes, bicicleta, estátuas etc.; como se já estivessem demarcando o início do espaço particular e pertencente exclusivamente a eles. Este tipo de espaço pode ser identificado em diversas arquiteturas de diversos períodos e lugares. Por exemplo, Lemos (1999) descreve no livro "Casa Paulista” o espaço com dupla função, de receber e resguardar a intimidade familiar, existente nas casas bandeiristas:

O fato é que houve em toda casa roceira colonial a presença obrigatória de alojamentos para hóspedes importantes no corpo da moradia, mas isolados das dependências familiares. Isolamento que tornou inevitável a definição de uma área de receber pessoas estranhas, área também utilizada para permanência de agregados e escravos enquanto estivessem assistindo a cerimônias religiosas efetuadas em oratórios ou capelas ali estrategicamente situados. $\mathrm{Na}$ verdade, uma faixa de recepção separando o público do privado, destinada a facilitar a permanência de pessoas de fora e resguardar a intimidade familiar. (LEMOS, I999, p. 31). 
- Vestíbulo externo: protege a porta da entrada habitação, a partir de várias maneiras, como por exemplo, criação de patamar mais elevado com relação ao nível do espaço exterior coletivo; criação de escadas de acesso quase particulares; criação de reentrância que protege a porta; passarelas deslocadas e destacadas da passagem coletiva. Para este espaço possuir qualidade o ideal é que não precise de grandes barreiras físicas de controle da permanência coletiva, ou seja, que seja possível perceber que já se trata de uma zona mais privativa naturalmente.

- Jardins entre coletivo e privativo: protegem principalmente as janelas no térreo, mas pode proteger janelas em passarelas, por exemplo, e evitam olhares indesejados sobre a intimidade dos moradores. Funciona também como barreira acústica contra barulhos do lazer ou convívio coletivo.

- Jardins de interesse comum: costumam ficar entre dois quintais ou terraços privativos, tem a mesma função de resguardar a privacidade de modo suave e gentil. Foram encontrados em alguns projetos que possuem terraços privativos na cobertura:Vila Fidalga, Simpatia 234 e Fidalga 772.

\subsection{I.I.4 ESPAÇO EXTERIOR PRÓPRIO}

\begin{abstract}
Os ambientes privados que dispõem de uma relação mais direta e próxima com a cidade são os espaços exteriores das unidades. São os lugares intermediários que relacionam a atividade pública com o retiro privativo e potenciam a socialização do habitante. Tanto varandas, coberturas e galerias, como pátios - comuns ou privados - incidem favoravelmente na identificação espacial do ser humano com a cidade, ao mesmo tempo em que podem propor perspectivas agradáveis e melhoras do controle climático. (MONTANER, et al; 2012, p. 306).
\end{abstract}

Os espaços exteriores próprios ficam entre o interior da unidade e o espaço público, mas principalmente e também com base nos estudos de caso selecionados, entre o espaço interior da unidade e o espaço exterior público por contato aéreo, ou seja, varandas, principalmente. Foram identificados nos projetos os seguintes tipos de espaços exteriores próprios:

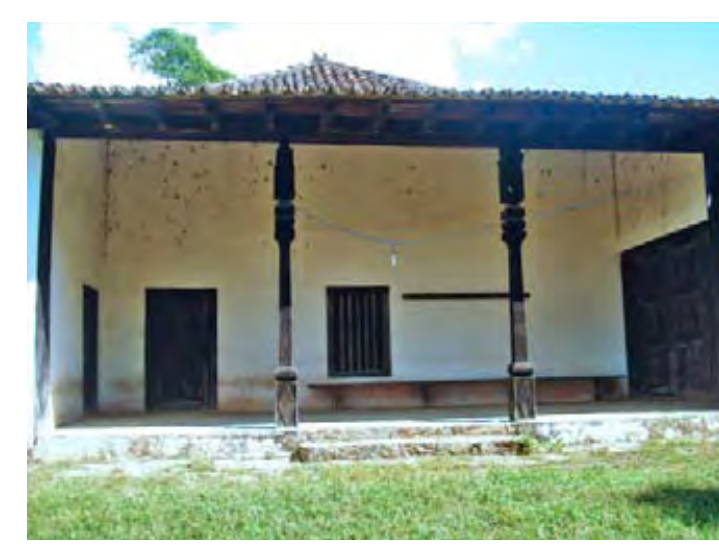

Figura 8 - Casa Bandeirista. Espaço de receber. Sítio do Padre Inácio, Cotia, São Paulo. 


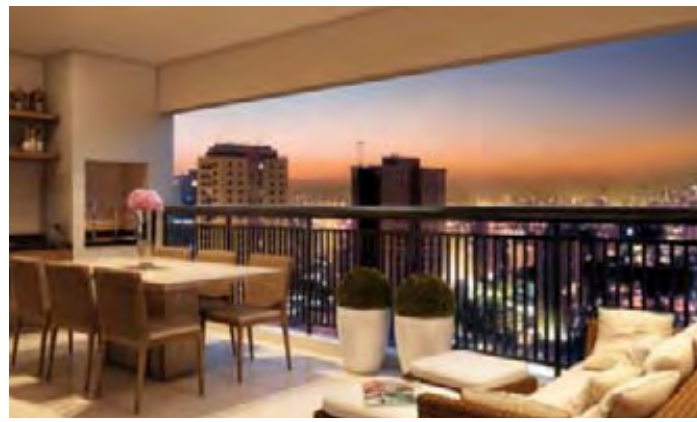

Figura 9 - Espaço Gourmet em varanda de apartamento.
- Quintal, pátio, varanda, balcão;

- Terraço na cobertura, inclusive alguns com piscina.

\subsection{I.2 ALGUMAS PAUTAS DE DISCUSSÃO SOBRE OTEMA}

- Varandas: Ao mesmo tempo em que os espaços exteriores próprios são extremamente importantes, pois colocam o edifício em contato com o espaço público (isto também dependendo da maneira como são posicionados e do gabarito de altura do edifício), também pode ser apenas uma estratégia de marketing dos empreendedores: segundo o código de obras e edificações da cidade de São Paulo: “I0.I2.I SALIÊNCIAS: Balcão e terraço aberto (sem caixilho) poderão avançar sobre passeio público $(40 \mathrm{~cm})$, recuos LPUOP (até $20 \%$ ), faixas “A” e “l” (até 10\%), com dimensão máxima de aumento sendo $10 \%$ da projeção da área ocupada no lote". Isto quer dizer, desde que ocupem no máximo $10 \%$ da projeção da área ocupada no lote, nas faixas de aeração e insolação, não contam como área computável. Por isso as varandas ficam sobrepostas na maioria dos empreendimentos, senão, ultrapassariam os $10 \%$ da projeção no lote. Isto acontece inclusive nos projetos da Idea!Zarvos, por exemplo, no estudo de caso Fidalga 772, no edifício 4 x 4 ou Simpatia 234, onde as varandas são sobrepostas. Geralmente, o custo de construção de uma varanda é inferior ao custo do espaço interior da unidade. Desse modo, a varanda tornase um atrativo de venda, pois é criada toda uma campanha de marketing pautada neste espaço, varandas gourmet, que custam pouco à construtora e não contam como área computável. Pior, muitos moradores depois da entrega do apartamento fecham este espaço. (figura 9). Porém, não é o fato de ter ou não varanda que implica na qualidade do projeto, e sim, se a varanda está bem posicionada, se funciona como extensão do espaço interior, e se melhora as questões climáticas do interior, por exemplo. Em habitação de interesse social, por exemplo, poderia se utilizar mais varandas, mais importante ainda em grandes conjuntos nos quais o interior e o exterior precisam estar mais vinculados, para garantir segurança, contato visual e auditivo com vizinhos, etc. 
- Unidades-Casa: Ao Há outro discurso acerca deste assunto, de que a presença de espaço exterior próprio converte um apartamento numa casa.Até mesmo nos projetos publicados frequentemente na revista SUMMA+, as “infiltrações urbanas”, este assunto está presente:

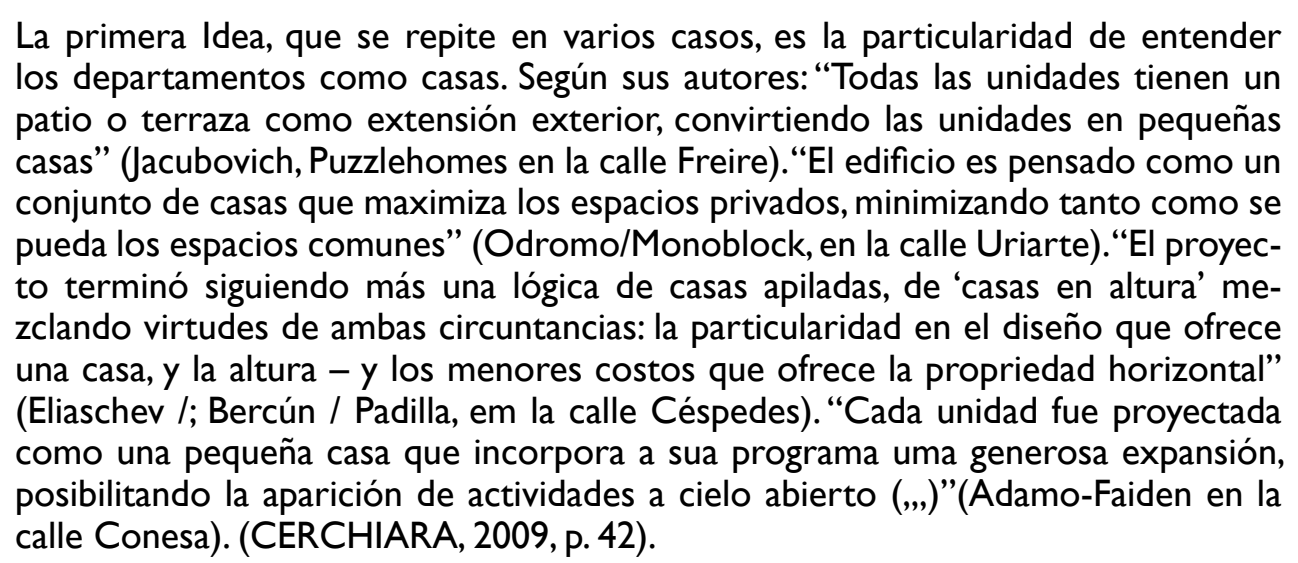

No edifício Fidalga 772, existem no pavimento térreo duas unidades habitacionais que se apropriam de grande parte da área do térreo, geralmente deixadas para o uso coletivo, chamadas de unidades-casas inclusive no folheto de vendas. O principal problema destas habitações é a falta térrea vizinha mantida ao lado do Fidalga 772 enfrenta, e talvez não seja um grande problema, pois pode abrigar usos que são muitas vezes impróprios para um apartamento, como por exemplo: espaços para animais de estimação, espaço para horta, jardins entre outros usos.

Neste sentido, esta tipologia permite algumas atividades que geralmente só são possíveis de acontecer em casas. Também se pensarmos na questão de compactar mais a cidade, dentro de um limite de infraestrutura e serviço existente, em alguns bairros, por exemplo, na Vila Madalena, será raro ver a construção de uma nova casa, adotando-se quase sempre habitação coletiva, utilizando todos os índices, de uso e ocupação do solo, possíveis. Neste caso, é importante a mescla de tipologias de unidades habitacionais, e a "unidade-casa"
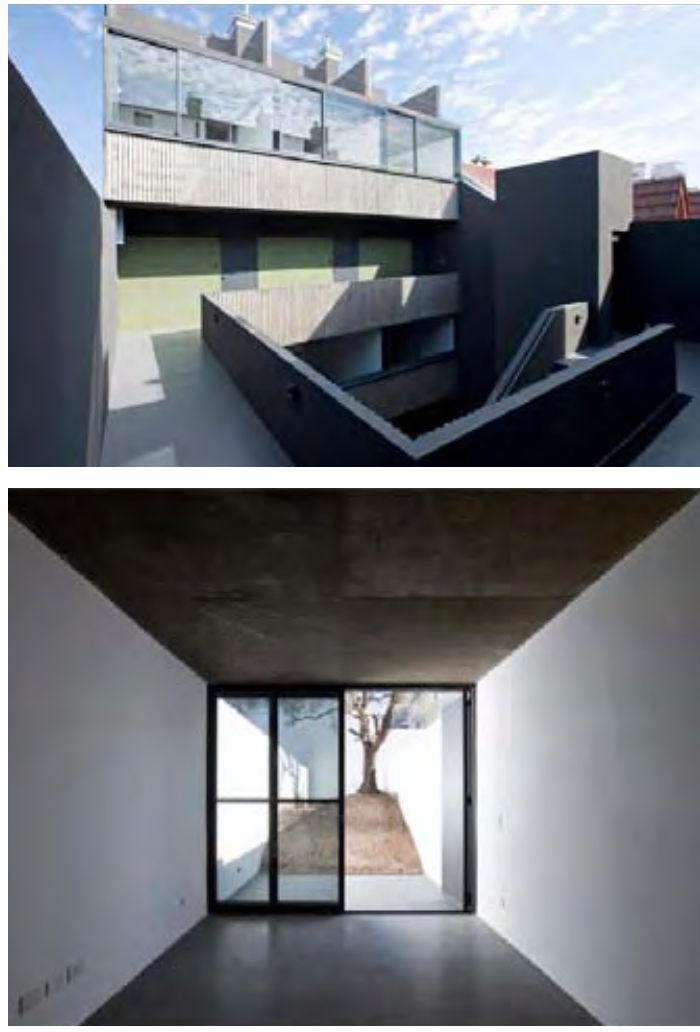

Figura 10 - Edificio Conesa, 4560, Bairro Saavedra, Buenos Aires. Adamo-Faiden Arquitectos. Edifício composto por nove unidades habitacionais e três espaços para trabalho. Segundo memorial dos autores, cada unidade foi projetada como uma pequena casa, que incorpora ao programa uma generosa expansão, possibilitando atividade a céu aberto. 


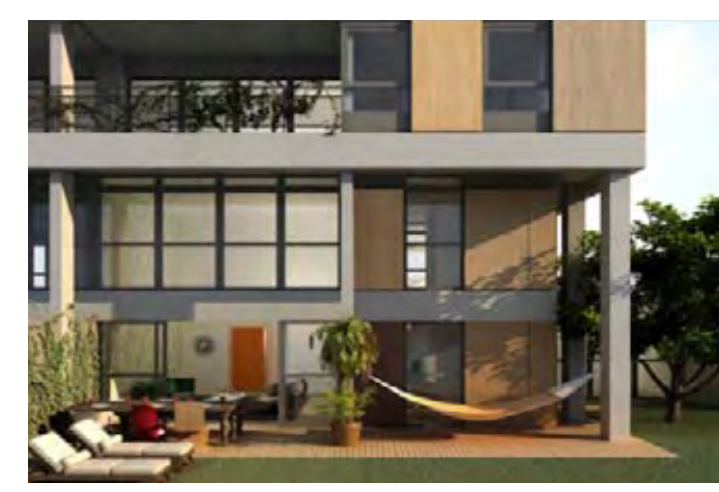

Figura I I - Unidade-casa, Fidalga 772. Ilustração folheto de vendas.

\subsubsection{OUTROS ESPAÇOS EXTERIORES}

Nos projetos selecionados, apenas no Fiori di Maggio,Vila Taguaí e Vila Butantã, existem espaços para múltiplos usos em espaço exterior, porém, fechado, como por exemplo, salão de jogos, salão para churrasco, reuniões de famílias, ou sala para ginástica. No Fiori di Maggio obviamente estas áreas são mais presentes pela situação peculiar de ser um edifícios para membros de uma mesma família. Nada comparado à quantidade excessiva destes espaços nos empreendimentos de mercado imobiliário, citados na introdução deste texto.

Outra tática interessante é tornar a garagem um local com "menos cara de garagem”, ou seja, melhorar a incidência de iluminação natural, melhorar o tratamento paisagístico, criar paginação de piso em continuidade ao da área coletiva, como ocorre no Simpatia 234, por exemplo. As piscinas coletivas, quando existem nos projetos selecionados, não são exageradas e possuem um desenho em conformidade com a arquitetura das áreas construídas, sem desenhos aleatórios. 


\section{TÁTICAS PROJETUAIS PARA OS ESPAÇOS EXTERIORES}

Após destaque gráfico nos projetos destes tipos de espaços exteriores descritos é possível observar e sintetizar algumas táticas projetuais de resolução dos espaços exteriores nos estudos de casos selecionados:

\section{VILA FIDALGA}

Característica principal: Os espaços coletivos balizam os limites dos privativos de forma clara, importante para impedir apropriações espontâneas não desejáveis. O equilíbrio e a maneira como o projeto resolve os espaços coletivos versus privativos, resulta em muita qualidade ao projeto e em espaços ideais para convívio entre os moradores da habitação coletiva. É importante a distribuição e equilíbrio do espaço exterior entre diferentes modalidades, para garantir o bem estar individual e coletivo.

\section{Táticas projetuais:}

- Distinção de materiais das áreas coletivas e privativas;

- Diferenciação de níveis;

- Garagem criada no subsolo, com utilização também para atividades e convívio o que também permite mais superfície útil de projeto;

- Posição estratégica das janelas e jardins de modo a criar harmonia no convívio individual versus coletivo;

- espaço coletivo em determinados pontos parece pertencer a uma única unidade: espaço coletivo soma ao privativo;

- Terraços bem posicionados às principais vistas da cidade.

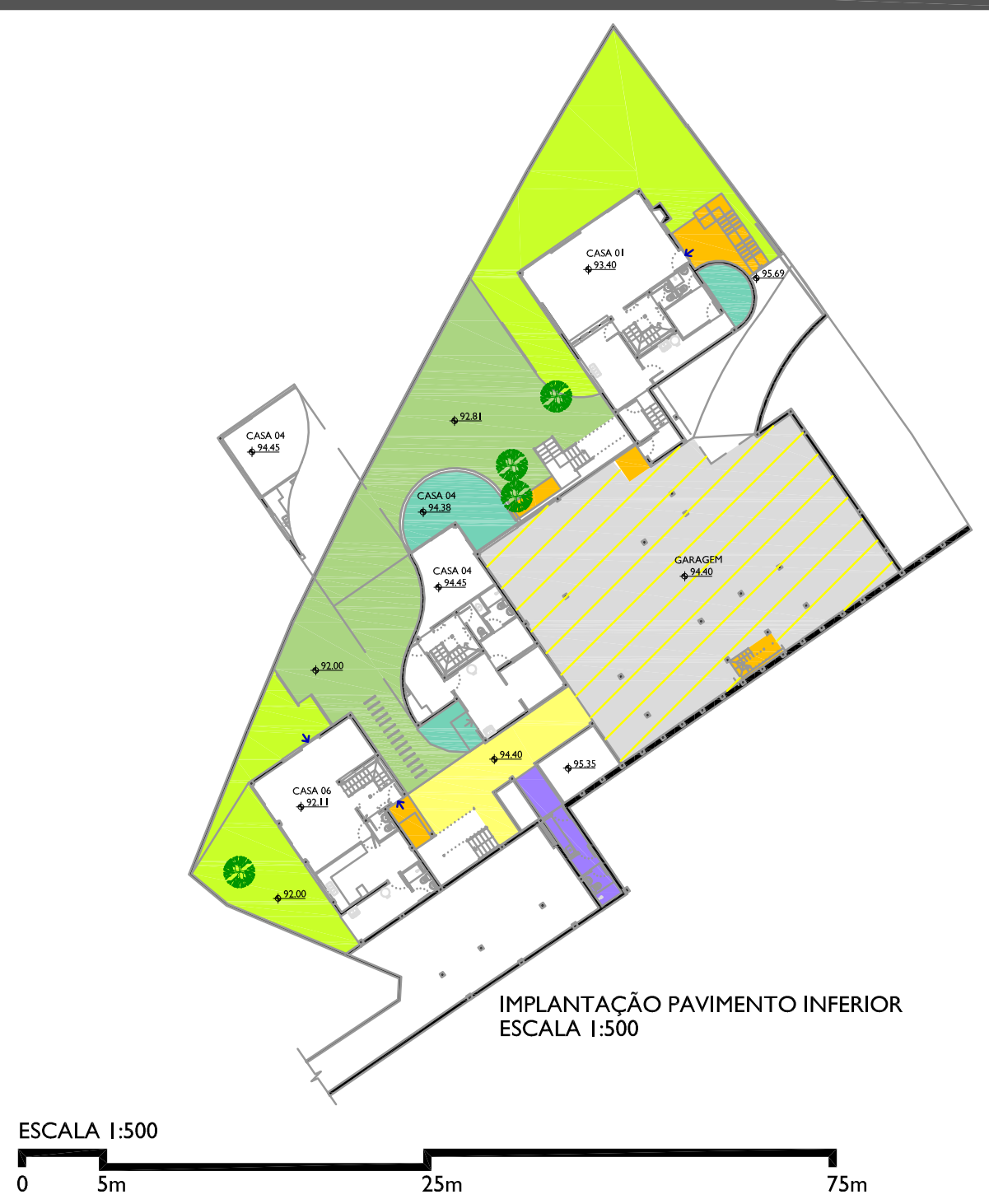

ESPAÇO EXTERIOR COLETIVO

PÁTIOS / CAMINHOS / PASSARELAS / ESCADAS ÁREAS VERDES / JARDINS TERRAÇO NA COBERTURA 


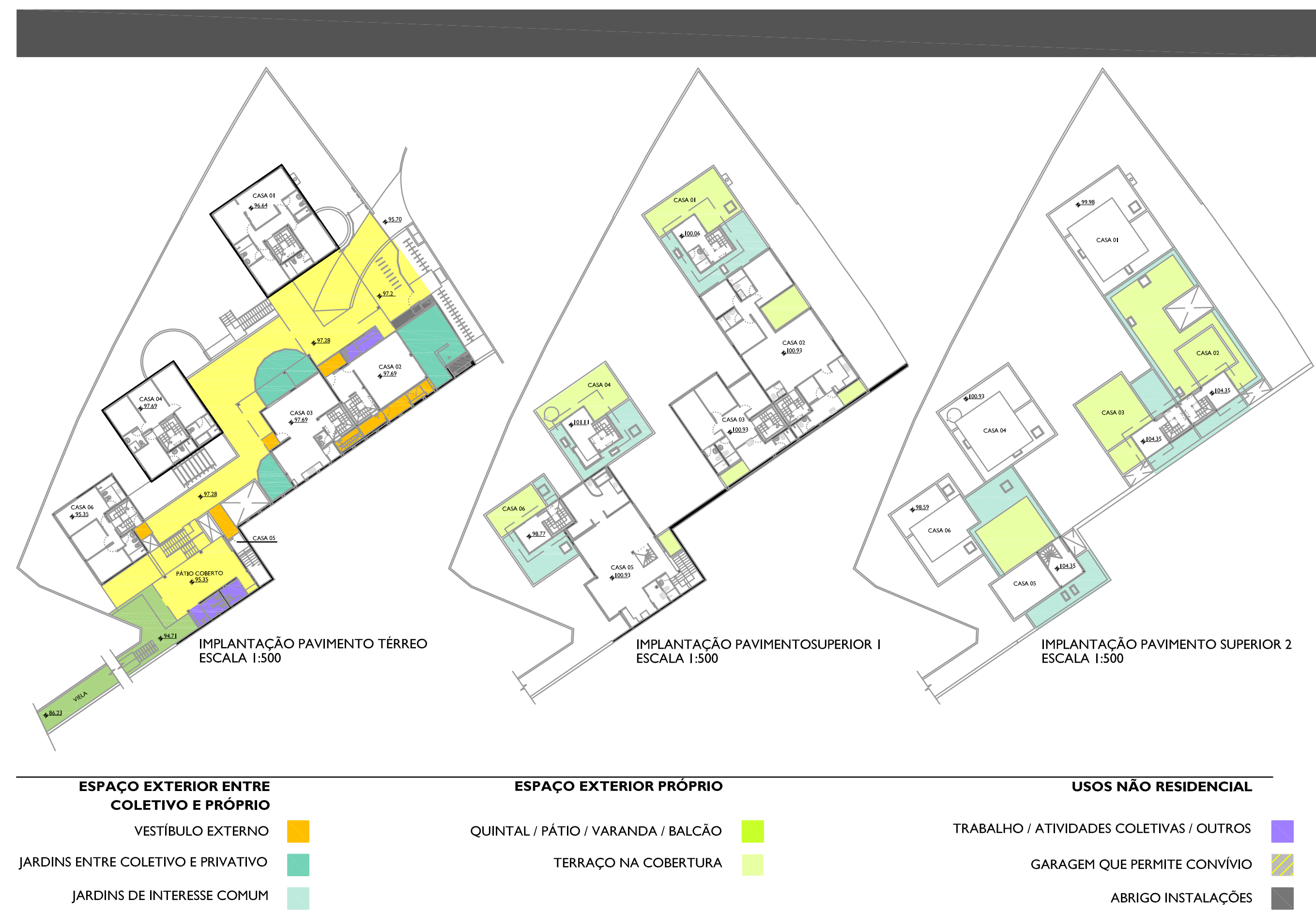




\section{VILA TAGUAÍ}

\section{VILA TAGUAí}

Característica principal: predomínio de áreas de jardins ou áreas verdes coletivas, e não propriamente espaços para interação entre vizinhos. Ao mesmo tempo, possui jardins ao redor das casas que funcionam como filtros entre os espaços coletivos e privativos, melhor solução do que utilização de cercas ou muros.

\section{ESPAÇO EXTERIOR COLETIVO}

PÁTIOS / CAMINHOS / ESCADAS

ÁREAS VERDES / JARDINS

\section{ESPAÇO EXTERIOR ENTRE COLETIVO E PRÓPRIO}

VESTÍBULO EXTERNO

JARDINS ENTRE COLETIVO E PRIVATIVO

ESPACCO EXTERIOR PRÓPRIO

QUINTAL / PÁTIO / VARANDA / BALCÃO

TERRAÇO NA COBERTURA

USOS NÃO RESIDENCIAL ATIVIDADES COLETIVAS / OUTROS

GARAGEM

ABRIGO INSTALAÇÕES

PISCINA / ESPELHOS D'ÁGUA
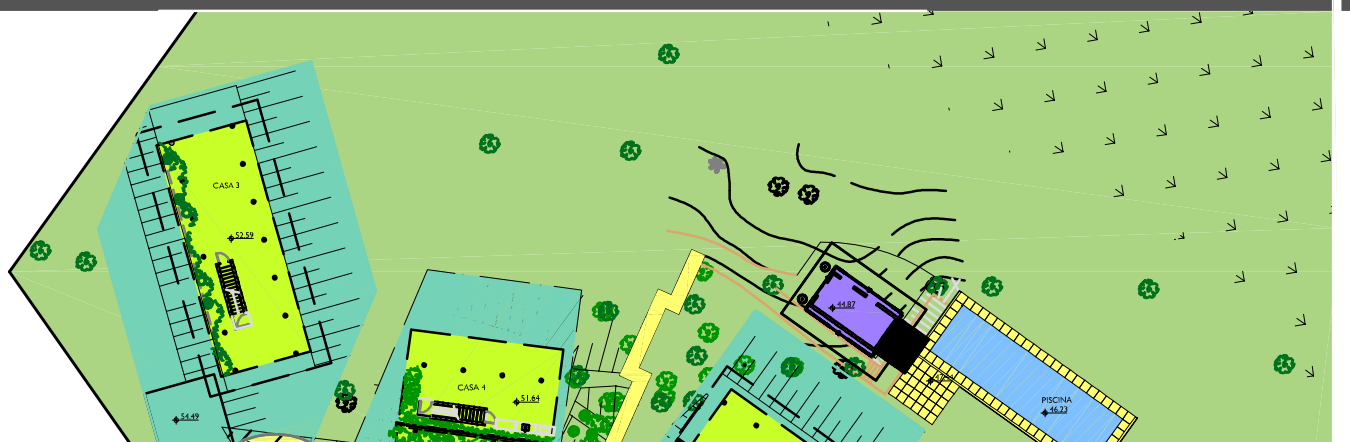

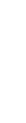

$-$

\section{.}

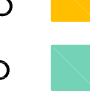

(1)

Bn-

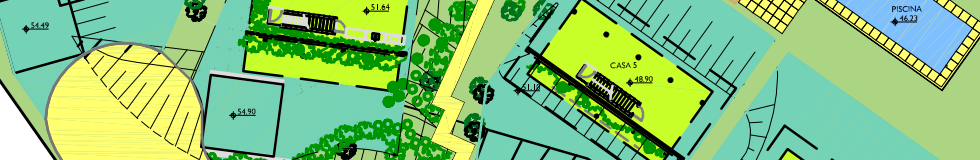

.

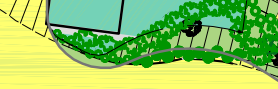
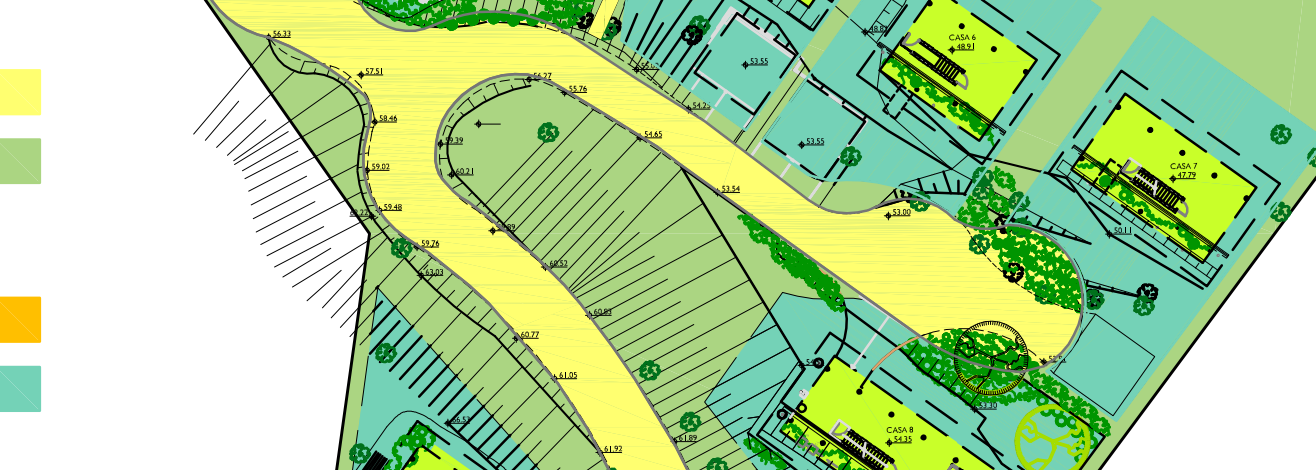

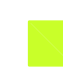

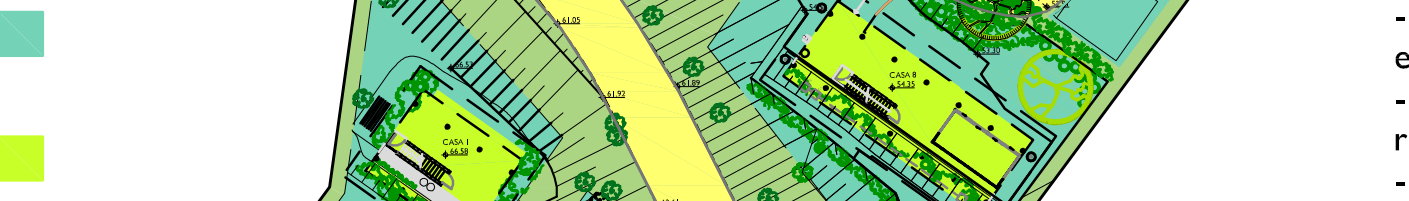

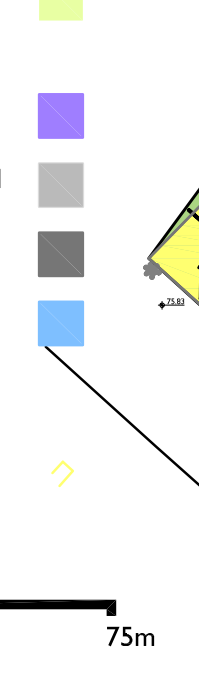

\section{VILA BUTANTÃ}

Característica principal: existência de espaços exteriores coletivos, exteriores próprios e intermediários entre estes dois tipos de espaços, importantes para o bem estar individual e coletivo dos moradores. Porém, o espaço coletivo é de uso simultâneo para acesso de veículos (que no Canaã foi solucionado com a posição das vagas no recuo frontal do terreno) e ocupa espaço do térreo (diferente da solução da Vila Fidalga, por exemplo, que cria nível inferior, deixando mais espaço livre para outras atividades).

\section{Táticas projetuais:}

- criação de pequenos desníveis entre os platôs das casas;

- grandes jardins protegendo a intimidade dos espaços privativos;

- casas deslocadas em planta, também para resguardar as unidades;

- redução dos recuos entre as casas pela metade, extinguir característica de corredor.
Táticas projetuais:

- grandes jardins ao redor das casas;

- terraços sob pilotis, nos espaços remanescentes à implantação da casa no terreno natural;

- permeabilidade visual do térreo para a estrada e vice-versa.

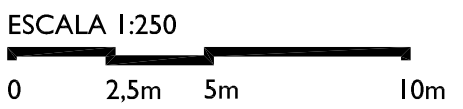




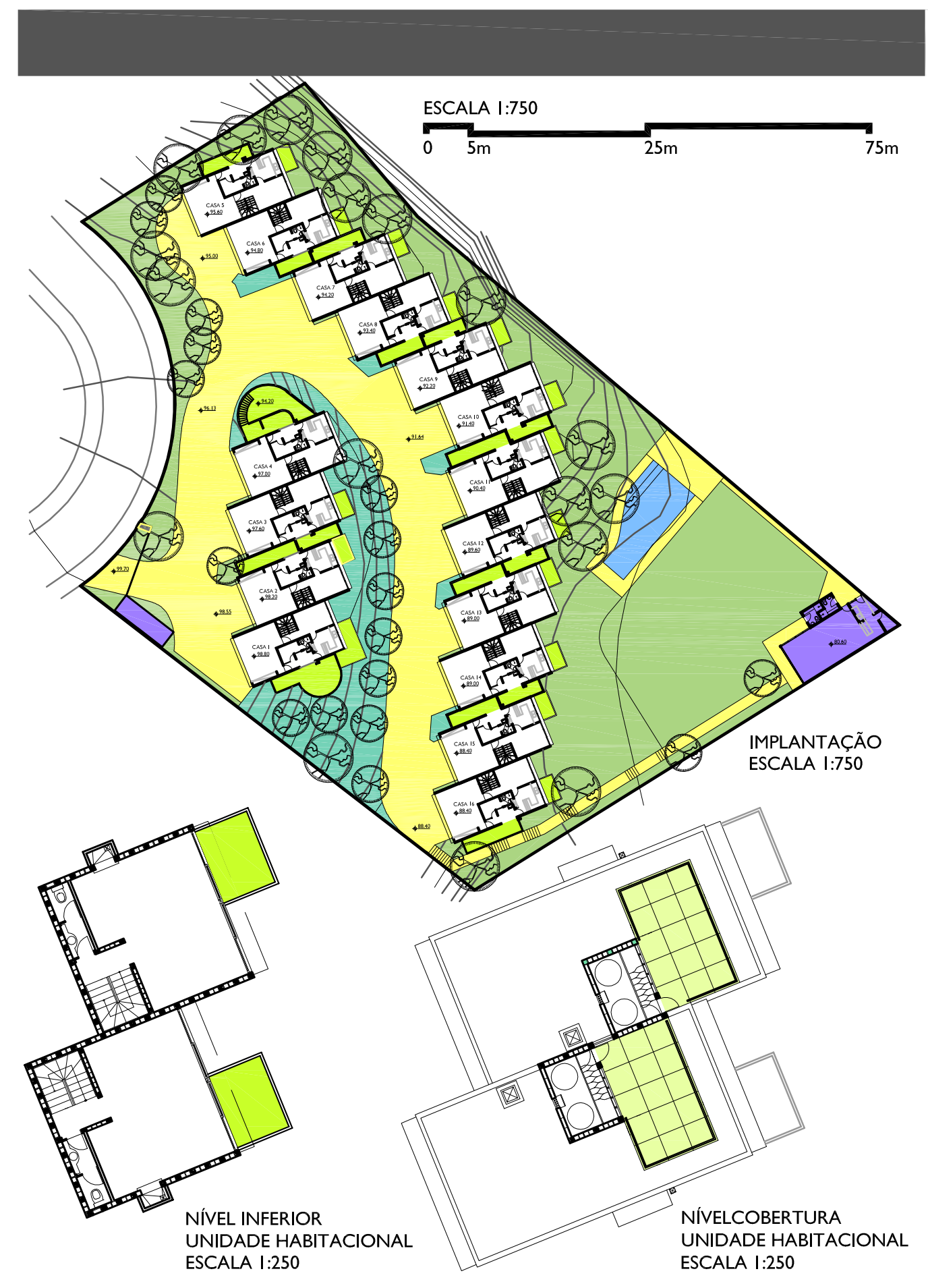

\section{CANAÃ}

Característica

predomínio das ar de espaço exterior próprio, maior entre as tipologias "casas" desta pesquisa, isto devido à presença do terraço privativo, o "lajão coberto". Os espaços privativos das unidades habitacionais são muito bem protegidos por jardins frontais e quintais ao fundo.

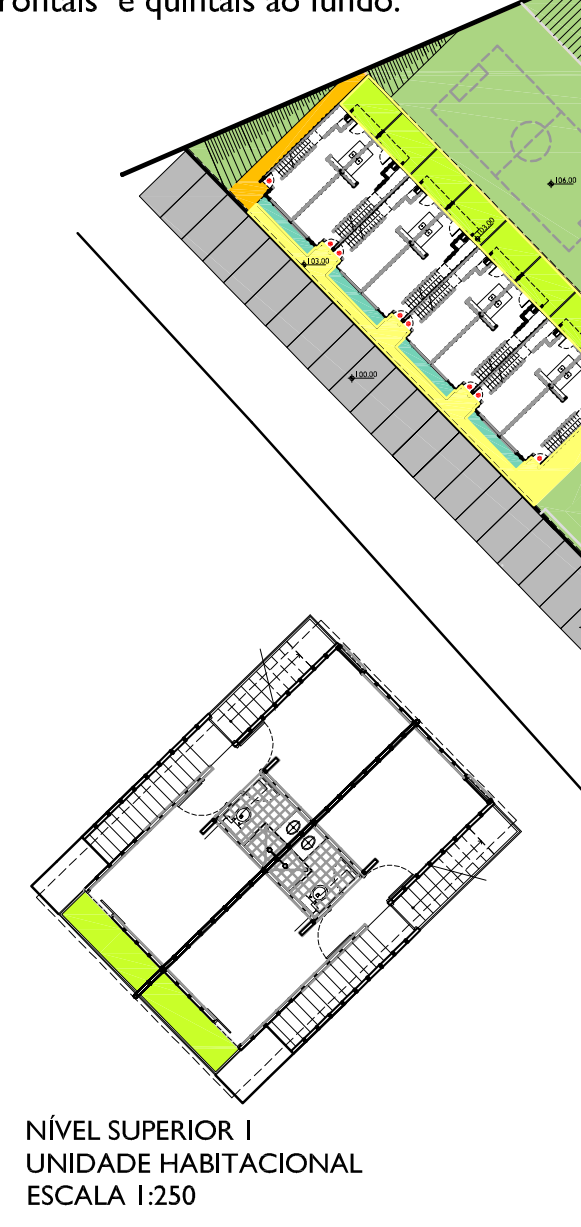

\section{Táticas projetuais:}

- jardins entre privativo e coletivo;

- vagas para automóveis com acesso pela rua, garantindo melhor uso dos espaços coletivos para pedestres;

- quintais, extensão da cozinha e também como filtro de proteção dos espaços privativos;

- "lajão coberto", ampliação das atividades da

unidade habitacional. 


\section{SIMPATIA 234}

Característica principal: neste projeto, os espaços coletivos não são tão reduzidos, e um dos níveis de garagem possui qualidades espaciais que permitem convívio entre vizinhos ou realização de atividades. Os espaços coletivos são mais para

contemplação da cidade e convívio.

Táticas projetuais:

- duplicação do térreo;

- terreno original e rasgos na laje do térreo que permitem que o subsolo tenha uma característica menos opressiva;

- paginação do piso do térreo extendida para primeiro nível inferior da garagem e também para as passarelas de acesso às unidades habitacionais;

- fluidez do térreo até o segundo nível inferior, para a Rua Medeiros Albuquerque;

- permeabilidade visual do térreo para as ruas e vice-versa.

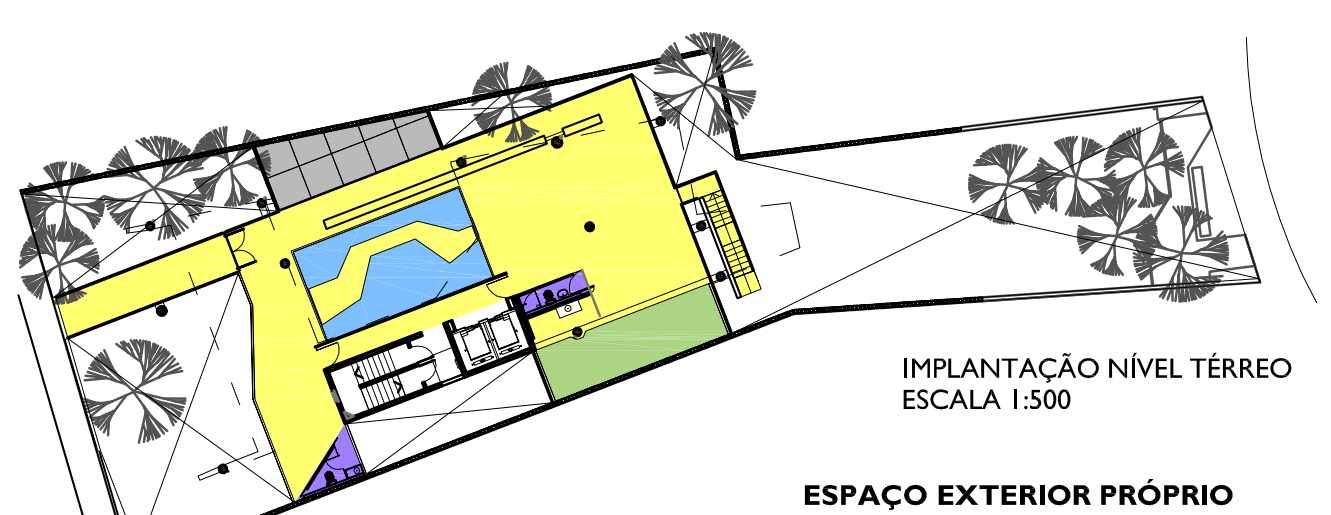

ESPACCO EXTERIOR PÚBLICO EXTENSÃO DO PASSEIO PÚBLICO

ESPAÇO EXTERIOR COLETIVO

PÁTIOS / CAMINHOS / ESCADAS

ÁREAS VERDES / JARDINS

\section{ESPACCO EXTERIOR ENTRE} COLETIVO E PRÓPRIO

VESTÍBULO EXTERNO

JARDINS DE INTERESSE COMUM
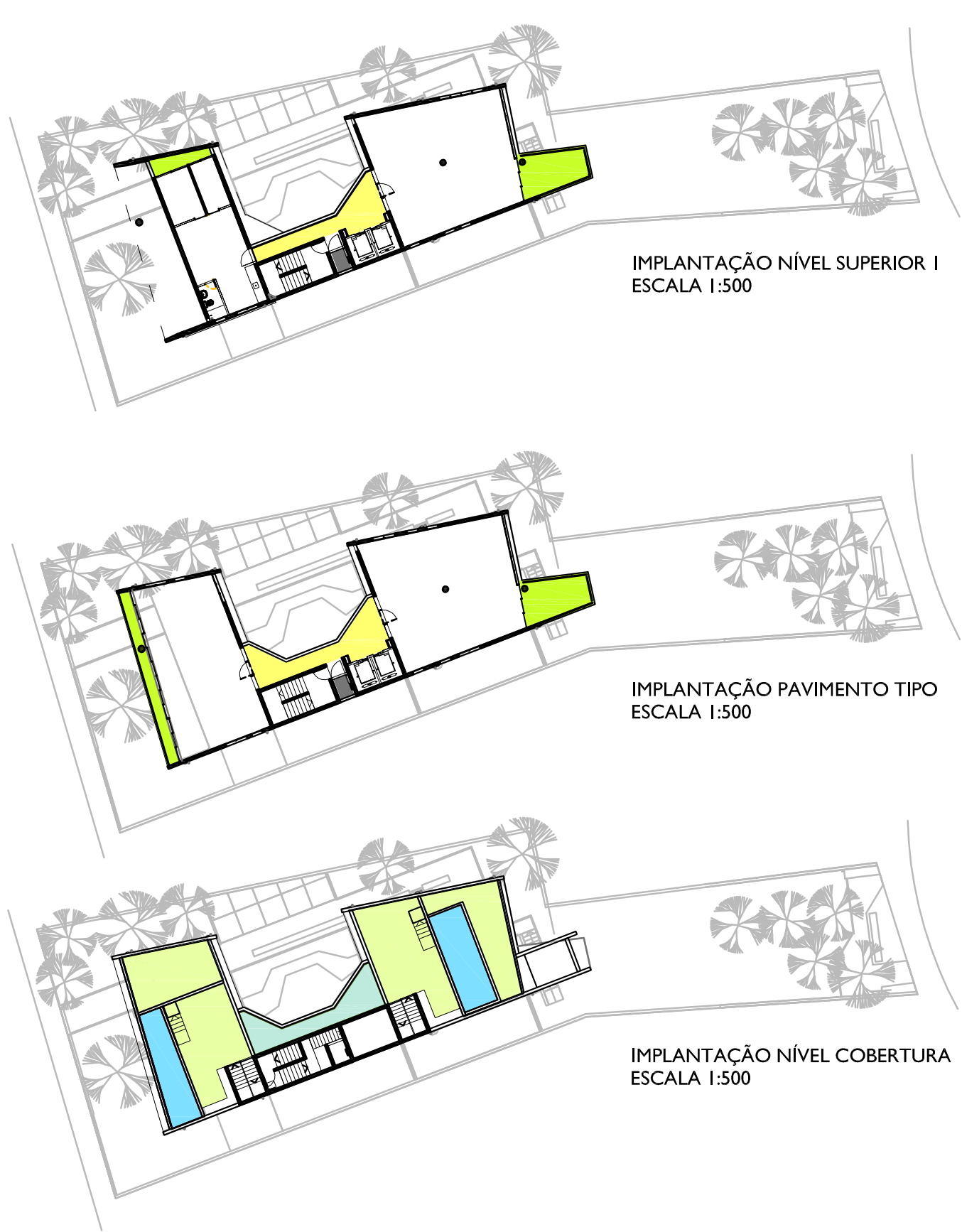

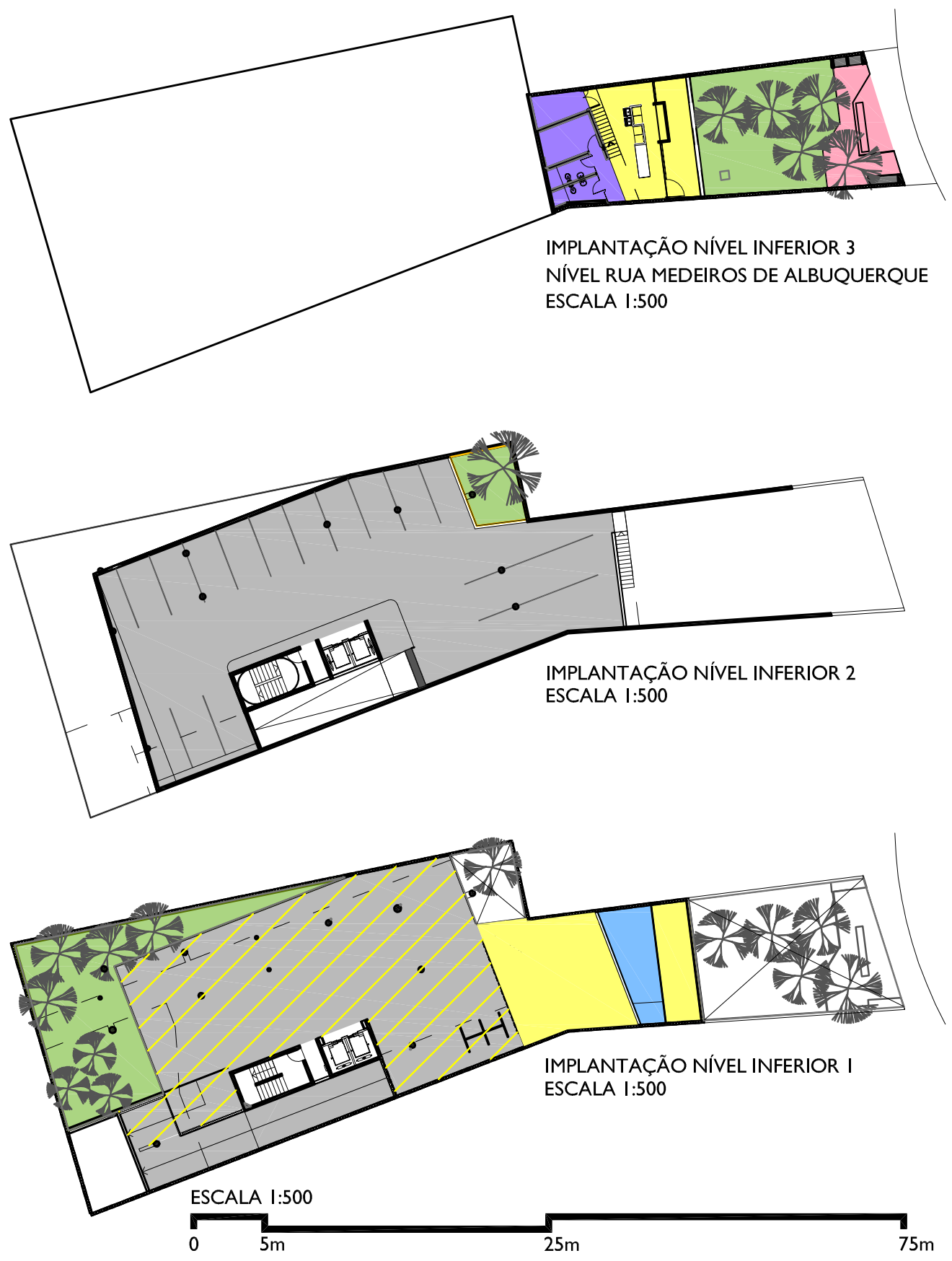

\section{FIORI DI MAGGIO}

Característica principal: ausência de espaços exteriores próprios, e predomínio das áreas coletivas, inclusive as fechadas, para realização de atividades variadas.

\section{Táticas projetuais:}

- rasgo entre os dois blocos até o subsolo, de modo a distânciar o espaço coletivo do térreo do salão para múltiplas funcionalidades;

- uso da cobertura para espaço de lazer coletivo;

- um dos blocos, no caso o do fundo, é erguido para criação de espaço coletivo no térreo.

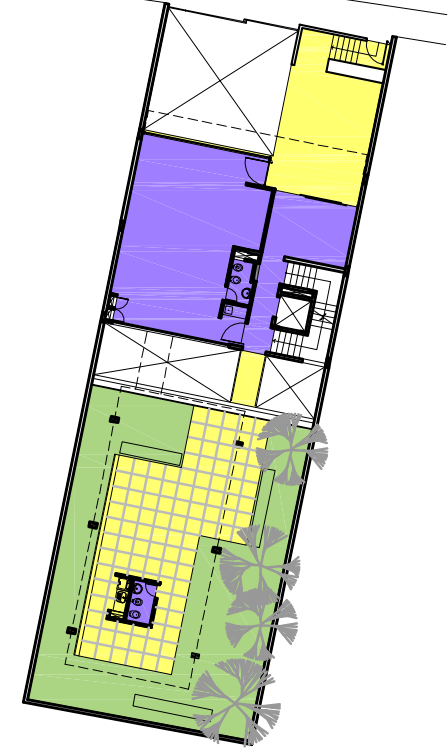

IMPLANTAÇÃO NÍVEL TÉRREO ESCALA I:500
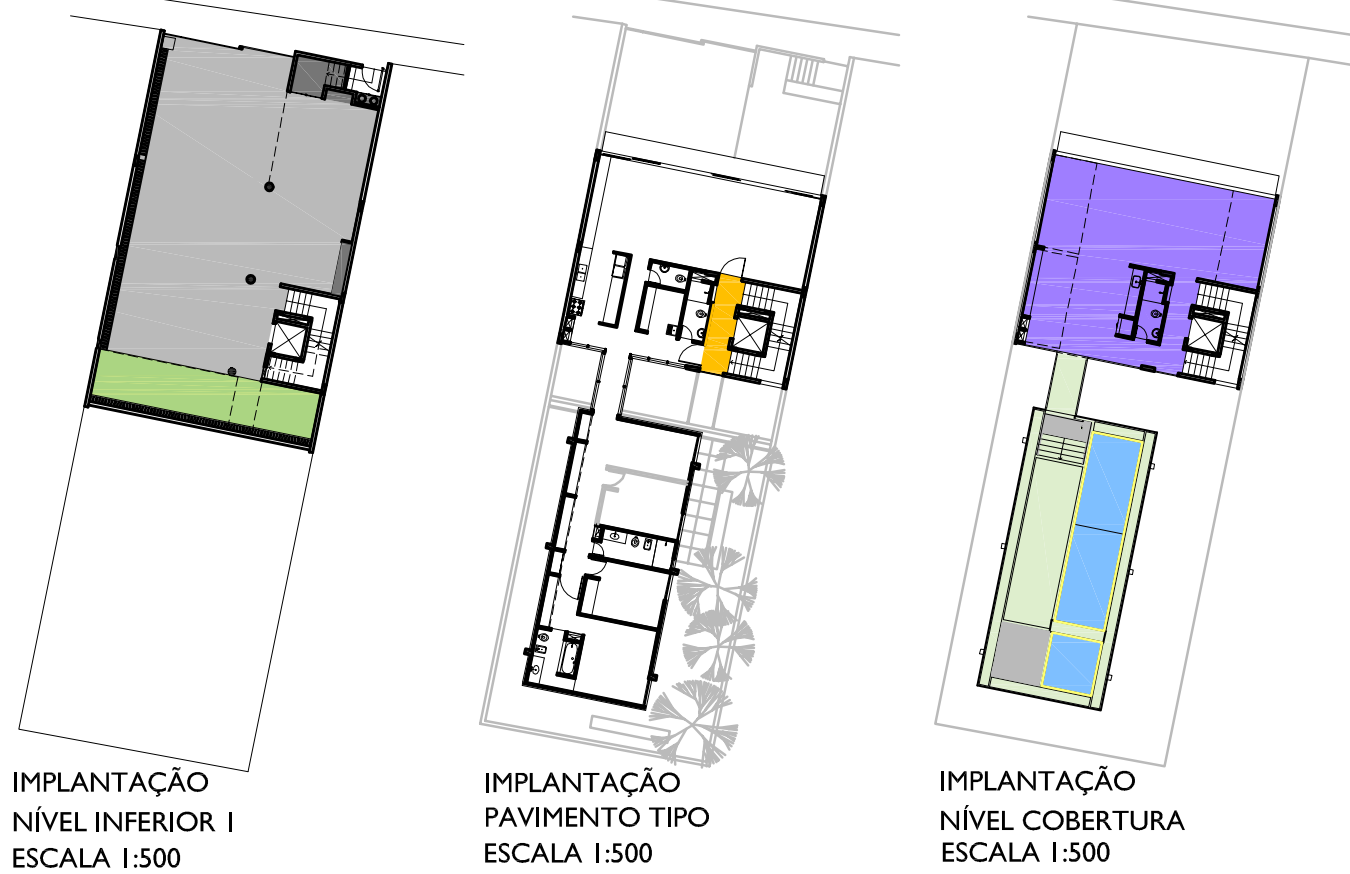


\section{FIDALGA 772}

Característica principal: predomínio dos espaços exteriores próprios. Poucas áreas coletivas: incentivo ao coletivo da cidade e não coletivo do interior do conjunto.

\section{Táticas projetuais:}

- no espaço do térreo, geralmente coletivo, são criadas unidades casas; - doação de pequeno espaço para ampliação da calçada pública;

- permeabilidade visual do térreo para a rua e vice-versa.

- pequeno trecho de terreno original é mantido no nível da rua, com paisagismo, para permitir um caráter menos opressivo à garagem;

- no nível térreo, a seis metros do nível da rua, é criada uma plataforma suspensa para contemplação da cidade;

- as varandas são sobrepostas, para não entrarem no cálculo de área construída;

- uso do espaço da cobertura para lazer privativo.

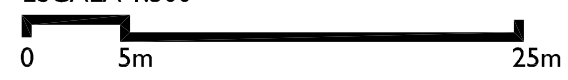

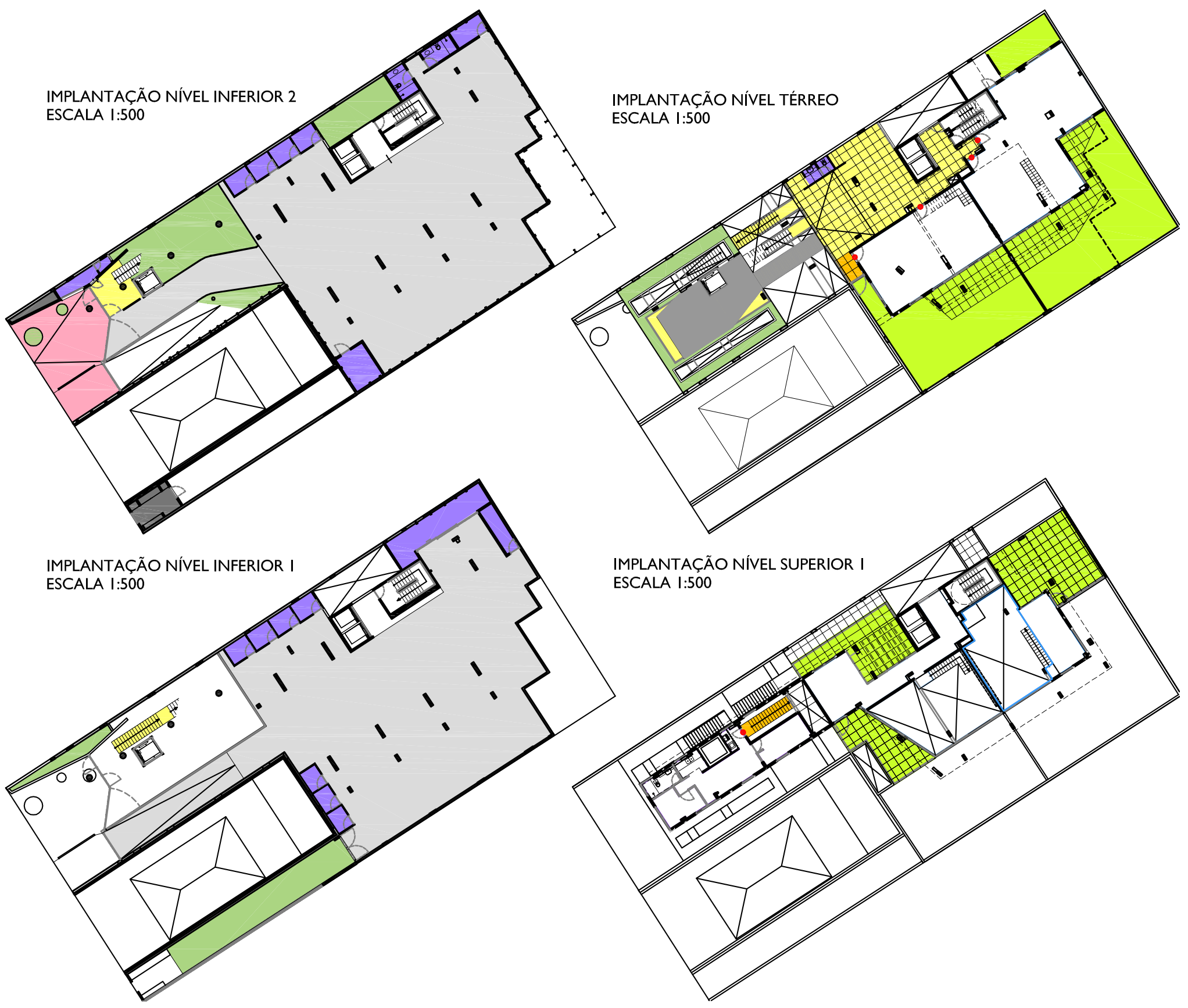



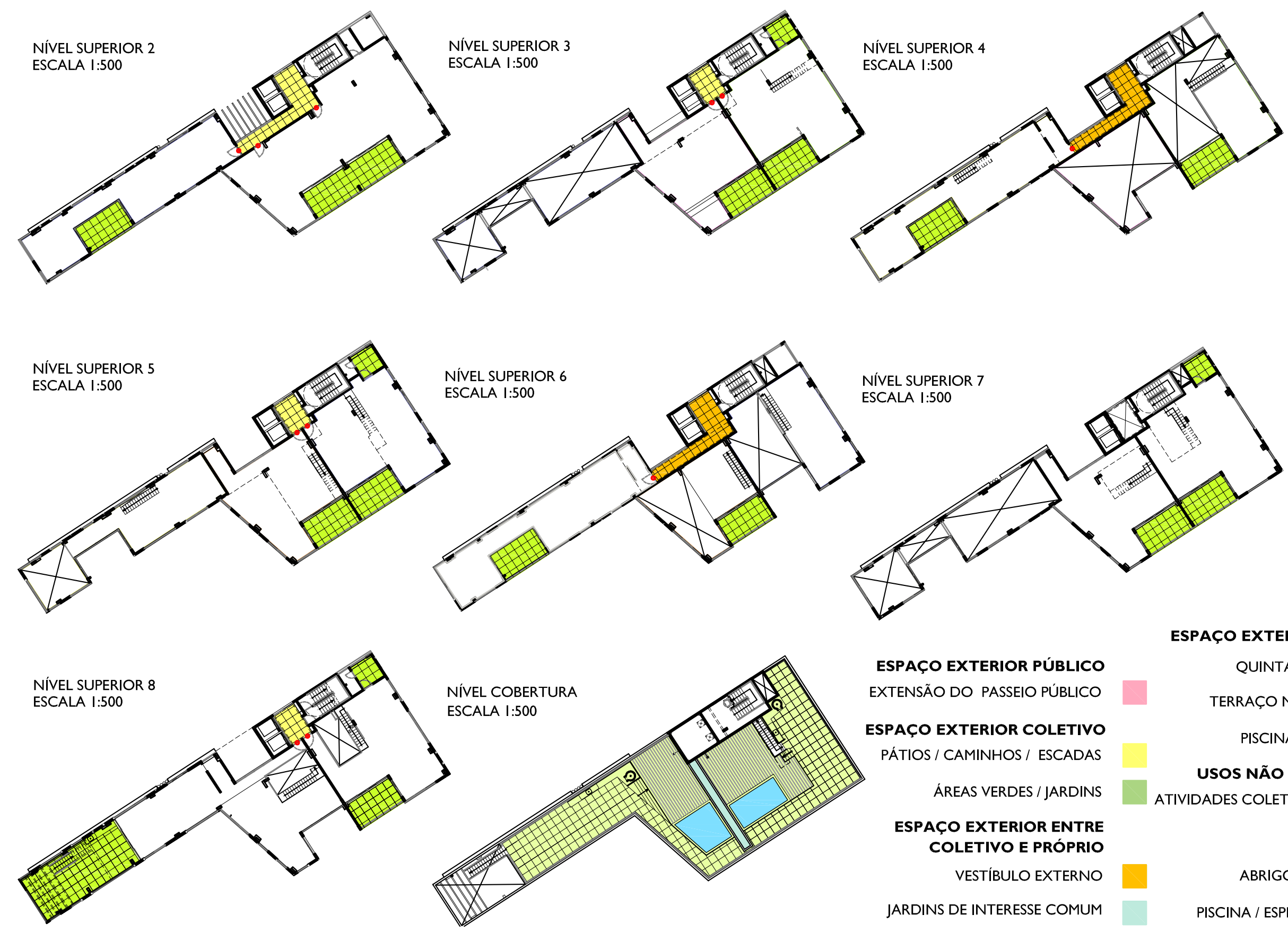

ESPAÇO EXTERIOR PÚBLICO EXTENSÃO DO PASSEIO PÚBLICO ESPAÇO EXTERIOR COLETIVO PÁTIOS / CAMINHOS / ESCADAS ÁREAS VERDES / JARDINS ESPAÇO EXTERIOR ENTRE COLETIVO E PRÓPRIO VESTÍBULO EXTERNO JARDINS DE INTERESSE COMUM

ESPAÇO EXTERIOR PRÓPRIO QUINTAL / VARANDA TERRAÇO NA COBERTURA PISCINA NO TERRAÇO USOS NÃO RESIDENCIAL ATIVIDADES COLETIVAS / OUTROS GARAGEM ABRIGO INSTALAÇÕES PISCINA / ESPELHOS D'ÁGUA 


\section{VILA PEDRO FACHINI}

\section{VILA PEDRO FACHINI}

Característica principal: Ausência de espaço exterior entre coletivo e privativo, sendo que para este tipo de situação, de menor área de terreno e maior densidade populacional, é primordial projetar espaços equilibrados neste sentido. Ao mesmo tempo, eixstem espaços exteriores próprios, mais positivo ainda por se tratar de habitação de interesse social de promoção pública, onde dificilmente se propõem varandas ou outros espaços do tipo.

\section{Táticas projetuais:}

- escada para acesso e lazer simultaneamente;

- criação de varandas contato com o exterior público e coletivo;

- quintais internos para permitir renovação de ar e insolação de espaços mais próximo à divisa.

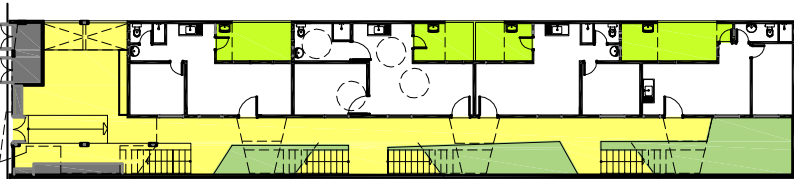

IMPLANTAÇÃo NÍVEL TÉRREO ESCALA |:500

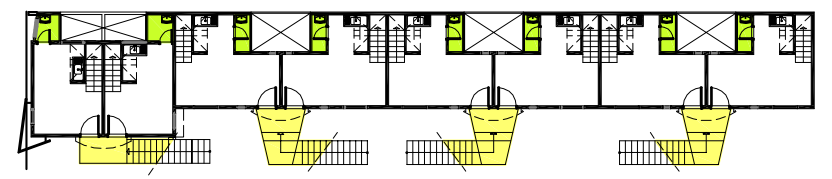

IMPLANTAÇÃO NÍVEL SUPERIOR ।

ESCALA I:500

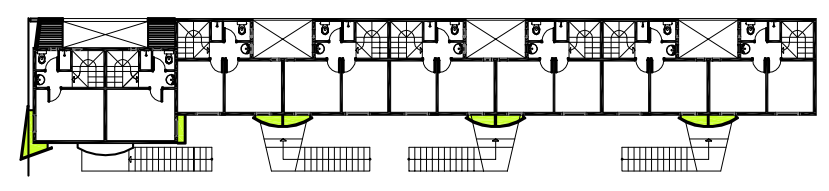

IMPLANTAÇÃO NÍVEL SUPERIOR 2

ESCALA |:500

ESCALA I:500

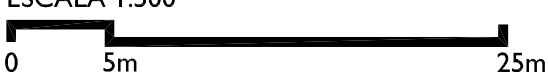

\section{QUADRO SÍNTESE}

PROJETO

TOTAL ÁREA DO TERRENO

\% OCUPAÇÃO DO TERRENO

EXTENSÃO DO PASSEIO PÚBLICO

PÁTIOS / CAMINHOS / PASSARELAS / ESCADAS

ÁREAS VERDES / JARDINS

TERRACCO NA COBERTURA

VESTÍBULO EXTERNO

JARDINS ENTRE COLETIVO E PRIVATIVO

JARDINS DE INTERESSE COMUM

QUINTAL / PÁTIO / VARANDA / BALCÃO

TERRAÇO NA COBERTURA

PISCINA NO TERRACCO

TRABALHO / ATIVIDADES COLETIVAS / OUTROS

GARAGEM

GARAGEM QUE PERMITE CONVÍVIO

ABRIGO INSTALAÇÕES

PISCINA / ESPELHOS D'ÁGUA
- ESPAÇO EXTERIOR PÚBLICO

ESPAÇO EXTERIOR COLETIVO

ESPAÇO EXTERIOR ENTRE

COLETIVO E PRÓPRIO

ESPAÇO EXTERIOR PRÓPRIO

$+$

USOS NÃO RESIDENCIAL

TOTAL ESPAÇO EXTERIOR

ESPACO EXTERIOR PÚBLICO

ESPAÇO EXTERIOR COLETIVO

ESPAÇO EXTERIOR ENTRE COLETIVO E PRÓPRIO

ESPACO EXTERIOR PRÓPRIO

USOS NÃO RESIDENCIAL 


\begin{tabular}{|c|c|c|c|c|c|c|c|c|c|c|c|c|c|c|c|}
\hline \multicolumn{2}{|c|}{ VILA FIDALGA } & \multicolumn{2}{|c|}{ VILA TAGUAÍ } & \multicolumn{2}{|l|}{ CANAÃ } & \multicolumn{2}{|c|}{ VILA BUTANTÃ } & \multicolumn{2}{|c|}{ SIMPATIA 234} & \multicolumn{2}{|c|}{ FIORI DI MAGGIO } & \multicolumn{2}{|l|}{ FIDALGA 772} & \multicolumn{2}{|c|}{ VILA PEDRO FACHINI } \\
\hline \multicolumn{2}{|l|}{$1300 \mathrm{M2}$} & \multicolumn{2}{|c|}{$12262,6 \mid$ M2 } & \multicolumn{2}{|l|}{$3200 \mathrm{M} 2$} & \multicolumn{2}{|l|}{$4439 \mathrm{M} 2$} & \multicolumn{2}{|l|}{$820 M 2$} & \multicolumn{2}{|l|}{$432 \mathrm{M} 2$} & \multicolumn{2}{|l|}{$860 M 2$} & \multicolumn{2}{|l|}{$320 \mathrm{M} 2$} \\
\hline \multicolumn{2}{|l|}{$49,46 \%$} & \multicolumn{2}{|l|}{$10,70 \%$} & \multicolumn{2}{|l|}{$27 \%$} & \multicolumn{2}{|l|}{$30 \%$} & \multicolumn{2}{|l|}{$32 \%$} & \multicolumn{2}{|l|}{$51,50 \%$} & \multicolumn{2}{|l|}{$43 \%$} & \multicolumn{2}{|l|}{$56,87 \%$} \\
\hline ÁREA (M2) & & ÁREA (M2) & & ÁREA (M2) & & ÁREA (M2) & & ÁREA (M2) & & ÁREA (M2) & & ÁREA (M2) & & ÁREA (M2) & \\
\hline- & $0 \%$ & - & $0 \%$ & - & $0 \%$ & - & $0 \%$ & $30,49 \mathrm{M} 2$ & $1,52 \%$ & - & $0 \%$ & $61,73 \mathrm{M} 2$ & $2,55 \%$ & - & $0 \%$ \\
\hline $360,14 \mathrm{M} 2$ & $36,40 \%$ & | 238,17 M2 & $74,72 \%$ & $392,36 \mathrm{M} 2$ & $55,71 \%$ & $845,42 \mathrm{M} 2$ & $46,83 \%$ & 497,95 M2 & $36,94 \%$ & | 1 4,32M2 & $44,10 \%$ & 193,56 M2 & $\mid 4,91 \%$ & 123,10M2 & $75,07 \%$ \\
\hline $253,15 \mathrm{M} 2$ & & $7925,49 \mathrm{M} 2$ & & | 290,74 M2 & & | 357, | | M2 & & 239,24 M2 & & I 38,35 M2 & & 166,33 M2 & & $36,50 \mathrm{M} 2$ & \\
\hline- & & - & & - & & - & & - & & $61,47 \mathrm{M} 2$ & & - & & - & \\
\hline $60,05 \mathrm{M} 2$ & $21,33 \%$ & - & | $3,48 \%$ & $53,78 \mathrm{M} 2$ & $6,43 \%$ & - & | $8,78 \%$ & - & $0,90 \%$ & 19,65 M2 & $2,75 \%$ & $64,36 \mathrm{M} 2$ & $2,95 \%$ & - & $0 \%$ \\
\hline 104,62 M2 & & $1653,08 \mathrm{M2}$ & & 140,78 M2 & & 339,15 M2 & & - & & - & & - & & - & \\
\hline 194,76 M2 & & - & & - & & - & & $17,98 \mathrm{M} 2$ & & - & & 6,84 M2 & & - & \\
\hline 193,42 M2 & $22,50 \%$ & $784,89 \mathrm{M} 2$ & $10,74 \%$ & 324,49 M2 & $28,38 \%$ & 240,09 M2 & $26,59 \%$ & 176,56 M2 & $16,17 \%$ & - & $0 \%$ & $593,97 \mathrm{M} 2$ & $35,27 \%$ & $45,10 \mathrm{M} 2$ & $21,21 \%$ \\
\hline \multirow[t]{2}{*}{$175,10 \mathrm{M} 2$} & & $533,04 \mathrm{M} 2$ & & $533,04 \mathrm{M} 2$ & & $240,00 \mathrm{M} 2$ & & |l1,51 M2 & & - & & $231,03 \mathrm{M} 2$ & & - & \\
\hline & & - & & - & & - & & $34,74 \mathrm{M} 2$ & & - & & $26,38 \mathrm{M} 2$ & & - & \\
\hline \multicolumn{16}{|l|}{-} \\
\hline 33,79 M2 & $19,75 \%$ & $57,51 \mathrm{M} 2$ & $1,04 \%$ & - & $9,46 \%$ & 78,91 M2 & 7,78\% & $43,64 \mathrm{M} 2$ & $44,45 \%$ & 176,90 M2 & $53,10 \%$ & $97,30 \mathrm{M} 2$ & $44,29 \%$ & - & $3,70 \%$ \\
\hline- & & - & & 275,95 M2 & & - & & $469,75 \mathrm{M} 2$ & & I 62,44 M2 & & $959,08 \mathrm{M} 2$ & & - & \\
\hline $290,90 \mathrm{M} 2$ & & - & & - & & - & & $316,7 \mid \mathrm{M} 2$ & & - & & - & & - & \\
\hline 8,07 M2 & & 5,82 M2 & & $10,00 \mathrm{M} 2$ & & I,0 M2 & & $2,30 \mathrm{M} 2$ & & $7,12 \mathrm{M} 2$ & & 12,67 M2 & & 7,88 M2 & \\
\hline- & & 64,61 M2 & & - & & $60,67 \mathrm{M} 2$ & & $54,73 \mathrm{M} 2$ & & $32,22 \mathrm{M} 2$ & & - & & - & \\
\hline I 684,55 M2 & $100 \%$ & $12795,7 \mathrm{M} 2$ & $100 \%$ & $3021,14 \mathrm{M} 2$ & $100 \%$ & $2471,16 \mathrm{M} 2$ & $100 \%$ & $\mid 995,60 \mathrm{M} 2$ & $100 \%$ & 712,47 M2 & $100 \%$ & $24 \mid 3,25 \mathrm{M} 2$ & $100 \%$ & $212,58 \mathrm{M} 2$ & $100 \%$ \\
\hline \multicolumn{2}{|l|}{$0 \%$} & \multicolumn{2}{|l|}{$0 \%$} & $0 \%$ & & $0 \%$ & & $1,52 \%$ & & $0 \%$ & & $2,55 \%$ & & $0 \%$ & \\
\hline 3 & $40 \%$ & t & $74,72 \%$ & 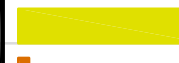 & $55,71 \%$ & & $46,83 \%$ & 36 & ,94\% & & $44,10 \%$ & $\mid 4,91 \%$ & & 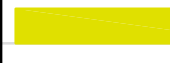 & $75,07 \%$ \\
\hline 21,33 & & $13,48 \%$ & & $6,43 \%$ & & $18,78 \%$ & & | $0,90 \%$ & & $2,75 \%$ & & $2,95 \%$ & & $0 \%$ & \\
\hline 22,50 & & $10,74 \%$ & & 28,38 & & 26,5 & & $16,17 \%$ & & $0 \%$ & & 35 & $27 \%$ & 21,21 & \\
\hline 19,75 & & ||1,04\% & & $9,46 \%$ & & $7,78 \%$ & & & $44,45 \%$ & & $53,10 \%$ & & $44,29 \%$ & $3,70 \%$ & \\
\hline
\end{tabular}


BAHAMÓN,A.; SANJINÉS, M. C. Alta densidad: Vivienda Contemporánea. Barcelona: Parramón ediciones, 2008.

CERCHIARA, Débora.Vivir em Grupo. SUMMA+, Buenos Aires, n. 101, p.42-43, abril de 2009.

FERREIRA, J. S.W. (Coordenação). Produzir casas ou construir cidades? Desafios para um novo Brasil Urbano. Laboratório de Habitação e Assentamentos Humanos da FAUUSP. São Paulo: LABHAB, FUPAM, 2012.

LEMOS, C. Casa Paulista, São Paulo, EDUSP, 1999.

MONTANER, J. M.; MUXÍ, Z. M. Habitar el Presente. Vivienda en España: Sociedad, ciudad, tecnología y recursos. Madri: Ministerio de Vivienda, 2006.

MONTANER, J. M.; MUXÍ, Z. M.; ZULIN, F.; CORADIN, R. Instrumentos de Avaliação de Projetos. Em: Do plano ao projeto: Novos Bairros e Habitação Social em São Paulo. Coleção: Política Municipal de Habitação: Uma construção coletiva. São Paulo: Secretaria Municipal de Habitação, Prefeitura de São Paulo, 2012, p. 252-313.

PFEIFER, G; BRAUNECK, P. Casas geminadas. Barcelona: Editorial Gustavo Gilli, 2009.Versão portuguesa: Cláudia Ardións Espasandin/ltinerário Editorial Ltda.

SCHNEIDER, F. (Org.). Atlas de plantas. Habitação. Barcelona: Editorial Gustavo Gilli, 2006. Iª edição em português.

WISSENBACH,T. C. A cidade e o mercado imobiliário: uma análise da incorporação residencial paulistana entre 1992 e 2007. 2008. Dissertação (mestrado pela Faculdade de Filosofia, Letras e Ciências Humanas), Universidade de São Paulo, São Paulo, 2008.

LEIS:

SÃO PAULO (município). Lei n II.228, de 25 de junho de 1992. Código de Obras e Edificações do Município de São Paulo. Dispões sobre as regras gerais, e específicas a serem obedecidas no projeto, licenciamento, execução, manutenção e utilização de obras e edificações, dentro dos limites dos imóveis, revoga a Lei $n^{\circ} 8.266$ de 20 de junho de 1975, com as alterações adotadas por leis posteriores, e dá outras providências.

SÂO PAULO (município). Decreto Municipal n 32.329 de 23 de setembro de 1992. Regulamenta a Lei n II.228 de 25 de junho de 1992 - Código de Obras e Edificações, e dá outras providências.

OUTROS:

VIGLIECCA, H. Construir a Cidadania. Conferência Museu da Casa Brasileira. São Paulo, MCB, 28 nov. 2012 


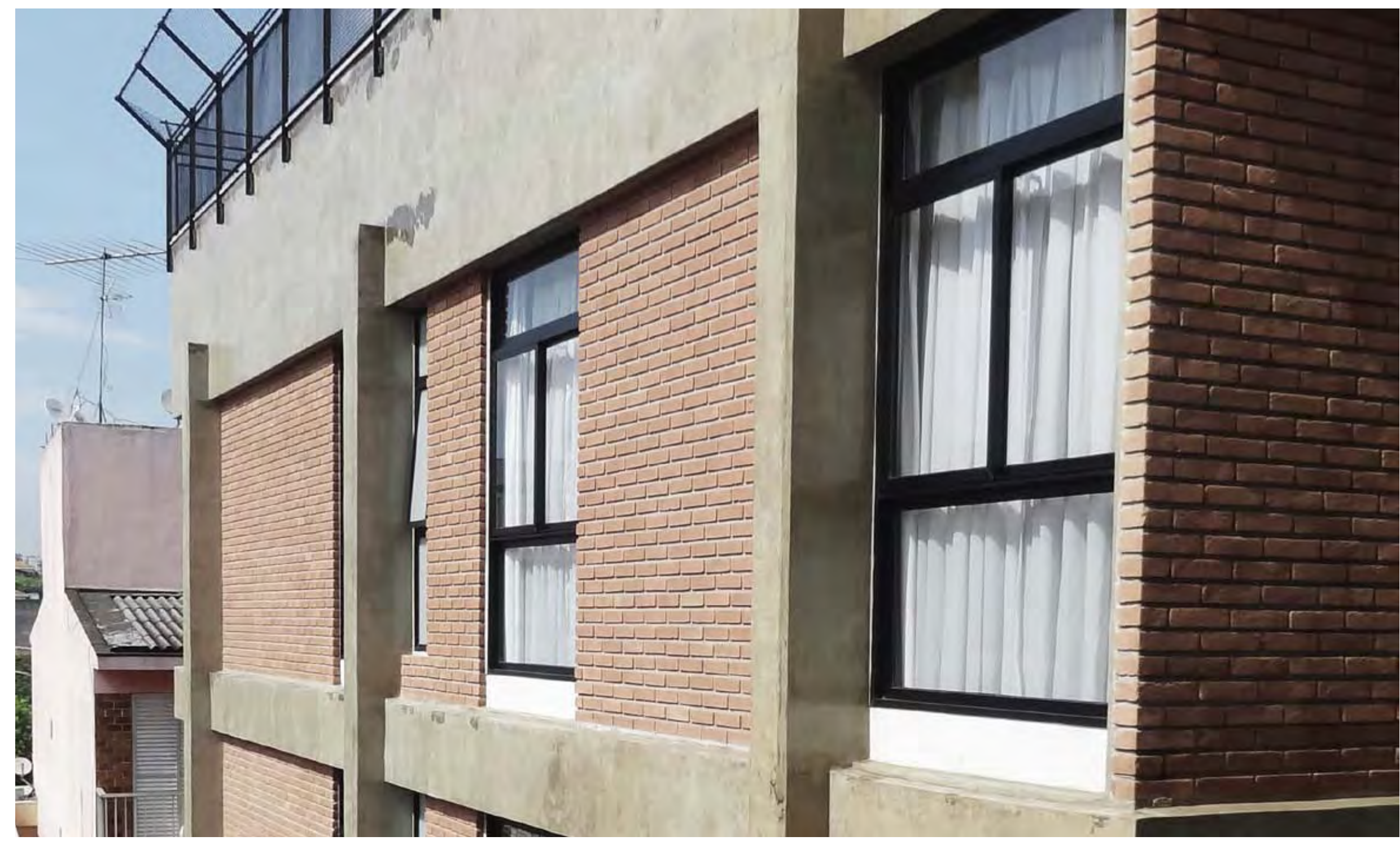

4. ANÁLISE COMPARATIVA E CONSIDERAÇÕES FINAIS POR TEMAS PRESENTES NOS PROJETOS SELECIONADOS 4.3 SISTEMA ESTRUTURAL, TÉCNICA CONSTRUTIVA E ENVOLTÓRIA 


\subsection{SISTEMA ESTRUTURAL E TÉCNICA CONSTRUTIVA}

O estudo do sistema estrutural aliado à técnica construtiva nos projetos selecionados nos permite identificar diversas soluções e resultados na arquitetura final resultante, que em parte é consequência das soluções referentes ao desenho da estrutura, conjugada às decisões de posição das instalações entre outras questões projetuais. O termo utilizado por Segawa (2007) para resumir a obra de Marcos Acayaba, "estética da lógica", também pode ser aplicado nos outros projetos desta pesquisa, porém, cada um com sua dosagem, sejam de estética ou de lógica. Uma comparação final coloca todas as propostas sobre as mesmas incógnitas, e fica mais fácil compreender o raciocínio projetual de cada um e o grau da racionalização das soluções.

Assim, como metodologia, houve o trabalho de redesenho dos projetos, destacando a estrutura, eixos por onde passam vigas, envoltória, instalações, núcleos de áreas molhadas etc., e na sequência, também com base nas leituras específicas da cada projeto, foi elaborada uma tabela síntese comparativa, dividia em três temas principais e correlacionados: Sistema Estrutural,Técnica Construtiva e Materiais. $O$ que foi possível obter desta metodologia, não são conclusões, e sim, possibilidades para a arquitetura contemporânea, afinal, os projetos selecionados representam uma pequena amostra ou parcela da arquitetura contemporânea habitacional paulista. Na sequência alguns resultados. 


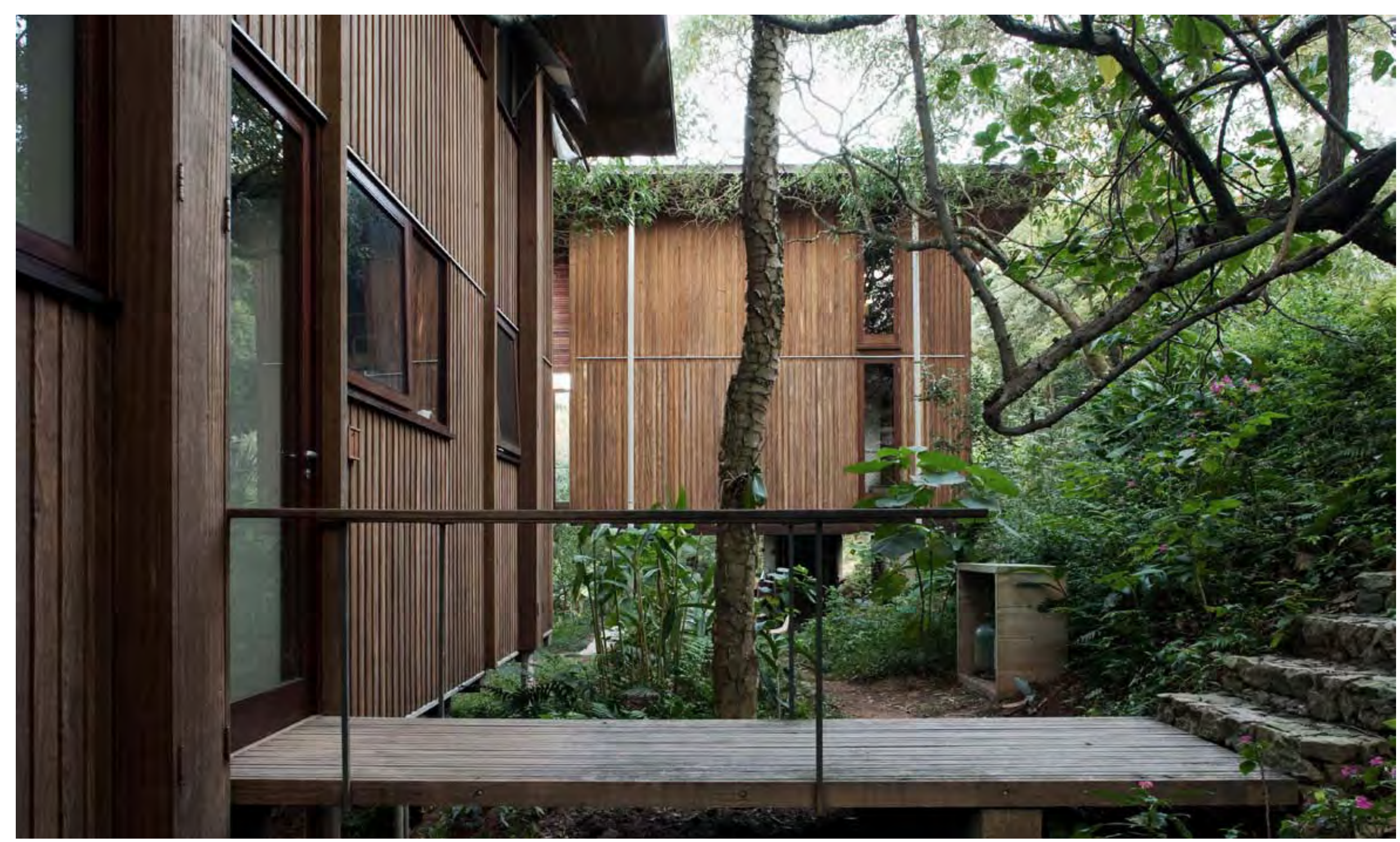

4.3.I.I COMPARAÇÃO GRÁFICA SISTEMA ESTRUTURAL E TÉCNICA CONSTRUTIVA 


\section{SISTEMA ESTRUTURAL E TÉCNICA CONSTRUTIVA}
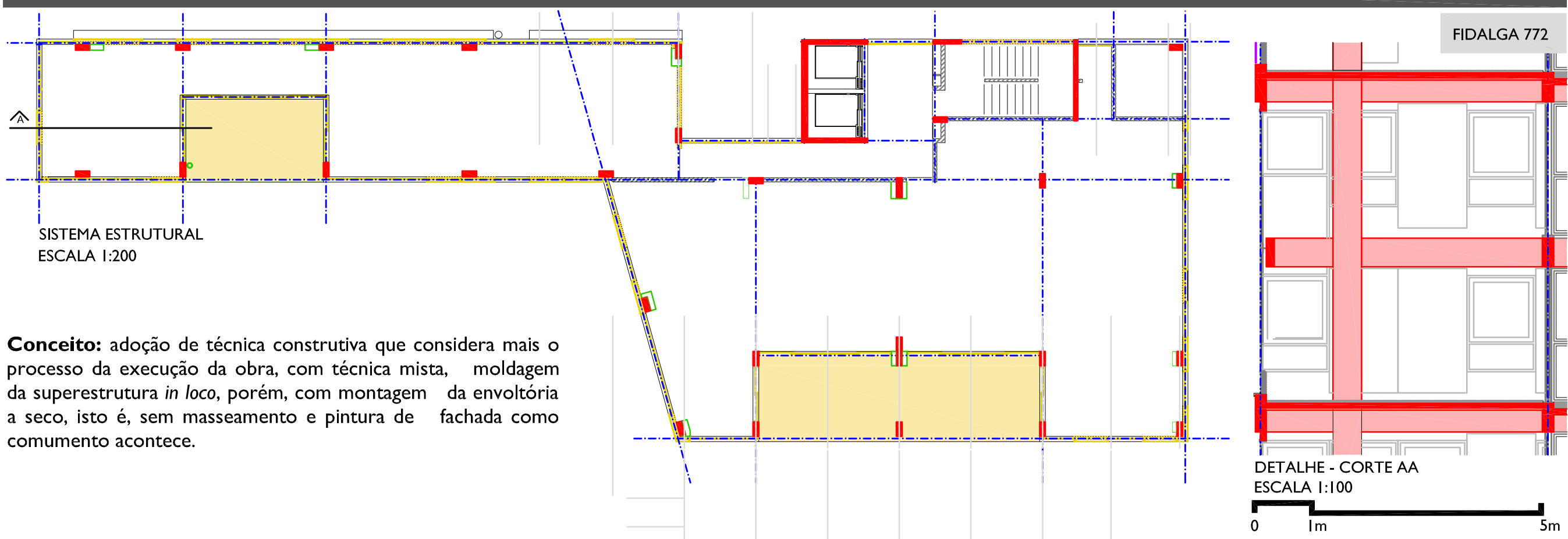

PAREDE ESTRUTURAL / PILAR

VIGAS

VEDAÇÃO / ALVENARIA

VEDAÇÃO / CONCRETO CELULAR

MADEIRA - ESTRUTURAL

MADEIRA

\section{ÁREA MOLHADA}

DUTOS / ISTALAÇÕES EXTERNAS ÀS PAREDES

VEDAÇÃO / ALVENARIA ENVOLTÓRIA

VARANDAS / SALIÊNCIAS

CAIXILHO ENVOLTÓRIA

PROJEÇÃO VAGAS PARA AUTOMÓVEIS NO SUBSOLO conceito: moldagem do monobloco, como se estivesse esculpindo o volume de forma retangular pura.

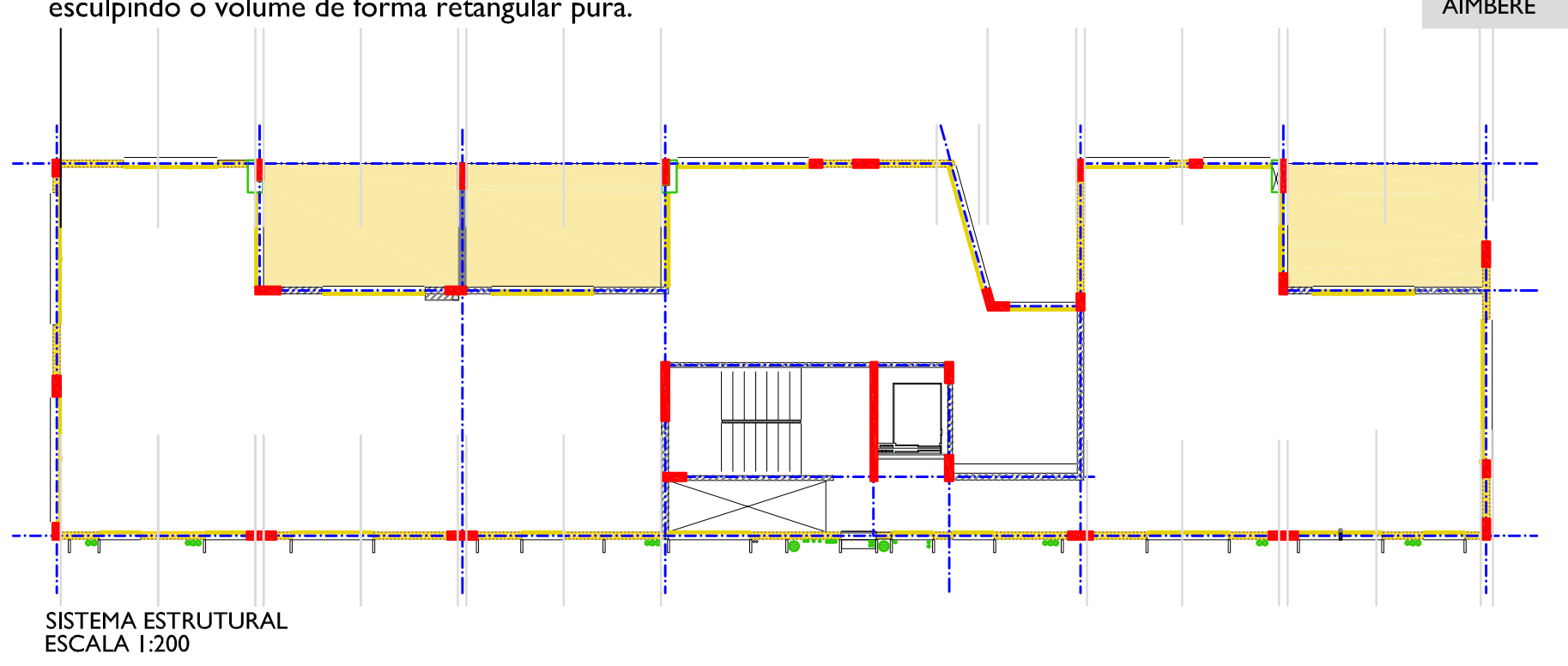



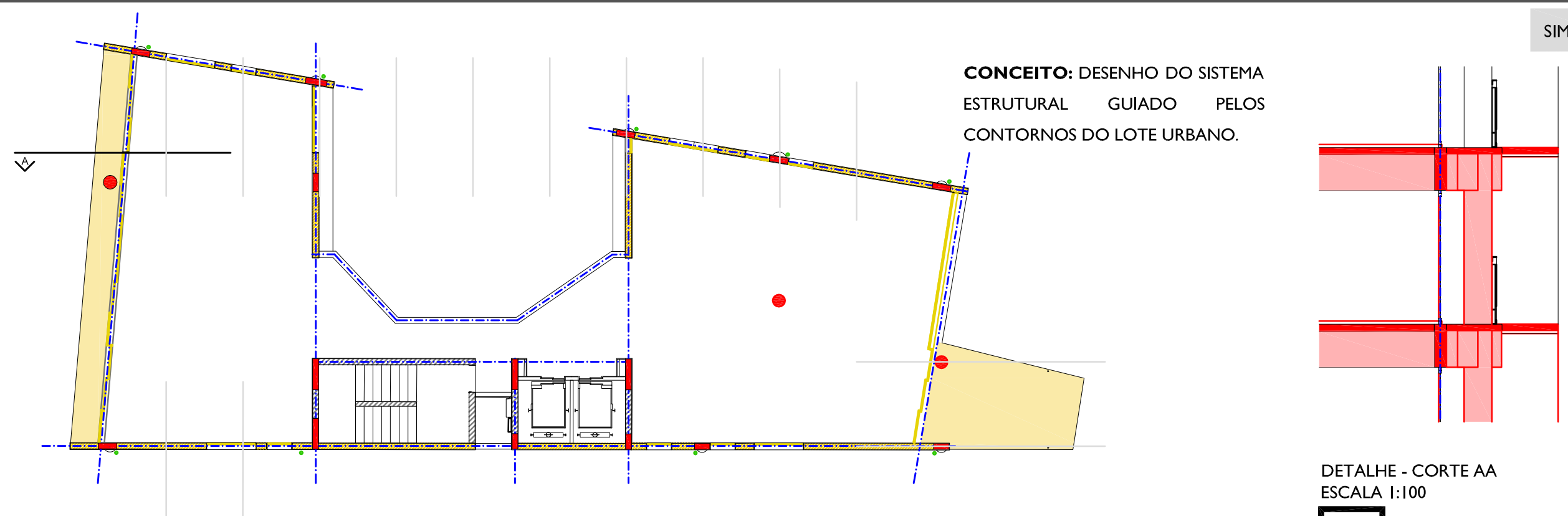

DETALHE - CORTE AA ESCALA I:100

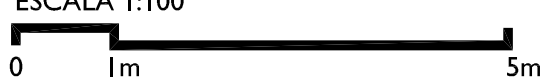

FIORI DI MAGGIO

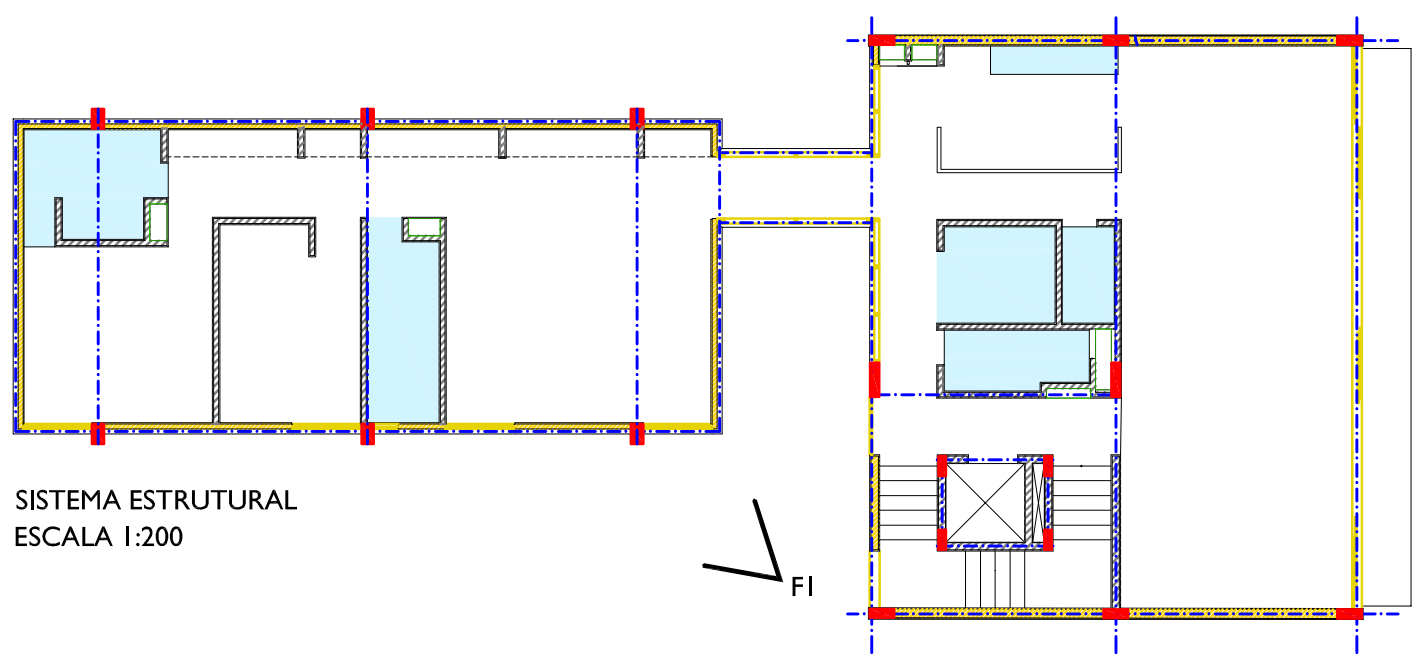

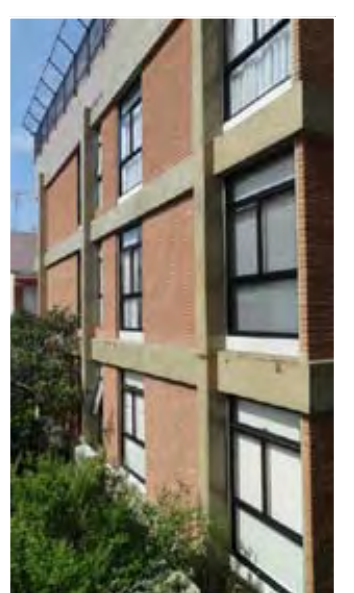

FI - FOTO FACE LESTE

EDFÍCIO POSTERIOR

ESCALA I:200

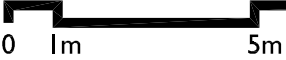

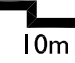

CONCEITO: CONSTRUÇÃO COMO

ORGANIZAÇÃO DO SISTEMA ESTRUTURAL 

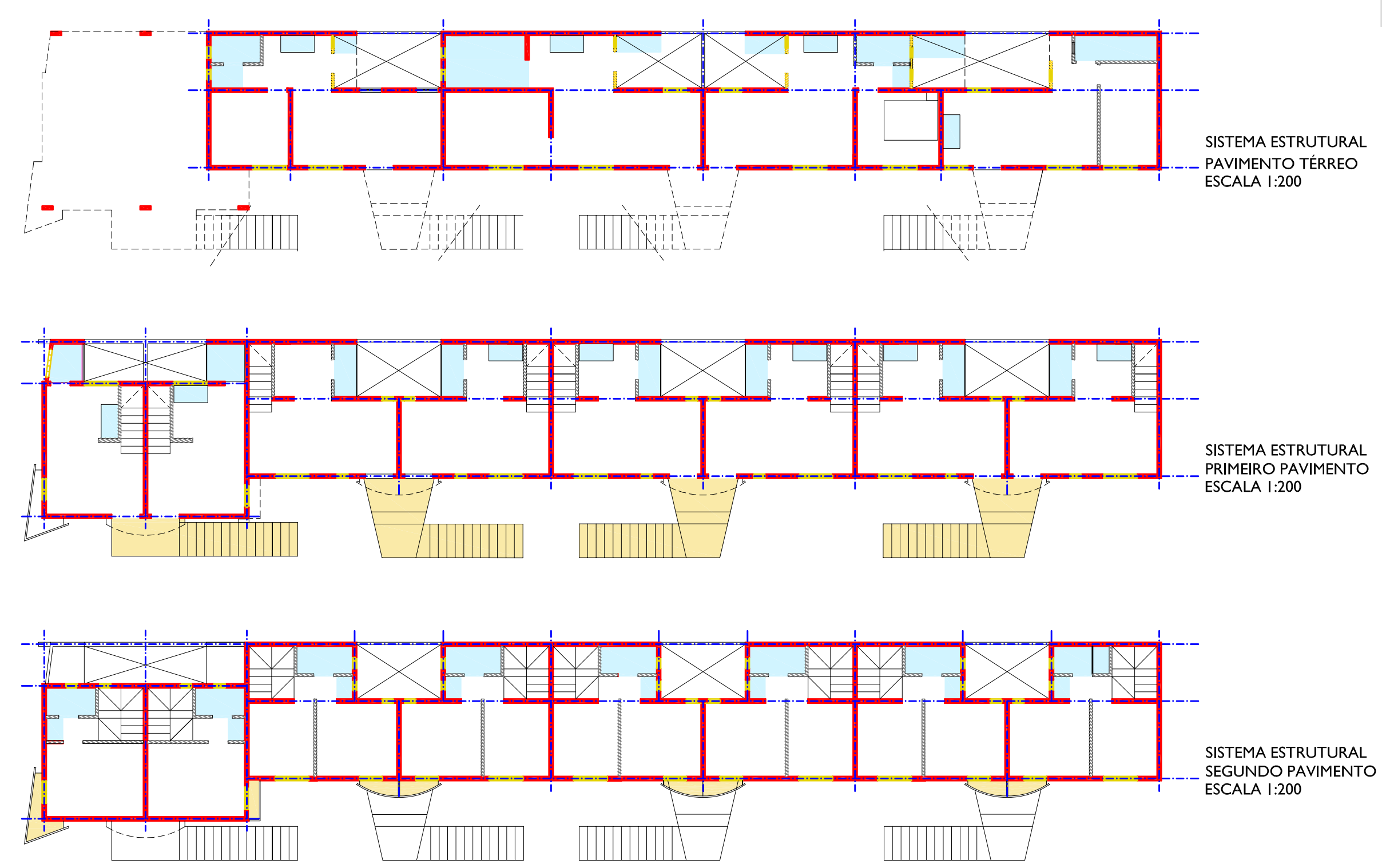

ESCALA ।:200

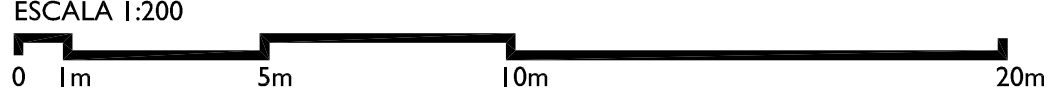

conceito: técnica construtiva adotada, alvenaria estrutura, é de baixo custo e rápida execução. esta técnica adotada incide no desenho dosistema estrutural e na forma final do edifício. 

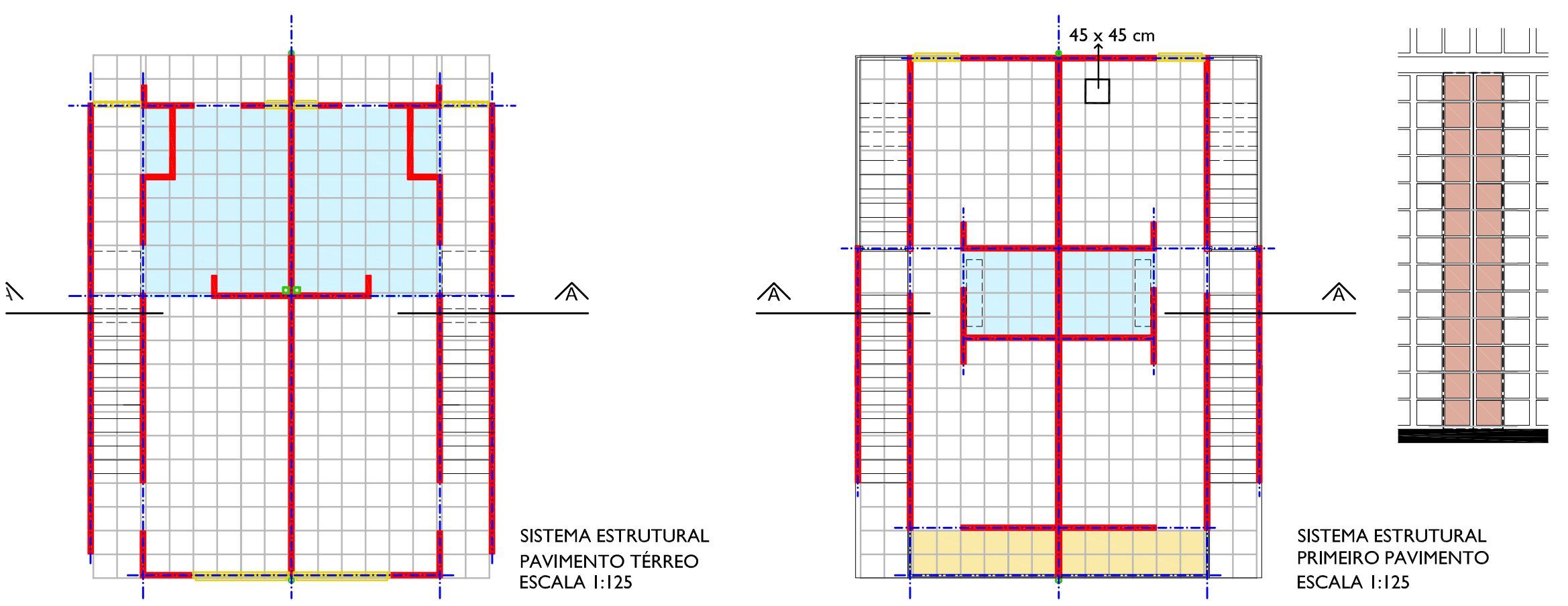

CANAÃ

PAVIMENTO TÉRREO CALA I:125

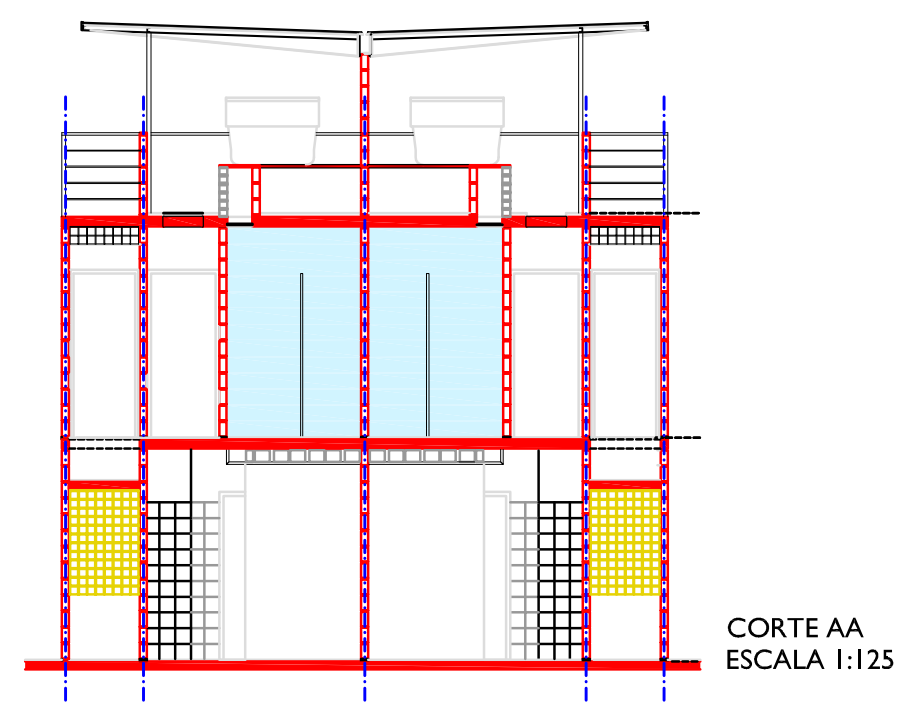

conceito: solução racional, compativel

com a cultura e economia local.

PAINEL CPC EM VISTA ESCALA I:50 ESCALA I:125

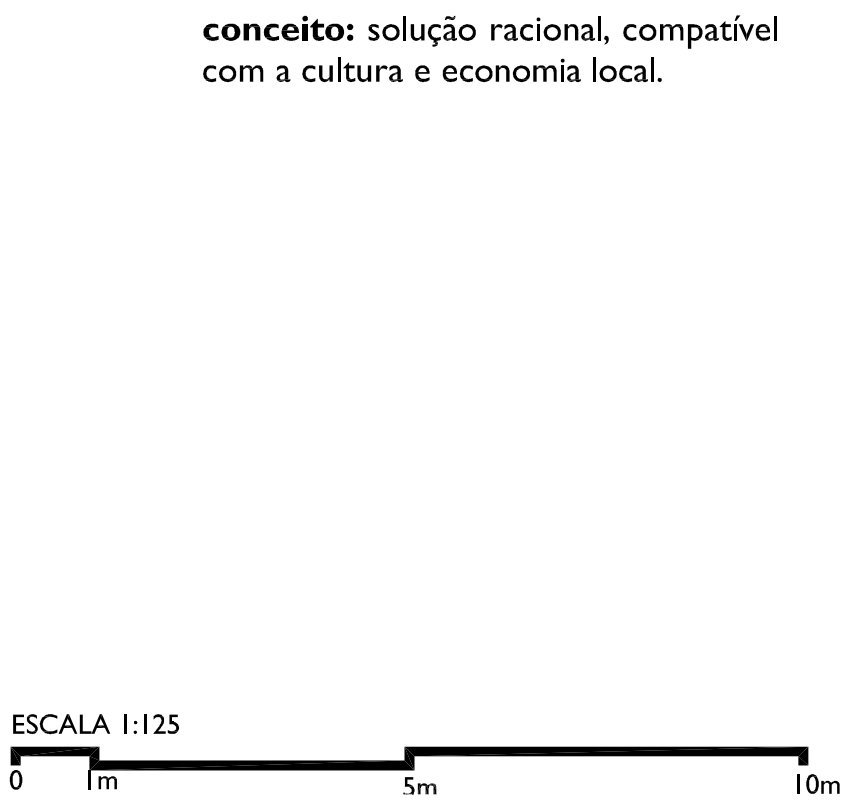

$\begin{array}{r}\text { PAREDE ESTRUTURAL / PILAR } \\ \text { EIXOS ESTRUTURAIS PRINCIPAIS } \\ \text { VEDAÇÃO / ALVENARIA } \\ \hline \text { VEDAÇÃO / CONCRETO CELULAR } \\ \text { MADEIRA - ESTRUTURAL } \\ \text { ÁREA MOLHADEIRA } \\ \hline \text { DUTOS / ISTALAÇÕES EXTERNAS ÀS PAREDES } \\ \text { VARANDAS / SALIÊNCIAS } \\ \hline \text { CAIXILHO ENVOLTÓRIA }\end{array}$




\section{SISTEMA ESTRUTURAL E TÉCNICA CONSTRUTIVA}
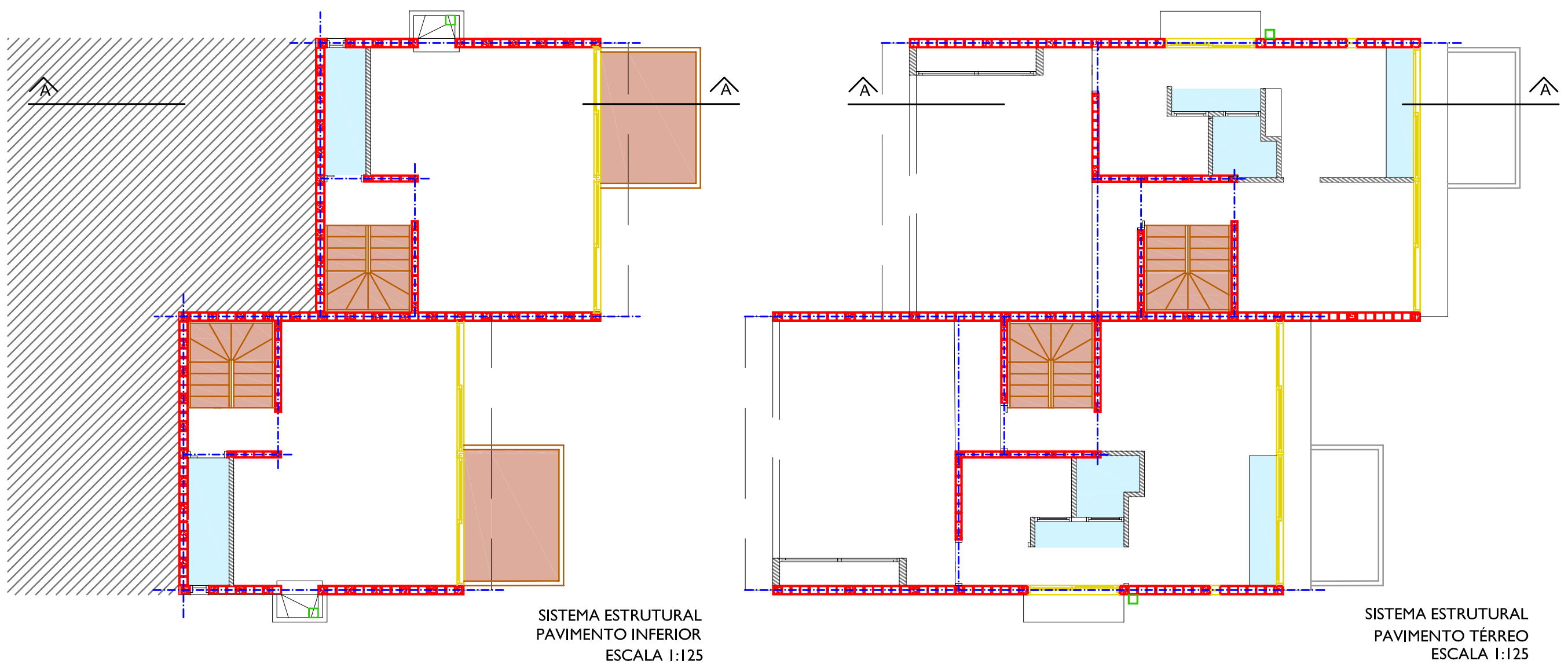

ESCALA |: 125

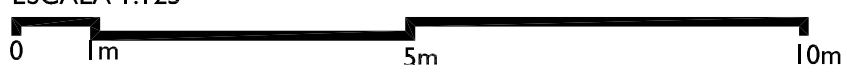



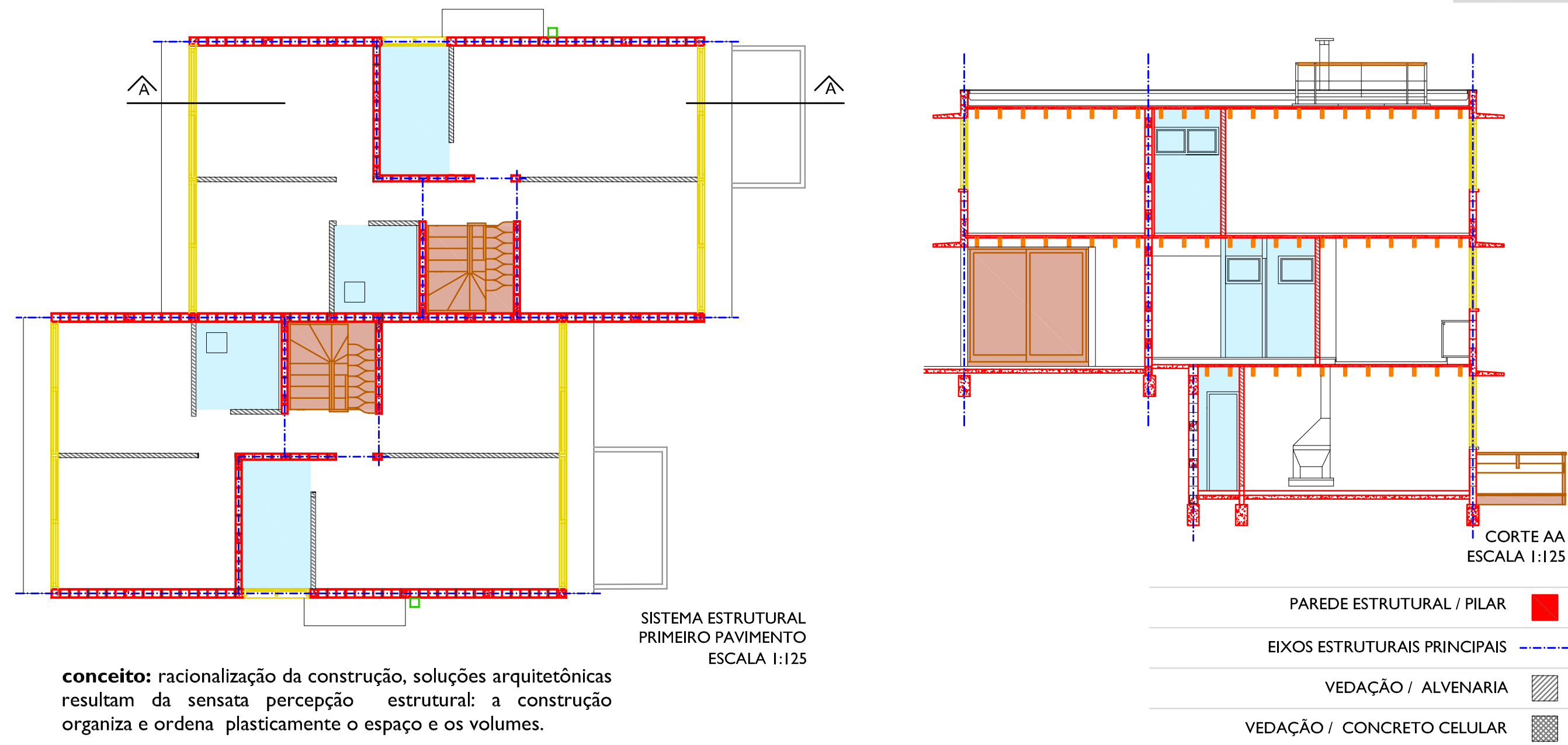

PAREDE ESTRUTURAL / PILAR

EIXOS ESTRUTURAIS PRINCIPAIS -.....-

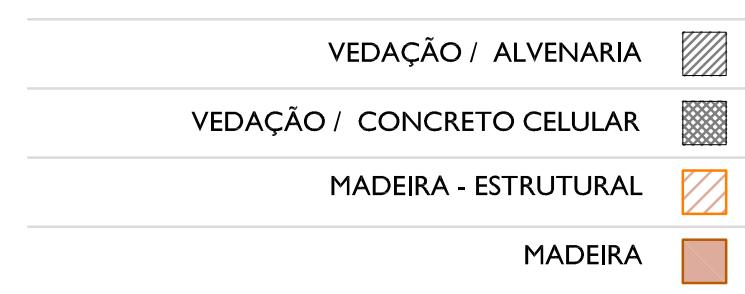

ÁREA MOLHADA

DUTOS / ISTALACC̃̃ES EXTERNAS ÀS PAREDES

VARANDAS / SALIÊNCIAS

CAIXILHO ENVOLTÓRIA 


\section{SISTEMA ESTRUTURAL E TÉCNICA CONSTRUTIVA}
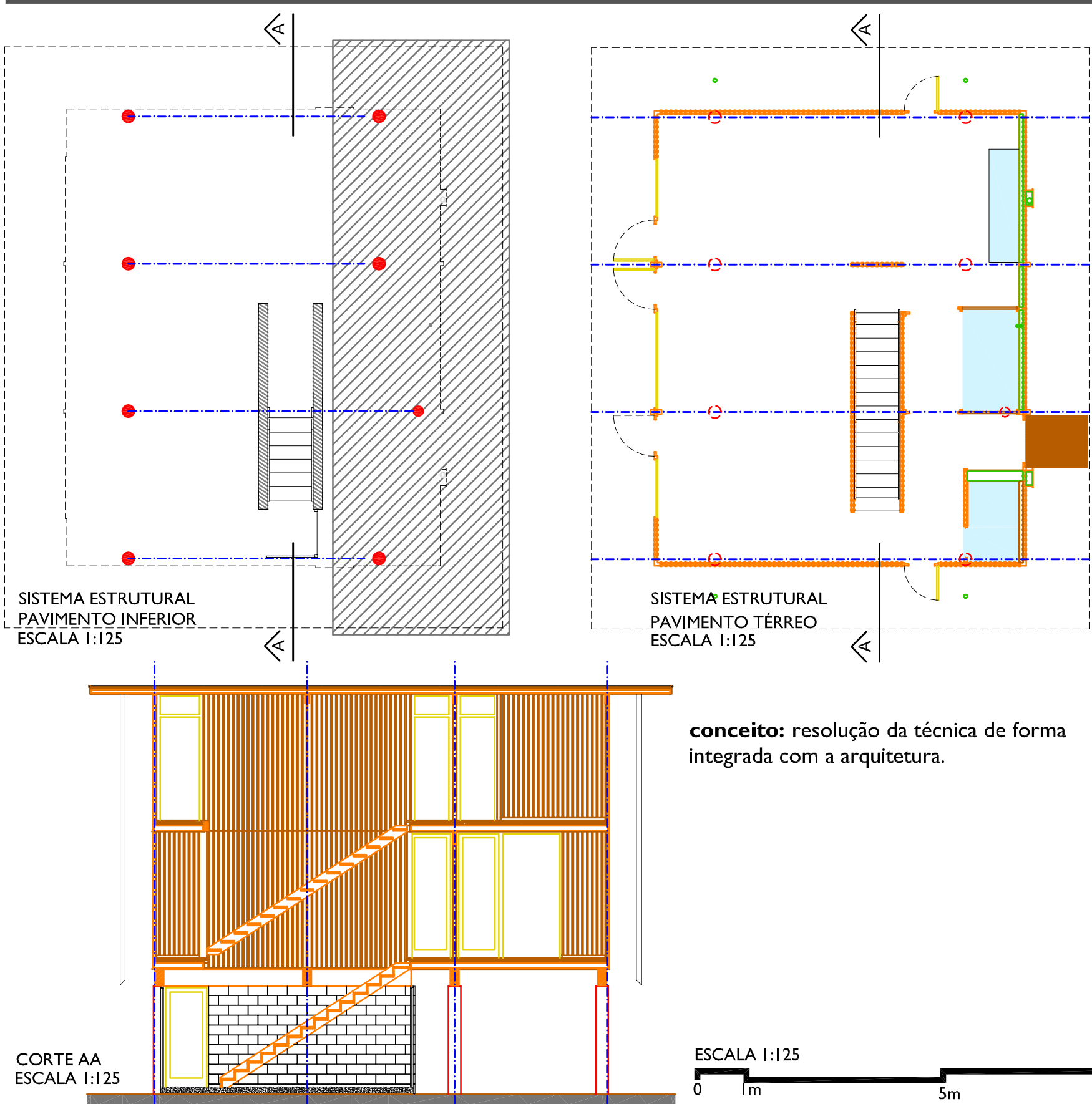

conceito: resolução da técnica de forma integrada com a arquitetura.

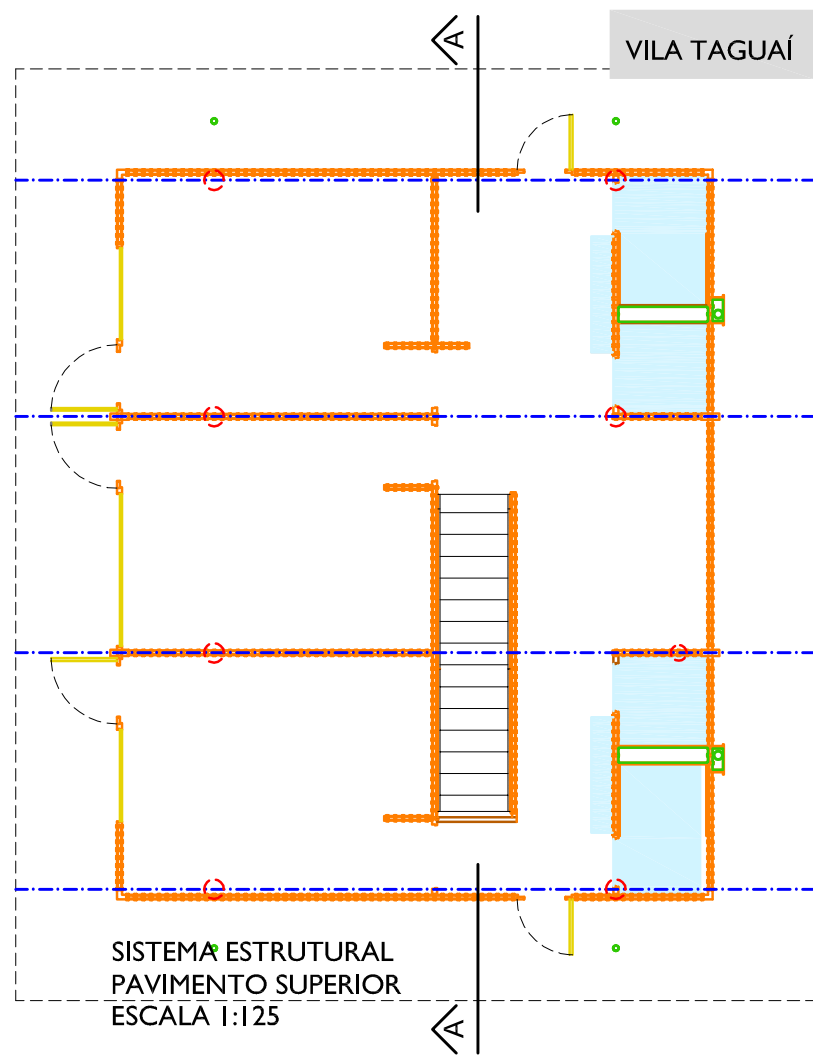

PAREDE ESTRUTURAL / PILAR

EIXOS ESTRUTURAIS PRINCIPAIS -...-.-

VEDAÇÃO / ALVENARIA

VEDAÇÃO / CONCRETO CELULAR

MADEIRA - ESTRUTURAL

MADEIRA

ÁREA MOLHADA

VARANDAS / SALIÊNCIAS

CAIXILHO ENVOLTÓRIA 

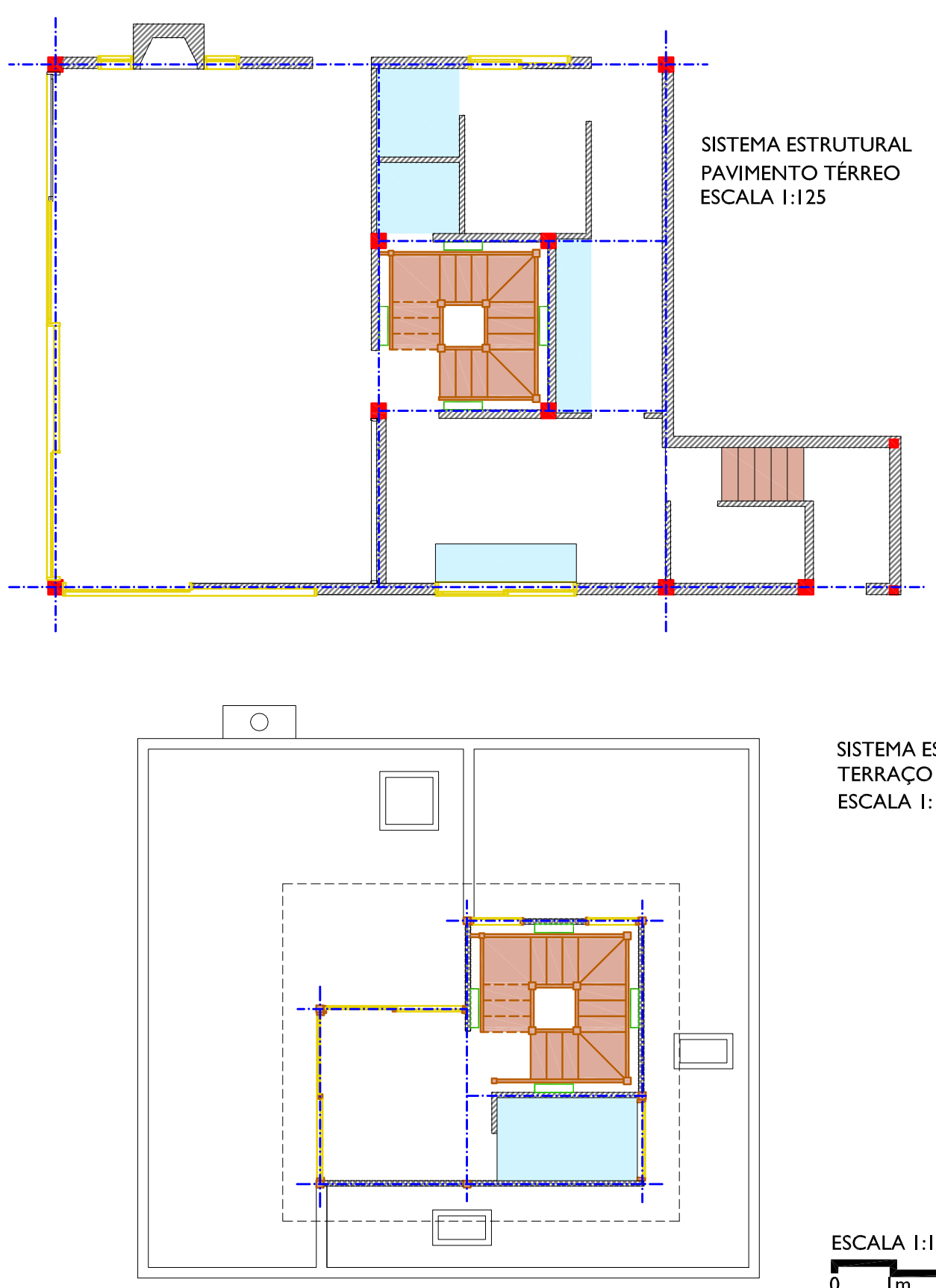

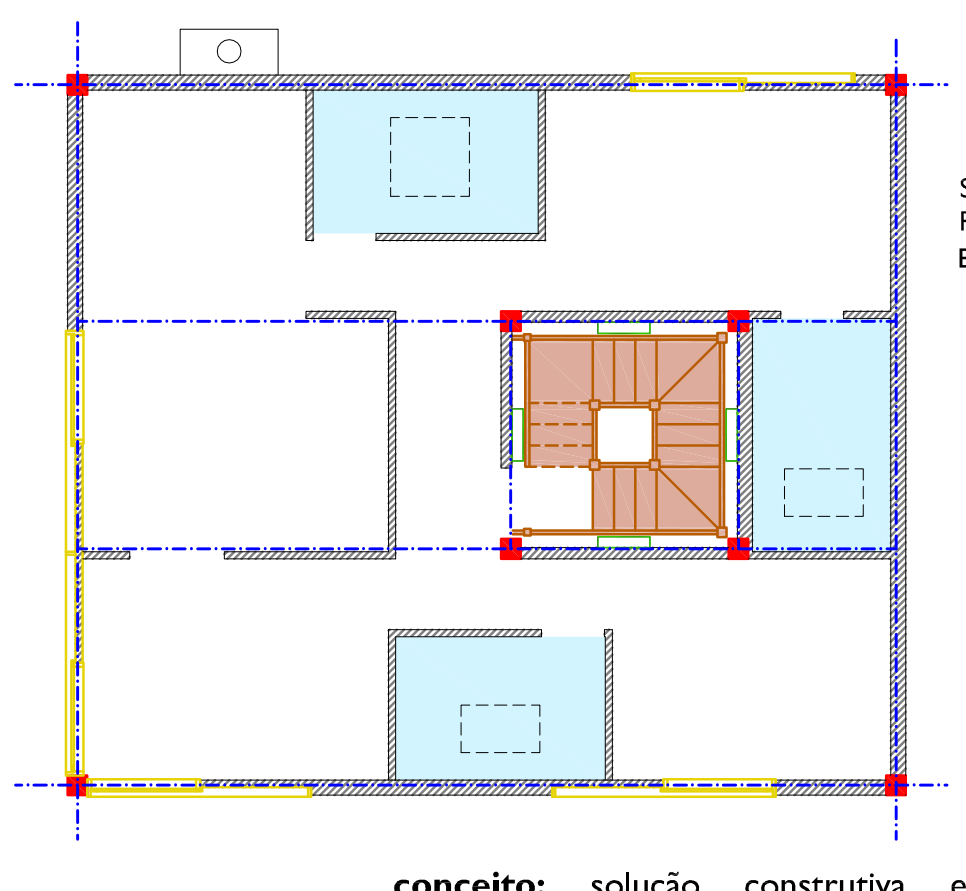

conceito: solução construtiva conceito estrutural único, porém, sem
SISTEMA ESTRUTURAL

TERRAÇO

ESCALA I:125
SISTEMA ESTRUTURAL PRIMEIRO PAVIMENTO ESCALA I:125

PAREDE ESTRUTURAL / PILAR

EIXOS ESTRUTURAIS PRINCIPAIS

VEDAÇÃO / ALVENARIA

VEDAÇÃO / CONCRETO CELULAR

MADEIRA - ESTRUTURAL

MADEIRA

ÁREA MOLHADA

DUTOS / ISTALAÇÕES EXTERNAS ÀS PAREDES 
FIDALGA 772

AIMBERÊ

\section{UNIDADES}

HABITACIONAIS

SOBREPOSTAS, EDIFÍCIO

MODERADAMENTE

VERTICALIZADO

(9 PAVIMENTOS +

COROAMENTO)
SIMPATIA 234

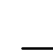

\begin{tabular}{|c|c|}
\hline \multirow[t]{2}{*}{ FIORI DI MAGGIO } & $\begin{array}{l}\text { UNIDADES } \\
\text { HABITACIONAIS }\end{array}$ \\
\hline & $\begin{array}{l}\text { SOBREPOSTAS, EDIFÍCIO } \\
\text { POUCO VERTICALIZADO } \\
\text { (3 A } 5 \text { PAVIMENTOS + }\end{array}$ \\
\hline
\end{tabular}

CANAÃ

\section{HORIZONTAIS \\ (UNIDADES \\ HABITACIONAIS NÃO \\ SOBREPOSTAS)}

VILA BUTANTÃ

VILA FIDALGA
DISPOSIÇÃO PILARES VERSUS VIGAS / ELEMENTOS ESTRUTURAIS

PILARES NO INTERIOR DA PLANTA, SEPARADOS DO PERÍMETRO ONDE

FICAM AS VIGAS E ENVOLTÓRIA = ENVOLTÓRIA + VIGAS LIVRES.

MAIORIA DOS PILARES NO PERÍMETRO DA EDIFICAÇÃO = PLANTA LIVRE

PILARES E VIGAS NO MESMO PLANO DO PERÍMETRO DA EDIFICAÇÃO =

SUPERPOSIÇ̃̃O DE PILARES, VIGAS E ENVOLTÓRIA

MAIORIA DOS PILARES NO PERÍMETRO DA EDIFICAÇÃO = PLANTA LIVRE

NAS FACES LATERAIS, PILARES E VIGAS NO MESMO PLANO DO PERÍMETRO DA EDIFICAÇÃO = SUPERPOSIÇÃO DE PILARES, VIGAS E ENVOLTÓRIA; NAS FACES FRONTAIS ÀS RUAS, OS PILARES FICAM SOLTOS EXTERNAMENTES = ENVOLTÓRIA + VIGA LIVRES. MAIORIA DOS PILARES NO PERÍMETRO DA EDIFICAÇÃO = PLANTA LIVRE

BLOCO POSTERIOR: PILARES SALIENTES PARA O EXTERIOR DA PLANTA, FUNDIDOS

PARCIALMENTE COM VIGAS E ENVOLTÓRIA , = PILARES DEFINEM ENVOLTÓRIA. BLOCO

FRONTAL: PILARES NAS ESTREMIDADES, ENVOLTÓRIA + VIGA LIVRES. GRANDE PARTE DOS

PILARES NO PERÍMETRO DA EDIFICAÇÃO = PLANTA COM ESPAÇOS CONSIDERAVÉIS LIVRES

SISTEMA DEFINIDO POR PAREDES ESTRUTURAIS. DEFINIÇÃO DE DOIS EIXOS LOGITUDINIS COM VÃO PARA APOIO DAS LAJES PRÉFABRICADAS E ESTRUTURAÇÃO DOS VAZIOS AO MESMO TEMPO. PAREDES ESTRUTURAIS NÃO FICAM LIMITADAS AO PERÍMETRO, DELIMITAM QUASE TODOS OS CÔMODOS.

SISTEMA DEFINIDO POR PAINÉIS PRÉ-FABRICADOS CERÂMICOS

ESTRUTURAIS. PAREDES ESTRUTURAIS DELIMITAM TODOS OS CÔMODOS.

SISTEMA DEFINIDO POR PAREDES ESTRUTURAIS. DEFINIÇÃO DE TRÊS EIXOS PRINCIPAIS (A CADA DUPLA DE CASAS GEMINADAS) QUE TRAVAM A ESTRUTURA E LIBERAM AS FACES
(ATISTINA PRINCIPAIS DA ESTRUTURA PARA ABERTURAS MAIS GENEROSAS. PAREDES ESTRUTURAIS MAIS LIMITADAS ÀS FACES LATERAIS- INTERIOR COM PLANTA MAIS FLEXÍVEL

PILARES E VIGAS NO MESMO PLANO DO PERÍMETRO DA EDIFICAÇÃO = SUPERPOSIÇÃO DE PILARES, VIGAS E ENVOLTÓRIA

PILARES NO PERÍMETRO DA EDIFICAÇÃO + NO PERÍMETRO DA CAIXA DE ESCADA

SISTEMA DEFINIDO POR PAINÉIS ESTRUTURAIS DE MADEIRA JATOBÁ. EMPENAS LATERAIS TRAVAM A ESTRUTURA E LIBERAM AS FACES COM VISUAIS MAIS INTERESSANTES. DEFINIÇÃO DE EIXOS TRANVERSAIS DE 3 EM3 METROS.
PLANOS ESTRUTURAIS

NÃO ORTOGONAIS

FENDAS NÃO ORTOGONAIS =

QUEBRA DOS PLANOS

ORTOGONAIS

\section{NÃO ORTOGONAIS}

(SEGUINDO CONTORNOS DO LOTE)

DOIS SISTEMAS ORTOGONAIS

INTERLIGADOS

ORTOGONAIS

ORTOGONAIS

ORTOGONAIS

\section{ORTOGONAIS}

ORTOGONAIS 


\begin{tabular}{|c|c|c|c|c|}
\hline INSTALAÇOES & ÁREAS MOLHADAS & SALIÊNCIAS & QUANTO À EXECUÇÃO / MONTAGEM & SUPERESTRUTURA \\
\hline $\begin{array}{l}\text { DUTOS JUNTOS AOS PILARES, PORÉM, EXTERNAMENTE } \\
\text { A ELES = DUTOS SE SOMAM AOS PILARES }\end{array}$ & INDEFINIDAS & $\begin{array}{l}\text { VARANDAS DENTRO DO } \\
\text { LIMITE ESTRUTURAL = } \\
\text { AUSÊNCIA DE SALIÊNCIAS }\end{array}$ & $\begin{array}{l}\text { SUPERESTRUTURA MOLDADA IN LOCO E } \\
\text { FECHAMENTOS EXTERNOS PRÉFABRICADOS E } \\
\text { COM INSTALAÇÃO À SECO = MISTO }\end{array}$ & CONCRETO ARMADO \\
\hline $\begin{array}{l}\text { DUTOS JUNTOS AOS PILARES, PORÉM, } \\
\text { EXTERNAMENTE } \\
\text { A ELES = DUTOS SE SOMAM AOS PILARES; E } \\
\text { INSTALAÇÕES APARENTES NA FACHADA }\end{array}$ & INDEFINIDAS & $\begin{array}{l}\text { VARANDAS DENTRO DO } \\
\text { LIMITE ESTRUTURAL = } \\
\text { AUSÊNCIA DE SALIÊNCIAS }\end{array}$ & $\begin{array}{l}\text { SUPERESTRUTURA MOLDADA IN LOCO } \\
\text { FUNDIDOS COM ALVENARIAS EXTERNAS } \\
\text { (MASSEADOS E PINTADOS } \\
\text { CONVENCIONALMENTE) }\end{array}$ & $\begin{array}{l}\text { CONCRETO ARMADO COM } \\
\text { LAJES TIPO "CUBETAS" }\end{array}$ \\
\hline $\begin{array}{l}\text { ASÊNCIA DE DUTOS = INSTALAÇÕES APARENTES } \\
\text { NA FACHADA }\end{array}$ & INDEFINIDAS & $\begin{array}{l}\text { VARANDAS FORA DO LIMITE } \\
\text { ESTRUTURAL = PRESENÇA } \\
\text { DE SALIÊNCIAS }\end{array}$ & $\begin{array}{l}\text { SUPERESTRUTURA MOLDADA IN LOCO } \\
\text { FUNDIDOS COM OS FECHAMENTOS } \\
\text { EXTERNOS LATERAIS }\end{array}$ & CONCRETO ARMADO \\
\hline $\begin{array}{l}\text { DUTOS JUNTOS ÀS ALVENARIAS DE VEDAÇÃO } \\
\text { PORÉM, EXTERNAMENTE A ELAS = DUTOS NO } \\
\text { MIOLO DA PLANTA }\end{array}$ & $\begin{array}{l}\text { NÚCLEOS } \\
\text { DIVERSOS E NÃO } \\
\text { CONCENTRADOS }\end{array}$ & $\begin{array}{l}\text { PASSARELA QUE INTERLIGA OS } \\
\text { DOIS SISTEMAS ESTRUTURAIS } \\
\text { PODE REPRESENTAR UMA } \\
\text { SALIÊNCIA }\end{array}$ & $\begin{array}{l}\text { SUPERESTRUTURA MOLDADA IN LOCO } \\
\text { FUNDIDOS COM ALVENARIAS EXTERNAS }\end{array}$ & $\begin{array}{l}\text { CONCRETO ARMADO COM } \\
\text { LAJES PRÉ-FABRICADA TIPO } \\
\text { "PAINEL TRELIÇADA" }\end{array}$ \\
\hline $\begin{array}{l}\text { AUSÊNCIA DE DUTOS: INSTALAÇÕES DENTRO } \\
\text { DAS ALVENARIAS DURANTE A OBRA }\end{array}$ & $\begin{array}{l}\text { NÚCLEOS } \\
\text { CONCENTRADOS } \\
\text { PARCIALMENTE }\end{array}$ & $\begin{array}{l}\text { SALIÊNCIAS: ESCADAS, } \\
\text { VARANDAS E BRISES. }\end{array}$ & $\begin{array}{l}\text { TÉCNICA CONST. DISPENSA MONTAGEM } \\
\text { DE FORMAS E CONCRETAGEM. LAJE } \\
\text { PRÉ-FABRICADA TORNA O PROCESSO DE } \\
\text { EXECUÇÃO AINDA MAIS RÁPIDO. }\end{array}$ & $\begin{array}{l}\text { ALVENARIA ESTRUTURAL } \\
\text { ARMADA DE BLOCO DE } \\
\text { CONCRETO E LAJE } \\
\text { PRÉFABRICADA COMUM. }\end{array}$ \\
\hline $\begin{array}{l}\text { DUTOS PARA ESGOTOS; OUTRAS INSTALAÇÕES } \\
\text { HIDRÁULICAS E ELÉTRICAS SÃO INCORPORADOS } \\
\text { AOS PAINÉIS NO MOMENTO DE SUA EXECUÇÃO E } \\
\text { NÃO DURANTE A OBRA. }\end{array}$ & $\begin{array}{l}\text { NÚCLEO } \\
\text { CONCENTRADO }\end{array}$ & $\begin{array}{l}\text { SALIÊNCIAS: ESCADA } \\
\text { EXTERNA DE ACESSO AO } \\
\text { TERRAÇO. }\end{array}$ & $\begin{array}{l}\text { PRÉFABRICAÇÃO DOS PAINÉIS CPC NO } \\
\text { PRÓPRIO CANTEIRO DE OBRAS }\end{array}$ & $\begin{array}{l}\text { PAINÉIS PRÉFABRICADOS } \\
\text { CERÂMICOS PARA TODOS OS } \\
\text { COMPONENTES: PAREDES E } \\
\text { LAJE. FUNDAÇÃO TIPO RADIER. }\end{array}$ \\
\hline $\begin{array}{l}\text { ASÊNCIA DE DUTOS = PRUMADA DE ESGOTO } \\
\text { APARENTE NA FACHADA / INSTALAÇÕES DE } \\
\text { FÁCIL ACESSO. PISO ELEVADO. }\end{array}$ & $\begin{array}{l}\text { NÚCLEOS } \\
\text { CONCENTRADOS } \\
\text { PARCIALMENTE }\end{array}$ & $\begin{array}{l}\text { SALIÊNCIAS: BALCÃO } \\
\text { EM MADEIRA }\end{array}$ & $\begin{array}{l}\text { EMPENAS DE ALVENARIA ARMADA } \\
\text { DISPENSA MONTAGEM DE FORMAS E } \\
\text { CONCRETAGEM. LAJE FOI MOLDADA IN LOCO, } \\
\text { FUNDIDAS, SEM CIMBRAMENTO, APOIADAS NAS } \\
\text { EMPENAS DE ALVENARIA ARMADA, }\end{array}$ & $\begin{array}{l}\text { ALVENARIA ESTRUTURAL } \\
\text { ARMADA DE BLOCO DE } \\
\text { CONCRETO PIGMENTADO E } \\
\text { LAJE NERVURADA MISTA DE } \\
\text { CONCRETO E MADEIRA. } \\
\end{array}$ \\
\hline $\begin{array}{l}\text { QUATRO SHAFTS NO PERÍMETRO DA CAIXA DE } \\
\text { ESCADA PARA TODAS AS INSTALAÇÕES; DE } \\
\text { FÁCIL ACESSO }\end{array}$ & $\begin{array}{l}\text { NÚCLEOS } \\
\text { CONCENTRADOS } \\
\text { PARCIALMENTE, } \\
\text { PRÓXIMOS AOS } \\
\text { SHAFTS } \\
\end{array}$ & $\begin{array}{l}\text { AUSÊNCIA DE } \\
\text { SALIÊNCIAS }\end{array}$ & $\begin{array}{l}\text { SUPERESTRUTURA MOLDADA IN LOCO } \\
\text { FUNDIDOS COM ALVENARIAS EXTERNAS } \\
\text { (FULGET NAS PAREDES EXTERNAS) }\end{array}$ & CONCRETO ARMADO \\
\hline $\begin{array}{l}\text { SHAFTS EXTERNOS AOS PAINÉIS E OUTROS JUNTO ÀS } \\
\text { ÁREAS MOLHADAS. PARA O CASO ESPECÍFICO DAS INST. } \\
\text { ELÉTRICAS, NO SENTIDO HORIZONTAL PASSAM POR UMA } \\
\text { CAMADA DE } 5 M \text { DE CONCRETO MAGRO SOBRE A LAJE. }\end{array}$ & $\begin{array}{l}\text { NÚCLEO } \\
\text { CONCENTRADO }\end{array}$ & $\begin{array}{l}\text { AUSÊNCIA DE } \\
\text { SALIÊNCIAS }\end{array}$ & $\begin{array}{l}\text { PRÉFABRICAÇÃO DOS PAINÉIS DE MADEIRA } \\
\text { FORA DO CANTEIRO DE OBRAS }\end{array}$ & $\begin{array}{l}\text { PAINÉIS DE MADEIRA PARA } \\
\text { TODOS OS COMPONENTES: } \\
\text { PAREDES E LAJES. PILARES NA } \\
\text { BASE, EM CONCRETO ARMADO } \\
\text { MOLDADO IN LOCO. }\end{array}$ \\
\hline
\end{tabular}




\begin{tabular}{|c|c|c|c|}
\hline & ENVOLTÓRIA & VEDAÇÕES INTERNAS & DETALHES \\
\hline FIDALGA 772 & $\begin{array}{l}\text { ALVENARIA + PAINÉIS HIGH DENSITY FIBERBOARD (HDF) } \\
\text { LAMINADOS PADRÃO MADEIRA DE VÁRIAS CORES E VIDRO } \\
\text { ESTRUTURADOS POR PERFIS METÁLICOS COR CINZA. }\end{array}$ & $\begin{array}{l}\text { QUASE INEXISTENTES: ALVENARIA } \\
\text { APENAS PARA SEPARAÇÃO DAS UNIDADES } \\
\text { HABITACIONAIS. }\end{array}$ & $\begin{array}{l}\text { METÁLICO, COR CINZA: PERGOLADOS, } \\
\text { GUARDA-CORPO (COM DETALHE DO } \\
\text { CORRIMÃO EM MADEIRA), }\end{array}$ \\
\hline AIMBERÊ & $\begin{array}{l}\text { ALVENARIA + VIDRO ESTRUTURADO POR PERFIS METÁLICOS } \\
\text { COR CINZA. OBS.: FACES EXTERNAS DO MONOBLOCO } \\
\text { RUGOSAS E NAS FENDAS, LISAS E MAIS BRANCAS (COM } \\
\text { EXCEÇÃO DA FENDA DA ENTRADA, EM MADEIRA) }\end{array}$ & $\begin{array}{l}\text { QUASE INEXISTENTES: ALVENARIA } \\
\text { APENAS PARA SEPARAÇÃO DAS UNIDADES } \\
\text { HABITACIONAIS. }\end{array}$ & $\begin{array}{l}\text { LAMELAS VERTICAIS BRANCAS NA FACE } \\
\text { SUDOESTE QUE ACOMPANHAM AS } \\
\text { TUBULAÇÕES }\end{array}$ \\
\hline SIMPATIA 234 & $\begin{array}{l}\text { ALVENARIA + VIDRO ESTRUTURADO POR PERFIS METÁLICOS } \\
\text { CORVERMELHO. OBS.: FACES FRONTAIS ÀS RUAS, NÃO POSSUEM } \\
\text { ALVENARIA PARA VEDAÇÃO, CAIXILHARIA COM VIDRO EM } \\
\text { TODO VÃO ESTRUTURAL. }\end{array}$ & $\begin{array}{l}\text { QUASE INEXISTENTES: ALVENARIA } \\
\text { APENAS PARA SEPARAÇÃO DAS UNIDADES } \\
\text { HABITACIONAIS. }\end{array}$ & $\begin{array}{l}\text { MADEIRA: BRISES NA FACE VOLTADA À RUA } \\
\text { SIMPATIA; METÁLICO, COR VERMELHA: } \\
\text { GUARDACORPOS, GRADIS, ETC.; CERÂMICA: } \\
\text { FACES LATERAIS; PAINEL ARTÍSTICO. }\end{array}$ \\
\hline FIORI DI MAGGIO & $\begin{array}{l}\text { BLOCO FRONTAL: VIDRO ESTRUTURADO POR PERFIS } \\
\text { METÁLICOS COR PRETA. BLOCO POSTERIOR: ALVENARIA } \\
\text { REVESTIDA COM TIJOLOS DE BARRO + VIDRO COM } \\
\text { CAIXILHARIA COR PRETA }\end{array}$ & $\begin{array}{l}\text { EXISTENTES: ALVENARIA NA DIVISÃO } \\
\text { DOS CÔMODOS }\end{array}$ & $\begin{array}{l}\text { METÁLICO, COR PRETO: GUARDACORPOS, } \\
\text { GRADIS, ETC; }\end{array}$ \\
\hline VILA PEDRO FACHINI & $\begin{array}{l}\text { PRÓPRIA ALVENARIA ESTRUTURAL, REVESTIDO COM PINTURA } \\
\text { GRANULADA NA COR VERMELHA E AMARELA + ABERTURAS: } \\
\text { CAIXILHARIA + VENEZIANAS + VIDRO. TAMBÉM PORTAS DE } \\
\text { MADEIRA NA ENVOLTÓRIA. }\end{array}$ & $\begin{array}{l}\text { EXISTENTES: ALVENARIA ESTRUTURAL NA } \\
\text { DIVISÃO DA MAIORIA DOS CÔMODOS. PARA } \\
\text { OS LOCAIS QUE DISPENSAM ESTRUTURAM } \\
\text { VEDAÇÃO COM BLOC DE } 9 \mathrm{~cm} \text { DE ESPESSURA. }\end{array}$ & $\begin{array}{l}\text { METÁLICO, COR BRANCA: ESCADAS, } \\
\text { GUARDA CORPOS, GRADIS, ETC. }\end{array}$ \\
\hline CANÃ̃ & $\begin{array}{l}\text { PRÓPRIOS PAINÉIS CERÂMICOS, PINTADAS EXTERNAMENTES } \\
\text { COM CORES VIVAS (VERDE, AZUL E AMARELO) + ABERTURAS: } \\
\text { CAIXILHARIA MADEIRA + + VIDRO. }\end{array}$ & $\begin{array}{l}\text { EXISTENTES: OS PRÓPRIOS PAINÉIS } \\
\text { ESTRUTURAIS CERÂMICOS, PORÉM, COM } \\
\text { REVESTIMENTO. }\end{array}$ & $\begin{array}{l}\text { METÁLICO, COR BRANCA: ESCADAS, } \\
\text { GUARDA CORPOS, GRADIS, ETC. }\end{array}$ \\
\hline VILA BUTANTÃ & $\begin{array}{l}\text { PRÓPRIOS EMPENAS PIGMENTADAS, + ABERTURAS: } \\
\text { CAIXILHARIA DE MADEIRA COM VENEZIANA + VIDRO + FAIXA } \\
\text { LARANJA DE ALVENARIA. }\end{array}$ & $\begin{array}{l}\text { PAREDES ESTRUTURAIS, SÃO QUASE } \\
\text { INEXISTENTES: PERMITE UM POUCO DE } \\
\text { FLEXIBILIDADE AO INTERIOR. }\end{array}$ & $\begin{array}{l}\text { MADEIRA: ESCADAS, BALCÃO, CERCA DE } \\
\text { DIVISÃO DO ESPAÇO EXTERIOR PRÓPRIO E } \\
\text { COLETIVO, GUARDA CORPOS, ETC. }\end{array}$ \\
\hline VILA FIDALGA & $\begin{array}{l}\text { PRÓPRIOS EMPENAS COM FULGET BRANCO+ ABERTURAS: } \\
\text { CAIXILHARIA DE MADEIRA COM VENEZIANAS + VIDRO }\end{array}$ & $\begin{array}{l}\text { EXISTENTES: ALVENARIA NA DIVISÃO } \\
\text { DOS CÔMODOS }\end{array}$ & $\begin{array}{l}\text { MADEIRA: ESCADAS, CERCA DE DIVISÃO DO } \\
\text { ESPAÇO EXTERIOR PRÓPRIO E COLETIVO, } \\
\text { GUARDA CORPOS +PEQUENAS CONSTRUÇÕES } \\
\text { SOBRE O TERRAÇO (FECHAMENTO EM } \\
\text { CONCRETO CELULAR) }\end{array}$ \\
\hline VILA TAGUAÍ & $\begin{array}{l}\text { PRÓPRIOS EMPENAS EM MADEIRA + ABERTURAS: VIDRO } \\
\text { ESTRUTURADO POR CAIXIKHARIA DE MADEIRA }\end{array}$ & $\begin{array}{l}\text { EXISTENTES: OS PRÓPRIOS PAINÉIS } \\
\text { ESTRUTURAIS E PARA AS ÁREAS } \\
\text { MOLHADAS MDF COM LAMINAÇÃO. }\end{array}$ & TODOS OS DETALHES EM MADEIRA \\
\hline
\end{tabular}




\subsection{I.2 DESENHO DO SISTEMA ESTRUTURAL}

\subsection{I.2.I DISPOSIÇÃO DOS PILARES VERSUS VIGAS, PAREDES ESTRUTURAIS, ENVOLTÓRIA INSTALAÇÕES E ÁREAS MOLHADAS}

Para o caso dos projetos que contam com estrutura formada por pilares, vigas e lajes, foi analisado o grau de incidência da posição destes elementos estruturais em corte, e quais consequências às diversas situações podem criar na fachada. Nos projetos, apareceram algumas situações:

I. Pilares no interior da planta, separados do plano onde ficam as vigas e envoltória. Neste caso é importante notar que as vigas acompanham a envoltória, não se trata de um pano de fechamento puro de laje a laje (exemplo, Fidalga 772);

2. Pilares no exterior da planta, separados do plano onde ficam as vigas e envoltória. Novamente, neste caso é importante notar que as vigas acompanham a envoltória, não se trata de um pano de fechamento puro de laje a laje;(exemplo, face voltada para a Rua Simpatia, do edifício Simpatia 234);

3. Pilares e vigas no mesmo plano do perímetro da edificação, resultando na superposição de pilares, vigas e envoltória, esta última preenche os espaços vazios entre a estrutura (exemplo,Aimberê);

4. Pilares salientes para o exterior da planta, porém, não deslocados das vigas de borda, fundidos parcialmente com as vigas e envoltória. Neste sentido, o ritmo dos pilares baliza a solução da envoltória (exemplo, edifício posterior Fiori di Maggio);

5. Pilares nas extremidades do plano estrutural, resultando numa fachada limpa, com apenas um pilar em cada extremidade, e no plano de fechamento, vigas e envoltória (exemplo,Vila Fidalga);

6. Situação mista num mesmo sistema estrutural, mesclando as situações 2 e 3 (exemplo, Simpatia 234); ou mesclando as situações 4 e 5 (exemplo, Fiori di Maggio) descritas acima. 
No artigo de Pablo Güiraldes, sobre a obra do arquiteto Mario Roberto Álvares, no qual são analisadas algumas obras de suas torres residenciais em Buenos Aires, são definidas algumas configurações básicas a partir da análise do sistema estrutural dos projetos, referência para as situações encontradas nos estudos de casos em análise nesta pesquisa.

\begin{abstract}
Dentro do paradigma moderno de estrutura independente e fachada livre, e depois de muitos ensaios realizados pelos mestres e os seus sucessores em diferentes países antes e depois da Segunda Guerra Mundial, podem-se definir as seguintes configurações básicas: I. Colunas separadas do perímetro localizadas no interior da planta, que liberam a área envoltória e permitem diferentes soluções de fachada livre. 2. Colunas e vigas localizadas em um mesmo plano do perímetro, e que se superpõem e intercalam com a área envoltória. Esta adquire o caráter de "painel de recheio". 3. Colunas soltas exteriores, suportando um volume puro, com a malha da fachada localizada por trás. Neste caso, a superfície de fechamento pode ser tratada como alguma variante das anteriores, às vezes como curtain wall, outras como sistemas mistos de aberturas e panos cegos. (GÜIRALDES, 20I I, p.22) .
\end{abstract}

Nos casos de edifícios de vários andares em terrenos pequenos sempre existem dificuldades em estabelecer as áreas para vagas e veículos e sua circulação nas garagens.

Há fortes relações entre o posicionamento dos pilares nestas áreas que implicam a estrutura do prédio e dos pavimentos como um todo. Isto pode ser observado nos desenhos referentes aos projetos Fidalga 772, Aimberê e Simpatia 234, onde foram sobrepostas estrutura e demarcação das vagas, comprovando a situação descrita.

Para o caso dos projetos que contam com soluções de paredes estruturais, por exemplo; de alvenaria estrutural armada, painel pré-fabricado cerâmico ou painel estrutural de madeira; a questão de liberar ou não fachada a partir do desenho da estrutura é também possível, a partir da criação de empenas estruturais que travam a estrutura num sentido e liberam ao menos uma face, como acontece na Vila Butantã ou Vila Taguaí, onde na última, utilizou-se caixilharia com vidro de piso a teto. Todos os projetos que contaram com soluções de paredes ou painéis estruturais 
utilizaram lajes, em sua maioria pré-fabricadas, que dispensam formas e cimbramentos, por isso também, a existência de planos ortogonais formando a estrutura.

Outra análise que pode ser realizada é sobre a questão da relação do sistema estrutural e a liberação de espaço livre na planta, ou seja, a flexibilidade interior do plano estrutural.

Para isso, não basta apenas olharmos para a posição dos pilares, é preciso observar também a posição das instalações e também das áreas molhadas. Por exemplo, no edifício Fiori di Maggio grande parte dos pilares estão posicionados no perímetro da edificação, por outro lado, existem shafts no miolo da planta, e as áreas molhadas são pouco concentradas, impedindo assim, grandes transformações futuras nos cômodos predefinidos no projeto. Os projetos realizados pela Idea!Zarvos são todos com planta livre, instalações no perímetro e ausência de área molhada. Isto é, muito flexível para o primeiro morador, e com grandes possibilidades de reformas futuras.

Para o caso dos sistemas com paredes estruturais, a flexibilidade do interior da planta pode ocorrer também, com o mesmo raciocínio, de posicionar os eixos estruturais o máximo possível na periferia, tentar concentrar áreas molhadas e posicionar instalações também no perímetro da edificação, o que inclusive facilita sua manutenção e atualização.

El objetivo es definir sistemas constructivos que no se conviertan en obstáculos para las transformaciones. Estos sistemas, concebidos de forma abierta y flexible, pueden traducirse en dispositivos técnicos que, por ejemplo, habiliten la possibilidad de crescimiento de superfícies, la modificación interna de los espacios o la actualización fácil de las instalaciones. (MONTANER; MUXí, 2006, p. 48)

\subsection{PLANOS ESTRUTURAIS}

Analisaram-se a ortogonalidade ou não dos planos estruturais. Foram identificadas três situações: 
I. Planos ortogonais, principalmente nos casos onde a edificação é mais autônoma com relação ao contorno do lote urbano e também para as soluções com componentes pré-fabricados ou de alvenaria estrutural, que exigem uma modulação mais rígida do sistema estrutural, também para acomodar as lajes pré-fabricadas;

2. Planos ortogonais, com fendas que quebram um pouco a ortogonalidade, situação encontrada no Aimberê. Neste projeto é utilizada a laje tipo "cubeta", maiores "perturbações" nos planos ortogonais inviabilizariam a utilização deste tipo de laje;

3. Planos não ortogonais: em situações onde a edificação acompanha o contorno do lote urbano ou para o caso de outra necessidade, como no Fidalga 772, o qual uma face foi inclinada levemente para ampliar visuais. Para estes casos, utilizou-se laje maciça.

\subsection{I.2.3 SALIÊNCIAS}

As saliências são elementos que surgem fora do polígono definido como sistema estrutural. Para o caso dos projetos analisados, surgiram situações interessantes. Por exemplo, nos dois projetos expostos do Andrade Morettin, foi optado por posicionar varandas dentro do plano estrutural, isto pode estar relacionado ao lote urbano exíguo, ou simplesmente por uma questão de linguagem arquitetônica dos arquitetos. Por exemplo, em outros projetos de sua autoria, como o Edifício de escritórios na Rua Wizard, Edifício residencial na rua Marcos Lopes ou no próprio edifício de Habitação social o qual venceram o " $22^{\circ}$ Concurso Internacional Living Steel para Habitação Sustentável”, não existem saliências, e por mais que existam varandas, elas não são destacadas do plano estrutural definido, são delimitadas por um polígono (Figuras 01, 02 e 03).

Nos projetos de situação de paredes estruturais surgiram situações interessantes, de mescla de materais: saliências em madeira para o caso da Vila Butantã e saliências metálicas, para o caso da Vila Pedro Fachini. Isto pode estar relacionado ao fato do tipo de estrutura não

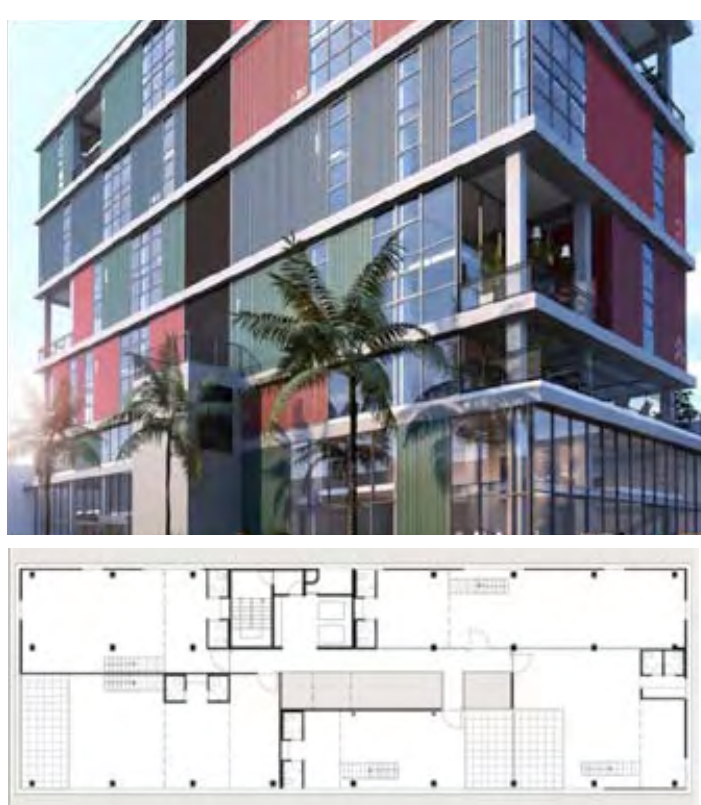

Figura I - Edifício de escritórios na Rua Wizard,Vila Madalena, Andrade Morettin Arquitetos Associados e Idea!Zarvos. Imagem ilustrativa do projeto e planta de um dos pavimentos.

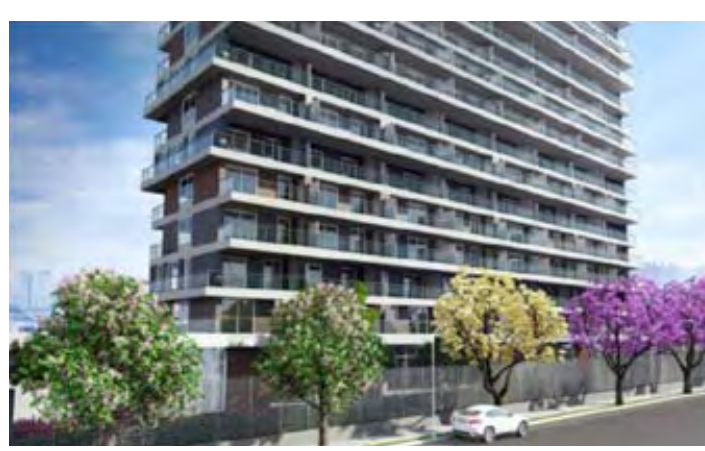

Figura 2 - Edifício Edifício residencial na Rua Marcos Lopes, Moema, de autoria do escritório Andrade Morettin Arquitetos Associados. Imagem ilustrativa do projeto. 

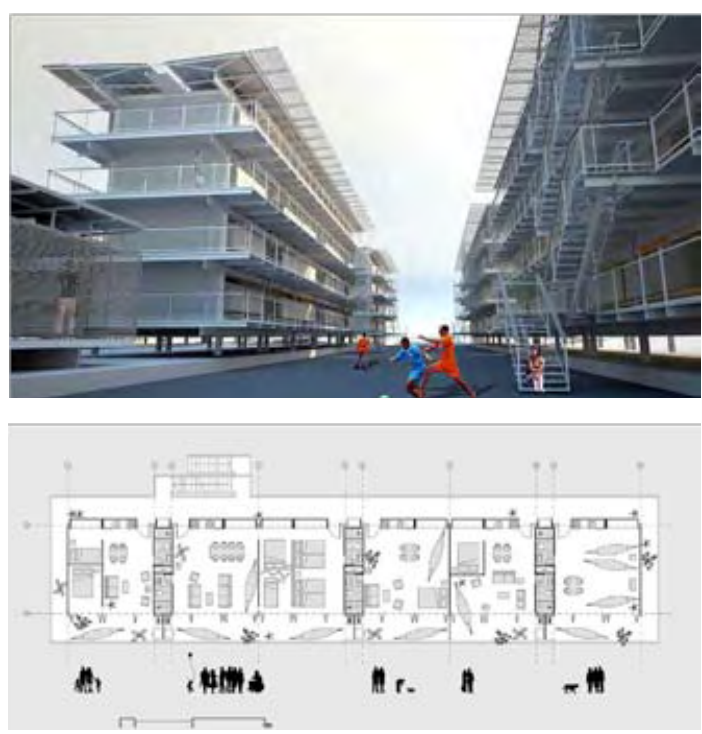

Figura 3 - Edifício de Habitação social para " $2^{\circ}$ Concurso Internacional Living Steel para Habitação Sustentável"no qual o escritório Andrade Morettin Arquitetos Associados saíram vencedores. permitir balanços grandes, sendo necessários complementos fixados na estrutura principal. Esta solução foi adotada também no Simpatia 234 , varandas metálicas salientes à estrutura principal.

\subsection{I.3 TÉCNICA CONSTRUTIVA}

\subsubsection{I EXECUÇÃO E MONTAGEM}

Foram identificadas nos projetos diferentes situações no que diz respeito à execução e montagem do sistema estrutural, situações que, dentro do possível, e conjuntamente com o desenho estrutural, são racionais e trazem soluções não usuais de pré-fabricação ou métodos que permitem execução a seco dos painéis de fechamento, como é o caso do edifício Fidalga 772. De fato, mesmo sendo projetos diferenciados, ainda nesta pequena amostra que está sendo analisada, há o predomínio por técnicas convencionais, inclusive nos projetos promovidos pela Idea!Zarvos, uma incorporadora que parece ter anseios por uma arquitetura diferenciada, mas que ao mesmo tempo, prefere as técnicas convencionais, saindo dos padrões mais na resolução flexível do espaço interior da planta ou na própria plástica das fachadas. Quando saiu do convencional, no caso do Fidalga 772, foi por mérito dos arquitetos.Assim, as técnicas não convencionais ocorrem mais nos casos onde os arquitetos e engenheiros são agentes empreendedores do seu próprio projeto. Foram identificadas assim, as seguintes situações nos projetos analisados:

- Superestrutura em concreto armado moldada in loco e fechamentos externos em alvenaria (que recebem algum tipo de revestimento, como cerâmica, tijolos de barro, fulget ou masseamento com pintura especial) e caixilharia com vidro. Esta situação foi identificada nos projetos: Simpatia 234, Fiori di Maggio,Vila Fidalga e Aimberê; 
- Superestrutura em alvenaria estrutural, com laje pré-fabricada. Esta situação foi identificada no projeto Vila Pedro Fachini, e por se tratar de um edifício de pequeno porte, a questão de "empilhar blocos", acaba sendo viável e de rápida execução, compensada pelo fato da dispensa de formas e cimbramentos;

- Superestrutura em concreto armado moldada in loco e fechamentos externos de painéis laminados e vidros estruturados por perfis de alumínio. Neste caso há uma mescla entre execução convencional, e instalação da envoltória a seco. Esta situação foi identificada no projeto Fidalga 772;

- Estrutura em alvenaria armada, com laje mista de concreto armado e madeira. Para este caso a execução da laje ocorreu in loco, mas sem cimbramento. Esta situação foi identificada no projetoVila Butantã. Para este caso, o desenho a partir da definição de empenas estruturais foi muito racional, permitindo maior agilidade na execução;

- Pré-fabricação de painel estrutural de madeira fora do canteiro de obras. Esta situação foi identificada na Vila Taguaí, interessante para situações onde o local a ser implantado o projeto, por exemplo, pela situação de terreno acidentado, não permite a pré-fabricação das peças no próprio canteiro;

- Pré-fabricação de painel estrutural cerâmico no próprio canteiro de obras, inclusive podendo utilizar a própria base da fundação radier, como esteira para solidificação dos painéis. Pode-se entender que a situação comum de "empilhar blocos" é racionalizada com este método, já que a partir de blocos criam-se painéis, facilitando ainda mais a execução. Esta situação foi identificada no projeto Canaã. 
Quanto à especificação dos materiais, os projetos foram organizados da seguinte maneira:

- SUPERESTRUTURA;

- ENVOLTÓRIA;

- VEDAÇÕES INTERNAS;

- DETALHES.

Fora a identificação dos materiais da superestrutura e envoltória foi feita também uma relação dos materiais utilizados para aquelas paredes internas não estruturais, e foi notado que, mesmo para estas vedações com função apenas de divisão de cômodos, há o predomínio do uso de alvenarias tradicionais, com exceção dos projetos da Idea!Zarvos, que são mais radicais neste sentido e eliminam as vedações internas, deixando as soluções do interior da planta a mercê dos moradores. Assim, poderia haver uma distinção maior entre fechamentos externos, estruturais, daqueles internos, apostando em soluções menos fixas e com maior facilidade para adaptações.

Por fim, estas considerações finais expõem como a estrutura e técnica construtiva interfere tanto na definição interior da planta quanto na fachada, porém, os assuntos referentes ao interior das unidades habitacionais, definição do pavimento tipo e o tema envoltória, serão abordados na sequência, de modo mais específico e com outras incógnitas.

Da mesma maneira como acontece em outros temas, "Espaços Exteriores", "Implantação" entre outros, no tema "Sistema Estrutural e Técnica Construtiva" é notável o salto que os projetos desta pesquisa dão em comparação com projetos que encontramos espalhados pela cidade de São Paulo, sendo possível associar o diferencial dos estudos de casos selecionados, boas arquiteturas, em parte aos bons arquitetos. 
Para exemplificar este salto qualitativo, podemos citar o caso da técnica construtiva "alvenaria estrutural”, atualmente expandindo sua utilização também para edifícios de médio e alto padrão, não sendo apenas associada à construção para baixa renda'. Mesmo este sistema construtivo possuindo vantagens;seja do baixo custo, rapidez na execução como também pela simplicidade da lógica projetual; as soluções propostas pelo mercado imobiliário parecem não possuir lógica na definição do sistema estrutural e correlações entre temas - sistema estrutural, técnica construtiva, Instalações, e materiais.

$\mathrm{Na}$ verdade, parecem resolver a distribuição do programa em planta, e depois engessar quase todas as paredes como estruturais, com exceção da parede entre sala e cozinha ou entre sala e "terceiro" dormitório (tão pequeno que seria melhor já estar incorporado à sala desde o princípio), flexibilidade que vendem com toda força. Não que não seja interessante poder ter a situação de sala integrada com a cozinha ou possibilidade de ampliação da sala, o problema,é que esta flexibilidade é mal resolvida, e a sala quando é ampliada ganha uma "janelinha" com cara de quarto, prova de que a flexibilidade está relacionada também com a definição mais neutra das aberturas, por exemplo (Figura 04).

Podemos também voltar ao passado, e refletir sobre referências do modernismo. Alan Colquhounm, na citação abaixo de 1962, sobre a produção massiva do pós-guerra, de crítica contra a ruptura radical do movimento moderno com o tipo e as teorias da imitação em favor da inovação, fala sobre a banalização da utilização de sistemas lógicos difundidos pelo modernismo.

É verdade que os arquitetos da maioria dos edifícios que se elevam hoje em dia usam o simples princípio de uma estrutura de concreto ou de aço recoberta com alguma forma de muro cortina. Mas as qualidades arquitetônicas de muitos desses edifícios são tão pobres que nos vemos forçados a nos perguntar se com a mera aplicação de um sistema aparentemente lógico, os aspectos essenciais da boa arquitetura não estão sendo descuidados. De fato, existe uma tendência entre os arquitetos, sempre que o programa permita-o, de escapar da simples estrutura com painéis para obter alguma forma de estrutura que possibilita que o edifício tenha uma maior flexibilidade plástica, e que outorgue a suas formas uma maior densidade. (COLQUHOUN, 1978 apud GÜIRALDES, 20II)

I Segundo Carlos Alberto Tauil (20II), arquiteto formado pela FAUUSP (Faculdade de Arquitetura e Urbanismo da Universidade de São Paulo) em 1967, especialista em alvenaria armada, coordenador do Manual Técnico de Alvenaria (ABCl, 1990) e coautor do livro Alvenaria Armada (1981), junto com o engenheiro Cid Racca.

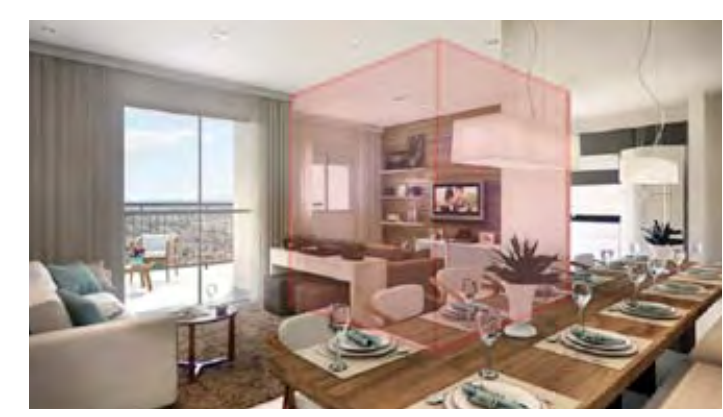

Figura 4 - Flexibilidade mal resolvida nos apartamentos do mercado imobiliário. 
Se antes o problema era a "mera aplicação de um sistema lógico", hoje o problema parece ser também a falta de aplicação de alguma lógica, seja ela qual for, afinal, muitos edifícios parecem apenas utilizar materiais de modo aleatório e adotar técnicas construtivas por imposição do mercado, ficando a resolução do sistema estrutural em segundo plano. Os projetos selecionados aqui utilizam princípios estruturais simples, e outros, apresentam mais inovação, com criação de novas técnicas. De todo modo, para ambos os casos, o resultado não é pobre e não se traduz a "mera aplicação de sistema lógico", pois resultam numa boa arquitetura.

\subsubsection{ENVOLTÓRIA}

Entende-se por envoltória a camada perimetral do edifício de contato com o meio exterior. Assim, o edifício se faz presente em determinada paisagem urbana, pela sua escala e por meio da envoltória. Atualmente, muitos edifícios que compõem a paisagem urbana da cidade de São Paulo e região metropolitana, não contribuem positivamente com a cidade, seja pela questão do isolamento, assunto abordado no tema "Espaços Exteriores", como também pela pobreza plástica, de conforto ambiental e ausência de novas soluções técnicas. Porém, não se trata de um problema recente, e muito menos restrito a São Paulo, edifícios “entediantes” podem ser identificados em vários períodos e localidades, temos alguns exemplos clássicos, como, a produção do BNH (Banco Nacional de Habitação) criado em 1964; edifícios promovidos pela secretaria de habitação de São Paulo pelo programaconhecido como "Cingapura", e os monótonos grands ensembles do pós-guerra, situados principalmente na França. Para estes exemplos clássicos, as queixas referentes à envoltória, quase sempre se referem à monotonia, repetitividade (dos blocos, janelas, etc.), falta de consideração das orientações e principais vistas, o que leva também à repetitividade das fachadas, entre outros problemas encontrados.

${ }^{2}$ Nome oficial é “Urbanização de Favelas com Verticalização - PROVER”, iniciado em 1993 durante gestão do prefeito Paulo Maluf. 
Abaixo, Comas (1986) fala sobre os conjuntos financiados pelo $\mathrm{BNH}$, e sobre a questão da desorientação que proporcionam às pessoas, não apenas pela grande escala, como também pela solução sem elementos marcantes que poderiam dar identidade ao conjunto.

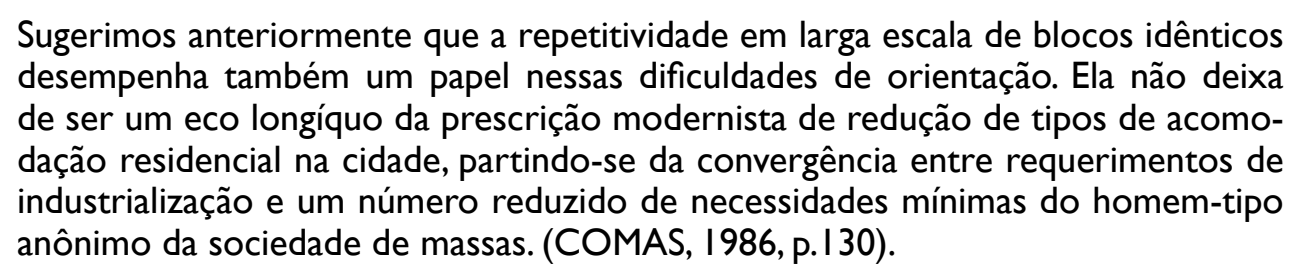

Considerando-se o recorte temporal desta pesquisa, o século XXI, os exemplos antagônicos não ficam restritos à promoção pública, já que os exemplares de promoção privada, produção típica do mercado imobiliário, predominam em quantidade e apresentam problemas semelhantes aos apontados nos clássicos BNH ou Cingapura (Figura 5). No caso da produção privada do mercado imobiliário, pode-se acrescentar a lista de problemas, a questão do estilo neoclássico presente mais nos empreendimentos voltados para a elite, mas que parece estar mudando, conforme artigo da Folha de São Paulo "Arquitetura de SP embarca no estilo contemporâneo. Prédios neoclássico, ornamentais, já são mais raros entre lançamentos" (CORREA, 20II), e também conforme artigo da revista ProjetoDesign "A reação ao neoclássico e a promessa para o futuro" que fala do apogeu e queda do neoclássico na década de 2000: "A década que vivenciou o apogeu e a queda do neoclássico na elite do mercado imobiliário residencial paulista - o maior do país - foi marcada, por outro lado, por uma espécie de reação silenciosa a esse tipo de projeto" (ProjetoDesign, 20 I I, p. 88). Esta reação silenciosa é retratada no artigo por alguns projetos estudados nesta pesquisa, como, Aimberê, Oiapoque eVila Fidalga, apenas para citar alguns nomes. Em artigo publicado recentemente na Folha de São Paulo, “Arquitetura feia, cidade doente”, o colunista Guto Requena ${ }^{3}$, usa vários

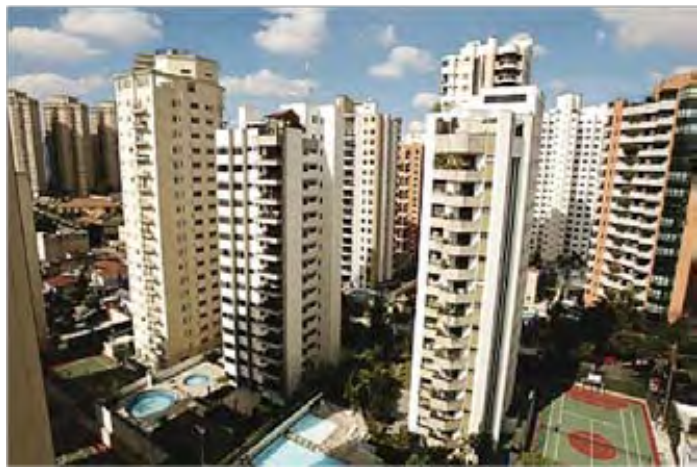

Figura 5 - Vista aérea de prédios residenciais no Bairro Tatuapé, São Paulo.

${ }^{3}$ Guto Requena, arquiteto (1999/2003) formado pela Escola de Engenharia de São Carlos da Universidade de São Paulo (EESC/USP) e mestrado (2007) pela mesma instituição com a pesquisa "Habitar Híbrido: Interatividade e Experiência na era da Cibecultura. 
adjetivos para caracterizar a cidade de São Paulo: "feia”, “doente”, "entediante” e a descreve como um "amontoado de edifícios, com inúmeras janelinhas, com repetição de formas, aglomerados ortogonais e variações cinza de um mesmo tema", sempre colocando como principal ponto a pobreza plástica das construções, citando apenas algumas exceções atuais, como por exemplo os edifícios da Idea!Zarvos e outros.

É claro, existem iniciativas importantes, como a recém-inaugurada Praça das Artes, do escritório Brasil Arquitetura, ou os experimentos residenciais contemporâneos da incorporadora Idea!Zarvos, na Vila Madalena. Mas são poucos os empresários preocupados com os desenhos de seus investimentos e suas relações com a cidade. (REQUENA, 2013).

Novamente, a envoltória é o contato com o meio externo, não apenas questões plásticas são relevantes, como também questões relacionadas ao conforto ambiental que proporciona ao interior do edifício, visuais mais interessantes entre outras questões. Assim, a partir dos estudos de casos selecionados pretende-se verificar possíveis soluções de envoltória.

La envolvente, al igual que La piel, es un elemento a través del cual el proyecto arquitectónico interactúa con su contexto y trabaja como punto de unión entre el exterior y el interior. Al desligar la fachada de la estructura, la solución de la envolvente adquirió una distinción suficiente para ser tratada como un tema específico dentro de la arquitectura. Elementos arquitectónicos como ventanas, persianas y balcones, así como otros acabados, permiten esa conexión particular entre lo público y lo privado, y se convierten, a la vez, en elementos compositivos que transmiten una imagen distintiva del proyecto. Su naturaleza envolvente no se limita entonces a ser sólo un plano de límite, sino que puede llegar a ser el medio de comunicación del edificio con los espacios que lo rodean. (BAHAMON; SANJINES, 2008, p. I34).

Com o objetivo de expor de modo claro e objetivo as soluções diversificadas presentes nos projetos em análise, houve primeiramente o trabalho de redesenho das fachadas dos projetos, destacando elementos importantes para a caracterização da envoltória, como por exemplo: materiais, cores, transparências, vazios e orientação de cada face. 
Também com base nas leituras específicas de cada projeto, foi elaborada uma tabela síntese comparativa dividida em temas principais correlacionados, as incógnitas específicas do tema: sistema estrutural, sólido geométrico (cheios e vazios), desenho da fachada, aberturas, cores/materiais, e por último, orientação/conforto ambiental.

Para cada incógnita, houve um objetivo específico, a ver na sequência:

- Sistema estrutural: qual a interferência da definição do sistema estrutural na envoltória;

- Sólido Geométrico: descrição do volume bruto externo, ou seja, como é formado o sólido geométrico, se existe adição ou subtração; qual a relação entre base, corpo e coroamento do edifício; ou seja, características que nos permitem visualizar o perfil do objeto ainda sem muitos detalhes de materiais, aberturas, etc.;

- Desenho da fachada: observação da posição da estrutura no plano da fachada; das aberturas; dos planos de fechamentos; cheios e vazios conjuntamente, sendo possível classificar a fachada como simétrica ou assimétrica; identificar se existe marcação vertical ou horizontal; se os planos são contínuos ou descontínuos; etc.;

- Aberturas: tipos (tamanhos e formatos); distribuição na fachada; luminosidade que proporciona; enquadramento etc.

- Cores e Materiais: tipos existentes e se existem variedades num mesmo projeto; etc.;

- Orientação/conforto ambiental: sendo a envoltória o limite do interior com o exterior, acaba tendo a função de proteger ou desproteger faces ou trechos específicos, conforme a orientação, elementos significativos externos (como por exemplo, massas arbóreas ou interferências de outros edifícios), fenômenos meteorológicos no geral; etc.

Foram identificados alguns resultados para cada subtema, específicos para cada projeto, que podem ser conferidos na tabela síntese comparativa, acompanhada dos desenhos correspondestes. 


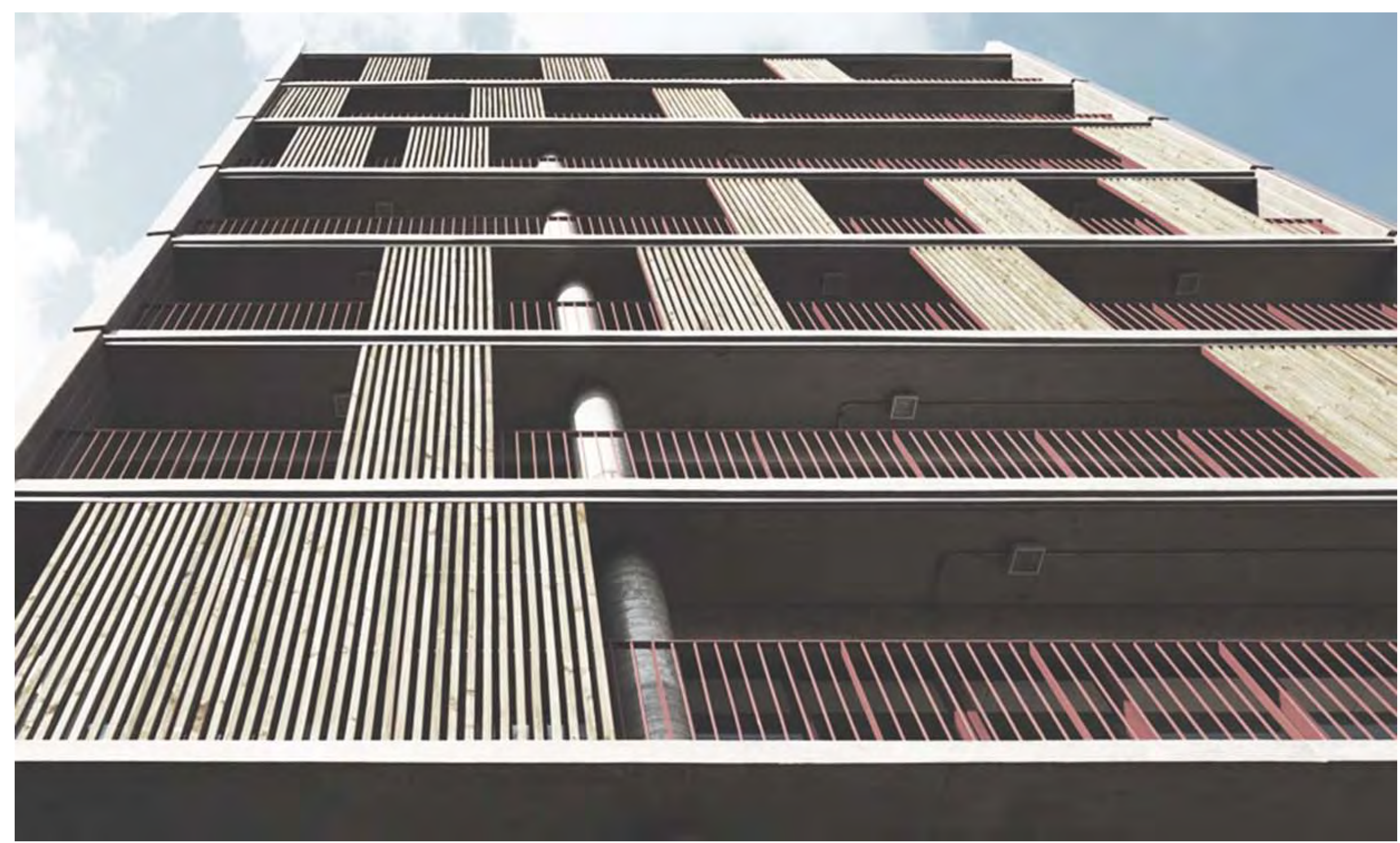

4.3.2.I COMPARAÇÃO GRÁFICA ENVOLTÓRIA 


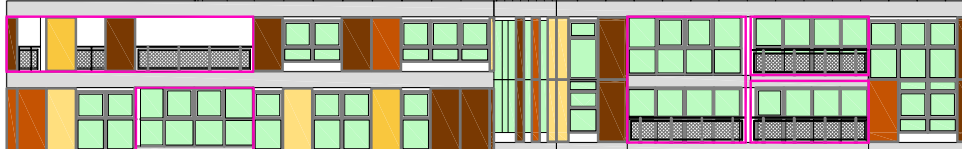
口ص

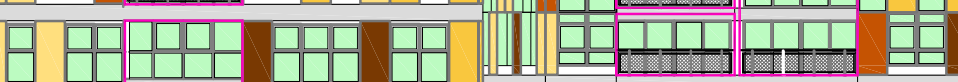

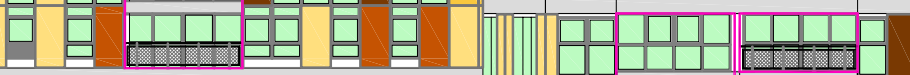

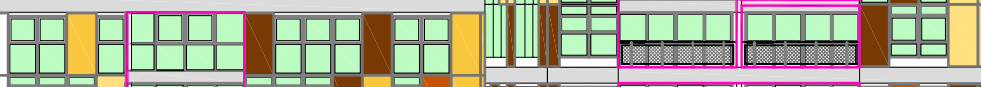

NO NE

so $\bigcup_{\text {SE }}$

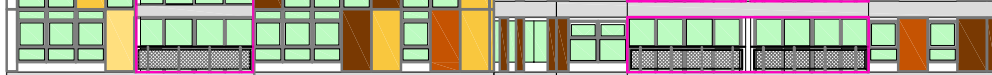

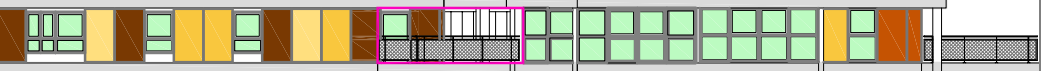

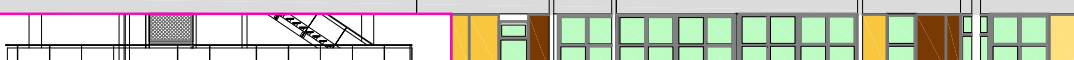

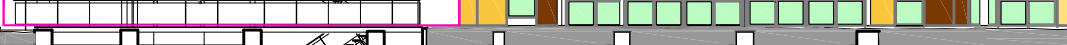
(1)

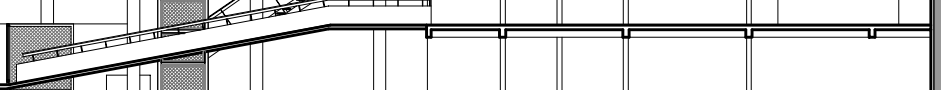

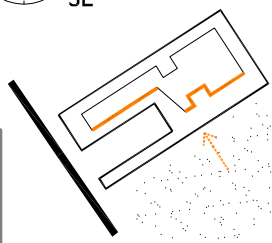

ELEVAÇÃO SUDESTE ESCALA |:400

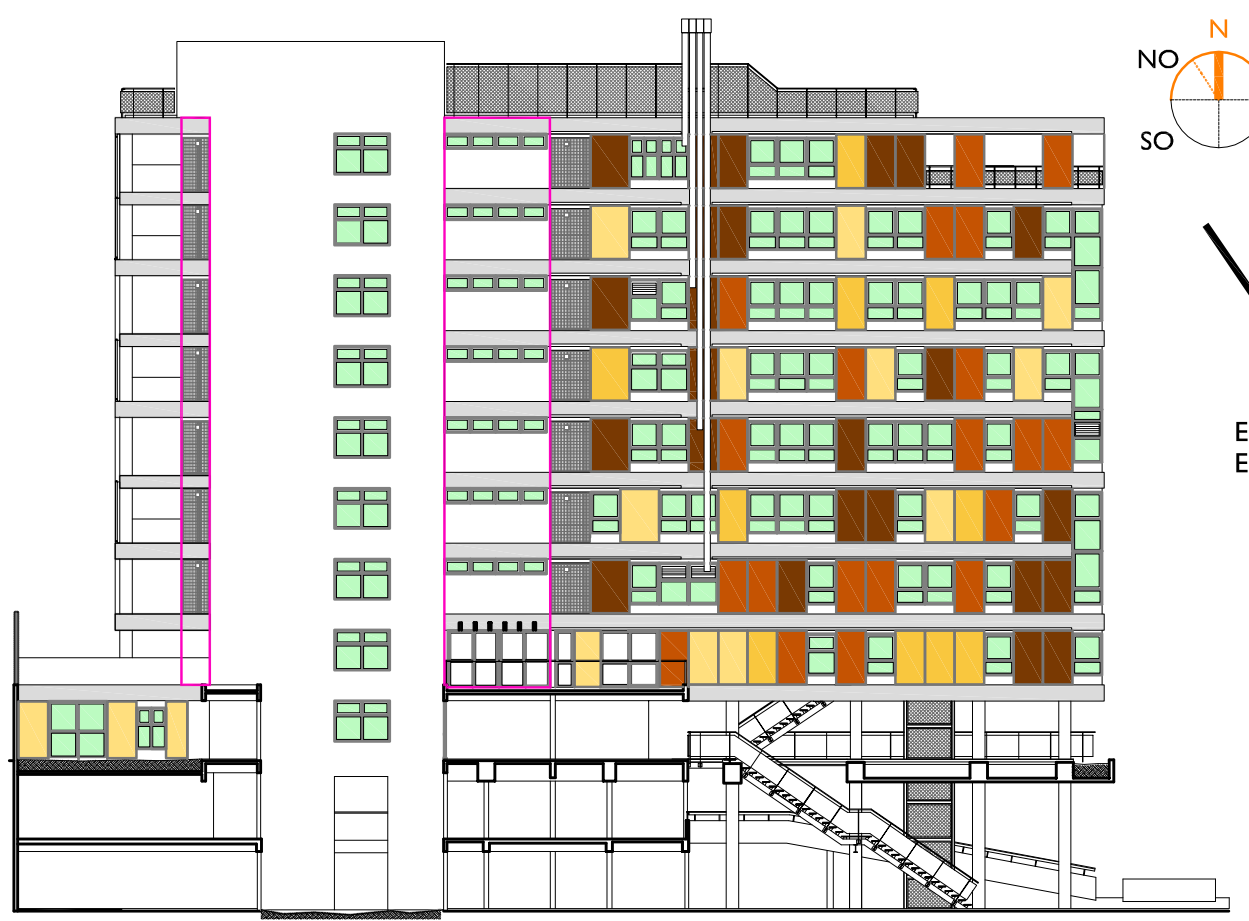

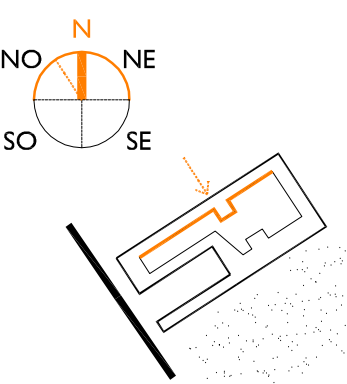

ELEVAÇÃO NOROESTE ESCALA I:400
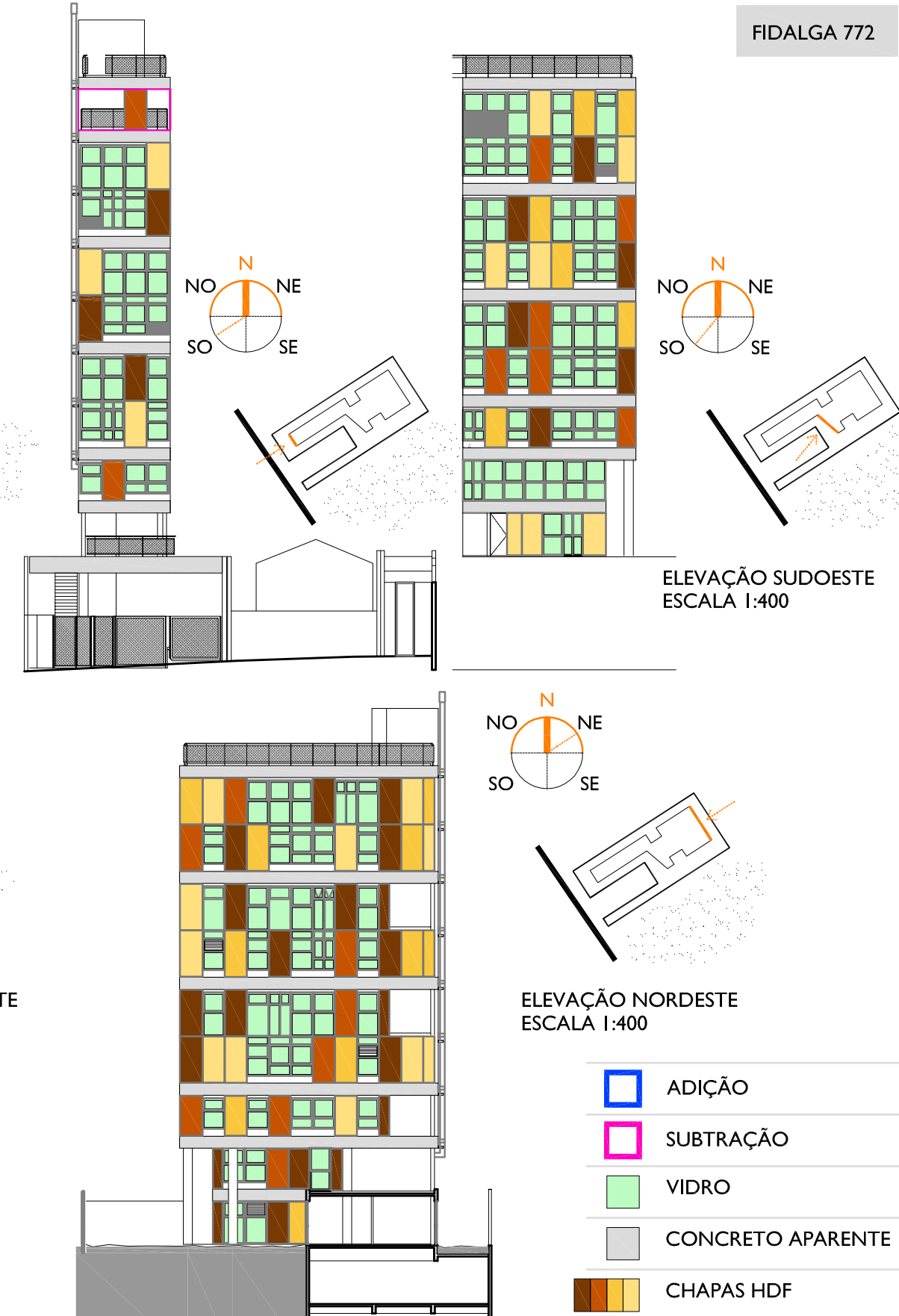


\section{ENVOLTÓRIA}

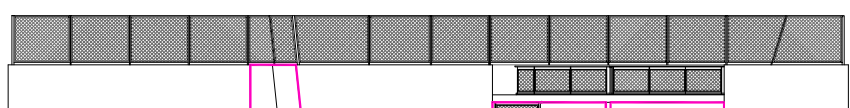

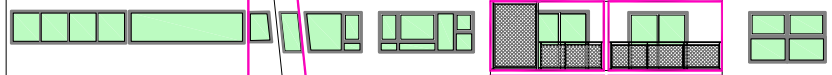

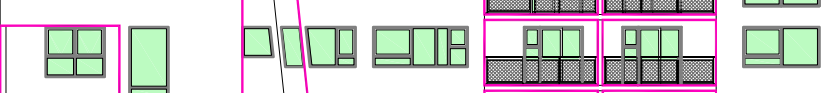

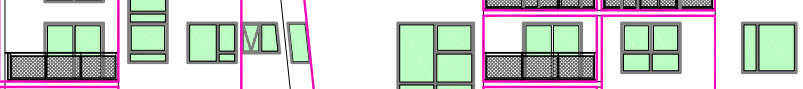

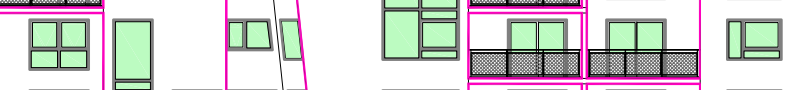

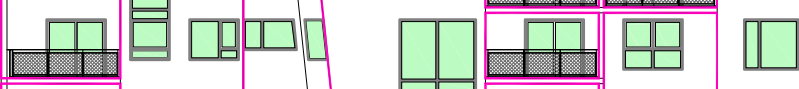

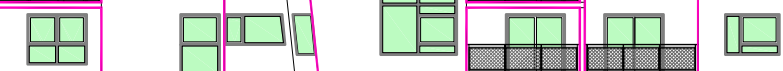
माप

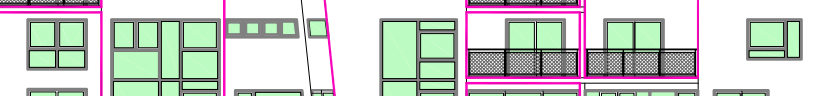

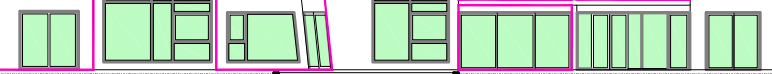
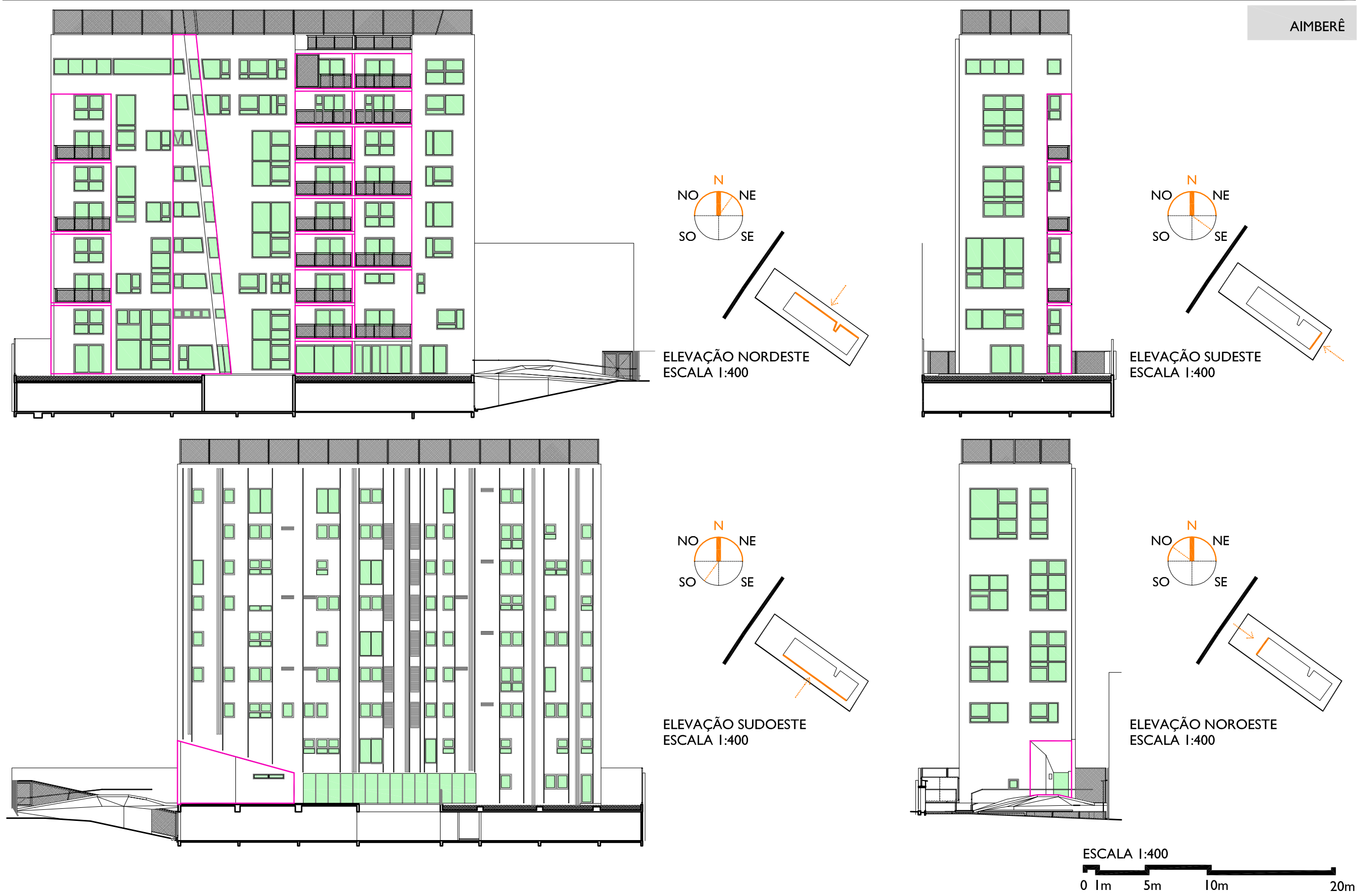


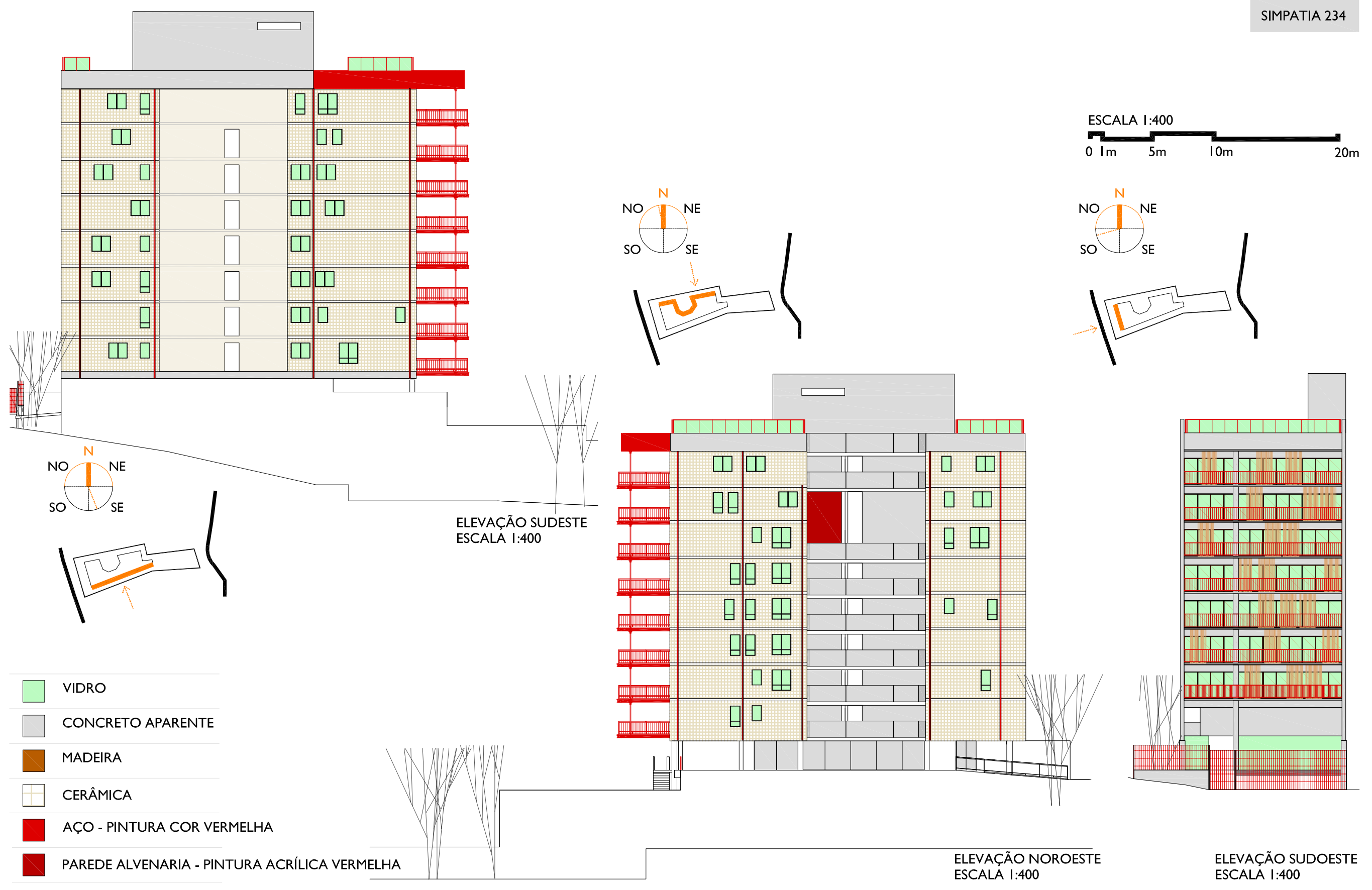




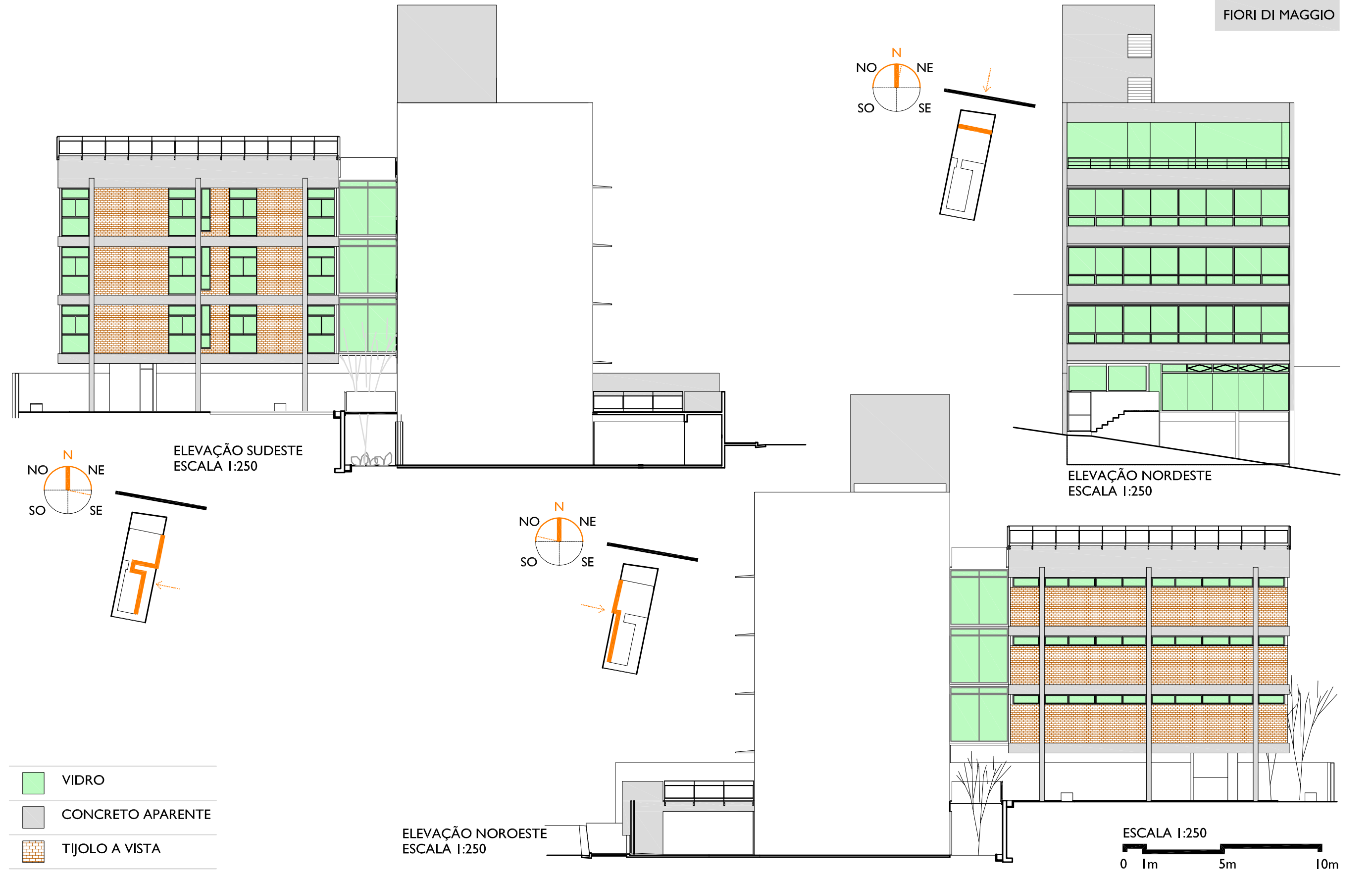




\section{ENVOLTÓRIA}
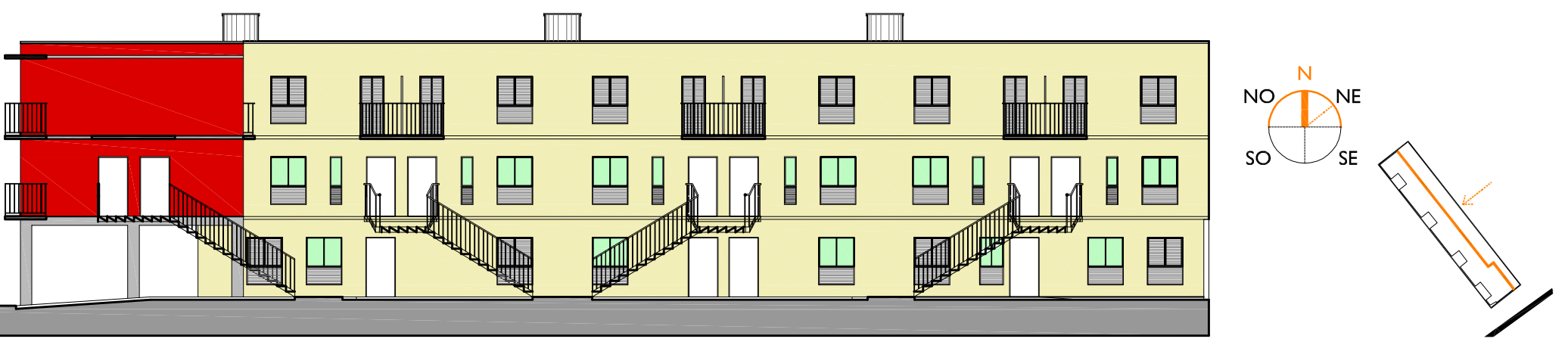

VILA PEDRO FACHINI W

ELEVAÇÃO NORDESTE ESCALA I:250

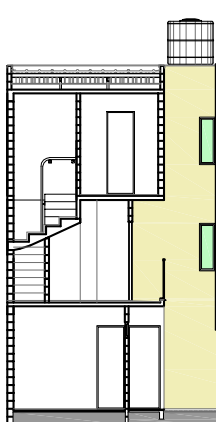

回

曲

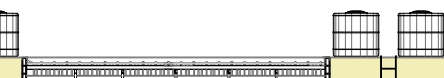
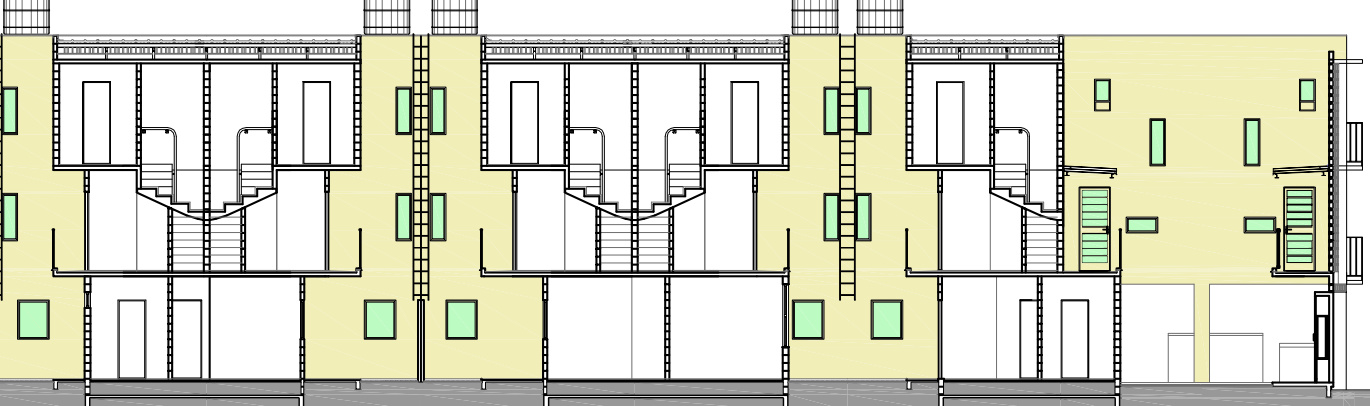

No NE

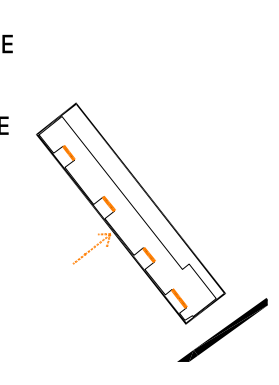

ELEVAC̄̃̃ SUDOESTE

ESCALA I:250
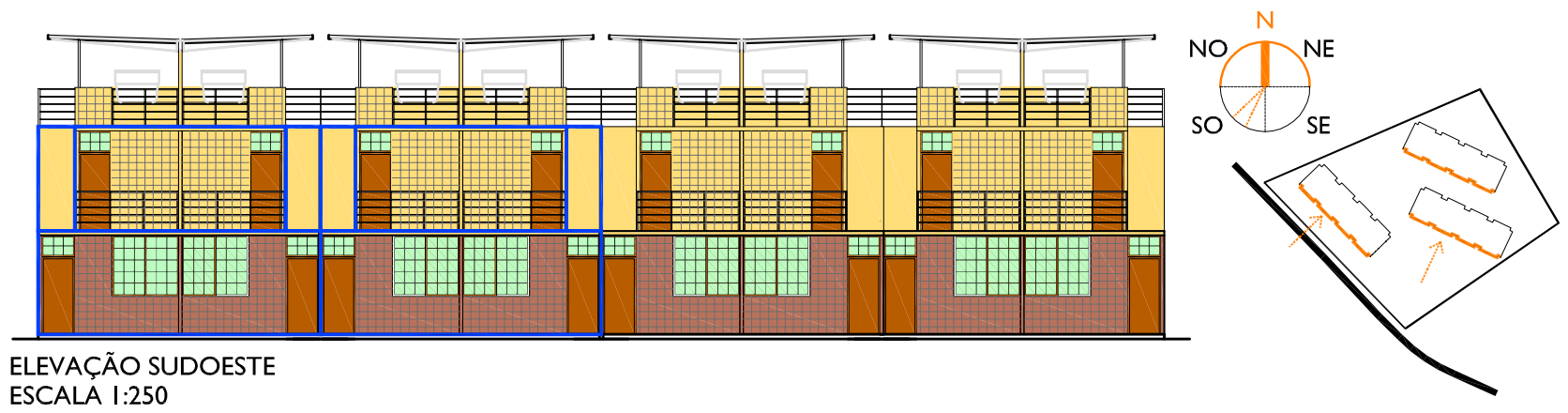

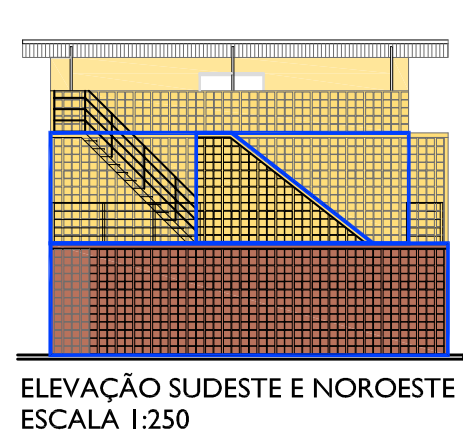

SO

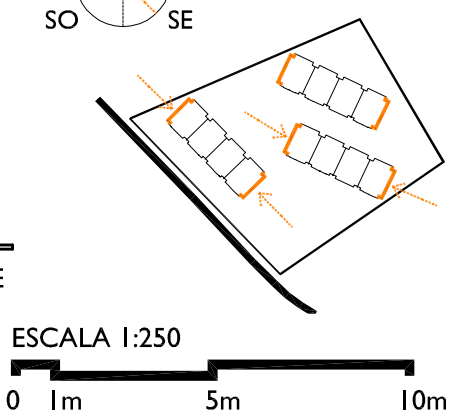



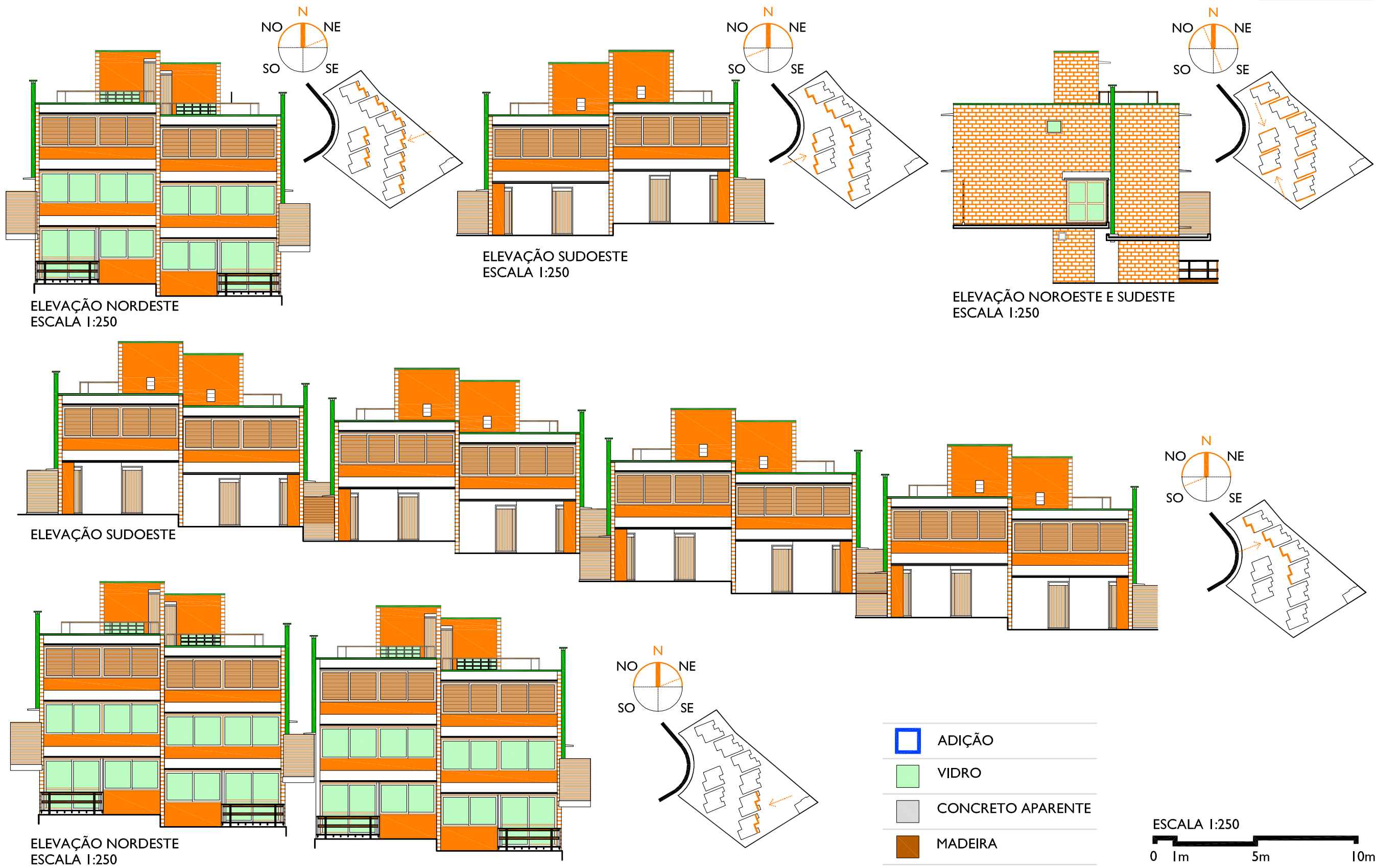

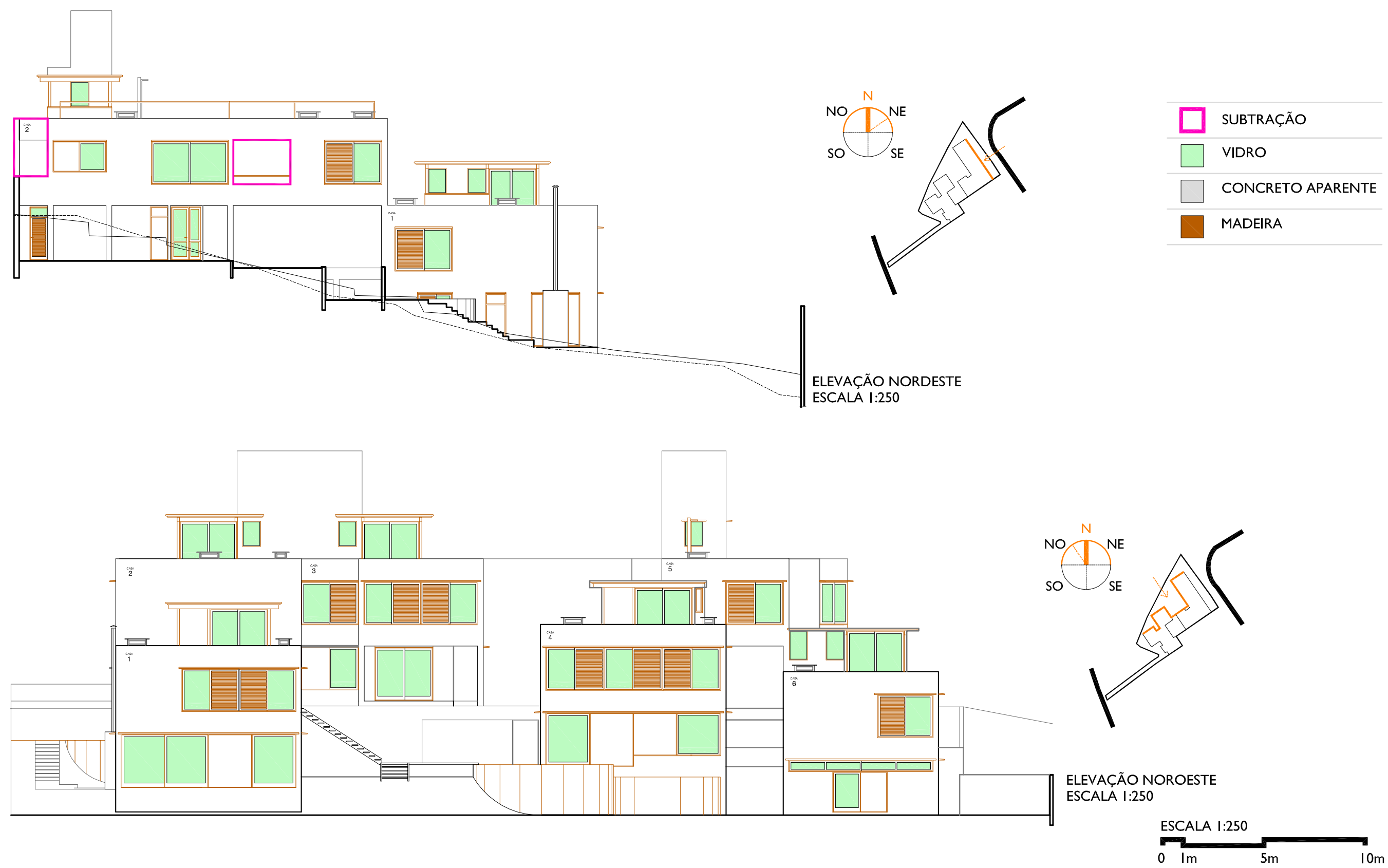

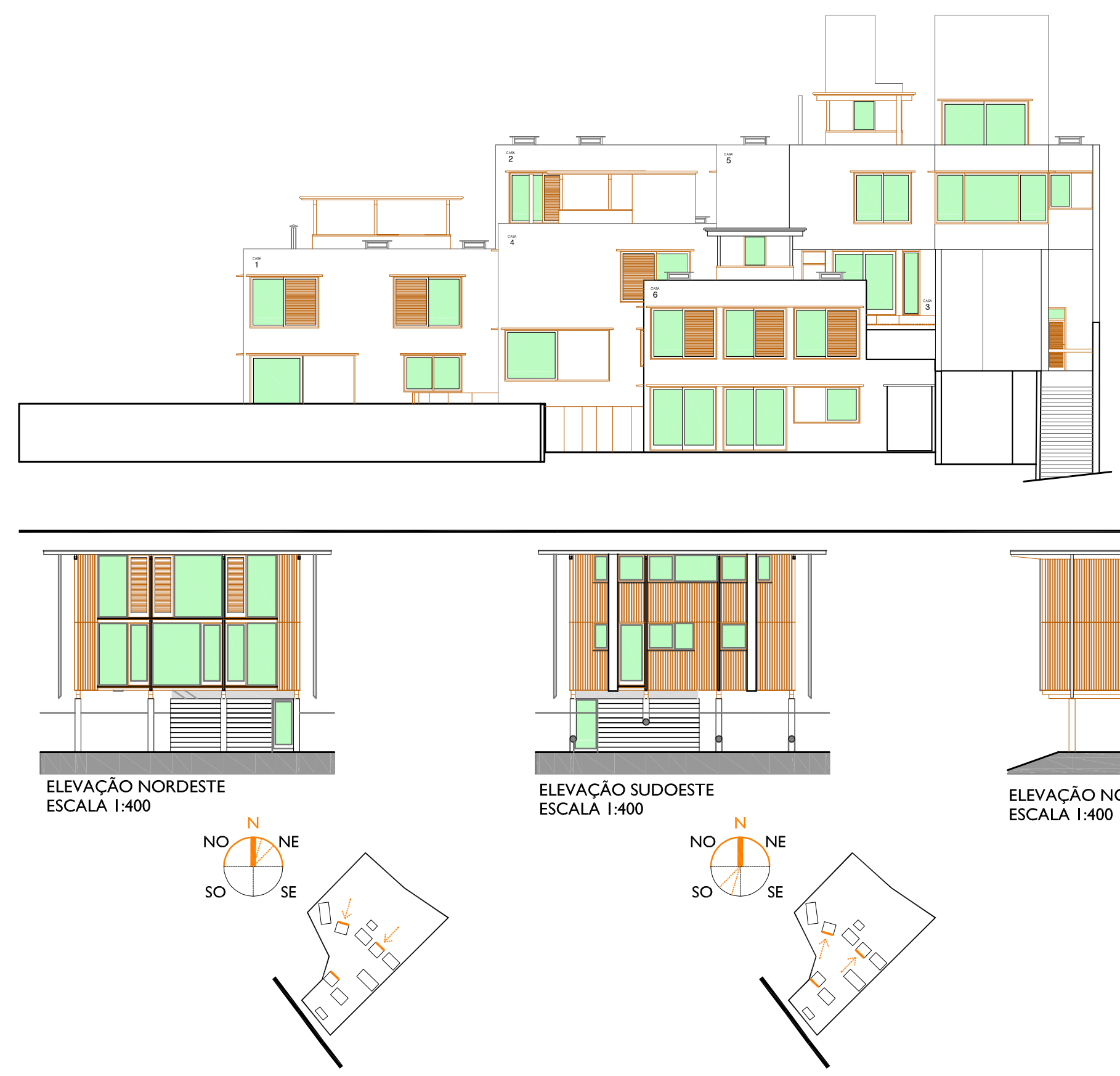

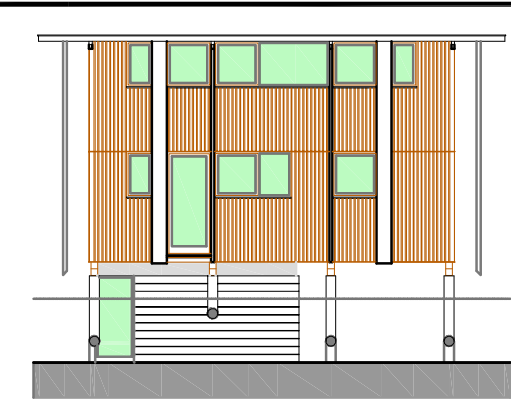

ELEVAÇÃO SUDOESTE

ESCALA I:400

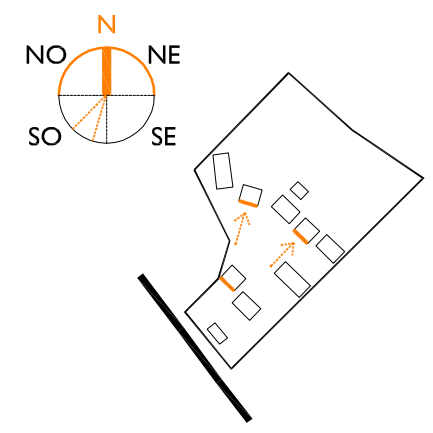

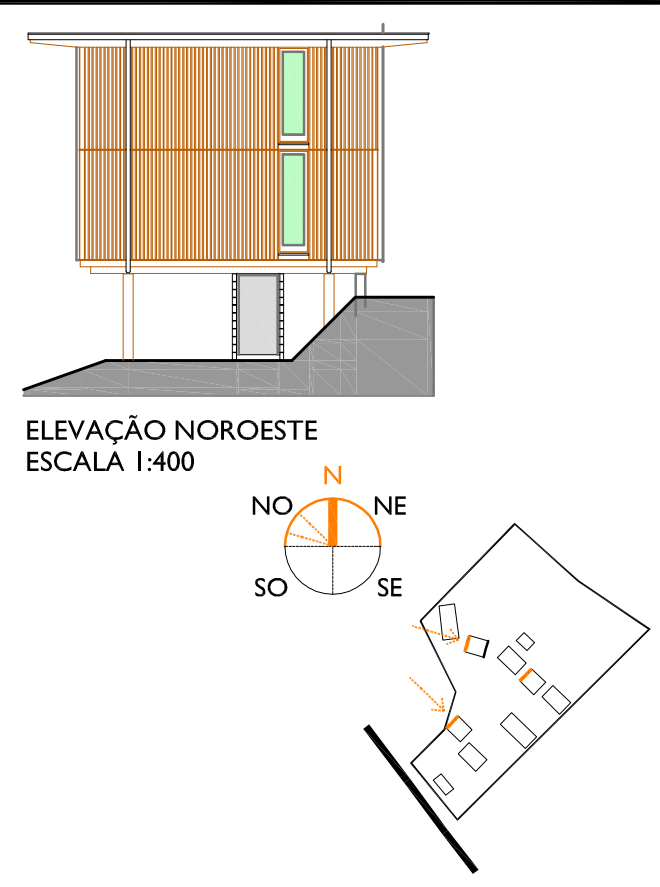

ESCALA I:250

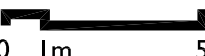

CONCRETO APARENTE

MADEIRA

\section{LVVAC̄̃̃ SUDOESTE}

ESCALA |:250 
FIDALGA 772

AIMBERÊ

SIMPATIA 234

FIORI DI MAGGIO

VILA PEDRO FACHINI

CANÃ̃

\section{UNIDADES \\ HABITACIONAIS NÃO SOBREPOSTAS}

(3 A 5 PAVIMENTOS +

COROAMENTO)

\section{SISTEMA ESTRUTURAL}

PILARES NO INTERIOR DA PLANTA, SEPARADOS DO PERÍMETRO ONDE FICAM AS VIGAS E ENVOLTÓRIA = ENVOLTÓRIA + VIGAS LIVRES. ESTRUTURA DE PERFIS DE ALUMÍNIO FIXADOS SOBRE A PERIFERIA DO PRÉDIO, OUE RECEBEU, DA MESMA MANEIRA, O CAIXILHO COM VIDRO OU OS PAINÉIS HIGH DENSITY FIBERBOARD (HDF)

PILARES E VIGAS NO MESMO PLANO DO PERÍMETRO DA EDIFICAÇÃO =

SUPERPOSIÇÃO DE PILARES, VIGAS E ENVOLTÓRIA, SENDO OUE A

ENVOLTÓRIA PREENCHE OS ESPAÇOS VAZIOS ENTRE A ESTRUTURA

NAS FACES LATERAIS, PILARES E VIGAS NO MESMO PLANO DO PERÍMETRO DA EDIFICAÇÃO = SUPERPOSIÇÃO DE PILARES, VIGAS E ENVOLTÓRIA; NAS FACES FRONTAIS ÀS RUAS, OS PILARES FICAM SOLTOS EXTERNAMENTES = ENVOLTÓRIA + VIGA LIVRES

BLOCO POSTERIOR: PILARES SALIENTES PARA O EXTERIOR DA PLANTA, FUNDIDOS

PARCIALMENTE COM VIGAS E ENVOLTÓRIA , = PILARES BALIZAM ENVOLTÓRIA

BLOCO FRONTAL: PILARES NAS ESTREMIDADES, EMPENAS CEGAS ESTRUTURAIS, E

ENVOLTÓRIA + VIGA LIVRES NAS FACES LIVRES

OBR

PAREDES ESTRUTURAIS NO MESMO PLANO DAS ABERTURAS

\section{PAREDES ESTRUTURAIS FORMADAS PELOS PAINÉIS}

PRÉ-FABRICADOS CERÂMICOS NO MESMO PLANO DAS ABERTURAS

DEFINIÇÃO DE EMPENAS ESTRUTURAIS QUE LIBERAM FACES PRIVILEGIADAS PARA

AMPLAS ABERTURAS

PILARES E VIGAS NO MESMO PLANO DO PERÍMETRO DA EDIFICAÇÃO = SUPERPOSIÇÃO DE PILARES, VIGAS E ENVOLTÓRIA, PORÉM, OS PILARES FICAM NAS ESTREMIDADES

DO PLANO ESTRUTURAL, LIBERANDO TRECHOS DA FACHADA PARA AMPLAS ABERTURAS.

SISTEMA DEFINIDO POR PAINÉIS DE MADEIRA JATOBÁ, PORÉM, DO MESMO MODO QUE

OCORREU NO PROJETO VILA BUTANTÃ, FORAM DEFINIDAS PAREDES MAIS SÓLIDAS PARA

TRAVAMENTO DA ESTRUTURA E LIBERAÇÃO DE FACES PARA POSICIONAR AMPLAS ABERTURAS,

DE PISO A TETO.
SÓLIDO GEOMÉTRICO (cheios e vazios)
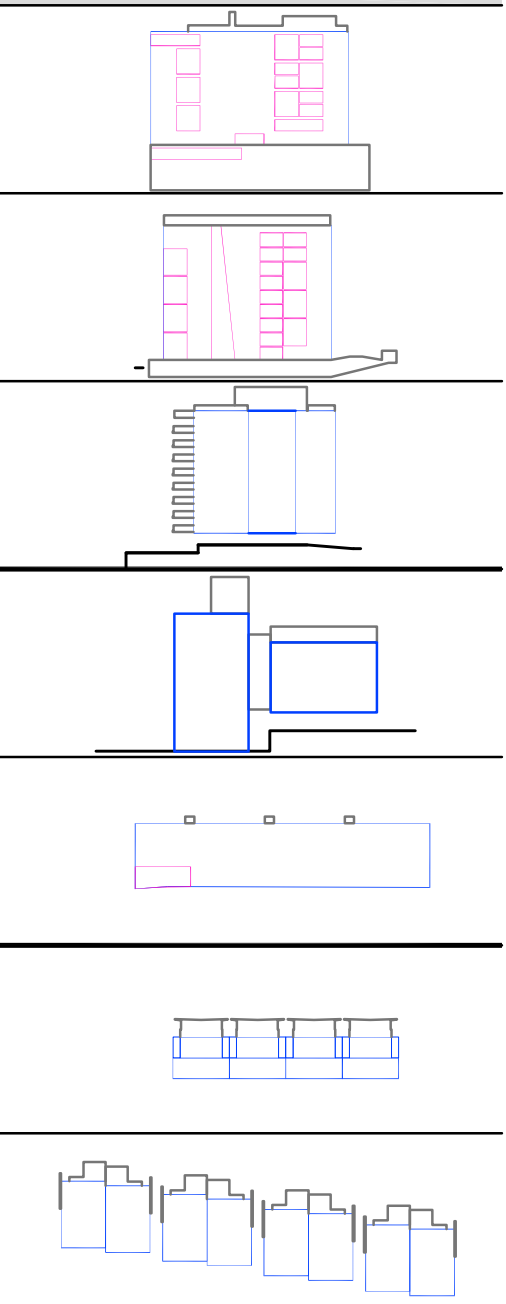

VILA FIDALGA

VILA TAGUAÍ 
CORPO DO EDIFÍCIO: PRISMA RETO IRREGULAR, COM UMA DAS FACES LEVEMENTE INCLINADAS, PORÉM, SEM SALIÊNCIAS. O CORPO É SOLTO PARCIALMENTE DA BASE, E O COROAMENTO É POUCO SALIENTE, JÁ QUE O PERÍMETRO DA COBERTURA É DELINEADO POR GUARDACORPOS QUE SUAVIZAM O VOLUME DA CAIXA D'ÁGUA. AS VARANDAS CONFIGURAM OS VAZIOS DESTE SÓLIDO, E SÃO ALTERNADAS COM PÉ-DIREITO SIMPLES E DUPLO;

CORPO DO EDIFÍCIO É UM PARALELEPÍPEDO RETANGULAR COM MESCLA DE VAZIOS REGULARES (VARANDAS ALTERNADA COM PÉ-DIREITO SIMPLES E DUPLO) E OBLÍQUOS (RASGO FACE NORDESTE E ENTRADA NO TÉRREO). O CORPO É APOIADO NA BASE E O COROAMENTO É RESOLVIDO POR GUARDACORPOS POSICIONADOS NO LIMITE DA LAJE DE COBERTURA. O VOLUME DA CAIXA D'ÁGUA É EMBUTIDO NO CORPO DO EDIFÍCIO.

CORPO DO EDIFÍCIO: PRISMA RETO IRREGULAR, COM FACES INCLINADAS CONFORME PERÍMETRO DO LOTE, O CORPO É SOLTO DA BASE, E O COROAMENTO É SALIENTE, PELO VOLUME DA CAIXA D'ÁGUA. AS VARANDAS CONFIGURAM SALIÊNCIAAS DESTE SÓLIDO.

DOIS PARALELEPÍPEDOS RETANGULARES, INTERLIGADOS POR PASSARELA EM TODOS OS ANDARES. PARA O CASO DO EDIFÍCIO FRONTAL, O CORPO É APOIADO NA BASE E O COROAMENTO É MARCADO PELO VOLUME DA CAIXA D'ÁGUA SALIENTE. PARA O CASO DO EDIFÍCIO POSTERIOR, ELE É SOLTO DA BASE E O COROAMENTO É RESOLVIDO POR GUARDACORPOS SOBRE VIGA DE CONCRETO, POSICIONADOS NO LIMITE DA LAJE DE COBERTURA.

PARALELEPIPEDO RETANGULAR REGULAR SOLTO DO SOLO NA PARTE FRONTAL E APOIADO NA BASE NO RESTANTE DO MONOBLOCO. O COROAMENTO É MARCADO PELOS VOLUMES DAS CAIXAS D'ÁGUA SALIENTES E METÁLICAS (EM FORMATO CILÍNDRICO, QUE LEMBRAM VENTILADORES DE TETO EXISTENTES NAS INDÚSTRIAS PRÓXIMAS A ESTE EDIFÍCIO). OS AUTORES DO PROJETO UTILIZAM A EXPRESSÃO “BLOCO VAGONAR” PARA CARACTERIZAR ESTE EDIFÍCIO, QUE SE REFERE A UM VAGÃO DE TREM.

O MÓDULO REPETIDOR, DUAS UNIDADES HABITACIONAIS GEMINADAS, É FORMADO PELA SOBREPOSIÇÃO DE DOIS PRISMAS RETANGULARES (SENDO O DA BASE MAIS ALARGADO) E ADICCÃO DO VOLUME IRREGULAR DA ESCADA EXTERNA NAS LATERAIS. QUANDO ANALISADOQUATRO UNIDADES GEMINADAS AGRUPADAS, PODE-SE VISUALIZAR TAMBÉM UM PARALELEPÍPEDO RETANGULAR REGULAR APOIADO NO SOLO. O COROAMENTO É MARCADO PELA COBERTURA EM FORMATO BORBOLETA.

O VOLUME DO MÓDULO REPETIDOR, DUAS UNIDADES HABITACIONAIS GEMINADAS, SÃO DOIS PRISMAS QUADRANGULAR, DESLOCADOS EM ELEVAÇÃO E EM PLANTA, COM SUBTRAÇÃO DE VOLUME PARA ENCAIXE NO TERRENO E PARA GARAGEM DE VEÍCULO ABERTA. O COROAMENTO É MARCADO PELO VOLUME DA CAIXA D'ÁGUA, CERCADO PELO GUARDA-CORPO, E COMO CONTRAPONTO, O VOLUME LINEAR VERTICAL E ESBELTO DA CHAMINÉ.

AS SEIS UNIDADES HABITACIONAIS, PRISMAS RETANGULARES COM ALGUMAS SUBTRAÇÕES NO VOLUME, JUNTAS FORMAM UM COMPOSIÇÃO IRREGULAR, ASSIMÉTRICA E NÃO HOMOGÊNEA. O COROAMENTO É MARCADO PELA PEQUENA CONSTRUÇÃO SALIENTE NO TERRAÇO, PORÉM, OS COROAMENTOS DE CADA UNIDADE SÃO DESALINHADOS ENTRE SIM.
DESENHO DA FACHADA

PRINCIPALMENTE FACE SUDESTE, ASSIMÉTRICA

DESCONTÍNUA: FAIXAS HORIZONTAIS QUE MARCAM A

FACHADA (VIGAS) SÃO INTERROMPIDAS EM ALGUNS MOMENTOS, DEVIDO A CRIAÇÃO DE PÉS-DIREITO DUPLO.

TRATAMENTO DIFERENCIADO PARA CADA FACE. NA SUDOESTE,

MARCAÇÃO VERTICAL POR BRISES ESBELTOS E PELA

TUBULAÇÃO APARENTE. A FACE NORDESTE É ASSIMÉTRICA PRINCIPALMENTE PELO RASGO OBLÍQUO E IRREGULAR.

FACES SUDOESTE E NOROESTE CONFIGURAM EMPENAS

(ESTRUTURA E VEDAÇÃO) COM ABERTURAS NO MESMO PLANO, SEM MARCAÇÃO HORIZONTAL OU VERTICAL FACES NORDESTE E SUDESTE, MARCAÇÃO HORIZONTAL DAS VIGAS.

MARCAÇÃO HORIZONTAL E SIMÉTRICA NO EDIFÍCIO FRONTAL PELAS VIGAS + LAMELAS DE CONCRETO (QUEBRA-SOL) + PANOS DE VIDRO. PARA O CASO DO EDIFÍCIO POSTERIOR, A MARCAÇÃO DA ESTRUTURA NOS DOIS SENTIDOS SE FAZ PRESENTE NAS FACES.

MARCAÇÃO HORIZONTAL DA FACE NORDESTE PELA PRÓPRIA GEOMETRIA DO SÓLIDO, E TAMBÉM PELO MODO COMO AS ABERTURAS SE POSICIONAM, ALINHADAS MAIS HORIZONTALMENTE DO QUE VERTICALMENTE.

FACHADAS SÃO MARCADAS PELA MALHA QUADRICULADA DA MODULAÇÃO DOS PAINÉIS PRÉ-FABRICADOS.

A ALTERNÂNCIA DO CAIXILHO, VIGAS E PEITORIL, MARCAM NO SENTIDO HORIZONTAL AS FACES ENTRE EMPENAS ESTRUTURAIS. AS EMPENAS ESTRUTURAIS MARCAM OS DESLOCAMENTOS VERTICAIS. A FACE DA EMPENA ESTRUTUAL É MAIS SÓLIDA.

AINDA ANALISANDO O CONJUNTO, E NÃO UNIDADES ISOLADAS, NÃO EXISTE MARCAÇÃO HORIZONTAL OU VERTICAL, JÁ QUE SÃO IMPLANTADAS DESALINHADAS, ACOMPANHANDO A TOPOGRAFIA DO TERRENO.

MARCAÇÃO VERTICAL EM TODAS AS FACES PELO SENTIDO DAS LÂMINAS DE MADEIRA DOS PAINÉIS ESTRUTURAIS. ABERTURAS SE ENCAIXAM DENTRO DA MODULAÇÃO, FORMANDO UM MOSAICO. 
FIDALGA 772 CAIXILHO ALTERNA VIDRO E PAINÉIS OPACOS DE MODO BRANDO E MESCLADO. A ENVOLTÓRIA DÁ IMPRESSÃO QUE EXISTE UM FUNDO ENVIDRAÇADO NO QUAL SÃO APOIADAS PLACAS OPACAS, REGULANDO DE MODO NÃO HOMOGÊNEO A ENTRADA DE LUZ NO INTERIOR DO EDIFÍCIO. ESTE EFEITO DE TRANSPARÊNCIA E OPACIDADE E DISTRIBUIÇÃO NÃO HOMOGÊNICA DAS ABERTURAS HABILITA A IDEIA DE INDETERMINAÇÃO DO USO INTERNO.

AIMBERÊ NÃO SÃO DISTRIBUÍDAS DE MODO HOMOGÊNEO E POSSUEM FORMATOS E TAMANHOS VARIADOS. A QUESTÃO DE HABILITAR A IDEIA DE INDETERMINAÇÃO DO USO INTERNO TAMBÉM OCORRE, HÁ DÚVIDAS SOBRE O USO INTERNO A PARTIR DA DISPOSIÇÃO DAS ABERTURAS PELO MODO DESIGUAL COMO ESTÃO DISTRIBUÍDAS, OU SEJA, PELA COMPOSIÇÃO DAS ABERTURAS NO VOLUME.

SIMPATIA 234

FACES SUDOESTE E NOROESTE COM ABERTURAS DEFINIDAS PELOS MORADORES, POSSUEM UMA APARÊNCIA DE ALEATÓRIA, COMO OCORRE EM CONJUNTOS DE CASAS UNIFAMILIARES NA CIDADE. NAS OUTRAS FACES, NORDESTE E SUDESTES, AS ABERTURAS PREENCHE DE MODO UNIFORME O ESPAÇO ENTRE VIGAS.

FIORI DI MAGGIO

PARA O CASO DO EDIFÍCIO FRONTAL, AS ABERTURAS SÃO OS ESPAÇOS ENTRE VIGAS, DANDO UM CARÁTER NEUTRO E NÃO DETERMINANTE DO USO INTERNO. PARA O CASO DO EDIFÍCIO POSTERIOR, SÃO BALIZADAS PELA ESTRUTURA, FICANDO ENTRE PILARES, OU ENTRE VIGAS, OU NOS CANTOS PREENCHENDO ESPAÇO ENTRE A ESTRUTURA;

VILA PEDRO FACHINI

CANÃ̃

COMPOSIÇÃO COM RITMO INTERESSANTE, MARCADO POR ABERTURAS DE TIPOS E TAMANHOS DIFERENCIADOS, VOLUMES DAS CAIXAS D'ÁGUA E ESCADARIAS. A VARIAÇÃO DE TAMANHO DAS ABERTURAS, PODE INDETERMINAR O USO INTERNO DESDE O EXTERIOR.

ABERTURAS SEMPRE GUIADAS PELA MODULAÇÃO DE 2 I X 2 I NO SENTIDO VERTICAL, E 45 X 45 NO SENTIDO HORIZONTAL. OS CAIXILHOS SÃO EM MADEIRA E OS VIDROS TAMBÉM SÃO QUADRICULADOS, DESSE MODO, MESMO FORA DA MODULAÇÃO DAS PEÇAS CERÂMICAS, REMETEM À MALHA QUADRICULADA MARCANTE NO PROJETO.

VILA BUTANTÃ

AMPLAS ABERTURAS NAS FACES ENTRE EMPENAS, E ABERTURAS PEQUENAS E ISOLADAS NAS EMPENAS ESTRUTURAIS, ALVENARIAS AUSTERAS E JANELAS NEUTRAS, NÃO PERMITEM SABER O QUE SE PASSA DETRÁS DELAS. PEQUENAS ABERTURAS NO VOLUME DA CAIXA D'ÁGUA COMPÕEM COM A FACHADA, INCLUSIVE COLABORANDO COM A INDETERMINAÇÃO DO USO INTERNO DESDE O EXTERIOR.

VILA FIDALGA

AMPLAS ABERTURAS NAS FACES ENTRE PILARES (EXTREMIDADES DO PLANO ESTRUTURAL) E VOLTADAS PRINCIPALMENTE PARA AS ORIENTAÇÕES NOROESTE E SUDOESTE, PRINCIPAIS VISUAIS. O EFEITO DE DESALINHAMENTO E DE CERTO MODO "BAGUNÇADO" INDETERMINA O USO INTERNO DESDE O EXTERIOR.

VILA TAGUAÍ
AMPLAS ABERTURAS NA FACE NORDESTE ENTRE EMPENAS, E ABERTURAS PEOUENAS E ISOLADAS NAS EMPENAS ESTRUTURAIS. FACHADAS MOSAICOS, OU ABERTURAS ISOLADAS, COLABORAM COM A INDETERMINAÇÃO DO USO INTERNO DESDE O EXTERIOR.
AS CORES DA FACHADA SÃO DOS PRÓPRIOS MATERIAIS, SEM PINTURA (COM EXCEÇÃO DA CAIXILHARIA QUE É NA COR CINZA): CONCRETO DAS VIGAS, VIDRO E TONS MADEIRADOS DAS PLACAS HDF (4 TONALIDADES);

ACABAMENTO: FACES EXTERNAS DO MONOBLOCO BRUTO SÃO RUGOSAS E MAIS RÚSTICAS; QUANDO ESCAVADAS, AS SUPERFÍCIES RESULTANTES SÃO LISAS E BRANCAS. NA ENTRADA, A SUPERFÍCIE RESULTANTE DA “ESCAVAÇÃO” É REVESTIDA COM MADEIRA.

PALETA DIVERSIFICADA DE MATERIAIS: FACES SUDOESTE E NOROESTE USA-SE O REVESTIMENTO CERÂMICO, MANTEM-SE O CONCRETO APARENTE NOS PANOS ESTRUTURAIS. BRISES EM MADEIRA E A COR VERMELHA DESTACA O EDIFÍCIO NA PASIAGEM.

HÁ O PREDOMÍNIO DE QUATRO TIPOS DE MATERIAIS APARENTES NO EXTERIOR: CONCRETO, TIJOLO DE BARRO, VIDRO E MASSEAMENTO BRANCO. NO EDIFÍCIO POSTERIOR, PREDOMINA O ACABAMENTO EM TIJOLINHO, E NO FRONTAL, O CONCRETO.

AS CORES VERMELHA E AMARELA DESTACAM OS DOIS SÓLIDOS: UM SOLTO DO CHÃO E OUTRO APOIADO NO MESMO.

PINTURA EXTERNA DOS PAINÉIS (FUGIR IMAGEM DEPRECIATIVA DO TIJOLO APARENTE), ENXERGA-SE OS "VINCOS" DA CERÂMICA. UMA COR PARA CADA RENQUE DE CASAS - VERDE, AZUL E AMARELO, E PARA O VOLUME DA BASE, "COR DE TERRA". COR LARANJA DO BLOCO ESTRUTURAL PIGMENTADO MARCAM AS EMPENAS. PARA O CASO DAS FACES ENTRE AS EMPENAS, AS FAIXAS NAS CORES LARANJA (PEITORIL EM ALVENARIA), O CONCRETO DAS VIGAS E OS AMPLOS CAIXILHOS EM MADEIRA FICAM ENTRE AS DUAS FAIXAS VERTICAIS LARANJAS DAS EMPENAS. PREDOMÍNIO DA COR BRANCA (FULGET), MADEIRA NOS DETALHES E MUITO VERDE REFERENTE AO PAISAGISMO.

PREDOMIINIO DA MADEIRA ASSOCIADO À TRANSPARÊNCIA DO VIDRO E O VERDE DA MASSA ARBÓREA EXISTENTE. 
ORIENTAÇÃO / CONFORTO AMBIENTAL

A SITUAÇÃO DO LOTE URBANO ACABOU DETERMINANDO A FACE MAIS PRIVILEGIADA, VOLTADA PARA ARVOREDO, E NÃO A ORIENTAÇÃO. A FACE NOROESTE FICA COMPROMETIDA PELA

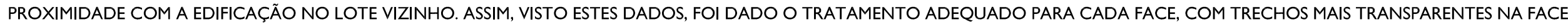

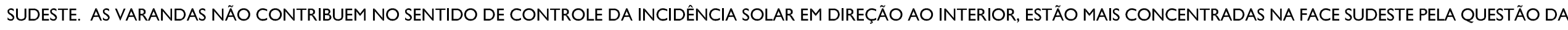

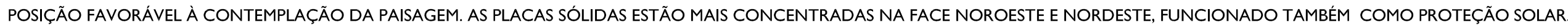

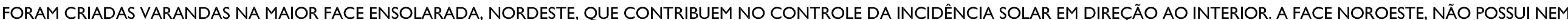

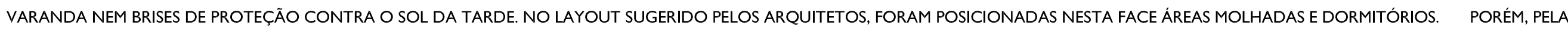

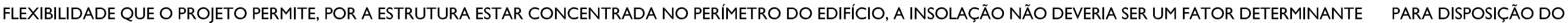
PROGRAMA NA UNIDADE, ISTO QUER DIZER, NUMA PROPOSTA FLEXÍVEL, O ESPAÇO INTERIOR DEVE ESTAR PREPARADA PARA AS MAIS DIVERSAS ATIVIDADES.

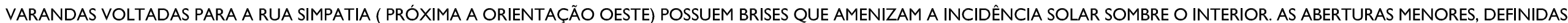

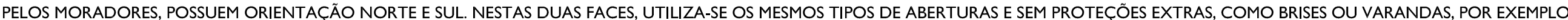
NESTE CASO A FACE NORTE FICA UM POUCO DESPROTEGIDA, PORÉM, OPTOU-SE POR ABERTURAS MENORES, O QUE PROPICIA MENOS INCIDÊNCIA SOLAR.

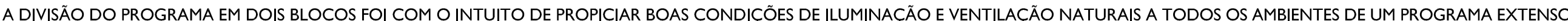

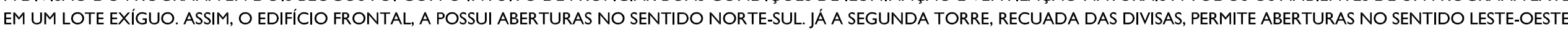

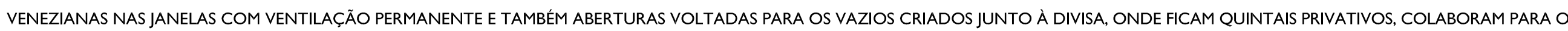
CONFORTO AMBIENTAL DAS UNIDADES HABITACIONAIS.

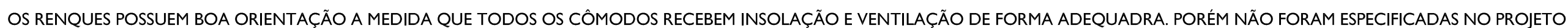
NENHUM TIPO DE PROTEÇÃO CONTRA A INSOLAÇÃO OU CHUVA PARA AS FACES SUDOESTE E NORDESTE. O LAJÃO COBERTO É UM LOCAL PROTEGIDO CONTRA O SOL E, QUE RECEBE VENTILAÇÃO CRUZADA MUITO AGRADÁVEL.

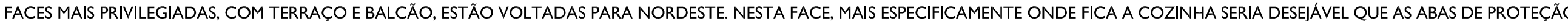
SOLAR FOSSEM MAIOR, POIS A COZINHA ACABA FICANDO UM POUCO DESPROTEGIDA.

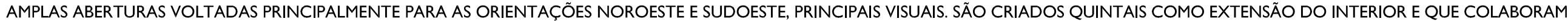
PARA O CONFORTO TÉRMICO DO INTERIROR, JÁ QUE AMORTECE A INCIDÊNCIA SOLAR DIRETA. 
É possível destacar o conceito da envoltória de cada projeto, conforme colocado abaixo:

- Fidalga 772: a envoltória é a mediadora do interior para o exterior e vice-versa. Ao mesmo tempo em que revela desde o ambiente interior a cidade, pelo tamanho das aberturas e grandes trechos transparentes, ela indetermina desde o exterior os ambientes e suas funções

- Simpatia 234: variação de materiais e cores torna o edifício marcante na paisagem

- Fiori di Maggio: Sistema estrutural baliza a envoltória;

- Vila Pedro Fachini: "bloco vagonar"4 marcado pelo ritmo das aberturas variadas;

- Canaã: fachada guiada pela malha dos painéis estruturais;

- Vila Butantã: fachada guiada pelas empenas estruturais;

- Vila Fidalga: fachada do conjunto desalinhada e acomodada à topografia acidentada;

- Vila Taguaí: empenas travam a estrutura e liberam faces para amplas aberturas.

Foi possível identificar também, uma situação pouco usual, efeito de "aleatoriedade" das aberturas na fachada, consequência do atendimento personalizado para cada cliente. No Simpatia 234 (Figura 06), foi dada a possibilidade do cliente decidir a posição e ritmo dos caixilhos nas faces noroeste e sudeste. Este efeito ocorre também em outro empreendimento da Idea!Zarvos, Ourânia (Figura 07), do arquiteto Gui Mattos. As “janelinhas”, conforme colocado por Guto Requena, nestes dois casos, possuem movimento.

Nesta amostra de soluções habitacionais contemporâneas paulistas, não existem exemplares onde a superfície externa se desliga por completo da estrutura, por exemplo, como acontece no edifício em Barcelona, “Illa de La Llum” do escritório Clotet I Paricio Associats, com painéis de fechamentos de laje a laje e com possibilidade de transformações na fachada, já que as varandas, extensão do espaço interior, recebem persianas móveis que possibilitam transformações na envoltória (Figura 08).

\footnotetext{
${ }^{4}$ Expressão criada pelos autores do projeto, Macelo Barbosa e Jupira Corbucci para caracterizar o volume concebido.
}

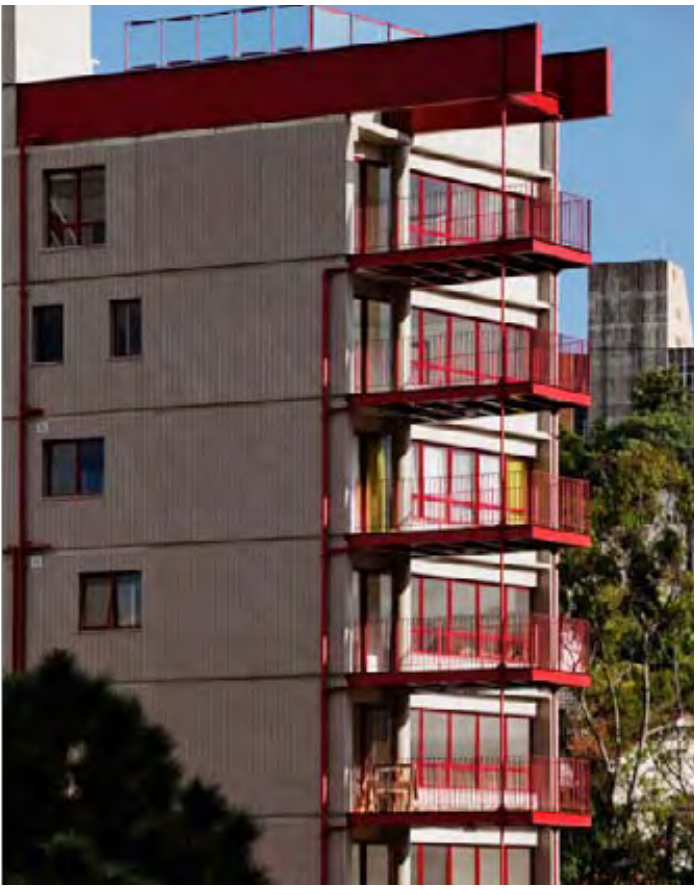

Figura 6 - Efeito "aleatório", no Simpatia 234.

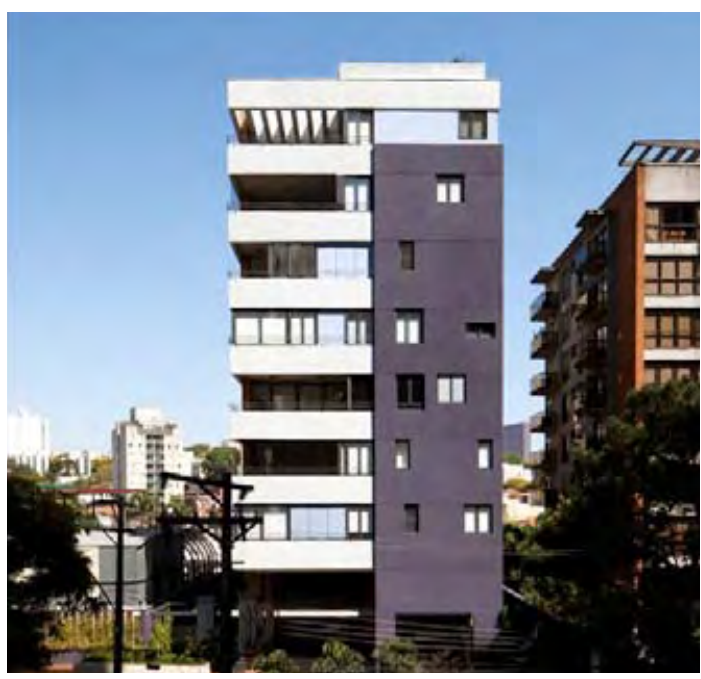

Figura 7 - Efeito “aleatório”, no Ourânia. 


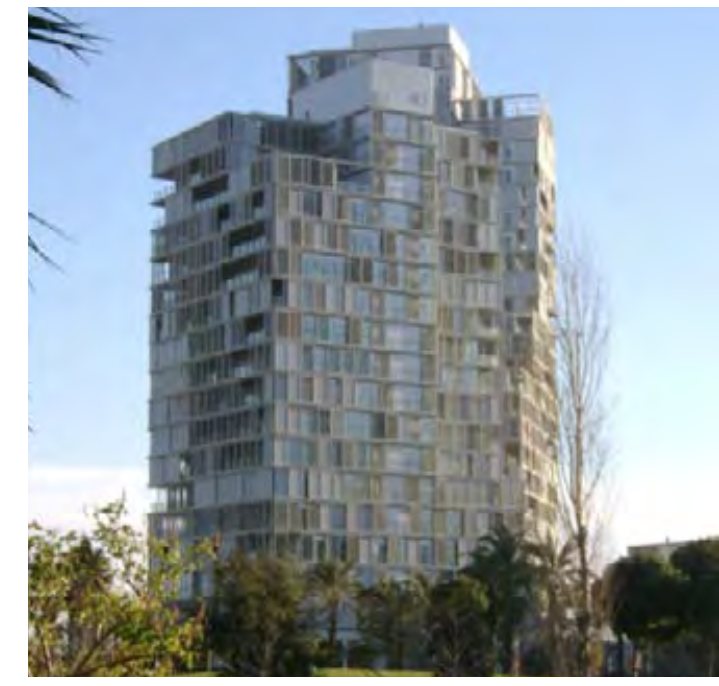

Figura 8 - "Illa de La Llum", do escritório Clotet I Paricio Associats, Barcelona, Espanha.

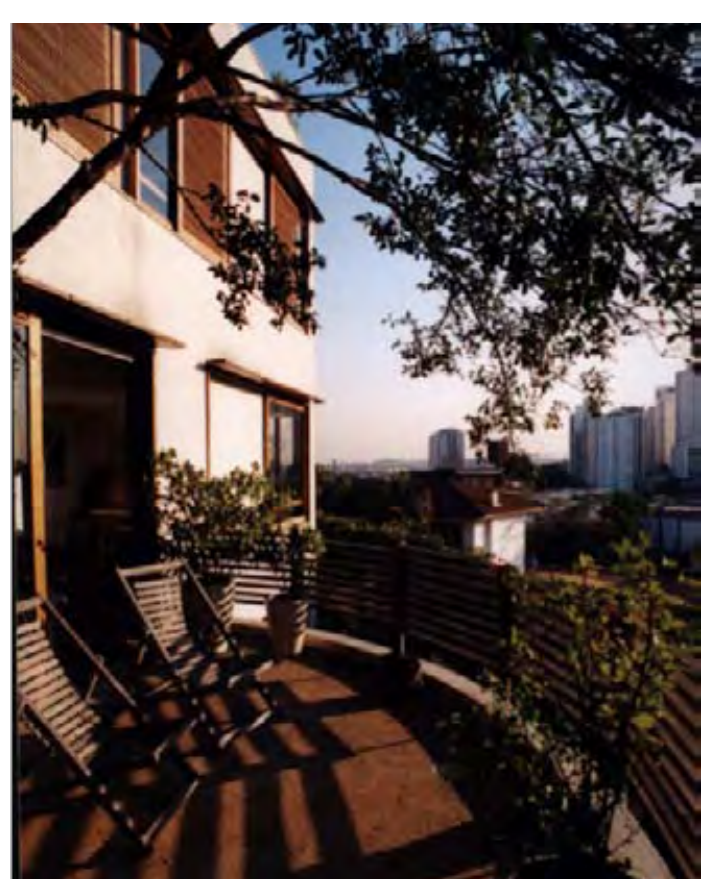

Figura 9 - Vila Fidalga.
Porém, existem diversas maneiras de adquirir contato com o ambiente externo, por exemplo, a partir de elementos que transmitem um contato positivo do edifício com o meio exterior, como, as próprias aberturas, as varandas, as cores e materiais utilizados.

Os projetos analisados possuem identidade própria, ou seja, cada um tem uma característica peculiar que os tornam diferenciados. Isto não significa ser destaque na paisagem, um exemplo é a Vila Fidalga, que é diferenciado por estar acomodada de modo sutil na paisagem (Figura 09), já o Simpatia 234 se destaca mais, pelos tons coloridos que o acompanha. São diferenciados pois não se enquadram na mesmice que o mercado imobiliário costumar oferecer, já que foram identificadas diversas soluções com formas, cores, materiais e ritmos diferentes. 
BAHAMÓN,A.; SANJINÉS, M. C. Alta densidad: Vivienda Contemporánea. Barcelona: Parramón ediciones, 2008.

COLQUHOUN,A. Aspectos simbólicos y literales da tecnología. Em:Arquitectura Moderna y Cambio Histórico: ensayos 1962 1976. Barcelona:Gustavo Gilli, 1978, páginas 28-33. (Versão original, inglês, 1962)

COMAS, Carlos Eduardo Dias. O espaço da arbitrariedade. Revista Projeto, n. 91, p. I27-130, setembro de 1986.

GÜIRALDES, Pablo.A matemática da torre ideal. Sobre as colunas duplas nas torres residenciais de Mario Roberto Álvarez. SUMMA+, Buenos Aires, n.I I3, p.20-3I, fevereiro. 20 II.

IMECMG (Instituto Mineiro da Engenharia Civil). Alvenaria estrutural. Entrevista com Carlos Alberto Tauil, 02 de maio de 201 I. Disponível em:< http://www.imecmg.org.br>.Acesso em: 23/01/2013.

MONTANER, J. M.; MUXÍ, Z. M. Habitar el Presente. Vivienda en España: Sociedad, ciudad, tecnología y recursos. Madri: Ministerio de Vivienda, 2006.

REQUENA, Guto.Arquitetura feia, cidade doente. Desenho de São Paulo é entediante; faltam políticas e concursos que incentivem ideias e jovens escritórios. Folha de São Paulo, São Paulo. 13 de janeiro de 2013. Disponível em: <http://wwwl.folha.uol.com.br/fsp/imoveis/88267-arquitetura-feia-cidade-doente.shtml>.Acesso em 14/01/2013.

SEGAWA, H. Marcos Acayaba, delineador de estruturas. Em: Marcos Acayaba. São Paulo: Cosac Naify, 2007.

PARICIO, Ignacio. La piel ligera. Maduración de uma técnica constructiva. Barcelona: Editorial ACTAR D, 20 I0.

PROJETODESIGN.A reação ao neoclássico e a promessa para o futuro. São Paulo, n.37I, p. 89, janeiro de 201 I. 


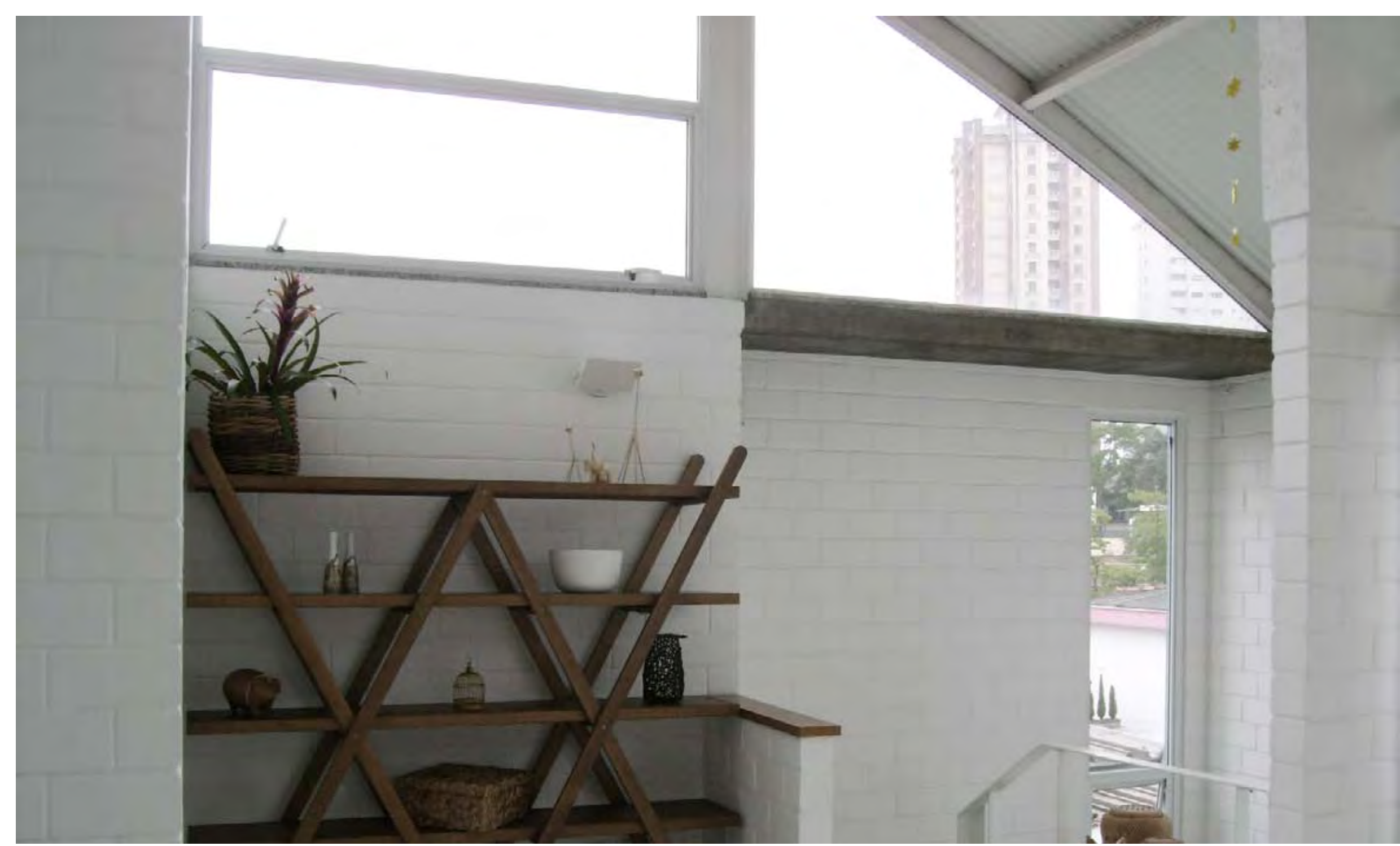

4. ANÁLISE COMPARATIVA E CONSIDERAÇÕES FINAIS POR TEMAS PRESENTES NOS PROJETOS SELECIONADOS 4.4 UNIDADE HABITACIONAL 
Com o objetivo de expor de modo claro e objetivo as soluções diversificadas presentes nos projetos em análise, relacionadas ao projeto da tipologia da unidade habitacional, houve o trabalho de redesenho das plantas das unidades, exposição de suas diversas formas de agrupação em planta ou em corte, e destaque de outros elementos relevantes que demonstram soluções projetuais não apenas congruentes, como também, em alguns casos, pouco usuais. Também com base nas leituras específicas de cada projeto, foi elaborada uma tabela síntese comparativa dividida por temas principais correlacionados, as incógnitas principais específicas a ver na sequência:

I. Multiplicidade tipológica versus repetição tipológica; variações nos tamanhos versus unidades habitacionais com mesmo tamanho; ausência de pavimento-tipo ou ausência de implantação com casas idênticas enfileiradas versus pavimento-tipo; implantação com casas idênticas enfileiradas;

2. Distribuição do programa em planta e graus de flexibilidade e adaptabilidade;

3. Unidades habitacionais com grandes proporções de espaço exterior próprio;

4. O posicionamento da escada (circulação vertical) nas unidades habitacionais com mais de um pavimento;

5. Possibilidade de ampliação das unidades habitacionais.

I. MULTIPLICIDADE TIPOLÓGICA VERSUS REPETIÇÃO TIPOLÓGICA; VARIAÇÕES NOS TAMANHOS VERSUS UNIDADES HABITACIONAIS COM MESMO TAMANHO;AUSÊNCIA DE PAVIMENTO-TIPO OU AUSÊNCIA DE IMPLANTAÇÃO COM CASAS IDÊNTICAS ENFILEIRADAS VERSUS PAVIMENTO-TIPO; IMPLANTAÇÃO COM CASAS IDÊNTICAS ENFILEIRADAS; 
A multiplicidade tipológica, ou seja, o projeto de diferentes tipologias num mesmo edifício ou conjunto residencial apareceu com mais intensidade nos seguintes projetos: Fidalga 772, Fidalga 897, Vila Pedro Fachini e Vila Fidalga.

Os projetos com maior variação no tamanho das unidades, ou seja, com unidades de diversos tamanhos num mesmo edifício ou conjunto residencial, incluindo o espaço exterior próprio, foram: Fidalga 772,Vila Fidalga e Simpatia 234, neste último, devido às unidades de cobertura. As variações de tipologias e tamanhos podem permitir não apenas acomodar diferentes perfis de famílias num mesmo empreendimento como também favorecer a presença de famílias com quantidade de membros ou poder aquisitivo variados dentro de um mesmo edifício ou conjunto residencial.

Uma edificação com ausência de pavimento-tipo (no caso da categoria com "unidades habitacionais sobrepostas"), ou uma implantação sem casas idênticas enfileiradas (no caso dos "conjuntos horizontais"), divergem dos padrões de agrupamentos de unidades habitacionais recorrentes. $\mathrm{Na}$ solução com ausência de pavimento-tipo, não existe a estratificação horizontal, com várias camadas iguais referentes ao agrupamento de pavimentos-tipos idênticos, situação que normalmente ocorre nos projetos, nos quais existem praticamente quatro tipos de plantas dos pavimentos: subsolo, térreo, pavimento-tipo e ático.

Diferentemente, o corte é pouco regular e com variações nos pés-direitos das unidades, entre outras características específicas do projeto. Esta solução ocorre nos projetos: Fidalga 772, Fidalga 897 e Vila Pedro Fachini.

Na solução sem casas idênticas enfileiradas, as unidades são agrupadas sem uma sequência lógica repetitiva, e sem multiplicação de elementos iguais. Esta característica ocorre no projeto Vila Fidalga. Nestas duas soluções descritas, de ausência de pavimento-tipo e sem casas idênticas enfileiradas a pouca repetição de tipologias e a variedade nos tamanhos das unidades são presentes. Por exemplo, no Fidalga 772, a unidade habitacional é um casco ou "carcaça vazia"', com variações de forma e área útil, através de adições ou subtrações dentro de um mesmo perímetro ou contorno do pavimento. 
Os arquitetos Andrade Morettin inclusive tiveram a ideia de criar a possibilidade de vender o espaço e não a unidade, em decorrência desta situação de indeterminação do interior. Estas unidades diferentes umas das outras, possuem variações no pé-direito e também intercalam hall de acesso à unidade individual e coletivo, situações que contribuem para a ausência de pavimento-tipo idêntico. Diferentemente, no Simpatia 234, duas tipologias formam a planta do pavimento que se repete cinco vezes na edificação, sendo diferente apenas os pavimentos referentes às coberturas ou o pavimento onde está implantada a unidade do zelador.

Na Vila Pedro Fachini existem praticamente duas tipologias, térrea e dúplex, sem grandes variações das áreas totais (entre 30 e $40 \mathrm{~m}^{2}$ aproximadamente), exíguas por se tratar de habitação de interesse social e também pela própria exigência da COHAB pelo maior número de unidades possíveis. As tipologias térreas possuem maior espaço exterior próprio, e possuem apenas um dormitório, sendo mais indicadas, para idosos ou pessoas que possuem animal doméstico, por exemplo. As unidades dúplex apresentam a área interna maior e possuem, em sua maioria, dois dormitórios com possibilidade de demolição da parede de separação entre eles. Dentro das limitações de tamanho, a variação tipológica permite atendimento a grupos de moradores com diferentes perfis.

Dentre os estudos de casos em análise, o Fidalga 897 foi o primeiro a oferecer aos clientes a possibilidade de personalização das unidades, conceito que permaneceu nos empreendimentos da Idea!Zarvos nos projetos subsequentes a este, porém com outra tática, da planta totalmente livre, como já citado nas leituras específicas dos projetos Fidalga 772 ou Simpatia 234. No caso do Fidalga 897, os usuários opinaram e participaram da definição da planta interna do apartamento, dentro de um limite pré-estabelecido pelo projeto global arquitetônico, do mesmo modo que ocorreu no projeto da Vila Fidalga, porém, de modo menos eficaz que na vila, já que os desejos individuais conseguiram algumas vezes exceder os limites previstos no próprio projeto arquitetônico, por exemplo,

' BAROSSI (20I0). 
ampliando indevidamente áreas privativas nos espaços definidos como coletivos no projeto. A variação tipológica, com mesclas de unidades dúplex e térreas no Fidalga 897, é uma determinação do projeto global, com base nas condições do lote, principais vistas, orientação, melhores condições de ventilação etc.

Do mesmo modo, no caso da Vila Fidalga, as seis tipologias diferentes foram decorrentes da boa compreensão da topografia, principais vistas, dos acessos, das orientações, entre outros aspectos importantes, e para limitar os desejos individuais sobre o espaço coletivo, os espaços exteriores foram bem definidos com um projeto capaz de "balizar" os espaços privativos, conforme explicado na leitura específica da Vila Fidalga. Assim, tratam-se de duas coisas diferentes: uma é a definição da "carcaça" das unidades habitacionais, diferentes pelo próprio limite com o exterior como também pela inserção no conjunto; e outra é a arquitetura do interior, situações que preferencialmente devem estar correlacionadas e resolvidas dentro do conjunto do projeto arquitetônico como um todo, e não possuir um projeto do interior a parte.

Os projetos da Cristina Xavier são diferentes nos dois sentidos. A questão de o interior ser definido pelo arquiteto conjuntamente com o morador, é um artifício de mercado, para venda das unidades, e exige maior investimento no atendimento, porém, com obtenção de resultados positivos.

O conceito da alta flexibilidade do interior proposta pela Idea!Zarvos é também apoiado na crença de que unidades com possibilidade de personalização são mais desejadas, porém, existe também a questão do investimento alto nas instalações, que são multiplicadas, e ocorre, em alguns casos, a definição do interior da unidade pela equipe de arquitetura da própria incorporadora, e não pelo escritório de arquitetura que concebeu o projeto.

Se o Fidalga 772 consegue eliminar a monotonia da repetição do pavimento-tipo idêntico e a estratificação horizontal típica (na categoria “unidades habitacionais sobrepostas”), o Fidalga 897, também foge da situação de casas idênticas sobrepostas (na categoria "duas unidades habitacionais sobrepostas”), e a Vila Fidalga cria uma alternativa para a situação típica de casas idênticas enfileiradas em 
conjuntos horizontais. Os três exemplos citados, não repetem tipologias e possuem variações nos tamanhos das unidades.

Os outros projetos, mais comuns dentro destas incógnitas, também possuem qualidades. Por exemplo, a Vila Butantã ou o próprio conjunto Canaã, mesmo com repetição das unidades, não chegam a representar estruturas lineares monótonas, pela própria maneira como os elementos mesmo repetidos são implantados no terreno, com deslocamentos entre unidades no sentido vertical e horizontal e criação de jardins ou reentrâncias que permitem uma transição suave entre o espaço coletivo e privativo das unidades:

\begin{abstract}
O grande potencial da casa geminada, como um tipo arquitetônico, reside em suas vantagens econômicas. $O$ princípio da adição, simples e racional, possibilita a edificação de um grande número de unidades residenciais em pouco tempo.Além disso, a junção das casas possibilita uma relação bem equilibrada entre espaço habitável, superfície e volumetria, gerando características muito vantajosas em termos de eficiência energética. Quando as áreas de circulação são projetadas de forma inteligente, a tipologia "casa geminada" possibilita múltiplas formas de acréscimo ou de subtração de unidades residenciais. (PFEIFER; BRAUNECK, 2009, p. 16).
\end{abstract}

Desse modo, soluções com ausência de pavimento-tipo ou sem casas idênticas enfileiradas, representam opções menos usuais, porém, não anulam outras soluções existentes. Temos bons exemplos nesta pesquisa da aplicação de diversas opções.

\title{
2. DISTRIBUIÇÃO DO PROGRAMA EM PLANTA E GRAUS DE FLEXIBILIDADE EADAPTABILIDADE
}

Existe diferença em dizer que uma planta é flexível ou dizer que é adaptável. Flexibilidade está relacionada à capacidade da solução estrutural e das instalações em liberar espaço no interior da unidade ou à utilização de elementos de divisão interna que não se tornem barreiras na 
transformação do espaço interior, ou seja, situações que permitam um alto grau de transformação no interior da unidade.

Já no caso da capacidade de adaptabilidade, esta se refere a transformações mais leves, ou seja, mudanças na distribuição do programa sem necessariamente ter que fazer uma verdadeira reforma, pode-se mudar de posição determinados itens do programa ou ampliar alguns ambientes, de modo mais simples e menos definitivo.Abaixo algumas citações que podem esclarecer esta diferença:

Adaptabilidade: capacidade de adaptação conforme o contexto e conforme as necessidades e preferências do usuário. Capacidade de adaptação às mudanças na distribuição, que podem ocorrer durante a vida útil do edifício, motivadas pela evolução temporal de diferentes situações familiares ou apenas pela troca de ocupantes/moradores. Relaciona-se com mudanças ou alterações do espaço imediatas e temporárias, que não envolvem grandes transformações. (MONTANER, et al; 2012, p. 188).

Flexibilidade: este conceito é mais amplo do que o da adaptabilidade, não se limitando a transformações imediatas ou temporárias. Dentre os itens que oferecem maior flexibilidade a um projeto, podemos destacar: solução estrutural que possibilite gerar vãos maiores, fachadas com modulação equidistante ds aberturas, utilização de elementos móveis e a posição das instalações de maneira que facilite seu acesso e manutenção. Com relação à distribuição dos interiores, a flexibilidade pode ser alcançada com a utilização de paredes ou divisórias mais leves, forro ou piso elevado por onde podem passar as instalações, oferecendo maior liberdade para ocupação e transformação. (MONTANER, et al; 20I2, p. I88).

A citação de Schneider (2006) a seguir é titulada de "Espaços de uso neutro", que não deixa de ser espaços com possibilidade de adaptabilidade, conforme pode ser observado:

Esta concepção não modifica o apartamento para ir ao encontro de novos desejos (como nas plantas flexíveis), mas sim modifica o uso em si dos espaços. Devido ao fato de os espaços não determinarem pelo seu tamanho, forma ou inter-relação, de que maneira eles deveriam ser utilizados, ampliam-se as possibilidades de 
exemplos de uso para uma mesma planta. (...) Os espaços necessitam de determinados tamanhos e proporções para poderem preencher estes requisitos, sendo ainda melhor um sistema de acessos independentes. Como conseqüência, tem-se um aumento das áreas de corredores e unidades espaciais, de tal forma que as melhores soluções desta tipologia encontram-se em prédios de apartamentos de classe alta. Recentemente têm sido criados espaços com caráter de uso neutro, desenvolvidos com freqüência dentro de sistemas esquemáticos, quase gráficos de projeto: um sistema estrutural ou uma superfície em planta são distribuídos em um determinado número de campos (compartimentos) de igual tamanho ou diferenciados, que podem ser ocupados com diferentes funções (cozinha, banheirol closets, dormitórios, sala de estar ou áres livre). (SCHNEIDER, 2006, p. 38).

Com relação à resolução do interior da unidade habitacional, foram identificadas no conjunto de projetos, algumas situações descritas abaixo, entre elas, aparece o tipo de unidade habitacional com capacidade de flexibilidade total ou parcial, a ver na sequência:

a. Sem distribuição do programa em planta: alta flexibilidade inicial;

b. Distribuição do programa em planta pelo arquiteto conjuntamente com o cliente: alta personalização das unidades;

c. Flexibilidade parcial em alguns cômodos;

d. Pouca possibilidade de mudança na distribuição do programa.

\section{a. SEM DISTRIBUIÇÃO DO PROGRAMA EM PLANTA:ALTA FLEXIBILIDADE INICIAL}

Esta situação é a que fica mais nítida nos desenhos, e foi identificada nos seguintes projetos: Fidalga 772 e Simpatia 234. Representa a situação da "carcaça" vazia, com multiplicação das prumadas com as instalações e pilares predominantemente no perímetro da planta, permitindo diversos tipos de layouts internos e favorecendo grandes transformações futuras das unidades. 


\section{b. DISTRIBUIÇÃO DO PROGRAMA EM PLANTA PELO ARQUITETO CONJUNTAMENTE COM O CLIENTE:ALTA PERSONALIZAÇÃO DAS UNIDADES}

Esta situação foi identificada nos seguintes projetos: Fidalga 897,Vila Fidalga e Fiori di Maggio. A situação de flexibilidade ou não é relativa, depende muito da definição do sistema estrutural, posição das áreas molhadas e instalações, assim, o que ocorre é a personalização, ou seja, a distribuição do programa em conformidade com desejos individuais, porém, dentro daquilo que o projeto arquitetônico permite. A personalização é efetivamente favorecida nestes casos, pois ainda em fase de projeto, algumas possibilidades para o interior da unidade são discutidas com o arquiteto.

$\mathrm{Na}$ Vila Fidalga, por exemplo, o projeto arquitetônico permite flexibilidade parcial já que a estrutural é concentrada no perímetro das unidades e na caixa de escada, que concentra shafts com as instalações. Assim, algumas definições das áreas molhadas puderam seguir as necessidades ou desejos dos moradores, desde que ficassem em local próximo aos shafts com as instalações. $O$ Fiori di Maggio é uma situação ainda mais peculiar, já que todo projeto e não apenas do interior da unidade, foi concebido conjuntamente com o cliente. Também permite flexibilidade parcial, em espaços liberados de estrutura e instalações.

\section{c. FLEXIBILIDADE PARCIAL EM ALGUNS CÔMODOS}

Esta situação foi identificada nos seguintes projetos: Unidades dúplex Vila Pedro Fachini,Vila Butanã,Vila Taguaí e Vila Maida. Na Vila Pedro Fachini, foi criada a possibilidade de unir dormitórios; na Vila Butantã, os cômodos com paredes estruturais, áreas molhada ou caixa de escada, estão concentrados mais ao centro da planta, deixando as extremidades livres, e possuem largura suficiente $(5,80 \mathrm{~m})$ para acomodar até dois quartos em cada extremidade. A Vila Maida, concentra as áreas molhadas e a caixa de escada numa extremidade deixando a outra livre. 
Esta situação pode ser comparada com a da Vila Taguaí: as paredes do perímetro são estruturais, e no interior, as áreas com instalações hidráulicas e caixa de escada são concentradas numa extremidade, para liberação da outra extremidade da planta. É possível notar que, a posição da escada é relevante nestes projetos onde o programa é agenciado em andares.

\section{d. POUCA POSSIBILIDADE DE MUDANÇA NA DISTRIBUIÇÃO DO PROGRAMA}

Esta situação foi identificada nos seguintes projetos: unidades térreas e algumas dúplex da Vila Pedro Fachini, Canaã e unidades destinadas aos zeladores, do Fidalga 772 e Simpatia 234. A pouca possibilidade de mudança na distribuição do programa, ou pouca flexibilidade e também adaptabilidade, está relacionada ao tamanho exíguo das unidades habitacionais, à definição do sistema estrutural e técnica construtiva, e pode ser decorrente também da própria posição da escada e formato da tipologia. Por exemplo, a Vila Maida, possui metragem quadrada do pavimento similar a do projeto Canaã $\left(\sim 25 \mathrm{~m}^{2}\right)$.

Pelo formato mais quadrangular (resultante da subtração dos recuos e divisão do espaço remanescente do lote por três unidades), optou-se por encostar a escada em uma das extremidades, liberando assim, espaço sem parede estrutural no trecho oposto. Para o caso do Canaã, com formato da planta mais profunda do que larga, a posição da área molhada no centro da planta, permite atendimento a dois dormitórios sem necessidades de grandes corredores de circulação.

Porém, não permite a junção dos dormitórios, já que existe um banheiro entre eles. De qualquer modo, dificilmente um dormitório seria suficiente para o perfil de família que mora no Canaã, no geral, famílias tradicionais com pais e filhos. Já para o caso da Vila Maida, a situação é bemvinda, já que em duas unidades moram casais sem filho(s), e em apenas uma mora uma família mais tradicional. Para o caso da Vila Fachini, a questão do lote pequeno acabou levando os arquitetos a terem outras prioridades, por exemplo, de criar vazios junto à empena da construção vizinha para 

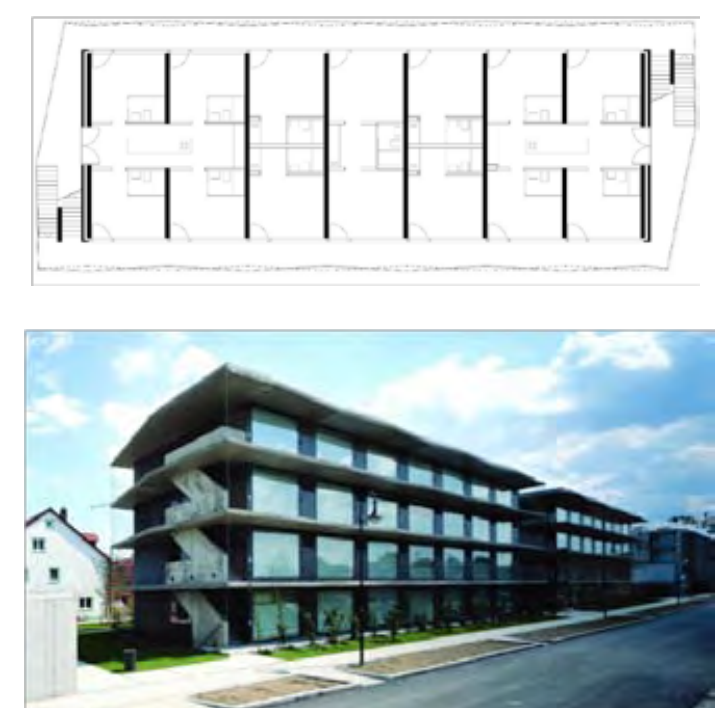

Figura I - Na busca por unidade com as características marcantes do conceito de adaptabilidade, foi encontrado alguns exemplos no livro DBOOK (2007), entre eles, um projeto para moradia estudantil, Garching Bei Munchen, do escritório FINK+JOCHER. melhorar o conforto térmico das unidades. As paredes estruturais, fundamentalmente tiveram que estruturar estes vazios, que geraram recortes na planta, deixando-a pouco flexível e adaptável. Assim, com relação à distribuição do programa em planta e graus de flexibilidade e adaptabilidade, para cada situação de projeto, pode ser adotada uma postura diferente com relação à adoção ou não da flexibilidade, um projeto bom, não precisa ser necessariamente flexível.

Por exemplo, o projeto de Joan Villà e Sílvia Chile, Canaã, possui pouca flexibilidade do espaço interior, porém, a distribuição dos cômodos e suas áreas são adequadas: os dormitórios possuem tamanhos similares; o banheiro não privilegia mais uma unidade do que outra, já que está entre os dois dormitórios; a cozinha é ampla e integrada à sala e ao espaço exterior próprio; e a unidade ainda conta com um terraço coberto, para realização das mais diversas atividades. A unidade atende aos moradores muito bem, mesmo sem flexibilidade.

As soluções altamente flexíveis, como as dos projetos da Idea!Zarvos acabam sendo muito caras, e, portanto, as vantagens de sua utilização, podem ser em alguns casos, duvidosas.

Já a adaptabilidade ainda é uma questão relativa e que gera dúvidas, pois pelo que parece não se trata apenas da unidade dar condições para a adaptação nas diversas trocas de usuário, depende também do grau de facilidade para ocorrer esta adaptação. Assim, quanto mais neutros forem os espaços, com tamanhos iguais, aberturas equidistantes, banheiros sem beneficiar mais um cômodo do que outro, sem tipos de dormitórios para crianças ou para casal, sem sala íntima ou sala de receber visitas, enfim, uma unidade habitacional sem espaços hierarquizados, como ocorre parcialmente na Vila Maida, por exemplo, pode facilitar uma melhor adaptabilidade dos mais diversos tipos de moradores.

Porém, há situações que exigem maior necessidade deste atributo do que outras, em situações nas quais ocorre maior rotatividade de moradores, por exemplo (Figura I). 


\title{
3. UNIDADES COM GRANDES PROPORÇÕES DE ESPAÇO EXTERIOR PRÓPRIO
}

Em alguns projetos, por exemplo, no Fidalga 772, Simpatia 234, Vila Fidalga, Canaã e Vila Taguaí, algumas unidades possuem metragem quadrada de espaço exterior próprio que ultrapassa $35 \%$ da metragem total da unidade (espaço interior + espaço exterior). São as unidades-casas ou unidades de cobertura, para o caso do grupo "unidades habitacionais sobrepostas"; e para o caso dos conjuntos horizontais, aquelas unidades com grandes quintais ou, como é o caso do Canaã, com presença de terraço coberto e aberto nas laterais. Este assunto já foi abordado no texto sobre o tema “Expaços Exteriores”, porém aqui é destacada sua relação e proporção em relação ao espaço interior da unidade, e não com o espaço exterior coletivo.

\section{O POSICIONAMENTO DA ESCADA (CIRCULAÇÃO VERTICAL) NAS UNIDADES COM MAIS DE UM PAVIMENTO}

\begin{abstract}
A posição e o tipo da escada são de grande importância quando examinamos os tipos de planta de uma casa geminada. Uma posição central na planta garante a redução da área de circulação nos pavimentos superiores. Amplos espaços de acesso podem substituir as áreas de circulação monofuncionais. Espaços que tenham algum caráter coletivo são a melhor opção: escritórios e ateliês, cozinhas ou cômodos multifuncionais. Escadas de meio nível, com patamares que se abrem para cômodos adjacentes, também podem contribuir para eliminar áreas exclusivas de circulação, criando, simultaneamente, um continuum espacial através dos vários pavimentos. (PFEIFER; BRAUNECK, 2009, p. I7).
\end{abstract}

Algumas situações relacionadas à posição da escada já foram mencionadas ao longo desta pesquisa, e inclusive neste texto, como a comparação da Vila Maida e Canaã. Assim, com o objetivo de deixar evidente algumas situações projetuais interessantes decorrente da posição da escada, primeiramente identificou-se as situações existentes nos projetos em análise: 
a. Em plantas com formato retangular (uma dimensão mais profunda do que larga):

Escada longitudinal interna:Vila Taguaí, Fidalga 897 (cobertura 04), e Fidalga 772 (lofts $4 \mathrm{I}$ e $5 \mathrm{I}$ );

Escada longitudinal externa: Canaã;

Presença de mais de uma escada longitudinal; Fidalga 897 (cobertura 03);

$\square$ Escada transversal:Vila Butantã;

Escada dentro do vazio: Fidalga 897 (cobertura 09 e 10).

b. Em plantas com formato quase quadrangular (duas dimensões parecidas):

Escada tangenciando duas faces da planta: Simpatia 234 (coberturas), Fidalga 897 (dúplex 05 e 06), Vila Fachini,Vila Fidalga (casa 05) e Vila Maida;

Escada tangenciando uma face da planta: Fidalga 897 (dúplex 07 e 08) e Vila Fidalga (casa 02, 03 e 06);

Escada em posição mais centralizada:Vila Fidalga (casa $0 \mathrm{l}$ e 04).

c. Em plantas com formato irregular:

Escada dentro de vazio: Fidalga 772 (unidade- casa 0 le 02 e cobertura II e I2);

Escada tangenciando vazio: Fidalga 772 (loft 06 e 09). 
Destacando algumas situações mais interessantes, podemos citar a solução da escada longitudinal externa do Canaã, que permite algumas explicações. De início, pela questão da malha estrutural, foi preferível ficar como um elemento à parte, externo, para não "pertubar" a modulação da laje pré-fabricada em painel cerâmico. Também, existe a possibilidade de estar posicionada logo à frente da entrada, situação muito encontrada e desejada nos bairros populares das periferias, nos quais, mesmo quando se constrói a casa inteira, considera-se a hipótese de futuras situações de recebimento temporário de filhos ou parentes que venham por ventura a morar na casa.

A posição da escada garante possível isolamento dos pavimentos superiores e criação de verdadeiras casas sobrepostas (caso tivesse banheiro em todos os andares), não deixando de ser uma situação de adaptabilidade. Esta escada, devido à sua posição, permite chegada individual a todos os pavimentos: térreo, primeiro e terraço.

$\mathrm{Na}$ Vila Butantã, a posição transversal da escada conjugada com as áreas molhadas próximas a ela, resultou em poucos espaços de circulação e flexibilidade nas duas extremidades da planta, conforme já citado. Também, no pavimento inferior, a escada fica no limite com o muro de arrimo, deixando a frente mais iluminada e ventilada, livre.

Na Vila Taguaí, a escada é o elemento divisor entre o espaço mais amplo e livre e o espaço onde estão concentradas as áreas molhadas. No nível inferior, onde fica o terraço sob pilotis, a escada está posicionada paralelamente às curvas de nível e próxima a elas, deixando a frente, com melhores condições de iluminação, ventilação e visuais interessantes, livre.

\section{POSSIBILIDADE DE AMPLIAÇÃO DAS UNIDASDES:}

Nos projetos Fidalga 772 e Vila Maida, é prevista a possibilidade de instalação de mezanino, permitindo a adição futura de área útil na unidade habitacional. Esta situação é decorrente também do limite máximo do coeficiente de aproveitamento do lote.

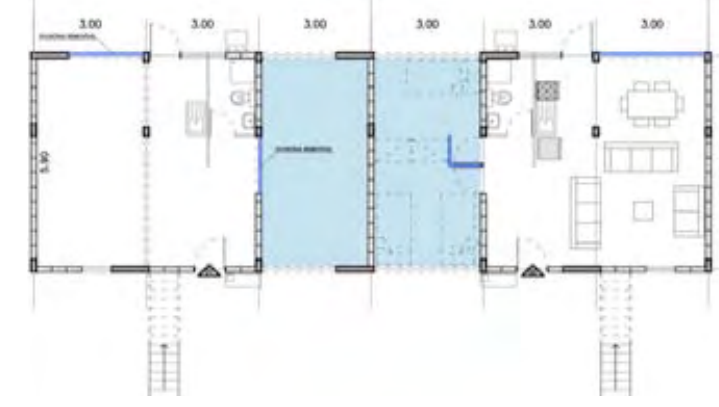

Figura 2 - Projeto Quinta Monroy, lquique, Chile, 2004, da Elemental. Planta pavimento térreo.

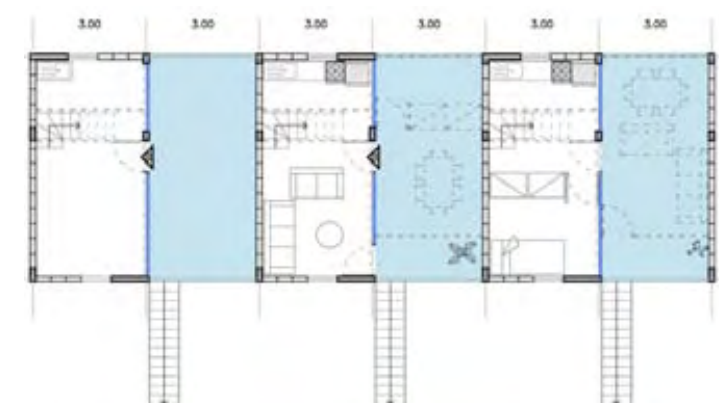

Figura 3 - Projeto Quinta Monroy, Iquique, Chile, 2004, da Elemental. Planta pavimento superior $\mathrm{I}$.

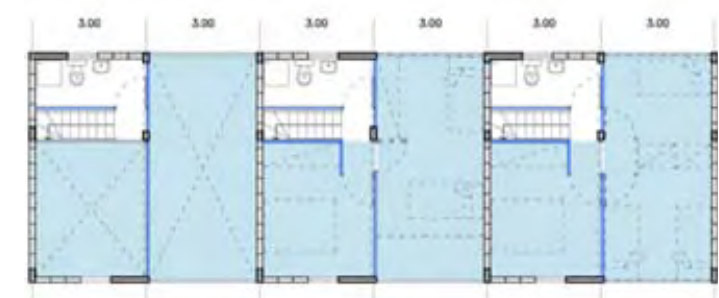

Figura 4 - Projeto Quinta Monroy, Iquique, Chile, 2004, da Elemental. Planta pavimento superior 2 . 


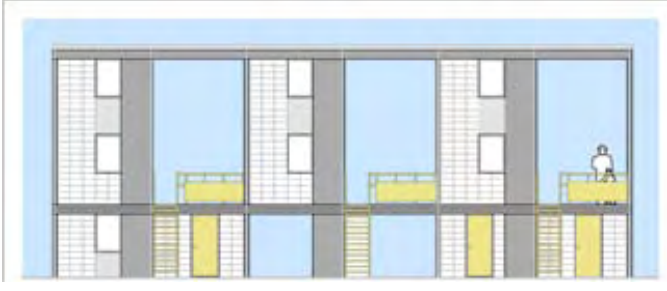

Figura 5 - Projeto Quinta Monroy, lquique, Chile, 2004, da Elemental. Elevação fronta.

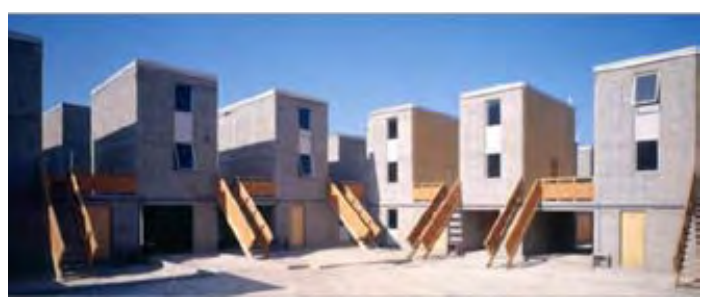

Figura 6 - Vista externa, ainda sem ampliações, do projeto Quinta Monroy, Iquique, Chile, 2004, da Elemental.
Para o caso do Fidalga 772, trata-se de uma zona mista de média densidade, com coeficiente máximo permitido de 2,0. O que ocorre, é que mesmo respeitando os recuos obrigatórios, e respeitando o gabarito máximo de altura, ainda assim, sobra espaço no volume interior para construção de mais área útil. Caso fossem criadas apenas unidades térreas preenchendo todo espaço possível, o coeficiente de aproveitamento seria excedido.Assim, criam-se situações de lofts, espaços com pé-direito duplo ou a "carcaça" inteira da unidade habitacional com pé-direito duplo livre, dando a possibilidade de instalação futura do mezanino, que pode ser fixado nas próprias vigas que já são preparadas para parafusamento de estrutura metálica para sustentar o mezanino.

Este situação ocorreu, por exemplo, no Edifício Havaí, de 1983, dos arquitetos Antonio Carlos Barossi, Jaime Cupertino e José Sales Costa, conforme pode ser conferida na citação abaixo:

O projeto deveria atender à diversidade das famílias e às especificidades de seus
moradores previstos, um espaço de trabalho. Porém, para viabilizar o empreendi-
mento, uma vez que não havia dinheiro disponível para a construção desse espaço
adicional, bem como, levando-se em consideração a legislação vigente, que não
permitia a construção dessa área adicional, os arquitetos pensaram na hipótese de
o apartamento em dois pisos contar com um espaço (salas de estar e jantar) de
pé-direito duplo, que no futuro pudesse ser ocupado pelos moradores para o fim
previsto, como mezanino. (FERRATA; SHUNDI, 20I2, p. 37).

Na Vila Maida a situação é um pouco diferente e muito mais tímida, com relação à área útil adicional permitida, equivalente a um cômodo.Após instalação do mezanino, o pé-direito resultante é pequeno, de 2,10 m, abaixo do mínimo permitido pelo código de obras do município. Porém, mesmo sendo baixo, é um espaço bem aberto e bem iluminado que permite algumas atividades, sendo, portanto, uma área adicional bem vinda à unidade habitacional.

Novamente temas da habitação coletiva de interesse social esbarram em temas da habitação coletiva privada. A ampliação da unidade habitacional de acordo com as necessidades dos moradores é frequente em casas nos assentamentos populares de diversas partes do Brasil. 
Tal situação é conhecida popularmente como “puxadinho", ampliação que pode proporcionar uma valorização no imóvel, tratando-se, portanto, de uma situação de moradia com capital crescente. ELEMENTAL ${ }^{2}$ é uma empresa chilena com forte atuação no mercado de habitação de interesse social. Seu reconhecimento mundial é devido, principalmente, a projetos que possuem esta mesma lógica de valorização - projetos com possibilidade de ampliação da unidade pelo próprio morador.

Os desenhos já preveem áreas para futuras ampliações, e assim, diferentemente do que acontece nos assentamentos irregulares, o "puxadinho" é formalizado (Figuras 2 a 6).

Esta iniciativa visualizou acima de tudo a oportunidade de mudar a abordagem da moradia social, de criar uma residência que, inserida na lógica da propriedade, fosse usada pela família como capital com valor crescente ${ }^{4}$, algo que embora já existisse, precisaria de uma aplicação mais coletiva e menos isolada: edifício com espaços para ampliação e não casas.

A lógica projetual dos projetos do ELEMENTAL, com possibilidade de ampliação de unidades habitacionais em edifícios com unidades sobrepostas, apresenta semelhanças com os projetos citados aqui, Fidalga 772 e Vila Maida, por exemplo. Nos projetos chilenos, também são reservados espaços vazios para futuras ampliações, alguns, inclusive, também são dotados de espaços com pédireito duplo. Porém, nem sempre existe a situação da "carcaça vazia" externa, por questões de redução de custo, ficando vazios na fachada.

A proposta da ELEMENTAL existe por consequência do baixo investimento na unidade inicial. Diferentemente, para os casos aqui citados, a questão da ampliação é decorrente, principalmente, do alcance do limite da área total construída permitida por lei. Em ambos os casos, após a ampliação, haverá uma valorização da unidade habitacional.

\footnotetext{
${ }^{2}$ A ELEMENTAL partiu de discussões e pesquisas acadêmicas com interesse em buscar perguntas capazes de melhorar o tema da habitação social.Alejandro Aravena, professor da Pontifícia Universidade Católica do Chilie, é o principal criador e diretor executivo desde 2006. Devido ao grande sucesso da iniciativa, a ELEMENTAL se associou também à companhia petrolifera Chilena, COPEC, revelando assim um interesse também comercial.

${ }^{3}$ A expressão "puxadinho formalizado" foi utilizada por Mauricio Horta na revista Arquitetura e Urbanismo, n. 186, p. 45, para se referir ao projeto Paraisópolis ELEMENTAL, no Brasil.

${ }^{4}$ GRUNOW, Evelise. Entrevista Alejandro Aravena. ProjetoDesign, São Paulo, n.347, p. 5, jan. 2009.
} 
ÁREA MOLHADA

UNIDADES COM ESPAÇO EXTERIOR PRÓPRIO ACIMA DE 35\% DA ÁREA TOTAL DA U.H

UNIDADE COM POSSIBILIDADE DE AMPLIAÇÃO

AUSÊNCIA DE PAVIMENTO-TIPO AUSÊNCIA DE IMPLANTAÇÃO COM CASAS IDÊNTICAS ENFILEIRADAS

SEM DISTRIBUIÇÃO DO PROGRAMA EM PLANTA DISTRIBUIÇÃO DO PROGRAMA EM PLANTA PELO ARQUITETO CONJUNTAMENTE COM O CLIENTE

FLEXIBILIDADE PARCIAL

POUCA POSSIBILIDADE DE MUDANÇA NA DISTRIBUIÇÃO DO PROGRAMA

CAIXA ESCADA

ESCADA LONGITUDINAL INTERNA ESCADA LONGITUDINAL EXTERNA PRESENÇA DE MAIS DE UMA ESCADA LONGITUDINAL

ESCADA TRANSVERSAL ESCADA DENTRO DO VAZIO ESCADA TANGENCIANDO DUAS FACES DA PLANTA ESCADA TANGENCIANDO UMA FACE DA PLANTA ESCADA EM POSIÇÃO MAIS CENTRALIZADA ESCADA DENTRO DE VAZIO ESCADA TANGENCIANDO VAZIO
DISTRIBUIC̃̃O DO PROGRAMA

EM PLANTA E GRAUS DE FLEXIBILIDADE E ADAPTABILIDADE NAS UNIDADES HABITACIONAIS COM MAIS DE UM PAVIMENTO 


\section{UNIDADE HABITACIONAL}

\section{UNIDADES HABITACIONAIS SOBREPOSTAS, MÉDIA VERTICALIZAÇÃO}

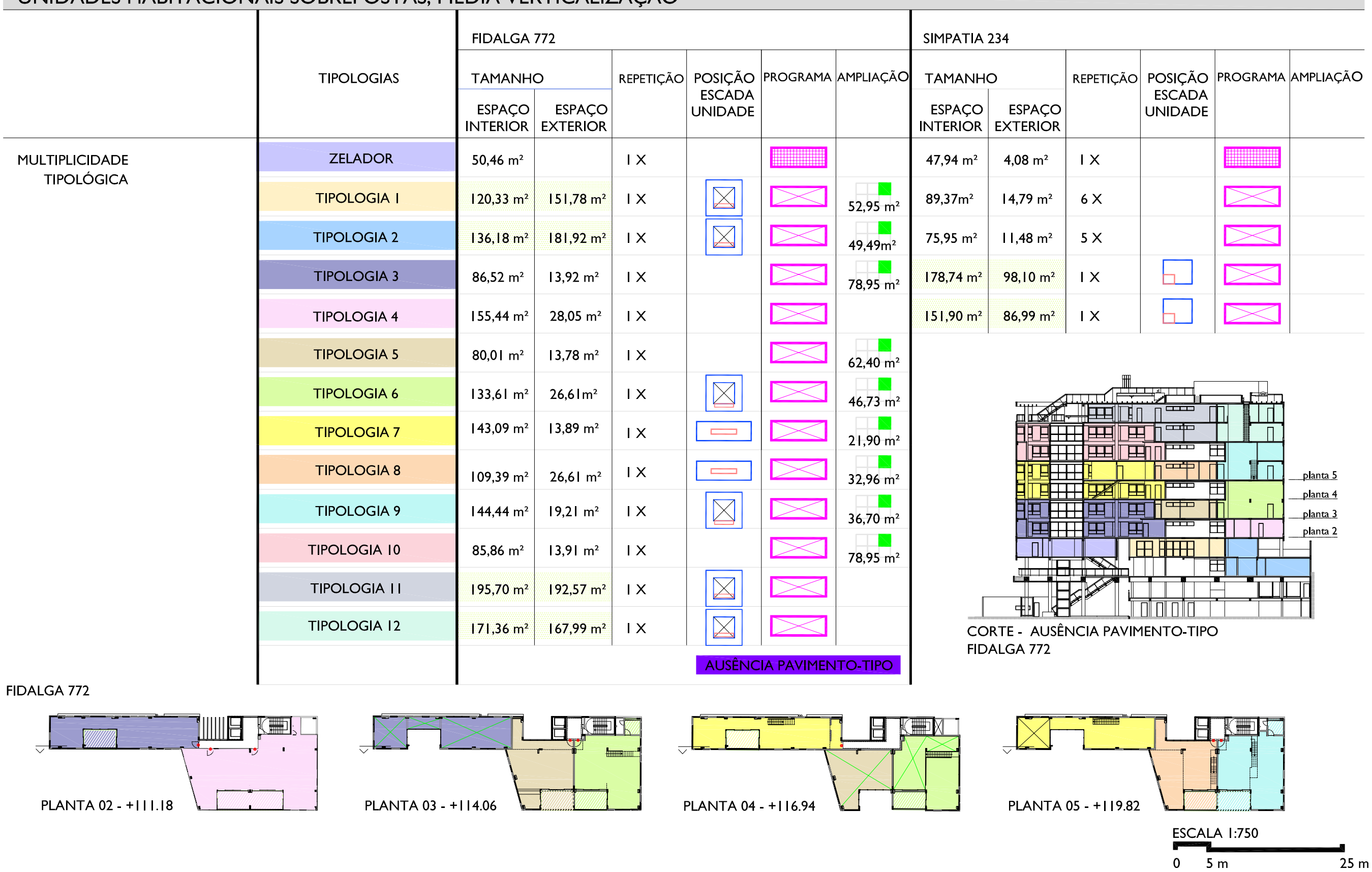




\section{UNIDADES HABITACIONAIS SOBREPOSTAS, POUCA VERTICALIZAÇÃO}

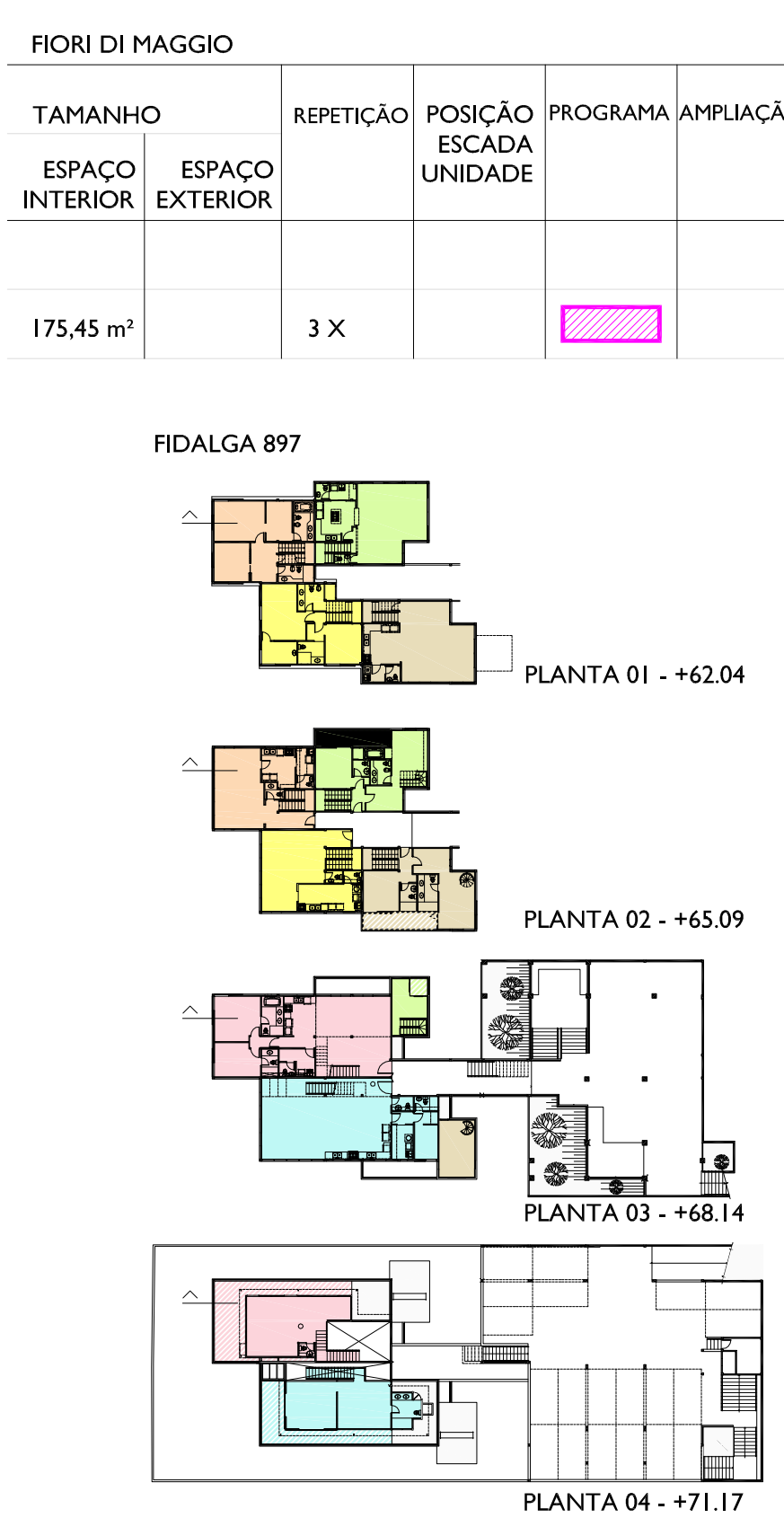

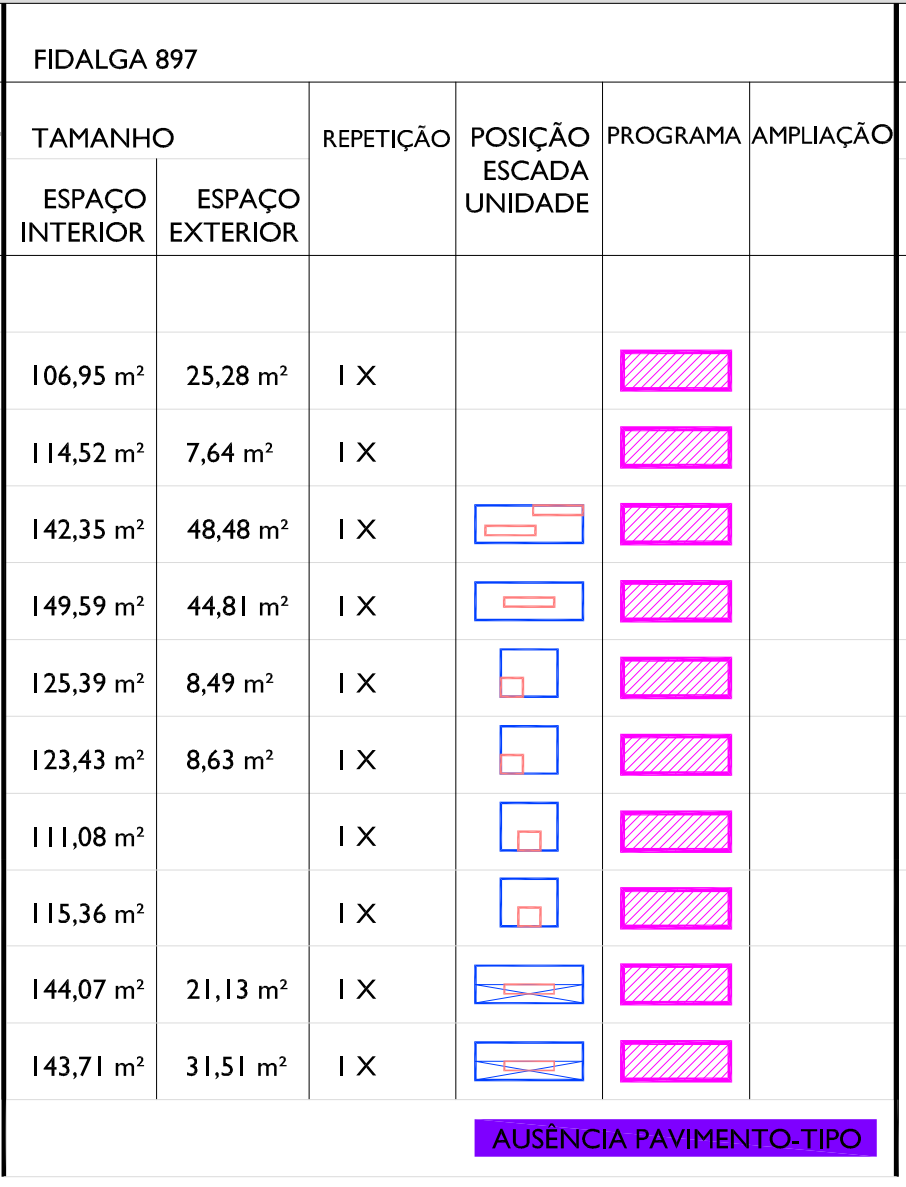

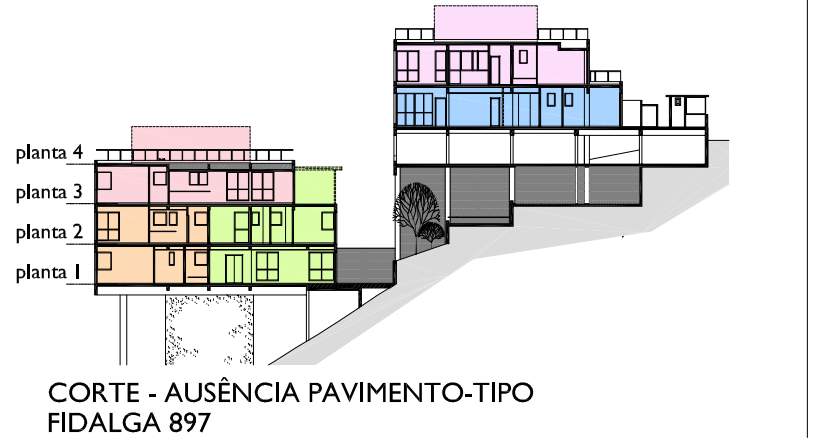

\section{VILA PEDRO FACHIN}

\begin{tabular}{|c|c|c|c|c|c|}
\hline \multicolumn{2}{|c|}{ TAMANHO } & \multirow[t]{2}{*}{ REPETIÇÃO } & \multirow{2}{*}{$\begin{array}{r}\text { POSIÇÃO } \\
\text { ESCADA } \\
\text { UNIDADE }\end{array}$} & \multirow[t]{2}{*}{ PROGRAMA } & \multirow[t]{2}{*}{ AMPLIAÇÃO } \\
\hline $\begin{array}{r}\text { ESPAÇO } \\
\text { INTERIOR }\end{array}$ & $\begin{array}{r}\text { ESPAÇO } \\
\text { EXTERIOR }\end{array}$ & & & & \\
\hline $29,06 \mathrm{~m}^{2}$ & $7,03 \mathrm{~m}^{2}$ & $1 x$ & & \# & \\
\hline $34,75 \mathrm{~m}^{2}$ & $5,75 \mathrm{~m}^{2}$ & $1 x$ & & \# & \\
\hline $34,46 \mathrm{~m}^{2}$ & $5,75 \mathrm{~m}^{2}$ & $1 x$ & & \#米 & \\
\hline $26,05 \mathrm{~m}^{2}$ & $9,79 \mathrm{~m}^{2}$ & $1 x$ & & \# & \\
\hline $29,20 \mathrm{~m}^{2}$ & $2,77 \mathrm{~m}^{2}$ & $1 x$ & 口 & 要册 & \\
\hline $29,20 \mathrm{~m}^{2}$ & $2,22 \mathrm{~m}^{2}$ & $1 X$ & b & \#册 & \\
\hline $38,18 \mathrm{~m}^{2}$ & I,95 $\mathrm{m}^{2}$ & $6 x$ & $\mathrm{Z}$ & 7 & \\
\hline
\end{tabular}

PLANTA 0 I

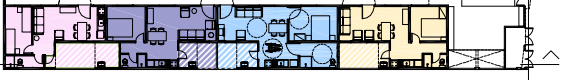

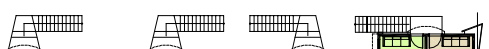

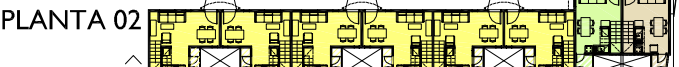
PLANTA 03
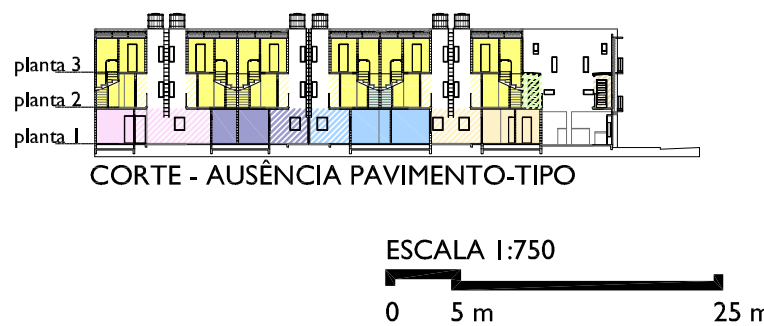


\section{UNIDADE HABITACIONAL}

\section{CONJUNTOS RESIDENCIAIS HORIZONTAIS}

MULTIPLICIDADE TIPOLÓGICA

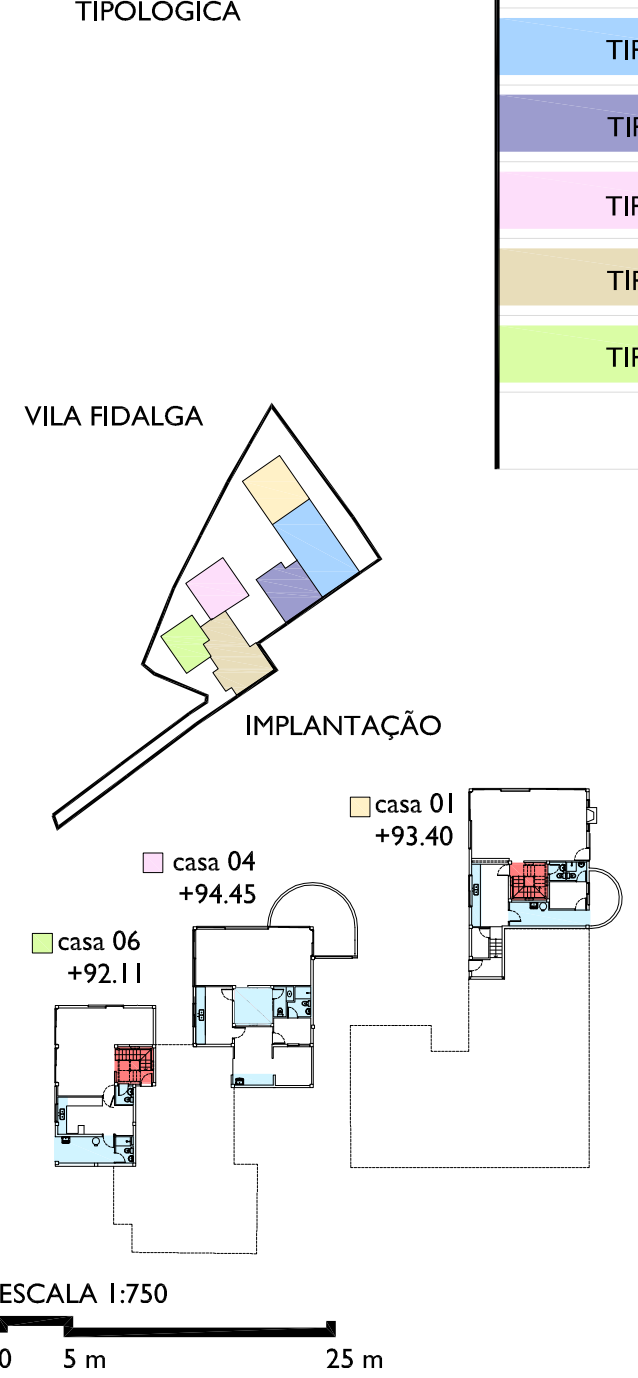

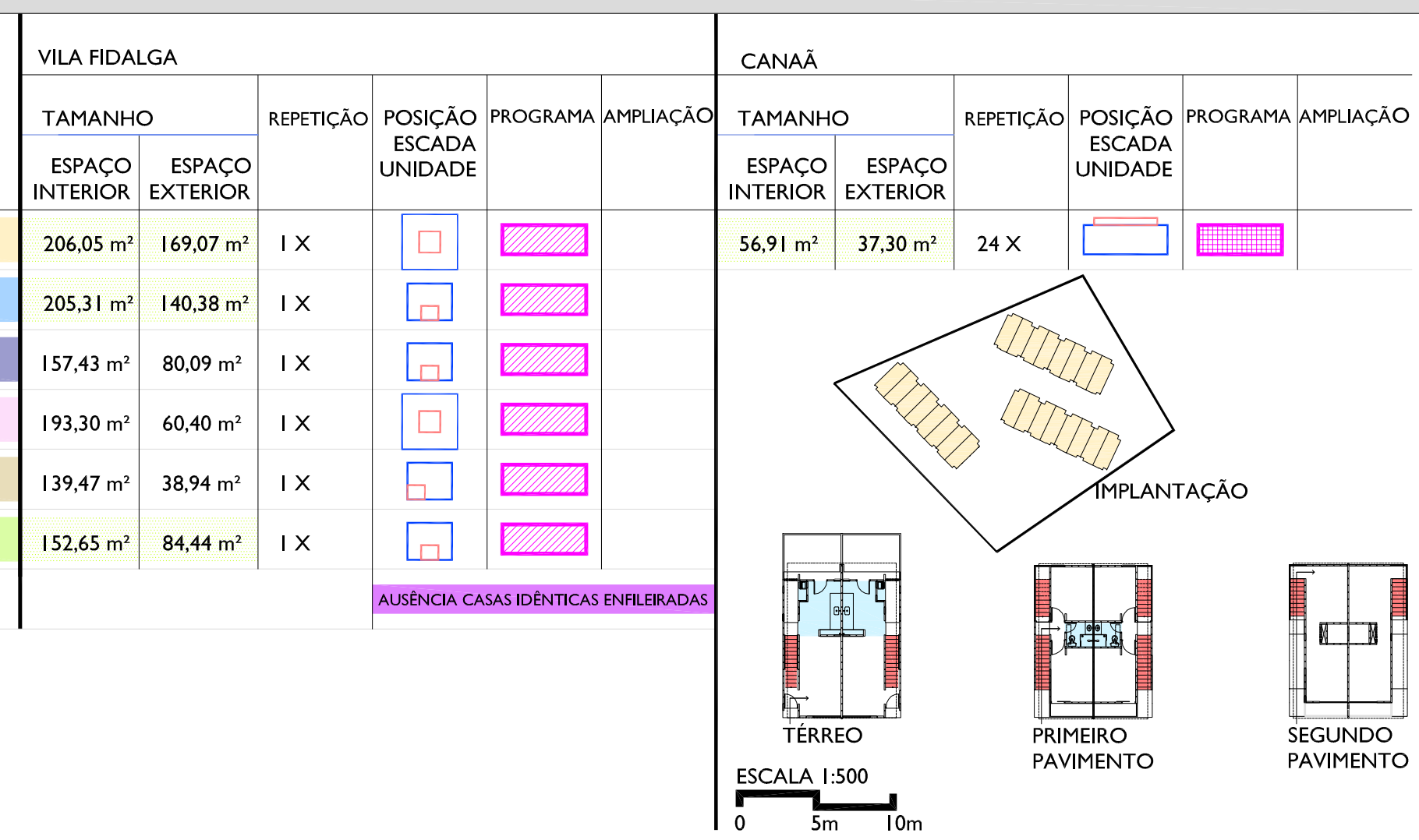

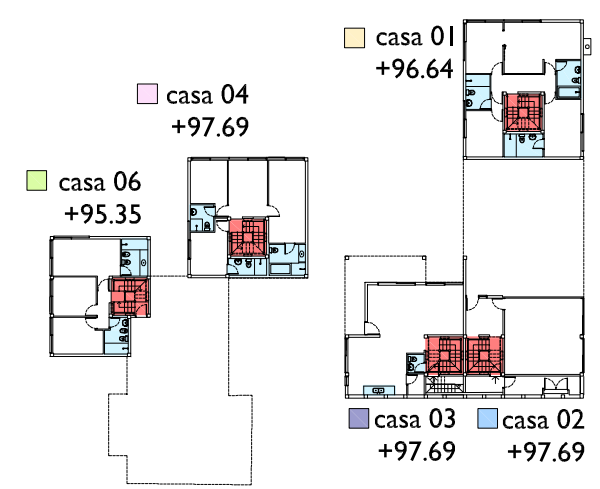

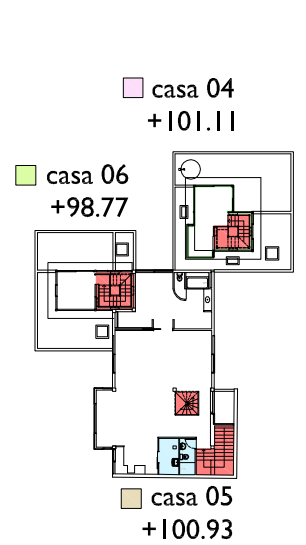

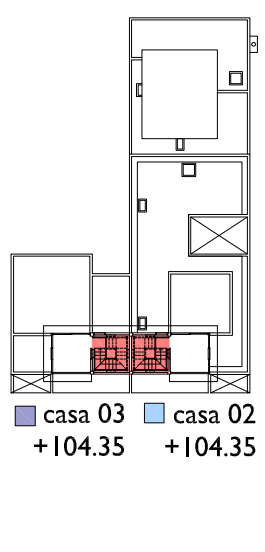




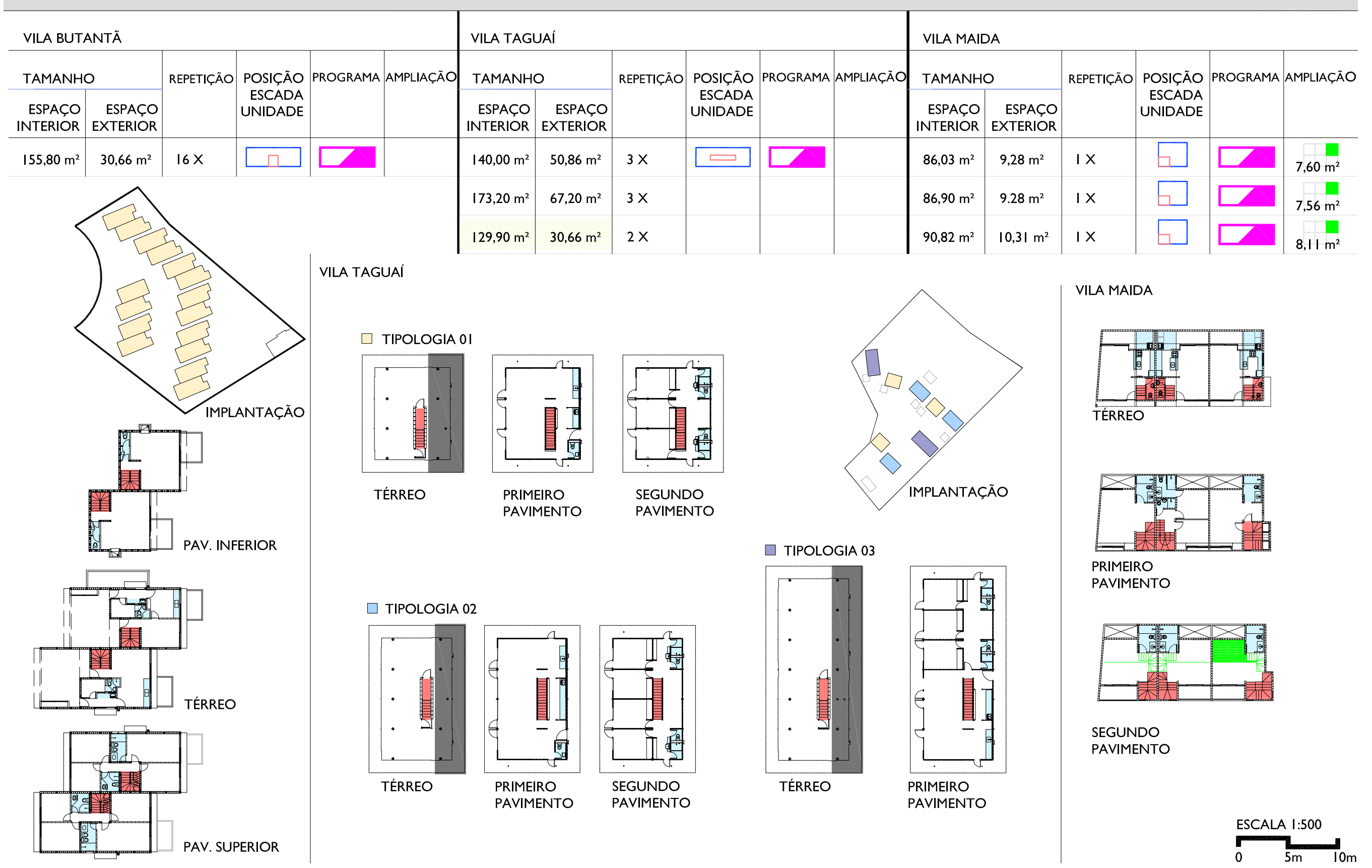


4.4.I BIBLIOGRAFIA DO CAPÍTULO

PFEIFER, G; BRAUNECK, P. Casas geminadas. Barcelona: Editorial Gustavo Gilli. 2009.Versão portuguesa: Cláudia Ardións Espasandin/ltinerário Editorial Ltda.

SCHNEIDER, F. (Org.). Atlas de plantas. Habitação. Barcelona: Editorial Gustavo Gilli. 2006. Iª edição em português.

FERRATA, C.A.; SHUNDI, C. I. (Orgs.). Antonio Carlos Barossi. São Paulo: Hedra :: Editora da Cidade, 2012.

GRUNOW, Evelise. Entrevista Alejandro Aravena. ProjetoDesign, São Paulo, n.347, p. 5, janeiro de 2009.

MONTANER, J. M.; MUXÍ, Z. M.; ZULIN, F.; CORADIN, R. Instrumentos de Avaliação de Projetos. In: Do plano ao projeto: Novos Bairros e Habitação Social em São Paulo. Coleção: Política Municipal de Habitação: Uma construção coletiva. São Paulo: Secretaria Municipal de Habitação, Prefeitura de São Paulo, 2012, p. 252-313. 


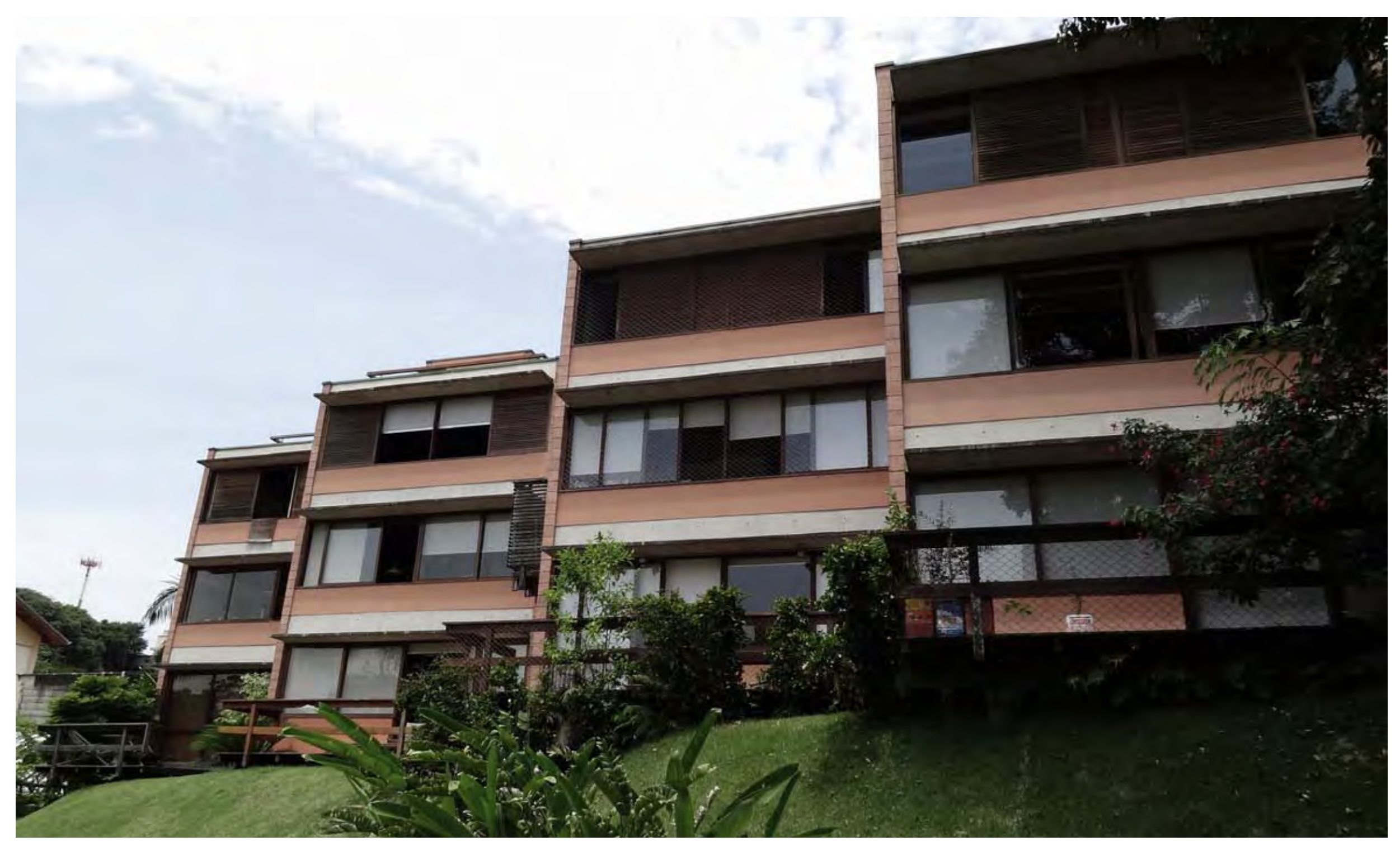

4. ANÁLISE COMPARATIVA E CONSIDERAÇÕES FINAIS POR TEMAS PRESENTES NOS PROJETOS SELECIONADOS 


\title{
4.5.I AGENTES DA PRODUÇÃO DE HABITAÇÃO COLETIVA CONTEMPORÂNEA DIFERENCIADA
}

Muitas vezes é atribuída a responsabilidade pela má qualidade da produção arquitetônica aos empreendedores, construtoras ou incorporadoras, por existir um interesse pela obtenção de lucros que, muitas vezes, excede o interesse pela boa arquitetura.

\begin{abstract}
No cenário habitacional brasileiro, a habitação verticalizada coletiva foi gradativamente ocupando espaço. Entre 1920 a 1950 esforços foram realizados pelos agentes do mercado no sentido de retirar da habitação em alturas a velha imagem degradada e promíscua dos cortiços que abarrotavam os bairros das cidades de maior porte na virada do século XIX para o século XX. Desde suas origens, verificamos que o controle da produção dos edifícios de apartamentos tem se concentrado nas mãos de empreendedores imobiliários interessados, na grande maioria dos casos, na obtenção de lucros e não necessariamente na manutenção e na garantia da qualidade destas habitações. (VILLA, 2008, p.25).
\end{abstract}

Também existem queixas sobre o pouco envolvimento dos arquitetos nos processos decisórios da construção, já que muitas vezes são submetidos às prioridades comerciais dos investidores, que estão pouco interessados em boas soluções arquitetônicas e acabam dando preferência à reprodução de soluções prontas, pois acreditam que sejam mais práticas, e consequentemente, mais lucrativas.

Há, por fim, um último aspecto importante: comentou-se no primeiro capítulo sobre como os valores da boa arquitetura foram esquecidos na produção atual do segmento econômico. Isso quer dizer que, de forma geral, há poucos arquitetos envolvidos nos processos decisórios ou, quando existem, devem submeter-se às diretrizes ditadas pelas prioridades comerciais. Reproduzem meros desenhos e não mais produzem boa arquitetura. (FERREIRA, 20I2, p. 52). 


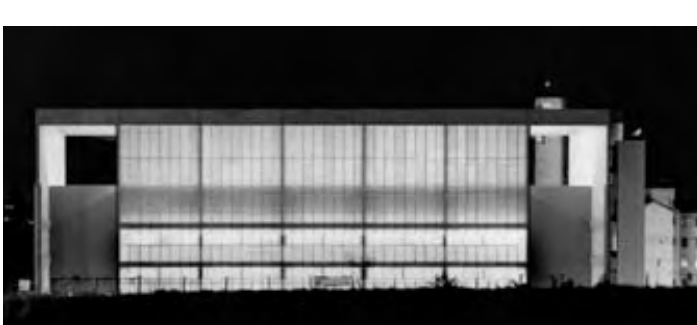

Figura I - Escola em Campinas (2003-200I4). UNA Arquitetos e promoção FDE.
Desse modo, há conflitos, já que as atribuições que deveriam pertencer ao profissional de arquitetura, nestes casos, são direcionadas a outro tipo de profissional, por exemplo, o agente publicitário, que define produtos para serem sucesso de vendas e não necessariamente bons projetos. Surgem assim, estilos aleatórios e fora de contexto, projetos nos quais a resolução arquitetônica espacial é ruim e pouco integrada à engenharia.

Neste sentido a "luta surda", mencionada por Paulo Mendes da Rocha na citação abaixo, possivelmente ocorre, pois, muitas vezes, não há interesse por parte do investidor imobiliário pelo conhecimento ou colaboração do arquiteto em algumas etapas do processo, principalmente na fase inicial, de definição do partido arquitetônico ou conceito do empreendimento, muitas vezes equacionado antes mesmo da contratação do projetista, ficando o papel do arquiteto reduzido a questões mais práticas de elaboração posterior de peças gráficas para aprovação e execução, por exemplo. Deste modo, parece não existir diálogo entre ambas as partes, o que alguns investidores querem é uma fórmula pronta e nada mais.

Hoje em dia no mercado imobiliário só há apartamentos que parecem um castelo medieval em miniatura, todo compartimentado. Talvez por minha educação, conheço as virtudes da espacialidade, de um salão grande, porque posso tocar piano, ou jogar bilhar, ou ter uma biblioteca. Não acredito nessa padronização do mercado; acho que há uma luta surda entre os arquitetos e esses empreendedores porque eles querem uma fórmula, assim qualquer um faz uma planta com sala em $L$ etc. (Paulo Mendes da Rocha em SERAPIÃO, 2009, p. 97).

Porém, existe a crença na mudança dos padrões de qualidade nos projetos de habitação coletiva, com base em experiências de outras áreas, como a educacional ou cultural, que são menos problemáticas em comparação com a residencial, já que apostam mais em projetos de autoria, para maior êxito das realizações. Os da Fundação para o Desenvolvimento da Educação (FDE) (Figura 0I) são bons exemplos neste sentido, porém há outras atuações também relevantes que acabam dando esperança por maiores avanços, inclusive os projetos estudos de caso desta pesquisa. 


\begin{abstract}
Enquanto os edifícios residenciais de hoje se apresentam uniformes e medíocres, de autoria anônima, a cidade apresenta bons projetos comerciais e institucionais, revelando a existência de empreendedores mais generosos e o trabalho sério de excelentes arquitetos; entre eles, Botti e Rubin, Aflalo e Gasperini, Carlos Bratke, Isay Weinfeld, Rui Ohtake, Paulo Mendes da Rocha e um bom grupo de jovens arquitetos cujas obras se destacaram na última bienal de Arquitetura. Há, portanto, salvação possível. Os empreendimentos poderão produzir lucro mesmo com projetos bons, livres da mão escondida que impõe programas, dimensões, estilos. Para fugir da mediocridade haveria alguns passos a dar. (WILHEIM, 2008).
\end{abstract}

Wilheim usa o termo "mão escondida" para se referir à produção unitária e sem criatividade de grande parte dos edifícios habitacionais em São Paulo e em outras grandes cidades do Brasil, que parece resultado de um único protagonista a desenhar com sua mão todos os projetos iguais que observamos, por exemplo, nos panfletos de vendas.

O valor autoral do arquiteto é desprezado ou pouco relevante nestes projetos. Agente é aquele que opera. Nesta pesquisa determinados agentes possuem parcela significativa de responsabilidade sobre o resultado final dos projetos executados, assim, é válido destacar os tipos de atores presentes nessa diversidade. Antes, cabe identificar os agentes típicos da produção imobiliária, para verificar algumas similitudes ou derivações na produção diferenciada em análise. Moraes e Perrone 388 (2012) identificam alguns agentes principais do mercado imobiliário, a ver na sequência:

- Empreendedor (investidor financeiro);

- Incorporador (promotor imobiliário);

- Construtor (empresa construtora);

- Projetista (arquiteto);

- Vendedor (empresa imobiliária);

- Profissionais ligados ao marketing (empresa publicitária). 
No dicionário da língua portuguesa', existem alguns significados para as palavras Incorporar e Empreender, muitas vezes confundidas por serem similares em algumas situações. Incorporar é dar forma corpórea, juntar num só corpo, reunir, realizar (o dono, o compromissário ou o titular de opção de venda de um terreno) contrato para construção de (edifício de apartamentos, lojas, etc.), em condomínio, começando logo a vender, em prestações, as futuras unidades. Já empreender significa pôr em execução ou realizar. É possível notar que a palavra "realizar" caracteriza as duas palavras. Assim, em Felippe (1996), é possível acrescentar mais características que definem melhor o significado de agente empreendedor:

(...) aquele capaz de deixar os integrantes da empresa surpreendidos, sempre pronto para trazer e gerir novas ideias, produtos, ou mudar tudo o que já existe. É um otimista que vive no futuro, transformando crises em oportunidades e exercendo influência nas pessoas para guiá-las em direção às suas ideias. É aquele que cria algo novo ou inova o que já existe e está sempre pesquisando. É o que busca novos negócios e oportunidades com a preocupação na melhoria dos produtos e serviços. Suas ações baseiam-se nas necessidades do mercado. (FELIPPE, 1996).

Já o significado de incorporar está mais relacionado ao tipo de possibilidade de comercialização, ou aquilo que promove ou dá impulso ao empreendimento.

Art. 29. Considera-se incorporador a pessoa física ou jurídica, comerciante ou não, que embora não efetuando a construção, compromisse ou efetive a venda de frações ideais de terreno objetivando a vinculação de tais frações a unidades autônomas, em edificações a serem construídas ou em construção sob regime condominial, ou que meramente aceite propostas para efetivação de tais transações, coordenando e levando a têrmo a incorporação e responsabilizando-se, conforme o caso, pela entrega, a certo prazo, preço e determinadas condições, das obras concluídas. (BRASIL, 1964). 
Empreendedor, é o investidor financeiro em sua essência, é o que cria novas possibilidades de negócio, é o que concebe aquilo que será realizado. Se muitas vezes a culpa pelo mau projeto acaba sendo atribuída principalmente aos agentes imobiliários, julgou-se importante nesta pesquisa observar o grau de relevância dos agentes desta produção diferenciada de habitação coletiva contemporânea. Assim, pelos estudos de casos principais, foram identificados diferentes tipos de agentes, numa mesma realização, a ver na sequência:

I. Arquiteto Empreendedor e Incorporador: foi o caso da Vila Fidalga, onde a arquiteta além de realizar o projeto, foi uma das sócias da "Taguaí Arquitetura e Incorporação" e também agente empreendedora do seu próprio projeto. No exemplo argentino, Edifício Once, também houve a incorporação pelos próprios arquitetos responsáveis pela concepção do empreendimento imobiliário; (Figura 02)

2. Arquiteto (e Engenheiro) Empreendedor e Construtor: foi o caso da Vila Maida e Oiapoque, onde os autores do projeto foram os investidores e também assumiram a responsabilidade pela obra;

3. Arquiteto (e Engenheiro) Empreendedor, construtor e Incorporador: foi o caso da Vila Taguaí, onde os autores do projeto conceberam o empreendimento conjuntamente, ficando o engenheiro responsável pelo projeto de engenharia e construção, e a arquiteta pelo projeto de arquitetura e paisagismo, e os dois sócios da Taguaí Empreendimentos Ltda. (Figura 04). Foi o caso também da Vila Butantã, onde a venda das unidades ocorreu após registro da incorporação (o arquiteto Marcos Acayaba e engenheiro Hélio Olga foram sócios) com algumas unidades já construídas e outras em execução. (Figura 03)

\section{Conjunto de agentes especiais, que contrata e acredita em bons arquite-}

tos: é o caso do Movimento Um, coletivo de agentes: incorporadora Idea!Zarvos (promotor imobiliário), Construtora CP3 (empresa construtora), Axpe Imóveis Especiais (empresa imo-

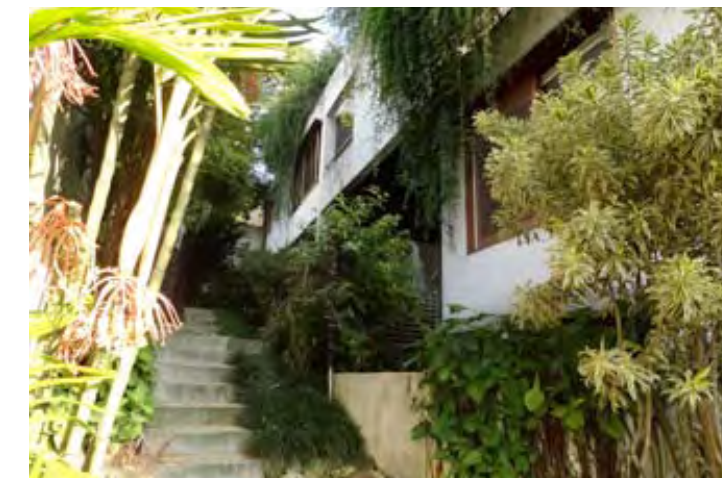

Figura 2 - Arquiteta Empreendedora e Incorporadora:Vila Fidalga (I999-200I), de autoria da arquiteta Cristina Xavier e incorporação da Taguaí Arquitetura e Incorporação. Fonte: autora.

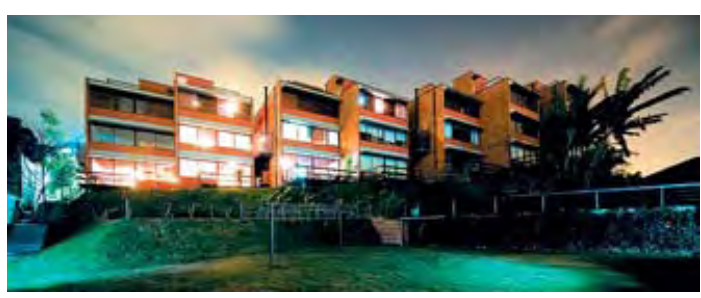

Figura 3 - Arquiteto (e Engenheiro) Empreendedor e Construtor:Vila Butantã (1998-2004), Ita Construtora (Hélio Olga) e Arquiteto Marcos Acayaba.

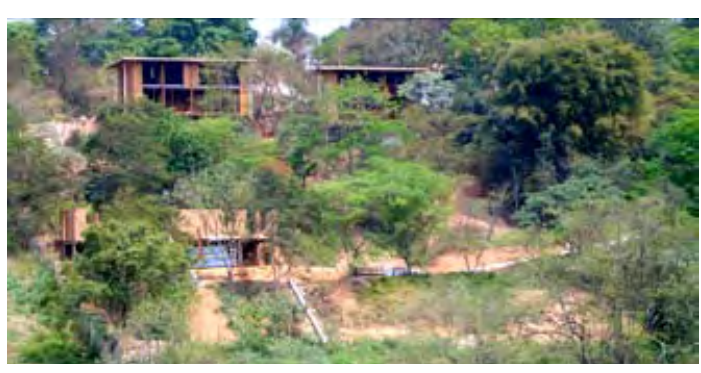

Figura 4 - Arquiteto (e Engenheiro) Empreendedor, Construtor e Incorporador:Vila Taguaí (2007-20 I0). Ita Construtora (Engenheiro Hélio Olga) e Arquiteta Cristina Xavier. 


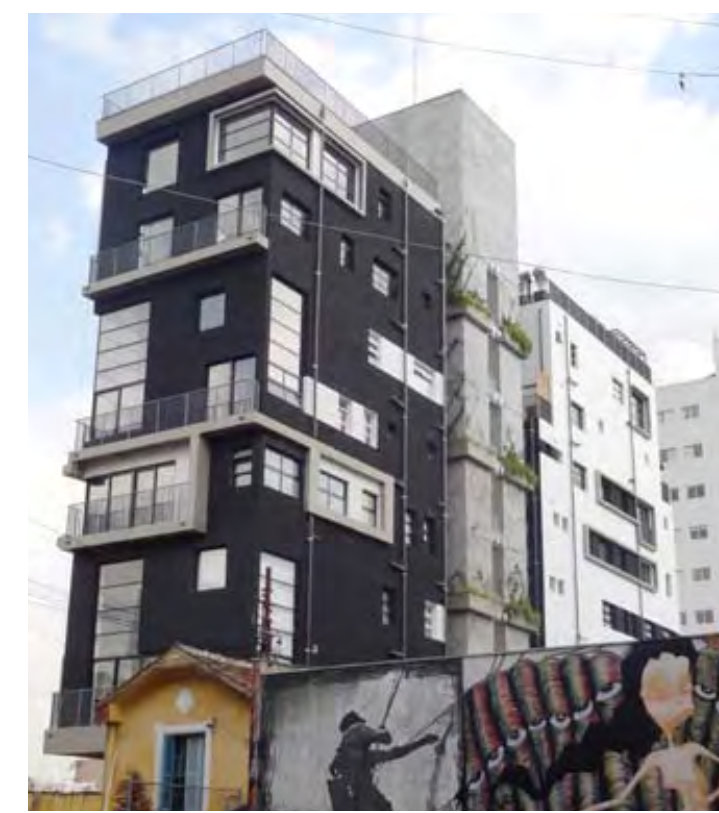

Figura 5 - Conjunto de agentes especiais, que contrata e acredita em bons arquitetos: Fidalga 727 (2010-20II). Idea!Zarvos, Construtora CP3. Axpe Imóveis Especiais e Triptyque Arquitetura.

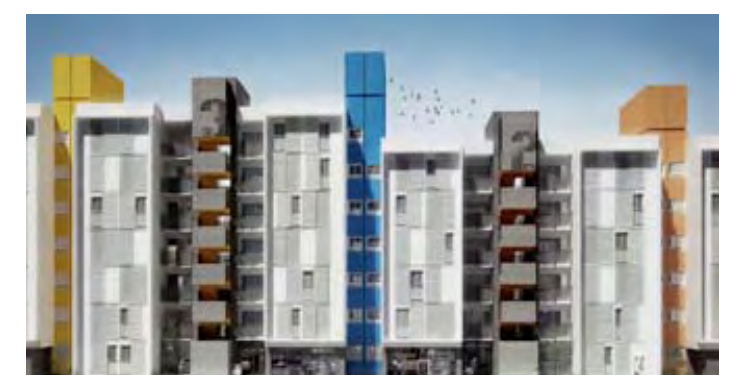

Figura 6 - Incentivo a projetos autorais pela Promoção Pública: Conjunto Heliópolis Gleba G (20|l-20|3). Coordenação do projeto: SEHAB - SP (Elisabete França,Vanessa Padiá e Marcelo Rebelo) e Biselli + Katchborian (Arquitetura). biliária), profissionais ligados ao marketing na equipe de vendas e escritório de arquitetura. A Idea!ZArvos neste caso, é o agente que se destaca, pois assume papel principal na concepção do empreendimento; (Figura 05).

\section{Empreendedores especiais, que contratam e conduzem a equipe de arqui-} tetura do mesmo modo que ocorreria num projeto de uma residência uni-

familiar: foi o caso do Fiori di Maggio, por exemplo, Milton de La Pietra foi empreendedor e responsável pela construção (dono da Joy Congero), e a equipe de Arquitetura teve papel relevante na realização pelo próprio projeto;

6. Incentivo a projetos autorais pela Promoção Pública: os agentes públicos responsáveis pela coordenação e os arquitetos, valorizados nestas ações, são responsáveis por projetos diferenciados; (Figura 06)

7. Pequena construtora que deposita confiança no arquiteto: foi o caso do Canaã, onde os agentes importantes foram a empresa construtora e a equipe arquitetura.

Os tipos de agentes onde o arquiteto é também empreendedor são os tipos mais corajosos e inventivos, enfrentam a competição do mercado e a legislação, assumem os riscos financeiros e, mesmo com tudo isso, e por tudo isso, trazem soluções novas e criativas, que beneficiam os clientes, a cidade, e o próprio negócio.

Em 1992, não muito distante do século XXI, recorte temporal desta pesquisa, Mario Biselli e Arthur Katchborian associados a Eurico Ramos Francisco e Lívia França realizaram um edifício de apartamentos no Morumbi (Figura 07) de iniciativa própria, já que Biselli e Katchborian tinham uma construtora. Desta atuação independente, surgiu uma proposta com consciência da legislação vigente, de tal modo a aproveitar ao máximo os índices de uso e ocupação do solo, sem deixar de representar uma boa solução arquitetônica.

Por exemplo, foi criada uma tipologia que comporta um apartamento e meio por andar, 
isto quer dizer, mescla de tipologia térrea e dúplex, que acaba resultando numa lâmina mais alta e esbelta, e que permite intercalar halls com acessos individuais, da mesma maneira que acontece, por exemplo, nos projetos Aimberê e Fidalga 772, dos arquitetos Andrade Morettin. Esta solução de pavimento tipo deixa a envoltória mesclada com um trecho composto pela simples sobreposição de apartamentos térreos, e outro com sobreposição de unidades-tipo dúplex. Inventividade dentro dos limites da legislação, e, diferente de soluções dirigidas por empreendedores com regras e soluções prontas de projeto.

Outra consequência dessa concepção de plantas é o fato de metade dos apartamentos comuns (oito unidades entre as 16) ganhar um hall social e de serviço exclusivo - sendo considerados, na nomenclatura do mercado imobiliário, do tipo "um por andar". (SERAPIÃO, 2000, p. 63).

O tema do arquiteto empreendedor aparece na revista ProjetoDesign novamente, no artigo de SERAPIÃO (2006) "Quatro pecados louváveis”, representado pelos projetos: Edifício Duquesa de Goiás (2000) (Figura 08) do Paulo Bruna Arquitetos Associados; Edifício na Rua Santonina (1999/200I) (Figura 09) do Reinach Mendonça Arquitetos Associados; Vila Fidalga (1999/200I) da arquiteta Cristina Xavier; e Vila Butantã (1998/2004) do arquiteto Marcos Acayaba, projetos com qualidade arquitetônica, e geridos pelos próprios autores.

O fato é que casos como os aqui relatados ainda são raros. É lógico que, para um arquiteto, incorporar um empreendimento imobiliário não é fácil. Primeiro, é preciso ter dinheiro, ou então conhecer e convencer quem o tenha. Por outro lado, os altos juros pagos pelo mercado financeiro minimizam qualquer tipo de lucro em um negócio como esse, em que a racionalização da construção está tornando a concorrência maior e os ganhos menores. Ou seja, não é fácil concorrer com grandes empresas. (SERAPIÃO, 2006, p. 87)

2SERAPIÃO utiliza a expressão "pecados louváveis", pois os casos poderiam ser vistos, do alto purismo ético fauuspiano, como uma heresia, um pecado mortal, já que, segundo ele, a ética da arquitetura paulista, projetistas que se prezem não devem se envolver diretamente com o mercado imobiliário. Os autores dos quatro projetos são procedentes da FAUUSP.

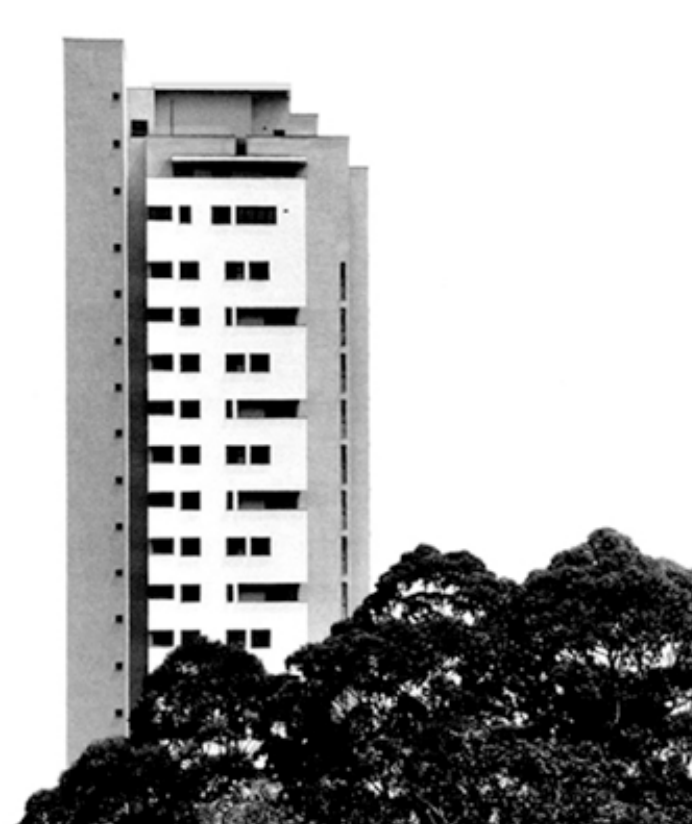

Figura 7 - Edifício no Morumbi, 1992.Autores: Mario Biselli e Arthur Katchborian associados a Eurico Ramos Francisco e Lívia França.

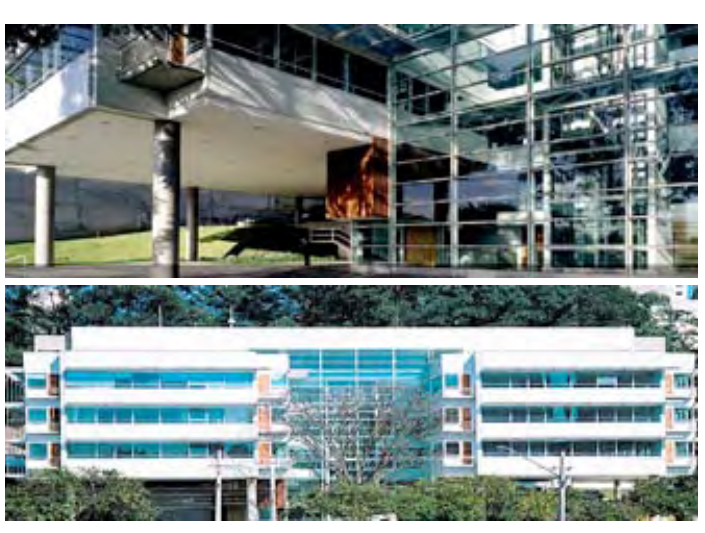

Figura 8 - Edifício com espaços comerciais Duquesa de Goiás, Real Parque, 2000, do escritório Paulo Bruna Arquitetos Associados. 


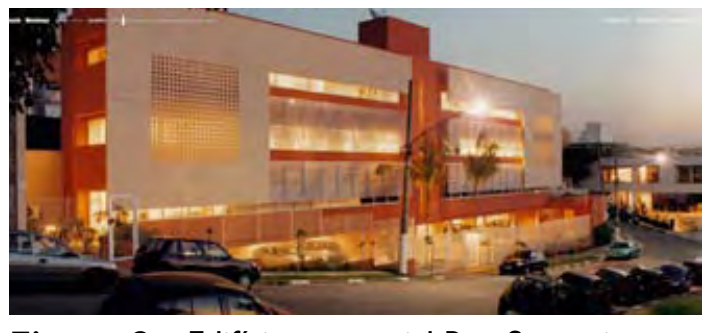

Figura 9 - Edifício comercial Rua Santonina, 1999-200I, dos Arquitetos Henrique Reinach e Maurício Mendonça (ao lado da Vila Fidalga).

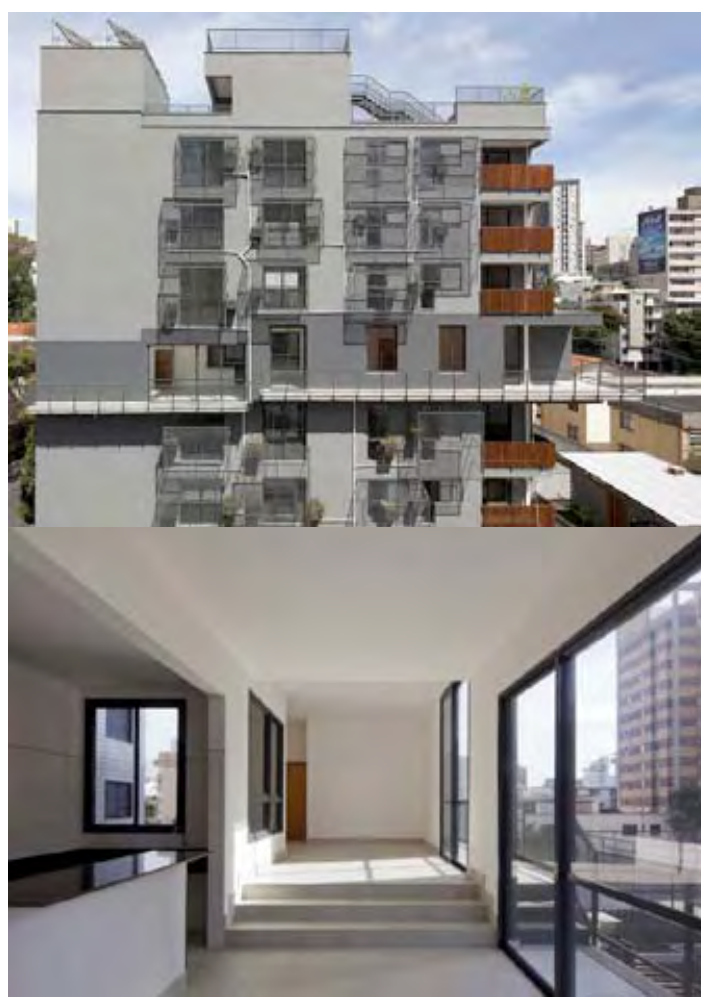

Figura 10 - Edifício Montevidéu 285, 20072010, em Belo Horizonte, do escritório Vazio Arquitetura dirigido por Carlos Teixeira.
Os dois casos residenciais citados, Vila Fidalga e Vila Butantã, junto a outros projetos identificados nas revistas na última década com mesmo tipo de agente "arquiteto empreendedor"; como a Vila Maida (2004-2006) da arquiteta Maristela Faccioli;Vila Taguaí (2007/2010) da arquiteta Cristina Xavier e Engenheiro Hélio Olga Jr.; Montevidéu 285 (2007-2010), (Figura 10) em Belo Horizonte, do escritório Vazio Arquitetura, liderado por Carlos Teixeira; e Oiapoque (200 I-2003), do escritório Vista Urbana, liderado pelo arquiteto Ararê Sennes; representam casos recentes, e também ainda raros, nos quais um dos agentes incorporadores é o próprio arquiteto.

$\mathrm{Na}$ última década, vem sendo publicado frequentemente na revista SUMMA+, edifícios de pequeno porte, empreendidos pelo próprio arquiteto, em bairros mais próximos ao limite da cidade autônoma de Buenos Aires, como Núñez, Vila Urquiza, Palermo, Colegiales, Saavedra, Boedo, Chacarita e Floresta principalmente (Figura I I). Como exemplo desta atuação, pode ser citado o caso do Edifício Zapiola 295I, em Núñez, do arquiteto Marcelo Del Torto, no qual a busca pelo terreno partiu da intenção do arquiteto em morar no local em uma das unidades com sua família; e ao mesmo tempo, produzir outras como forma de viabilizar o empreendimento.

Assim, o lote regular, de $8,66 \times 45 \mathrm{~m}$ e $780 \mathrm{~m}^{2}$, deu lugar a dez unidades habitacionais, com variadas tipologias (Figura 12). Olhando o pequeno edifício da rua, não parece que comporta dez unidades, parecendo inclusive, que se trata de apenas uma casa.

Actuando no solo como proyectistas, sino también como promotores y constructores, aportando la visión de una posibilidad que solo su afinada sensibilidad podía poner en evidencia, convenciendo a pequeños inversores y encontrando la manera de dar a conocer nuevos conceptos y posibilidades en la vivienda. Para estos jóvenes arquitectos, las tácticas de infiltración fueron, al mismo tiempo, la manera de encontrar trabajo, creando ellos mismos las condiciones con las que realizar su trabajo en sintonía con sus intereses y sensibilidad arquitectónica. (DIEZ, 20 I0, p.35). 
Esta situação é similar com a da Vila Maida, que foi realizada em terreno da própria família por iniciativa da própria arquiteta em conjunto com alguns primos engenheiros, da família Maida. Foram construídos três sobrados tríplex no pequeno terreno de $220 \mathrm{~m}^{2}$ na cidade de Santo André, grande São Paulo. A arquiteta Maristela Faccioli ficou com uma das unidades, a outra ficou com um dos primos sócios, e comercializaram a terceira, para arcar com os custos da construção.

Pelos estudos de casos selecionados e outros complementares, perceberam-se algumas características positivas principais neste tipo de atuação: primeiro, o empreendimento geralmente envolve pesquisa de novas técnicas construtivas. Por exemplo, na Vila Butantã, foi criada a laje nervurada mista de concreto e madeira, e na Vila Taguaí, houve a pesquisa do painel estrutural em madeira.

Segundo, notou-se um aproveitamento maior de terrenos residuais, sem uso anterior, principalmente os mais acidentados:Vila Butantã,Vila Fidalga,Vila Taguaí e Oiapoque. E, por último, o equilíbrio entre técnica e eficiência comercial na produção de habitação, de modo a beneficiar também o morador.

\begin{abstract}
O preenchimento da fase de concepção do produto imobiliário pelo arquiteto de forma mais efetiva pode ser positivo para o mercado como um todo: nele o arquiteto poderia agregar à criação de empreendimentos imobiliários a sua capacidade de pensar na escala humana, de projetar, praticar, debater e influenciar no sistema de produção de habitações atual, de modo que a sua competência contribuísse para equilibrar a balança entre a qualidade técnica e a eficiência comercial na produção de habitação, com vantagens para o usuário final. (MORAES; PERRONE, 20I2).
\end{abstract}

Recentemente a revista Arquitetura e Urbanismo (n.218, maio 20I2) apresentou três edifícios geridos por arquitetos, entre estes, o Edifício Once, (Figura 13) tema da capa, na qual é escrita em letras grandes nas próprias aberturas do edifício "ARQUITETO EMPREENDEDOR”.

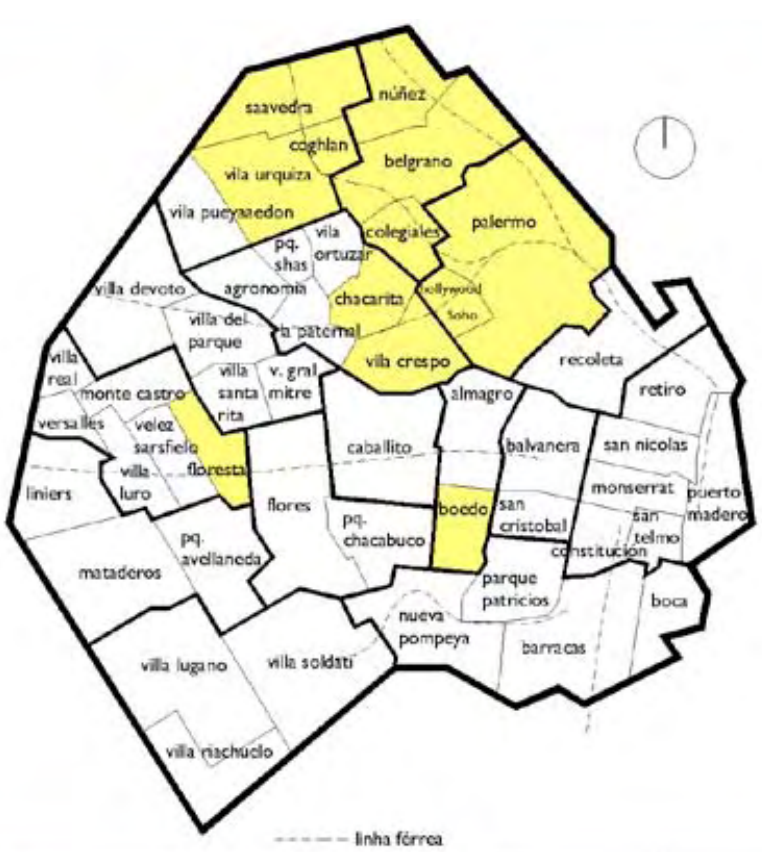

Figura I I - Mapa esquemático de Buenos Aires. Em destaque, bairros onde estão mais presentes as "infiltrações urbanas" e também atuações de "arquitetos empreendedores".

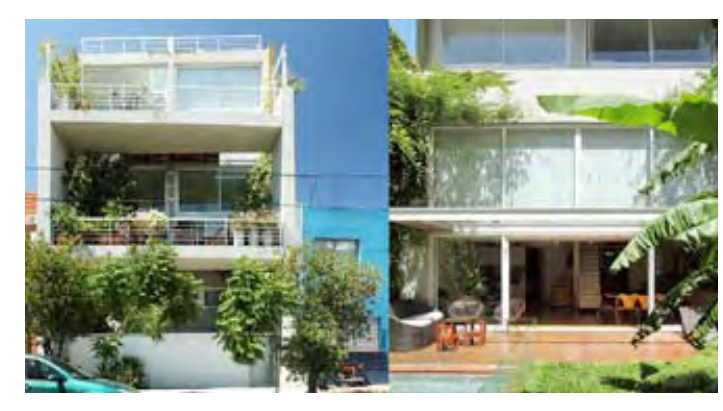

Figura 12 - Edifício Zapiola 295I, em Núñez, do arquiteto Marcelo Del Torto. 


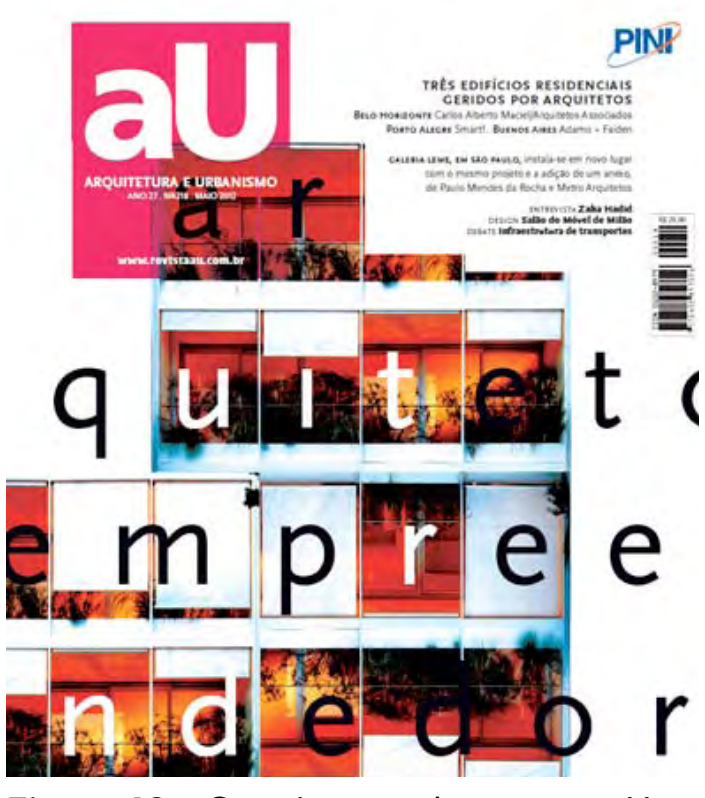

Figura 13 - Capa da revista Arquitetura e Urbanismo, n.2I8, maio de 20I2, na qual o edifício Once é o tema da capa.

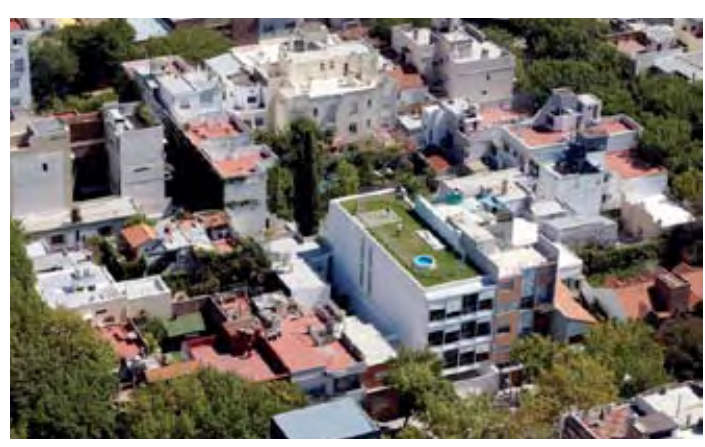

Figura I 4 - Imagem aérea e inserção no bairro do Edifício Once, em Núñez, Buenos Aires, dos Arquitetos Adamo-Faiden. As fachadas de fundo e frente são iguais, porém, pela foto aérea, é possível ver a face frontal.
À frente deles estão arquitetos que resolveram assumir outras responsabilidades, além da prancheta, para ver concretizar o que acreditam que deva ser um edifício residencial em uma grande cidade. Carlos Alberto Maciel em Belo Horizonte, o escritório Smart! em Porto Alegre e os arquitetos do Adamo-Faiden em Buenos Aires juntaram-se com outros investidores e construíram edifícios seguindo seus projetos. (ANTUNES, 20I2, p. 4).

Com o edifício Once (2009/20I I) (Figura 14) do escritório argentino Adamo-Faiden, também se retiram algumas lições, que complementam as encontradas nos projetos tema desta pesquisa. O edifício fica em Núnez, bairro onde os arquitetos encontraram um terreno, fizeram um projeto com seis unidades habitacionais de $85 \mathrm{~m}^{2}$ cada, e depois foram em busca dos futuros moradores e financiadores do empreendimento. Com todas as unidades preenchidas por investidores, iniciou-se a construção. Houve um planejamento muito bem detalhado de todos os gastos mensais, com mão de obra, materiais de construção, com a equipe de arquitetura e de administração; e, depois de finalizada a obra, as unidades foram quitadas pelos moradores.

Segundo Troncoso (20I2), existem vários ganhos para os arquitetos, já que há a formação de uma equipe de arquitetura preparada para a materialização de projetos, com desenhos que são colocados em prática, algo que é bem recebido por investidores futuros, e assim, acaba se tornando uma corrente, na qual um empreendimento chama outro. Essa é uma característica presente nos projetos Vila Fidalga, Vila Butantã ou Vila Taguaí, de ter uma relação muito conexa entre projeto e prática, ganho não apenas para os arquitetos, como também aos clientes que são beneficiados com a qualidade construtiva e arquitetônica.

No projeto em Núñez, usa-se o artifício de deixar os espaços interiores livres, com definição apenas dos núcleos de áreas molhadas, neste caso, por questões econômicas: a fase de investimento "coletivo" acontece dentro de um limite orçamentário pequeno, depois, quem pode mais financeiramente, investe melhor no interior da unidade.

Com isso, este tipo de atuação consegue atender principalmente jovens que estão comprando 
seu primeiro imóvel, ou seja, o perfil dos investidores leva a criação de unidades mais enxutas e flexíveis. Mas esta é apenas uma situação. Por exemplo, na Vila Fidalga, também foi estabelecido antes da construção um grupo de moradores, porém, ao contrário do exemplo em Núñez, houve o trabalho de personalização do interior da unidade acompanhado pela própria arquiteta, inclusive com valores de investimento diferenciados para cada tipo de unidade, não apenas pelas definições dos interiores, já que as unidades são primordialmente diferentes umas das outras. Assim, existem tipos de soluções para vários perfis de moradores.

Com relação ao tipo "Conjunto de agentes especiais, que contrata e acredita em bons arquitetos", foram identificados alguns projetos realizados por um agente incorporador em comum: Idea!Zarvos. As informações contidas nas próprias revistas, ProjetoDesign e Arquitetura e Urbanismo, em especial o artigo “Mudança de Ares”, por Serapião (2009) e a entrevista com Otávio Zarvos, "Cidade Incorporada" realizada por Floresta (201 I), como também o conhecimento dos projetos publicados na última década nestas revistas, em especial aqueles de habitação coletiva, permitiram não apenas identificar uma produção atual considerada diferenciada, como também, compreender um pouco da trajetória de alguns agentes especiais desta produção, como por exemplo, a incorporadora Idea!Zarvos, que confia seus negócios a bons arquitetos que possuem obras publicadas nestas mesmas revistas e com diversas premiações em âmbito nacional e internacional. Casos de incorporadores apreciadores e confiantes de uma boa arquitetura atualmente são raros, porém, é possível citar alguns exemplos em São Paulo, geralmente engenheiros ou construtoras, como o caso do Walid Yazigi ${ }^{3}$ ou da FormaEspaço ${ }^{4}$. A construtora FormaEspaço, por exemplo, no final da década de 1960 e início da década de 1970, conseguiu soluções ímpares a partir de projetos modulados, já que cada arquiteto contratado para realizar o projeto dos edifícios em série,

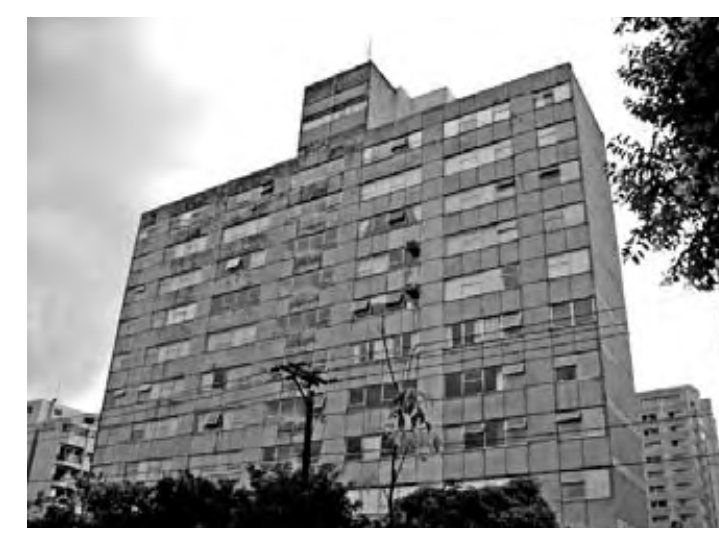

Figura 15 - Edifício Modular Beta,Abrahão Sanovicz, 1970, no bairro Indianopolis, São Paulo. Um dos protótipos iniciais dos edifícios modulados da construtora FORMAESPAÇO.

\footnotetext{
${ }^{3}$ Artigo especial sobre Walid Yazigi em: SERAPIÃO, F. Onde estão os Walids? ProjetoDesign, São Paulo, n. 353, p. 94, jul. 2009. ${ }^{4}$ Pesquisa realizada sobre a produção da construtora Formaespaço em: Imbronito, Maria Isabel. "Três edifícios de habitação para a
} Formaespaço: Modulares, Gemini e Protótipo”, São Paulo, dissertação de mestrado na FAUUSP, 2003. 


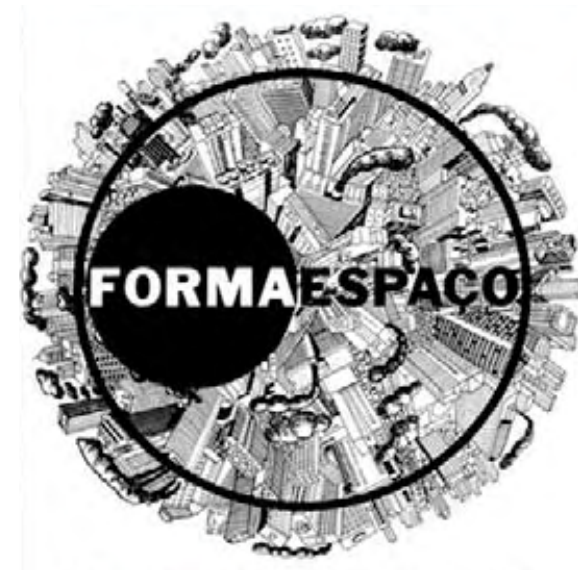

Vamos mudar a imagem negativa da nossa cidade.

Figura 16 - Publicidade da FormaEspaço, de março de 1973. Mensagem traz:“A FormaEspaço está trabalhando para transformar São Paulo numa cidade agradável e descontraída. Onde o bom gosto e o progresso se complementarão. As construções da FormaEspaço não são amontoadas. As fachadas de seus prédios não escondem gente vivendo apertada. (...) Nós não inventamos o bom gosto, apenas não o esquecemos. FormaEspaço S.A. Construções.

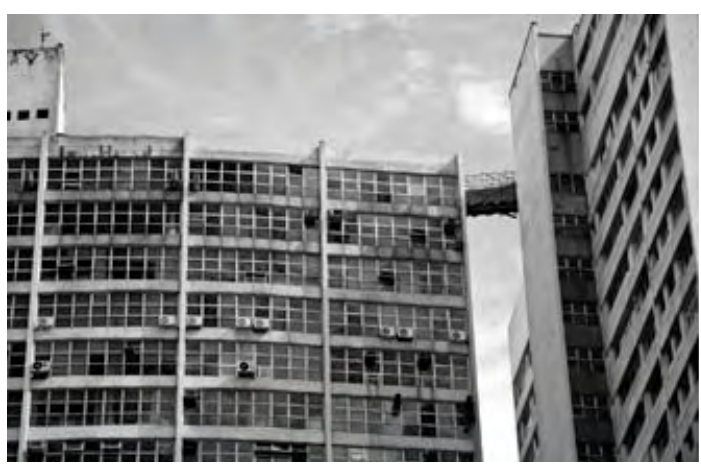

Figura $I 7$ - Conjunto Zarvos, do arquiteto Júlio Neves, no centro de São Paulo, na Av. São Luís com a Consolação. conseguiu atender o cliente com soluções individuais, cada um com sua própria arquitetura: os edifícios Modulares, por Abrahão Sanovicz; os edifícios Gemini por Eduardo de Almeida; e o edifício Protótipo de Paulo Mendes da Rocha. (Figuras 15 e 16).

Walid Yázigi também foi responsável por edifícios assinados por arquitetos com uma produção reconhecida, como por exemplo, Paulo Mendes da Rocha. É colocado no final da citação abaixo, o benefício que este tipo de atuação pode trazer inclusive para a arquitetura da cidade.

\begin{abstract}
Walid Yazigi, responsável por edifícios assinados por Paulo Mendes da Rocha, Miguel Juliano, Botti Rubin e Salvador Candia, por exemplo, é um incorporador que tem uma história para contar (...). Este ano, Walid Yazigi completa 50 anos de trabalho. Planeja editar outro catálogo para comemorar. $O$ atual tem um curto texto de apresentação de Paulo Mendes da Rocha, que logo no início afirma:"Os arquitetos devem saudar esta colocação de obras publicadas aqui enquanto uma notícia rara da produção técnica e artística da arquitetura, no nosso meio, magistralmente amparada pelo capital privado". Em outras palavras, se a notícia não fosse rara e houvesse dezenas de profissionais como Walid Yazigi à frente das construtoras de São Paulo, a cidade teria arquitetura melhor. (SERAPIÃO, 2009, p. 97).
\end{abstract}

Otávio Zarvos, mesmo sem ser engenheiro, não deixa de estar relacionado à engenharia e construção. É formado em administração, porém, filho de construtor, Tito Zarvos ${ }^{5}$, que dirigiu durante anos a empresa de engenharia da família e entre os principais trabalhos, realizou no início da década de 1960 o "Conjunto Zarvos” (Figura 17) do arquiteto Júlio Neves, no centro de São Paulo, na Av. São Luís com a Consolação. Otávio dirigiu com seu irmão engenheiro, Fábio Zarvos, a construtora Zarvos Engenharia, criada por eles na década de 1990, pela qual realizaram, principalmente, obras residenciais. Após fase inicial da empresa, marcada pela construção de casas de alto padrão em bairros mais nobres da cidade, ainda seguindo "estilos" que o mercado propunha na época;

${ }^{5}$ Dirigiu e empresa da família durante anos, entre as atuações da construtora , realizou o conjunto Zarvos, do arquitetos Júlio Neves, localizado no centro de São Paulo, em frente ao prédio Hotel Jaguará, conhecido popularmente como "Estadão". 
começaram a realizar, depois de alguns trabalhos frustrantes, alguns empreendimentos já com alguns conceitos relacionados à personalização e ao bem-estar equiparado ao de uma unidade tipo casa, por exemplo, o Fidalga 897 (1996), de autoria da arquiteta Cristina Xavier ou o Madaloft ${ }^{6}$ (19961999) (Figura 18), na Rua Agissê, do escritório liderado pelo arquiteto Luiz Fernando Rocco, ambos na Vila Madalena. O Madaloft, por exemplo, tinha o conceito, segundo os arquitetos autores do projeto, de "produzir unidades residenciais independentes que se aproximassem ao máximo da ideia de casas autônomas, embora obviamente reunidas num prédio", com a intenção, portanto, de oferecer algumas comodidades da tipologia casa.

Depois, já sem o irmão, Otávio ainda constrói alguns edifícios na Vila Madalena. Um deles é o Roof Madalena (2003-2005) ${ }^{7}$, novamente de autoria do escritório liderado por Luiz Fernando Rocco, realizado por uma parceria entre a Zarvos Engenharia, construtora BKO e incorporação da construtora Pombeva. Trata-se de um projeto com setorizações pré-determinadas e com poucas possibilidades de adaptações. Este projeto foi citado no capítulo referente ao projeto Simpatia 234, por criar uma situação negativa à cidade, com grande muro voltado à rua Simpatia, já que o lote possui frente voltada a dois viários, Simpatia e Madalena. Outra realização ainda como Zarvos Engenharia, ou seja, ainda como construtora, seria o conjunto comercial Módulo Fidalga (Figura 19), projeto do arquiteto Valter Gola, onde está instalado o escritório da incorporadora Idea!Zarvos. Deste projeto, a importância para este breve relato da trajetória de Otávio Zarvos, fora a questão da permanente atuação na Vila Madalena, é dos espaços comerciais do Módulo Fidalga terem sido locados na época pela imobiliária Axpe Imóveis Especiais, início de uma futura parceria da Idea!Zarvos (Incorporadora), Axpe (Imobiliária) e CP3 (Construtora),

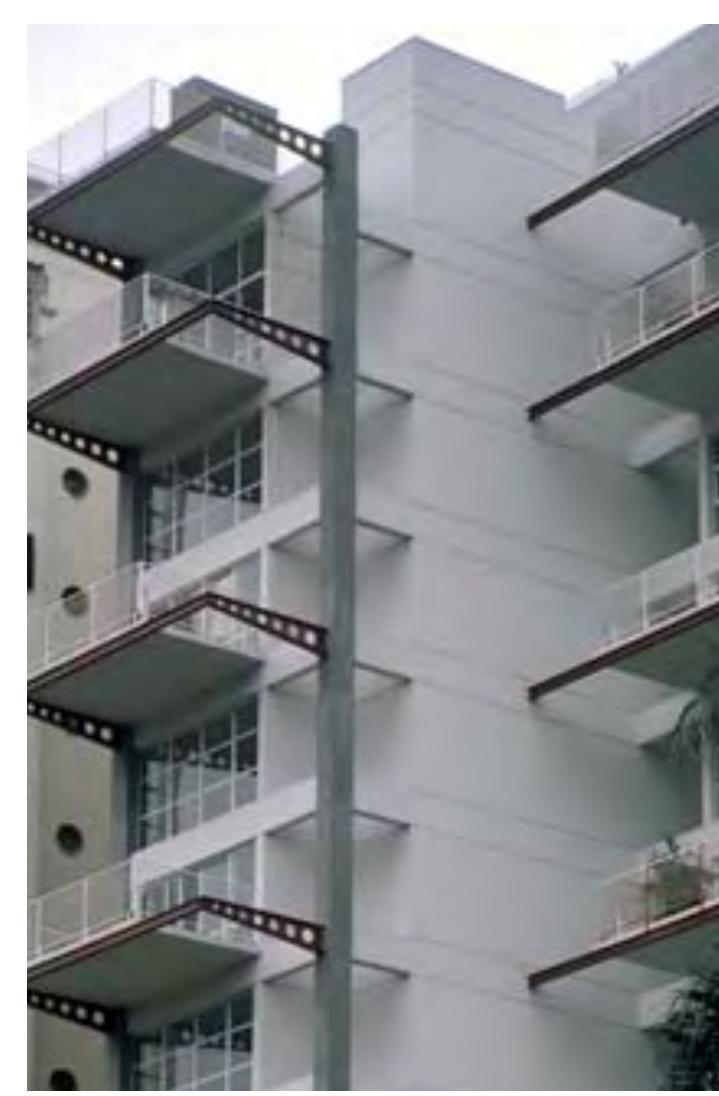

Figura 18 - Edifício, Madaloft, 1996-1999, na Rua Agissê, do escritório liderado pelo arquiteto Luiz Fernando Rocco.

\footnotetext{
${ }^{6}$ Autores: Luiz Fernando Rocco, Vasco Lopes e Eduardo Brandileoni.
}

${ }^{7}$ Autores: Luiz Fernando Rocco e Fernando Vidal. 


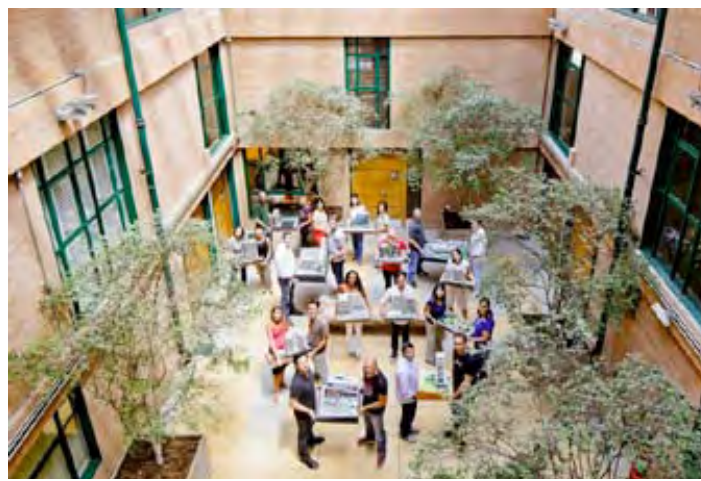

Figura 19 - Conjunto comercial Módulo Fidalga, construído pela Zarvos Engenharia, e onde está localizado o escritório da Idea!Zarvos. empresa que recebeu o nome de Movimento $\mathrm{Um}^{8}$ e que teve como primeira realização o projeto Aimberê (2005-2008), dos arquitetos Andrade Morettin, marcando o início de uma fase com algumas características que podem ser observadas nos projetos analisados nesta pesquisa, Fidalga 772 e Simpatia 234, dentre elas, o espaço interior da unidade habitacional inteiramente livre.

Alguns projetos principais desta fase, porém, nem todas pela Movimento Um, porém, da Incorporadora Idea!Zarvos são: 4 x 4 (2006-2008) e Ourânia (2007-2008), do arquiteto Gui Mattos; Fidalga 772 (2007-20 I I), dos arquitetos Andrade Morettin; Simpatia 234 (2007-20I I), do GRUPO SP; Fidalga 727 (2010-20II) do Triptyque e outros projetos incluindo alguns comerciais.

Não estou interessado naqueles especialistas em prédios de apartamentos, que aprovam rápido e fazem o que o mercado quer. Aliás, tenho horror a isso (...). $\mathrm{O}$ que eu quero é uma resposta de arquitetura contemporânea, que esses jovens conseguem dar. Como eles nunca trabalharam com o mercado imobiliário, dou todo o suporte de legislação e construção para que criem com segurança. É isso que eles sabem fazer. (Otávio Zarvos em: SERAPIÂO, 2009, p. 74).

A partir de informações colhidas nos sites das empresas citadas é possível identificar algumas características. A Axpe utiliza o slogan "Um olhar diferente sobre o morar", ou seja, comercializa edifícios fora de padrões. Também, sempre deixam evidente o atendimento diferenciado por corretores especializados e com mesmo nível intelectual e cultural dos compradores:

${ }^{8}$ Tanto a C.P.A. Engenharia e Construções Ltda. como a CP3 Incorporação tem o Engenheiro Rafael Canto Porto como responsável. Tonico Canto Porto, sobrinho de Rafael e oriundo do mercado financeiro, aparece em algumas notas da imprensa como dono da CP3 Incorporação, enquanto Rafael Canto Porto é citado como dono da C.P.A. Engenharia e Construções Ltda. Faz parte da empresa Movimento Um, a CP3 Incorporação. O site da Axpe Negócios Imobiliários Ltda.foi fundada em 2003 por José Eduardo Cazarin Silva, formado em economia e com experiência profissional em grandes agências de publicidade antes da abertura de sua própria empresa. O escritório de arquitetura liderado por Henrique Reinach e Maurício Mendonça fez alguns projetos pessoais para José Cazarin assim, Otávios Zarvos e Cazarin se conheceram por intermédio deles em 2003. 
Nossos corretores têm uma visão de mundo muito próxima a sua porque eles vêm de diferentes experiências e formações profissionais. Somos publicitários, arquitetos, advogados, engenheiros, profissionais de moda, de marketing e do mercado financeiro e optamos por trazer nossas referências e estilo para o mercado imobiliário. (SITE AXPE).

A Idea!Zarvos, por exemplo, enfatiza a importância à arquitetura autoral contemporânea e também o respeito pelo bairro ou entorno imediato ao empreendimento.

A valorização da arquitetura contemporânea e autoral é um deles. Nossa ideia é construir edifícios que continuem sempre atuais e admirados, daqui a 5, 50 ou I50 anos. Para isso, trabalhamos com arquitetos não só conceituados, mas também conceituais. Outro valor do qual nunca abrimos mão é a preocupação com o entorno. Nossas obras sempre incorporam soluções como uso misto, recuos generosos, calçadas mais largas e pequenas praças abertas ao público. (SITE IDEA!ZARVOS).

O site da C.P.A. Engenharia e Construções utiliza poucos argumentos relacionados aos novos valores da vida contemporânea, como fazem a Idea!Zarvos e a Axpe, por outro lado, menciona os parceiros, como por exemplo,Aflalo e Gasperini, Barossi \& Nakamura Arquitetos, Reinach Mendonça Arquitetos Associados, Zanetinni Arquitetura, Mauro Munhoz, para posicionar e fortalecer sua marca de construtora voltada para projetos autorais. A junção dos conceitos das empresas formam os mandamentos da empresa Movimento $\mathrm{Um}^{9}$, que podem ser acompanhadas pelas imagens ao lado: (Figura 20).

Também foi identificado outro tipo de agente:"'Empreendedor especial, que contrata e conduz o arquiteto para projetar uma habitação coletiva do mesmo modo que seria num projeto de uma residência unifamiliar", no projeto Fiori di Maggio, por exemplo.

Sr. Milton Della Pietra, dono da construtora Joy Congero, encomentou aos arquitetos Carlos Ferrata, Apoena e Moracy Amaral, Pablo Hereñú e Eduardo Ferroni um projeto de um edifício de

\footnotetext{
${ }^{9}$ Disponível em: < www.movimentoum.com.br>.Acesso em: 2010. Observação: encontrava-se fora de ar em julho de 2012.
}

Um

Figura 20 - 10 Mandamentos do Movimento Um.

01. PODERIAMOS TER ABERTO MAIS UMA INCORPORADORA. MAS PREFERIMOS LANCAR UM MOVIMENTO.

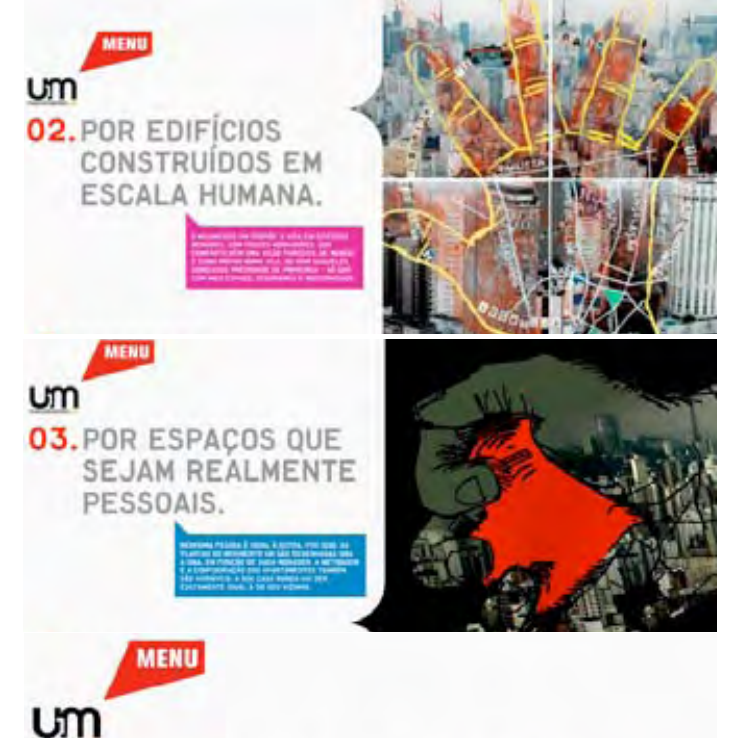

04.POR APARTAMENTOS QUE ACOMPANHEM AS FASES DA VIDA DE SEUS DONOS.

um

05. POR PRÉDIOS OUE POR PRÉDIOS QUE
APROXIMEM SEUS APROXIMEM SEUS
MORADORES DO MELHO
QUE A CIDADE TEM A OFERECER.

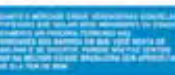

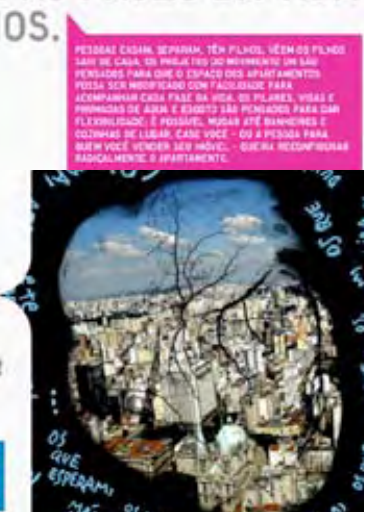


06.POR IMÓVEIS QUE SEJAM MAIS QUE INVESTIMENTO: SEJAM OBJETOS DE DESEJO.

\section{MENU \\ um \\ 07. POR UMA ARQUITETURA QUE CONTINUE ADMIRADA DAQUI A 100 ANOS.}
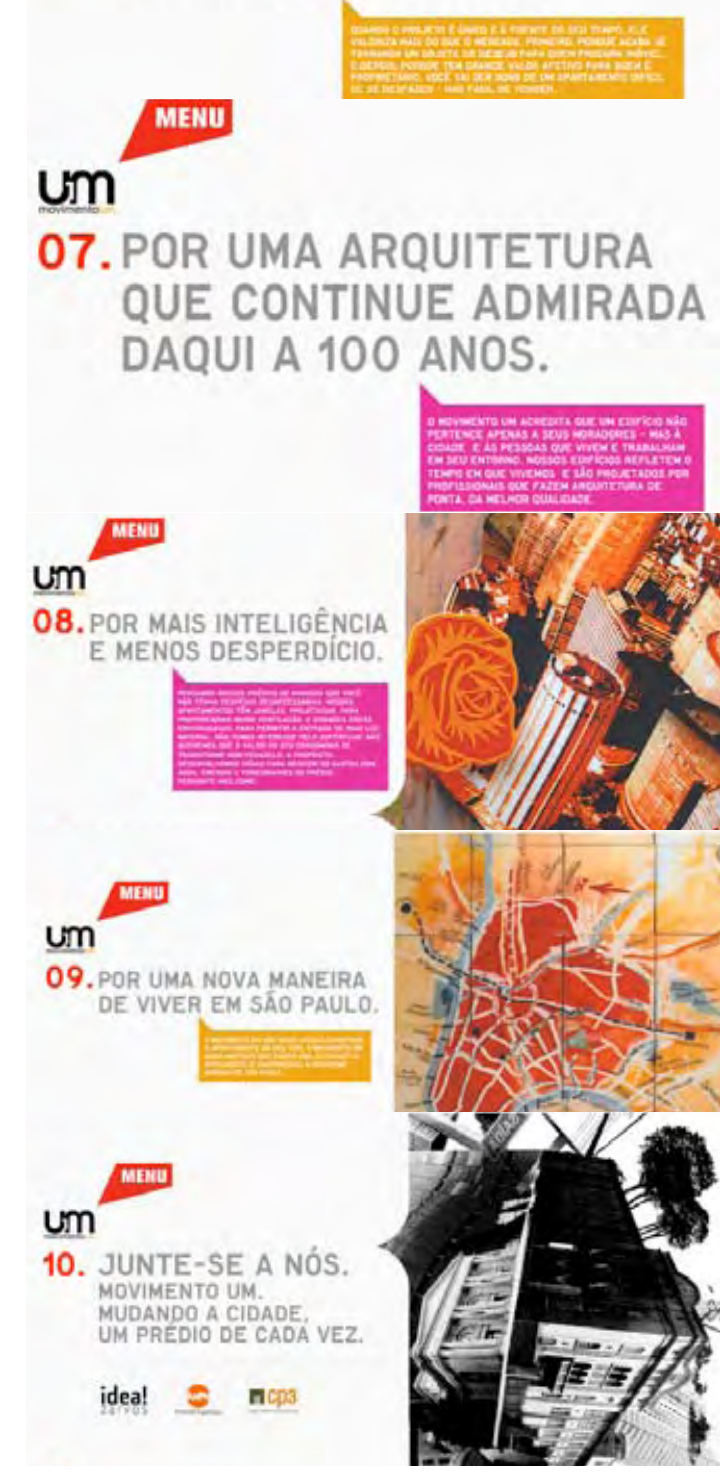

pequeno porte, para abrigar três unidades habitacionais, uma para cada filho, além do escritório da construtora da família, segundo o próprio Milton "um verdadeiro sonho da família". O tipo de relacionamento entre o contratante e os arquitetos foi parecido ao relacionamento para realização de projeto de residência unifamiliar: as soluções são específicas para a família, não se trata de um projeto impessoal ou de caráter neutro. Ao mesmo tempo, não resultou numa unidade diferente da outra, já que os irmãos, junto aos pais, aprovaram uma mesma tipologia que atenderia bem a todos. Os espaços exteriores foram aprovados conjuntamente pela família - onde ficariam as áreas de lazer, principalmente a cobertura com piscina; o escritório da família, etc.

Pelo porte maior de obra, em comparação com um projeto de residência unifamiliar, é coerente que esta atuação tenha partido de um dono de uma construtora, pela viabilidade, inclusive. Sr. Milton Della Pietra comentou que muitos materiais de revestimentos foram aqueles que ele já tinha disponível no estoque da construtora, sobras de outras obras, e também, que o projeto foi realizado à medida que o orçamento permitia ou quando a empresa não estava muito sobrecarregada com outros serviços. Por isso também a demora na execução.

Também em Buenos Aires, no bairro Floresta, os arquitetos Adama-Faiden foram encarregados de projetar um edifício para a família Lago: projeto Casas Lago (2007), (Figura 2I) composto por duas unidades habitacionais, uma para cada filho, e no terraço, uma pequena fábrica de calçados onde trabalham quatro membros da família. Assim, também houve a situação de projetar habitação coletiva, do mesmo modo que se projeta uma residência unifamiliar.

Cada una de las casas se organiza como un único espacio previendo su futura subdivisión para el momento en el que cada uno de los hijos forme su propia familia. El resto de las decisiones se corresponden con un presupuesto muy ajustado y con una voluntad de simplificación que tiene como fin la intensificación del habitar contemporáneo (Adamo-Faiden, sobre Casas Lago). 
Para os outros dois casos, Vila Pedro Fachini e Canaã, agentes de "Incentivo a projetos autorais pela Promoção Pública" e "Microempreendedor que deposita confiança no arquiteto”, como existe apenas um exemplar selecionado de cada tipo, nas próprias leituras específicas de cada projeto foi feito um breve relato sobre os agentes.

Para o caso do microempreendedor, trata-se um tipo mais genérico, onde a singularidade é mais voltada à técnica construtiva altamente econômica criada por Joan Villà, do painel pré-fabricado cerâmico. Também, como a atuação representava uma novidade, afinal, seria o primeiro empreendimento da Construtora Zénica para o perfil de baixa renda, e principalmente, utilizando aquela técnica construtiva muito específica, houve uma confiança maior na vasta experiência no ramo que a equipe de arquitetura possuía, obviamente, sem sair do orçamento previsto.

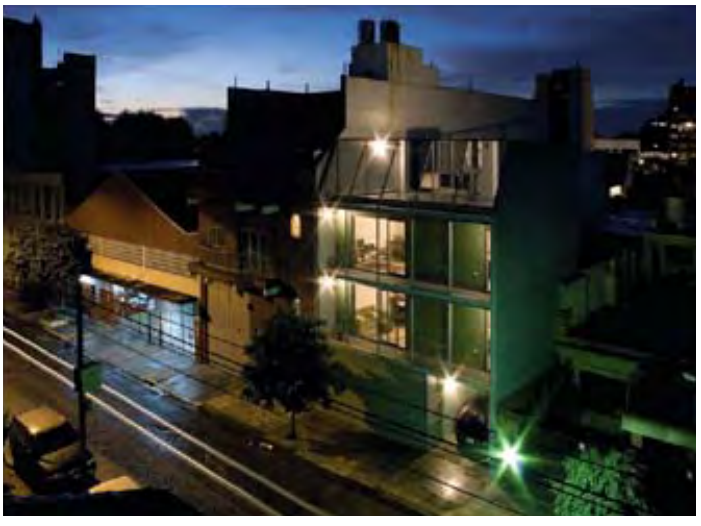

Figura 2 I - Casas Lago, 2007, Arquitetos Adamo-Faiden, Buenos Aires. 
ANTUNES. Bianca. Frentes de trabalho. Arquitetura e Urbanismo, São Paulo, n. 2 I8, maio de 2012.

ARQUITETURA E URBANISMO. Inovador na forma e no meio. São Paulo, n. I86, setembro de 2009.

BARIANI, Márcio. Poesia sem formalismo. ProjetoDesign, São Paulo, n. 333, p. 102, novembro de 2007.

CORBIOLI, Nanci. Plantas flexíveis agregam valor à escala reduzida. ProjetoDesign, São Paulo, n. 360 , p. $62-65$, fevereiro de 2010.

DIEZ. Fernando Tácticas de Infiltración. Diez años de experimentación en Buenos Aires. SUMMA+, Buenos Aires, n. I07, p.34-39, abril de 20 I0.

FELIPPE, Maria Inês. Empreendedorismo: buscando o sucesso empresarial. Sala do Empresário, São Paulo, 1996, v.4, n. I6, pl 0-12 (suplemento).

fERREIRA, A. B. H. (Ed.). Novo Dicionário da Língua Portuguesa. São Paulo: Positivo Livros, $4^{\mathrm{a}}$ edição, 2010.

FLORESTA, Cleide. Cidade incorporada. Arquitetura e Urbanismo, São Paulo, n. 207, p. 66-7I, junho de 20 II.

IMBRONITO, M. I. Três edifícios de habitação para a Formaespaço: Modulares, Gemini e Protótipo. 2003. Dissertação (mestrado em Arquitetura e Urbanismo), Universidade de São Paulo, São Paulo, 2003.

MELENDEZ,Adilson. Mirante de concreto. ProjetoDesign, São Paulo, n.287, p., janeiro de 2004.

MORAES, S. R. C.; PERRONE, R.A. C. O repensar na participação do arquiteto na fase de concepção do produto imobiliário na cidade de São Paulo. CLEFA SJO 20 I 2. XXIV Conferencia Latinoamericana de Esculeas y Facultades de Arquitectura:Arquitectura y Urbanismo em Latinoamérica. Tendencias emergentes. San José da Costa Rica, Antigua Aduana, 16 a 21 de abril de 2012.

MOURA, Éride. Generosas aberturas permitem integração com o exterior. ProjetoDesign, São Paulo, n.241, p. 57-59, março de 2000.

ROSSO, Silvana Maria.Arquiteto Incorporador. Arquitetura e Urbanismo, São Paulo, n.205, p. 26-3I, abril de 201 I. 
SABBAG, Haifa Y. Beleza com conteúdo. Arquitetura e Urbanismo, São Paulo, n. I 45, p.48-55, abril de 2006.

SERAPIÃO, F. Coexistência pacífica: no mesmo andar, apartamentos comum e dúplex. ProjetoDesign, São Paulo, n. 24I, p. 60-63, março de 2000. Mudança de ares. ProjetoDesign, São Paulo, n.353, p. 68-79, julho de 2009.

. e edifício invisível e a cidade inexistente. ProjetoDesign, São Paulo, n. 24I, p. 94, março de 2000.

Onde estão os Walids? ProjetoDesign, São Paulo, n. 353, p. 94, julho de 2009.

Quatro pecados louváveis. ProjetoDesign, São Paulo, n. 313, p. 88, março de 2006.

. Silêncio e anonimato. ProjetoDesign, São Paulo, n. 3 I I, p. 94, janeiro de 2006.

TRONCOSO, Ursula.Arquitetura Propositiva.Arquitetura e Urbanismo, São Paulo, n. 218, maio de 20I2, p. 60-65.

VILLA, S. B. Morar em Apartamentos: a produção dos espaços privados e semi-privados nos edifícios ofertados pelo mercado imobiliário no século XXI em São Paulo e seus impactos na cidade de Ribeirão Preto. 2008. Tese (Doutorado em arquitetura e Urbanismo), Universidade de São Paulo, São Paulo, 2008.

WILHEIM, Jorge. Mão escondida projeta arquitetura medíocre. São Paulo:Vitruvius, 096.04, julho 2008. Disponível em: < http://www. vitruvius.com.br/revistas/read/arquitextos/>.Acesso em: 04/02/20I3. 
SITES:

http://ideazarvos.com.br

http://www.adamo-faiden.com/casas-lago/

http://www.axpe.com.br/

http://www.cpaeng.com.br/arquitetos.htm

LEIS:

BRASIL (federal). Lei $n^{\circ} 4.591$, de 16 de dezembro de 1964. Dispões sobre o condomínio em edificações e as incorporações imobiliárias. 



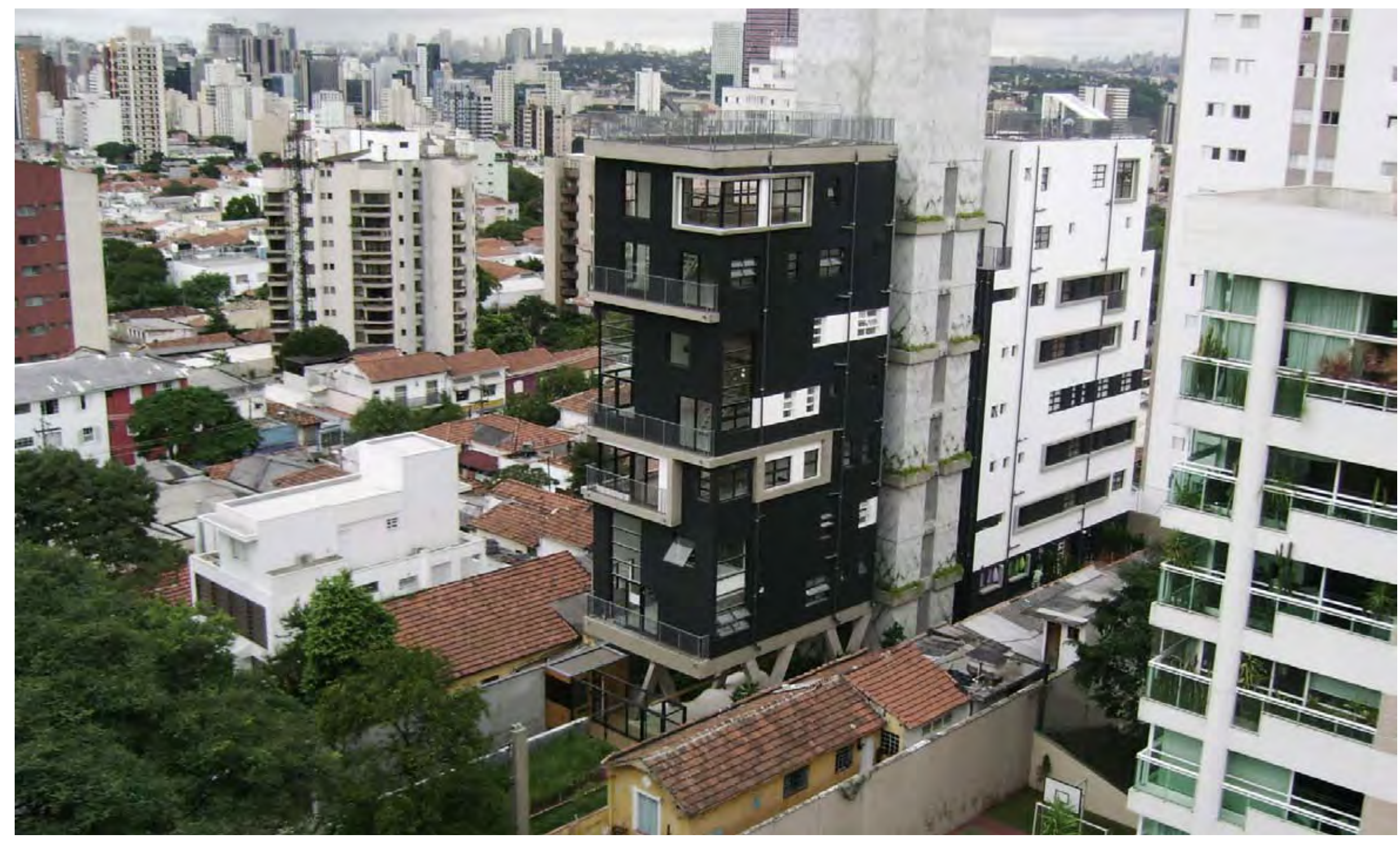

5. CONSIDERAÇÕES FINAIS 
As análises e comparações gráficas apresentadas mostram a dificuldade de se colocar apenas um tema como principal e mais notável nos projetos apresentados, por exemplo, dizer que são obras diferenciadas apenas pelas soluções das envoltórias, ou pelas múltiplas resoluções dos espaços exteriores, ou apenas pela análise da implantação do projeto no lote urbano, por exemplo. Também, o grau de importância dos temas será diferente em cada projeto, ou seja, existem questões mais significativas do que outras para cada obra. Desse modo, os projetos estão vinculados a múltiplos sistemas de valoração conformados por variáveis, sendo árduo colocá-las e verificá-las nos projetos sempre dentro do mesmo grupo tipológico, tratando-se, portanto, de uma rede complexa de correlações ou interdependências.

Por isso, a leitura individual e focada em cada projeto foi necessária e anterior a qualquer tipo de comparação, pois as obras possuem um conjunto de características e processos de realização muito particulares. Uma comparação final é também importante para evidenciar que as obras não pertencem a grupos tipológicos rígidos e sempre iguais, e sim, apresentam algumas ideias parecidas e que, não necessariamente por isso, irão pertencer em todos os temas ao mesmo grupo tipológico ou de sistematização geral do mestrado (Conjuntos Residenciais Horizontais, Edifícios pouco verticalizados com unidades habitacionais sobrepostas e Edifícios verticalizados com unidades habitacionais sobrepostas).

Este estudo também pode representar uma contribuição importante na busca por parâmetros de qualidade em projetos de habitação coletiva, visto que, atualmente, prevalece na paisagem das cidades uma arquitetura enfraquecida que possivelmente referencia jovens ingressantes das inúmeras faculdades de arquitetura ou até os muitos profissionais já graduados'. Assim, pesquisas sobre e por meio de projetos são necessárias como referência e incentivo a uma boa arquitetura, afinal, quais são as referências atuais evidentes?

Parece contraditório o fato de que, mesmo com o aumento do número de arquitetos graduados pelas universidades, o que predominantemente se constrói parece ser cada vez menos determinado pelos instrumentos projetuais aprendidos e principalmente valorizados numa boa instituição. Sim, a "Mão escondida" que "projeta arquitetura mediocre”, pode ser a mão de um arquiteto graduado; porém, traz alívio perceber que também existem arquiteturas com qualidades expressivas ou marcantes, por exemplo, pela diferenciação, que também são projetadas por arquitetos, havendo portanto, mudança possível. No primeiro caso, a atribuição do arquiteto é pouco valorizada, no segundo caso, é engrandecida, mesmo que para isso seja necessário o próprio arquiteto ser um dos agentes promotores do empreendimento ou contar com agentes empreendedores especiais, elevando a importância do projeto e do próprio arquiteto, que se sobressaem pela valorização dentro de um processo maior, que reconhece a importancia de outras fases para sua realização e atuação: escolha do terreno, concepção do empreendimento, execução e fase após a construção.

'Segundo SAVATORI (2008) em 2008, o número de escolas de arquitetura no Brasil chegava a quase 200, e o número de profissionais formados em arquitetura registrados no sistema CREA/CONFEA chegava a quase 100000. 
Os exemplares desta pesquisa conseguem aproximar duas situações possíveis para a arquitetura: uma arquitetura com qualidade, que coloca em prática conceitos aprendidos, verificados e em alguns casos, ensinados na academia (já que muitos arquitetos atores protagonistas desta pesquisa são docentes em universidades de arquitetura); com uma arquitetura voltada a uma necessidade prática. Por exemplo, no projeto Vila Fachini, encomendado pela Companhia de Habitação Municipal de São Paulo, houve assimilação ou inspiração em eventos trazidos da vida academia, por exemplo, da tese sobre Franz Heep elaborada por Marcelo Barbosa. No caso da Vila Butantã, não apenas foi um projeto como também uma pesquisa técnica, a partir do desenvolvimento de uma laje nervurada mista de concreto e madeira, testada e patenteada pelo Departamento de Estruturas da Escola Politécnica da Universidade de São Paulo. Para o caso do Simpatia 234, mesmo atendendo solicitações extremamentes comerciais e respostas a necessidades práticas, consegue manter referências da escola paulista de arquitetura.

Desse modo, os projetos de destaque nesta pesquisa, não representam contraponto entre uma arquitetura de proposição e a arquitetura de produção, primeiro porque não são iniciativas ligadas diretamente à universidade, e segundo, pois conseguem estabelecer aproximação e interrelação entre estas duas facetas dando respostas às necessidades práticas com certo grau de sofisticação devido a conhecimentos não apenas adquiridos na academia como também difundidos na prática profissional: efeitos concretos da prática profissional na boa construção da cidade.

Una arquitectura de proposición, normalmente ligada a la universidad y principal objeto de discusión de la crítica.Por el otro, una arquitectura de producción cuyo principal objetivo es dar respuesta a las necesidades prácticas, al encargo, produciendo la mayoría de los edificios contruidos en una ciudad bajo las normas, las condiciones técnicas y económicas, y con los procedimientos corrientes disponibles. (DIEZ, 2008, p. 70).

Desse modo, o que pode estar também faltando na arquitetura que marca e domina negativamente as cidades, é a influência da arquitetura de proposição sobre a de produção (não apenas uma coisa ou outra). Os estudos de caso alcançam esta positiva inter-relação, porém, representaria um êxito maior e mais significativo uma produção ampliada e não apenas casos isolados.

Aunque a veces menospreciada como subalterna y llamada con el peyorativo término "profesionalista", la arquitectura de producción es la que constituye la masa edificada que da forma a las ciudades y expressa el êxito o fracaso social de la disciplina como profesión. Entendidas de esta manera, la arquitectura de proposición y de producción son complementarias. (DIEZ, 2008, p. 70) 
Assim, fica como contribuição desta pesquisa, uma pequena parcela de produção de arquitetura contemporânea com propósitos diferenciados, já que foi realizada por varios arquitetos, cada um com sua linguagem e repertorio próprio; concebida por diferentes agentes; em terrenos e localidades com condicionantes variadas; com programas específicos; com consideração das varias possibilidades de técnicas construtivas e mão de obra disponível; para atendimento aos diferentes desejos e necessidades dos moradores; enfim, uma produção que não foi configurada, segundo Wilheim (2008), pela "mão escondida”, protagonista que desenha plantas com dimensões iguais, que desenha sempre as mesmas fachadas, com os mesmos tons de beje, e que dificilmente divulga a autoria pelos projetos. Poderia-se dizer, que a mão escondida pertence a um arquiteto robô comandado por um agente imobiliário, ou simplesmente a um arquiteto que precisa sobreviver. Em todo caso as lamentações com relação a esta situação decadente e lamentável já são suficientes, o melhor é apostar em atitudes concretas que instigam novos rumos à arquitetura habitacional coletiva que parecem estar se aproximando. 


\section{I BIBLIOGRAFIA DO CAPÍTULO}

DIEZ. Fernando.Arquitectura de proposición y arquitectura de producción. SUMMA+, Buenos Aires, n.94, p.70-79, junho de 2008.

SAVATORI, Elena.Arquitetura no Brasil: ensino e profissão. Arquiteturarevista, vol. 4, n.2, p. 52-77, julho/dezembro de 2008.

WILHEIM, Jorge. Mão escondida projeta arquitetura medíocre. São Paulo:Vitruvius, 096.04, julho 2008. Disponível em: < http://www. vitruvius.com.br/revistas/read/arquitextos/>. Acesso em: 04/02/2013. 



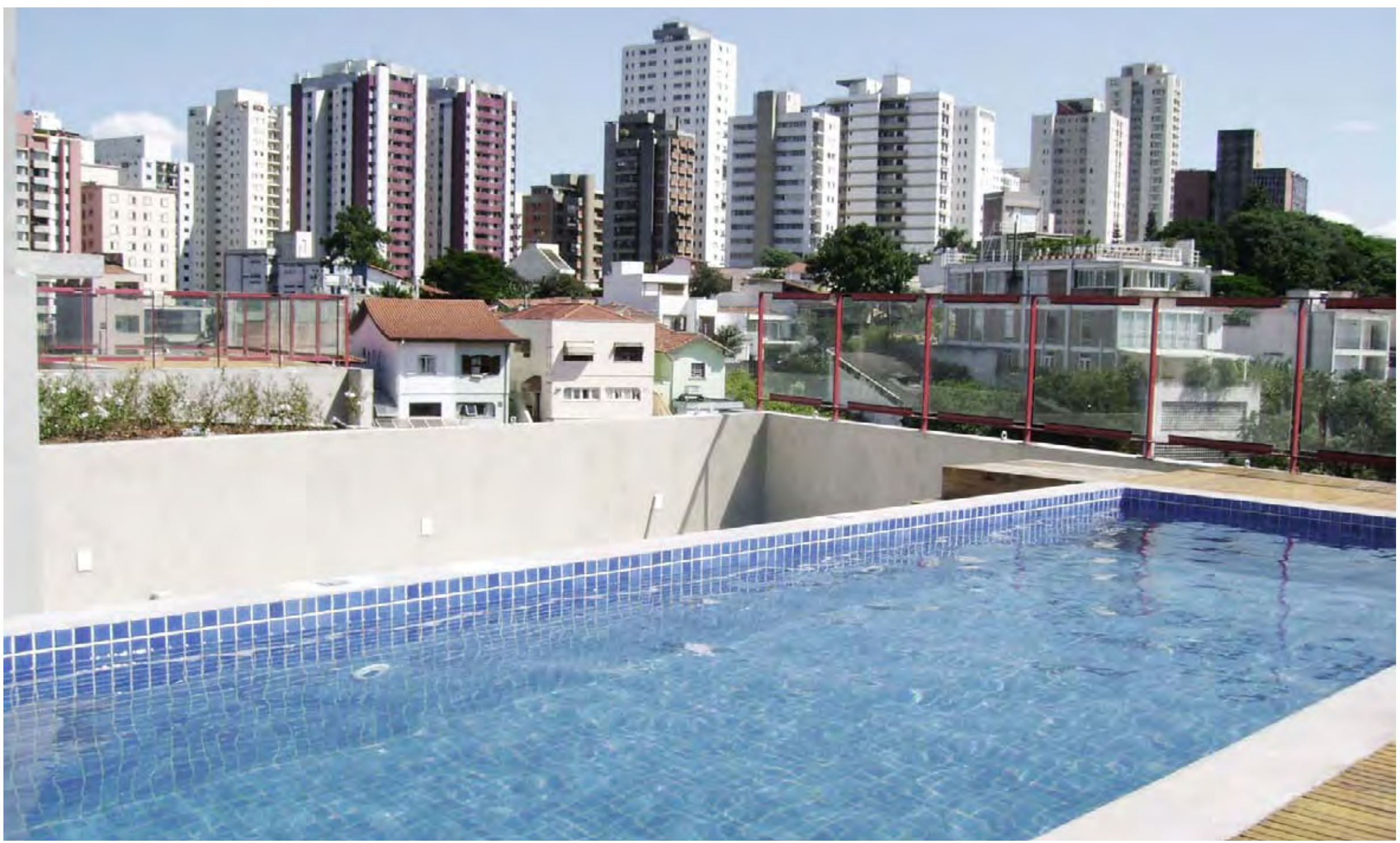

ÍNDICE DE IMAGENS E REFERÊNCIAS BIBLIOGRÁFICAS 


\section{APRESENTAÇÃO:A BOA ARQUITETURA}

Figuras I e 2 - Revista AU: da Edição 87 (dez 1999) e Edição 207 (junho 20I I), a última é uma edição especial de edifícios residenciais.

Figuras 3 e 4 - Revista ProjetoDesign: da Edição 238 (dez 1999) e Edição 37I (jan 201 I), a última é uma edição especial anos 00 , recorte temporal da pesquisa.

Figura 5 - Condominium Club Up Side e East Side Club Condominium Konogsberger,Vannucchi Arquitetos Associados, Paraíso, zona Sul, São Paulo. MELENDEZ, Adilson. Condomínios substituem fábrica onde projeto Brahma fracassou. ProjetoDesign. São Paulo, n.299, p. 98, janeiro de 2005.

Figura 6 - Vila da Barca (2003-2007), Escritório Cooperativa, Belém, Pará. MOURA, Éride. Poliedros regulares. Arquitetura e Urbanismo. São Paulo, n. 170, p.32-37, maio de 2008.

Figura 7 - Temístocles 12 (2006), JSA Arquitetosm Cidade do México, México. LEAL, Ledy Valporto. Jogos de planos e volumes. Arquitetura e Urbanismo. São Paulo, n. I72, p.60-63, julho de 2008.

Figura 8 - Amélia Teles 315 (2009-20I I), Smart!Lifestyle+Design. Arquitetos empreendedores projetam um novo futuro para os edifícios residenciais de Porto Alegre. Arquitetura e Urbanismo. São Paulo, n. 189, p. I4, dezembro de 2009.

Figura 9 - Box House (2007-2008), Yuri Vital. CAPOZZI, Felipe. Inovação a baixo custo. Arquitetura e Urbanismo. São Paulo, n. 194, p. 48-53, maio de 2010. PROJETODESIGN. São Paulo, n.348, fevereiro de 2009.

Figura 10 - Panorama (2006-2007), Isay Weinfeld. GRUNOW, Evelise. Retrofit adiciona volume frontal à antiga edificação. ProjetoDesign. São Paulo, n.340, p. 66-7I, junho de 2008. LEAL, Ledy Valporto. Área livre.Arquitetura e Urbanismo.

São Paulo, n. I7I, p.32-39, junho de 2008.

\section{I.I VILA BUTANTÃ: ESTÉTICA DA LÓGICA}

Figura I - Vista do núcleo residencial de llha Solteira. Fonte:TSUKUMO, 1994, p. 102.

Figura 2 - Entrada Vila Butantã. Fonte: autora.

Figura 3 - Conjunto de Casas no Alto da Boa Vista. Foto da entrada (1973-74). Fonte:ACAYABA, 2007.

Figura 4 - Exemplo de tipologia em lote estreito e comprido, na cidade de São Bernardo do Campo, com problemas de ventilação e insolação. Planta Pavimento Térreo. Fonte: autora. 
Figura 5 - Exemplo de tipologia em lote estreito e comprido, na cidade de São Bernardo do Campo, com problemas de ventilação e insolação. Planta Pavimento Superior. Fonte: autora.

Figura 6 - Exemplo de tipologia em lote estreito e comprido, na cidade de São Bernardo do Campo, com problemas de ventilação e insolação. Foto fachada. Fonte: Google Street View.

Figura 7 - Exemplo de tipologia em lote estreito e comprido, na cidade de São Bernardo do Campo, com problemas de ventilação e insolação. Foto corredor. Fonte:Autora.

Figura 8 - Perspectiva do conjunto de casas no Alto da Boa Vista. Fonte:ACAYABA, 2007.

Figura 9 - Cortes do conjunto de casas no Alto da Boa Vista. Fonte:ACAYABA, 2007.

Figura 10 - Plantas do conjunto de casas no Alto da Boa Vista. Fonte:ACAYABA, 2007.

Figura I I - Sede da Fazenda Pindorama, Cabreúva, São Paulo (1974-1975). Fonte:Acervo Marcos Acayaba.

Figura 12 - Residência Milan, Bairro Cidade Jardim, São Paulo (1972-1975). Fonte:Acervo Marcos Acayaba.

Figura 13 - Implantação Nova Tatuapé, Residencial I. Fonte:TREVISAN, 2006.

Figura 14 - Vista aérea Nova Tatuapé, Residencial I. Fonte: Google Maps.

Figura 15 - Portaria do conjunto Nova Tatuapé, Residencial I. Fonte: Google Street View.

Figura 16 - Foto do trecho do renque de doze casas desde o viário interno da Vila Butantã. Fonte: autora.

Figura 17 - Primeira casa do renque maior (casa 05), junto ao muro de divisa na Vila Butantã. Espaço externo privativo aberto ao espaço coletivo, de maneira similar a que acontece na Vila Taguaí. Fonte: autora.

Figura 18 - Vista da área de lazer coletiva em direção às últimas casas do renque de doze casas na Vila Butantã.

Figura 19 - Ao fundo, prédios na Av. Caxingui que rompem com a horizontalidade predominante da Vila Pirajussara. A torre mais alta, Ed. Quatiara, é projeto de Rui Othake de 1972. Fonte: autora.

Figura 20 - Dormitório: barrotes de madeira aparente. Fonte: autora.

Figura 2 I- Pavimento intermediário: área de serviços com tábua de passar roupa em madeira. Fonte: autora.

Figura 22 - Detalhe da cobertura acessível: mesma solução adotada na Vila Fidalga, o guarda-corpo é fixado na placa de concreto que por sua vez é fixada no contrapiso, evitando, assim, furações na estrutura e, consequentemente, infiltrações.

Figura 23 - Detalhe do guarda-corpo,Vila Fidalga. Fonte:Acervo Cristina Xavier.

Figura 24 - Detalhe de luminária na garagem. Fonte: autora.

Figura 25 - Detalhe da ausência de local adequado para instalar luminária na passarela do Conjunto Habitacional 
Figura 26 - Pavimento intermediário: armário na garagem, elemento integrado à estrutura da unidade. Fonte: autora.

Figura 27 - Pavimento intermediário: cozinha integrada com a sala de jantar, vão de 6m sem paredes divisórias. F. autora.

Figura 28 - Cobertura do "Espaço Pacaembu" de autoria do Arquiteto Marcos Acayaba e arquiteta Adriana Aun, 1999. mesma solução de guarda-corpo na cobertura. Fonte:Acervo Marcos Acayaba.

Figura 29 - Terraço acessível, Vila Butantã. Fonte: autora.

Figura 30 - Residência Bettiol, Lago Sul, Brasília, (1976) - Zanine Caldas. Fonte: ProjetoDesign, n. 262, abril de 2010.

Figura 3 I e 32 - Casa de Hélio Olga Jr. Construída em I 980 - 1982, com estrutura e desenho de Zanine.AFLALO, 2005. 50

Figura 33 - Galpão da Ita Construtora, em Vargem Grande Paulista, e os funcionários trabalhando. Fonte:AFLALO, 2005.5 I

Figura 34 - Residência de Hélio Olga, arquitetura contemporânea com o uso da madeira. 1987-1990.

Acervo Marcos Acayaba

Figura 35 - Implantação Kingohusene (1958-60), em Helsingor, de Jørn Utzon. Fonte: Google.

Figura 36 - Kingohusene (1958-60), em Helsingor, de Jørn Utzon. Fonte: <http://eng.archinform.net/projekte/I75I.htm>. Acesso em: 23/10/2012.

Figura 37 - Conjunto Soholm (1950/55), em Klampenbold, de Arne Jacobsen. Fonte: <http://hokuouzemi.exblog.jp/il 29/>. Acesso em: 23/10/2012.

Figura 38 - Implantação do conjunto Soholm (1950/55), em Klampenbold, de Arne Jacobsen. Fonte: <http://www.greatbuildings.com/buildings/Soholm_Housing_Estate.html> Acesso em: 23/10/2012.

Figura 39 - Implantação do conjunto Habitacional Bakkedraget (habitação com pátio interno) de 1963, em Fredensborg, Dinamarca, de Jørn Utzon. Fonte: <http://architecture.about.com/library/blutzon-fredensborg.htm> Acesso em: 23/l0/2012.

Figura 40 - Conjunto Habitacional Bakkedraget (habitação com pátio interno) de 1963, em Fredensborg, Dinamarca, de Jørn Utzon. Fonte: <http://architecture.about.com/library/blutzon-fredensborg.htm> Acesso em: 23/I0/20I2.

\section{I.2 VILA FIDALGA: UNIDADES DIFERENTES UMAS DAS OUTRAS}

Figura I - Vila Fidalga desde a Praça Dolores Ibarruri. Fonte: autora.

Figura 2 - Segunda casa da arquiteta e pela arquiteta em Carapicuíba, 1992. Fonte:Acervo Cristina Xavier.

Figura 3 - Residência Pato, Cotia, 1988. Fonte: João Batista Xavier. 
Figura 4 - Projeto concurso para o Paço Municipal de Osasco, I99।. Fonte: MELENDEZ, 200 I.

Figura 5 - Projeto reforma do Galpão da O2 Filmes (2007-2012),Vila Leopoldina, São Paulo. Fonte: Pedro Kok. Disponível em: <http://www.vilataguai.com.br/>.Acesso em: 06/01/2013.

Figura 6 - Projeto reforma do Galpão da O2 Filmes (2007-20I2),Vila Leopoldina, São Paulo. Fonte: Pedro Kok. Disponível em: <http://www.vilataguai.com.br/>. Acesso em: 06/01/2013.

Figura 7 - Projeto reforma do Galpão da O2 Filmes (2007-2012),Vila Leopoldina, São Paulo. Fonte: Pedro Kok. Disponível em: <http://www.vilataguai.com.br/>.Acesso em:06/01/2013.

Figura 8 - Projeto reforma do Galpão da O2 Filmes (2007-20I2),Vila Leopoldina, São Paulo. Fonte: Pedro Kok. Disponível em: <http://www.vilataguai.com.br/>. Acesso em:06/0I/2013.

Figura 9 - Material gráfico referente ao projeto da Vila Fidalga para auxílo durante a venda das unidades. Fonte:Acervo Cristina Xavier.

Figura 10 - Trecho do quarteirão da Rua Fidalga com alta declividade. Fonte: autora.

Figura I I - Trecho da Rua Fidalga de zona de média densidade, onde as transformações e substituição de casas unifamiliares por edifícios ou casas sobrepostas é mais notável. Fonte: autora.

Figura 12 - Fidalga 955, visto desde a Rua Fidalga. Fonte: Google Street View.

Figura 13 - À direita, Fidalga 897, de autoria da Arquiteta Cristina Xavier. À esquerda, conjunto habitacional na altura do número 955 da mesma Rua. Realizações na mesma quadra em que está localizada a Vila Fidalga. Fonte: João Xavier.

Figura 14 - Vista da Vila Fidalga desde a rua inclinada. Fonte: autora.

Figura 15 - Vista da Rua Fidalga e praça desde o espaço de uso coletivo da vila. Fonte: autora.

Figura 16 - Espaço de uso coletivo na vila, entre as unidades habitacionais. Ao fundo, casa 3, à direita, acesso casa 5 e, à esquerda, empena casa 4. Fonte: autora.

Figura 17 - Espaço de uso coletivo na vila: à direita, espaço para uso do porteiro. Fonte: autora.

Figura 18 - Algumas árvores existentes no terreno, que foram mantidas, são importantes na definição dos espaços abertos. Fonte: autora.

Figura 19 - Posição da garagem em nível abaixo do espaço de uso coletivo. Fonte: autora.

Figura 20 - Casa 02 à direita e acima, casa 01 à esquerda. Fica difícil entender qual o limite de cada uma, pois são fundidas numa arquitetura única. Fonte: autora.

Figura 2 I - Casa 04: espaço exterior coletivo x privativo. Fonte: autora. 
Figura 22 - Casa 06 vista desde a Casa 04: exemplo de uma área privativa de interesse comum. Fonte: autora.

Figura 23 - Casa 02 vista desde o espaço de uso coletivo: vestíbulo externo, filtro entre as relações coletivas e privativas. Fonte: autora.

Figura 24 - Detalhe casa 04. lluminação zenital no banheiro. Fonte: autora.

Figura 25 - Detalhe casa 04. Notar shafts para instalações no perímetro da caixa de escada. Fonte: autora. 75

Figura 26 - Casa 04:área social. Fonte: autora.

Figura 27 - Casa 04: área social. Fonte: autora.

Figura 28 - Detalhe casa 04.Varanda, como extensão do interior, permite comunicação da unidade com o espaço que a rodeia. Fonte:Acervo Cristina Xavier.

Figura 29 - Brechas com vista para a cidade entre as casas 04 e 06, algumas supresas que a vila oferece. Fonte: autora.

Figura 30 - Casa 04: acesso à área de serviço. Fonte: autora.

Figura 3 I - Casa 04: vista da área de serviço desde o espaço de uso coletivo. Fonte: autora.

Figura 32 - Planta térrea da Residência Roberto Millan, 1960, arquitetura Carlos Millan. Fonte:ACAYABA, 201 I.

Figura 33 - Planta pavimento superior da Residência Roberto Millan, 1960, arquitetura Carlos Millan. Em destaque, dormitório da empregada. Fonte:ACAYABA, $20 \mathrm{II}$.

Figura 34 - Condomínio Bosque das Videiras, Aldeia Aldeota, Ceará. Casas padronizadas e espalhadas no terreno. Fonte disponível em:<http://www.skyscrapercity.com/showthread.php?t=465703>. Acesso em:06/0I/20I3.

418 Figura 35 - Conjunto Habitacional Nova Naval, Diadema, São Paulo. Foi concebido em três pavimentos, para não existir um choque cultural muito grande - pois antes essa famílias viviam em favelas -, porém, em limites individuais. Fonte:Acervo SEHAB Diadema, 2010.

Figura 36 - Casas no Vera Cruz,Av. Dr. Ulisses Guimarães, Diadema, São Paulo.A prefeitura entregou uma casa térrea, de aproximadamente $30 \mathrm{~m} 2$, e quase que imediatamente a população a transformou de acordo com suas vontades.

Fonte: Google Street View.

Figura 37 - Detalhe do guarda-corpo no terraço: sem furações na estrutura, evitando infiltrações pela laje. Fonte: autora. 
Figura 0 I - Conjunto Canaã. Renque de oito casas em harmonia com a topografia existente. Fonte: autora.

Figura 02 - Conjunto Canaã. Relação do renque verde com o azul. Fonte: autora.

Figura 03 - Moradia Estudantil da Unicamp (1992), Barão Geraldo, Campinas, SP. Fonte: Júlia Risi. Disponível em: <http://www.flickr.com/photos/juliarisi2/391760924I/in/photostream/>.Acesso em: I4 /09/20I2.

Figura 04 - Ensaio do primeiro painel de laje (1985). Fonte:VILLÀ, 2005, p.5.

Figura 05 - Mulheres trabalhando na construção de moradias em mutirão autogerido. Fonte:ARANTES, 2002.

Figura 06 - Autoconstrução com adoção de práticas comuns por pessoa sem ofício ou habilidade no ramo, Diadema, SP (20I I). Fonte: autora.

Figura 07 - Sarcelles, França. Conjunto Habitacional dos anos 60. Grande escala, monotonia e grandes problemas sociais. Fonte disponível em: <http://www.hipcescu.com/20I I/02/welcome-to-sarcelles/>. Acesso em: 14/09/2012.

Figura 08 - Escola rural para 50 alunos em esquema de montagem. Abadiânia, Goiás. Desenho de João Figueiras Lima, anos 80. Fonte: EKERMAN, 2005.

Figura 09 - Igreja de San Pedro em Durazno, Uruguai. Eladio Dieste, 1969-7I. Fonte disponível em: <http://marionfeldmannarquitetura.blogspot.com.br/20 I2/02/agroindustria-massaro-juanico-o.html>.Acesso em I4/09/2012.

Figura 10 - Cenas do Filme Super 8, das cooperativas Uruguaias. O Eng. Guilherme Henrique Pinto Coelho divulgou muito este filme em São Paulo, principalmente para a comunidade de Vila Nova Cachoeirinha, no início dos anos 80. Fonte: BAVARELLI, 2006.

Figura I I - Pista de montagem de painéis CPC em formato curvo. Fonte:VILLÀ, 2005, p.7.

Figura 12 - Casa-embrião COHAB Raposo Tavares, anos 80, período próximo à entrega da unidade. Segundo diagnóstico do Arq. Hector Vigliecca, o espaço frontal sem definição fica a mercê de um crescimento descontrolado dos habitantes. Fonte: acervo pessoal Hector Vigliecca.

Figura 13 - Casa-embrião COHAB Raposo Tavares, anos 80, alguns anos depois da entrega da unidade. Segundo diagnóstico do Arq. Hector Vigliecca, o espaço frontal sem definição fica a mercê de um crescimento descontrolado dos habitantes. Fonte: acervo pessoal Hector Vigliecca.

Figura 14 - Vista para o entorno a partir do terraço de uma unidade do renque amarelo. Fonte: autora.

Figura 15 - Rua de acesso ao conjunto. À direita, vagas externas ao espaço condominial. Fonte: autora.

Figura 16 - Três renques, cada um com uma cor e nível diferentes e a base possui cor "terra": destaque e integração na paisagem ao mesmo tempo. Fonte:VILLÀ, 2005, capa. Foto: Nelson Kon.

Figura 17 - Pelo projeto, era para existir neste espaço uma quadra esportiva. Fonte: autora. 
Figura 18 - Pelo projeto, era para existir neste espaço um pavilhão de lazer. Fonte: autora.

Figura 19 - Execução de um painel Pré-fabricado Cerâmico. Fonte:VILLÀ, 2005, p.07.

Figura 20 - Qualidade de acabamento dos painéis pré-fabricados: juntas regulares, ortogonalidade e efeito plástico da marcação rebaixada da junção de $4 \mathrm{~cm}$ de concreto entre os blocos cerâmicos. Mesmo com a pintura, a técnica está aparente. Fonte: autora.

Figuras 2 I e 22 - O terraço coberto: partiu da observação e do desejo popular. Fonte: autora.

Figura 23 - Casas na cidade de Congonhas do Campo, Minas Gerais: uso corrente do “lajão” coberto.

Fonte: Google Street View.

Figura 24 - Casas autoconstruídas no Bairro Alvarenga, em S. B. do Campo, divisa com a cidade de Diadema (20I I). Fonte: Google Street View.

Figura 25 - Casas no Jabaquara, favela Alba, SP (201 I). Fonte: autora.

Figura 26 - Esqueleto estrutural da Maison Dom-ino, 19|4-15. Le Corbusier. Fonte disponível em:

<http://www.e-flux.com/journal/architecture-without-architects\%E2\%80\%94another-anarchist-approach/>.

Acesso em: 14/09/2012.

Figura 27 - Casa em Pessac, França. tipologia 4 com dois pavimentos independentes e com terraço acessível.

Fonte disponível em: <http://www.bifurcaciones.cl/003/Kale.htm>. Acesso em: 14/09/2012.

Figura 28 - Elevação e planta da tipologia 4, do projeto de Le Corbusier em Pessac, França.

Fonte: BOUDON, 1985, p.42.

Figura 29 - Plantas da tipologia 3, do projeto de Le Corbusier em Pessac, França. Fonte: BOUDON, 1985, p.42.

Figura 30 - Crianças espiando apartamento do térreo no conjunto habitacional “SABESP” em Heliópolis, São Paulo.

\section{I.4VILA TAGUAÍ: PARCERIA ENTRE ARQUITETURA E ENGENHARIA}

Figura I - Entrada Vila Taguaí: exemplo singular de vila contemporânea. Fonte: autora.

Figura 2 - Portaria de condomínio fechado próximo à Vila Taguaí. Fonte: autora.

Figura 3 - Favela próxima à Vila Taguaí. Fonte: Google Street View.

Figura 4 - Estrada Taguaí, tratamento diferenciado da pavimentação. Fonte: autora. 
Figura 5 - Casa em Carapicuíba, UNA Arquitetos, 1998. Fonte: autora.

Figura 6 - Casa em Carapicuíba, UNA Arquitetos, 1998. Fonte disponível em:

<http://www.unaarquitetos.com.br/site/projetos/detalhes/2/casa_em_carapicuiba>.Acesso em: 28/09/2012.

Figura 7 - Representação da implantação no folheto de vendas, com definição do que seria o limite do lote, situação que, na realidade, não fica evidente. Fonte: folheto de vendas Vila Taguaí.

Figura 8 - Espaço entre casas 6 e 7: caminho de pedras que leva ao espaço de lazer comunitário ao fundo e inexistência de cercamentos ou divisas entre as casas. Fonte: autora.

Figura 9 - Espaço no nível dos pilotis: ambiente intermediário entre o coletivo e o privativo. Fonte autora.

Figura 10 - Casa 5: ocupação do espaço do nível dos pilotis. Fonte: autora.

Figura I I - Casa 3: acesso no nível intermediário. Fonte: autora.

Figura 12 - Casa em condomínio fechado em Carapicuíba: recuo mínimo entre as casas e muro de divisa. Fonte disponível em: <http://carapicuiba.olx.com.br/magnolias-casa-em-condominio-dentro-de-um-bairro-fechado-iid-52749066>. Acesso em: 28/09/201 2.

Figura 13 - Condomínio recém loteado na cidade de Sarandi, vizinha a Maringá, no estado do Paraná - muro com mais de $1 \mathrm{~km}$ de extensão, isolamento do uso residencial e nenhuma preocupação com a preservação do meio ambiente, mesmo beirando córrego. Fonte: Beatriz Fleury.

Figura 14 - A existência de conjuntos residenciais isolados, tanto aqueles destinados à população de baixa renda, quanto para população da classe $A$ e $B$, está relacionada, também, ao custo do solo muito elevado nas cidades. Foto de um conjunto promovido pelo programa “Minha Casa Minha Vida” em Sarandi, Paraná. Fonte: Beatriz Fleury.

Figuras 15 e 16 - Exemplo de folheto publicitário e stand de vendas típicos do mercado imobiliário, mas que, para a Vila Taguaí, foram inexistentes. Fonte disponível em: $<$ http://www.blogdomadeira.com.br/informe-publicitario/plantao-de-vendasdo-bairro-treviso-neste-fim-de-semana/>. Acesso em: 28/09/2012.

Figura 17 - Folheto de vendas da Vila Taguaí: apresentação arquitetônica e não publicitária. Fonte: Folheto de vendas Vila Taguaí.

Figura 18 - Detalhe do painel laje apoiado nos pilotis de concreto. Fonte: autora.

Figura 19 - Detalhe do painel, módulo construtivo do projeto. Fonte: Ita Construtora.

Figura 20 - Execução da camada de $5 \mathrm{~cm}$ de concreto magro do painel tipo laje. Fonte: Ita Construtora.

Figura 21 - Painéis estruturais de madeira: estocagem e montagem na obra. Fonte: Ita Construtora.

Figura 22 - Montagem da casa com as peças pré-fabricadas. Fonte: Ita Construtora. 
Figura 23 - Shafts externos, visíveis na fachada. Fonte: autora.

Figura 24 - Shafts em destaque. Fonte: autora.

Figura 25 - Detalhe dos shafts visto em planta. Fonte: autora.

Figura 26 - Wohnanlage Ölzbündt, em Dornbirn, Vorarlberg, Áustria, do arquiteto Architekten Hermann Kaufmann ZT GmbH. Fonte disponível em: <http://www.hermann-kaufmann.at>. Acesso em: 15//2/201 2.

Figura 27 - Montagem com painéis pré-fabricados do projeto Wohnanlage Ölzbündt, em Dornbirn,Vorarlberg, Áustria, do arquiteto Architekten Hermann Kaufmann ZT GmbH. Fonte disponível em: <http://www.hermann-kaufmann.at>.

Acesso em: 15/12/2012.

Figura 28 - Etapas de fabricação de madeira laminada colada de eucalipto na Ita Construtora: após a recepção da matéria prima e controle por amostragem (densidade, umidade, módulo de elasticidade), é realizado o desdobro (foto 0I) e

determinação das perdas (foto 02). Após eliminar os trechos defeituosos da madeira, as lâminas são unidas no sentido do comprimento, pelo processo denominado "Finger-jointe" (foto 03). Na sequência, a colagem é feita manualmente com cola PU (foto 04) e após esta etapa é realizado o controle por amostragem, ou seja, ensaios para determinação da capacidade de carga. Depois, é realizada a padronização da espessura das lâminas $(30 \mathrm{~mm})$, no processo denominado aparelhamento (foto 05 ). São coladas as lâminas resultantes com cola PU novamente, porém, no sentido da altura da seção (foto 06). Na sequencia, a prensa é alimentada (foto 07) e a laminação é concluída com o fechamento da prensa, que proporciona peças de até $12 \mathrm{~m}$. A usinagem normalmente é realizada manualmente (foto 09) e depois é aplicado "stain" (hidrofugante, cupinicida, fungicida). Novos ensaios por amostragem são realizados após a peça MLC pronta. Fonte: Ita Construtora. Disponível em: <http://www.itaconstrutora.com.br/novidades/downloads/files/TAGUAl.pdf>.Acesso em: I5/I2/20I2.

Figura 29 - Haras Polana, Arquiteto Mauro Munhoz. Fonte: Ita Construtora.

Figura 30 - Hannover Expo 2000 (Germany) by Thomas Herzog and Julius Natterer. Disponível em http://www.skyscrapercity.com/showthread.php?t=339347\&page=8. Acessado em 27/07/2012.

Figura 31 - Estádio Altusried, Alemanha, do arquiteto Alsturied Mohr, 1999. Fonte disponível em: <http://www.altusried.de/kultur/fotosbau.html>.Acesso em: 27/09/ 2012.

Figura 32 - Remanescente de casa enxaimel, em Blumenau, Santa Catarina. Fonte:André Paiva. Disponível em: <http://www.andrepaiva.com.br/index.php?lang=pt-br\&cmd=galeria\&id=2I\&foto=233>. Acesso em: $16 / 12 / 2012$.

Figura 33 - Espaço junto aos quartos na VilaTaguaí, unidade 5. Fonte: autora.

Figura 34 - Peças sanitárias separadas na VilaTaguaí, unidade 5. Fonte: autora.

Figura 35 - Arquitetura Contemporânea com o uso da madeira,Vila Taguaí, unidade 6. Fonte: autora.

Figura 36 - Foto atual externa da Casa de Vidro, Morumbi, da arquiteta Lina Bo Bardi, 195I. Fonte: autora. 
Figura 37 - Foto atual interna da Casa de Vidro, Morumbi, da arquiteta Lina Bo Bardi, I95।. Fonte: autora.

Figura 38 - Área social Vila Taguaí: sensação de vertigem da Casa de Vidro de Lina Bo Bardi. Fonte: Daniel Ducci.

Figura 39 - Detalhes do projeto apresentado por Lúcio Costa para a Villa de Monlevade, 1934. Fonte: Revista da Diretoria de Engenharia da Prefeitura do Distrito Federal, vol.3, ${ }^{\circ} 3$.

Figura 40 - Residência Antônio Cunha Lima,Arquiteto Joaquim Guedes, Pacaembu, 1958-63. Fonte disponível em: $<w w w . v i v e r c i d a d e s . o r g . b r>$.Acesso em: 01/08/2012

\subsection{VILA PEDRO FACHINI: HABITAÇÃO DE INTERESSE SOCIAL NA CIDADE DE SÃO PAULO}

Figura I - Moradores da Vila Pedro Fachini. Fonte:Acervo BACCO Arquitetos Associados.

Figura 2 - Ministério das Finanças na França (1989). Arquitetura Chemetov + Huidibro, escritório no qual Jupira Corbucci trabalhou durante sua estadia na França na década de 1980. Fonte disponível em: <http://www.paris-architecture.info/PA-076.htm>. Acesso em:09/02/2013.

Figura 3 - Ao fundo, Sede do Conselho Regional de Contabilidade do Estado de São Paulo, edifício construído a partir de Concurso Nacional do qual Marcelo Barbosa, Roberto Amá e Jupira Corbucci saem vencedores em 1991. Em primeiro plano, projeto da ampliação realizado em 2008 pelo escritório BACCO Arquitetos Associados, contratado por notório saber. Fonte: acervo BACCO Arquitetos Associados.

Figura 4 - Publicações no âmbito da arquitetura de habitação social lançadas recentemente pela Secretaria de Habitação da Prefeitura de São Paulo. I. Do Plano ao Projeto: Novos Bairros e Habitação Social em São Paulo (20 I2). 2. O Urbanismo nas Preexistências Territoriais e o Compartilhamento de Ideias (20I2). 3. Livro Renova São Paulo (20II). 3. Entre o Céu e a água - O Cantinho do Céu (20I2). São Francisco (20I2).Vila Nilo (20I I).

Fonte: http://www.habisp.inf.br/theke/documentos/publicacoes/.Acesso em: 09/02/2013.

Figura 5 - Revistas especiais no âmbito da habitação social ou intervenções em favelas, algo, que começou a ficar mais frequente a partir do ano de 2009 aproximadamente. Fonte: revista Arquitetura e Urbanismo n. I86, setembro de 2009; revista Arquitetura e Urbanismo n.200, novembro de 2010; Revista ProjetoDesign n.384, fevereiro de 2012 e revista Monolito n.07, fevereiro/março de 2012.

Figura 6 - Projeto Cingapura em primeiro plano (construído durante a gestão do prefeito Paulo Maluf na década de 1990), ao fundo, favela Real Parque, São Paulo. Fonte: Rubens Chaves. Disponível em: <http://www.pulsarimagens.com.br/details.php?tombo=07RC206\&search=mostviewed>.Acesso em: 06/0I/20I3.

Figura 7 - Alguns projetos de Habitação de Interesse Social publicados nas revistas ProjetoDesign ou Revista Arquitetura 
e Urbanismo na década de 2000.

- OI.Conjunto Paraisópolis (2008-20II). Paraisópolis, São Paulo.Arquiteto Edson Elito. Fonte: autora.

- 02.Conjunto Alexandre Mackenzie (2008-2009). Nova Jaguaré, São Paulo. Boldarini Arquitetura e Urbanismo. Fonte: autora.

- 03.Conjunto Residencial Itaoca (2008-2009). Morro do Alemão, Rio de Janeiro.Arquitetos Jorge Mario Jaurégui e Mauricio Santos. Fonte: Sérgio Huoliver.

- 05.Conjunto Mutirão Paulo Freire (200I-2010). Cidade Tiradentes, São Paulo. Projeto do USINA - Centro de trabalhos para o Ambiente Habitado. Fonte: http://www.usinactah.org.br/.Acesso em: 09/02/2013.

- 06.Conjunto SABESP (2008-2012), Heliópolis, São Paulo. Arquiteto Ruy Ohtake. Fonte: autora.

- 07.Condomínio Princesa Isabel (2004-2006). Porto Alegre. Meta Arquitetura. Fonte: autora.

- 08.Urbanização da área Colinas D’Oeste/Morro do Socó (2007-2010). Osasco, RMSP.Vigliecca Arquitetos Associados. Fonte: acervo Vigliecca Arquitetos Associados.

- 09.Quinta Monroy (2004). Iquique, Chile. ELEMENTAL. Fonte: <http://www.elementalchile.cl> .Acesso em: 09/02/2013.

Figura 8 - Projeto Vila dos Idosos. Vigliecca Arquitetos Associados. Fonte:Acervo Vigliecca Arquitetos Associados.

Figura 9 - Projeto Casarão do Carmo.Vigliecca Arquitetos Associados. Fonte:Acervo Vigliecca Arquitetos Associados.

Figura 10 - Projeto Parque Novo Santo Amaro V.Vigliecca Arquitetos Associados. Fonte disponível em:

<http://www.livingdesign.net.br/20I2/I I/hector-vigliecca-fala-sobre-cidadania-e-urbanismo-em-palestra-nomcb.html/parque-novo-santo-amaro-v>.Acesso em: 27//2/2012.

Figura I I - Edifício Rua Senador Feijó - unidades para locação social - COHAB/SP. Fonte:Autora

Figura 12 - COHAB Carlos Gomes, São Paulo, 2004. Projeto elaborado para a COHAB a partir de uma licitação pública. $O$ edifício possui estacionamento independente e 64 unidades habitacionais. Fonte: Portifólio BACCO.

Figura 13 - Edifício Madre de Deus, localizado na Rua Madre de Deus, Mooca, São Paulo. O projeto inicial foi desenvolvido pela Superintendência de Habitação Popular (HABI), coordenada pelo Arq. Claudio Manetti. A execução do empreendimento foi realizada mediante o estabelecimento de um convênio com a associação especialmente formada para a construção por mutirão: Associação de Construção por Mutirão Madre de Deus. O projeto foi desenvolvido pela assessoria técnica $A D$, que também foi responsável pelo acompanhamento das obras. Fonte: Google Street View.

Figura 14 - Projeto Imoroty. Peabiru - Trabalhos Comunitários e Ambientais. Fonte:Acervo Peabiru.

Figura 15 -Vila Pedro Fachini. Situação do lote urbano. Fonte:Autora.

Figura 16 -Vila Pedro Fachini. Escadas no recuo de três metros. Fonte:Autora. 
Figura 17 - Vila Pedro Fachini.Vista lateral do conjunto desde a Rua Pedro Fachini. Fonte:Acervo BACCO Arquitetos Associados.

Figura 18 -Vila Pedro Fachini. Maquete eletrônica e fachada frontal da versão preliminar do projeto. Fonte:Acervo BACCO Arquitetos Associados.

Figura 19 -Vila Pedro Fachini.Vista do espaço, no recuo frontal de cinco metros. Fonte: autora.

Figura 20 -Vila Pedro Fachini.Varandas e escadarias como meio de contato audiovisual do edifício e seus moradores com o espaço externo. Fonte:Autora.

Figura 2 I - Layouts em que foram traçados círculos com diâmetro de 2,80 m, mostrando uma boa adaptação do mobiliário básico nesta proporção. Fonte/Referência: MONTANER MUXÍ ARQUITECTES. Definición, condiciones y critérios de diseño para la vivienda Del siglo XXI en Andalucía, 2008.

Figura 22 - Vila Pedro Fachini.Vista do lavatório externo. Fonte:Autora.

Figura 23 -Vila Pedro Fachini.Vista do Pátio Interno como extensão da cozinha. Fonte:Autora.

Figura 24 - Vila Maida. Pátio interno integrado com o espaço de estar da unidade habitacional.Arquiteta Maristela Faccioli. Fonte:Autora.

Figura 25 - Edifício Icaraí (terceiro edifício da direita para a esquerda).Arquiteto Franz Heep. Fonte:Autora.

Figura 26 - Projeto Paraisópolis. Arquiteto Edson Elito. Fonte:Autora.

Figura 27 - Projeto Alexandre Mackenzie, Boldarini Arquitetura e Urbanismo. Fonte:Autora.

Figura 28 -Vila Pedro Fachini. Caixilhos com grelha de ventilação permanente. Fonte: autora.

Figura 29 - Envoltória VilaPedro Fachini. Mesclas e variedades de tipos de aberturas e cores da fachada. Fonte:Autora.

Figura 30 -Tipologia pavimento-tipo "Prédio Conectável” utilizada no projeto do Conjunto Paraisópolis. Arquiteto Edson Elito. Paredes não estruturais em vermelho. Fonte:Acervo SEHAB.

\subsubsection{FIORI DI MAGGIO:ARQUITETURA CONTEMPORÂNEA PAULISTA COLETIVA}

Figura I - Edifício Fiori di Maggio. Inserção do Edifício na Rua Santa Adelaide, em trecho do bairro predominantemente horizontal.Fonte: Pregnolato \& Kusuki Estúdio Fotográfico.

Figura 2 - Residência na Lapa em construção, de 1998-1999, Bela Vista Arquitetos. Fonte disponível em:

<http://www.centro.arq.br/1998/tipo/habitacional/residencia-na-lapa/>.Acesso em: I0//2/2012. 
Figura 3 - Casa em Perdizes, 1996-1998, SPRB, na qual Pablo Hereñú colaborou ainda como estudante de arquitetura. Equipe:Angelo Bucci, Fernando de Mello Franco, Marta Moreira e Milton Braga. Colaboradores: Judith Hardy, Alvaro Puntoni, Carmem Morais, Keila Costa e Pablo Hereñu. Fonte disponível em: <http://www.spbr.arq.br/>.

Acesso em: 5/10/2012.

Figura 4 - Residência em Aldeia da Serra, 200I, MMBB, na qual Eduardo Ferroni colaborou ainda como estudante de arquitetura. Equipe:Angelo Bucci, Fernando de Mello Franco, Marta Moreira e Milton Braga. Colaboradores:Anna Helena Vilella, Eduardo Ferroni, Maria Júlia Herklotz e André Drummond. Fonte disponível em:

<http://www.mmbb.com.br/projects/view/I9>.Acesso em: 5/10/2012.

Figura 5 - Concurso HabitaSampa 2004. Menção Honrosa 2: Conjunto Cônego Vicente M. Marino. Equipe formada pelos Arquitetos Cooperantes: Pablo Emilio Hereñú, Anna Helena Vilella, Eduardo Ferroni, Fernanda Neiva, Fernanda Palmieri, Maria Julia Herklotz, Paula Cardoso e Silvio Oksman. Fonte disponível em:

<http://www.vitruvius.com.br/revistas/read/projetos/04.040/2290>.Acesso em:5/I0/20I 2.

Figura 6 - Concurso HabitaSampa 2004. Menção Honrosa 5: Conjunto Cônego Vicente M. Marino. Equipe GRUPO SP: Álvaro Puntoni, João Clark Sodré e Jonathan Davies. Fonte disponível em:

<http://www.vitruvius.com.br/revistas/read/projetos/04.040/2290>. Acesso em: 5/10/2012.

Figura 7 - Concurso HabitaSampa 2004. Menção Honrosa I: Conjunto Cônego Vicente M. Marino. Equipe Núcleo de Arquitetura: Luciano Margotto Soares, Marcelo Ursini e Sergio Salles. Fonte disponível em:

<http://www.vitruvius.com.br/revistas/read/projetos/04.040/2290>.Acesso em: 5/10/2012.

Figura 8 - Conjunto Ponte dos Remédios, 20I I, Marcos Acayaba e H+F arquitetos. Equipe: Eduardo Ferroni, Marcos Acayaba, Pablo Hereñú, Luisa Fecchio, Natália Tanaka, Tammy Almeida, Thiago Moretti, Carolina Millani, Thiago Benucci, Danilo Hideki, Eliana Uematsu, Joel Sanabra, Luca Mirandola, Mariana Puglisi, Marta Pavão, Diogo Pereira, Diogo Cavalari, Stela da Dalt, Gabriel Roccheti, Paula Saito. disponível em: <http://www.hf.arq.br/projeto/conjunto-ponte-dos-remedios/>. Acesso em: 5/10/2012.

Figura 9 - Conjunto Jardim Edith. São Paulo, 2008-20I2, MMBB e H+F arquitetos. Equipe: Eduardo Ferroni, Fernando de Mello Franco, Marta Moreira, Milton Braga, Pablo Hereñú Eduardo Martini, Marina Sabino, Giovanni Meirelles, Cecília Góes, Gleuson Pinheiro, Adriano Bergemann, André Costa, Maria João Figueredo, Nana Rocha,Tiago Girao, Guilherme Pianca, Giselle Mendonça, Eduardo Pompeu, Tammy Almeida, Joel Bages, Natália Tanaka, Diogo Pereira, Gabriel Rocchetti, Thiago Benucci, Mariana Puglisi, Luca Mirandola,Thiago Moretti, Bruno Nicoliello e Renan Kadomoto. Fonte disponível em:

$<$ http://www.hf.arq.br/projeto/conjunto-jardim-edith/>.Acesso em: 5/I0/2012.

Figura 10 - Escola Estadual Aparecidinha, 2006-2009, Sorocaba, Centro Arquitetura. Equipe: Carlos Ferrata, Carolina Bueno Andrade Silva, Cecília Reichstul, Moracy Amaral e Almeida e Tiago Oakley. Coordenador do Projeto: FDE; arquitetas Mirela Geiger de Mello e Vânia Regina Pierri de Oliveira. Fonte disponível em:

<http://www.centro.arq.br/2006/tipo/institucional/e-e-aparecidinha/>.Acesso em: 5/I0/2012. 
Figura I I - Casa em Bragança, São Paulo, 2008-2009, Centro Arquitetura. Equipe: Carlos Ferrata e Patrícia Grimaldi Abud. Fonte disponível em: <http://www.centro.arq.br/2009/ tipo/habitacional/casa-braganca/>.Acesso em: 5/I0/20I2.

Figura 12 - Concurso HabitaSampa 2004. 3 Prêmio: Conjunto Assembleia. Equipe: César Shundi Iwamizu, Ricardo Bellio, Alexandre Mirandez de Almeida, Carlos Ferrata, Cássia Buitoni, Daniel Pollara, Luciana Yamamura, Marcelo Pontes de Carvalho, Mariana Viegas e Moracy Amaral. Fonte disponível em: <http://www.vitruvius.com.br/revistas/read/projetos/04.040/2290>. Acesso em: $5 / 10 / 2012$.

Figura 13 - Arquitetos recebendo o prêmio no $8^{\circ}$ Prêmio Jovens Arquitetos, promovido pelo IAB-SP, categoria obra executada, com o projeto do Edifício Fiori di Maggio. Fonte disponível em:

<http://www.arqbacana.com.br/aconteceu/8o+Pr\%C3\%AAmio+Jovens+Arquitetos>.Acesso em: 5/I0/2012.

Figura 14 - Fachada do Edifício Fiori di Maggio na Rua Santa Adelaide, em São Bernardo do Campo, São Paulo.

Figura 15 - Edifício Havaí, I 983. Equipe:Antonio Carlos Barossi, Jaime Cupertino e José Sales Costa. Fonte: FERRATA e SHUNDI (Org.), 20I2, p. 38.

Figura 16 - Vista do Edifício Fiori di Maggio desde a Rua Santa Adelaide. Fonte:Autora, 19 dez. 2012.

Figura 17 - Vista das edificações na Rua Santa Adelaide. Fonte:Autora, 19 dez. 2012.

Figura 18 - Esquema vista frontal e relação do gabarito máximo de altura permitido. Fonte: autora.

Figura 19 - Implantação do conjunto de habitação coletiva, de 1973, em Celerina, na Suíça, do arquiteto Luiggi Snozzi. Fonte disponível em: <http://celulaf5.blogspot.com.br/>.Acesso em: 5/10/2012.

Figura 20 - Planta tipo e elevação do conjunto de habitação coletiva, de 1973, em Celerina, na Suíça, do arquiteto Luiggi Snozzi. Fonte disponível em: <http://celulaf5.blogspot.com.br/>.Acesso em: 5/10/2012.

Figura 2 I - Fresta de três metros entre os dois volumes do Fiori di Maggio, que chega até o nível inferior, onde há um jardim. Fonte: autora.

Figura 222 - Corte Ed. Havaí. Fonte: FERRATA e SHUNDI (Org.), 2012, p. 42.

Figura 23 - Cobertura do Fiori di Maggio. Fonte: autora. 206

Figura 24 - Espaço flexível transformado em cinema. Fonte: autora. 206

Figura 25 - Unidade Habitacional Edifício Havaí. Fonte: FERRATA e SHUNDI (Org.), 2012, p. 49.

Figura 26 - Armários no corredor da unidade habitacional do Fiori di Maggio. Fonte: autora. 207

Figura 27 - Detalhe no canto da fachada leste do Edifício Fiori di Maggio. Fonte: autora. 208 


\subsection{FIDALGA 772: ENVOLTÓRIA CONTEMPORÂNEA}

Figura I - Relação do edifício Fidalga 772 com as construções vizinhas existentes. Fonte autora.

Figura 2 - Trecho sem saída da Rua Fidalga devido à topografia acidentada presente no bairro. Fonte autora.

Figura 3 - Relação do pátio da escola municipal e a face sudeste do edifício Fidalga 772. Fonte autora.

Figura 4 - Nota-se, pela foto da obra, o sinal de corte de terra ao fundo do terreno, comprovando o forte aclive que existia antes da obra. Fonte:Acervo Andrade Morettin Arquitetos Associados.

Figura 5 - Entrada do Edifício Fidalga 772 e terraço no térreo oficial voltado para a rua. Fonte autora.

Figura 6 - Térreo oficial.Ao fundo, terraço voltado à rua. Fonte autora.

Figura 7 - Trecho do folheto publicitário do Fidalga 772. Fonte: Folheto de vendas Fidalga 772 . Fonte autora.

Figura 8 - Imagem de área de lazer coletiva em folheto de vendas da GAFISA. Disponível em:

<http://www.gafisa.com.br/imoveis/sp/sao-paulo/easy-vila-romana\#2>.Acesso em:08/06/2012.

Figura 9 - Imagem da área de uso coletivo no Fidalga 772: área reduzida e sem espaços para atividades coletivas.

Fonte: SUMMA+, n. I20, p. 79, 2012.

Figura 10 - Entre os 10 mandamentos do Movimento Um, o quinto é com relação ao Habitar Coletivo em comunhão com a cidade. Disponível em: <www.movimentoum.com.br>. Acesso em: 01/05/2010.

Figura I I - St. Edward's University New Residence and dining hall de autoria do arquiteto chileno Alejandro Aravena. F onte: SUMMA+, n. 106, 2010.

Figura 12 - Edifício Aimberê: monobloco esculpido, as faces externas são mais rugosas e rústicas e as faces escavadas são brancas e lisas. Fonte: SUMMA+, n. 107, p. 29, 2010.

Figura 13 - Fachada Fidalga 772. Fonte autora.

Figura 14 - Casa em Carapicuíba (1997). Disponível em: <www.andrademorettin.com.br>.Acesso em: I5/07/2012.

Figura 15 - Casa em Ubatuba (2006). Fonte: ProjetoDesign, n. 333.

Figura 16 - Fidalga 772: revelação da cidade pelas fachadas que mesclam painéis transparentes e opacos. Fonte autora. 
Figura 17 - Edifício de escritórios na rua Wizard (2009 - em execução). Fonte: Monolito, n. II, p. I 3 I.

Figura 18 - Edifício Aimberê: desde a primeira proposta para a Zarvos os arquitetos seguem a linha de raciocínio a partir do corte. Fonte: SUMMA+, n. 107, p. 29, 2010.

Figura 19 - Edifício Ourânia, do arquiteto Gui Mattos, ausência de pavimento-tipo. Fonte:Arquitetura e Urbanismo, n. 201, p. 46, 2011.

Figura 20 - Fidalga 800, Reinach Mendonça: pensado a partir da planta, resultando em estratificação horizontal e pavimentos-tipo idênticos. Disponível em: <http://fidalga800.com.br>.Acesso em: 15/07/20I2.

Figura 2 I - Espaço com pé-direito duplo: viga já preparada para instalação do mezanino. Fonte autora.

Figura 22 - Apartamento com mezanino instalado. Fonte autora

\subsubsection{SIMPATIA 234:ARQUITETURA CONTEMPORÂNEA PAULISTA}

Figura I - Edifício Simpatia 234 e sua relação com o bairro. Fonte: Nelson Kon.

Figura 2 - Planta Baixa do projeto vencedor para o Pavilhão do Brasil na EXPO 92, em Sevilha. Fonte disponível em: $<w w w . g r u p o s p . a r q . b r />$.Acesso em: 08/09/2012.

Figura 3 - Maquete do projeto vencedor para o Pavilhão do Brasil na EXPO 92, em Sevilha. Fonte disponível em: $<w w w . g r u p o s p . a r q . b r />$.Acesso em: 08/09/2012.

Figura 4 -Volume saltado do escritório da Casa em Carapicuíba (2003-2007). Fonte disponível em: $<w w w . g r u p o s p . a r q . b r />$.Acesso em: 08/09/2012.

Figura 5 - Corte transversal da Casa em Carapicuíba (2003-2007). Fonte disponível em: <www.gruposp.arq.br/>. Acesso em: 08/09/2012.

Figura 6 - Pátio interno da Sede para SEBRAE em Brasília (2008-2010). Projeto de Alvaro Puntoni, Luciano Margotto, João Sodré e Jonathan Davies. Fonte: autora.

Figura 7 - Empena Estrutural em concreto moldado in loco da Sede para SEBRAE. Fonte: autora.

Figura 8 -Vista externa geral na qual é possível ver as duas empenas estruturais e os painéis metálicos quebra-sóis que garantem a integridade do conjunto. Sede para SEBRAE em Brasília (2008-2010). Foto: Nelson Kon.

Figura 9 - Implantação. Projeto para o Concurso Nacional para o Porto Olímpico do Rio de Janeiro, 20I I. Projeto de Alvaro Puntoni, João Sodré, João Yamamoto e André Nunes (GRUPO SP); Luciano Margotto (Republica Arquitetura); 
Marcos Acayaba; Claudio Libeskind, Sandra Llovet, Marina Rosa, Natalia Leardini e Sabrina Chibani (libeskindllovet); e Andre Procopio (urbano). Fonte disponível em: <www.gruposp.arq.br/>.Acesso em: 08/09/2012.

Figura 10 - Perspectiva. Projeto para o Concurso Nacional para o Porto Olímpico do Rio de Janeiro, 20I I. Fonte: disponível em: <www.gruposp.arq.br/>.Acesso em: 08/09/2012.

Figura I I - Projeto em desenvolvimento para a SEHAB (20I2) - São Paulo, para a área 32 (Rua Porcelana), para atendimento de famílias dentro do Perímetro da Operação Urbana Consorciada Água Espraiada. Equipe: GRUPO SP (Alvaro Puntoni, João Sobré, João Yamamoto,Andre Nunes e Alexandre Mendes) e República Arquitetura (Luciano Margotto, Gustavo Delonero e Diogo Gouveia). Fonte:Acervo SEHAB.

Figuras 12 e 13 - Implantação e Pavimento Tipo do projeto para a área 32 (Rua Porcelana), na OUCAE. Fonte:Acervo SEHAB.

Figura 14 - Edifício com 17 unidades habitacionais - Amsterdam 315, Col. Condesa, Cidade do México, 2005. JSa Arquitetura (antes Higuera + Sánchez). Fonte disponível em: <http://www.jsa.com.mx/>.Acesso em: 08/09/2012.

Figura 15 - Corte Edifício Amsterdam 315, Col. Condesa, Cidade do México, 2005. Fonte disponível em: <http://www.jsa.com.mx/>.Acesso em: 08/09/2012.

Figura 16 - Perspectiva do Edifício Itacolomi 445 em Higienópolis, dos arquitetos do GRUPO SP, segunda experiência com a Zarvos (finalizada em 2012). Fonte disponível em: <http://ideazarvos.com.br/>. Acesso em: 08/09/20I2.

Figura 17 - Foto aérea do trecho da Vila Madalena (1958), com destaque ao local onde está hoje o edifício Simpatia 234 e o leito original do Córrego Verde. Fonte: GEOPORTAL, 1958.

Figura 18 - Plano para a Vila Madalena de Davis Brody Band (2012). Fonte:Acervo SEHAB.

Figura 19 - Vista de zona verticalizada ao fundo e algumas casas unifamiliares em primeiro plano, que aos poucos vem sendo substituídas por edifícios de habitação coletiva.Vista desde o Edifício Simpatia 234. Fonte: autora.

Figura 20 - Simulação do potencial construtivo máximo na Vila Madalena. Plano para a Vila Madalena de Davis Brody Band (20I2). Fonte:Acervo SEHAB.

Figura 2 I - Edifício Roof Madalena (2003-2005) do escritório Rocco Associados. Fonte: autora.

Figura 22 - Primeira versão do Simpatia 234 apresentada ao cliente, antes da junção da terceira matrícula. Fonte: acervo GRUPO SP.

Figura 23 - Algumas regras de uso e ocupação do solo acabaram interferindo no formato do edifício. Fonte: redesenho e foto autora.

Figura 24 - Partido de implantação que considera a relação com a topografia e principais visuais. 
Figura 25 - Partido de implantação que considera as pré-existências das construções vizinhas. Fonte:Acervo GRUPO SP.

Figura 26 - O térreo com visibilidade para a rua e duplicado com o subsolo. Fonte: autora.

Figura 27 - Projeto para a sede da CAPES em Brasília (2007), menção honrosa.Autores:Alvaro Puntoni, João Sodré, Jonathan Davies (GRUPOSP) e Luciano Margotto (Republica Arquitetura). Fonte:Acervo GRUPO SP.

Figura 28 - O térreo do Simpatia 234 e o espelho d'água. Fonte: autora.

Figura 29 - Pracinha "generosidade urbana”, conforme autores, voltada para a Rua Albuquerque Medeiros. Fonte: autora.

Figura 30 -Varanda de convivência. Fonte: autora.

Figura 3 I - Edifício 4 × 4, Gui Mattos. Criação de um espaço mais resguardado que antecede a entrada da unidade habitacional. Fonte: autora.

Figura 32 - Edifício 4 × 4, Gui Mattos. $2^{\circ}$ subsolo, vazios desde o térre. Fonte: autora.

Figura 33 - Definição da posição das áreas molhadas pelo próprio morador. Fonte: autora.

Figura 34 - Chapas de madeira dão movimento à fachada voltada para a Rua Simpatia. Fonte: autora.

Figura 35 - Varanda metálica e aberturas (definidas pelos moradores). Fonte: autora.

Figura 36 - Edifício Ourânia, arquiteto Gui Mattos, também com aberturas definidas pelos moradores.

\section{I INSERÇÃO URBANA}

Figura I - Situação de inserção de empreendimento padrão imobiliário em quadra urbana.Villagio Maggiori,Vila Gonçalves, São Bernardo do Campo, São Paulo. Duas torres com 25 andares e 200 apartamentos, num terreno de aproximadamente $5000 \mathrm{~m}^{2}$ (quota de aproximadamente $25 \mathrm{~m} 2$ vinculada a cada unidade habitacional). Fonte: <http://www.classificados.com/fborges-imoveis-vende-villaggio-maggiore-158m-163742>. Acesso em: I I/0I/20I 2.

Figura 2 - Situação de inserção de empreendimento padrão imobiliário em gleba urbana, à beira da via expressa Anchieta. Ânima Parque Clube, São Bernardo do Campo, São Paulo. Dez torres, com 26 andares cada, mais de I 000 unidades habitacionais que irão causar grandes impactos principalmente no trânsito do bairro onde está inserido. Fonte: <http://saobernardodocampo.olx.com.br/>.Acesso em: II/0I/2013.

Figura 3 - Situação de inserção de loteamento em gleba rural, na cidade de Sarandi, Paraná. Muro com mais de I km de extensão, isolamento do uso residencial e nenhuma preocupação com a preservação ambiental, mesmo beirando córrego. Fonte: Beatriz Fleury. 
Figura 4 - Escala monumental do Mirador (2004), Madri, MVRDV + Blanca Lléo. Fonte: <http://www.mvrdv.nl>. Acesso em: $11 / 01 / 2013$.

Figura 5 - Habitação num ensanche de Barcelona (200I-2003), Carlos Ferrater Arquitectos Asociados. São dois edificios de habitação coletiva, com 60 unidades habitacionais com tipologias variadas e reabilitação do interior da quadra. Representa um exemplo de arquitetura flúida com a cidade. Fonte: MONTANER, MUXÍ, 2006, p. 171.

Figuras 6 e 7 - Na primeira foto, à direita ao fundo, está o edifício $360^{\circ}$, localizado na Rua Camboriú, 65I, Alto de Pinheiros, do Arquiteto Isay Wenfeld e incorporação da Idea!Zarvos. Nota-se um contexto urbano com variações morfológicas, tapete formado por casas térreas, alguns edifícios verticalizados e algumas torres mais altas, entre elas, $\circ 360^{\circ}$. Pelo ponto de vista à distância, o edifício $360^{\circ}$ consegue mostrar sua beleza arquitetônica plástica e estrutural e imposição na paisagem. Fonte: Pedro Kok. Disponível em: http://www.pedrokok.com.br.Acesso em: I I/0 I/20 I3. Pela segunda foto, do mesmo edifício, o que parece, é que foi concebido para ser observado de longe: está totalmente fora do contexto local e não possui relação com a rua. Fonte: Google Street View. Acesso em: 03/02/20 I 3.

Figura 8 - Outro exemplo de projeto que apresenta mesma situação de inserção em lote com alta declividade, grande e irregular: Espaço Móbile II (projeto e construção 2002/2003), do escritório Mauro Munhoz Arquitetura. O projeto está localizado na Rua Dom Paulo Pedrosa, I 50, Morumbi, São Paulo, em lote de $3229 \mathrm{~m}^{2}$. Apresenta doze unidades habitacionais justapostas, e com pouca variação tipológica. Possui maior compromisso com o contorno do lote urbano em comparação aos três exemplos que representam este grupo:Vila Butantã, Canaã e Vila Taguaí.

Fonte: http://www.mauromunhoz.arq.br/.Acesso em: I I/0I/2013.

Figura 9 - Outro exemplo de projeto que apresenta mesma situação de inserção em lote com alta declividade: Edifício Oiapoque (projeto e construção 200I/2003, do escritório Vista Urbana Arquitetura, liderado pelos arquitetos Ararê Sennes, Caio Marin e Guilherme Carvalho. O projeto está localizado na Rua Aecri,Alto de Pinheiros, em lote de $550 \mathrm{~m}^{2}(8,25 \times 50 \mathrm{~m})$. Apresenta apenas duas unidades habitacionais sobrepostas, onde inclusive uma delas pertence ao arquiteto Ararê Sennes, ou seja, mais uma situação do arquiteto empreendedor do seu próprio projeto.

Fonte: http://vistaurbana.com.br/ Acesso em: I I/0I/2013.

Figura 10 - Fidalga 897 visto desde a Rua Fradique Coutinho com a Rodésia. Fonte: João Batista Xavier.

Figura I I - Outro exemplo de projeto que apresenta mesma situação de inserção em lote médio e irregular:

Edifício 4 x 4 (projeto e construção 2006/2008), do escritório Gui Mattos Arquitetura. O projeto está localizado na Rua Cristiano Viana, Jardim América em lote de 1063 m2.Apresenta 18 unidades habitacionais sobrepostas e trata-se de mais uma realização da Idea!Zarvos. Fonte: autora.

Figura 12 - Exemplo de projeto que apresenta situação de inserção em lote médio e irregular: Edifício Ourânia (projeto e construção 2007/2008), do escritório Gui Mattos Arquitetura. O projeto está localizado Rua Ourânia, 77, Alto de Pinheiros, em lote de 1104 m2. Apresenta 15 unidades habitacionais diversificadas e trata-se de mais uma realização da Idea!Zarvos. Fonte: <http://arqurbanismol I.blogspot.com.br/20 I/03/edificio-ourania-sao-paulo-sp.html>. Acesso em: II/0I/2013. 
Figura 13 - Projeção da carta de uso e ocupação do solo do Plano diretor de São Paulo no Bairro da Vila Madalena. Em vermelho, destaque para algumas "articulações paulistanas" citadas nesta pesquisa (marcação autora).

Fonte: Plano de Bairro Vila Madalena elaborado em parceria entre a incorporadora Idea!Zarvos e o escritório de arquitetura Davis Brody Bondy.

Figura 14 - Foto para divulgação de empreendimentos imobiliários na região, por incorporadoras e construtoras mais comuns. O que diferencia a inserção urbana das realizações da Idea!Zarvos das outras realizações? Principalmente a boa arquitetura do edifício, que ao mesmo tempo que se limite ao lote, não se limita apenas a solucionar bem a arquitetura do edifício. A boa arquitetura se abre para a cidade, principais vistas, para a rua na medida do possível, evita propor um verdadeiro clube dentro do limite privativo da área condominial. É diferente de empilhar andares, o que acontece nas maioria das outras realizações. É possível avistar edifícios nesta imagem com grandes empenas cegas, com janelas pequenas e todas iguais, levando monotonia à cidade, é possível, mesmo que de longe, ver grandes piscinas e cercamentos, e também uma escala de implantação com maiores proporções se comparada com a do edifício Fidalga 772 ao fundo.

Fonte: http://www.livingdesignvilamadalena.com/.Acesso em: I I/0I/20I3.

Figura 15 - Edifício Fidalga 727 (à esquerda) e Fidalga 772 (à direita). Estes dois projetos e outros foram denominados por Fernando Dize, editor da revista portenha SUMMA+ de "articulações paulistanas". Fonte: Pedro Kok. Disponível em: http://www.pedrokok.com.br.Acesso em: II/01/2013.

Figura 16 - Pelo plano de bairro da Vila Madalena, a preocupação exposta é com relação a descaracterização das ruas e fachadas devido a presença de novas construções de prédios. Fonte: Plano de Bairro Vila Madalena elaborado em parceria entre a incorporadora Idea!Zarvos e o escritório de arquitetura Davis Brody Bondy.

Figura 17 - Pelo plano de bairro da Vila Madalena, a solução para o problema é incentivar a ocupação do miolo de quadra e preservação da escala das construções lindeiras. Fonte: Plano de Bairro Vila Madalena elaborado em parceria entre a incorporadora Idea!Zarvos e o escritório de arquitetura Davis Brody Bondy.

Figura 18 - O plano de bairro incentiva a criação de passagens públicas a partir da transferência do potencial construtivo para os terrenos a serem incorporados, impedindo, assim, os adensamentos desenfreados, já que estariam vinculados à criação de espaços públicos, na própria quadra urbana, mantendo de certa maneira, a densidade construtiva da região. Fonte: Plano de Bairro Vila Madalena elaborado em parceria entre a incorporadora Idea!Zarvos e o escritório de arquitetura Davis Brody Bondy.

Figura 19 - Exemplo de projeto que apresenta situação de inserção em lote pequeno e regular:Vila Maida (projeto e construção 2004/2006), da arquiteta Maristela Faccioli. O projeto está localizado na Travessa Santo Hilário, 60, Santo André, Grande São Paulo, em lotes de 220 m2. Apresenta 3 unidades habitacionais e trata-se de um empreendimento realizado pela própria arquiteta conjuntamente com primos engenheiros (Família Maida). Fonte: autora. 
Figura I - Essenza Residencial Club. Área das piscinas e ao lado implantação do condomínio-clube.

Fonte:< http://www.mbigucci.com.br/>.Acesso em: I4/0I/2013.

Figura 2 - Pátio Carioca Residencial Clube. Fonte: <http://cidaderiodejaneiro.olx.com.br>.Acesso em: 14/0I/2013.

Figura 3 - Brookfield llha das Flores, Goiânia. Fonte: <www.br.brookfield>. Acesso em: |4/0I/2013.

Figura 04 -Vila residencial Medeiros, em Jundiaí. Fonte:< http://www.abrasil.com.br/> Acesso em: I4/0I/20I3.

Figura 05 - Detalhe subsolo em edifício residencial típico do mercado imobiliário. Fonte:

<http://imoveisja.blogspot.com.br/20I l/0I/arcadia-sao-bernardo-do-campo.html>.Acesso em:03/02/20l3.

Figura 06 - Pavimento inferior, subsolo para garagem, no Simpatia 234: paisagismo, incidência de iluminação natural e especificação do mesmo piso ao existente no pavimento térreo. Fonte:Autora.

Figura 07 - Hall de entrada dos apartamentos: ausência de contato físico ou visual com o ambiente exterior. Fonte: <http://I.bp.blogspot.com/> Acesso em: 03/02/2013.

Figura 08 - Casa Bandeirista. Espaço de receber. Sítio do Padre Inácio, Cotia, São Paulo. Fonte: FAU Barbosa. Disponível em: <http://www.flickr.com/photos/huides/72766425 I8/>.Acesso em: I4/01/2013.

Figura 09 - Espaço Gourmet em varanda de apartamento. Fonte:<http://www.tadecorado.com/2012/03/espacos-ouvarandas-gourmet.html>. Acesso em: |4/01/2013.

Figura 10 - Unidade-casa, Fidalga 772. llustração folheto de vendas. Fonte: folheto de vendas Idea!Zarvos.

Figura I I - Edifício Conesa, 4560, Bairro Saavedra, Buenos Aires. Adamo-Faiden Arquitectos. Edifício composto por nove unidades habitacionais e três espaços para trabalho. Segundo memorial dos autores, cada unidade foi projetada como uma pequena casa, que incorpora ao programa uma generosa expansão, possibilitando atividade a céu aberto. Disponível em: http://www.adamo-faiden.com.ar/Show I 4/Extras0 I.html.Acesso em: 04/I I/2009.

\subsection{SISTEMA ESTRUTURAL,TÉCNICAS CONSTRUTICAS E ENVOLTÓRIA}

Figura I - Edifício de escritórios na Rua Wizard,Vila Madalena, de autoria do escritório Andrade Morettin Arquitetos Associados e realização da Idea!Zarvos. Imagem ilustrativa do projeto e planta de um dos pavimentos.

Fonte: <http://ideazarvos.com.br/?tag=obras>. Acesso em: I8/0I/20I3. 
Figura 02 - Edifício residencial na Rua Marcos Lopes, Moema, de autoria do escritório Andrade Morettin Arquitetos Associados. Imagem ilustrativa do projeto. Fonte: <http://nyspbrooklin.wix.com>.Acesso em: 18/0I/20I 3.

Figura 03 - Edifício de Habitação social para "2 Concurso Internacional Living Steel para Habitação Sustentável” no qual o escritório Andrade Morettin Arquitetos Associados saíram vencedores. Fonte: <http://theurbanearth.wordpress.com/ tag/living-steel/>.Acesso em: 19/01/2013.

Figura 04 - Flexibilidade mal resolvida nos apartamentos do mercado imobiliário. Fonte: <http://imoveiscompreoseu. blogspot.com.br/2012/04/breve-lancamento-vila-prudente.html>. Acesso em: 19/01/2013.

Figura 05 - Vista aérea de prédios residenciais no Bairro Tatuapé, São Paulo. Fonte: http://perfilimobiliario.com/site/ ?m=20100I. Acesso: 23/01/2013.

Figura 06 - Fachada efeito "aleatório" no Simpatia 234. Fonte: Nelson Kon.

Figura 07 - Fachada efeito "aleatório" no Ourânia, realização Idea!Zarvos, do arquiteto Gui Mattos. Fonte:

< http://ideazarvos.com.br/wp-content/uploads/2012/07/ourania77_fotos_04.jpg>.Acesso em: 31/0I/20I3.

Figura 08 - Edifício “llla de La Llum”, do escritório Clotet I Paricio Associats, Barcelona, Espanha. Fonte: autora.

Figura 09 -Vila Fidalga. Fonte: João Batista Xavier.

\subsection{UNIDADE HABITACIONAL}

Figura I - Na busca por unidade com as características marcantes do conceito de adaptabilidade, foi encontrado alguns exemplos no livro DBOOK (2007), entre eles, um projeto para moradia estudantil, Garching Bei Munchen, do escritório FINK+JOCHER. Fonte: http://www.archello.com Acesso em: 28/0I/20I 3 Dispnível também em: PER, A. F; MOZAS, J.;ARPA, J. DBOOK. Density, Data, Diagrams, Dwellings. Análisis visual de 64 proyectos de vivienda colectiva.Vitoria-Gasteiz, A+T edicionaes, 2007.

Figura 2 - Projeto Quinta Monroy, Iquique, Chile, 2004, da Elemental. Planta pavimento térreo. Fonte: autora. 376

Figura 3 - Projeto Quinta Monroy, Iquique, Chile, 2004, da Elemental. Planta pavimento superior I. Fonte: autora. 376

Figura 4 - Projeto Quinta Monroy, Iquique, Chile, 2004, da Elemental. Planta pavimento superior 2. Fonte: autora. 376

Figura 5 - Projeto Quinta Monroy, Iquique, Chile, 2004, da Elemental. Elevação frontal. Fonte: autora. 377

Figura 6 -Vista externa, ainda sem ampliações, do projeto Quinta Monroy, lquique, Chile, 2004, da Elemental. Fonte: Arquitetura e urbanismo, São Paulo, n. I72, p. 48, julho 2008. 


\subsection{AGENTES}

Figura I - Escola em Campinas (2003-200I4). UNA Arquitetos e promoção FDE. Fonte:

<www.unaarquitetos.com.br>.Acesso em: I I/02/20I3.

Figura 02 - Arquiteta Empreendedora e Incorporadora:Vila Fidalga (1999-200I), de autoria da arquiteta Cristina Xavier e incorporação da Taguaí Arquitetura e Incorporação. Fonte: autora.

Figura 03 - Arquiteto (e Engenheiro) Empreendedor e Construtor:Vila Butantã (1998-2004), Ita Construtora (Hélio Olga) e Arquiteto Marcos Acayaba. Fonte: <http://www.arcoweb.com.br/arquitetura/fotos/667/entrecada.jpg>. Acesso em: II/02/20I2.

Figura 04 - Arquiteto (e Engenheiro) Empreendedor, Construtor e Incorporador:Vila Taguaí (2007-20I0). Ita Construtora (Engenheiro Hélio Olga) e Arquiteta Cristina Xavier. Fonte: <http://www.itaconstrutora.com.br/>.Acesso em: I I/02/20I3.

Figura 05 - Conjunto de agentes especiais, que contrata e acredita em bons arquitetos: Fidalga 727 (2010-201 I). Idea!Zarvos, Construtora CP3,Axpe Imóveis Especiais e Triptyque Arquitetura. Fonte: autora.

Figura 06 - Incentivo a projetos autorais pela Promoção Pública: Conjunto Heliópolis Gleba G (20I I-20I3). Coordenação do projeto: SEHAB - SP (Elisabete França,Vanessa Padiá e Marcelo Rebelo) e Biselli + Katchborian (Arquitetura). F. SEHAB

Figura 07 - Edifício de apartamentos no Morumbi, 1992. Autores: Mario Biselli e Arthur Katchborian associados a

Eurico Ramos Francisco e Lívia França. Fonte: http://www.bkweb.com.br/about/ Acesso em: 29/01/2013.

Figura 08 - Edifício com espaços comerciais Duquesa de Goiás, Real Parque, 2000, do escritório Paulo Bruna Arquitetos Associados. Fonte:Acervo Paulo Bruna Arquitetos Associados.

Figura 09 - Edifício comercial Rua Santonina, 1999-200I, dos Arquitetos Henrique Reinach e Maurício Mendonça (ao lado da Vila Fidalga). Fonte: Patrícia Cardoso Disponível em: http://www.rmaa.com.br/pt-BR/projects/santoninabuilding. Acesso em: 28/0I/2013.

Figura 10 - Edifício Montevidéu 285, 2007-2010, em Belo Horizonte, do escritório Vazio Arquitetura dirigido por Carlos Teixeira. Fonte: http://vazio.com.br.Acesso em I I/I2/201 I.

Figura I I - Mapa esquemático da cidade autônoma de Buenos Aires. Em destaque, bairros onde estão mais presentes as "infiltrações urbanas" e também atuações de "arquitetos empreendedores". Fonte:Autora.

Figura I 2 - Edifício Zapiola 295I, em Núñez, do arquiteto Marcelo Del Torto. Fonte: http://www.marcelodeltorto.com.ar Acesso em: 29/01/2013.

Figura 13 - Capa da revista Arquitetura e Urbanismo, n.218, maio de 2012, na qual o edifício Once é o tema da capa. 
Figura 14 - Vista aérea e inserção no bairro do Edifício Once, em Núñez, Buenos Aires, dos Arquitetos Adamo-Faiden. As fachadas de fundo e frente são iguais, porém, pela foto aérea, é possível ver a face frontal. Fonte:

http://www.archdaily.com.br.Acesso em: 29/0I/20I3.

Figura 15 - Edifício Modular Beta, Abrahão Sanovicz, I 970, no bairro Indianopolis, São Paulo. Um dos protótipos iniciais dos edifícios modulados encomendados pela construtora FORMAESPAÇO. Fonte: http://www.arquiteturabrutalista.com.br/ fichas-tecnicas/DW\%201970-123/1970-123-fichatecnica.htm Acesso em: 05/01/20 I3.

Figura 16 - Nesta propagando publicitária da construtora Formaespaço, de março de 1973, em letras pequenas, diz o seguinte:"A FormaEspaço está trabalhando para transformar São Paulo numa cidade agradável e descontraída. Onde o bom gosto e o progresso se complementarão. As construções da FormaEspaço não são amontoadas. As fachadas de seus prédios não escondem gente vivendo apertada. (...) Nós não inventamos o bom gosto, apenas não o esquecemos. FormaEspaço S.A. Construções" Fonte:Acervo arquiteta Priscylla Lima, disponível no Acervo Jornal Folha de São Paulo, março 1973.

Figura 17 - Conjunto Zarvos, do arquiteto Júlio Neves, no centro de São Paulo, na Av. São Luís com a Consolação. Fonte: Julio Perestrelo. Disponível em: http://www.flickr.com/photos/juperestrelo/683 1536927/sizes///in/photostream/ Acesso em: 27/0I/2013.

Figura 18 - Edifício, Madaloft, 1996-1999, na Rua Agissê, do escritório liderado pelo arquiteto Luiz Fernando Rocco. Fonte: http://www.roccovidal.com.br Acesso em: 30/0I/2013.

Figura 19 - Conjunto comercial Módulo Fidalga, construído pela Zarvos Engenharia, e onde está localizado o escritório da Idea!Zarvos. Fonte: Pedro Kok. Disponível em: http://www.pedrokok.com.br Acesso em: 30/01/2013.

Figura 20 - Os dez mandamentos do Movimento Um. Fonte: www.movimentoum.com.br/ Acesso: 2010.

Figura 2 I - Casas Lago, 2007,Arquitetos Adamo-Faiden, Buenos Aires. Fonte: http://www.adamo-faiden.com/casas-lago/ Acesso em: 29/01/2010. 
- Livros, teses e artigos científicos.

ACAYABA, M.Projeto, pesquisa, construção. 2004.Tese (Doutorado em Arquitetura e Urbanismo). Universidade de São Paulo,São Paulo, 2004. Crônica de uma formação. Em: Marcos Acayaba. São Paulo: Cosac Naify, 2007.

ACAYABA. M. M. Residências em São Paulo 1947- 1975. São Paulo: Romano Guerra Editora, 201 I.

AFLALO, M. (Org.). Madeira como estrutura. A história da Ita. São Paulo: Paralaxe, 2005.

ARANTES, P. F. Arquitetura Nova. Sérgio Ferro, Flávio Império e Rodrigo Lefévre, de artigas aos mutirões. São Paulo: Editora $34,2002$.

ARANTES, P. F. (Org.). Sergio Ferro. Arquitetura e trabalho livre. São Paulo: Cosac Naify, 2006.

BAHAMÓN,A.; SANJINÉS, M. C. Alta densidad: Vivienda Contemporánea. Barcelona: Parramón ediciones, 2008.

BARBOSA, M. C; CORBUCCI, J. COHAB Pedro Facchini, uma proposta habitacional viável. Seminário Internacional da LARES - Latin American Real Estate Society. São Paulo, setembro de 2006.

BARBOSA, M. C. Adolf Franz Heep: um arquiteto moderno. 2012. Tese (Doutorado em Arquitetura e Urbanismo). Universidade Presbiteriana Mackenzie, São Paulo, 2012.

São Paulo, São Paulo, 2002

A obra de Adolf Franz Heep no Brasil. 2002. Dissertação (Mestrado em Arquitetura e Urbanismo). Universidade de

BAROSSI,A. C. Trabalhos profissionais e uma identidade. Ensino de projeto na Faculdade de Arquitetura e Urbanismo de São Paulo. 2005. Tese (Doutorado em Arquitetura e Urbanismo). Universidade de São Paulo, São Paulo, 2005 , p. 09.

438 BASTOS, M.A.J.; ZEIN, R.V. Brasil: arquiteturas após 1950. São Paulo: Perspectiva, 2010.

BAVARELLI, J. E. O cooperativismo uruguaio na Habitação Social de São Paulo. Das cooperativas FUCVAM à Associação de Moradia Unidos de Vila Nova Cachoeirinha. 2006. Dissertação (Mestrado em Arquitetura e Urbanismo), Universidade de São Paulo, São Paulo, 2006.

BONDUKI, N. Origens da Habitação Social no Brasil. São Paulo: Estação Liberdade, 1998.

BOUDON, P. Pessac de Le Corbusier: Estude socio-architecturale, 1929-1985. Aspects de L'urbanisme, Dewey: Dunod, 1985.

BRUNA, P.J.V. Arquitetura, Industrialização e Desenvolvimento. $2^{\mathrm{a}}$ ed. São Paulo: Editora Perspectiva, 2002.

. Os primeiros arquitetos modernos. Habitação Social no Brasil 1930- 1950. São Paulo: EDUSP, 2010.

CAIXA ECONÔMICA FEDERAL (CEF). Engenharia para prédios-caixão na região metropolitana de Recife. Brasília, 2012.

CAMBI, E. Viviendas en bloques alineados. México: Gustavo Gilli, 1992. 
Viviendas en Bloques aislados. México: Gustavo Gilli, 1992.

COLQUHOUN, A. Aspectos simbólicos y literales da tecnología. Em:Arquitectura Moderna y Cambio Histórico: ensayos 1962 - 1976. Barcelona:Gustavo Gilli, 1978, páginas 28-33. (Versão original, inglês, 1962)

DEILMANN, H. EI Habitat. Barcelona: Gustavo Gilli, 1973.

DIAS, M. L. R. P. Desenvolvimento urbano e habitação popular em São Paulo, 1870 a 19 I4. São Paulo: Nobel, 1989.

DIESTE, E. Las tecnologías apropiadas y la creatividad. In: GUTIÉRREZ, R. (Coord.). Arquitectura latinoamericana en el siglo XX. Buenos Aires: Cedodal, 1998, p. 44.

DIEZ, Fernando. Crisis de Autenticidad. Cambios en los modos de producción de la arquitectura argentina. Buenos Aires: SUMMA+ Libros, 2008.

EKERMAN, S. K. Um quebra-cabeça chamado Lelé. São Paulo:Vitruvius, 064.03, setembro 2005. Disponível em: < http://www.vitruvius. com.br/revistas/read/arquitextos/06.064/423>. Acesso em: 12/09/2012.

FERNÁNDEZ PER,A.;ARPA, J. Density projects: 36 nuevos proyectos de vivienda colectiva.Vitoria-Gasteiz:A + T ediciones, 2007.

FERRATA, C.A.; SHUNDI, C. I. (Orgs.). Antonio Carlos Barossi. São Paulo: Hedra :: Editora da Cidade, 2012.

FERreirA, A. B. H. (Ed.). Novo dicionário da Língua Portuguesa. São Paulo: Positivo Livros, $4^{\mathrm{a}}$ edição, 2010.

FERREIRA, J. S.W. (Coordenação). Produzir casas ou construir cidades? Desafios para um novo Brasil Urbano. Laboratório de Habitação e Assentamentos Humanos da FAUUSP. São Paulo: LABHAB, FUPAM, 2012.

FERRO, S.A casa popular (1969). Em: FIORI, P.A. (Org.) Arquitetura e trabalho livre. São Paulo: Cosac Naify, 2006.

O canteiro e o desenho (1976). Em: FIORI, P.A. (Org.) Arquitetura e trabalho livre. São Paulo: Cosac Naify, 2006.

FIGUEROA, M. Habitação Coletiva em São Paulo, I 927 - 1972. 2002. Tese (Doutorado em Arquitetura e Urbanismo), Universidade de São Paulo, São Paulo, 2002.

FISHER, S. Os Arquitetos da Poli. Ensino e profissão em São Paulo. São Paulo: EDUSP, 2005.

FRENCH, H. Os + Importantes Conjuntos Habitacionais do Século XX: plantas, cortes e elevações. Tradução Alexandre Salvaterra. Porto Alegre: Bookman, 2009.

FUNDAÇÃo Bienal de São Paulo. VILA BUTANTÃ - Marcos Acayaba. Em: $6^{\text {a }}$ Bienal Internacional de Arquitetura de São Paulo. São Paulo: Instituto de Arquitetos do Brasil, 2005.

GOVERNO DO ESTADO DE SÃO PAULO. Diretrizes do Desenho Universal na Habitação de Interesse Social no Estado de São Paulo. São Paulo, março de 2010.

GOULART, N. R. F. Quadro da Arquitetura no Brasil. II ${ }^{\text {a }}$ ed. São Paulo: Perspectiva, 20 I0. P. 94. 
IMBRONITO, M. I.Três Edifícios de Habitação para a Formaespaço: Modulares, Gemini e Protótipo. Em: Docomomo 5, 2003, São Carlos. 5. Seminário DOCOMOMO Brasil, 2003.

IMBRONITO, M. I. Três edifícios de habitação para a Formaespaço: Modulares, Gemini e Protótipo. 2003. Dissertação (mestrado em Arquitetura e Urbanismo), Universidade de São Paulo, São Paulo, 2003.

IMECMG (Instituto Mineiro da Engenharia Civil). Alvenaria estrutural. Entrevista com Carlos Alberto Tauil, 02 de maio de 201 I. Disponível em:< http://www.imecmg.org.br>.Acesso em: 23/01/2013.

JACOBS, J. Morte e vida de grandes cidades. $2^{\mathrm{a}}$ ed. São Paulo: Martins Fontes, 2009.

JUNQUEIRA, M. C. Joaquim Guedes - Espaços Da Arte Brasileira. São Paulo: Cosac Naify, 2000.

KAMITA, J. M. Vilanova Artigas. Coleção Espaços da Arte Brasileira, São Paulo: Cosac Naify, 2004, I ${ }^{a}$ edição.

KATINSKY, J. O arquiteto e seu destino. Em: Marcos Acayaba. São Paulo: Cosac Naify, 2007.

KOK, P. Registros Fotográficos De Arquitetura. As obras dos jovens arquitetos da FAUUSP. 2009. Monografia (Trabalho Final de Graduação pela faculdade de arquitetura e urbanismo). Universidade de São Paulo, São Paulo, 2009.

LEMOS, C. Casa Paulista, São Paulo, EDUSP, 1999.

LINO, S. F. A obra de Eladio Dieste: flexibilidade e autonomia na produção arquitetônica. São Paulo:Vitruvius, 096.04, maio 2008. Disponível em: < http://www.vitruvius.com.br/revistas/read/arquitextos/08.096//42 >. Acesso em: 13/06/2012.

LUCCAS, Luís Henrique Haas. Arquitetura contemporânea no Brasil: da crise dos anos setenta ao presente promissor. Arquitextos Vitruvius. São Paulo, n. 101.00, ano 09, outubro de 2008. Disponível em <http://www.vitruvius.com.br/revistas/read/arquitextos/09. I0I/99>. Acesso em: 0l/09/20 I I.

440 LUCCHINI. E. J. Adolf Franz Heep: edifícios residenciais. Um estudo da sua contribuição para a habitação coletiva vertical em São Paulo nos anos 1950. 2010. Dissertação (Mestrado em Arquitetura e Urbanismo). Universidade Presbiteriana Mackenzie, São Paulo, 2010.

MARICATO, E. Brasil, Cidades alternativas para a crise urbana. Rio de Janeiro: Editora Vozes, $200 \mathrm{I}$.

MARQUES, R.T. Condomínios tipo Vila em São Paulo. 2006. Dissertação (mestrado em Arquitetura e Urbanismo), Universidade de São Paulo, São Paulo, 2006.

MATERA, S. Carlos Millan: Um Estudo Sobre a Produção em Arquitetura. 2005. Dissertação (Mestrado em Arquitetura e Urbanismo). Universidade de São Paulo, 2005.

MILHEIRO,A.V.; NOBRE, A. L.;WISNIK, G. Coletivo - 36 projetos de arquitetura paulista contemporânea. São Paulo, Cosac Naify, 2006. p. $36-39$.

MONTANER, J. M.; MUXÍ, Z. M. Habitar el presente. Vivienda en España: Sociedad, ciudad, tecnología y recursos. Madri: Ministerio de Vivienda, 2006. 
Joan Villà, construções para a sociedade. La Vanguardía, Barcelona, maio de 20I I.Tradução Sílvia Chile.

MONTANER MUXÍARQUITECTES. Definición, condiciones y critérios de diseño para la vivienda del siglo XXI en Andalucía, 2008.

MONTANER, J. M.; MUXÍ, Z. M.; ZULIN, F.; CORADIN, R. Instrumentos de Avaliação de Projetos. En: Do plano ao projeto: Novos Bairros e Habitação Social em São Paulo. Coleção: Política Municipal de Habitação: Uma construção coletiva. São Paulo: Secretaria Municipal de Habitação, Prefeitura de São Paulo, 2012, p. 252-3I3.

MORAES, S. R. C.; PERRONE, R.A. C. O repensar na participação do arquiteto na fase de concepção do produto imobiliário na cidade de São Paulo. CLEFA SJO 201 2. XXIV Conferencia Latinoamericana de Esculeas y Facultades de Arquitectura:Arquitectura y Urbanismo em Latinoamérica. Tendencias emergentes. San José da Costa Rica,Antigua Aduana, 16 a 21 de abril de 2012.

MOURA, Éride. Generosas aberturas permitem integração com o exterior. ProjetoDesign, São Paulo, n.24I, p. 57-59, março de 2000.

NAKANISHI,T. M. e FABRICIO, M. M. Arquitetura e domínio técnico nas obras de Marcos Acayaba. Risco, Rev. Pesqui. Arquit. Urban. (Online) n.9, São Carlos, 2009.

NESBITT, K. (org.). Uma nova agenda para a arquitetura. Antologia Teórica 1965- 1995. São Paulo: Cosac Naify, $2^{\mathrm{a}}$ ed. rev., 2008. OLGA, H. Experiência Brasileira na fabricação de laminado colado de eucalipto. 20I2a. Disponível em: <http://www.itaconstrutora.com.br/>.Acesso em: 15/12/2012.

OLGA, H. A linguagem da madeira no mundo contemporâneo. 20 I 2b. Disponível em: <http://www.itaconstrutora.com.br/>.Acesso em: I5/I2/20I2.

PARICIO, Ignacio. La piel ligera. Maduración de uma técnica constructiva. Barcelona: Editorial ACTAR D, 2010.

PATARRA, I. O governo Luiza Erundina. Cronologia de quatro anos de administração do PT na cidade de São Paulo, de 1989 a 1992 . São Paulo: Geração Editorial, 1996.

PETRUCCI, C. Balanço do mercado Imobiliário. 200 I - 20 I O.A década da retomada. São Paulo, SECOVI-SP, 2010.

PFEIFER, G; BRAUNECK, P. Casas geminadas. Barcelona: Editorial Gustavo Gilli, 2009.Versão portuguesa: Cláudia Ardións Espasandin/ltinerário Editorial Ltda.

PHAIDON(Org.):ALMEIDAAA.(Org.).The Phaidon Atlas of 2 I st Century World Architecture.London:PHAIDONPRESS,2008.v.0 I. 163 p. PIOCCHI, S. Relatório Técnico da COHAB/SP. São Paulo, 2005.

PIZA, Daniel. Em alta, os prédios 'com design'. O Estado de São Paulo, São Paulo, 8 de fevereiro de 2009.

POMPÉIA, R.A. Os laboratórios de Habitação no ensino da arquitetura. Uma contribuição ao processo de formação do arquiteto. 2006. Tese (doutorado em Arquitetura e Urbanismo), Universidade de São Paulo, São Paulo, 2006.

PREFEITURA DE SÃO PAULO. Catálogo do Programa “Morar no Centro”. São Paulo, 2004. 
PUNTONI,A. Estruturas Habitacionais Urbanas - Um ensaio de ocupação de vazios na Ladeira da Memória. 1998. Dissertação (Mestrado em Arquitetura e Urbanismo), Universidade de São Paulo, São Paulo, 1998.

Paulo, 2005.

Estruturas Habitacionais Urbanas. 2005. Tese (Doutorado em Arquitetura e Urbanismo), Universidade de São Paulo, São

QUIROGA, Fernando A. Del tipo a la Idea. Herramientas teóricas del proyecto arquitectónico moderno y contemporâneo. São Paulo: Seminário IV Projetar, 2009.

ROGERS, R. Cidades para um pequeno planeta. Barcelona: Editorial Gustavo Gili, 200 I.

RUBANO, L. M. Habitação social: temas da produção contemporânea. São Paulo,Vitrúvius, 2008. Disponível em:<http://www.vitruvius.com.br/revistas/read/arquitextos/08.095/I53>.Acesso em: 04/01/201 I.

RUGGIERO,A. S. Jorge Caron: uma trajetória. 2006. Dissertação (mestrado em Arquitetura e Urbanismo), Escola de Engenharia de São Carlos, Universidade de São Paulo, São Carlos, 2006.

SANTOS,V. C. Concursos de Arquitetura em São Paulo. 2002. Dissertação (mestrado em arquitetura e urbanismo), Universidade de São Paulo, São Paulo, 2002

SCHNEIDER, F. (Org.). Atlas de plantas. Habitação. Barcelona: Editorial Gustavo Gilli, 2006. I a edição em português.

SEGAWA, H. Marcos Acayaba, delineador de estruturas. Em: Marcos Acayaba. São Paulo: Cosac Naify, 2007.

SOMEKH, N.; CAMPOS, C. M. N. A Cidade que não pode parar: Planos urbanísticos de São Paulo no século XX. São Paulo: Ed. Mackpesquisa, 2002.

TAGLIARI,A. M. F. Os princípios orgânicos na obra de Frank Lloyd Wright: Uma abordagem gráfica de exemplares residenciais. 2008. Dissertação (Mestrado em Arquitetura e Urbanismo), Campinas, Universidade Estadual de Campinas, 2008.

TRAMONTANO, M. C. Novos modos de vida, novos espaços de morar, Paris, São Paulo, Tokyo uma reflexão sobre a habitação contemporânea. 1998. Tese (Doutorado em Arquitetura e Urbanismo), Universidade de São Paulo, São Paulo, 1998.

TSUKUMO, N. M. J. (coord.). Arquitetura na CESP. São Paulo: CESP, 1994.

VILLÀ, J. A construção com componentes pré-fabricados cerâmicos: sistema construtivo desenvolvido entre I984 e 1994, em São Paulo. 2002. Dissertação (mestrado em Arquitetura e Urbanismo), Universidade Presbiteriana Mackenzie, São Paulo, 2002.

Construções. São Paulo: Centro Universitário Belas Artes de São Paulo, 2005.

VILLA, S. B. Morar em Apartamentos: a produção dos espaços privados e semi-privados nos edifícios ofertados pelo mercado imobiliário no século XXI em São Paulo e seus impactos na cidade de Ribeirão Preto. 2008. Tese (Doutorado em Arquitetura e Urbanismo), Universidade de São Paulo, São Paulo, 2008.

WHITAKER, J. S. Perspectivas e desafios para o jovem arquiteto no Brasil. Qual o papel da profissão? São Paulo,Vitrúvius, 
20II. Disponível em: <http://www.vitruvius.com.br/revistas/read/arquitextos/I2.133/3950>.Acesso em: 24 novembro de 2012.

WILHEIM, J. Mão escondida projeta arquitetura medíocre. São Paulo:Vitruvius, 096.04, julho 2008. Disponível em: < http://www.vitruvius.com.br/revistas/read/arquitextos/>. Acesso em: 04/02/2013.

WISNIK, Guilherme. Exercício de Liberdade. Em: Marcos Acayaba. São Paulo: Cosac Naify, 2007.

WISSENBACH, T. C. A cidade e o mercado imobiliário: uma análise da incorporação residencial paulistana entre 1992 e 2007. 2008. Dissertação (mestrado pela Faculdade de Filosofia, Letras e Ciências Humanas), Universidade de São Paulo, São Paulo, 2008.

WISSENBACH,V.; BONDUKI, N.; RUBANO, L. M.; MARICATO, E. Habitação social: direito à arquitetura. São Paulo, 2006. No prelo.

ZEIN, R.V. e BASTOS, M.A.J. B. Brasil: Arquiteturas após I950. São Paulo: Perspectiva, 2010. P. 303-3I8.

ZULIN, F.Viviendas en la Calle Grécia: Buena Arquitectura compatíble con la cultura y economía locales. $X$ Seminario Investigación Urbana y Regional. Políticas de vivienda y derechos habitacionales. Pontifícia Universidad Javeriana y Instituto Javeriano de Vivienda y Urbanismo. Bogotá, 2012.

\section{- Artigos de Revistas e jornal}

ANELLI, Renato. Expo 92, Sevilha: O Concurso para o Pavilhão Brasileiro. ARQTEXTO (UFRGS), v. 16, p. 106-127, 2010.

Tênue transparência. Monolito, São Paulo, n.II, p. 32-37, abril/maio de 2011 .

ANTUNES. Bianca. Frentes de trabalho. Arquitetura e Urbanismo, São Paulo, n. 2 I8, maio de 2012.

ARQUITETURA E CONSTRUÇÃO. Por fora parece uma casa, por dentro são seis. São Paulo, abril de 2003.

Especial Habitação. São Paulo, n. 186, setembro de 2009.

Especial Intervenções em favelas. São Paulo, n. 200, novembro de 2010.

. Inovador na forma e no meio. São Paulo, n. 186, setembro de 2009.

Investidores trazem nova proposta de arquitetura aos edifícios residenciais paulistanos. São Paulo, n. I6I, p.I2, agosto de 2007. São Paulo terá mais um edifício com o selo do movimento um. São Paulo, n. I82, p. 10, maio de 2009.

BARBOSA, M. C. Do público ao privado: a habitação coletiva na obra de Franz Heep. ProjetoDesign, São Paulo, n. 272 , setembro de 2002. BARIANI, Márcio. Poesia sem formalismo. ProjetoDesign, São Paulo, n. 333, p. 102, novembro de 2007.

CERCHIARA, Débora.Vivir em Grupo. SUMMA+, Buenos Aires, n. 101, p.42-43, abril de 2009.

COMAS, Carlos Eduardo Dias. O espaço da arbitrariedade. Projeto, n. 9I, p. 1 27-130, setembro de 1986. 
CORBIOLI, Nanci. Entre o público e o privado. ProjetoDesign, São Paulo, n.287, p., janeiro de 2004.

Plantas flexíveis agregam valor à escala reduzida. ProjetoDesign, São Paulo, n. 360 , p. 62-65, fevereiro de 2010.

. Proposta assegura total flexibilidade de layout. ProjetoDesign, São Paulo, n.353, p. 54 - 61, julho de 2009.

CORREA,Vanessa.Arquitetura de São Paulo embarca no estilo contemporâneo. Folha de São Paulo, Cotidiano, cl, 22 de maio de 201 I.

CORTI, Carolina; DIEZ, Fernando; DI PECO, Martín; KOMMERS, Rodrigo W; SORIA, Soledad. Estratégicas de aglomeração e convivência. SUM-

MA+, Buenos Aires, n. I20, p.26-27, março 2012.

DIEZ, Fernando. Tácticas de Infiltración. Diez años de experimentación en Buenos Aires. SUMMA+, Buenos Aires, n. 107, p. 34-39, abril de 2010. .Arquitectura de proposición y arquitectura de producción. SUMMA+, Buenos Aires, n.94, p.70-79, junho de 2008.

. Grande versus pequeno. SUMMA+, Buenos Aires, n. I 13, p.66-67, novembro de 201 I.

ELOY, Edison; BOGÉA, Marta; REBELLO,Yopanan. Invenção: popular e erudito. Arquitetura e Urbanismo, São Paulo, n. 141 , dezembro de 2005.

FELIPPE, Maria Inês. Empreendedorismo: buscando o sucesso empresarial. Sala do Empresário, São Paulo, 1996, v.4, n. 16 , pl 0-12 (suplemento).

FLORESTA, Cleide. Cidade incorporada. Arquitetura e Urbanismo, São Paulo, n. 207, p. 66-7I, junho de 201 I.

GEROLLA, Giovanny. Fachada customizada. Arquitetura e Urbanismo, São Paulo, n.20I, p. 45-49, dezembro de 2010.

.Vila Operária. Arquitetura e Urbanismo. São Paulo, n. 186, p. 27-31, setembro de 2009.

GRUNOW, Evelise. Entrevista Alejandro Aravena. ProjetoDesign, São Paulo, n.347, p. 5, janeiro de 2009.

. Moradia Social vai requalificar a cidade. Concurso Renova SP. ProjetoDesign, n. 384, fevereiro de 2010.

Partido mantém integridade, apesar da obra tumultuada. ProjetoDesign, São Paulo, n. 353, p. 50-53, julho de 2009.

GÜIRALDES, Pablo.A matemática da torre ideal. Sobre as colunas duplas nas torres residenciais de Mario Roberto Álvarez. SUMMA+, Buenos Aires, n.II3, p.20-3I, fevereiro. 2011.

HELVÉCIA, Heloísa, STEPHAN, Danae e SHROEDES, Renato. Criação Coletiva. Nova geração de arquitetos doma a vaidade, dispensa o personalismo e começa a ganhar mais espaço trabalhando em equipe. Revista da Folha: Morar, São Paulo, 31/08/2007.

HOLCK, Teodoro. Suave abraço. Arquitetura e Urbanismo, São Paulo, n.207, p. 46-53, junho de 201 I.

JUNQUEIRA, Monica de Camargo.Arquétipo verdadeiro. ProjetoDesign, São Paulo, n. 37I, p. 90, janeiro de 201 I.

.Arte como construção. Arquitetura e Urbanismo, São Paulo, n. I46, maio de 2006.

LEAL, Ledy Valporto.V. Jogo de morar. Arquitetura e Urbanismo, São Paulo, n. 196, p. 34-4I, julho de 2010.

LESSA, Kátia. Os condomínios empobrecem SP. Folha de São Paulo, São Paulo, 05 de maio de 201 I. 
LORES, Raul Juste.Arquitetura é Investimento. Folha de São Paulo, São Paulo, 2 - 8 de setembro de 2012.

MELENDEZ, Adilson. Bacco completa 20 anos e leva projeto por notório saber. ProjetoDesign, São Paulo, n. 386, p. 102 , abril de 2012. . Diversidade de tipologias e medidas, em desenho inusitado. ProjetoDesign, São Paulo, n.353, p. 62 - 67, julho de 2009.

Mirante de concreto. ProjetoDesign, São Paulo, n.287, janeiro de 2004.

ro de 2001, p. 134.

Na Década que Separa Sevilha de Orlândia, Mudaram os Arquitetos ou Mudou a Crítica? ProjetoDesign, São Paulo, n. 25 I, janei-

O golpe do concurso... ProjetoDesign, São Paulo, n.254, abril de 200 I.

MELENDEZ, Adilson; SERAPIÃO, Fernando. Entrevista Hélio Olga Jr. ProjetoDesign, São Paulo, n.264, fevereiro de 2012.

MONOLITO. Habitação Social em São Paulo, n. 7, fevereiro/março de 2012.

NAKAMURA, Juliana. Repertório de Idéias. Grupo de Jovens arquitetos projeto edifício residencial com referências de Luigi Snozzi, Eduardo de Almeida e Carlos Millan. Arquitetura e Urbanismo, São Paulo, n. 162, p. 34-39, set. 2007.

OLIVEIRA, Roberto de.Arquitetos tentam mudar a sina da falta de criatividade que transforma os projetos de moradia popular em caixotões sem alma e sem graça. Revista da Folha, caderno Morar, São Paulo, agosto de 2007.

PROJETODESIGN. A reação ao neoclássico e a promessa para o futuro. São Paulo, n.37I, p. 89, janeiro de 201 I.

. Da Filosofia à arquitetura. São Paulo, n.263, janeiro de 2002.

Uma vila desafia o mercado imobiliário. São Paulo, n.263, janeiro de 2002.

Uma vila vertical. São Paulo, n.297, dez.2004.

REQUENA, Guto.Arquitetura feia, cidade doente. Desenho de São Paulo é entediante; faltam políticas e concursos que incentivem ideias e jovens escritórios. Folha de São Paulo, São Paulo. 13 de janeiro de 2013. Disponível em: <http://wwwl.folha.uol.com.br/fsp/imoveis/88267-arquitetura-feia-cidade-doente.shtml>.Acesso em 14/0I/20I3.

RIBEIRO, Bruno. Paulistanos trocam a capital por condomínios no interior. Folha de São Paulo, São Paulo, 29 março de 201 I.

ROSSO, Silvana Maria.Arquiteto Incorporador. Arquitetura e Urbanismo, São Paulo, n.205, p. 26-3I, abril de 201 I.

SABBAG, Haifa Y. Beleza com conteúdo. Arquitetura e Urbanismo. São Paulo, n. 145, p.48-55, abril de 2006.

Eduardo de Almeida. Indiferente aos dogmas do modernismo e da escola paulista, o arquiteto fala sobre seus quase 50 anos de atividade profissional. ProjetoDesign, São Paulo, n.376, jun. 201 I.

SANT'ANNA, Antonio Carlos. Concurso Paço em Osasco: Um depoimento comprometido. Arquitetura e Urbanismo, São Paulo, ${ }^{\circ} 37$, Pp.89 a 99, agosto/setembro de 1991. 
SAVATORI, Elena.Arquitetura no Brasil: ensino e profissão. Arquiteturarevista, vol. 4, n.2, p. 52-77, julho/dezembro de 2008.

SAYEGH, Simone. Arquitetura popular brasileira. Arquitetura e Urbanismo, São Paulo, n. I26, setembro de 2004.

. Para (vi)ver como se quer. Arquitetura e Urbanismo, São Paulo, n. 183, p. 40 - 47, junho de 2009.

SEGAWA, Hugo. Pavilhão do Brasil em Sevilha: deu em vão. Projeto, São Paulo, n. I38, fevereiro de 199 I.

SERAPIÃO, F. Coexistência pacífica: no mesmo andar, apartamentos comum e dúplex. ProjetoDesign, São Paulo, n. 24I, p. 60-63, março de 2000. . Fernando.A década da "geração de Sevilha", do Pritzker de Mendes da Rocha, dos estrangeiros e do novo milagre. ProjetoDesign, São Paulo, n.37I, janeiro de 2011. . Brasileiro nas cores e nas intenções. ProjetoDesign, São Paulo, n. 278, abril de 2003.

Edifício de apartamentos na Rua Fidalga. Monolito, São Paulo, n.II, p. 122-129, abril/maio de 201 I.

Experimental, conjunto de casa transpira soluções ambientais. ProjetoDesign. São Paulo, n.369, p. 44-53, novembro de 2010. Mudança de ares. ProjetoDesign, São Paulo, n.353, p. 68-79, julho de 2009. Partido Arquitetônico encontra definição entre o módulo e a topografia. ProjetoDesign, São Paulo, n. 3 I 3, p. 38-45, março de 2006. Quando a favela vira cidade. Urbanização de favelas, concursos, intercâmbios e verbas milionárias incitam debate sobre projetos de interesse social em curso na capital paulista. ProjetoDesign, n. 369, novembro de 2010.

. Quatro pecados louváveis. ProjetoDesign, São Paulo, n. 313, p. 88, março de 2006.

Residência em Carapicuíba. ProjetoDesign, São Paulo, n.342, agosto de 2008.

. O edifício invisível e a cidade inexistente. ProjetoDesign, São Paulo, n. 24I, p. 94, março de 2000.

. Onde estão os Walids? ProjetoDesign, São Paulo, n. 353, p. 94, julho de 2009.

. Silêncio e anonimato. ProjetoDesign, São Paulo, n. 3 I I, p. 94, janeiro de 2006.

SUMMA+, Construindo a Topografia e o Vazio. Buenos Aires, n. I20, p. 82-87, março de 2012.

SUMMA+.Variación y flexibilidad. Buenos Aires, n. 107, p. 28-33, abril de 2010.

TEIXEIRA, Regiane. Fora da mesmice. Cidade vive boa safra de prédios residenciais com visual ousado, que já começam a despontar fora do setor privado e dos bairros nobres. Folha de São Paulo, São Paulo, 2 - 8 de setembro de 2012.

TEPERMAN, Sérgio. Boa Arquitetura. Arquitetura e Urbanismo, São Paulo, n. 185, p. 79, agosto de 2009.

TRONCOSO, Ursula.Arquitetura Propositiva.Arquitetura e Urbanismo, São Paulo, n. 218, maio de 20I2, p. 60-65. Simpatia gera gentileza. Arquitetura e Urbanismo, São Paulo, n.207, p. 54-6I, junho de 201 I. 
Enfrentar a cidade real. Arquitetura e Urbanismo. São Paulo, n. 225, p. 48-57, dezembro de 2012.

WISNIK, Guilherme. O espaço coletivo como baliza. Revista Novos Estudos - CEBRAP, São Paulo, n. 64, novembro de 2002.

ZEIN, Ruth Verde.A arquitetura em exposição: Sevilha 92. Projeto, São Paulo, n. I38, fevereiro de 199 I.

\section{- Palestras, conferências, documentários e outros tipos de fontes:}

ACAYABA, M. Construção em terrenos difíceis. Palestra no Simpósio Internacional WoodWorks. Construindo com madeira no Brasil e na Suíça. São Paulo: FAUUSP, 09 de outubro de 2012

ALVIM,A. B. Por uma cidade compacta. Entrevista. São Paulo, SP20 14, março 2012. Disponível em: <http://sp2040.net.br/>.Acesso em:09/0I/20I3. ANDRADE,V.;MORETTIN,M.Mudança de Rumo.Conferência Museu da Casa Brasileira. São Paulo:ARQBACANA, MCB,25 de maio de 20 I I. BACHOFNER, R. Construção em madeira pelo país. Simpósio Woodworks: construindo com madeira no Brasil e na Suíça. São Paulo: FAUUSP, 09 de outubro de 2012.

BOND, D. B. Ideias para um desenvolvimento sustentável da Vila. Estudos preliminares (plano urbanístico), agosto de 2012.

BONDUKI, N. Outras Histórias. Entrevista Nabil Georges Bonduki. MUSEU DA PESSOA, 30 de Setembro de 2008. Disponível em: http:// www.museudapessoa.net/MuseuVirtual/.Acesso em: 13/05/2012.

BOSH, F. P.; MAIA, G.; MENEGUETTI, M.;AZEVEDO,V. Entrevista Angelo Bucci e João Paulo Meirelles de Faria - SPBR. ENTRE, novembro de 2009. Disponível em <http://www.entre.arq.br/pdfs/Entre_SPBREntrevista.pdf>.Acesso em: I0/10/201 I.

MOREIRA, R. Documentário Ernest Robert de Carvalho Mange - Urbanista. Encontros do Itaú Cultural sobre artistas e outras personalidades da história do Brasil. Disponível em: <http://www.youtube.com/watch?v=cCMdjyXTlxo>.Acesso em: 10/I0/2012.

OLGA, H. Construções em madeira no Brasil: situação atual e perspectivas. Simpósio Woodworks: construindo com madeira no Brasil e na Suíça. São Paulo: FAUUSP, 09 de outubro de 2012.

VIGLIECCA, H. Construir a Cidadania. Conferência Museu da Casa Brasileira. São Paulo, MCB, 28 nov. 2012.

\section{- Leis, Decretos e Normas Técnicas.}

BRASIL (federal). Lei n 4.59 I, de 16 de dezembro de 1964. Dispões sobre o condomínio em edificações e as incorporações imobiliárias. SÃO PAULO (município). Lei n I l.228, de 25 de junho de 1992. Código de Obras e Edificações do Município de São Paulo. Dispões sobre as regras gerais, e específicas a serem obedecidas no projeto, licenciamento, execução, manutenção e utilização de obras e edificações, dentro dos limites dos imóveis, revoga a Lei $\mathbf{n}^{\circ} \mathbf{8 . 2 6 6}$ de 20 de junho de 1975, com as alterações adotadas por leis posteriores, e dá outras providências. SÂO PAULO (município). Decreto Municipal n 32.329 de 23 de setembro de 1992. Regulamenta a Lei $n^{\circ}$ II.228 de 25 de junho de 1992 - Código de Obras e Edificações, e dá outras providências.

BRASIL. Lei n I I.605, de I 2 de julho de 1994: Dispõe sobre a criação da subcategoria de uso residencial R3-03, conjunto residencial - 
vila, e dá outras providências.

SÃO BERNARDO DO CAMPO (município). Lei $\mathbf{n}^{\circ} \mathbf{4 . 4 4 6}$ de $\mathbf{2}$ de agosto de I 996 . Estabelece o zoneamento, regulamenta o uso do solo nas diversas zonas; define gabaritos e dá outras providências. Projeto de lei n 14I/95 - Prefeito José Demarchi.

BRASIL. Lei $\mathbf{n}^{\circ} \mathbf{1 0 . 0 4 8}$, de 08 de novembro de 2000. Dá prioridade de atendimento às pessoas que especifica, e dá outras providências. BRASIL. Lei $\mathbf{n}^{\circ} \mathbf{1 0 . 0 9 8}$, de 19 de dezembro de 2000. Estabelece normas gerais e critérios básicos para a promoção da acessibilidade das pessoas portadoras de deficiência ou com mobilidade reduzida, e dá outras providências.

SÃO PAULO (município). Lei $\mathbf{n}^{\circ} \mathbf{1 3 . 4 3 0}$, de 13 de setembro de 2002. Plano Diretor Estratégico de São Paulo.

SÃO PAULO (município). Decreto Municipal n 44.667 de 26 de abril de 2004. Regulamenta a Lei $n^{\circ}$ I 3.430 de 13 de setembro de 2002 - que institui o Plano Diretor Estratégico, relativas às Zonas Especiais de Interesse Social e aos respectivos Planos de Urbanização, e dispõe sobre normas específicas para a produção de Empreendimentos de Habitação de Interesse Social Habitação de Interesse Social e Habitação do Mercado Popular.

SÃO PAULO (município). Decreto Municipal no 45.127 de 13 de agosto de 2004. Altera disposições do Decreto $n^{\circ} 44.667$, de 26 de abril de 2004, que dispõe sobre Zonas Especiais de Interesse Social e seus respectivos Planos de Urbanização, produção de Empreendimentos de Habitação de Interesse Social, Habitação de Interesse Social e Habitação do Mercado Popular; regulamenta os artigos $4^{\circ}$ e $5^{\circ}$ da Lei $n^{\circ}$ I3.657, de 31 de outubro de 2003, que concedem isenção de taxas incidentes sobre as edificações que discrimina; prevê a dispensa do pagamento de preços públicos nas hipóteses que especifica; e estabelece normas de competência.

SÃO PAULO (município). Lei n 1 3.885, de 25 de Agosto de 2004. Planos Regionais Estratégicos das Subprefeituras de São Paulo.

BRASIL. Decreto-lei $\mathbf{n}^{\circ}$ 5.296, de 02 de dezembro de 2004. Estabelecem atendimento prioritário, normas gerais e critérios básicos para a promoção da acessibilidade das pessoas com deficiência ou mobilidade reduzida. Idoso e Deficiente, prioridades - Regulamenta as Leis 10.048 de 2000 e 10.098 de 2000.

ASSOCIAÇÃO BRASILEIRA DE NORMA TÉCNICA (ABNT). NBR 9050 - Acessibilidade a edificações, mobiliário, espaços e equipamentos urbanos. Rio de Janeiro, RJ, 2004.

SÃO PAULO (município). Decreto Municipal n 47.702 de 19 de setembro de 2006. Dá nova redação aos artigos 31 e 52 do Decreto $n^{\circ} 44.667$, de 26 de abril de 2004, bem como dispõe sobre as edificações de Habitação de Interesse Social - HIS e de Habitação de Mercado Popular - HMP implantadas fora dos perímetros das Zonas Especiais de Interesse Social - ZEIS.

SÃO BERNARDO DO CAMPO (município). Lei no 5.716 de 23 de agosto de 2007. Dispõe sobre o uso e ocupação do solo para o Município de São Bernardo do Campo, define parâmetros reguladores, e dá outras providências.

\section{- Entrevistas com Arquitetos ou agentes}

- Arquitetos Alvaro Puntoni e João Sodré - 28 de abril de 201 I (Local: escritório GRUPO SP), Sobre Simpatia 234. 
- Arquiteta Cristina Xavier - 5 de abril de 201 I (Local:Vila Fidalga), I4 de dezembro de 2012 (Local: escritório Cristina Xavier), I7 de março de 2012 (Local:Vila Taguai), 09 de maio de 2012 (Local: Fidalga 897) - Sobre Fidalga 897,Vila Taguaí e Vila Fidalga.

- Arquitetos Joan Villà e Sílvia Chile - 29 de junho de 2012 (Local: escritório/residência arquitetos), Sobre Canaã.

- Arquiteto Marcelo Barbosa - 03 de dezembro de 2012 (Local: escritório BACCO Arquitetos Associados), Sobre Vila Fachini.

- Arquiteto Carlos Ferrata - 25 de outubro de 2010 (Local: Centro Arquitetura), Sobre edifício Fiori di Maggio.

- Milton Della Pietra e Ivie Pietra - 25 de outubro de 2010 (Local: Fiori di Maggio), Sobre edifício Fiori di Maggio.

- Arquiteto Vinicius Andrade - 05 de março de 2012 (Local: escritório Andrade Morettin Arquitetos), Sobre Fidalga 772 e Aimberê.

- Arquiteto Marcos Acayaba - 09 de fevereiro de 2012 (Local:Vila Butantã), Sobre Vila Butantã.

- Arquiteta Maristela Faccioli - 23 de julho de 2010 (Local: escritório Maristela Faccioli), Sobre Vila Maida.

- Arquiteto Fábio Mendes - 22 de abril de 201 I (Local: escritório Gui Mattos Arquitetos), Sobre Edifício 4 x 4 e Ourânia.

- Arquiteta Fabiana Stuchi - 24 de maio de 201 I (Local: escritório Piratininga Arquitetos Associados), Sobre Vila Marco Aurélio.

\section{- Principais Sites consultados:}

http://ideazarvos.com.br

http://www.adamo-faiden.com/casas-lago/

http://www.axpe.com.br/

http://www.cpaeng.com.br/arquitetos.htm

http://www.gruposp.arq.br

http://www.bacco.com.br

http://www.usinactah.org.br

http://www.vigliecca.com.br

http://www.vilataguai.com.br/

http:// www.marcosacayaba.arq.br/

http:// www.itaconstrutora.com.br/ 



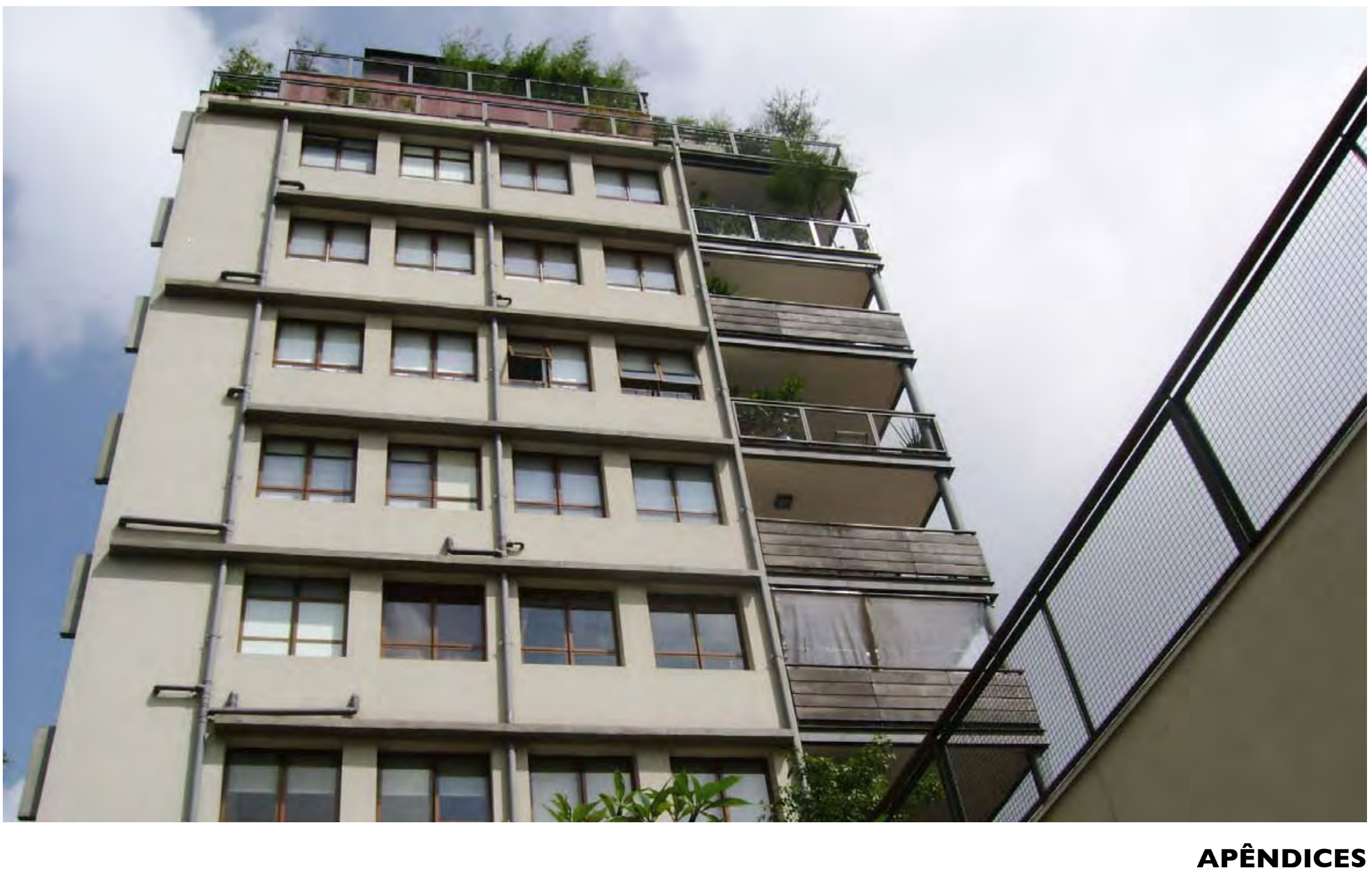




\section{APÊNDICE I}

Foi realizado no primeiro semestre de 2010, como atividade programada do mestrado, consulta a revistas especializadas em arquitetura, ProjetoDesign e Arquitetura e Urbanismo, com o objetivo de identificar aquilo que estava sendo realizado e publicado na primeira década do século XXI, no âmbito da habitação coletiva.

Foram pré-selecionadas mais de cem obras de habitação coletiva publicadas nestas revistas no período de dezembro de 1999 até junho de 201 I, de diversas partes do Brasil e do mundo e por agentes promotores variados. Não tiveram critérios bem definidos de seleção nesta etapa, sendo realizada uma identificação geral, eliminando projetos referentes a trabalhos acadêmicos ou outros projetos não executados ou sem possibilidade de serem concretizados.

\section{Revistas pesquisadas}

Revista AU: da Edição 87 (dez 1999) até Edição 207 (junho 201 I), a última se refere a uma edição especial de edifícios residenciais, caracterizando um fechamento do tema. O edifício Fidalga 772 e o Simpatia 234, que até o momento não tinham matéria exclusiva, são destaques nesta edição daAU. Total: 121 revistas.

Revista ProjetoDesign: da Edição 238 (dez 1999) até Edição $37 \mathrm{I}$ (jan 201I), a última se refere a uma edição especial anos 00, justamente o recorte temporal da pesquisa, também caracterizando um fechamento do tema. Muitas obras presentes na pesquisa são mencionadas no artigo sobre habitação coletiva do século XXI: Espaço Móbile II, Oiapoque, Aimberê, 4x4, Vila Fidalga, Panorama, Vila dos Idosos e até mesmo o conjunto habitacional na favela de Paraisópolis do arquiteto Edson Elito. Total: 134 revistas.

OBS.: as imagens que estão destacadas com numeração dentro de um quadrado se referem a uma primeira filtragem desta seleção para maior aprofundamento e conhecimento numa segunda atividade programada (APÊNDICE 2). 


\section{PROJETO 2011}

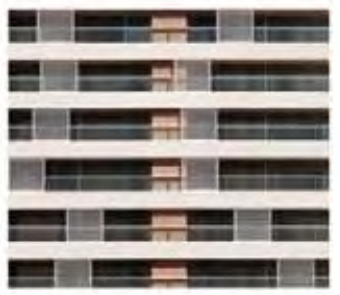

Edifício Breeze (2004 -2008) Aflalo \& Gasperini Arquitetos Alto da Lapa, São Paulo

Terreno: $2600 \mathrm{~m} 2$

a. construida: $21200 \mathrm{~m} 2$ unidade: $234 \mathrm{~m} 2$

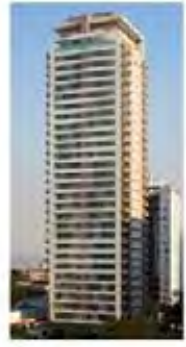

Gui Mattos

Pinheiros, São Paulo

(Rua Cristiano Viana)

terreno: $1063 \mathrm{m2}$

terreno: construida: $4010 \mathrm{m2}$

a. construida: $4010 \mathrm{~m} 2$
unidade: $63,50-552 \mathrm{~m} 2$

371

PROJETO 2010

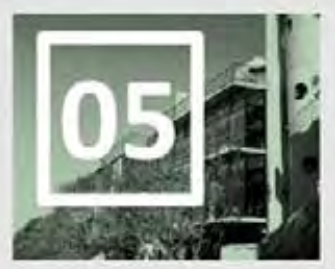

Edificio Oiapoque (2001-2003) Associados - Ararê Sennes, Cai Marin e Guilherme Carvalhe Alto de Pinheiro, Săo Paulo terreno: $550 \mathrm{~m} 2$

a. construida: $550 \mathrm{~m}$

unidade: $150 \mathrm{~m} 2$

371 Vista Urbana Arquiteto

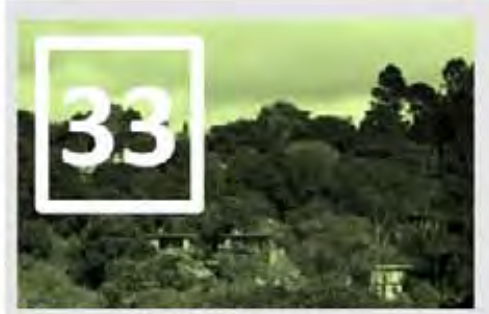

Vila Taguaí (2007-2010)

Cristina Xavier

Carapicuiba, São Paulo

terreno $12.000 \mathrm{~m}^{2}$

a. construida $1.250 \mathrm{~m}^{2}$

Unidade:

371

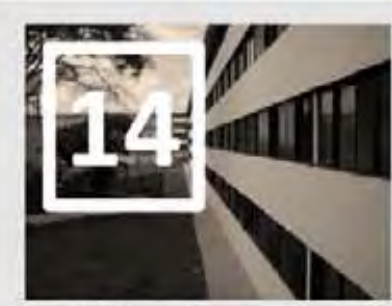

Vila dos Idosos

Vigliecca \& Associados

Pari, São Paulo

terreno: $7270 \mathrm{~m} 2$

a. construida

unidade:

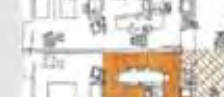

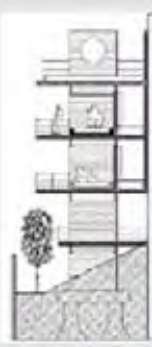

comosors
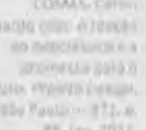

371
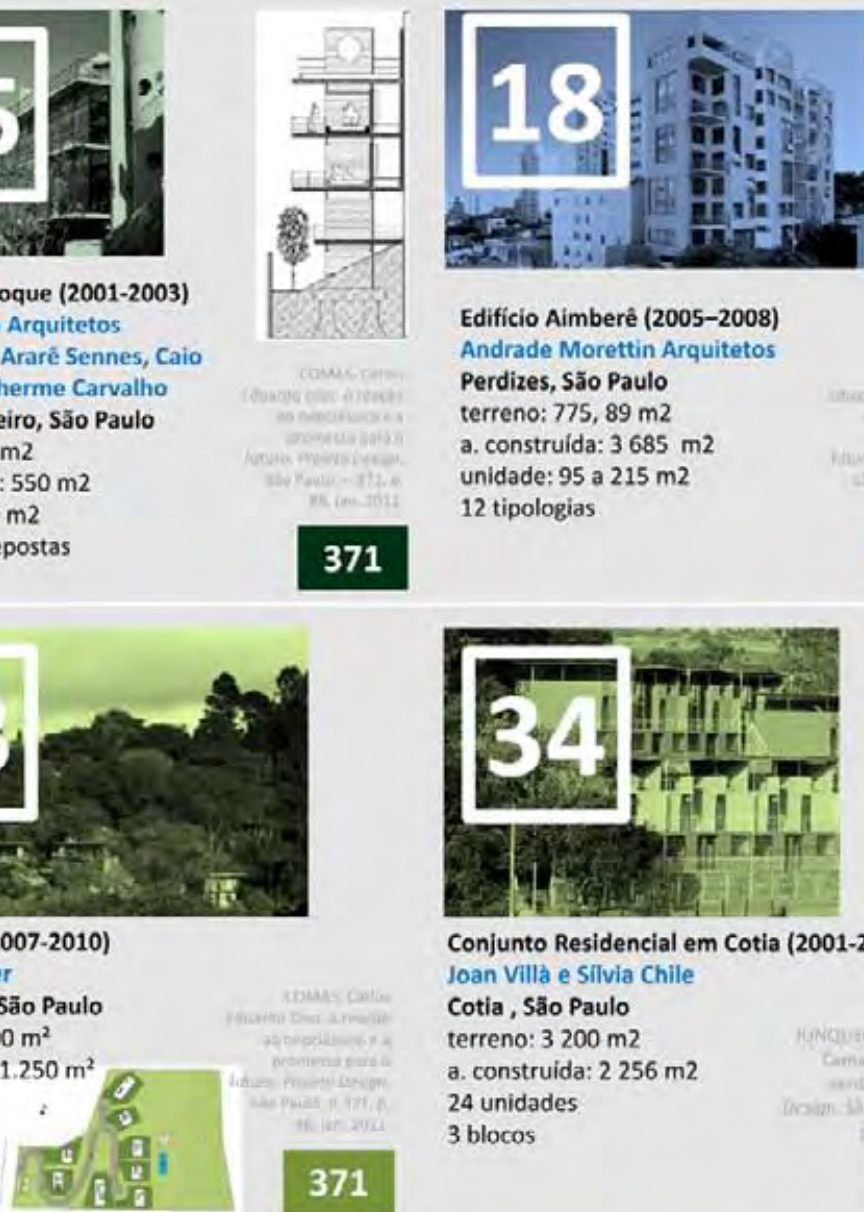

Edificio Aimberê (2005-2008) Andrade Morettin Arquitetos Perdizes, São Paulo

a. construida: $3685 \mathrm{m2}$

a. construida: $3685 \mathrm{m2}$
unidade: 95 a $215 \mathrm{m2}$

12 tipologias

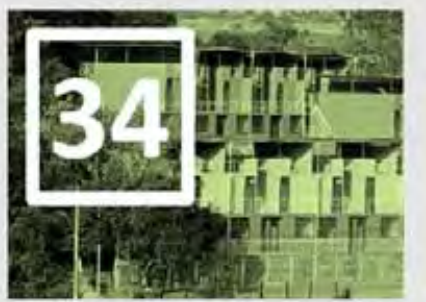

Conjunto Residencial em Cotia (2001-2002 Joan Villa e Silvia Chile

Cotia , São Paulo

Cotia, São Paulo

a. construida: $2256 \mathrm{m2}$

24 unidades

3 blocos

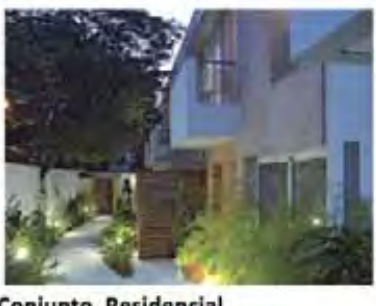

Conjunto Residencia

Reinach Mendonça Arquitetos

Associados

Sumaré, Săo Paulo

terreno: $1.145 \mathrm{~m}^{2}$

a. construida: $1180 \mathrm{~m}^{2}$

unidade: $300 \mathrm{~m} 2$

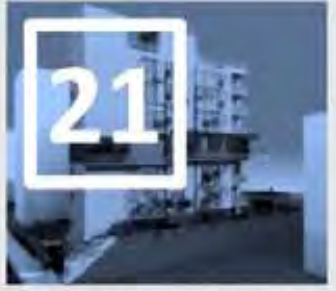

Edificio montevidéu 285 (2007-2010)

Vazio Arquitetura

Terreno: $480 \mathrm{~m} 2$

a. construida: $1500 \mathrm{mz}$

Unidade: $-105 \mathrm{m2}$

7 unidades 


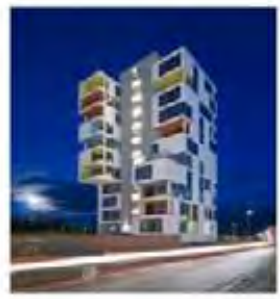

C. F. Moller Architects e

Christian Carlsen Arkitektfirma

Logten, Dinamarca
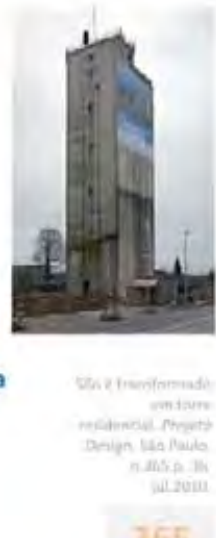

365
The Sill(o)houette (2010)

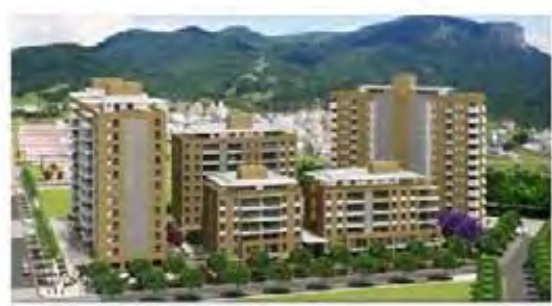

Centro de Bairro em Pedra Branca

Marchetti + Bonetti

Palhoça, Santa Catarina

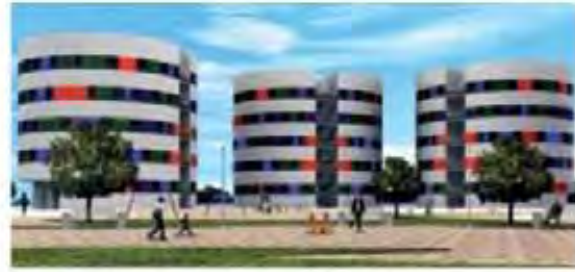

Conjunto em Heliópolis (2010)

Ruy Ohtake

Heliópolis, São Paulo

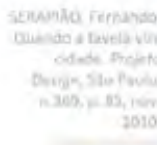

369

PROJETO 2009

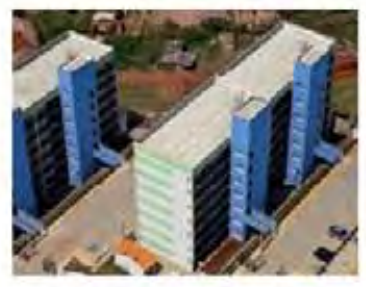

Săo Francisco (2010)

Claus Bantel e Stetson Laureau

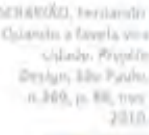

369

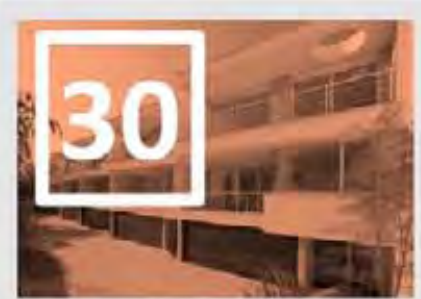

Condomínio Residencial Giardino Pirandello São Paulo 2004-2008 Monica Drucker Arquitetos

Associados

Brooklin, Săo Paulo

Terreno:2100m2

a. construida: $2400 \mathrm{~m} 2$

Unidade: $380 \mathrm{~m} 2$

6 casas geminadas

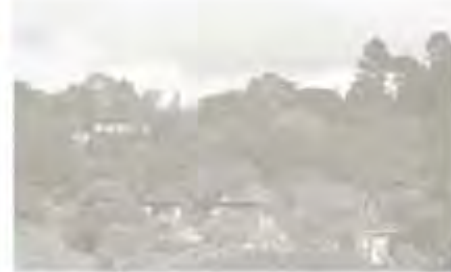

Vila Taguaí (2007-2010) Cristina Xavier

Carapicuiba, São Paulo

Carapicuiba, Săo

a. construida $1.250 \mathrm{~m}^{2}$

366 Unidade:

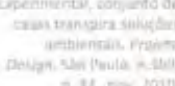

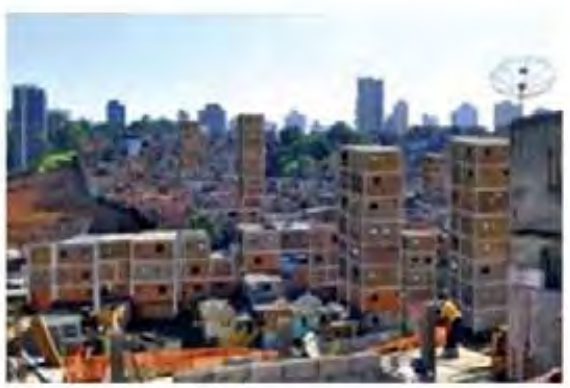

Intervenção em Paraisópolis

Christian Kerez

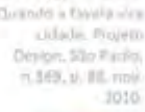

369

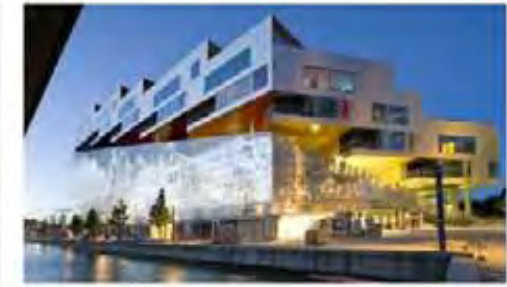

19 World Architectural Festival Mountain Dwellings, Dinamarca BIG - Bjarke Ingels Group Barcelona, Espanha

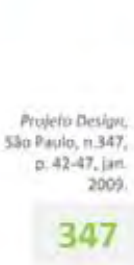

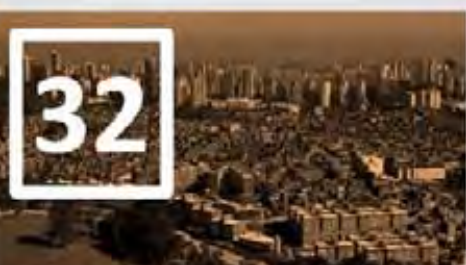

Conjunto Pascoal Melantonino

Celso dos Santos (2010)

Edson Elito, Abrahảo Sanocivz, Joăo

Honório darilho

Paraisópolis, São Paulo

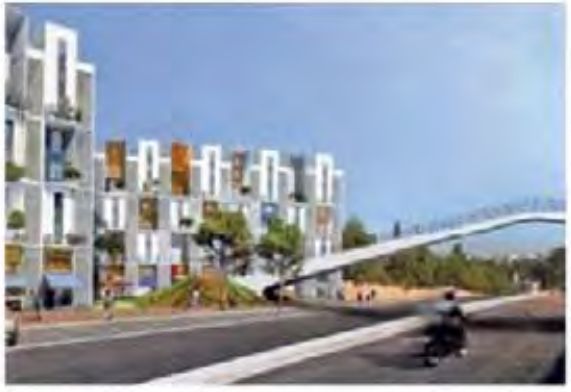

Elemental Paraisópolis

Alejandro Aravena

Terreno: $5000 \mathrm{mz}$

a. construida:

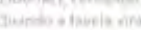

369

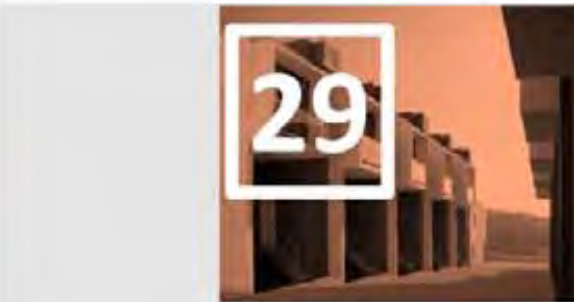

Box House (2007-2008)

Yuri Vital

Brasilândia, São Paulo

terreno: $1115 \mathrm{~m}^{2}$ aprox.

a. construida: 1011

17 unidades

3 renques: 3,6 e 7 unidades

Propere Derion.

348 


\section{9 स्वृताing:

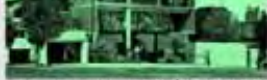 \\ Premiação IAB/SP 2008}

Categoria edificio habitacional - projeto

Edificio Simpatia 236 (2007)

Alvaro Puntoni, Jos̆o Sodré e Jonathan Davies

GRUPOSP

Vila Madalena, São Paulo

terreno: $800 \mathrm{~m} 2$

a. construida:

unidade: $95-215 \mathrm{~m} 2$

n. andares: 11

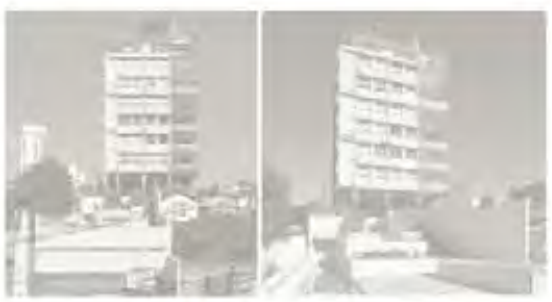

Edificio $4 \times 4$ (2006-2008)

Gui Mattos

Pinheiros, São Paulo

(Rua Cristiano Vian

terreno: $1063 \mathrm{~m} 2$

a. construída: $4010 \mathrm{~m} 2$

unidade: $63,50-552 \mathrm{~m} 2$

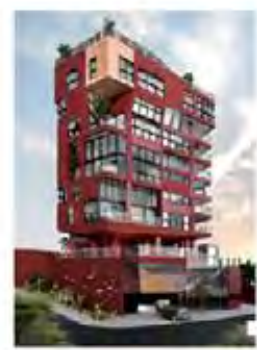

Edificio Girassol 1206

José Alves e Juliana Corradin

Vila Madalena, Sã̀ Paulo

terreno: $2800 \mathrm{~m} 2$

a. construida: $\mathrm{m} 2$

unidade: $85 / 154 / 494 \mathrm{~m} 2$

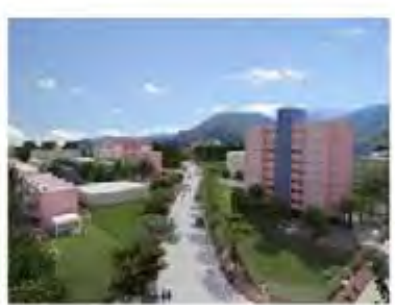

Premiação IAB/SP 2008

Categoria habitação pública de interesse sacial

Loteamento Rubens Lara (2006)

Cubatăo, Săo Paulo

Adriana Levisky e Eduardo Martins Ferreira

a. construida:

$n$. andares:

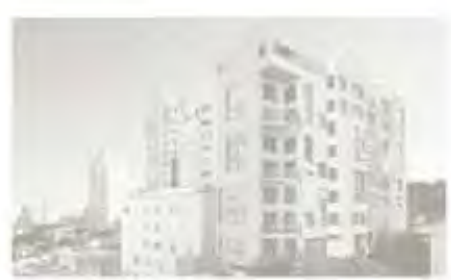

Edificio Aimberè (2005-2008) Andrade Morettin Arquitetos Perdizes, Săo Paulo terreno: $775,89 \mathrm{m2}$ a. construida: $3685 \mathrm{m2}$ unidade: 95 a $215 \mathrm{~m} 2$ 12 tipologias
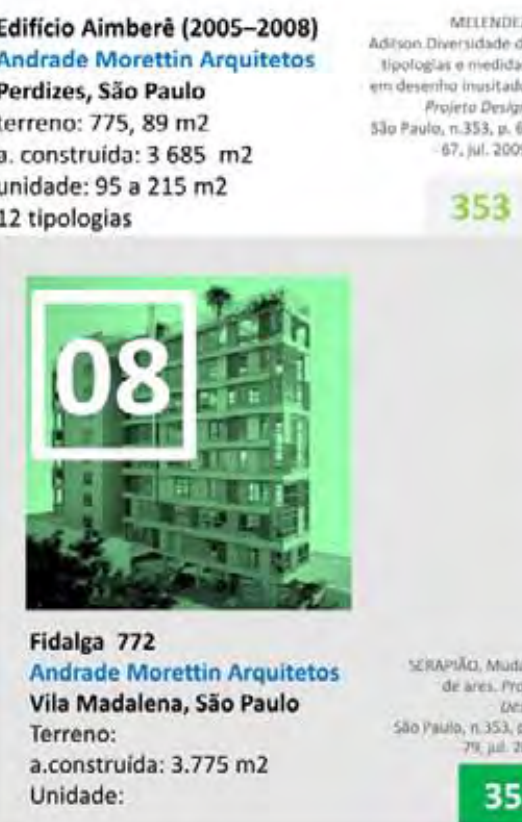

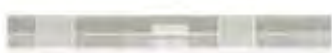

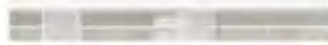

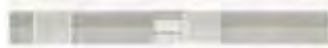

Bif

필

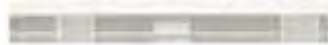

Edifício Breeze (2004 -2008) Aflalo \& Gasperini Arquitetos

Alto da Lapa, São Paulo

Terreno: $2600 \mathrm{~m} 2$

a. construida: $21200 \mathrm{~m} 2$

unidade: $234 \mathrm{~m} 2$

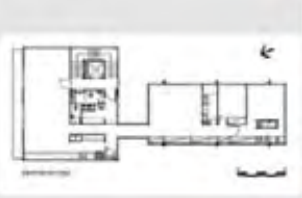

$-$

Edificio Fiori do Maggio

(1999-2007)

Apoena e Moracy Amaral, Carlos Ferrata, Eduardo

Ferroni e Pablo Hereñu

S. B. do Campo, São Paulo

terreno: $432 \mathrm{~m} 2$

a. Construida: $1151 \mathrm{mz}$

unidade: $205 \mathrm{~m} 2$

3 unidade + escritório

$t+3+$ cobertura
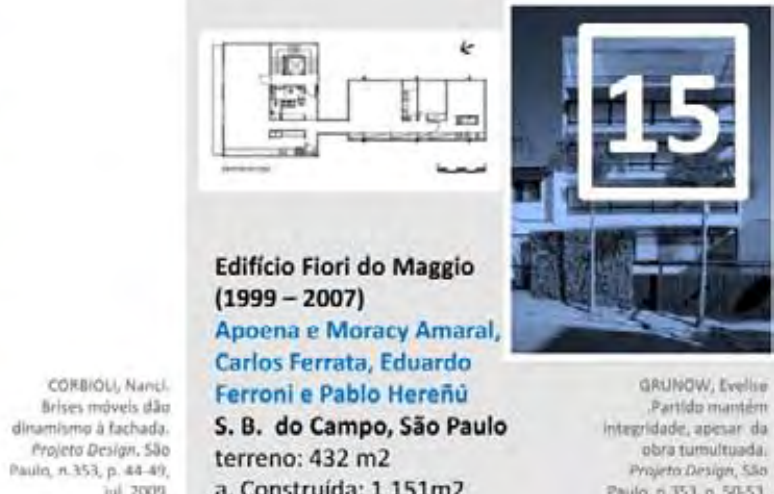

353
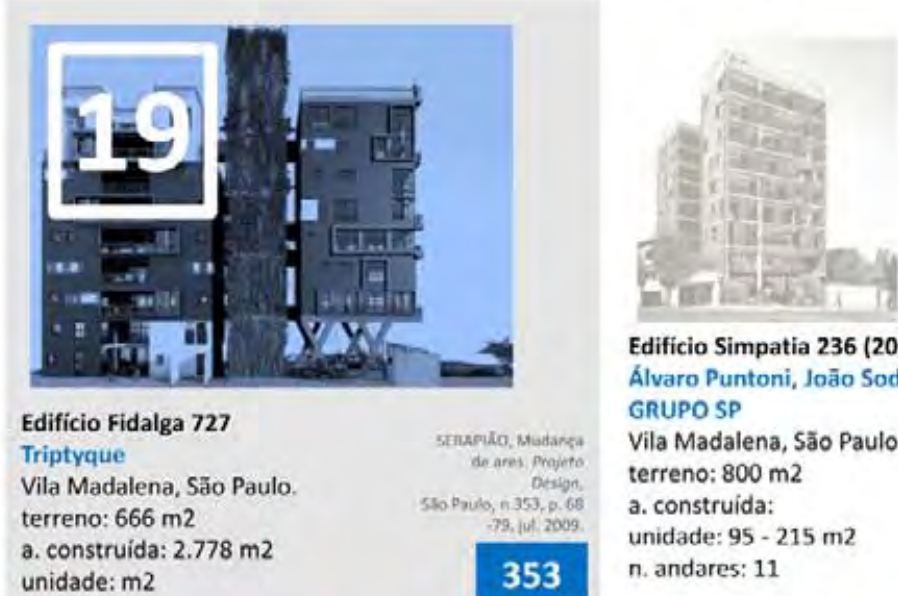

Edificio Simpatia 236 (2007)

Alvaro Puntoni, Joẫo Sodrẻ e Jonathan Davies GRUPO SP

Vila Madalena, São Paulo

terreno: $800 \mathrm{~m} 2$

a. construida:

nidade: $95-215 \mathrm{m2}$

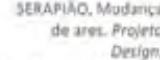

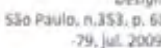

a. construida: $2.778 \mathrm{mz}$

n. andares: 1

353

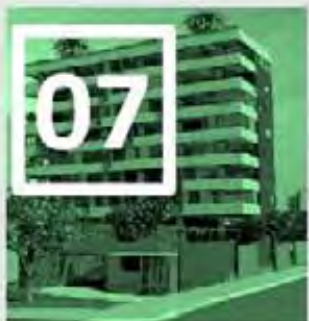

Edifício Ourânia (2007-2009)

Gui Mattos

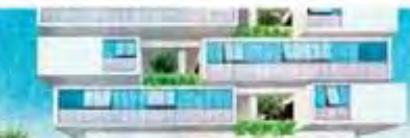

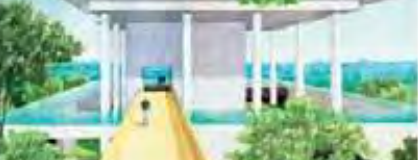

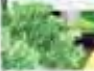

Edificio 360 ?

Isay Weinfeld

Alto de Pinheiros, S5̆o Paulo

Alto de Pinheirc

15 apartamentos

de ares. Proper

terreno:

terionstida

a. Constru

353

Unidade: 


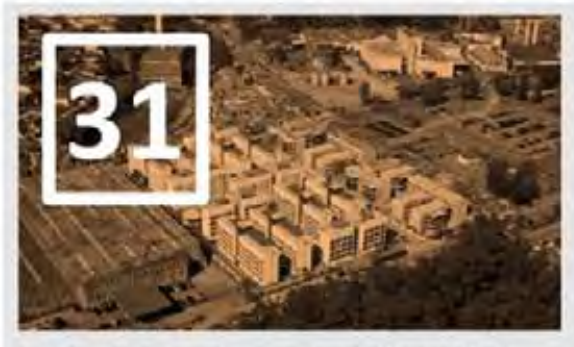

Residencial Alexandre Mackenzie (2008-2009) Boldarini Arquitetura e Urbanismo

Nova Jaguaré, São Paulo

terreno: $20670 \mathrm{m2}$

a. Construida: $32.722,08 \mathrm{m2}$

296 aptos CDHU

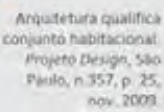

357

Nova Jaguare, São Pay

Vigliecca \& Associados

Pari, Săo Paulo

terreno: $7270 \mathrm{~m} 2$

a. construida: $8290 \mathrm{mz}$

unidade:
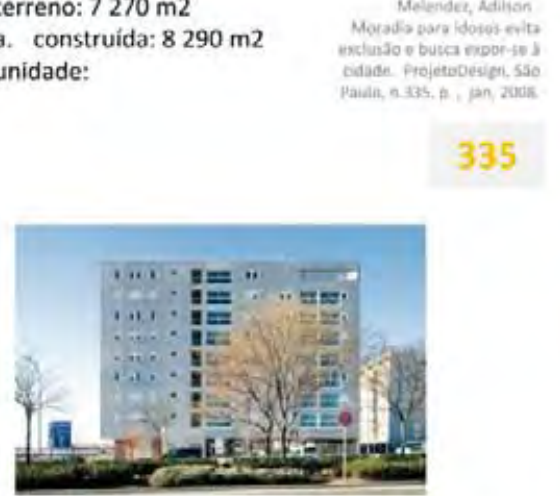

Ensanche de Vallecas (2004-2007) Paulo Mendes da Rocha e Bellosillo Associados (autores); MMBB Arquitetos, Anja Koehler, Joana Martins e Patricia Mayor

(colaboradores)

Madri, Espanha

Area do terreno 1.390,15 m²

Area construida $5.468 \mathrm{~m}^{2}$

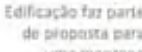

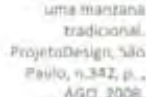

$\mathrm{Nac}, 200$
3610

342

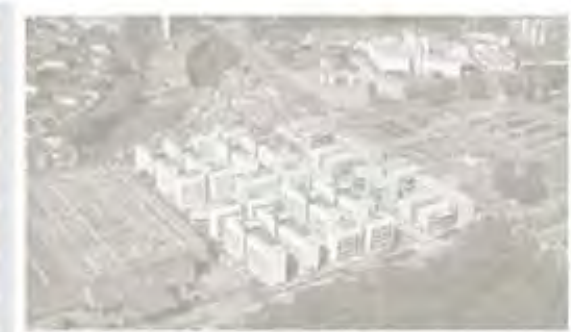

Residencial Alexandre Mackenzie (2008-2009) Boldarini Arquitetura e Urbanismo

Nova Jaguaré, Săo Paulo

a. Construida: $32,722,08 \mathrm{m2}$

unidade:

296 aptos CDHU
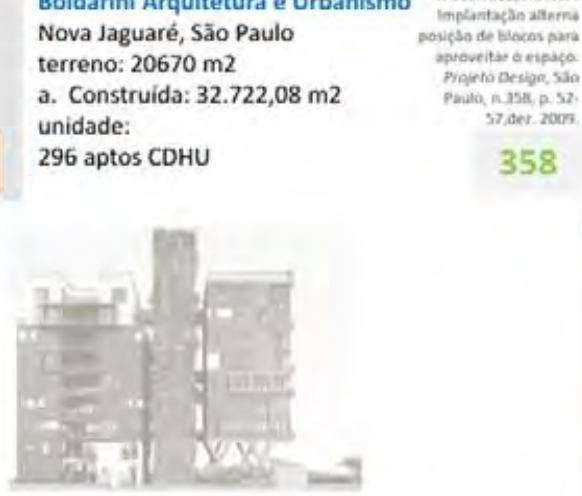

Edifício Fidalga 727

Triptyque

Vila Madalena, São Paulo.

terreno: $666 \mathrm{m2}$

a. construída: $2.778 \mathrm{m2}$

unidade: $\mathrm{m} 2$

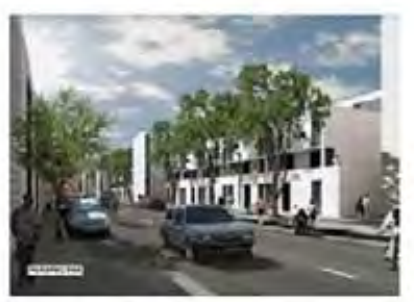

358

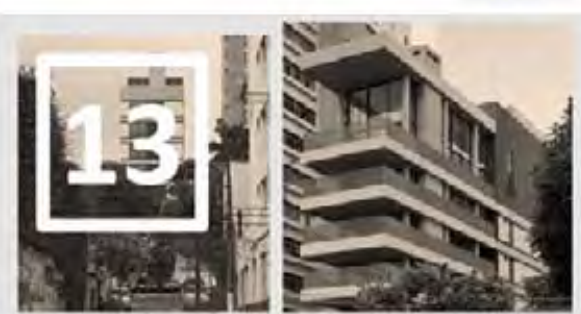

a. construida: $4.149 \mathrm{~m}^{2}$ (antigo)

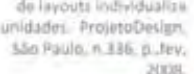

336

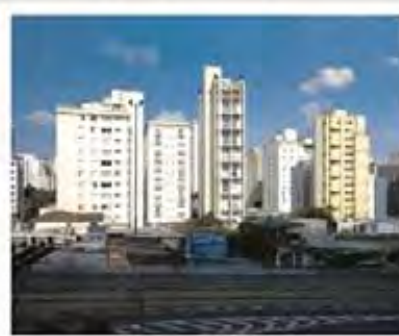

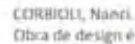

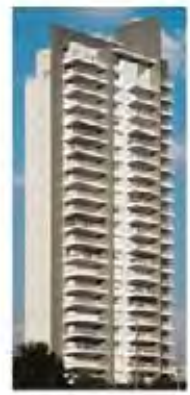

Edificio Arte Arquitetura Itai (2005-2007)

Rocco Associados

Itaim-Bibi, Săo Paulo

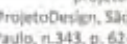
69. 2et 2008
Colinas D'Oeste

(em projeto desde 2006)

Hector Vigliecca \& Associados

Morro do Socó e Portal,

Osasco, São Paulo

Retrofit Edifício Residencia

Panorama (2006-2007)

Isay Weinfeld

Vila Nova Conceiçăo, São Paulo

terreno: $1186 \mathrm{m2}$ (70 m de comp.)

a. construida: $807 \mathrm{~m}^{2}$ (novo)

unidade: $430 \mathrm{~m}^{2} / 582 \mathrm{~m}^{2} / 609 \mathrm{~m}^{2}$

8 andares +2 subsolos

PROJETO 2008

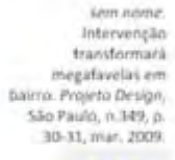

349
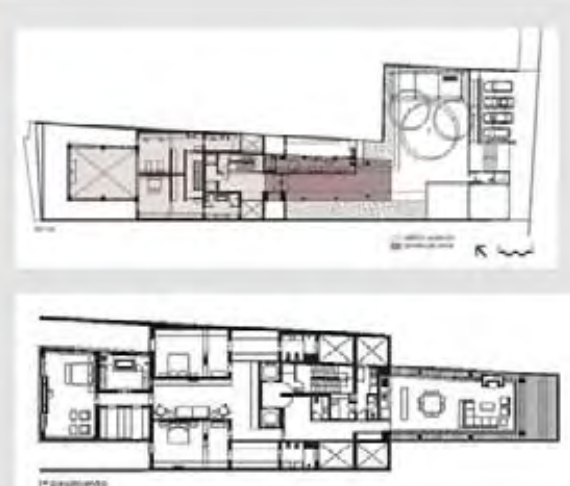

340

Edificio Arte House (2004-2006) Rocco Associados

Jardins, São Paulo

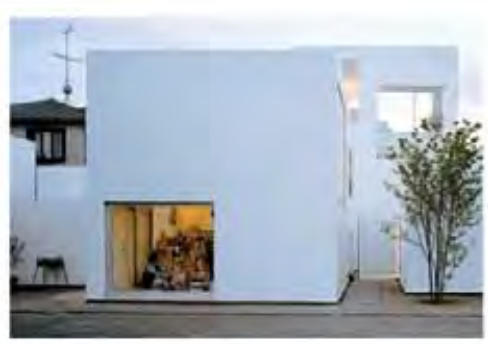

Conjunto residencial Ryue Nishizawa (2002-2005) Kazuo Sejima Tóquio, Japåo

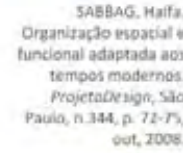

344 


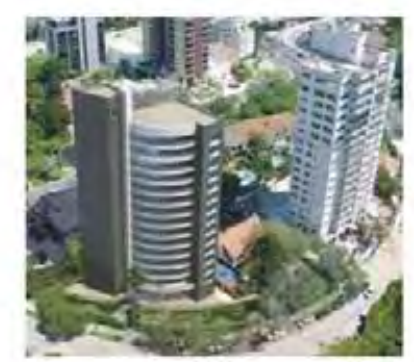

Edificio Villagio di Carrara (2003-2007)

Dino Damiani Arquitetos + Designers

Porto Alegre
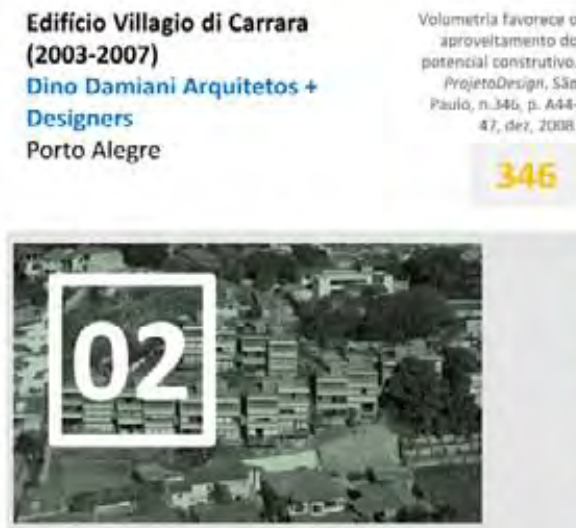

Conjunto residencial Vila Butantă (1998-2004)

Marcos Acayaba

Rua Afonso Vaz, Vila Pirajussara,

São Paulo, Brasil

Nurmero de unidades: 16

Tamanho das unidades: $173.69 \mathrm{~m}^{2}$

Area ocupada: $1140 \mathrm{~m}^{2}$ (25.7\%)

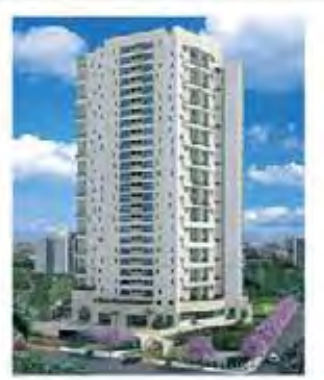

Condominium Club Up Side e East Side Club Condominium Konogsberger Vannucchi

Arquitetos Associados

Paraiso, zona Sul, Săo Paulo sempilo, Fermendio

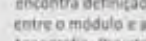

313

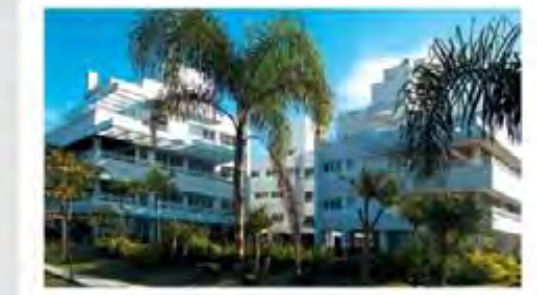

Condomínio residencial Arte dell'Acqua (2002-2005)

Pedro Gabriel Arquitetos

Praia de Jurerê Internacional,

Florianopolis, SC

Area do terreno $3.600 \mathrm{mz}$

Área construida $10.400 \mathrm{~m}$

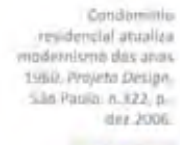

322

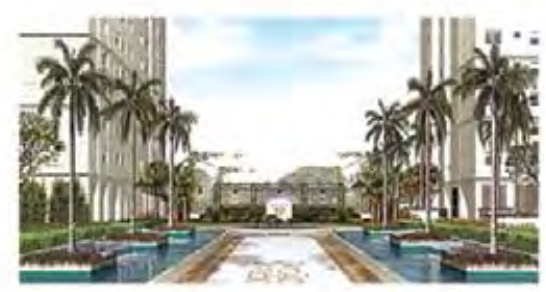

Vereda Paraiso

Márcio Curi E

Azevedo Antunes Arquitetura

junç̧̄o das ruas Martiniano de

Carvalho, Pio 12 e Artur Prado,

Paraiso, zona sul de São Paulo

Área do lote: $10000 \mathrm{mz}$

\section{PROJETO 2007}

PROJETO 2006

PROJETO 2005

Solar das Palmeiras (2002-2006) Dino Damiani Neto Bairro Petrópolis, Porto Alegre, RS Área do terreno $1.336,41 \mathrm{m2}$
Área construida $6.556,36 \mathrm{m2}$

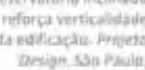
322

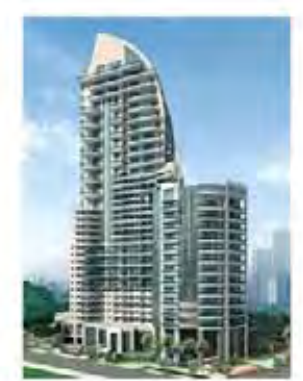

\section{Çiragan (Tchiraan)}

Itamar Berezin

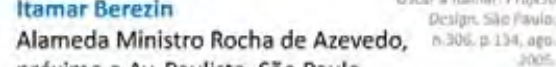
próximo a Av. Paulista, São Paulo
PROJETO 2004 


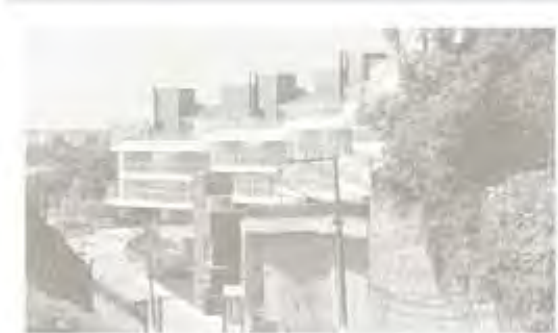

Espaço Móbile II (2002-2003)

Mauro Munhoz Arquitetura

Morumbi, São Paulo

Terreno: $3229 \mathrm{m2}$

construida das casas:

$353 \mathrm{~m} 2$ e $413 \mathrm{~m} 2$

12 casas geminadas

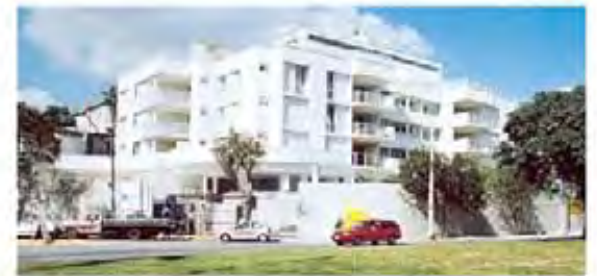

Condominio Parque Villa-Lobos

1999 (edificio 1)

2000 (edificio 2)

2001 (edificio 3)

Donini Arquitetura

City Boaçava, na zon

oeste de Săo Paulo

Area do terreno

$1925 \mathrm{mz}$;

$1585 \mathrm{m2}$;

$2606 \mathrm{mz}$

Área construída

$2251 \mathrm{m2}$;

$688 \mathrm{m2}$

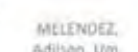

metsons

297

PROJETO 2003

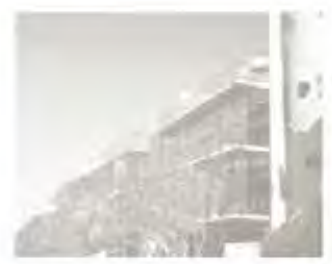

Edificio Oiapoque (2001-2003) Vista Urbana Arquitetos Associados - Ararê Sennẹs, Caí Marin e Guilherme Carvalhe Alto de Pinheiro, São Paulo terreno: $550 \mathrm{~m} 2$

a. construida: $550 \mathrm{~m} 2$

unidade: $150 \mathrm{~m} 2$

2872 casas sobrepostas

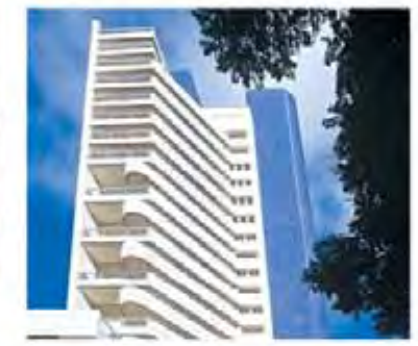

Edificio Site (1997-2004)

Eduardo Martins Ferreira

Sumaré, Săo Paulo

Área do terren

$900 \mathrm{~m} 2$

Área construida
$4250 \mathrm{~m} 2$

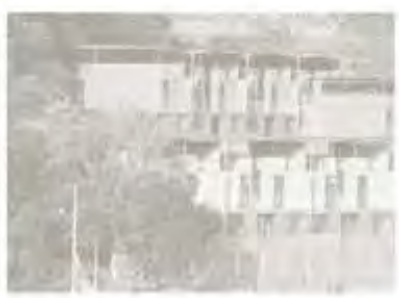

Conjunto Residencial em Cotia (2001-2002) Joan Villà e Silvia Chile

Cotia , São Paulo

a. construida: $2256 \mathrm{m2}$

24 unidades

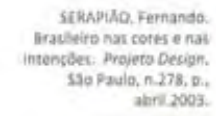

3 blocos

278

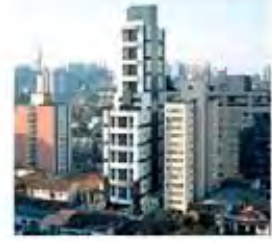

Helbor Loft Evolution II (2000-2003)

EGC Arquitetura - Elizabeth Goldfarb e

Wilson Marchi Júnior

São Paulo

torre escalonada com 20 andares

Area do terreno

$1050 \mathrm{~m} 2$

Área construída

$7096,94 \mathrm{mz}$

De 221 a $302 \mathrm{m2}$

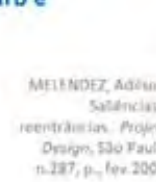

287

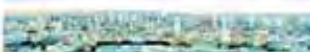 \\ benes $=5$

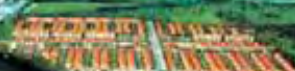

eserva Ibatyba (2001-2003)

EGC Arquitetura - Elizabeth Goldfarb e Wilson Marchi Júnior

Santo André, São Paulo

Área do terreno

$149707,50 \mathrm{~m} 2$

Área construida

$62421,06 \mathrm{~m} 2$

926 unidades, das quais 606 são

320 , apartamentos.

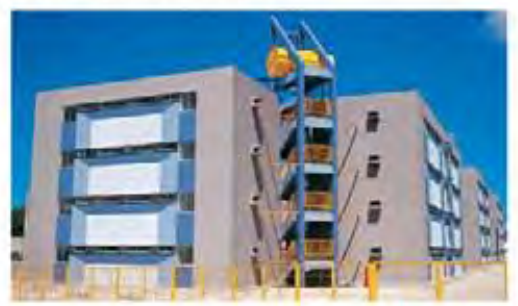

Conjunto Habitacional Galápagos (2002-2003) Rubem Wanderley Filho,

Rafael del Águila e Mauricio Cacho

Maceió, Alagoas

Terreno: $5806 \mathrm{m2}$

a. construida: $9001 \mathrm{mz}$

10 blocos e 128 apartamentos

com dois dormitórios e 42 metros

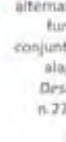

Condominio Residencial Giardino Pirandello São Paulo 2004-2008

Monica Drucker Arquitetos Associados

Brooklin, São Paulo

Terreno: $2100 \mathrm{~m} 2$

a. construida: $2400 \mathrm{~m}$

Unidade: $380 \mathrm{~m} 2$

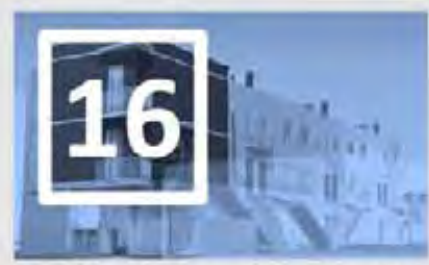

Cohab - Unidade Pedro Facchin (2002-2004)

Barbosa \& Corbucci

Arquitetos Associados

Ipiranga, Säo Paulo

Área do terreno

$320 \mathrm{~m} 2$

Área construída

$525 \mathrm{~m} 2$

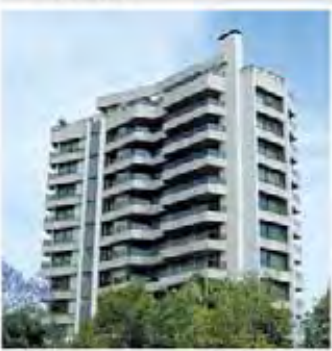

Conjunto Habitacional Galápagos (2002-2003) Edificio Residencial ( 1998-2002) Valle Arquitetos

Edgar, Cristina e Sandra do Valle

Porto Alegre, RGS

278 a. construida: $7500 \mathrm{~m}$

Unidade: $800 \mathrm{~m}^{2} / 1$ por andar

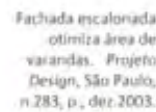

278 


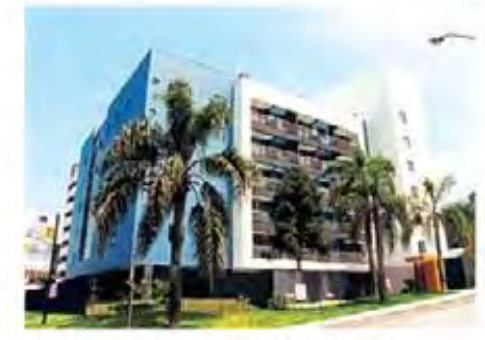

Edificio Residencial ( 1998-2000)

PinAA -

Clodualdo Pinheiro Júnio

Curitiba, Paraná

Terreno: $1600 \mathrm{m2}$

a. construida: $5632,77 \mathrm{~m} 2$

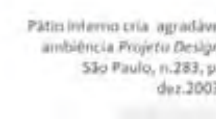

283

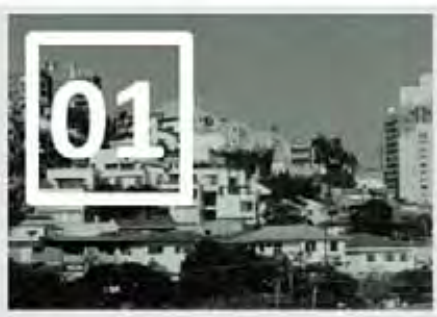

Conjunto Residencial

Vila Fidalga (1999)

Cristina Xavier

Vila Madalena, Săo Paulo

Terreno: $1340 \mathrm{m2}$

a. construida:

6 unidades

Tamanho das unidades:

$120 \mathrm{~m} 2$ a $260 \mathrm{~m}$

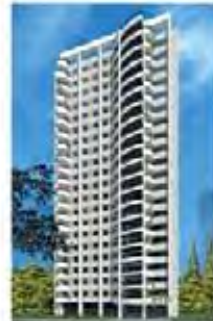

Edificio Marambaia (2000-2003)

Roberto Candusso

Arquitetos Associados

Jardim Paulista, São Paulo

Terreno: $1462,63 \mathrm{mz}$

a. construida: $634,41 \mathrm{m2}$ (acresci Asbea 200

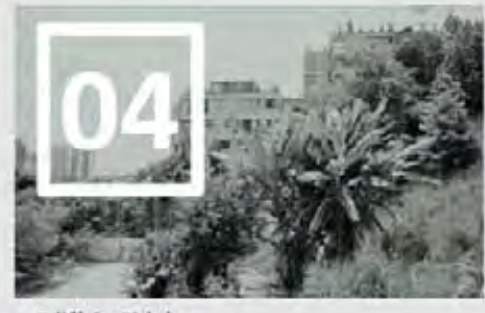

Edifício Fidalga

Cristina Xavier

Vila Madalena, São Paulo

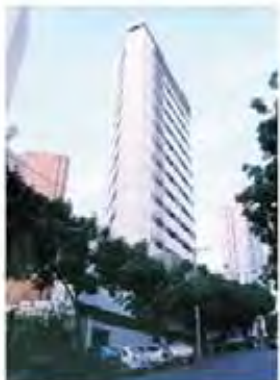

Prédio Residencial

Flávia Araújo Badaró, Ana

Paola Araújoe Renato

Pimenta

Belo Horizonte, Minas Gerais

Terreno: $630 \mathrm{~m} 2$
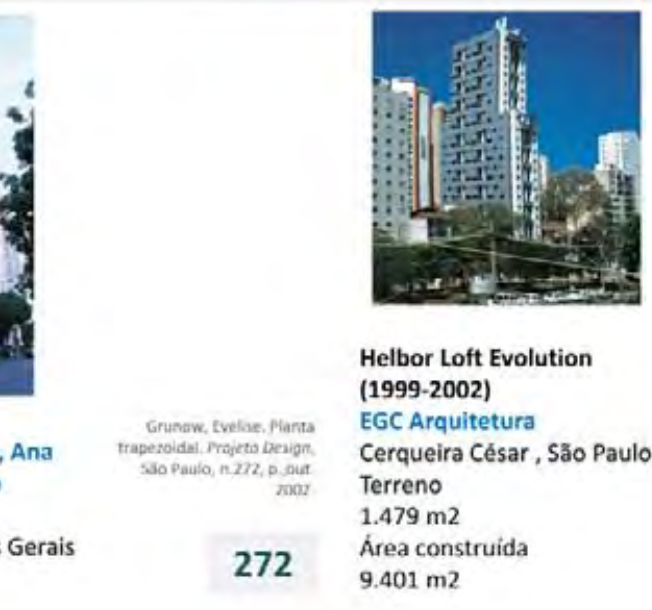

Helbor Loft Evolution

(1999-2002)
EGC Arquitetura

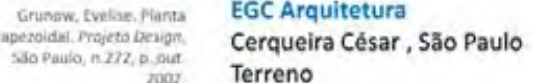

Terreno

272 Área construida

$272 \quad 9.401 \mathrm{m2}$

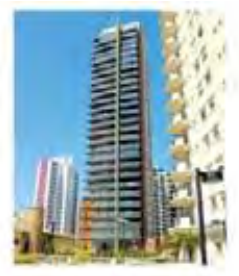

PROJETO 2002

Edificio Ville Cap Ferrat (1999-2002)

Paulo Segall Arquitetura

Chácara Klabin, São Paulo

terreno: $4170 \mathrm{m2}$

a. construída: $14953 \mathrm{mz}$

unidade: $375 \mathrm{~m} 2$

24 apartamentos-tipo

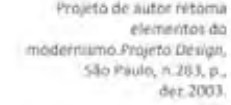

+ cobertura dúplex

283

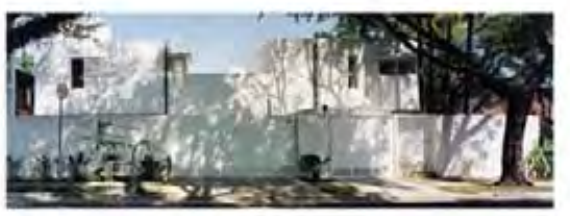

Residências

Andre Vainer $\mathrm{e}$

Guilherme Paoliello

Alto de Pinheiros, São Paulo

Duas casas

263

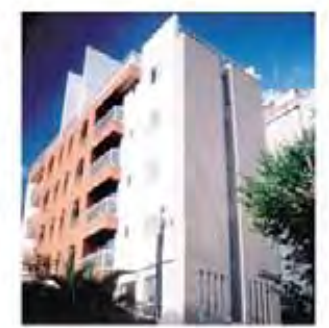

Edificio Residencia

José Ricardo Fois e

Marcelo Alvarenga

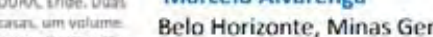
Aptos de $65 \mathrm{~m} 2$

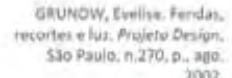

264

270

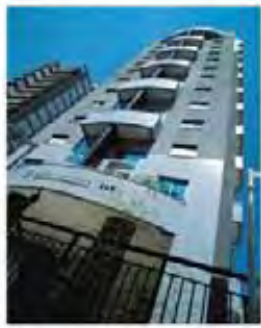

Dúplex Top Tower

(1998-2002)

Pinheiros, São Paulo

Área do terreno

$1380 \mathrm{~m} 2$

$274 \quad \begin{gathered}\text { Área construid } \\ 9356,70 \mathrm{~m} 2\end{gathered}$

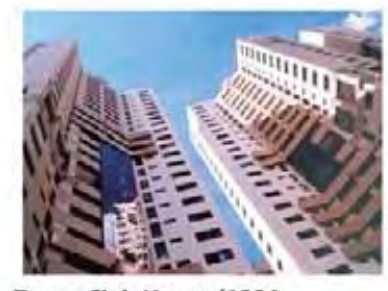

Tower Club House (1994.

1996)

Frederico Carstens

e Antônio José Gonçalves

Júnior

Terreno

Área construida

$26.376 \mathrm{~m} 2$

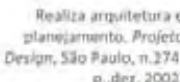

274 


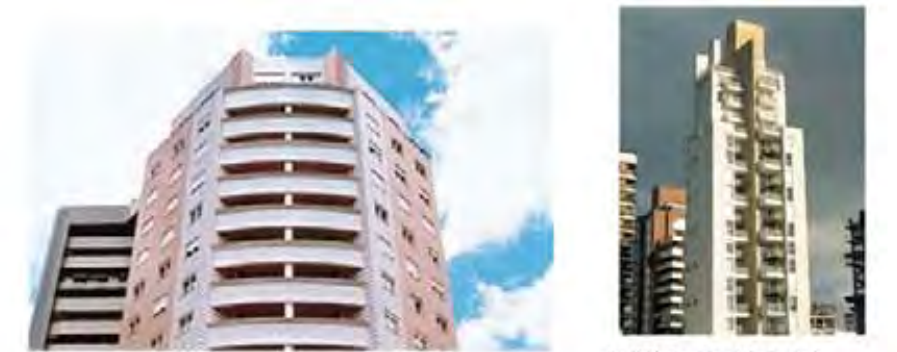

Edificio Obra Prima (1999-2000)

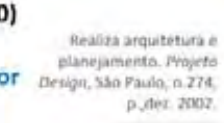

Terreno: $3.011 \mathrm{mz}$

274

Área construida : $26.376 \mathrm{m2}$

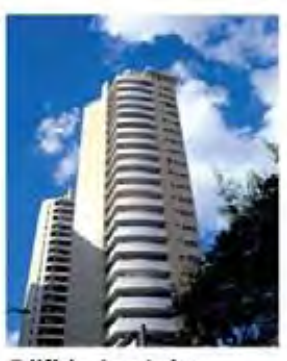

Edifício Ana Luiza

Padovano \& Associados

Arquitetura

Săo Paulo

torre com apenas 21

apartamentos-tipo, um por

andar
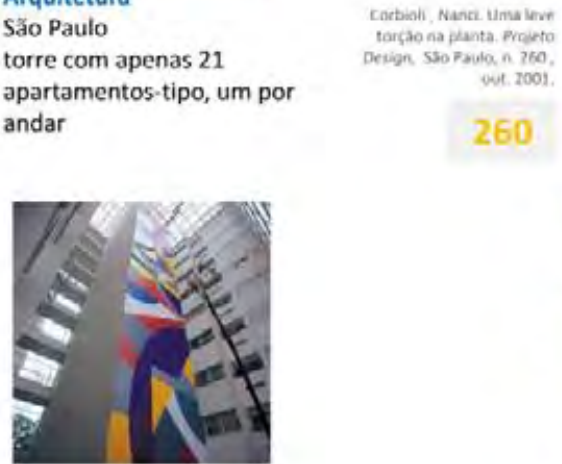

Edificio Spazio 2222

Décio Tozzi

Sumaré, São Paulo

\section{Edifício Residencial}

Rocco Arquitetos Associados

unidades dúplex do tipo loft,

de $90 \mathrm{~m} 2$ a $110 \mathrm{~m} 2$ de área

útil e até très dormitórios. 0

terreno, em forma de seta,

levou à volumetria e à

tipologia diferenciadas.

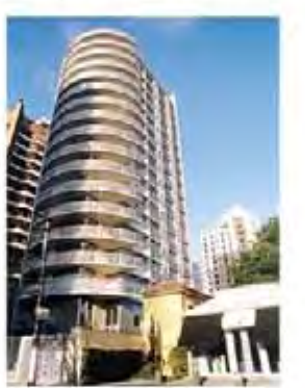

Edificio Palazzo Ducale

Marco Donini e Francisco

Zelesnikar

15 unidades, uma por

andar.

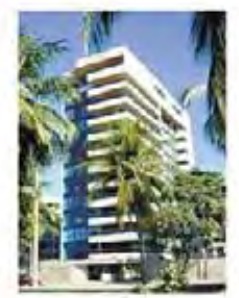

Edificio Puerto Ban

Pontual Arquitetos

Recife

Terreno: $1940 \mathrm{mz}$

lajes-tipo com $552 \mathrm{m2}$

\section{PROJETO 2001}

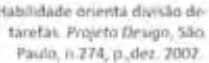

274

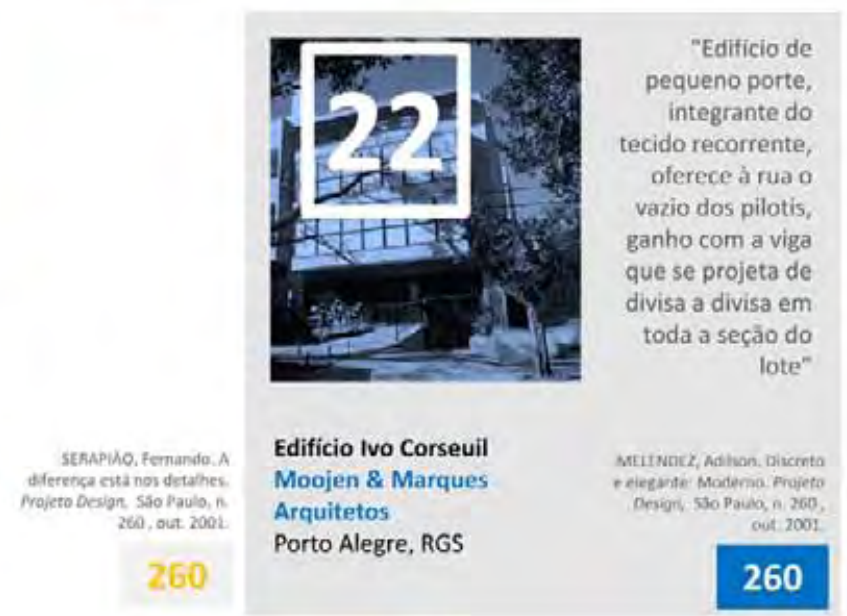

PROJETO 2000

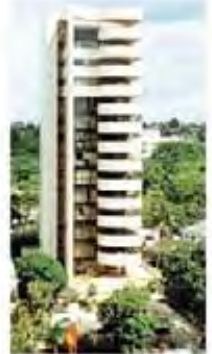

Edifício Residencial das

Ubaias

Rangel Moreira

Arquitetura

Recife

24112 apartamentos, um por

andar

Edificio de uso misto

Augusto Guelli

Porto Ferreira, São Paulo

$30 \mathrm{~m}$ de frente

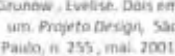

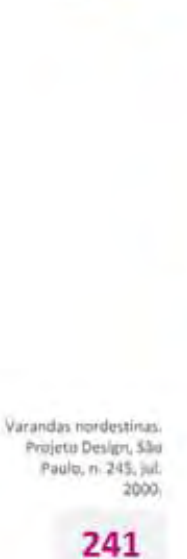

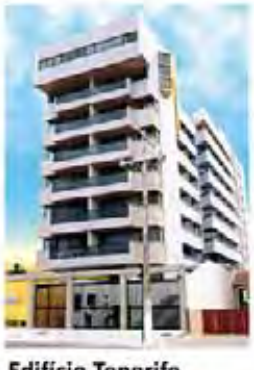

Edificio Tenerife

Ruben Wanderley Filho

36 unidades

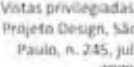

245

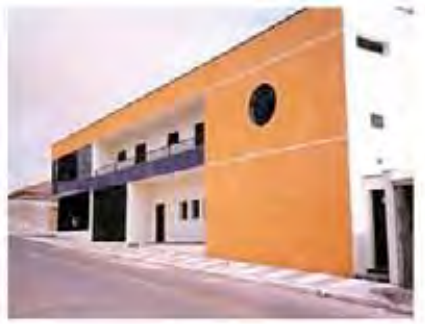




\section{AU 2011}

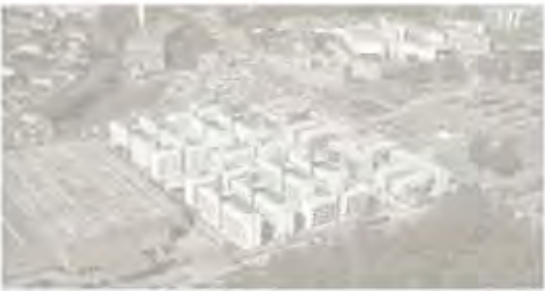

Residencial Alexandre Mackenzie (2008-2009) Boldarini Arquitetura e Urbanismo

Nova Jaguaré, Săo Paulo

RLoresta, Cleide
Casas sobresostas

terreno: $20670 \mathrm{~m}$

a. Construída: $32.722,08 \mathrm{m2}$

unidade:

296 aptos $\mathrm{CDHU}$

urbuniamo, SAo Paulo
n203, p. 42-43,jar

203

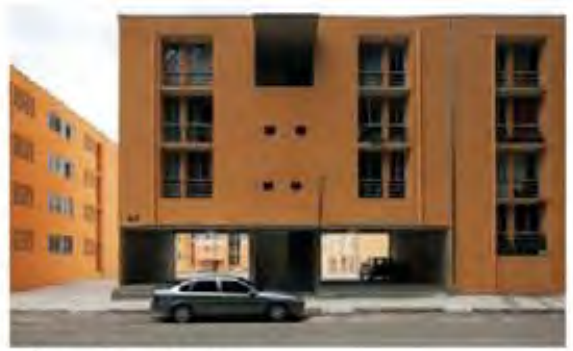

Área dos Portais

\section{8-2010)}

Vigliecca \& Associados

Portal Menk e Portal Camp

Osasco, Săo Paulo

$$
\begin{aligned}
& \text { FLonesta Cleits. }
\end{aligned}
$$

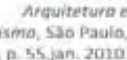

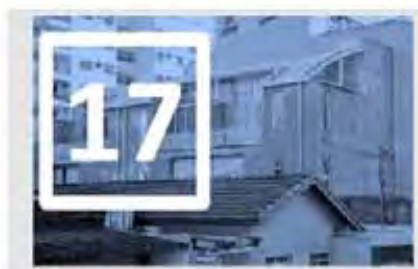

Vila Maida (2004-2006) Maristela Faccioli

Vila Bastos, Santo André, SP

três casas geminadas

Terreno: $220 \mathrm{mz}$

Área Construida: $300 \mathrm{~m}$

Santo André, São Paulo

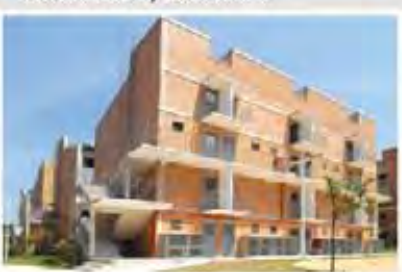

Conjunto Residencial Itaoca (2008-2009)

Projeto: MPU - Metrópolis

Projetos Urbanos Arquitetura e

Urbanismo:

Aranitetos Jorge Mário Jáuregui

Arquitetos Jorge Mário Jáuregu e Mauricio Santos

Morro do Alemão, Rio de Janeiro Terreno: $20900 \mathrm{m2}$

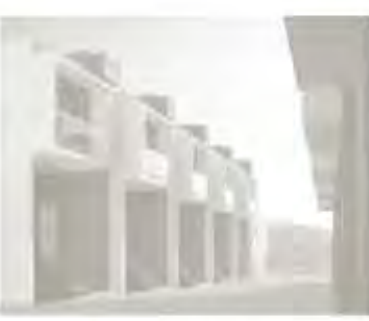

Box House (2007-2008)

$$
\text { Yuri Vital }
$$

Brasilândia, Sāo Paulo

terreno: $1115 \mathrm{~m}^{2}$ aprox

a. construida: $1011 \mathrm{~m}^{2}$

unidade: $46 \mathrm{~m}^{2}$

3 renques: 3,6 e 7 unidades

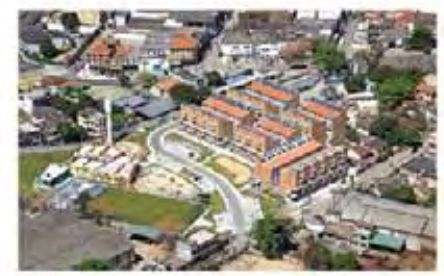

Conjunto Mutirã̃o Paulo Freire (2001-2010)

LLAL, ledryationto Arquitetura: USINA - Centro de

trabalhos para o Ambiente

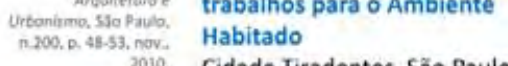

Terreno: $20900 \mathrm{mz}$

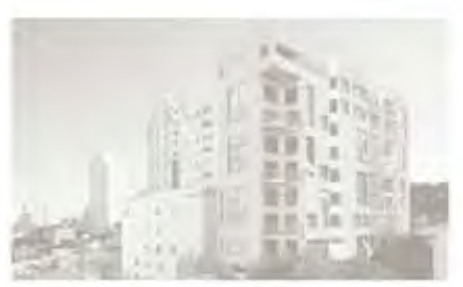

Edificicio Aimberê (2005-2008) Andrade Morettin Arquitetos Perdizes, São Paulo terreno: $775,89 \mathrm{~m} 2$

a. construida: $3685 \mathrm{mz}$

unidade: 95 a $215 \mathrm{~m} 2$

12 tipologias

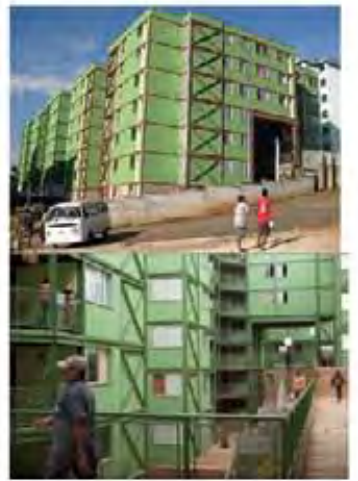

2015

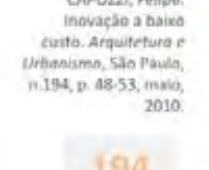

199

\section{s

.

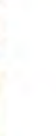

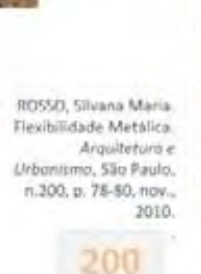

200

\section{AU 2010}

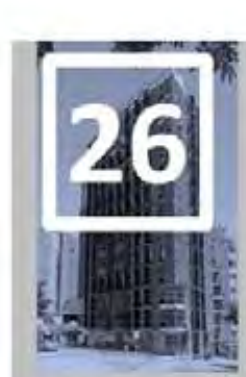

Edificio Residencial
Guernika (2007)
Miguel Angel Roca
Córdoba, Argentina.

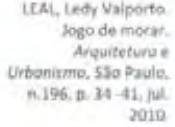$$
203 .
$$

203

\section{Edificio Ourânia (2007-2009)}

Gui Mattos

Alto de Pinheiros, São Paulo

Terreno: 1100

a. construida: 4.440

Unidade $52 \mathrm{~m} 2 /$

15 apartamentos

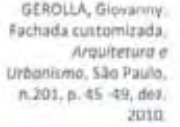

8 andares 


\section{AU 2009}

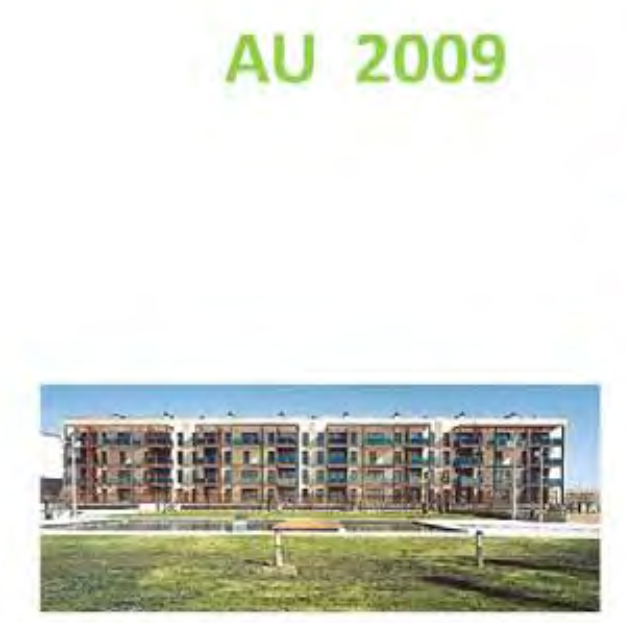

\section{Edificio Residencial Cubelles} Carlos Marti Aris Barcelona, Espanha
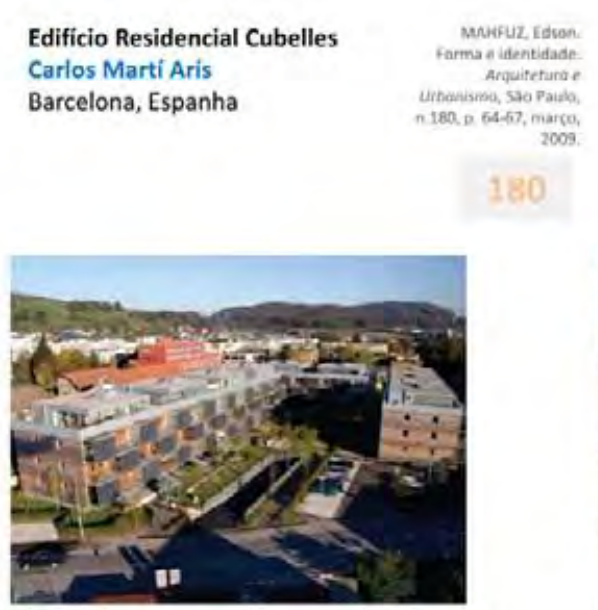

Piano Forte (2002-2003) RD2B

Wettingen, Suiça

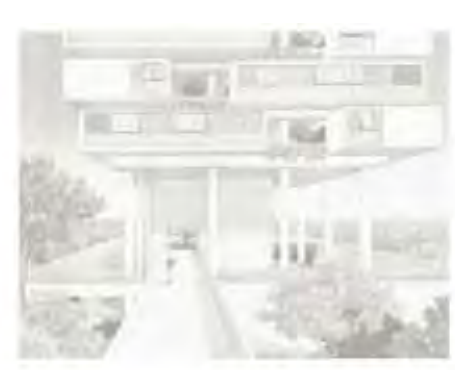

Edificio $360^{\circ}$

Alto de Pinheiros, São Paulo

terreno:

a. Construída:

Unidade:
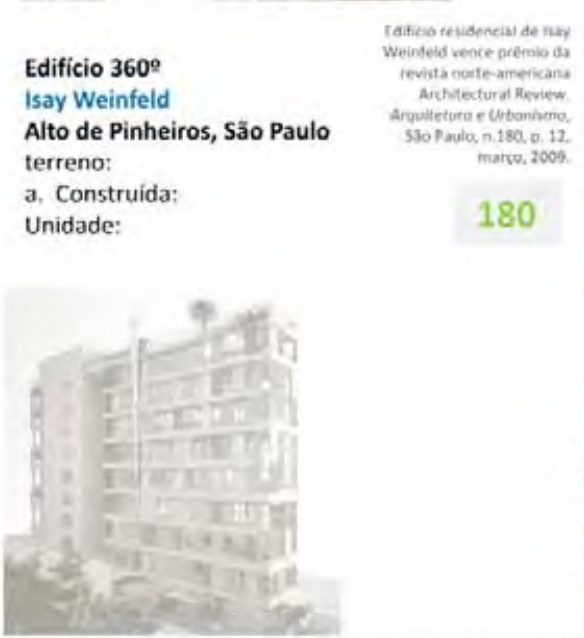

Fidalga 772

Andrade Morettin Arquitetos

Vila Madalena, São Paulo

Terreno:

a.construída: $3.775 \mathrm{~m} 2$

Unidade:

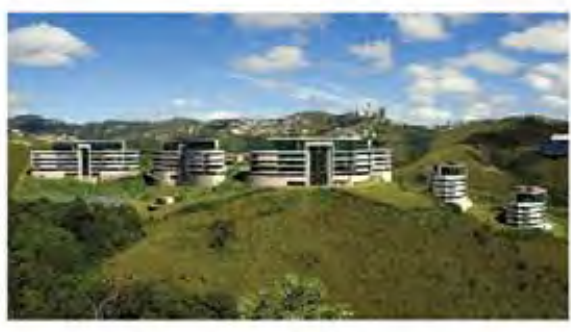

Vila Gardner (2004-2005)

Gustavo Penna

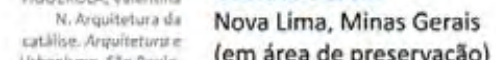

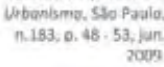

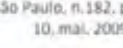

180

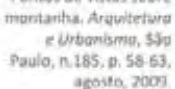
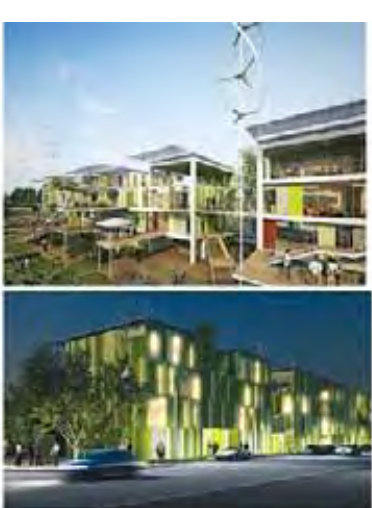

Casa 100KE (2007-2008)

Mario Cucinella

Itália
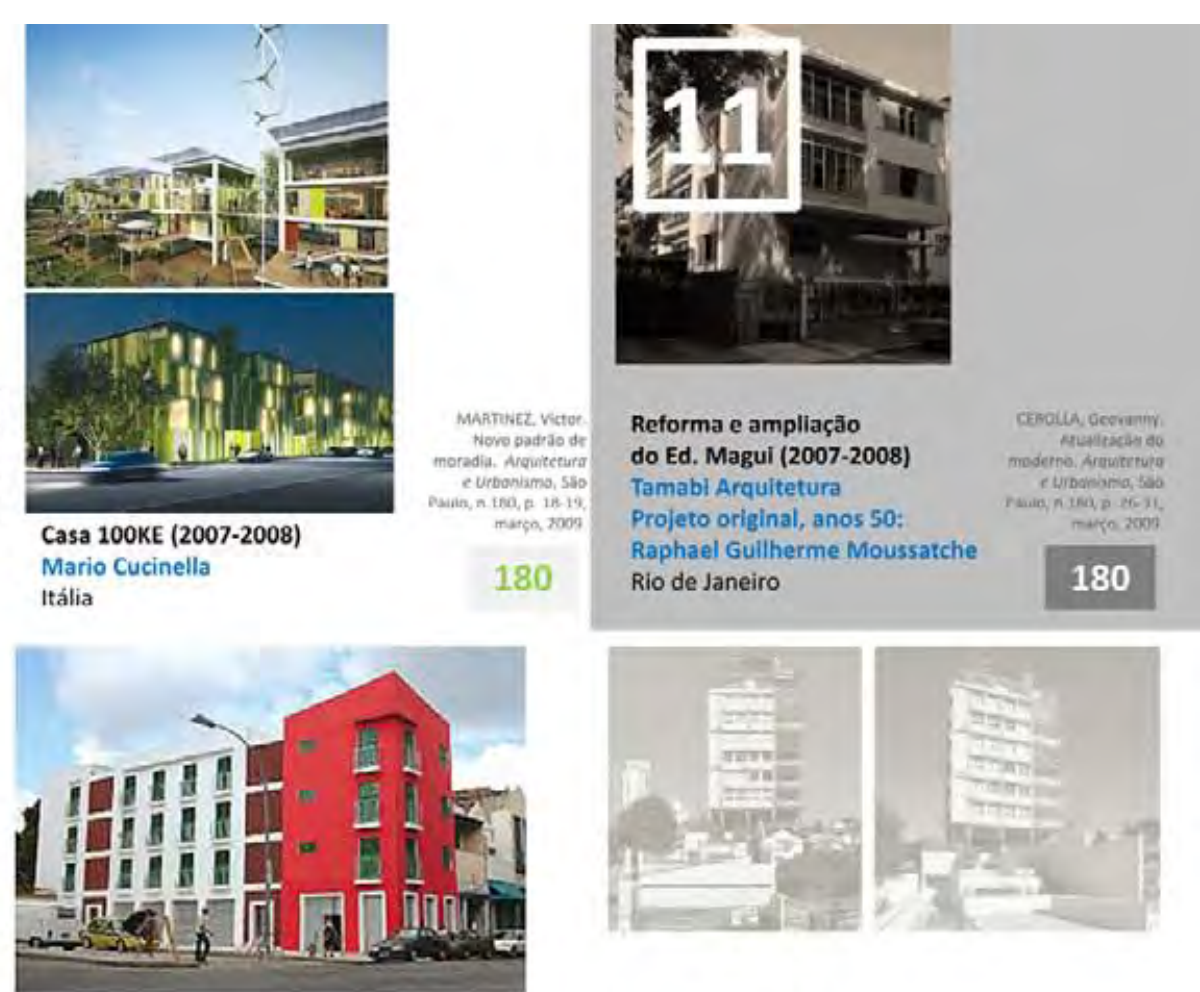

Edificio Residencial (2002)

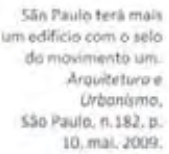

Flavio Ferreira e Pedro Rivera,

Rodrigo Azevedoe

Washington Fajardo

Rua do Santana, Centro do Rio

de Janeiro
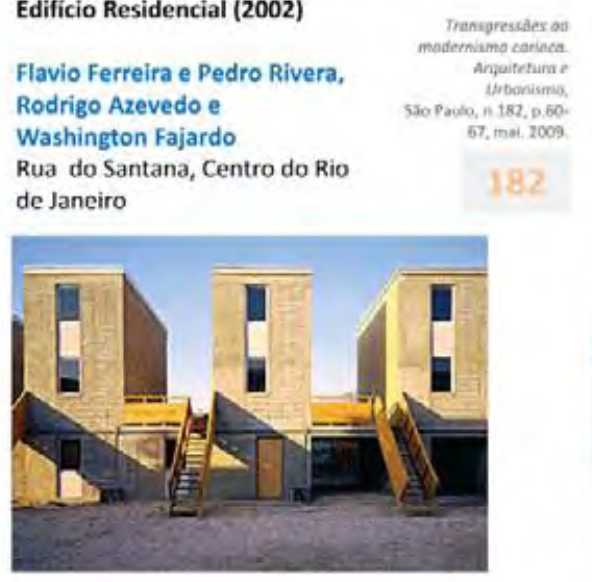

Quinta Monroy (2003-2004)

Alejandro Aravena ELEMENTAL

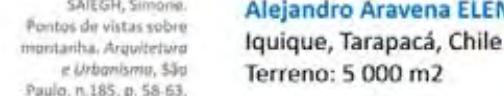

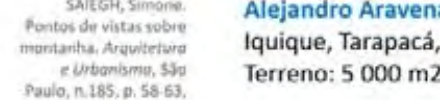

185

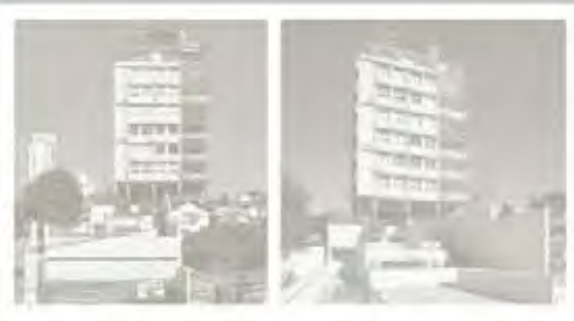

Edifício $4 \times 4(2006-2008)$

\section{Gui Mattos}

Pinheiros, São Paulo

(Rua Cristiano Viana)

terreno: $1063 \mathrm{~m} 2$

a. construida: $4010 \mathrm{m2}$

unidade: $63,50-552 \mathrm{m2}$
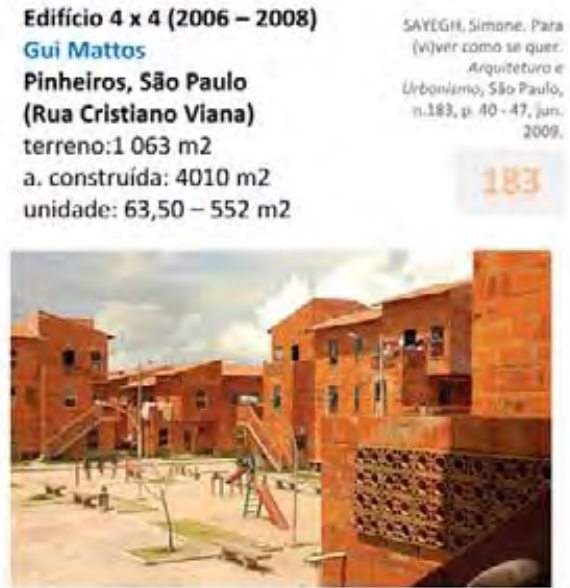

Vila da Barca (2003-2007)

Escritório carloca Cooperativa

Belém, Pará

Terreno: $14003,48 \mathrm{~m} 2$

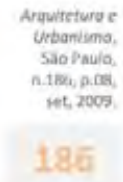




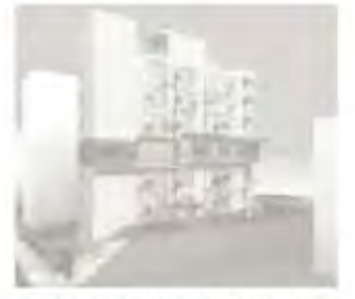

Edificio montevidéu 285 (2007-2010)

Sion, Belo Horizonte

construida: 1500

Unidade: $\sim 105 \mathrm{mz}$

7 unidades

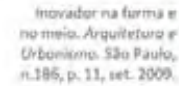

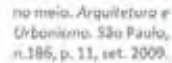

(2)

186

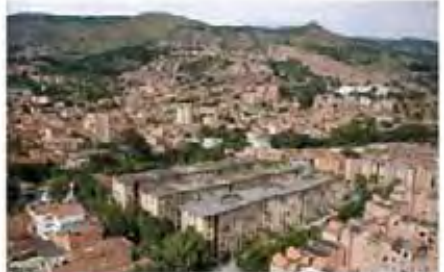

\section{La Playa Apartamentos}

(2000-2004)

Ana Elvira Vélez Villa \& Juan

Bernardo Echeverri

Medelin, Colômbia

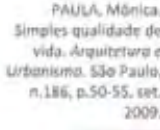

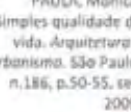

186

\section{Cohab - Unidade Pedro Facchin} (2002-2004)

Barbosa \& Corbucci

Arquitetos Associados

Ipiranga, São Paulo

Área do terreno

$320 \mathrm{~m} 2$

Área construida

$525 \mathrm{~m} 2$

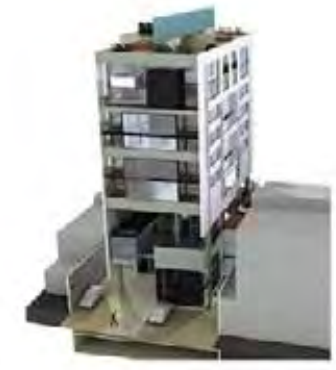

Habitação e comércio na Vila Madalena

Projeto - menção honrosa

Arquitetura SIAA

Vila Madalena, Sz̃o Paulo

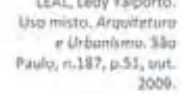

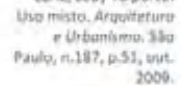

199

Reinach Mendonça

Vila Madalena, São Paulo

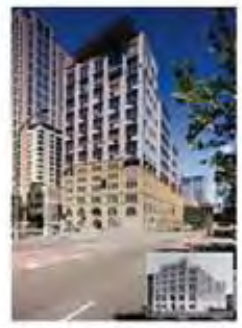

AU 2008

- Demhab Prefeitura de Porto Alegre Porto Alegre

Terreno: $19648,09 \mathrm{~m} 2$

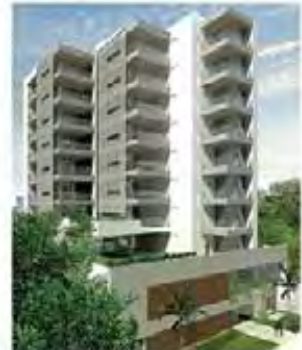

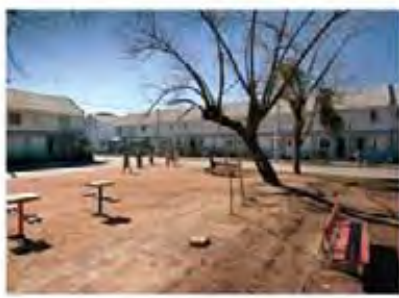

Loteamento Jardim Navegantes

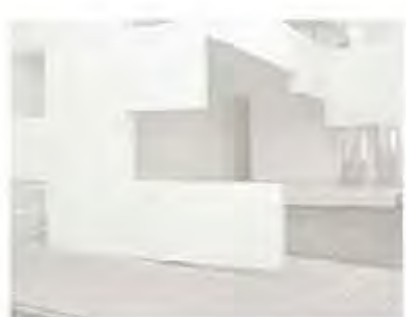

Scots Church Redevelopment (2000. 2005)

Tonkin Zulaikha Greer Architects Área construida: $18900 \mathrm{~m} 2$ Área do terreno: $1694 \mathrm{m2}$ Sydney, Austrália

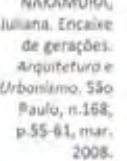

168
Edificio Altamira (1998-2001) Rafael iglesia

Rosário, Argentina

Area do terreno: $147 \mathrm{m2}$
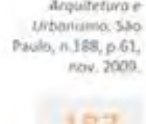

187

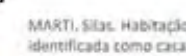

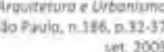

$$
186
$$

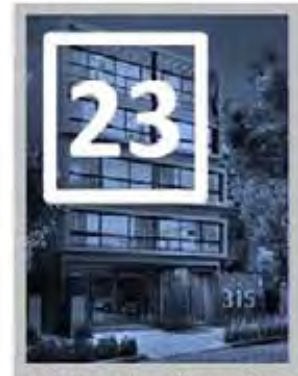

Edifício Amélia Teles 315

Márcio Carvalho e Ricardo

Ruschel

Porto Alegre

... pequeno porte com arquitetura

contemporênes autoral
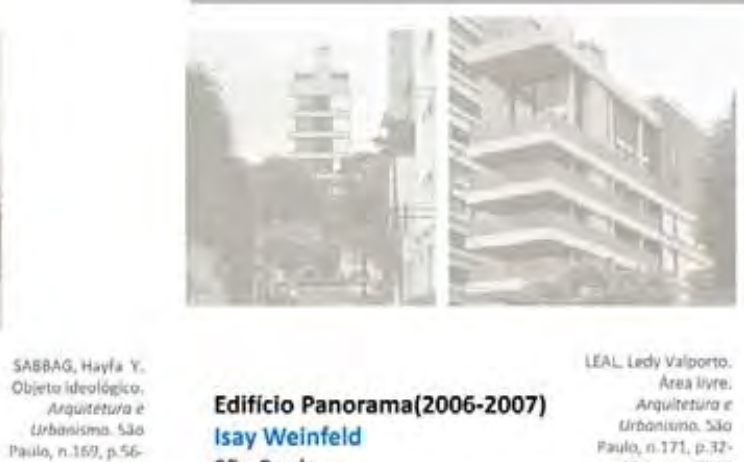

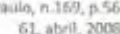

Isay Weinfeld

Área do terreno: $1186,27 \mathrm{~m} 2$

Área construida: $4956,26 \mathrm{m2}$

LaL Ledy valoonto.

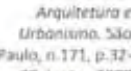

171 


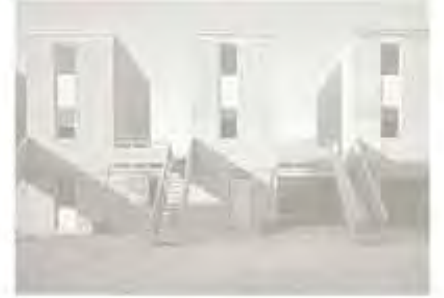

Quinta Monroy (2003-2004)

ELEMENTAL - Alejandro Aravena FEAsindoEs, Anderen:

Iquique, Chile

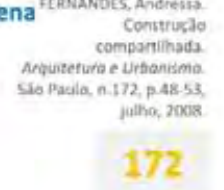

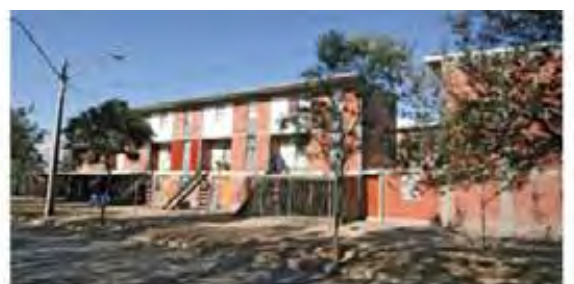

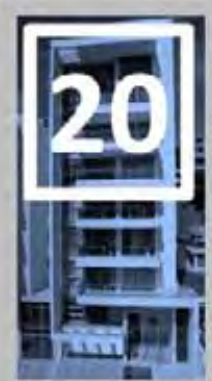

Edificio Maiorda (2005-2007)

Lourenço Sarmento

Arquitetos

Juiz de Fora, Minas Gerais

Área do terreno: $600 \mathrm{m2}$

Área construida: $3300 \mathrm{~m} 2$

174

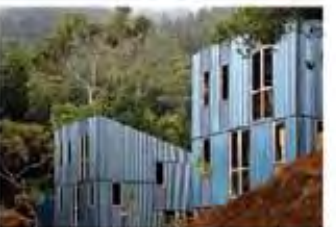

Conjunto de habitaçăo social

Escritório Owar

Arquipélago Juan Fernánde

(a $600 \mathrm{~km}$ da costa chilena)

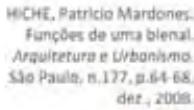

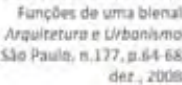

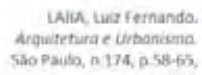

\section{AU 2007}

Lo Espejo (2003-2007)

ELEMENTAL - Alejandro Araven

Lo Espejo, Chile

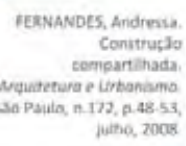

172

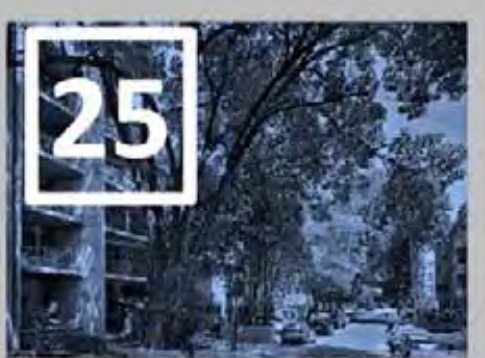

Temístocles 12 (2006)

JSA Arquitetos

Cidade do México, México

Terreno: $150 \mathrm{~m} 2$

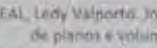

172

172

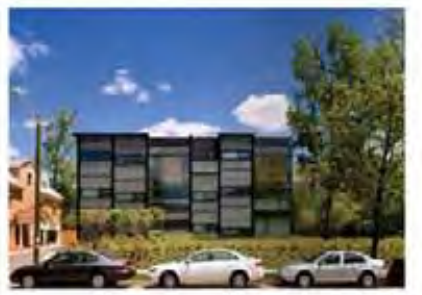

1315 Hill St. Apartments (2005-

2007)

Kieran \& Timberiake and associates

Ann Harbor, EUA

Volume máximo:

$8 \mathrm{~m} \times 18 \mathrm{~m} \times 18 \mathrm{~m}$

uublico-alvo: estudantes

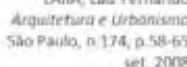

174

\section{Gar}

Residencial Accordia

Feilden Clegg Bradley Studlos,

Alison Brooks Architects

Maccreanor Lavington

Architects.

Vencedor do Riba National

rde Riba European Award

Cambridge, Inglaterra

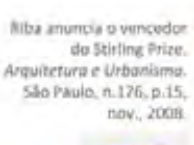

Residencial Cald

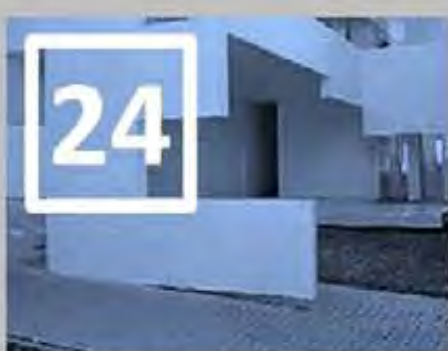

Edificio Altamira (1998-2001)

Rafael iglesia

Rosário, Argentina

Area do terreno: $147 \mathrm{~m} 2$

Área construida: $1180 \mathrm{~m} 2$

172
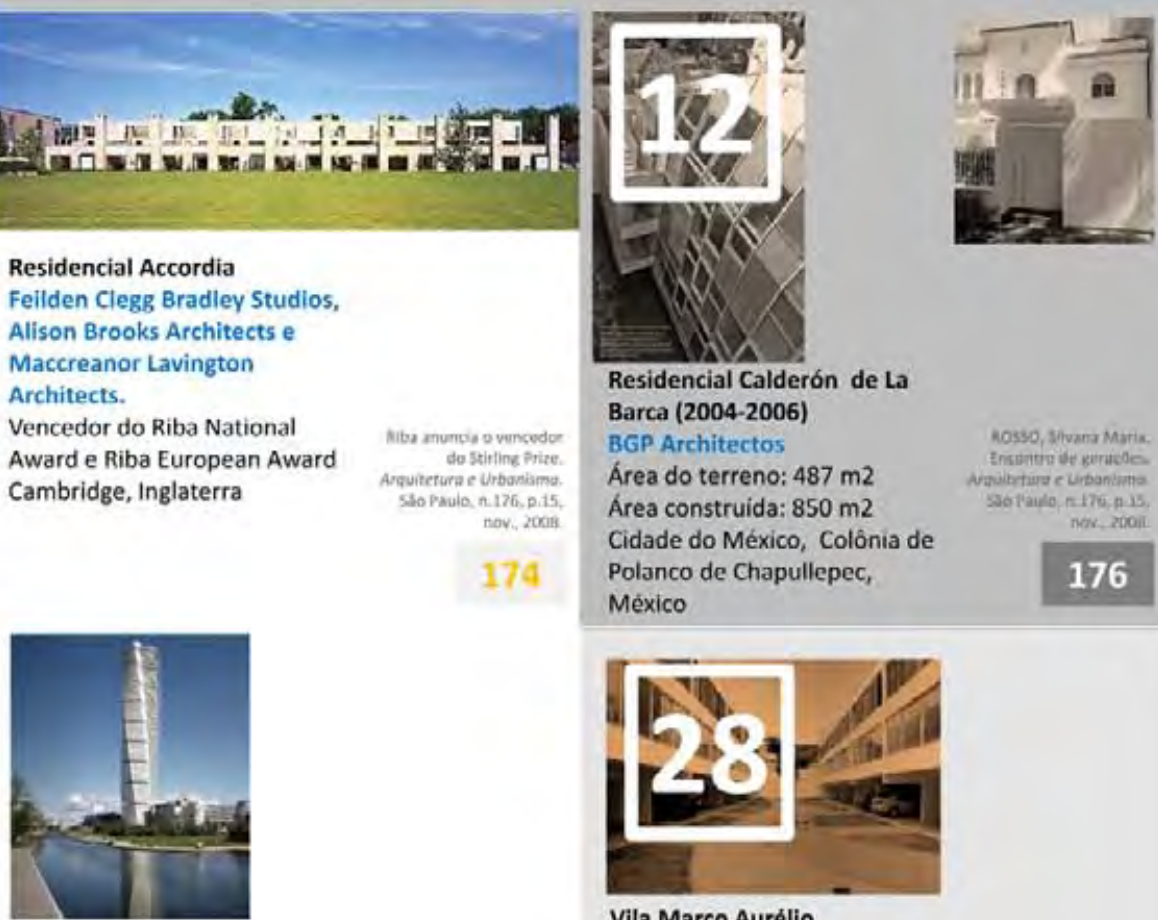

174

Área do terreno: $487 \mathrm{m2}$

Área construida: $850 \mathrm{m2}$

Cidade do México, Colônia de

Polanco de Chapullepec,

México

Turning Torso, torre uso misto (1999-2005)

Santiago Calatrava

Malmo, Suécia

Área construída: $18 \mathrm{mil} \mathrm{m2}$

Area residencial: $13,5 \mathrm{mil} \mathrm{m2}$

Altura: $190 \mathrm{~m}$

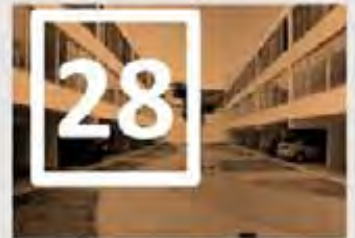

Vila Marco Aurélio

\section{(2004-2005)}

Piratininga Arquitetos Associados

Vila Romana, Lapa, São Paulo

Terreno: $1440,00 \mathrm{M} 2$

Área construída: $2044,11 \mathrm{m2}$. 20550. sivana Marla Tamanho das unidades: $185,82 \mathrm{~m} 2$ intonoma slo pasio. (área privativa coberta)

Área privativa descoberta: 71,80 $\mathrm{m} 2$ por unidad 


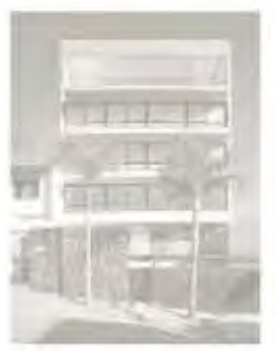

Ed. Santa Adeliade (Fiori di Maggio/

(2004-2005)

Arquitetos: Apoena Amaral,

Carlos Ferrata,

Eduardo Ferroni, Kátia Melani,

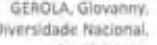

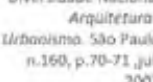

160

Moracy Amaral e Pablo Hereñ.

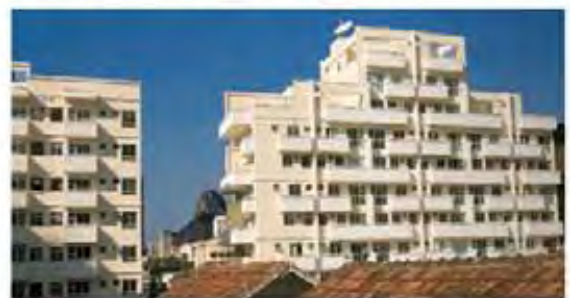

Residencial Duo Prime (2003-2006) SMLEH Simone. Ment

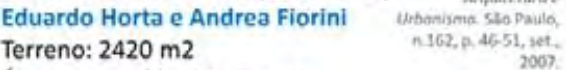

Area Construida: $11800 \mathrm{mz}$

n. unidades: 80 (duplex, triplex e lineares)

Area das unidades: $65-130 \mathrm{mz}$

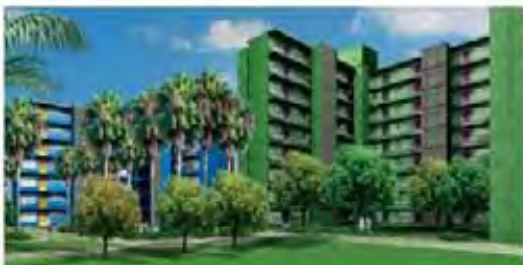

Conjunto habitacional Ser apto

Beto Faria, Edson Tani,

Isabel Cabral, Juģara

Märcia Mikai, Rafael

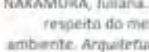

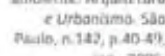

Lazzarini e Ricardo

Gaboni.

142

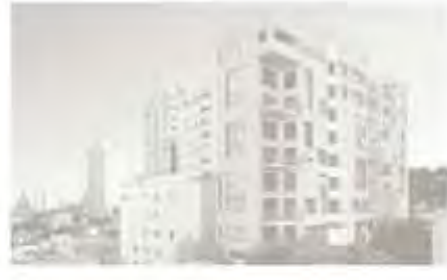

Edifício Aimberê (2005 - 2008)

Andrade Morettin Arquitetos

Santo André, Săo Paulo

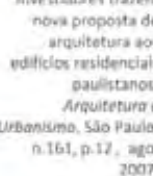

161

\section{AU 2006}

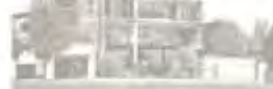

Edificio Simpatia 236 Álvaro Puntonl

61

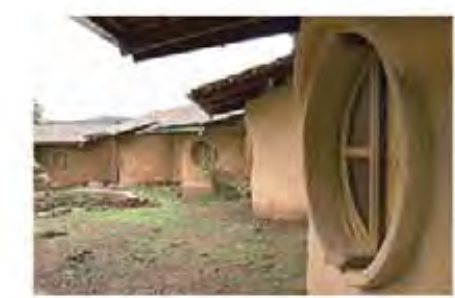

Vila dos Estudantes (2005) PEC - Instituto de Permacultur Ecovilas do Cerrado Pirenópolis, Goiás Conjunto de 5 casas

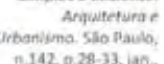

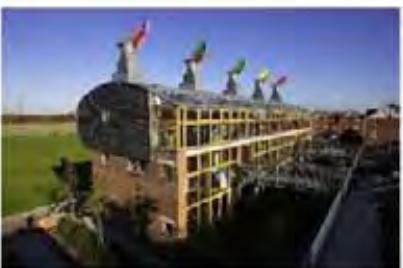

Bedzed

Bill Dunster

Sul de Londres, Inglaterr

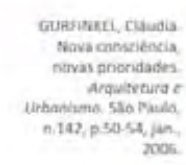

142

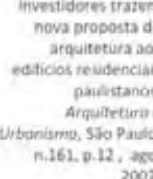

161

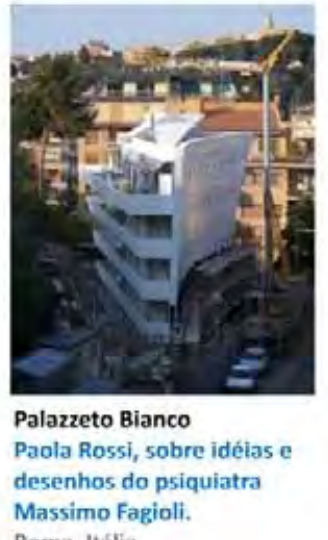

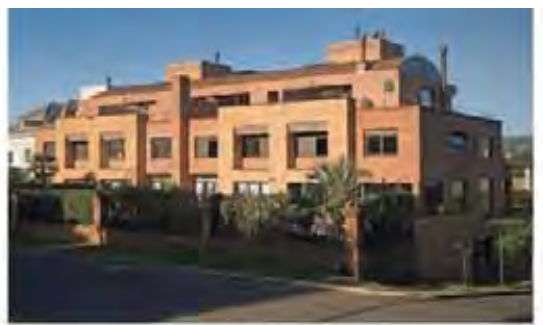

Vila Iracema (1999-2004)

. Trajano Silva: Prja siva.

Grande do Sul 4 unidades residenciais geminadas $n .161 .0 .50 .57 .250$. com 5 pavimentos cada

Area terreno: $1452 \mathrm{~m} 2$

Area construida: $3250 \mathrm{mz}$

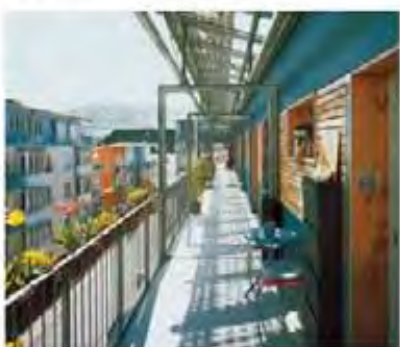

Conjunto de 16 residências e 4

\section{escritórios}

Escritório Common \& Gies

Friburgo, Alemanha

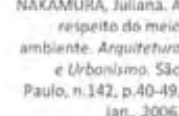

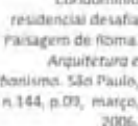

Parque vilis

(1999-2004)

Donini Arquitetura

associados

Sảo Paulo, SP

144

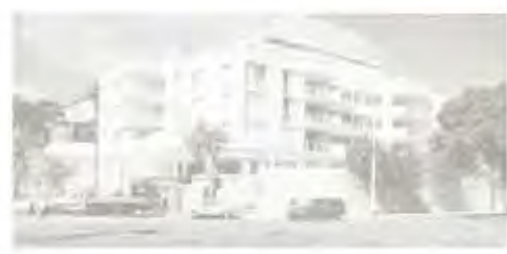

Roma, Itália

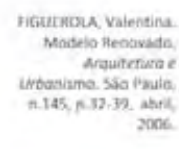

145 


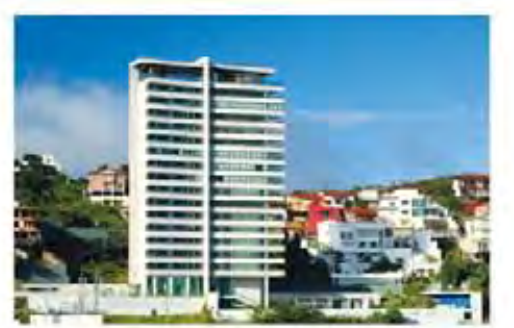

Residencial PARC Nimbus (1999-2003) Gustavo Penna

Belo Horizonte, Minas Gerais Area do terreno: $5636,00 \mathrm{~m} 2$ Area construida: 7 993,25 m2 17 andares

Apto de $353 \mathrm{~m} 2$ por andar

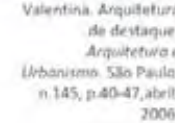

145

\section{AU 2005}

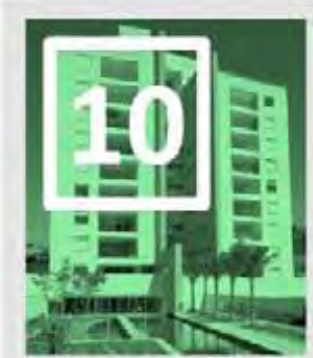

Roof Madalena (2003-2005) Rocco Associados Saro Paulo, Sdo Paulo Area do terreno:

8 andares, 34505. Apto 120 aptos.

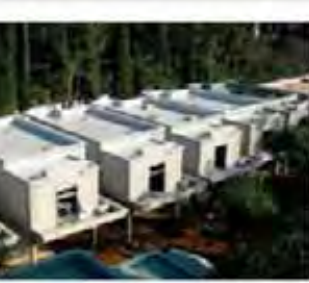

Condomínio Palm Hill (um dos três vencedores do

concurso Melhor prática em

construção sustentável)

Gabriel Kalili e Freitas

Alto da Boa Vista, São Paulo

34 casas, de 220 a $248 \mathrm{mz}$

Área total construida: $7500 \mathrm{~m} 2$
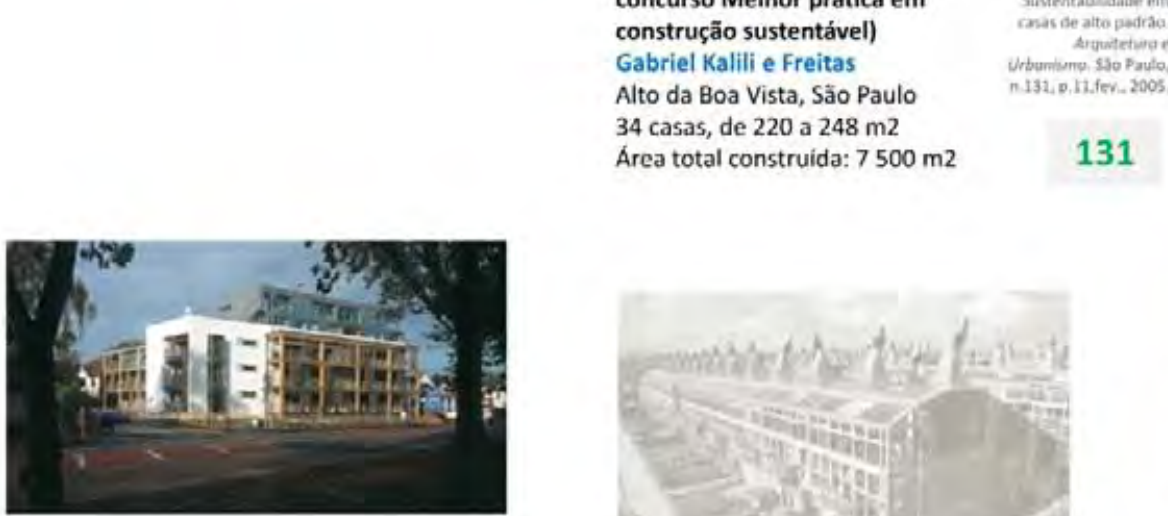

Choriton Park (1999-2002) Stephenson Bell Architects Manchester, UK

3 pavimentos residenciais. Area da unidade de $45 \mathrm{~m} 2,67$ $\mathrm{m} 2$ e $78 \mathrm{~m} 2$.

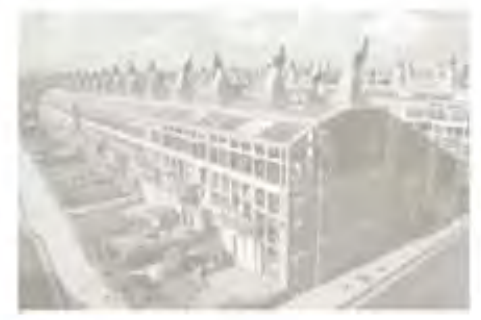

\section{Bedzed (2002)}

Bill Dunster Architects Hackbridge, Londres

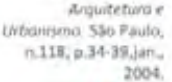

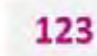

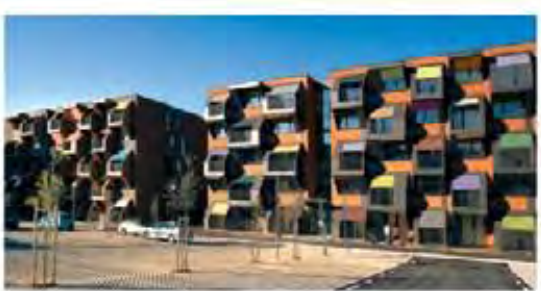

\section{APARTMENT BLOCKS ON THE COAST}

(2003-2005)

Ofis Arhitkti

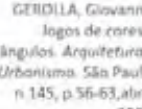

145

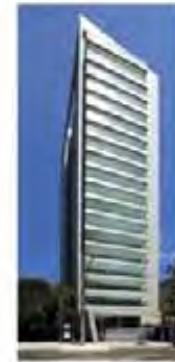

(1992-2002)

Gustavo Penna

Belo Horizonte, Minas Gerais

Area terreno: $1764 \mathrm{mz}$

Área total construida: $5292 \mathrm{mz}$

21 pavimentos

16 pavimentos-tipo de $363,81 \mathrm{m2}$

um apto por andar.

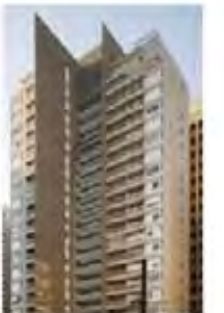

\section{Arte Arquitetura}

Rocco Associados

São Paulo

26 andares, 22 com

apartamentos-tipo, très

cobertura duplex e térreo com

pé-direito duplo.

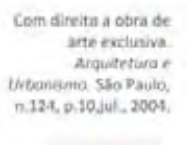

124

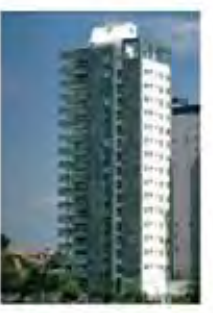

Edificio Piazza Diamante, (2004-2005)

Humberto Hermeto Arquitetura

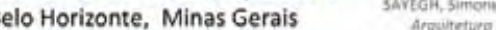

Área do terreno: $2770 \mathrm{m2}$ unbanom.

Área do apto:: $243 \mathrm{mz}$

15 aptos, um por andar

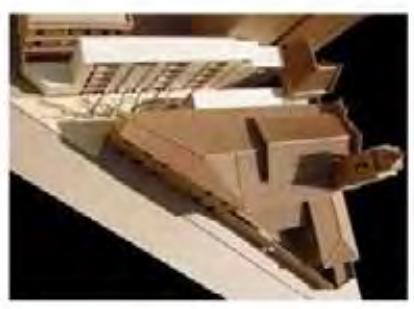

Casarão do Carmo

Vigliecca Associados

Centro, São Paulo

AU 2004

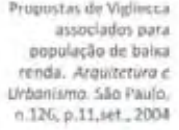




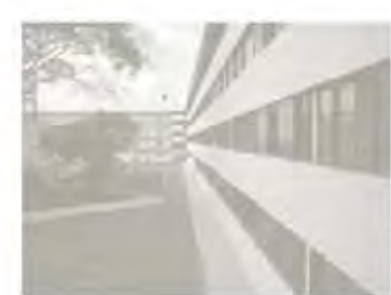

Vila dos Idosos

Vigllecca Associados

Pari, São Paulo

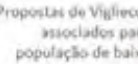

poputackbo de bo

AU 2003

AU 2002

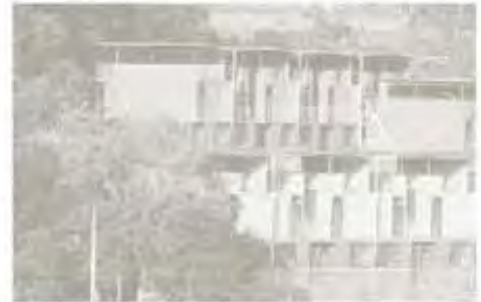

\section{Conjunto Residencial em Cotia}

\section{1-2002)}

Villà e Silvia Chile

Cotia, São Paulo.

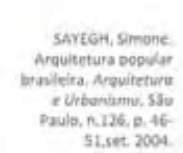

126

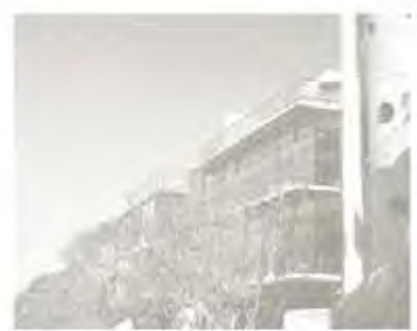

Edificio Olapoque

II Prêmio Cauê de Arquitetura

Categoria obras realizadas

Arquitetos: Ararê Sennes,

Bacci Marin e Guilherme

Săo Paulo, SP

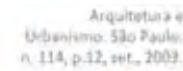

114
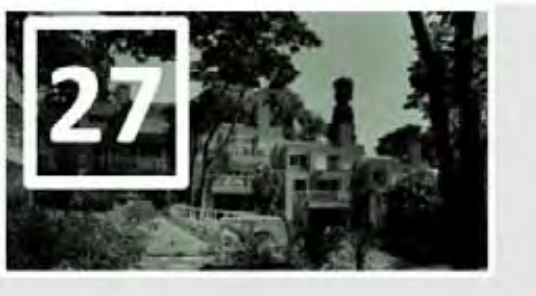

Chácara Sant'Anna (1996-2001)

Aflalo \& Gasperini Arquitetos

Alto da Boa Vista,

Zona sul de Săo Paulo.

Terreno: $6245 \mathrm{~m}^{2}$

Área construida: $6429 \mathrm{~m}^{2}$

Número de unidades: 13

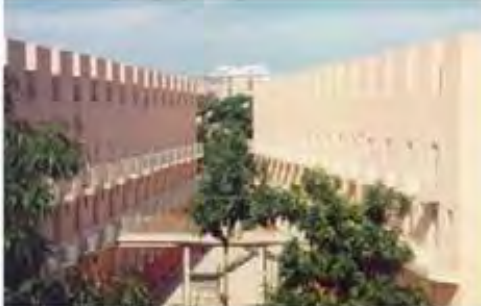

Conjunto Favela dos Macacos Jorge Mario Jáuregui Rio de Janeiro, RJ

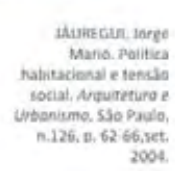

126

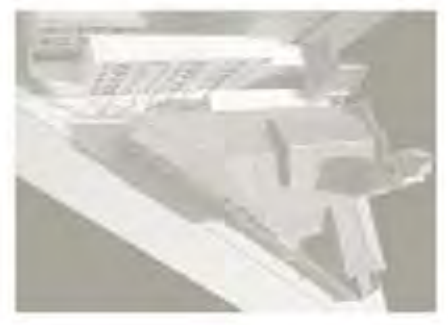

Revitalização do Casarão do

\section{Carmo}

Hector Vigliecca

25 unidades

Centro, Sa̋o Paulo, SP

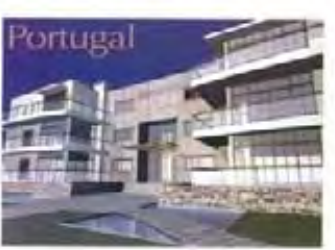

117

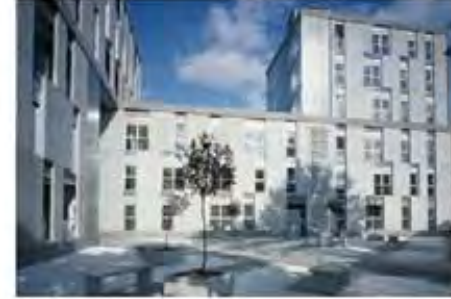

Viviendas de protección oficial para la

EMVS en Atocha

Maria Jose Pizarro, Oscar Rueda

Madri, Espanha

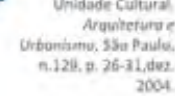

129

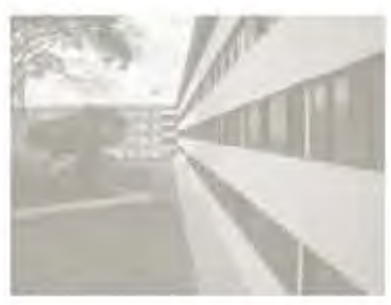

Vila do Idosos

Hector Vigliecca

145 unidades

Pari, Centro, Săo Paulo, SP

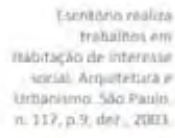

117

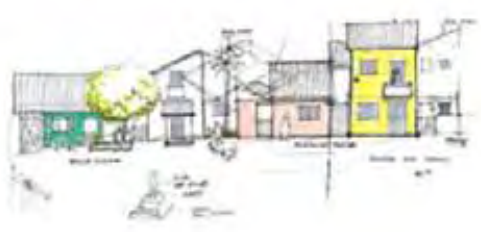

Edificio de apartamentos em

Carregal do Sal

Escritório Wey D'Horta

Carregal do Sal, Portugal

(próximo a Coimbra)

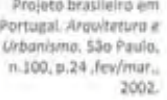

Projeto Habitacional

Morro Santa Maria

Carlos Eduardo Gomes Carneiro

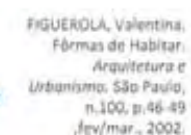

99 


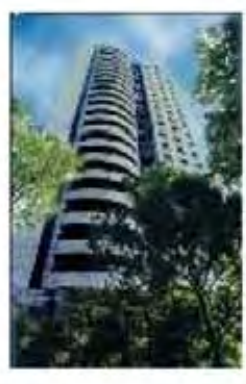

Edificio Residencial Menotti Priori

Alexandre Costa e Silva

Jaqueira, Recife

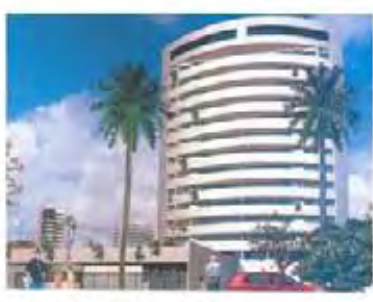

Mansảo Carlos Chagas

Eduardo Carlomagno

Praia Atalaia, Aracaju, Sergipe

2 Aptos de $170 \mathrm{~m} 2$ por andar

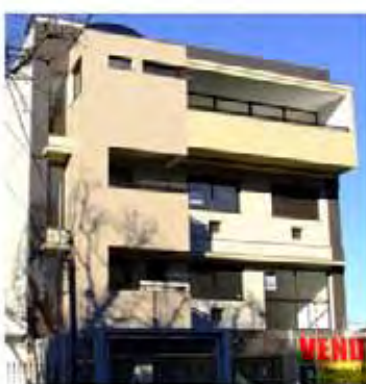

Edificio Luzitana

Gustavo Masotti-Studio 1

Arquitetura e Design

Porto Alegre, RGS

Area construida: $1.076,00 \mathrm{~m}^{2}$

5 unidades

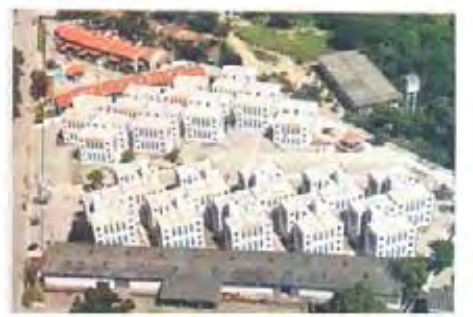

Residencial Itha Vitória

Ruben Wanderley, Luiz Fernando

Carneiro e Mauricio Espinos

Maceió, Alagoas

Complexo de 10 prédios

Programa PAR

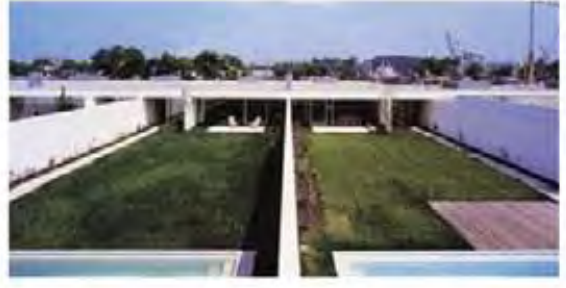

AU 2001
Casas-Pátio (1993-1999)

Eduardo Souto de Moura

Matosinhos, Portugal

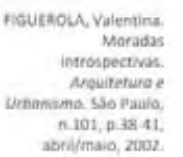

101 


\section{APÊNDICE 2}

Da primeira seleção de projetos de habitação coletiva (APÊNDICE I) foram mantidas obras construídas, localizadas na América Latina, e mais relacionadas ao lote ou quadra urbana onde estão inseridas, dentro de uma hipótese inicial de que muitos projetos na cidade, considerados sem qualidade arquitetônica, eram projetos muito similares ou representavam meras replicações de padrões ditados pelo mercado imobiliário. Deste modo, foi levantada a suposição de que lotes urbanos pequenos, irregulares, com topografia acidentada entre outros condicionantes relevantes do lote, seriam aqueles com maiores restrições para implantação de tipologias “carimbos".

Também foram eliminados projetos que, num primeiro olhar, pareciam ter o partido do empreendimento definido e/ou conduzido pelo agente imobiliário. Buscou-se neste trabalho de seleção arquiteturas com ideias diferenciadas das propostas correntes ditas comerciais, que predominam nas grandes cidades, inclusive São Paulo. Neste caminho, foram selecionados 34 projetos, apresentados na banca de qualificação que ocorreu em fevereiro de 2012. Foi realizada uma ficha gráfica de cada projeto com dados básicos, obtidos, principalmente, nas próprias publicações. Estas fichas foram bases gráficas importantes para condução do trabalho. 


\section{Lotecom: \\ ALTA DECLIVIDADE \\ Densidade: \\ $230 \% / \mathrm{HA}$}

VILA FIDALGA Cristina Xavier

Número de habitantes: 30 Área do lote: $1300 \mathrm{~m}^{2}$ Dimensōes do lot: Número de pavimentos: 3 Número de unidades: 6 150 a $220 \mathrm{~m} 2$

Nümerode tipologias: 6 Estacionamento: sim

Localizaçăo:

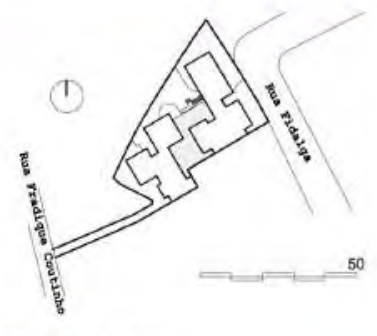

Rua Fidalga 1055, Vila Madalena, São Paulo, Brasil
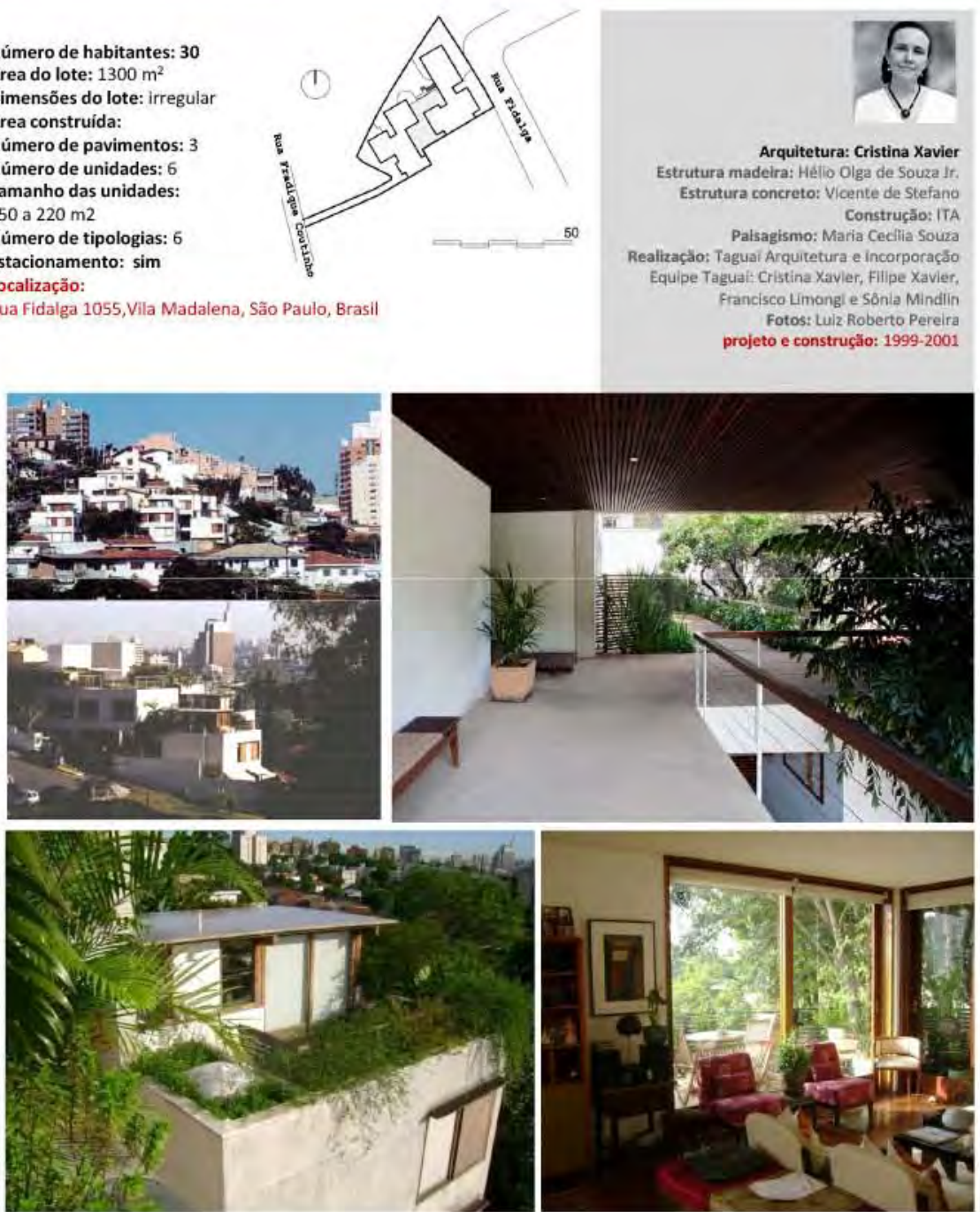

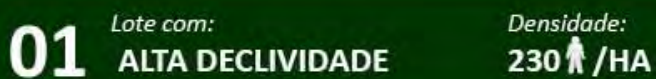

VILA FIDALGA Cristina Xavier

\section{Fontes:}

Uma vila desafia o mercado imobiliário. Projeto Design, São Paulo, n.263, jan. 2002.

Da Filosofia a arquitetura. Projeto Design, São Paulo, n.263, jan. 2002 .

Por fora parece uma casa, por dentro são seis. Revista Arquitetura e Construção, São Paulo, abril 2003.

WISNIK, Guilherme. O espaço coletivo como baliza. revista Novos Estudos - CEBRAP, São Paulo, n. 64, nov. 2002.

SERAPIÃo, Fernando. Quatro pecados louváveis. São Paulo, n. 313, p. 88, mar. 2006.

Fotos

Acervo arquiteta Cristina Xavier e Fabricia Zulin

Desenhos:

Acervo arquiteta Cristina Xavier 


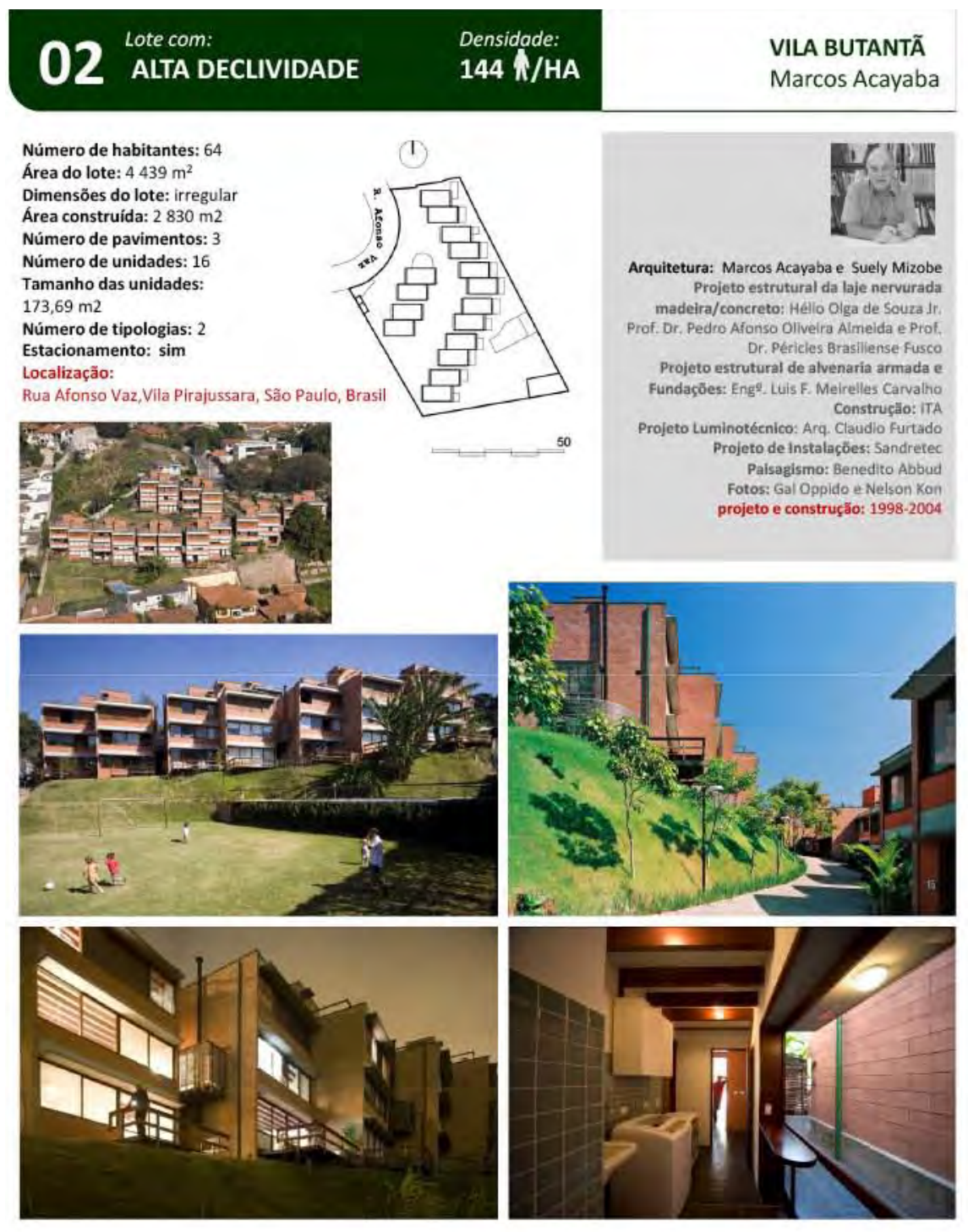

$\begin{array}{lll}02 \text { Lote com: } & \text { Densidade: } & \text { VILA BUTANTÃ } \\ \text { Marcos Acayaba }\end{array}$

Fontes:

SERAPIÃo, Fernando. Partido Arquitetônico encontra

definição entre o módulo e a topografia. Projeto Design, São Paulo, n.313, p. 38-45, mar.2006.

SERAPIÃo, Fernando. Quatro pecados louváveis. São Paulo, n. 313, p. 88, mar. 2006 .

FUNDAÇ̃̃o Bienal de São Paulo. VILA BUTANTÃ - Marcos Acayaba. In: 6a Bienal Internacional de Arquitetura de São Paulo. São Paulo: Instituto de Arquitetos do Brasil, 2005 .

ACAYABA, Marcos. Marcos Acayaba. São Paulo: COSAC NAIFY, 2007, p. 232-241.

Fotos:

www. marcosacayaba.arq.br 


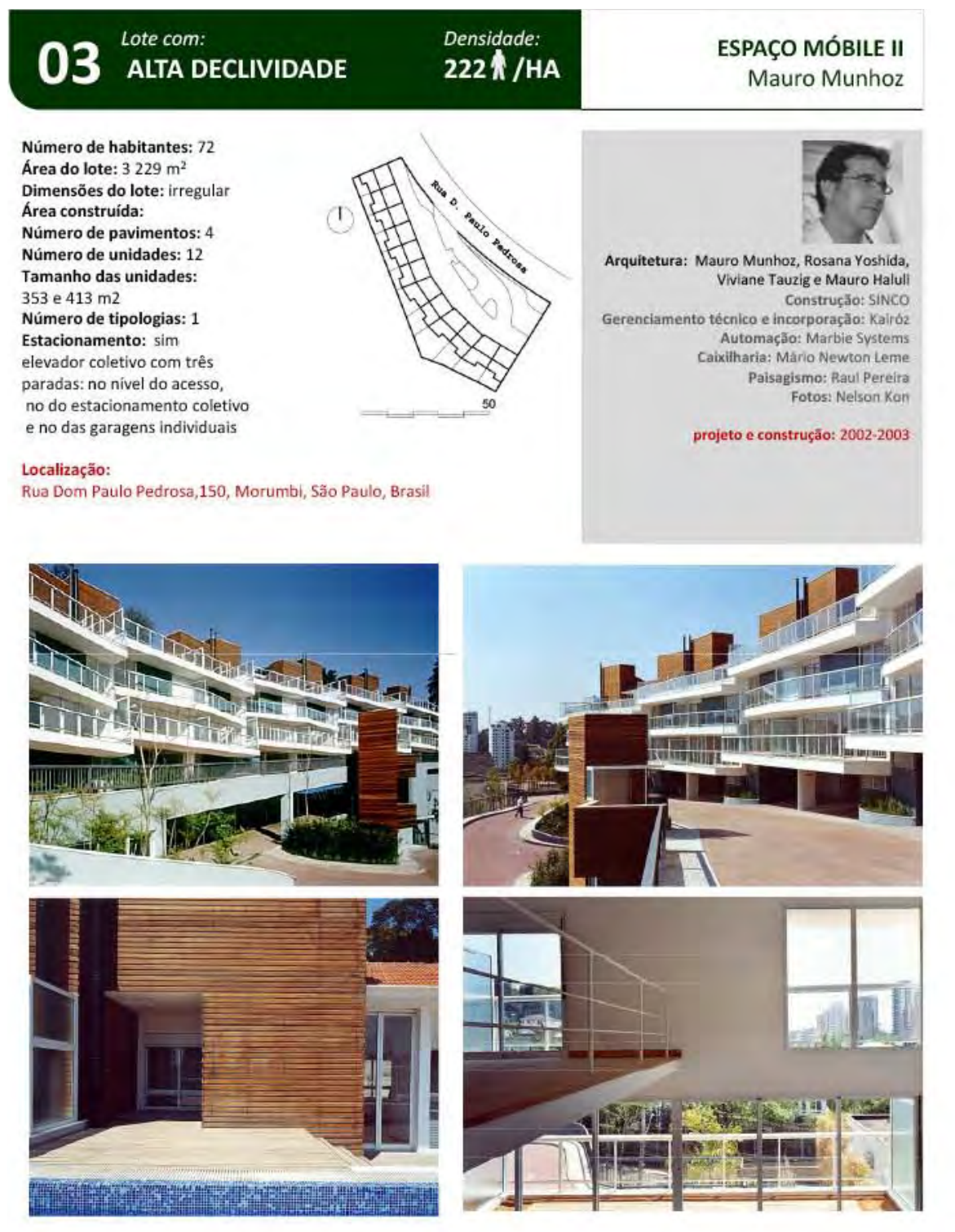

\begin{tabular}{|c|c|c|}
\hline 03 Lote com: & $\begin{array}{l}\text { Densidade: } \\
222 / / \mathrm{HA}\end{array}$ & $\begin{array}{l}\text { ESPAÇO MÓBILE II } \\
\text { Mauro Munhoz }\end{array}$ \\
\hline
\end{tabular}
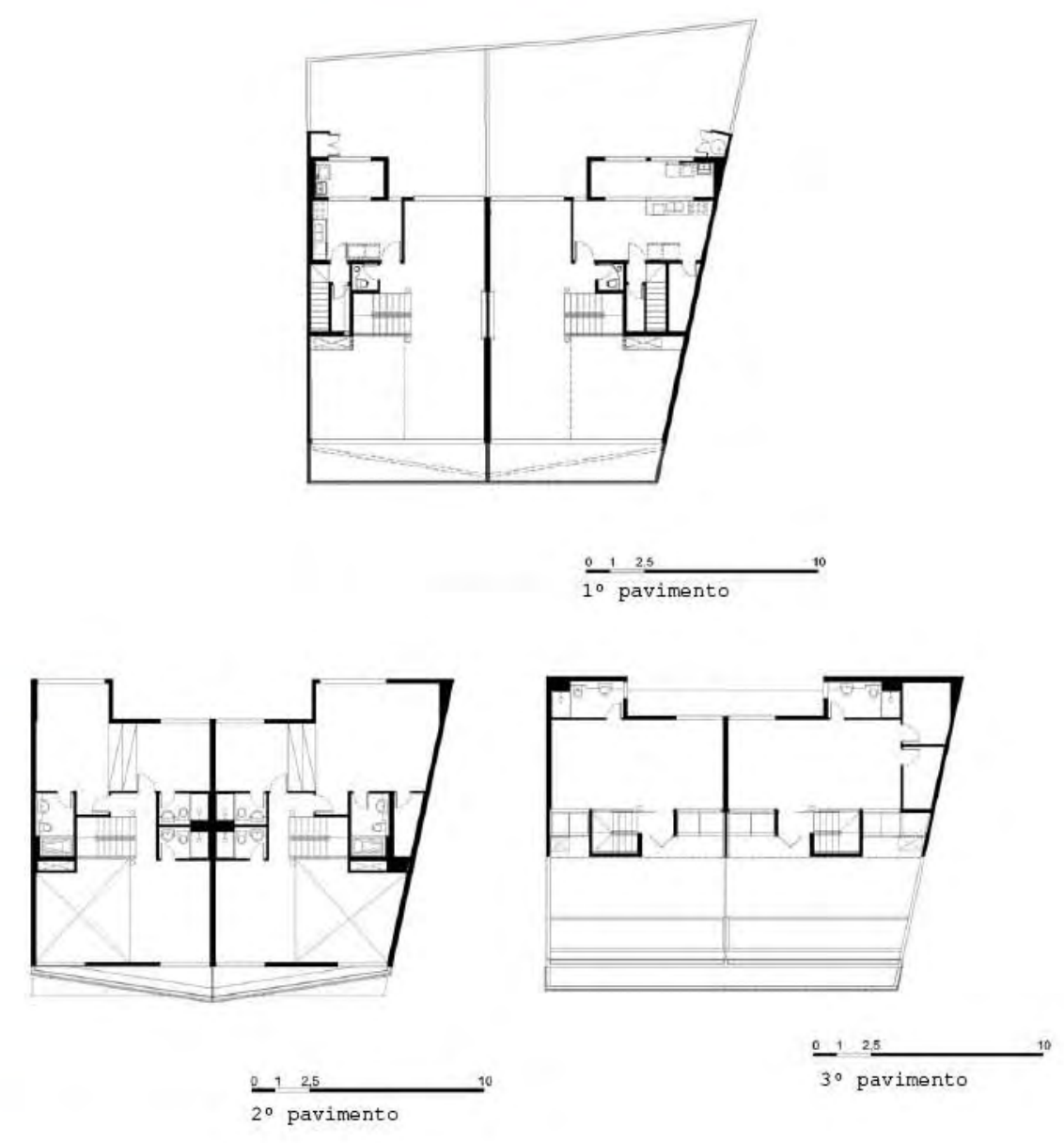


\section{Lotecom:

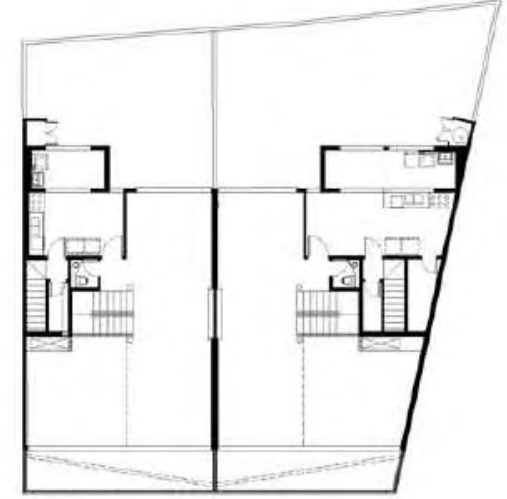

$\frac{0}{10} 25$

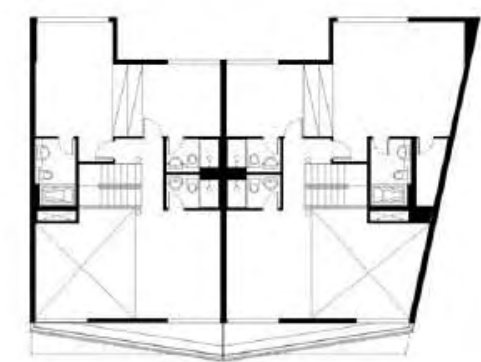

$0-1 \quad 25$

$2^{\circ}$ pavimento

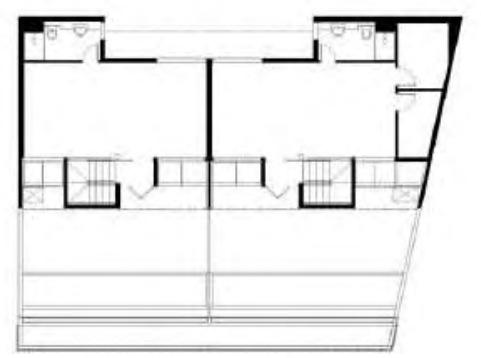

$0-12$

3o pavimento

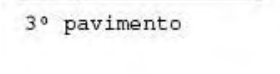

\section{Fontes:}

A reação ao neoclássico e a promessa para o futuro.

Projeto Design, São Paulo, n.371, p. 88, jan. 2011.

CORBIOLI, Nanci. Entre o público e o privado. Projeto Design, São Paulo, n.287, p., jan.2004.

Fotos:

http://www.mauromunhoz.arq.br/ 


\section{Lote com: \\ Densidade:
$400 \mathrm{~W} / \mathrm{HA}$ \\ Número de habitantes: 40 Area do lote: $1000 \mathrm{~m}^{2}$
Dimensōes do lote: $20 \times 50 \mathrm{~m}$ \\ Área construída: \\ Número de pavimentos: 6 \\ Número de unidades: 10 \\ Tamanho das unidades: \\ Número de tipologias: 10 \\ Estacionamento: sim \\ Localizaçăo: \\ Rua Fidalga 897, Vila Madalena, São Paulo, Brasil

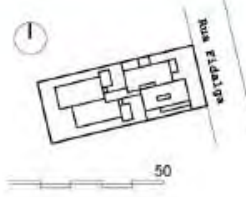

FIDALGA Cristina Xavier
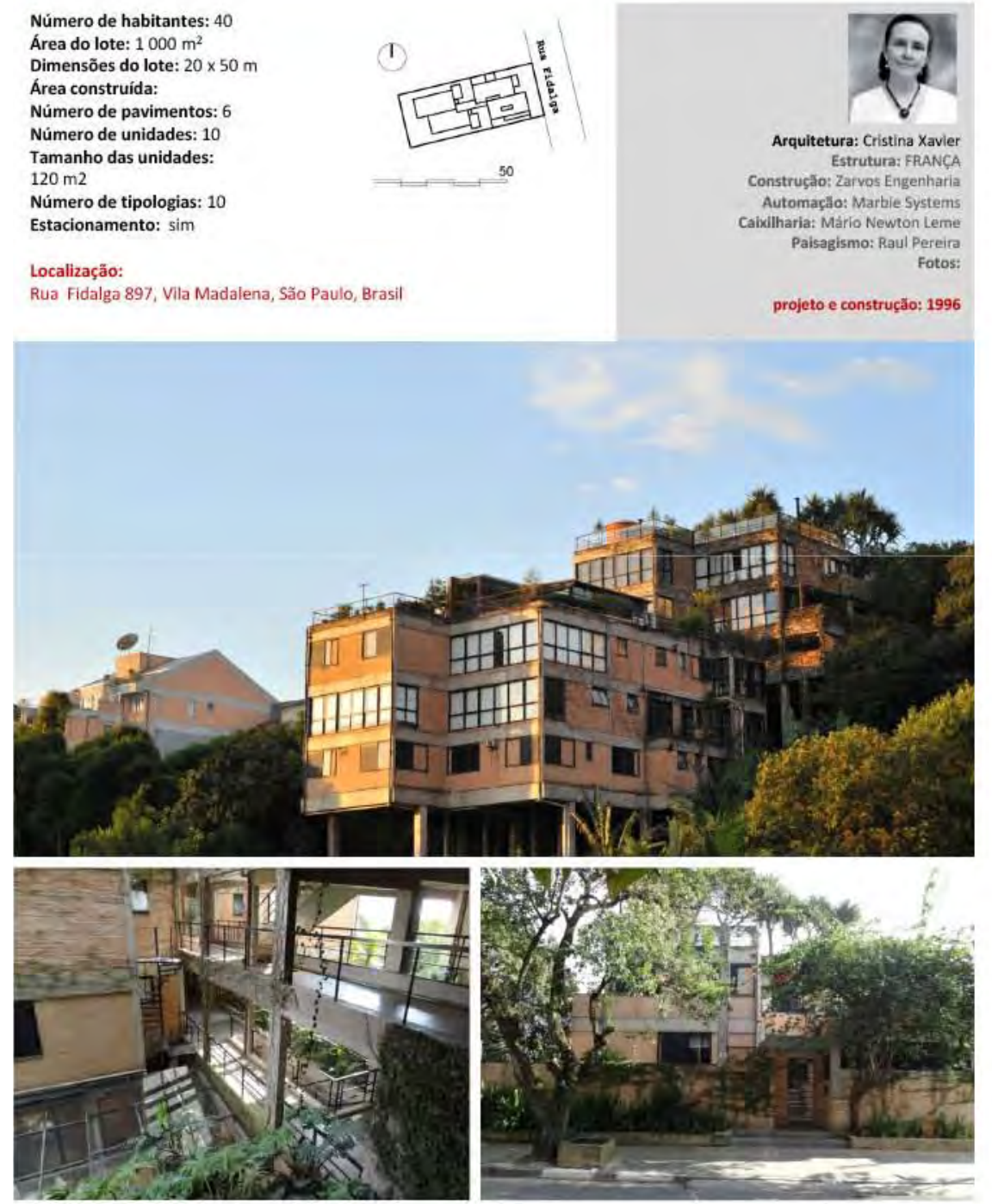

\section{$\begin{array}{ll}04 \text { Lote com: } & \text { Densidade: } \\ \text { ALTA DECLIVIDADE } & 400 \mathrm{H} / \mathrm{HA}\end{array}$}

FIDALGA Cristina Xavier
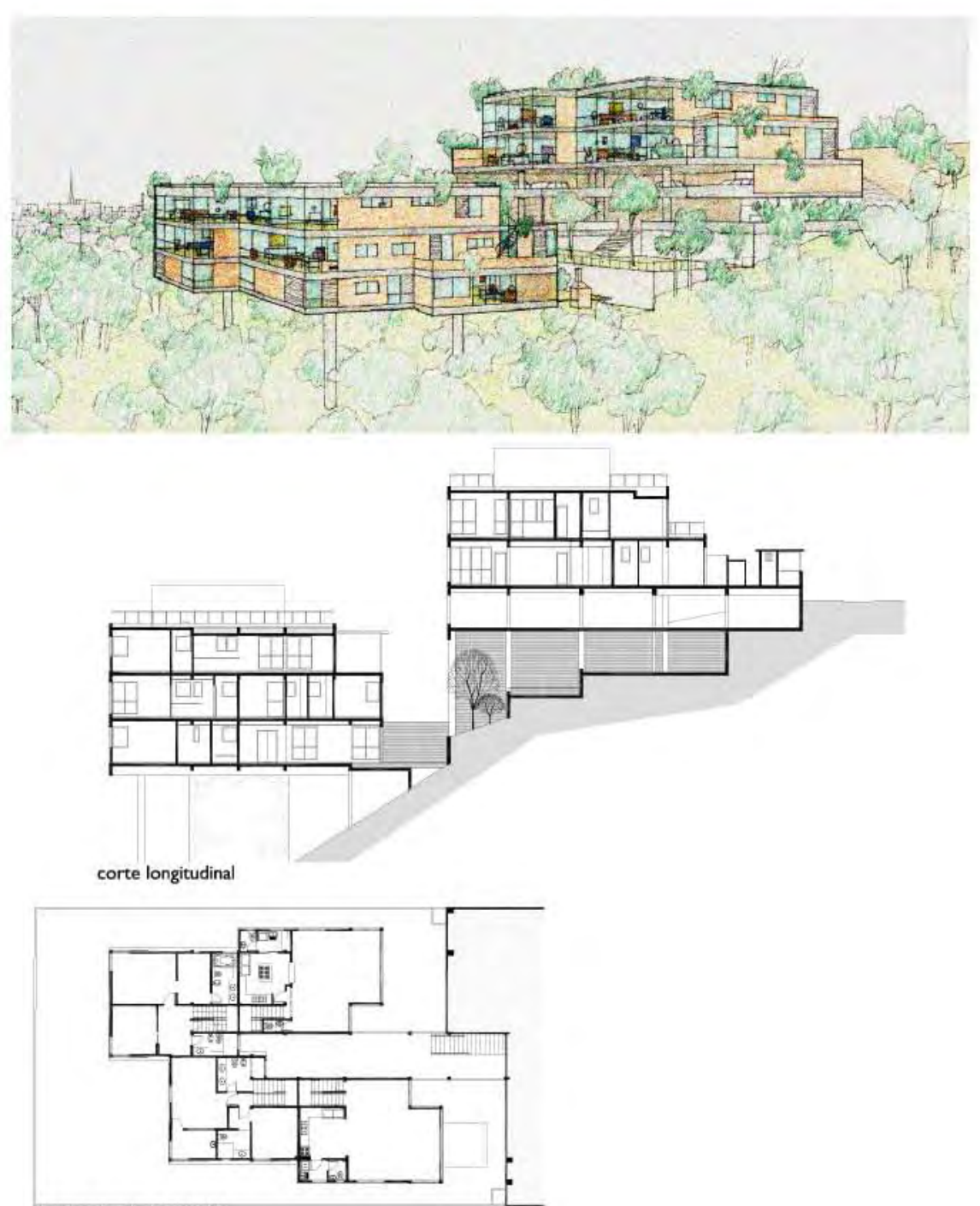

pavimento nivel $+62,04$ 


\section{Lote com:

\section{$\begin{array}{ll}04 & \text { Lote com: } \\ \text { ALTA DECLIVIDADE } & 400 \% / H A\end{array}$}

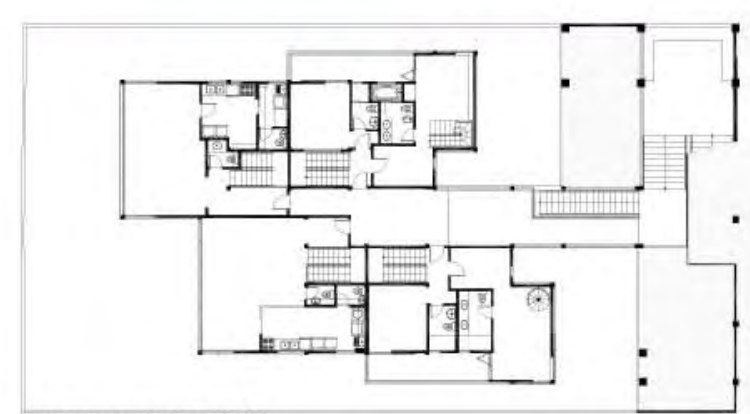

pavimento nivel $+65,09$

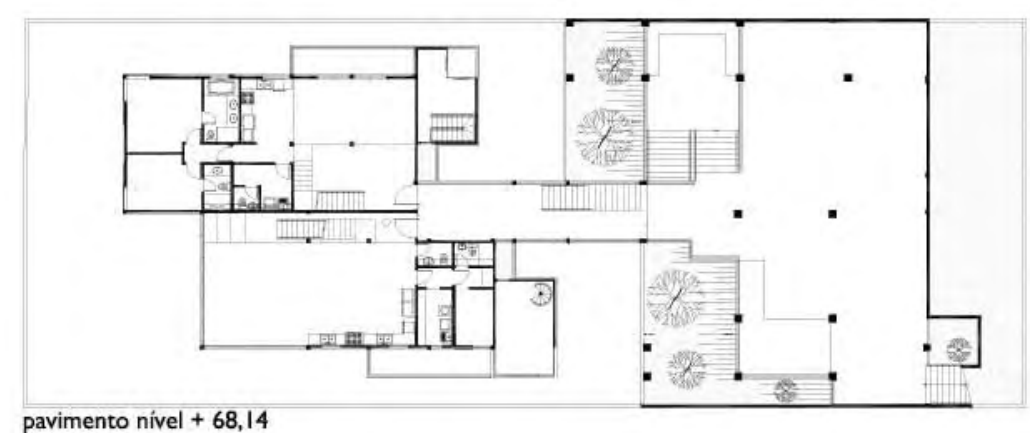

nivel $+68,14$

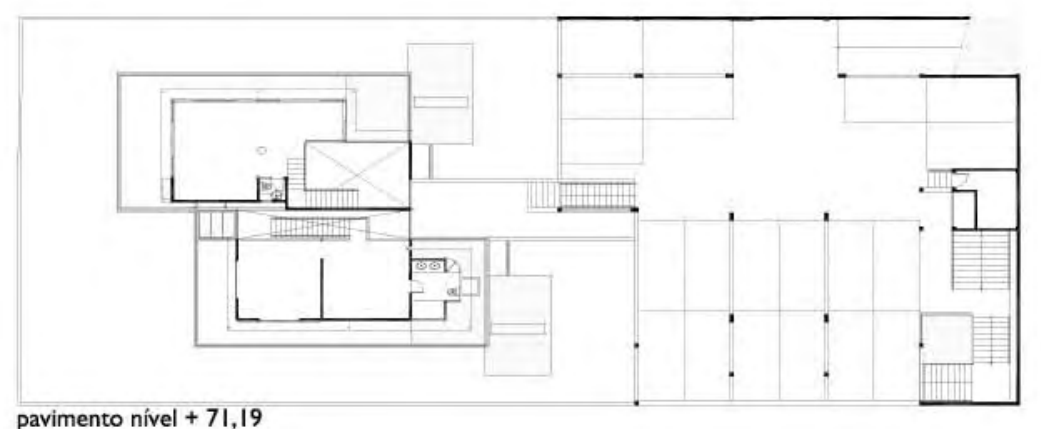

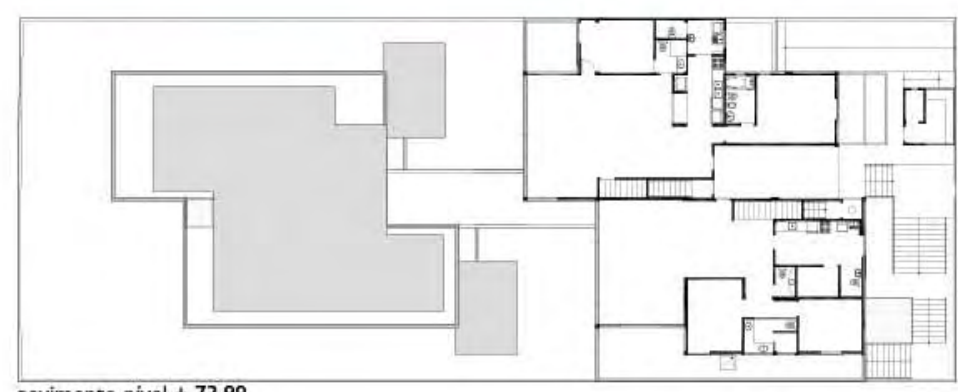

pavimento nivel $+73,89$
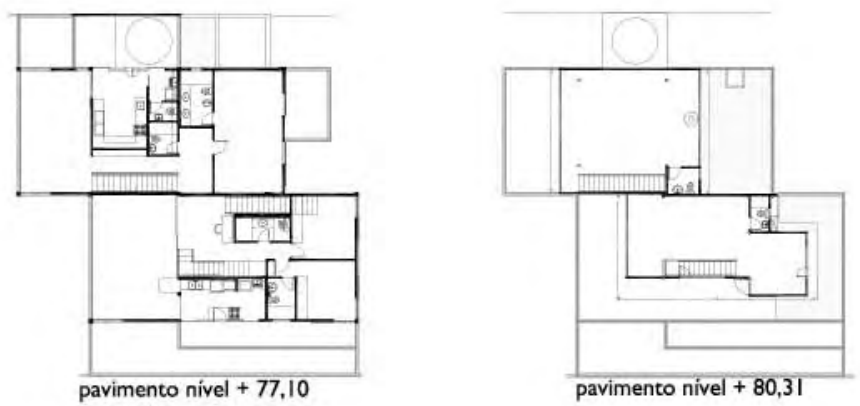

Fontes :

Da Filosofia a arquitetura. Projeto Design, São Paulo, n.263, jan. 2002 .

Fotos:

Acervo Cristina Xavier Arquitetura e Fabricia Zulin

Desenhos:

Acervo Cristina Xavier Arquitetura 


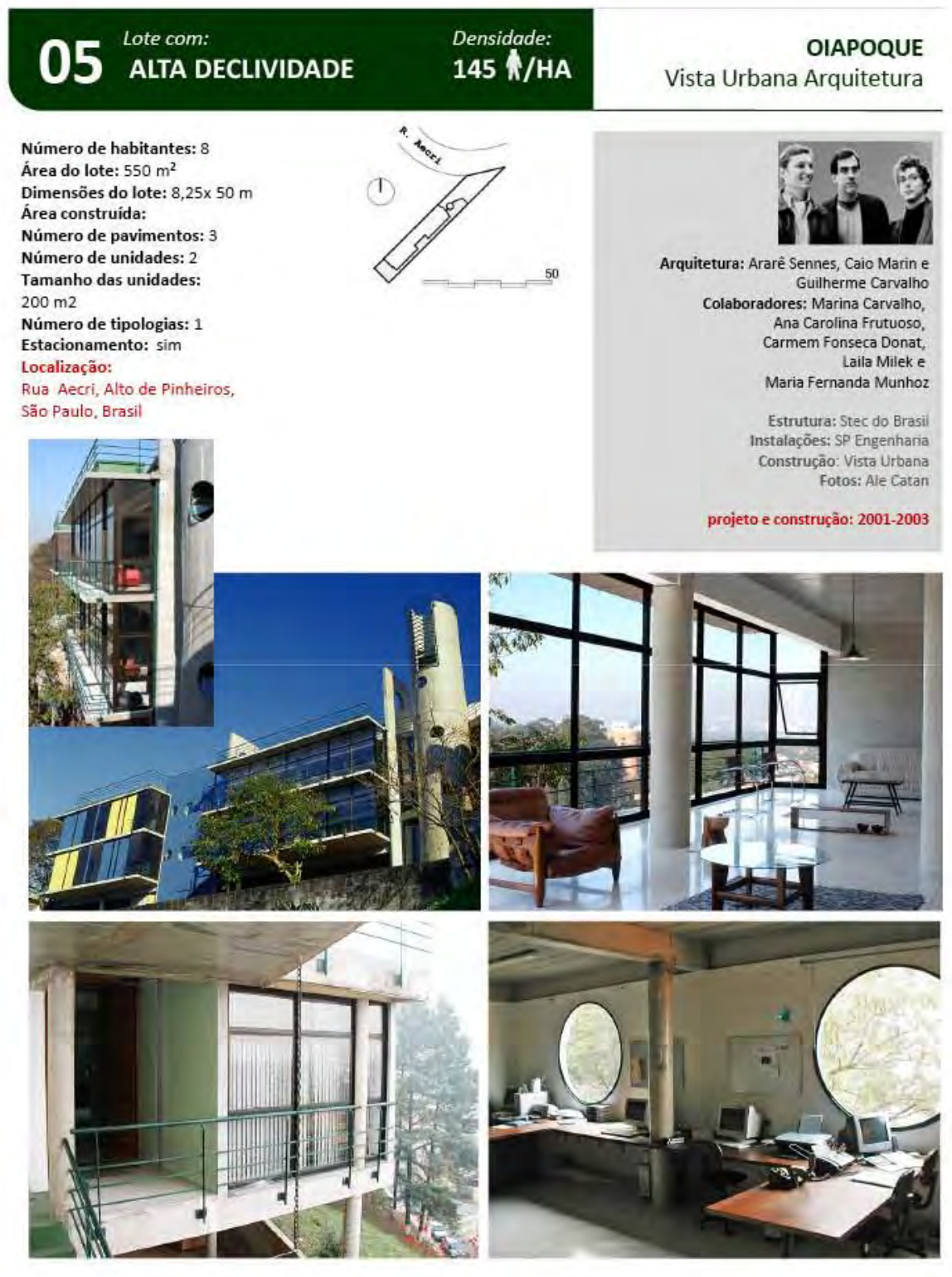

\begin{tabular}{|c|c|c|}
\hline 05 Lote com: & $\begin{array}{l}\text { Densidade: } \\
145 \text { W/HA }\end{array}$ & $\begin{array}{r}\text { OIAPOQUE } \\
\text { Vista Urbana Arquitetura }\end{array}$ \\
\hline
\end{tabular}
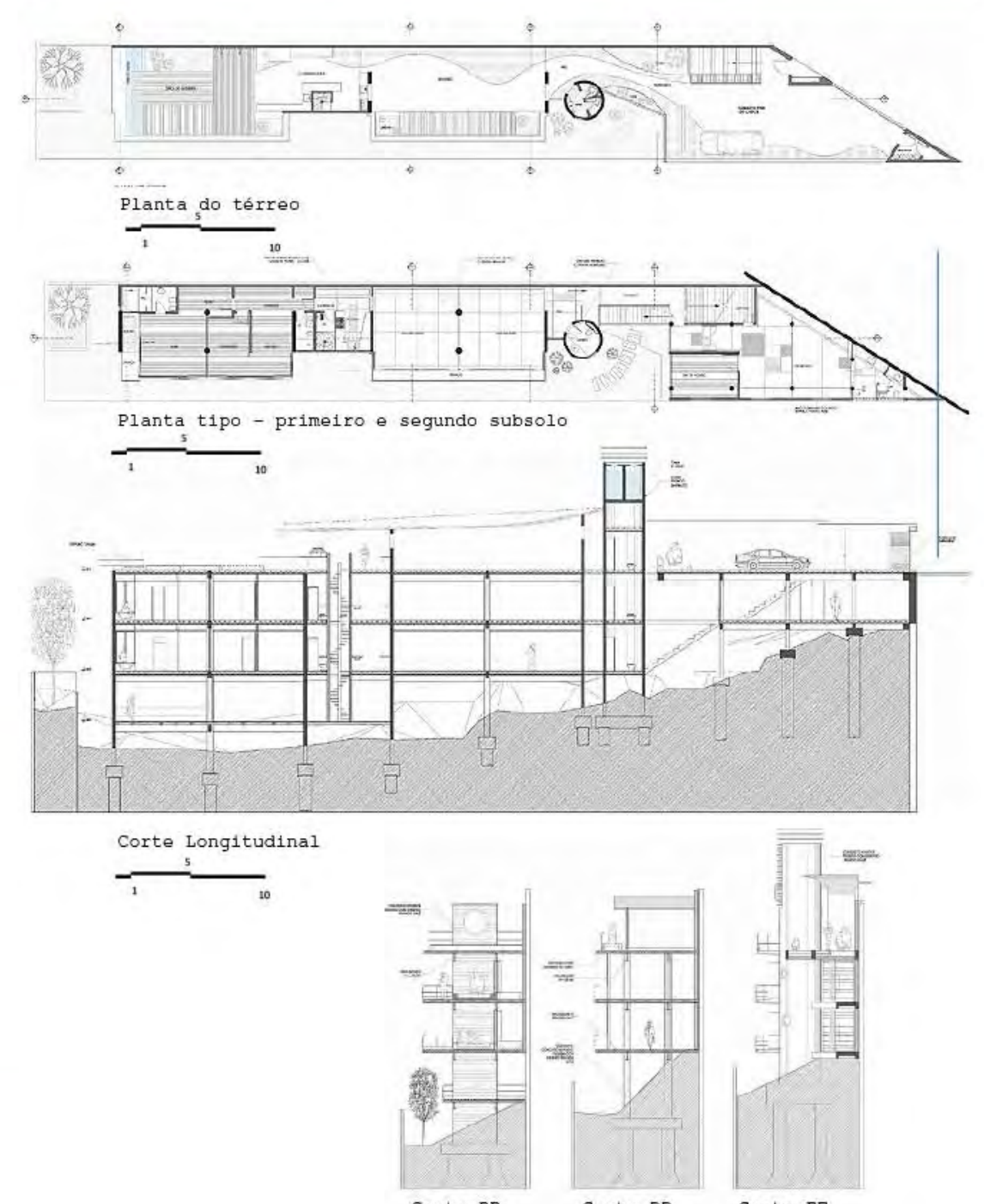

Corte BB

Corte DD

Corte EE 


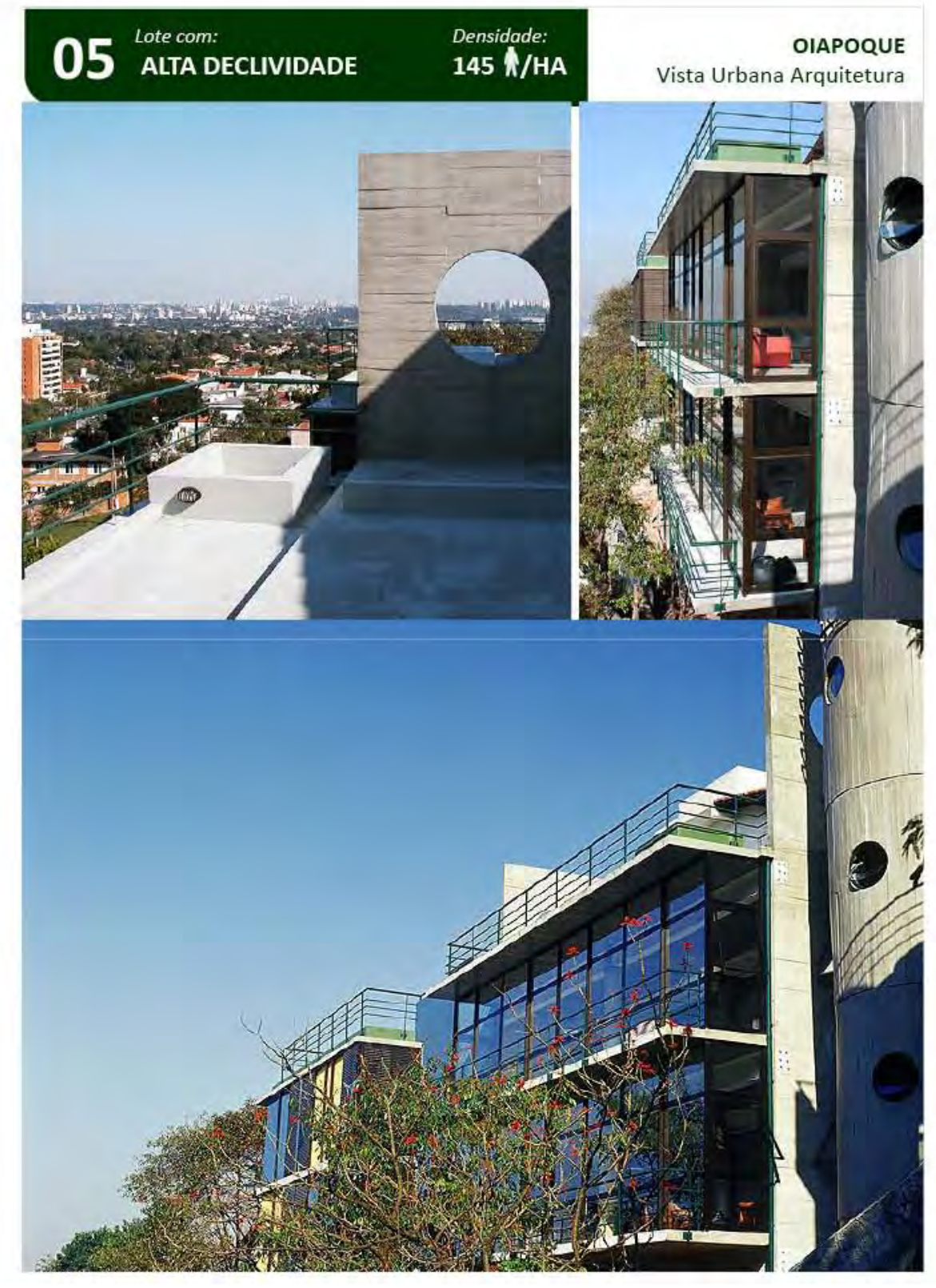

\section{Fontes:}

A reação ao neoclássico e a promessa para o futuro. Projeto Design, São Paulo, n.371, p. 88, jan. 2011.

MELENDEZ, Adilson. Mirante de concreto. Projeto Design, São Paulo, n.287, p., jan.2004. Arquitetura e Urbanismo. São Paulo. n. 114, p.12, set., 2003.

\section{Fotos e desenhos:}

http://www.vistaurbana.com.br 

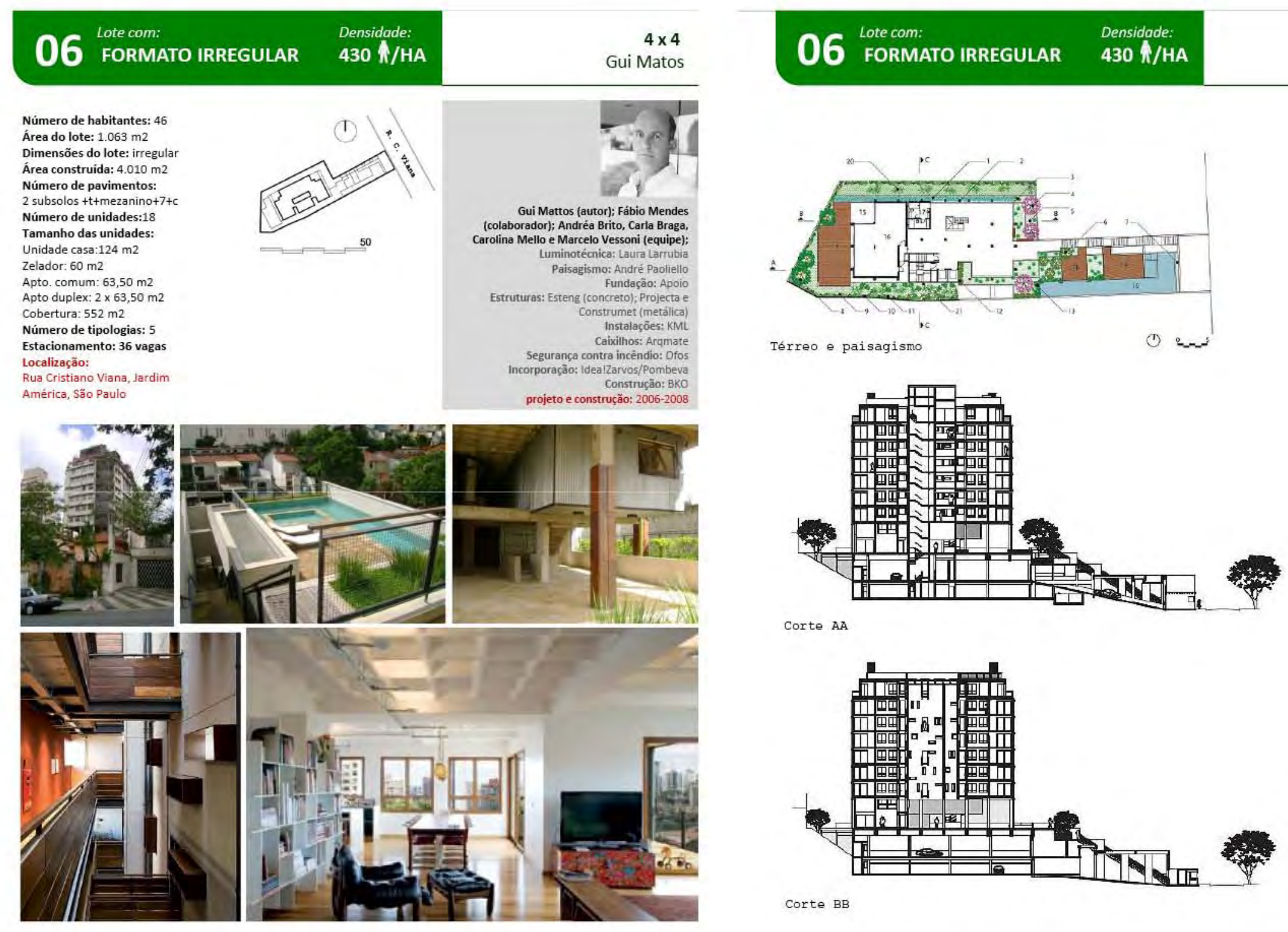
Corte AA

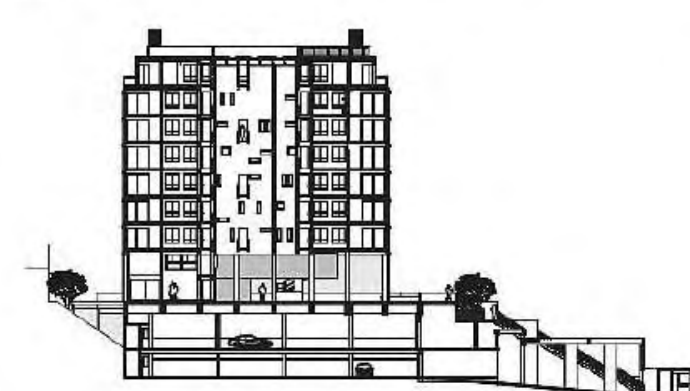

Corte BB

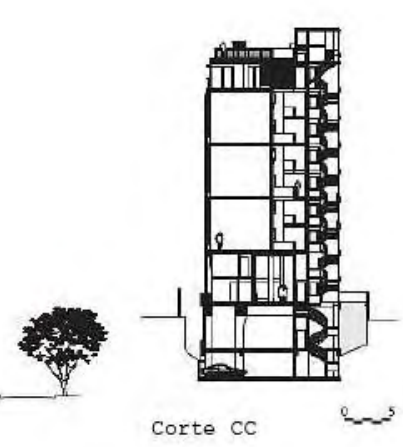




\section{Lote com:}

FORMATO IRREGULAR

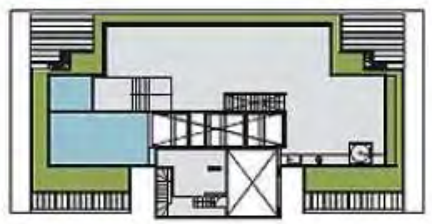

Terraço - cobertura

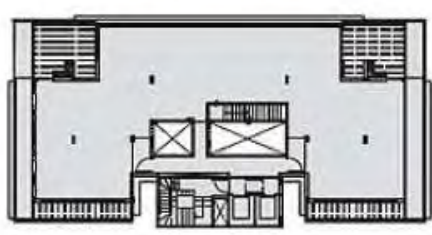

Cobertura

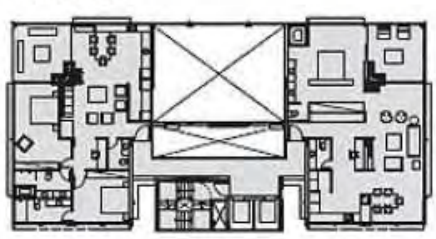

Pavimento tipo 2

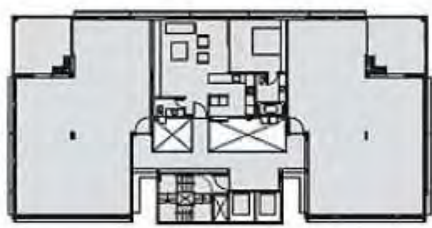

Pavimento tipo 1

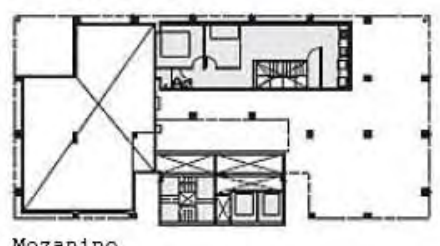

Mezanino
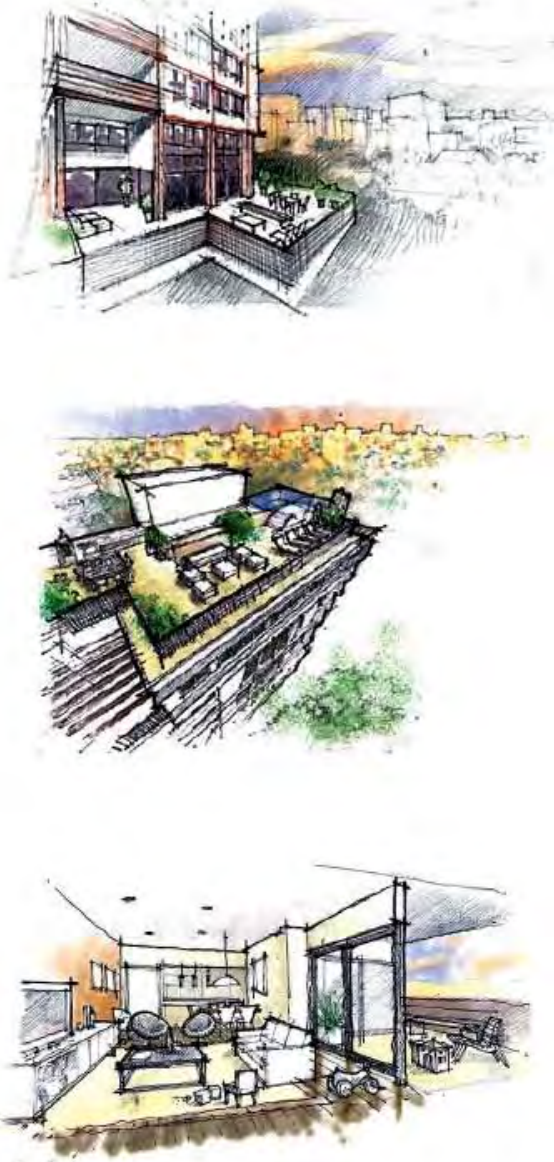

(1)
06 FORMATO IRREGULAR $\quad \begin{aligned} & \text { Densidode: } \\ & 430 \mathrm{~N} / \mathrm{HA}\end{aligned}$

$4 \times 4$ Gui Matos

\section{Fontes :}

A reação ao neoclássico e a promessa para o futuro. Projeto Design, São Paulo, n.371, p. 88, jan. 2011.

CORBIOLI, Nanci. Proposta assegura total flexibilidade de layout. Projeto Design, São Paulo, n.353, p. $54-61$, jul. 2009.

SAYEGH, Simone. Para (vi)ver como se quer. Arquitetura e Urbanismo, São Paulo, n.183, p. 40 - 47, jun. 2009.

SERAPIÃO, Mudança de ares. Projeto Design, São Paulo, n. 353, p. $68-79$, jul. 2009.

\section{Fotos:}

http: //www.arquiteturaguimattos.com.br Fabricia Zulin 


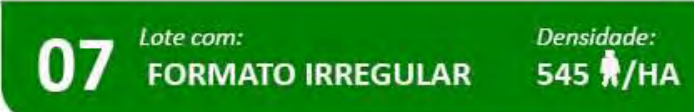

Ourânia Gui Matos

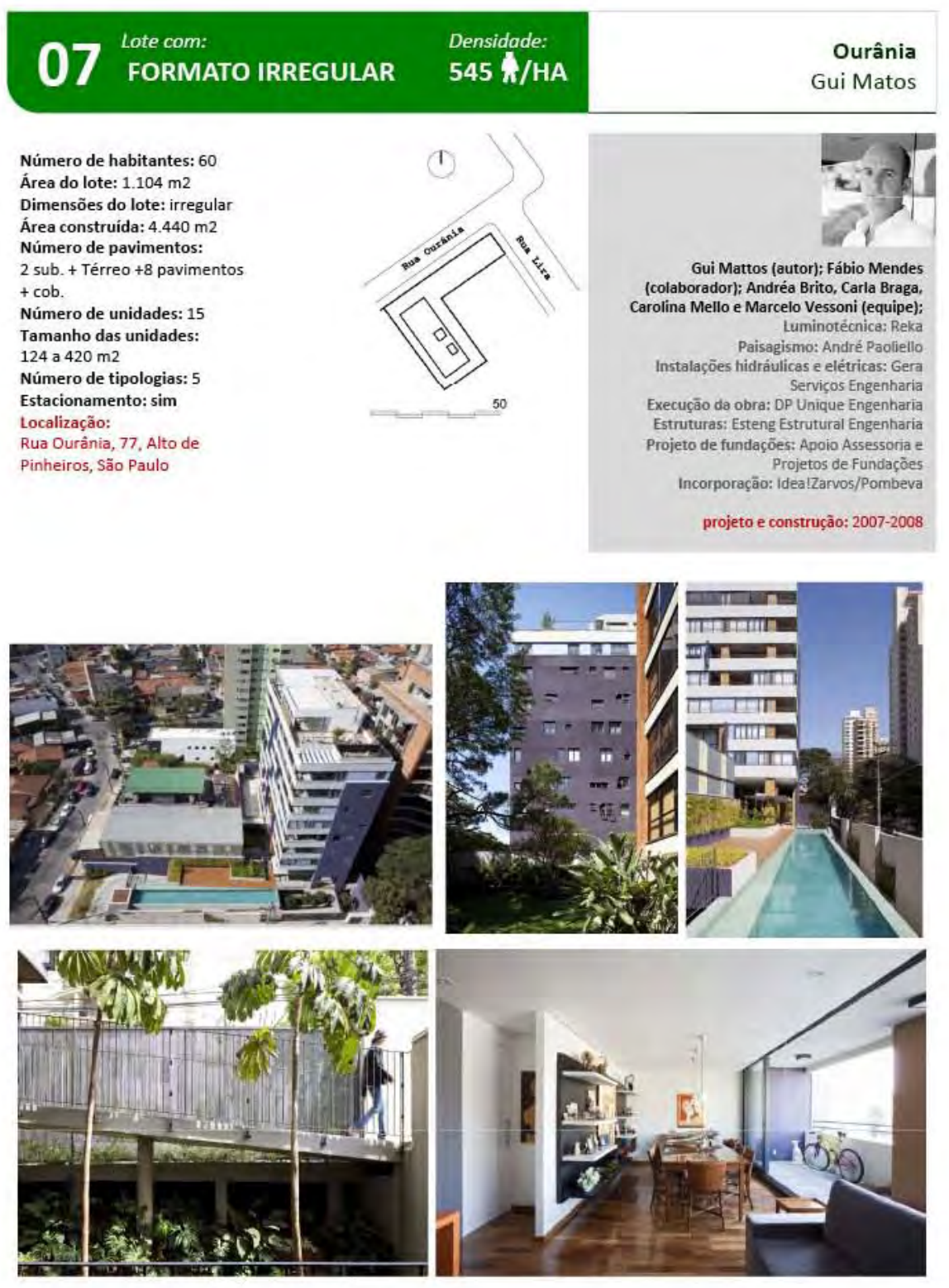

Número de habitantes: 60 Dimensões do lote: irregu

o de tipologia

Pinheiros, São Paul

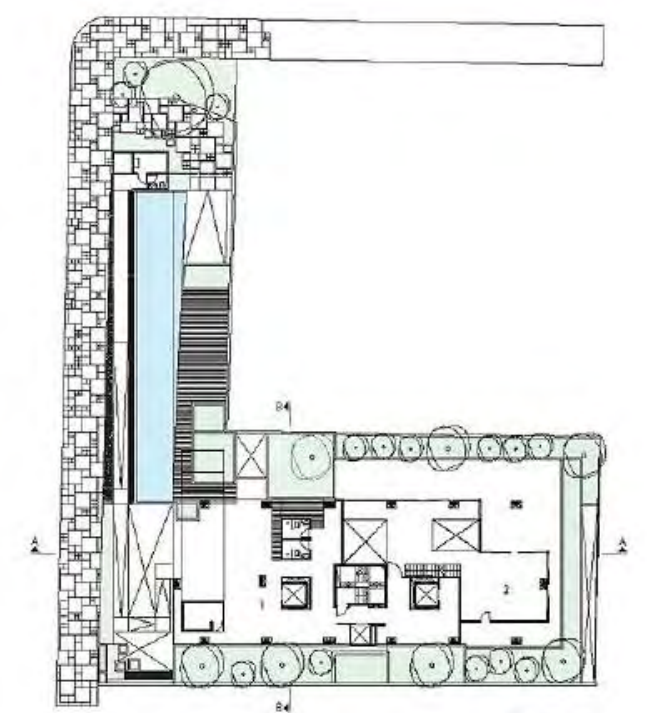

Térreo

o
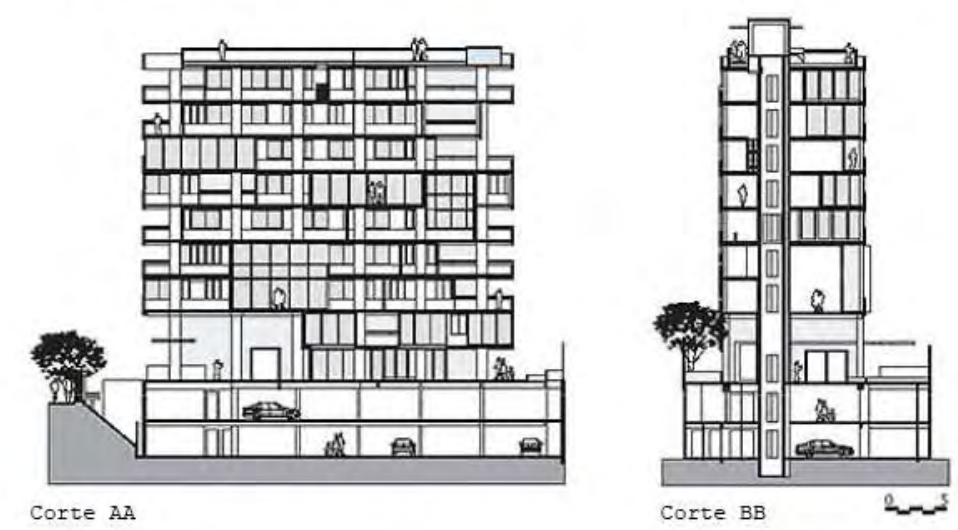


\section{Lote com: \\ FORMATO IRREGULAR
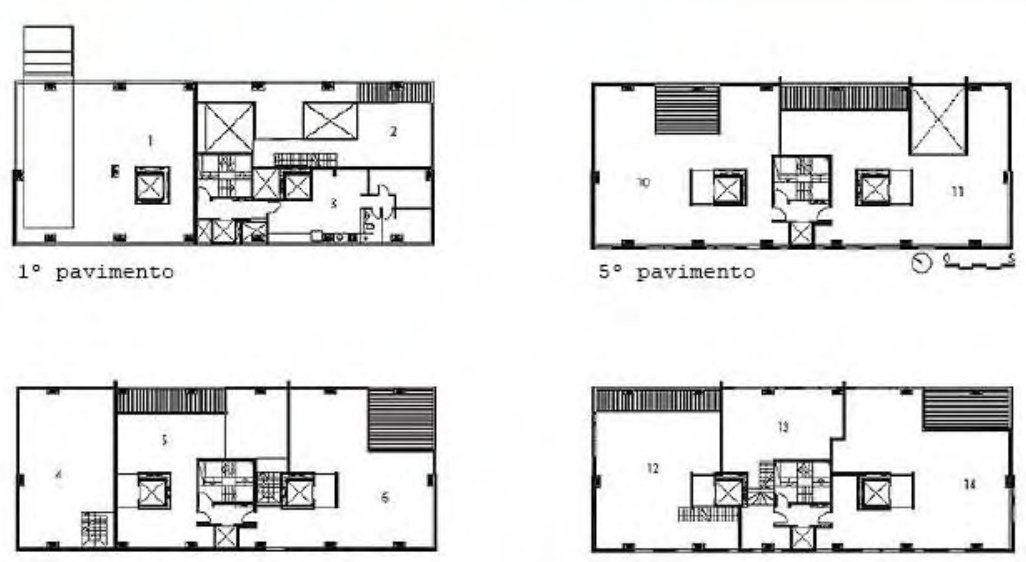

$2^{\circ}$ pavimento

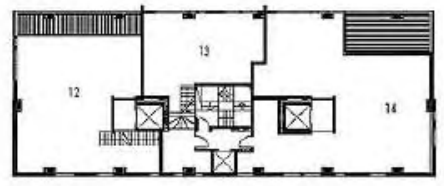

$6^{\circ}$ pavimento

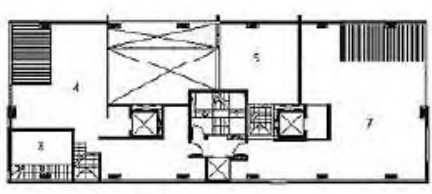

$3^{\circ}$ pavimento

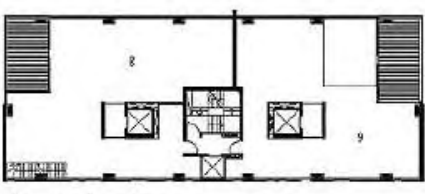

$4^{\circ}$ pavimento
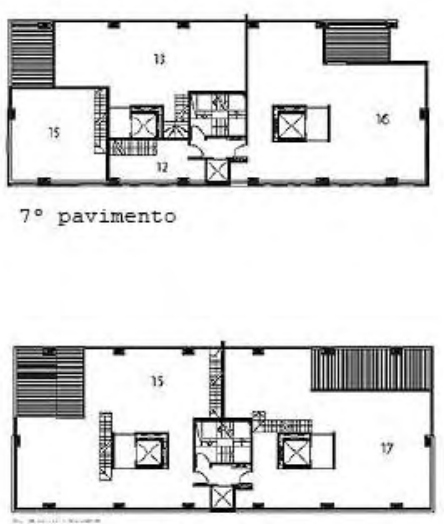

$8^{\circ}$ pavimento
Fontes:

GEROLLA, Giovanny. Fachada customizada. Arquitetura e Urbanismo, São Paulo, n.201, p. 45 -49, dez. 2010.

SERAPIÃo, Mudança de ares. Projeto Design, São Paulo, n. 353 , p. $68-79$, jul. 2009.

Revista Area, Itália, n.114.

\section{Fotos:}

http://www. arquiteturaguimattos.com.br 


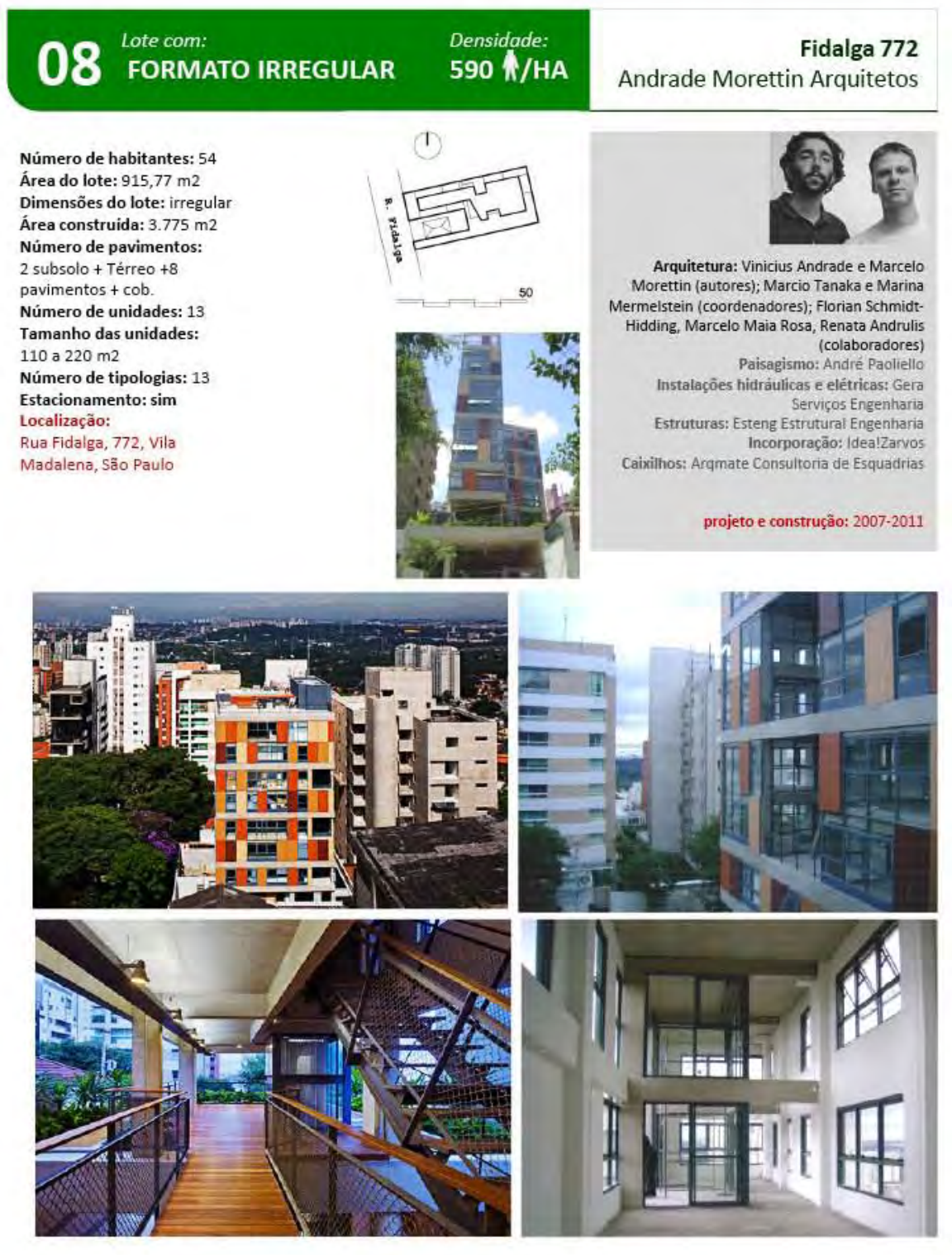

\begin{tabular}{ll|r} 
Lote com: & Densidade: & Fidalga 772 \\
Formato IRREgULAR & 590 / $/ \mathrm{HA}$ & Andrade Morettin Arquitetos
\end{tabular}
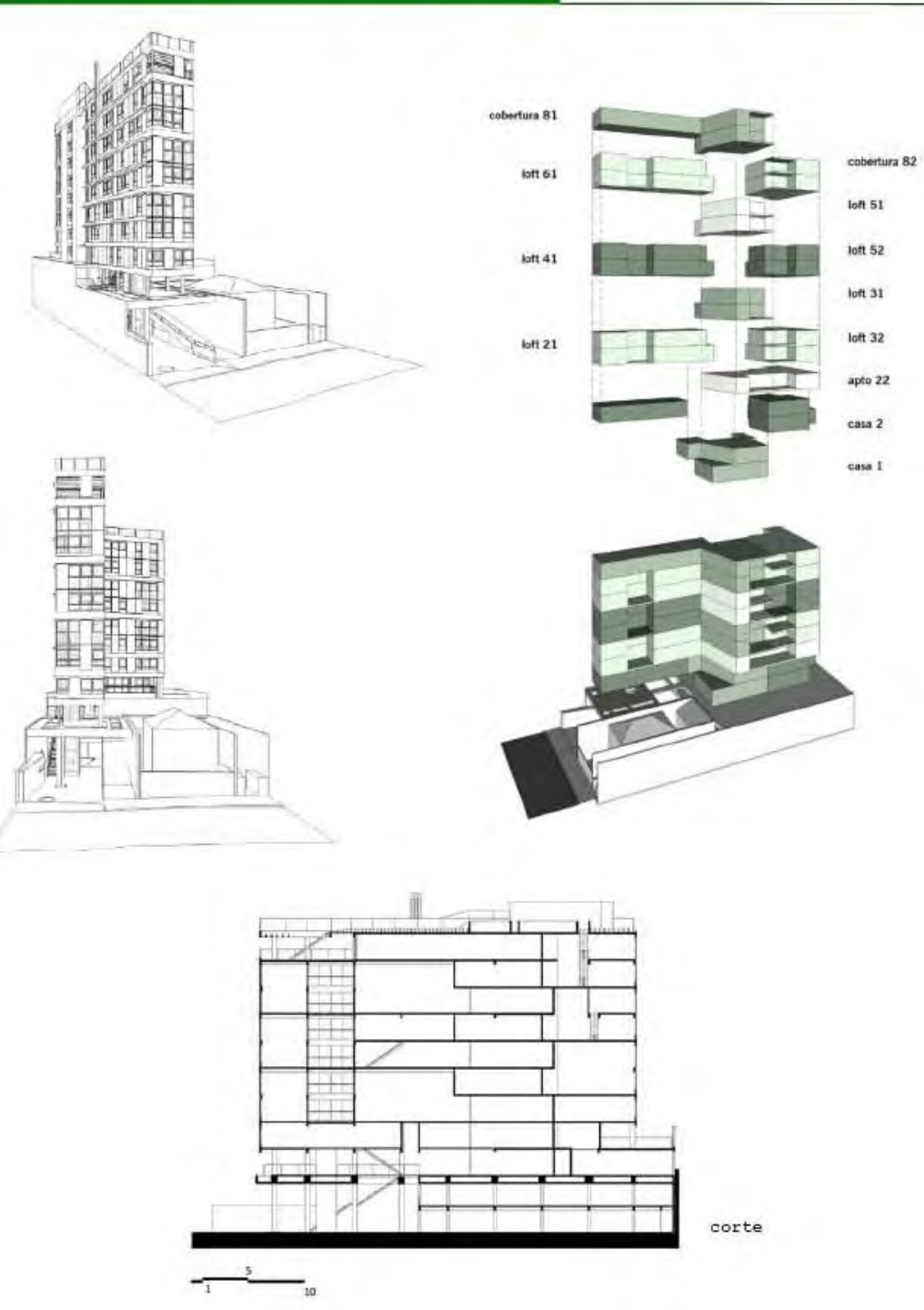


\section{$08 \stackrel{\text { lotecom: }}{\text { Fopm: }}$ \\ FORMATO IRREGULAR \\ Densidade:
$590 \% / \mathrm{HA}$ \\ Andrade Morettin Arquitetos}
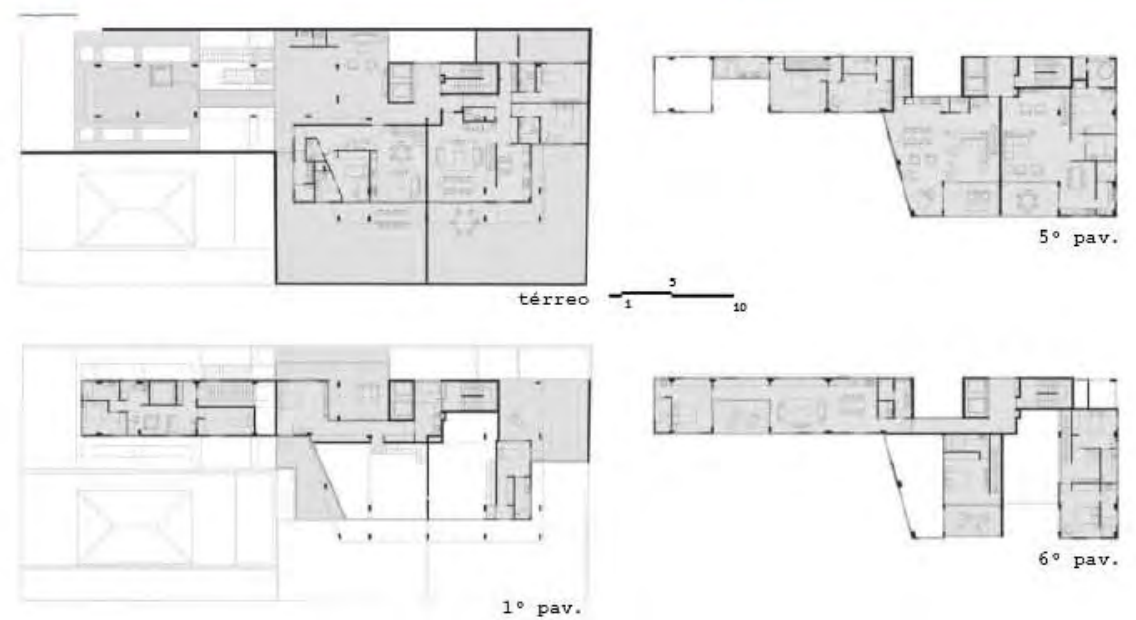

$1 \circ$ pav.

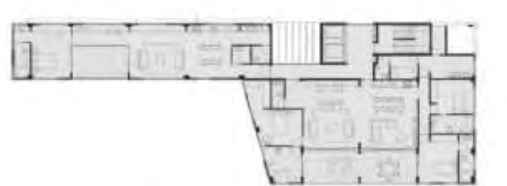

$2^{\circ}$ pav.
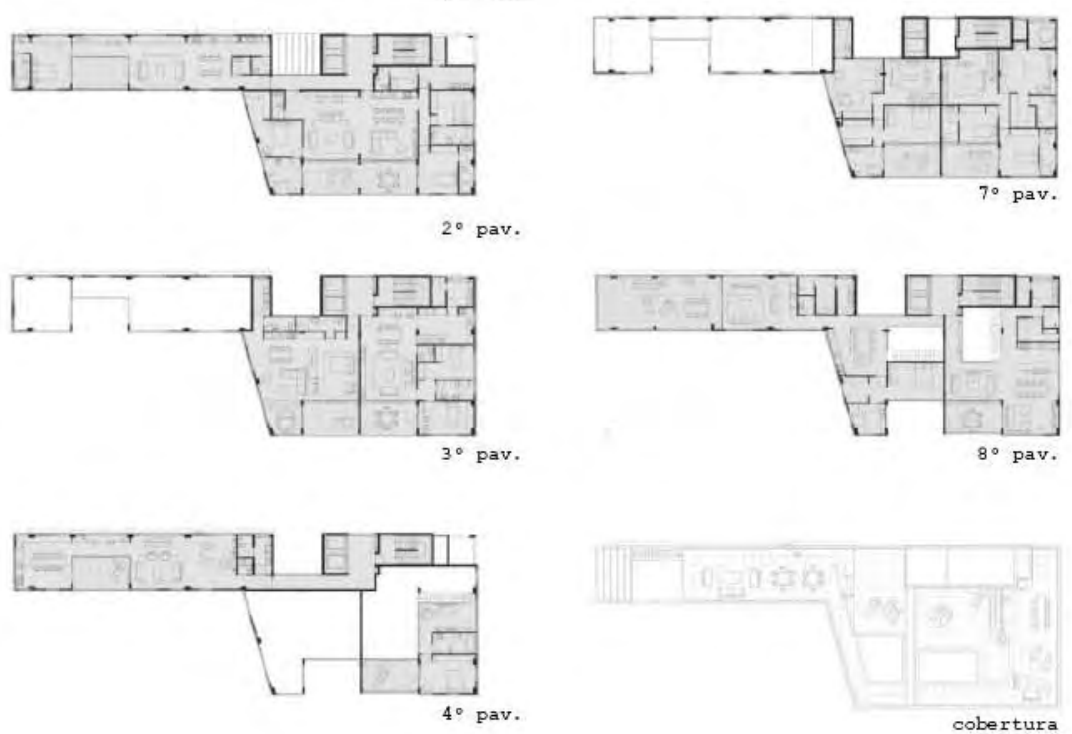

\section{FORMATO IRREGULAR}

\section{Fontes:}

HOLCK, Teodoro. Suave abraço. Arquitetura e Urbanismo, São Paulo, n.207, p. 46-53, jun. 2011

SERAPIÃo, Mudança de ares. Projeto Design, São Paulo, n. 353, p. $68-79$, jul. 2009.

São Paulo terá mais um edifício com o selo do movimento um. Arquitetura e Urbanismo, São Paulo, n.182, p. 10, mai. 2009.

Edifício de apartamentos na rua Fidalga. Monolito, São Paulo, n.II, p. 122-129, abril/maio 2011.

\section{Fotos:}

Fabricia Zulin

http://www. andrademorettin. com. br

http://www2. nelsonkon.com.br 


\section{9 \\ Lote com:
FORMATO IRREGULAR \\ Densidade:}

Número de habitantes: 36
Área do lote: $823 \mathrm{~m}^{2}$

Dimensôes do lote: irregular

Área construída: $1646 \mathrm{~m}^{2}$

Número de paviment

Númerode unidades: 14

Tamano unidades: 14

$95,65 \mathrm{~m}^{2}$ (5 unidades)

$112,09 \mathrm{~m}^{2}$ (6 unidades)

$275,33 \mathrm{~m}^{2}$ (01 cobertura)

$316,45 \mathrm{~m}^{2}(01$ cobertura)

$\sim 60 \mathrm{~m}^{2}$ (01 zelador)

Número de tipologias: 5

Lscalizacâão: Rua Simpatia, 236,

Vila Madalena, Säo Paulo

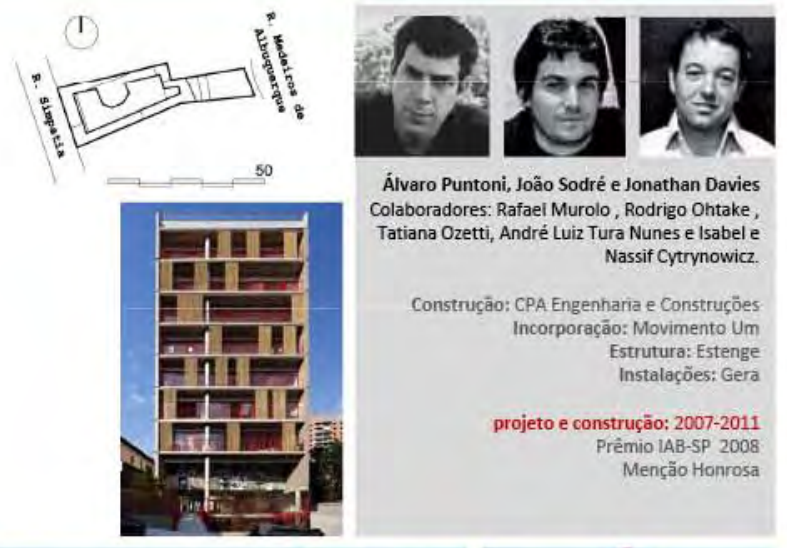

Simpatia 234 GRUPO SP
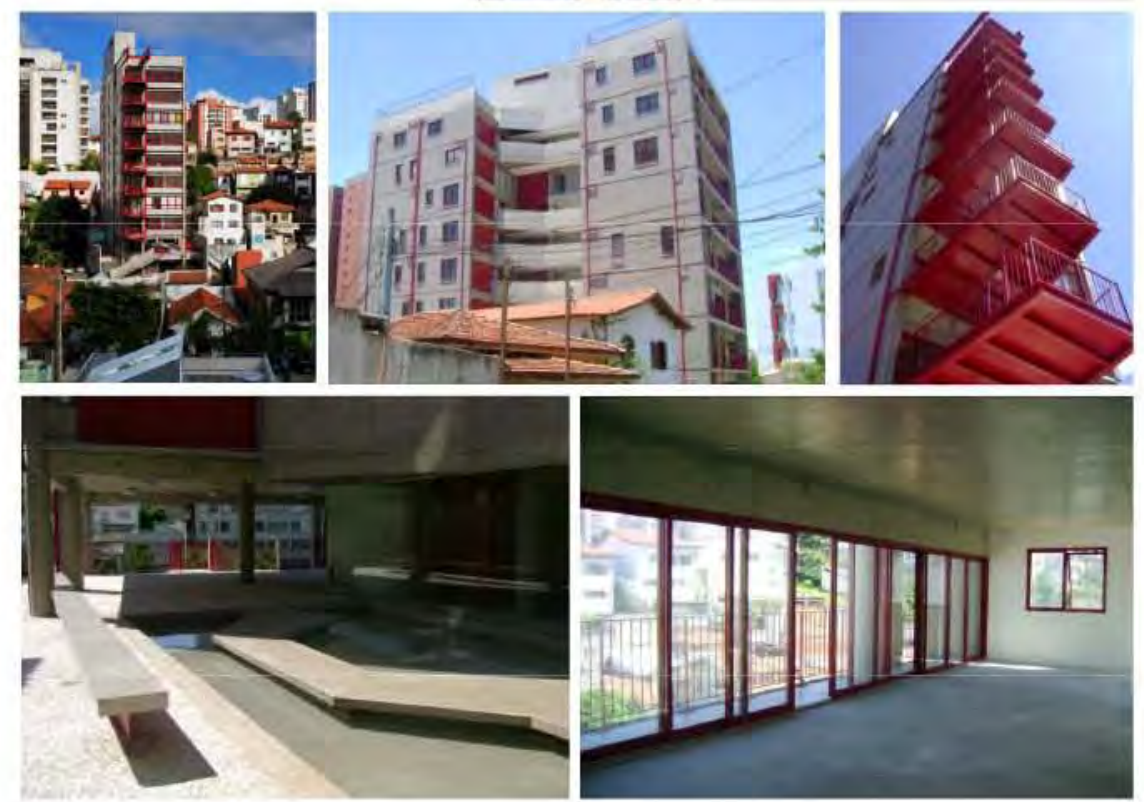

09 Lote com:

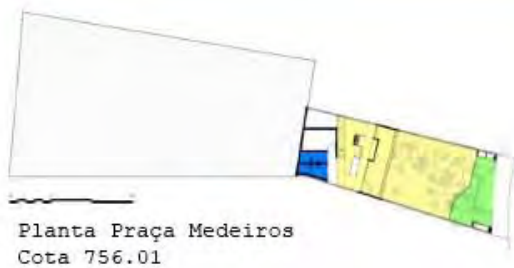

Cota 756.01

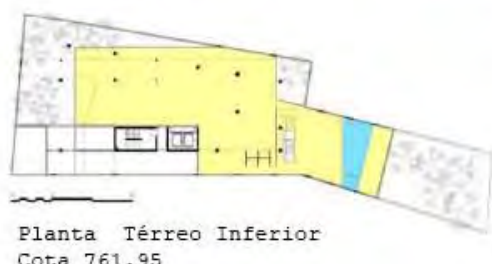

Densidade:
475 / $/ \mathrm{HA}$

Simpatia 234 GRUPO SP

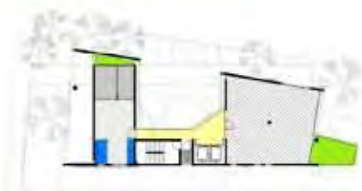

Planta Mezanino

Cota 767.68

Cota 761.95
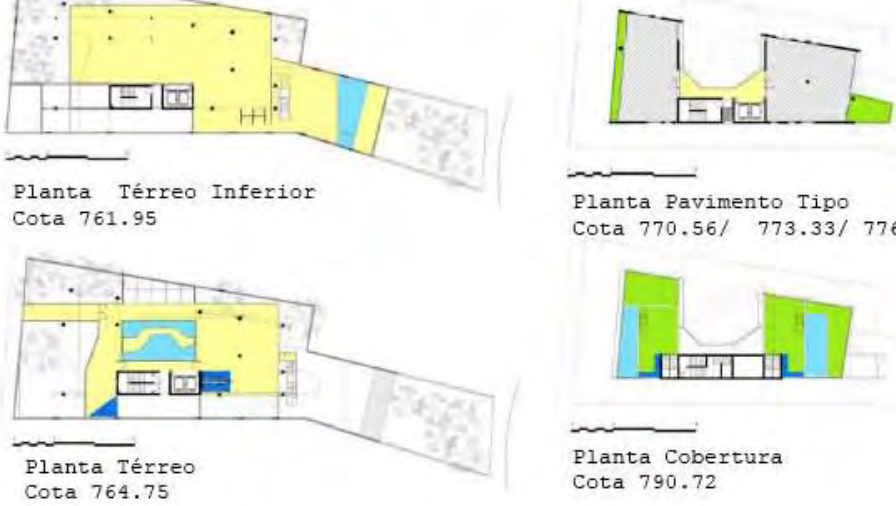

Planta Pavimento Tipo
Cota $770.56 / 773.33 / 776.32 / 779.20 / 782.08$

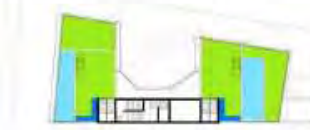

Planta Cobertur

Cota 790.72

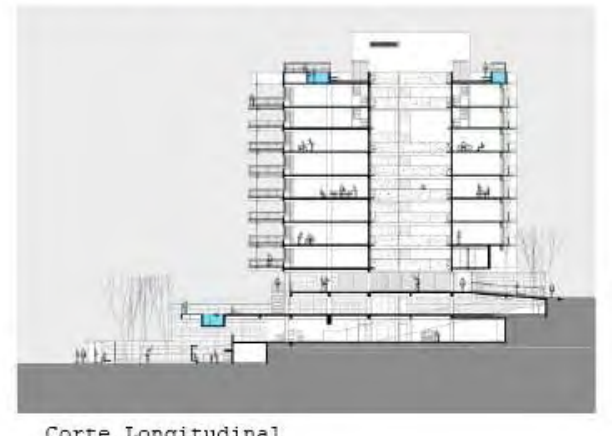

Corte Longitudinal

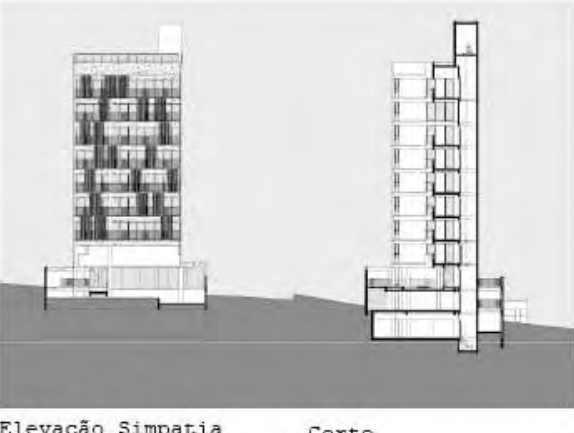

$\begin{array}{ll}\text { Elevação Simpatia } & \begin{array}{l}\text { Corte } \\ \text { Transversa }\end{array}\end{array}$ 


\section{Fontes:}

TRONCOSO, Ursula. Simpatia gera gentileza. Arquitetura $e$ Urbanismo, São Paulo, n.207, p. 54-61, jun. 2011

SERAPIÃo, Mudança de ares. Projeto Design, São Paulo, n.353, p. $68-79$, jul. 2009 .

Fotos :

Fabricia Zulin

Nelson Kon

http://www .gruposp.arq.br

http://www.archdaily.com/160951/simpatia-street-housing-

gruposp-arquitetos/

\section{$\begin{array}{ll}10 & \text { Lote com: } \\ \text { FORMATO IRREGULAR } & \mathbf{7 6 3} \mathrm{h} / \mathrm{HA}\end{array}$ \\ Roof Madalena Rocco Associados}

Número de habitantes: 84 Área do lote: $1100 \mathrm{~m}^{2}$

Dimensões do lote: irregular

Area construida: $6.524 \mathrm{~m}^{2}$

2 sub $+T+8+$ cob

Número

Tamanho das unidades:

97 e $120 \mathrm{~m} 2$

1)

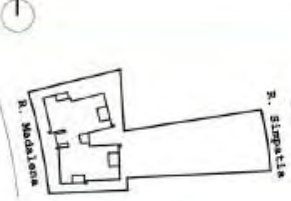

Estacionamento: sim

Localização: Rua Madale

Säo Paulo

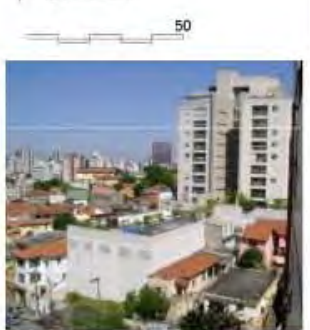
Arquitetura: Luiz Fernando Rocco

Conçä: Construtora Pombeva Zarvos Engenharia

projeto e construção: 2003-2005
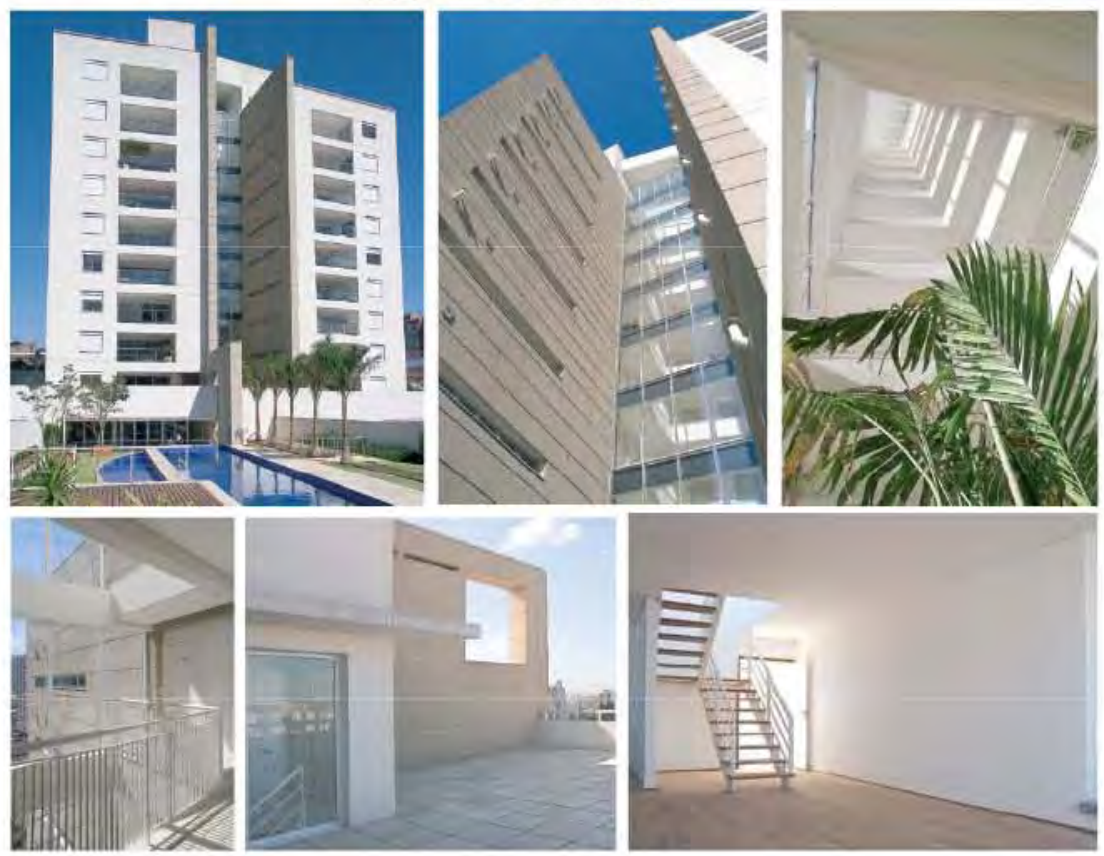


\section{FORMATO IRREGULAR $\quad \begin{aligned} & \text { Densidade: } \\ & 763 \boldsymbol{h} / \mathrm{HA}\end{aligned}$}

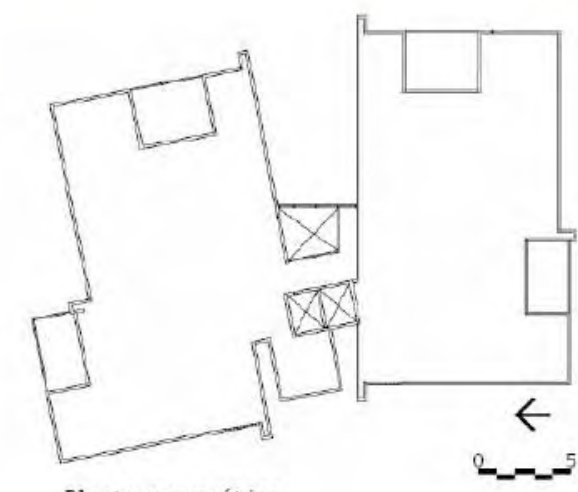

Planta esquemática

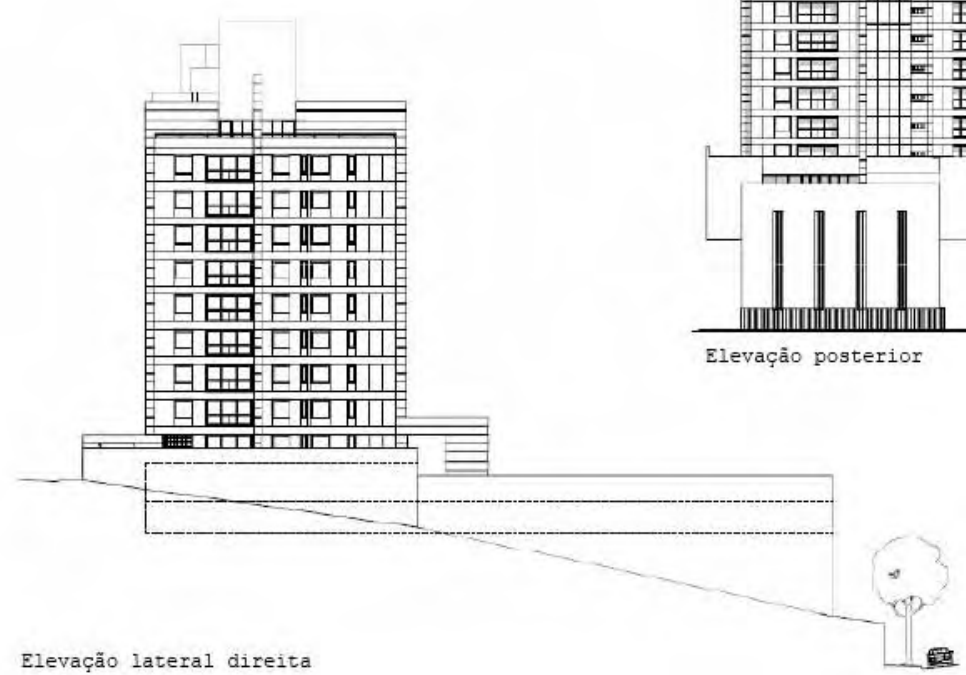

Roof Madalena Rocco Associados
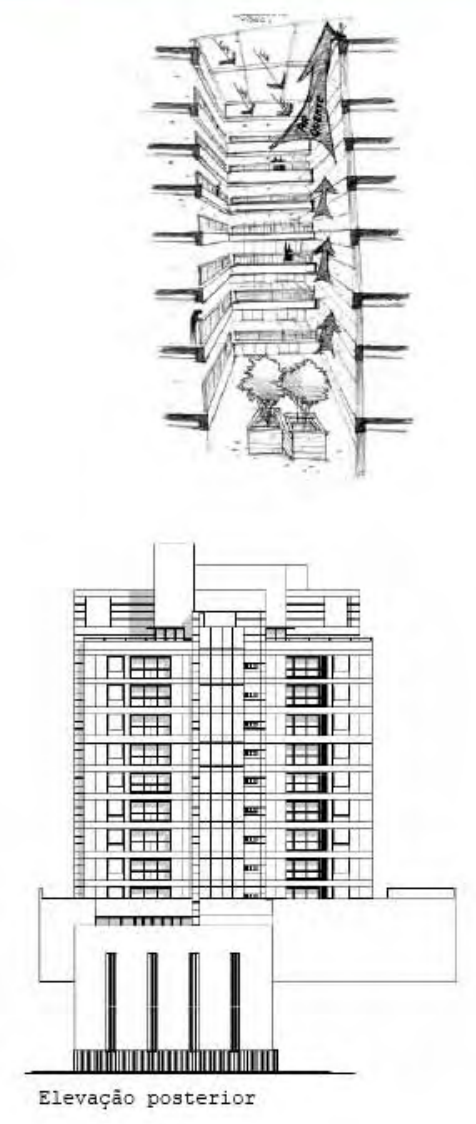

direit
10 Lote com:
FORMATO IRREGULAR
Densidade:
Roof Madalena Rocco Associados

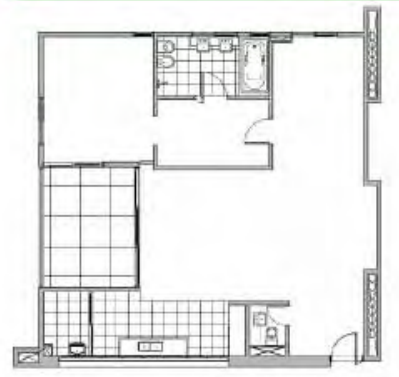

Planta tipo - opção person
(final 1 e $2,-120 \mathrm{~m} 2$
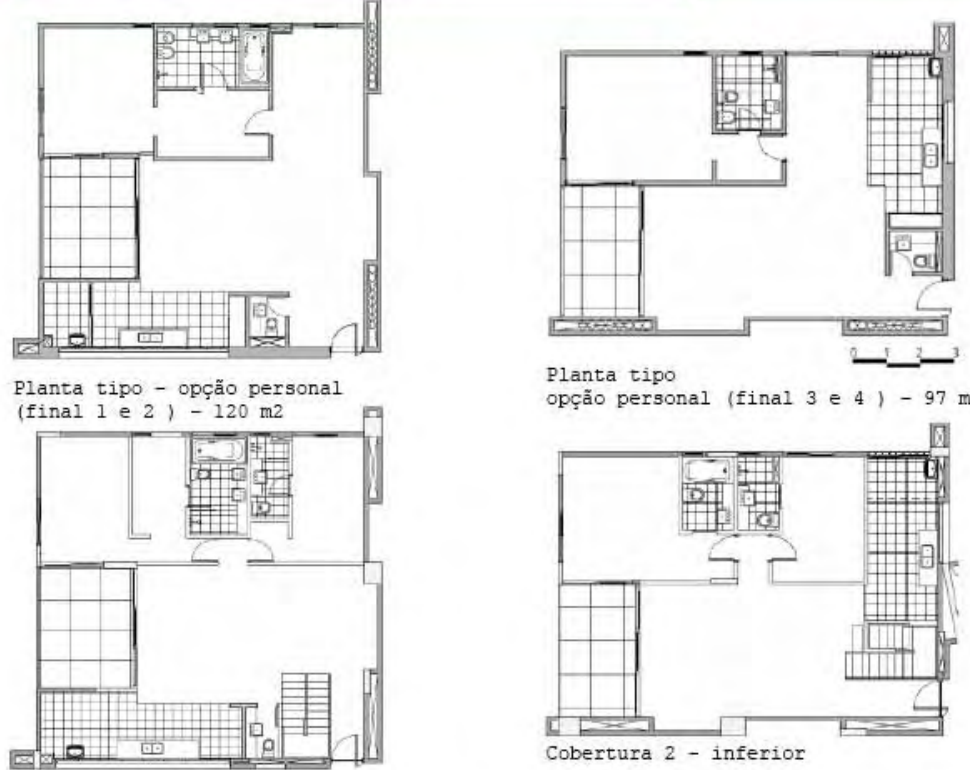

Planta tipo
opção personal (final 3 e 4 ) - $97 \mathrm{~m} 2$
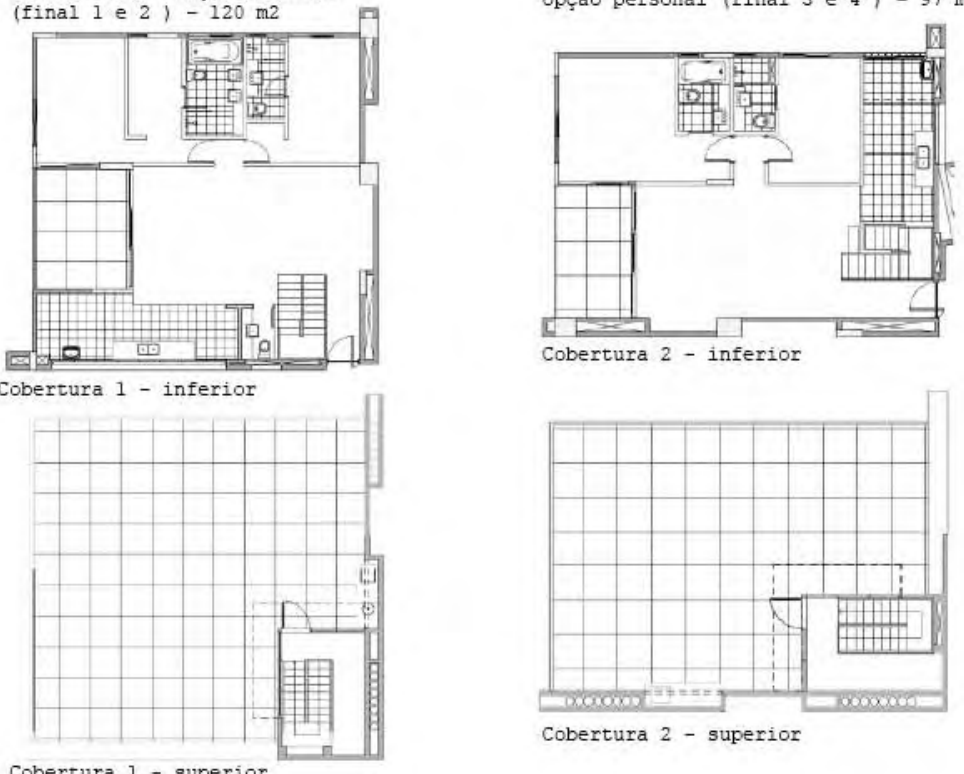

Cobertura 1 - superior

Fontes:

SABBAG, Haifa y. Beleza com conteúdo. Arquitetura e Urbanismo. São Paulo, n.145, p.48-55,abril, 2006.

http://www.roccovidal.com.br/ 


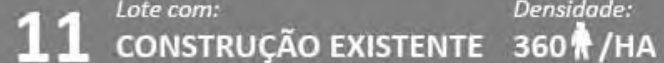

Magui

Número de habitantes: 36 Área do lote: $422 \mathrm{~m} 2$

Dimensões do lote: $32 \times 14$
Área construída: $935 \mathrm{~m} 2$

Número de pavimentos: $3+$

Número de unidades: $8+1$

Número de tiplade. 234 m

Estacionamento: não Ano edificio original: 1951

Localização: Rua Benjamin Batis Jardim Botânico, Rio de Janeir
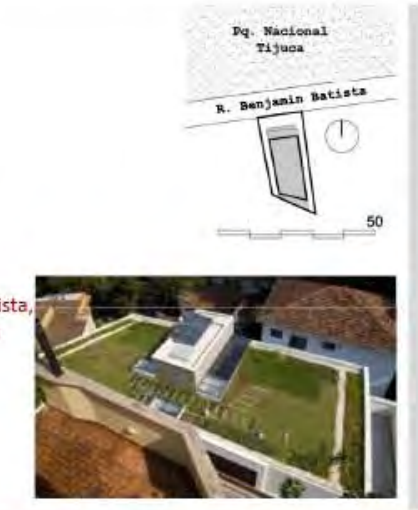

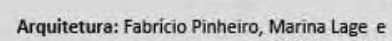

Arquitetura: Fabricio Pinheiro, Marina Lage e
Tatiana Letier Consultoria para aprovacáo: Imagentlana-

Fernando Alencar Cálculo Estrutural: Mauro Capuã
instalaç̧óes elétricas e hidraúlicas: Helio Sérgio Pereira Garcia verde: Cosch-Uso
Racional da Agua projeto e construção: 2007-2008
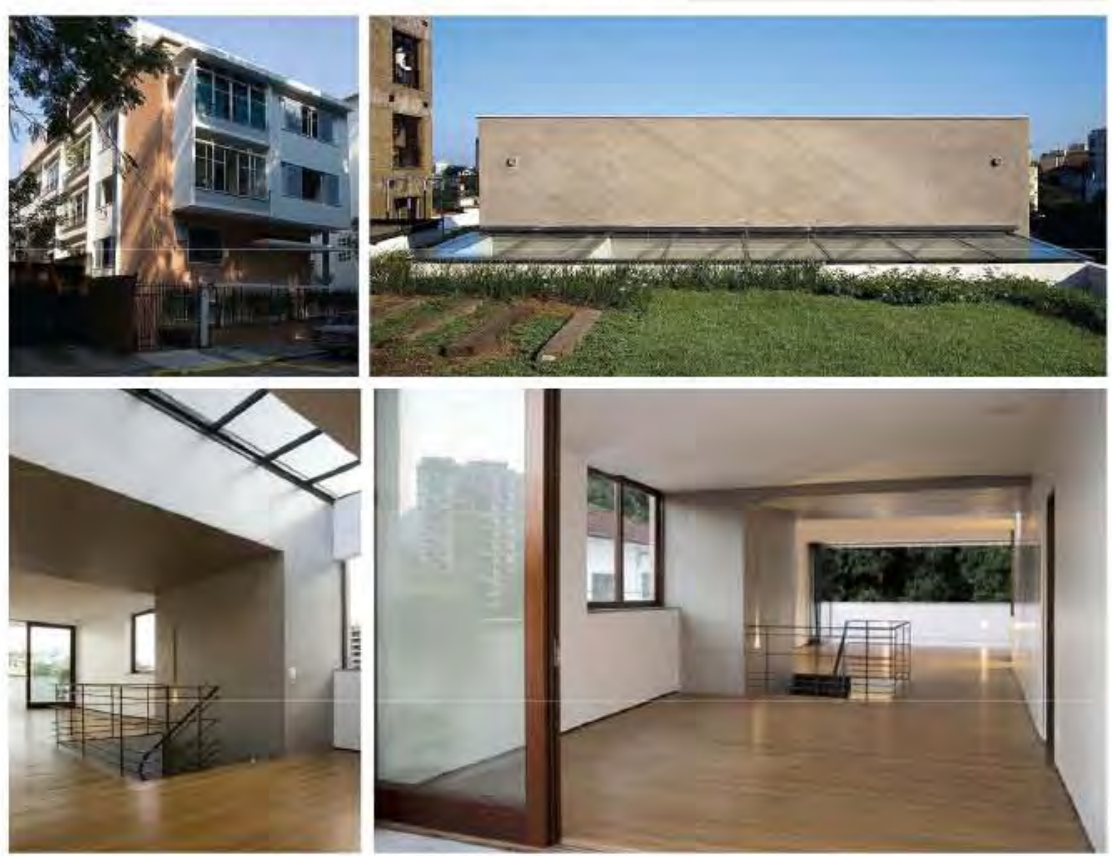

11 Lote com: $\begin{aligned} & \text { Densidade: } \\ & \text { CONSTRUÇÃO EXISTENTE } 360 \hat{H} / \mathrm{HA}\end{aligned}$

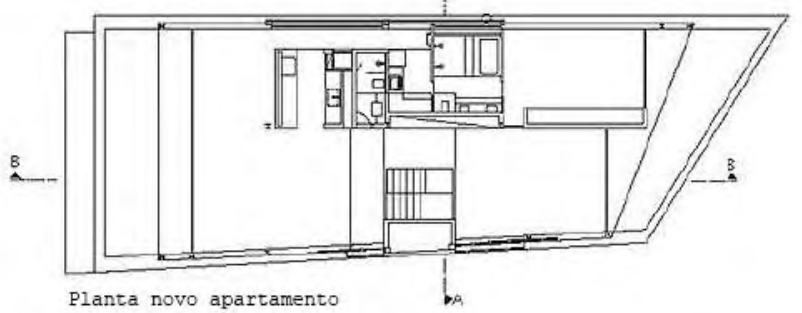

Planta novo apartamento

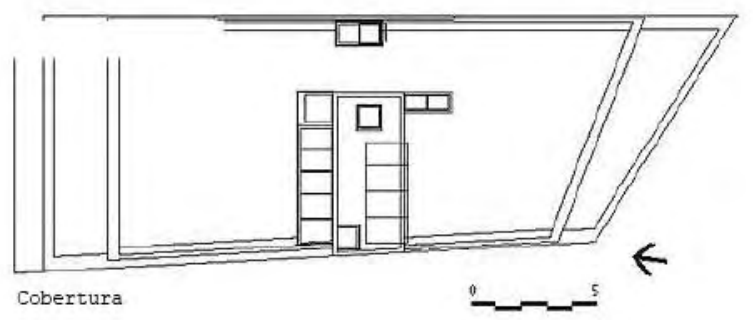

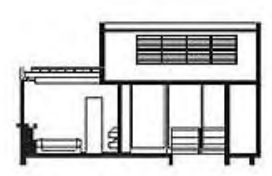

Elevação frontal

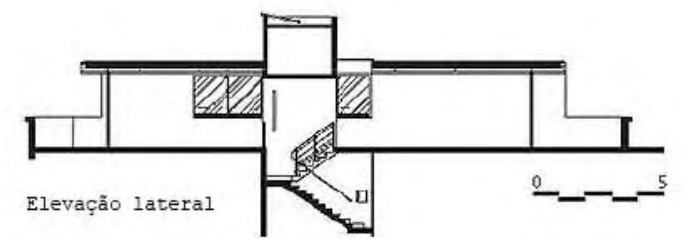

Fontes:

CEROLLA, Geovanny. Atualização do moderno. Arquitetura e Urbanismo, São Paulo, n.180, p. 26-31, março, 2009.

\section{Fotos:}

http://www.arqbrasil.com.br/arq/TAMABI arquitetura/tamabi

arquitetura.html

http://www.tamabi.com.br 


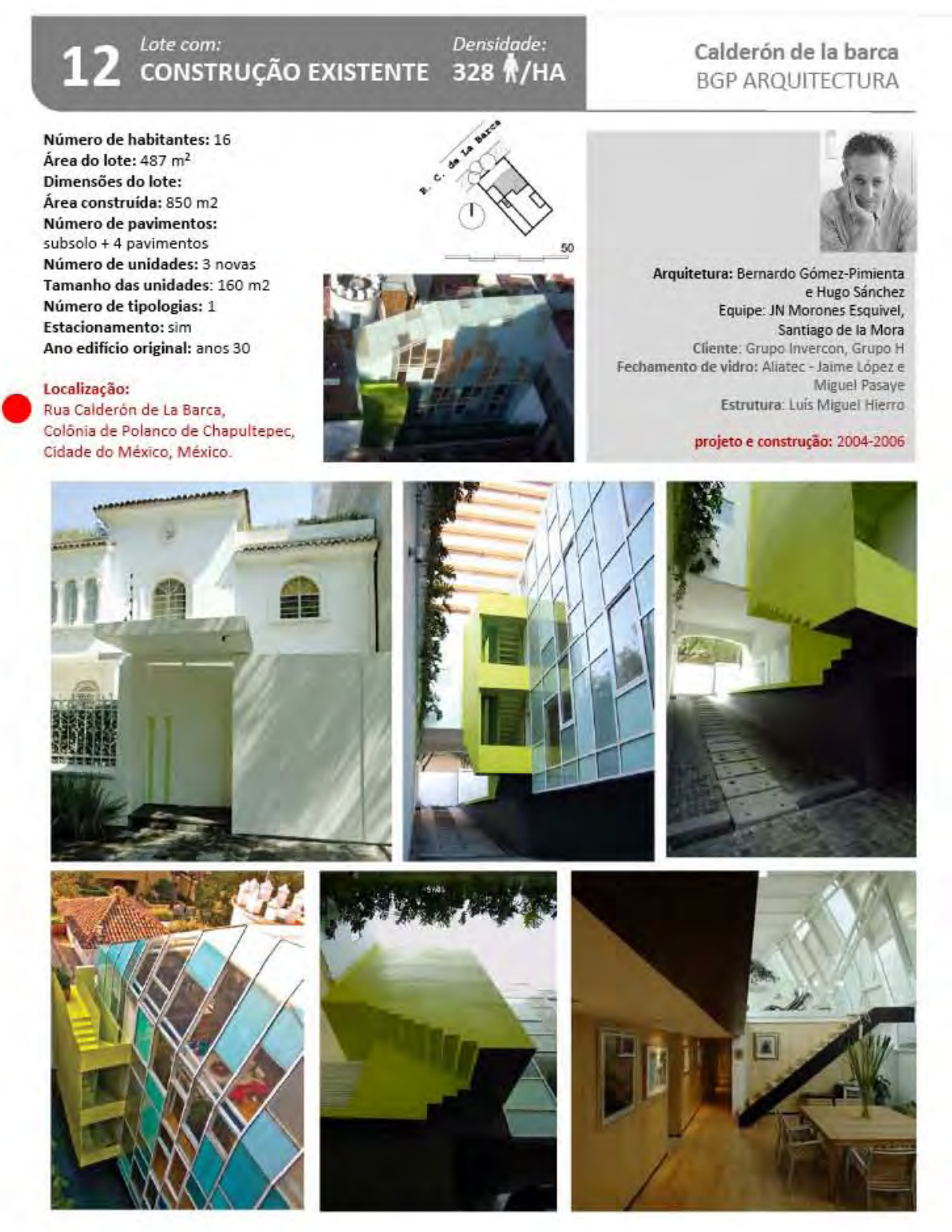

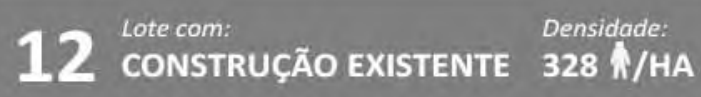

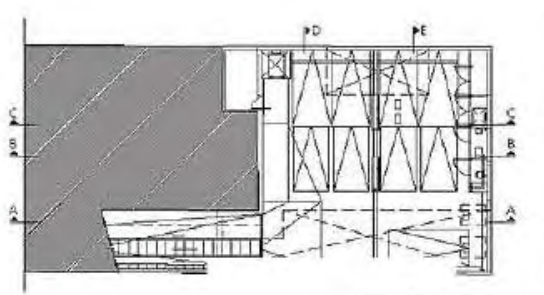

$\kappa 2$

planta subsolo

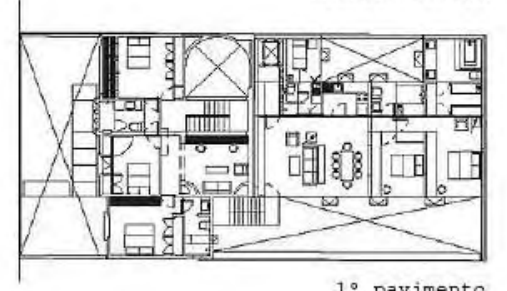

1. pavimento

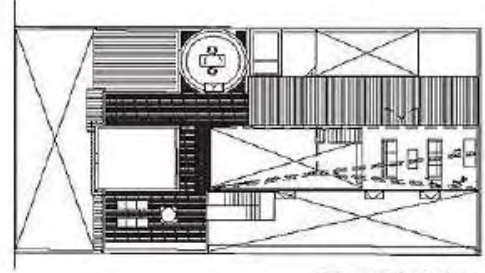

$3^{\circ}$ pav

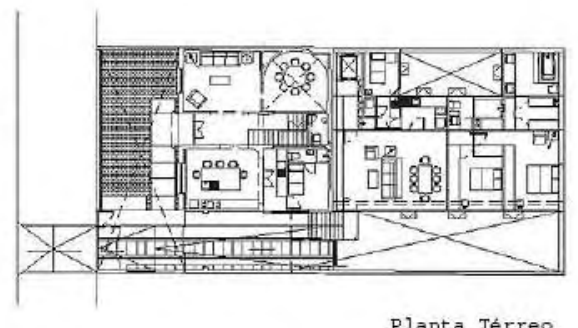

planta Térreo
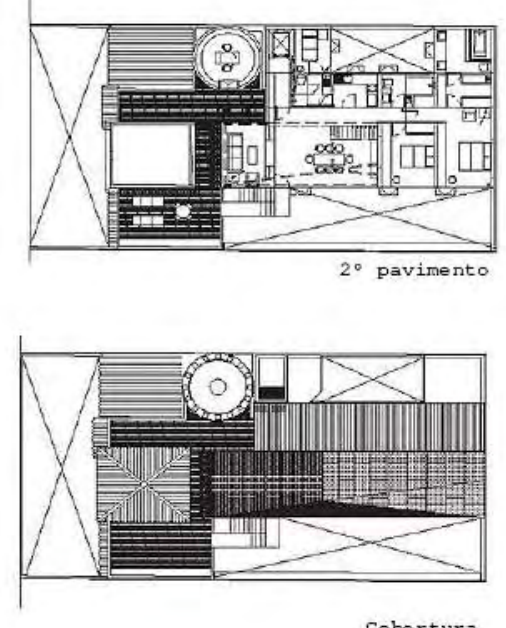

Cobertura 


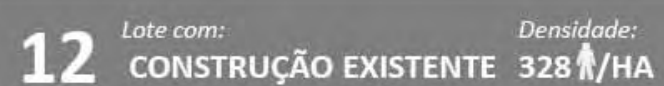
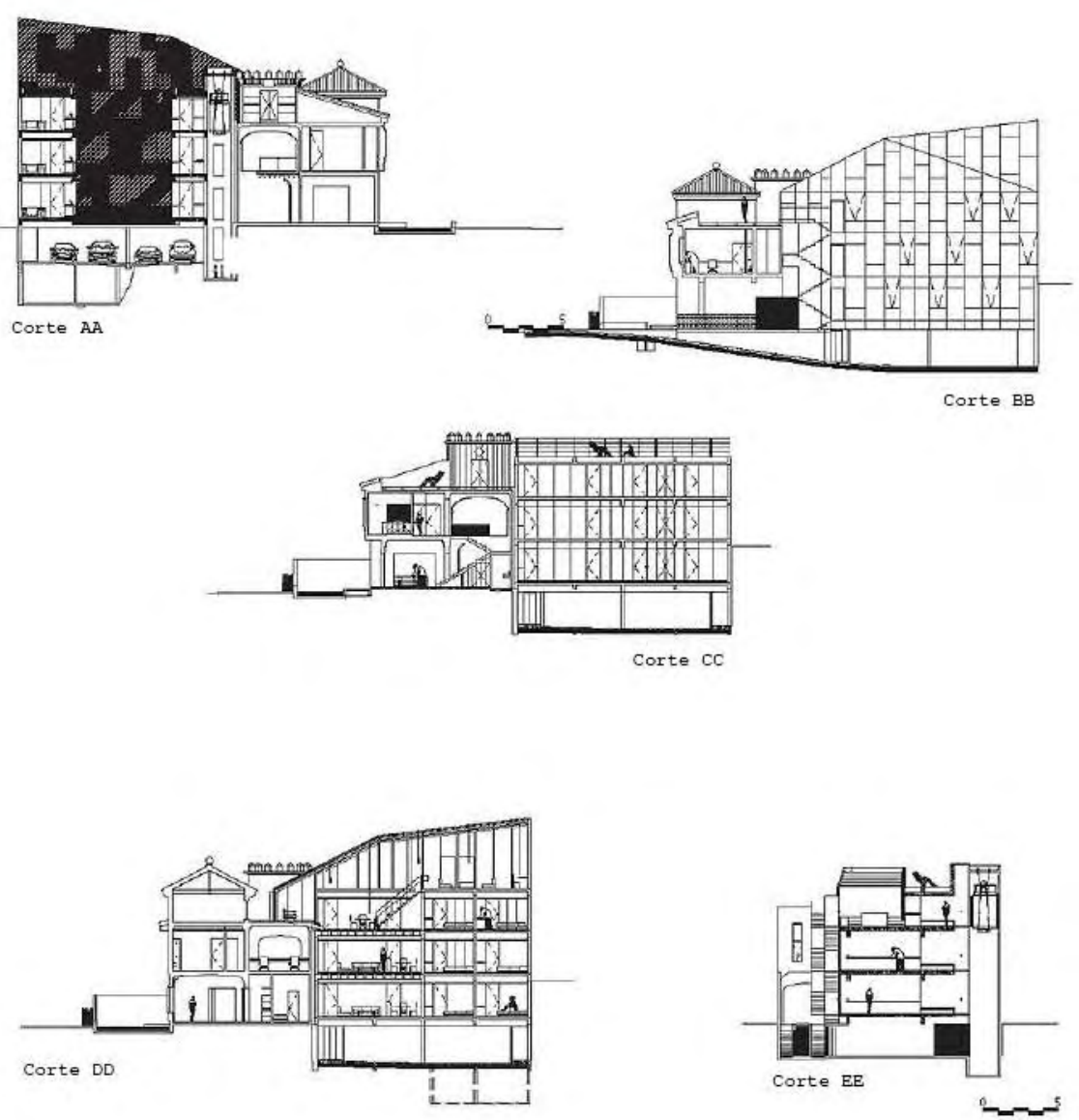

Corte BB

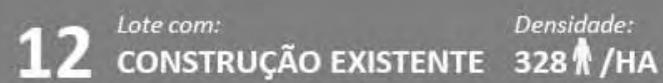




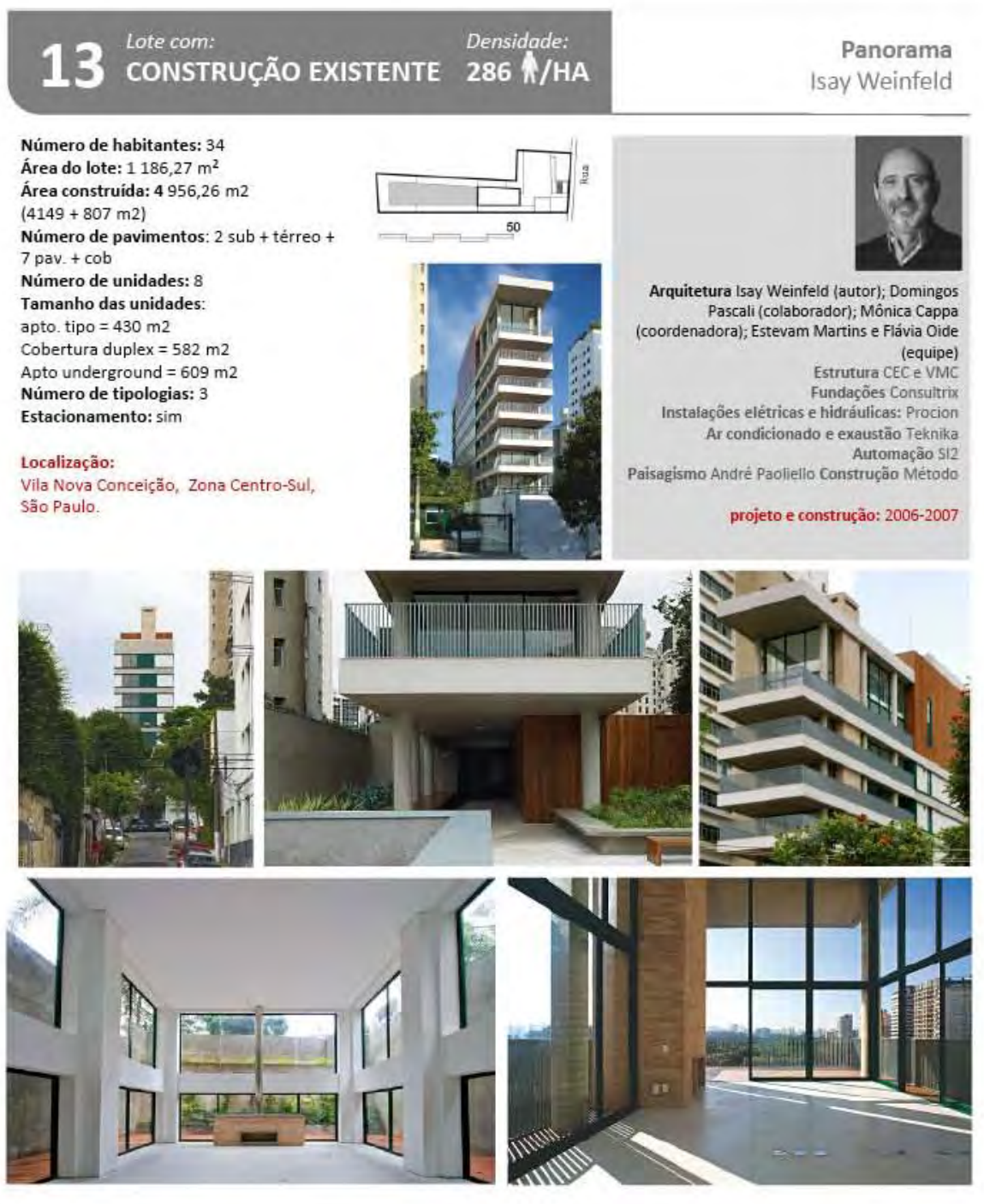

$13 \begin{aligned} & \text { Lote com: } \\ & \text { coNSTRUÇÃo EXISTENTE }\end{aligned} \begin{aligned} & \text { Densidade: } \\ & 286 \text { N/HA }\end{aligned} \quad \begin{array}{r}\text { Panorama } \\ \text { Isay Weinfeld }\end{array}$

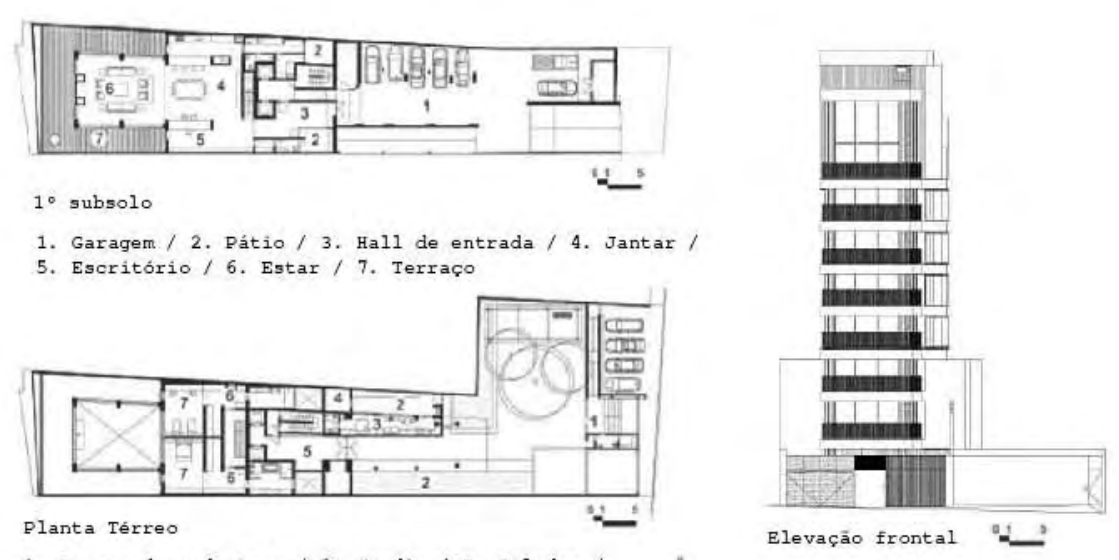

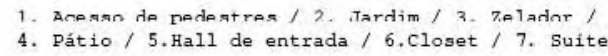

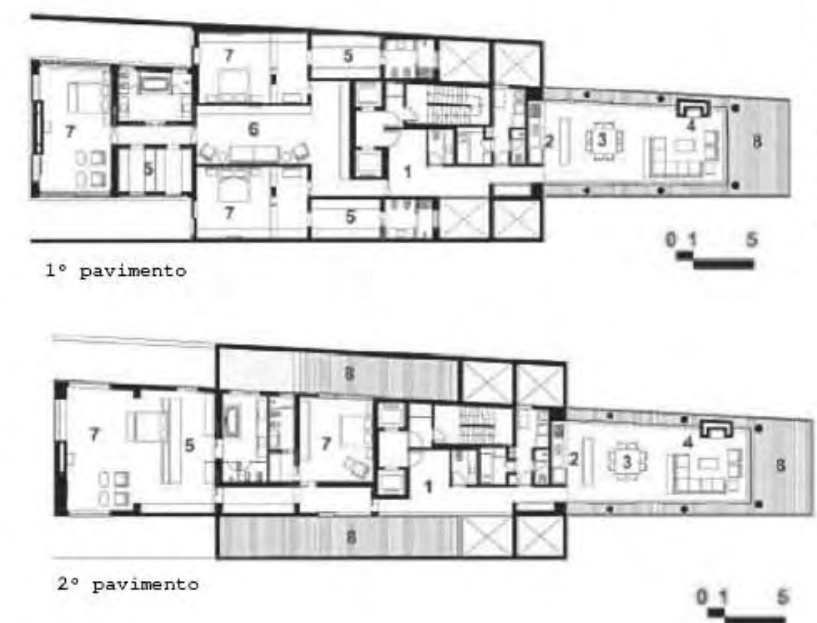

$1^{\circ}$ ao $8^{\circ}$ pavimentos

2. Cozinha

3. Jantaz

5. Closet

pavimento 


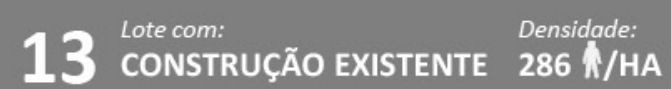

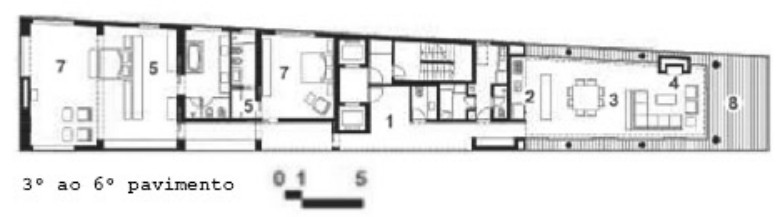

10 ao $8^{\circ}$ pavimento:

1. Hall

2. Cozinha

4. Estar

5. Closet
6. Estar intim

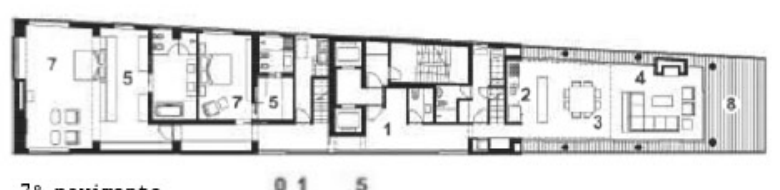

8. terraç

$7 \circ$ pavimento

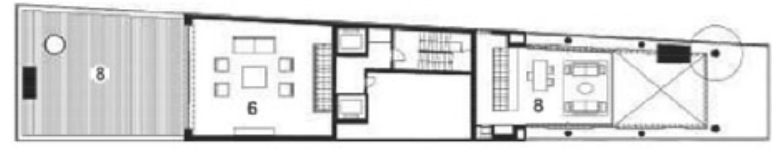

$8^{\circ}$ pavimento
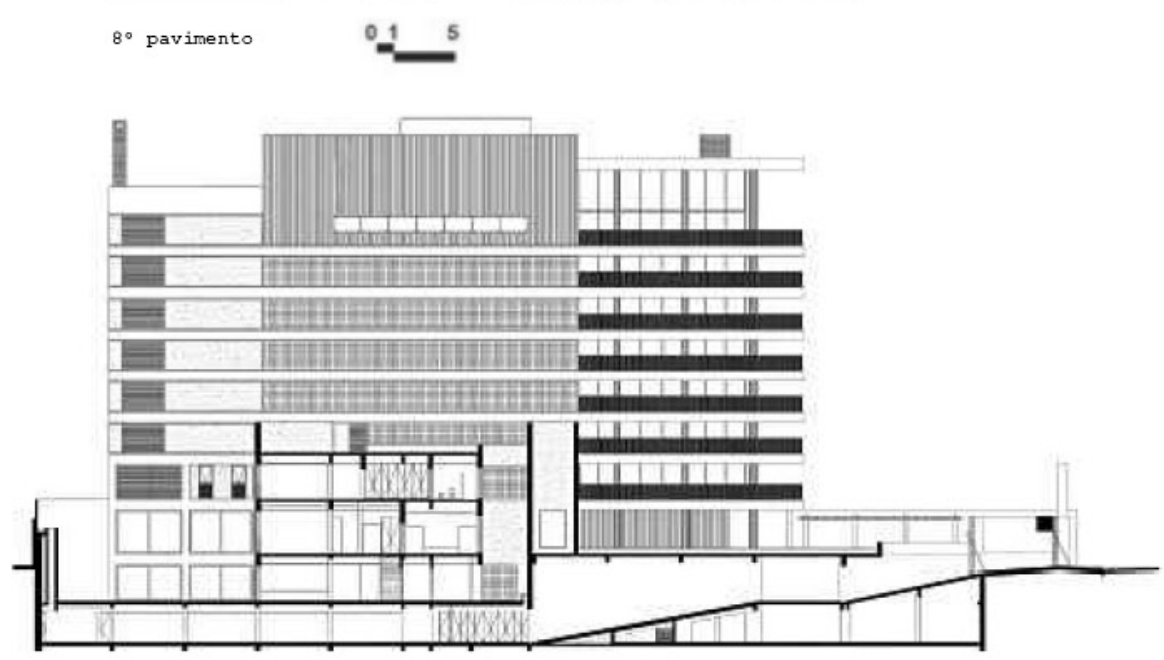

Elevação sudeste

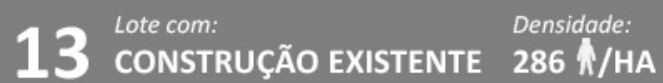

\section{Fontes:}

GRUNOW, Evelise. Retrofit adiciona volume frontal à antiga edificação. ProjetoDesign, São Paulo, n.340, p. 66-71, jun, 2008 .

LEAL, Ledy Valporto. Área livre. Arquitetura e Urbanismo. São Paulo, n.171, p.32-39, junho, 2008

\section{Fotos:}

http://www. isayweinfeld.com/site/

Nelson Kon 

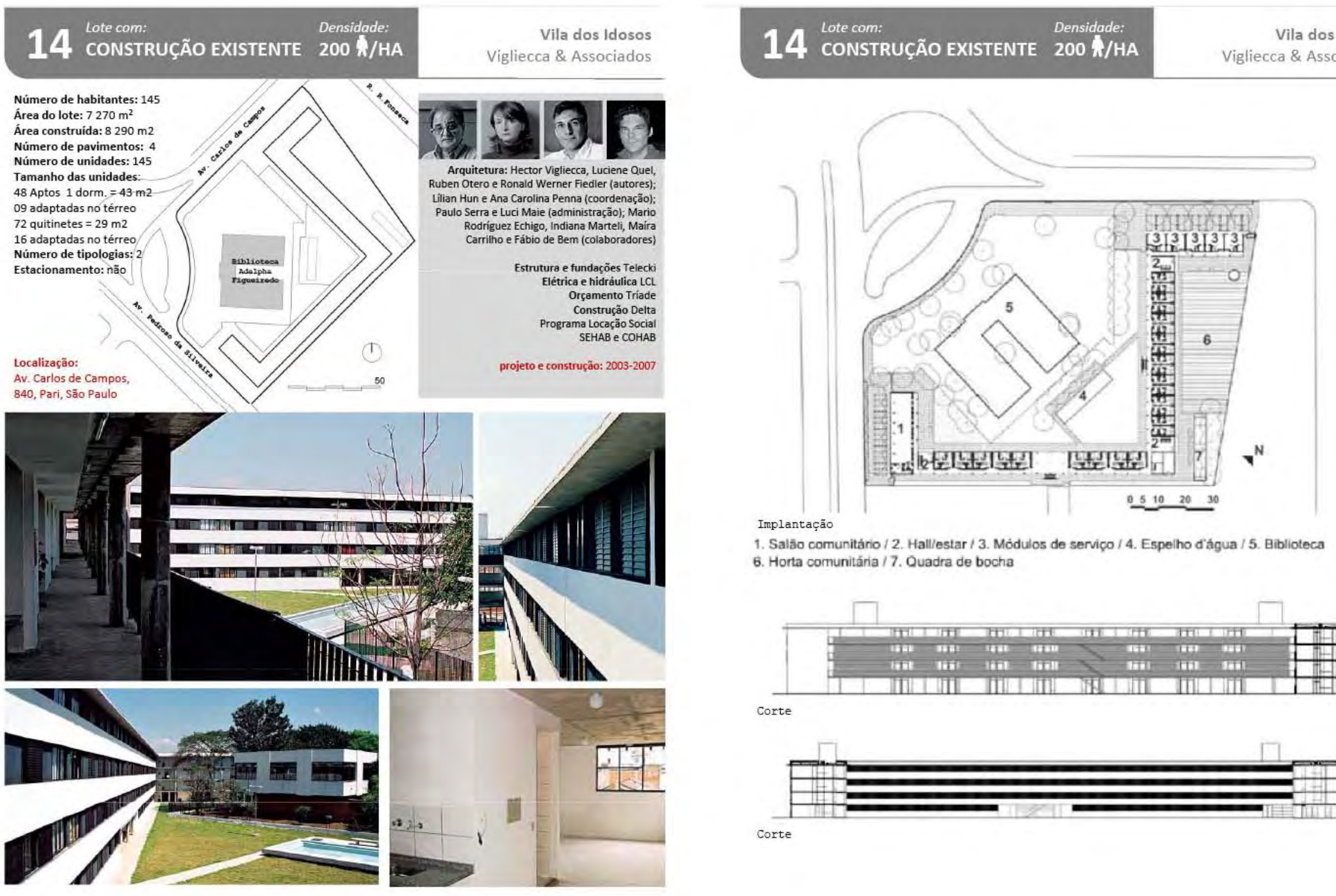

1. Salấo comunitário /2. Hall/estar / 3. Módulos de serviço / 4. Espelho d’água / 5 . Biblioteca 6. Horta comunitária /7. Quadra de bocha

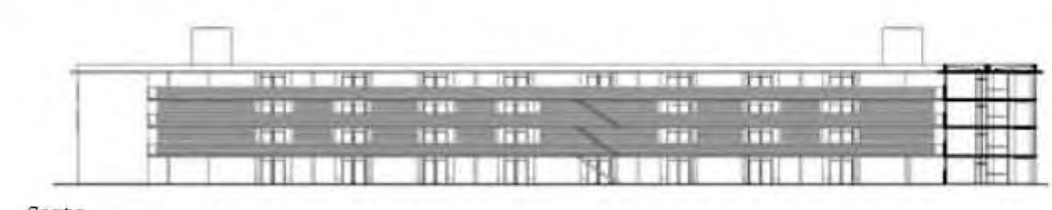
Corte

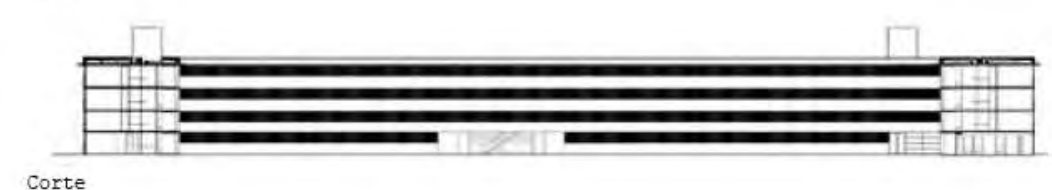




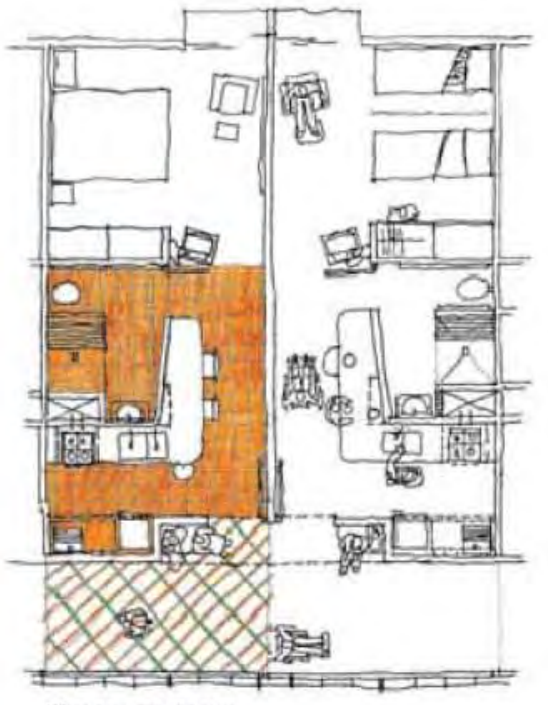

Planta quitinete
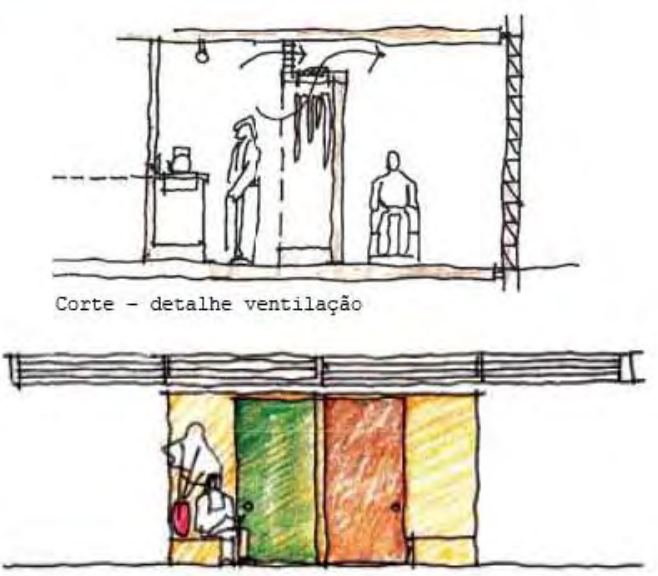

Elevação - entrada do apartamento

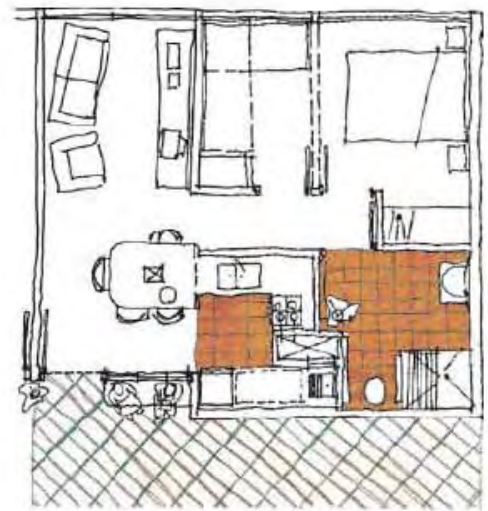

Planta apto. 1 dorm.

\section{Fontes:}

MELENDEZ, Adilson . Moradia para idosos evita exclusão e

busca expor-se à cidade. ProjetoDesign, São Paulo, n.335, p., jan, 2008 .

Propostas de Vigliecca associados para população de baixa renda. Arquitetura e Urbanismo. São Paulo, n.126, p.11, set., 2004.

ALVES, Suelma Inês de Deus. Um modelo de moradia para idosos: o caso da Vila dos Idosos do Pari-São Paulo (SP). Caderno Temático Kairós Gerontologia, 8, São Paulo, novembro 2010: 195-213.

\section{Fotos:}

http://www.vigliecca.com.br/ 


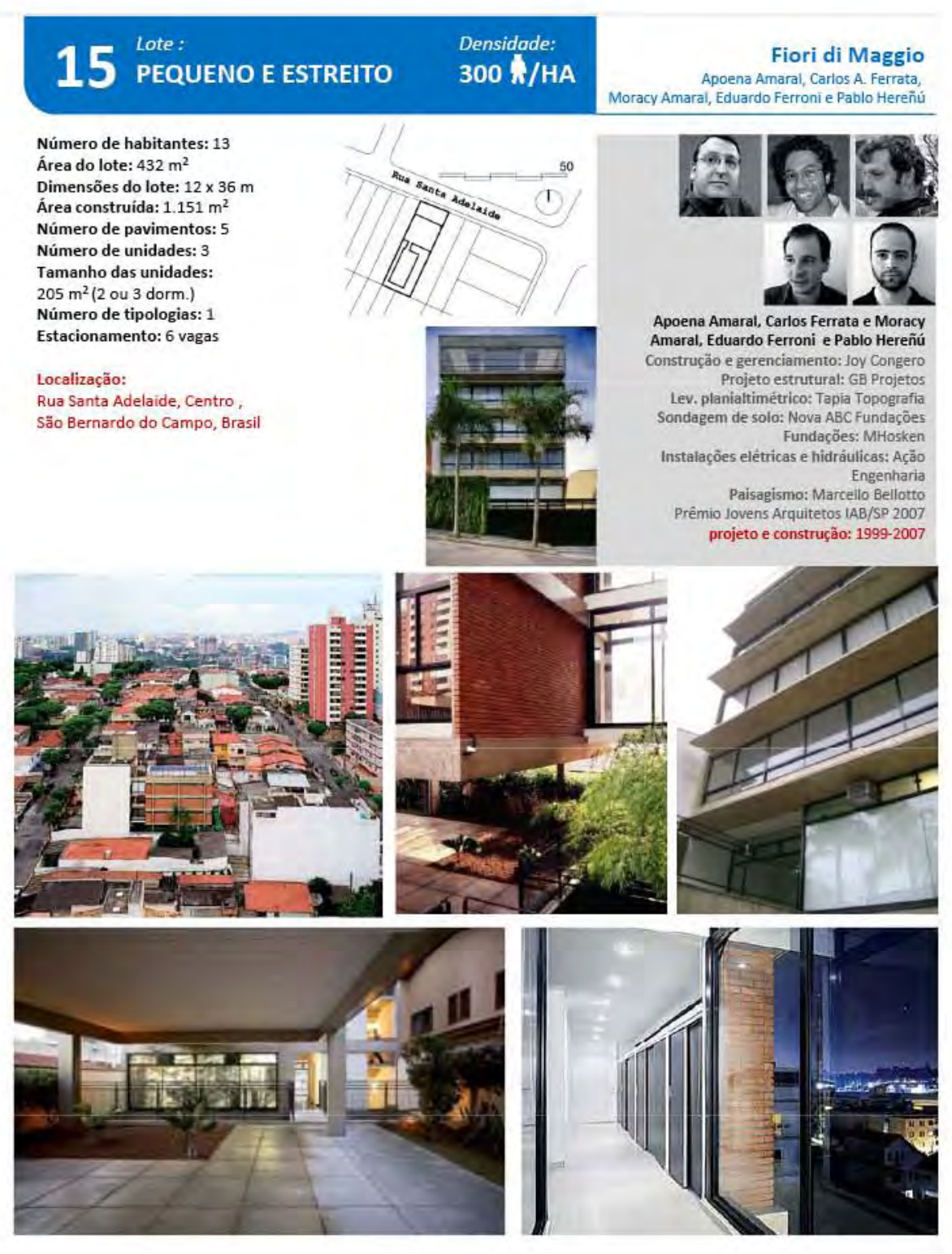
$\begin{array}{ll}15 \text { Lote: } & \text { Densidade: } \\ 300 \text { N/HA } & \text { Fiori di Maggio }\end{array}$ 15 PEQUENO E ESTRETH
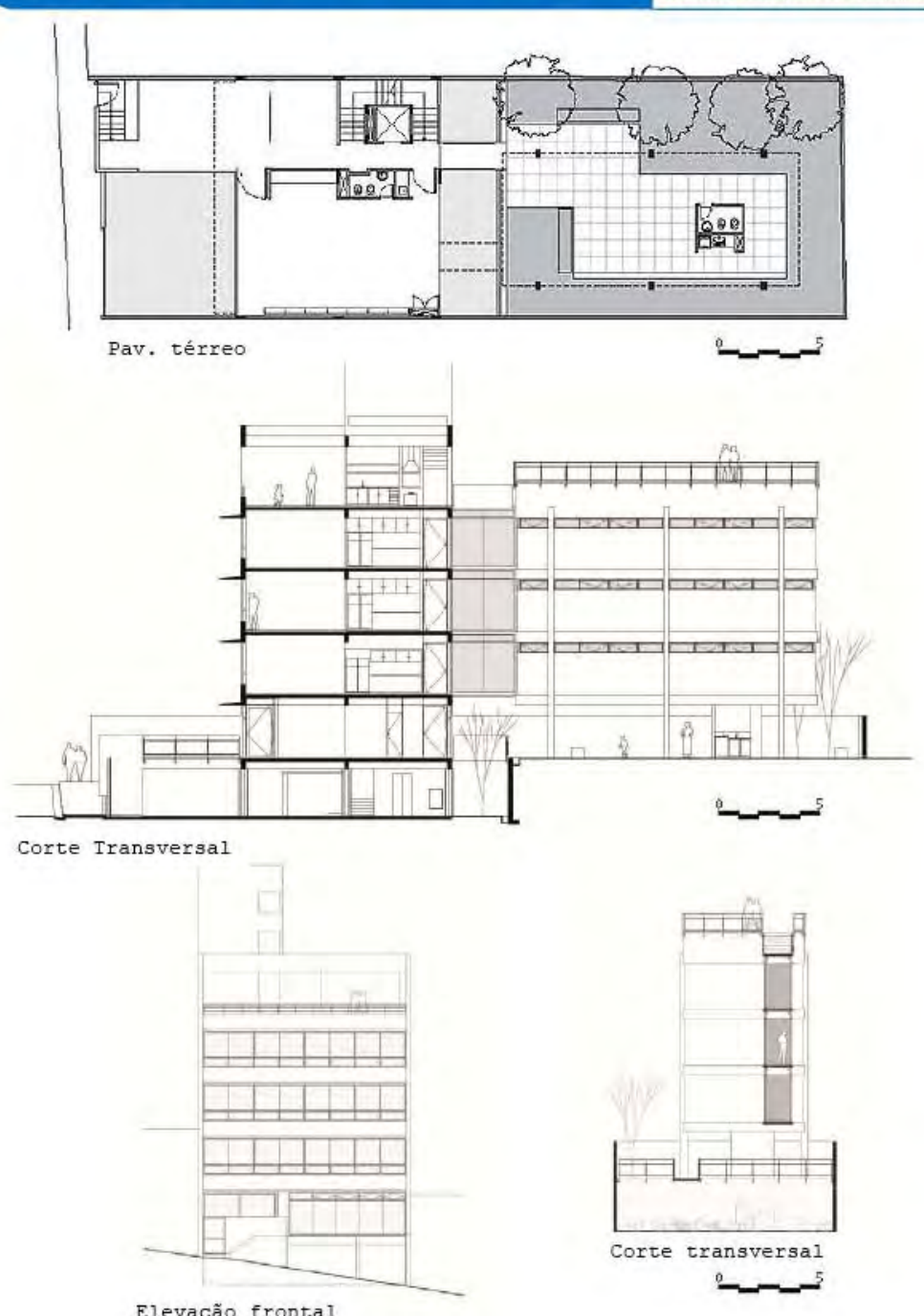

Elevação frontaI 


\section{Lote: \\ PEQUENO E ESTREITO \\ Densidade: \\ Fiori di Maggio Apoena Amaral, Carlos A. Ferrata,}
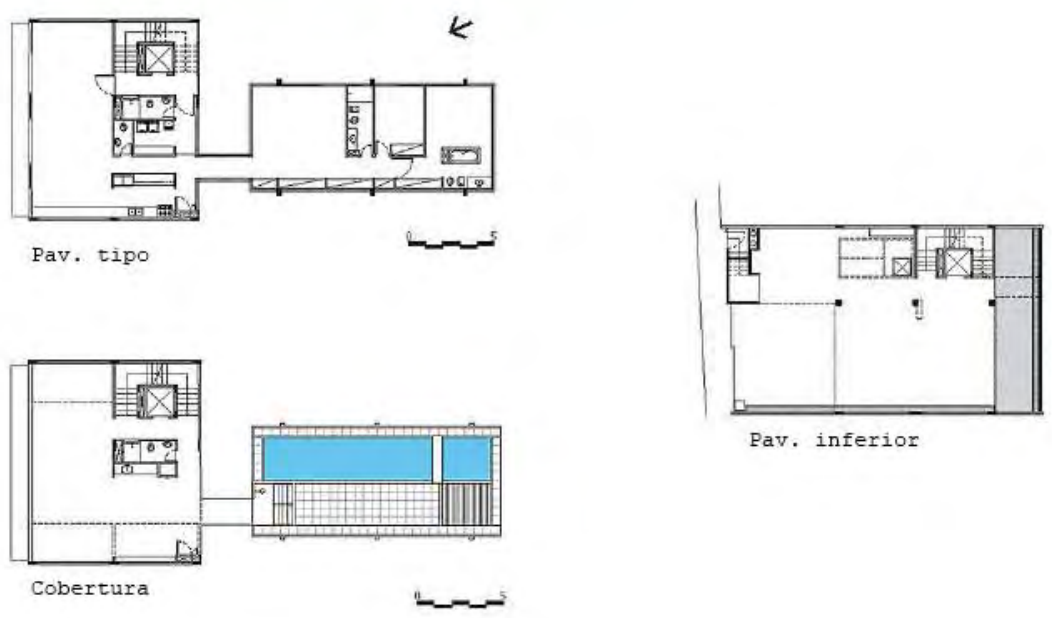

Pav. inferior
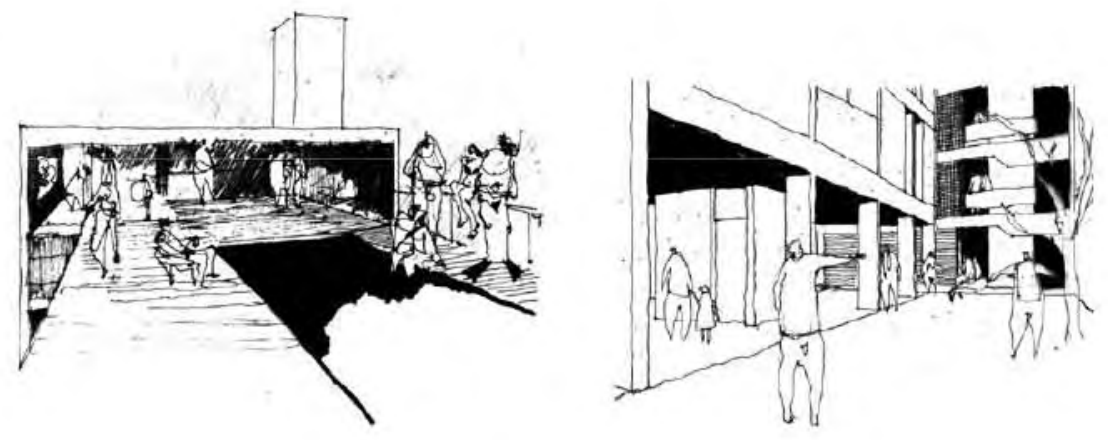

\section{LEte: $\begin{aligned} & \text { Densidade: } \\ & 300 \mathrm{~N} / \mathrm{HA}\end{aligned}$}

Fiori di Maggio Apoena Amaral, Carlos A. Ferrata,

\section{Fontes:}

GRUNOW, Evelise. Partido mantém integridade, apesar da obra tumultuada. Projeto Design, São Paulo, n.353, p. 5053, jul. 2009.

NAKAMURA, Juliana. Repertório de Idéias. Revista

Arquitetura e Urbanismo, São Paulo, n. 162, p. 34-39, set. 2009 .

\section{Fotos:}

Fabricia zulin

Pedro Kok. REGISTROS FOTOGRÁFICOS DE ARQUITETURA. AS obras dos jovens arquitetos da fauusp. Trabalho Final de

Graduação FAU-USP. Junho de 2009. Orientação: Profa Dra Mônica Junqueira de Camargo 


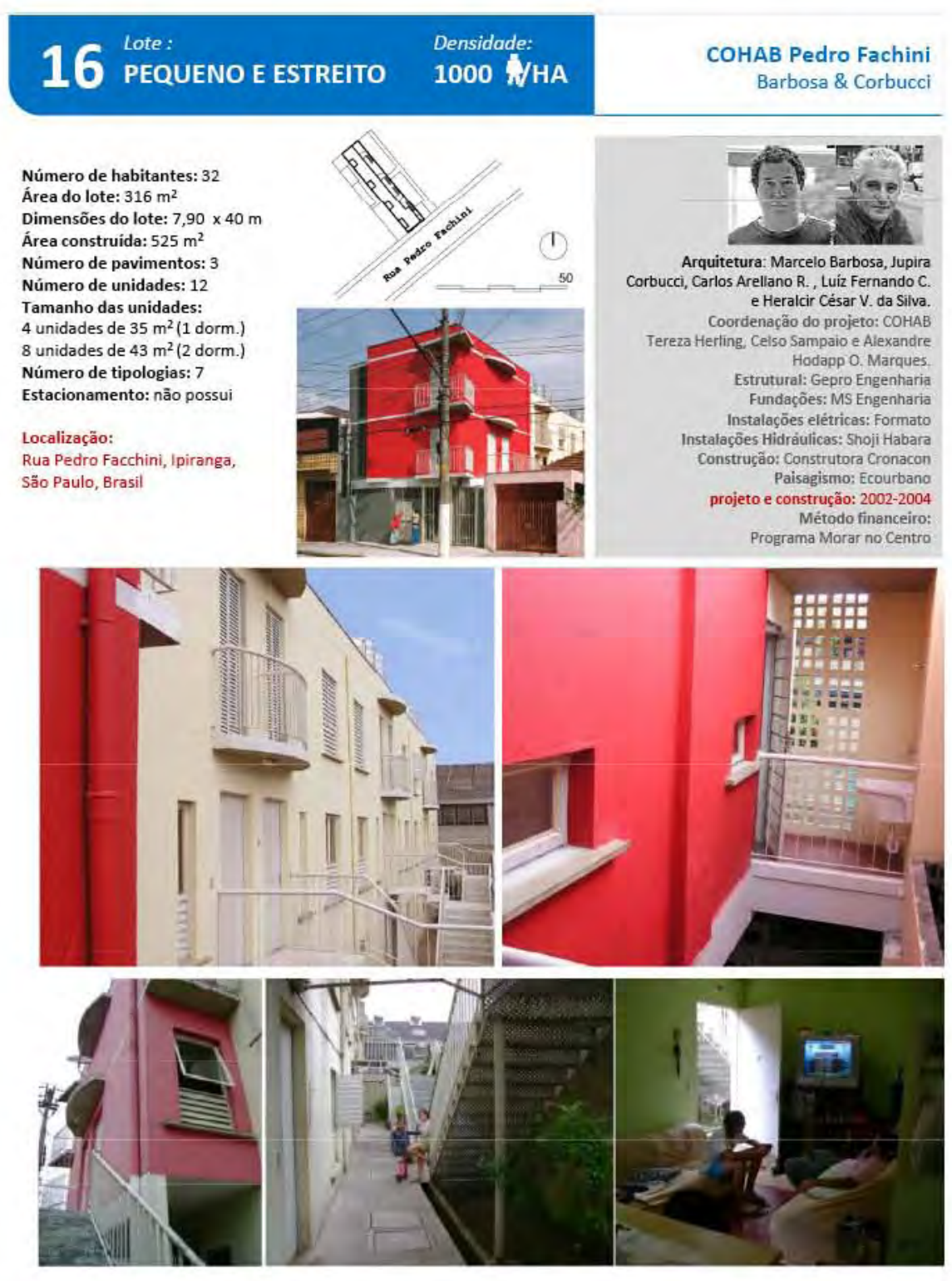

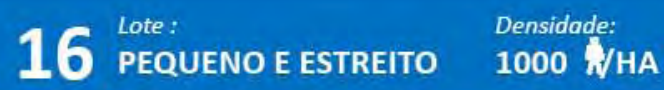

COHAB Pedro Fachini Barbosa \& Corbucci
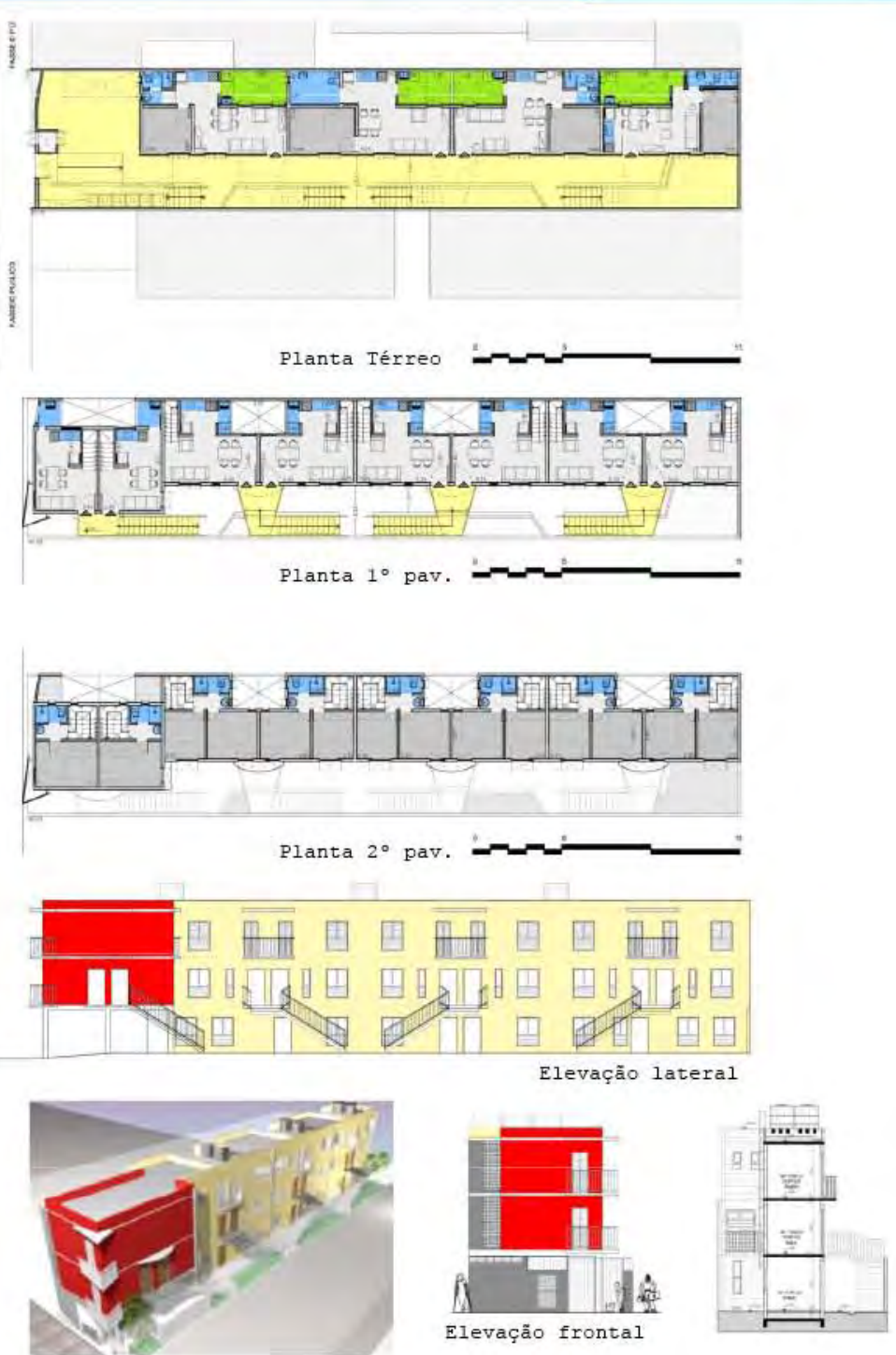


\section{PEQUENO E ESTREITO}

\section{PEQUENO E ESTREITO 1000 W/HA}
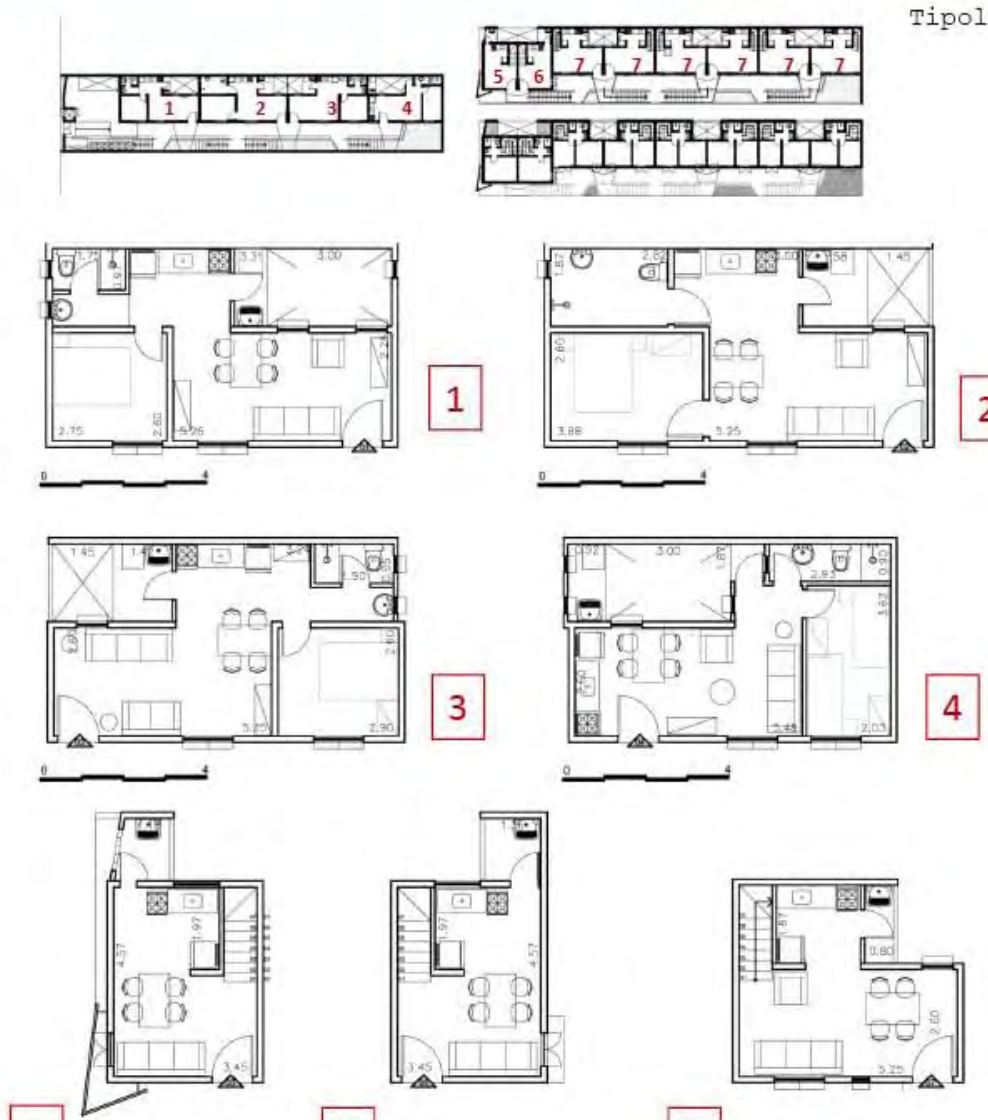

5

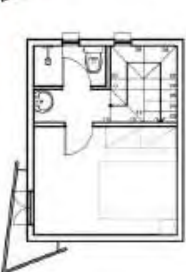

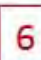

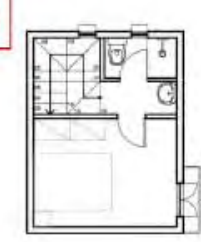

Tipologias

A

Fontes:

GEROLLA, Giovanny.Vila operária.Arquitetura e Urbanismo. São Paulo, n.186, p.27-31, set. 2009

Uma vila vertical. Projeto Design, São Paulo, n.297, p., dez. 2004 .

BARBOSA, Marcelo e CORBUCCI, Jupira . COHAB Pedro Facchini, uma proposta habitacional viável. São Paulo. BRASIL. VI Seminário Internacional da LARES. Latin American Real Estate Society . Set 2006

\section{Fotos:}

Fabricia zulin

http://www.bacco.com.br/ 


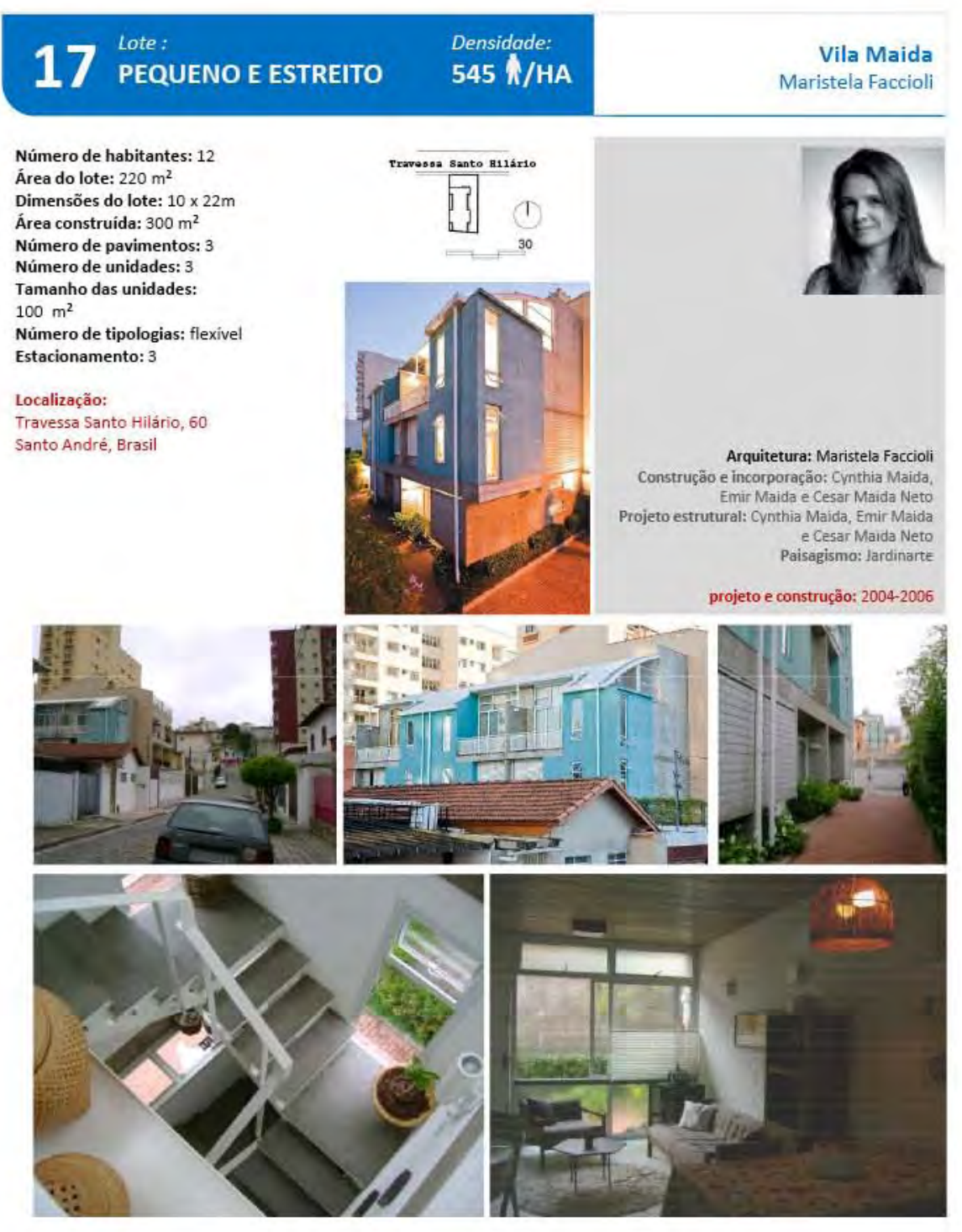

\begin{tabular}{|ll|r}
17 Lete: & $\begin{array}{l}\text { Densidade: } \\
\text { PEQUENO E ESTREITO }\end{array}$ & $\begin{array}{r}\text { Vila Maida } \\
\text { Maristela Faccioli }\end{array}$ \\
\hline
\end{tabular}
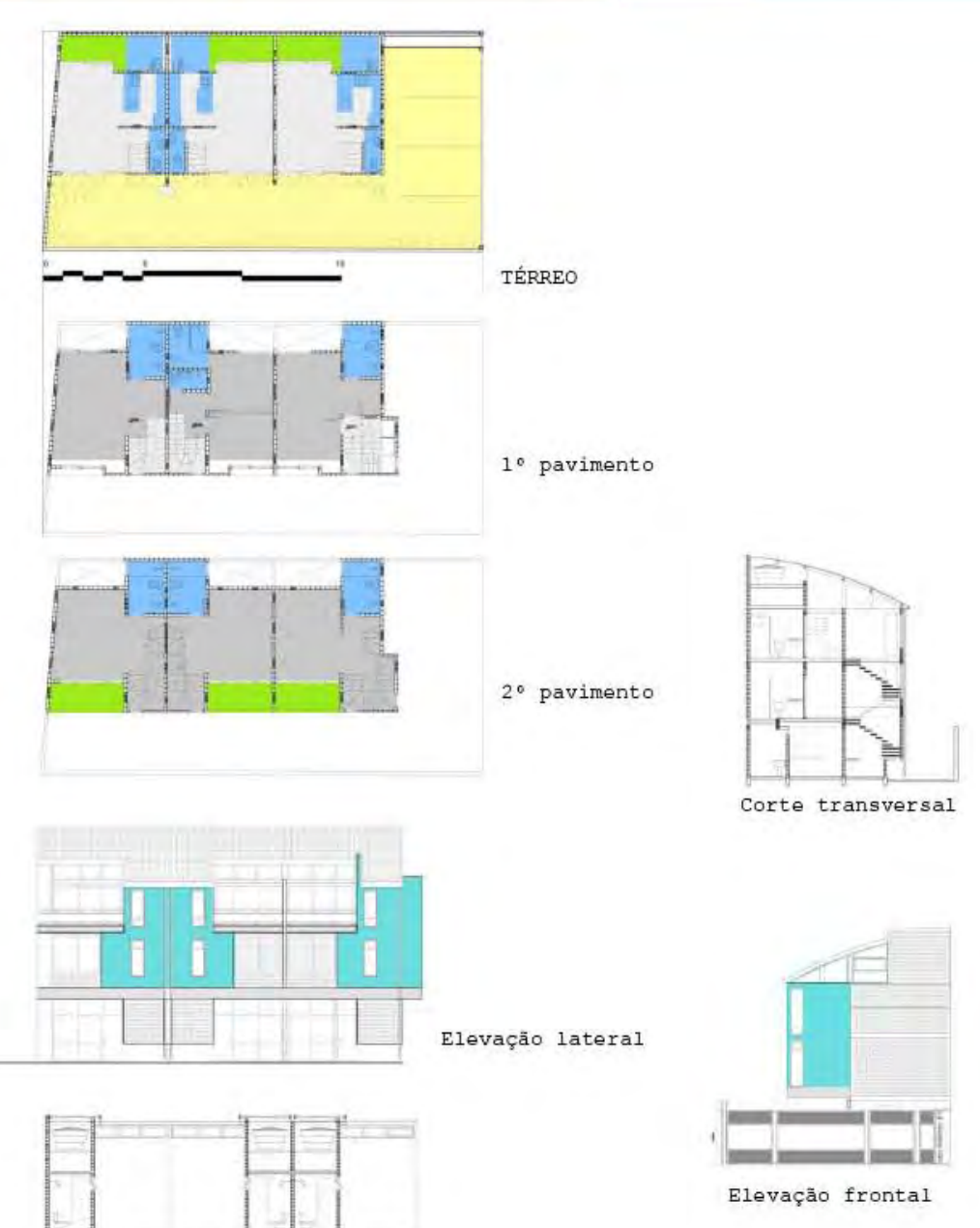


\section{PEQTUENO E ESTREITO
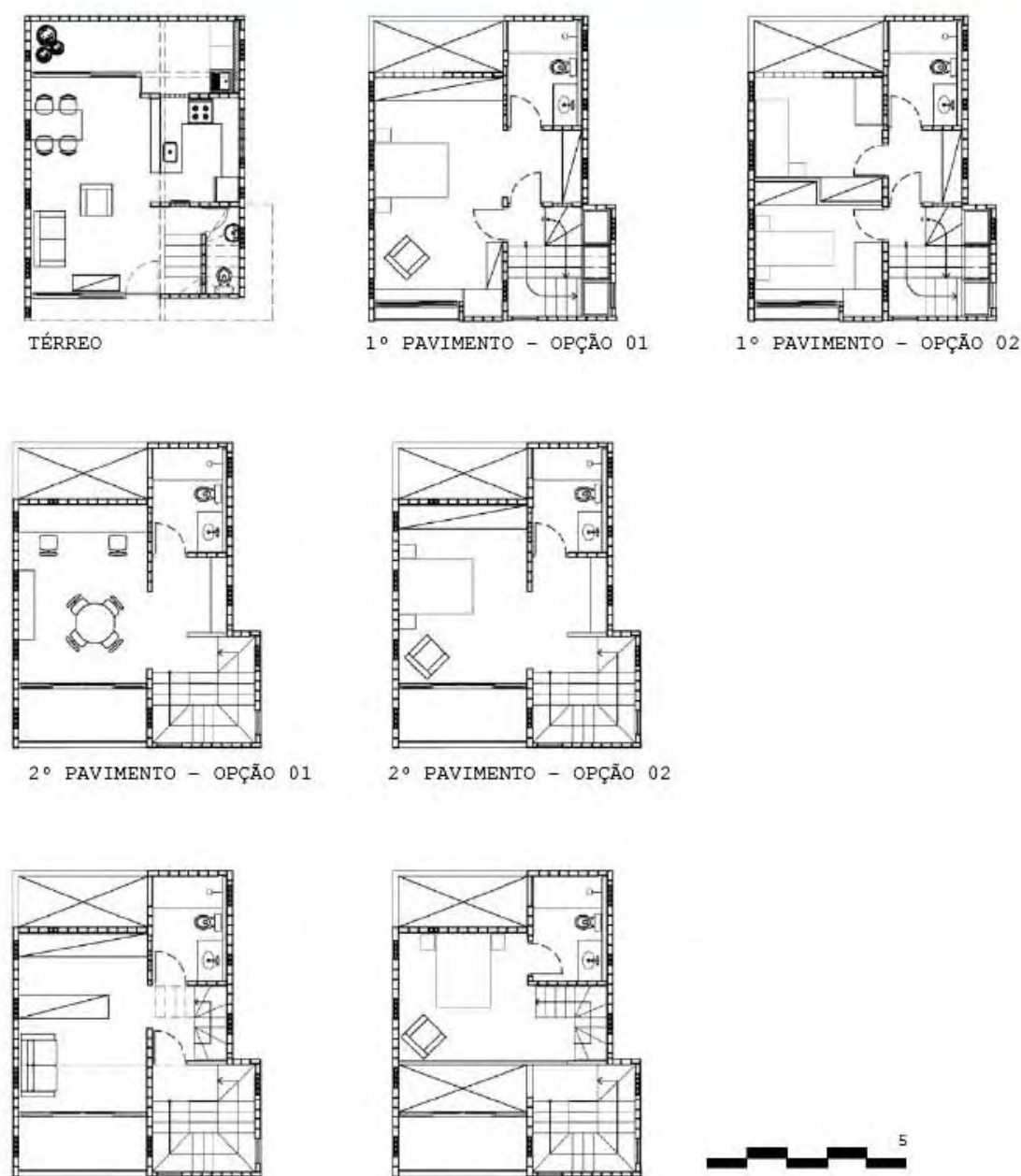

2. PAVIMENTO - OPÇÃ̄O 03

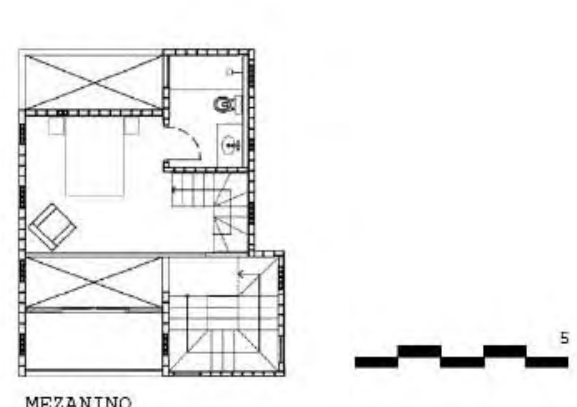

MEZANINO
17 PEQTUENO E ESTREITO
Fontes:

Rosso, Silvana Maria. Vila Flexível. Arquitetura e Urbanismo, São Paulo, n.193, p. 46-51, abril, 2010.

\section{Fotos:}

Fabricia zulin

http://www.maristelafaccioli.com.br/arquitetura/abertura.h $\operatorname{tm} 1$ 


\section{PEQUENO E ESTREITO \\ Densidade: \\ Aimberê Andrade Morettin Arquitetos}

Número de habitantes: 45 Área do lote: $775,89 \mathrm{~m} 2$ Área construida: $3685 \mathrm{~m}^{2}$ 2 sub + térreo + 8 pav. + co Número de unidades: 12 Tamanho das unidades: 95 a $215 \mathrm{~m}^{2}$

Estacionamento: sn

Rua Aimberê, Perdizes,

Săo Paulo, Brasil
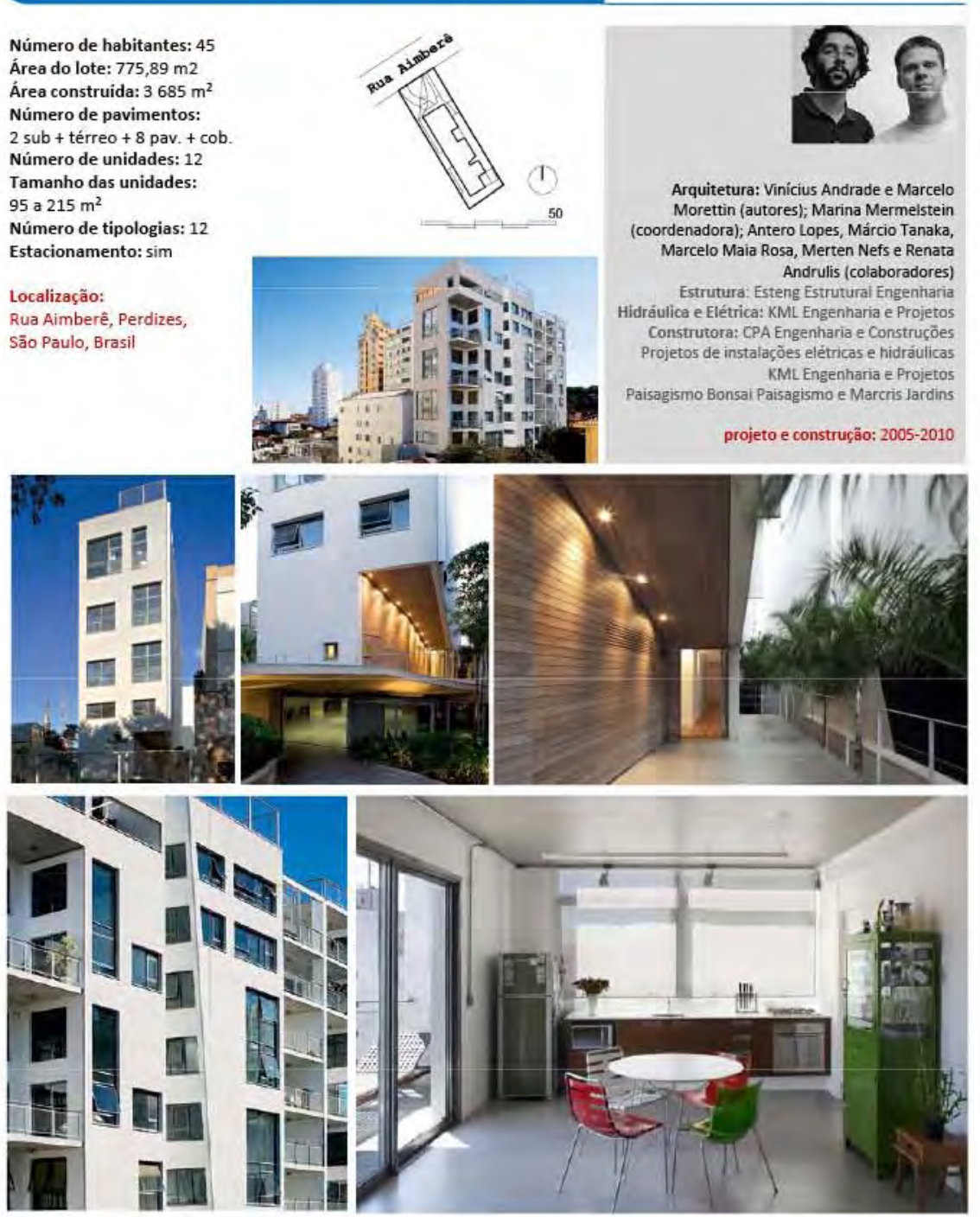

18 PEQUENO E ESTREITO $\quad 580 \% / \mathrm{HA}$

Aimberê Andrade Morettin Arquitetos
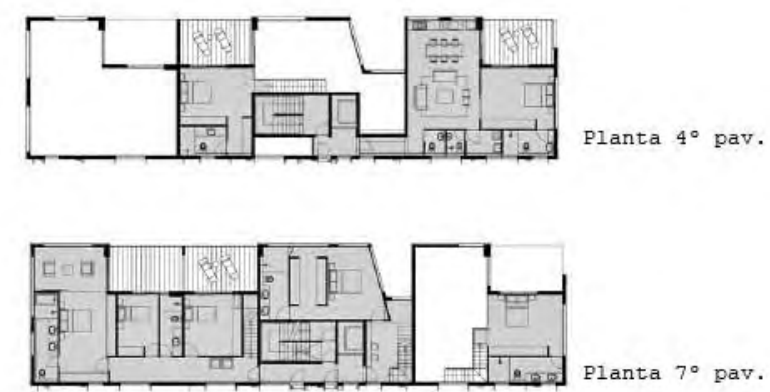

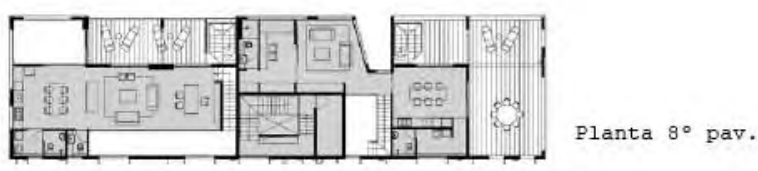

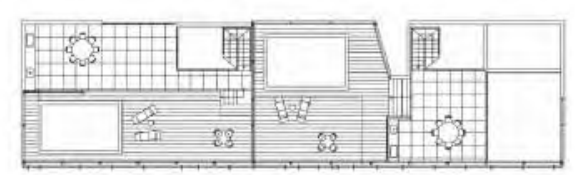




\section{$18{ }^{\text {Lote: }}$ Prov \\ PEQ: : \\ PEQUENO E ESTREITO \\ Densidade: \\ $580 \% / H A$ \\ Andrade Morettin Arquitetos}

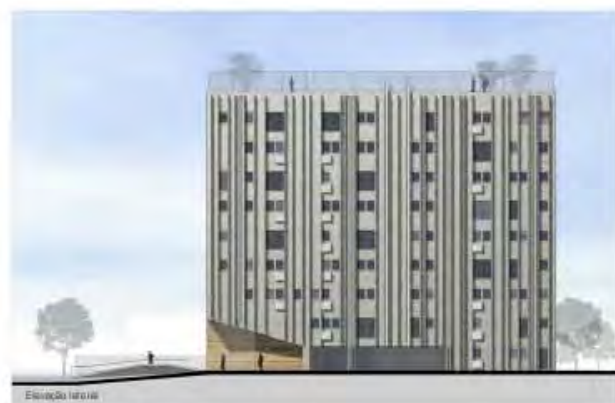

Elevação lateral

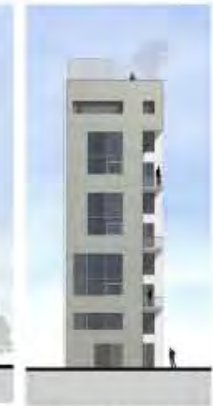

Elevação posterior

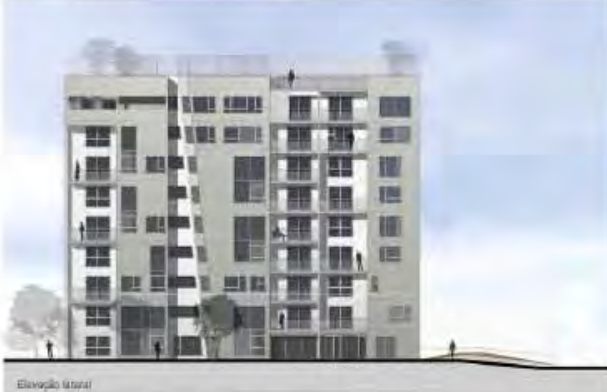

Elevação latera1

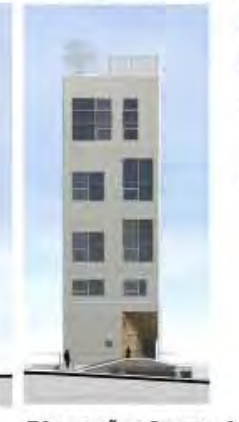

Elevação frontal

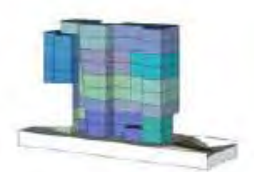

18 Lote:

PEQUENO E ESTREITO

\section{Fontes:}

A reação ao neoclássico e a promessa para o futuro. Projeto Design, São Paulo, n.371, p. 89, jan. 2011.

MELENDEZ, Adilson.Diversidade de tipologias e medidas, em desenho inusitado. Projeto Design, São Paulo, n.353, p. 62 - 67, jul. 2009 .

Investidores trazem nova proposta de arquitetura aos edifícios residenciais paulistanos. Ar Urbanismo, São Paulo, n.161, p.12, ago. 2007.

Variación y flexibilidad. SUMMA + , Buenos Aires, n. 107, p. 28-33, abril 2010 .

Edifício de apartamentos na rua Aimberê. Monolito, São Paulo, n.II, p. 72-79, abril/maio 2011.

\section{Fotos:}

Fabricia Zulin

http://www . andrademorettin.com.br/ 


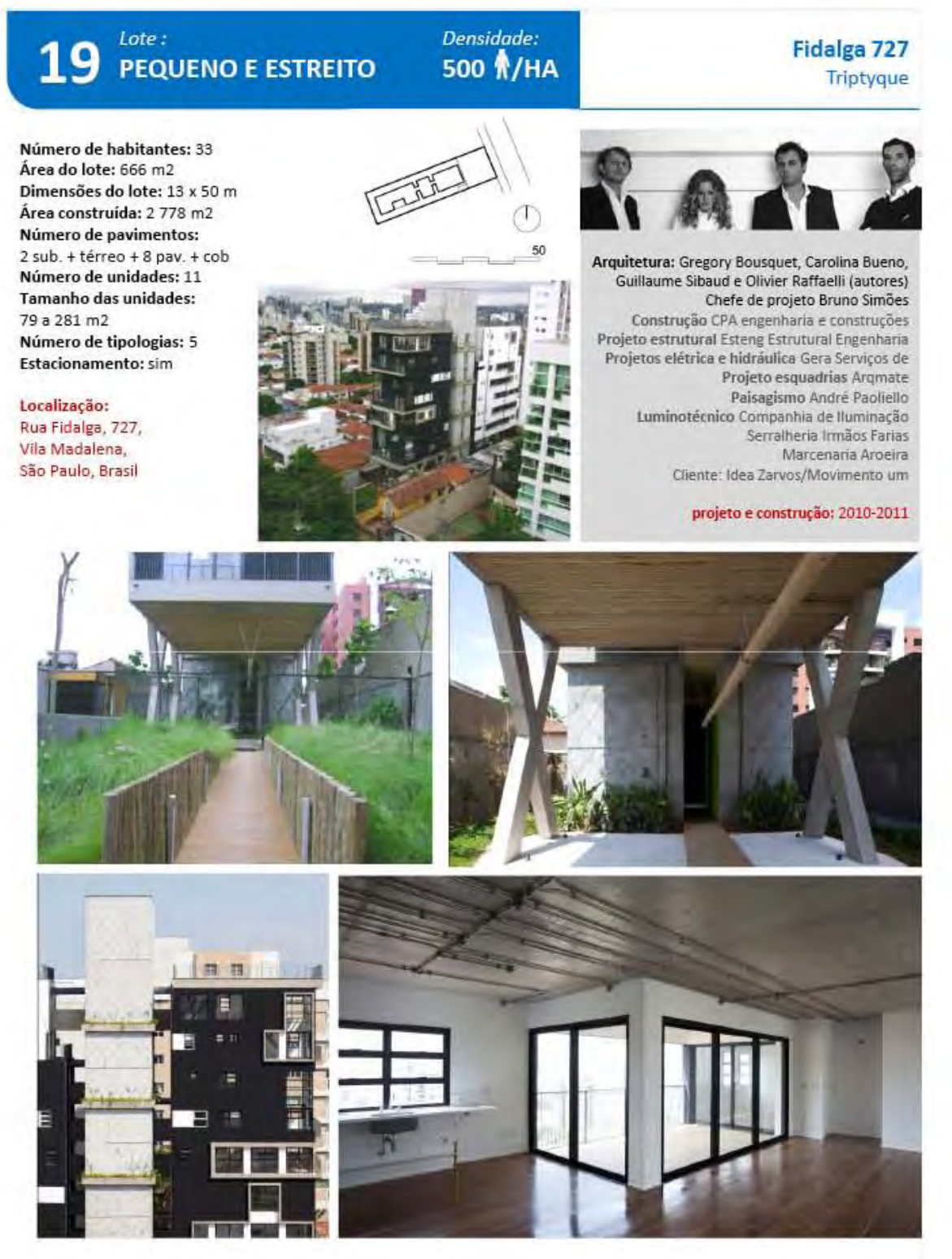

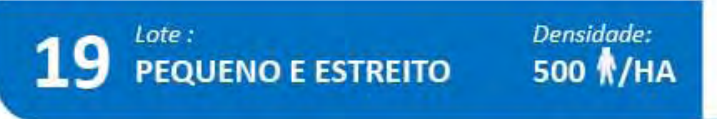

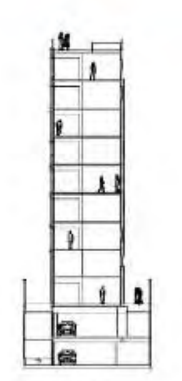

Corte AA
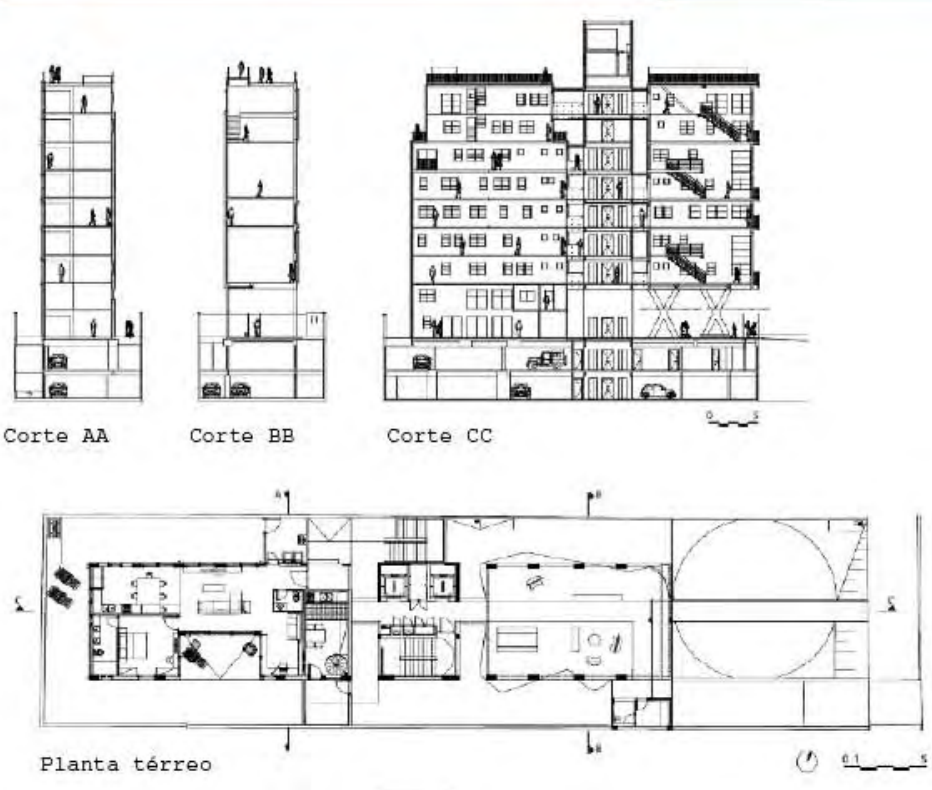

Planta terreo

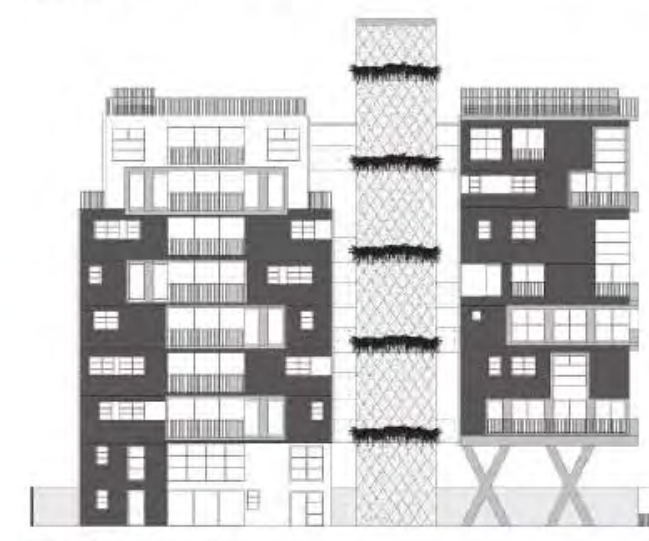

Elevaçăo latera1 
19 PEQUENO E ESTREITO $\quad \begin{aligned} & \text { Densidade: } \\ & 500 \mathrm{~N} / \mathrm{HA}\end{aligned}$

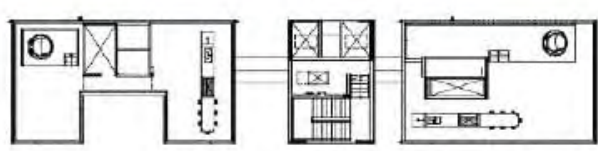
90 pavimento

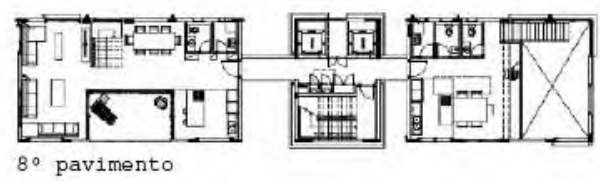

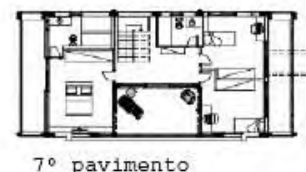

$7^{\circ}$ pavimento

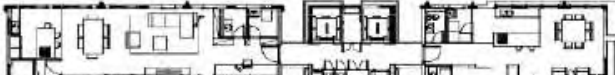
造 $4^{\circ}$ pavimento

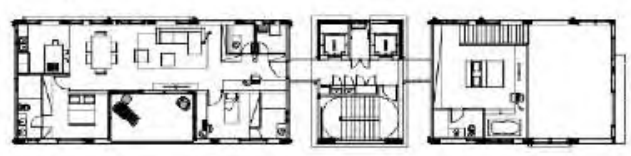

30 e 60 pavimento

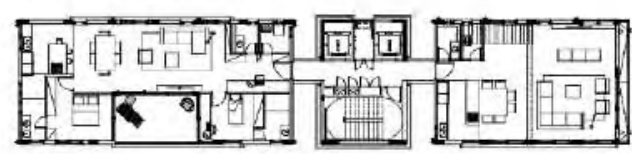
$2^{\circ}$ e $5^{\circ}$ pavimento

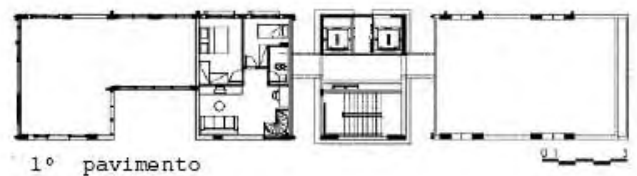

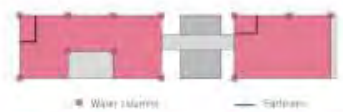
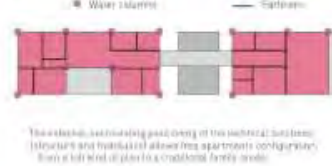

mevare puacu
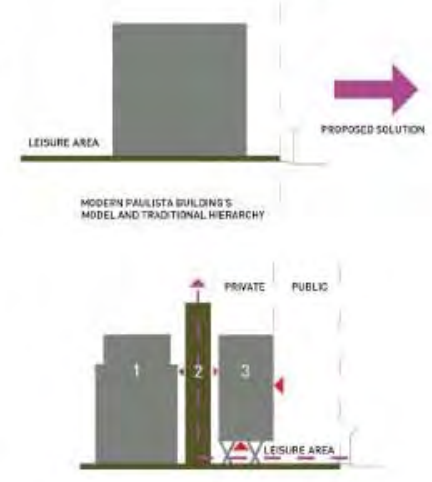

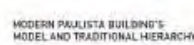
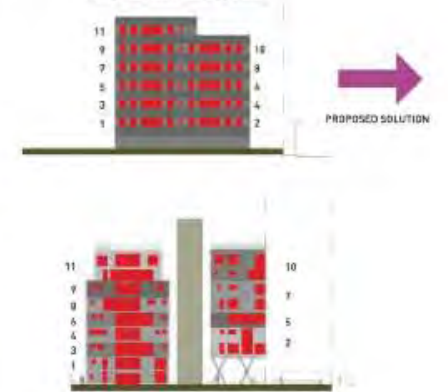

19 Lote:

PEQUENO E ESTREITO

Densidade:
Fontes :

SAYEGH, Simone, Um diferente do outro. Revista

Arquitetura e Urbanismo, São Paulo, n. 203, p. 24-29, jan. 2011.

SERAPIÃo, Mudança de ares. Projeto Design, São Paulo, n. 353 , p. $68-79$, jul. 2009.

Fotos:

Fabricia Zulin

http://www.triptyque.com/

Acervo escritório Triptyque 
lote:

PEQUENO E ESTREITO

$600 \mathrm{~N} / \mathrm{HA}$

Maiorca

Número de habitantes: 36

Área construida: 3300

Número de pavimentos: 9

2 garagens +5 pavimentos +

Apto cobertura (2 pav.)

Número de unidades: 6

Tamanho das unidades:

Nímero

Localização:

Bom pastor, Juiz de fora,

Minas Gerais, Brasil

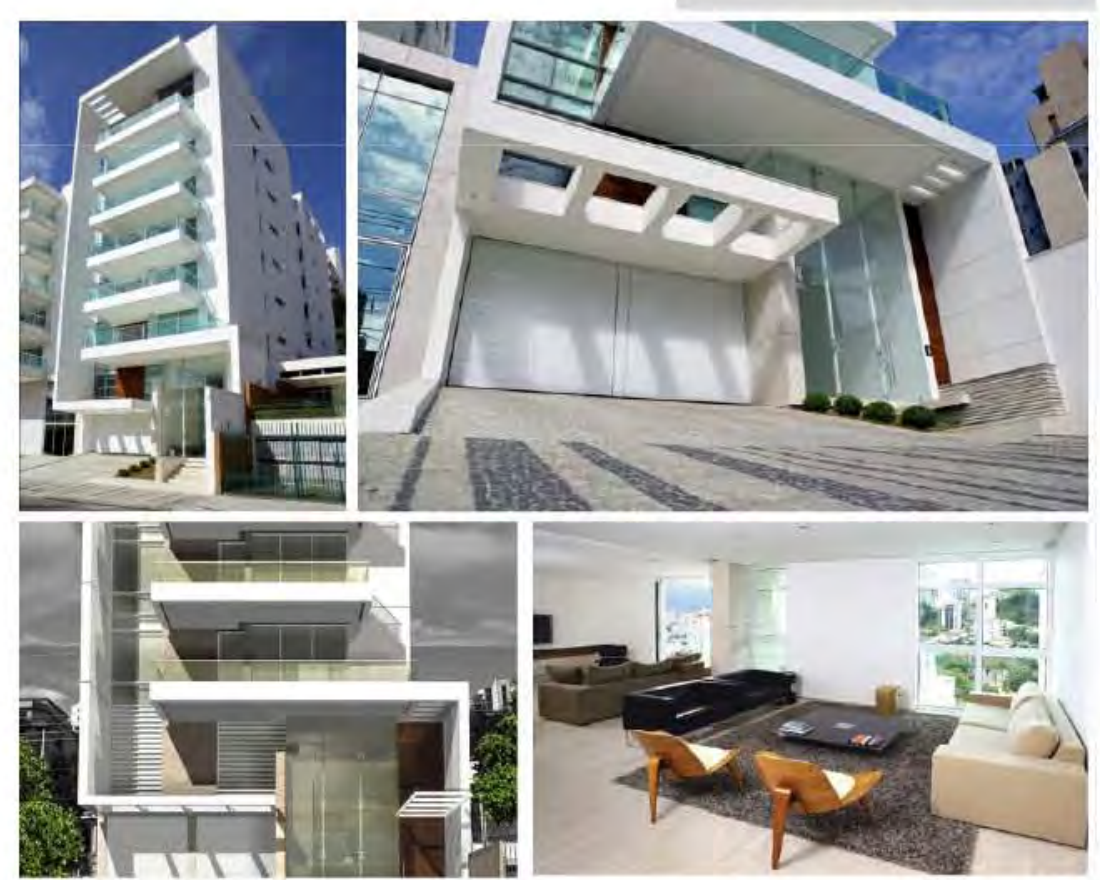

Lourenço Sarmento Arquitetos
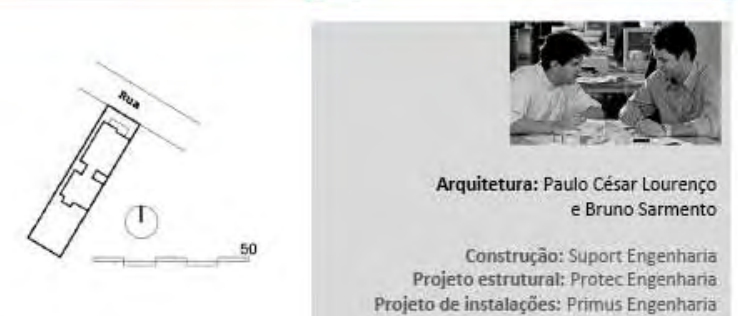

projeto e construçâo: 2005-2007

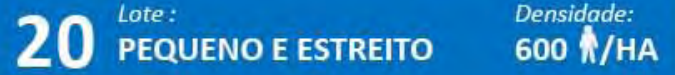

Maiorca
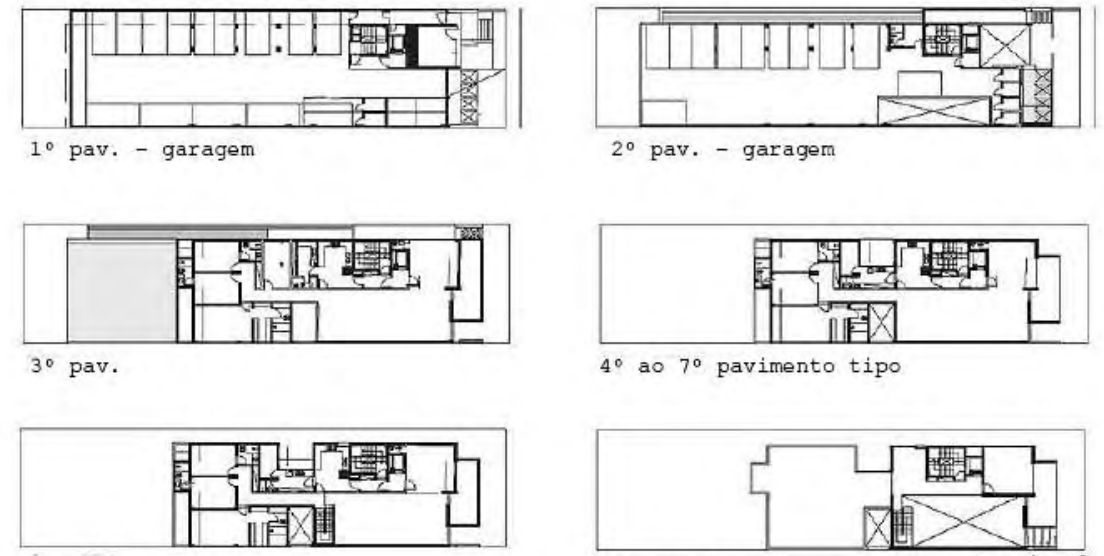

Cobertura inferior
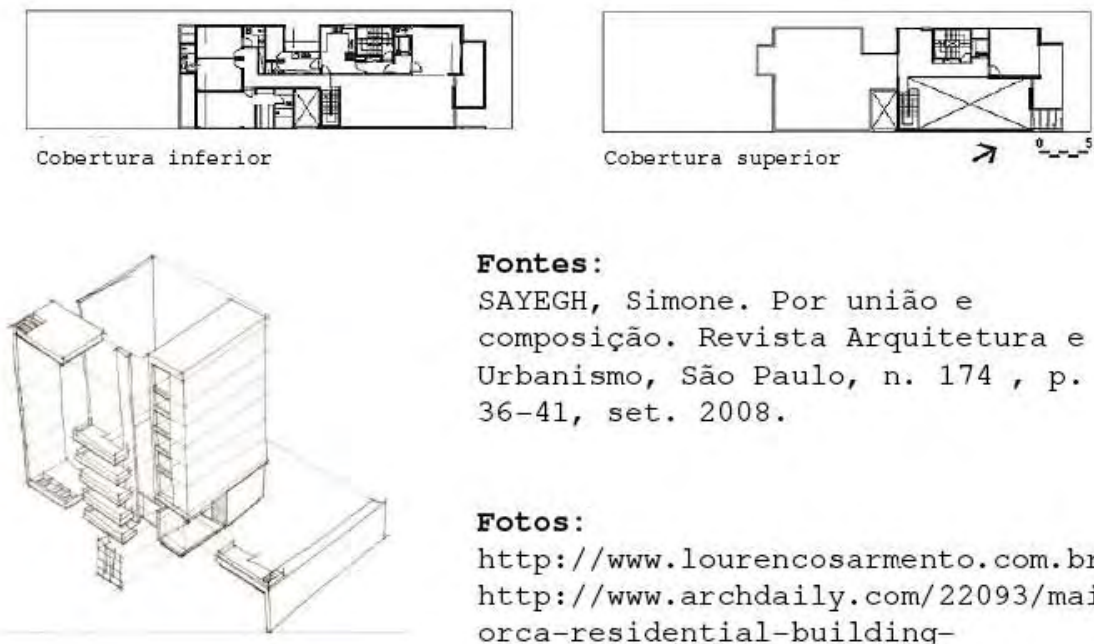

Fontes :

SAYEGH, Simone, Por união composição. Revista Arquitetura e Urbanismo, São Paulo, n. $174, \mathrm{p}$. $36-41$, set. 2008 .

\section{Fotos:}

http://www. lourencosarmento.com. br http://www.archdaily.com/22093/mai orca-residential-building-

lourenco-sarmento/ 


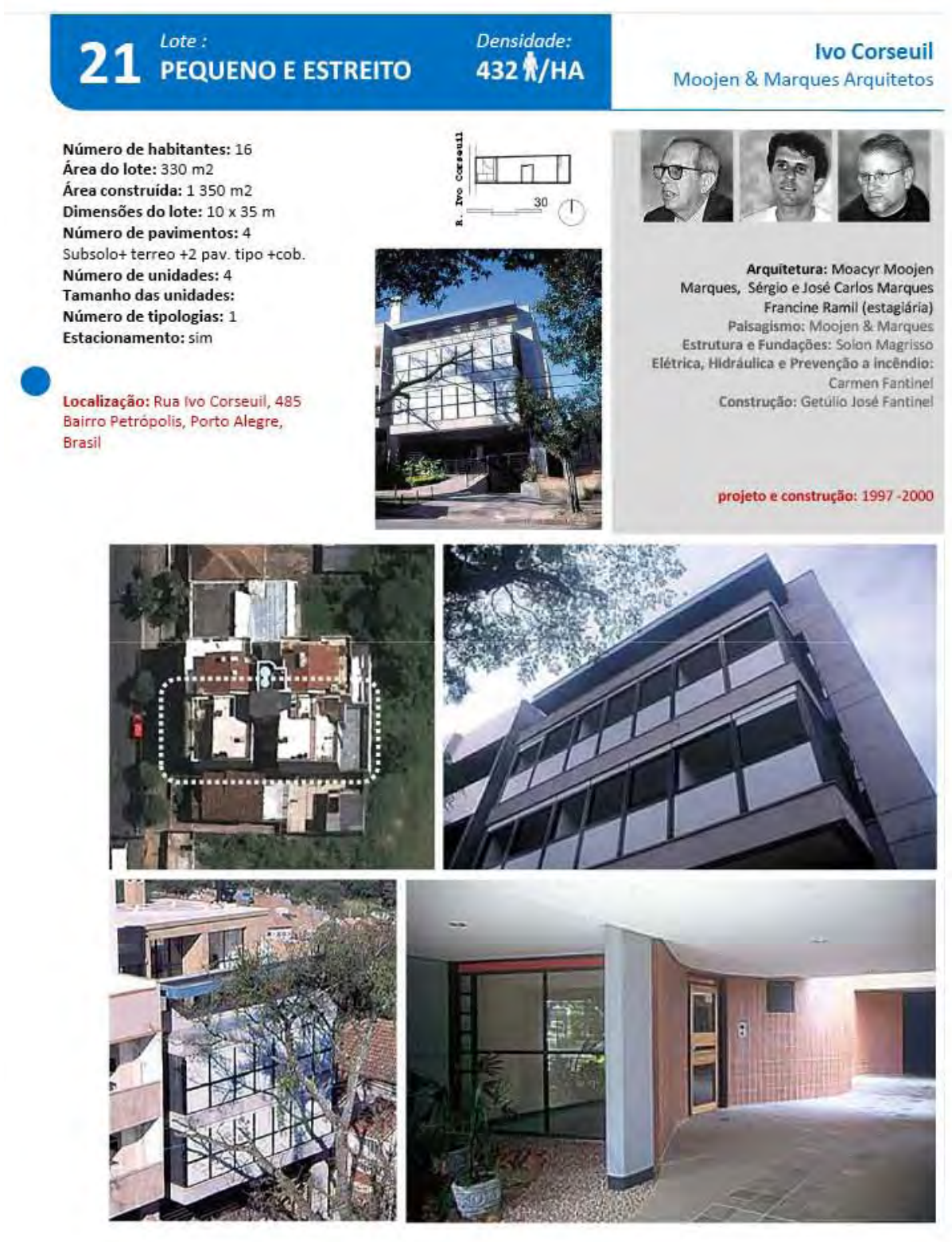

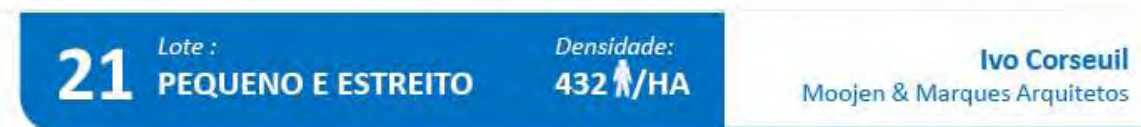
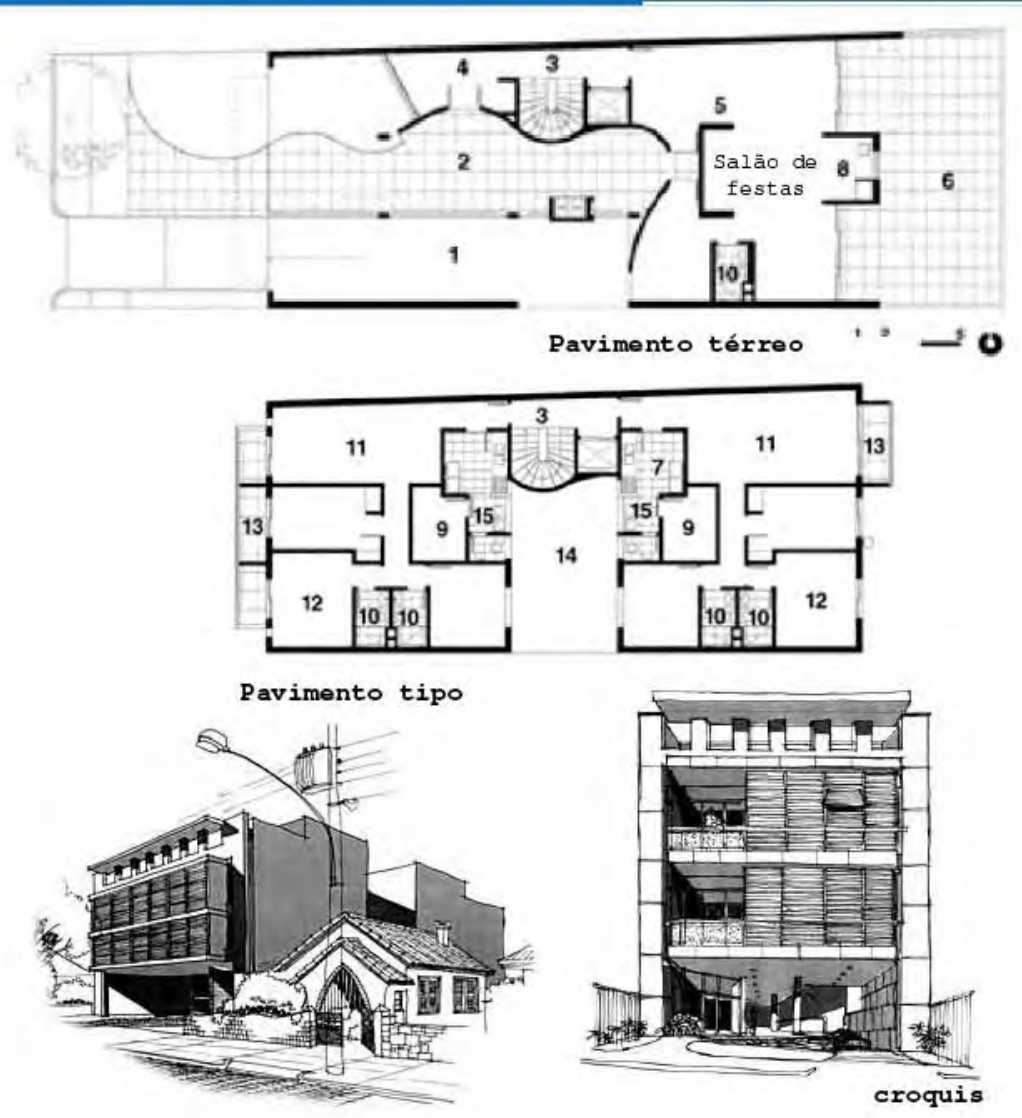

Fontes:

MELENDEZ, Adilson. Discreto e elegante: Moderno. Projeto Design, São Paulo, n. 260 , out. 2001. 


\section{Lote:}

Densidode:
$583 / \mathrm{HA}$

Montevidéu 285

Número de habitantes: 28

Área do lote: $480 \mathrm{~m} 2$

Área construida: $1500 \mathrm{mo}$

Número de pavimentos: 7

Apto cobertura

Número de unidades: 7

Tamanho das unidades:

Tí $\mathrm{A} 260 \mathrm{~m} 2$

Número de tipologias: 3

Localização: Rua montevidéu, 285 Sion, Belo Horizonte, Minas Gerais, Brasil
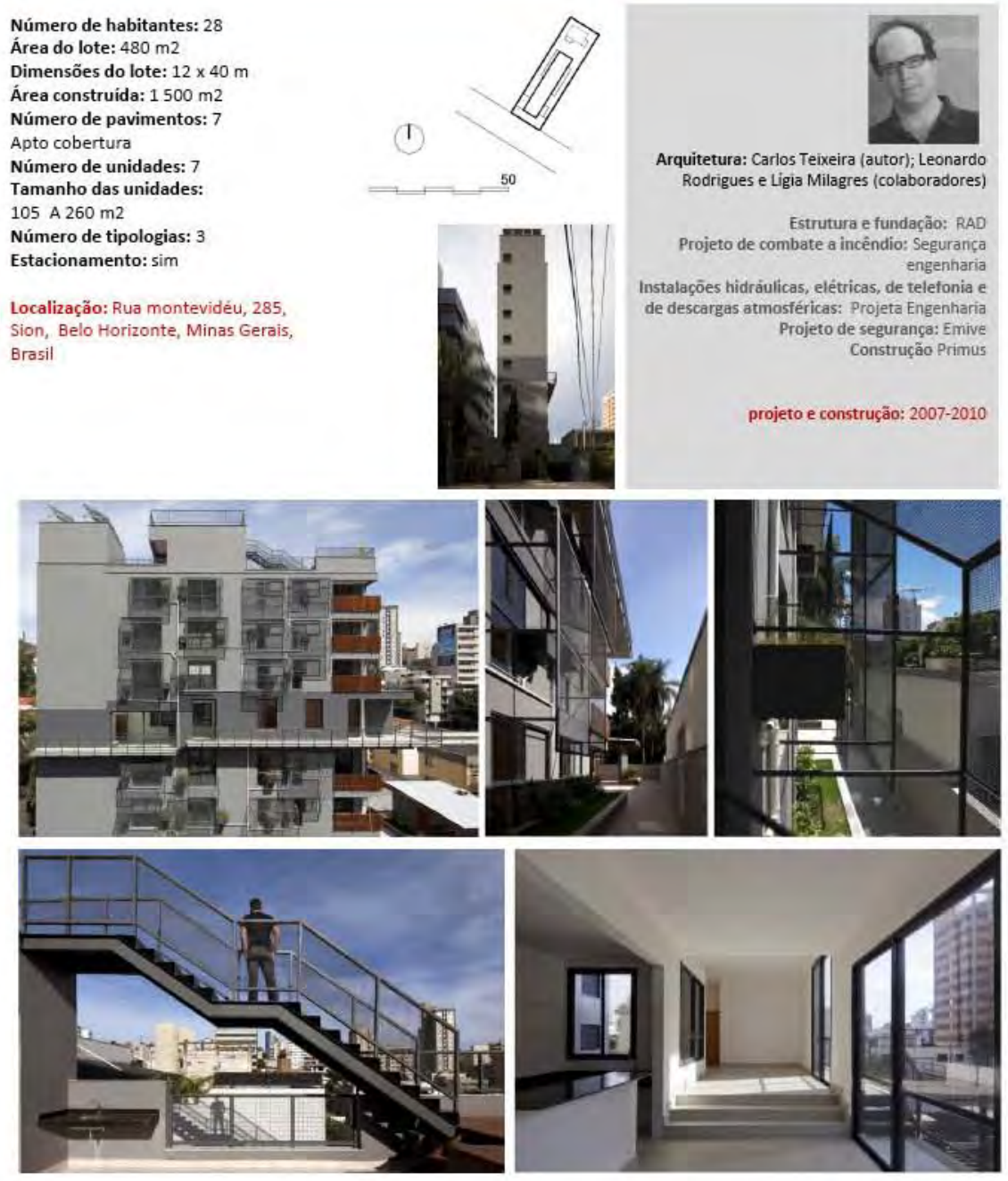

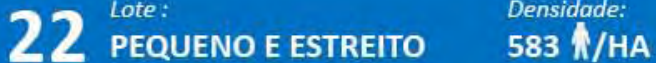

Montevidéu 285 Vazio Arquitetura

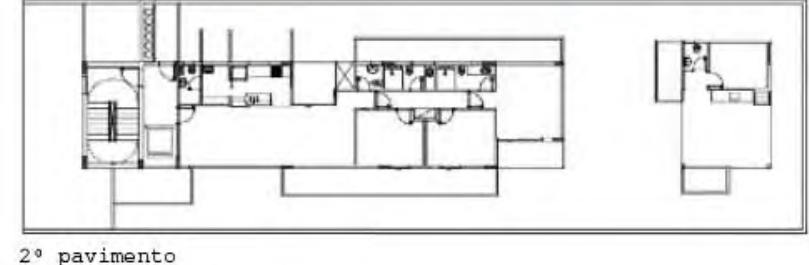

$2^{\circ}$ pavimento

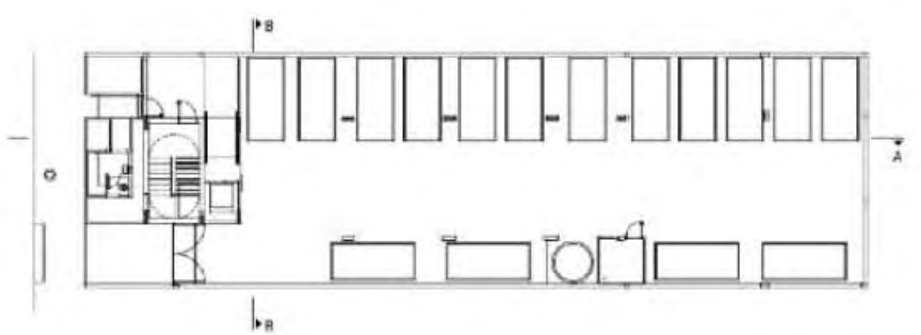

Térreo / garagem
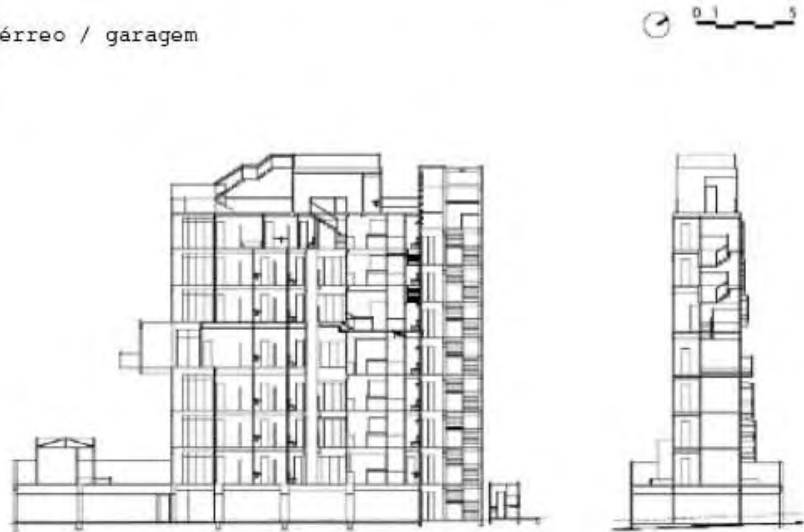

Corte $A A$

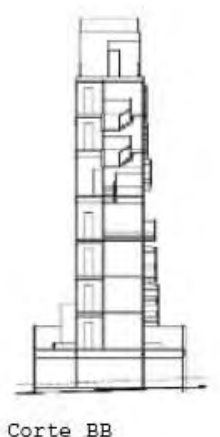




\section{Lote: Pequeno e estreito

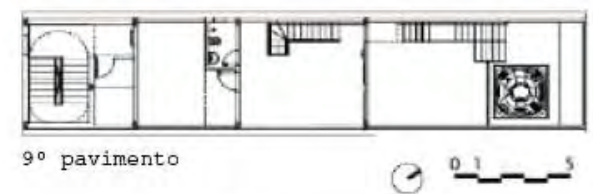

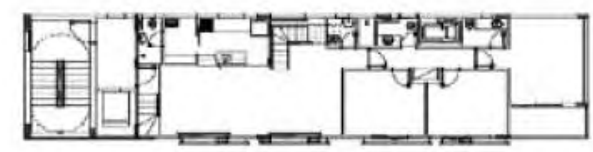

80 pavimento

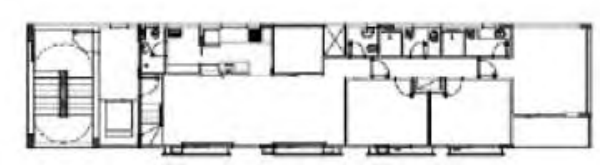

$7^{\circ}$ pavimento

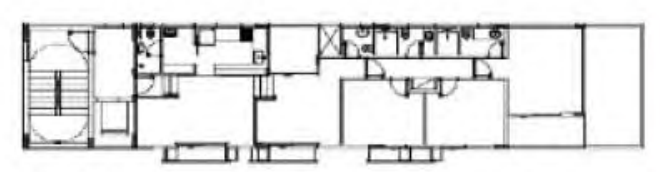

$6^{\circ}$ pavimento

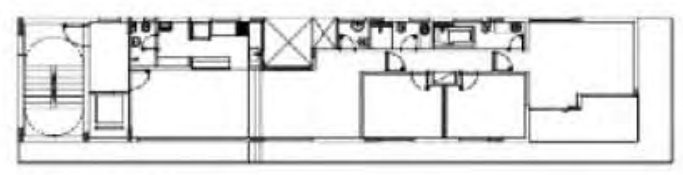

$5^{\circ}$ pavimento

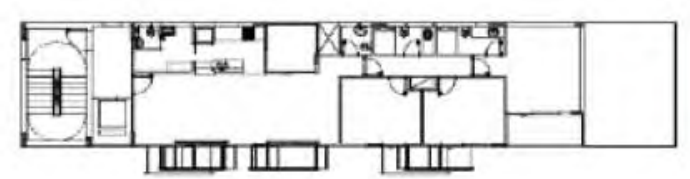

$3^{\circ}$ e $4^{\circ}$ pavimento
22 Lote:

Fontes:

Rosso, Silvana Maria. Arquiteto Incorporador. Revista Arquitetura e Urbanismo, São Paulo, n.205, p. 26-31, abril 2011.

CORBIOLI, Nanci. Plantas flexíveis agregam valor à escala reduzida. Revista Projeto Design, São Paulo, n. 360 , p. $62-65$, fev. 2010.

Inovador na forma e no meio. Revista Arquitetura e Urbanismo, São Paulo, n. 186, set. 2009.

\section{Fotos:}

http://vazio.com.br

http://www. arqbacana.com.br/arq! aqui/CARLOS+M+TEIXEIRA, +VA ZIO+S_A 


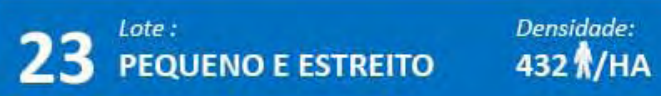

Amélia Teles 315 Smart!Lifestyle+Design

Número de habitantes: 16 Dimensöes do lote: $9,5 \times 39 \mathrm{~m}$ Área construída: $1190 \mathrm{~m} 2$ Número de pavimentos: Térreo + 4 pav.

Número de unidades: 8

101 a $127 \mathrm{~m} 2$

Número de tipologis: 2

Estacionamento: sim

Localização: Rua Amélia Telles, 315 Bairro Petrópolis, Porto Alegre, Bras
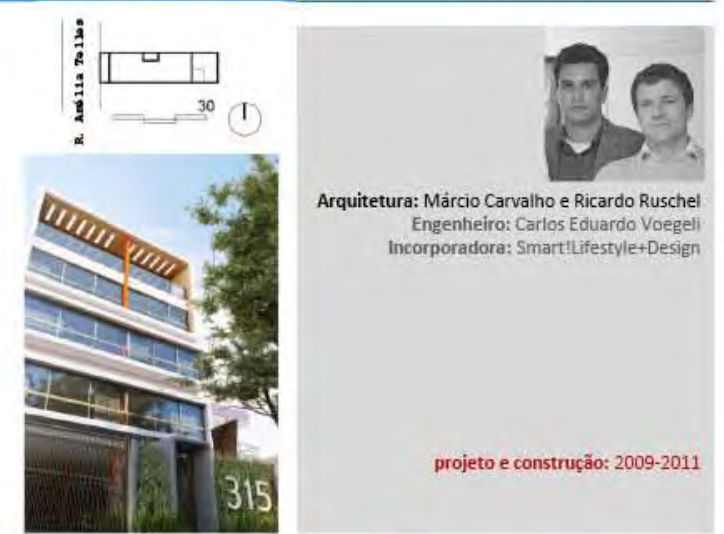

Arquitetura: Märcio Carvalho e Ricardo Rusche! Engenheiro: Carlos Eduardo Voege
incorporadora: Smartl lifestyle+Desigh
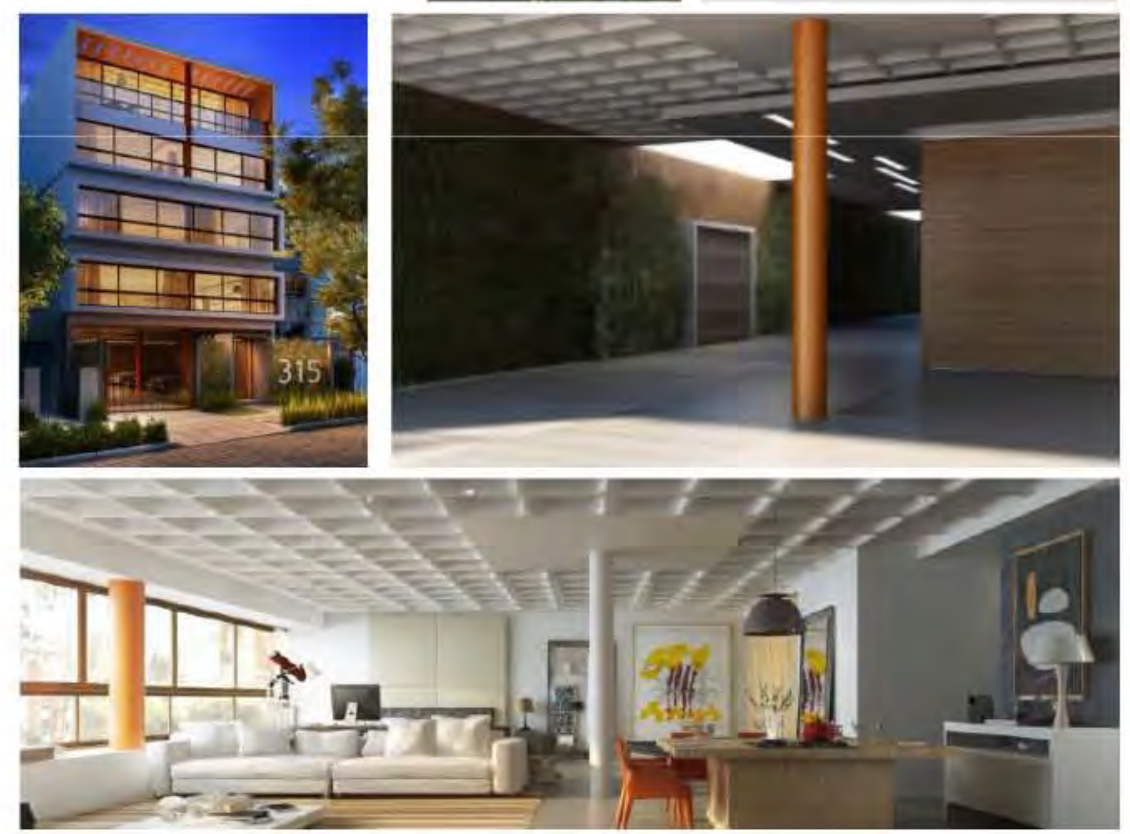

23 PEQUENO E ESTREITO $\quad \begin{aligned} & \text { Densidade: } \\ & \mathbf{4 3 2} \text { /HA }\end{aligned}$

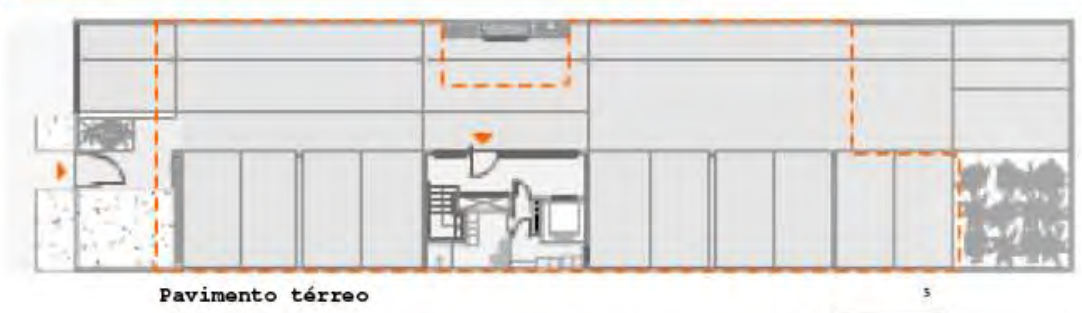

mento térreo

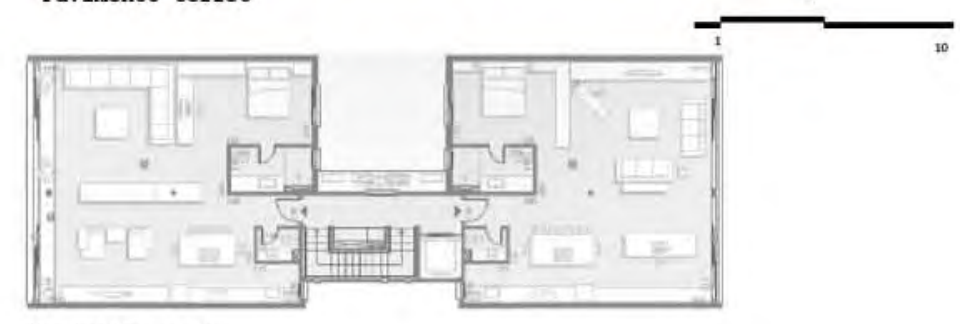

Pavimento tipo

Tipos de layout
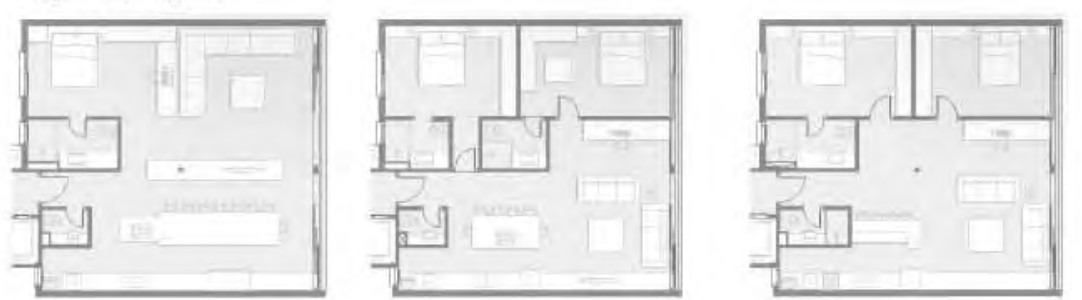

Fontes:

Arquitetos empreendedores projetam um novo futuro para os edifícios residenciais de Porto Alegre. Arquitetura e Urbanismo. São Paulo, n.189, p.14, dez. 2009.

Fotos :

http://www. smart.arq.br/ 


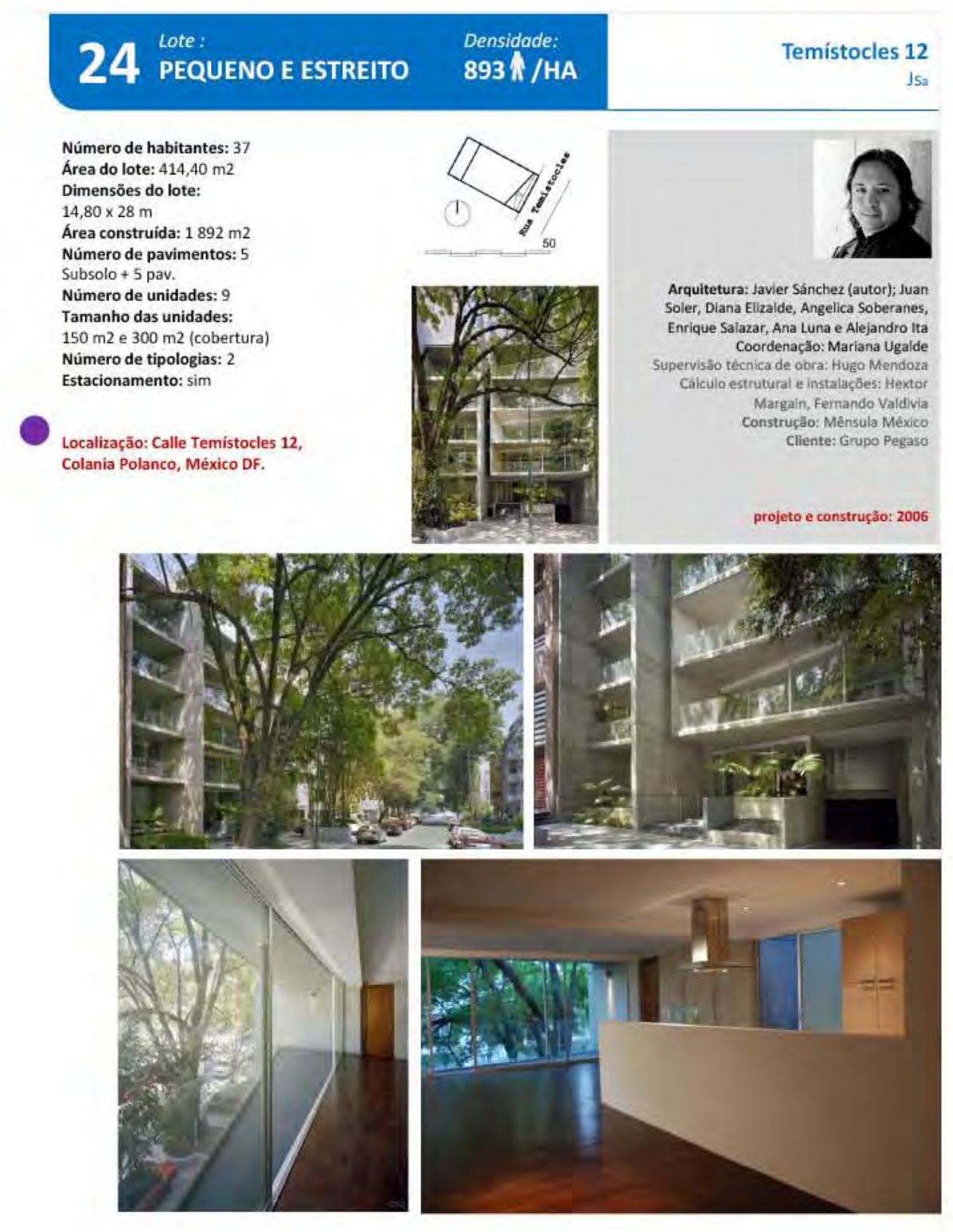
$\begin{array}{ll}\text { Lote: } & \text { Densidade: } \\ \text { PEQUENO E ESTREITO } & 893 / / \mathrm{HA}\end{array} \quad$ Temístocles 12 $\mathrm{Jsa}$

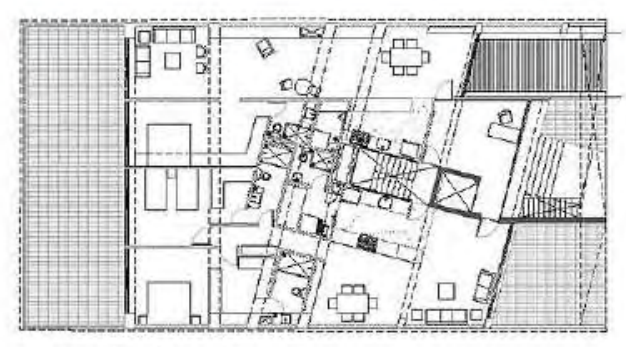

Pavimento térreo

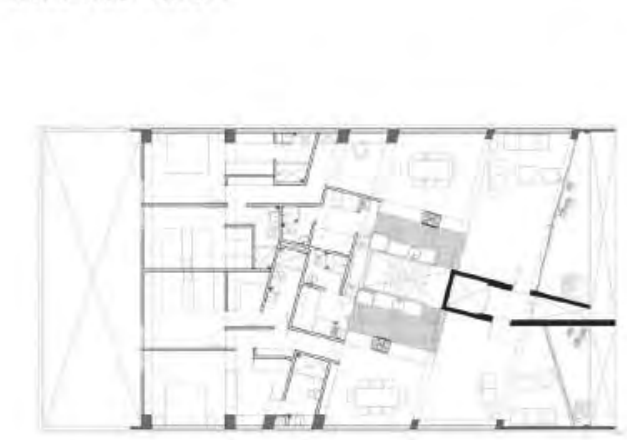

Pavimento tipo
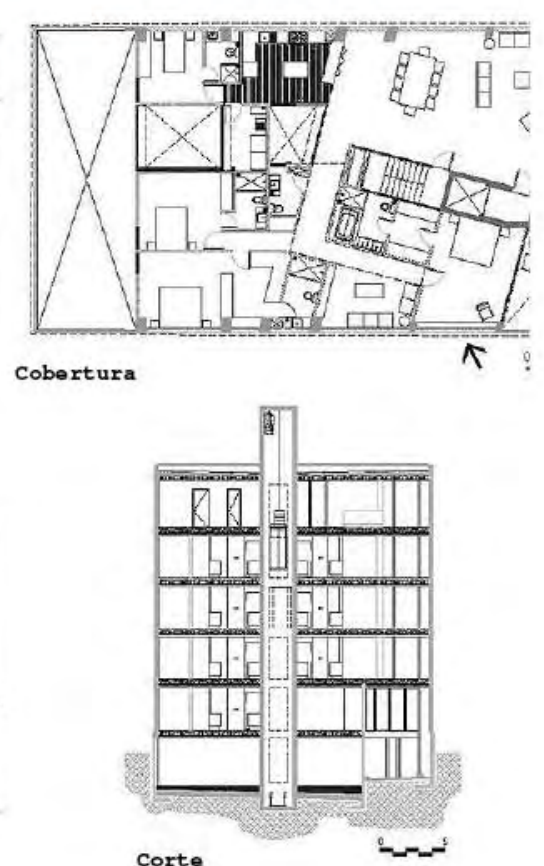

Corte

Fontes:

LEAL, Ledy Valporto. Jogos de planos e volumes. Arquitetura

e Urbanismo. São Paulo, n.172, p.60-63, julho, 2008.

Fotos:

http://www.jsa.com.mx/ 


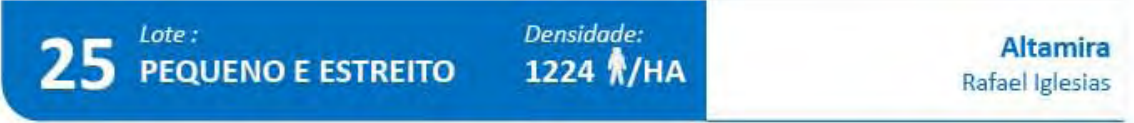

Número de habitantes: 18

Área construida: $1180 \mathrm{~m}$

Número de pavimentos: 13

Térreo duplo $+12+$ cob.

Número de unidades: 12

Tamanho das unidades:

$100-120 \mathrm{~m} 2$

Estacionamento: sim

Localização: Calle San Luis, 470,

Rosario, Argentina
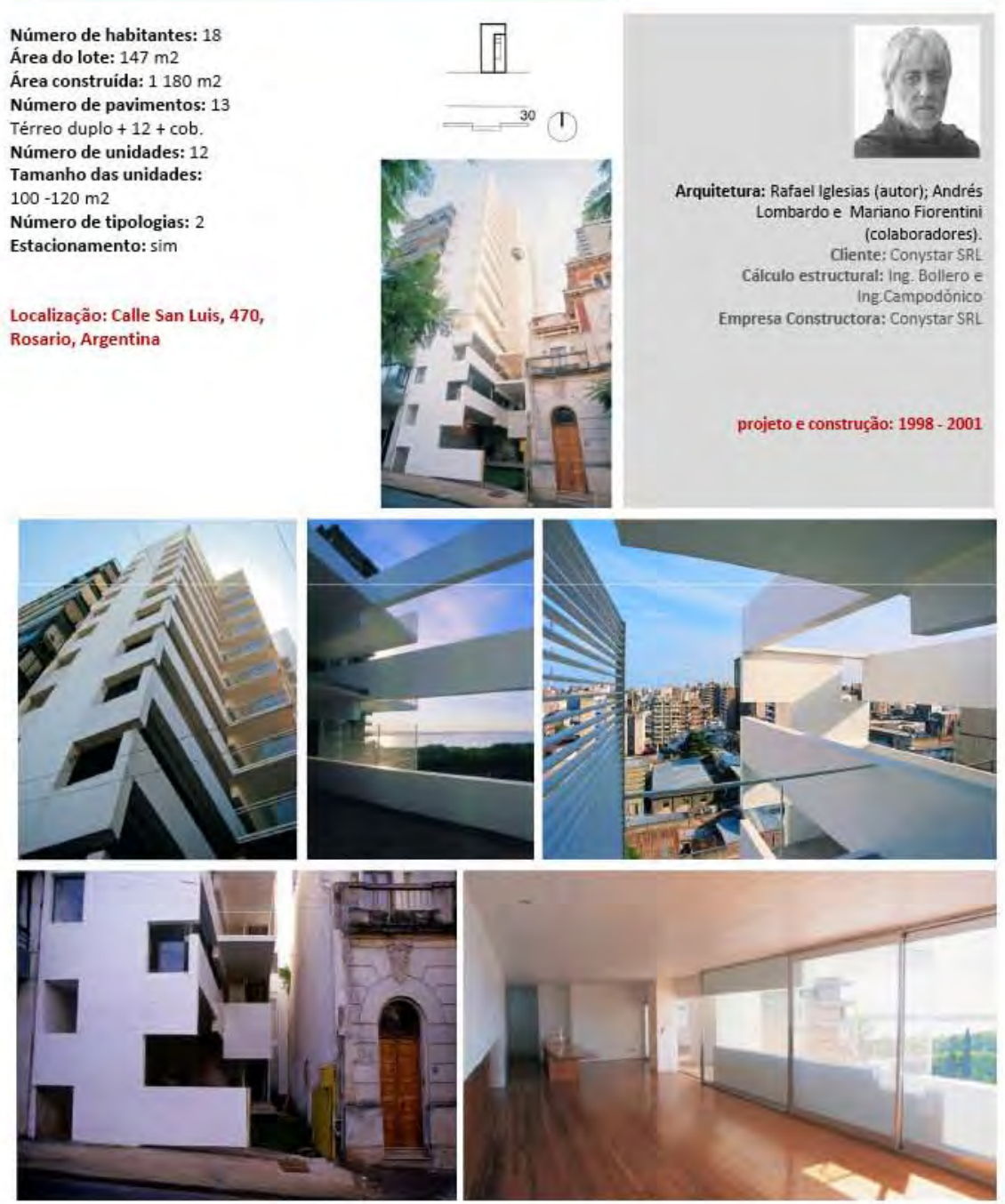

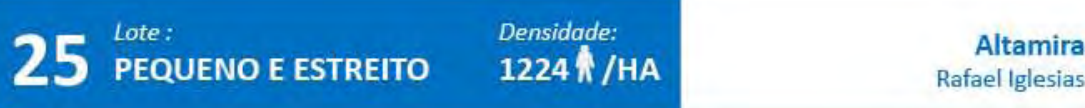

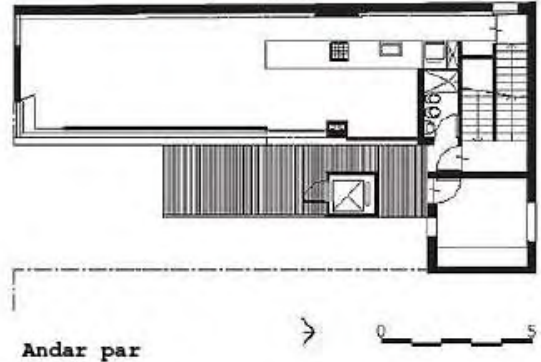

Andar par

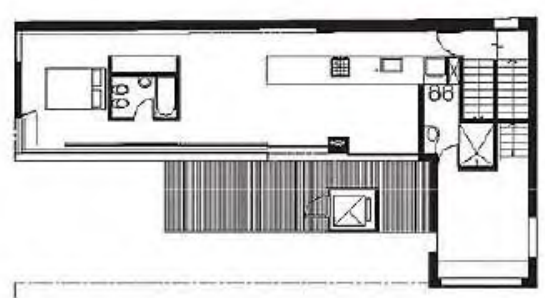

Andar ímpar
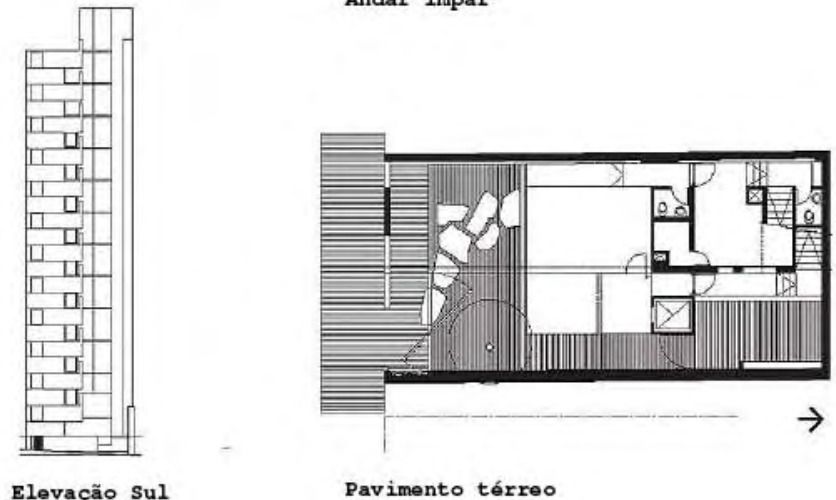


\section{Lote: Rafael Iglesias}

Elevação Leste

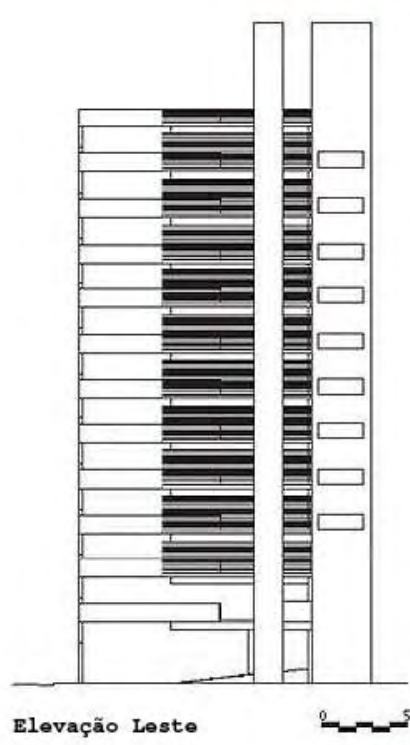

$2-a^{5}$

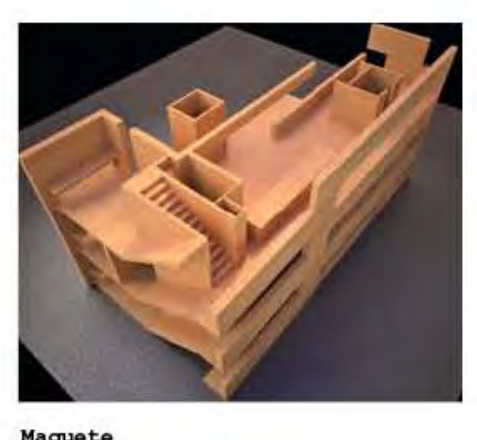

Cortes

\section{PEQUENO E ESTREITO $\quad \begin{aligned} & \text { Densidade: } \\ & 1224 \Uparrow / \mathrm{HA}\end{aligned}$}

Altamira Rafael Iglesias
Maquete

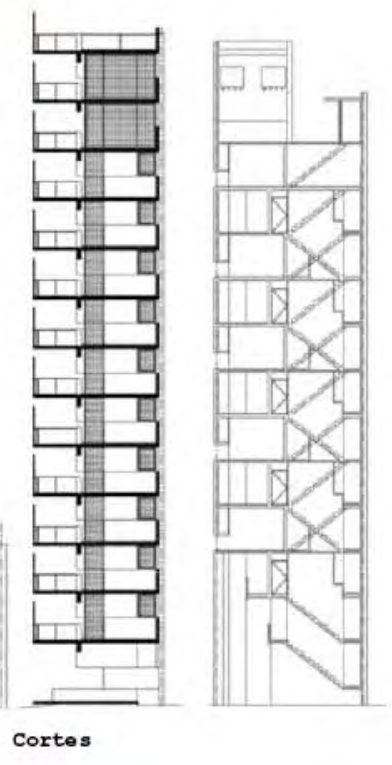

Fontes:

PUNTONI, Álvaro. Desconstruindo muros imaginários.

Arquitetura e Urbanismo. São Paulo, n.172, p.80-82, julho, 2008 .

SABBAG, HAIFA Y. Objeto Ilógico. Arquitetura e Urbanismo. São Paulo, n.169, p.56-61, abril, 2008.

\section{Fotos:}

http://www.edificioaltamira.com.ar/

http://www.rafaeliglesia.com.ar/first-NF.htm 


\section{Lote: $\begin{aligned} & \text { Densidade: } \\ & 2400 \pi / \mathrm{HA}\end{aligned}$}

Gernika Miguel Angel Roca

Número de habitantes: 72 Área construida: 3490

Número de pavimentos: 13

Área do pav. tipo: $300 \mathrm{~m} 2$

Sub. + Térreo + 12 pav. + cobertur

Número de unidades: 50

Estacionamento: sim

Localizaçâa: Av. Ambrosio Olmos, 950, Córdoba, Argentina

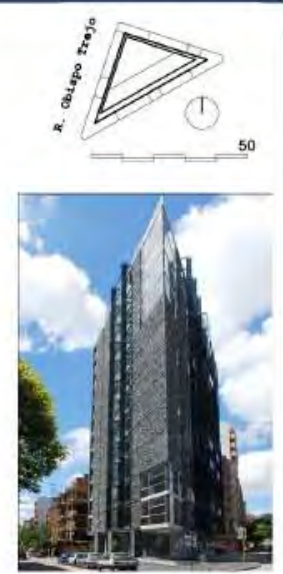

projeto e construçẫ: 2004-2006
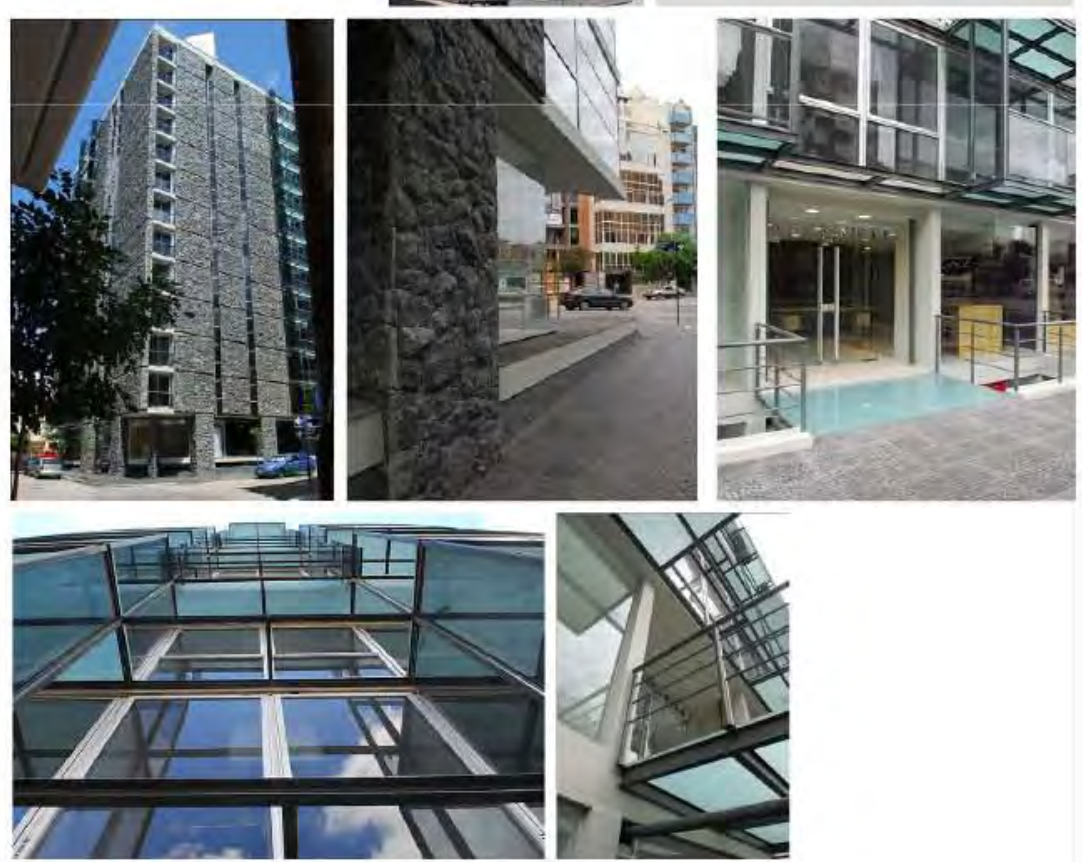

\section{6 configurando QUADRA $2400 \% / \mathrm{HA}$}

Gernika Miguel Angel Roca

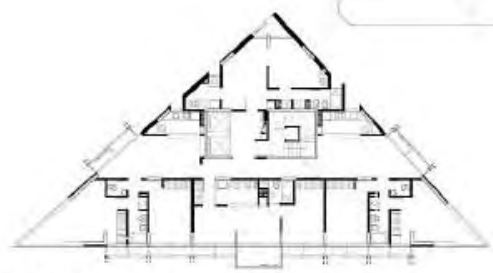

Planta tipo 1

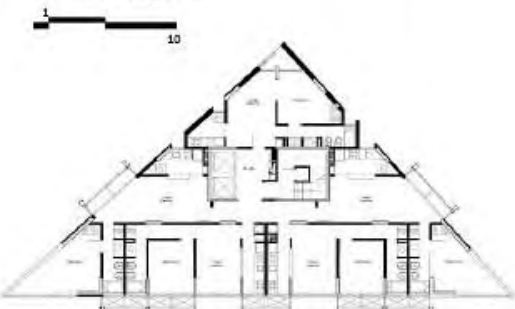

Planta tipo

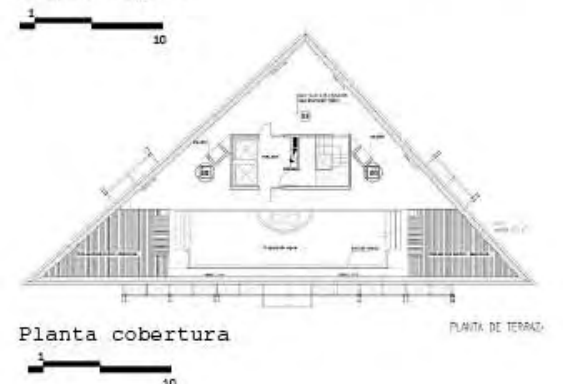

Fontes :

SEGRE, Roberto. A cidade como uma casa grande; casa como uma cidade pequena. Arquitetura e Urbanismo, São Paulo, n.196, p.73 -77, jul. 2010. Proa a la ciudad. SUMMA+, Buenos Aires, n.94, p. 411, junho 2008.

\section{Fotos:}

http: // www.miguelangelroca. com 


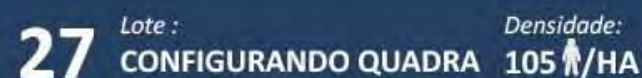

Chácara Sant'Anna Aflalo \& Gasperini

Número de habitantes: 65

Área construida: $6429 \mathrm{~m}$

Número de pavimentos: 3

Número de unidades: 13

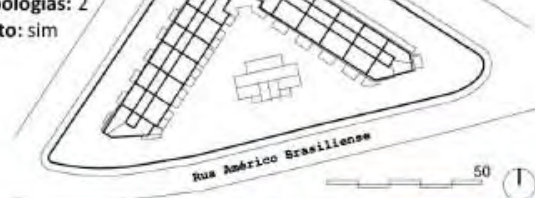

${ }_{50}^{5}(\mathrm{~T}$

Localizaçăo: Rua Américo Santo Am, 82, Alto da Boa Vista,
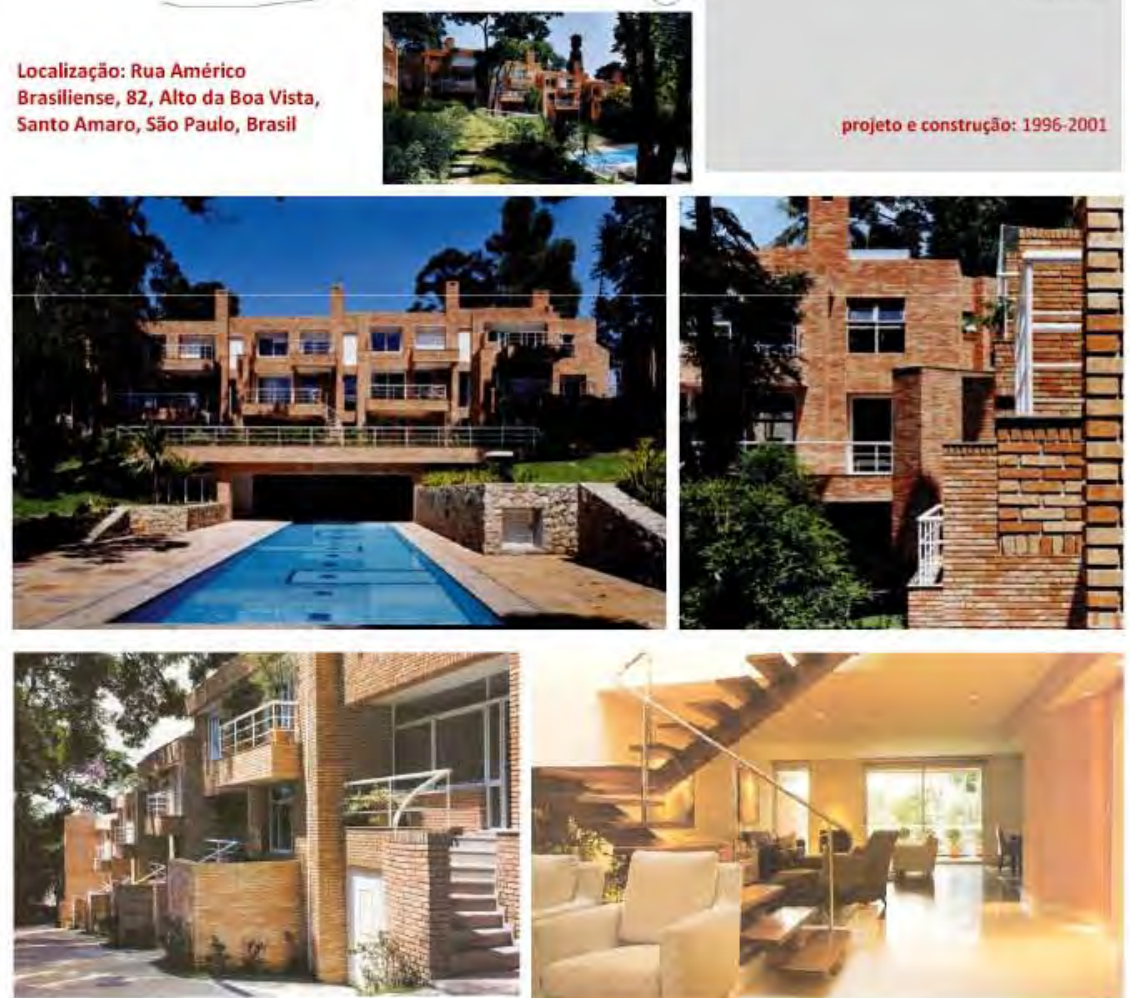

Colaboredoreres: Léa Validergorin Gernand Prandi e Antonio Carlos Ogando de Oliveira. Projeto Paisagistico: Benedito Abbud

Consultoria de Marketing: I. Kozel \&
Associados

projeto e construç̧a: 1996-2001

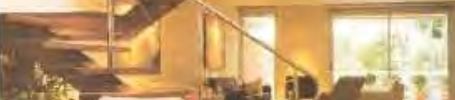
सी

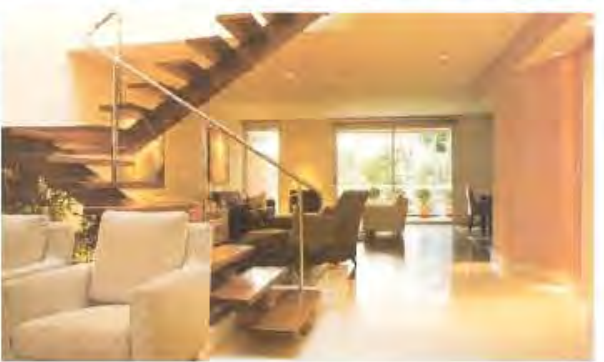

27 Lote: $\begin{aligned} & \text { Densiddede: } \\ & 105 / \text { HA }\end{aligned}$
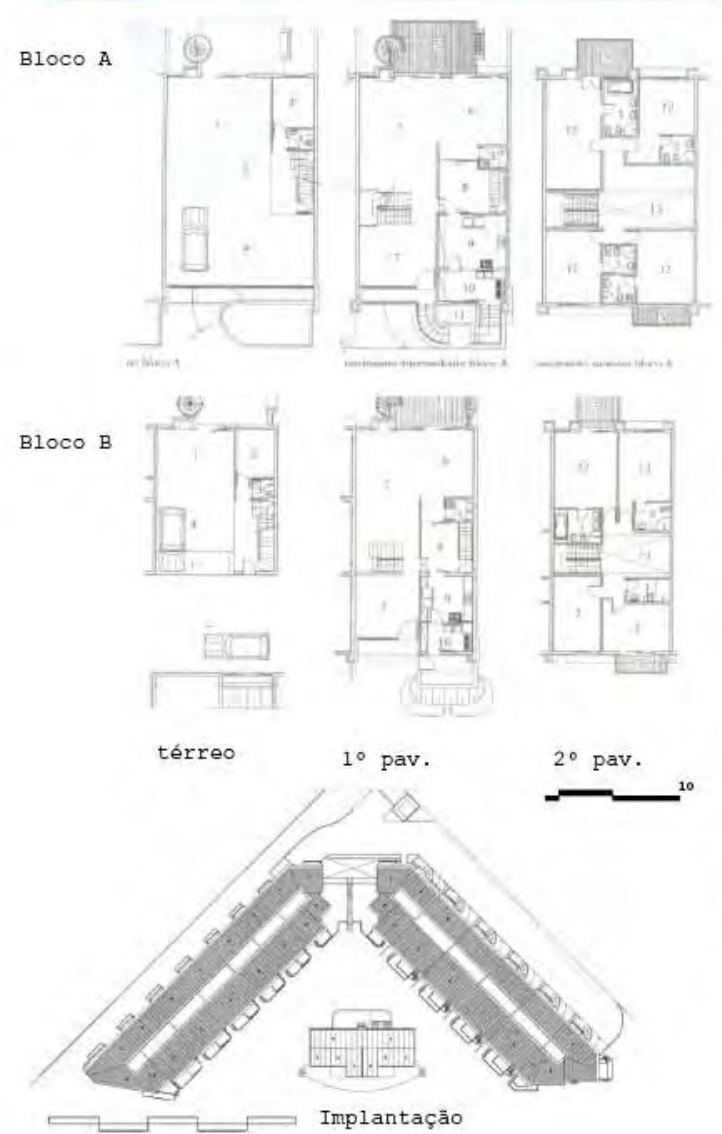

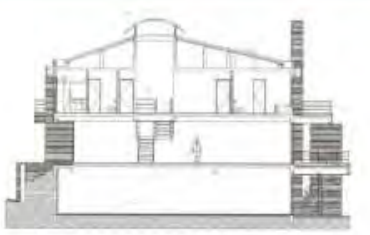

Corte bloco A

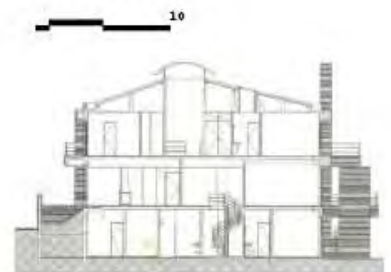

Corte bloco B

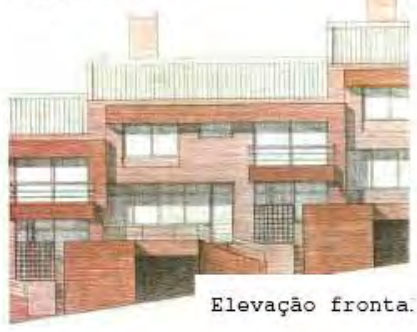

Fontes :

SILVA, Vânia. Fora

de série.

Arquitetura e

Urbanismo. São

Paulo, n.99, p.50-

55, dez/jan., 2002.

Fotos:

http://www.aflaloeg

asperini.com.br/ 


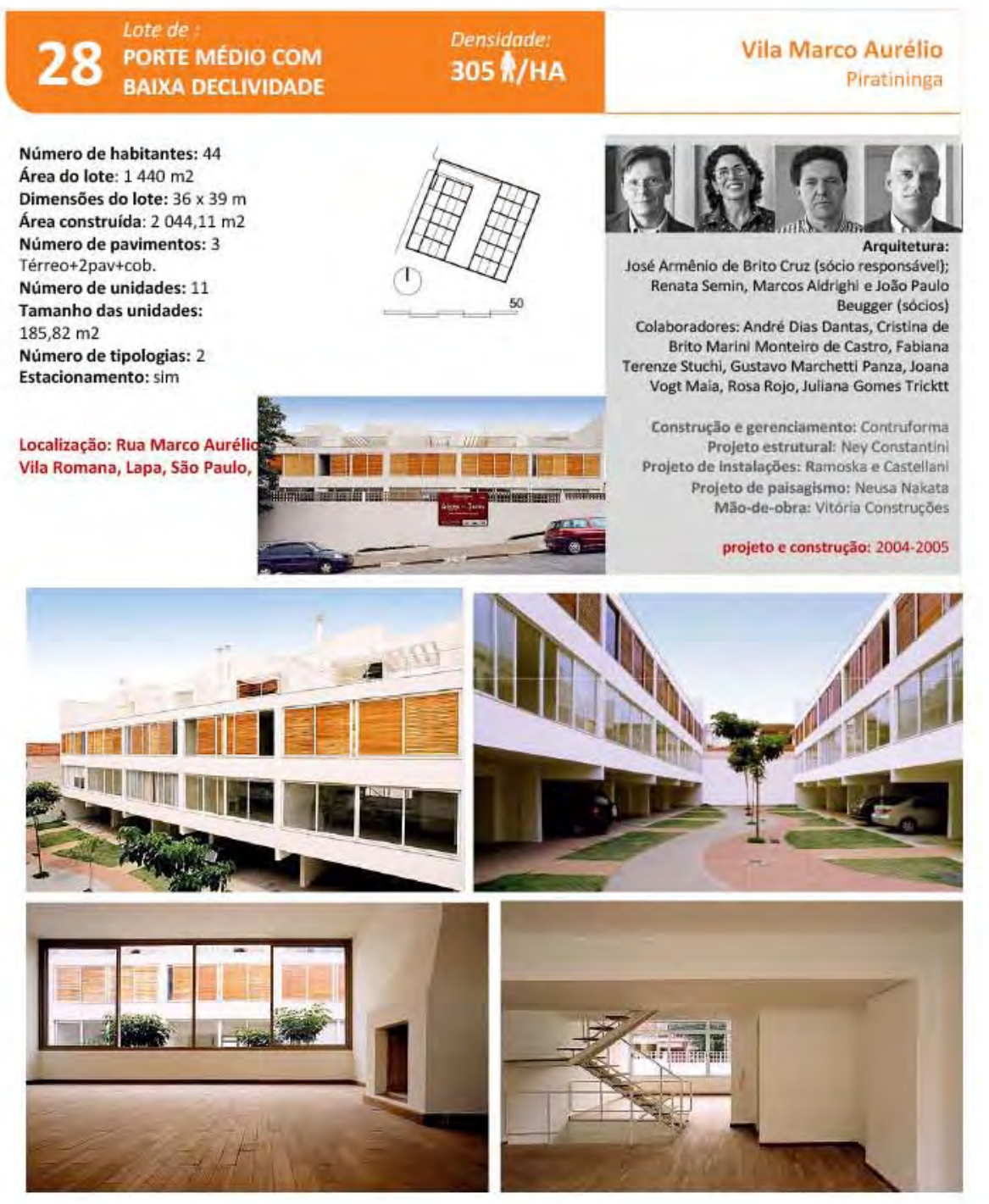

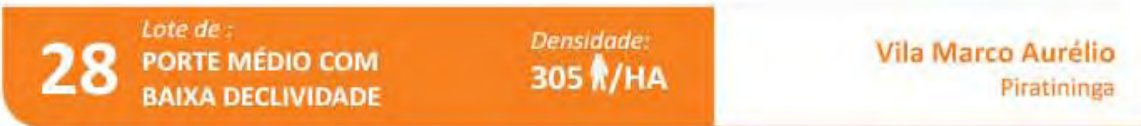
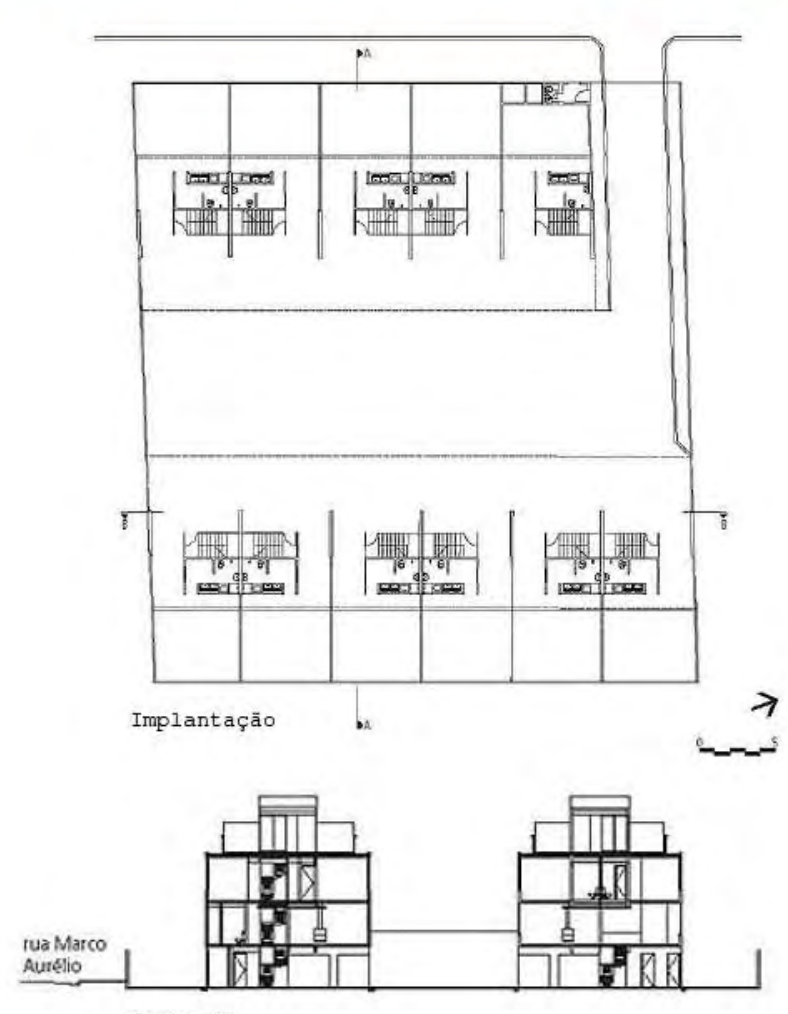

Corte AA

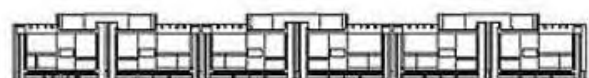

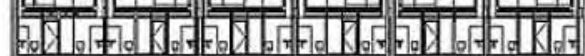

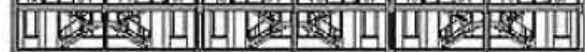

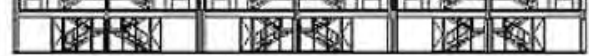

corte BB

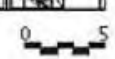




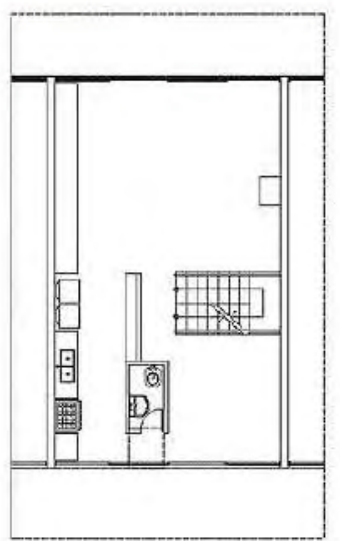

$1^{\circ}$ pavimento

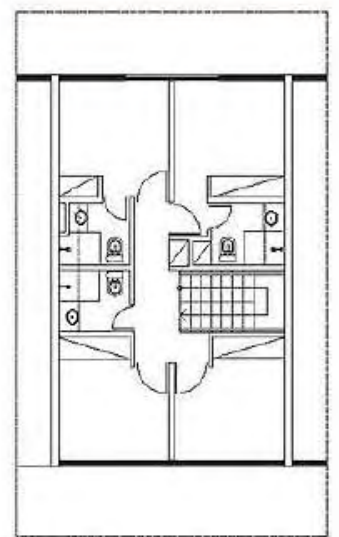

$2^{\circ}$ pavimento

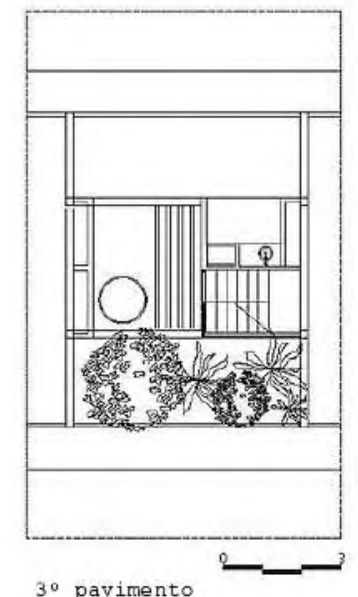

$3^{\circ}$ pavimento
Plantas alternativas
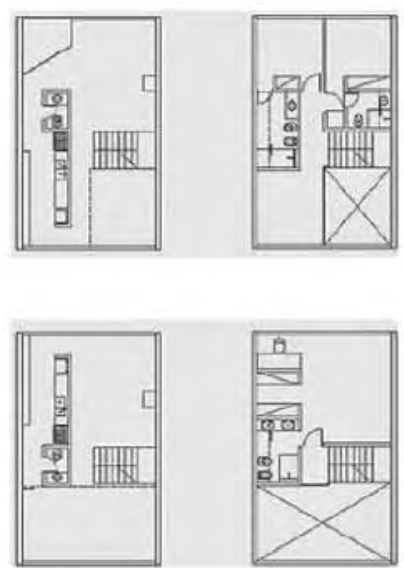

Opção 1

Opção 2

\section{Fontes:}

ROSSO, Silvana Maria. Nova Vila. Arquitetura e Urbanismo. São Paulo, n.157, p.28-33,abril., 2007.

\section{Fotos:}

http://www.piratininga.com.br/projeto_vilas_residenciais.h tml 


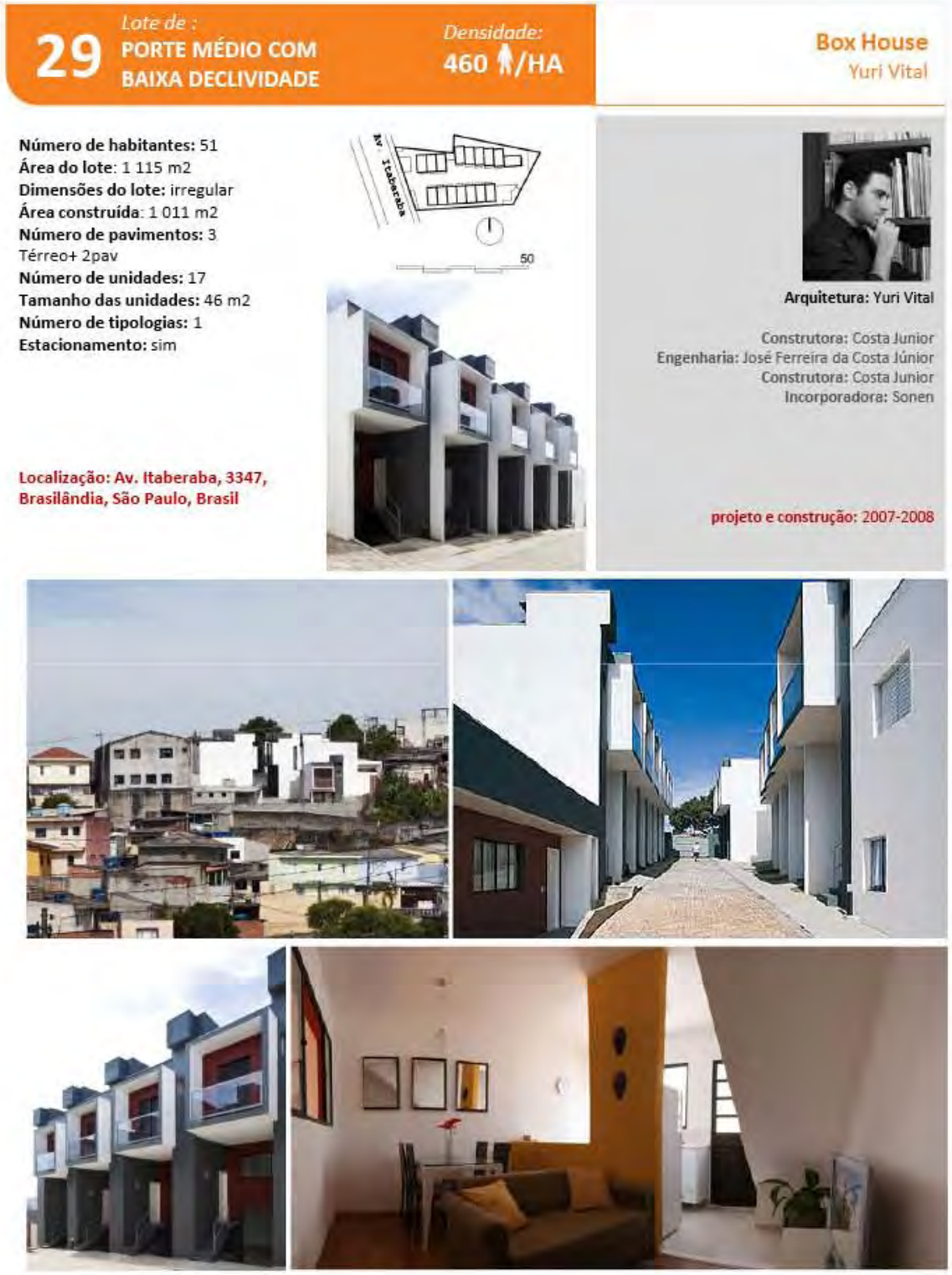

$\begin{array}{ll}29 & \text { Lote de: } \\ \text { PORTE MÉDIO COM } & \text { Densidade: } \\ \text { BAIXA DECLIVIDADE } & 460 \mathrm{M} / \mathrm{HA}\end{array}$

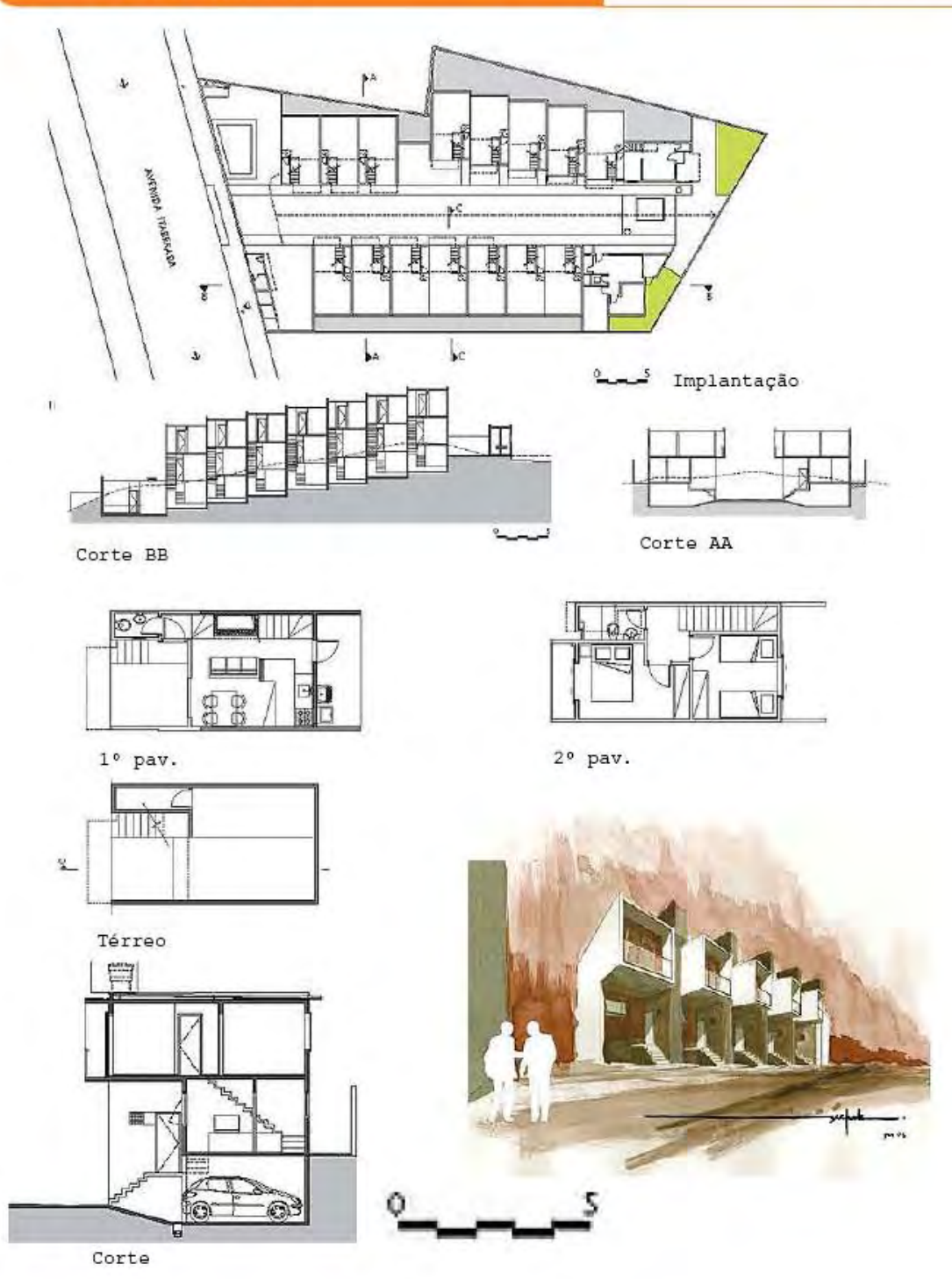


Número de pavimentos: 3

Número de unidades: 6

Tamanho das unidades: $380 \mathrm{~m} 2$

Número de tipologias: 1

Localizaçäo: Rua Tomé Portes

$/$ Rua Vicente Leporace

Brooklin Paulista, São Paulo, Brasil
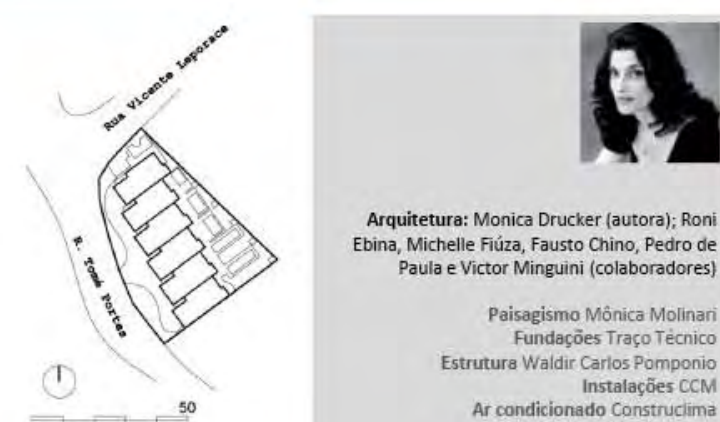

Arquitetura: Monica Drucker (autora); Roni bina, Michelle Fiúza, Fausto Chino, Pedro de Paisagismo Mônica Molinar Prtura Waldirie Carlos Pomponio Ar condicionado Construcicim Construçãa Pirrandello

projeto e construçâo: 2004-2008

\section{Fontes:}

CAPOZZI, Felipe. Inovação a baixo custo. Arquitetura e Urbanismo, São Paulo, n.194, p. 48-53, maio, 2010.

Projeto Design, São Paulo, n.348, fev. 2009.
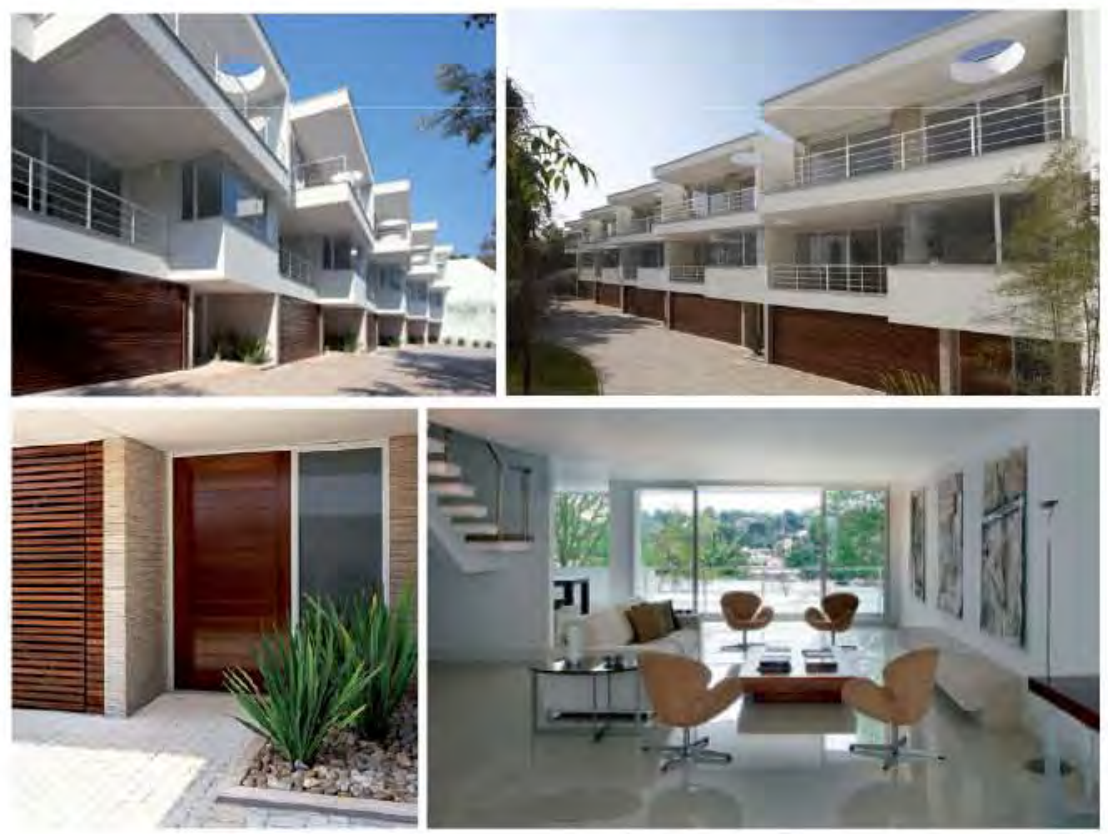


\section{0}

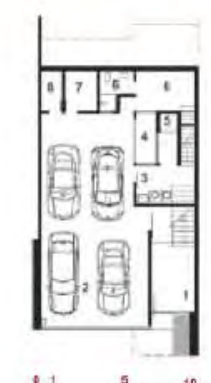

, Térreo

\section{Ha1l social}

2. Garagen

4. Poço ventilą̧ă̊

5. Vazio para elevador

6. Dependencias de enpregad

1. Depósito

8. Casa de máquinas

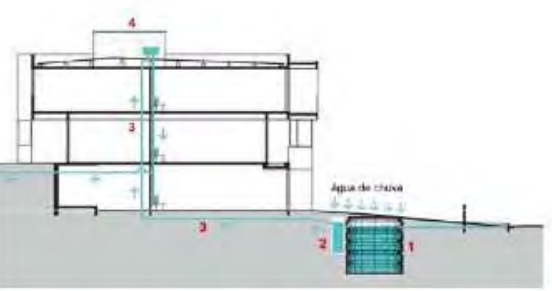

1. Área social

2. Cozinha

3. Lavabo

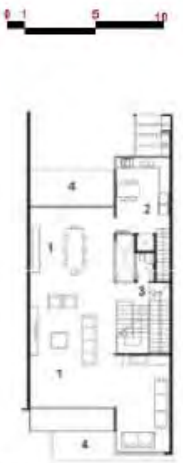

Pav. Intermediário

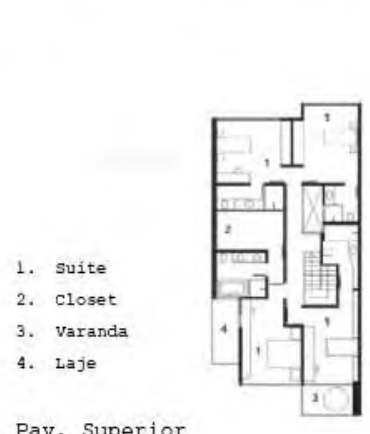

Pav. Superior
Detalhe / abastecimento água

1. Reservatório subterrânea; 2. Filtro;

3. Tubulaçăo; 4. Caixa d'água para água de reuso

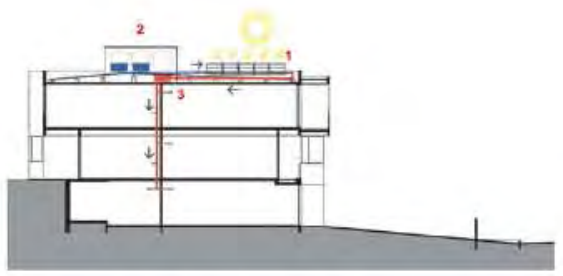

Detalhe / aquecimento solar

1.coletores solares; 2. Caixa d'água

3. Boyer (reservatório térnico)

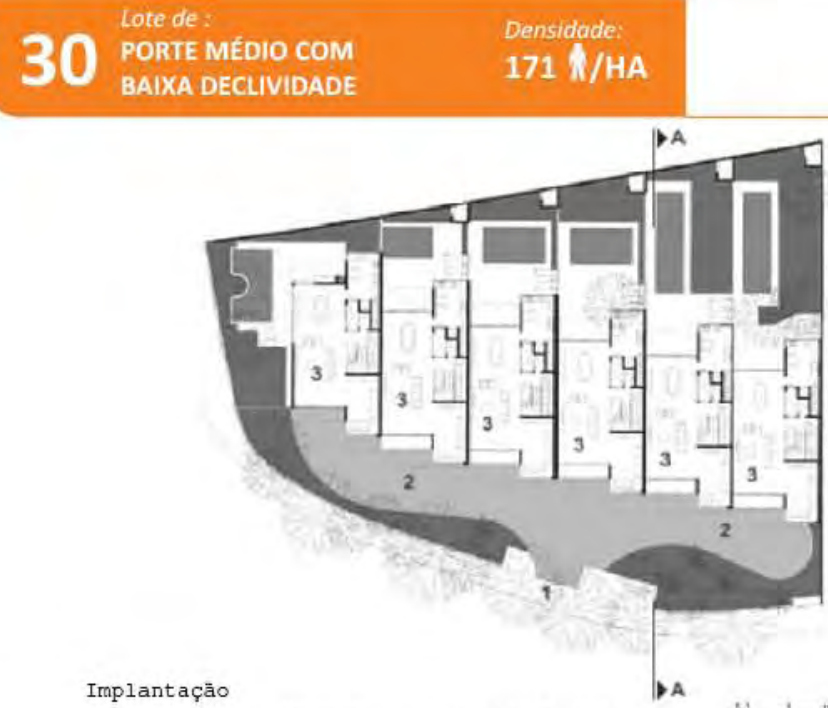

1. Acesso / 2. Area Comum / 3. Residência

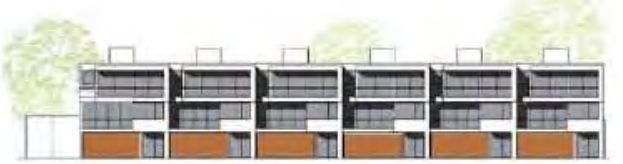

Elevação

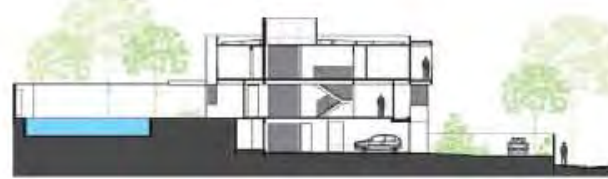

Corte AA

Fontes:

CORBIOLI, Nanci. Soluções racionais reúnem conforto e redução de custos. Projeto Design, São Paulo, n.347, p. 4247, jan. 2009.

\section{Fotos:}

http: //www.monicadrucker.com.br/ 


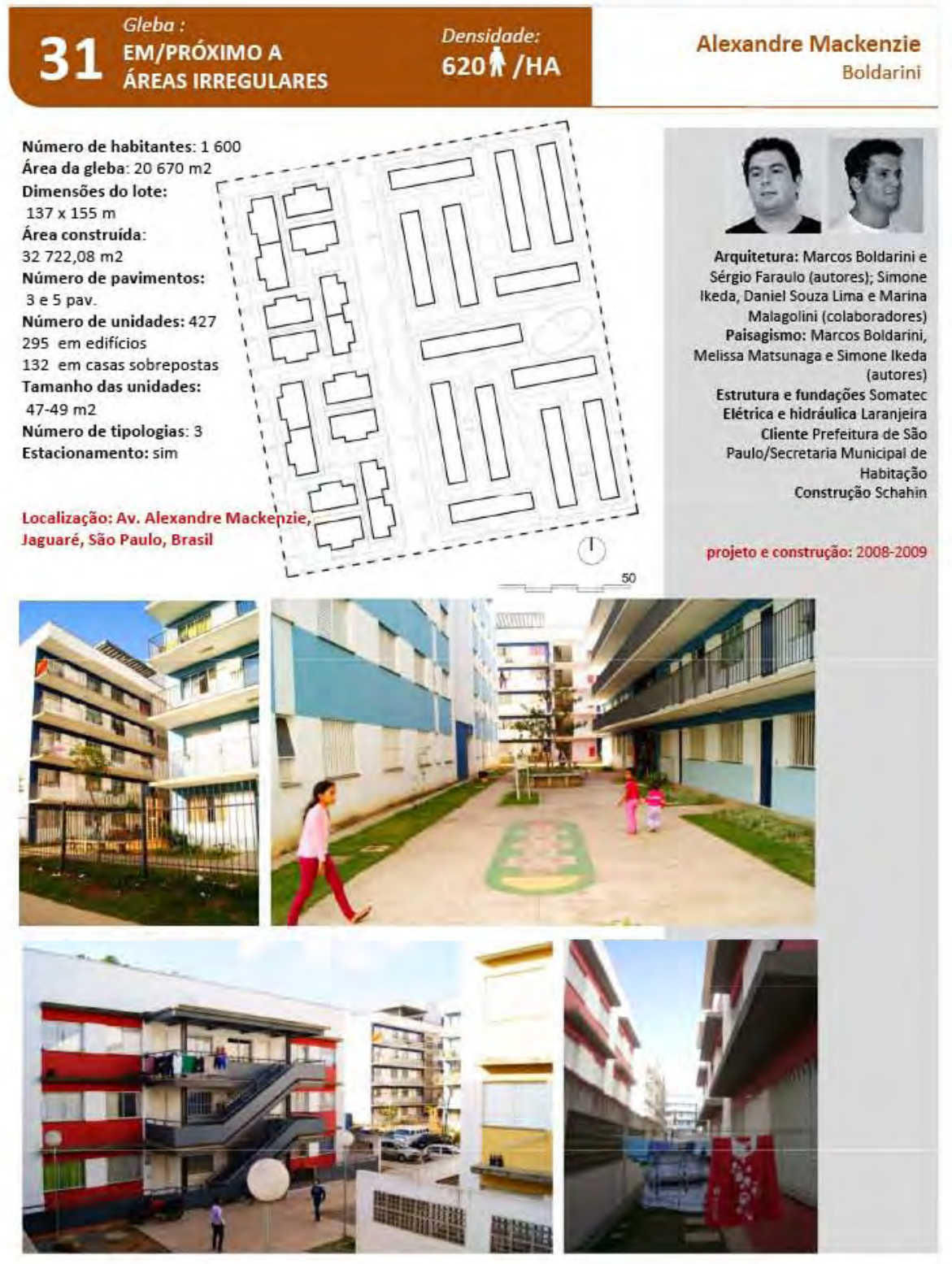

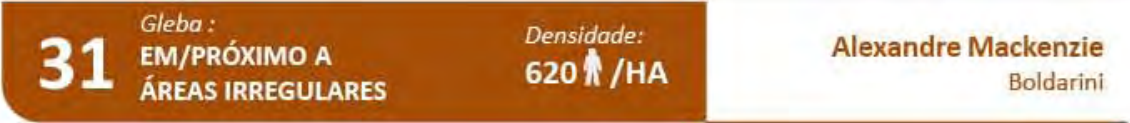
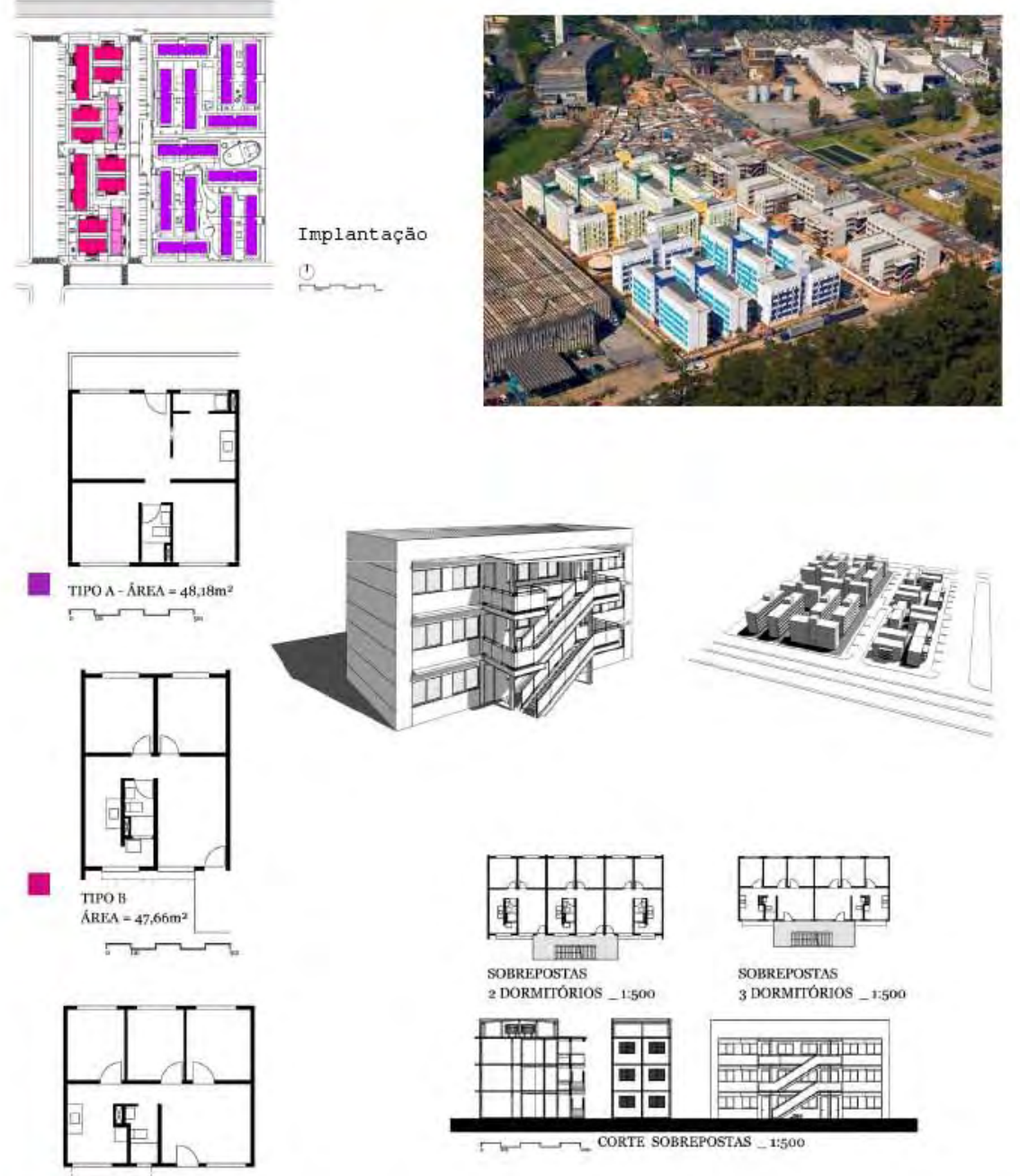

IIRPC 
31 EM/PRÓXIMO A ÁreAs IRREguLARES

Densidade

$620 \mathrm{~K} / \mathrm{HA}$

Alexandre Mackenzie Boldarini

\section{Fontes:}

Arquitetura qualifica conjunto habitacional. Projeto

Design, São Paulo, n.357, p. 25, nov. 2009.

MELENDEZ, Adilson. Implantação alterna posição de blocos para aproveitar o espaço. Projeto Design, São Paulo, n.358, p. 52-57, dez. 2009.

FLORESTA, Cleide. Casas sobrepostas. Arquitetura e Urbanismo, São Paulo, n.203, p. 42-43, jan. 2010.

Acervo Boldarini Arquitetura e Urbanismo

\section{Fotos:}

Fabricia Zulin

Rodrigo Inácio Cenzi

Renata Coradin

Daniel Ducci

\section{EM/Pr:}

M/PRÓXIMO A

ÁREAS IRREGULARES

Número de habitantes: 2430

Área do lote: 30400

$A=5700 \mathrm{~m} 2$
$B=5000 \mathrm{~m} 2$

$\mathrm{C}=8700 \mathrm{~m} 2$

$\mathrm{D}=7000 \mathrm{~m} 2$

$F=4000$

Número de pavimentos: 5 a 9 pav.

Número de unidades: 810

Número de tipologias: 2

Estacionamento: sim

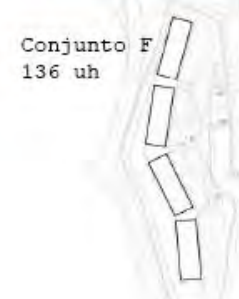

Arquitetura: Edson Elito, Joana Elito

projeto e construşâa: 2008-2011

Localizaçâa: Paraisópolis, Zona Sul, São Paulo

Conjunto A $E$ B

$154+206$ uh
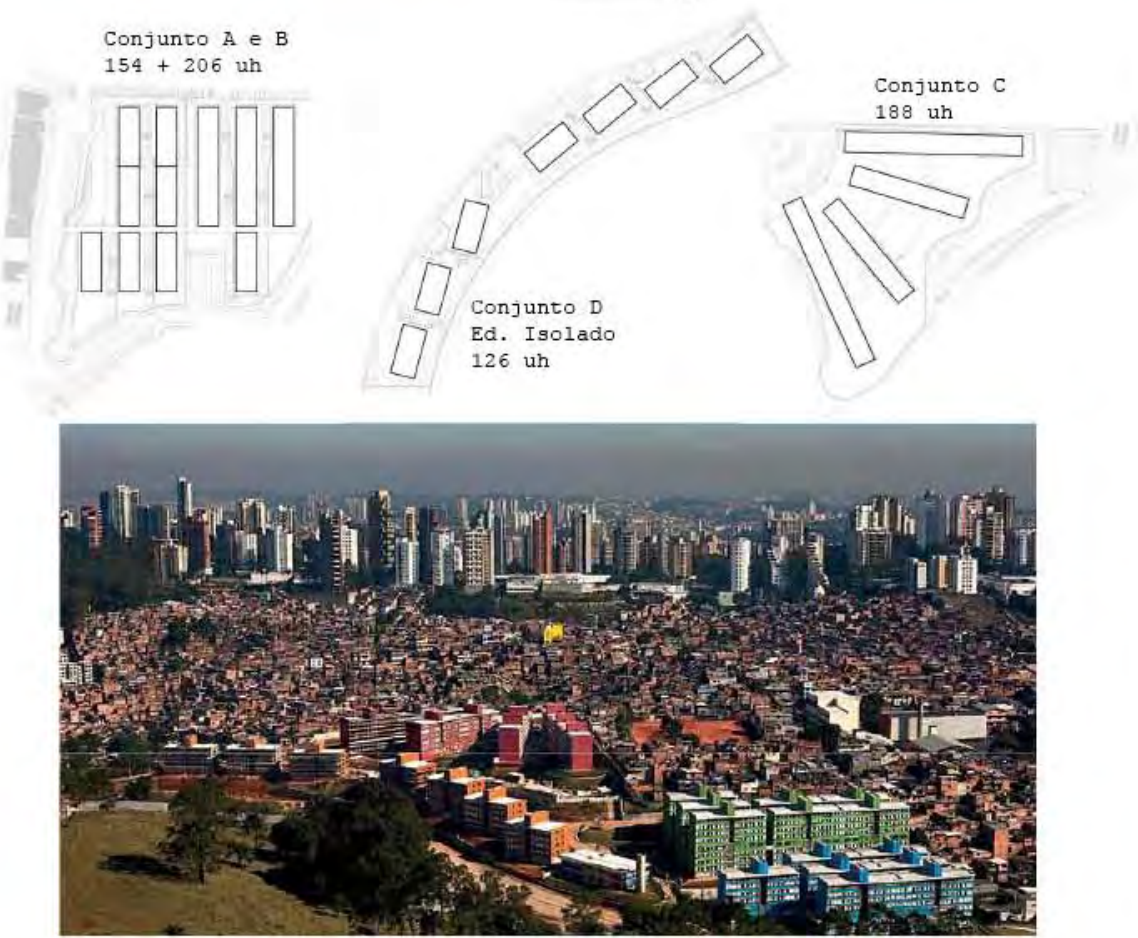


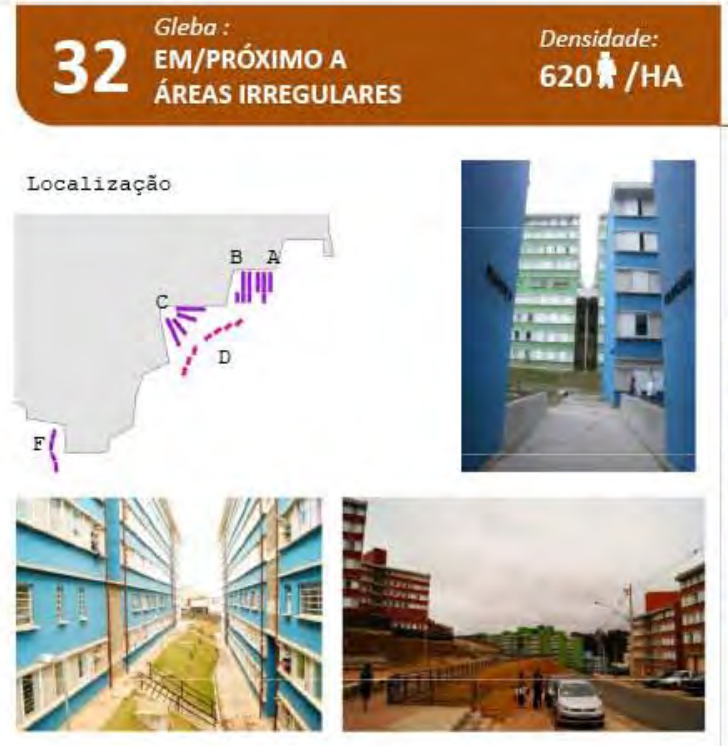

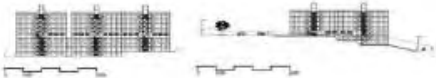

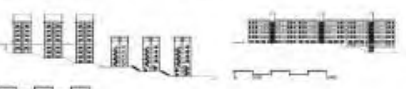
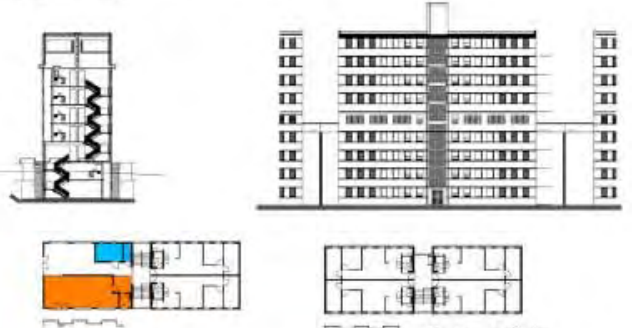

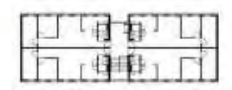

térreo

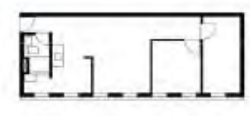

는

Habitacional

Pav. tipo
Alexandre Mackenzie Boldarini

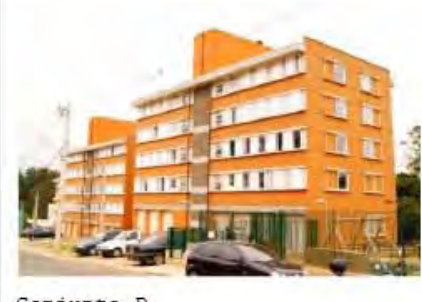

Conjunto D
Ed. Isolado

HALHA térreo

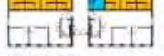

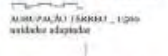

[म]

E-1]

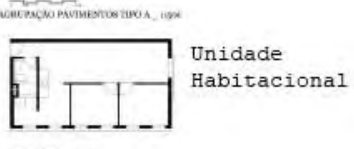

\section{Giebo:}

32 EM/PRÓXIMOA
Fontes:

SERAPIÃo, Fernando. Quando a favela vira cidade. Projeto Design, São Paulo, n.369, p. 88, nov. 2010.

A reação ao neoclássico e a promessa para o futuro. Projeto Design, São Paulo, n.371, p. 88, jan. 2011.

Acervo SEHAB - Secretaria de Habitação da Prefeitura de São Paulo

\section{Fotos:}

Fabricia Zulin

Rodrigo Inácio Cenzi

Renata Coradin 


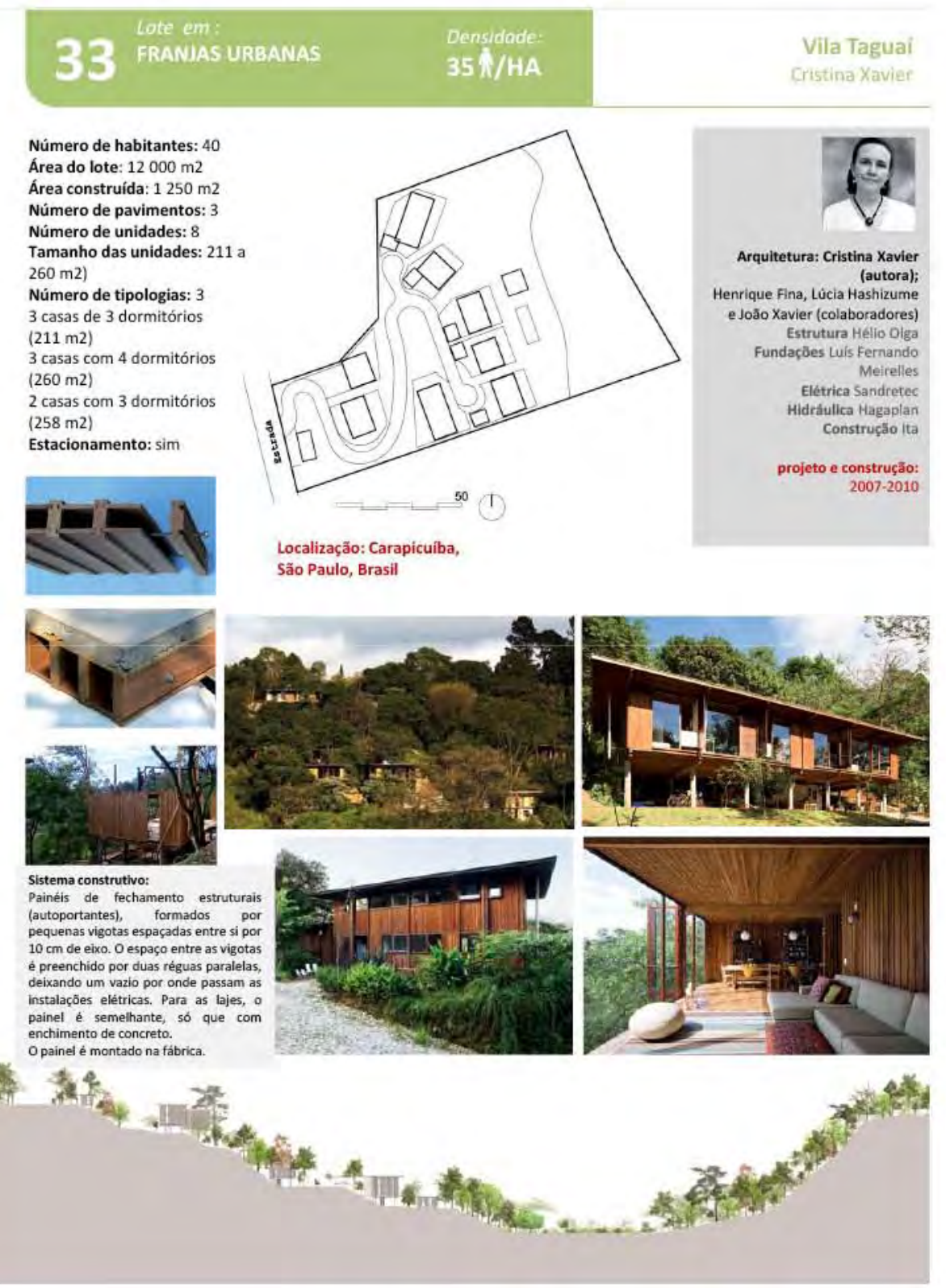

$\begin{array}{ll}33 \text { FRANIAS URBANAS } & \text { Densidadei } \\ & 35 \mathrm{HA}\end{array}$
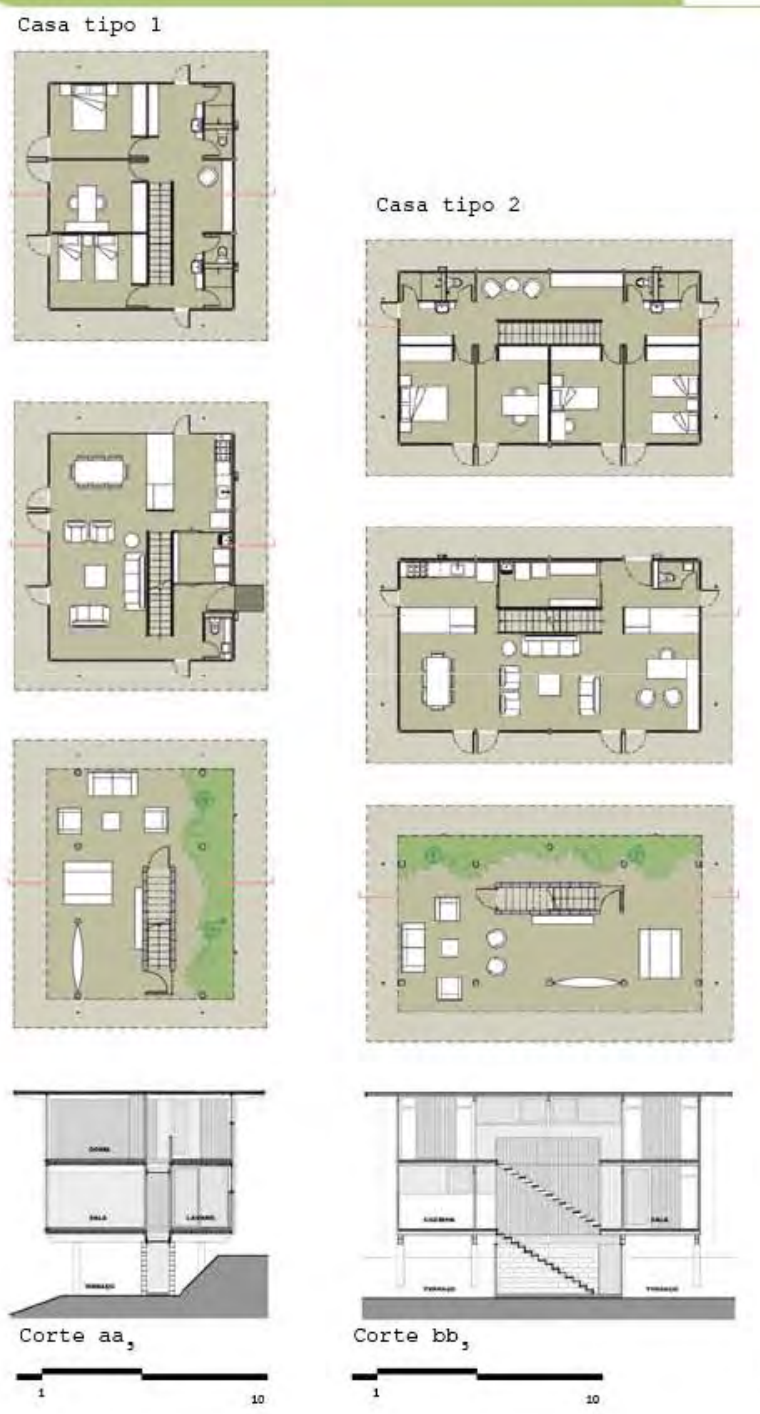

Vila Taguai Cristina Xavier
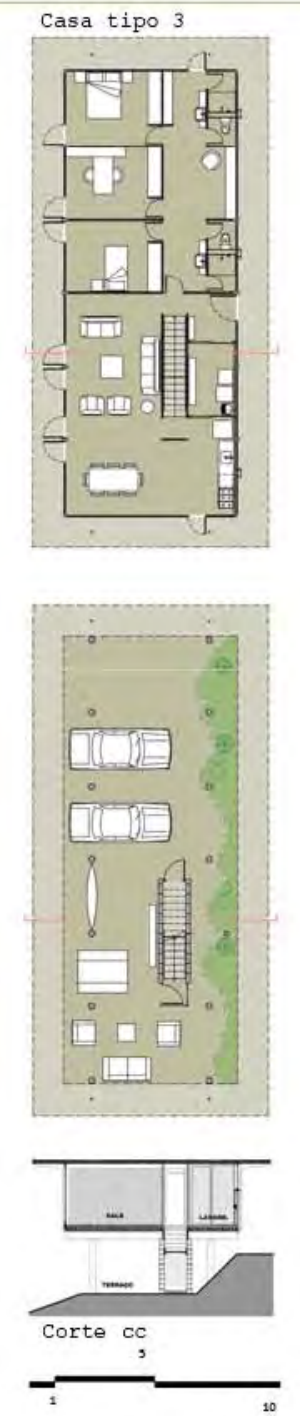
Fontes:

SERAPIÃO, Fernando. Experimental, conjunto de casa

transpira soluções ambientais. Projeto Design. São Paulo, n.369, p. 44-53, novembro, 2010.

A reação ao neoclássico e a promessa para o futuro. Projeto Design, São Paulo, n.371, p. 88, jan. 2011.

Fotos:

www danielducci,com, br

\section{$\begin{array}{ll}34 & \text { Denanidade: } \\ & 300 \mathrm{~N} / \mathrm{HA}\end{array}$} Joan Villă e Silvia Chile

\section{Número de habitantes: 96} Área construida: $2256 \mathrm{m2}$ Número de pavimentos: 3 Número de unidades: 24

Tamanho das unidades: $95 \mathrm{~m} 2$ $160 \mathrm{mz}+35 \mathrm{~m} 2$ cobertura

Estacionamento: sim, junto à via

Estacion
pública
módulos

módulos pré-fabricados de

paineis de tijolos cerâmicos
solidarizados: $43 \mathrm{~cm} \times 3 \mathrm{~m}$ (L)

de para execuçãao de paredes,

lajes e coberturas.
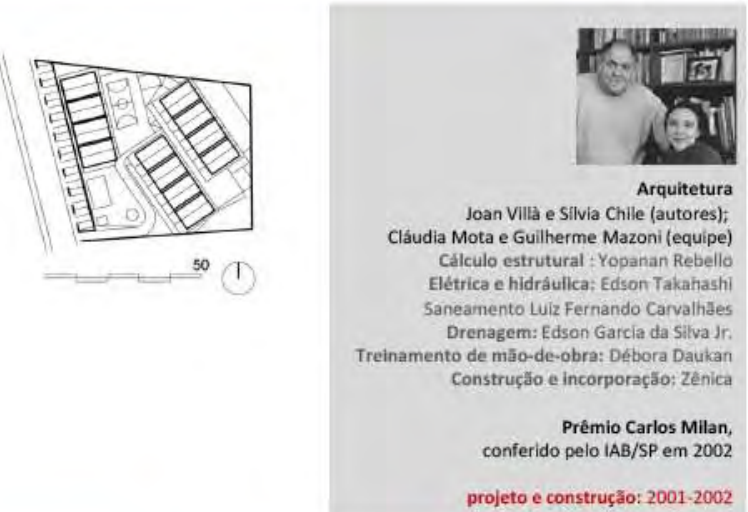

Localizaçăo: Rua Grécia, Cotia São Paulo, Brasil.

projeto e construção: 2001-2002

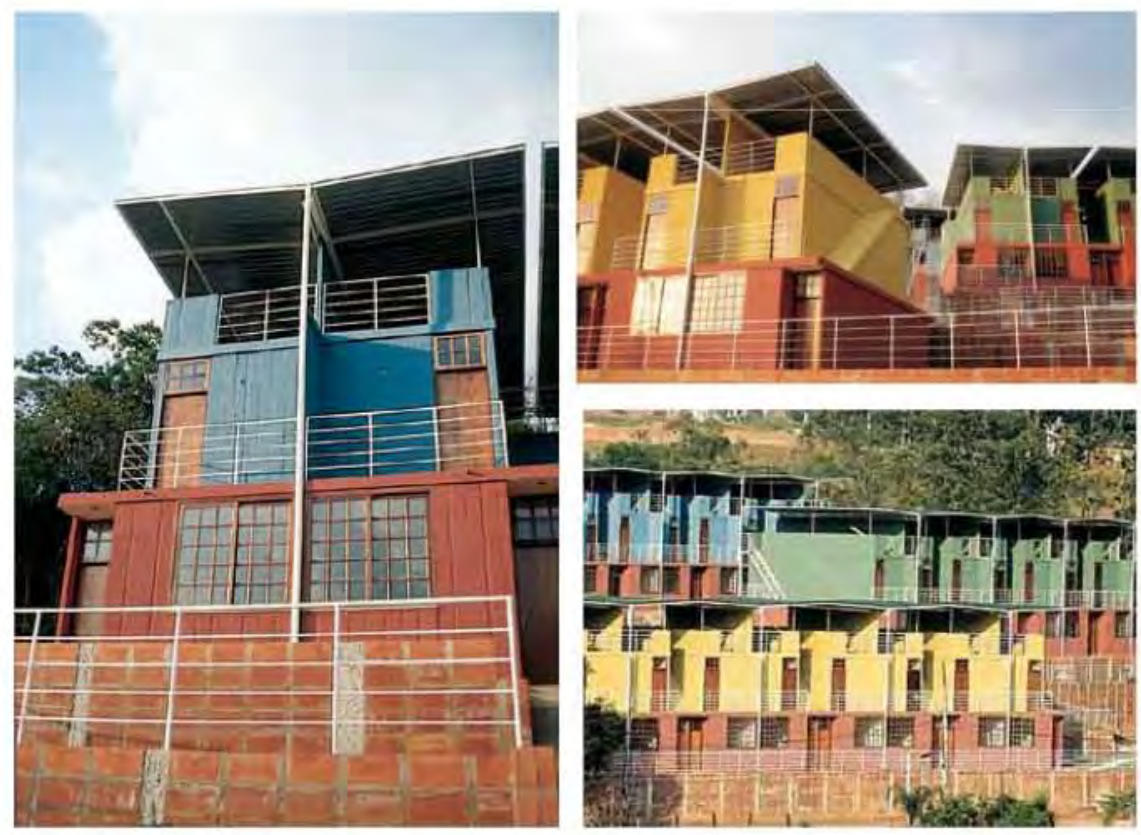




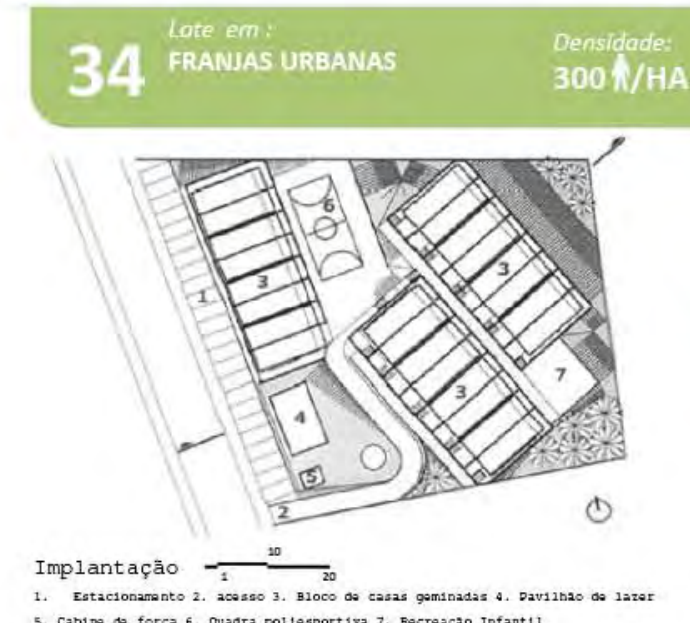

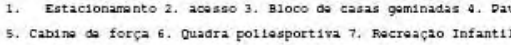

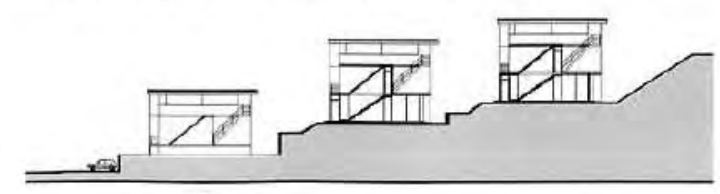

corte -10
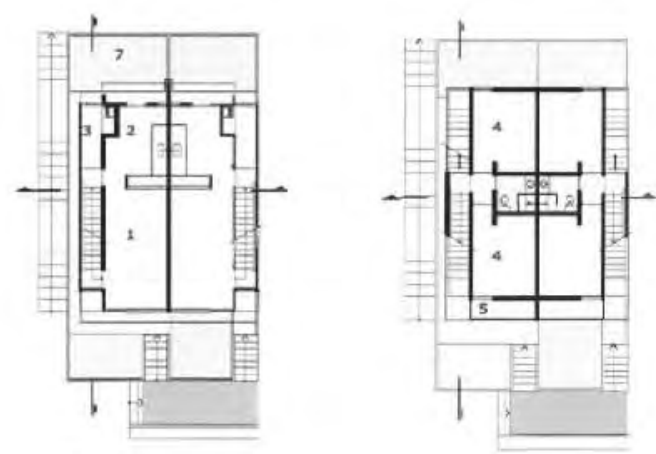

\section{Térreo}

1. Sala

2. Cozinha
3. Lavanderia

12 pavimento

4. Dornitón

7. quinta1
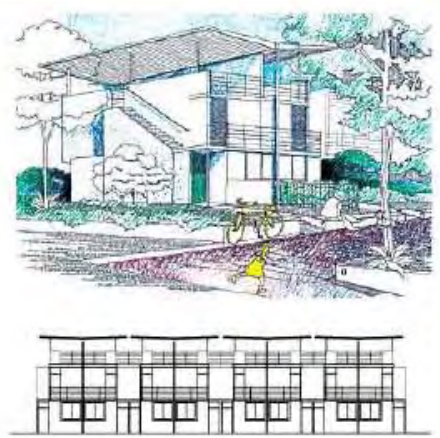

Elevaçăo geral -1
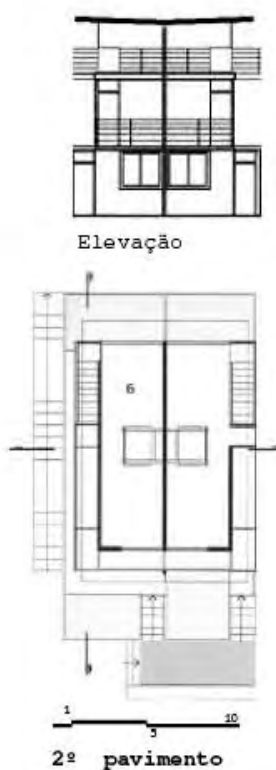

6. Terraço

\section{Fontes:}

JUNQUEIRA, Mônica de Camargo. Arquétipo verdadeiro. Projeto Design, São Paulo, n.371, p. 90, jan. 2011

SERAPIÃO, Fernando. Brasileiro nas cores e nas intenções. Projeto Design, São Paulo, n.278, p., abril, 2003.

SAYEGH, Simone. Arquitetura popular brasileira. Arquitetura e Urbanismo, São Paulo, n.126, setembro, 2004.

OLIVEIRA, Roberto. Arquitetos tentam mudar a sina da falta de criatividade que transforma os projetos de moradia popular em caixotões sem alma e sem graça. Revista da Folha, caderno Morar, São Paulo, agosto, 2007. 
